\title{
INTERNATIONAL GONFERENGE ON EURASIAN ECONOMIES 2019
}




\title{
INTERNATIONAL CONFERENCE ON EURASIAN ECONOMIES 2019
}

\author{
Editors: \\ Selahattin Sarı \\ Mehmet Balcilar \\ Alp H. Gencer
}

\author{
Copyright (C) 2019 \\ Eurasian Economists Association
}

\begin{abstract}
ALL RIGHTS RESERVED.
This book contains material protected under International and Federal Copyright Laws and Treaties. Any unauthorized reprint or use of this material is prohibited. No part of this book may be reproduced or transmitted in any form or by any means, electronic or mechanical, including photocopying, recording, or by any information storage and retrieval system without express written permission from the publisher.
\end{abstract}

ISBN: 978-605-9595-26-1

Typesetting: Hülya Üzümcü \& Alp H. Gencer

Print: Eastern Mediterranean University Press 


\section{INTERNATIONAL GONFERENGE ON EURASIAN ECONOMIES 2019}

\section{Famagusta \\ Turkish Republic of Northern Cyprus}

11-13 June 2019 


\section{FOREWORD}

We are proud to have completed the $11^{\text {th }}$ International Conference on Eurasian Economies, held in Famagusta, Turkish Republic of Northern Cyprus with the cooperation of Eastern Mediterranean University, Beykent University, Kyrgyz-Turkish Manas University, and Eurasian Economists Association on 11-13 June 2018.

In total, 140 abstracts were submitted to the conference from nine countries and 67 were selected to be presented at the conference and included in this proceedings book. There were also non-presenting participants to the conference, with the total participants around 140. The conference, now organized for more than 10 years, continues to serve as a platform bringing together regular participants without no loss in interest, indicating its significant success.

As in previous years, papers presented at the conference are collected in this proceedings book. A considerable amount of time and effort is put into evaluating and formatting the papers for the book. Each paper undergoes a rigorous three-stage selection process. We would like to thank our reviewers, scientific and organization committee members who contributed their valuable time and support to evaluating every paper. Additionally, we would like to extend our gratitude to Dr. Alp Gencer, who designed our web platform with great patience despite all the difficulties and prepared the proceedings for publication.

Our appreciation is also extended all members of Eastern Mediterranean University, who put every effort for the perfect organization. Administrative staff of Eastern Mediterranean University made every effort to make this conference a reality, as well as the Serdivan Tourism owner Hakan Genç. We extend our kindest thanks to all of them.

We would like to extend our greatest appreciation for their generous contribution to Prof. Dr. Necdet Osam, Rector of Eastern Mediterranean University and Prof. Dr. Tanju Besler, Vice Rector; Beykent University's Board of Trustees' Chairman and members, Prof. Dr. Murat Ferman, Rector, and Public Relations Department, as well as the administrative staff; and lastly to Prof. Dr. Sebahattin Balc1, Rector of Kyrgyz-Turkish Manas University. We would also like to thank Rifat Günay, chairman of the Central Bank of Turkish Republic of Northern Cyprus, which acted as the main sponsor of the conference, as well as Serkan Kayalar, chairman of the Turkish Coorperation and Coordination Agency (TIKA). The family of Prof. Dr. Mükerrem Hiç and Eurasian Economists Association continued their support by awarding best papers presented at the conference.

Finally, our greatest appreciation goes to all the academicians, researchers, and participants whose contributions have made this conference a success. We hope and believe that the International Eurasian Conference 2019 has made important contributions to the Eurasian region and scientific community at large.

We hope to see you at the 12th International Conference on Eurasian Economies.

\section{Prof. Dr. Selahattin Sarı and Prof. Dr. Mehmet Balcılar}

Conference Co-Chairs 


\section{ÖNSÖZ}

Onbirinci Uluslararası Avrasya Ekonomileri Konferansı, Doğu Akdeniz Üniversitesi, Beykent Üniversitesi, Kırgızistan-Türkiye Manas Üniversitesi ve Avrasya Ekonomistler Derneği'nin ortak organizasyonuyla 11-13 Haziran 2018 tarihlerinde Kuzey Kıbrıs Türk Cumhuriye’tinin Gazimağusa şehrinde gerçekleştirilmiştir.

Konferansa özet gönderim aşamasında 9 ülkeden 140 başvuru olmuştur. Hakem değerlendirmeleri sonucunda 67 bildirinin konferansta sunulması ve kitapta yayınlanması uygun bulunmuştur. Konferansa bildirisi olmayan öğretim üyesi, sektör temsilcileri ve dinleyiciler de iştirak etmiş ve konferans 140 civarında katılımcının iştiraki ile gerçekleşmiştir. On yılı aşkın bir süredir düzenlenen konferans düzenli katılımcımları ile Avrasya bölgesi ekonomistleri için bir araya gelme platformu olma özelliğini ilgi azalması olmadan devam ettirmektedir.

Konferansta sunulan bildiriler elinizde bulunan bu kitapta toplanmıştır. Gerek bildirilerin değerlendirilmesi aşamasında, gerekse kitap haline getirilmesi aşamasında ciddi emek sarf edilmektedir. Her bildiri üç aşamalı bir değerlendirme sürecinden geçmektedir. Bu değerlendirmelere zaman ayıran ve destek veren hakemlerimize, bilim kurulu üyelerimize, konferans hazırlıklarının başlamasından itibaren çok yoğun mesai harcayan organizasyon komitesindeki arkadaşlarımıza, web sayfası dizaynında her türlü müdahaleye rağmen sabırla işlemleri yerine getiren Dr. Alp Gencer'e teşekkürler.

Uluslararas1 Avrasya Ekonomileri Konferansı'nın onbirincisinin eksiksiz ve mükemmel olarak gerçekleştirilmesinde, planlama aşamasından konferansın sonlandırılmasına kadar her türlü desteği etkin bir şekilde veren Doğu Akdeniz Üniversitesinde idari personeli ve Hakan Beyin şahsında Serdivan Turizm'in çok önemli katkısı olmuştur.

Konferensa başta Doğu Akdeniz Üniversitesi rektörü Prof. Dr. Necdet Osam ve rektör yardımcıs Tanju Besler olmak üzere; Beykent Üniversitesi Mütevelli Heyet Başkan ve üyeleri ve rektörü Prof. Dr. Murat Ferman; Kırgızistan-Türkiye Manas Üniversitesi rektörü Prof. Dr. Sebahattin Balcı her konuda büyük destek vermişlerdir. Kendilerine sonsuz teşekkürler. Konferansa ana sponsor olarak destek sağlayan Kuzey Kıbrıs Türk Cumhuriyeti Merkez Bankası başkanı Rifat Günay ve yurt dışından gelen katımcılara katkı sağlayan Türkiye Cumhuriyeti Türk İşbirliği ve Koordinasyon Ajansı (TİKA) başkanı Serkan Kayalar'a teşekkür ederiz. Konferansın organizasyonunda birlikte hareket ettiğimiz Prof. Dr. Jusup Primbaev'in şahsında Kırgızistan-Türkiye Manas Üniversitesi'nin temsilcilerine ve bu konferansta da sağladıkları ödül desteği ile konferansı destekleyen Prof. Dr. Mükerrem Hiç ailesi ve Avrasya Ekonomistler Derneği'nin tüm yöneticilerine teşekkürler.

En büyük teşekkürümüz elbette ki konferansın oluşmasını sağlayan ve teşvikleriyle bizleri cesaretlendiren akademisyen, araştırmacı ve katılımcılaradır. Uluslararası Avrasya Ekonomileri Konferansının onbirincisinin başta Avrasya ülkeleri olmak üzere bilim dünyasına katkı sağlayacağı inanç ve dileğiyle konferans organizasyon heyeti adına teşekkür ve saygılarımızı sunuyoruz.

12. Uluslararası Avrasya Ekonomileri Konferansı'nda buluşmak üzere.

\section{Prof. Dr. Selahattin Sarı ve Prof. Dr. Mehmet Balcılar}

Konferans Eş Başkanları 


\section{ADVISORY BOARD}

- Prof. Dr. Ali Murat Ferman (Rector, Beykent University, Turkey)

- Prof. Dr. Necdet Osam (Rector, Eastern Mediterranean University, TR of Northern Cyprus)

- Prof. Dr. Sevin Uğural (Vice Rector, Eastern Mediterranean University, TR of Northern Cyprus)

- Prof. Dr. Turgut Özkan (Dean, Faculty of Economic and Administrative Sciences, Beykent University, Turkey)

- Prof. Dr. Eralp Bektaş (Dean, Faculty of Economics and Business Administration, Eastern Mediterranean University, TR of Northern Cyprus)

\section{ORGANIZING COMMITTEE}

- Prof. Dr. Selahattin Sarı (Beykent University, Turkey)

- Prof. Dr. Mehmet Balcilar (Eastern Mediterranean University, TR of Northern Cyprus)

- Prof. Dr. Jusup Pirimbaev (Kyrgyzstan-Turkey Manas University, Kyrgyzstan)

- Prof. Dr. Ayşen Hiç Gencer (Beykent University, Turkey)

- Assoc. Prof. Dr. Kamil Sertoğlu (Eastern Mediterranean University, TR of Northern Cyprus)

- Prof. Dr. Neşe Algan (Çukurova University, Turkey)

- Asst. Prof. Dr. Ainura Turdalieva (Kyrgyzstan-Turkey Manas University, Kyrgyzstan)

- Asst. Prof. Dr. Junus Ganiev (Kyrgyzstan-Turkey Manas University, Kyrgyzstan)

- Asst. Prof. Dr. Sitk1 Sönmezer (Beykent University, Turkey)

- Prof. Dr. İlyas Sözen (İzmir Kavram MYO, Turkey)

\section{WEB \& PRINT DESIGN}

- Dr. Alp Gencer (Germany)

- Ms. Hülya Üzümcü (Turkey)

- Mr. Alpin Gencer (Germany) 


\section{SCIENTIFIC BOARD}

- Prof. Dr. Ahmet Ay (Selçuk University, Turkey)

- Prof. Dr. Harun Bal (Çukurova University, Turkey)

- Prof. Dr. Viktor Barhatov (Chelyabinsk State University, Russia)

- Prof. Dr. Tansu Barker (Brock University, Canada)

- Prof. Dr. Mustafa Besim (Eastern Mediterranean University, TR of Northern Cyprus)

- Prof. Dr. Ersan Bocutoğlu (Avrasya University, Turkey)

- Prof. Dr. Cihan Çobanoğlu (University of South Florida, United States of America)

- Prof. Dr. Mustafa Kemal Değer (Karadeniz Technical University, Turkey)

- Prof. Dr. Ljubomir Drakulevski (Ss. Cyril and Methodius University, Macedonia)

- Prof. Dr. Hüseyin Avni Egeli (Dokuz Eylül University, Turkey)

- Prof. Dr. Ömer Selçuk Emsen (Atatürk University, Turkey)

- Prof. Dr. Cevat Gerni (Doğuş University, Turkey)

- Prof. Dr. Ahmet İncekara (İstanbul University, Turkey)

- Prof. Dr. Mustafa İsmihan (Eastern Mediterranean University, TR of Northern Cyprus)

- Prof. Dr. Danijela Jacimovic (University of Montenegro, Montenegro)

- Prof. Dr. Gani Kaliev (Academy of Agricultural Sciences, Kazakhstan)

- Prof. Dr. Zeynep Karaçor (Selçuk University, Turkey)

- Prof. Dr. S. Ridvan Karluk (Anadolu University, Turkey)

- Prof. Dr. Nuriddin Kayumov (Tajikistan Academy of Sciences, Tajikistan)

- Prof. Dr. Obidjon Khamidov (Tashkent State University of Economics, Uzbekistan)

- Prof. Dr. Merim Koichueva (National Academy of Sciences, Kyrgyzstan)

- Prof. Dr. Recep Kök (Dokuz Eylül University, Turkey)

- Assoc. Prof. Dr. Igor Kokh (Kazan Federal University, Russia)

- Prof. Dr. Makhfirat Kosimova (Tashkent State University of Economics, Uzbekistan)

- Prof. Dr. Turar Koychuev (National Academy of Sciences, Kyrgyzstan)

- Prof. Dr. Nosir Makhmudov (Tashkent State University of Economics, Uzbekistan)

- Prof. Dr. Sherzod Mustafaqulov (Tashkent State University of Economics, Uzbekistan)

- Prof. Dr. Fevzi Okumuş (University of Central Florida, United States of America)

- Prof. Dr. Zekai Özdemir (Istanbul University, Turkey)

- Prof. Dr. Tatiana Pyshkina (Academy of Economic Studies of Moldova (ASEM), Moldova)

- Prof. Dr. Farhad Rahmanov (Azerbaijan State Economy University, Azerbaijan)

- Prof. Dr. Alisher Rasulev (Institute of Economics, Uzbekistan)

- Prof. Dr. Orazaly Sabden (Institute of Economics, Kazakhstan)

- Prof. Dr. Mehmet Sarışık (Sakarya Applied Sciences University, Turkey)

- Prof. Dr. Haldun Soydal (Selçuk University, Turkey)

- Prof. Dr. Euphrasia Susy Suhendra (Gunadarma University, Indonesia)

- Prof. Dr. Ferenec Szavai (Kaposvar University, Hungary)

- Prof. Dr. Erdoğan Taşkın (Beykent University, Turkey)

- Prof. Dr. Muammer Tekeoğlu (Çukurova University, Turkey)

- Prof. Dr. Mustafa Topaloğlu (Özyeğin University, Turkey)

- Prof. Dr. Khodjamahmad Umarov (Tajik National University, Tajikistan)

- Prof. Dr. Bahadir Umurzakov (G.V. Plekhanov Russian University of Economics in Tashkent, Uzbekistan) 


\section{Contents}

SESSION 1A: Makroekonomi

Session Chair: Prof. Dr. Süreyya Hiç

\#2322: Enflasyon ve Faiz Oranı Arasındaki Nedensellik İlişkisi: Seçilmiş Ülkeler İçin Ampirik Bir Analiz 1

- Prof. Dr. Harun Bal (Çukurova University, Turkey)

- Ph.D. Candidate Esma Erdoğan (Çukurova University, Turkey)

- Ph.D. Candidate Berk Palandökenlier (Çukurova University, Turkey) *

\#2309: Enflasyon ve İşsizliğin Gelir Eşitsizliği Üzerine Asimetrik Etkisi: Türkiye Örneği

- Ph.D. Candidate Duygu Serin Oktay (Çukurova University, Turkey) *

\#2349: İşsizlik ve Enflasyon Çerçevesinde Phillips Eğrisinin Türkiye Üzerindeki Geçerliliğinin Vektör

Otoregresif ve Markov Rejim Değişim Modelleriyle Sınanması

- Ph.D. Candidate Fatih Y1lmaz (Beykent University, Turkey) *

- Ph.D. Candidate Onur Şeker (Beykent University, Turkey)

- Ph.D. Candidate Eren Pektaş (Beykent University, Turkey)

\#2305: OECD Ülkeleri İçin Reel Ücret, Enflasyon ve İşgücü Verimliliği Arasındaki İlişkinin Panel Tahmini ..29

- Ph.D. Candidate Sevilay Konya (Selçuk University, Turkey) *

- Prof. Dr. Zeynep Karaçor (Selçuk University, Turkey)

- Ph.D. Candidate Mücahide Küçüksucu (Necmettin Erbakan University, Turkey)

SESSION 2A: Growth

Session Chair: Prof. Dr. Mehmet Balcular

\#2296: The Export-Led Growth Hypothesis: A Panel Cointegration Approach in the Middle East and North Africa Countries (1980-2017)

- Ph.D. Candidate Ayat Abdelrahim Suliman Esaa (Çukurova University, Turkey)*

- Prof. Dr. Harun Bal (Çukurova University, Turkey)

- Asst. Prof. Dr. Erhan İşcan (Çukurova University, Turkey)

\#2293: A Different Look at Cointegration Relationship between Quarterly Inflation Rates and Growth via Seasonal Integration Tests

- Ph.D. Candidate Sera Şanlı (Çukurova University, Turkey) *

- Prof. Dr. Mehmet Özmen (Çukurova University, Turkey)

\#2265: The Importance Of SMEs On World Economies

- Ph.D. Candidate Murat Bayraktar (Çukurova University, Turkey) *

- Prof. Dr. Neşe Algan (Çukurova University, Turkey)

\#2274: Unemployment Hysteresis Revisited: The Case of Turkey

- Ph.D. Candidate Ufuk Can (Çukurova University, Turkey) *

- Ph.D. Candidate Zeynep Gizem Can (Çukurova University, Turkey)

- Prof. Dr. Harun Bal (Çukurova University, Turkey) 
SESSION 3A: Finance

Session Chair: Prof. Dr. Ayşen Hiç Gencer

\#2301: The Long-Run and Short-Run Endogeneity of Money Supply in the Republic of Macedonia: An

Empirical Analysis

- Ph.D. Candidate Milica Milosheska Gavrovska (Komercijalna Banka AD Skopje, Macedonia)

- Prof. Dr. Trajko Slaveski (Ss. Cyril and Methodius University, Macedonia)*

\#2279: The Aftermath of Quantitative Easing in Advanced Economies: The Empirical Evidences .84

- Prof. Dr. Harun Bal (Çukurova University, Turkey)

- Ph.D. Candidate Shahanara Basher (Çukurova University, Turkey) *

- Ph.D. Candidate Abdulla Hil Mamun (Çukurova University, Turkey)

\#2258: Blockchain Technology and its Impact on the Global Economy .98

- Dr. Burcu Sakız (Istanbul Aydın University, Turkey) *

- Prof. Dr. Ayşen Hiç Gencer (Beykent University, Turkey)

\#2247: Foreign Direct Investment as an Important Source of External Development Financing: New Evidence in Turkey .... 106

- Mohamed Isse Ibrahim (İstanbul Commerce University, Turkey) *

SESSION 4A: Sectoral Analysis

Session Chair: Prof. Dr. Mustafa Besim

\#2278: Highlighting Cross-cultural Differences as Rhetorical Strategies in Tourism Marketing for Eurasian Countries

- Asst. Prof. Dr. Ayca Oralkan (Beykent University, Turkey)*

\#2310: The Comparative Advantage of Crude Oil in the Top 10 Oil-Producing Countries

- Ph.D. Candidate Osama Elsalih (Eastern Mediterranean University, TR of Northern Cyprus)

- Assoc. Prof. Dr. Kamil Sertoğlu (Eastern Mediterranean University, TR of Northern Cyprus)

- Prof. Dr. Mustafa Besim (Eastern Mediterranean University, TR of Northern Cyprus)

- Asst. Prof. Dr. Abdelhakim Embaya (Sabratha University, Libya) *

SESSION 5A: Productivity

Session Chair: Prof. Dr. Mustafa İsmihan

\#2303: The Impact of Research and Development on Productivity: Case of Turkey

- Prof. Dr. Muammer Tekeoğlu (Çukurova University, Turkey)

- Prof. Dr. Neşe Algan (Çukurova University, Turkey)

- Asst. Prof. Dr. Erhan İşcan (Çukurova University, Turkey)

- Ph.D. Candidate Duygu Serin Oktay (Çukurova University, Turkey) *

\#2350: The Impact of External Instability and Socio-economic Infrastructure on the Productivity Dynamics of North Cyprus

- Prof. Dr. Mustafa İsmihan (Eastern Mediterranean University, TR of Northern Cyprus)

- Prof. Dr. Mustafa Besim (Eastern Mediterranean University, TR of Northern Cyprus) *

- Assoc. Prof. Dr. Kamil Sertoğlu (Eastern Mediterranean University, TR of Northern Cyprus) 
SESSION 1B: Uluslararası İlişkiler

Session Chair: Prof. Dr. Muammer Tekeoğlu

\#2314: Dünyadaki Ekonomik İşbirlikleri ve Ütopik Avrasya 134

- Assoc. Prof. Dr. Hakkı Çiftçi (Çukurova University, Turkey) *

\#2267: Kuzey Kıbrıs Türk Cumhuriyetinin 36. Kuruluş Yıldönümünde Kıbrıs Sorunu

- Asst. Prof. Dr. Çetin İlhan Akbulut (Kavram MYO, Turkey)*

\#2219: Ambargodan Ablukaya Doğru: Dış Politikada İktisadi Araçların Kullanımı Bağlamında Amerika Birleşik Devletleri’nin İran'a Yönelik İktisadi Yaptırımları Üzerine Bir Değerlendirme 158

- Asst. Prof. Dr. Nuri Gökhan Toprak (Kirklareli University, Turkey)*

SESSION 2B: Mikroekonomi

Session Chair: Prof. Dr. Ayşe Irmiş

\#2259: Ekonomik Karar Vermede Duyguların Rolü 153

- Asst. Prof. Dr. Aslı Öztopçu (Maltepe University, Turkey)*

\#2254: Kırgızistan'da Öğrencilerin Akademik Başarılarını Etkileyen Psikolojik Faktörler 160

- Asst. Prof. Dr. Raziya Abdiyeva (Kyrgyzstan-Turkey Manas University, Kyrgyzstan) *

- Dr. Kadiyan Boobekova (Kyrgyzstan-Turkey Manas University, Kyrgyzstan)

\#2233: Yöneticilerin Empatik Eğilim Düzeylerinin, Yönetsel Yetkinlikleri Üzerindeki Etkisi 165

- Asst. Prof. Dr. Hilal Çelik (Beykent University, Turkey)

- Ph.D. Candidate Ufuk Özen (Beykent University, Turkey) *

- Ph.D. Candidate Ebru Bağçı (Beykent University, Turkey)

\#2246: Gösterişçi Tüketim Üzerine Ampirik Bir Araştırma: Kırklareli Üniversitesi Örneği 171

- Asst. Prof. Dr. Aslı Okay Toprak (Kırklareli University, Turkey) *

- Prof. Dr. Zekai Özdemir (Istanbul University, Turkey)

SESSION 3B: Büyüme-Teknoloji

Session Chair: Prof. Dr. Feyzullah Eroğlu

\#2294: Teknolojik Yayılımının Gelir Dağılımı Üzerine Etkisi: OECD Ülkeleri Üzerine Bir Uygulama 179

- Prof. Dr. Neşe Algan (Çukurova University, Turkey)

- Asst. Prof. Dr. Erhan İşcan (Çukurova University, Turkey)

- Ph.D. Candidate Duygu Serin Oktay (Çukurova University, Turkey)*

\#2261: Linder Hipotezinin Geçerliliğinin Çekim Modeli ile Test Edilmesi: Türkiye ve Seçilmiş Geçiş

Ekonomileri

- Prof. Dr. Harun Bal (Çukurova University, Turkey)

- Asst. Prof. Dr. Müge Manga (Erzincan Binali Yıldırım University, Turkey)

- Ph.D. Candidate Esma Erdoğan (Çukurova University, Turkey) *

\#2277: Kapsayıcı Büyüme ve Küreselleşme: Türkiye Örneği

- Ph.D. Candidate Zeynep Gizem Can (Çukurova University, Turkey) *

- Ph.D. Candidate Ufuk Can (Çukurova University, Turkey)

- Prof. Dr. Harun Bal (Çukurova University, Turkey) 
SESSION 4B: Büyüme

Session Chair: Prof. Dr. Selahattin Sarl

\#2340: İşsizlik ve Göç Arasındaki İlişki: OECD Ülkeleri Uygulaması (2008-2018)

- Prof. Dr. Selahattin Sarı (Beykent University, Turkey) *

- Prof. Dr. Ahmet Ay (Selçuk University, Turkey)

- Ph.D. Candidate Melike Köksal (Selçuk University, Turkey)

\#2319: Türkiye ve Rusya Ekonomilerinin Girdi-Çıktı Analizi Kullanılarak Karşılaştırılması

- Assoc. Prof. Dr. Tuncer Özdil (Manisa Celal Bayar University, Turkey)

- Asst. Prof. Dr. Ainura Turdalieva (Kyrgyzstan-Turkey Manas University, Kyrgyzstan)*

- Prof. Dr. Cengiz Yilmaz (Konya Food and Agriculture University, Turkey)

\#2348: Doğu Akdeniz’deki Mücavir Ekonomik Bölge Enerji Kaynaklarının AB, Türkiye ve Kıbrıs Yönünden

Değerlendirilmesi

- Assoc. Prof. Dr. Kamil Uslu (Kavram MYO, Turkey)*

SESSION 5B: Girişimcilik

Session Chair: Prof. Dr. Lutfiye Özdemir

\#2287: Girişimcilik Öykülerinden Rekabet Stratejisi Analizi

- Asst. Prof. Dr. Şeyma Gün Eroğlu (Muğla S1tkı Koçman University, Turkey)

- Prof. Dr. Ayşe İrmiş (Pamukkale University, Turkey)*

\#2282: Mizah Tarzları ile Girişimcilik Eğilimi Arasındaki İlişki Üzerine Bir Araştırma

- Asst. Prof. Dr. Şeyma Gün Eroğlu (Muğla Sitkı Koçman University, Turkey)

- Merve Vural (Pamukkale University, Turkey)

- Prof. Dr. Feyzullah Eroğlu (Pamukkale University, Turkey) *

\#2307: Ağ ve Teknoloji Odaklı Uygulamalı Girişimcilik (ATOG) Programının Gençlerin Girişimcilik Bilgi ve Beceri Gelişimine Etkisi

- Assoc. Prof. Dr. Ömer Lütfi Antalyalı (Kyrgyzstan-Turkey Manas University, Kyrgyzstan)*

- Dr. Pınar Göktaş (Süleyman Demirel University, Turkey)

SESSION 1C: Para ve Bankacılık

Session Chair: Prof. Dr. Neşe Algan

\#2345: Kripto Para Bitcoin ve Türkiye’ deki Bitcoin Piyasas1

- Assoc. Prof. Dr. Hakan Acet (Selçuk University, Turkey)*

- Ph.D. Candidate Ayşe Özge Diken (Selçuk University, Turkey)

\#2266: Avrasya Ekonomik Birliği’nde Döviz Kuru İşbirliği Perspektifi

- Asst. Prof. Dr. Junus Ganiev (Kyrgyzstan-Turkey Manas University, Kyrgyzstan) *

- Asst. Prof. Dr. Damira Baigonushova (Kyrgyzstan-Turkey Manas University, Kyrgyzstan)

\#2260: Kurala Dayalı ve İhtiyari Para Politikası Tartışmaları Kapsamında Türkiye Ekonomisi İçin Taylor Kuralının Analizi .279

- Prof. Dr. Harun Bal (Çukurova University, Turkey)

- Asst. Prof. Dr. Mustafa Ildırar (Çukurova University, Turkey)

- Ph.D. Candidate Esma Erdoğan (Çukurova University, Turkey)* 
\#2351: İkili Uyarlanma Yaklaşımı: Türkiye için Yatırım Fonksiyonu Uygulaması (1963-2017) 289

- Prof. Dr. Mustafa İsmihan (Eastern Mediterranean University, TR of Northern Cyprus) *

- Dr. Mustafa Can Küçüker (Atılım University, Turkey)

SESSION 2C: Sektörel Analiz

Session Chair: Prof. Dr. Harun Bal

\#2336: Ziraat Fakültesi Öğrencilerinin Tarımın Geleceğine Yönelik Bakış Açıları: Tekirdağ İli Örneği 294

- Asst. Prof. Dr. Burçin Başaran (Namık Kemal University, Turkey)

- Ph.D. Candidate Zehra Meliha Tengiz (Namik Kemal University, Turkey) *

- Prof. Dr. Yasemin Oraman (Namık Kemal University, Turkey)

\#2346: Devlet Hastanelerinin Hizmet Performans1

- Dr. Seniha Avcil (Memorial Şişli Hospital, Turkey) *

\#2218: Eğitim Kalitesini Etkileyen Faktörlerin PISA Tabanlı Test Puanları Kullanılarak Değerlendirilmesi: Asya Ülkeleri Örneği

- Prof. Dr. Ebru Çağlayan Akay (Marmara University, Turkey)

- Asst. Prof. Dr. Zamira Oskonbaeva (Kyrgyzstan-Turkey Manas University, Kyrgyzstan)*

\#2241: Gıda Atıklarının Tarımda Gübre Olarak Kullanılabilme Olanakları

- Asst. Prof. Dr. Müjgan Hacığlu Deniz (İstanbul University, Turkey)

- Assoc. Prof. Dr. Özlen Hiç (İstanbul University, Turkey)*

\#2352: Türkiye Arıcılığının İleriye Yönelik Projeksiyonu

- Dr. Yusuf Ziya Tengiz (Kadir Has University, Turkey)

- Ph.D. Candidate Zehra Meliha Tengiz (Namık Kemal University, Turkey)

SESSION 3C: Hukuk

Session Chair: Prof. Dr. Mustafa Topaloğlu

\#2347: Yabancıların Türkiye'de Sınırlı Ayni Haklardan Yararlanmaları

- Prof. Dr. Adnan Deynekli (Bahçeşehir University, Turkey) *

\#2334: Kamu Denetçiliği Kurumu Kararlarının İnsan Hakları Bakımından Değerlendirilmesi

- Asst. Prof. Dr. Ezgi Cankurt (Beykent University, Turkey)*

\#2230: Yabancı Yatırımcıların Türkiye'de Şirket Kurması ve Hisse Devralması

- Prof. Dr. Mustafa Topaloğlu (Özyeğin University, Turkey)*

\#2275: Türk ve Fransız Anayasalarında Laiklik İlkesi

- Assoc. Prof. Dr. Ebru Karaman (Beykent University, Turkey)*

\#2273: Kümülâtif Etki Değerlendirmesinin Yarg1sal Denetimi

- Assoc. Prof. Dr. Gürsel Özkan (Turkish State Council, Turkey)* 
SESSION 4C: Finans

Session Chair: Prof. Dr. Turgut Özkan

\#2304: Varlık Yönetim Şirketleri ve Türkiye Ekonomisindeki Yeri 362

- Ph.D. Candidate Ayşe Özge Artekin (Selçuk University, Turkey) *

- Prof. Dr. Haldun Soydal (Selçuk University, Turkey)

\#2337: İtibar Katsayısı Ölçeğinin Geçerlik ve Güvenirliğinin Bankacılık Sektöründe İncelenmesi

- Prof. Dr. Lutfiye Özdemir (İnönü University, Turkey)

- Dr. Uyum Elitok (Batman University, Turkey)

- Asst. Prof. Dr. Yavuz Elitok (Batman University, Turkey)*

\#2248: Türkiye'de Konut Piyasası Dinamikleri

- Asst. Prof. Dr. Sitk1 Sönmezer (Beykent University, Turkey)

- Gürol Aytüre (Beykent University, Turkey) *

\#2263: Kredi Kartı Kullanımı: Üniversite Öğrencileri Üzerine Amprik Bir Araştırma 386

- Asst. Prof. Dr. Aslı Okay Toprak (Kırklareli University, Turkey) *

- Asst. Prof. Dr. Canan Özge Eğri (Kirklareli University, Turkey)

- Asst. Prof. Dr. Güldenur Çetin (İstanbul Ticaret University, Turkey)

SESSION 5C: Kamusal

\section{Session Chair: Prof. Dr. Zekai Özdemir}

\#2237: Kırgızistan'da Öznel Refah ve Güvenlik

- Asst. Prof. Dr. Mahmut Erdoğan (Kyrgyzstan-Turkey Manas University, Kyrgyzstan)

- Asst. Prof. Dr. Ainura Turdalieva (Kyrgyzstan-Turkey Manas University, Kyrgyzstan) *

- Asst. Prof. Dr. Raziya Abdiyeva (Kyrgyzstan-Turkey Manas University, Kyrgyzstan)

\#2290: Türk Ekonomisinin Bilgi Ekonomisi Kapsamında Performansına Dair Bir Değerlendirme 399

- Prof. Dr. Zeynep Karaçor (Selçuk University, Turkey) *

- Ph.D. Candidate Mücahide Küçüksucu (Necmettin Erbakan University, Turkey)

- Ph.D. Candidate Sevilay Konya (Selçuk University, Turkey) 
SESSION 1D: Turizm

Session Chair: Prof. Dr. Mehmet Sarışık

\#2343: Kariyer Planlaması ve Kişilik Özellikleri Arasındaki İlişkinin Belirlenmesine Yönelik Otel

İşletmelerinde Bir Araştırma ..... 408

- Prof. Dr. Mehmet Sarışık (Sakarya Applied Sciences University, Turkey)*

- Ph.D. Candidate Hasan Önal Şeyhanlıŏlu (Sakarya Applied Sciences University, Turkey)

\#2326: Otel Web Sitelerinin İçerik Analizi Yöntemiyle Değerlendirilmesi: Bişkek’te Bir Araştırma 416

- Asst. Prof. Dr. Azamat Maksüdünov (Kyrgyzstan-Turkey Manas University, Kyrgyzstan) *

\#2325: Kirsal Turizm Alanında Tarım ve Kırsal Kalkınmayı Destekleme Kurumu (TKDK) Destekleri:

Kastamonu Örneği

- Mr. Fatih Gürel (Çankırı Karatekin University, Turkey)

- Ph.D. Candidate Zehra Meliha Tengiz (Namık Kemal University, Turkey) *

- Ph.D. Candidate Osman İnan (Namık Kemal University, Turkey)

\#2344: Gastronomi Akımları ile Renklerin İlişkisi Üzerine Bir İnceleme

- Prof. Dr. Mehmet Sarışık (Sakarya Applied Sciences University, Turkey) *

- Ph.D. Candidate Nazlı Kardeş (Sakarya Applied Sciences University, Turkey)

SESSION 2D: Экономический рост

Session Chair: Prof. Dr. Jusup Pirimbaev

\#2256: Анализ и Моделирование Неравномерности Экономического Роста Регионов Кыргызской Республики в Новых Условиях

- Assoc. Prof. Dr. Kalybek Choroev (Kyrgyzstan-Turkey Manas University, Kyrgyzstan) *

\#2240: Экономическое Развитие Кыргызстана в Контексте Углубления Интеграции

- Ph.D. Candidate Asel Dzhailova (Kyrgyz University of Economics, Kyrgyzstan)*

\#2283: О Прогнозе Развития Евразийского Экономического Союза

- Prof. Dr. Jusup Pirimbaev (Kyrgyzstan-Turkey Manas University, Kyrgyzstan) *

- Dr. Zalkar Kamalov (University of Central Asia, Kyrgyzstan)

SESSION 3D: Предпринимательство

Session Chair: Prof. Dr. Damira Japarova

\#2225: Проблемы Реализации Стартап Проектов В Кыргызской Республике

- Ph.D. Candidate Aizhan Rakhmanalieva (Kyrgyz-Russian Slavic University, Kyrgyzstan) *

\#2228: Умная Специализация Как Возможность Роста Инновационной Активности Регионов

Кыргызской Республики

- Ph.D. Candidate Diliara Suleeva (Kyrgyz-Russian Slavic University, Kyrgyzstan)*

\#2270: Обучение Предпринимательству Как Драйвер Устойчивого Развития: Опыт Сибирского Института Управления -Филиала Российской Академии Народного Хозяйства и Государственной Службы При Президенте Российской

- Asst. Prof. Dr. Tatyana Gurunyan (The Russian Presidential Academy of National Economy and Public Administration, Russia) * 
SESSION 4D: Сельское хозяйство

Session Chair: Assoc. Prof. Dr. Akylbek Umetaliev

\#2291: ЕАЭБ Өлкөлөрүндө Айыл-Чарба Тармагын Колдоо Чаралары 476

- Asst. Prof. Dr. Damira Baigonushova (Kyrgyzstan-Turkey Manas University, Kyrgyzstan) *

- Asst. Prof. Dr. Junus Ganiev (Kyrgyzstan-Turkey Manas University, Kyrgyzstan)

- Ph.D. Candidate Mairam Baigonusheva (Marmara University, Turkey)

\#2244: Проблемы Питания в Кыргызской Республике и Пути Их Рещения 483

- Prof. Dr. Bermet Djurupova (Kyrgyz University of Economics, Kyrgyzstan)

- Prof. Dr. Jusup Pirimbaev (Kyrgyzstan-Turkey Manas University, Kyrgyzstan)

- Dr. Gulmira Samatova (Kyrgyzstan-Turkey Manas University, Kyrgyzstan)

\#2245: Создание Цепи Ценности Экспорта Меда 488

- Assoc. Prof. Dr. Akylbek Umetaliev (Kyrgyz State Technical University, Kyrgyzstan) *

SESSION 5D: Секторный анализ

Session Chair: Prof. Dr. Anara Kamalova

\#2235: Формирование Рыночной Модели В Финансировании Здравоохранении Кыргызской Республики.

- Prof. Dr. Damira Japarova (Kyrgyzstan-Turkey Manas University, Kyrgyzstan) *

\#2231: Проблемы И Перспективы Развития Инфраструктуры Туризма В Кр 497

- Prof. Dr. Anara Kamalova (Kyrgyz National University, Kyrgyzstan) *

\footnotetext{
* Presenting author
} 


\title{
Enflasyon ve Faiz Oranı Arasındaki Nedensellik İlişkisi: Seçilmiş Ülkeler İçin Ampirik Bir Analiz
}

\section{The Relationship Between Inflation and Nominal Interest Rate: Case of Selected Countries}

\author{
Prof. Dr. Harun Bal (Çukurova University, Turkey) \\ Ph.D. Candidate Esma Erdoğan (Çukurova University, Turkey) \\ Ph.D. Candidate Berk Palandökenlier (Çukurova University, Turkey)
}

\begin{abstract}
When the empirical studies in the literature on inflation and interest relation are examined, it can be seen that a positive or negative change in one of these two variables has a significant effect on the other variable. This situation reveals the necessity of evaluating the relationship between variables within the framework of cause and effect. In this study, the relationship between inflation, interest rates, showing similar macroeconomic structures Turkey, Indonesia and Brazil the country for the period 1985-2018 using annual data sets separately for each country were explained by the VAR model. The results showed only right way for Turkey to reciprocate the nominal rate of inflation variables for Indonesia and Brazil were found bidirectional causality between countries.
\end{abstract}

\section{Giriş}

Enflasyon son dönemlerde özellikle Gelişmekte olan ülkeler (GOÜ)'de temel makroekonomik istikrarsızlık kaynaklarından birisi olarak görülmektedir. Özellikle söz konusu ülke ekonomileri için fiyatlar genel düzeyindeki sürekli artışlar ekonomik performansın yavaşlamasına ve istikrarsızlı̆̆ın devamlılık kazanmasına neden olmaktadır. Yüksek enflasyon söz konusu ekonomilerde var olan kırılganlığı daha da derinleştirmekte ayrıca genel fiyatlardaki hızlı artışlar ile uluslararası alanda rekabet güçlerini de iyice zayıflamaktadır. Bu durum genel olarak hem ödemeler dengesini ciddi anlamda bozmakta hem de bu ülke ekonomileri için belirsizliği artırmaktadır. Belirsizliğin temel kaynağı ise enflasyon oranlarının yüksek olduğu dönemlerde göreli fiyatlardaki değişimlerin iktisadi birimler tarafindan net olarak algılanamamasından ileri gelmektedir. Dolayısıyla bu durum gerek yerli gerekse yabancı yatırımcıların kâr ve maliyet hesaplarını zorlaştırmakta bu ise tasarrufların daha yüksek reel getiri sağlayacak yatırım araçlarına gitmesine neden olmaktadır. Çünkü yüksek enflasyon büyük ölçüde faiz oranlarının da yükselmesine neden olmakta bu da konuya ilişkin literatürde yüksek enflasyonun mu faizin yükselmesine neden olduğu yoksa yüksek faizin mi enflasyonun yükselmesinin bir nedeni olduğu biçimindeki neden-sonuç tartışmalarına bizi götürmektedir.

Genel olarak merkez bankalarının temel hedefi fiyat istikrarını sağlamak yönündedir. Fiyat istikrarını sağlama sorumluluğuna sahip merkez bankaları ise bu görevi parasal politikalar aracılığıyla yürütmektedirler. Bu amaçla merkez bankalarının para politikası uygulamaları parasal aktarım mekanizmasına dayanmakta ve bu bankalar fiyat istikrarını sağlama konusunda en önemli araç olarak faizleri kullanmaktadır. Söz konusu aktarım mekanizmasına göre faizler yükseldiğinde ekonomide mal ve hizmetlere yönelik toplam talep azalacaktır. Bu da aşırı talepten kaynaklı enflasyonun (talep enflasyonu) düşmesine neden olacaktır. Diğer taraftan faizlerdeki yükseliş, yurt içinde döviz arzı fazlasına bağlı olarak kurların düşmesine bu da girdi maliyetlerindeki yükselişe bağlı maliyet enflasyonunun düşmesine neden olacaktır. Ancak diğer açıdan, yüksek enflasyon oranlarının da faizlerin yüksek düzeylerde belirlenmesine neden olduğu söylenebilir. Tüm bunlar dikkate alındığında bu iki parasal değişken arasında salt açıdan doğrusal bir ilişki bulunmayabilir. Dolayısıyla ülkelerin kendilerine özgü gerek ekonomik gerekse yapısal farklılıklar enflasyon ile faiz arasındaki ilişkiyi farklılaştırabilir. Bu nedenle politika yapıcılarının verecekleri faiz kararının enflasyona nasıl bir etki yapabileceğini araştırılması gerekir-

Bu çalışma, yeni yükselen piyasa ekonomileri içerisinde de yer alan Türkiye, Endonezya ve Brezilya ülkeleri için enflasyon ve faiz oranları arasındaki nedensellik ilişkisini araştırmaktadır. Söz konusu ülkeler, ulusal paraları dolar karşısında en fazla değer kaybı gösteren ve bu çerçevede enflasyon oranlarında yüksek artışlar ve ayrıca yüksek cari açık ve düşük büyüme performansı ve benzeri pek çok yönden benzer makroekonomik yapılar gösterdiklerinden enflasyon ve nominal faizler arasındaki nedenselliğin yönü bu ülkeler için ortaya konmaya çalışılmıştır. Seçili üç gelişmekte olan ülkeler için enflasyon ve faiz oranı arasındaki nedensellik ilişkisini ampirik olarak araştırmayı amaçlayan bu çalışmanın birinci kısımda, faiz ve enflasyon kavramları, enflasyon türleri ve çeşitleri açıklanacaktır. İkinci kısımda, enflasyon ve faiz arasındaki ilişki teorik çerçevesi ile izah edilecek ve söz konusu beş ülke için enflasyon ve nominal faiz serilerinin seyri grafikler eşliğinde gösterilmeye çalışılacaktır. Çalışmanın üçüncü kısımda ise konu ile ilgili teorik ve ampirik literatür taraması yapılacak ve yapılan çalışmalar tarihsel sıralamasına uygun bir biçimde gösterilecektir. Dördüncü kısımda 1985-2018 dönemlerine ait veri setleri kullanılarak enflasyon ve nominal faiz oranları arasındaki ilişkinin yönü Granger nedensellik analizi ile 
belirlenmeye çalışılacaktır. Çalışmamız, analizlerden elde edilen bilgilerin değerlendirildiği sonuç bölümü ile tamamlanacaktır.

\section{Kavramsal Boyutuyla Enflasyon ve Faiz Oranı}

Enflasyon, genel olarak bir ekonomideki ortalama fiyatlar genel seviyesindeki hızlı, kalıcı ve sürekli yüksek artışlar olarak tanımlanmaktadır (Asoguo, 1991, s. 15). Bu durumda enflasyon olgusu ile sadece belli bir malın veya hizmetin fiyatındaki bir defalık artış değil, fiyatlar genel seviyesindeki sürekli bir artış kastedilmektedir (TCMB, 2004, s. 3). Dolayısıyla günümüzde iktisatçılar arasında da enflasyonun fiyatlar genel seviyesindeki sürekli artışlar olduğu biçimindeki tanımlama büyük ölçüde kabul görmektedir (Parasız, 1995, s. 367).

Bir ekonomide enflasyonun nedenleri ile ilgili pek çok görüş bulunmaktadır. Bu konu üzerinde ciddi tartışmalar olmakla birlikte genel olarak nedenlerine göre enflasyon türlerini 3 başlık altında toplayabiliriz. Bunlar; talep enflasyonu, maliyet enflasyonu ya yapısal enflasyondur. Ekonomi tam istihdam seviyesindeyken toplam talepte meydana gelecek bir artış aşırı talebe yol açacak ve bu durum fiyat artışlarına neden olacaktır. Ekonomideki mal ve hizmetlere yönelik aşırı talebi karşılamak amacıyla firmaların daha fazla faktör talep etmesiyle faktör fiyatlarında da artış meydana gelecektir. Dolayısıyla tam istihdam seviyesindeyken gerek mal piyasasında gerekse faktör piyasasındaki fiyat artı̧̧ları toplam talebi artışına neden olacak ve aşırı toplam talep, enflasyonun en önemli nedeni olacaktır (Parasız, 1995, s. 367-368). Ayrıca ekonomideki fiyat artışları maliyetlerdeki genel artışlardan da kaynaklanabilir. Faiz kavramsal olarak, bir borçlunun sahip olmadığı paranın kullanımı için ödediği fiyat olarak tanımlanmaktadır (Devereux, 2002. s. 11-12). Faiz değişik iktisatçılar tarafından farklı biçimlerde tanımlanmıştır. Örneğin Eugen von Böhm-Bawerk'e (1889) göre faiz, dolambaçlı üretim yöntemi ile çalışmanın maliyetidir. Irving Fisher'a $(1907,1930)$ göre, sabırsızlığın bedeli, John Maynard Keynes'e (1953) göre ise likidite rahatlığının bedeli olmaktadır. Faiz enflasyona göre nominal ve reel faiz olmak üzere ikiye ayrılmaktadır. Fisher (1930)'a göre nominal faiz, işlem anında geçerli olan faiz oranı olup, paranın fiyatı olarak paranın zaman değerini belirtmektedir (Fisher, 1930:12). Diğer taraftan nominal faizin reel faizden önemli bir farkı enflasyonu hesaba katmamasıdır. Bir diğer ifadeyle fiyatlar genel seviyesinde meydana gelen değişimlere göre ayarlanmayan faiz oranını ifade etmektedir. Reel faiz oranı ile nominal faiz oranı arasındaki fark temelde enflasyona bağlı olmaktadır. Dolayısıyla reel faiz oranı, nominal faizin içindeki enflasyon etkisinin arındırılmasından sonra kalan orandır. Ancak genel anlamda reel faiz oranı, nominal faiz oranı ile enflasyon oranı arasındaki farktan kalan oranı tanımlamamaktadır. $\mathrm{Bu}$ çerçevede reel faiz aşağıdaki formüllerle hesaplanabilmektedir (Sayılgan, 2013: 5-6). Dolayısıyla nominal faizin reel faizden önemli bir farkı enflasyonu hesaba katmamasıdır. Bir diğer ifadeyle nominal faiz oranı, fiyatlar genel seviyesinde meydana gelen değişimlere göre ayarlanmayan faiz oranını ifade etmektedir.

\section{Enflasyon ve Faiz İlişkisi}

Enflasyon ve faiz arasındaki ilişki, makroekonomik dengenin oluşumu açısından son derece önemlidir. $\mathrm{Bu}$ çerçevede ekonomik performansın gidişatı hakkında önemli bir gösterge niteliğinde olan bu parasal değişkenler arasındaki ilişki teorik boyutu ile bu bölümde izah edilmeye çalışılacaktır.

Klasik iktisat teorisinin en önemli varsayımlarından birisi, nominal değişkenlerdeki bir değişimin reel ekonomik değişkenler üzerinde hiçbir etkisinin olmamasıdır. Klasiklere göre paranın uzun dönemde yansız olması ile doğrulanabilecek bu sonuç, temelde enflasyon oranındaki sürekli dalgalanmaların denge reel faiz oranı üzerinde herhangi bir etkisinin olmadığını ima etmektedir. Bu olguyu ifade etmenin geleneksel bir yolu, nominal faiz oranlarının beklenen enflasyonu ve reel faiz oranını yansıtan iki ayıı bileşene ayrıştırılması ile mümkün olacaktır. Dolayısıyla enflasyon ve nominal faizler arasındaki ilişkiyi ilk kez ifade eden Fisher, 1930'da yayınladığı eserinde (The Theory Of Interest) bu ilişkiyi iyi bilenen Fisher denklemiyle aşağıdaki biçimde göstermiştir;

$$
R_{t}=\pi_{t}^{e}+r_{t}
$$

Burada $R_{t}$ nominal faiz oranını, $\pi_{t}^{e}$ beklenen enflasyon oranın ve $r_{t}$ ise beklenen (ex-ante) reel faiz oranını ifade etmektedir. Bu son değişken ekonomik modellerde, yatırımcı tercihleri veya sermayenin marjinal verimliliği gibi derin yapısal parametrelerle belirlenir ve uzun dönemde sabit olduğu kabul edilir. Bu çerçevede herhangi bir para aldanması (money illusion) olmaması halinde beklenen enflasyon oranındaki bir değişim reel faizde bir değişim olmadan nominal faizle birebir ilişki içinde olacaktır (Clemente vd., 2017). Fisher'ın hipotezine göre enflasyon, faiz oranlarının ana belirleyicisi olmakta ve enflasyon oranı yüzde bir arttığında faiz oranı da aynı oranda artış göstermektedir (Teker vd., 2012, s. 41-42). Mankiw (2009, s. 94-95), Fisher denklemi göre nominal faiz oranının iki nedenden ötürü değişeceğini ileri sürmektedir. Buna göre nominal faizdeki değişim ya reel faiz oranındaki değişiklikten ya da enflasyon oranındaki değişiklikten kaynaklanmaktadır. Ayrıca Fisher denklemi ve Miktar Teorisi birlikte parasal büyümenin nominal faiz oranını nasıl etkilediğini anlatmaktadır. Miktar teorisine göre, parasal genişlemedeki \%1'lik artış, enflasyon oranındaki \%1'lik artışa neden olmaktadır. Fisher denklemine göre ise, enflasyon oranındaki \%1'lik artış, nominal faiz oranında \%1'lik artışa neden olmaktadır. Enflasyon oranı ile nominal faiz oranı arasındaki bu bire bir ilişkiye de "Fisher Etkisi" denilmektedir. 
Fisher'ın ilişkisi, bazı iktisatçılar tarafından kabul görmekle birlikte önemli eleştirilere de uğramıştır. Fisher teorisini kabul eden Darly Feldstein'ın teorisine göre, faiz oranlarındaki değişim önemli ölçüde olsa bile, faiz ve enflasyon arasındaki birebir ilişki nedeniyle faiz oranı enflasyon ile birlikte yükselmekte ya da düşmektedir. Buna karşın Robert Mundell ve James Tobin gibi iktisatçılar, enflasyon oranındaki değişimlerin beklenen (ex-ante) reel faiz oranını ters yönde etkilediğini ileri sürerek Fisher ilişskisini eleştirmiştir. Daha açık bir ifadeyle bu iki iktisatçıya göre, enflasyon oranı yükselirse faiz oranı düşmekte ve bu durumun tersi de geçerli olmaktadır. Enflasyon oranındaki artışlar yatırımların gerçek değerini azalmasına neden olmakta ve yatırımcılar, yatırımın azalan değerini telefi etmek için daha fazla tasarruf yapmak zorunda kalacaklardır. Dolayısıyla yüksek enflasyon nedeniyle artan tasarruflar beklenen reel faiz oranını azaltacaktır. Buna karşın düşük enflasyon tersi bir etki yaratacaktır. Ayrıca Mundell ve Tobin, beklenen reel faiz oranının sabit olmadığını, nominal faiz oranının enflasyonla aynı yönde değiştiğini ancak bu değişimin aynı oranda olmayıp daha küçük oranda gerçekleştiğini savunmuşlardır (Moraşan ve Zubaş, 2015, 149-150).

Teorik olarak enflasyon, nominal ve reel faizler arasındaki ilişkiler Fisher eşitliği ile açıklanmaktadır. Ancak enflasyon ve faiz gibi parasal değişkenler arasındaki ilişkiler açıklanırken bir ekonomide var olan enflasyonun nedenlerinin de neler olabileceğinin tartışmaya açık olması gerekir. Enflasyonun nedenlerine yönelik çeşitli düşünce okullarına dahil olan iktisatçılar arasında farklı görüşler bulunmaktadır. Örneğin Klasiklere göre, enflasyonun kaynağı Irwing Fisher'ın miktar kuramına dayalı olarak açıklanmaktadır. Miktar kuramına göre, ekonomide para arzı artışı fiyatlar genel düzeyini aynı yönde ve oranda artıracak ve bu enflasyona neden olacaktır. Keynesyenlere göre enflasyon, ekonomi tam istihdam düzeyindeyken ortaya çıkan aşırı talepten kaynaklanmaktadır. Diğer taraftan Milton Friedman'ın da dahil olduğu monetarist iktisatçılara göre ekonomide aşırı para arzı artışı enflasyona neden olmakta ve enflasyonun reel üretimin üzerinde bir para arzı artışının sonucu olduğu belirtilmektedir. Bununla birlikte Yapısalcılar, bir ekonomide enflasyonun maliyet kaynaklı olduğunu ileri sürerken, Yeni Klasik iktisatçılar ise para arzındaki bir artışın iktisadi ajanlar tarafından beklenmesi ile parasal genişlemenin etkilerinin hem kısa dönemde hem de uzun dönemde enflasyonist olacağını vurgulamaktadırlar (Taban ve Şengür, 2016). Enflasyon ve faiz ilişkisinde nedensellik yönü ise son derece karmaşık ve tartışmalı bir konu olarak karşımıza çıkmaktadır. Nedenselliğin yönü bakımından pek çok iktisatçı arasında görüş ayrılıkları mevcut olmakla birlikte genel olarak nominal faiz oranlarının daha yüksek enflasyonla birlikte daha yüksek olma eğiliminde olduğu ileri sürülmektedir. Diğer bir ifadeyle yüksek faiz yüksek enflasyonun bir sonucu olmaktadır.

\section{Literatür Özeti}

Çalışmanın bu bölümünde öncelikle enflasyon ve faiz oranı arasındaki ilişkiler, GOÜ’i kapsayan değişik ülke örnekleri ve dönemler için farklı çalışmalar ile ortaya konulmaktadır. Nitekim literatürde enflasyon ve faiz arasındaki nedensellik ilişkisini araştırmaya yönelik pek çok çalışma bulunmaktadır. Bu çerçevede konuya ilişkin çalışmalarda uygulanan yöntemler ve elde edilen bulgular şu şekilde özetlenebilir; 


\begin{tabular}{|c|c|c|c|c|}
\hline Yazarlar & Dönem & Ülke & Yöntem & Sonuç \\
\hline $\begin{array}{l}\text { Çinko } \\
(2017)\end{array}$ & $\begin{array}{l}\text { 2003:M1- } \\
\text { 2017:M2 }\end{array}$ & Türkiye & $\begin{array}{c}\text { Engle-Granger } \\
\text { Eşbütünleşme testi }\end{array}$ & $\begin{array}{l}\text { Çalışmada yapılan eşbütünleşme testi sonucunda iki değişken arasında uzun dönemli } \\
\text { bir ilişkiye rastlanmıştır. Elde edilen sonuçlara göre enflasyon oranı teorik } \\
\text { beklentilere uygun olarak nominal faiz oranlarını pozitif ve yüksek derecede } \\
\text { etkilediği görülmüştür. Çalışmada ele alınan dönemler için Fisher hipotezinin Türkiye } \\
\text { için geçerli olduğu sonucuna ulaşılmıştır. }\end{array}$ \\
\hline $\begin{array}{l}\text { Garcia } \\
(1993)\end{array}$ & $\begin{array}{l}\text { 1973:M1- } \\
\text { 1990:M6 }\end{array}$ & Brezilya & EKK & $\begin{array}{l}\text { Çalışmada nominal faiz oranları için endekslenmemiş mevduat sertifikaları faiz oranı } \\
\text { kullanılırken, enflasyon için bir önceki ayın fiyat endeks değerleri kullanılmıştır. } \\
\text { Çalışmadan elde edilen bulgulara göre beklenen enflasyon oranının nominal faiz } \\
\text { oranlarındaki hareketlerin \% 99'unu açıkladığı dolayısıyla enflasyondan nominal faiz } \\
\text { oranlarına doğru kuvvetli bir nedenselliğin bulunduğu görülmüştür. }\end{array}$ \\
\hline$\left|\begin{array}{ll}\text { Said } & \text { ve } \\
\text { Janor } & \\
(2001) & \end{array}\right|$ & $1986-1996$ & $\begin{array}{l}\text { Malezya, Tayland, } \\
\text { Endonezya, Güney } \\
\text { Kore ve Filipinler }\end{array}$ & $\begin{array}{l}\text { Engle-Granger } \\
\text { Eşbütünleşme, } \\
\text { Nedensellik }\end{array}$ & $\begin{array}{l}\text { Çalışmada yazarlar ADF birim kök testi ve Engle-Granger testi uygulayarak } \\
\text { değişkenlerin durağanlığını ve eşbütünleşme özelliklerini araştırmışlardır. ADF birim } \\
\text { kök testi sonuçlarına göre tüm ülkeler için birinci farklarında durağan oldukları } \\
\text { görülmüştür. Granger test sonuçlarına göre tüm ülkeler ççin enflasyon ve faiz oranları } \\
\text { arasında çift yönlü nedensellik tespit edilmiştir. Ancak Endonezya hariç diğer dört } \\
\text { ülke için değişkenler arasında uzun vadeli denge ilişkisi çerçevesinde eşbütünleşme } \\
\text { ilişskisi bulunamamıştır. Bu çerçevede elde edilen bulgular dört ülke için Fisher } \\
\text { hipotezinin geçerli olmadığını göstermiştir. }\end{array}$ \\
\hline $\begin{array}{l}\text { Carneiro } \\
\text { vd. }(2002)\end{array}$ & $\begin{array}{l}\text { 1980:M1- } \\
\text { 1997:M12 }\end{array}$ & $\begin{array}{l}\text { Arjantin, Brezilya ve } \\
\text { Meksika }\end{array}$ & $\begin{array}{l}\text { Eşbütünleşme ve } \\
\text { Nedensellik Testi }\end{array}$ & $\begin{array}{l}\text { Çalışmada yazarlar her bir ülke için nominal faiz oranını temsilen mevduat faiz } \\
\text { oranını, enflasyon için de tüketici fiyat endeksi kullanmışlardır. Bu çerçevede iki } \\
\text { değişken arasındaki ilişkiyi araştırmak için Johansen eşbütünleşme testi çerçevesinde } \\
\text { zayıf dışsallık testi uygulanmıştır. Ayrıca nedenselliğin yönünün enflasyondaki } \\
\text { değişikliklerden faiz oranlarındaki değişikliğe doğru olup olmadığ belirlenmeye } \\
\text { çalış1lmıştır. Dolayısılla yapılan çalış̧ada Fisher etkisinin geçerli olduğu yani faiz } \\
\text { oranlarının enflasyon oranındaki değişmelere uyum sağladığı tespit edilmiştir. }\end{array}$ \\
\hline $\begin{array}{l}\text { Bozoklu } \\
\text { ve Yilanc1 } \\
(2011)\end{array}$ & 1996:M1- & $\begin{array}{l}\text { Arjantin, Brezilya, } \\
\text { Çin, Endonezya, } \\
\text { Filipinler, Güney } \\
\text { Afrika, Güney Kore, } \\
\text { Hindistan, Hong } \\
\text { Kong, Malezya, } \\
\text { Meksika, Singapur, } \\
\text { Şili, Tayland, Türkiye }\end{array}$ & $\begin{array}{c}\text { Panel Brim Kök } \\
\text { Testi }\end{array}$ & $\begin{array}{l}\text { Çalışmada nominal faiz oranları olarak, farklı ülkeler için farklı proxyler kullanılmış } \\
\text { olup genel olarak bunlar, Şili, Çin, Türkiye ve Arjantin için mevduat faiz oranı, } \\
\text { Filipinler, Endonezya, Brezilya, Güney Afrika, Güney Kore, Tayland, Singapur ve } \\
\text { Hong Kong için bankalar arası para piyasası faiz oranı, Malezya ve Meksika için ise } \\
3 \text { aylık hazine bonosu faiz oranı ve son olarak Hindistan için borç verme faiz oranı } \\
\text { kullanmışlardır. Ayrıca enflasyon oranı için TÜFE değişim oranı kullanmışlardır. } \\
\text { Çalışmadan elde edilen bulgulara göre nominal faiz oranlarının enflasyon için iyi bir } \\
\text { gösterge olduğu ve nominal faizlerdeki değişimin beklenen enflasyon oranında da } \\
\text { değişimlere neden olacağı tespit edilmiştir. }\end{array}$ \\
\hline $\begin{array}{l}\text { Tsong ve } \\
\text { Hachicha } \\
(2014)\end{array}$ & $\begin{array}{l}\text { 1995M1- } \\
2011 \mathrm{M} 6\end{array}$ & $\begin{array}{l}\text { Endonezya, Güney } \\
\text { Afrika, Rusya, } \\
\text { Malezya }\end{array}$ & $\begin{array}{l}\text { Engle-Granger } \\
\text { Eşbütünleşme Ve } \\
\text { Xiao (2009) Kantil } \\
\text { Eşbütünleşme } \\
\text { Testleri }\end{array}$ & $\begin{array}{l}\text { Çalışmada yazarlar nominal faiz oranlarına vekil olarak Endonezya için vadesiz } \\
\text { krediler, Malezya için bankalararası gecelik faiz oranları, Rusya ve Güney Afrika için } \\
\text { para piyasası faiz oranı, enflasyon için de TÜFE kullanılmıştır. Çalışmada yöntem } \\
\text { olarak Engle-Granger eşbütünleşme ve Xiao (2009) kantil eşbütünleşme testleri } \\
\text { kullanmışlardır. Buna çerçevede Engle-Granger eşbütünleşme test sonuçlarına göre } \\
\text { nominal faiz oranları ile enflasyon arasında bir uzun dönemli ilişkiye rastlanmamışstır. } \\
\text { Ayrıca yine bu test sonuçlarına göre nominal faiz oranları, enflasyondaki değişmelere } \\
\text { daha az tepki verdiği ancak yüksek enflasyon durumunda enflasyonu düşürmek için } \\
\text { nominal faiz oranlarının artırılması gerektiği tespit edilmiştir. Buan karşın Xiao } \\
\text { (2009) eşbütünleşme testi sonuçlarına göre iki değişken arasında uzun vadeli bir } \\
\text { ilişkiye rastlanmıştır }\end{array}$ \\
\hline $\begin{array}{l}\text { Y1ldırım } \\
(2016)\end{array}$ & $1997-2014$ & $\begin{array}{l}\text { Hindistan, Türkiye, } \\
\text { Brezilya, Endonezya } \\
\text { ve Güney Afrika }\end{array}$ & \begin{tabular}{|} 
Pedroni \\
Eşbütünleşme Testi, \\
Pedroni FMOLS, \\
Pedroni DOLS, \\
Dumitrescu Ve \\
Hurlin (2012), Panel \\
Granger Nedensellik \\
Analiz Yöntemleri
\end{tabular} & $\begin{array}{l}\text { Çalışmada faiz oranı olarak Merkez Bankası politika faizinde dolaysız olarak } \\
\text { etkilenen kredi (borç verme) faizleri ile enflasyon için } 2010=100 \text { bazlı TÜFE } \\
\text { verilerini kullanılmıştır. Yapılan ampirik çalışmada panel birim kök testi sonuçlarına } \\
\text { göre seriler birinci farklarında durağan haline gelmişlerdir. Ardından Pedroni ve Kao } \\
\text { eşbütünleşme testi yapılarak seriler arasındaki uzun vadeli ilişkiler araştırılmış ve } \\
\text { uzun dönemli bir eşbütünleşik ilişkiye rastlanmıştır. Ayrıca Panel FMOLS ve Panel } \\
\text { DOLS yöntemleri ile elde edilen bulgular anlamlı çıkmıştır. Sonuçlara göre faizler } \\
\text { enflasyonu kontrol etmede önemli bir araç olarak kullanılabilir. Son olarak } \\
\text { nedensellik analizine göre enflasyon ve faiz arasında çift yönlü bir nedensellik ilişkisi } \\
\text { bulunmuştur. }\end{array}$ \\
\hline $\begin{array}{ll}\text { Bayat } & \text { vd. } \\
(2017) & \end{array}$ & 2000:M1- & $\begin{array}{l}\text { Brezilya, Hindistan, } \\
\text { Endonezya, Güney } \\
\text { Afrika ve Türkiye }\end{array}$ & $\begin{array}{c}\text { Panel Eşbütünleşme } \\
\text { Ve Panel } \\
\text { Nedensellik Testleri, } \\
\text { Nedensellik }\end{array}$ & $\begin{array}{l}\text { Çalışmada enflasyon için TÜFE verileri kullanılırken nominal faiz oranları için } \\
\text { politika faiz oranları kullanılmıstır. Panel eşbütünleşme testi sonuçlarına göre } \\
\text { değişkenler arasından uzun vadeli bir ilişki bulunmuştur. Diğer taraftan } \\
\text { Emirmahmutoğlu ve Köse (2011) tarafından geliştirilen panel nedensellik test } \\
\text { sonuçlarına göre, sadece Brezilya ve Endonezya için enflasyon ve nominal faiz } \\
\text { oranları arasında çift yönlü nedensellik bulunmuştur. Türkiye ve Güney Afrika için } \\
\text { faizden enflasyona doğru tek yönlü bir nedenselliğe rastlanırken, buna karşın } \\
\text { Hindistan için böyle bir nedensellik ilişkisine rastlanmamıştır. }\end{array}$ \\
\hline $\begin{array}{l}\text { Tiraşoğlu } \\
(2018)\end{array}$ & 1990:M1- & $\begin{array}{l}\text { Meksika Endonezya, } \\
\text { Nijerya ve Türkiye }\end{array}$ & $\begin{array}{l}\text { Eşik Değerli ARDL } \\
\text { Eşbütünleşme Testi }\end{array}$ & $\begin{array}{l}\text { Çalışmada ele alınan dört ülke için enflasyon ve nominal faiz oranları arasında uzun } \\
\text { dönemli bir ilişsi tespit edilmiştir. Elde edilen bu sonuç MINT ülkeleri için Fisher } \\
\text { hipotezinin geçerliliğini destekler niteliktedir. }\end{array}$ \\
\hline
\end{tabular}

Tablo 1. Enflasyon ve Faiz Oranları Arasındaki Nedensellik İlişkisine Yönelik Literatür Özeti 


\section{Veri Seti}

Türkiye'nin enflasyon ve faiz oranı arasındaki nedensellik ilişkisini incelemek için, 2003:01-2015:02 dönemine TÜFE ve faiz oranları serileri kullanılmıştır. Veriler Hazine Müsteşarlığı ve Türkiye Cumhuriyet Merkez Bankası (TCMB) Elektronik Veri Dağıtım Sistemi’nden temin edilmiştir. Kullanılan değişkenlere ait detaylı bilgiler Tablo 1'de gösterilmiştir. Modelde DİBS (Devlet İç Borçlanma Senetleri) faiz oranları ve TÜFE olmak üzere iki değişken kullanılmıştır. Çalışmada, Gelişmekte olan ülkeler grubu içerisinde yer alan Türkiye, Endonezya ve Brezilya ekonomilerinde enflasyon ve faiz oranı arasındaki nedensellik ilişkisini incelemek için, 1985-2018 dönemine ait TÜFE (bir önceki yılın aynına göre artış oranı) ve mevduat faiz oranı serileri kullanılmıştır. Veriler Uluslararası Para Fonu (International Monetary Fund- IMF)'nun veri tabanı olan İnternational Financial Statistics (IFS)'den elde edilmiştir. Model tahmini ve analizde kullanılan testler için Eviews 9 paket programı kullanılmıştır.

\subsection{Yöntem}

Çalışmada ilk olarak serilerin durağanlığı; Augmented Dickey Fuller (ADF) ve Phillips-Perron (PP) birim kök testleriyle incelenmiştir. Brim kök testlerinden ADF; genel kullanıma sahip olduğu ve PP; trend içeren serilerin durağanlığını test etmede daha güçlü olduğu olduğundan dolayı tercih edilmiştir. Seriler arasında nedensellik ilişkisinin varlığ

Sims (1980) tarafından önerilen VAR modelleri zaman serisi analizlerinde yaygın olarak kullanılmaktadır. Var modelleri bir takım katı kuramsal kısıtlamalar getirmediğinden modelde kullanılan değişkenlerin içsel-dışsal ayırımından kaçınmakta bu çerçevede söz konusu modeller, eşanlı denklem sistemlerinden büyük ölçüde ayrılmaktadır. Ayrıca kısa vadeli tahmin amaçlı olarak bu yaklaşım, geleneksel modellerin bir sınırlaması olarak eksojen (dışsal) değişkenlerin açık bir şekilde tahmin etme ihtiyacını da ortadan kaldırmaktadır (Robinson, 1996, s. 7). VAR modeli ayrıca istatistiksel testlerde de çok sık kullanılmaktadır. Bu metodoloji değişkenler arasındaki karşılıklı bağımlılık ve dinamik ilişkileri belirlemede yarar sağlar ve bu model istatistiksel olmayan önsel (a priori) bilgilerin katılımıyla da zenginleştirilmiştir (Pfaff, 2008, s. 1). Diğer taraftan bu modele dayanan etki-tepki analizleri ile değişkenlerden birinde meydana gelecek bir birimlik şoka diğer değişkenlerin buna verdikleri tepkilerin ölçülmesine olanak sağlamaktadır (Wickens ve Motto, 2001, s. 371-372). Bu çerçevede söz konusu model içsel tepkiyle dışsal tepkiyi ayırt edebilmeyi mümkün kılmaktadır (Karacan, 2017, s. 145). Bununla birlikte model geleneksel büyük ölçekli makroekonometrik modellere göre karmaşık yapılar içermeyip tahmin sonuçları kolayca yorumlanabilmektedir (Bjornland, 2000, s. 5). Çünkü bu model çeşitli şokların makroekonomik değişkenler üzerindeki göreli önemini dinamik etkisini ele almayı mümkün kılmakta ve politika yapıcıların ekonomik değişkenlerin şoklara karşı nasıl tepkiler verdiği konusundaki anlayışlarını derinleştirerek sürekli değişen koşullara daha iyi yanıt vermelerini sağlamaktadır (Sarte, 1997, s. 45).

\subsubsection{Birim Kök Testi;}

Çalışmada serilerin durağanlık sınaması için Genişletilmiş Dickey Fuller (ADF) ve Phillips-Perron (PP) birim kök testleri kullanılmıştır. Değişkenler arasında istatistiksel olarak anlamlı ilişkiler bulunabilmesi için serilerin durağan hale getirilmesi gerekmektedir. ADF testi aşağıda yer alan üç denklemle yapılabilmektedir;

$$
\begin{aligned}
& \Delta Y_{t}=(\alpha-1) y_{t-1}+u_{t} \\
& \Delta Y_{t}=\beta_{0}+(\alpha-1) y_{t-1}+u_{t} \\
& \Delta Y_{t}=\beta_{0}+\beta_{1} t+(\alpha-1) y_{t-1}+u_{t}
\end{aligned}
$$

Denklem 2, sabitsiz ve trendsiz modeli, Denklem 3, sabitli modeli, Denklem 4 ise sabitli ve trendli modeli tanımlamaktadır (MacKinnon, 1996, s. 2). Yapılan ADF testi sonucunda ADF test istatistikleri McKinnon kritik değerleri ile karşılaştırıldığında, test istatistiği mutlak değer olarak kritik değerden küçükse serinin durağan olmadığını ve birim kök içerdiğini göstermekte $H_{0}: \gamma=0$, buna karşın test istatistiği mutlak değer olarak kritik değerden büyükse serinin durağan olup birim kök içermediğini $H_{1}: \gamma \neq 0$ göstermektedir (Şimşek, 2017, s. 111; Yıldırım vd., 2013, s. 82). Diğer taraftan Phillips-Perron (PP) birim kök testi ise durağanlık sınamalarında yaygın olarak kullanılan ve yapısal kırılmaları dikkate almayan test olmaktadır (Gültekin ve Hayat, 2016, s. 615). Yapılan ADF testi sonucunda ADF test istatistikleri McKinnon kritik değerleri ile karşılaştırıldığında, test istatistiği mutlak değer olarak kritik değerden küçükse serinin durağan olmadığını ve birim kök içerdiğini göstermekte $H_{0}: \gamma=0$, buna karşın test istatistiği mutlak değer olarak kritik değerden büyükse serinin durağan olup birim kök içermediğini $H_{1}: \gamma \neq 0$ göstermektedir. Phillips-Perron (PP) testi için denklem aşağıdaki gibi olmaktadır;

$$
\Delta Y_{t}=\beta_{0}+(\theta) y_{t-1}+\beta_{1}\left[t \frac{T}{2}\right]+u_{t}
$$

PP testi için kurulacak hipotezlerin yorumlanması ADF testi ile aynı olmaktadır. Zaman serisi analizleri için öncelikle serilerin durağan olup olmadıklarının araştırılması gerekmektedir. Durağan olmayan serilerle yapılan regresyon tahmini ile elde edilecek sonuçlar tümüyle sahte olacaktır. Bu bakımdan analizlere birim kök testleri yapılarak başlanmış olup VAR analizi için kullanılacak olan değişkenlerin durağan özellikler gösterip göstermedikleri ADF ve Phillips-Perron (PP) testleri ile araştırılmış ve elde edilen sonuçlar Tablo 2'de sunulmuştur. 


\begin{tabular}{|c|c|c|c|c|c|c|c|}
\hline \multirow[b]{3}{*}{ Ülkeler } & \multirow[b]{3}{*}{ Değişkenler } & \multicolumn{3}{|c|}{ ADF Testi } & \multicolumn{3}{|c|}{ PP Testi } \\
\hline & & \multicolumn{2}{|c|}{ Seviyede } & \multirow{2}{*}{$\begin{array}{c}\begin{array}{c}\text { Birinci } \\
\text { Farklarda }\end{array} \\
\text { None }\end{array}$} & \multicolumn{2}{|c|}{ Seviyede } & \multirow{2}{*}{$\begin{array}{c}\begin{array}{r}\text { Birinci } \\
\text { Farklarda }\end{array} \\
\text { None }\end{array}$} \\
\hline & & $\begin{array}{c}\text { Sabit terimli } \\
\text { model }\end{array}$ & \begin{tabular}{|c|}
$\begin{array}{c}\text { Sabit } \\
\text { terimli ve } \\
\text { trendli model }\end{array}$ \\
\end{tabular} & & $\begin{array}{l}\text { Sabit terimli } \\
\text { model }\end{array}$ & $\begin{array}{l}\text { Sabit terimli ve } \\
\text { trendli model }\end{array}$ & \\
\hline \multirow{2}{*}{ Türkiye } & ENF & $\begin{array}{l}-0.924983 \\
(0.7675)\end{array}$ & $\begin{array}{l}-3.131401 \\
(0.1195)\end{array}$ & $\begin{array}{c}-5.664983 \\
(0.0000)\end{array}$ & $\begin{array}{l}-0.971300 \\
(0.7518)\end{array}$ & $-1.918875(0.6222)$ & $\begin{array}{l}-5.667764 \\
(0.0000)\end{array}$ \\
\hline & FAİZ & $\begin{array}{l}-0.674171 \\
(0.8393) \\
\end{array}$ & $\begin{array}{l}-1.984599 \\
(0.5880) \\
\end{array}$ & $\begin{array}{l}-7.946245 \\
(0.0000) \\
\end{array}$ & $\begin{array}{l}-1.171979 \\
(0.6746) \\
\end{array}$ & $\begin{array}{c}-1.903888 \\
(0.6299) \\
\end{array}$ & $\begin{array}{l}-7.575894 \\
(0.0000) \\
\end{array}$ \\
\hline \multirow{2}{*}{ Brezilya } & ENF & $\begin{array}{l}-3.229139 \\
(0.0296)\end{array}$ & $\begin{array}{l}-6.488003 \\
(0.0001)\end{array}$ & $\begin{array}{l}-8.738144 \\
(0.0000)\end{array}$ & $\begin{array}{l}-3.031855 \\
(0.0422)\end{array}$ & $\begin{array}{c}-3.740481 \\
(0.0334)\end{array}$ & $\begin{array}{l}-9.590406 \\
(0.0000)\end{array}$ \\
\hline & FAİZ & $\begin{array}{l}-3.134086 \\
(0.0368)\end{array}$ & $\begin{array}{l}-6.751878 \\
(0.0000)\end{array}$ & $\begin{array}{l}-3.771758 \\
(0.0006)\end{array}$ & $\begin{array}{l}-3.238251 \\
(0.0265)\end{array}$ & $\begin{array}{c}-3.611922 \\
(0.0441)\end{array}$ & $\begin{array}{l}-10.24262 \\
(0.0000)\end{array}$ \\
\hline \multirow[b]{2}{*}{ Endonezya } & ENF & $\begin{array}{l}-4.635862 \\
(0.0008)\end{array}$ & $\begin{array}{l}-4.719957 \\
(0.0032)\end{array}$ & $\begin{array}{l}-7.073888 \\
(0.0000)\end{array}$ & $\begin{array}{l}-4.635862 \\
(0.0008)\end{array}$ & $\begin{array}{c}-4.722534 \\
(0.0032)\end{array}$ & $\begin{array}{l}-20.18638 \\
(0.0000)\end{array}$ \\
\hline & FAİZ & $\begin{array}{l}-2.137642 \\
(0.2320)\end{array}$ & $\begin{array}{l}-3.226510 \\
(0.0968)\end{array}$ & $\begin{array}{l}-6.311150 \\
(0.0000)\end{array}$ & $\begin{array}{l}-2.137642 \\
(0.2320)\end{array}$ & $\begin{array}{c}-3.189949 \\
(0.1038)\end{array}$ & $\begin{array}{l}-7.224428 \\
(0.0000)\end{array}$ \\
\hline
\end{tabular}

Tablo 2. ADF ve PP Birim Kök Testi Sonuçları

Not: d: Serilerin birinci farkını göstermektedir. ADF ve PP birim kök testleri için kritik değerler MacKinnon (1996) tarafindan elde edilmiştir. Parantez içinde yer alan değerler olasılık değerleri olup \% 5 seviyesindeki anlamlılı̆̆ göstermektedir.

Tablo 2'teki sonuçlara bakıldığında Enflasyon ve Faiz oranlarının düzey değerinde I(0) durağan durağan olmadığı, birinci farkı alındığında durağan hale geldiği yani I(1) olduğu görülmektedir.

\subsubsection{Granger Nedensellik}

İktisadi değişkenler arasındaki ilişkinin yönü iktisat teorisi tarafindan belirlenemediği durumlarda, değişkenler arasındaki etkileşimin varlığı ve yönü, Granger (1969) testi yardımı ile belirlenebilmektedir. Ayrıca bu testte değişkenler bağımlı bağımsız olarak ayrılmamaktadır. Granger nedensellik testinde değişkenler arasındaki etkileşim eşanlı olarak analiz edilebilmektedir. VAR modeli Granger nedensellik testini temel almakta ve modelde bulunan her değişken hem kendisinin hem de modeldeki diğer değişkenlerin geçmiş değerlerinin bir fonksiyonu biçiminde yazılmaktadır (Gacaner, 2005, s. 110). Bu çerçevede VAR modelinde bağımlı değişkenlerin geçmiş değerlerinin yer alması geleceğe dönük güçlü tahminlerin yapılmasını sağlamaktadır (Tarı ve Bozkurt, 2006, s. 45). Ayrıca bu yöntemde, modelin her bir eşitliğinde bulunan tüm içsel değişkenlerin gecikmelerinin birlikte anlamlı olup olmadıkları test edilmektedir (Taban ve Şengür, 2016, s. 55-56).

Kurulan iktisadi modellerde yer alan değişkenler arasındaki ilişkileri belirleyebilmek ve test edebilmek amacıyla öncelikle değişkenlerin içsel ya da dişsal olup olmadıkları tespit edilmesi gerekir (Tarı ve Bozkurt, 2006, s. 5). Bu amaçla Howrey, tek yönlü nedensel modellerin nasıl tanımlanabileceğini ve tahmin edilebileceğini gösterirken, Paul Newbold ve Granger, 1977 yılında yayınlanan kitaplarında geri bildirim (feedback) veya iki yönlü nedensel modellerin potansiyel olarak tanımlanabileceği bir yöntem önermişlerdir (Granger, 1980, s. 340). Bu çerçevede VAR modeli iki değişken için aşağıdaki gibi kurulmaktadır;

Bu çerçevede kurulacak hipotezler;

$$
\begin{aligned}
Y_{t} & =\sum a_{i} y_{t-i}+\sum \beta_{i}+X_{t-i}+u_{1 t} \\
X_{t} & =\sum a_{i} x_{t-i}+\sum \beta_{i}+y_{t-i}+u_{2 t}
\end{aligned}
$$

$$
\begin{array}{ll}
H_{0}=\sum \beta_{i}=0 & (X \text { değişkeninden } Y \text { değ } \text { işkenine Nedesellik Yoktur } . \\
H_{1}=\sum \beta_{i} \neq 0 & (Y \text { değişkeninden } X \text { değ gşskenine Nedesellik Vardır. }
\end{array}
$$

Yukarıdaki iki değişkenli olarak oluşturulan VAR modelleri sadece gecikmeli değerlere dayalı olarak kurulmuş olup, sıfır hipotezi reddedilemezse X değişkeninden Y'ye bir nedensellik olmayacaktır. Buna karşın alternatif hipotez kabul edilirse Y değişkeninden X'e nedensellik olacaktır (Maddala, 1989, 329-330). Var analizinde gecikmeli değerler olarak bağımlı değişkenlerin gecikmesinin kullanılmasının nedenleri olarak; 1) Modele dahil edilmemiş değişkenlerin telafi edilmesi 2) Modele dahil edilmemiş değişkelerin olası etkilerinin hesaba katılmasını sağlamak 3) Yapılan tahminlerin doğruluğunun iyileştirilmesi gösterilmektedir (Kumar vd., 1995, s. 365). Sims'in metodolojisine göre, VAR modeline dahil edilecek değişkenler için uygun gecikme uzunluğunun belirlenmesi gerekmektedir. $\mathrm{Bu}$ amaçla seçilecek olan gecikme uzunluğunun değişkenler arasındaki dinamik ilişkileri yakalayacak nitelikte olmalıdır. Genel olarak çeşitli bilgi kriterlerinden Akaike bilgi kriteri (AIC) ve Schwarz bilgi 
kriteri (SIC) ile modelde yer alan değişkenler için optimum gecikme uzunlukları belirlenebilmektedir (Gacaner, 2005, s. 110).

Modelde yer alan değişkenler arasındaki nedenselliğin yönünün araştırılması amacıyla VAR modeline dayanan Granger nedensellik testi yapılmıştır. Granger nedensellik, modelde yer alan değişkenler arasında eş zamanlı bir iliş̧inin var olup olmadığı araştırmakta ve VAR analizi için gerekli olmaktadır (Bozdağlığlu ve Özpınar, 2011, s. 49). Bu çerçevede elde edilen test sonuçları aşağıda yer alan Tablo 3'da sunulmuştur.

\begin{tabular}{|c|c|c|c|c|}
\hline \multirow{2}{*}{ Ülkeler } & Boş Hipotez & Ki-Kare & $\begin{array}{c}\text { Serbestlik } \\
\text { Derecesi }\end{array}$ & Olasılık \\
\hline \multirow{3}{*}{ Türkiye } & Nominal faizler, Enflasyonun Granger nedeni değildir. & 0.122707 & 1 & 0.7261 \\
\cline { 2 - 5 } & Enflasyon, Nominal Faizlerin Granger nedeni değildir. & 8.296183 & 1 & $\mathbf{0 . 0 0 4 0 *}^{*}$ \\
\hline \multirow{2}{*}{ Brezilya } & Nominal faizler, Enflasyonun Granger nedeni değildir. & 66315.05 & 7 & $\mathbf{0 . 0 0 0 0}^{*}$ \\
\cline { 2 - 5 } & Enflasyon, Nominal Faizlerin Granger nedeni değildir. & 49591.51 & 7 & $\mathbf{0 . 0 0 0 0}^{*}$ \\
\hline \multirow{3}{*}{ Endonezya } & Nominal faizler, Enflasyonun Granger nedeni değildir. & 15.52218 & 7 & $\mathbf{0 . 0 2 9 9 *}^{*}$ \\
\cline { 2 - 5 } & Enflasyon, Nominal Faizlerin Granger nedeni değildir. & 15.34693 & 7 & $\mathbf{0 . 0 3 1 8}^{*}$ \\
\hline
\end{tabular}

Not: (*) \% 5 düzeyindeki anlamlılı̆̆ göstermektedir. VAR'da tespit edilen optimum gecikme uzunluğu kullanılmıştır.

\section{Tablo 3. Granger Nedensellik Test Sonuçları}

Granger nedensellik analiz sonuçlarına göre Türkiye için $\% 5$ anlamlılık düzeyinde enflasyondan nominal faize doğru tek yönlü nedensellik ilişkisine rastlanırken, Brezilya ve Endonezya için enflasyon ve nominal faiz oranları arasında çift yönlü bir ilişki bulunmuştur. Buna karşılık Hindistan için enflasyon ve nominal faiz oranları herhangi bir nedensellik ilişkisine rastlanamamıştır. VAR modelinin tahmin edilmesi sonucunda elde edilen parametrelerin yorumlanması son derece karmaşık olmaktadır. Bu nedenle değişkenlere ait katsayı yorumu yerine genel olarak Etki-Tepki (Impulse-Response) analizi ile Varyans Ayrıştırması (Variance Decomposition) yöntemleri uygulanmakta ve bunlara ilişkin değerlendirmeler baz alınmaktadır.

\subsubsection{Etki-Tepki Analizi}

Granger nedensellik testi ile elde edilen sonuçlar çerçevesinde modelde yer alan değişkenler arasındaki ilişkileri belirlemek gereğinden çalışmanın bu kısmında etki-tepki ve varyans ayrıştırması analizlerine yer verilmektedir. Etki-tepki fonksiyonları, rassal hata terimlerinden birindeki bir standart hatalık şokun, içsel değişkenlerin şimdiki ve gelecekteki değerlerine olan etkisini göstermektedir. Değişkenler arasında en etkili değişkenin hangisi olduğuna varyans ayrıştırmasıyla, burada etkili bulunan değişkenin politika aracı olarak kullanılabilir olup olmadığı ise etkitepki analizi ile belirlenmektedir (Özgen ve Güloğlu, 2004, 97). 


\section{TÜRKIYE}

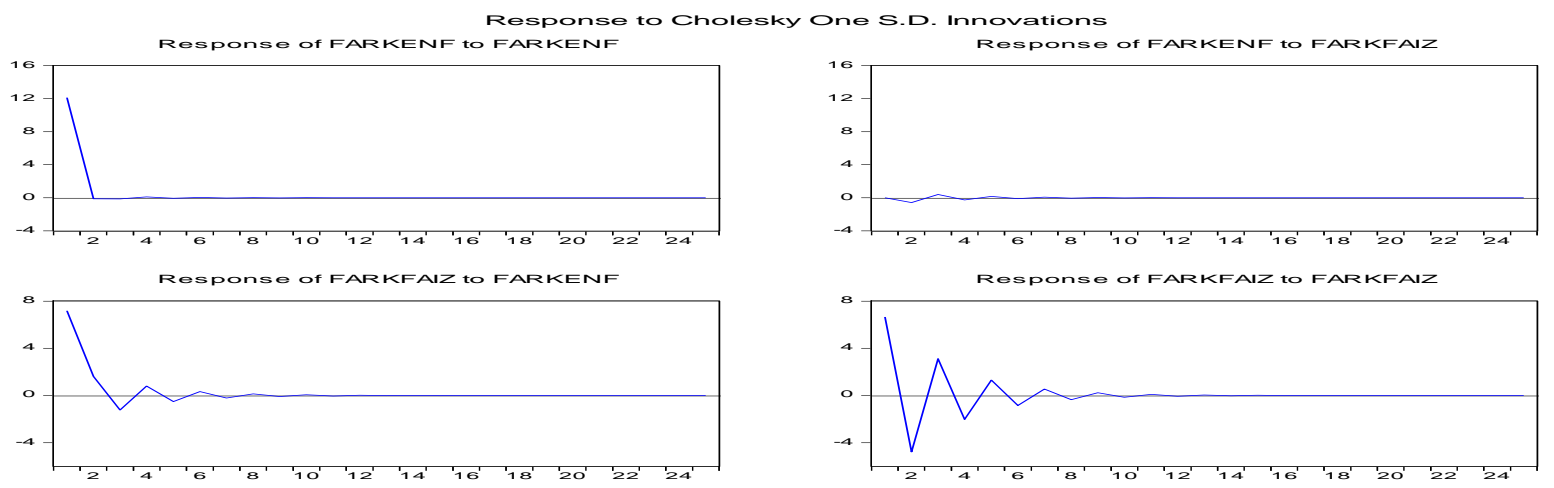

BREZILYA

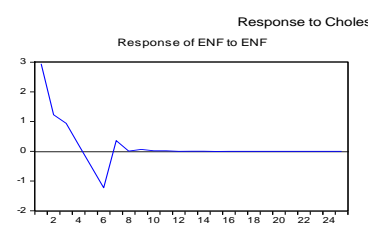

Response of FAI to ENF

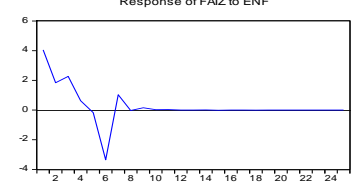

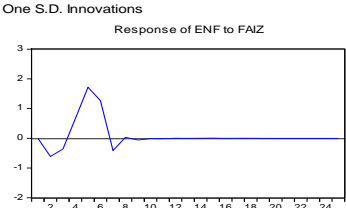

Response of FAIZ to FAIZ

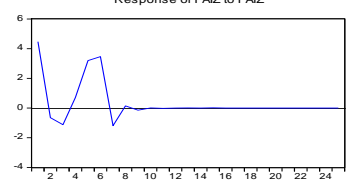

ENDONEZYA

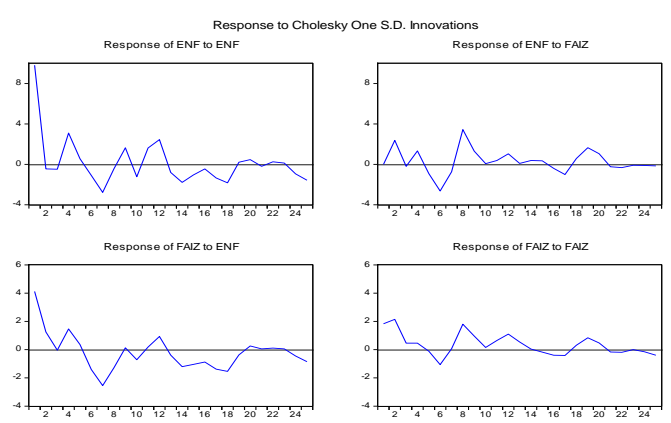

Grafik 1. Enflasyon ve Nominal Faiz Oranlarının Etki-Tepki Grafikleri ( \pm 2 Standard Hata Düzeyinde)

Türkiye için; Enflasyona uygulanan bir standart sapmalık şoka faiz oranlarının gösterdiği tepkiler 1. dönemden itibaren pozitifte seyir izlemekte en belirgin tepkiyi ise, 3. dönemle birlikte negatiften pozitife doğru yön değiştirerek göstermektedir. 3. dönemden 4. döneme kadar faiz oranlarının tepkisi pozitif olmakla birlikte daha sonraki dönemler dalgalı bir seyir izleyerek uzun dönemde durağan hale gelmektedir. Faiz oranına uygulanan bir standart sapmalık şoka enflasyonun tepkileri ise çok küçük olmakla birlikte genel olarak durağan bir seyir izlemektedir. Brezilya için; Enflasyona uygulanan bir standart sapmalık şoka faiz oranı 1. dönemden 5. döneme kadar pozitifte azalan tepkiler, 5. dönemden 6. döneme kadar negatifte azalan tepkiler göstermektedir. Buna karşılık nominal faizler en belirgin tepkiyi 6. dönemde göstermekte ve negatifte artan tepkiler gösteren 7. dönemle birlikte pozitifte artan tepkiler göstermekte ve uzun dönemde pozitifte durağan bir hale gelmektedir. Faiz oranına uygulanan bir standart sapmalık şoka enflasyon en belirgin tepkiyi 5. dönem göstermekte ve daha sonraki dönemler (uzun dönem) ise enflasyonun gösterdiği tepkiler pek değişmemekte, durağan olmaktadır. Endonezya için; Enflasyona uygulanan bir standart sapmalık şoka nominal faizler, pozitif ve negatifte sırasıyla artan ve azalan tepkiler göstermekte, en güçlü tepki 9. dönemde ortaya çıkmakta ve uzun dönemde bu tepkiler durağan bir hale gelmektedir. Faiz oranına uygulanan bir standart sapmalık şoka enflasyonun tepkisi dalgalı bir görünüm sergilemekle birlikte en belirgin tepkiyi 7. dönemle birlikte göstermekte ve bu tepkiler uzun dönemde pozitif ve negatifte artış ve azalış göstererek sıfıra yaklaşmaktadır.

\section{Sonuç ve Değerlendirme}

Enflasyon ve nominal faizler arasındaki ilişki, teorik yönlü çalışmalara dayandığı kadar ampirik çalışmalara da konu olmaktadır. Bu çalışmada enflasyon ve nominal faiz oranları arasındaki nedensellik ilişkisi ve bunun yönünün tespiti amacıyla, 1985-2018 dönemi yıllık veriler kullanılarak seçili gelişmekte olan ülkeler (Türkiye, Endonezya ve Brezilya) için nominal faiz oranları olarak mevduat faiz oranı ve enflasyon oranı olarak da tüm ülkeler bir önceki yılın aynı dönemine göre TÜFE değişim oranları (yüzde) değişkenleri kullanılmıştır.

Çalışmanın amacı doğrultusunda değişskenler arasındaki ilişsiler VAR modeline dayanan Granger nedensellik, etki-tepki ve varyans ayrıştırması analizleri ile araştırılmıştır. Bu çerçevede elde edilen test sonuçları söz konusu seçili üç gelişmekte olan ülke içinde literatürdeki sonuçlar ile büyük oranda tutarlı olduğu söylenebilir. Yapılan analizde Granger nedensellik testi sonucunda Türkiye için tek yönlü, Brezilya ve Endonezya için değişkenler arasında çift yönlü nedensellik ilişkisi bulunmuştur. Ancak değişkenler arasındaki etkileşim tek bir boyutta ele alınamayacak kadar karmaşık bir yapı sergilemektedir. Nitekim Merkez Bankaları parasal aktarım mekanizması aracılığıyla faizleri kullanarak enflasyonu çeşitli kanallardan etkilemeleri mümkün olmaktadır. Para otoritesinin belirlediği faiz oranları, enflasyonu çeşitli kanallar aracılığıyla etkilerken, faiz oranlarının sürece uyum hızı yavaş olmakta ve faiz oranlarındaki değişim sonucunda enflasyon oranlarının etkilenmesi gecikmeli olarak ortaya 
çıkmaktadır. Bu durum enflasyon ile faizler arasında bir nedensellik olmasına rağmen söz konusu değişkenlerin birbirleri üzerindeki etkilerinin şiddeti konusunda belirsizliğe neden olmaktadır. Genel olarak literatürde enflasyondan faiz oranlarına doğru bulunan nedensellik ilişkisinde enflasyonun yükselmesi iktisadi karar birimlerinin para talebinin artmasına bu da dolaylı olarak faiz oranlarının yükselmesine neden olmaktadır. Faizlerden enflasyona doğru bir nedensellik ilişkisinde ise döviz kurları, girdi maliyetleri vb. faktörler aracılığıyla yurt içi fiyat düzeyini dolayısıyla enflasyonu etkilemektedir. Diğer bir ifadeyle yüksek faizler girdi maliyetlerini yükseltmesiyle yurt içi enflasyonu tetiklemektedir. Dolayısıyla söz konusu parasal değişkenler arasındaki etkileşimlerde gerek yüksek faizler gerekse yüksek enflasyonun nedenlerinin hem kendi dinamikleri çerçevesinde hem de onları etkilediği düşünülen diğer makro değişkenler çerçevesinde dikkate alınmalıdır. Ayrıca varyans ayrıştırması sonuçlarına göre enflasyon ve nominal faiz oranları arasında Türkiye için tek yönlü, Brezilya ve Endonezya için çift yönlü nedenselliğin bulunduğu seçili üç ülke için enflasyonun nominal faiz oranlarındaki değişimleri açıklamada daha etkili olması, politika yapıcıların kısa vadede enflasyonu kontrol altına alacak, uzun vadede ise fiyat istikrarını sağlayacak nitelikte politika önlemlerini hayata geçirmeleri gerekmektedir.

\section{Kaynakça}

- A Asogu, J. O. (1991), “An Economic Analysis of the Mature and Causes of Inflation in Nigeria,” CBN Economic Financial Review Vol. 9 (3).

- Bayat, T. (2011). Türkiye'de Fisher Etkisinin Geçerliliği: Doğrusal Olmayan Eşbütünleşme Yaklaşimi. Erciyes Üniversitesi İktisadi ve İdari Bilimler Fakültesi Dergisi, (38), 47-60.

- $\quad$ Bayat, T., Kayhan, S. \& Taşar, İ. (2017), Re-Visiting Fisher Effect for Fragile Five Economies, Journal of Central Banking Theory and Practice, 2018, 2, pp. 203-218.

- Bozdağlığlu, E. Y., \& Özpınar, Ö. (2011). Türkiye'ye Gelen Doğrudan Yabancı Yatırımların Türkiye'nin İhracat Performansına Etkilerinin Var Yöntemi İle Tahmini. Dokuz Eylül Üniversitesi Sosyal Bilimler Enstitüsü Dergisi, 13(3), 39-63.

- Çinko, L. Türkiye’de Fisher Hipotezinin Geçerliliğinin Sınanması. Sosyal Bilimler Araştırma Dergisi, 6(1), 53-64.

- $\quad$ Demirgil, B. \& Türkay, H. (2018). Enflasyon-Faiz İlişkisi Ardl/Sınır Testi Uygulaması, Hitit Üniversitesi Sosyal Bilimler Enstitüsü Dergisi, Y11 11, Say1 1, Haziran 2018, 515-528.

- $\quad$ Doğan, B., Eroğlu, Ö., \& Değer, O. (2016). Enflasyon ve Faiz Oranı Arasındaki Nedensellik İlişkisi: Türkiye Örneği. Çankırı Karatekin Üniversitesi İ̈BF Dergisi, 6(1), 405-425.

- Enders, W. (1995), Applied Econometric Time Series: Wiley Series in Probability and Mathemathical Statistics, New York, John Wiley Inc.

- $\quad$ Fatima, N., \& Sahibzada, S. A. (2012). Empirical evidence of Fisher effect in Pakistan. World Applied Sciences Journal, 18(6), 770-773.

- Fisher, I. (1930). TheTheory Of İnterest, New York, The Macmillan Company.

- Francisco G. Carneiro, José Ângelo, C. A. Divino IV \& Carlos H. Rocha (2002) Revisiting The Fisher Hypothesis For The Cases Of Argentina, Brazil And Mexico, Applied Economics Letters, 9:2, 95-98.

- Gacener, A. (2005). Türkiye Açısından Wagner Kanunu'nun Geçerliliğinin Analizi, D.E.Ü.İ.I.B.F.Dergisi, Cilt: 20 Sayı: 1, 103-122.

- Garcia, M. G. (1993). The Fisher Effect İn A Signal Extraction Framework The Recent Brazilian Experience. Journal of Development Economics, 41(1), 71-93.

- Granger, C. W. (1980). Some Comments On The Role Of Time-Series Analysis İn Econometrics. In Evaluation of Econometric Models (pp. 339-341). Academic Press.

- Gültekin, Ö. E., \& Hayat, E. A. (2016). Altin Fiyatini Etkileyen Faktörlerin Var Modeli ile Analizi: 20052015 Dönemi/Analysis of Factors Affecting The Gold Prices Through Var Model: 2005-2015 Period. Ege Akademik Bakis, 16(4), 611.

- Güriş, S. vd., (2016). Interest Rates, Fisher Effect and Economic Development in Turkey, Revista Galega de Economia, 25, ss. 95-100.

- Incekara A. vd., (2012). "Validity of Fisher Effect for Turkish Economy: Cointegration Analysis", Procedia Socialand Behavioral Sciences, 8th International Strategic Management Conference, İstanbul Üniversitesi.

- Janor, H. (2001). The Long-Run Relationship between Nominal Interest Rates and Inflation of the Asian Developing Countries. Jurnal Ekonomi Malaysia, 35, 3-1.

- $\quad$ Kanca, O., Üzümcü, A., \& Deniz, A.(2015), Fısher Etkisi Türkiye Ekonomisi İçin Geçerli Mi? Bir Zaman Serisi Analizi: 1980-2013. Verimlilik Dergisi, (3), 45-66. 
- Karacan, R. (2017), Türkiye’de Döviz Kuru Değişimlerinin Gıda Harcamalarına Etkisi Üzerine Ampirik Bir Çalışma, Akademik Sosyal Araştırmalar Dergisi, Yı1: 5, Sayı: 40, 142-152.

- Kasman, S., Kasman, A. \& Turgutlu, E. (2006). Fisher hypothesis revisited: A fractional cointegration analysis. Emerging Markets Finance and Trade, 42(6), 59-76.

- Kazdağlı, H. (1996), T. C Merkez Bankasının Kuruluş Tarihçesi Ve 1934-1938 Dönemindeki Para Politikasının Var Yöntemi İle Analizi. Hacettepe Üniversitesi İktisadi ve İdari Bilimler Fakültesi Dergisi, 14(2), 23-53.

- $\quad$ Kumar, V., Leone, R. P., \& Gaskins, J. N. (1995). Aggregate and disaggregate sector forecasting using consumer confidence measures. International Journal of Forecasting, 11(3), 361-377.

- $\quad$ Levieuge, G., Lucotte, Y., \& Ringuedé, S. (2018). Central Bank Credibility And The Expectations Channel: Evidence Based On A New Credibility İndex. Review Of World Economics, 154(3), 493-535.

- Loayza, N., \& Schmidt-Hebbel, K. (2002). Monetary Policy Functions And Transmission Mechanisms: An Overview. Monetary Policy: Rules And Transmission Mechanisms, 1, 1-20.

- Maddala, G. S. (1989), Introduction to Econometrics, New York, Macmillan publishing Company.

- Moraşan, G. \& Zubaş, I. M. (2015), Interest Rate, Exchange Rate and Inflation In Romania. Correlates and Interconnection, Journal of Public Administration, Finance and Law.

- Mucuk, M., \& Alptekin, V. (2008). Türkiye'de Vergi ve Ekonomik Büyüme İlişkisi: VAR Analizi (19752006). Maliye Dergisi, 155, 159-174.

- Ozcicek, O. \& Douglas Mcmillın W. (1999), Lag Length Selection in Vector Autoregressive Models: Symmetric and Asymmetric Lags, Applied Economics, 31:4, 517-524.

- Sayılgan, G. (2013), "Soru ve Yanıtlarla İşletme Finansmanı”, 6. Bası, Turhan Kitabevi.

- Şimşek, E. (2017), Türkiye'de Reel Döviz Kuru, Tarımsal İhracat ve Tarımsal İthalat Arasındaki Nedensellik İlişkisi. Türk Tarım ve Doğa Bilimleri Dergisi, 4(2), 109-118.

- Taban, S., \& Şengür, M. (2016). Türkiye'de Enflasyonun Kaynağının Belirlenmesine Yönelik Ekonometrik Bir Analiz. Erciyes Üniversitesi Íktisadi ve İdari Bilimler Fakültesi Dergisi, (47), 47-64.

- $\quad$ Tarı, R., \& Bozkurt, H. (2006). Türkiye'de İstikrarsız Büyümenin Var Modelleri İle Analizi (1991.1 -2004.3). Ekonometri ve Istatistik e-Dergisi, (4), 1-16.

- $\quad$ Teker, D., Alp, E. A., \& Kent, O. (2012). Long-Run Relation between Interest Rates and Inflation: Evidence from Turkey. Journal of Applied Finance and Banking, 2(6), 41.

- Tiraşoğlu, M. (2018). Fisher Hipotezinin MINT Ülkeleri için İncelenmesi: Eşik Değerli Adl Eşbütünleşme Testi Yaklaşımı. Ekonometri ve İstatistik e-Dergisi, 14(28), 31-43.

- Türkiye Cumhuriyet Merkez Bankası, (2013), “Enflasyon ve Fiyat İstikrarı”, http://www.tcmb.gov.tr/ Erişim Tarihi: 04.12.2018.

- Yıldırım, K., Mercan, M., \& Kostakoğlu, S. F. (2013). Satın Alma Gücü Paritesinin Geçerliliğinin Test Edilmesi: Zaman Serisi ve Panel Veri Analizi. Eskişehir Osmangazi Üniversitesi İktisadi ve İdari Bilimler Dergisi, 8(3).

NOT: Bu Çalışma, Türkiye Bilimsel ve Teknolojik Araştırma Kurumu (TÜBİTAK) 2211-A Yurt İçi Doktora Burs Programı tarafindan desteklenmiştir. 


\title{
Enflasyon ve İşsizliğin Gelir Eşitsizliği Üzerine Asimetrik Etkisi: Türkiye Örneği
}

\section{Asymmetric Impact of Inflation and Unemployment on Income Inequality: The Case of Turkey}

\author{
Ph.D. Candidate Duygu Serin Oktay (Çukurova University, Turkey)
}

\begin{abstract}
Income inequality is a major economic problem for all developed or developing countries. Income inequality can be international, or among different regions within the country, even among individuals. Turkey is also known to be confronted with this problem and possible to see differences in income between different regions. Therefore, understanding income inequality and reasons that lie behind the problem became the primary research interests of the literature. In macroeconomic perspective, unemployment and inflation are two interconnected economic variables that may affect income inequality. Many of the researchers have tried to examine the impact of inflation and unemployment on income inequality and analyzed the role of government in controlling inflation, unemployment, and income. Certainly, parts of the macroeconomic aims which the government struggles to accomplish the economic growth, full employment, and stable domestic price level. These aims are pursued in order to advance mass welfare. Therefore, the purpose of this study is to contribute to the literature using the asymmetric model to examine the impact of inflation and unemployment on income inequality in Turkey utilizing annual data. In order to examine this impact, Nonlinear Autoregressive Distributed Lag(NARDL) model was used to analyze the nonlinear relationships between variables. It is investigated the asymmetric relationship between the variables and estimated short and long term coefficients. Accordingly, the light of the conclusion of the current study should introduce new ideas to policymakers which promote economic growth and development in the country so that income inequality can be reduced.
\end{abstract}

\section{Giriş}

Günümüzde gelir eşitsizliği hem gelişmiş hem de gelişmekte olan ülkelerin en önemli sorunlarından biridir. Gelir eşitsizliği yalnızca ülkeler arasında var alan bir sorun olmamakla birlikte, aynı zamanda bir ülkenin bölgeleri ve kişileri arasında da ortaya çıkmaktadır. Bu şekilde yoksulun daha yoksul ve zenginin daha zengin olduğu mevcut durum OECD ve Dünya Bankası gibi kuruluşların verilerinde dikkat çekmektedir. Dolayısıyla, iktisat politikasının en önemli hedeflerinden biri gelir eşitsizliğinin azaltılmasıdır. Bu kapsamda, para ve maliye politika araçları ile ekonomilere müdahale edilerek, milli geliri arttırmak, genel fiyatlar seviyesinde istikrarı sağlamak ve işsizliği azaltmak hedeflenmektedir. Gelir eşitsizliği çok boyutlu bir kavramdır. Genel olarak gelir eşitsizliği, gelirin nüfus arasında eşit olmayan bir şekilde dağıtılma derecesi olarak tanımlanmaktadır. Gelir sadece ödeme yoluyla alınan para olmamakla birlikte, aynı zamanda çalışma sonucu elde edilen tüm gelirleri (ücretler, maaşlar, ikramiyeler vb.), tasarruf hesaplarından faiz ve hisse senetlerinden temettü gibi yatırımları, tasarrufları, devlet yardımlarını, emekli aylıklarını ve kiraları da kapsamaktadır.

Çin ve Hindistan gibi ülkelerde olağanüstü ekonomik büyümenin gerçekleşmesi nedeniyle, dünyadaki genel gelir eşitsizliği durumu göz önüne alındığında, göreceli küresel gelir eşitsizliğinin son 35 yılda, gini katsayısının 1975 'te 0.74 'ten 2010 'da 0,63'e düştüğü görülmektedir (UNDP, 2016). Ancak, mutlak gelir eşitsizliği için ise gini endeksi 1975 ve 2010 arasında 0,65 'ten 0,72 'ye yükselmiştir. Göreceli gelir eşitsizliği oransal eşitsizlik seviyesini gösterirken, mutlak eşitsizlik kesin seviyeyi göstermektedir. Ayrıca, UNDP (2016) raporunda 1988 ve 2011 yılları arasındaki toplam gelir artışının \% 46'sının en zengin \% 10'luk kesime gitmesinden dolayı ekonomik büyümenin faydalarından en çok yararlananların en zengin kesim olduğunu ifade etmektedir. Daha da kötüsü, dünya servetindeki artışın \% 50'si, en zengin \%1'lik gruba giderken, bu artışın en yoksul \%50'lik kesime sadece \%1'i ulaşmıştır. 2000 'den 2010 yllına kadar en zengin \%1'lik kesim, dünya serveti daha fazla yoğunlaştığ için servetlerini \% 32'den \% 46'ya yükseltmiştir. Dolayısıyla, dünya geliri ve servet eşitsizliğinin son yıllarda arttığı tespit edilmiştir (UNDP, 2016).

Gelir eşitsizliğinin ortaya çıkmasına neden olan faktörleri anlamak ekonomi üzerindeki etkisini yorumlayabilmek açısından önem arz etmektedir. Piyasa yapısı gelir eşitsizliğine neden olmakta, ancak kullanılan politika araçları ise piyasa yapısını etkileyen temel bir faktör olmaktadır. Günümüzde makro ekonomik araçlar gelir eşitsizliği üzerinde etkili olmaktadır. Çünkü devlet politikalarının geliri üst kesimden alıp orta ve alt kesime dağıtabilme ya da tam aksini yapabilme gücü de vardır (Stiglitz, 2012).

Literatürde son yıllarda gelir eşitsizliğine neden olan faktörler ile ilgili bir çok değişkenin yer aldığ 1 görülmektedir. Gelir eşitsizliğine neden olan başlıca etkenler, işsizlik, enflasyon, küreselleşme, kaynakların eşitsiz dağılımı, teknolojik değişim ve eğitim gibi temel faktörler olarak belirlenmektedir (Sileika ve Bekeryte, 2013). 
Ekonomi karmaşık bir olgu olduğundan dolayı ve bu ekonomik işleyişi anlayabilmek için makroekonomik değişkenlerin birlikte değerlendirilmesi gerekmektedir. Ancak bu şekilde uygulanan politikaların gerçek etkisi fark edilmektedir (Hassan, 2016). Bu kapsamda çalışma da gelir eşitsizliğini etkileyen önemli faktörlerden olan işsizlik ve enflasyon üzerinde durulmaktadır.

1970'li yıllardan itibaren literatürde makroekonomik politikalar açısından devam eden tartışmaların odak noktaların temelini enflasyon ve işsizlik oluşturmaktadır. Enflasyon ve işsizlik, ekonomik politikalarla ilgili iki önemli sorundur. Ülkelerin bu sorunların üstesinden gelmek için çeşitli politika uygulamalarına sahip olmalarına rağmen, enflasyon ile işsizlik arasındaki ters ilişki nedeniyle ülkelerin aynı anda onlardan kurtulmaları mümkün olamamaktadır (Aije, 2017).

Ekonomide kısa dönem dalgalanmaların ve fiyatlar genel seviyesinde gelişmelerin de gelir eşitsizliği ile yakından ilişkili olduğu ve buna bağlı olarak değişik yer ve zamanlarda farklı derecelerde etkili olmaktadır. Kısa dönem dalgalanmaların gelişmiş ülkelerde, enflasyonun ise daha çok az gelişmiş ülkelerde özellikle etkili olduğu görülmektedir (Şenses, 2017). Enflasyon, ekonomik koşulların belirlenmesinde önemli bir rol oynamaktadır ve enflasyonu kontrol etmekten sorumlu olan çeşitli parasal otoriteler tarafindan önem arz etmektedir. Enflasyon, fiyat, ücret, tüketim, yatırım gibi ekonomik kararları etkilemektedir. Enflasyon doğrudan veya dolaylı olarak ekonomi üzerinde etkili olmaktadır. Bireyler enflasyonun yüksek olduğunu algıladığı zaman, bu durum genel ekonomiyi etkilemektedir (Supryadı ve Kausar, 2017). Enflasyonun gelir eşitsizliği üzerinde etkisi çift yönlü olabilmektedir. Enflasyon artarsa kişiler finansal araçlara yatırım yapabilmekte, bunun nedeni parayı elde tutmak yerine daha çok kazanç elde etme isteğidir. Enflasyondan en fazla etkilenen kesim düşük gelirli bireylerdir. Düşük gelirli bireyler finansal araçlara yatırım yapabilecek kadar gelire sahip değildir. Diğer taraftan, enflasyonun düşük gelirli kişilere olumlu etkisi de olabilmektedir. Çoğunlukla, düşük gelirli bireyler daha fazla borca sahip olmaktadır. Enflasyonun artması göreli olarak borç miktarını azaltabilmektedir. Bu durumda enflasyon borç veren taraftan borç alana doğru bir dağıtım işlevi göstermektedir. Ancak enflasyon sabit ve düşük gelir sahiplerini daha çok etkilemektedir. Çünkü enflasyon kişilerin satın alma güçlerini ve reel gelirlerini azaltmaktadır. Yüksek gelirli kişiler ise, enflasyona karşı gelirlerini koruma gücüne sahip olduklarından dolayı bu olumsuz durumdan daha az zarar görmektedir. Bu kapsamda enflasyon kişiler arasında gelir eşitsizliğinin daha fazla derinleşmesine neden olabilmektedir (Lunderberg ve Squire, 2003). Dolayısıyla gelir eşitsizliği ve enflasyon arasındaki ilişkinin yönü çeşitli olabilmektedir. Dolayısıyla henüz bu ilişkinin yönünü ortaya koyan kesin bir teorik altyapı oluşturulmamıştır.

Gelir eşitsizliğinin temel nedenlerinden biri de işsizliktir. Yoksul kişilerin çoğunlukla büyük kısmının işsiz olduğu dikkat çekmektedir. İşsizlik, üretim ve tüketim dengesinin bozulmasına, yatırımların azalmasına yol açarak yoksulluğu derinleştirmekte ve gelir dağılımını daha da bozmaktadır. Çalışma çağındaki nüfusun istihdam edilememesi, kişilerin gelir sahibi olmasını engellemekte ve gelir eşitsizliğine neden olmaktadır.

Günümüzde istihdam ve işsizlik hem ekonomik hem de sosyal sonuçları ile tüm ülkelerin en önemli sorunu haline gelmiş̧ir. Bunun nedenlerinden biri, emek yoğun üretim sisteminden sermaye yoğun üretim sistemine geçilmesinin nitelikli iş gücü talebini arttırırken, niteliksiz ve daha az nitelikli işgücünün işsiz kalmasına neden olmasıdır. Bu durum gelir dağılımı eşitsizliğini derinleştirmektedir (Öztürk, 2017). Bununla birlikte, gelir eşitsizliği de işsizlik üzerinde etkili olabilmektedir. Bunun nedeni gelir eşitsizliğinin gelir dağılımının alt kesimlerinde kişilerin yeteri kadar kaynak elde edememesinden dolayı beșeri sermayeye yatırım yapamamasına ve buna bağlı olarak iş bulma konusunda güçlük çekmesine yol açmaktadır. Beşeri sermaye yatırımını yeteri kadar yapamaması sonucu ortaya çıkan işsizlik kalıcı olabilmekte ve mevcut durumda zaten düşük gelir sahibi olan bireyi zor durumda bırakmaktadır. Ancak beşeri sermaye yatırımı yapabilen kişiler yüksek ücretler almakta ve gelir eşitsizliğinin artmasına neden olmaktadır. Diğer taraftan beşeri sermaye bakımından yüksek gelire sahip kişiler için yapılan yatıımların süreklilik kazanması durumunda bu yatıımların marjinal verimliliği azalma eğilimi göstermektedir. Bunun yerine beşeri sermaye yatırımı yapamayan kişilerin devlet tarafından desteklenmesi sayesinde yatırımların artması ile gelir eşitsizliğinin azalmasına katkı sağlamaktadır (Keller, 2010).

$\mathrm{Bu}$ açılamalar doğrultusunda, makroekonomik değişkenlerde yaşanan dalgalanmaların etkisi ekonomilerde dikkat çeken konulardan biridir. Ayrıca, birçok ülke tarafından imzalanan Binyıl Kalkınma Hedeflerinin (MDGs), temel hedeflerinden biri dünyadaki yoksulluk seviyesini ve gelir eşitsizliğini azaltmak olduğu bilinmektedir. Bu amaçla birçok program uygulanmakla birlikte, yaşanan ekonomik istikrarsızlık nedeniyle, programların olumlu etkileri yeterince görülmemektedir (Sugema vd, 2010). Bu nedenle enflasyon ve işsizlik oranlarının gelir eşitsizliği üzerine etkisinin ne kadar olduğunun incelenmesi gerekmektedir. Bu durum çalışmanın ana odak noktasını oluşturmaktadır. Tahmini sonuçlar gelecekteki karar verme için faydalı olmakla birlikte, mevcut durumu iyileştirme konusunda politika önerileri sunma açısından önem arz etmektedir.

Birçok çalışma ulusal ve uluslararası düzeyde gelir eşitsizliği tanımları ve ölçümlerini ele almıştır. Ancak gelir eşitsizliğini etkileyen başlica makroekonomik değişkenler üzerine Türkiye'ye özel bir atıfta bulunan çok az çalışma yapılmıştır. Bu nedenle, çalışma, Türkiye'de enflasyon, işsizlik gibi makroekonomik değişkenlerin gelir eşitsizliği üzerindeki etkisini kısa ve uzun dönemde incelemeyi amaçlamaktadır. Çalışmada 1991-2016 dönemi verilerini kapsayan doğrusal olmayan sınır testi yaklaşımı (NARDL) kullanılmaktadır. Analiz bulguları enflasyonun ve işsizliğin pozitif şoklarının gelir eşitsizliği üzerinde etkisini ortaya koyarken, diğer taraftan uzun dönemde 
enflasyon ve işsizliğin gelir eşitsizliği üzerindeki etkisinin asimetrik olduğunu ifade etmektedir. Çalışma hem incelenen ekonometrik model hem de asimetrik etkilerin ele alınması kapsamında Türkiye için araştıran ilk çalışma olması kapsamında mevcut literatüre katkı sağlamayı hedeflemektedir. Çalışmanın geri kalanı şu şekilde düzenlenmiştir. İkinci bölüm, Türkiye'de gelir eşitsizliğinin genel görünümünü belirlemek amaciyla enflasyon ve işsizlik oranları kapsamında ele alınmaktadır. Üçüncü bölümde ilgili literatür özetine yer verilmektedir. Devamında ilgili model kapsamında ampirik analiz yer almakta ve son bölümde çalışmanın genel bulguları değerlendirilmektedir.

\section{Türkiye'de Gelir Eşitsizliği}

Türkiye'de gelir dağılımı eşitsizliği ile ilgili çalışmalar farklı aralıklarla ve çeşitli kapsamlarda ele alınmış olmasına rağmen, 1994 yılında hanehalklarına uygulanan tüketim harcamaları anketi ve 1995 yılında uygulanan gelir dağılımı anketi dışında Türkiye genelini analiz edebilecek daha farklı çalışmalar yapılmamıştır. 2006 yılından sonra bu gereksinimi karşılayabilmek amacıyla yeni bir çalışma yapılmıştır. Bu çalışma Avrupa Birliği uyum kapsamında "Gelir ve Yaşam Koşulları Araştırması" olarak ifade edilmektedir. TÜİK bu çalışmadan önce gelir dağılımı eşitsizliğinin incelenmesi için 1987 yılında Hanehalkı Gelir ve Tüketim Harcamaları Anketini uygulamıştır.

Gelir dağılımı eşitsizliği analizlerinde en sık kullanılan ölçümlerden biri İtalyan istatistikçi Corrada gini tarafından geliştirilen gini katsayısıdır. Gini katsayısı eşitsizlik seviyesini bir sayı ile ifade etmesinden dolayı farklı gelir dağılımı eşitsizliklerinin kıyaslamasının yapılmasını sağlamaktadır. Gini katsayısı "0" ve "1" arasında değişmektedir. Gelir dağılımı eşitsizlikleri azalma eğilimi gösterdikçe katsayı sıfıra, aksi halde bire yaklaşmaktadır. Şöyle ki, gini katsayısının artması eşitsizliğin arttığını ifade ederken, azalması gelir eşitsizliğinin azaldığını ifade etmektedir. Gini katsayısı, sıfır ise gelir dağılımı adil olarak paylaşılmaktadır. Eğer katsayı bir ise, gelir dağılımında tam eşitsizlik söz konusudur (Haughton ve Khandker, 2009). Daha eşit toplumların gini katsayısı 0.3 veya bunun altındadır. İsveç, Almanya ve Norveç bu ülkelere örnektir (UNDP, 2012). Eşitsizlik seviyesi en yüksek toplumların gini katsayıları 0.5 veya bunun üzerindedir. Bu ülkeler içerisinde Afrika'nın ve Latin Amerika'nın bazı ülkeleri yer almaktadır. Türkiye 'de ise gelir eşitsizliği durumunu ifade eden gini katsayısı 1987 yılında 0.43 iken 2017 yılında 0.40 olarak belirlenmiştir. Bu durum yıllar itibariyle azalma eğilimi göstermiş olmasına rağmen, işsizlik ve enflasyon gibi çeşitli makro ekonomik göstergelerin seviyelerine bakıldığında Türkiye'de gelir eşitsizliği sorunun varlığına işaret etmektedir. Bu durum Şekil 1'de yıllar itibariyle gösterilmektedir.

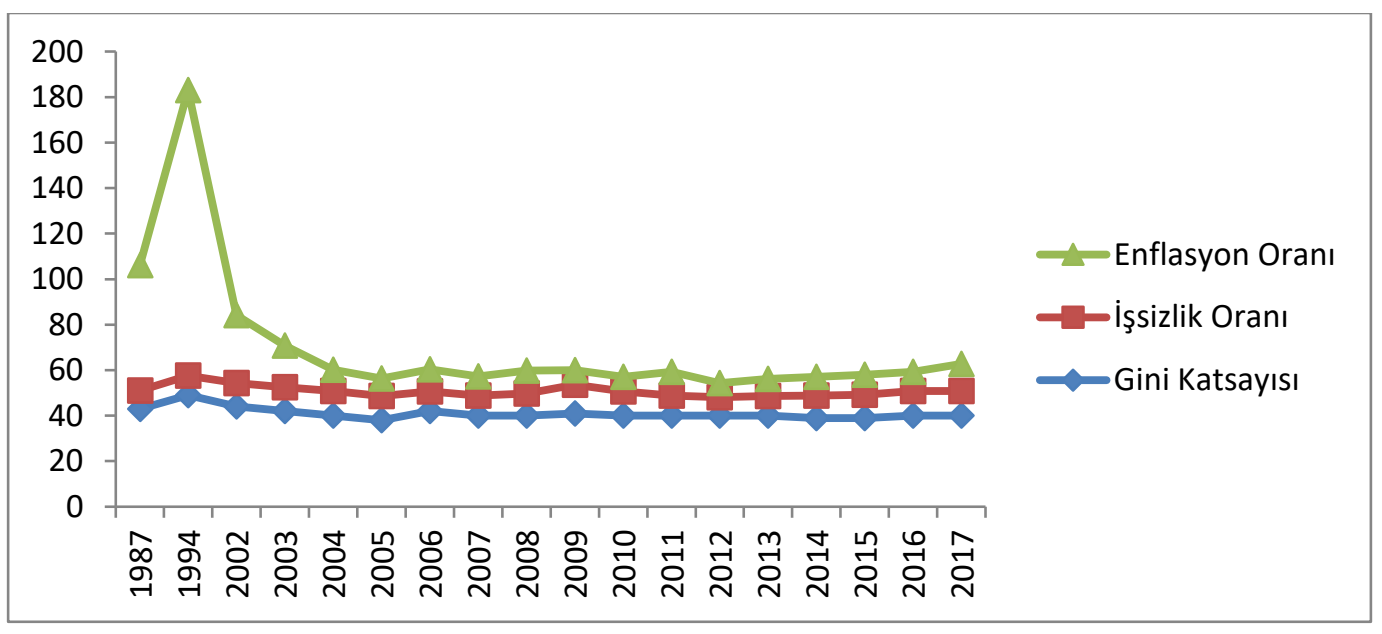

Şekil 1: Gini Katsayısı ve Diğer Göstergeler- Türkiye Kaynak: WB Databank

Türkiye'de gelir eşitsizliği araştırmaları sonucunda elde edilen göstergeler Tablo 1'de yer almaktadır. Gelir dağılımı dilimlerin aldığı paylar incelendiğinde göreceli bir iyileşme dikkat çekmektedir. Alt kesimlerin gelirden aldıkları pay artarken, üst gelir kesimlerinde az da olsa gerileme olmuştur. Buna rağmen, Türkiye'de gelir dağılımı eşitsizliğine yön verebilen kesim beşinci \%20'lik dilim olmaktadır. Bu rakam 2017 yılında \% 46.7 olmakla birlikte, eşitsizliğin ne kadar büyük olduğunu ifade etmektedir. 


\begin{tabular}{|l|l|l|l|l|l|}
\hline Y1llar & Birinci \%20 & İkinci \%20 & Üçüncü \%20 & Dördüncü\%20 & Beşinci \%20 \\
\hline 1987 & $\mathbf{5 . 2}$ & $\mathbf{9 . 6}$ & $\mathbf{1 4 . 1}$ & $\mathbf{2 1 . 2}$ & $\mathbf{4 3 . 0}$ \\
\hline 1994 & $\mathbf{4 . 9}$ & $\mathbf{8 . 6}$ & $\mathbf{1 2 . 6}$ & $\mathbf{1 9 . 0}$ & $\mathbf{5 4 . 9}$ \\
\hline 2002 & $\mathbf{5 . 3}$ & $\mathbf{9 . 8}$ & $\mathbf{1 4 . 0}$ & $\mathbf{2 0 . 8}$ & $\mathbf{5 0 . 1}$ \\
\hline 2005 & $\mathbf{6 . 1}$ & $\mathbf{1 1 . 1}$ & $\mathbf{1 5 . 8}$ & $\mathbf{2 2 . 6}$ & $\mathbf{4 4 . 4}$ \\
\hline 2008 & $\mathbf{6 . 4}$ & $\mathbf{1 0 . 9}$ & $\mathbf{1 5 . 4}$ & $\mathbf{2 2 . 0}$ & $\mathbf{4 5 . 3}$ \\
\hline 2010 & $\mathbf{6 . 5}$ & $\mathbf{1 1 . 1}$ & $\mathbf{1 5 . 6}$ & $\mathbf{2 1 . 9}$ & $\mathbf{4 4 . 9}$ \\
\hline 2011 & $\mathbf{6 . 5}$ & $\mathbf{1 1 . 0}$ & $\mathbf{1 5 . 5}$ & $\mathbf{2 1 . 9}$ & $\mathbf{4 5 . 2}$ \\
\hline 2012 & $\mathbf{6 . 5}$ & $\mathbf{1 1 . 0}$ & $\mathbf{1 5 . 6}$ & $\mathbf{2 2 . 0}$ & $\mathbf{4 5 . 0}$ \\
\hline 2013 & $\mathbf{6 . 6}$ & $\mathbf{1 0 . 9}$ & $\mathbf{1 5 . 4}$ & $\mathbf{2 1 . 8}$ & $\mathbf{4 5 . 2}$ \\
\hline 2014 & $\mathbf{6 . 5}$ & $\mathbf{1 1 . 0}$ & $\mathbf{1 5 . 6}$ & $\mathbf{2 2 . 2}$ & $\mathbf{4 4 . 7}$ \\
\hline 2015 & $\mathbf{6 . 3}$ & $\mathbf{1 0 . 9}$ & $\mathbf{1 5 . 5}$ & $\mathbf{2 2 . 0}$ & $\mathbf{4 5 . 3}$ \\
\hline 2016 & $\mathbf{6 . 3}$ & $\mathbf{1 0 . 6}$ & $\mathbf{1 5 . 2}$ & $\mathbf{2 1 . 6}$ & $\mathbf{4 6 . 3}$ \\
\hline 2017 & $\mathbf{6 . 3}$ & $\mathbf{1 0 . 6}$ & $\mathbf{1 5 . 1}$ & $\mathbf{2 1 . 4}$ & $\mathbf{4 6 . 7}$ \\
\hline
\end{tabular}

Tablo 1: Türkiye'de Yıllar İtibariyle Gelir Dă̆ılımı Kaynak: TÜIKK

\section{Literatür İncelemesi}

Ekonomilerin gelişmesine paralel olarak gelir eşitsizliği ve bu eşitsizliğin iktisadi etkilerini incelemek önemlidir. Günümüzde gelir dağılımı eşitsizliği artma eğilimi göstermektedir ve özellikle 1970'li yıllardan itibaren gelir eşitsizliği üzerine yapılan çalışmalar dikkat çekmeye başlamıştır (Sundrum, 1990). Ancak gelir eşitsizliği kapsamında yapılan çalışmaların temeli uzun yıllar olmasına rağmen, yaşanılan mevcut durum hemen hemen tüm dünyada eşitsizliğin hala çok yüksek seviyeye ulaşmasıdır. Bu nedenle gelir eşitsizliği ve eşitsizliğin makro ekonomik değişkenler arasındaki etkisinin araştırılması gündemdeki önemini korumakta ve ekonomiler gelir eşitsizliğinin derinleşmesi sorunu ile mücadeleyi sürdürmektedir.

Literatürde gelir eşitsizliğinin çok boyutlu olmasından dolayı, bu eşitsizliği belirleyen büyüme, enflasyon, verimlilik, eğitim ve işsizlik gibi bir çok iktisadi değişkenle etkileşimi içeren birçok çalışma yer almaktadır. Literatür incelemesi sonucunda ele alınan değişkenler arasındaki ilişkilerde farklı bulguların söz konusu olduğu görülmektedir. Şöyle ki, gelir eşitsizliği ve işsizlik arasındaki ilişkiyi inceleyen çalışmalara bakıldığında değişkenler arasında ilişkinin olduğunu savunan çalışmalar söz konusudur. Oduwole (2015) ve Yousaf ve Ali (2014) çalışmalarında işsizlik ve gelir eşitsizliği arasında pozitif ilişki olduğunu; Odeh ve Okoye (2014), bir ekonominin nüfusunun çoğunun yoksulluk sınırının altında yaşadığı ve gelir eşitsizliğinin yüksek olduğu sırada işsizliğin asıl sebep olduğunu tespit etmiştir. Bununla birlikte, gelir eşitsizliği ve işsizlik arasında kesin bir ilişki bulamayan çalışmalarda bulunmaktadır (Gustafsson ve Johansson, 1999; Mehrara ve Mohammadian, 2015).

Literatürde enflasyon ve gelir eşitsizliği arasındaki ilişkiye yönelik çalışmalarda da farklı sonuçlar dikkat çekmektedir. Ravallion (1998) ve Braumann (2004), gelir eşitsizliği ve enflasyonun pozitif yönde ilişkili olduğunu bulmuştur. Bununla birlikte, Ravallion ve Datt (2002) değişkenler arasındaki ilişkiyi incelemekte ve enflasyonun Hindistan'daki gelir eşitsizliği üzerinde olumsuz bir etkiye yol açtığı sonucuna varmıştır. Cardoso (1992) ise, enflasyonun gelir eşitsizliği üzerinde çift yönlü bir etkisi olduğunu bulurken, Talukdar (2012), düşük gelirli ülkelerde enflasyonun gelir eşitsizliği üzerinde bir etkisi olmadığını tespit etmiştir. Aşağıda Tablo 2'de analize konu olan değişkenlerle ilgili çalışmaların kısa bir literatür incelemesi yer almaktadır. 


\begin{tabular}{|c|c|c|}
\hline Yazar(lar) & Model - Yöntem & Bulgular \\
\hline Bulir (2001) & $\begin{array}{l}\text { Enflasyon ve gelir dağılımı } \\
\text { eşitsizliği arasındaki ilişki } \\
\text { incelenmiş. } 22 \text { yıllık dönem için } \\
75 \text { ülkenin verileri ile panel veri } \\
\text { tekniği kullanılmıştır. }\end{array}$ & $\begin{array}{l}\text { Düşük ve yüksek enflasyonun } \\
\text { gelir dağılımı üzerinde etkileri } \\
\text { farklıdır. İlişki doğrusal değildir. } \\
\text { Düşük enflasyon rakamlarının } \\
\text { gelir eşitsizliği üzerine olumlu } \\
\text { etkisi varken, yüksek enflasyonun } \\
\text { gelir eşitsizliğini arttırıcı etkisi } \\
\text { vardır. }\end{array}$ \\
\hline Meo vd (2018) & $\begin{array}{l}\text { Enflasyon ve işsizliğin yoksulluk } \\
\text { üzerine asimetrik etkisini Pakistan } \\
\text { için analiz etmiştir. 1970-2016 } \\
\text { dönemi kapsamında NARDL } \\
\text { yöntemi kullanılmıştır. }\end{array}$ & $\begin{array}{l}\text { Yoksulluğun pozitif ve negatif } \\
\text { şoklarının enflasyon ve işsizlik } \\
\text { üzerinde etkisi olduğu sonucuna } \\
\text { ulaşılmıştır. Enflasyonun } \\
\text { yükselmesi ve düşmesinin } \\
\text { yoksulluk üzerinde arttırıcı etkisi } \\
\text { varken; işsizliğin ise gelir } \\
\text { eşitsizliği üzerinde arttırıcı etkisi } \\
\text { olduğu tespit edilmiştir. }\end{array}$ \\
\hline Dişbudak ve Süslü (2007) & $\begin{array}{l}\text { Türkiye için gini katsayısı ile } \\
\text { büyüme, enflasyon ve dışa açıklık } \\
\text { arasındaki ilişkiyi zaman serisi } \\
\text { analizi ile test etmiştir. }\end{array}$ & $\begin{array}{l}\text { Enflasyon oranının gelir dağılımı } \\
\text { eşitsizliği üzerinde bozucu etkisi } \\
\text { söz konusu iken, büyüme ve dışa } \\
\text { açıklık katsayılarının ise, gini } \\
\text { katsayısında düşürücü etkisi } \\
\text { olduğu tespit edilmiştir. }\end{array}$ \\
\hline Fahim Al-Marhubi(1997) & $\begin{array}{l}\text { Gelir eşitsizliği ve enflasyon } \\
\text { arasındaki ilişkiyi siyasi } \\
\text { istikrarsızlık, MB bağımlılık } \\
\text { derecesi ve dışa açıklık } \\
\text { değişkenlerini modele dahil ederek } \\
\text { analiz etmiştir. }\end{array}$ & $\begin{array}{l}\text { Yüksek eşitsizlik oranına sahip } \\
\text { ülkelerde aynı zamanda yüksek } \\
\text { enflasyon oranları görüldüğü } \\
\text { sonucuna ulaşılmıştır. }\end{array}$ \\
\hline Dolmas vd (2000) & $\begin{array}{l}\text { Gelir dağılımı ile enflasyon } \\
\text { arasındaki ilişkiyi demokrasi ve } \\
\text { MB bağımsılığı kapsamında } \\
\text { analiz etmiştir. }\end{array}$ & $\begin{array}{l}\text { Enflasyon ve gelir eşitsizliği } \\
\text { arasında pozitif bir ilişki olduğu, } \\
\text { aynı zamanda ülkelerin } \\
\text { demokratik olma ve olmama } \\
\text { açısından sonuçların farklılık } \\
\text { gösterdiği tespit edilmiştir. }\end{array}$ \\
\hline Galli ve Hoeven (2001) & $\begin{array}{l}\text { Enflasyon ile para politikasındaki } \\
\text { eşitsizlik arasındaki ilişkiyi ABD } \\
\text { ve onbeş OECD ülkesi için analiz } \\
\text { etmiştir. }\end{array}$ & $\begin{array}{l}\text { Enflasyonun yüksek görüldüğü } \\
\text { ülkelerde enflasyonun düşmesinin } \\
\text { gelir eşitsizliğini azaltıcı etkisi } \\
\text { varken, enflasyonun düşük olduğu } \\
\text { ülkelerde enflasyon oranlarının } \\
\text { düşme eğilimi göstermesi gelir } \\
\text { eşitsizliğini arttırıcı etkisi olduğu } \\
\text { sonucuna ulaşılmıştır. }\end{array}$ \\
\hline Monnin (2014) & $\begin{array}{l}\text { Gelir eşitsizliği ve enflasyon } \\
\text { arasındaki ilişkiyi 1971-2010 } \\
\text { kapsamında on OECD ülkesi için } \\
\text { analiz etmiştir. }\end{array}$ & $\begin{array}{l}\text { Enflasyon oranı ile gelir eşitsizliği } \\
\text { arasındaki ilişkinin uzun dönemde } \\
\text { U-şeklinde olduğu tespit } \\
\text { edilmiştir. Buna göre, enflasyon } \\
\text { oranlarının düşük olması } \\
\text { durumunda gelir eşitsizliği } \\
\text { yüksek; enflasyon arttıkça } \\
\text { eşitsizliğin azaldığ1 ve \%13 } \\
\text { seviyesinde minimum olduğu ve } \\
\text { bu değerden sonra eşitsizliğin } \\
\text { tekrar arttığ1 sonucuna ulaşılmıştır. }\end{array}$ \\
\hline
\end{tabular}

Tablo 2: Literatür Özeti

İlgili literatürün incelenmesinden sonra, gelir eşitsizliğinin çok önemli ve küresel bir mesele olduğu açıktır ve birçok araştırmacı gelir eşitsizliğinin belirleyicilerini araştırmak için çalışmalar yapmıştır. Bu durum, Türkiye'de enflasyonun ve işsizliğin gelir eşitsizliği üzerindeki etkisini test etmek için bir çalışma yapılması için önemli bir altyapı sağlamıştır. Ayrıca, gelir eşitsizliğinin belirleyicileri üzerine yapılan ampirik çalışmalar enflasyon ve 
işsizliğin gelir eşitsizliği üzerindeki etkisinin, farklı sonuçlar nedeniyle belirsiz kaldığını ortaya koymaktadır. Sonuç olarak, gelir eşitsizliğinin belirleyicilerini Türkiye ekonomisi kapsamında araştırmak önemlidir. Aynı zamanda metodoloji açısından ise, literatür asimetrik modellemenin önemini de vurgulamaktadır. Anoruo (2011), simetrik ve asimetrik modelleme analiz aşamalarını karşılaştırmış ve doğrusal modellemenin zaman içindeki değişkenlerin asimetrik davranışını ölçmede etkili olmadığını; asimetrik modellerin daha iyi açıklayıcı güce sahip olduğunu savunmaktadır. Bu çalışma, gelir eşitsizliği ve belirleyicileri arasındaki asimetrileri dikkate alarak literatüre katkıda bulunmaktadır. Sonuç olarak, gelir eşitsizliği asimetrik bir çerçevede modellenmiştir.

\section{Veri Seti ve Metodoloji}

Çalışmada enflasyon, işsizlik ve gelir eşitsizliği arasında kısa ve uzun dönemli asimetrik ilişkinin olup olmadığ araştırılmaktadır. Enflasyon, işsizlik ve gelir eşitsizliği serileri 1991-2016 dönemini ele alacak şekilde yıllık bazdadır. Uygulamada değişkenlere ait zaman serileri Dünya Bankası veri tabanından elde edilmiştir. Değişkenler logaritmik formda kullanılmıştır. Değişkenler ve açıklamaları Tablo 3'de verilmiştir.

\begin{tabular}{lll}
\hline Değişken & Açıklama & Kaynak \\
\hline GINI & Gini katsayısı & SWIID 7.0 (Solt, 2017) \\
INF & Enflasyon oranı (Tüketici fiyat & WB Databank \\
& $\begin{array}{l}\text { endeksinin bir önceki yıla göre \% } \\
\text { değişim oranı) }\end{array}$ & \\
UMP & İşsizlik oranı (\% toplam işgücü) & WB Databank \\
\hline
\end{tabular}

Tablo 3: Analizde Kullanılan Değişkenler ve Açıklamaları

Analizde Shin vd (2014) tarafından geliştirilmiş Doğrusal Olmayan Gecikmesi Dağıtılmış Oto Regresif Model (NARDL) kullanılmıştır. Asimetrik ARDL yöntemi, doğrusal ARDL modelinin asimetrik uzantısı olarak değerlendirilmektedir. NARDL modeli incelenen değişkenlerin kısa ve uzun dönem asimetrik etkilerini dikkate alarak doğrusal olmayan ilişkiyi analiz eden bir yöntemdir. Bu kapsamda, değişkenler arasında kısa ve uzun dönem asimetrik etkiler ayrıştırılmakta ve bağımsız değişkenlerde ortaya çıkan negatif ve pozitif değişimlerin bağımlı değişken üzerindeki etkileri analiz etmektedir. NARDL modelinin klasik eşbütünleşme modellerine göre bazı avantajları vardır. İlk olarak, NARDL modelinde küçük örneklem büyüklügünde dahi etkin sonuçlara ulaşılabilmektedir (Romilly vd, 2001). İkincisi, NARDL için değişkenlerin durağan olmaları koşulu zorunlu değildir. Değişkenlerin farklı entegre derecesinde olması durumunda da etkin sonuçlar vermektedir. Ancak modelin sınırlılığı serilerin ikinci dereceden entegre olması durumunda bu yöntemin kullanılmamasıdır (Pesaran, 1997). Bu nedenle değişkenler arasında kısa ve uzun dönem ilişkileri analiz etmek için bu yöntem tercih edilmiştir. Modelde gelir eşitsizliğini temsil eden gini katsayısının enflasyon ve işsizlikten etkilendiği düşünülmektedir. Bu nedenle uzun dönem ilişkiyi gösteren model aşağıdaki gibi kurulmuştur (Denklem 1).

$$
G I N I_{t}=\beta_{0}+\beta_{1}(\mathrm{INF})+\beta_{2}(\mathrm{UMP})+u_{t}
$$

Model uzun dönem ilişkiyi analiz ederken, hata düzeltme modeli ise kısa dönem ilişkiyi ifade etmektedir. Değişkenler arası kısa dönem etkilerin tahmin edilmesi için, denklem (1) hata düzeltme modeli yaklaşımı olarak şu şekilde yazılmaktadır (Denklem 2)

$$
\begin{aligned}
\quad & \Delta G I N I_{t}=\alpha_{0}+\sum_{k=1}^{p 1} \alpha_{k} \Delta G I N I_{t-k}+\sum_{k=0}^{p 2} \alpha_{k} \Delta I N F_{t-k}+\sum_{k=0}^{p 3} \alpha_{k} \Delta U M P_{t-k}+\lambda_{1} G I N I_{t-1}+\lambda_{2} I N F_{t-1}+\lambda_{3} U M P_{t-1} \\
+ & u_{t}
\end{aligned}
$$

Doğrusal olmayan ARDL modeli için, modelde yer alan enflasyon ve işsizlik serilerinin asimetrik etkilerinin incelenmesi için pozitif ve negatif iki farklı seriye ayrılması gerekmektedir. Ayrıştırma aşaması aşağıda yer alan denklemlere göre yapılmaktadır:

$$
\begin{aligned}
& I N F^{+}=\sum_{i=1}^{t} \Delta I N F_{i}^{+}=\sum_{i=1}^{t} \max \left(\Delta I N F_{i}, 0\right) \\
& I N F^{-}=\sum_{i=1}^{t} \Delta I N F_{i}^{-}=\sum_{i=1}^{t} \min \left(\Delta I N F_{i}, 0\right) \\
& U M P^{+}=\sum_{i=1}^{t} \Delta U M P_{i}^{+}=\sum_{i=1}^{t} \max \left(\Delta U M P_{i}, 0\right) \\
& U M P^{-}=\sum_{i=1}^{t} \Delta I N F_{i}^{-}=\sum_{i=1}^{t} \min \left(\Delta U M P_{i}, 0\right)
\end{aligned}
$$

Enflasyon ve işsizliğin pozitif ve negatif kısmi serileri toplamı denklem (2)'ye ilave edilerek asimetrik ARDL modeli elde edilmektedir (Denklem 7).

$$
\begin{gathered}
\quad \Delta \mathrm{GINI}_{\mathrm{t}}=\alpha_{0}+\sum_{\mathrm{k}=1}^{\mathrm{p} 1} \alpha_{\mathrm{k}} \Delta \mathrm{GINI}_{\mathrm{t}-\mathrm{k}}+\sum_{\mathrm{k}=0}^{\mathrm{p} 2} \alpha_{\mathrm{k}} \Delta \mathrm{INF}_{\mathrm{t}-\mathrm{k}}^{+}+\sum_{\mathrm{k}=0}^{\mathrm{p} 3} \alpha_{\mathrm{k}} \Delta \mathrm{INF}_{\mathrm{t}-\mathrm{k}}^{-}+\sum_{\mathrm{k}=0}^{\mathrm{p} 3} \alpha_{\mathrm{k}} \Delta \mathrm{UMP}_{\mathrm{t}-\mathrm{k}}^{+} \\
+\sum_{\mathrm{k}=0}^{\mathrm{p} 4} \alpha_{\mathrm{k}} \Delta \mathrm{UMP}_{\mathrm{t}-\mathrm{k}}^{-}+\lambda_{1} \mathrm{GINI}_{\mathrm{t}-1}+\lambda_{2} \mathrm{INF}_{\mathrm{t}-1}^{+}+\lambda_{3} \mathrm{INF}_{\mathrm{t}-1}^{-}+\lambda_{3} \mathrm{UMP}_{\mathrm{t}-1}^{+}+\lambda_{3} \mathrm{UMP}_{\mathrm{t}-1}^{-}+\mathrm{u}_{\mathrm{t}}
\end{gathered}
$$




\section{Analiz Sonuçları}

Asimetrik ARDL modeli tahmininden önce tüm değişkenlerin sıfir ve birinci dereceden durağan olmalarının incelenmesi amacıyla Dickey-Fuller (ADF) ve Phillips-Perron (PP) birim kök testi uygulanmıştır. Tablo 4'te tahmin sonuçları yer almaktadır. Tabloda değişkenler için birim kök sonuçları ADF testi ve PP testi için benzer olduğu görülmektedir. Buna göre, tüm değişkenler I(1) olarak belirlenmiştir. Modelde yer alan değişkenler asimetrik ARDL için gerekli şartları sağlamaktadır.

\begin{tabular}{|l|l|l|l|l|}
\hline & \multicolumn{2}{|l|}{ ADF Testi } & PP Testi & Sabit ve Trend \\
\hline Değişkenler & Sabit & Sabit ve Trend & Sabit & -2.183 \\
\hline GINI & -0.250 & -2.083 & -0.314 & -1.872 \\
\hline INF & -1.541 & -1.677 & -1.467 & 0.763 \\
\hline UMP & 0.300 & -2.314 & 0.294 & $-5.163^{*}$ \\
\hline $\boldsymbol{\Delta G I N I}$ & $-5.190^{*}$ & $-5.081^{*}$ & $-5.258^{*}$ & $-4.510^{*}$ \\
\hline $\boldsymbol{\Delta I N F}$ & $-4.360^{*}$ & $-4.511^{*}$ & $-4.398^{*}$ & $-3.971^{*}$ \\
\hline $\boldsymbol{\Delta U M P}$ & $-4.189^{*}$ & $-4.052^{*}$ & $-4.134^{*}$ & \\
\hline
\end{tabular}

Tablo 4: Birim Kök Test Sonuçları

Birim kök testlerinin ardından uygun modelin seçilmesinde ilk adım uygun gecikme uzunluğunun belirlenmesidir. Modelde, değişkenlerin optimal gecikme uzunluğu kriteri minimum AIC değeri dikkate alınarak 4 olarak elde edilmiştir. Enflasyon, işsizlik ve gelir eşitsizliği arasında eşbütünleşme ilişkisinin varlığının incelenmesi için sınır testi sonuçları Tablo 5'te verilmiştir. \%5 anlamlılık seviyesinde hesaplanan $\mathrm{F}$ istatistiği değeri, üst kritik sınır değerinden büyüktür. Dolayısıyla değişkenler arasında eşbütünleşme varlığına işaret edilmektedir.

\begin{tabular}{|l|l|l|l|}
\hline & & \multicolumn{3}{|l|}{ KritikDeğerler (\%5) } \\
\cline { 3 - 4 } $\mathrm{k}$ & & Alt Sinır & Üst Sınır \\
\hline 3 & F-ist & & \\
\hline
\end{tabular}

Tablo 5: Sinır Testi Sonuçları

Enflasyon, işsizlik ve gelir eşitsizliği arasında asimetrik ilişkileri incelemek amacıyla doğrusal olmayan NARDL yöntemi tahmin sonuçları Tablo 6'da verilmiştir. Tablo kısa ve uzun dönem katsayılarını, ayrıca değişen varyans, otokorelasyon, normallik ve değişen varyans tanısal test sonuçlarını içermektedir. Wald testi ise, negatif ve pozitif uzun dönem katsayılarının birbirine eşit olduğu sıfır hipotezini test ederek, uzun dönemde asimetrik etkilerin olup olmadığını araştırmaktadır. Modelde enflasyonun gelir eşitsizliği üzerine etkisinin asimetrik olduğu $\left(W_{L R, \imath n f}=\right.$ 8.50) tespit edilirken, buna karşıllı işsizliğin gelir eşitsizliği üzerine etkisinin asimetrik değil, simetrik olduğu $\left(W_{L R, u m p}=4.68\right)$ sonucuna ulaşılmıştır. 


\begin{tabular}{|c|c|c|}
\hline \multicolumn{3}{|l|}{ a. Asimetrik ARDL Sonuçları } \\
\hline Değişken & Katsayı & $\mathrm{t}$ istatistiği \\
\hline$\Delta$ GINI $(-1)$ & 1.389 & $7.198(0.000)$ \\
\hline$\Delta$ GINI $(-2)$ & 0.400 & $2.501(0.051)$ \\
\hline$\Delta$ GINI $(-3)$ & 1.056 & $6.961(0.000)$ \\
\hline$\Delta I N F^{+}$ & -0.249 & $-6.476(0.001)$ \\
\hline$\Delta I N F^{+}(-1)$ & -0.087 & $-2.062(0.094)$ \\
\hline$\Delta I N F^{+}(-3)$ & 0.179 & $5.965(0.001)$ \\
\hline$\Delta \mathrm{INF}^{-}$ & 0.068 & $4.965(0.004)$ \\
\hline$\Delta I N F^{-}(-1)$ & -0.072 & $-4.068(0.009)$ \\
\hline$\Delta I N F^{-}(-2)$ & 0.044 & $2.573(0.049)$ \\
\hline$\Delta I N F^{-}(-3)$ & -0.060 & $-3.720(0.013)$ \\
\hline$\Delta \mathrm{UMP}^{+}(-1)$ & -0.116 & $-3.613(0.06)$ \\
\hline$\Delta \mathrm{UMP}^{+}(-2)$ & -0.141 & $-4.969(0.038)$ \\
\hline$\Delta \mathrm{UMP}^{-}$ & 0.123 & $7.534(0.017)$ \\
\hline$\Delta \mathrm{UMP}^{-}(-1)$ & -0.139 & $-5.68(0.02)$ \\
\hline$\Delta \mathrm{UMP}^{-}(-3)$ & -0.116 & $-5.704(0.029)$ \\
\hline Sabit & 0.39 & $9.899(0.000)$ \\
\hline \multicolumn{3}{|l|}{ b. Tanısal Test Sonuçları } \\
\hline Breusch Godfrey LM $2.040(0.22)$ & \multirow{2}{*}{\multicolumn{2}{|c|}{$\begin{array}{c}\text { White } 1.726(0.282) \\
\text { Reset } 3.686(0.127) \\
W_{L R, \text { Inf }},=8.50(0.03)^{*} W_{L R, u m p},=4.68(0.16)\end{array}$}} \\
\hline $\begin{array}{l}\text { Jarque Bera } 0.265(0.87) \\
R^{2}=0.972 \quad \text { Düzeltilmiş- } R^{2}=0.72 .4\end{array}$ & & \\
\hline \multicolumn{3}{|l|}{$\begin{array}{l}\text { c. Uzun Dönem } \\
\text { Katsayıları }\end{array}$} \\
\hline 0.165 & & $3.107(0.089)^{* *}$ \\
\hline 0.104 & & $6.693(0.021)^{*}$ \\
\hline $\mathrm{UMP}^{+}$ & & $6.220(0.02)^{*}$ \\
\hline $\mathrm{UMP}^{-}$ & & $4.030(0.442)$ \\
\hline
\end{tabular}

Tablo 6: NARDL Modeli Tahmin Sonuçları

Tabloda uzun dönem katsayılar incelendiğinde, enflasyon oranlarındaki artış ve azalışların uzun dönemde gelir eşitsizliği üzerindeki etkilerini gösteren katsayılar istatiksel açıdan anlamlıdır. Bu bulgular Cardoso (1992), Easterly ve Fischer (2001), Ivanic ve Martin (2008) sonuçlarına uygundur. Uzun dönemde pozitif enflasyon katsayısı 0.165 iken, uzun dönem negatif katsayısı 0.104 olarak bulunmuştur. Şöyle ki, enflasyon oranlarındaki $\% 100$ 'lük bir artış sonucunda gelir eşitsizliği yaklaşık \%16.5 artış gösterirken, enflasyon oranlarındaki \%100'lük azalış gelir eşitsizliğini \%10.4 arttırmaktadır. Böylece etkisi incelenen dönemde, Türkiye'de enflasyon oranlarında pozitif ve negatif değişimlere gelir eşitsizliği artma eğilimi göstermektedir. Buna karşılık işsizliğin gelir eşitsizliği üzerine etkisi simetriktir. Bununla birlikte, işsizlik artışlarının gelir eşitsizliği üzerine etkisi anlamlı ve pozitiftir. Azalışların etkisi ise anlamlı değildir. Bu durum işsizliğin pozitif katsayısında artışın Türkiye'de gelir eşitsizliği üzerinde önemli bir etkiye sahip olduğunu göstermektedir. Çünkü işsizlik oranlarında artış, işgücü kaynaklarının atıl olmasına ve gelirlerin azalmasına neden olmaktadır. Gelirdeki azalışlar ekonomide ihtiyaç ve isteklerin karşılanma eğilimini azaltmaktadır. Sonuç olarak, gelir eşitsizliğini arttırmaktadır.

\section{Sonuç}

Bu çalışma, Türkiye'de gelir eşitsizliği, enflasyon ve işsizlik gibi temel makroekonomik değişkenlerin 1991 ile 2016 yılları arasındaki etkilerini belirlemek için ekonometrik bir gelir eşitsizliği modeli oluşturmayı amaçlamıştır. Bu kapsamda gözden geçirilen çalışmaların çoğunlukla simetrik modeller kapsamında incelendiği görülmektedir. Ancak değişkenler arasında asimetrik ilişkilerin olabileceği modellerin simetrik yöntemler çerçevesinde incelenmesi politika uygulayıcıları açısından yanlış yönlendirmelere neden olabilmektedir. Bu nedenle değişkenler arasında asimetrik ilişkilerin olup olmadığının incelenmesi modelin daha etkili sonuçlar sağlaması için uygun görülmektedir. Bu amaçla literatürde bu boşluğu doldurmak için NARDL yaklaşımı ile, enflasyon ve işsizliğin gelir eşitsizliği üzerine asimetrik etkisi araştırılmıştır. Ampirik sonuçlar değerlendirildiğinde, uzun dönemde enflasyon ve gelir eşitsizliği arasında anlamlı ve asimetrik etkinin olduğu tespit edilmiştir. Enflasyon oranlarında artış (INF +) gelir eşitsizliğini artırma eğilimindeyken, enflasyon oranlarındaki düşüş (INF-) de uzun vadede gelir 
eşitsizliği artışına yol açmaktadır. Enflasyondaki pozitif değişimler ile gelir eşitsizliği arasındaki pozitif ilişki için çeşitli nedenler söz konusudur; birincisi, yüksek enflasyon oranı ekonomide yatırım riskine neden olarak nispi fiyatlarda yüksek dalgalanma yaratmaktadır. İkincisi, artan enflasyon, paranın satın alım gücünü olumsuz etkileyerek emtiaların piyasa fiyatını yükseltmektedir. Böylece, insanların istek ve ihtiyaçları için ödeyebilecekleri parasal miktar azalmaktadır. Ayrıca, enflasyondaki negatif değişimler ise, toplam talebi ve toplam arzı azaltma eğilimindedir. $\mathrm{Bu}$ durum ekonomide işsizlik oranının yükselmesine neden olmaktadır. Sonuç olarak, politika yapıcılar güçlü ve sürdürülebilir bir istikrar politikası düzenlemesi elde etmek için istikrar politikasının oluşturulması ve uygulanmasında şeffaflığı ve güvenilirliği sağlamalıdır. Bu politikalar, ekonomik faaliyetleri motive eden olumlu bir enflasyon seviyesini sürdürme çabasının temel parçalarıdır. Diğer taraftan, pozitif işsizlik katsayısı ile gelir eşitsizliği arasında da pozitif ve anlamlı bir etki söz konusudur. Bireylerin düzenli olarak istihdam edilmeleri yaşam koşullarının iyileşmesi için önem arz etmektedir. Çünkü işsizlik, yani piyasanın bir çok kişi için yeterli istihdam sağlayamaması, piyasa başarısızlıklarının en kötüsü olmakla birlikte, verimsizliğin en büyük kaynağı ve eşitsizliğin de en önemli sebebi olmaktadır. Bu nedenle, işsizliğin azaltılmasını teşvik edecek politikalar, gelir eşitsizliğinin azaltılmasına karşı önemli bir araç olmaktadır.

\section{Kaynakça}

- $\quad$ Ajie, H. A., Ani, E. C., \& Ameh, O. E. (2017). An examination of the impact of unemployment and inflation on the Nigerian economy: A bounds testing approach. Journal of Public Policy and Administration, 1(1), 22.

- Al-Marhubi, F. (1997). A note on the link between income inequality and inflation. Economics Letters, 55(3), 317-319.

- Braumann, B. (2004). High inflation and real wages. IMF Staff Papers, 51(1), 123-147.

- Bulir, A., (2001) Income inequality: does inflation matter?, IMF Staff Papers, 4 (2001) (1).

- Cardoso, E. (1992). Inflation and poverty (No. w4006). National Bureau of Economic Research.

- Dolmas, J. Huffman, G. W. ve Wynne, M. A. (2000), “Inequality, inflation, and central bank independence", Canadian Journal of Economics/Revue canadienne d'économique, 33(1), 271-287.

- Galli, R. ve Hoeven, R., (2001), "Is inflation bad for income inequality? The importance of the initial rate of inflation", Working Paper, The University of Lugano, Switzerland.

- Gustafsson, B., \& Johansson, M. (1999). In search of smoking guns: What makes income inequality vary over time in different countries? American Sociological Review, 64(2), 585-605.

- Hassan, M. U., Khalid, M. W., \& Kayani, A. S. (2016). Evaluating the Dilemma of Inflation, Poverty and Unemployment. Bulletin of Business and Economics (BBE), 5(2), 67-82.

- Haughton, J.ve Khandker, S.R., (2009). Handbook on Poverty and Inequality, The World Bank, Washington, DC.

- Keller, K.R.I. (2010). How Can Education Policy Improve Income Distribution?: An Empirical Analysis of Education Stages and Measures on Income Inequality. The Journal Of Developing Areas, 43 (2), 51-77.

- Lundberg M., \& Squire, L. (2003). The Simultaneous Evolution of Growth and Inequality. The Economic Journal, 113, 326-344.

- Mehrara, M., \& Mohammadian, M. (2015). The determinants of gini coefficient in Iran based on bayesian model averaging. Hyperion Economic Journal, 3(1), 20-28.

- Meo, M. S., Khan, V. J., Ibrahim, T. O., Khan, S., Ali, S., \& Noor, K. (2018). Asymmetric impact of inflation and unemployment on poverty in Pakistan: new evidence from asymmetric ARDL cointegration. Asia Pacific Journal of Social Work and Development, 28(4), 295-310.

- Monnin, P. (2014), "Inflation and Income Inequality in Developed Economies”, CEP Working Paper Series.

- Odeh, M. A., \& Okoye, C. (2014). Poverty reduction policy and youth unemployment in Nigeria. Public Policy and Administration Research, 3(4), 92-103.

- Oduwole, T. A. (2015). Youth unemployment and poverty in Nigeria. International Journal of Sociology and Anthropology Research, 1(2), 23-39.

- Öztürk, N. (2017). Gelir Dağılımının İktisadi Analizi. İstanbul. Ekin yayınevi

- Ravallion, M. (1998). Reform, food prices and poverty in India. Economic and Political Weekly, 33(2), 2936.

- $\quad$ Romilly, P., Song, H., \& Liu, X. (2001). Car ownership and use in Britain: A comparison of the empirical results of alternative cointegration estimation methods and forecasts. Applied Economics, 33(14), 18031818.

- $\quad$ Šileika, A., \&Bekerytė, J. (2013). Theoretical Issues of Relationship between Unemployment, Poverty and Crime in Sustainable Development. Journal of Security and Sustainability Issues, 2(3), 59-70. 
- $\quad$ Solt, Frederick. 2016. IThe Standardized World Income Inequality Database." Social Science Quarterly 97. SWIID Version 7.0, July 2018.

- Stiglitz, J. E. (2012). Eşitsizliğin Bedeli. İstanbul: İletişim.

- Sugema, I., Irawan, T., Adipurwanto, D., Holis, A., \& Bakhtiar, T. (2010). The impact of inflation on rural poverty in Indonesia: An econometrics approach. International Research Journal of Finance and Economics, 58, 51-57.

- $\quad$ Sundrum R.M. (1990), Income Distribution in Less Developed Countries, 1.Basım, London: Routledge, 1990, s.14.

- Supriyadi, E., \& KAUSAR, D. R. K. (2017). Impact of inflation, exchange rate toward the unemployment and the poverty in Indonesia.(case study: the small and medium industry at the tourist area in Lombok). Revista de turism-studii si cercetari in turism, (23).

- Şenses, F. (2017). Küreselleşmenin Öteki Yüzü Yoksulluk. İstanbul: İletişim

- Talukdar, S. R. (2012). The effect of inflation on poverty in developing countries: A panel data analysis (Doctoral dissertation).

- United Nations Development Programme (2016). Human Development Report: Human Development for Everyone, New York: The United Nations Development Programme.

- Yousaf, H., \& Ali, I. (2014). Determinants of poverty in Pakistan. International Journal of Economics and Empirical Research (IJEER), 2(5), 191-202. 


\title{
İşsizlik ve Enflasyon Çerçevesinde Phillips Eğrisinin Türkiye Üzerindeki Geçerliliğinin Vektör Otoregresif ve Markov Rejim Değişim Modelleriyle Sınanması
}

\section{Testing The Validity of The Phillips Curve for Turkey With Vector Autoregressive and Markov Switching Models on The Basis of Inflation and Unemployment}

\author{
Ph.D. Candidate Fatih Y1lmaz (Beykent University, Turkey) \\ Ph.D. Candidate Onur Şeker (Beykent University, Turkey) \\ Ph.D. Candidate Eren Pektaş (Beykent University, Turkey)
}

\begin{abstract}
In this study, we tested the validity of the Phillips Curve for Turkey. We used Markov Switching Model for examine the relationship between two variables in different regime periods, Engle Granger Causality Test for detect the causality between two variables, Johansen Cointegration Test for observe the long term equilibrium relationship and The Impulse Response Analysis and Variance Decomposition Analysis for investigate the explanatory effect of two variables on each other. As a result of the analysis, it was determined that Inflation and Unemployment act together in the short and long term. Between 2010M01 and 2017M10, it was determined that the Phillips Curve is ineffective for Turkey.
\end{abstract}

\section{Giriş}

İşsizlik ve Enflasyon ilişkisinin kabul gören teorilerinden olan Phillips Eğrisi ilk olarak 1958 yılında William Phillips tarafından keşfedildiğinde parasal ücretlerin değişim oranı ile işsizlik oranı arasındaki negatif ilişkiyi açıklamak için kullanılmıştır. Bu düzlemde işsizliğin negatife düşemeyeceği gerçeğiyle birlikte parasal ücretlerin maksimum limiti olacağı keşfedilmiştir.

Phillips Eğrisi, daha sonraki dönemde Samuelson ve Solow tarafından enflasyon oranı ve işsizlik oranı arasındaki doğrusal olmayan negatif yönlü ilişkiyi açıklayacak bir eğriye dönüştürülmüş ve bu haliyle genel kabul görmüştür.

\section{Enflasyon ve İşsizlik Çerçevesinde Kısa ve Uzun Dönem Phillips Eğrisi}

\subsection{Kısa ve Uzun Dönemlerde Phillips Eğrisi}

Phillips Eğrisi kısa ve uzun dönem olarak iki dönemde incelenmelidir. Farklı iktisadi görüşlerde Phillips eğrisinin enflasyon ile işsizlik arasındaki ilişkiyi genel olarak açıkladığı kabul edilse de gerçekler bunu yansıtmamaktadır. 1960'larda Ortodoks Keynesyen Paradigmaların tamamlayıcı parçası olarak kabul edilen Phillips eğrisi bu ekolde farklı işsizlik düzeyleri ile enflasyon oranları arasında bir seçim yelpazesi sunan, hem kısa hem de uzun dönemde geçerli ve istikrarlı bir ilişkiyi temsil ettiğini düşünmüşlerdir (Akkuş, 2013).

Phillips'in keşfi olan teorisine uygun olmayan bu görüş Phillips’e göre “Kalıcı ve önemsiz olmayan enflasyon oranları, işsizlik oranlarında sürdürülebilir azalmalar gerçekleştiremez”di. 1960'lı yılların sonlarına gelindiğinde M. Friedman ve E. Phelps' in birbirlerinden bağımsız olarak orijinal Phillips eğrisine beklentileri dahil etmeleri ve böylece "Doğal İşsizlik Oranı" kavramını iktisat teorisine kazandırmalarıyla enflasyon ve işsizlik arasındaki nedenselliğin açıklanmasına kısa ve uzun dönem ayrımını dahil etmişlerdir. Dönemsel olarak bakıldığında kısa
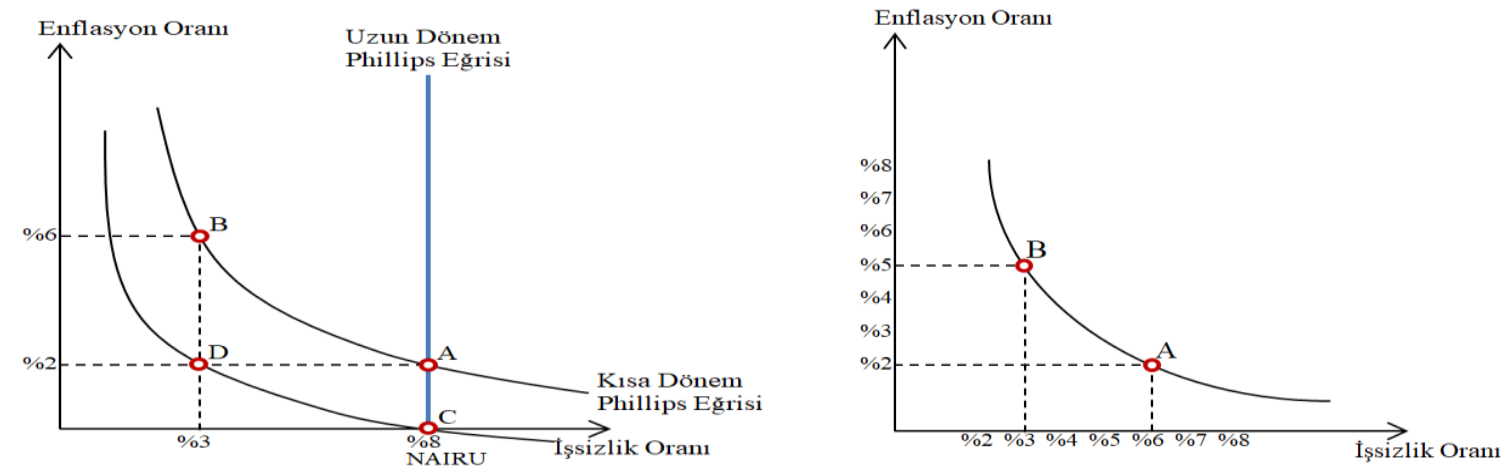

Şekil 1: Orijinal Phillips Ĕ̆risi ve Doğal İssizliğin Entegre Edildiği Phillips Ĕ̆risi 
dönemde Phillips eğrisinin negatif ilişkisi üzerine çalışmaya devam edilirken uzun dönemde ekonomik göstergeler 1şı̆̆ında negatif ilişkinin görülmediği saptanmıştır (Akkuş, 2013).

\section{2 İşsizlik ve Doğal İşsizlik Oranı}

İşsiz, referans dönemi içinde istihdam halinde olmayan kişilerden iş aramak için son üç ay içinde iş arama kanallarından en az birini kullanmış ve 15 gün içinde işbaşı yapabilecek durumda olan kurumsal olmayan çalışma çağındaki tüm kişilerdir (Türkiye İstatistik Kurumu, 2019).

İşsizliği belirleyen faktörler: 15 yaşından büyük olduğu halde; iş aramayan ancak 2 hafta içinde işbaşı yapmaya hazır olduğunu belirten kişiler, mevsimlik çalışanlar, ev işleriyle meşgul olanlar, öğrenciler, emekliler, belirli sebeplerle çalışamaz halde olanlar, ailevi yada kişisel sebeplerle iş aramayan ve iş başı yapmaya hazır olmayan kişilerdir (Türkiye İstatistik Kurumu, 2019).

Doğal işsizlik oranı, bir ekonomide tam istihdam düzeyinde ortaya çıkan işsizlik oranını ifade etmektedir. Gelişmekte olan ülkelerde bu oran gelişmiş ülkelere kıyasla daha yüksek oranlarda çıkmaktadır. Ancak bu tanım hiçbir zaman sıfıra düşmeyecek olan işsizlik oranını kronik bir problem olmaktan çıkarıp ekonomik bir araç olarak kullanmak üzere çözüm üretici hale getirmiştir (Karadeniz Teknik Üniversitesi, 2019).

\section{3 İşsizlik Yaratmayan Enflasyon: NAIRU}

NAIRU kavramı ilk kez 1975 y1lında Modigliani ve Papademos tarafından enflasyonist olmayan işsizlik oranı NIRU (Non-Inflationary Rate of Unemployment) olarak adlandırılmış ancak 1980 yılında Tobin tarafindan NAIRU (Non-Accelarated Inflation Rate of Unemployment) olarak geliştirilmiştir (Temurlenk, Başar, 2012). NAIRU enflasyonu arttırmayan işsizlik oranı olarak tanımlanabilir. NAIRU diğer bir ifadeyle doğal işsizlik oranını ifade etmektedir. "İşsizlik oranının NAIRU'nun altında kaldığı zaman enflasyonda bir artış, aksi durumda ise enflasyonda bir düşme eğilimi beklenmektedir.” (Wikipedia, 2019). Bu tanımın kabul edilmesinin getirisi olarak düşük enflasyon durumunda işsizlik yüksek olsa dahi ekonomik bir başarısızlıktan söz edilmeyecektir.

\subsection{Enflasyon Tanımı ve Doğal Enflasyon}

Enflasyon, fiyatlar genel seviyesinin devamlı yükselmesi nedeniyle paranın sürekli olarak değer kaybetmesi ve bunun sonucu olarak tüketicilerin satın alma gücünün zayıflamasıdır (TÜİK, 2008).

Doğal Enflasyon, bir ekonomide kabul edilebilir ve yükselme oranı çok düşük olan genel fiyatlar seviyesinin yüksekliği oranıdır.

\section{Literatür Taraması}

\begin{tabular}{|c|c|c|c|c|}
\hline Yazar & Değişkenler & Ülkeler & Yöntem & Sonuç \\
\hline $\begin{array}{l}\text { Emine Türkan AYVAZ } \\
\text { GÜVEN ve Yusuf } \\
\text { Yüksel AYVAZ }\end{array}$ & $\begin{array}{l}\text { İşsizlik ve } \\
\text { Enflasyon }\end{array}$ & Türkiye & VAR Analizi & $\begin{array}{l}\text { İşsizlik oranından Enflasyon oranına doğru bir } \\
\text { nedensellik tespit edilmiştir. }\end{array}$ \\
\hline Nurudeen ABU & \begin{tabular}{|l|} 
İşsizlik ve \\
Enflasyon \\
\end{tabular} & Nijerya & \begin{tabular}{|l|} 
ARDL, Granger \\
Nedensellik Testi \\
\end{tabular} & $\begin{array}{l}\text { İşsizlikten Enflasyona doğru tek yönlü } \\
\text { nedensellik tespit edilmiştir. }\end{array}$ \\
\hline Serhat YÜKSEL & $\begin{array}{l}\text { İşsizlik, } \\
\text { Enflasyon } \\
\text { ve } \\
\text { Ekonomik } \\
\text { Büyüme } \\
\end{array}$ & Rusya & $\begin{array}{l}\text { Toda Yamamoto, } \\
\text { Engle Granger } \\
\text { Nedensellik Testleri }\end{array}$ & $\begin{array}{l}\text { Engle Granger sınamasına göre işsizlik ve } \\
\text { enflasyon arasında nedensellik bulunamamış } \\
\text { ancak Toda Yamamoto sınamasına göre } \\
\text { Enflasyondan işsizliğe tek yönlü bir nedensellik } \\
\text { tespit edilmiştir. }\end{array}$ \\
\hline $\begin{array}{l}\text { Doğan UYSAL ve } \\
\text { Savaş ERDOĞAN }\end{array}$ & \begin{tabular}{|l} 
Fiyat \\
Düzeyi ve \\
İşsizlik \\
\end{tabular} & Türkiye & $\begin{array}{l}\text { Granger Nedensellik } \\
\text { Testi }\end{array}$ & $\begin{array}{l}1990 \text { ve } 2002 \text { yılları arasında negatif yönlü, } \\
19801990 \text { yılları arasındaysa pozitif yönlü bir } \\
\text { ilişkinin varlığı tespit edilmiştir. }\end{array}$ \\
\hline $\begin{array}{l}\text { Adem KORKMAZ ve } \\
\text { Orhan ÇOBAN }\end{array}$ & $\begin{array}{l}\text { Asgari } \\
\text { Ücret, } \\
\text { İşsizlik ve } \\
\text { Enflasyon } \\
\end{array}$ & Türkiye & $\begin{array}{l}\text { Johansen } \\
\text { Eştümleşme ve } \\
\text { Pairwise Granger } \\
\text { Nedensellik Testi } \\
\end{array}$ & $\begin{array}{l}\text { İşsizlik ve enflasyon arasında uzun dönemli bir } \\
\text { ilişki tespit edilmiş ancak iki değişken arasında } \\
\text { herhangi bir nedensellik tespit edilmemiştir. }\end{array}$ \\
\hline $\begin{array}{l}\text { Metin BAYRAK ve } \\
\text { Osman Cenk KANCA }\end{array}$ & $\begin{array}{l}\text { Enflasyon } \\
\text { ve İşsizlik }\end{array}$ & Türkiye & $\begin{array}{l}\text { Engle Granger } \\
\text { Eştümleşme Testi }\end{array}$ & $\begin{array}{l}\text { Uzun dönemde değişkenler arasında bir ilişki } \\
\text { mevcut değilken kısa dönemde iki değişken } \\
\text { arasında bir trade off tespit edilmiştir. }\end{array}$ \\
\hline $\begin{array}{l}\text { Çağlayan TABAR ve } \\
\text { Işın KIRIŞKAN ÇETIN }\end{array}$ & $\begin{array}{l}\text { İşsizlik ve } \\
\text { Enflasyon }\end{array}$ & Türkiye & Eştümleşme Testleri & $\begin{array}{l}\text { Phillips Eğrisinin kısa ve uzun vadede } \\
\text { Türkiye'de geçerli olduğu tespit edilmiştir. }\end{array}$ \\
\hline $\begin{array}{l}\text { Bülent ALTAY, Can } \\
\text { Tansel TUĞCU ve Mert } \\
\text { TOPÇU }\end{array}$ & $\begin{array}{l}\text { İşsizlik ve } \\
\text { Enflasyon }\end{array}$ & $\begin{array}{l}\text { G8 } \\
\text { Ülkeleri }\end{array}$ & $\begin{array}{l}\text { Eştümleşme ve } \\
\text { Nedensellik Testleri }\end{array}$ & $\begin{array}{l}\text { Kisa dönemde enflasyon işsizliği tetiklerken, } \\
\text { uzun dönemde ise işsizliğin enflasyona neden } \\
\text { olduğu tespit edilmiştir. }\end{array}$ \\
\hline Emilia HERMAN & $\begin{array}{l}\text { İşsizlik ve } \\
\text { Enflasyon }\end{array}$ & Romanya & $\begin{array}{l}\text { Pearson Korelasyon } \\
\text { Testi }\end{array}$ & $\begin{array}{l}\text { İşsizlik ve Enflasyon arasında Phillips tipi bir } \\
\text { ilişki tespit edilememiştir. }\end{array}$ \\
\hline Aycan HEPSAĞ & $\begin{array}{l}\text { İşsizlik ve } \\
\text { Enflasyon }\end{array}$ & Türkiye & Sinır Testi & $\begin{array}{l}\text { İki değişken arasında kısa dönemde bir ilişki } \\
\text { tespit edilememiş ancak uzun dönemde bir } \\
\text { değiş tokuş ilişkisi tespit edilmiştir. }\end{array}$ \\
\hline
\end{tabular}

Tablo 1. Literatür Taraması 


\section{Veri, Ekonometrik Yöntem ve Bulgular}

Çalışmada Türkiye için enflasyon ve işsizlik değişkenleri arasındaki ilişki incelenmiştir. 2010M01 - 2017M10 dönemini kapsayan veriler OECD’den alınmıştır. İki değişkenin belirtilen zaman dilimi içerisindeki değişimleri Şekil 2'de gösterilmiştir. Bu çalışmada enflasyon ve işsizlik değişkenleri arasındaki ilişki Eştümleşme, Nedensellik, Varyans Ayrıştırma ve Markov Rejim Değişim analizleriyle incelenecektir.

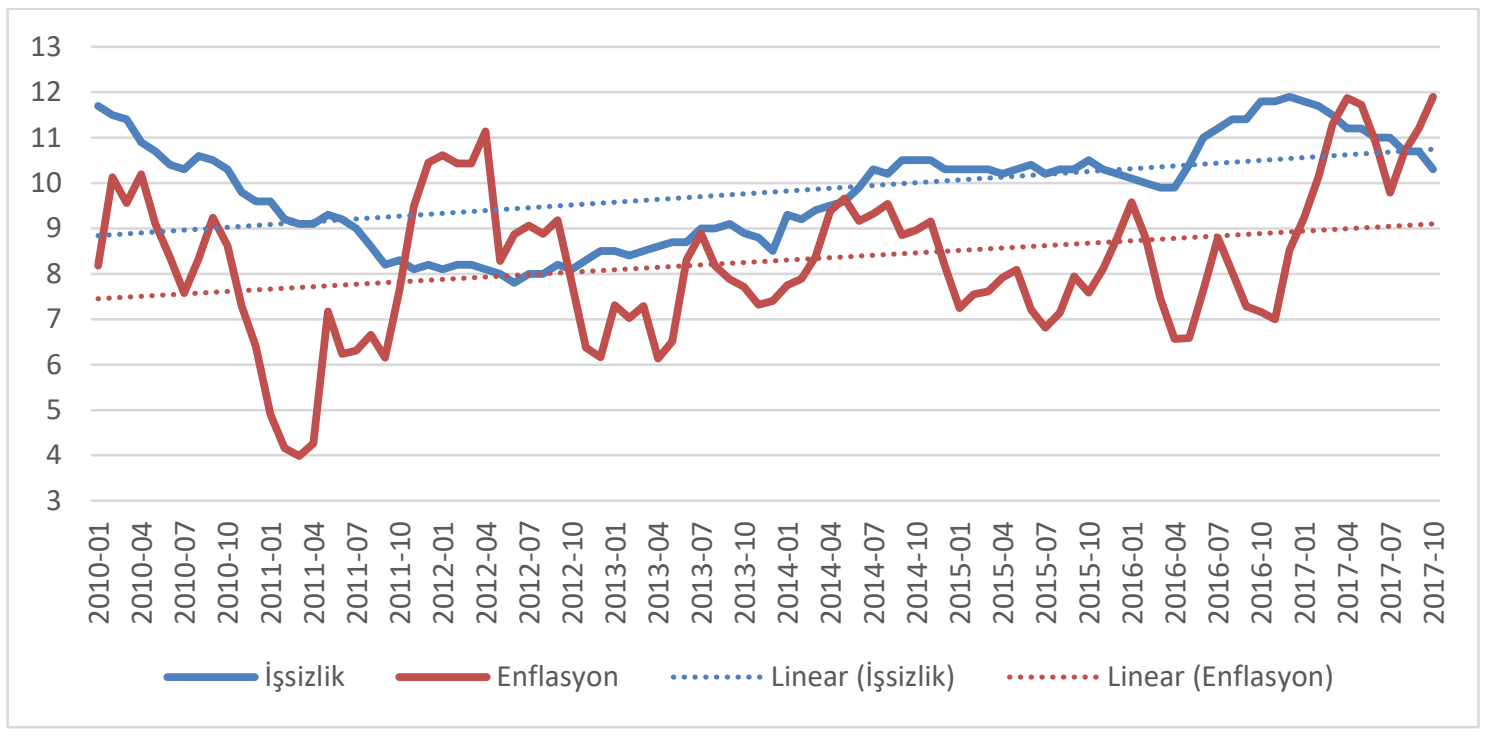

Şekil 2. Enflasyon ve İssizlik Değişkenlerinin Yıllar İçerisindeki Değişimi

\subsection{Markov Rejim Değişim Modeli}

Ekonomik analizlerde zaman serileri global veya lokal krizler, savaşlar, doğal afetler, siyasi ve politik dengeler gibi bağımsız değişkenlere bağlı olarak değişmekte ve bu dönemlerde serilerde kırılmalar gözlemlenebilmektedir. Bu kırılmalar rejim değişim modelleri ile açıklanabilmektedir. Markov Rejim Değişim Modeline göre herhangi bir zaman serisinin $t_{1}$ anında koşulsuz ortalamasında bir kırılmaya sahip olduğu varsayılırsa, $t_{1}$ anından önceki gözlem değerleri için 1. Model, $t_{1}$ anından sonraki gözlem değerleri için ise 2. model kullanılır.

$\gamma_{t}-\mu_{1}=\varnothing\left(\gamma_{t-1}-\mu_{1}\right)+u_{t}, t<t_{1} i c ̧ i n$

$\gamma_{t}-\mu_{2}=\emptyset\left(\gamma_{t-1}-\mu_{1}\right)+u_{t}, t \geq t_{1} i c ̧ i n$

Burada $u_{t} \sim \operatorname{iidN}\left(0, \sigma^{2}\right)$ ve $|\varnothing|<1$ 'dir (Bildirici, vd, 2010).

\begin{tabular}{|l|l|l|l|}
\hline Rejim 1 & Katsay1 & Standart Hata & Olasılık Değeri \\
\hline İşsizlik & 0.589322 & 0.149339 & 0.0001 \\
\hline C & 1.801374 & 1.433714 & 0.2090 \\
\hline \multicolumn{5}{|l}{} \\
\hline Rejim 2 & Katsay1 & Standart Hata & Olasılık Değeri \\
\hline İşsizlik & 0.399880 & 0.292037 & 0.1709 \\
\hline C & 6.290968 & 2.366499 & 0.0079 \\
\hline
\end{tabular}

Tablo 2. Markov Rejim Değişim Modeli

Tablo 2'de Markov Rejim Değişim Modelinin tahmin sonuçları verilmiştir. Modelden elde edilen bulgulara göre her iki rejimde de işsizlik oranındaki değişimlerin enflasyon oranına yaptığı etki aynı yöndedir. İşsizlik oranlarının enflasyon oranları üzerindeki etkisi birinci rejimde ikinci rejime göre daha güçlü olduğu görülmüştür. Birinci rejimde işsizlik değişkeni istatistiksel olarak anlamlıyken ikinci rejimde istatistiksel anlamlılık sağlanamamıştır.

\subsection{Augmented Dickey Fuller Birim Kök Testi}

Vektör Otoregresif Modellerin kurulabilmesi ve değişkenler arasındaki ilişkinin incelenebilmesi için ilk aşamada değişkenlere ait serilerin durağanlık derecelerinin belirlenmesi gerekmektedir. Literatürde birim kök sınamalarında genellikle Augmented Dickey Fuller (ADF) testi kullanılmaktadır. Serilerde birim kök olması durumunda seriler durağandır ve ortalamaya tekrar dönme eğilimi göstermesi beklenmektedir. Serilerin durağanlık durumlarına göre sabit varyansa sahiplik durumu ve rassal şoklardan kalıcı olarak etkilenme durumu hakkında çıkarımlar yapılmaktadir.

Ekonometrik yöntemler genellikle durağanlık varsayımına göre yapılır ve göz ardı edildiği durumlarda sahte regresyon sorunu ile karşılaşılmaktadır. Birim kök sınaması uygun ekonometrik metodun seçilmesi konusunda da son derece önemlidir. 
Değişkenler arasında anlamlı sonuçlar elde edilebilmesi için serilerin durağanlaştırılması gerekmektedir. Yukarıda değinilen ve yaygın olarak kullanılan ADF aşağıdaki şekilde formüle edilebilir (Sayar Özkan, Çelik, 2018).

$\Delta Y_{t}=\beta_{1}+\beta_{2} t+\alpha Y_{(t-1)}+\alpha_{1}+\omega_{t}$

$\Delta$ farkı, t zaman serisini, $\omega$ hata terimini temsil etmektedir. ADF Testi sabit varyans varsayımına dayanmakta ve gecikme uzunluğu sınamanın güvenilirliği açısından önem arz etmektedir. ADF Testinin hipotezleri aşağıdaki gibidir;

$\mathrm{H}_{\mathrm{o}}$ : Birim kök vardır ve seri durağan değildir.

$\mathrm{H}_{\mathrm{a}}$ : Birim kök yoktur ve seri durağandır.

Enflasyon ve İşsizlik değişkenleri için yapılan birim kök analizleri sonucunda Tablo 3'de görüldüğü gibi 2 değişkenin de düzey hallerinde durağan olmadığı tespit edilmiştir. Serilerin durağanlaştırılması için birinci dereceden farklar alınmıştır. Tablo 3'deki sonuçlara bakıldığında ise 2 değişken de birinci dereceden farkları alındığında dură̆an hale gelmiştir.

\begin{tabular}{|l|l|l|l|}
\hline \multicolumn{3}{|c|}{ Augmented Dickey Fuller (ADF) Testi } \\
\hline Değişkenler & \multirow{2}{*}{ Düzeyde } & Olasılık Değeri & Karar \\
\hline Enflasyon & & 0,6815 & Ho: Reddedilemez \\
\cline { 3 - 4 } & & 0,4781 & Ho: Reddedilemez \\
\hline Issizlik & \multirow{2}{*}{ Birinci Fark } & 0,0000 & Ho: Reddedilir \\
\cline { 3 - 4 } & & 0,0000 & Ho: Reddedilir \\
\hline
\end{tabular}

Tablo 3. ADF Birim Kök Testi Sonuçlarl

\subsection{Uygun Gecikme Uzunluğunun Belirlenmesi}

Uygun gecikme uzunluğunu belirleyebilmek için model seçim kriterleri kullanılmıştır. Tablo 4'te seçim kriterlerinin sonuçları görülmektedir. LR, FPE, AIC, HQ kriterlerine göre uygun gecikme uzunluğu 2 SC kriterine göre ise uygun gecikme uzunluğu 0 olarak belirlenmiştir. Vektör Otoregresif Modellerde 2. gecikme uzunluğu dikkate alınacaktır.

\begin{tabular}{|l|l|l|l|l|l|l|}
\hline Gecikme & LogL & LR & FPE & AIC & SC & HQ \\
\hline 0 & -114.9847 & N/A & 0.041307 & 2.489036 & $2.543149^{*}$ & 2.510894 \\
\hline 1 & -110.7555 & 8.188450 & 0.041108 & 2.484159 & 2.646497 & 2.549732 \\
\hline 2 & $-102.5516^{*}$ & $15.53494^{*}$ & $0.037597^{*}$ & $2.394716^{*}$ & 2.665279 & $2.504004^{*}$ \\
\hline 3 & -100.3302 & 4.112074 & 0.039060 & 2.432557 & 2.811346 & 2.585560 \\
\hline 4 & -97.74060 & 4.683292 & 0.040276 & 2.462566 & 2.949580 & 2.659284 \\
\hline 5 & -93.58472 & 2.842629 & 0.042418 & 2.513424 & 3.108663 & 2.753857 \\
\hline
\end{tabular}

Tablo 4. Vektör Otoregresif Modeller Iç̧in Uygun Gecikme Uzunluğunun Belirlenmesi

\subsection{Johansen Eştümleşme Testi}

Johansen Eştümleşme Analizi değişkenler arasındaki uzun dönem denge ilişkilerini incelemek için kullanılır. Johansen Eştümleşme Analizinin uygulanabilmesi için serilerin aynı dereceden durağan olması gerekmektedir. Aynı dereceden durağanlığı sağlanan seriler belirlenen uygun gecikme uzunluğuna göre analiz edilir. Johansen Eştümleşme Testinin hipotezleri aşağıdaki gibidir;

$\mathrm{H}_{\mathrm{o}}$ : Seriler arasında eştümleşme yoktur.

$\mathrm{H}_{\mathrm{a}}$ : Seriler arasında eştümleşme vardır.

Enflasyon ve işsizlik değişkenlerinin uzun dönem ilişkisini belirlemek için Johansen Eştümleşme Testi kullanılmıştır. Tablo 5 ve Tablo 6'da Johansen Eştümleşme Testi sonuçları verilmiştir. Trace ve Max-Eigen istatistiğine göre eştümleşme vektörü bulunduğu ve değişkenlerin uzun dönemde birlikte hareket ettiği tespit edilmiştir.

\begin{tabular}{|l|l|l|l|l|}
\hline Hipotezler & Özdeğer & Trace & Kritik Değer - \%5 & Olasılık Değeri \\
\hline Yok & 0.324584 & 52.17536 & 12.32090 & 0.0000 \\
\hline En Fazla 1 & 0.150095 & 15.28731 & 4.129906 & 0.0001 \\
\hline
\end{tabular}

Tablo 5. Trace İstatistiğine Göre Eştümleşme Testi 


\begin{tabular}{|l|l|l|l|l|}
\hline Hipotezler & Özdĕ̆er & Max-Eigen & Kritik Değer - \%5 & Olasılık Değeri \\
\hline Yok & 0.324584 & 36.88805 & 11.22480 & 0.0000 \\
\hline En Fazla 1 & 0.150095 & 15.28731 & 4.129906 & 0.0001 \\
\hline
\end{tabular}

Tablo 6. Max-Eigen İstatistiğine Göre Eştümleşme Testi

\subsection{Engle Granger Nedensellik Analizi}

Granger, zaman serileri arasındaki nedenselliğin sınanması için Granger Nedensellik Testi’ni geliştirmiştir. İlgili test değişkenler arasındaki nedensellik ilişkisinin varlığını ve ilişkinin yönünü belirlemek için yaygın olarak kullanılmaktadır. Granger, nedensellik sınamasını ' $Y$ 'nin öngörüsü, $X$ 'in geçmiş değerleri kullanıldığında X'in, geçmiş değerleri kullanılmadığı duruma göre daha başarılı ise X, Y'nin Granger nedenidir” şeklinde ifade etmiştir. Granger Nedensellik Analizi yapılırken aşağıdaki denklemler kullanılmaktadır (Granger, 1988).

$Y_{t}=\propto_{0}+\sum_{i=1}^{m} \beta_{i} x_{t-i}+\sum_{i=1}^{m} \rho_{i} Y_{t-i}+u_{t}$

$X_{t}=\theta_{0}+\sum_{i=1}^{m} \lambda_{i} y_{t-i}+\sum_{i=1}^{m} z_{i} X_{t-i}+w_{t}$

Yukarıdaki denklemlerde $(u)$ hata terimini, $(m)$ gecikme uzunluğunu temsil etmektedir. Birinci denklemde X'den Y'ye bir nedensellik olduğu, ikinci denklemde ise Y'den X'e bir nedensellik olduğu varsayımı gösterilmiştir.

Değişkenler arasındaki nedenselliğin varlığı iki denklemdeki katsayıların ( $\beta$ ve $\lambda)$ anlamlılı̆̆ı üzerinde belirlenmektedir. İki katsayının da anlamlı olduğu durumlarda iki yönlü bir nedenselliğin var olduğu, iki katsayının da anlamsız olduğu durumlarda ise herhangi bir nedensellik ilişkisi bulunmadığı sonucuna varılmaktadır. Değişkenler arasındaki kısa dönem ilişkiyi incelemek adına Engle Granger Nedensellik Analizi kullanılmıştır. Engle Granger Nedensellik Analizinin hipotezleri aşağıdaki gibidir;

$\mathrm{H}_{\mathrm{o}}$ : Nedensellik ilişkisi yoktur.

$\mathrm{H}_{\mathrm{a}}$ : Nedensellik ilişkisi vardır.

Bu hipotezler \%5 hata payı ile sınandığında enflasyon ve işsizlik arasında tek yönlü bir nedensellik olduğu ve enflasyonun işsizliğin nedeni olduğu sonucuna varılır.

\begin{tabular}{|l|l|l|l|}
\hline Nedenselliğin Yönü & Olasılık Değeri & Gecikme Uzunluğu & Karar \\
\hline İşsizlik $\rightarrow$ Enflasyon & 0.2956 & 1 & Ho: Reddedilemez \\
\hline Enflasyon $\rightarrow$ İşsizlik & 0.0399 & 1 & Ho: Reddedilir \\
\hline
\end{tabular}

Tablo 7. Granger Nedensellik Testi

\subsection{Vektör Otoregresif (VAR) Analizi}

İktisadi modellerde kullanılacak değişkenlerin içsel-dışsal ayrımının yapılamadığı durumlarda Vektör Otoregresif Modeller kullanılmaktadır. VAR analizinde seçilen tüm değişkenler ayrı ayrı bağımlı değişken olarak bütünsellik içerisinde incelenmektedir.

İki değişken içeren bir VAR Modelinin gösterimi aşağıdaki gibidir;

$y_{1, t}=c_{1}+A_{1,1} y_{1, t-1}+A_{1,2} y_{2, t-1}+e_{1, t}$

$y_{2, t}=c_{2}+A_{2,1} y_{1, t-1}+A_{2,2} y_{2, t-1}+e_{2, t}$

VAR denklemlerinin matris yardımıyla gösterimi aşağıdaki gibidir;

$\left[\begin{array}{l}y_{1, t} \\ y_{2, t}\end{array}\right]=\left[\begin{array}{l}c_{1} \\ c_{2}\end{array}\right]+\left[\begin{array}{ll}A_{1,1} & A_{1,2} \\ A_{2,1} & A_{2,2}\end{array}\right]\left[\begin{array}{l}y_{1, t-1} \\ y_{2, t-1}\end{array}\right]+\left[\begin{array}{l}e_{1, t} \\ e_{2, t}\end{array}\right]$

Yukarıdaki denklemlerde ve matris formunda $y_{1, t}$ ve $y_{2, t}$ aralarındaki ilişki araştırılan değişkenleri, $e_{1, t}$ ve $e_{2, t}$ hata terimini, $c_{1}$ ve $c_{2}$ sabit terimi temsil etmektedir.

Enflasyon ve işsizlik değişkenleri için tahmin edilen VAR Modeli Tablo 8'de gösterilmiştir.

1. ENFLASYON $=0.0506335302288+0.223537537592 * E N F L A S Y O N(-1)-$ $0.0844254963958 *$ ENFLASYON(-2) + 0.614489732805*ISSIZLIK(-1) $0.353957169251 * \operatorname{ISSIZLIK}(-2)$

2. ISSIZLIK $=-0.00330942001071+0.00452515550782 * \operatorname{ENFLASYON}(-1)-$ $0.0617435863707 *$ ENFLASYON $(-2)+0.117938240418 * \operatorname{ISSIZLIK}(-1)+$ $0.313475055503 * \operatorname{ISSIZLIK}(-2)$ 


\begin{tabular}{|l|l|l|}
\hline Değişkenler & Enflasyon & İşsizlik \\
\hline Enflasyon(-1) & 0.223538 & 0.004525 \\
\hline Enflasyon(-2) & -0.084425 & -0.061744 \\
\hline İssizlik(-1) & 0.614490 & 0.117938 \\
\hline İssizlik(-2) & -0.353957 & 0.313475 \\
\hline $\mathrm{C}$ & 0.050634 & -0.003309 \\
\hline
\end{tabular}

Tablo 8. Vektör Otoregresif (VAR) Model Tahmin Sonuçları

AR karakteristik polinomunun ters köklerinin birim çember içerisinde bulunduğu konumlar göz önüne alınarak modelin durağanlığı hakkında çıkarımlar yapılabilmektedir. Grafikte ters köklerin birim çemberin içerisinde yer aldığ 1 görülmüş ve modelin durağan olduğu tespit edilmiştir.

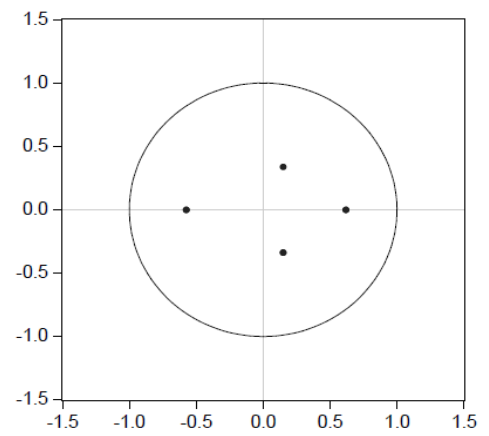

\begin{tabular}{|l|l|}
\hline Kökler & Modüller \\
\hline 0.617838 & 0.617838 \\
\hline-0.574114 & 0.574114 \\
\hline $0.148876-0.337727 \mathrm{i}$ & 0.369085 \\
\hline $0.148876+0.337727 \mathrm{i}$ & 0.369085 \\
\hline
\end{tabular}

\section{Şekil 3. Vektör Otoregresif Model Dură̆anlık Grafĭ̆i}

\subsection{Otokorelasyon ve Değişen Varyans Testleri}

Tahmin edilen vektör otoregresif modelindeki hata terimleri arasında ilişki bulunup bulunmadığını tespit etmek amacıyla LM Otokorelasyon Testi yapılmıştır. Tablo 9' da gösterilen olasılık değerlerinden görüldüğü gibi model $\% 5$ hata payıyla sinandığında otokorelasyon yoktur.

Tahmin edilen Vektör Otoregresif Modelde varyansların tüm gözlemlerde aynı olduğunu, yani değişen varyans sorununun bulunmadığını, ortaya koymak için White Değişen Varyans Testi uygulanmıştır. Olasılık değerinden hareketle modelde değişen varyans sorunu bulunmamaktadır.

\begin{tabular}{|l|l|l|}
\hline Gecikme & LRE & Olasılık Değeri \\
\hline 1 & 8.338018 & 0.0800 \\
\hline 2 & 1.559599 & 0.8160 \\
\hline 3 & 2.120718 & 0.7136 \\
\hline Ki-Kare & Gecikme Uzunluğu & Olasılık Değeri \\
\hline 21.83888 & 24 & 0.5889 \\
\hline
\end{tabular}

Tablo 9. LM - Otokorelasyon Testi ve White Değişen Varyans Testi

\subsection{Etki - Tepki Analizi ve Varyans Ayrıştırma}

Etki - Tepki fonksiyonları değişkenlerdeki bir birimlik standart sapmalık şokun diğer değişken üzerindeki etkisini gösterir. Etki - Tepki ve Varyans Ayrıştırma Analizleri değişkenler arasındaki ilişkinin yönünü ve gücünü belirlemek adına literatürde en sık kullanılan analizlerdir.

Etki - Tepki fonksiyonu iki değişkenli VAR matris formunda yazılırsa,

$\left[\begin{array}{l}y_{t} \\ z_{t}\end{array}\right]=\left[\begin{array}{l}a_{10} \\ a_{20}\end{array}\right]+\left(\begin{array}{ll}a_{11} & a_{12} \\ a_{21} & a_{22}\end{array}\right)\left[\begin{array}{l}y_{t-1} \\ z_{t-1}\end{array}\right]+\left[\begin{array}{l}e_{1 t} \\ e_{2 t}\end{array}\right]$

Hareketli ortalama sunumu $\left\{\varepsilon_{y t}\right\}$ ve $\left\{\varepsilon_{z t}\right\}$ serileri açısından,

$\left[\begin{array}{l}y_{t} \\ z_{t}\end{array}\right]=\left[\begin{array}{l}\bar{y} \\ \bar{z}\end{array}\right]+\sum_{i=0}^{\infty}\left(\begin{array}{ll}\Phi_{11(i)} & \Phi_{12(i)} \\ \Phi_{21(i)} & \Phi_{22(i)}\end{array}\right)\left[\begin{array}{l}\varepsilon_{y t-1} \\ \varepsilon_{z t-1}\end{array}\right]$

veya daha özet formda,

$x_{t}=\mu+\sum_{i=0}^{\infty} \Phi_{i} \varepsilon_{t-i}$

şeklinde yazılabilir. 

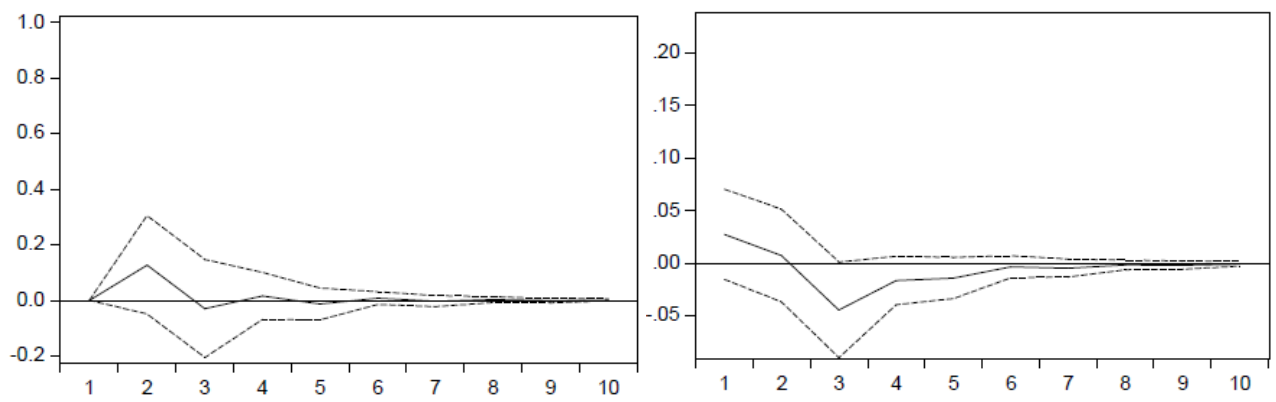

Şekil 4. Enflasyon ve İşsizlik Değişkenleri Arasındaki Etki - Tepki Grafikleri

Şekil 4'te değişkenlerden birinin diğer değişkende meydana gelen bir birim standart sapmalık şokun vermiş olduğu tepki gösterilmektedir. İşsizlik oranlarında meydana gelen bir birim standart sapmalık şoka enflasyon oranlarının verdiği tepki ikinci dönemden sonra sıfıra yaklaşmıştır. Buna karşılık enflasyon oranlarındaki bir birim standart sapmalık şoka işsizlik oranlarının verdiği tepki altıncı döneme kadar etkisini sürdürmüştür.

\begin{tabular}{|l|l|l|l|l|l|l|}
\hline Periyot & Standart Hata & Enflasyon & İşsizlik & Standart Hata & Enflasyon & İşsizlik \\
\hline 1 & 0.889153 & 100.0000 & 0.000000 & 0.208872 & 1.729950 & 98.27005 \\
\hline 2 & 0.923733 & 98.10278 & 1.897224 & 0.210420 & 1.823749 & 98.17625 \\
\hline 3 & 0.924773 & 98.00291 & 1.997091 & 0.225669 & 5.466219 & 94.53378 \\
\hline 4 & 0.926561 & 97.98097 & 2.019033 & 0.226398 & 5.957469 & 94.04253 \\
\hline 5 & 0.926666 & 97.96063 & 2.039374 & 0.228132 & 6.251377 & 93.74862 \\
\hline 6 & 0.926700 & 97.95362 & 2.046377 & 0.228197 & 6.270302 & 93.72970 \\
\hline 7 & 0.926711 & 97.95255 & 2.047446 & 0.228419 & 6.298407 & 93.70159 \\
\hline 8 & 0.926715 & 97.95175 & 2.048247 & 0.228433 & 6.302885 & 93.69712 \\
\hline 9 & 0.926716 & 97.95160 & 2.048400 & 0.228463 & 6.307756 & 93.69224 \\
\hline 10 & 0.926717 & 97.95152 & 2.048480 & 0.228466 & 6.308506 & 93.69149 \\
\hline
\end{tabular}

Tablo 10. Enflasyon ve İssizlik Değişkenleri İçin Varyans Ayrıştırma Tablosu

Tablo 10'da görüldüğ̈̈̈ üzere;

1.dönemde enflasyon değişkeni tamamen kendi gecikmeli değerleri etkisi altında kalmıştır. İşsizlik oranlarının, enflasyon oranları üzerindeki açıklayıcı etkisi 10.dönemde \%2'ye ulaşmıştır.

1.dönemde işsizlik değişkeni çoğunlukla kendi gecikmeli değerlerinin etkisi altında kalmıştır. Enflasyon oranlarının faiz oranları üzerindeki açıklayıcı etkisi ilerleyen dönemlerde sürekli artarak devam etmiş ve 10 . dönemde \%6.3'e ulaşmıştır.

\section{Sonuç}

Enflasyon ve İşsizlik arasındaki yaygın kabul edilen Phillips eğrisi, 1958 yılında William Phillips tarafından parasal ücretlerin değişim oranı ile işsizlik oranı arasındaki negatif ilişkiyi açıklamak için keşfedilen, ardından Samuelson ve Solow tarafından enflasyon oranı ve işsizlik oranı arasındaki doğrusal olmayan negatif yönlü ilişkiyi açıklayacak bir eğriye dönüştürülerek genel kabul almıştır.

Phillips eğrisinde işsizliğin negatife düşemeyeceği gerçeğini göz önüne alarak doğal işsizlik tanımı üretilmiş ve bu bağlamda işsizliğin her daim var olacağı bir minimum değer göz önüne alınmıştır. Doğal işsizlik denen bu miktarın enflasyonu körüklemeyeceğini ifade eden teorilerin ilki NIRU (Enflasyonist Olmayan İşsizlik Oranı) gelecek yıllarda yerini NAIRU (Enflasyon Arttırmayan İşsizlik Oranı)'ya bırakmıştır.

Analizde kullanılan 2010M01 - 2017M10 arasındaki İşsizlik ve Enflasyon verileri OECD’den alınmıştır. Çalışmada iki değişken arasındaki kısa ve uzun dönemli ilişki ve değişskenlerin farklı rejim dönemlerindeki davranışları incelenmiştir. Analiz sonuçlarına göre İşsizlik ve Enflasyon değişkenlerinin uzun dönemde birlikte hareket ettiği ve Enflasyondan İşsizliğe doğru tek yönlü bir nedensellik olduğu tespit edilmiştir. Varyans Ayrıştırma Analizi sonuçlarına göre Enflasyon oranlarının İşsizlik oranları üzerindeki açıklayıcı etkisinin \%6' ya kadar ulaştığı tespit edilmiştir. Bu sonuçlar nedensellik sınamasıyla paralellik göstermektedir. Değişkenlerin düzey halleri kullanılarak kurulan Markov Rejim Değişim Modelinin sonuçlarına göre ise iki değişkenin farklı rejim dönemlerinde benzer yönlü davranışlar gösterdiği tespit edilmiştir.

Analiz sonucu elde edilen bulgulara göre, alınan dönem içerisinde İşsizlik ve Enflasyon birlikte yükselen bir trend göstermiştir. Bu durum Phillips Eğrisinin incelenen dönem içerisinde Türkiyede etkinsiz olduğunu göstermektedir. 
İlerleyen dönemlerde bu çalışma farklı analiz ve veri setleriyle aşağıdaki gibi geliştirilebilir;

- Veri seti genişletilerek farklı ülkeler için analiz yapılması ve ekonomik krizleri kapsayan dönemlerde kukla değişkenler kullanılması,

- Çalışmaya döviz kuru, büyüme oranları ve faiz gibi değişkenlerin entegre edilmesi,

- Sinamaların doğrusal olmayan yöntemlerle yapılması,

- Dezenflasyon politikalarının incelenmesi ve beklentiler ile entegre edilmesi,

- Histeri etkisinin gelecek döneme etkilerinin dikkate alınması.

\section{Kaynakça}

- Abu, N . "Inflation and Unemployment Trade-off: A Re-examination of the Phillips Curve and its Stability in Nigeria". Contemporary Economics vol.13, issue 1 (2019): 21-34

- $\quad$ Akkuş, G . "Phillips Eğrisi: Enflasyon-İsssizlik Değiş-Tokuşu Teorik Bir İnceleme". İstanbul Üniversitesi Iktisat Fakültesi Mecmuası 62 (2013): 99-151

- $\quad$ Altay, B., Tuğcu, C.T., Topçu, M. "İşsizlik ve Enflasyon Oranları Arasındaki Nedensellik İlişkisi: G8 Ülkeleri Örneği”. Afyon Kocatepe Üniversitesi İIBF Dergisi, Sayı:13 (2011): 1-29

- Bayrak, M., Kanca, O. "Türkiye'de Phillips Eğrisi Üzerine Bir Uygulama” Üzerine Bir Uygulama". Eskişehir Osmangazi Üniversitesi İ̈BF Dergisi, 8(3), Aralık (2013): 97-115

- Bildirici E. Melike, Alp Aykaç Elçin, Ersin Ö. Özgür, Bozoklu Ümit. "İktisatta Kullanılan Doğrusal Olmayan Zaman Serisi Yöntemleri". Türkmen Kitabevi (2010)

- Granger, C . "Causality, Cointegration, and Control". Journal of Economic Dynamics and Coltrol vol.12, issue 2-3 (1988): 551-559

- Güven, E.A.” Türkiye'de Enflasyon Ve İşsizlik Arasındaki İlişsi: Zaman Serileri Analizi”. Kahramanmaraş Sütçü İmam Üniversitesi Sosyal Bilimler Dergisi Cilt:13 Sayı:1 (2016) 242-260

- Hepsağ, A., “Türkiye'de Enflasyon ile İşsizlik Arasındaki İlişsinin Analizi: Sınır Testi Yaklaşımı”. İktisat Fakültesi Mecmuası, Cilt:59, Sayı:1 (2009): 169-190

- Herman, E. "Inflation and Unemployment in the Romanian Economy" Annals of the University of Petroşani, Economics, 10(2), (2010): 157:170

- Karadeniz Teknik Üniversitesi, BMYO. “İstihdam ve İşsizlik.” Erişim 21 Nisan, 2019. http://www.ktu.edu.tr/dosyalar/bmyo_8bc28.pdf

- Korkmaz, A., Çoban, O. "Emek Piyasasıda Asgari Ücret, İşsizlik ve Enflasyon Arasındaki İlişkilerin Ekonometrik Bir Analizi: Türkiye Örneği (1969 - 2006)". Maliye Dergisi Sayı:151 Temmuz Aralık (2006): $16-22$

- Sayar Özkan, G, Çelik, H . "Bilgi İletişim Teknolojileri ile Ekonomik Büyüme Arasındaki İlişki: Türkiye İçin Bir Uygulama". Uluslararası Ticaret ve Ekonomi Araşttrmaları Dergisi 2 (2018): 1-15

- Tabar, Ç., Kırışkan, Çetin I. "Türkiye Ekonomisi Özelinde Phillips Eğrisi Analizi”. Journal of Life Economics 3(4), (2016): 79-100

- Temurlenk, M, Başar, S . "Türkiye İçin Enflasyonu Hızlandırmayan İşsizlik Oranı (NAIRU) Tahmini". Dokuz Eylül Üniversitesi İktisadi İdari Bilimler Fakültesi Dergisi 27 (2012): 71-83

- Türkiye İstatistik Kurumu. "Fiyat Endeksleri ve Enflasyon: Sorularla Resmi İstatistikler Serisi - 3". Türkiye İstatistik Kurumu Matbaası (2008)

- Türkiye İstatistik Kurumu. "TÜIK, Meta Veri, Tanım ve Kavramlar." Erişim 22 Nisan, 2019. http://www.tuik.gov.tr/MicroVeri/Hia_2012/turkce/metaveri/tanim/index.html

- Uysal, D., Erdaoğan, S. "Enflasyon ile İşsizlik Oranı Arasındaki İlişki ve Türkiye Örneği (1980-2002)". Selçuk Üniversitesi IİBF Sosyal ve Ekonomik Araştırmalar Dergisi Sayı:6 (2003): 35-47

- Wikipedia. "NAIRU." Erişim 22 Nisan, 2019. https://tr.wikipedia.org/wiki/NAIRU

- Yüksel, S . "Rusya Ekonomisinde Büyüme, İşsizlik ve Enflasyon Arasındaki Nedensellik İlişkileri”. Finans Politik \& Ekonomik Yorumlar Cilt: 53 Sayı: 614 (2016) : $43-57$ 


\title{
OECD Ülkeleri İçin Reel Ücret, Enflasyon ve İşgücü Verimliliği Arasındaki İlişkinin Panel Tahmini
}

\section{Panel Estimation for the Relationship between Real Wage, Inflation and Labor Productivity for OECD Countries}

\author{
Ph.D. Candidate Sevilay Konya (Selçuk University, Turkey) \\ Prof. Dr. Zeynep Karaçor (Selçuk University, Turkey) \\ Ph.D. Candidate Mücahide Küçüksucu (Necmettin Erbakan University, Turkey)
}

\begin{abstract}
There are studies examining the relationship between real wage, inflation and labor productivity in the economic literature. Increase in real wages causes to an increase in labor productivity. On the other hand, productivity increases also induce inflation to fall. Therefore, the aim of this study is to investigate the relationship between real wage, inflation and labor productivity in the 22 OECD countries (Australia, Belgium, Canada, Chile, Czech Republic, France, Greece, Hungary, Japan, Korea, Latvia, Luxembourg, Mexico, Netherlands, New Zealand, Poland, Portugal, Slovak Republic, Slovenia, Spain, Turkey, United States) in the period of 1995-2017 by panel data methods. According to results, the cointegration relationship between real wage, inflation and labor productivity was found. In addition, mutual causality was determined between the variables we discussed.
\end{abstract}

\section{Giriş}

Reel ücretler, enflasyon ve işgücü verimliliği değişkenleri arasındaki ilişkinin yönü farklı ekonomik teori ve görüşlerden beslenmektedir. Bunları kısaca özetlemek, çalışmanın temeli ve kavramsal çerçevesini çizme hususunda yardımcı olacaktır.

Reel ücretlerdeki artışın verimlilik düzeyini artırdığına ilişkin görüşler Etkin Ücret Teorisi kapsamında ele alınmalıdır. Etkin ücret teorisine göre, ücret düzeyi verimliliğini belirleyen en önemli unsurdur (Millea, 2002). Reel ücretin düşüklüğü işgücü performansını olumsuz etkilerken, yüksek reel ücret ile ödüllendirilen işçide işini kaybetme korkusu olacağından, verimli çalışma güdüsü artacaktır.

İşücü verimliliğinden reel ücretlere doğru bir ilişkiden söz ediliyorsa Marjinal Verimlilik Teorisi geçerli demektir. Bir ekonomide tam rekabet koşulları geçerliyse, işçinin reel ücretini belirleyen unsur marjinal verimliliktir. İşverenler işçilere ancak üretime yaptıkları kadar ücret vermeye razı olacaklardır. Şayet reel ücretler marjinal işgücü verimliliğinden yüksekse, işverenler aldığı ücrete oranla daha düşük üretim katkısı olan işçiyi işten çıkaraktır. Şayet verimlilik ücretten fazla ise sendikalar devreye girip ücret artışı talep edecektir (Öztürk, 2005).

İşü̈cü verimliğinin enflasyona neden olduğu Standart Teorik Görüşte izah bulmaktadır. Bu teoriye göre verimlilik dışsaldır ve enflasyon üzerinde etki sahibidir. Şayet bir ekonomide işgücü verimliliği artarsa, toplam arz artar ve enflasyon oranı düşer. Enflasyonist baskılar, işgücü verimliliğinde azalmaya neden olacak ve azalan verimlilik enflasyonu şiddetlendirecektir. Enflasyondan verimliliğe doğru tek yönlü ilişki karşımıza Alternatif Standart Görüşü çıkarmaktadır. Yükselen enflasyon verimliliği negatif yönde etkilemektedir. Çünkü, yükselen enflasyon işçilerin satın alma gücünü azaltacak ve daha az kazandığı düşüncesiyle işçiler daha verimsiz çalışacaktır. Enflasyon sermaye birikimini azaltmak ve yatırımları azaltmak suretiyle işgücü verimliliğinin azalmasına neden olmaktadır (Y1ldırım, 2015).

Yukarıda yer alan temel tartışmalar ışı̆̆ında bu çalışmanın amacı, 22 OECD ülkesinde reel ücret, enflasyon ve işgücü verimliliği arasındaki ilişkileri araştırmaktır. $\mathrm{Bu}$ nedenle çalışmada Pedroni eşbütünleşme, Kao eşbütünleşme, Johansen Fisher eşbütünleşme, Pedroni DOLS tahmincisi, Dumitrescu ve Hurlin (2012) panel nedensellik testleri uygulanmıştır. Öncelikle, reel ücret, enflasyon ve işgücü verimliliği arasındaki ilişki önceden yapılmış olan çalışmalar üzerinden ortaya konulmuş, daha sonrasında ise 1995-2017 dönemine ait 22 OECD ülkesi için reel ücret, enflasyon ve işgücü verimliliği arasındaki ilişkiler araştırılmıştır. Çalışmada kullanılan yöntemlerden yola çıkılarak literatürde bütün bu yöntemleri bir arada kullanılan çalışma olmadığı belirlenmiştir. $\mathrm{Bu}$ nedenle bu çalışma literatürdeki çalışmalardan farklılık göstermektedir. Bu sebeple bu çalışmanın literatüre katkı sağlaması beklenmektedir.

\section{Literatür}

Literatür araştırması yaparken ele aldığımız üç değişken olan; reel ücret, işgücü verimliliği ve enflasyon verilerini içeren çalışmaların kısıtlılığı nedeniyle, diğer değişkenler arasındaki ilişkilere dair çalışmalara da bu bölümde yer verilmiştir.

Eşiyok (1999), 1970-1995 dönemi yıllık verileri ile imalat sanayinde kamu ve özel sektör ayrımına giderek, reel ücret ve işgücü verimliliğine ilişkin değişkenleri çift logaritmik regresyon ve Granger nedensellik testleri ile analiz 
etmiştir. Kamu sektörü açısından söz konusu iki değişken arasında herhangi bir nedensellik ilişskisi tespit edemeyen yazar, özel sektörde, işgücü verimliliğinden ücretlere doğru tek yönlü bir nedensellik ilişkisi olduğunu ifade etmiş̧tir. Buna göre, reel ücretlerde meydana gelen bir birimlik artış, işgücü verimliliğini 0.41 birim artırmaktadır.

Millea (2002), imalat sanayi sektörü özelinde reel ücretler ve işgücü verimliliği ilişkisini, OECD üyesi ülkeler arasından seçtiği ekonomiler için 1950-1998 yılları dahilinde analiz etmiştir. Değişkenler arasındaki ilişkilerin tespiti için standart EKK yöntemi kullanılmıştır. Çalışmadan, reel ücretler ve işgücü verimliliğinin karşılıklı bir ilişki içerisinde olduğu sonucuna ulaşan yazar, ülkeden ülkeye ilişkinin gücünün değiştiğini vurgulamıştır.

Dritsakis (2004), 1990-2003 yılları arasındaki dönemi üçer aylık verilerle koentegrasyon testi ve Granger nedensellik testi yöntemlerini kullanarak Romanya ekonomisi için analiz etmiştir. Sözü edilen dönemlerde Romanya ekonomisinde verimlilik ve genel fiyat düzeyinin sürekli olarak artışını anlatan enflasyon arasında bir nedensellik bağı olduğu doğrulanmıştır. Her iki değişken de birbirinin Granger nedenidir.

Marquetti (2004), işgücü verimliliği ve reel ücretler arasındaki ilişkiyi ortaya koymak adına, ABD için 18691999 dönemi yıllık verilerini kullanmıştır. Engle-Granger koentegrasyon testi ve standart Granger nedensellik tekniklerinin kullanıldığı çalışmada, reel ücretler ve işgücü verimliliğinin koentegre olduğu görülmüştür. İşgücü verimliliği ve reel ücretler arasında, ücretlerden işgücü verimliliğine doğru tek yönlü bir nedensellik ilişkisinin olduğu tespit edilmiştir.

Wakeford (2004), 1983-2002 yıllarına ait üçer aylık verilerden istifade ederek Güney Afrika ekonomisi için ortalama reel ücretler ile işgücü verimliliği arasındaki ilişkiyi analiz etmiştir. Söz konusu dönem içerisinde 1990 yılında yapısal bir kırılmanın olduğunu belirleyen yazar, kırılmanın etkilerini tespit edebilmek adına 1990-2002 dönemine ait bir analiz daha yapmıştır. 1983-2002 dönemindeki koentegrasyon ilişkisinin, 1990-2002 döneminde daha güçlü olduğu, işgücü verimliliğindeki $\% 1^{\prime}$ lik bir artışın, reel ücretlerde $\% 0.58$ 'lik artış meydana getirdiği belirlenmiş̧tir.

Christopoulos (2005), Avrupa Birliği ülkelerinden; Belçika, İngiltere, Norveç, Danimarka, İspanya, İtalya, Fransa, Finlandiya, Hollanda, Almanya, İrlanda ve Portekiz'e ait verilerle, işgücü verimliliği ile reel ücretler arasındaki ilişkiyi, 1961-1996 yılları için test etmiştir. Ücretler ve verimlilik arasında panel koentegrasyon yöntemine göre uzun dönemli bir ilişki vardır.

Kumar, Weber ve Perry (2009), Avustralya ekonomisi için yıllık verilerle 1965-2017 arasındaki dönemi analiz etmişlerdir. Enflasyon, reel ücretler ve işgücü verimliliği değişkenleri arasındaki ilişkilerin ortaya konulmasında, koentegrasyon, Granger nedensellik testi ve yapısal değişim testlerinden yararlanılmıştır. Buna göre, 1985 yılında yapısal kırılma vardır. Ele alınan dönemde $\% 1$ 'lik bir ücret artışı, verimlilikte $\% 0,5$ ila $\% 0,8$ oranında bir artışa neden olmaktadır. Enflasyon ve verimlilik arasındaki ilişki sınırlandırılmış bir istatistiki öneme sahiptir. Granger nedensellik testine göre enflasyon ve reel ücretler uzun dönemde işgücü verimliliğinde artışa neden olmaktadır.

Trpeski ve Tashevska (2009), Makedonya için 1995-2007 döneminde net ücretler ile işgücü verimliliği arasındaki ilişkiyi OLS Regresyon yöntemi ile analiz etmişlerdir. Çalışmada, net ücretler ile işgücü verimliliği arasında, özellikle tarım, balıkçılık, ormancılık, su yönetimi, sanayi ve maden sektörlerinde güçlü bir ilişki olduğu sonucuna varmışlardır.

Türedi ve Terzi (2009), 1950-2001 yıllarında Türk ekonomisi için yıllık veriler kullanarak özel sektör ve kamu kesimi arasında ayrıma giderek reel ücretler ile işgücü verimliliği arasındaki ilişkiyi analiz etmişlerdir. Kamu sektörü açısından VAR nedenselliğinin yönü ücretlerden verimliliğe doğru tek yönlü ve pozitiftir. Özel sektör açısından işgücü verimliliği ve ücretler arasında çift yönlü VAR nedenselliği mevcuttur.

Narayan ve Smith (2011), 1969-2004 yılları, G7 ülke grubu için enflasyon, reel ücretler ve işgücü verimliliği verilerini panel koentegrasyon yönteminden istifade ederek analiz etmişlerdir. Test sonuçları göstermiştir ki, reel ücretlerdeki \%1'lik artış verimlilikte \%0,6 artışa neden olmaktadır. Enflasyon verisi ise verimliliğe etki etmesi bağlamında istatistiki olarak anlamlı değildir.

Tang (2014), Malezya ekonomisi için 1970-2007 yılları arasındaki dönemi reel ücretler, işgücü verimliliği ve enflasyon bağlamında, koentegrasyon testi ve Granger nedensellik analizinden yararlanarak analiz etmiştir. Uzun dönemde bu üç değişken arasında anlamlı bir ilişki olduğunu vurgulayan yazar, reel ücretler ve verimlilik arasındaki ilişkinin pozitif yönlü, enflasyon ve verimlilik arasındaki ilişkinin negatif yönlü olduğunu belirtmiştir. Reel ücretler işgücü verimliliğinin Granger nedenidir. Enflasyon ve verimlilik arasında çift yönlü bir nedensellik ilişkisi mevcuttur.

Islam, Kinyondo ve Nganga (2015), Tanzanya ekonomisini baz alarak yaptıkları çalışmada, 1967- 2010 yılları arasında analiz etmişlerdir. Çalışmanın sonucunda reel ücretler ile işgücü verimliliği arasında herhangi bir ilişki olmadığı çıkarımında bulunmuşlardır.

\section{Veri Seti, Ekonometrik Yöntem ve Araştırma Bulguları}

\subsection{Veri Seti}

Araştırmada 1995-2017 dönemi için yıllık verilerle Türkiye'nin de içinde yer aldığı 22 OECD ülkesinde (Avustralya, Belçika, Kanada, Şili, Çek Cumhuriyeti, Fransa, Yunanistan, Macaristan, Japonya, Kore, Letonya, 
Lüksemburg, Meksika, Hollanda, Yeni Zelanda, Polonya, Portekiz, Slovak Cumhuriyeti, Slovenya, İspanya, Türkiye ve ABD) reel ücret, enflasyon ve işgücü verimliliği arasındaki ilişki araştırılmıştır. Uygulanacak panel veri analizlerinde reel ücret (RW), enflasyon (INF) ve işgücü verimliliği (LP) değişkenleri kullanılmıştır. İlgili veriler OECD veri tabanından elde edilmiştir.

Tablo 1'de değişkenlere ait tanımlayıcı istatistikler gösterilmektedir.

\begin{tabular}{|l|l|l|l|l|l|}
\hline Değișken & Gözlem Say1S1 & Ortalama & Standart Sapma & Minimum Değer & Maximum Değer \\
\hline RW & 506 & 12273.53 & 6199.581 & 100.57 & 23776.98 \\
\hline INF & 506 & 34.46565 & 17.00881 & 7.447577 & 98.52255 \\
\hline LP & 506 & 4.573588 & 9545864 & -1.736046 & 89.11331 \\
\hline
\end{tabular}

Tablo 1. Tanımlayıcı Ístatistikler

Bu çalışmada yapılan panel veri analizlerinde Stata 13 ve Eviews 10 programları kullanılmıştır.

\subsection{Ekonometrik Yöntem}

Çalışmamızın uygulama kısmında öncelikle birim kök testleri uygulanacaktır. Levin, Lin ve Chu (LLC, 2002) tarafından geliştirilen birim kök testinin denklemsel ifadesi şu şekildedir:

$$
\Delta y_{i t}=u_{i t}+\theta_{t}+\delta_{i t}+P y_{i t-1}+\sum_{j=1}^{k} a_{j} \Delta y_{i t-j}+\varepsilon_{i t}
$$

Denklemde ifade edilen $y$ birim kök testini, $\Delta$ birinci fark1, $u_{i}$ sabit etkileri, $\theta_{t}$ zaman etkilerini ve $t$ trendi ifade etmektedir. LLC (2002) testi homojen paneller için yapılır ve yatay kesit bağımlılı̆̆ dikkate almamaktadır. Bu doğrultuda LLC panel birim kök testinin geçerli ve alternatif hipotezleri şunlardır: $H_{O}: P=0$ (birim kök içermektedir) ve $H_{1}: P<0$ (birim kök içermemektedir)

Harris-Tsavalis(1999) testinde sabitsiz, sabitli ve sabit ve trend içeren üç farklı model kullanılmaktadır.

$H_{o}: \partial=1$ : Seride birim kök vardır.

$H_{o}: \partial<1$ : Seri durağandır.

$\partial$ şu formül yardımıyla hesaplanmaktadır (Tatoğlu, 2017).

$$
\partial-1=\left[\sum_{i=1}^{n} \gamma_{i,-1}^{\prime} \mathrm{C}_{\mathrm{T}} \gamma_{i,-1}^{\prime}\right]^{-1}\left[\sum_{i=1}^{n} \gamma_{i,-1}^{\prime} \mathrm{C}_{T} u_{i}\right]
$$

Hadri testinde temel hipotezler diğer birim kök testlerinden farklı olmaktadır. Temel hipotezde tüm panelin durağan olduğunu, alternatif hipotezde ise panel içerisinde bazı birimlerin birim köklü olduğu belirtilmektedir. Hadri LM (2000) birim kök testinin formülasyonu aşağıdaki şekildedir:

$$
\begin{gathered}
Y_{i t}=Z_{i t}+\varepsilon_{i t} \\
Y_{i t}=Z_{i t}+\propto_{i t}+\varepsilon_{i t}
\end{gathered}
$$

olmak üzere iki modelden hareket edilmektedir. İlk model sabit etkili iken, ikinci model sabit ve trend etkilidir. Im, Pesaran ve Shin (IPS, 2003) birim kök testinde birinci dereceden otoregresif süreç ele alınmaktadır.

$$
\Delta Y_{i t}=u_{i}+\partial_{i} Y_{i t-1}+\varepsilon_{i t}
$$

Bu doğrultuda IPS (2003) testinde geçerli ve alternatif hipotezler şu şekilde olmaktadır:

$H_{o}: \partial_{i}=0$ (tüm i'ler için)

$H_{1}: \partial_{i}<0\left(\mathrm{i}=1,2, \ldots \ldots, N_{i}\right), \partial_{i}=0\left(\mathrm{i}=N_{1+1}, N_{1+2}, \ldots, N\right)$ IPS (2003), testinin temel hipotezi tüm birimler birim kök içermektedir, alternatif hipotez ise bazı birimler durağandır şeklindedir.

Choi (2001), her bir birim için hesaplanan ADF ve Phillips Perron testlerinin tüm panel için birleştirilmesi için panel birim kök testi önerisinde bulunmuştur (Tatoğlu, 2017). Augment Dickey Fuller (ADF) temelli birim kök testinin panel birim kök testi için geliştirilmesini Maddala ve Wu (1999) yapmıştır. Bu test Fisher tipi ADF testini önermektedir. Formülasyon aşağıdaki gibidir:

$$
P=-2 \sum_{i=1}^{N}\left(\rho_{i}\right) \rightarrow x_{2 N}^{2}
$$

Denklemde ifade edilen $\rho_{i}$, i birimi için birim kök testinin olasılık değerini ifade etmektedir.

Birim kök testleri ile durağanlığın araştırılmasının ardından Pedroni, Kao ve Johansen Fisher eş bütünleşme testi uygulanmıştır.

Pedroni $(1999,2004)$ eş bütünleşme testi aşağıdaki regresyon denklemi ile ifade edilmektedir:

$$
\Delta Y_{i t}=a_{i}+\partial_{i t}+\beta_{i} X_{i t}+u_{i t}
$$

Yukarıda ifade edilen denklemde Y bağımlı değişkeni, $a_{i}$ sabit katsayıyı, t zaman trendini, X bağımsız değişkeni göstermektedir. Pedroni testlerinin temel hipotezleri şunlardır:

$H_{o}$ : panelin tüm birimleri için eş bütünleşme yoktur. 
$H_{1}$ : panelin tüm birimleri için eş bütünleşme vardır.

Pedroni $(1999,2004)$ eş bütünleşme testi 7 farklı test içermektedir. Bunlardan 4 tanesi panel, üçü de grup test istatistiğidir. Bütün testler normal dağılım göstermektedir. Yedi test istatistiği aşağıdaki şekilde gösterilecektir. Panel istatistikleri;

$$
\begin{aligned}
& \text { Panel } v \text { istatistiğ } i(v): T^{2} N^{3 / 2}=\frac{1}{\left(\sum_{i=1}^{N} \sum_{t=1}^{T} \hat{L}_{11 i}^{-2} \hat{2}_{i t-1}^{2}\right)} \\
& \text { Panel } p \text { istatistiğ } i(r h o): T \sqrt{N} \frac{\sum_{i=1}^{N} \sum_{t=1}^{T} \hat{L}_{11 i}^{-2}\left(\hat{e}_{i t-1} \Delta \hat{e}_{i t}-\widehat{\lambda}_{i}\right.}{\left(\sum_{i=1}^{N} \sum_{t=1}^{T} \hat{L}_{11 i}^{-2} \hat{e}_{i t-1}^{-2}\right)} \\
& \text { Panel } t \text { istatistiği(non - parametrik model }): Z_{\hat{t}_{N T}}=\frac{\sum_{i=1}^{N} \sum_{t=1}^{T} \hat{L}_{11 i}^{-2}\left(\hat{e}_{i t-1} \Delta \hat{e}_{i t}-\widehat{\lambda}_{i}\right)}{\sqrt{\left(\breve{c}_{N, T}^{2} \sum_{i=1}^{N} \Sigma_{t=1}^{T} \hat{L}_{11 i}^{-2} \hat{e}_{i t-1}^{2}\right)}} \\
& \text { Panel } t \text { istatistiği(parametrik model, adf) }=Z_{t N T}^{*}=\frac{\sum_{i=1}^{N} \sum_{t=1}^{T} \hat{L}_{11 i}^{-2}\left(e_{i t-1}^{*} \Delta \hat{e}_{i t}^{*}\right.}{\sqrt{\left(\breve{s}_{N, T}^{* 2} \sum_{i=1}^{N} \sum_{t=1}^{T} \hat{L}_{11 i}^{-2} \hat{e}_{i t-1}^{* 2}\right)}}
\end{aligned}
$$

Grup istatistikleri ise,

$$
\begin{aligned}
& \text { Grup } p \text { istatistiği(rho): } T N^{-1 / 2} \sum_{i=1}^{N} \frac{\sum_{t=1}^{T}\left(\hat{e}_{i t-1} \Delta \hat{e}_{i t}-\widehat{\lambda}_{i}\right.}{\sum_{i=1}^{T} \hat{e}_{i t-1}^{2}} \\
& \text { Grup } t \text { istatistiği(non - parametrik model }): N^{-1 / 2} \sum_{i=1}^{N} \frac{\sum_{t=1}^{T}\left(\hat{e}_{i t-1} \Delta \hat{e}_{i t}-\widehat{\lambda}_{i}\right.}{\widehat{\sigma}_{i}^{2} \sum_{i=1}^{T} \hat{e}_{i t-1}^{2}} \\
& \text { Grup t istatistiği(adf): } N^{-1 / 2} \sum_{i=1}^{N} \frac{\sum_{t=1}^{T}\left(\hat{e}_{i t-1}^{*} \Delta \hat{e}_{i t}^{*}\right)}{\left(\sum_{t=1}^{T} \hat{S}_{i}^{* 2} \hat{e}_{i t-1}^{* 2}\right)}
\end{aligned}
$$

Şeklinde olacaktır.

İkinci uygulanan eşbütünleşme testi Kao (1999) eşbütünleşme testidir. Kao (1999) eşbütünleşme testinde temel hipotezleri şunlardır:

$H_{o}$ : Değişkenler arasında eşbütünleşme yoktur.

$H_{1}$ : Değişkenler arasında eşbütünleşme vardır.

Üçüncü uygulanan eşbütünleşme testi ise Johansen Fisher(1988) eşbütünleşme testi olmuştur. Bu eşbütünleşme testinin temel hipotezi değişkenler arasında eşbütünleşme yoktur, alternatif hipotezi ise değişkenler arasında eşbütünleşme vardır şeklinde kurulmaktadır.

Değişkenler arasında eşbütünleşme ilişkisinin varlığının ardından katsayı tahmini yapılacaktır. DOLS tahmincisi yardımıyla model tahmini aşağıdaki denklem aracılığıyla yapılacaktır.

$$
Y_{t}=\beta_{0+} \beta_{1} t+\beta_{2} z_{t}+\sum_{i=\omega}^{n} \theta_{i} \Delta X_{t-i}+\varepsilon_{t}
$$

$Y$ bağımlı değişken, $\mathrm{t}$ zaman, $\mathrm{z}$ bağımsız değişken, $\omega$ gecikme uzunluğu, $\Delta$ fark işlemcisi ve $\varepsilon_{t}$ hata terimini temsil etmektedir.

Değişkenler arasında uzun dönemli ilişkinin tespitinin ardından kısa dönemli ilişkilerin tespiti Dumitrescu ve Hurlin (2012) nedensellik testi ile bulunacaktır. Dumitrescu ve Hurlin (2012) nedensellik testine ait denklemin gösterim şekli aşağıdaki gibidir:

$$
Y_{i t}=a_{i}+\sum_{k=1}^{K} \gamma_{i}^{(k)} Y_{i t-k}+\sum_{k=1}^{K} \beta_{i}^{(k)} X_{i t-k}+\varepsilon_{i t}
$$

Dumitrescu ve Hurlin nedensellik testinin temel hipotezleri şunlardır.

$H_{o}$ : tüm panel için X'den Y'ye nedensellik yoktur.

$H_{1}$ : En az bir birimde nedensellik ilişkisi vardır.

\subsection{Araştırma Bulguları}

Değişkenlerin durağanlığının sınanması için ilk olarak birim kök testleri uygulanacaktır. Uygulanacak birim kök testleri sirasıyla Levin, Lin ve Chu(2002), Harris\& Tsavalis (1999), Hadri (2000), Im, Pesaran ve Shin (2003), Maddala ve Wu (1999) ve Choi (2001) birim kök testleridir. 


\begin{tabular}{|c|c|c|c|c|c|}
\hline Değişkenler & Test & \multicolumn{2}{|c|}{ Sabit } & \multicolumn{2}{|c|}{ Sabit+Trend } \\
\hline \multicolumn{6}{|c|}{ Düzey Dĕ̌ger } \\
\hline & & İstatistik & p-değer & İstatistik & p-değer \\
\hline \multirow{6}{*}{ RW } & LLC & -1.6213 & 0.0525 & -4.0117 & 0.0000 \\
\hline & Harris-Tsavalis & 0.9162 & 0.9318 & 0.7062 & 0.5618 \\
\hline & Hadri & 21.7577 & 0.0000 & 6.7066 & 0.0000 \\
\hline & IPS & 3.4637 & 0.9997 & 5.9020 & 1.0000 \\
\hline & Maddala ve $\mathrm{Wu}$ & 31.7569 & 0.9159 & 53.9002 & 0.1457 \\
\hline & Choi & 26.3191 & 0.9841 & 8.5623 & 1.0000 \\
\hline \multirow{6}{*}{ INF } & LLC & -12.1475 & 0.0000 & -9.3994 & 0.0000 \\
\hline & Harris-Tsavalis & 0.8586 & 0.2772 & 0.8375 & 0.9997 \\
\hline & Hadri & 45.8879 & 0.0000 & 38.9342 & 0.0000 \\
\hline & IPS & -9.1204 & 0.0000 & -1.5944 & 0.0554 \\
\hline & Maddala ve Wu & 107.5455 & 0.0000 & 76.8532 & 0.0016 \\
\hline & Choi & 256.0838 & 0.0000 & 152.7263 & 0.0000 \\
\hline \multirow{6}{*}{ LP } & LLC & -6.6732 & 0.0000 & -0.3139 & 0.3768 \\
\hline & Harris-Tsavalis & 0.9264 & 0.9682 & 0.7170 & 0.6644 \\
\hline & Hadri & 53.0057 & 0.0000 & 27.6449 & 0.0000 \\
\hline & IPS & 1.4994 & 0.9331 & -1.3794 & 0.0839 \\
\hline & Maddala ve Wu & 40.0486 & 0.6416 & 39.1656 & 0.6786 \\
\hline & Choi & 56.1196 & 0.1040 & 16.0673 & 1.0000 \\
\hline \multicolumn{6}{|c|}{ Birinci Fark } \\
\hline & & İstatistik & p-değer & İstatistik & p-değer \\
\hline \multirow{6}{*}{ RW } & LLC & -13.8626 & 0.0000 & -12.2230 & 0.0000 \\
\hline & Harris-Tsavalis & 0.0768 & 0.0000 & 0.2494 & 0.0000 \\
\hline & Hadri & 4.2380 & 0.0000 & 5.5581 & 0.0000 \\
\hline & IPS & -12.8455 & 0.0000 & -10.4786 & 0.0000 \\
\hline & Maddala ve $\mathrm{Wu}$ & 160.6849 & 0.0000 & 105.9176 & 0.0000 \\
\hline & Choi & 315.4913 & 0.0000 & 247.3169 & 0.0000 \\
\hline \multirow{6}{*}{ INF } & LLC & -17.8353 & 0.0000 & -16.2076 & 0.0000 \\
\hline & Harris-Tsavalis & 0.1739 & 0.0000 & 0.2594 & 0.0000 \\
\hline & Hadri & 6.6587 & 0.0000 & 0.4392 & 0.3303 \\
\hline & IPS & -17.7936 & 0.0000 & -16.0961 & 0.0000 \\
\hline & Maddala ve $\mathrm{Wu}$ & 378.2827 & 0.0000 & 309.6353 & 0.0000 \\
\hline & Choi & 567.8403 & 0.0000 & 469.7055 & 0.0000 \\
\hline \multirow{6}{*}{ LP } & LLC & -16.3607 & 0.0000 & -14.3041 & 0.0000 \\
\hline & Harris-Tsavalis & 0.0457 & 0.0000 & 0.1706 & 0.0000 \\
\hline & Hadri & 3.3287 & 0.0004 & 1.9500 & 0.0256 \\
\hline & IPS & -12.7235 & 0.0000 & -11.4108 & 0.0000 \\
\hline & Maddala ve $\mathrm{Wu}$ & 162.8556 & 0.0000 & 157.9591 & 0.0000 \\
\hline & Choi & 322.4970 & 0.0000 & 301.0771 & 0.0000 \\
\hline
\end{tabular}

Tablo 2. Birim Kök Testi Sonuçları

Reel ücret, enflasyon ve işgücü verimliliğine ilişkin birim kök testi sonuçları Tablo 2'de gösterilmiştir. Birim kök testi sonuçlarına göre reel ücret Hadri(2000) testine göre düzey değerinde durağan olduğu ancak Levin, Lin ve Chu(2002), Harris\& Tsavalis (1999), Im, Pesaran ve Shin (2003), Maddala ve Wu(1999) ve Choi(2001) birim kök testlerine göre birinci farkında durağandır. Enflasyon Levin, Lin ve Chu(2002), Hadri(2000), Maddala ve $\mathrm{Wu}(1999)$ ve Choi(2001) birim kök testlerine göre düzey değerinde durağan olduğu belirlenirken, Harris\& Tsavalis (1999), Im, Pesaran ve Shin (2003) testlerine göre birinci farkında durağandır. İşgücü verimliliğinin ise, Levin, Lin ve Chu(2002) ve Hadri(2000) birim kök testlerine göre durağan olduğu tespit edilirken, Harris\& Tsavalis (1999), Im, Pesaran ve Shin (2003), Maddala ve Wu(1999) ve Choi(2001) birim kök testlerine göre birinci 
farkında durağan olduğu belirlenmiştir. Elde edilen sonuçlar neticesinde uzun dönemli ilişkinin tespiti için Pedroni, Kao ve Johansen Fisher Eşbütünleşme testi uygulanmıştır.

Tablo 3'de Pedroni eşbütünleşme testi sonuçları gösterilmiştir.

\begin{tabular}{|l|l|l|l|l|}
\hline \multicolumn{1}{|c|}{ Metot } & \multicolumn{1}{c|}{ Test İstatistiği } & \multicolumn{1}{c|}{ Probability } & \multicolumn{1}{c|}{ Test İstatistiği } & \multicolumn{2}{c|}{ Probability } \\
\hline \multicolumn{3}{|c|}{ Sabit } & \multicolumn{2}{c|}{ Sabit+trend } \\
\hline Panel v testi & 59.79811 & 0.0000 & 25.26845 & 0.0000 \\
\hline Panel rho testi & -6.200387 & 0.0000 & -4.990385 & 0.0000 \\
\hline Panel PP testi & 2.024133 & 0.9785 & -1.500658 & 0.0667 \\
\hline Panel ADF testi & -1.041555 & 0.1488 & -1.864984 & 0.0311 \\
\hline Grup rho testi & 1.00351 & 0.8555 & 2.737396 & 0.9969 \\
\hline Grup PP testi & -0.124436 & 0.4505 & 0.715072 & 0.7627 \\
\hline Grup ADF testi & -0.787460 & 0.2155 & -2.943982 & 0.0016 \\
\hline
\end{tabular}

Tablo 3. Pedroni Eşbütünleşme Testi Sonuçları

Tablo 3'te görüldüğü üzere, Panel PP testi hem sabit hem de sabit ve trendli modelde değişkenler arasında eşbütünleşme ilişkisi olmadığını ifade ederken, Panel v ve Panel rho testleri hem sabit hem de sabit ve trendli modelde eşbütünleşme olduğunu göstermektedir. Panel ADF testi ise değişkenler arasında sabitli modelde eşbütünleşme ilişkisi olmadığını ifade ederken sabit ve trendli modelde eşbütünleşme ilişkisinin varlığı ortaya çıkmaktadır. Pedroni tarafından önerilen sabitli modelde 7 testten 5 tanesi eşbütünleşme olmadığını, sabit ve trendli modelde ise 7 testten 3 tanesi eşbütünleşme olmadığını göstermektedir. Bu durumda tüm testlerde boş hipotez kabul edilmiş ve eşbütünleşme varlığı reddedilmiştir.

\begin{tabular}{|l|l|l|}
\hline Metot & Test İstatistiği & Probability \\
\hline ADF & 2.903618 & 0.0018 \\
\hline Residual Variance & 0.056102 & \\
\hline HAC Variance & 0.056616 & \\
\hline
\end{tabular}

Tablo 4. Kao Eşbütünleşme Testi Sonuçları

Tablo 4'de Kao eşbütünleşme testinin sonuçları gösterilmektedir. Elde edilen sonuçlara göre boş hipotez reddedilmiştir. Yani değişkenler arasında eşbütünleşme olduğu bulunmuştur.

\begin{tabular}{|l|l|l|l|l|}
\hline $\begin{array}{l}\text { Hypothesised No. } \\
\text { of CE(s) }\end{array}$ & $\begin{array}{l}\text { Fisher stat } \\
\text { (from trace test) }\end{array}$ & Probability & $\begin{array}{l}\text { Fisher stat } \\
\text { (max eigen test }\end{array}$ & Probability \\
\hline None & 185.1 & 0.0000 & 135.7 & 0.0000 \\
\hline At most 1 & 92.88 & 0.0000 & 65.96 & 0.0177 \\
\hline At most 2 & 102.1 & 0.0000 & 102.1 & 0.0000 \\
\hline
\end{tabular}

Tablo 5. Johansen Fisher Eşbütünleşme Testi Sonuçlarl

Johansen Fisher Panel Eşbütünleşme Testi sonuçlarına göre, iki değişken arasında bir ilişki olmadığı sıfır hipotezi reddedilmiş ve eşbütünleşmenin varlığını destekleyen alternatif hipotez kabul edilmiştir.

Modelde eşbütünleşme varlığını belirlemek için yapılan üç testten Kao ve Johansen Fisher Panel Eşbütünleşme Testleri eşbütünleşme olduğunu göstermiştir. Ancak, Pedroni Eşbütünleşme Testi değişkenler arasında bir korelasyon olmadığını ortaya koymuştur. Yaptığımız testlerin çoğunluğu modeldeki eşbütünleşmenin varlığını ortaya çıkardığından, uzun vadede OECD ülkeleri için reel ücret, enflasyon ve işgücü verimliliği arasında bir korelasyon olduğu kabul edilmiştir. Değişkenler arasında uzun dönemli ilişkinin tespitinin ardından Pedroni tarafından geliştirilen DOLS tahmincisi kullanılmıştır. 


\begin{tabular}{|l|l|l|l|l|}
\hline & \multicolumn{2}{|c|}{ ENFLASYON } & \multicolumn{2}{c|}{ İSGÜCÜ VERIMLİL̇̈̆̇ं } \\
\hline & Katsay1 & t-istatistik & Katsay1 & t-istatistik \\
\hline Avustralya & -0.002768 & -0.992 & $0.1669^{* *}$ & 16.47 \\
\hline Belçika & -0.003108 & -0.3654 & -0.0007799 & -0.04634 \\
\hline Kanada & $-0.1031^{* *}$ & -3.982 & $0.2552^{* *}$ & 5.291 \\
\hline Şili & -0.0154 & -1.856 & $0.4673^{* *}$ & 14.53 \\
\hline Çek Cumhuriyeti & $-0.05886^{* *}$ & -2.28 & $0.4073^{* *}$ & 1.973 \\
\hline Fransa & -0.005492 & -0.3115 & $0.2371^{* *}$ & 5.345 \\
\hline Yunanistan & $0.05594^{* *}$ & 8.578 & $0.3849^{* *}$ & 4.946 \\
\hline Macaristan & -0.03718 & -4.509 & $0.1831^{* *}$ & 1.91 \\
\hline Japonya & 0.01647 & 1.207 & $0.4087^{* *}$ & 7.798 \\
\hline Kore & 0.017 & 1.999 & $1.001^{* *}$ & 29.47 \\
\hline Letonya & -0.003062 & -0.5346 & $1.209^{* *}$ & 15.64 \\
\hline Lüksemburg & 0.006466 & 1.196 & $0.238^{* *}$ & 16.87 \\
\hline Meksika & 0.001778 & 1.148 & $0.05517^{* *}$ & 1.805 \\
\hline Hollanda & 0.01675 & 2.01 & $0.07684^{* *}$ & 3.069 \\
\hline Yeni Zelanda & 0.01936 & 1.825 & $0.6895^{* *}$ & 22.49 \\
\hline Polonya & -0.001619 & -0.3829 & $0.7948^{* *}$ & 19.41 \\
\hline Portekiz & 0.04508 & 2.209 & $0.5084^{* *}$ & 7.785 \\
\hline Slovak Cumhuriyeti & -0.001235 & -0.1161 & $0.5426^{* *}$ & 7.301 \\
\hline Slovenya & 0.005077 & 0.1516 & $0.7223^{* *}$ & 1.736 \\
\hline İspanya & $0.05988^{* *}$ & 1.309 & $0.4456^{* *}$ & 2.523 \\
\hline Türkiye & -0.003523 & -1.124 & $0.2761^{* *}$ & 1.722 \\
\hline ABD & $-0.07899 * *$ & -2.013 & $-0.1893^{* *}$ & -1.949 \\
\hline Panel Geneli & $\mathbf{- 0 . 0 0 3 3 9 5}$ & $\mathbf{0 . 6 7 5}$ & $\mathbf{0 . 4 0 3 6 * *}$ & $\mathbf{3 9 . 6 7}$ \\
\hline & & & & \\
\hline
\end{tabular}

Tablo 6. Panel DOLS Testi Sonuçları

Not: Bağımlı değişken reel ücrettir. ** yüzde 5 düzeyinde anlamlılı̆̆ göstermektedir.

Tablo 6'da panel DOLS tahmincisi sonuçları hem ülke olarak hem de panel genelini kapsayacak şekilde gösterilmiştir. DOLS tahmincisi sonuçlarına göre reel ücret ile işgücü verimliliği arasında uzun dönemli bir ilişki vardır. Ancak enflasyonun reel ücret üzerinde etkisi tespit edilememiştir. Avustralya, Şili, Fransa, Macaristan, Japonya, Kore, Letonya, Lüksemburg, Meksika, Hollanda, Yeni Zelanda, Polonya, Portekiz, Slovak Cumhuriyeti, Slovenya, Türkiye için bulunan sonuçlar panel genelinde çıkan sonucu desteklemektedir. Belçika için bulunan sonuçlara göre reel ücret üzerinde hem enflasyon hem de işgücü verimliliğinin etkisi bulunamamıştır. Kanada, Çek Cumhuriyeti, Yunanistan, İspanya ve ABD için bulunan sonuçlarda ise reel ücretler üzerinde hem enflasyon hem de işgücü verimliliği etkili olmaktadır.

Değişkenler arasında nedenselliğin yönünün belirlenmesi için Dumitrescu ve Hurlin (2012) tarafindan geliştirilen nedensellik testi uygulanmış ve elde edilen sonuçlar Tablo 7'de gösterilmiştir.

\begin{tabular}{|l|l|l|}
\hline & W-Stat & Probability \\
\hline Reel Ücret $\rightarrow$ Enflasyon & 7.0201 & 0.0000 \\
Enflasyon $\rightarrow$ Reel Ücret & 13.1654 & 0.0000 \\
\hline Reel Ücret $\rightarrow$ İş̧̈̈̈cü Verimlilĭği & 15.7847 & 0.0000 \\
İşücü Verimliliği $\rightarrow$ Reel Ücret & 7.1457 & 0.0000 \\
\hline Enflasyon $\rightarrow$ İşgücü Verimliliği & 3.5727 & 0.0000 \\
İşgücü Verimliliği $\rightarrow$ Enflasyon & 7.7734 & 0.0000 \\
\hline
\end{tabular}

Tablo 7. Dumitrescu ve Hurlin (2012) Nedensellik Testi Sonuçları

Ele aldığımız değişkenler arasındaki kısa dönemli ilişkinin tespiti için Dumitrescu ve Hurlin (2012) nedensellik testi uygulanmıştır. Reel ücret ile enflasyon arasında çift yönlü nedensellik ilişkisi belirlenmiştir. Reel ücret ile işgücü verimliliği karşılıklı etkileşim içerisindedir. Enflasyon ve işgücü verimliliği arasında ise çift yönlü ilişki bulunmuştur.

\section{Sonuç}

Bu çalışmada 22 OECD ülkesinin 1995-2017 dönemine kapsayan verilerle reel ücret, enflasyon ve işgücü verimliliği arasındaki kısa ve uzun dönemli ilişkiler incelenmiştir. Çalışma dengeli panel veri yöntemleri ile analiz edilmiştir. Birim kök testleri ile değişkenlerin durağanlığı sınanmış, eşbütünleşme testleri ile değişkenler arasındaki uzun dönemli ilişki belirlenmiştir. Nedensellik analizi ile değişkenler arasındaki kısa dönemli ilişki belirlenmiştir. 
Yapılan analiz sonuçlarına göre değişkenler arasında uzun dönemli ilişki tespit edilmiştir. DOLS tahmincisi sonuçlarına göre enflasyonun reel ücret üzerinde etkisi bulunamamıştır. Ancak işgücü verimliliğinin reel ücret üzerindeki etkisi olumlu ve anlamlıdır. İşgücü verimliliğinden reel ücretlere doğru bir ilişkiden söz ediliyorsa Marjinal Verimlilik Teorisi geçerli demektir. Bir ekonomide tam rekabet koşulları geçerliyse, işçinin reel ücretini belirleyen unsur marjinal verimliliktir. İşverenler işçilere ancak üretime yaptıkları kadar ücret vermeye razı olacaklardır. Şayet reel ücretler marjinal işgücü verimliliğinden yüksekse, işverenler aldığı ücrete oranla daha düşük üretim katkısı olan işçiyi işten çıkaraktır. Şayet verimlilik ücretten fazla ise sendikalar devreye girip ücret artışı talep edecektir. OECD ülke grubu açısından işgücü verimliliğinde meydana gelen artış, reel ücret düzeyinin de artmasıyla sonuçlanmaktadır. Bu bakımdan çalışmamız, teori ve literatür çalışmaları ile desteklenmektedir.

Değişkenler arasında kısa dönemli ilişkinin tespiti için Dumitrescu ve Hurlin (2012) nedensellik testi yapılmıştır. Nedensellik sonuçlarına göre, reel ücret ile enflasyon arasında, reel ücret ile işgücü verimliliği arasında ve enflasyon ile işgücü verimliliği arasında çift yönlü nedensellik ilişkisi belirlenmiştir.

\section{Kaynakça}

- Christopoulos, K. D. 2005. “A Note on the Relationship Between Real Wages and Employment: Further Evidence from Panel Cointegration Tests", Journal of Economic Studies, 32(1), p. 25-32.

- Choi, I. 2001. "Unit root tests for panel data”, Journal of International Money and Finance, 20, p. 249-72.

- Dritsakis, N. 2004. “A Causal Relationship between Inflation and Productivity: An Empirical Approach for Romania” American Journal of Applied Sciences, 1, p.121-128.

- Dumitrescu, E., Hurlin, C. 2012. "Testing for Granger non-causality in heterogeneous panels", Economic Modelling, 29 (2012), p.1450-1460.

- $\quad$ Eşiyok, B. Ali, 1999. "İmalat Sanayinde Kamu-Özel Sektör Ayrımı Ekseninde Ücret ve Verimlilik Serilerinin İstatistiki ve Ekonometrik Bir Analizi”, Türkiye Kalkınma Bankası Araştırma Müdürlüğü, Ankara.

- Hadri, K. 2000. “Testing for Unit Roots in Heterogeneous Panel Data”, Econometrics Journal, 3, p.148-161.

- Haris, R. D.F., Tzavalis, E. 1999. "Inference for Unit Roots in Dynamic Panels Where the Time Dimension is Fixed", Journal of Econometrics, 91, p.201-226.

- Im, K. S., Pesaran, M. H. ve Shin, Y. 2003. "Testing for unit roots in heterogeneous panels”, Journal of Econometrics, 115, p. 53-74.

- Islam, R., Kinyondo, A. ve Nganga, J. 2015. "Real Wages and Labour Productivity in Tanzania: How do They Link" Journal of African Studies and Development, 7(3), p.81-98.

- Johansen, S. 1988. "Statistical Analysis of Cointegration Vectors", Journal of Economic Dynamics and Control, 12(2-3), p. 231-254.

- Kao, C. 1999, "Spurious regression and residual-based tests for cointegration in panel data", Journal of Econometrics, 90(1), p.1-44.

- Kumar, S., Webber, D.J. ve Perry, G. (2009), "Real Wages, Inflation and Labour Productivity in Australia" Applied Economics, 44, p.2945-2954.

- Levin, A., Lin, C. F. ve Chu, C. S. J. 2002. "Unit root test in panel data: asymptotic and finite sample properties", Journal of Econometrics, 108, p. 1-24.

- Maddala, G. S.ve Wu, S. 1999. "A comparative study of unit root tests with panel data and a new simple test”, Oxford Bulletin of Economics and Statistics, special issue, p.631-52.

- Marquetti, A. 2004. "Do Rising Real Wages Increase the Rate of Labor-Saving Technical Change? Some Econometric Evidence”, Metroeconomica, 55(4), p. 432-441.

- Millea, M. 2002. "Disentangling the Wage-Productivity Relationship: Evidence from Select OECD Member Countries", IAER, 8(4), p. 314- 323.

- $\quad$ Narayan, P. ve Smyth, R. 2009. "The Effect of Inflation and Real Wages on Productivity: New Evidence from a Panel of G7 Countries” Applied Economics, 2009 (41), p.1285-1291.

- Öztürk, N. 2005. "Ücret Kuramında Yeni Yaklaşımlar” Gazi Üniversitesi İktisadi ve İdari Bilimler Fakültesi Dergisi, 7(1), p. 29-49.

- Pedroni, P. 1999. "Critical values for cointegration tests in heterogeneous panels with multiple regressors", Oxford Bulletin of Economics and Statistics, 61, p.653-670.

- Pedroni, P. 2001. "Purchasing Power Parity Tests in cointegrated panels", Review of Economics and Statistics, 83, p.727-731.

- Pedroni, P. 2004. "Panel cointegration: asymptotic and finite sample properties of pooled time series tests with an application to the PPP hypothesis: new results". Econometric Theory, 20, p.597-627. 
- Tang, C. F. 2014. "The Effect of Real Wages and Inflation on Labour Productivity in Malaysia" Applied Economics, 28 (3), p.311-322.

- Tatoğlu, F.Y. 2017. Panel Veri Analizi. Beta Yayınevi, İstanbul.

- Trpeski, P. ve Tashevska, B. 2009. "Labor Productivity and Wages in the Republic of Macedonia" Business Statistics-Economic Informatics, The Young Economists Journal, p.103-111.

- Türedi S. ve Terzioğlu H. 2009. “Türkiye’de Kamu-Özel İmalat Sanayinde Ücret ve İşgücü Verimliliği İlişkisi”, Eskişehir Osmangazi Üniversitesi Sosyal Bilimler Dergisi, 10(1), p.144-164

- Wakeford J. 2004. "The Productivity-Wage Relationship in South Africa: an Empirical Investigation”, Development Southern Africa, 21(1), p. 109-132.

- Yildirim, Z. 2015. "Relationship Among Labour Productivity, Real Wages and Inflation in Turkey" Economic Research-Ekonomska Istraživanja, 28(1), p.85-103. 


\title{
The Export-Led Growth Hypothesis: A Panel Cointegration Approach in the Middle East and North Africa Countries (1980- 2017)
}

\author{
Ph.D. Candidate Ayat Abdelrahim Suliman Esaa (Çukurova University, Turkey) \\ Prof. Dr. Harun Bal (Çukurova University, Turkey) \\ Asst. Prof. Dr. Erhan İşcan (Çukurova University, Turkey)
}

\begin{abstract}
This study examines the hypothesis of the Export-Led Growth in the seven selected Middle East and North Africa countries, the hypothesis state that export growth driven by export promotion policies enhances overall economic growth. Empirical investigations have tended to focus attention on the direction of causality between exports and economic growth using Granger causality tests. However, the empirical results based on these tests are, at best, mixed and often contradictory.

The paper employs panel data analysis by utilizing the Pedroni panel cointegration, Pedroni Dynamic Ordinary Least Squares and Fully Modify Ordinary Least Squares, and Canning-Pedroni causality methods, a recent development in panel data econometrics, properties of integration and cointegration and consistency of parameters. The study considers the following three variables; Real Gross Domestic Product (GDP), Real exports (EXP) and Real import (IMP). Annual secondary data are obtained from the World Bank Development Indicator for seven MENA countries, Namely, Algeria, Egypt, Sudan, Jordan, Saudi Arabia, UAE, and Qatar.

The empirical results emphasize the existence of a positive relationship between Export and GDP. Results of waled and Z-bar Group statistics indicate the long-run unidirectional causality between Export and GDP, operates from Export to the GDP. It confirms the validity of Export-led growth hypothesis of the seven selected MENA countries. Empirical evidence suggests significant policy prescriptions; these countries should focus more on supporting export orientated industries through aid-for-trade, trade-capacity building schemes and other types of policies in order to promote economic growth.
\end{abstract}

\section{Introduction}

The export-led growth (ELG) hypothesis has been tested by many empirical studies in order to examine whether export growth driven by export promotion policies enhances overall economic growth. The determination of the causal relationship among exports and output growth bears significance owing to its important policy implications concerning convenient growth and development strategies and policies to pursue.

Previous studies on the ELG hypothesis, for the most part, confirmed its validity due to the high correlation amongst exports and output. Recent empirical investigations have would in general spotlight consideration on the direction of causality among exports and output growth utilizing Granger causality tests. Nevertheless, empirical evidence primarily lean on these tests are mixed and overwhelmingly contradictory (Aamer and Abu-Bader, 2001). The absence of a consistent causality relation among exports and output growth in ELG studies in general and for the MENA region, in particular, may be explained, in part, by the differences in the measures of exports, sample period considered and methodologies adopted.

Many developing countries, incorporating those in the MENA region, have pursued trade liberalization and export promotion policies as a desirable strategy for development and growth, especially, after the sturdy export performance and high economic growth rates of some East Asian countries. This change in the development strategies is based on the expectations that trade liberalization in general and export promotion, in particular, would result in the following: i) exports expand the market and help exploit economies of scale; ii) exportation mitigates the binding foreign exchange constraint to permit importation of the requirements of domestic production and exports from intermediate goods and capital, consequently increasing the production possibilities economy; iii) exports reinforce domestic efficiency via raise competition; and iv) exportation fosters the prevalence of technical knowledge through the suggestions of foreign buyers and learning by doing (Melise and Caroline, 2015).

A study of (Behar and Freund, 2011) shows that exports of MENA countries had been increasing extra rapidly compared to the exports from the rest of the world, refers to some proofs of convergence. However, based on the historical records of growth rate, in order to reach potential trade level, this would take 20 years for MENA countries. Moreover, the progress of export overall performance over the years is very slow and indicates that it can take two times as long to attain a potential level.

Economic growth in MENA countries has been comparatively slow since 1980. When East Asia and South Asia registered over threefold increase in real per capita income against 60 percent for that of the world, it was only 30 percent for MENA region (Behar and Freund, 2011). Although there are various conceivable contributing factors, several studies indicate a robust connection between income per capita and international trade flows. Whereas 
Greater openness encourages the movement of resources to the most productive use, which catalyzes returns on investment and thereby raises living standards.

Due to some constraints on trade regimes, MENA countries have missed out on global trade integration. Where trade policies such as high and complex tariffs have been referred to as the fundamental policy-induced barrier to intra-Arab trade (Saidi and Prasad, 2018). Also, factors such as insufficient skills and high logistics costs have been mentioned too in a publication of World Bank (1992). For that reason, many consider that inadequate integration is one of the causes of poor economic performance in the MENA region (Haddad, 1993).

The aim of this study is to examine the causality among exports and output growth, the direction, and size of this relation for seven selected MENA countries: Algeria, Egypt, Sudan, Jordan, Saudi Arabia, UAE, and Qatar. To serve the purpose, the study primarily consults and summarizes the results of earlier studies to develop a better framework of the study. It then proceeds to investigate the relation among real exports and output growth for the MENA countries stated above during 1980-2017 using Pedroni panel cointegration tests. Finally, a long-run cointegrating relation has been estimated in a panel set applying Fully Modified OLS (FMOLS) and Dynamic OLS (DOLS) along with the investigation of the causality among real exports and output growth adopting approach found by Canning and Pedroni (2008).

\section{Literature Review}

The relation between exports and output growth in an economy has for quite some time been a zone in international and development economics accepting a lot of research consideration. Depending on the basic concepts of economic theory, it can be suggested that exports contribute to output growth through the multiplier effect of foreign trade. The foreign trade multiplier analysis affirms that given the expenditure function; an export surplus will have an expansionary effect extent will depend on the marginal propensity to imports. Transmit of rare resources from low-productivity domestic industries to higher-productivity export industries leads to a rise in total productivity speeding up the growth of output.

A considerable number of studies have investigated the causality relation among exports and output growth. However, only a few researchers addressed particularly the subject for the MENA region. Some findings indicate that a significant and positive relationship exists among export and output growth. Most ELG studies on the MENA countries did not apply cointegration tests when the causality be examined among exports and output growth, also the majority of these studies are time series studies while the current study uses panel data analysis.

Pompino (1996) examined the validity of ELG hypothesis in some MENA countries applying cointegration and error correction model (ECM), a unidirectional causality from output growth to exports has been found in Algeria and Tunisia, while there is no causality for Sudan, Morocco, and Turkey. However when the investment has been introduced as a third variable, a bidirectional causality was found for Turkey and Tunisia and no change was found in the results for Algeria, Morocco, and Sudan. Using the error correction model (ECM) and vector autoregressive, Abu-Qarn and Abu-Bader(2001) attempted to examine the causality among exports and output growth in nine MENA countries. Empirical results show that when aggregate exports were considered estimation shows that the Export-led Growth hypothesis is not valid in the majority of the countries analyzed. While in case of manufactured exports only been considered, they found that there is no existence of causality in countries with relatively low shares of manufactured exports in total merchandise exports while there is a bidirectional causality for countries with relatively high shares. Husein (2010) investigated the ELG hypothesis in eight (MENA) countries in a multivariate framework by including trade as a third variable. He utilized the Johansen and Juselius cointegration procedure and error correction modeling to examine the ELG hypothesis. Empirical evidence affirms that a stable long-run equilibrium relation exists among real exports, real output, terms of trade.

In the case of the bivariate studies, Abual-Foul (2004) tested the validity of the ELG hypothesis in Jordan during the period (1976-1997). Citing a lack of a long sample, unit root tests have not carried and hence did not test for cointegration. As an alternative, three bivariate models have been employed, namely, a vector autoregressive (VAR) in levels, a vector autoregressive (VAR) in first differences, and an error correction model (ECM). Based on the three bivariate models, the study pointed out a unidirectional causality runs from exports to output. Hamdi (2013) examined the ELG hypothesis for Tunisia and Morocco employing a model based on the procedure of Toda and Yamamoto (1995). Empirical results affirm the validity of the ELG hypothesis in Tunisia, while in the case of Morocco results reveal the existence of import-led growth policy oriented. Also, there is no existence of bidirectional causality among imports and exports for both Tunisia and Morocco.

Applying Johansen-Juselius cointegration tests and error correction model, Husein (2009) tested the validity of the ELG hypothesis in Jordan, he found a presence of cointegration amongst real exports, real output, and terms of trade. Moreover, Granger causality tests based on the ECM suggested that there is a bidirectional causality amongst real exports and real output growth. Chia Yee Ee (2015) applied a panel data approach to investigate the validity of the export-led growth hypothesis for selected Sub-Saharan African (SSA) countries. Based on FMOLS and DOLS estimations, the empirical findings revealed that there is a long-run relationship among exports and economic growth. Additionally, results indicate a positive effect of exports, investment and government 
expenditure on economic growth. Athanasia and Emmanuel (2017) tested the validity of ELG hypothesis for the United Arab Emirates, concentrating on the causality among manufactured exports, primary exports and economic growth, the analysis revealed that the long-run contribution of manufactured exports to economic growth is more than primary exports. Also, results point out that over the long-run the Growth-Led Exports (GLE) hypothesis is valid in UAE, and there is a short-run bidirectional causal relation among manufactured exports and economic growth.

\section{Data and Methodology}

\subsection{Data Sources}

The analysis of panel data considers seven selected the Middle East and North Africa (MENA) countries. The priority of selecting has been specified to the countries with accessible data over 1980-2017 periods. In the study, data on variables (Exports, Gross Domestic Product, Imports, and consumer price index) have been obtained from the World Development Indicator (WDI) of the World Bank. Whereas, the data of exports and imports of goods and services and GDP have been divided by the consumer price index (CPI) to obtain real terms of variables. All the variables are used in the logarithmic form.

The general function can illustrate as follows;

$$
\ln G D P=f(\ln E X P, \ln I M P)
$$

\subsection{Econometric Model}

The inference of ELG hypothesis requires empirical investigation. With this objective, theoretical models for the study intending to analyze the causality relation between exports and output have been specified below.

$$
\begin{aligned}
& E X P=f(G D P) \\
& G D P=f(E X P)
\end{aligned}
$$

Since Granger Causality is figured by performing bivariate relapses, there are various distinctive ways to test causality for Granger in a panel data. Generally, bivariate regressions in a panel data can be illustrated as:

$$
\begin{aligned}
& y_{i, t}=\alpha_{0, i}+\alpha_{1, i} y_{i, t-1}+\cdots+\alpha_{k, i} y_{i, t-k}+\beta_{1, i} x_{i, t-1}+\cdots+\beta_{k, i} x_{i, t-k}+\epsilon_{i, t} \\
& x_{i, t}=\alpha_{0, i}+\alpha_{1, i} x_{i, t-1}+\cdots+\alpha_{k, i} x_{i, t-k}+\beta_{1, i} y_{i, t-1}+\cdots+\beta_{k, i} y_{i, t-k}+\epsilon_{i, t}
\end{aligned}
$$

$\mathrm{t}$ indicates the size of the panel time periods and $\mathrm{i}$ denote the size of the cross-section. The forms of panel causality tests vary in the hypotheses on the homogeneity of the coefficients in the cross-sections. This study employs the approach developed by Dumitrescu-Hurlin (2012), which permits the coefficients to be different across sections:

$$
\begin{gathered}
\alpha_{0, z} \neq \alpha_{0, j}, \neq \alpha_{1, i} \neq \alpha_{1, j}, \ldots, \alpha_{l, i} \neq \alpha_{\iota, j}, \forall_{i, j} \\
\beta_{1, i} \neq \beta_{1, j}, \ldots, \beta_{1, i} \neq \beta_{l, j} \neq \beta_{l, j}, \forall_{i, j}
\end{gathered}
$$

This test is calculated by exaggerating standard Granger causality regressions for each cross-section independently. Then taking the average of the statistics from the test, which are called W-bar statistics, shows the standardized version of this statistic, and follows a standard normal distribution called the Z-bar statistic.

\section{Empirical Results and Discussion}

\subsection{Unit root test}

In order to examine the presence of unit root in the panel data analysis, DF (Dickey-Fuller) and the ADF ( Augmented Dickey-Fuller) tests have been extended in order to perform a multi-unit root test for panel data approach. Heterogeneity in panel data analysis considers as a significant factor reflects complexity in time series. That means each individual in the panel set may not have the same features, and thus time series may differ in terms of being stationary or non-stationary (Chia Yee Ee,2016).

This study uses unit root tests of most leading works concerns panel data models include; Levin, Lin, and Chu (2002), Im, Pesaran, and Shin ( 2003), ADF (Augmented Dickey-Fuller) and Fisher tests. The logarithm of the variables; output growth (GDP), real Exports (EXP) and real Import (IMP) has been decided and then unit root tests are performed. Table 1. displays the results of unit root tests examined in levels, based on $\mathrm{T}$ statistics and probability values the variables are non-stationary at level [I (0)] which indicate a presence of unit root. Consequently, the first differences of the series were tested. Considering the first differences of variables, results show that series are stationary at [I (1)]. 


\begin{tabular}{|l|l|l|l|l|l|l|}
\hline \multicolumn{1}{|c|}{ variable } & \multicolumn{2}{c|}{ Ln(GDP) } & \multicolumn{2}{c|}{ Ln(Exp) } & \multicolumn{2}{c|}{$\begin{array}{l}\text { Ln(IMP) } \\
\text { trend }\end{array}$} \\
\hline & constant & $\begin{array}{l}\text { Constant and } \\
\text { trend }\end{array}$ & constant & $\begin{array}{l}\text { Constant and } \\
\text { trend }\end{array}$ & constant & \multicolumn{2}{c|}{ level } \\
\hline \multicolumn{7}{|c|}{} \\
\hline Levin,lin & 2.068 & 0.563 & 2.756 & 0.830 & 1.373 & -1.355 \\
\hline IPS & 2.118 & 0.559 & 2.042 & -0.706 & 2.195 & 0.097 \\
\hline ADF-fisher & 14.244 & 14.475 & 11.671 & 16.619 & 19.302 & 18.062 \\
\hline \multicolumn{7}{|c|}{ First difference } \\
\hline Levin,lin & $-4.855^{* *}$ & $-3.166^{* *}$ & $-8.241^{* *}$ & $-4.505^{* *}$ & $-7.843^{* *}$ & $-6.790^{* *}$ \\
\hline IPS & $-7.499^{* *}$ & $-6.526^{* *}$ & $-9.900^{* *}$ & $-8.413^{* *}$ & $-8.044^{* *}$ & $-7.148^{* *}$ \\
\hline ADF-fisher & $88.453^{* *}$ & $73.965^{* *}$ & $118.587^{* *}$ & $94.821^{* *}$ & $87.635^{* *}$ & $73.405^{* *}$ \\
\hline
\end{tabular}

Table 1: Results of Panel Unit Root Test

Note: ${ }^{* *}$, denote the rejection of the null hypothesis at $5 \%$ significance level.

\subsection{Panel cointegration test}

Stationarity of all the variables at first difference allows performing the Pedroni cointegration test so as to identify if there is any long-run relation exist amongst the variables. Pedroni $(2000,2004)$ proposes panel cointegration tests that consider heterogeneity by utilizing particular parameters that were permitted to differ crosswise over individual groups of the sample. There are seven different cointegration statistics in Pedroni tests, the first category includes four tests pooled "within" size and the second category consists of three other tests in the size "between" (group mean) effects.

Table 2 illustrates the cointegration tests results, the analysis reveals that five of the seven statistics in the Pedroni cointegration show that there is cointegration while the remain other tests show the opposite. Therefore, it can be declared that the three variables of analysis have a long-run cointegrating relation. Which means that output growth, 1 real Export, and real import act together in long-run for the selected MENA countries.

\begin{tabular}{|c|c|c|}
\hline \multicolumn{3}{|c|}{$\operatorname{Ln}_{G D P}=\beta_{0}+\beta_{1} \ln \mathrm{EXP}_{\mathrm{i}}+\beta_{2} \ln \mathrm{IMP}_{\mathrm{i}}+\mathrm{u}_{\mathrm{i}}$} \\
\hline & Without trend & With trend \\
\hline \multicolumn{3}{|l|}{ Within dimension } \\
\hline Panel V-stat & $6.1120 * * *$ & $7.3306 * * *$ \\
\hline Panel ROH-stat & $-1.6905^{*}$ & $-1.8976^{*}$ \\
\hline Panel PP-stat & -1.0062 & $-2.2378 *$ \\
\hline Panel ADF-stat & $-3.0770 * *$ & $-5.4475 * * *$ \\
\hline \multicolumn{3}{|c|}{ Between dimension } \\
\hline Group ROH-stat & -0.1736 & 0.8260 \\
\hline Group PP-stat & 0.4766 & 0.7821 \\
\hline Group ADF-stat & $-1.4996 *$ & $-2.0239 *$ \\
\hline
\end{tabular}

Table 2: Pedroni Cointegration Test Results

Note: ***, **, *, refers to statistical significance at $1 \%, 5 \%$, and $10 \%$ levels.

\subsection{Panel cointegration estimation of DOLS and FMOLS}

The analysis of Pedroni's cointegration only examines the existence of cointegration, however, it does not have the ability to estimate the long-run relationship among the variables in the panel framework. Thus, Fully Modified Ordinary Least Square (FMOLS) and Dynamic Ordinary Least Square (DOLS) are employed in this study. The main point of applying two different estimation techniques is to examine the consistency of results to make a precise decision. In the cointegrated panel regression, FMOLS and DOLS estimators consider more reliable (Kao and Chiang, 2000).

FMOLS estimation corrects the problems of deviations in the standard fixed effect estimator that be caused by the existence of heteroscedasticity or/and autocorrelation problem. The method of DOLS has a characteristic of resolving the problem of deviations in the static regression that be caused by endogeneity (Fatih and Mehmet,2014). Moreover, FMOLS estimation allowing significant heterogeneity among the individual sections, consider the possibility of correlation exists amongst the constant and regressors and error term (Asteriou and Hall, 2007). 


\begin{tabular}{|c|c|c|c|}
\hline \multicolumn{4}{|c|}{$\operatorname{Ln} \mathrm{GDP}_{\mathrm{i}}=\beta_{0}+\beta_{1} \ln \mathrm{EXP}_{\mathrm{i}}+\beta_{2} \ln \mathrm{IMP}_{\mathrm{i}}+\mathrm{u}_{\mathrm{i}}$} \\
\hline variables & Coefficient & t statistic & P-value \\
\hline $\operatorname{Ln}(\mathrm{EXP})$ & 0.888254 & 2.649301 & 0.0087 \\
\hline Ln(IMP) & -0.711941 & -2.104718 & 0.0366 \\
\hline \multicolumn{4}{|c|}{$\operatorname{Ln} \mathrm{EXP}_{\mathrm{i}}=\beta_{0}+\beta_{1} \ln \mathrm{GDP}_{\mathrm{i}}+\beta_{2} \ln \mathrm{IMP}_{\mathrm{i}}+\mathrm{u}_{\mathrm{i}}$} \\
\hline variables & Coefficient & t statistic & P-value \\
\hline Ln(GDP) & 0.086422 & 2.521749 & 0.0125 \\
\hline Ln(IMP) & 0.984048 & 163.2938 & 0.0000 \\
\hline
\end{tabular}

Table 3: Results of panel DOLS estimation

Note: statistical significance accepts at 5\%.

Results of DOLS estimation in Table 3 show that there is a statistically significant long-run relationship among variables, exports in a positive and imports in a negative statistical way in accordance with the theoretical expectation. The elasticity of export variable was calculated as 0.888 . Which indicates that over long-run, a $1 \%$ increase in export volume across the 7 selected MENA countries brings about $0.88 \%$ percent increase in output. The second part of the results shows that output also affects the volume of real export in a positive statistically significant way in accordance with the theoretical expectation. The elasticity of output was estimated at 0.086 . Hence across the 7 selected MENA countries, a 1\% increase of output in the long-run the volume of real export nearly $0.086 \%$ constitutes an increase.

\begin{tabular}{|c|c|c|c|}
\hline \multicolumn{4}{|c|}{$\mathrm{Ln} \mathrm{GDP}_{\mathrm{i}}=\beta_{0}+\beta_{1} \ln \mathrm{EXP}_{\mathrm{i}}+\beta_{2} \ln \mathrm{IMP}_{\mathrm{i}}+\mathrm{u}_{\mathrm{i}}$} \\
\hline variables & Coefficient & t statistic & P-value \\
\hline $\operatorname{Ln}(\mathrm{EXP})$ & 0.619512 & 2.608580 & 0.0096 \\
\hline Ln(IMP) & -0.440176 & -1.842512 & 0.0666 \\
\hline \multicolumn{4}{|c|}{$\operatorname{Ln~EXP}_{\mathrm{i}}=\beta_{0}+\beta_{1} \ln \mathrm{GDP}_{\mathrm{i}}+\beta_{2} \ln \mathrm{IMP}_{\mathrm{i}}+\mathrm{u}_{\mathrm{i}}$} \\
\hline variables & Coefficient & t statistic & P-value \\
\hline Ln(GDP) & 0.078642 & 2.214157 & 0.0277 \\
\hline Ln(IMP) & 0.985089 & 152.3052 & 0.0000 \\
\hline
\end{tabular}

Table 4: Results for Panel FMOLS

Note: statistical significance accepts at $5 \%$.

Table 4 displays the results of FMOLS method, the analysis points out that in the long-run both exports and imports affect output, respectively, in a positive and negative statistically significant signs. The elasticity of export was estimated as 0.6195 . Thus, in the long run, a $1 \%$ increase in the volume of Export across the 7 selected MENA countries causes an increase of around $0.62 \%$ in output. Also, the second part of the analysis reveals that output affects the volume of exports in a positive and statistically significant sign. The elasticity of output was estimated as 0.0786 . Which means that a $1 \%$ increase in output in the long run across the 7 selected MENA countries leads to $0.079 \%$ increase in the volume of real exports.

\subsection{Panel Causality Findings}

As indicated by the cointegration approach, if there is a long-run relation amongst variables in all groups, a causality link must exist in no less than one direction. The causality relationship among Exports and output growth has been researched utilizing the technique prescribed by Canning and Pedroni (2008). This technique bears pivotal significance in that it gives information about the existence as well as the direction of long-run causality among the variables and also the sign of this causal relation (Melike and Eda, 2015).

\begin{tabular}{|l|l|c|c|l|}
\hline direction & Null hypothesis & Wald stat & Zbar-stat & p-value \\
\hline EXP $\rightarrow$ GDP & EXP does not homogeneously cause GDP & 6.90734 & 9.81253 & 0.0000 \\
\hline GDP $\rightarrow$ EXP & GDP does not homogeneously cause EXP & 1.33013 & 0.44932 & 0.6532 \\
\hline
\end{tabular}

Table 5: Panel Causality Results of Export and Economic Growth

Note: statistical significance accepts at 5\%.

According to the panel causality results, as Table 5 illustrates, the Waled and Z-bar statistics indicate a unidirectional causality relation among export and output. when the causality at the first phase across the panel running from export to the output is examined, the null hypothesis H0 (EXP does not homogeneously cause GDP) is rejected at 5\% level of significance. Within this frame, the results of the panel causality point out the existence of a long-run causality relation ranging from export to output. The second phase when a long term causality from GDP to real export was tested, the null hypothesis H0 (GDP does not homogeneously cause EXP) cannot be rejected at $5 \%$ level of significance. Therefore, the findings demonstrate no existence of a long-run causality link ranging from output to export. 


\section{Conclusions}

Using Johansen approach to panel cointegration, this study attempts to investigate the validity of ELG hypothesis in seven selected MENA countries, namely, Algeria, Egypt, Sudan, Jordan, Saudi Arabia, UAE, and Qatar. Unequivocally, in the case of encouraging exportation, as has been recommended by numerous international foundations and notable economists is the main strategy in order to improve the growth in the economy.

From the empirical results, it was seen that the first differences of time series utilized in the investigation of panel unit root are stationary at the 5\% level of significance, implying that the investigated variables (Exports (lnexp), Imports (lnimp) and output (lnGDP)) are integrated of order [I(1)]. Accordingly, the cointegration analysis has been performed. Results of Pedroni cointegration tests refer to the existence of a long-run cointegrating relation amongst the variables.

The long-run cointegration relationship is examined by utilizing FMOLS and DOLS estimators. As indicated by the estimations of DOLS test, GDP elasticity of real exports volume is determined as 0.888 . In other words, a $1 \%$ increase in real export in the seven selected MENA countries results in nearly $0.89 \%$ percent increases in GDP over the long-run. Moreover, as pointed out by DOLS estimators, in the long-run the elasticity of real export of GDP is computed as 2.649. This indicates that a 1\% increase in GDP for the seven selected MENA countries gives a rise of around $2.65 \%$ in the total real export.

As specified by FMOLS estimators, GDP elasticity of real export is calculated as 0.6195 . That is to say, over the long-run a $1 \%$ increase in real exports across the seven selected MENA countries leads to an increase of around $0.62 \%$ in GDP. Also, the FMOLS results refer to that the real export elasticity of GDP is indicated as 0.0786 . In other words, over the long-run, a 1\% increase in GDP in the seven selected MENA countries leads to an increase of nearly $0.079 \%$ in the real export. Eventually, it can be concluded that both the results from FMOLS and DOLS estimators are consistent with each other.

Based on statistics of waled and z-bar, panel Granger causality results point out unidirectional causality relations among export (EXP) and output (GDP), this unidirectional causality relationship runs from Export towards output at the $5 \%$ level of significance. Which confirm the validity of Export-led growth hypothesis over the data of seven selected MENA countries during (1980-2017). These empirical findings have an important implication whether seem to propose that export plays a significant role as an engine for economic growth, hence, policy-makers should, therefore, pursue policies that promote export expansion.

\section{References}

- Aamer Abu-Qarn and Suleiman Abu-Bader, 2001. "The Validity of the ELG Hypothesis in the MENA Region: Cointegration and Error Correction Model Analysis", Department of Economics, Ben-Gurion University of the Negev, MPRA 1116.

- Alberto Behar and Caroline Freund, 2011. "The Trade Performance of the Middle East and North Africa", International Monetary Fund, world bank, Working Paper 53, p. 24-27.

- Baltagi, B. H, 2011. Econometrics. Fifth Edition, Springer, New York.

- Bassam Abual-Foul (2004) Testing the export-led growth hypothesis: evidence from Jordan, Applied Economics Letters, 11, p. 393-396.

- Canning D. \& Pedroni, P, 2008. "Infrastructure, Long-run Economic Growth and Causality Tests for Cointegrated Panels", The Manchester School, 76 (5).

- Chia Yee, 2016, "Export-Led Growth Hypothesis: Empirical Evidence from Selected Sub-Saharan African Countries", Procedia Economics and Finance, p. 232 - 240.

- Dimitrios Asteriou and Stephen G.Hall, 2007. Applied Econometrics: A modern Approach using E.views and Microfit, Palgrave Macmillan, New York.

- Diwan, Ishac Squire, Lyn MNA Diwan, Ishac Squire, 1992. Economic and social development in the Middle East and North Africa, World Bank, http://documents.worldbank.org/curated/en/191861468753028968/Economic-and-social-development-inthe-Middle-East-and-North-Africa.

- Faith yardimcioglu, T. G. and M. Altundemir, 2014. "Education and Economic Growth: A Panel Cointegration Approach in OECD Countries (1980-2008)", Education and science, 39.

- Gujarati, D. N., 2004. Basic Econometrics, Fourth Edition, the McGraw-Hill, New York.

- Haddad Mona, 1993. The link between trade liberalization and multi-factor productivity: the case of Morocco (English). Middle East and North Africa working paper, World Bank. http://documents.worldbank.org/curated/en/772151468774000940/The-link-between-trade-liberalizationand-multi-factor-productivity-the-case-of-Morocco. 
- Helmi Hamdi, 2013. "Testing Export-led Growth in Tunisia and Morocco: New Evidence using the Toda and Yamamoto procedure", Cergam CAE- Aix-Marseille University.

- Husein, J., 2009. "Export-Led Growth Hypothesis: A Multivariate Cointegration and Causality Evidence for Jordan", The Journal of Developing Areas, 42 (2).

- Im, K. S. Pesaran, M. H. \& Shin, Y. ,2003. "Testing for unit roots in heterogeneous panels", Journal of Econometrics, 115, p.53-74.

- Jamal Husein, 2010. "Export-led Growth Hypothesis in the MENA region: a multivariate cointegration, causality and stability analysis", Applied Econometrics and International Development, Applied Economics Letters, 11, p.393-96.

- Kao, C., Chiang, M.H., 2000. "On the estimation and inference of a cointegrated regression in panel approach”, Economic Modeling, 23, p.987-992.

- $\quad$ Levin, A., Lin, C. \& Chu, C.J., 2002. "Unit root tests in panel data: Asymptotic and finite sample properties", Journal of Econometrics, 108, p.1-24.

- Melike Bidirici , Eda Bohur ,2015. "Design and Economic Growth: Panel Cointegration and Causality Analysis”, Procedia - Social and Behavioral Sciences, 210 , p.193 - 202.

- Melise Jaud and Caroline Freund, 2015. "Promoting Exports in the Middle East and North Africa", first MENA Trade Workshop, Tunis, p.14-15.

- Pedroni, P., 2000. "Fully-Modified OLS for Heterogeneous Cointegrated Panels", Advances in Econometrics, 15, p.93-130.

- Pedroni, P., 2001. "Purchasing power parity tests in cointegrated panels", Review of Economics and Statistics, 83, p.727-731.

- Pomponio, X.Z., 1996. “A Causality Analysis of Growth and Export Performance”, Atlantic Economic Journal, 24, p. 168-176.

- $\quad$ Rifat Tekin, 2012. "Economic growth, exports and foreign direct investment in Least Developed Countries: A panel Granger causality analysis”, Economic Modelling, 29, p.868-878. 


\title{
A Different Look at Cointegration Relationship between Quarterly Inflation Rates and Growth via Seasonal Integration Tests
}

\author{
Ph.D. Candidate Sera Şanlı (Çukurova University, Turkey) \\ Prof. Dr. Mehmet Özmen (Çukurova University, Turkey)
}

\begin{abstract}
Detecting the direction of inflation-growth relationship has been a controversial issue in terms of the theoretical framework, notedly since the rise of Mundell-Tobin effect which is based upon the assumption of substitutability between money and capital. In this study, it has been aimed to investigate the cointegrating relationship and its direction between inflation and economic growth covering the period 1998Q1:2014Q4 for Turkey as grounded on the testing sequence that is illustrated by Ilmakunnas (1990) in order to handle unit root testing in a seasonal context by testing the appropriate order of differencing and concerns with the case where $\operatorname{SI}(2,1)$ (seasonally integrated of order $(2,1)$ ) is the maximum order of seasonal integration. It has been also utilized from ADF unit root test and DHF, HEGY \& OCSB seasonal unit root tests in seasonal integration analysis. In the study, five cointegration regressions have been considered in the level, seasonally averaged, quarterly differenced, first differenced and twice differenced forms and two series have been found to have the same degree of seasonal integration as SI(1,1). Applying various residual tests have revealed the presence of a cointegrating relationship between two variables. In addition, the inflation-growth relationship in Turkey has been concluded to perform in an opposite direction.
\end{abstract}

\section{Introduction}

Inflation is one of the most important facts in our daily life referring to a sustained increase in consumer prices which can be measured through consumer price index (CPI), producer price index (PPI) or gross domestic product (GDP) deflator. Along with economic growth, they take place among the most crucial macroeconomic indicators giving information about the economic structure of a country and analysing the inflation-growth relationship has been a fundamental issue in empirical economic research especially starting from the rise of Mundell-Tobin effect which has been grounded on the assumption of substitutability between money and capital. Besides, the high inflation rates that have been experienced after World War II also gave rise to economists to put more weight on this issue.

The pioneering study by Phillips (1958) can be regarded as the most crucial approach which claimed a positive relationship between inflation and economic growth via Phillips curve analysis and this analysis reveals a negative correlation between inflation and unemployment rate. Thus, high inflation rates and decreased unemployment rates due to high employment relationship will contribute to economic growth in a positive direction. However, later studies have shown that this relationship will be able to be valid in the case of short run and expected inflation (Cetintas, 2003). According to the Mundell-Tobin framework, an increase in the rate of inflation will result in a positive influence on capital accumulation in the long run by creating a shift towards capital in the household portfolios through an increase in the cost of holding money and therefore will also lead to a higher economic growth. Consequently, as expressed by the Tobin (1965), one more time it can be mentioned about a positive relationship between inflation and economic growth (De Gregorio, 1996). The devaluation of the Turkish lira in the year 1970 and the continuous increases in oil prices in the same years increased the cost of imported capital goods and formed the starting point and the basis of the high inflation process. Depending upon increasing inflationary pressures and also due to hampered capital accumulation and technical progress, Turkey faced with a very serious balance of payments crisis in 1978. These developments resulted in a decreasing growth \& rapidly increasing inflation and therefore, 1970s can be specified as the years in which inflation is imported from outside (Cetintas, 2003). On the other hand, along with many macroeconomists, Friedman (1977) has suggested that greater inflation uncertainty followed by an increase in inflation may create negative output growth effects coming out through inflation uncertainty that will lessen economic efficiency. When evaluated from this point of view, the sign of the relationship between inflation and economic growth has been frequently a controversial issue with respect to both theoretical framework and application results.

In the literature, although many studies investigating the relationship between inflation and economic growth are separated as linear or nonlinear; no clear picture has been put forward in the empirical studies presented on the relationship between these variables.

Mallik and Chowdhury (2001) have tried to reveal the relationship between inflation and GDP growth for four South Asian countries using Johnsen-Juselius co-integration test and error correction models covering the periods 1974-1997 for Bangladesh; 1961-1997 for India; 1957-1997 for Pakistan and 1966-1997 for Sri Lanka. As a result, findings have shown the presence of a long-run positive relationship between GDP growth rate and inflation. 
Wilson (2006) has made a research on the association between inflation, inflation uncertainty and output growth using Japanese CPI and real GDP data for post-war period covering 1957Q4-2002Q3 and carried out a bivariate exponential generalized autoregressive conditional heteroskedasticity in mean (EGARCH-M) model as related to output growth and inflation in the analysis. As a result, the Engle-Granger and Johansen cointegration tests have pointed to the absence of cointegration between the logarithms of the CPI and real GDP in Japan.

Erbaykal and Okuyan (2008) have examined the existence of long-term relationship between the inflation and economic growth covering the period 1987Q1-2006Q2 by using Bound Test developed by Pesaran, Shin \& Smith and found a cointegration relationship between two series. However, ARDL models have revealed a negative statistically significant short-run relationship, but no statistically significant long-run relationship between economic growth and inflation series.

In their study, Adrián Risso and Sánchez Carrera (2009) have made an investigation on the long-run relationships and threshold effects between inflation and economic growth for the Mexican Economy using annual data for the period 1970-2007 and found a significant and negative long-run relationship between these variables using Johansen's cointegration approach.

Karacor, Saylan and Ucler (2009) have analysed the relationship between quarterly inflation and economic growth series in Turkey over the period 1990-2005 using Johansen cointegration test. Max eigenvalue and trace statistics have shown that inflation and economic growth are cointegrated at the long-run. Also, inflation has been found to influence economic growth in a negative direction.

Kasidi and Mwakanemela (2013) have examined the relationship between inflation and growth variables through the data covering the period 1990-2011 for Tanzania. They have investigated the impact of inflation on economic growth by modifying the model proposed by Khan and Senhadji (2001) and using reduced form regression equation and found a negative effect of inflation on economic growth. In addition, Johansen cointegration results have revealed the absence of co-integration between inflation and economic growth in Tanzania.

Behera (2014) have tried to reveal the links between inflation and economic growth for seven south Asian countries using panel data analysis covering annual data for the period of 1980-2013 and found a negative association between variables in question. In addition, panel cointegration test proposed by Pedroni (1999) has pointed to the presence of a long-run relationship between inflation and GDP growth.

Epaphra (2016) covers a nonlinear relationship between inflation and economic growth in Tanzania by trying to determine the presence of threshold effects between these series by making use of annual data for the period 19672015 based on a quadratic and threshold endogenous models. Johansen cointegration test results have revealed a stable long-run relationship between economic growth, inflation rate, the squared term of inflation rate, total investment-to-GDP ratio, trade-to-GDP ratio, population growth rate and economic reform variables. Also, a negative relationship has been observed between inflation and growth series that are also statistically significant in Tanzania.

Behera and Mishra (2016) have examined the relationship between inflation and economic growth for BRICS countries covering the period 1980-2012 and utilized from Autoregressive Distributed Lag Model (ARDL) bound testing approach to reveal cointegration relationship. According to the Trace and eigen value statistics findings given in Johansen test results, it has been reported that only China and South Africa have experienced a long run (cointegrating) positive relationship between inflation and economic growth at 5\% significance level and there has been found no long-run relationship between given variables for the rest of the BRICS countries. On the other hand, ARDL test results have not detected any long-run relationship for BRICS countries.

In her study, Topcu (2017) has aimed to investigate the cointegration and causality relationship between inflation and economic growth over the period 2006Q1-2017Q2 for Turkish economy through Granger causality test. According to the Johansen (1988) cointegration test results, no long-run relationship has been detected between two variables and it has been found a uni-directional causality from economic growth to inflation.

In this study, it has been aimed to investigate the cointegrating relationship between quarterly inflation and economic growth variables covering the period 1998Q1:2014Q4 for Turkey as based on the seasonal integration tests proposed by Ilmakunnas (1990).

The rest of the paper has been structured as follows: Section 2 introduces the theoretical framework regarding seasonal unit roots and seasonal integration testing sequence for quarterly data proposed by Ilmakunnas (1990). Section 3 presents data set used throughout the research and application results. Finally, Section 4 provides a brief summary of general conclusions of the study as combined with discussions.

\section{Theoretical Framewok for Testing Seasonal Integration}

It has been utilized from Augmented Dickey Fuller (ADF) unit root test and some seasonal unit root tests which are DHF test proposed by Dickey, Hasza \& Fuller (1984), HEGY test proposed by Hylleberg, Engle, Granger \& Yoo (1990) and OCSB test proposed by Osborn, Chui, Smith \& Birchenhall (1988) test in seasonal integration analysis. However, in order to save space, these tests will not be discussed here. 
The nonstationary stochastic process $y_{t}$, observed at $\mathrm{S}$ equally spaced time intervals per year, is said to be seasonally integrated of order $\mathrm{d}$, denoted $y_{t} \sim S I(d)$, if $\Delta_{S}^{d} y_{t}$ is a stationary, invertible ARMA process. Here $\Delta_{S}$ denotes the seasonal differencing filter. Applying seasonal differencing to a deterministic seasonal process prompts the existence of first order annual differencing operator $\Delta_{S}$ in the MA operator and this will lead to noninvertibility of MA operator. Therefore, a deterministic seasonal process and a seasonally integrated process are not identical processes (Ghysels and Osborn, 2001).

Another definition for a seasonally integrated series is a simplified version of the definition given by Engle, Granger and Hallman (1989) for a seasonally integrated series as: A nonstationary series is said to be seasonally integrated of order $(d, D)$, denoted $S I_{s}(d, D)$, If it can be transformed to a stationary series by applying sdifferences $D$ times and then differencing the resulting series $d$ times using first differences.

In a simple manner, a seasonal difference is the difference between an observation and its value for the corresponding season one year before. If the series is measured s times per annum (for quarterly data, $s=4$ and for monthly data $s=12$ ) and it displays a seasonal pattern, then the differencing to remove seasonality should be $s$ rather than one. So, the type of operator to be applied here is $x_{t}-x_{t-s}$ (representing seasonal difference) instead of $x_{t}-x_{t-1}$. Here, the transaction to get these variables is called seasonal differencing or s-differencing. Generally, it is very rare to use s-differencing more than once in order to remove seasonality. Taking seasonal differences transforms a linear trend with an additive seasonal effect to a constant (that is, to a variable with no trend or seasonal pattern). If this transaction is applied to a quadratic trend (where the trend is nonlinear) with additive seasonality, it brings about a series still including a trend component but with no seasonal pattern. So, in order to make such a series is stationary, first differencing of the s-differences may be required (Charemza and Deadman, 1992).

Ilmakunnas (1990) has tried to illustrate a testing sequence in order to test the appropriate order of differencing in quarterly data. Introducing this testing sequence requires two alternative definitions of seasonal integration. According to the first definition which is the one defined by Osborn et al. (1988), a time series is said to be integrated of order $(d, D)$, denoted $I(d, D)$ if the series becomes stationary subsequent to first-differencing $d$ times and seasonally differencing $D$ times. In other saying; if $(1-L)^{d}\left(1-L^{S}\right)^{D} x_{t}=\Delta^{d} \Delta_{S}^{D} x_{t}$ becomes stationary, $x_{t}$ is said to be $I(d, D)$. In the paper proposed by Ilmakunnas (1990), since the focus is on the quarterly time series $s=4$, it is concerned with the case where $I(1,1)$ is the maximum order of integration. The second alternative definition for seasonal integration comes from Engle, Granger and Hallman (1989) that has already been mentioned above. To this definition; if $(1-L)^{d} S(L)^{D} x_{t}=\Delta^{d} S(L)^{D} x_{t}$ is stationary, $x_{t}$ is said to be seasonally integrated of orders $d$ and $D$ expressed as $S I(d, D)$ where $S(L)$ is a seasonal filter used in transforming the variables to moving sums. In the case of quarterly data, seasonal filter is stated as $S(L)=1+L+L^{2}+L^{3}$ and it takes place in the decomposition of $\Delta_{4}=(1-L) S(L)=(1-L)(1+L)(1+i L)(1-i L)$. Since $\quad \Delta_{4} \quad$ is decomposed as $(1-L)^{2} S(L) \quad$ or $(1-L)[(1-L) S(L)]=(1-L)\left(1-L^{4}\right), S I(2,1)$ and $I(1,1)$ are the same. In the same manner, $S I(1,0)$ is the same as $I(1,0)$ and also $S I(1,1)$ and $I(0,1)$ are the same.

To illustrate the testing sequence for quarterly data, starting point is taken as the maximum order of seasonal integration, i.e. the case $S I(2,1)$. This testing sequence has been shown in Figure 1. The representation in Figure 1 pursues the view proposed by Dickey and Pantula (1987). According to their view, if it is mentioned about multiple unit roots, the best thing is to start the testing sequence from the maximum number of unit roots in hand and in this case the nominal test size is preserved. Therefore, it can be expressed that determining the suitable integration order is based on the starting point of the testing sequence (Ilmakunnas, 1990). Ilmakunnas (1990) mentions about how to handle unit root testing in a seasonal context considering the initial test of the ${ }^{S I(2,1)}$ null hypothesis. In the study, it is expressed that $S I(2,1)$ is tested against $S I(2,0), S I(1,1)$ and $S I(1,0)$ alternatives using the HEGY test regression applied to $\Delta X_{t}$ rather than to $X_{t}$ (for seasonal integration tests associated with different hypotheses in details, see Ilmakunnas, 1990). 


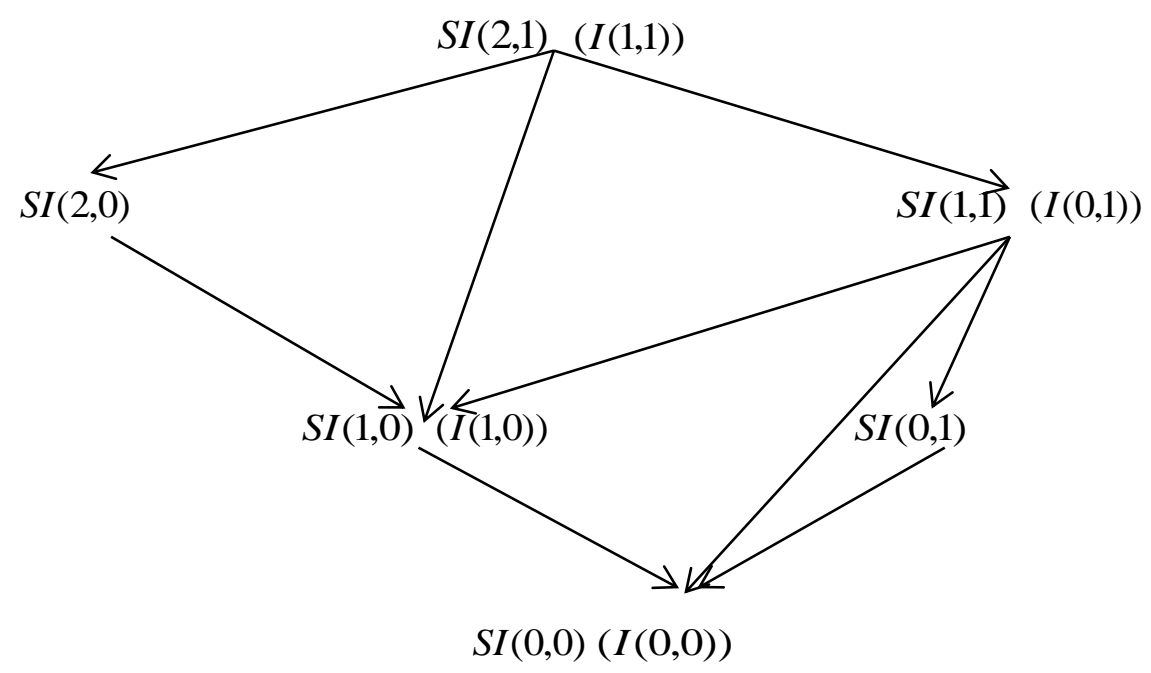

Figure 1. The Testing Sequence for Determining the Appropriate Seasonal Integration Order in Quarterly Data (Source: Ilmakunnas, 1990).

In case we reject the null hypothesis in favour of either $S I(1,1)$ or $S I(1,0)$ alternatives, we have to check the presence of zero frequency unit root against $S I(0,1)$ or $S I(0,0)$ processes, respectively continuing for testing against lower orders of integration (Ghysels and Osborn, 2001).

\section{Data Set and Application}

Inflation is one of the most important facts in our daily life referring to a sustained increase in consumer prices and it can be measured through CPI, PPI or GDP deflator. However, it is generally measured as a change in the harmonized index of consumer prices (HICP) that has been harmonized across all European Union member states. Holmes (2014) has presented the definition of HICP as "The HICP is the measure of inflation which the governing council uses to define and assess price stability in the Euro area as a whole in quantitative terms." (p.16). With respect to providing a joint measure of inflation by making international comparisons easier, in this study it has been utilized from HICP in order to measure inflation.

In the application part, first seasonal integration tests will be applied in a unified approach for inflation rates and growth variables and after determining the seasonal integration orders of these variables, the cointegration relationship between them will be investigated. Inflation data have been derived through $I N F=\frac{C P I_{t}-C P I_{t-1}}{C P I_{t-1}} .100$ and real gdp growth rates have been obtained by $G R=\frac{G D P_{t}-G D P_{t-1}}{G D P_{t-1}} .100$ transformation where INF denotes inflation rate, $C P I_{t}$ denotes consumer price index at time $t$ and $C P I_{t-1}$ denotes consumer price index at time $t$-1, GR denotes real gdp growth rate and GDP denotes real GDP. For deriving inflation data, we have utilized from quarterly HICP data (with Index 2010=100) as CPI for Turkey and HICP data have been obtained from Organization for Economic Co-operation and Development. On the other hand, GDP data have been collected from Central Bank of the Republic of Turkey (CBRT). In Figure 2, plots of inflation and growth variables have been presented in the same graph in terms of giving a clue about their cointegrating relations. Since it is seen that they are moving together in the graph, they are highly possible to be cointegrated.

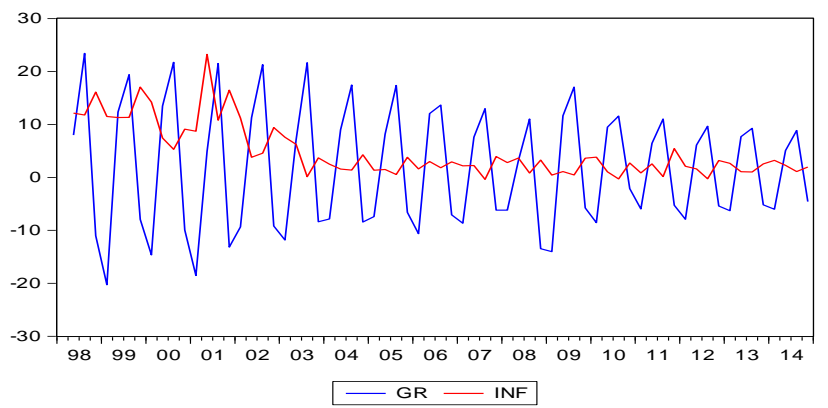

Figure 2. Graphs of Quarterly Growth Rates and Inflation Rates Together against Time over 1998Q1-2014Q4 Period 
In this application, seasonal integration tests will be applied for quarterly data on the real gdp growth rates and inflation over 1998Q1:2014Q4 period by taking the study of Ilmakunnas (1990) as basis. When looked at the graphs in Figure 2, it is apparent to see the seasonal behaviors of both INF and GR variables. In ADF and HEGY test applications, constant term and seasonal dummies have been included in the regressions to be applied and seasonal means have not been removed in DHF and OCSB tests. As seen in Figure 2, a decrease (increase) in gdp growth is generally matched by a corresponding increase (decrease) in inflation. Depending on the clear seasonal patterns of these two series, we can recourse to seasonal differencing procedure in order to capture such patterns. Because two series have quarterly frequency, seasonally differenced variables have been obtained by using $\left(1-L^{4}\right)$ operator. Therefore our transformed series that will be called D4INF and D4GR respectively for inflation and growth can be expressed as $D 4 I N F=I N F_{t}-I N F_{t-4}$ and $D 4 G R=G R_{t}-G R_{t-4}$. As a result of these transformations, D4INF and D4GR variables which are seasonally integrated of order SI $(1,1)$ (or integrated of order $I(0,1))$ have been graphed together in Figure 3:

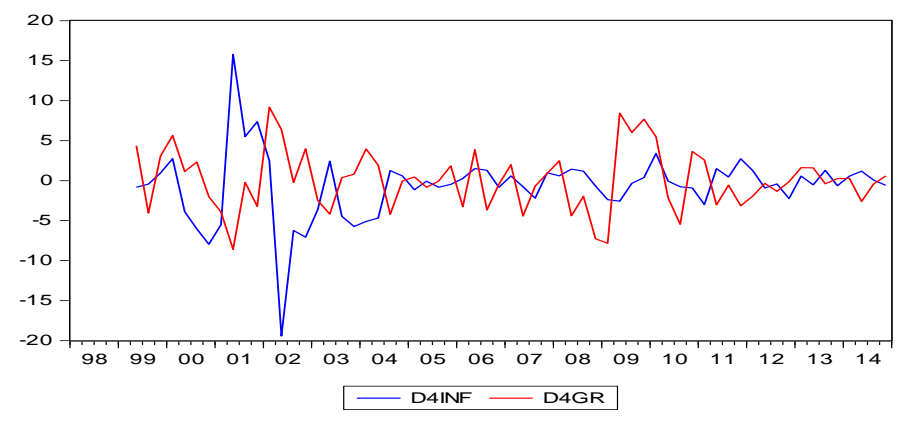

Figure 3. Graph of Seasonally Differenced Growth Rates and Inflation Rates Together

Figure 3 also shows that these seasonally differenced two series are moving together, but at an opposite direction. Thus, it supports the idea that they seem to be cointegrated. 


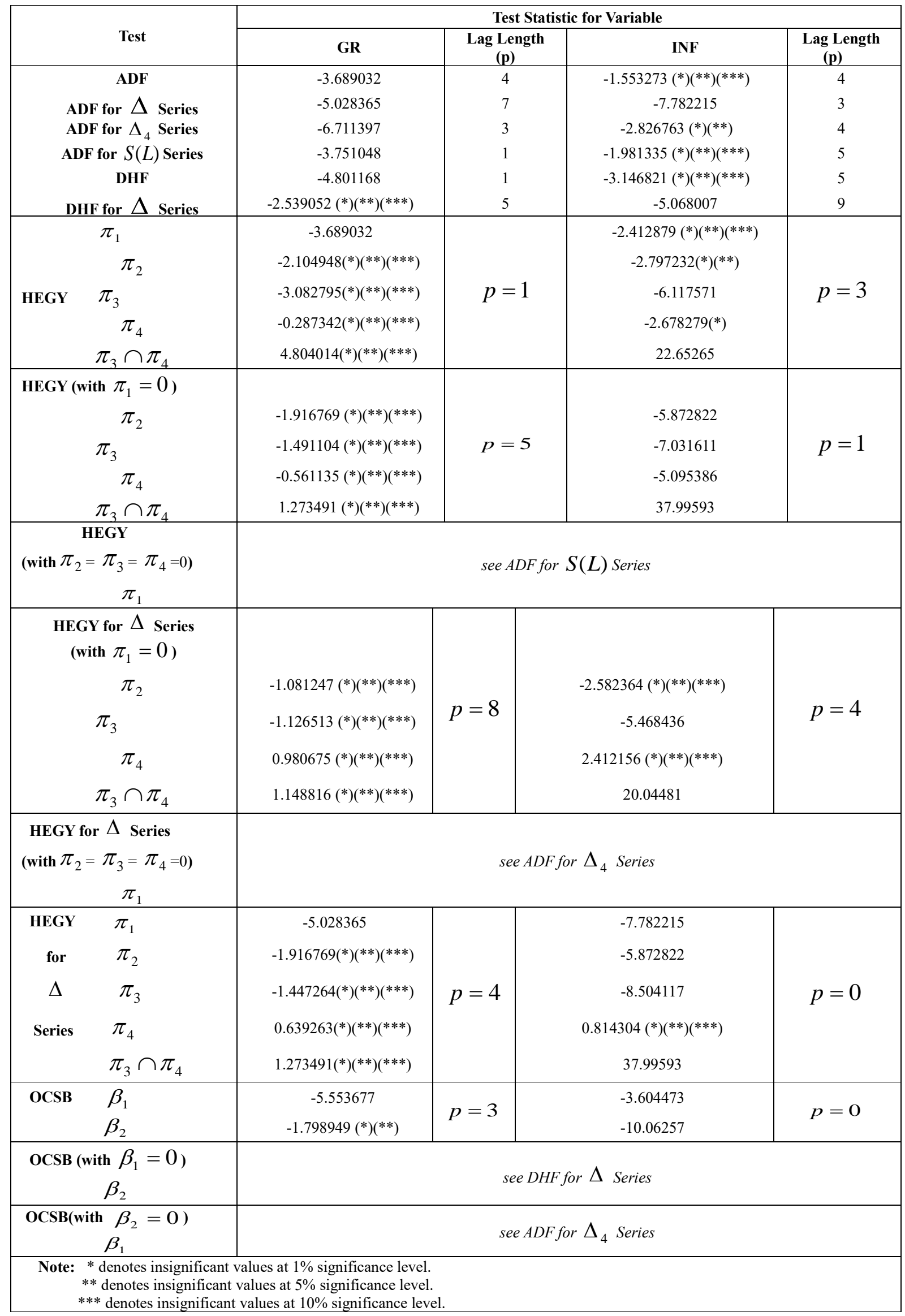

Table 1. Seasonal Integration Test Results for Inflation and Growth Series 
Table 1 presents the results of different seasonal integration tests in order to decide about integration orders of both INF and GR variables. In this application, the selection of lags $(p)$ has been made in a way not to have autocorrelation and heteroscedasticity problems apart from the examination of correlogram of residuals. First, it is necessary to choose appropriate integration orders for inflation and growth by utilizing from the given information in Table 1. In Table 1, the column GR presents the estimates of growth variable and the column for INF gives the estimates for inflation variable under the different regression models. The null and alternative hypotheses corresponding to different models have been mentioned in Ilmakunnas (1990). Therefore, we have three (null) hypotheses that will be used as the starting point of testing sequence: starting point may be either $\operatorname{SI}(2,1)$, SI $(1,1)$ or SI $(1,0)$. As a conclusion of a thorough evaluation on Table 1, the results of these three cases are given in Table 2 along with the accepted hypotheses shown in bold type.

Table 2 presents the accepted hypotheses of growth and inflation variables under the different forms of ADF, DHF, HEGY and OCSB tests. The second "GR" column gives the accepted hypotheses for this variable under the given tests and third column "INF" presents the accepted hypotheses for this variable under the given tests. In addition, the mostly accepted hypotheses for two variables when they are considered together are shown in bold type in Table 2 so that if the starting point is $\operatorname{SI}(2,1)$, mostly $\operatorname{SI}(2,1)$ has been accepted for two variables and if the starting point is $\operatorname{SI}(1,1)$, mostly $\operatorname{SI}(1,1)$ has been accepted.

\begin{tabular}{|c|c|c|}
\hline Case 1: If the starting point is $\mathrm{SI}(2,1)$, & GR(growth) & INF (inflation) \\
\hline$A D F$ for $\Delta_{4}$ & $\operatorname{SI}(1,1)$ & $\begin{array}{l}\text { SI }(2,1) \text { may be accepted for } 1 \% \text { and } 5 \% \text { levels (and } \\
\text { SI }(1,1) \text { may be accepted for } 10 \% \text { level). }\end{array}$ \\
\hline DHF for $\Delta$ & ) & $\mathrm{SI}(1,0)$ \\
\hline $\begin{array}{l}\text { HEGY for } \Delta: \\
\text { while } \pi_{1}=0, \pi_{2}, \pi_{3}, \pi_{4} \text { tested } \\
\qquad \begin{aligned} \pi_{1}, \pi_{2}, \pi_{3}, \pi_{4} \text { tested } \\
\text { while } \pi_{2}=\pi_{3}=\pi_{4}=0, \pi_{1} \text { tested }\end{aligned}\end{array}$ & $\begin{array}{l}\operatorname{SI}(2,1) \\
\operatorname{SI}(2,1)\end{array}$ & $\begin{array}{l}\text { SI }(2,1) \text { can be accepted because of the presence of } \\
\text { unit roots at } \pi_{2} \text { and } \pi_{4} \text {. } \\
\text { SI }(1,0) \text { may be accepted since there is no biannual and } \\
\text { annual unit roots. } \\
\left.\text { (See } A D F \text { for } \Delta_{4}\right)\end{array}$ \\
\hline \multicolumn{3}{|c|}{$\begin{array}{l}* \text { The results of the case "while } \pi_{2}=\pi_{3}=\pi_{4}=0, \pi_{1} \text { tested" in HEGY test for } \Delta \text { are the same as ADF for } \Delta_{4} \text { results. The } \\
\text { results for two series are not certain if the starting point is } \operatorname{SI}(2,1) \text {. However in most cases the hypothesis SI(2,1) cannot be rejected for } \\
\text { growth series and inflation series may be accepted as either SI }(2,1) \text { or SI }(1,0) \text {. }\end{array}$} \\
\hline Case 2: If the starting point is $\mathrm{SI}(1,1)$, & GR(growth) & INF (inflation) \\
\hline$A D F$ for $S(L)$ & $\mathrm{SI}(0,1)$ & 1) \\
\hline DHF: & & \\
\hline $\begin{array}{l}\text { HEGY: } \\
\text { while } \pi_{1}=0, \pi_{2}, \pi_{3}, \pi_{4} \text { tested } \\
\qquad \pi_{1}, \pi_{2}, \pi_{3}, \pi_{4} \text { tested } \\
\text { while } \pi_{2}=\pi_{3}=\pi_{4}=0, \pi_{1} \text { tested }\end{array}$ & $\begin{array}{l}\text { SI }(1,1) \\
\operatorname{SI}(0,1)\end{array}$ & $\begin{array}{c}\text { For \%1 level, SI(1,1) may be accepted. } \\
\text { SI }(\mathbf{1}, \mathbf{1})\end{array}$ \\
\hline OCSB: $\beta_{1} \neq 0, \beta_{2}$ tested & SI( & $\mathrm{SI}$ \\
\hline \multicolumn{3}{|c|}{$\begin{array}{l}\text { *The results of the case "while } \pi_{2}=\pi_{3}=\pi_{4}=0, \pi_{1} \text { tested" in HEGY test are the same as ADF for } S(L) \text { results. As it is seen } \\
\text { obviously, the result of two variables may be in the form of SI(1,1) dominates. }\end{array}$} \\
\hline Case 3: If SI $(1,0)$ is tested, & GR(growth) & INF (inflation) \\
\hline ADF: & $\mathrm{S}$ & \\
\hline $\begin{array}{c}\text { HEGY: } \\
\text { while } \pi_{2}, \pi_{3}, \pi_{4} \neq 0, \pi_{1} \text { tested }\end{array}$ & $\operatorname{SI}(0,0)$ & $\mathrm{SI}(1,0)$ \\
\hline OCSB: $\beta_{2} \neq 0, \beta_{1}$ tested & $\mathrm{SI}(0,0)$ & $\mathrm{SI}(0,0)$ \\
\hline \multicolumn{3}{|c|}{$\begin{array}{l}\text { Note. }{ }^{1} \text { Bold expressions have been used to highlight mostly accepted hypotheses under the starting point in interest. } \\
{ }^{2} \text { For } 1998 \mathrm{Q} 1-2014 \mathrm{Q} 4 \text { period (that is, } 68 \text { observations), in most cases, } \mathrm{N}=100 \text { (observations) has been taken as basis in critical } \\
\text { values tables. } \\
{ }^{3} \mathrm{ADF} \text { critical values have been considered as }-3.51 \text { for } 1 \%,-2.89 \text { for } 5 \% \text { and }-2.58 \text { for } 10 \% \text { significance level for the model } \\
\text { with constant and no trend }(\mathrm{N}=100 \text { ) (Critical values have been cited from Fuller (1976). } \\
{ }^{4} \mathrm{DHF} \text { critical values have been cited from the table (percentiles, the studentized statistic for the seasonal means model) in } \\
\text { Dickey et al.(1984). For quarterly data, } \mathrm{d} \text { has been considered as } 4 \text { and for DHF test, } \mathrm{n}=\mathrm{md} \text { (total number of observations) has been taken } \\
\text { as } 80 \text { (seasonal means have not been removed). Percentiles of the studentized statistic for the seasonal means model are given as: }-4.78 \text { for } \\
1 \%,-4.11 \text { for } 5 \% \text { and }-3.78 \text { for } 10 \% \text {. } \\
{ }^{5} \mathrm{Critical} \text { values have been obtained from Osborn et al. (1988) for OCSB test (with no seasonal mean subtraction). } \\
{ }^{6} \text { Critical values for HEGY test have been taken from Hylleberg et al. (1990) for the model with intercept and seasonal dummies. }\end{array}$} \\
\hline
\end{tabular}


As Ilmakunnas (1990) expressed, the conclusion on the appropriate order of integration depends on the starting point of testing sequence. If starting from the most general model (case 1 in Table 2), the result is that in most cases the growth variable is stationary after both first differencing and quarterly differencing (in most cases, the null of SI $(2,1)$ is accepted against the other alternative hypotheses) and according to this starting point, it may be concluded that inflation series may be either $\operatorname{SI}(2,1)$ or $\operatorname{SI}(1,0)$ (given in "INF" column). If the starting point is case 2 in Table 2 (or quarterly differencing (that is, SI(1,1)), we cannot obtain accurate results for variables: While INF series may be accepted as $\operatorname{SI}(1,1)$ in most cases, GR series may be $\operatorname{SI}(0,1)$, $\operatorname{SI}(1,1)$ or $\operatorname{SI}(0,0)$.

When looked at the DHF test result in Case 2 where the null hypothesis is $\operatorname{SI}(1,1)$ and the alternative is $\operatorname{SI}(0,0)$, GR variable can be said to reach full stationarity with $\mathrm{SI}(0,0)$ seasonal integration order. The other tests apart from DHF in Case 2 imply that seasonal frequency unit roots clearly can be accepted (or cannot be rejected) for GR variable. However, the evidence is not certain for INF series (it may also be $\operatorname{SI}(1,0)$ or $\operatorname{SI}(0,0)$ other than $\operatorname{SI}(1,1)-$ in other words, it may not include seasonal unit roots).

It is worth mentioning about some equivalences between the seasonal integration tests. In case the main hypothesis to be tested is the presence of seasonal frequency unit roots, i.e. $\pi_{2}=\pi_{3}=\pi_{4}=0$ in the HEGY test, the test regression does not differ from $\mathrm{ADF}$ test for seasonally averaged ( $S(L)$ ) data. In a similar manner, in the case of $\pi_{2}=\pi_{3}=\pi_{4}=0$ in the HEGY test for first differenced data, the test regression is the same as the ADF test for seasonally differenced data. This is also the same as the OCSB test with $\beta_{2}=0$. At last, the OCSB test with $\beta_{1}=0$ is the same as the DHF test for first-differenced data (Ilmakunnas, 1990).

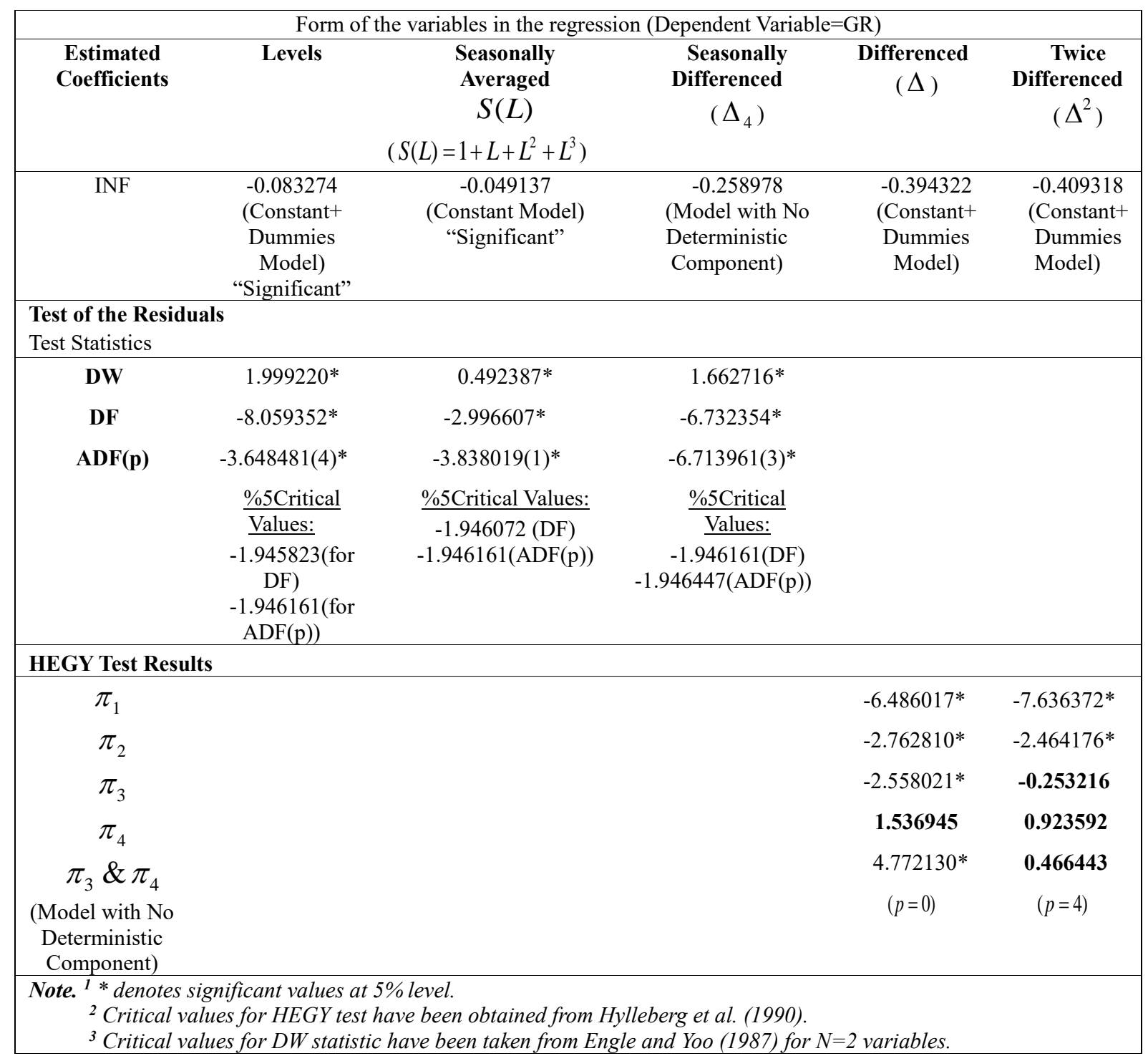

Table 3. Cointegration Results for Growth Equation 
One of the most important problems in applying integration tests is the appropriate choice of the value of lag length $\mathrm{p}$ to be used: too low a value gives rise to invalid statistics due to autocorrelation left in the residuals; on the other hand, the implication of an extremely high lag length is a reduction in power (Osborn et al., 1988). In this application, in selecting the appropriate lag lengths, LM test statistics for residual autocorrelation have been calculated and examined up to order four for all test regressions. Lag lengths have been increased one by one until detecting no significant autocorrelations at the 5\% level. All applications in this section have been carried out in R.3.1.3. version and Eviews 7.

Now we will have a different look at cointegration relationship between INF and GR series for growth equation in which dependent variable is economic growth (GR) and independent variable is inflation (INF). Table 3 shows the cointegration results for growth equation. Since there are two variables in our model, at most one cointegrating relation can be found. In Table 3, "p" shows the necessary lag numbers that will be included in the regressions applied.

When the growth equation is taken into consideration, it can be said that the resulted statistics can be used to give a clue about whether the variables are cointegrated or not at seasonal frequencies. For the first three models in Table 3 which are given in level form, seasonally averaged form and seasonally differenced form, respectively; all tests of the residuals (DW, DF, ADF) strongly suggest that the variables are cointegrated (where the null hypothesis is $H_{0}$ : no cointegration and the alternative one is $H_{1}$ : cointegration exists) (in other saying, the evidence against no-cointegration is said to be very strong).

When we look at the first differenced $(\Delta)$ and twice differenced variables $\left(\Delta^{2}\right)$, it is seen that the evidence of cointegration is strong when differenced variables are considered with significant $\pi_{i}$ estimates at seasonal

frequencies. However in the twice differenced form, since $\pi_{3}$ and $\pi_{4}$ estimates regarding annual unit root are not significant, we cannot strictly say that twice differenced variables are cointegrated at seasonal frequencies even though only $\pi_{2}$ is significant.

Level form regression results show the existence of one cointegrating relation with significant residual test statistics which are Durbin-Watson (DW), DF and ADF test statistics. The seasonally averaged form results (S(L)) also support this result with significant ADF, DW statistics obtained for the residuals of given regressions.

Empirical results reveal that all forms of the variables except twice-differenced $\left(\Delta^{2}\right)$ form show the sign of cointegration. Therefore, this analysis in which GR is dependent variable and INF is independent variable has revealed that the variables in question are $\mathrm{SI}(1,1)$. Since seasonally averaged $(S(L))$ variables have been found to be cointegrated of order 1 at zero (non-seasonal) frequency and first differenced variables $(\Delta)$ have been found to be cointegrated at seasonal frequencies. Thus, it can be said that in growth-inflation model, it would be suitable to incorporate the variables in $\Delta_{4}$ form into the regression.

\section{Conclusion}

At the core of this analysis, how different seasonal integration tests can be carried out in a unified approach lies. In the study, various seasonal integration tests have been carried out in order to detect the appropriate order of seasonal integration. Seasonal integration results imply that growth and inflation variables may be either SI $(2,1)$ or $\mathrm{SI}(1,1)$ in the dominant sense. Therefore we have taken five cointegration regressions in the level, seasonally averaged $(\mathrm{S}(\mathrm{L}))$, quarterly differenced $\left(\Delta_{4}\right)$, first differenced ( $\Delta$ ) and twice differenced ( $\Delta^{2}$ ) forms. In the level form, GR series has been regressed on INF series. In the level, differenced and twice differenced forms; a constant and three seasonal dummies have been included and in the seasonally averaged form, a constant has been added. As a result of the application, two series have been found to have the same degree of seasonal integration as $\operatorname{SI}(1,1)$. Thus, based on the information that inflation and growth series have the same integration order (both are SI $(1,1)$ ) and by applying various tests (DW, DF, ADF, HEGY) to the residuals obtained from the regression equations formed by using difference operators and raw data, whether there is a long-term relationship between the series or not has been examined through the cointegration analysis and the analysis has revealed that both series in their level forms are cointegrated. When the results of regression analyses are considered in terms of economic interpretation, the inflation-growth relationship in Turkey has been understood to be in an opposite direction. This has been confirmed by the negative sign of the coefficient of INF variable in any case. According to the results of regression analyses applied, increases in inflation will reduce economic growth over 1998Q1-2014Q4 period.

To summarize, this application addresses the cointegrating relationship between inflation and growth from a different view adopting the approach proposed by Ilmakunnas (1990) by taking the concept of seasonality into consideration. As a result, the presence of a cointegrating relationship has been determined between two variables 
and this means a real long-term relationship. In addition, there should be further reductions in inflation in order to increase the average growth rate declining gradually in recent years.

\section{References}

- Adrián Risso and Sánchez Carrera, 2009. "Inflation and Mexican Economic Growth: Long-Run Relation and Threshold Effects", Journal of Financial Economic Policy, 1, pp. 246-263.

- Behera, 2014. "Inflation and Economic Growth in Seven South Asian Countries: Evidence from Panel Data Analysis". EPRA International Journal of Economics and Business Review, 2, pp. 15-20.

- Behera and Mishra, 2016. "Inflation and Economic Growth Nexus in BRICS: Evidence from ARDL Bound Testing Approach", Asian Journal of Economic Modelling, 4, pp. 1-17.

- Cetintas, 2003. "Türkiye'de Enflasyon ve Büyüme”, Istanbul University Journal of the Faculty of Political Sciences, 28, pp. 141-153.

- Charemza and Deadman, 1992. New Directions in Econometric Practice: General to Specific Modelling, Cointegration and Vector Autoregression. Edward Elgar, UK: Aldershot.

- De Gregorio, 1996. "Inflation, Growth and Central Banks: Theory and Evidence" (Policy Research Working Paper No. 1575), The World Bank.

- Dickey, Hasza and Fuller; 1984. “Testing for Unit Roots in Seasonal Time Series”, Journal of the American Statistical Association, 79, pp. 355-367.

- Dickey and Pantula, 1987. "Determining the Order of Differencing in Autoregressive Processes", Journal of Business and Economic Statistics, 5, pp. 455-461.

- Engle, Granger and Hallman; 1989. "Merging Short and Long Run Forecasts: An Application of Seasonal Cointegration to Monthly Electricity Sales Forecasting", Journal of Econometrics, 40, pp. 45-62.

- Engle and Yoo, 1987. "Forecasting and Testing in Co-Integrated Systems", Journal of Econometrics, 35, pp. 143-159.

- Epaphra, 2016. "Nonlinearities in Inflation and Growth Nexus: The Case of Tanzania", Journal of Economics and Political Economy, 3, pp. 471-512.

- Erbaykal and Okuyan, 2008. "Does Inflation Depress Economic Growth? Evidence from Turkey", International Research Journal of Finance and Economics, 17, pp. 40-48.

- Friedman, 1977. "Nobel Lecture: Inflation and Unemployment”, Journal of Political Economy, 85, pp. 451472.

- Fuller, 1976. Introduction to Statistical Time Series. John Wiley \& Sons, New York.

- Ghysels and Osborn, 2001. The Econometric Analysis of Seasonal Time Series. Cambridge University Press, Cambridge.

- Holmes, 2014. Economy of Words - Communicative Imperatives in Central Banks. University of Chicago Press, Chicago.

- Hylleberg, Engle, Granger and Yoo; 1990. "Seasonal Integration and Cointegration”, Journal of Econometrics, 44, pp. 215-238.

- Ilmakunnas, 1990. "Testing the Order of Differencing in Quarterly Data: An Illustration of the Testing Sequence", Oxford Bulletin of Economics and Statistics, 52, pp. 79-88.

- Johansen, 1988. "Statistical Analysis of Cointegration Vectors", Journal of Economic Dynamics and Control, 12, pp. 231-254.

- Karacor, Saylan and Ucler; 2009. "Türkiye Ekonomisinde Enflasyon ve Ekonomik Büyüme İlişsisi Üzerine Eşbütünleşme ve Nedensellik Analizi (1990-2005)”, Niğde University Journal of Faculty of Economics and Administrative Sciences, 2, pp. 60-74.

- Kasidi and Mwakanemela, 2013. "Impact of Inflation on Economic Growth: A Case Study of Tanzania", Asian Journal of Empirical Research, 3, pp. 363-380.

- Khan and Senhadji, 2001. "Threshold Effects in the Relationship between Inflation and Growth”, IMF Staff Papers, 48, pp. 1-21.

- Mallik and Chowdhury, 2001. "Inflation and Economic Growth: Evidence from Four South Asian Countries", Asia-Pacific Development Journal, 8, pp. 123-135.

- Osborn, Chui, Smith and Birchenhall; 1988. "Seasonality and the Order of Integration for Consumption", Oxford Bulletin of Economics and Statistics, 50, pp. 361-377.

- Pedroni, 1999. "Critical Values for Cointegration Tests in Heterogeneous Panels with Multiple Regressors", Oxford Bulletin of Economics and Statistics, 61, pp. 653-670. 
- Phillips, 1958. "The Relation between Unemployment and the Rate of Change of Money Wage Rates in the United Kingdom, 1861-1957”, Economica, 25, pp. 283-299.

- Sanli, 2015. The Econometric Analysis of Seasonal Time Series: Applications on Some Macroeconomic Variables, Master's Thesis, Cukurova University, Adana.

- Tobin, 1965. "Money and Economic Growth”, Econometrica, 33, pp. 671-684.

- Topcu, 2017. “Enflasyon Oranı - Ekonomik Büyüme İlişkisi: Türkiye Örneği”, Nevşehir Hacı Bektaş Veli University Journal of Institute of Social Sciences, 7, pp. 180-191.

- Wilson, 2006. “The Links between Inflation, Inflation Uncertainty and Output Growth: New Time Series Evidence from Japan”, Journal of Macroeconomics, 28, pp. 609-620.

\section{Information Notes}

* This study has been derived from the Master Thesis that has been prepared in consultancy of Assoc. Prof. Mehmet Ozmen called "The Econometric Analysis of Seasonal Time Series: Applications on Some Macroeconomic Variables (Sanli, 2015)".

* This study has been supported by TUBITAK (The Scientific and Technological Research Council of Turkey) - BIDEB (Scientist Support Department) within the scope of 2211-E Direct National Scholarship Programme for PhD Students.

* This study has been supported by Cukurova University - Scientific Research Projects (BAP) Coordination Unit (Project Number: SBA-2019-11667). 


\title{
The Importance Of SMEs On World Economies
}

\author{
Ph.D. Candidate Murat Bayraktar (Çukurova University, Turkey) \\ Prof. Dr. Neşe Algan (Çukurova University, Turkey)
}

\begin{abstract}
The importance of SMEs to world economies is well reported. SMEs (firms with 200 or less employees) construct the biggest business sector in each global economy therefore governments around the world are increase the effort to promote and support SME expansion as their national development strategy. Micro firms and SMEs are forming the majority of firms in most countries (which $95 \%$ on average) and for the large majority of jobs. While SMEs are dominating of very great numbers, SMEs are significant due to their importance as priority drivers to employment, economic growth and innovation. According to the World Trade Organization SMEs represent over $90 \%$ of the business population, $60-70 \%$ of employment and $55 \%$ of GDP in developed economies. SMEs held for around $20 \%$ of patents, one measure of innovation, in biotechnology-related fields in the Europe. As the world economy faces with prevailing challenges, governments increasingly start to turn on SMEs as a significant element of sustainable and inclusive economic growth. The importance of SMEs to; economic growth, poverty reduction, innovation and job creation also social cohesion are major key.
\end{abstract}

\section{Introduction}

The SMEs (small and medium enterprises) have a very important part to modern economies and their contribution to economic development is recognized. These social and economic roles led to consideration of SME sector as a strategic interest for economy (Avasilicai, 2009). In order to achieve the G20's $2 \%$ growth agenda till 2018 will only be feasible as governments' dedication to empower by private sector led growth and entrepreneurship. Economic policies that back up the competitiveness of economies for support to more healthy, sustainable, and inclusive growth. These kinds of policies are important for firms of all sizes in particular for the many SMEs which are performing in global economies. In taking part to global value chains, they have the essential goal for encouraging world trade and investment and also improving their productivity level and potential to innovate as well. SMEs account for $95 \%$ of businesses globally also contribute more than half of total employment, whereas around 200 million firms widespread lack from the financing they need to invest, develop with generate emerging jobs (BIAC, 2016). Around $90 \%$ of the world's jobs are generated by the private sector and some $50 \%$ by SMEs.

According to the World Trade Organization (WTO, 2016) SMEs represent over 90 per cent of the business population, $60-70 \%$ of employment and $55 \%$ of GDP in developed economies.

As SMEs contribute strongly to achieve crucial goals to an economy they represent main motivation of economic development and backbone of socio-economical development (Drucker, 2009).

Traditional SMEs have weaknesses and strengths of their leaders and their capacities of human resources, usually established on founder's courage and talent. Leaders of these enterprises risk their assets and capital (Vaduva, 2004).

There are two types of SMEs: the small traditional enterprise that make goods inherited from past generations and the modern enterprise uses high technology, search of new markets to maximize their efficiency In developed countries $20 \%$ of new SMEs last no more than a year, $20 \%$ last only two years and $50 \%$ last not more than five years. As a result only $10 \%$ of SMEs have a chance to survive more than five years. The success of an economy depends on number and dynamic of SMEs and success on the market. SMEs serve as a source of entrepreneur skills, innovation and employment also they stimulate competition for prices, product design and efficiency. If there are no SMEs, big enterprises become monopoly. SMEs also help big enterprises such as supplying raw materials and parts and distributing products made by them. A study from US showed SMEs makes four times higher profit for a dollar invested than big companies (Neagu, 2016).

\section{Body}

The European Commission (EC, 2005) describes SMEs: enterprises hiring less than 250 persons, that have an aftermarket of below 50 million euros and/or a balance sheet total of below 43 million euros. SMEs are also divided as micro, small and medium enterprises that stated in Table 1. OECD defines to SMEs as the firms hiring up to 249 persons and diversifies like: micro (1 to 9), small (10 to 49) and medium (50-249). United States (US) describes them with employees below 500 (Natarajan and Wyrick, 2011). 


\begin{tabular}{|c|c|c|c|}
\hline Enterprise Category & Persons employed & Turnover or & Balance sheet Total \\
\hline Medium & $<250$ & $\leq € 50$ million & $\leq € 43$ million \\
\hline Small & $<50$ & $\leq € 10$ million & $\leq € 10$ million \\
\hline Micro & $<10$ & $\leq € 2$ million & $\leq € 2$ million \\
\hline
\end{tabular}

Table 1. Medium, Small and Micro -Sized Enterprises as Employment Levels (EC) Source: Eurostat, 2018.

E-commerce was started first in 1995 and now classified into business-to-consumer, business to business and consumer to consumer. Laudon and Traver (2011) pointed that revenue of B2B reached four trillion dollars in year 2011. Due to its advantages, SMEs in developing countries have been using e-commerce thus many problems still remain (Moertini, 2012). The share of internet for global economy has been maturating tremendously from last decade to around 5\% of GDP for G20 group and for some countries around 10\%, that represent an exceptional opportunity to SMEs, deeply throughout global value chains, to cut costs and add to their target markets. Due to global production are recently shifting and becoming more compound so firms must accordingly adjust their strategies. SMEs which usefully tackle the ability of digitization to modify their companies will succeed in extensive competitiveness also can achieve notable growth (BIAC, 2016).

Small and medium-sized enterprises consist foundation for the Asian economies such as construct around $96 \%$ of whole Asian businesses and two out of three private sector jobs on the region. Hence, SMEs are critical for economic success of Asian economies but SMEs confront major challenges to get cheap finance mostly because of the asymmetric information difficulties among suppliers and demanders of financial funds and the costly transaction costs that lead to more corroboratory requirements for lending to SMEs with higher lending interest rates as a result interrupt their growth potential. As big enterprises can find chance to list their firms shares to the stock markets also can issue their securities to bond markets, publish their financial statements and accounts also working with accountants and auditing companies to certify them, on the other hand many SMEs have no integration to the capital markets. Because the financial institutions can detect the borrowers closely but with more costly to do for borrowers who demand less amount of loans. As a result the absence of information base for SMEs, escalates the information asymmetry issue (Yoshino and Taghizadeh-Hesary, 2018).

For the OECD countries the SMEs are main type of enterprise, for nearly $99 \%$ of whole businesses, supply the primary cause of employment (around 70\% of jobs), main sources to value creation (around 50\% and 60\%) of value added on. SMEs are crucial for increasing the inclusive globalization and economic growth. SMEs are the main players for economy and the broader eco-system of businesses (OECD, 2017). For emerging economies, SMEs give nearly $45 \%$ of whole employment, $33 \%$ of their GDP and with adding the contribution of the informal firms SMEs causes to more than half of employment and GDP in many countries regardless of their income volumes (IFC, 2010).

A survey from the Asian Development Bank (Asia SME Finance Monitor) carried out to 20 countries indicated that SMEs responsible for $96 \%$ of total enterprises, $62 \%$ of the national work forces of Central, East, South, Southeast Asia, and for the Pacific area. SMEs in the China and India formed for more than $40 \%$ of the total export amounts, $26 \%$ in Thailand, $19 \%$ in the Republic of Korea, and 16\% in Indonesia (ADB 2015). Whereas $70 \%$ of the Indian, $80 \%$ of the Chinese, and $90 \%$ of the Malaysian financial system rests on of bank loans (Yoshino and Taghizadeh-Hesary, 2015) some researchers frequently describe Asian economies such as the bank controlled financial markets and lagging capital markets where the venture capital (VC) market is not fully grown so banks are still remain as the primary source to finance. As banking system has become better importantly since the Asian financial crisis from end of 1990s, banks still have been cautious about disbursing to them although these firms are responsible for the big proportion of their economic task. The start-up companies find increasingly complicated to obtain funds from banks due to harsh Basel capital requirements. New Basel III measures may limit banks in providing long-term credit to the businesses and also may limit the financing options for SMEs as including the presence of financing trade. The more riskier SMEs reconciled to difficulty for borrowing money from banks because for banks it is hard to consider SMEs because they regularly do not have reliable accounting structures. Most SMEs in Asia region borrow money while paying high charges of interest to the banks and offering expensively collateral, many times most banks decide on to lend to big enterprises on instead of the SMEs (ADB 2015).

Around eight years ago economies in the OECD were in an importance of topmost risk that in the Euro region economies product output was falling very quickly and unemployment was on the rise (OECD, 2016a, 2016b). The OECD countries feature the structural confronts due to moderate productivity growth with increasing the inequality problems. The productivity growth is estimated less than it was before financial crisis for many OECD economies and although the U. S. has productivity growth been too slow as well (OECD, 2016c).

Almost eight years after the most severe global economic crisis since 1929 Great Depression, outlooks for global economy stay low and the global GDP growth is estimated to be 3\% in 2016 only a little advance prediction for year 2017. Economic growth stands subtle for developed economies, as under the pre-crisis rate but has declined down for emerging economies, largely for the items exporters. High but diminishing unemployment rates in the Euro Area and low wage growth in the US and Japan set aside private consumption thus resulting to inflated 
inequalities. Due to the productivity growth is the source for as a whole to the economic growth, utilizing proper steps the opportunity to access to capitalize SMEs for the additional investments in research, infrastructure, developing barter, improving the taxation systems, changing the immigration methods and other moves are crucial to assist the increase for the productivity increase (BIAC, 2016).

As the global economy faces due to prevailing confrontation with, governments increasingly start to turn on SMEs such as a significant element to sustainable and inclusive economic growth. The significance of SMEs to economic growth, innovation and job formation and to the social cohesion are major keys. In OECD countries the SMEs are normally responsible more than $50 \%$ of business sector operation and almost two-thirds of jobs. And for the emerging economies the SMEs carry on more around 40\% of GDP and 50\% of jobs but the business conditions have been declining in many OECD economies also the indications of slowdown productivity in the SME sector can be seen for mostly in micro and small businesses. To increase investment and productivity levels of SMEs is essential to recover the healing and for protect the economic growth patterns. In order to help small businesses that take advantage of international markets deeply along involvement and improving into the international value chains is a key. Accessing to funds alone is not the only act for small businesses to innovate, raise, become happen to further productive and take part into the international markets but a key part for opening up their capacities. Credit to SMEs increased in Greece more around 2\% in 2014 and in Chile, Colombia and Turkey, the yearly expansion in SME loan surpassed $10 \%$ but these progresses has been contrasts for example for Spain, nevertheless a strong growth of 8.5\% between 2013 and 2014, amount of lending to SMEs are located at only $36 \%$ of its pre-crisis amount (OECD, 2016d, 2016e, 2016f). The SME Finance Forum (2016) calculates total unfulfilled international request for credit by SMEs in year 2016 is around $\$ 3$ trillion thus a surprising amount of around 200 million SMEs without access to credit globally.

SMEs can be an important method of social inclusion (for example providing opportunities for women, underrepresented groups to participate in economic activities) also are a key channel for poverty alleviation. The World Bank's 'Doing Business' Report indicates that a well SME sector links with a reduced level of informal activities. SMEs are therefore important an important part of to manage the UN Sustainable Development Goals (SDGs), such as 'promote inclusive and sustainable economic growth, employment and decent work for all' (SDG8 ) and 'build resilient infrastructure, promote sustainable industrialization and foster innovation' (SDG- 9) (IFAC, 2018). Small businesses are extremely heterogeneous in their size, age, sector, ownership, business models and aspirations and not easily addressed by any one-size-fits-all approach. The European Union Entrepreneurship 2020 Action Plan states that around 450,000 SMEs change ownership yearly and affecting more than 2 million employees, but up to one-third of these transfers may not be successful, thus endangering around 150,000 enterprises and 600,000 jobs.

Digital transformation is starting to shape the many elements of SMEs businesses. First, digitalization is encouraging switch the way SMEs access to funds. Second the digital trend is now having a huge outcome on the access to international value chains because the e-Commerce will meet a further major role for the actions of SMEs. Third, the laws and processes encountered by SMEs are changing because of new moves such as latest technologies are supporting with the complicated techniques that companies required executes as launching their business, export/ import needs or bankruptcy procedures (BIAC, 2016).

In the 21st Century, globalization will be described by moves of data and information trans-border. The data moves are come down nearly 45 times increase for the 2005-2014 period (McKinsey Global Institute, 2016). According to a research by Accenture and Alibaba Group forecasted that total amount of the international B2C eCommerce will expand the amount of US $\$ 230$ billion in 2014 to US\$ 994 billion in 2020 thus $29.3 \%$ of the global business to consumer (B2C) e-Commerce market and almost 13.9\% of international consumer goods' marketing. By e-Commerce increases the SMEs entrance to foreign buyers and making possible firms to more systematically encourage their products, services and process payments (Accenture and Alibaba Group, 2015). By the internet technology is causing the SMEs' acquire to fund due to the developments of latest option financing processes and decreases the hazard and fee of servicing the SMEs by emerging credit rating instruments based on the mining transaction data associated with networked marketplaces related by sellers and buyers. Thus governments need to imply strategic plans to regulation such as restricting unsuitable costs and difficult to deal for firms while urging innovation and involvement of SMEs to the digital economy. Some recent studies mentioned that innovative activities are particularly challenging for SMEs because of their crucial financial restraints and information asymmetries (Barbaroux, 2014).

Some up to date articles mention that big firms are more vulnerable to abroad business cycles than SMEs are (Moscarini and Postel-Vinay. 2012). Due to trade integration, globalization and industry consolidation makes big enterprises become ever bigger and important in defining business cycles and economic situations. Large companies are account for the big share of a country's economic production when international demand for even one commodity declines that economy can reconciled to serious outcomes for example for case of "Nokia" company in Finland (Ali-Yrkkö, 2010).

SMEs held for around $20 \%$ of patents, a measure of innovation, such as in biotechnology in the Europe (Eurostat, 2014). The help of SMEs to innovation processes has increased and transforming technologies have gave SMEs 
to intensify their comparative advantages capacity (OECD, 2017). In OECD countries innovative SMEs play a major task for ecoindustry and clean-tech markets, in the UK and Finland, SMEs express accordingly over $90 \%$ and $70 \%$ of clean technology positions (Carbon Trust, 2013; ETLA, 2015). SMEs are especially advantaged to occupy opportunities of greener supply chains at native clean tech markets, not so attractive for big MNFs, including in emerging and low-income economies (IBRD, 2014). Across OECD countries the median value in the federal SME share of business R\&D is around $35 \%$.

SMEs create employment opportunities in all geographic regions and sectors, employing various parts of the work force even for low-skilled employees and allowing opportunities for skills growth and aid to assist their employees' admission for health care and social services (OECD, 2017b). SME performance also differ in size over sectors like in services, SMEs responsible for around $60 \%$ or more of whole jobs and value added in almost whole countries (OECD, 2017c).

SMEs can also constitute a useful apparatus to address societal needs that provide public goods and services. Social enterprises come up with innovative solving problems to the poverty, social exclusion and unemployment. In many countries, the economic weight of social enterprises has increased progressively in newly years, including in the outcome of the worldwide crisis. For example in France in year 2014 the social economy rated for $10 \%$ of the GDP and in Belgium between 2008-2014 period employment in social enterprises increased by $12 \%$ and rated in year 2015 for $17 \%$ of total private employment (EU, 2016).

In some countries in the case of unincorporated MSMEs, the process of individual defaulters is very agonizing, leaving full personal responsibility for future years even after abolishment of their firms (Bergthaler et al., 2015). In some cases, tax agreement costs for small businesses may even go beyond their tax cash premiums (Eichfelder and Vaillancourt, 2014).

Bank loans can assist firms enhance their job quality and productivity, but are often difficult to get for SMEs. Therefore policy-makers should look into new ways to maintain simple for SMEs to access these external funding (ILO, 2017). Also the spread in the interest rates charged to SMEs and to large firms has considerably open out compared to pre-crisis interval though the costs of financing have been decreasing regularly over recent years.

SMEs play a key part in many economies in developing countries. Formal SMEs give up to $60 \%$ of total employment and up to $40 \%$ of GDP in emerging economies and these numbers are much higher when informal SMEs are added. SMEs have less possibility to be able to acquire bank credits than large firms so most of the times they depend on inner funds (cash from friends and family) to start and at the start to run their enterprises. Around half of formal SMEs don't have access to legal credit and this financing hole is even bigger when micro and informal enterprises are taken into consideration. Overall, around 70\% of whole MSMEs in emerging markets are cannot access to the credit particularly in Africa and Asia regions. The present credit gap for formal SMEs is calculated to be US\$1.2 trillion and the entire credit gap for both formal and informal SMEs is about US\$2.6 trillion. A World Bank Group article states that in emerging markets there are around 365-445 million MSMEs (25-30 million are formal SMEs, 55-70 million are formal micro enterprises and 285-345 million are informal enterprises). To move informal SMEs into the formal sector can have big advantages for the SMEs such as better access to credit and to government services, also to the whole economy like increasing tax revenues and superior regulation. After improving the SMEs' access to finance and finding solutions to open sources of fund is important to enable this potentially dynamic sector to get bigger and contribute jobs (World Bank, 2019).

SMEs are both the engine of job formation and same time a significant factor in job destruction, making them the realization of Schumpeter's "creative destruction" the disruptive process of transformation that goes side by side with innovation, to confirming these observations, an EU estimate indicated that as few as $50 \%$ of firms that started business in 2001 survived beyond five years (ISO, 2015).

\section{Conclusion}

SMEs play a major tool for achieving more inclusive globalization and growth. SMEs are lead actors to economy and to vast eco-system of the companies. SMEs have an important role to achieve the Sustainable Development Goals (SDGs) and to promote inclusive and sustainable economic growth, employment, fostering innovation and to decrease income inequalities around the world. SMEs in many countries still proceed with to fight the extended effect of 2007-08 global crisis, which strike new and small firms. Economic policy strategies should foresee the changes in regulations, markets and technologies that happen internationally which may influence the SMEs' opportunities and conduct. SME development can assist to economic diversification and flexibility mainly important for resource-rich countries that are vulnerable to commodity price variations. The contribution of SMEs to innovation dynamics has increased in late decades due to knowledge-based economy. SMEs part in the transformation to high sustainable patterns of production and consumption is decisive for the greening of the economic development. In many OECD countries, innovative SMEs play a key position in the ecoindustry and clean-tech markets. Trade and investment openness, protection of intellectual property, infrastructure and institutional quality are important factors for SMEs commitment to the global markets. Impoverished physical and ICT infrastructure halts SMEs to operate efficiently and to access global markets with competitive costs. The 
government policies should take into consideration of upgrading the workforce skills in SMEs, assist SMEs to acquire ICT and to the digital revolution, ensuring that their national R\&D policy is inclusive of SMEs and let an effective and inclusive federal innovation system.

\section{References}

- Accenture and Alibaba Group, 2015. Global cross-border eCommerce Market Report.

- Ali-Yrkkö, 2010. "Nokia and Finland in a Sea of Change". (Eds). ETLA B244, pp. 37-67, Taloustieto Oy, Helsinki, Finland,

- Asian Development Bank (ADB), 2015. Asia SME Finance Monitor 2014. Manila.

- Avasilicai (coord.), 2009. "Entrepreneurship: applied research", Cluj-Napoca: Tedosco.

- Barbaroux, 2014. "From market failures to market opportunities: Managing innovation under asymmetric information". Journal of Innovation and Entrepreneurship, 3 (5), p.1-15.

- Bergthaler, Kang, Liu, and Monaghan, 2015. "Tackling Small and Medium Sized Enterprise Problem Loans in Europe", IMF Staff Discussion Note, March 2015, International Monetary Fund, https://www.imf.org/external/pubs/ft/sdn/2015/sdn1504.pdf.

- BIAC, B20 China, World SME Forum, SME Finance Forum, 2016. Financing Growth; SMEs in Global Value Chains. http://biac.org/wp-content/uploads/2016/06/Financing-Growth-SMEs-in-Global-ValueChains.pdf.

- Carbon Trust, 2013. Low carbon entrepreneurs: The new engines of growth, https://www.carbontrust.com/resources/reports/technology/low-carbon-entrepreneurs/.

- Druker,2009. Innovation and Entrepreneurship, New York: Harper Collins.

- EC, 2005. The new SME definition: User guide and model declaration. Enterprise and Industry Publications.

- Eichfelder and Vaillancourt, 2014. "Tax Compliance Costs: A Review of Cost Burdens and Cost Structures", Hacienda Pública Española, vol. 210, issue 3, p.111-148.

- ETLA, 2015. From Cleantech to Cleanweb. The Finnish Cleantech Space in Transition, ETLA Paper No 43, ETLA - The Research Institute of the Finnish Economy, https://www.etla.fi/wpcontent/uploads/ETLARaportit-Reports-43.pdf.

- Eurostat, 2014. Patent Statistics at Eurostat. Mapping the contribution of SMEs in EU patenting. Eurostat Manuals and Guidelines, Luxembourg, http://ec.europa.eu/eurostat/documents/3859598/6064260/KS-GQ14-009-EN-N.pdf/caa6f467-11f8- 43f9-ba76-eb3ccb6fab6d.

- Eurostat, 2018. https://ec.europa.eu/eurostat/statisticsexplained/index.php?title=File:Criteria_for_medium,_small_and_micro-sized_enterprises.png.

- IBRD, 2014. Building competitive green industries: the climate and technology opportunity for developing countries, International Bank for Reconstruction and Development/The World Bank, Washington D.C.

- IFC, 2010. Scaling-Up SME Access to Financial Services in the Developing World, International Finance Corporation, World Bank Group, Washington D.C., http://www.enterprisedevelopment.org/wpcontent/uploads/ScalingUp_SME_Access_to_Financial_Services.pdf.

- IFAC, 2018. Foundation for Economies Worldwide=Small Business. https://www.ifac.org/globalknowledge-gateway/finance-leadership-development/discussion/foundation-economies-worldwide.

- ILO, 2017. World Employment Social Outlook 2017. Sustainable enterprises and jobs: Formal enterprises and decent work. Geneva: ILO, 2017.

- ISO, 2015. International Organization for Standardization. The big business of small companies. https://www.iso.org/news/2015/03/Ref1937.html.

- Laudon and Traver,2011. E-commerce 2011 business technology society 7th ed. Pearson Education, Inc., England.

- McKinsey Global Institute, 2016. Digital Globalization: the new era of digital flows.

- Moertini, 2012. "Small Medium Enterprises: On Utilizing Business-to-Business eCommerce to Go Global". Procedia Economics and Finance 4 (2012), p. 13 - 22.

- Moscarini and Postel-Vinay, 2012. 'The Contribution of Large and Small Employers to Job Creation in Times of High and Low Unemployment.' American Economic Review, 102(6), p.2509-39.

- Natarajan and Wyrick, 2011. Framework for Implementing Sustainable Practices in SMEs in the United States. Proceedings of the World Congress on Engineering 2011, WCE 2011. 1, p. 750-754.

- Neagu, 2016. The importance and role of small and medium-sized businesses. Theoretical and Applied Economics Volume XXIII (2016), No. 3(608), Autumn, p. 331-338. 
- OECD, 2016a. Quarterly GDP (indicator). doi: 10.1787/b86d1fc8-en.

- $\quad$ OECD, 2016b. Harmonised unemployment rate (HUR) (indicator). doi: 10.1787/52570002-en.

- $\quad$ OECD, 2016c. Labour productivity forecast (indicator). doi: 10.1787/cb12b189-en.

- OECD, 2016d. OECD Economic Outlook 2016, OECD Publishing, Paris.

- OECD 2016e. OECD Business and Finance Outlook 2016, OECD Publishing, Paris.

- OECD, 2016f. Financing SMEs and Entrepreneurs 2016: An OECD Scoreboard, OECD Publishing, Paris.

- OECD, 2017. Enhancing the Contributions of SMEs in a Global and Digitalised Economy. Meeting of the OECD Council at Ministerial Level Paris, 7-8 June 2017.

- OECD, 2017. Entrepreneurship at a Glance 2017, OECD Publishing, Paris, forthcoming

- OECD, 2017a. Small, Medium, Strong. Trends in SME Performance and Business Conditions, OECD Publishing, Paris.

- OECD, 2017b. Increasing productivity in small traditional enterprises: programmes for upgrading management skills and practices, OECD Working Party on SMEs and Entrepreneurship, CFE/SME (2016)6.

- OECD, 2017c. Entrepreneurship at a Glance 2017, OECD Publishing, Paris, forthcoming.

- World Bank, 2019. Small And Medium Enterprises (Smes) Finance. https://www.worldbank.org/en/topic/smefinance.

- WTO, 2016. World Trade Report 2016. Levelling the trading field for SMEs. https://www.wto.org/english/res_e/publications_e/wtr16_e.htm.

- Văduva, 2004. Entrepreneurship, Bucharest: Economica.

- Yoshino and Taghizadeh-Hesary, 2018. "The Role of SMEs in Asia and Their Difficulties in Accessing Finance”. ADBI Working Paper 911. Tokyo: Asian Development Bank Institute. https://www.adb.org/publications/role-smes-asia-and-theirdifficulties-accessing-finance. 


\title{
Unemployment Hysteresis Revisited: The Case of Turkey
}

\author{
Ph.D. Candidate Ufuk Can (Çukurova University, Turkey) \\ Ph.D. Candidate Zeynep Gizem Can (Çukurova University, Turkey) \\ Prof. Dr. Harun Bal (Çukurova University, Turkey)
}

\begin{abstract}
This study aims to investigate the stability of unemployment rate in Turkey with the data set covering approximately a century and starting from 1923. The stability of the unemployment rate is examined the unit root tests, the variance ratio tests and the fractional integration models by following the studies in the literature. Almost all tests and models indicate that the unemployment rate series is not stationary. These findings show that the shocks in the economy and the stabilization policies implemented bring about permanent changes in the natural rate of unemployment. While the unemployment hysteresis leads to increasing costs in reducing inflation, it also reveals the necessity of structural reforms to reduce increased unemployment as a result of inflation control or changes in structural factors. In order to eliminate the impact of this hysteresis on economy, it is necessary to give weight to the expansionary monetary and fiscal policies, which in the short term may be costly, but this impact can be eliminated in the long term.
\end{abstract}

\section{Theoretical Framework}

Unemployment can be defined as the idleness of labor due to the various reasons such as shortage of demand, lack of accumulation and low mobility. Unemployment is one of the most researched topics by economists, due to its financial and social damages, that's why all schools of economics put forth theories trying to explain the topic. To put it chronologically, in the neoclassical school, unemployment is defined as the unavailability of work despite of the fact that there is a desire to work at the prevailing level of wages and search for employment, meaning that it is the case of being out of work involuntarily. It is said that there is always full employment within the economy via the invisible hand mechanism, but the existence of both short-term frictional unemployment that can stem from job circulation or mobility and long-term unemployment that can arise from the structural changes within the economy and changes of demand is acknowledged. The fact that the neoclassical school could not explain substituting role of the automation in place of labor during production process and the rise of the concept of technological unemployment is seen as the shortcoming of the school and the Marxist economic theory steps in. According to Marxist theory, which is based on labor theory of value, value of any good is determined by the indirect labor which includes production factors except labor and the direct labor which produces the good by using other production factors. According to Marx who describes the indirect labor within production factors as unchanged or fixed capital and the value of the direct labor as variable capital, capital accumulation process and automation gives rise to the emergence of spare labor and downside pressure on real wages. The increasing organic blending of the technology and capital makes investment lessen and causes unemployment by decreasing profit margins.

The Great Depression which starts in 1929 and Keynes' General Theory of 1936 dramatically changes points of view on unemployment. Keynesian school analyzes underemployment by emphasizing imperfect competition conditions, sticky prices and wages and involuntary unemployment. According to Keynes who contributes to the literature by defining the unemployment which changes based on cyclical fluctuations as conjunctural unemployment, unemployment is an outcome of the insufficient demand. Keynes, stating that firms demand less labor because of the fact that individuals demand fewer goods, is of the view that government must intervene in markets to find a solution for the unemployment problem. Although the Keynesian viewpoint on unemployment prevails until the oil shocks, the studies that try to understand dynamic nature of the unemployment steps up as a global unemployment wave spreads out due to oil shocks. The pioneers of monetarist and neoclassical schools, Phelps (1967, 1968), Friedman (1968) and Phelps (1994) state that unemployment rate would incline to return to it is long-run equilibrium level. Assuming that natural or nan-accelerating inflation rate of unemployment (NAIRU) and prevalent unemployment rate may differ, it is asserted that unemployment rate would come back to it is natural level although there may be an adverse relationship between inflation and unemployment rates in the short run as stated in the Philips Curve. Blanchard and Summers (1986), as the representatives of the NeoKeynesian School which try to examine substantial increases in the current account deficits and unemployment rates of various countries, asserts that unemployment rate may diverge from the natural level in the long-run in a persistent way. The case of persistently high unemployment rate is called as unemployment hysteresis, meaning that cyclical fluctuations have a constant impact on unemployment in the countries where the labor market is inflexible and that's why series of unemployment are not stationary (Christopoulos and León-Ledesma, 2007). This hypothesis, which asserts there is not only one natural unemployment rate, requires that the series of unemployment rate have unit-root from an econometric perspective (Stanley, 2004). Unemployment hysteresis can be formulated as follows (Song and $\mathrm{Wu}, 1998)$ : 
$u_{t}^{*}=u_{t-1}{ }^{*}+\rho\left(u_{t-1}-u_{t-1}^{*}\right)$

where $u_{t}{ }^{*}, u_{t-1}{ }^{*}$ and $u_{t-1}$ represents present unemployment rate, natural rate of unemployment rate in the previous periods and actual unemployment rates in the previous periods respectively. If $\rho \neq 0$, natural unemployment rate partially converges to actual one and this situation does not confirm the hypothesis of unemployment hysteresis. On the other hand, natural unemployment rate does not converge to actual one and the hypothesis of unemployment hysteresis is validated if $\rho=0$.

The lasting effects of external shocks on unemployment hysteresis are explained via various theories. Pissarides (1992) stresses that the unemployed loses their abilities as well as their motivations and the period of benefiting unemployment insurance negatively affects the unemployed's re-entry desire into labor market. Furthermore, the theory of insider-outsider put forth by Lindbeck and Snower (1986) assumes that insiders(employed) does not care about outsiders (unemployed) and only think of themselves. According to the theory, while some people lose their jobs in case of a negative economic shock, insiders care about their own interests only and ask for new employment contracts which call for higher wages. Since unionized insiders would have more bargaining powers against firms, while the outsiders would need time and training to learn how to do job, firms would be forced to accept the demands of the insiders. In addition, the rise in layoff costs, capital shortages, failures in coordination and the factors like stigma effects of unemployment may be the causes of unemployment hysteresis (Christopoulos and León-Ledesma, 2007).

Various models are frequently used for the purpose of testing natural unemployment rate and hysteresis such as traditional models, breakpoint unit root tests, panel and non-linear unit root tests, variance ratio tests and long memory models. As the new developments arise in econometrics they are also applied on updated time series. Once unemployment rate series are stationary, it's accepted that natural unemployment hypothesis is valid. If there is unit root problem in unemployment rate series, it's accepted that unemployment rate does not incline to converge to its equilibrium level in the wake of an external shock and this situation supports the existence of unemployment hysteresis. The fact that shocks have lasting on unemployment necessitates governments to intervene in economy by designing and implementing policies that will solve unemployment problem, especially in recessionary periods of time, economic damages that the unemployment would cause would aggravate in line with the existence of unemployment hysteresis.

Unit root tests are the most frequently used method in testing the unemployment hysteresis hypothesis in the literature. Blanchard and Summers (1986), Neudorfer et al. (1990) and Roed (1996) conduct traditional unit root tests which are based on the testing of null hypothesis $\rho=0$ on unemployment rate series.

$\Delta \mathrm{u}_{\mathrm{t}}=\alpha+\rho \mathrm{u}_{\mathrm{t}-1}+\sum_{\mathrm{i}=1}^{\mathrm{k}} \Delta \mathrm{u}_{\mathrm{t}-\mathrm{i}}+\epsilon_{\mathrm{t}}$

Gustavsson and Osterholm (2006), Chang (2011) and Ozkan and Altınsoy (2015) test unemployment hysteresis by means of nonlinear unit root tests. Due to the fact that traditional unit root tests may have biased outcomes in case of data constraints, the variables that affect unemployment rate may differentiate and the difficulties faced in collecting data, unit root tests, which are trusted more in relation to traditional unit root tests, would be required to be used to test the stationarity of unemployment rate. If it is assumed that unemployment rate does not have a linear structure due to economic shocks and government policies, nonlinear models, simply, are based on the testing null hypothesis $\theta=0$.

$u_{t}=\alpha+\tau\left[1-\exp \left(-\theta u_{t-1}^{2}\right)\right] u_{t-1}+\epsilon_{t}$

On the other hand, the said null hypothesis does not provide any information related to the coefficient, $\tau$, the equation may be rewritten thanks to Taylor method and null hypothesis $\delta=0$ is tested.

$\Delta u_{t}=\delta u_{t-1}^{3}+\epsilon_{t}, \quad \delta=\tau \theta$

Gomes and Silva (2008), Y1lancı (2009) and Lee et al (2010) tests the validity of unemployment hysteresis via breakpoint unit root tests which take structural breaks into consideration. This method is based on testing the breaks in the breakpoint and trend, assuming that short term economic shocks or structural breaks may make unemployment rate deviate from its long term equilibrium, under the assumption of existence of structural breaks in unemployment rate series.

$\Delta u_{t}=\alpha+\rho u_{t-1}+\vartheta_{1} D U(\theta)+\vartheta_{2} D V(\theta)+\sum_{i=1}^{k} \Delta u_{t-i}+\epsilon_{t}$

Song and $\mathrm{Wu}$ (1998), Johansen (2002), Gozgor (2012) use panel unit root tests which don't take structural breaks into consideration to test the hypothesis of unemployment hysteresis, whereas, Christopoulos and León-Ledesma (2007), Guloglu and Ispir (2011) use panel root tests which take structural breaks into consideration. These tests are demonstrated as similar to the equations (2) and (5), except $\mathrm{m}$ panel data are shown by generalizing like $\mathrm{j}=1$, $2, \ldots, \mathrm{m}$.

In addition to unit root tests, Fève et al. (2003) and Mikhail et al. (2005) use variance ratio tests. Unemployment rate has a random walk process since its $\mathrm{k}^{\text {th }}$ order differential variance is $\mathrm{k}$ times its first order differential variance (Cochrane, 1988).

$\operatorname{Var}\left(V_{t}-V_{t-k}\right)=k \cdot \operatorname{Var}\left(V_{t}-V_{t-1}\right)$ 
Accordingly, in the null hypothesis that can be reorganized as $\operatorname{VR}=(1 / k) \cdot \operatorname{Var}\left(V_{t}-V_{t-k}\right) / \operatorname{Var}\left(V_{t}-V_{t-1}\right)$, the fact that variance ratio(VR) smaller than 1 means that unemployment rate is stationary and mean-reverting, while the fact that VR is equal to 1 means that unemployment rate has a random walk process. If VR is greater than 1 , it means that unemployment rate is super-persistent in not-reverting to the mean.

Lastly, Crato and Rothman (1996), Gustavsson and Österholm (2006), and Kurita (2010) explain long term memory in unemployment rate series by using Autoregressive Fractional Integrated Moving Average (ARFIMA) Model developed by Granger and Joyeux (1980), Granger (1980) and Hosking (1981). In ARFIMA (p, d, r) model, $\mathrm{d}, \mathrm{L}$ and $\mu$ signify degree of integration, lagging operator and mean respectively, while $\Phi(\mathrm{L})$ and $\Theta(\mathrm{L})$ stand for lag polynomials.

\begin{tabular}{ll}
$\Phi(L)(1-L)^{d}\left(q_{t}-\mu\right)=\Theta(L) \epsilon_{t}, \quad \epsilon_{t}=$ i.i.d. $\left(0, \sigma^{2}\right)$ \\
\hline $\mathbf{d}$ & Unemployment Rate \\
\hline $\mathbf{1} \mathbf{1 , 0}$ & Unemployment rate is not stationary \\
$\mathbf{0 , 5 - 1 , 0}$ & Deviations mean-reverting, but not stationary \\
$\mathbf{0 - 0 , 5}$ & Deviations mean-reverting and stationary in the long term \\
$\mathbf{0}$ & Deviations stationary and mean-reverting. Unemployment rate is stationary. \\
\hline
\end{tabular}

Table 1. Relationship between the Parameter d and Unemployment Rate Source: Villeneuve and Handa (2006)

\section{Data and Methodology}

The unemployment rate series examined in this study consist of 96 annual observations from 1923 to 2018. Data are compiled from Bulutay (1995) and TURKSTAT. Bulutay (1995) assumes that investment per capita in fixed prices can be used as a basis for determining the unemployment rate and he calculated the unemployment rate series for period 1923-1995 by dividing the number of unemployed given by DE (1988) in the relevant years to the change in the investment index per capita. The unemployment rate data in the joint years are consistent with the data announced by TURKSTAT and the data after 1995 are compiled from TURKSTAT. The unemployment rate $\left(u_{t}\right)$ is shown in Figure 1.

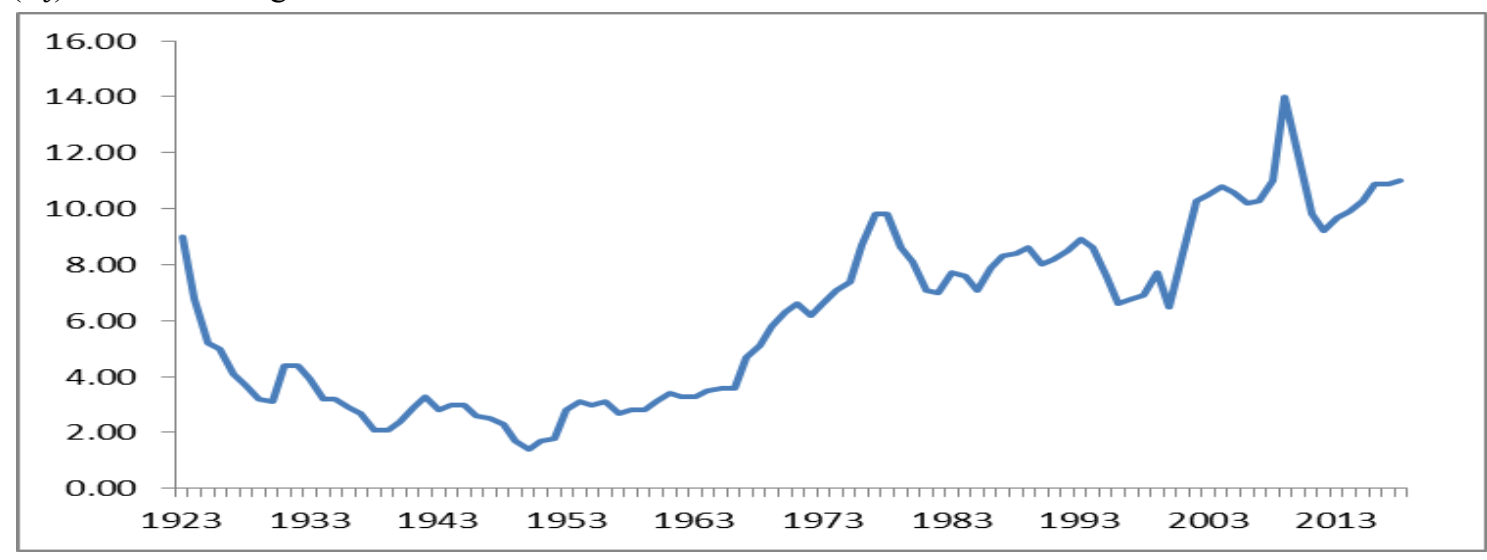

Figure 1. Unemployment Rate (1923-2018)

Traditional, breakpoint and nonlinear unit root tests, variance ratio tests and autoregressive fractional integrated moving average (ARFIMA) model are used in the literature to test the validity of the unemployment hysteresis hypothesis. Firstly, the stability of the $u_{t}$ series is analyzing with the help of Dickey-Fuller (Augmented DickeyFuller, ADF) by formulating Dickey and Fuller (1981), Dickey-Fuller Generalized Least Squares (DF-GLS) proposed by Elliott et al. (1996), Phillips-Perron (PP) developed by Phillips and Perron (1988), Ng -Perron (NP) formulated by $\mathrm{Ng}$ and Perron (2001) and Kwiatkowski-Phillips-Schmidt-Shin (KPSS) developed by Kwiatkowski et al. (1992) traditional unit root tests. The optimal lag length in ADF and DF-GLS tests is determined by the method of Lagrange Multiplier (LM) and by the General-to-Specific (GtoS) method proposed by Hall (1994), as well as by the modified Akaike Information Criteria (MAIC) developed by $\mathrm{Ng}$ and Perron (1995).

The fact that the unemployment rate series is exposed to structural breakpoints in the period makes the results of the traditional unit root test suspicious. Therefore, the stability of the $u_{t}$ series is re-examined in three groups by unit root tests taking into account the existence of structural breaks. In the first group, the breakpoint unit root tests based on Perron (1989) and developed by Perron and Vogelsang (1992), Perron (1997) and Clemente et al. (1998) are applied. The Perron-Vogelsang (PV) and Perron tests allow for a single break, while the ClementeMontanes-Reyes (CMR) test allows for two breaks. In the second group, the breakpoint unit root tests based on ADF test and developed by Zivot and Andrews (1992), and Lumsdaine and Papell (1997) are applied. The Zivot 
and Andrews (ZA) test allows for a single break, while the Lumsdaine and Papell (LP) test allows for two breaks. In the third and the last group, the stationary of $u_{t}$ series is examined by the breakpoint unit root tests based on LM test and developed by Lee and Strazicich (2004) allowing for a single break, and Lee and Strazicich (2003) allowing for two breaks.

While traditional and breakpoint unit root tests are applied, the $u_{t}$ series is assumed to be linear. Therefore, Kapetanios-Shin-Snell (KSS) test based on exponential smooth transition autoregressive (ESTAR) proposed by Kapetanios et al. (2003) and Sollis test based on asymmetric exponential smooth transition autoregressive (AESTAR) formulated by Sollis (2009) are applied against nonlinearity.

Unit root tests necessitate an integer degree of integration of a series (d). In fact, most of the economic and financial time series are not conformity with neither zero order $(\mathrm{I}(0))$, nor the first order $(\mathrm{I}(1))$ process (Banerjee and Urga, 2005). ARFIMA models, unlike unit root tests, allow the degree of integration to take real values. In these models, the null hypothesis $\left(H_{0}: d=0\right)$ in which the $u_{t}$ series is stationary can be tested directly, but the null hypothesis $\left(H_{0}: d-1=0\right)$, which is not stationary like the unit root tests, can be tested. Following Baum et al. (1999), $d^{*}$ parameter is predicted with semi-parametric approach developed by Geweke and Porter-Hudak (1983), Robinson (1995) and Phillips (1999a, b) by taking the first difference of q series while $d^{*}=d-1$.

Unit root tests allow testing between two endpoints that a series is either stationary or not stationary. However, the series can contain both stationary and non-stationary elements. If a series has these two elements simultaneously, unit root tests have a tendency not to reject the null hypothesis that the series is not stationary (Maeso-Fernandez, 1998). Therefore, variance ratio tests are used to determine the non-stationary element in a series. Firstly, it is investigated whether the $u_{t}$ series follows the random walking process under homoscedasticity and heteroscedasticity as suggested by Lo and MacKinlay (1988). Secondly, rank, rank score and sign tests developed by Wright (2000) are applied.

Before the econometric analysis, Figure 1 shows that the downward trend in the unemployment rate seen until the 1950s was later replaced by the upward trend. $u_{t}$ series is not stationary and therefore the unemployment hysteresis hypothesis is valid in Turkey. In fact, when the correlogram of $u_{t}$ series is examined, the autocorrelation function decreases very slowly and it takes a long time for any shock to disappear its effect on the $u_{t}$ series (Table 2). This increases the probability of nonstationary of $u_{t}$ series.

\begin{tabular}{llllllll}
\hline $\mathbf{k}$ & AC & Q-stats & Prob. & Lags & AC & Q-stats & Prob. \\
\hline 1 & 0.952 & 88.662 & 0.00 & 6 & 0.764 & 436.54 & 0.00 \\
2 & 0.896 & 169.97 & 0.00 & 7 & 0.743 & 494.83 & 0.00 \\
3 & 0.851 & 243.24 & 0.00 & 8 & 0.716 & 549.67 & 0.00 \\
4 & 0.816 & 311.30 & 0.00 & 9 & 0.675 & 598.94 & 0.00 \\
5 & 0.789 & 375.60 & 0.00 & 10 & 0.628 & 642.05 & 0.00 \\
\hline
\end{tabular}

Table 2. Correlogram of Unemployment Rate

Notes: (1) $k$ and $Q$ indicate the number of lags and the test statistics developed by Ljung and Box (1978) for testing the null hypothesis there is no autocorrelation until $k^{\text {th }}$ lags, respectively. (2) This test is performed with the help of Eviews 10.

\section{Empirical Findings}

Initially, the stationarity of the $u_{t}$ series is tested with the ADF, DF-GLS, PP, NP and KPSS traditional unit root tests with the optimal lag lengths determined by the LM, GtoS and MAIC information criteria. According to these methods, $u_{t}$ series is not stationary except for some of the ADF and PP test forms. KPSS test results is significant at $1 \%$ critical value, but unlike the other traditional unit root tests, KPSS test is stated that the series is stationary in $\mathrm{H}_{0}$ hypothesis and $\mathrm{H}_{1}$ hypothesis is not stationary in the series. It means this test cannot accept that $u_{t}$ series is stationary. Even though the traditional unit root tests indicate that the $u_{t}$ series are not stationary, the null hypothesis that $u_{t}$ series is not stationary cannot be rejected in the PV, CMR and LP tests with constant break, but rejected in other breakpoint unit root tests. Traditional and breakpoint unit root tests implicitly assume that the $u_{t}$ series is linear. KSS and Sollis tests taking into account the non-linearity of the $u_{t}$ series show that the $u_{t}$ series is not stationary.

Due to fact that unit root tests allow testing between two endpoints that a series is either stationary or not stationary and necessitate an integer degree of integration of a series (d), VR (Lo and MacKinlay, Wright, Chow and Denning) and ARFIMA (Geweke and Porter-Hudak, Robinson, Phillips) tests are applied to increase the reliability of unit root tests. As a result, the null hypothesis that $u_{t}$ series follows random processes cannot be rejected. 


\begin{tabular}{|c|c|c|c|}
\hline Tests & & Constant & Constant and Trend \\
\hline $\mathbf{A D F}_{L M}$ & & $-0.327(8)$ & $-3.003(8)$ \\
\hline ADFGtos $_{\text {G }}$ & & $-1.052(1)$ & $-3.775(1)^{* *}$ \\
\hline ADF $_{\text {MAIC }}$ & & $-0.667(2)$ & $-4.562(0)^{*}$ \\
\hline DF-GLSLM & & $-0.932(8)$ & $-0.961(8)$ \\
\hline DF-GLS GtoS & & $-1.175(1)$ & $-1.487(1)$ \\
\hline DF-GLSMAIC & & $-0.845(2)$ & $-1.066(2)$ \\
\hline PPMaic & & $-0.896(2)$ & $-4.562(0)^{*}$ \\
\hline \multirow{2}{*}{ NPMaIC } & $\mathbf{M Z a}$ & $-2.803(2)$ & $-2.351(0)$ \\
\hline & $\mathbf{M Z} \mathbf{Z}_{\mathrm{t}}$ & $-0.878(2)$ & $-1.017(0)$ \\
\hline KPSS MAIC $_{\text {M }}$ & & $116.20(2)^{*}$ & $5.614(0)^{*}$ \\
\hline
\end{tabular}

Table 3. Traditional Unit Root Tests

Notes: (1) The critical values are obtained from Fuller (1976) for ADF and PP tests, from Elliott et al. (1996) for DF-GLS test, from Ng and Perron (2001) for NP test and from Kwiatkowski et al. (1992) for KPSS test. (2) The number of observations for the ADF, DF-GLS and PP tests is accepted to be 100. (3) The critical values of $1 \%$ and $5 \%$ significance levels in ADF and PP tests are -3.51 and -2.89 , respectively, for models with only intercept, while -4.04 and -3.45 for models with intercept and trend. These critical values are, respectively, -2.58 and -1.94 and -3.58 and 3.03 for the DF-GLS test; -13.80 and -8.10 to -23.80 and -17.30 for $N P / M Z_{a},-2.58$ and -1.98 to -3.42 and -2.91 for $N P / M Z_{t} ; 0.739$ and 0.463 and 0.216 and 0.146 for the KPSS test, respectively. (4) OLS-detrended procedure is used in PP, NP and KPSS tests. (5) The values in parenthesis represent the optimal lag length. The maximum lag length is 8 . (6) * and ** indicate that the null hypothesis is rejected at $1 \%$ and $5 \%$ significance levels. (7) The tests are carried out with EViews 10.

\begin{tabular}{|c|c|c|c|c|}
\hline \multirow[t]{3}{*}{ Tests } & \multicolumn{4}{|l|}{ Intercept Break } \\
\hline & \multicolumn{2}{|l|}{ Additive Outlier } & \multicolumn{2}{|l|}{ Innovational Outlier } \\
\hline & t-stats & Break Dates & t-stats & Break Dates \\
\hline PV & $-4.045(1)^{* *}$ & 1970 & $-3.978(1)$ & 1965 \\
\hline CMR & $-2.972(6)$ & 1970,2003 & $-6.650(1)^{*}$ & 1965,1999 \\
\hline \multirow[t]{4}{*}{ Perron } & & & $-4.590(1)$ & 1966 \\
\hline & Trend Break & & \multicolumn{2}{|c|}{ Intercept and Trend Break } \\
\hline & Additive Outlier & & Innovational Outlier & \\
\hline & t-stats & Break Date & t-stats & Break Date \\
\hline Perron & $-4.204(1)$ & 1946 & $-4.922(1)$ & 1966 \\
\hline
\end{tabular}

Table 4. Breakpoint Unit Root Tests (Based on Perron)

Notes: (1) The critical values are obtained from Perron and Vogelsang (1992) for PV test, from Clemente et al. (1998) for CMR test, from Perron (1997) for Perron test. The number of observations for the PV and Perron tests is accepted to be 100. (2) The critical values of $1 \%$ and $5 \%$ significance levels in PV test are -4.38 and -3.64 , respectively, for models with only intercept break and additive outlier, while -4.95 and -4.22 for models with intercept break and innovational outlier. These critical values are, respectively, -5.96 and -5.49 for CMR test with intercept break both additive outlier and innovational outlier. The critical values of $1 \%$ and $5 \%$ significance levels in Perron test are -5.70 and -5.10 for models with only intercept break and innovational outlier, -5.45 and -4.83 for models with only trend break and additive outlier, while -6.21 and -5.55 for models with intercept and trend break and innovational outlier, respectively. (3) The PV and CMR tests include only intercept, while Perron test contains both intercept and trend. (4) The values in parenthesis represent the optimal lag length determined by the GtoS approach. The maximum lag length is $8 .(5) *$ and $* *$ indicate that the null hypothesis is rejected at $1 \%$ and $5 \%$ significance levels. (6) The trimming parameter is 0.15. (7) PV and CMR tests are performed by Stata 14.2 and Perron by Eviews 10.

\begin{tabular}{lllllll}
\hline \multirow{2}{*}{ Tests } & \multicolumn{2}{l}{ Intercept Break } & \multicolumn{2}{c}{ Trend Break } & \multicolumn{2}{c}{ Intercept and Trend Break } \\
\cline { 2 - 7 } & t-stats & Break Dates & t-stats & Break Dates & t-stats & Break Dates \\
ZA & $-4.612(1)$ & 1967 & $-4.177(1)$ & 1947 & $-4.943(1)$ & 1967 \\
LP & $-6.531(1) * *$ & 1966,2000 & $-5.085(1)$ & 1957,1974 & $-5.740(1)$ & 1989,2004 \\
\hline
\end{tabular}

Table 5. Breakpoint Unit Root Tests (Based on ADF)

Notes: (1) The critical values are obtained from Zivot and Andrews (1992) for ZA test, from Lumsdaine and Papell (1997) for LP test. (2) The critical values of $1 \%$ and $5 \%$ significance levels in ZA test are -5.34 and -4.80 for models with only intercept break, -4.93 and -4.42 for models with only trend break and -5.57 and -5.08 for models with intercept and trend break, respectively. This values -6.94 and $-6.24,-7.24$ and -6.65 and -7.34 and -6.82 for LP test with the same models. (3)These tests include both intercept and trend. (4) The values in parenthesis represent the optimal lag length determined by the GtoS approach. The maximum lag length is 8. (5) ** indicates that the null hypothesis is rejected at 5\% significance level. (6) The trimming parameter is 0.15 . (7) ZA and LP test is performed by EViews 10 and RATs 8.0, respectively. 


\begin{tabular}{lllll}
\hline \multirow{2}{*}{ Tests } & \multicolumn{2}{l}{ Intercept Break } & \multicolumn{2}{l}{ Intercept and Trend Break } \\
\cline { 2 - 5 } LS1 & t-stats & Break Dates & t-stats & Break Dates \\
LS2 & $-1.241(1)$ & 1982 & $-3.321(1)$ & 1946 \\
\hline
\end{tabular}

Table 6. Breakpoint Unit Root Tests (Based on LM)

Notes: (1) The critical values are obtained from Lee and Strazicich (2004) for LS1 test, from Lee and Strazicich (2003) for LS2 test. (2) The critical values of $1 \%$ and 5\% significance levels in LS1 test are -4.24 and -3.57 for models with only intercept break, -5.15 and -4.45 for models with intecept and trend break, respectively. This values -5.44 and $-3.84,-6.41$ and -5.74 for LS2 test with the same models. (3)These tests include both intercept and trend. (4) The values in parenthesis represent the optimal lag length determined by the GtoS approach. The maximum lag length is 8. (5) The trimming parameter is 0.15 . (6) These tests are carried out with RATs 8.0.

\begin{tabular}{lll}
\hline Tests & Intercept & Intercept and Trend \\
\hline KSS & $2.120(2)$ & $2.127(2)$ \\
Sollis & $3.975(2)$ & $3.397(2)$ \\
\hline
\end{tabular}

Table 7. Nonlinear Unit Roots Tests

Notes: (1) The critical values are obtained from Kapetanios et al. (2003) for KSS test, from Sollis (2009) for Sollis test. (2) The critical values of $1 \%$ and $5 \%$ significance levels in KSS test are -3.48 and -2.93 for models with only intercept break, -3.93 and -3.40 for models with intecept and trend break, respectively. This values -6.89 and $-4.89,-8.80$ and -6.55 for Sollis test with the same models. (3) The number of observations for the Sollis test is accepted to be 50. (4) Sollis test is based on F statistics. (5) The values in parenthesis represent the optimal lag length determined by the GtoS approach. The maximum lag length is 8. (6) These tests are performed by EViews 10.

\begin{tabular}{llllllll}
\hline $\mathbf{m}$ & & $\mathbf{0 . 4 5}$ & $\mathbf{0 . 5 0}$ & $\mathbf{0 . 5 5}$ & $\mathbf{0 . 6 0}$ & $\mathbf{0 . 6 5}$ & $\mathbf{0 . 7 0}$ \\
\hline \multirow{2}{*}{ Geweke and } & $\mathrm{d}^{*}$ & 0.22 & 0.00 & -0.11 & -0.05 & 0.06 & 0.06 \\
Porter-Hudak & t-stats & 0.79 & 0.00 & -0.58 & -0.31 & -0.46 & -0.58 \\
& Prob. & 0.47 & 1.00 & 0.58 & 0.76 & 0.65 & 0.57 \\
\multirow{2}{*}{ Robinson } & $\mathrm{d}^{*}$ & 0.21 & 0.00 & -0.01 & -0.05 & -0.06 & -0.06 \\
& t-stats & 0.79 & -0.01 & -0.07 & -0.31 & -0.47 & -0.64 \\
& Prob. & 0.46 & 0.99 & 0.95 & 0.76 & 0.65 & 0.53 \\
Phillips & d* & 0.12 & -0.07 & -0.16 & -0.10 & -0.12 & -0.10 \\
& t-stats & 0.43 & -0.30 & -0.85 & -0.61 & -0.89 & -0.96 \\
& Prob. & 0.68 & 0.77 & 0.41 & 0.55 & 0.39 & 0.35 \\
\hline
\end{tabular}

Table 8. ARFIMA Tests

Notes: (1) m shows the number of optimal ordinates. (2) These tests are carried out with Stata 14.2.

\begin{tabular}{|c|c|c|c|c|c|c|}
\hline \multicolumn{6}{|c|}{ Individual Tests } & \multirow{2}{*}{$\begin{array}{l}\text { Joint Test } \\
\operatorname{Max}|z|\end{array}$} \\
\hline $\mathbf{k}$ & 5 & 10 & 15 & 20 & 25 & \\
\hline \multicolumn{7}{|c|}{ Lo and MacKinlay Test } \\
\hline VR(k) & 0.997 & 0.872 & 0.770 & 0.845 & 0.836 & \\
\hline $\mathbf{Z 1}$ & -0.015 & -0.614 & -0.529 & -0.304 & -0.285 & 0.614 \\
\hline Prob. & 0.993 & 0.685 & 0.718 & 0.842 & 0.845 & 0.901 \\
\hline $\mathbf{Z 2}$ & -0.010 & -0.484 & -0.443 & -0.267 & -0.261 & 0.484 \\
\hline Prob. & 0.989 & 0.704 & 0.686 & 0.819 & 0.832 & 0.918 \\
\hline \multicolumn{7}{|c|}{ Wright Test } \\
\hline VR(k) & 1.270 & 1.078 & 1.052 & 1.061 & 1.002 & \\
\hline $\mathbf{R 1}$ & 1.204 & 0.225 & 0.120 & 0.120 & 0.003 & 1.204 \\
\hline Prob. & 0.239 & 0.863 & 0.953 & 0.949 & 1.000 & 0.460 \\
\hline $\operatorname{VR}(\mathbf{k})$ & 1.145 & 0.911 & 0.870 & 0.884 & 0.819 & \\
\hline $\mathbf{R 2}$ & 0.644 & -0.258 & -0.299 & -0.228 & -0.315 & 0.644 \\
\hline Prob. & 0.556 & 0.847 & 0.829 & 0.896 & 0.875 & 0.869 \\
\hline $\operatorname{VR}(k)$ & 1.455 & 1.419 & 1.399 & 1.368 & 1.320 & \\
\hline $\mathbf{S}$ & 2.023 & 1.209 & 0.915 & 0.723 & 0.557 & 2.023 \\
\hline Prob. & 0.046 & 0.291 & 0.486 & 0.653 & 0.779 & 0.057 \\
\hline
\end{tabular}

Table 9. Variance Ratio Tests

Notes: (1) VR(k) indicates the variance ratio in lag $k$. (2) Z1 and Z2 show the Z statistics proposed by Lo and MacKinlay (1988) calculated under the assumption of homoskesdacity and heteroskesdacity, respectively. $R 1, R 2$ and $S$ show the $Z$ statistics calculated by Wright (2000), based on sign, sign score, and ranks, respectively. The distribution of variance ratios is obtained 
by the wild bootstrap technique proposed by Kim (2006) in all five tests, (3) Max $|z|$ shows Chow and Denning (1993) test statistics. (4) These tests are performed by EViews 10.

\section{Conclusion}

Although the unemployment hysteresis and natural unemployment rate hypotheses are one of the most studied subjects on macroeconomics, these concepts are not fully understood due to the differentiation of the techniques and variables used. Therefore, the results are re-examined in favor of the natural unemployment rate hypothesis with every new technique developed in the field of econometrics and the results are generally in favor of unemployment hysteresis especially in the studies using long-term data sets. In this study, the stability of unemployment rate is investigated in Turkey with the data set covering approximately a century and starting from 1923.

The stability of the unemployment rate is examined the unit root tests, variance ratio tests and fractional integration models by following the studies in the literature. Almost all tests and models indicate that the unemployment rate series is not stationary. These findings show that the shocks in the economy and the stabilization policies implemented lead to permanent changes in the natural rate of unemployment. While the unemployment hysteresis leads to increasing costs in reducing inflation, it also reveals the necessity of structural reforms to reduce increased unemployment as a result of inflation control or changes in structural factors. In order to eliminate the effect of this hysteresis on unemployment, it is necessary to give weight to the expansionary monetary and fiscal policies, which in the short term may be costly, but in the long term, this impact can be eliminated.

\section{References}

- $\quad$ Banerjee, A., Urga, G. (2005). Modelling Structural Breaks, Long Memory and Stock Market Volatility: An Overview. Journal of Econometrics, 129(1): 1-34.

- $\quad$ Baum, C. F., Barkoulas, J. T., Caglayan, M. (1999). Long Memory or Structural Breaks: Can Either Explain Nonstationary Real Exchange Rates under the Current Float?. Journal of International Financial Markets, Institutions and Money, 9(4), 359-376.

- Blanchard, O. J., \& Summers, L. H. (1986). Hysteresis and the European Unemployment Problem. NBER Macroeconomics Annual, 1, 15-78.

- Bulutay, T. (1995). Employment, Unemployment and Wages in Turkey. International Labour Organization.

- Chang, T. (2011). Hysteresis in Unemployment for 17 OECD Countries: Stationary Test with a Fourier Function. Economic Modelling, 28(5), 2208-2214.

- Chow, K.V., Denning, K.C. (1993). A Simple Multiple Variance Ratio Test. Journal of Econometrics, 58(3): 385-401.

- Christopoulos, D. K., \& León-Ledesma, M. A. (2007). Unemployment Hysteresis in EU Countries: What Do We Really Know About It?. Journal of Economic Studies, 34(2), 80-89.

- Clemente, J., Montanes, A., Reyes, M. (1998). Testing for a Unit Root in Variables with a Double Change in the Mean. Economics Letters, 59(2): 175-182.

- Cochrane, J. H. (1988). How Big is the Random Walk in GNP?. Journal of Political Economy, 96(5), 893920 .

- Crato, N., \& Rothman, P. (1996). Measuring Hysteresis in Unemployment Rates with Long Memory Models. Greenville, Carolina del Sur: Department of Economics, East Carolina University.

- Dickey, D. A., Fuller, W. A. (1981). Likelihood Ratio Statistics for Autoregressive Time Series with a Unit Root. Econometrica: Journal of the Econometric Society, 1057-1072.

- $\quad$ Elliott, G., Rothenberg, T., Stock, J. H. (1996). Efficient Tests for an Autoregressive Unit Root. Econometrica, 64(4): 813-836.

- Friedman, M. (1968). The Role of Monetary Policy.

- Fuller, W.A. (1976). Introduction to Statistical Time Series. Wiley: New York.

- Geweke J., Porter-Hudak, S. (1983). The Estimation and Application of Long Memory Time Series Models. Journal of Time Series Analysis, 4(4): 221-238.

- Gomes, F., \& da Silva, C. G. (2008). Hysteresis vs. Natural rate of Unemployment in Brazil and Chile. Applied Economics Letters, 15(1), 53-56.

- Gozgor, G. (2012). Hysteresis in Regional Unemployment Rates in Turkey. International Journal of Economics and Finance, 4(9), 175. 
- Granger, C. W. (1980). Long Memory Relationships and the Aggregation of Dynamic Models. Journal of econometrics, 14(2), 227-238.

- Granger, C. W., Joyeux, R. (1980). An Introduction to Long-Memory Time Series Models and Fractional Differencing. Journal of Time Series Analysis, 1(1), 15-29.

- Güloğlu, B., \& İspir, M. S. (2011). Is Natural Rate of Unemployment or Hysteresis? Sector-Specific Panel Unit Root Test Analysis for Turkey. Ege Academic Review, 11(2), 205-215.

- Gustavsson, M., \& Österholm, P. (2006). Hysteresis and Non-linearities in Unemployment Rates. Applied Economics Letters, 13(9), 545-548.

- Hall, A. (1994). Testing for a Unit Root in Time Series with Pretest Data-Based Model Selection. Journal of Business and Economic Statistics, 12(4): 461-470.

- Hosking, J. R. (1981). Fractional Differencing. Biometrika, 68(1), 165-176.

- Johansen, K. (2002). Hysteresis in Unemployment: Evidence from Norwegian Counties.

- Kapetanios, G., Shin, Y., Snell, A. (2003). Testing for a Unit Root in the Nonlinear STAR Framework. Journal of Econometrics, 112(2): 335-346.

- Kurita, T. (2010). A Forecasting Model for Japan's Unemployment Rate. Eurasian Journal of Business and Economics, 3(5), 127-134.

- $\quad$ Kwiatkowski, D., Phillips, P.C.B., Schmidt, P., Shin, Y. (1992). Testing the Null Hypothesis of Stationarity against the Alternative of a Unit Root. Journal of Econometrics, 54(1): 159-178.

- $\quad$ Lee, H. Y., Wu, J. L., \& Lin, C. H. (2010). Hysteresis in East Asian Unemployment. Applied Economics, 42(7), 887-898.

- $\quad$ Lee, J., Strazicich, M. C. (2003). Minimum Lagrange Multiplier Unit Root Test with Two Structural Breaks. Review of Economics and Statistics, 85(4): 1082-1089.

- Lee, J., Strazicich, M. C. (2004). Minimum LM Unit Root Test with One Structural Break. Appalachian State University Department of Economics Working Paper, No: 04-17.

- $\quad$ Lindbeck, A., \& Snower, D. J. (1986). Wage Setting, Unemployment, and Insider-Outsider Relations. The American Economic Review, 76(2), 235-239.

- $\quad$ Lo, A.W., MacKinlay, A. C. (1988). Stock Market Prices Do Not Follow Random Walks: Evidence From a Simple Specification Test. Review of Financial Studies, 1(1): 41-66.

- $\quad$ Lumsdaine, R. L., Papell, D. H. (1997). Multiple Trend Breaks and the Unit Root Hypothesis. Review of Economics and Statistics, 79(2): 212-218.

- Maeso-Fernandez, F. (1998). Econometric Methods and Purchasing Power Parity: Short and Long-Run PPP. Applied Economics, 30(11): 1443-1457.

- Neudorfer, P., Pichelmann, K., \& Wagner, M. (1990). Hysteresis, NAIRU and Long Term Unemployment in Austria. In Hysteresis Effects in Economic Models (pp. 109-121). Physica-Verlag HD.

- $\quad$ Ng, S., Perron, P. (1995). Unit Root Test in ARMA Models with Data Dependent Methods for the Selection of the Truncation Lag. Journal of the American Statistical Association, 90(429): 268-281.

- Ng, S., Perron, P. (2001). Lag Length Selection and the Construction of Unit Root Tests with Good Size and Power. Econometrica, 69(6): 1519-1554.

- Özkan, Y., \& Altınsoy, A. (2015). İşsizlik ve İstihdamda Histeri Etkisi (Türkiye, 1988-2014). Siyaset, Ekonomi ve Yönetim Araştırmaları Dergisi.

- Perron, P. (1989). The Great Crash, the Oil Price Shock and the Unit Root Hypothesis. Econometrica, 57(6): 1361-1401.

- $\quad$ Perron, P. (1997). Further Evidence from Breaking Trend Functions in Macroeconomic Variables. Journal of Econometrics, 80(2): 355-385.

- Perron, P., Vogelsang, T. J. (1992). Nonstationarity and Level Shifts with an Application to Purchasing Power Parity. Journal of Business and Economic Statistics, 10(3): 301-320.

- Phelps, E. S. (1967). Phillips Curves, Expectations of Inflation and Optimal Unemployment over Time. Economica, 254-281.

- $\quad$ Phelps, E. S. (1968). Money-wage Dynamics and Labor-market Equilibrium. Journal of Political Economy, 76(4, Part 2), 678-711.

- $\quad$ Phelps, E. S. (1994). Structural Slumps: The Modern Equilibrium Theory of Unemployment, Interest, and Assets. Harvard University Press. 
- $\quad$ Phillips, P. C. B. (1999a), Discrete Fourier Transforms of Fractional Processes. Yale University Cowles Foundation for Research in Economics Working Paper, No: 1243.

- $\quad$ Phillips, P. C. B. (1999b). Unit Root Log Periodogram Regression. Yale University Cowles Foundation for Research in Economics Working Paper, No: 1244.

- Pissarides, C. A. (1992). Loss of Skill during Unemployment and the Persistence of Employment Shocks. The Quarterly Journal of Economics, 107(4), 1371-1391.

- $\quad$ Robinson, P. M. (1995). Log-Periodogram Regression of Time Series with Long Range Dependence. Annals of Statistics, 23(3): 1048-1072.

- $\quad$ Røed, K. (1996). Unemployment Hysteresis-macro Evidence from 16 OECD Countries. Empirical Economics, 21(4), 589-600.

- $\quad$ Schmidt, P., Phillips, P. C. B. (1992). LM Tests for a Unit Root in the Presence of Deterministic Trends. Oxford Bulletin of Economics and Statistics, 54(3): 257-287.

- Sollis, R. (2009). A Simple Unit Root Test against Asymmetric STAR Nonlinearity with an Application to Real Exchange Rates in Nordic Countries. Economic Modelling, 26(1): 118-125.

- $\quad$ Song, F. M., \& Wu, Y. (1998). Hysteresis in Unemployment: Evidence from OECD Countries. The Quarterly Review of Economics and Finance, 38(2), 181-192.

- Stanley, T. D. (2004). Does Unemployment Hysteresis Falsify the Natural Rate Hypothesis? A Metaregression Analysis. Journal of Economic Surveys, 18(4), 589-612.

- Villeneuve, J. F., \& Handa, J. (2006). Purchasing Power Parity as a Long-term Memory Process: Evidence from Canada. Applied Financial Economics, 16(1-2), 109-117.

- Wright, J. H. (2000). Alternative Variance-Ratio Tests Using Ranks and Signs. Journal of Business and Economic Statistics, 18(1): 1-9.

- Yılancı, V. (2009). Yapısal Kırılmalar Altında Türkiye için İşsizlik Histerisinin Sınanması.

- Zivot, E., Andrews, D. W. K. (1992). Further Evidence on the Great Crash, the Oil Price Shock and the Unit Root Hypothesis. Journal of Business and Economic Statistics, 10(3): 251-270. 


\title{
The Long-Run and Short-Run Endogeneity of Money Supply in the Republic of Macedonia: An Empirical Analysis
}

\author{
Ph.D. Candidate Milica Milosheska Gavrovska (Komercijalna Banka AD Skopje, Macedonia) \\ Prof. Dr. Trajko Slaveski (Ss. Cyril and Methodius University, Macedonia)
}

\begin{abstract}
The aim of this paper is to assess the endogenous and exogenous approaches on the money creation process on empirical grounds, through analysis in the case of the Republic of Macedonia.

Using the ARDL econometric model, it has been determined that the money supply in the Republic of Macedonia in the period January 2003 - August 2018 is endogenously determined in the long run. The empirical results in the short term show bidirectional causality between deposits and monetary base, as well as between deposits and loans.

However, in the end, the central bank in the Republic of Macedonia has an influence on the money supply. The exogenous monetary policies based on money supply control, can positively influence the amount of liquidity held by commercial banks and, hence, increase the supply of loans, but the demand for loans is still important when stimulating the entry of liquidity in the real economy.
\end{abstract}

\section{Introduction}

After the financial crisis and the great recession (2007-2009) that has recently upset the world economy, the public is preoccupied with how the banks came to so much money. Until this period, in the economics textbooks, the traditional theory of the money creation process was mainly represented as a product of the monetary base and the money multiplier, i.e. the money supply was considered exogenous. Experts in economic and professional circles believe that they know how the money is created.

But the Great Recession opened a debate about "who creates money," through a bond of money in circulation offered by the central bank, and inside money, created by commercial banks. The essence of money is closely related to the process of their creation. It does not matter what the money is, but the effect it has. The fact that the deep recession hit the advanced economies that had solid institutions and well-informed regulatory authorities was surprising.

The Post-Keynesian economists seriously questioned the validity of the traditional theory of the money creation process. Based on historical events and empirical evidence, the researchers strongly suggested that the money supply was endogenous and determined by the demand for credit money. This is considered a post-Keynesian invention.

In the modern economy, most money is in the form of bank deposits. The main way in which bank deposits are created is via commercial banks that approve loans. Namely, in the modern banking system, banks create money using the lending mechanism, but only generate money in the form of bank deposits. Banks create deposits as a by-product of their lending. Whenever the bank approves a loan, it creates an appropriate deposit in the bank account of the borrower, creating new money. Only central banks create cash. The amount of money created in the economy in the end, depends on the monetary policy of the Central Bank.

After the Great Recession, banks are increasingly incorporated into macroeconomic models. Until then, banks were not part of the macroeconomic models. The reason for this is that in the past decades, and as a result of careful banking regulation, the private banking system was not an important source of instability. But the great recession has caused a dramatic change. The role of the banks in the economy attracted attention more than ever, whereupon the creators of the monetary policy clearly recognizing the importance of a sound banking system for the real economy.

This paper will consider the current issue of creating money in the case of the Republic of Macedonia, by analyzing the connection between the variables determining the money supply, and taking into account the characteristics of the Macedonian banking system. The paper is organized as follows: the second part gives an overview of theoretical and empirical literature, the third part explains the endogenous and exogenous process of money creation, in the fourth part the role of the banks in the money creation process is reviewed, the fifth part describes the data and methodology and presents the empirical results. The conclusions and political implications follow in the last section.

\section{Literature Review}

A considerable body of literature is devoted to the money creation. To the best of our knowledge, no one attempted to test the endogenous hypothesis for the less developed countries, except Ahmad, N. \& Ahmet, F. (2006) for Pakistan. Ironically, low-income countries are blessed with high unemployment and corruption. A 
recommendation that is often suggested by the Keynesians is to follow active monetary and fiscal policies to avoid the problem of high unemployment. Researches in this area have not been found in Macedonian literature.

The fact that banks create their own funds through lending is also emphasized in the older economic literature. One of the earliest statements is according to Wicksell (1906): "The lending operations of the bank will consist rather in its entering in its books a fictitious deposit equal to the amount of the loan...”. Rogers (1929): “... a large proportion of ... [deposits] under certain circumstances may be manufactured out of whole cloth by the banking institutions themselves."

The theoretical literature proposed arguments to support the endogeneity of money. To test this theoretical argument, the empirical literature on money endogeneity for different economies has shown that the money supply is endogenously determined. For example, Enrico, S., L. and Matteo, D. (October, 2017), Paul, M. and Joshua, W. (2013), Milena, L. (August 2014), Haghighat, J. (2012), Alexey, P. (2016), Vera, AP (2001), Shanmugam, B., Nair, M. and Li, O.W. (2003) presented a time analysis to test the money-endogeneity hypothesis in the case of the United States, the Eurozone countries, Iran, the emerging economies, Spain, and Malaysia, respectively.

The empirical results show that there is a causal link between loans to bank deposits, monetary base, and monetary aggregates. But in addition to these studies that prove the endogenous process of money creation, there are also studies where the obtained results prove that in some periods the money supply is exogenously determined. For example, according to Ahmad's empirical findings, N. \& Ahmet, F. (2006), in their research on the short-term and long-term endogeneity of the money supply in Pakistan, the money supply is endogenously determined only in the short term, the time period is not longer than 18 months, but in the long run the money supply is exogenous, that is, the central bank has a significant influence on the money supply in the long run. The result of their analysis is that monetary policy can really affect the financial environment in the long run.

\section{Exogenous versus Endogenous Money Creation Process}

The ideological division between proponents of the theory of endogenous (horizontal) and exogenous (verticalist) money supply was fiercely expressed in the debates between the Post-Keynesians and the Monetarists from the late 1950 s to the early 1990s.

Economists have long talked about whether the money supply curve is vertical or horizontal. Verticalists claim that the money supply depends on the total reserves, while the reserves are the central bank's liabilities and are exogenously determined by the central bank, so the money supply should be displayed as a vertical line. While the Horizontalists argue that during the "market period", the central bank sets the interest rate and adjusts it to determine the liquidity of bank deposits, regardless of what reserves are required. Hence, the Horizontalists consider that the interest rate is exogenously determined, and the money supply is endogenously determined.

Modern undergraduate texts express the exogenous money creation (Blanchard, 2011; Mankiw, 2012; Frank \& Bernanke, 2013), that is a call to witness to the widespread acceptance of the Monotheistic view that is dominant. Given the importance of this issue, the endogenous view of bank money creation has relatively discreetly emerged as a view expressed by modern monetarists (McLeay, Radia, \& Thomas, 2014a \& 2014b), which probably provoked excessive controversy. With the exogenous view as a precedent in the past half-century, the unfortunate by-product was focused on money creation, which focused on money supply, treating the given demand for money as a past. Despite the change in the endogenous explanation of the money supply, the focus of monetary policy remained on the offer side, with a relatively small focus on the basic demand for money, despite its recognized importance in the theory of endogenous money.

According to the horizontal description of bank money creation, the bank approves a loan to a client, whereby it lends its bank account with the amount of deposit equal to the size of the loan. This is bank money creation. No physical cash is required for these accounting records. This description represents an endogenous approach to the money creation process, and this process is specified as "loans create deposits" (McLeay, Radia, \& Thomas, 2014b). Hence, the money supply is determined by the demand for credit money. Debtors base the demand for credits considering their expectations for future income. The endogeneity of money causes a causative direction from loans to bank deposits. At the same time, deposits created with new loans are used to finance the rise in aggregate demand. And monetary policy has an impact both on the monetary base and on the money supply. The change in money supply causes interest rate fluctuations, which further affects investment and income.

According to the Verticalists' view, the bank borrows cash that the clients previously physically deposited in the bank. Loan approval once again, creates an entry on the deposit obligation; however, bank money was created in this process after the bank will transfer the existing physical cash deposits to customers. This process is specified as "deposits creating loans" and is an exogenous view of the money supply.

With the acknowledged inability of central banks to directly control the supply of money, the discussion on monetary policy focused on banks as money generators. However, a superficial treatment of the money demand and the focus of the banks as money generators, it explains fundamentally the role of banks in the money creation process. 


\section{The Role of Banks in the Money Creation Process}

The role of the banks in the economy attracted attention more than ever, whereupon the monetary policy makers clearly recognize the importance of a sound banking system for the real economy.

According to Jan (2014), the main activity of banks is to facilitate the process of inter-time exchange of transactions between buyers and sellers through loan agreements. Banks are financial intermediaries which accept deposits, give loans and provide accounts for their clients.

One feature of the banks significantly differs them from other financial intermediaries. It is that their obligations, or at least their liabilities for sight deposits, serve as a generally accepted means of payment (James, 1963). In addition to banknotes and coins, deposit money is considered "money".

On the other hand, other financial institutions, unlike banks, do not generate money, and the amount of their assets is limited to the amount of their liabilities. They cannot count on receiving a "deposit" to coincide with any expansion of their lending. Only commercial banks have that freedom. And since they only have that key to unlimited expansion, the process of creating money is limited by regulatory factors - the central bank (reserve requirements). From the perspective of banks, the money creation is limited by the need for banks to lend profitably, and also from micro and macro prudential regulations. While the central bank affects the process of creating money by banks through its interest rate policy, which affects the financial and portfolio decisions of banks through different transmission channels.

\section{Analysis of the monetary base, bank deposits and bank credits in the case of the Republic of Macedonia}

\subsection{Data}

The analysis carried out in this paper is based on monthly data for the period January 2003 - August 2018, taken by the National Bank of the Republic of Macedonia for the following time series:

- total bank deposits,

- $\quad$ total bank credits and

- monetary base.

The time span allows us to use 188 observations in our time analysis. For all calculations the statistical software STATA is used. Before carrying out the analysis, a descriptive analysis of the time series was made.

\subsection{Methodology}

Since all variables assume positive value, the time series analysis will begin by transforming them into a logarithmic form and excluding the impact of seasonal variations with the MOVING AVERAGE technique.

We will apply times series models able to take into consideration and solve issues related to endogeneity. In order to arrange the data accurately, we implement the following steps.

Firstly, in order to understand the stationarity (or the order of integration) of considered variables, a standard unit root test is conducted on selected series. More specifically, two tests will be applied, including: Augmented Dickey-Fuller (ADF) and Phillips-Perron. Results concerning unit root, led us to use alternative econometric models in order to test short- and long-run causality between the variables.

Secondly, if the series are of the same order of integration, Johansen Cointegration Test will be applied to determine if there is cointegration among the variables. At the same time, VAR and VECM econometric models can be applied in order to determine the short- and long-run causality between the considered variables. The VAR model will estimate the short-run causality with the Granger non-Causality test, and VECM will estimate the shortrun causality with (Short-run Causality: Wald Test) and Long-Run Causality Test. However, if a unit root test shows that the variables are of different order of integration, i.e. I (0) and I (1), then the VECM model cannot be applied, but the alternative econometric model ARDL can also be applied because it estimates short- and long-run causality. ARDL model (Autoregressive Distributed Lag Modelling Approach) is developed by Pesaran(1997), Pesaran and Shin (1995, 1999),Pesaran and Smith, (1998), and Pesaran et al. (1996,2001).

\subsection{Empirical results and discussions}

For time series analysis, the data are taken in their logarithmic form, smoothing and seasonal adjustment is made with the MOVING AVERAGE technique. The smoothing is done with window (2 13 ):

$$
(1 / 6) *[\mathrm{x}(\mathrm{t}-2)+\mathrm{x}(\mathrm{t}-1)+1 * \mathrm{x}(\mathrm{t})+\mathrm{x}(\mathrm{t}+1)+\mathrm{x}(\mathrm{t}+2)+\mathrm{x}(\mathrm{t}+3)] ; \mathrm{x}(\mathrm{t})
$$




\begin{tabular}{|l|c|c|r|r|r|}
\hline Variables & Obs & Mean & Std. Dev. & Min & Max \\
\hline logmonetarybase ma & 188 & 3.848139 & .4700829 & 2.817185 & 4.538062 \\
\hline logtotalcredits ma & 188 & 5.032601 & .6248373 & 3.675591 & 5.726892 \\
\hline logtotaldeposits ma & 188 & 5.176848 & .5379969 & 3.98584 & 5.870641 \\
\hline
\end{tabular}

Table 1. Descriptive Statistics of the Considered Variables Source : Own Calculations

According to the obtained results with the Augmented Dickey-Fuller (ADF) and Phillips-Perron stationary tests, it has been established that the loans and deposits are stationary at level I (0), and the monetary base is stationary at first difference I (1), (Appendix2 ).

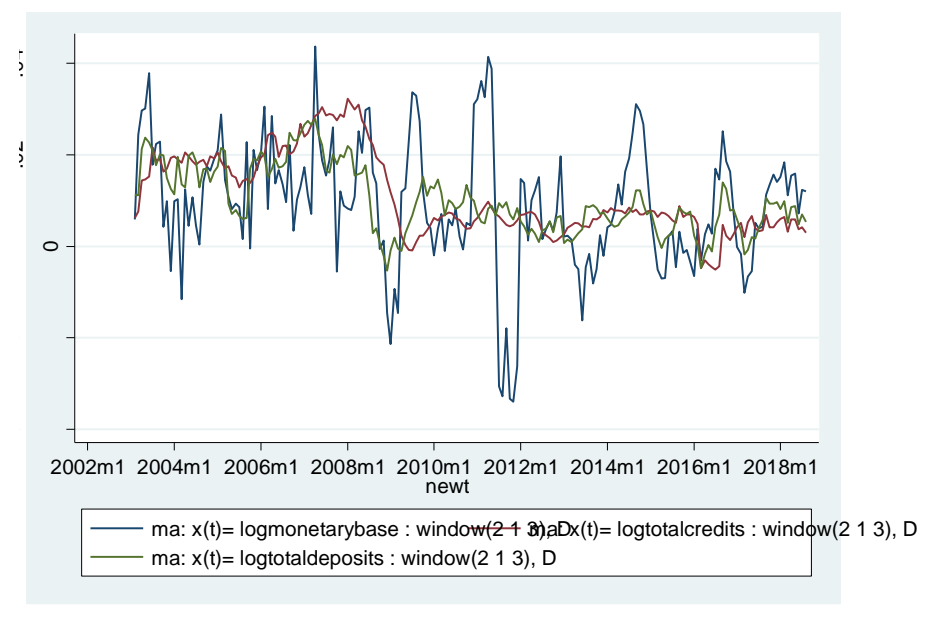

Graph 1. Graphical Representation of Stationary Time Series

Given that all three variables are at different order of integration, i.e. I (0), I (1) and I (1), it can be deduced that the ARDL econometric model can be implemented (Pesaran et al., 2001) that allows testing cointegration of the time series (the long-run equilibrium relationship between two or more variables). Additionally, the ARDL model provides an analysis of the causality even if the independent variables are endogenous, allowing the variables to have different optimal lag lengths and provides an opportunity to examine the short-run dynamics of the model versus the long-run relationship of the dependent and independent determinants. The theoretical ARDL is presented in the equation:

$$
\mathbf{y}_{t}=\beta_{0}+\beta_{1} \mathbf{y}_{t-1}+\ldots \ldots . .+\beta_{k} y_{t-p}+\alpha_{0} x_{t}+\alpha_{1} x_{t-1}+\alpha_{2} x_{t-2}+\ldots \ldots . . .+\alpha_{q} x_{t-q}+\varepsilon_{t}
$$

where, $y_{t}$ represents the dependent variable, $x_{t}$ represents the independent variable, $\varepsilon_{t}$ is standard long-term error, the symbols $\left(\beta_{1}-\beta_{\mathrm{k}}\right)$ in the first part of the equation denote the short-run coefficients, the symbols $\left(\alpha_{0}-\alpha_{\mathrm{q}}\right)$ denote the long-run coefficients, $p$ is the optimal time lag length.

To test whether there is a long-run relationship between the dependent variable and the independent variables in the model, i.e. whether there is a statistically significant cointegration between the time series we use the so-called "bound test", an approach developed by Pesaran and Pesaran (1997) and Pesaran et al. (2001). The zero hypothesis is that there is no statistically significant cointegration or long-run relationship between the dependent variable and the independent variables (Ho: $\beta 1=\beta 2=0$ ), contrary to the alternative hypothesis that at least one long-run coefficient is different from zero, which implies the existence of at least one long-run causality between a dependent and independent variable $(\mathrm{H} 1: \beta 1 \neq \beta 2 \neq 0)$.

The ARDL boundary test is based on the Wald test (F-statistics). The asymptotic distribution of the Wald test is non-standard in conditions of zero hypothesis when there is no cointegration between the determinants. Pesaran and Pesaran (1997) and Pesaran et al. (2001) set two critical values (lower and upper bounds) to test the cointegration. The lower critical bound value assumes that all variables are integrated at first difference $\mathrm{I}(1)$, while the upper bound critical value assumes that the determinants are integrated at zero difference $\mathrm{I}(0)$. Thus, if the obtained F-statistics exceeds the upper critical value, then the zero hypothesis is rejected, i.e. the alternative hypothesis that there is cointegration is accepted. On the other hand, if the obtained F-statistic does not exceed the lower critical value, then the zero hypothesis cannot be rejected, that indicates that there is no cointegration.

Given the assumption that all three variables in the paper are considered endogenous, three ARDL tests were made, each of the variables being dependent once. The results presented below, determine that there is a 1 (one) cointegration relationship in the long run, and therefore, loans and deposits have a significant impact on the monetary base in log-run.

The obtained test results presented in the table below indicate that the null hypothesis can be rejected, which means that there is a long-run relationship, i.e. cointegration between the determinants in the model (monetary 
base, total loans and total deposits). The obtained F-statistics is $\mathbf{6 . 3 4 5}$, that exceeds the upper critical value determined by Pesaran et al. (2001) with two regressors $(\mathrm{k}=2)$ at $1 \%$ level of significance.

\begin{tabular}{|c|c|c|c|c|c|c|c|}
\hline$[$ I_0] & {$\left[\mathrm{I} \_1\right]$} & {$\left[\mathrm{I} \_0\right]$} & {$\left[\mathrm{I} \_1\right]$} & {$\left[\mathrm{I} \_0\right]$} & {$\left[\mathrm{I} \_1\right]$} & {$\left[\mathrm{I} \_0\right]$} & {$\left[\mathrm{I} \_1\right]$} \\
\hline \multicolumn{2}{|c|}{$\mathbf{1 0}$} & \multicolumn{2}{|c|}{$\mathbf{2 \%}$} & \multicolumn{2}{|c|}{$\mathbf{2 . 5 \%}$} & \multicolumn{2}{c|}{$\mathbf{1 \%}$} \\
\hline Lower & Upper & Lower & Upper & Lower & Upper & Lower & Upper \\
\hline 2.17 & 3.19 & 2.72 & 3.83 & 3.22 & 4.50 & 3.88 & 5.30 \\
\hline
\end{tabular}

Table 2. Results of the Bound Test for Cointegration Source: Own calculations

Before calculating the long-term coefficients of the basic ARDL model, it is necessary to determine the optimal number of lags. For this purpose, we use the Akaike Information Criterion (AIC).

I. According to the decision based on the AIC criterion, the chosen model where the dependent variable is the monetary base is ARDL (4 4 2).

The results of the specified ARDL model, with determined optimum lag length on the determinants, and the dependent variable is the monetary base, are presented in Table 3.

\begin{tabular}{|l|c|c|c|}
\hline Dependent variable: logmonetarybase ma & ( \\
\hline Independent variables & Coefficient & t -statistics & -4.20 \\
\hline logmonetarybase ma L1. & -.0664813 & 2.23 & 0.000 \\
\hline logtotalcredits ma & .3315815 & 2.92 & 0.027 \\
\hline logtotaldeposits ma & .4315119 & 0.004 \\
\hline
\end{tabular}

Table 3. Long-run Coefficients Based on the ARDL Model Source: Own Calculations

From the obtained results it is concluded that the loans and deposits have a positive and statistically significant impact on the monetary base in long-run.

The short-run dynamics of the model along with the coefficients of adjustment are presented below.

\begin{tabular}{|l|c|c|c|}
\hline \multicolumn{2}{|l|}{ Dependent variable: D.logmonetarybase ma } & t -statistics & p - value \\
\hline Independent variables & Coefficient & 7.82 & 0.000 \\
\hline logmonetarybase maLD. & .5579357 & 2.81 & 0.005 \\
\hline logmonetarybase maL2D. & .2290205 & -0.73 & 0.467 \\
\hline logmonetarybase maL3D. & -.0538357 & 0.89 & 0.377 \\
\hline logtotalcredits ma D1. & .3533214 & 0.38 & 0.702 \\
\hline logtotalcredits ma LD. & .1919 & -0.67 & 0.506 \\
\hline logtotalcredits ma L2D. & -.3255217 & -1.20 & 0.231 \\
\hline logtotalcredits ma L3D. & -.4420204 & 2.84 & 0.005 \\
\hline logtotaldeposits ma D1. & .6917571 & -2.39 & 0.018 \\
\hline logtotaldeposits ma LD. & -.610349 & & \\
\hline
\end{tabular}

Table 4. Short-run Coefficients Based on the ARDL Model Source: Own calculations

From the obtained results of the short-run dynamics, it can be concluded that deposits have an impact on the monetary base, with 1 (one) and 2 (two) lags delay.

II. According to the decision based on the AIC criterion the selected model where the dependent variable are the total deposits, is ARDL (2 4 4).

The results of the specified ARDL model are presented in Table 5.

\begin{tabular}{|l|c|c|c|}
\hline \multicolumn{2}{|l|}{} \\
\hline Dependent variable: logtotaldeposits ma & p - value \\
\hline Independent variables & Coefficient & t -statistics & 0.126 \\
\hline logtotaldeposits ma L1. & .005936 & 1.54 & 0.229 \\
\hline logtotalcredits ma & .6580631 & 1.21 & 0.556 \\
\hline logmonetarybase ma & .4267911 & 0.59 & \\
\hline
\end{tabular}

Table 5. Long-run Coefficients Based on the ARDL Model Source: Own calculations

The results obtained in the long run are inconsistent; the zero hypothesis that there is causality in the long run between these three variables can neither be confirmed nor rejected, as it lies between the lower and upper bounds. The short-run dynamics of the model along with the coefficients of adjustment are presented below. 


\begin{tabular}{|l|c|c|c|}
\hline \multicolumn{2}{|l|}{} \\
\hline Dependent variable: D.logtotaldeposits ma & t -statistics & p - value \\
\hline Independent variables & Coefficient & 15.17 & 0.000 \\
\hline logtotaldeposits ma LD. & .7946709 & 3.21 & 0.002 \\
\hline logtotalcredits ma D1. & .3853894 & -1.59 & 0.114 \\
\hline logtotalcredits ma LD. & -.2443061 & -0.48 & 0.631 \\
\hline logtotalcredits ma L2D. & -.0725855 & -0.22 & 0.829 \\
\hline logtotalcredits ma L3D. & -.024542 & 3.26 & 0.001 \\
\hline logmonetarybase ma D1. & .0711001 & -1.11 & 0.271 \\
\hline logmonetarybase ma LD. & -.0282185 & -1.51 & 0.134 \\
\hline logmonetarybase ma L2D. & -.0384266 & 1.10 & 0.272 \\
\hline logmonetarybase ma L3D. & .0250746 & & \\
\hline
\end{tabular}

Table 6. Short-run Coefficients Based on the ARDL Model Source: Own Calculations

From the obtained results of the short-run dynamics it can be concluded that the total credits and the monetary base have a positive influence on the increase of the total deposits with 1 (one) lag period.

III. According to the decision based on the AIC criterion, the selected model where the dependent variables are the total credits, is ARDL (4 30 ).

The results of the specified ARDL model are presented in Table 7.

\begin{tabular}{|l|c|c|c|}
\hline \multicolumn{4}{|l|}{ Dependent variable: logtotalcredits_ma } \\
\hline Independent variables & Coefficient & t -statistics & p - value \\
\hline logtotalcredits_ma L1. & -.0016129 & -0.83 & 0.409 \\
\hline logtotaldeposits_ma & 1.024959 & 0.84 & 0.402 \\
\hline logmonetarybase_ma & -.1243067 & -0.08 & 0.940 \\
\hline
\end{tabular}

Table 7. Long-run Coefficients Based on the ARDL Model Source: Own Calculations

From the obtained results it is concluded that the total deposits and the monetary base have no impact on the total loans in the long-run.

The short-run dynamics of the model along with the coefficients of adjustment are presented below.

\begin{tabular}{|l|c|c|c|}
\hline \multicolumn{2}{|l|}{ Dependent variable: D.logtotalcredits_ma } \\
\hline Independent variables & Coefficient & t -statistics & p - value \\
\hline logtotalcredits_ma LD. & .7785161 & 10.90 & 0.000 \\
\hline logtotalcredits_ma L2D. & .0271216 & 0.30 & 0.762 \\
\hline logtotalcredits_ma L3D. & .0441749 & 0.66 & 0.507 \\
\hline logtotaldeposits_ma D1. & .1710992 & 3.99 & 0.000 \\
\hline logtotaldeposits_ma LD. & -.1541381 & -2.62 & 0.009 \\
\hline logtotaldeposits_ma L2D. & .1750923 & 3.90 & 0.000 \\
\hline
\end{tabular}

Table 8. Short-run Coefficients Based on the ARDL Model Source: Own Calculations

From the obtained results of the short-run dynamics it can be concluded that the total deposits have a significant impact on the total loans.

The results of the short and long run obtained by the ARDL econometric model in all three previously analyzed cases can be presented in the following table:

\begin{tabular}{|l|l|}
\hline Long-run & logtotalcredits $\mathrm{ma} \mathrm{и} \mathrm{logtotaldeposits} \mathrm{ma} \rightarrow$ logmonetarybase ma \\
\hline Short-run & logtotaldeposits $\mathrm{ma} \leftrightarrow$ logmonetarybase ma \\
\cline { 2 - 2 } & logtotalcredits $\mathrm{ma} \leftrightarrow$ logtotaldeposits ma \\
\hline
\end{tabular}

\section{Table 9. Conclusion}

The results obtained in the short-run, along with their channel of interpretation through the credit transmission mechanism, support the theory of endogenous money, as bank loans affect the level of bank deposits, which in turn affect the level of the monetary base, i.e. the money creation process in the Republic of Macedonia is mainly determined by the lending activity of commercial banks towards households and firms. The monetary base in the long-run is driven by the demand for and supply of loans.

Although we have shown that the monetary base in the short run can affect the level of bank deposits, we still saw that both bank deposits in the short run have an impact on bank loans. In other words, the exogenous increase in the monetary base may affect the demand for deposits, because it increases the amount of liquidity held by 
commercial banks. This amount of deposits (i.e. new liquidity created by the central banks) further influences the level of loans approved by commercial banks. The outcome that the causality between loans and deposits goes in the opposite direction can be explained by the fact that bank deposits are the largest percentage of the total private wealth in Macedonia, because due to weak investment opportunities and for the sake of security people save in bank, while in highly developed economies a small portion of the total wealth is in deposits.

From all of the above, it follows that the money supply in the Republic of Macedonia is endogenously determined by the credit activity of the commercial banks in the long and short run, yet the central bank has a significant influence on the money supply in the short run. Namely, if according to the theory of endogenous money, demand for credits plays an important role for entering new money in the real economy (eg. to increase the demand for loans to firms and households, instead of increasing the supply of funds by the central bank), in the Republic of Macedonia, besides the demand for loans, the exogenous setting of the money supply by the central bank is not excluded, especially during the shocks in the real economy. In other words, exogenous monetary policies based on control of the supply of money can positively affect the amount of liquidity held by commercial banks and, hence, increase the supply of loans, but the demand for loans still matters when stimulating the entrance of liquidity into the real economy.

\section{Conclusion}

Using logarithmic and deseasonalized data on the monetary base, total loans and total deposits, the ARDL econometric model was implemented to examine the hypothesis of the Post-Keynesian view of the endogeneity of the money supply in the case of the Republic of Macedonia.

In the long run, empirical findings suggest that there is causality, i.e. loans and deposits have an impact on the monetary base, which is in line with the theory of endogenous money. The monetary base in long-run is driven by the demand for and supply of loans. The money creation process in the Republic of Macedonia is mainly determined by the credit activity of the commercial banks towards households and firms.

The results obtained in the short run suggest a bidirectional causality between the total loans and the total deposits, as well as between the total deposits and the monetary base. It follows that bank loans affect the level of bank deposits, which in turn affect the level of the monetary base. However, on the other hand, the fact that the monetary base has an impact on deposits, and hence deposits on loans, is not in line with the theory of cash endowment. This means that exogenous monetary policies based on the control of money supply, can positively affect the amount of liquidity held by commercial banks and, hence, to increase the supply of loans, but the demand for loans still matters when stimulating the entrance of liquidity into the real economy. It follows that the central bank can effectively determine the money supply especially in the short run.

Considering the fact that the Republic of Macedonia has a fixed exchange rate regime, the monetary base is largely determined by the foreign exchange interventions of the NBRM, i.e. the need to defend the exchange rate, regardless of lending. For small and open economy like the Republic of Macedonia, the monetary policy control over the money supply is greater. We should also have in mind that bank deposits are the largest percentage of the total private wealth in Macedonia because, due to weak investment opportunities and for safety, people save in a bank, while in highly developed economies only a small part of the total wealth is in deposits.

The implications of this analysis suggest that the lending activity of commercial banks has a significant share in the money creation process in the Republic of Macedonia, which can facilitate the economic growth and markets development. Monetary policy can really affect the financial environment in the short and long run. Consistent monetary policies facilitate the economic activity.

\section{References}

- Ahmad, N. and Ahmet, F. (2006), "The long-run and Short-run Endogeneity of Money Supply in Pakistan: An Empirical investigation”. State Bank of Pakistan - Research Bullettin, Vol.2.

- Alexey, P. (2016), “A note on money creation in emerging market economies”, Bank of Finland, BOFIT Institute for Economies in Transition, Discussion Papers.

- Blanchard, O. (2011). Macroeconomics (5th ed.). Boston: Pearson.

- $\quad$ Enrico, S., L. and Matteo, D. (October, 2017), “The money creation process: A theoretical and empirical analysis for the US”, Roma Tre University, MPRA Paper No. 81970.

- $\quad$ Frank, R. H. \&Bernanke, B. S. (2013). Principles of economics (5th ed.). New York: McGraw-Hill/Irwin.

- Haghighat, J. (2012), “The Endogenous Money In Iran: What it is and Why it Matters", International Journal of Trade, Economics and Finance, Vol. 3, No. 2.

- James, T.(July 24, 1963), "Commercial Banks as Creators of "Money"', Cowles foundation for research in Economics, Yale University, Paper No.159.

- Jan, G. (October 2, 2014), "Introduction to money creation”, TAOLAM. 
- Mankiw, N. G. (2012). Principles of Macroeconomics (6th ed.). Mason, OH: Cengage Learning.

- Michael, M.L., Amar, R. \& Ryland, T. (2014a). "Money in the modern economy: An introduction", Bank of England. Quarterly Bulletin, Q1, 2014.

- Michael, M.L., Amar, R. \& Ryland, T. (2014b). "Money creation in the modern economy”, Bank of England. Quarterly Bulletin, Q1, 2014.

- Milena, L. (August 2014), “The Endogenous Money Hypothesis: An Empirical Study of the Euro Area (1999- 2010)", Scientific Papers, Journal of Knowledge Management, Economics and Information Technology, Vol. IV, Issue 4.

- $\quad$ Paul, M. and Joshua, W. (2013), “The Endogenous Money Hypothesis - Empirical Evidence from the United States (1959-2008)", SSRN eJournals, available at https://papers.ssrn.com/sol3/papers.cfm?abstract_id=2355178.

- Pesaran M. H., and Pesaran, B. (1997) "Working with Microfit 4.0: Interactive Econometric Analysis", Oxford University Press.

- Pesaran M. H., Shin, Y., and Smith, R. (1996) "Testing the Existence of A long-run Relationship", DAE WP 9622, Department of Applied Economics, University of Cambridge.

- Pesaran, M. H. (1997) “The Role of Economic Theory in Modelling the Long-run”, Economic Journal, vol. 107: 178-91.

- $\quad$ Pesaran, M. H. and R. P. Smith, (1998). Structural analysis of cointegrating VARs. Journal of EconomicSurveys, 12, 471-505.

- $\quad$ Pesaran, M. H. and Shin, Y. (1999). “An autoregressive distributed lag modelling approach to cointegration analysis", Chapter 11 in S. Strom (ed.), Econometrics and Economic Theory in the 20th Century: The Ragnar Frisch Centennial Symposium, Cambridge University Press, Cambridge. (Discussion Paper version).

- Pesaran, M. H., and Shin, Y. (1995) “Autoregressive Distributed Lag Modelling Approach to Cointegration Analysis”, DAE WP 9514, Department of Applied Economics, University of Cambridge.

- $\quad$ Pesaran, M. H., Shin, Y. and Smith, R. J., (2001), "Bounds testing approaches to the analysis of level relationships", Journal of Applied Econometrics, 16, 289-326.

- Rogers, J. (1929), “The Process of Inflation in France 1914-1927”, New York: Columbia University Press.

- Shanmugam, B., Nair, M. and Li, O.W. (2003), “The Endogenous Money Hypothesis: Empirical Evidence from Malaysia (1985-2000)".Journal of Post Keynesian Economics, Vol. 25, Issue 4, pp. 599-611.

- Vera, A.P. (2001), “The Endogenous money hypothesis: some evidence from Spain (1987-1998)”. Journal of Post Keynesian Economics Vol. 23, Issue 3, pp. 509-526.

- Wicksell, K. (1906), Lectures on Political Economy, Volume Two: Money, Lionel Robbins, ed., London: Routledge and Sons, Ltd.

- www.nbrm.mk 


\section{Appendix}

\section{Appendix 1: Time series in logarithmic form and eliminated seasonal influences}

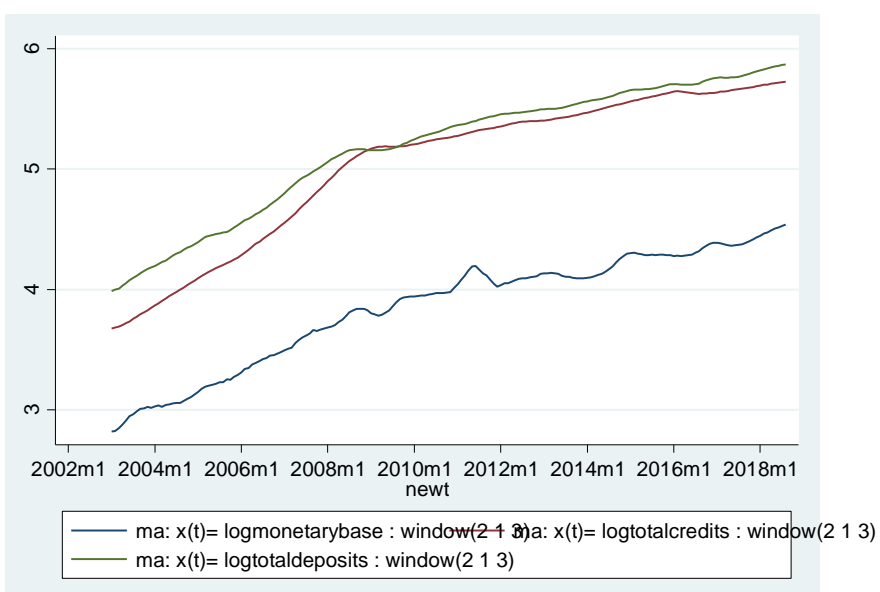

\section{Appendix 2: Unit root test}

2.a. Unit root test: Augmented Dickey-Fuller: logmonetarybase_ma, logtotalcredits_ma, logtotaldeposits_ma

$\mathrm{H}_{0}$ : Variable at level has unit root

\begin{tabular}{|l|c|c|c|c|c|}
\hline \multirow{2}{*}{ Variable } & \multicolumn{5}{|c|}{ Interpolated Dickey-Fuller } \\
\cline { 2 - 6 } & $\begin{array}{c}\text { Test } \\
\text { Statistic } \\
\mathbf{z}(\mathbf{t}) *\end{array}$ & $\begin{array}{c}\mathbf{1 \%} \\
\text { Critical } \\
\text { Value }\end{array}$ & $\begin{array}{c}\mathbf{5 \%} \text { Critical } \\
\text { Value }\end{array}$ & $\begin{array}{c}\mathbf{1 0 \%} \\
\text { Critical } \\
\text { Value }\end{array}$ & Заклучок \\
\hline logmonetarybase_ma & -1.645 & -3.482 & -2.884 & -2.574 & $\mathrm{I}(1)$ \\
\hline logtotalcredits_ma & -3.421 & -3.482 & -2.884 & -2.574 & $\mathrm{I}(0)$ \\
\hline logtotaldeposits_ma & -3.522 & -3.482 & -2.884 & -2.574 & $\mathrm{I}(0)$ \\
\hline
\end{tabular}

Note: Because the Augmented Dickey-Fuller test has autocorrelation problems, it is necessary to determine the lag length before it is applied. This is done in the statistical software STATA for each time series and are determined 2 lags for the monetary base, 2 lags for loans and 2 lags for deposits.

* $z(t)$ is a statistical test that applies for series with over 30 observations and standard normal distribution

Source: Own calculations

2.b. Unit root test: Phillips-Perron:Iogmonetarybase_ma,logtotalcredits_ma, logtotaldeposits_ma $\mathrm{H}_{0}$ : Variable at level has unit root

\begin{tabular}{|l|c|c|c|c|c|}
\hline \multirow{2}{*}{ Variable } & \multicolumn{5}{|c|}{ Interpolated Dickey-Fuller } \\
\cline { 2 - 6 } & $\begin{array}{c}\text { Test } \\
\text { Statistic } \\
\mathbf{z}(\mathbf{t}) *\end{array}$ & $\begin{array}{c}\mathbf{1 \%} \\
\text { Critical } \\
\text { Value }\end{array}$ & $\begin{array}{c}\mathbf{5 \%} \text { Critical } \\
\text { Value }\end{array}$ & $\begin{array}{c}\mathbf{1 0 \%} \\
\text { Critical } \\
\text { Value }\end{array}$ & Заклучок \\
\hline logmonetarybase_ma & -2.354 & -3.481 & -2.884 & -2.574 & $\mathrm{I}(0)$ \\
\hline logtotalcredits_ma & -5.927 & -3.481 & -2.884 & -2.574 & $\mathrm{I}(1)$ \\
\hline logtotaldeposits_ma & -6.201 & -3.481 & -2.884 & -2.574 & $\mathrm{I}(1)$ \\
\hline
\end{tabular}

Source: Own calculations 


\section{Appendix 3:_Bound test for cointegration}

\subsection{Dependent variable: monetary base}

Pesaran/Shin/Smith (2001) ARDL Bounds Test

HO: no levels relationship $\quad F=6.345$

$t=-4.196$

Critical Values (0.1-0.01), F-statistic, Case 1

\begin{tabular}{r|ccccccccr}
$\mid$ & {$\left[I_{-} 0\right]$} & {$\left[I_{-} 1\right]$} & {$\left[I_{-} 0\right]$} & {$\left[I_{-} 1\right]$} & {$\left[I_{-} 0\right]$} & {$\left[I_{-} 1\right]$} & {$\left[I_{-} 0\right]$} & {$\left[I_{-} 1\right]$} \\
$\mid$ & $L_{-} 1$ & $L_{-} 1$ & $L_{-} 05$ & $L_{-} 05 \mid$ & $L_{-} 025$ & $L_{-} 025$ & $L_{-} 01$ & $L_{-} 01$ \\
-1 & 2.17 & 3.19 & 2.72 & 3.83 & 3.22 & 4.50 & 3.88 & 5.30
\end{tabular}

accept if $F<$ critical value for $I(0)$ regressors

reject if $F>$ critical value for I(1) regressors

Critical Values (0.1-0.01), t-statistic, Case 1

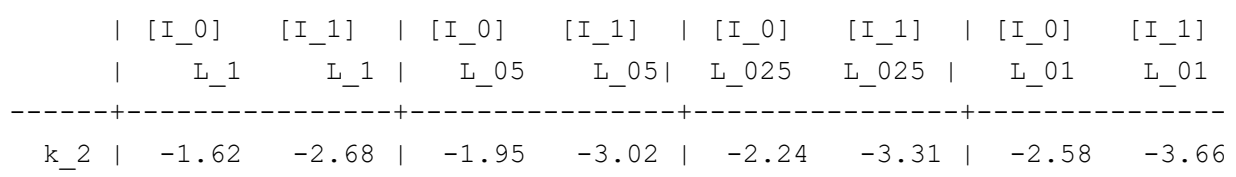

accept if $t>$ critical value for $I(0)$ regressors

reject if $t<$ critical value for $I(1)$ regressors

$\mathrm{k}$ : \# of non-deterministic regressors in long-run relationship

Critical values from Pesaran/Shin/Smith (2001)

\subsection{Dependent variable: Total deposits}

Pesaran/Shin/Smith (2001) ARDL Bounds Test

HO: no levels relationship $\quad F=2.176$

$$
\mathrm{t}=1.538
$$

Critical Values (0.1-0.01), F-statistic, Case 1

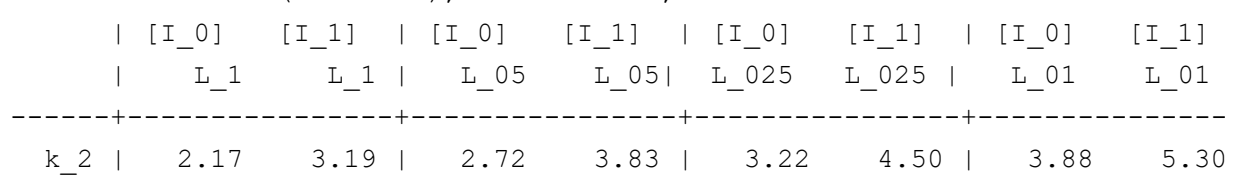

accept if $F<$ critical value for $I(0)$ regressors

reject if $F>$ critical value for $I(1)$ regressors

Critical Values (0.1-0.01), t-statistic, Case 1

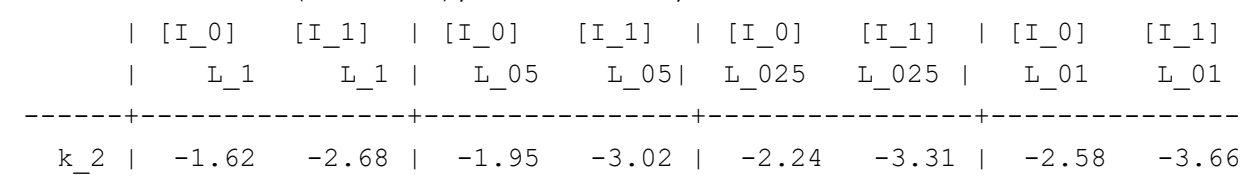

accept if $t>$ critical value for $I(0)$ regressors

reject if $t<$ critical value for $I(1)$ regressors

$\mathrm{k}$ : \# of non-deterministic regressors in long-run relationship

Critical values from Pesaran/Shin/Smith (2001) 


\subsection{Dependent variable: total loans}

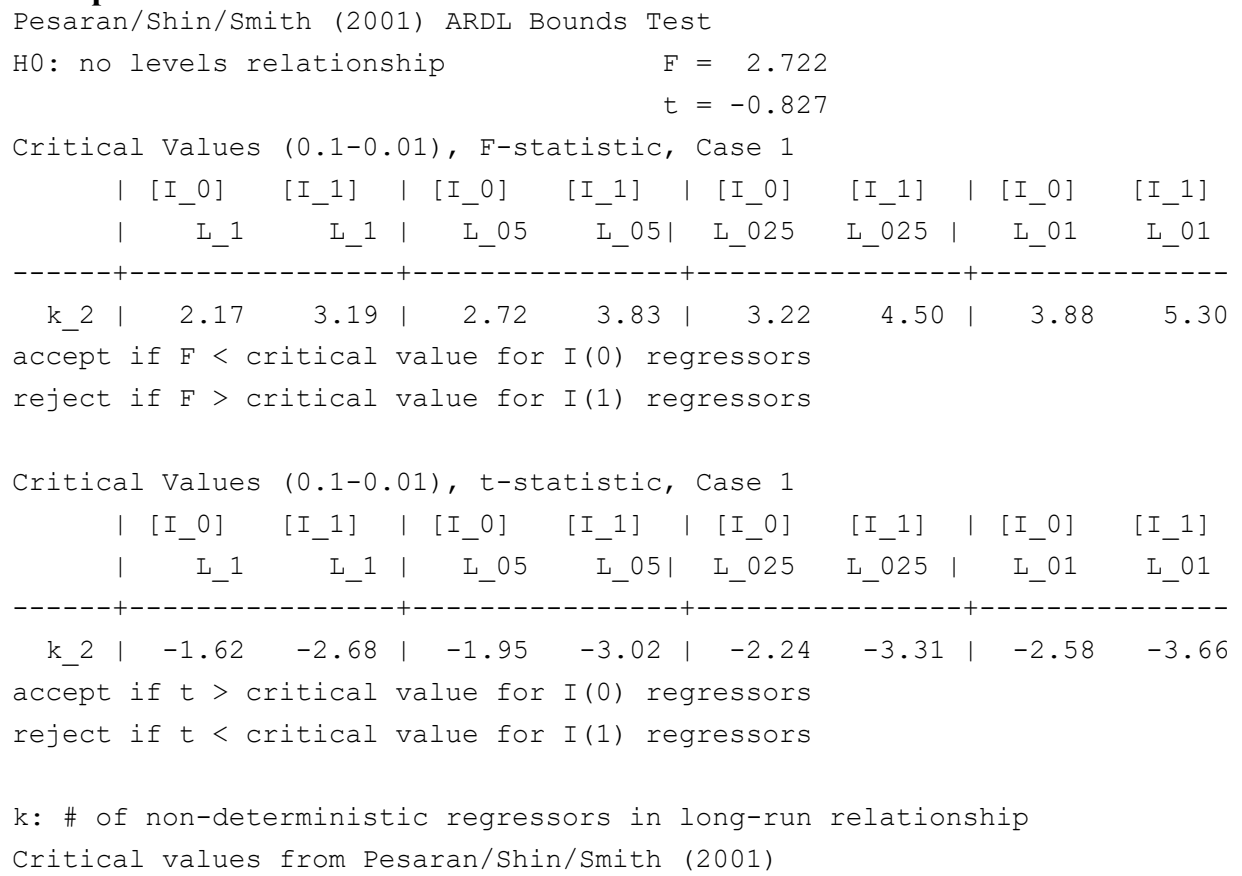

\section{Appendix 4: Estimating the long-run causality and short-run dynamics of the ARDL model - dependent variable: monetary base}

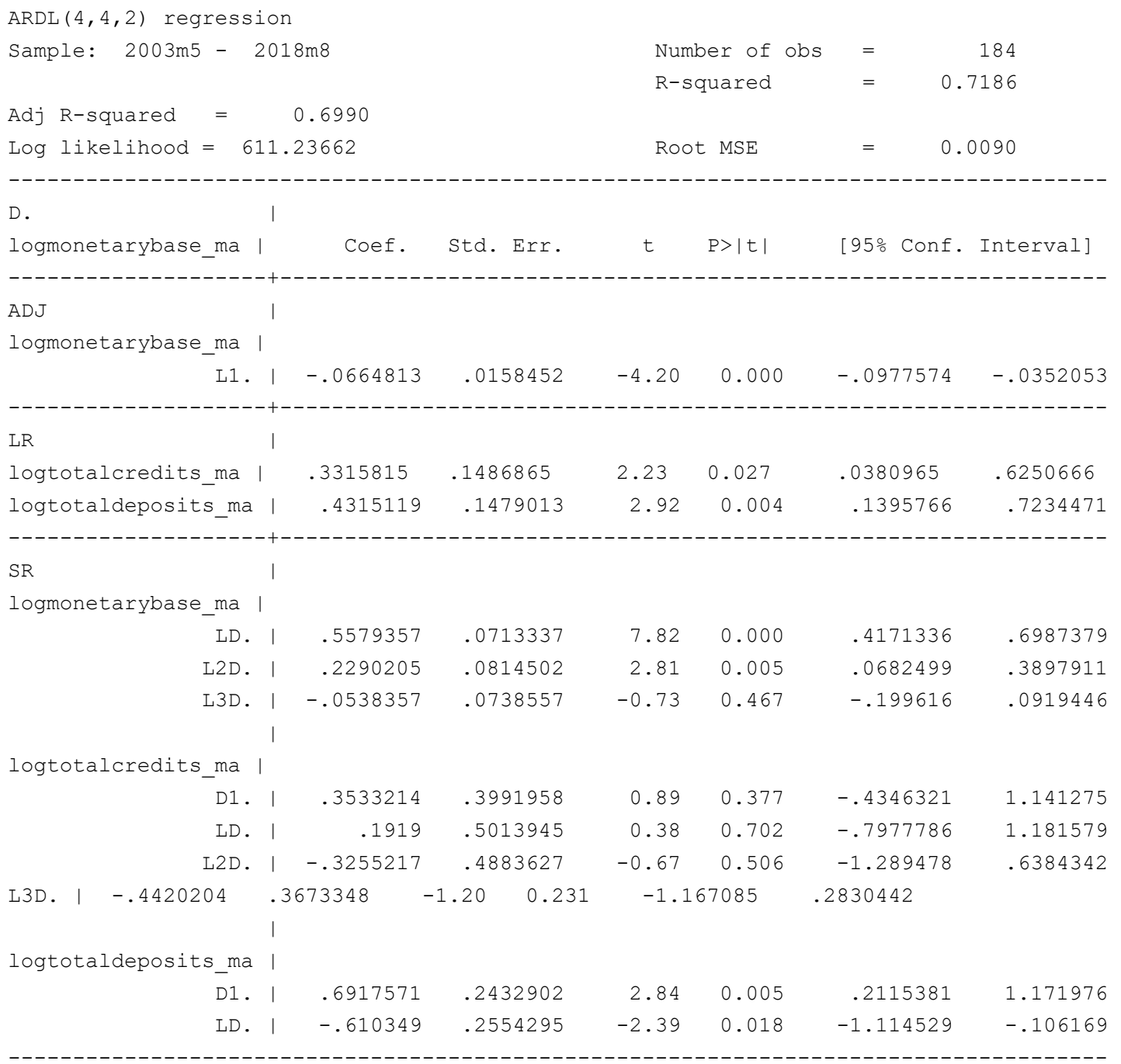


Appendix 5: Estimating the long-run causality and short-run dynamics of the ARDL model - dependent variable: total deposits

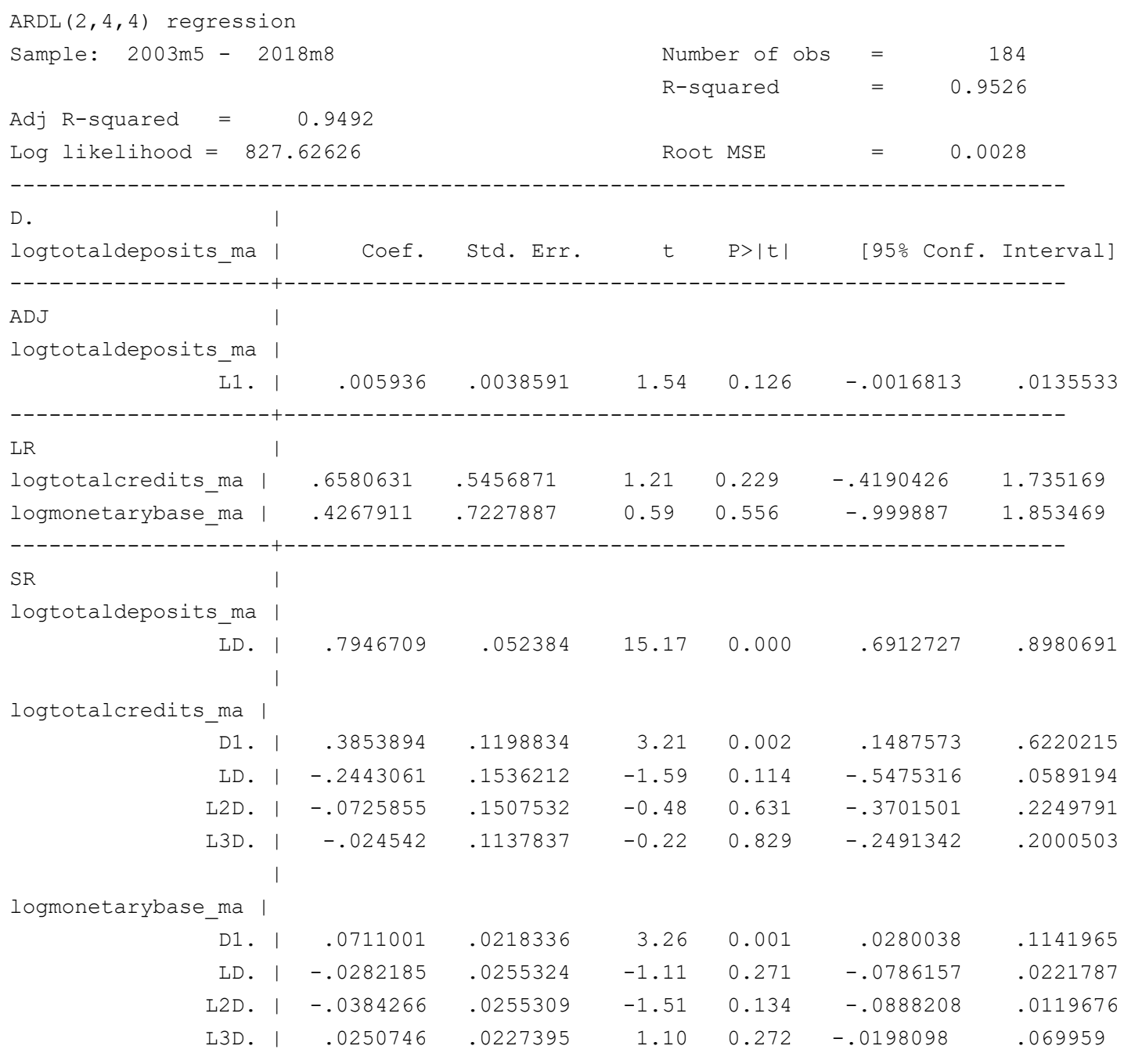


Appendix 6: Estimating the long-run causality and short-run dynamics of the ARDL model - dependent variable: total loans

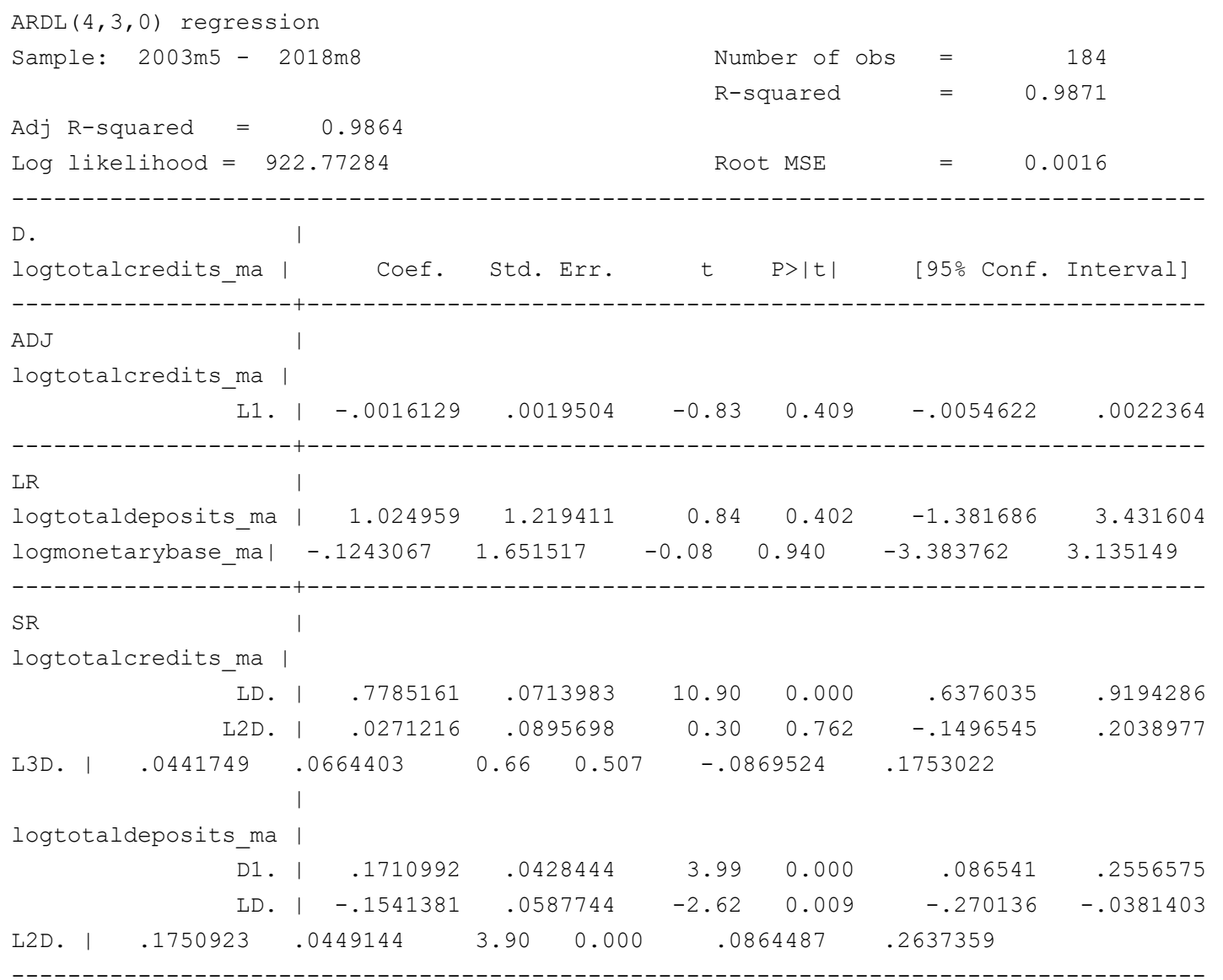




\title{
The Aftermath of Quantitative Easing in Advanced Economies: The Empirical Evidences
}

\author{
Prof. Dr. Harun Bal (Çukurova University, Turkey) \\ Ph.D. Candidate Shahanara Basher (Cukurova University, Turkey) \\ Ph.D. Candidate Abdulla Hil Mamun (Çukurova University, Turkey)
}

\begin{abstract}
Quantitative easing (QE), as a measure of unconventional monetary policy (UMP), has been followed by many of the central banks of advanced economies to boost the economy by stimulating investment and consumption. The study identifies the most recent QE programs undertaken by central banks of four major advanced economies, namely, Federal Reserve (Fed), Bank of England (BOE), Bank of Japan (BOJ) and European Central Bank (ECB), and examines its impact on major macroeconomic indicators, namely output growth, inflation, exchange rate indices and stock market indices, employing vector autoregressive (VAR) models. Findings of the study suggest that QE was only favorable for real GDP growth of USA and the development of stock market of euro area. However, such an UMP failed to bring about changes in appropriate directions among the other economic indicators of these advanced economies. QE at an adequate scale to offset the recessionary forces could help achieve the expected results of the policy action. At the same time, policy makers should think over other supplementary measures that can support and expedite the impact of QE in favourable directions to achieve the desired goals of such UMP.
\end{abstract}

\section{Introduction}

In order to deal with the financial crisis in 2008, many of the central banks round the world have pursued different unconventional monetary policies (UMP) to boost up their economies, primarily through the purchase of longduration assets in the name of large scale asset purchase programs (LSAPs) (Maggio et al., 2016). Among the largest central banks of the world in the advanced economies, monetary easing or quantitative easing (QE) of the US Federal Reserve (Fed), the Bank of England (BOE), the Bank of Japan (BOJ), and the European Central Bank (ECB) has drawn particular attention of researchers particularly because of its widespread impact on respective economies. All these four central banks have embarked on QE in the shade of UMP so as to inject more money into the economy to combat against economic downturn. QE is expected to be effective in stimulating the economy by influencing banks to offer more loans lowering interest rates. The view is that banks buy assets taking new money to replace the assets they have sold to the central bank. It results in rise in stock prices and fall in interest rates, which consequently boosts investment and consumers' spending, and thereby aggregate demand. Regardless of the recent worldwide popularity of LSAPs, the degree to which they are effective in producing anticipated result and the channels by which they affect the real economy have been at the core of a policy and academic discussion (Maggio et al., 2016).

The academic debate on the success of QE is largely dominated by the notion of "liquidity trap".

If banks consider short- term risk- free assets (government bonds in particular) and central bank money mostly identical at the zero lower bound on interest rates, purchases of assets by central banks will than cause banks holding of short- term government bonds to fall and rise in the amount of money hoarded by central bank correspondingly. Purchases of these assets for monetary policy purposes would then be "neutral" in that they would have no effect on real economic activity and goods prices (Bundesbank, 2016).

In the aftermath of global financial crisis, there was limited scope to insert additional money into the economy by lowering policy rates as it was almost near to zero in most of the industrialized advanced economies (Hausken $\&$ Ncube, 2013). It drives the policy makers to sort out an unconventional way so as to work as a propeller to put more money into the economy. Policy makers vote for lowering the long-term interest rate through the LSAPs of central banks to fight the recession. QE or LSAPs, generating a decreasing tendency in term premium or stimulating inflation expectation, alters long-term interest rate (Joyce et al., 2012). Such an UMP has thus been accepted to be taken on unusual situations (Bouraoui, 2015).

If we examine episodes across countries, there is prudently clear evidence that QE programs have lowered yields on long-term government debt. The APPs of central banks cause bond prices to rise and yields to drop since they are correlated inversely. As most of the central banks pursued QE to combat great depression in 2008, Figure 1 shows that yields of long term bond declined in the following years.

In japan, long term bond yields have been falling since the great depression of 2008. After the expansion of QE in April 2013, bond yields dropped below 5 percent and turn into negative all through 2016. Bond yield in euro area was around 3.5 to 4.5 percent through 2008 to the second quarter of 2012 and was nearly 3 percent till December 2013. Following the global crisis of 2008, bond yields decreased from over 5 percent to below 3.5 percent, but apart from the theoretical expectation, it remained stable around 2 to 3 percent during and beyond the 
course of QE program and then again started to fall from the beginning of 2015. Most exceptionally, US bond yields jumped by more than 1 percent to 2.74 percent in first 10 months after the implementation of APPs in December 2012, however, again registered a decline in the preceding months till late 2016.

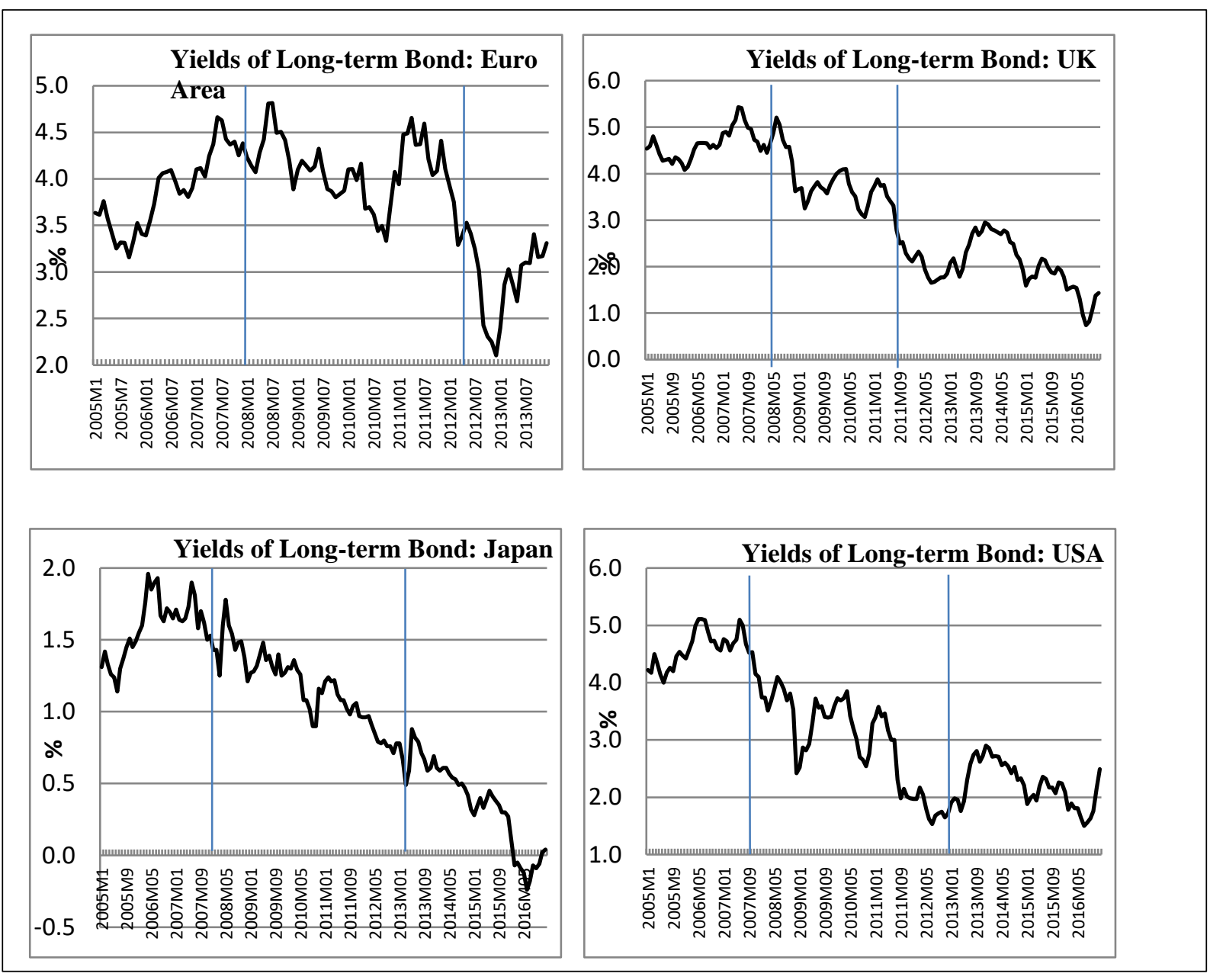

Figure 1: Long-term Bond Yields Source: OECD, Main Economic Indicators (database), http://dx.doi.org/10.1787/data-00052-en (Accessed on June 20, 2018)

Through vast amounts of asset purchases, the central bank can still promote total output and prices by liquidity enhancement even in situation when the lower round of short-term interest rate is clogged near to zero (Mishkin 1996). A greater monetary based confirmed by increased liquidities reduce term premium through Tobin's (1969) portfolio balance channel. Alternatively, stoking inflation expectations by 'committing to be irresponsible' is another channel through which LSAP might work (Eggertsson, 2006).

Irrespective of the channel, QE should have a positive effect on the economy as a whole. The drop in real interest rate is expected to have a satisfactory influence on consumer spending and business investments. QE interventions have also inclined to be associated with fluctuations in prices of other asset, such as equities, corporate bonds and exchange rates. The interventions of central banks at an unprecedented scale have become a key and recent area of study by central banks, researchers and market experts alike. There have been a significant number of recent studies assessing the impact of QE. The aim of QE by all these four central banks was to boost the economy by stimulating investment and consumption. The main purpose of the study is to investigate the impact of QE on a range of macroeconomic indicators of these advanced economies. In this regard, the study identifies the most recent $\mathrm{QE}$ programs of central banks of the aforementioned economies and then evaluates the impacts on major economic indicators, namely output growth, inflation, exchange rate indices and stock market indices, based on VAR models. Assessing what would have occurred to these economies in the absence of QE programs is one of the major interests of this study. 


\section{QE: Channels of Operation}

Central bank purchases assets most of which are government bonds, as it has a large market and thus offer opportunity to buy bulk quantities of them fairly quickly. Central banks asset purchase program injects money into the economy through different ways that can be explained using the Figure 2.

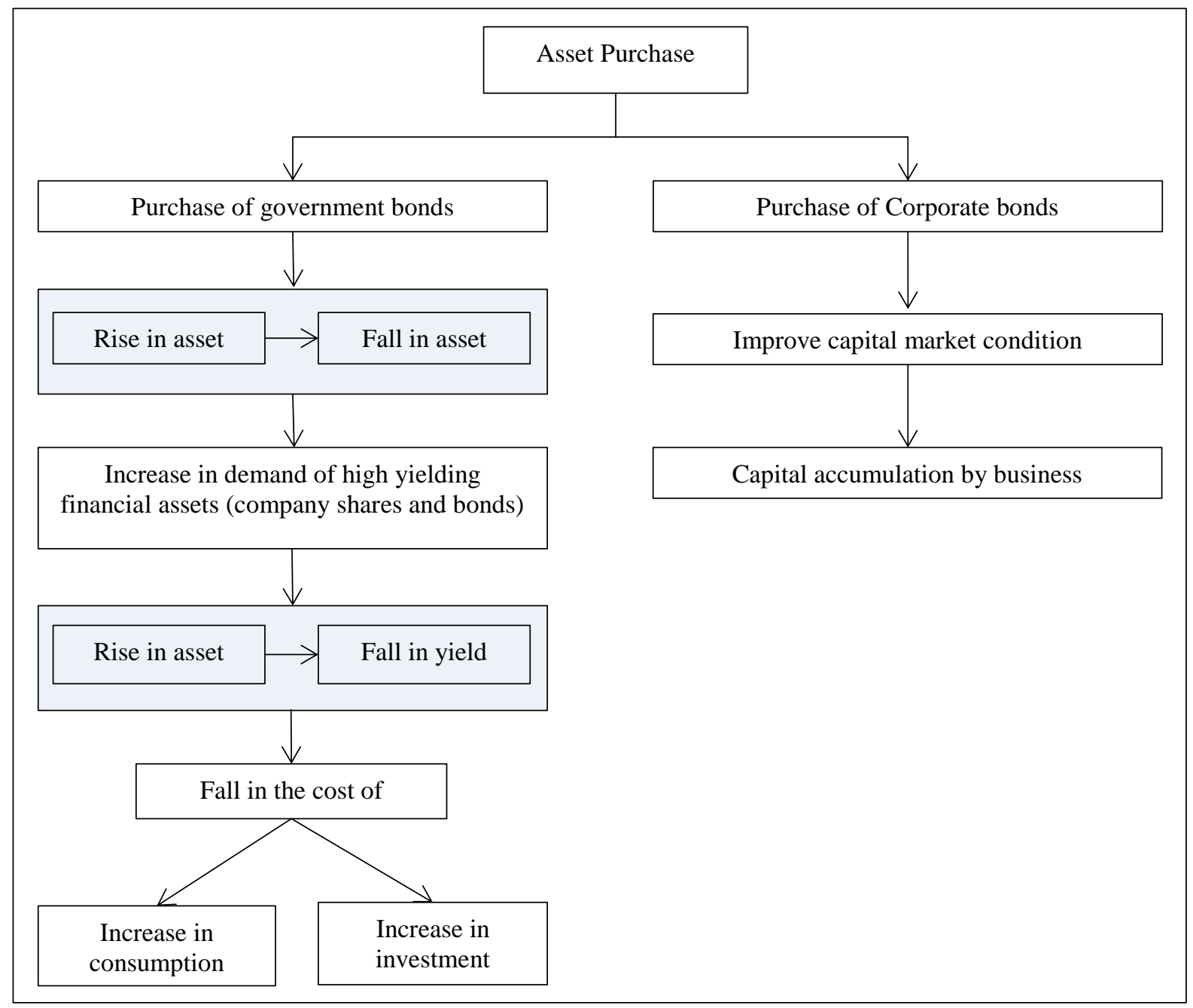

Figure 2: QE: As a Means to Stimulate the Economy Source: Developed by Authors

Purchase of government bonds that reduce yields of financial assets of both government and private firms can stimulate economic activity by raising consumer spending and investment. Again, buying corporate bonds, central banks help develop stock market which eventually supports businesses to accumulate capital.

The channels through which QE influences macroeconomic developments are much alike conventional interest rate policy. It works similar to the way that asset prices or yields are affected by purchases of government bonds (Bundesbank, 2016). The probable channels through which QE may be expected to work are explained below.

QE policies like LSAPs are seemed to have beneficial impact in reducing long-term bond yields when nontraditional monetary policy serves as a credible commitment by the central bank to maintain low interest rates even after the economy recovers (Eggertson, 2003). Central banks can achieve such an obligation in QE by purchasing assets of long duration in a large denomination (Clouse, et. al., 2000). CB's readiness to commence an unconventional policy like QE affects interest rates of bond market as it signals that the period of low policy rate $\mathrm{CB}$ plans to hold is going to be prolonged. Consequently, long- term interest rates would remain to fall according to the expectations hypothesis which will bring about a positive impact on credit demand and thereby stimulate aggregate demand and increase inflation. The same impact can be produced through the purchases of long-term bonds with greater duration by commercial banks to adjust their portfolios in response to the drop in long-term yield caused by LSAPs of CB in order to maintain their optimal profitability and risk structure, the so called portfolio rebalancing channel. On the other hand, liquidity channel asserts that QE raises yields on the most liquid bonds by reducing liquidity premium increasing the liquidity in the hand of investors. According to the bank capital and balance sheet channel, asset purchases surge asset prices and so does the assets of a bank, which ultimately make commercial banks' able to fulfil the higher capital requirement of growing loan portfolio raising their capital. 
It has a stimulating effect on external financing both by banks and borrowers and hence promotes aggregate demand and inflation. On exchange rate channel of $\mathrm{QE}$, an asset purchase program may result in depreciation of domestic currency by reducing domestic currency denominated assets' yield and their demand to foreign investors that may help achieve competitiveness of domestic goods and thereby spur domestic aggregate demand and inflation.

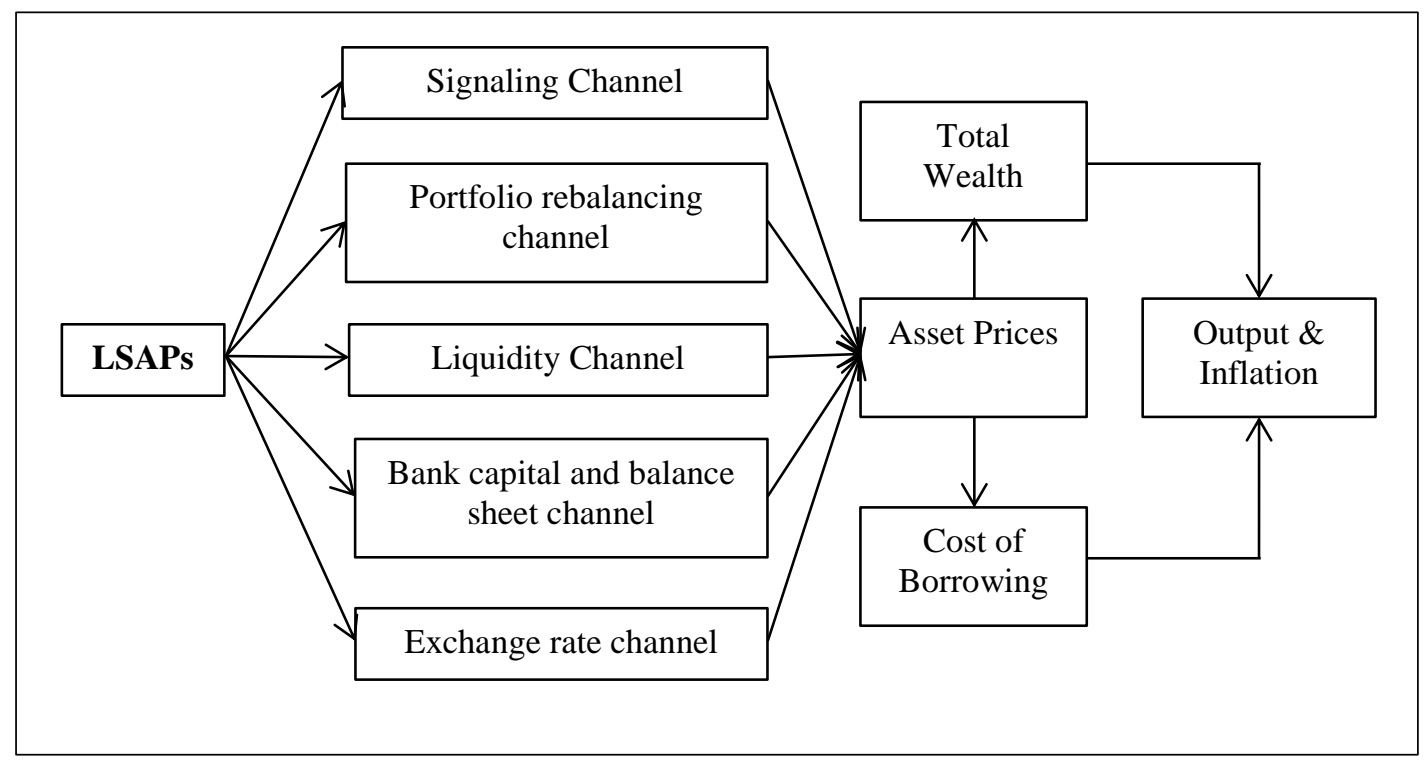

Figure 3: Transmission Channels of QE Source: Developed by Authors

\section{QE: A Brief Review}

QE started with the purchase of government bonds supported by the creation of central bank reserves of BOJ in 2001. Following Japan, the US Federal Reserve and the BOE adopted QE in 2008 and 2009, as they neared the lower bound for nominal interest rates and desired to supply additional monetary stimulus. In 2015, the ECB as well started escalating its balance sheet as it approached the lower bound for interest rates. Three of these four central banks were continuing to expand their balance sheets in the second half of 2016 (Haldane et al., 2016).

\section{a. QE of BOJ}

The economy of Japan has been locked in a liquidity trap since the mid-90s. Since then different strategies has been adopted by the BOJ to fight the recession and boost-up the economy (Michaelis \& Watzka, 2017). BOJ bought government securities from the banking sector so as to enhance cash reserves held in the banking system which was not possible by reducing the money market interest rates as they had already been at their Zero Lower Bound. It was expected that the high level of reserves would be adequate for ensuring higher liquidity in the broader economy and thereby raise asset prices and eliminate forces causing deflationary pressure. Apart from the purchase of government bonds in response to the financial crisis, BOJ also purchased corporate bonds to stimulate businesses. BOJ increasingly increases the scale of its comprehensive monetary easing to as much as $¥ 101$ trillion by the end of 2012. More recently, in April 2013, the announcement of the expansion of asset purchase program of BOJ by 60 to 70 trillion Yen a year popularized as Abonomics possibly the largest monetary easing in recent history with the purpose to double the monetary base in two years by purchasing government bonds aggressively, exchange-traded funds, as well as real estate investment trusts with the hope to bring Japan from deflation to inflation, aiming for $2 \%$ inflation. Later, the BOJ declared further extension of its bond purchasing program to yearly 80 trillion Yen of bonds in October 2014.

\section{b. QE of FED}

Fed implemented a series of $\mathrm{QE}$ to deal with the crisis. It was the most active central bank in implementing LSAPs in several rounds. The first round of QE that aims to stabilize the financial market and US economy from the financial crisis was declared and put into effect in November 2008 under which $\$ 600$ billion mortgage-backed securities was purchased by Fed. The second round of Fed's QE that includes purchase of US Treasury securities by the amount of $\$ 600$ billion started in November 2010. The final round of QE implemented by Fed was launched in September 2012 which involved monthly \$85-billion booster through buying mortgage-backed and longer-term Treasury securities. The Fed buys government or other bonds and then makes this money available for banks to borrow, thereby expanding the amount of money circulating in the economy, which in turn reduces long-term interest rates. Fed starts to compress the program as the "tapering" takes root at the beginning of 2014 and announces the historic end to the program from October 2017. 


\section{c. QE of BOE}

BOE's launched QE by undertaking its LSAPs between March 2009 to January 2010 and October 2011 to July 2012. Starting in March 2009, the BOE had purchased nearly $£ 165$ billion in assets as of September 2009 and about $£ 175$ billion in assets by the end of October 2009. On November 2009, the Monetary Policy Committee supported to expand asset purchases to $£ 200$ billion. Though the Bank has purchased limited quantities of high-quality private-sector assets, but the assets purchased have been dominated by UK government securities. In December 2010, BOE called for another $£ 50$ billion extension of QE program, while there was dispute for an increase in interest rates due to inflation being above the $2 \%$ target rate. In October 2011, the BOE declared another round of QE, creating an additional $£ 75$ billion. In February 2012 an additional $£ 50$ billion APPs is announced and in July 2012 another $£ 50$ billion is declared, taking the amount to $£ 375$ billion in total. In August 2016 , the BOE announced to buy an additional $£ 60$ billion of UK government bonds and $£ 10$ billion of corporate bonds addressing ambiguity over Brexit and uncertainties about productivity and economic growth.

\section{d. QE of ECB}

Following the lead of the United States, the United Kingdom and Japan, the ECB has announced its programme of QE on 22 January 2015 and has started purchases of treasury bonds and other bonds by the amount of $€ 60$ billion every month in the QE framework from March 2015. ECP expands its APPs to $€ 80$ billion per month in March 2016 and announces that it will continue its QE programme until the end of 2017. From April 2017, QE program is cut to $€ 60$ billion a month from April 2017. In a recent declaration on October 2017, ECB reduces its current monthly purchase of $€ 60$ billion to a new monthly purchase of $€ 30$ billion from January 2018 until the end of September 2018.

\section{Performance of the Major Economic Indicators Following Recent QE}

\section{a. Asset-GDP Ratio}

In response to the Great Recession, all major central banks approved several UMPs intended to foster a more robust economic recovery. Of these policies, LSAPs, that is "QE", led to the largest expansion of the balance sheet of these central banks which is evident from Figure 4 as it is observed that there were sharp rises in asset-GDP ratio of FED, $\mathrm{BOE}, \mathrm{BOJ}$ and $\mathrm{ECB}$. The central banks continue and regularly revised their asset purchase program to achieve economic resilience. As the study is concerned with the most recent QE programs undertaken by the banks addressed above, Figure 4 illustrates that there is an increase in asset-GDP ratio of the banks immediately after the approval of their APPs.

Just after the announcement of an increase in the amount of open-ended purchases from $\$ 40$ billion to $\$ 85$ billion per month by the Federal Open Market Committee of Fed On December 2012, asset-GDP ratio of Fed increased from 17.84 percent to 25.07 percent over the next ten quarters. For the case of BOE, expanded APPs was announced and revised from last quarter of 2011 through third quarter of 2012. In response to this statement, assetGDP ratio of BOE increased from 70.34 percent in the last quarter of 2011 to 93.03 percent in the second quarter of 2013 .

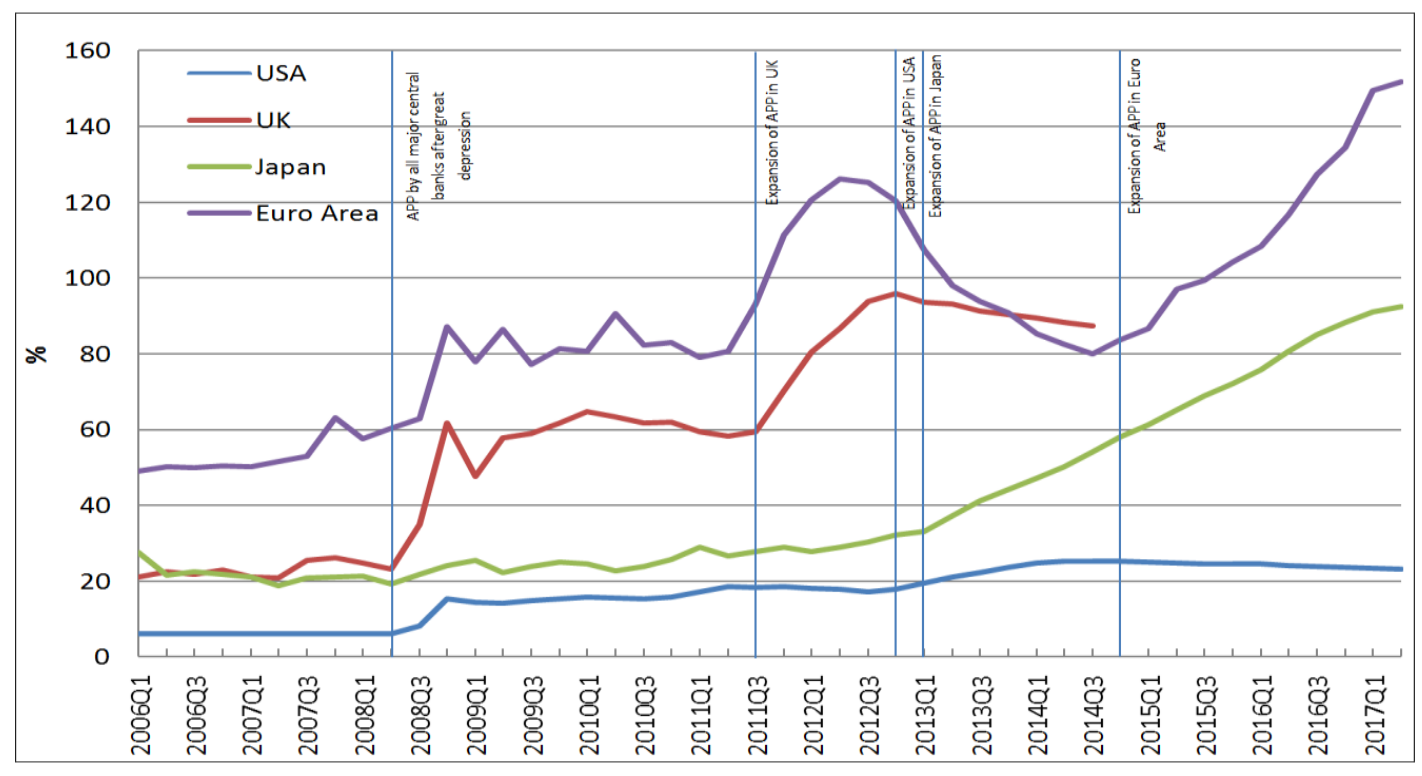

Figure 4: Total Assets as Percent of GDP Source: European Central Bank and FRED, https://fred.stlouisfed.org/series/ECBASSETS, Accessed on June 20, 2018. 
After the major expansion statement of asset purchase by BOJ in April 2013 by 60 to 70 trillion Yen a year and which was further extended to 80 trillion Yen a year in October 2014 that has still been in effect, its asset-GDP ratio started to jump from 37.22 percent in second quarter of 2013 to 92.51 percent in the second quarter of 2017. Massive APPs of ECB amounting to $€ 60$ billion per month of euro-area bonds was declared in January 2015 and it was long drawn and increased to $€ 80$ billion on March 2016. Consequently, asset-GDP ratio that was 86.57 percent in January 2015 reached to 151.74 percent in April 2017.

\section{b. Inflation}

Another objective of QE is to keep inflation on track to meet the 2 percent target inflation rate set by the governments of the economies to stimulate business and consumer confidence. Critical examination of the annual inflation of the economies under investigation reveals that except for Japan, year-to-year trend of inflation are very similar for UK, USA and Euro Area. However, QE of the central banks were successful in attaining inflation targets in the short and over the medium term, but fail to perform better in the long run.

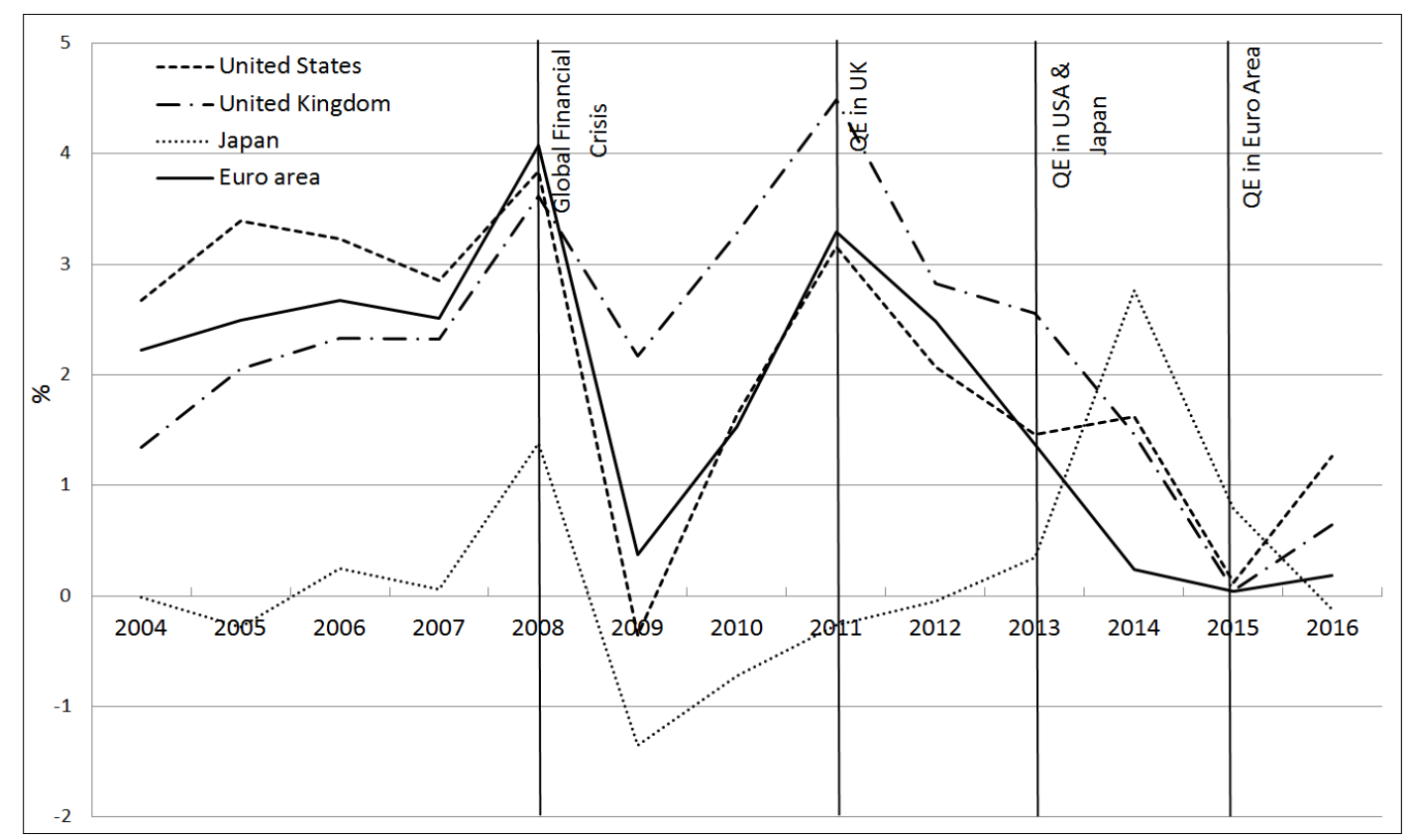

Figure 5: Inflation Rates (CPI Based) Source: World Bank, World Development Indicators, Accessed on June $20,2018$.

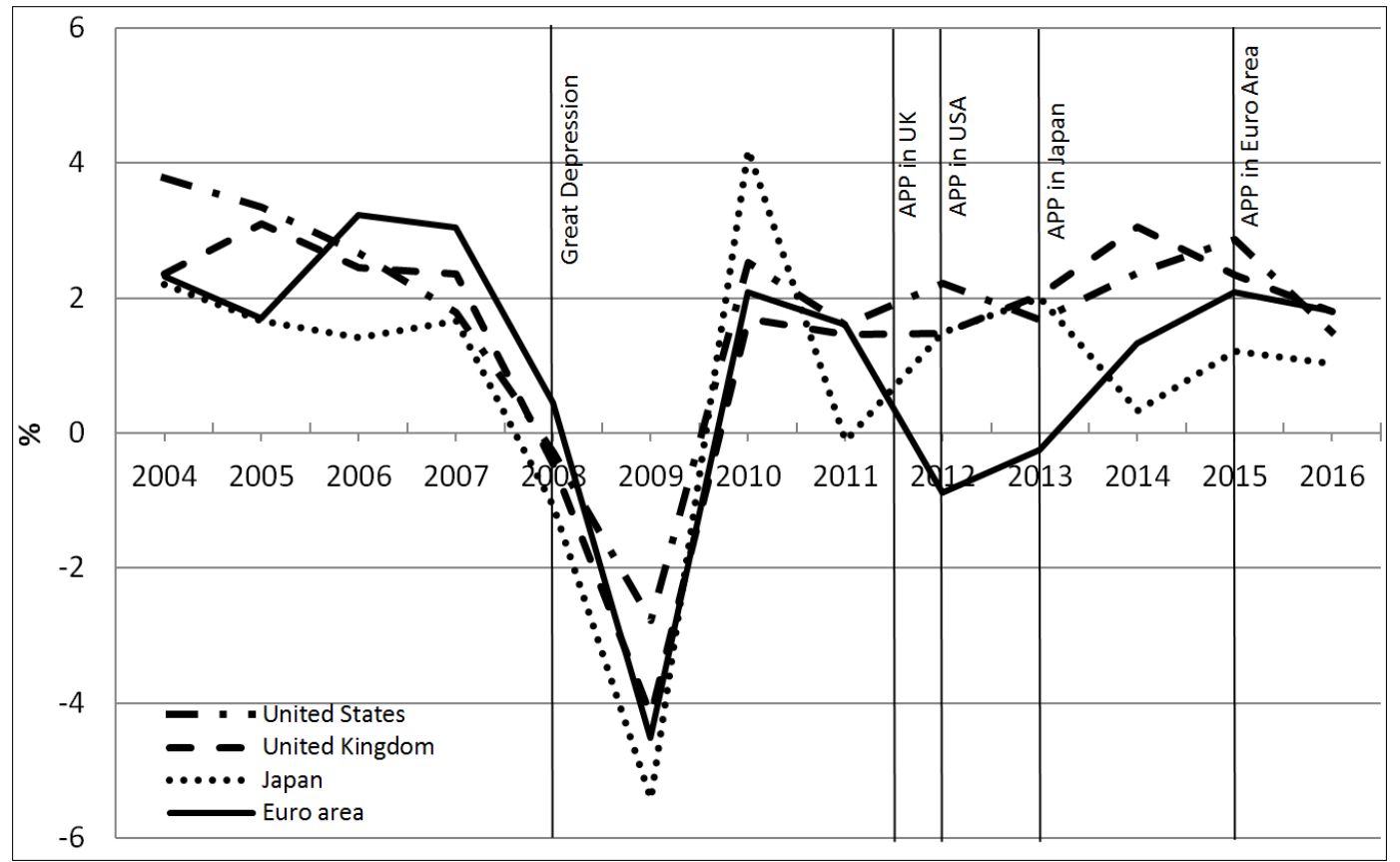

Figure 6: Real GDP Growth Source: World Bank, World Development Indicators, Accessed on June 20, 2018. 


\section{c. Real GDP growth}

Real GDP growth of all the economies had been negative in 2009. Though they recovered in 2010 owing to the UMP of the respective economies, they again slide into recession in the following year. What is common for USA, Japan and UK is that, there was a time lag in realizing positive growth effect following the LSAPs of the economies as growth rate initially dropped and then recovered. For Euro Area, similar trend is visible after the QE of ECB approved in January 2015.

\section{Literature Review}

The impacts of monetary policy like QE, a measure different from its conventional doctrine, have been investigated in a number of studies.

Baumeister and Benati (2013) examine the spreads of lower long-run bond for the recessionary period of 20009 applying a time-varying parameter structural VAR for the US, Euro area, Japan and the UK. The study identifies strong impact of a compression in the spread of long-term yield on inflation and growth of output. Such an unconventional policy measure, as the counterfactual simulations find, prevented the risks of deflation and collapses of output significantly both in the US and UK.

Chung et al. (2012) evaluates the effect of LSAPs undertaken by the Fed on the US economy with the help of simulations technique employing the Fed's FRB/US macroeconomic model augmented with a simple portfolio balance effects model and find that the LSAP1 and LSAP2 together raises the real GDP level and inflation by 3 percent and 1 percent respectively from the base set by the model. In a similar study, Chen et al. (2012) identifies an increase around 0.13 percent in real GDP and 0.03 percent in inflation of US following the LSAP2 programme. De Graeve and Theodoridis (2016) examines the impact of Fed's "Operation Twist" that includes the purchase and sale of bonds nearly $2 \%$ of US GDP and find the it causes US real GDP to rise by 0.6 percent and inflation by 0.3 percentage point. Gertler and Karadi (2013), in a calibrated version of their model, assess the output and inflation effects of US LSAP with a size of $2.5 \%$ of GDP and find that it has $1 \%$ and 1.5 percentage points impact on output and inflation, respectively remaining the policy rates unaltered, and $0.2 \%$ and 0.2 percentage points respectively for an active standard monetary policy rule and partially amends the effects of expansionary QE by increasing short-term rate.

While investigating the impact of LSAPs of Fed, Gagnon et al. (2011) find that it leads to a fall in long-term interest rates of securities included or not included in the asset purchase programme. Hamilton and Wu's (2012) estimation of bond pricing model also identify a fall of rate of interest. In another study on the long-term rate of interest rate, stock market and unemployment, Bhar, Malliaris, and Malliaris (2015) find that Fed's QE has a relatively strong effect on stock market compared to interest rate.

The VAR estimation aiming to simulate interest rate effect of QE for UK conducted by Joyce et al. (2011) reveals the evidence of fall in rate of interest rate in response to QE. Asset purchase program of BOE and its impact on UK GDP and inflation is examined by Kapetanios et al. (2012) using three VAR models including structural change in alternative ways. Results of the study indicate that the highest effect of QE on output level and annual CPI inflation are $1.5 \%$ and 1.25, respectively, a finding largely similar to those obtained by Bridges and Thomas (2012).

Studies on the macroeconomic effects of the ECB's policy interventions are also noteworthy. In one of the earlier work, Lenza et al. (2010) suggests that the compression of spreads owing to the unconventional policies of ECB has impact identical to the shock of standard monetary policy in normal times that causes significant change in loans and rates of interest, moderate effects on broad money, and hovers the enhancement of real activity and inflation. ECB's unconventional policy measures, as found by Giannone et al. (2012), increases the industrial production of euro-area by 2 percent than it would have been otherwise.

Sahuc (2016) adopts the model offered by Gertler-Karadi for the evaluation of asset purchases of ECB which was about 9\% of GDP of Euro Area. Sahuc (2016) finds that the policy rate that gives a maximum QE effect on output growth and inflation of 0.2 and 0.1 percentage points in 2015-16 raises the average output growth and inflation effect in 2015-16 to 0.6 and 0.6 percentage points if maintained for another year. And hence, Similar to Gertler and Karadi (2013), Sahuc (2016) based on his assessment emphasizes the significance of maintaining low short-run policy rates for extended period.

Schenkelberg and Watzka (2013) attempt to analyze the performance of QE program of BOJ. Influenced by a New Keynesian DSGE model, they rely on an SVAR with sign restrictions and identify that a shock produced by QE program was effective in cutting down the long-term interest rate and stimulating aggregate output in the short run. However, Baumeister and Benati (2013), based on a VAR with a built-in counterfactual interest rate spread scenario, determine a robust direct impact of QE on aggregate output.

Studies on the impact of QE on exchange rate include Ueda (2012), Glick and Leduc (2012), Neely (2012) and Fratzscher et al. (2018). Ueda (2012) shows that policy measures taken by the BOJ was successful to bring about an expected change in asset prices leaving insignificant impact on exchange rate. In case of US and UK, the study of Glick and Leduc (2012) demonstrates that QE announcements result in lower long-term interest rates and both 
the US dollar and British pound depreciates on the declaration dates. In a similar study, Neely (2012) finds that the first LSAP program by the Fed reduces yields of bond in other countries along with US and causes notable depreciation of the US dollar. In contrast, Fratzscher et al. (2018) opposes Neely (2012) and provides evidence that there was inflow of funds after the first LSAP that causes an appreciation of USD. However, he finds the second LSAP leading to the opposite results.

Kenourgios et al. (2015) study the impacts of the announcements of QE by the ECB, the BoJ and the BoE on dynamics of exchange rate employing intra-day data of three major exchange rates, namely- EUR/USD, GBP/USD and JPY/USD resorting a univariate APARCH $(1,1)$ model. The study concludes that QE programs of BoE and BoJ have a direct negative impact on their respective currencies without any impact on their volatility around the declaration date. It is also evident that ECB's QE announcement has a delayed devaluation effect on euro with a rise in the volatility around the announcement date.

The VAR estimation of Joyce et al. (2011) also identifies a remarkable drop in the stock index volatility at the onset of QE, a finding similar to Steeley and Matyushkin (2015).

\section{Data Sources}

The study employs quarterly data of real GDP growth; change in exchange rate index, inflation (CPI based), change in stock price index and yields of long-term bonds that are seasonally adjusted. Sources and periods are summarized below in Table 1 for central banks of different economies.

\begin{tabular}{|c|c|c|c|}
\hline Variables & Sources & Description & Period \\
\hline Real GDP Growth & FRED & \multirow{5}{*}{$\begin{array}{l}\text { Quarterly, } \\
\text { Seasonally } \\
\text { Adjusted }\end{array}$} & \multirow{5}{*}{$\begin{array}{l}\text { 2003Q1-2014Q4 } \\
\text { 2001Q3-2012Q4 } \\
\text { 2000Q1-2016Q4 } \\
\text { 2000Q1-20017Q2 }\end{array}$} \\
\hline Change in Exchange Rate Index & IMF & & \\
\hline Inflation (CPI Based) & IMF & & \\
\hline Change in Stock Price Index & FRED & & \\
\hline Yields of long-term bonds & FRED & & \\
\hline
\end{tabular}

Table 1: Variables- Sources and Periods

The study also identifies the recent QE programs of the respective central banks of the four economies in order to make projections in the preceding quarters. Table 2 below summarizes the recent QE programs of the central banks along with the projection period-

\begin{tabular}{|c|c|c|}
\hline Central Bank & Date of Announcement & Projection Period \\
\hline FED & December 2012 & 2013Q1-2014Q4 \\
\hline BOE & October 2011 & 2011Q4-2012Q4 \\
\hline BOJ & April 2013 & 2013Q2-2016Q4 \\
\hline ECB & January 2015 & 2015Q1-2017Q2 \\
\hline
\end{tabular}

Table 2: Recent QE and Projection Periods

\section{Methodology}

The structural VAR model considered for the study can be given as-

$$
A_{0} y_{t}=A_{1} y_{t-1}+A_{2} y_{t-2}+\cdots+A_{k} y_{t-k}+\varepsilon_{t}
$$

where $y_{t}$ is an $\mathrm{m} \times 1$ vector of endogenous variables and $\varepsilon_{t} \sim \mathrm{N}\left(0, \mathrm{I}_{\mathrm{m}}\right)$ with $\mathrm{E}\left(\varepsilon_{t} \mid y_{t-j}: j \geq 1\right)=0$.

The coefficient matrix $\mathrm{Aj}$ for $\mathrm{j}=0, \ldots \ldots, \mathrm{k}$ is an $\mathrm{m} \times \mathrm{n}$ matrix.

In our specification $\mathrm{y}_{\mathrm{t}}$ includes five variables: real GDP growth, change in exchange rate index, inflation (CPI based), change in stock price index, yields of long-term bonds. Inclusion of yields of long-term bonds is based on the assumption that the macroeconomic impacts of QE work entirely through its impact on yields of long-term bonds. As observed, yields of long term bond declined in the following years after pursuing QE.

Baseline simulation and simulation in a particular scenario designed to describe the impact when QE is absent making necessary adjustment in the long-term bond yields have been performed under the VAR specified above. Both the simulation types have been compared with the actual data of the variables used to explain the impact of QE on four major macroeconomic indicators of USA, UK, Japan and Euro Area. Necessary diagnostic checks have been performed for the VAR model for each of the economies separately and found to be suitable for making the projections. The models are found to be stable, residuals are white noise, and correlated, variables are free from short-run correlation and seasonality. 


\section{Empirical Results}

Model projection under baseline simulation represents performance of macroeconomic indicators due to QE. An alternative scenario tuning the long-term bonds yield yields performance of the indicators in the absence of QE. Results for different economies are presented in the subsequent figures.

\section{a. Experience from the USA}

The Federal Open Market Committee declared the per month open-ended asset purchases to increase from the amount of $\$ 40$ billion to $\$ 85$ billion on 12 December 2012. Its impacts have been studied from first quarter of 2013 onward until last quarter of 2014. To attain the alternative scenario, that is, the no-QE scenario, long term bond yields have been set unchanged over the forecast period at the rate observed at the end of 2012. Figure 7 compares the predictions for the major economic indicators under the scenarios of QE and no-QE. The figure shows that model projections defined under baseline simulation that considers QE programs into account fit reasonably well with no QE simulations for all the indicators.

Panel A shows the estimated effect of QE pursued by Fed on real GDP growth of USA. It is clear that the model projection based on baseline simulation deteriorates in the second half of the projection period, that is, in 2014 . The same is true for alternative scenario representing no QE. For the first two quarters, real GDP growth projection does not differ from model projection to no QE simulation, but for the rest of the period, model projection lies above the no QE scenario. It means that QE supports real GDP growth to perform better compared to no QE.

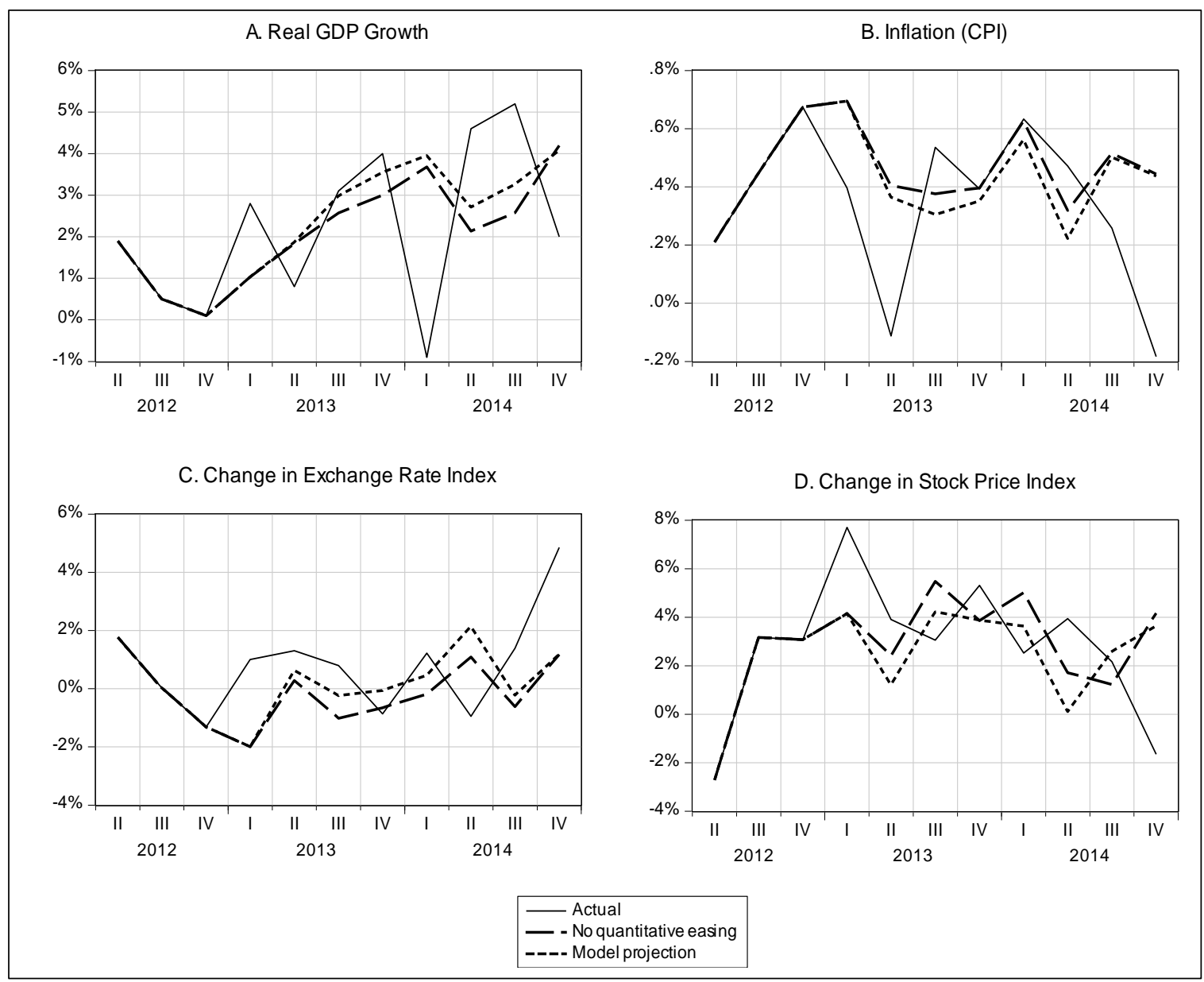

Figure 7: Simulations for the USA

The impact of Fed's QE on CPI inflation is illustrated by panel B. It shows that both the model projection and no QE scenario work good at the middle of the projection period, particularly from the second quarter of 2013 to second quarter of 2014. For the first two period, they are almost identical with that of the actual values. CPI inflation under model projection lies below the alternative scenario and therefore US CPI inflation would have been higher if Fed did not implement QE. The maximum impact of Fed's QE on CPI inflation was in the second quarter of 2014, 18 months later than the implementation of QE. It is obvious that Fed fails to maintain its target inflation rate of 2 percent despite the execution of QE, and no QE could bring about a better outcome at least in view of higher inflation expectation. 
It appears from panel $\mathrm{C}$ that both the QE and no QE simulation reasonably capture the trend in the actual data and they are less volatile. The minimum change in exchange rate index was in the first quarter of 2013 and the maximum change was in the second quarter of 2014. However, as the model projection and projection under no QE do not differ significantly, one cannot conclude that QE supports US dollar throughout the projection period.

Stock price index was volatile in the first and last few quarters of the projection period as illustrated in panel D. Apart from these two periods, stock market performs better with no QE as the projection backed by baseline simulation lay below the projection made under no QE scenario.

To conclude, while QE was found supportive for real GDP growth of USA, its impact on CPI inflation, change in exchange rate index and stock price index was not found to be conducive.

\section{b. Experience from the UK}

The second round QE of additional $£ 75$ billion announced by the BOE in October 2011 was extended by $£ 50$ billion in February 2012 and then by another $£ 50$ billion in July 2012 bringing the total amount to $£ 375$ billion. Thus the impacts of these QE announcements have been evaluated from the last quarter of 2011 to last quarter of 2012. The alternative scenario, that is, the no-QE scenario, is designed setting the long term bond yields at a level perceived at the end of 2011 along with the baseline scenario. Figure 8 compares the model projection with noQE simulation.

Panel A illustrates that as time passes away, both the model based and alternative scenario based projections of real GDP growth deteriorate. However, there is no significant difference found between the QE based and no-QE based projections at least for first three quarters of the projection timeline, while QE is less contributing to real GDP growth for the rest of the period. It indicates that real GDP growth would have been better in the absence of QE.

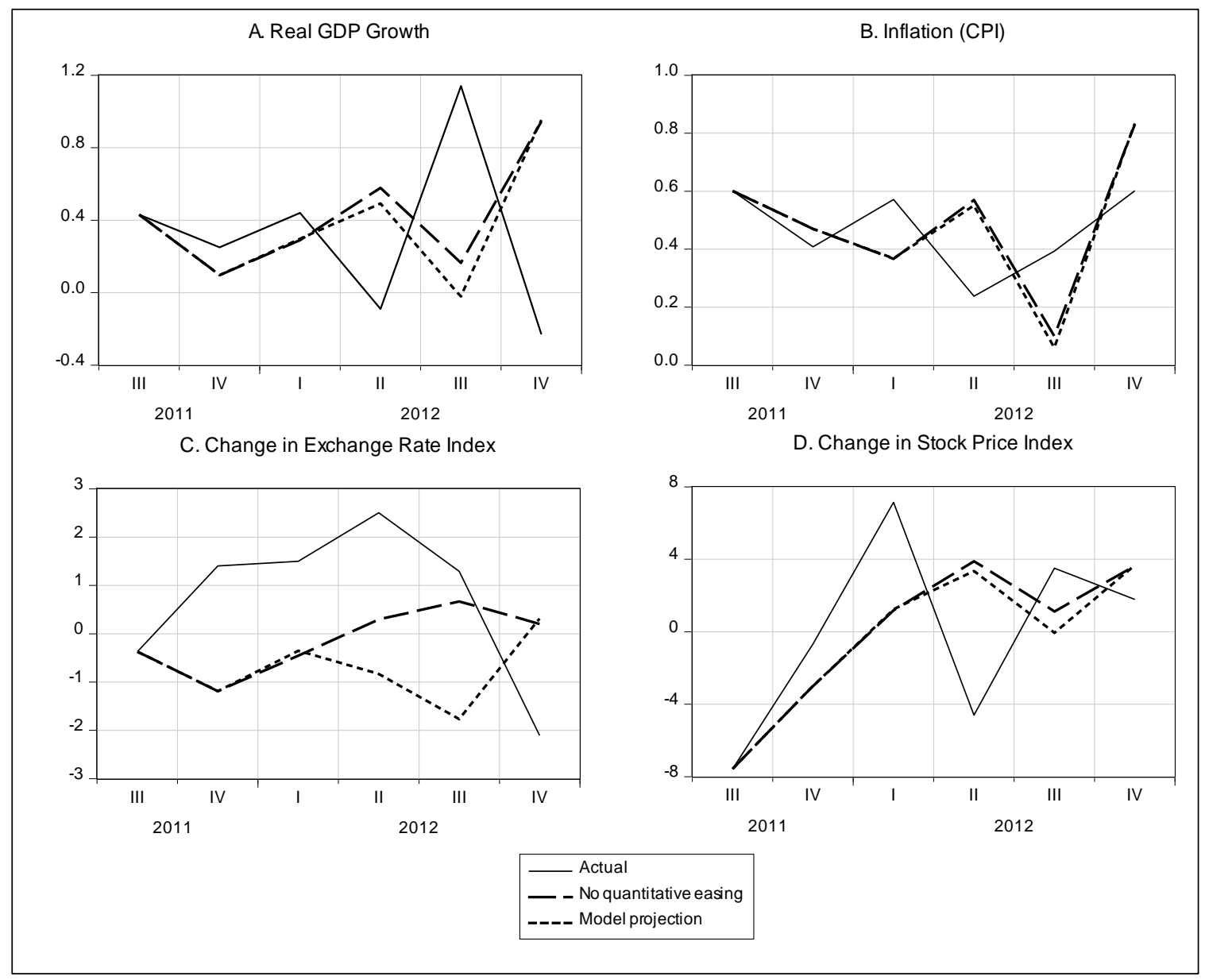

Figure 8: Simulations for the UK

From panel B, it is clear that projection of CPI based inflation under QE and no-QE simulations are very close to each other. As the projection does not differ between alternative scenarios, it stands to mean that the impact of QE on inflation of UK is negligible.

For the case of change in exchange rate index, it is obvious that both the baseline and no-QE simulation based projection fail to reflect the trend in the actual data which is somewhat volatile all through the projection period. 
As shown by panel C, results obtained under QE and no-QE scenario does not differ significantly for the first two quarters following the QE announcement and thus QE has insignificant influence on change in exchange rate index. However, from the first quarter of 2012, QE weakens the domestic currency of UK that starts to recover after the third quarter of 2012 and takes time till the end of the projection period.

Forecasting the change in stock price index of UK using different simulation types reveals that they well-capture the trend in the actual data. For the first six months after QE, there was no difference between model projections and no-QE scenario. But for the rest of the projection period, there was a clear indication that QE was not helpful for stock market development as the no-QE simulation lies above the baseline simulation.

Overall, QE is found to be unsuccessful in achieving desired result in terms of GDP growth and inflation expectations in UK. However, starting with an insignificant impact, QE gradually weakens the domestic currency of UK and its stock market.

\section{c. Experience from Japan}

The BOJ announced the expansion of its asset purchase program by 60 to 70 trillion Yen a year on April 2013, which was nominal in earlier years, only 2 trillion Yen a year. A further extension of its bond buying program to 80 trillion Yen a year was announced by BOJ on October 2014. The study thus examined the impact of the extension of asset purchase program from the second quarter of 2013 to the last quarter of 2016. In this respect, the model projection based on QE is compared with the no-QE simulation in Figure 9 considering the long-term bond yields constant at a rate maintained at the end of June 2013.

It is observed from panel A that projection both by baseline and no-QE simulation well fits with the trend in the actual data of real GDP growth for the first four and last seven quarters but deviates largely, predominantly opposite in nature, at the middle of the projection period. Actual data of real GDP growth mostly lie above the model forecasting. Moreover, projection by no-QE simulation lies entirely above the model based forecasting and therefore it is evident that real GDP growth would have been better if BOJ had not adopted QE.

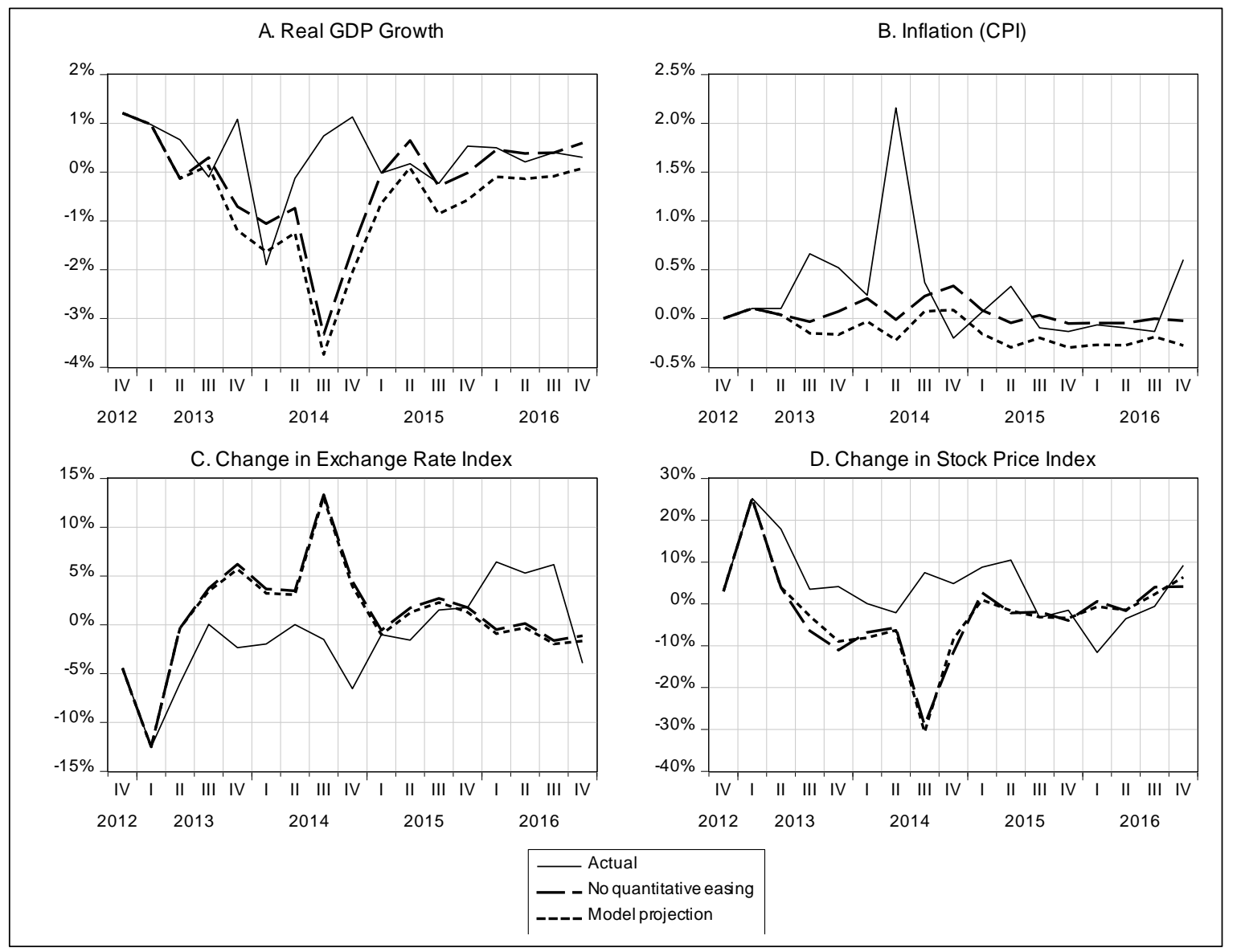

Figure 9: Simulations for Japan

Panel B shows the impact of BOJ's QE on CPI inflation in Japan. Clearly, QE of Japan fails to achieve the targeted 2 percent inflation rate. Moreover, the projected inflation under QE scenario is typically negative over the projection period and always lies below than that of no-QE scenario, which clearly indicates that no-QE would have been better for Japan in realizing inflation goals. 
The effects of QE on exchange rate index and stock price index are illustrated in panel C and D, respectively. Clearly, no noticeable difference is observed between the model projection and no-QE simulation throughout the forecast period both for the change in the index of exchange rate and stock prices and therefore BOJ's QE was not found to be effective in supporting the currency of Japan and its stock market.

In general, QE of BOJ's was not successful in bringing favorable outcomes for the major economic indicators considered for the study.

\section{d. Experience from the Euro Area}

Asset purchase program of ECB started in 2009 was insignificant and irregular till 2015. In January 2015, an expanded asset purchase program was announced by ECB in January 2015 with an aim to purchase euro-area bonds amounting to 60 billion euro per month from central governments, agencies and European institutions. The incentive was scheduled to last till September 2016 at the earliest with a total QE of no less than 1.1 trillion euro. ECB amplified its purchases of bond from $€ 60$ billion to $€ 80$ billion on monthly basis on March 2016 and started to comprise corporate bonds under the program of asset purchases and declared new ultra-cheap four-year loans to banks. The impacts of these expanded asset purchase program on major macroeconomic indicators are investigated from the first quarter of 2015 to the second quarter of 2017. Simulation results are shown in Figure 10.

If one compares the model projection and no-QE scenario based projection for real GDP growth in euro area as sown in panel A, it is difficult to identify a systematic pattern as none of them are consistently higher than the other. Thus, the simulation results indicate that the impact of QE on the real GDP growth of euro area is not certain.

Panel B demonstrations that the baseline projection and the no-QE simulation based projection are not discernable for the first two quarters of the forecast horizon. Otherwise, the model projection lies above the noQE simulation for the rest of the projection period which indicates that inflation in the Euro area would have been lower and impact would have been adverse if ECB had not undertaken QE.

The impact of QE on the change of exchange rate index of euro area is illustrated in panel C. Baseline simulation was identical to no-QE simulation for the first quarter of the projection horizon, while lies below it thereafter. It is a clear sign of the fact that QE did not support Euro throughout the projection horizon.

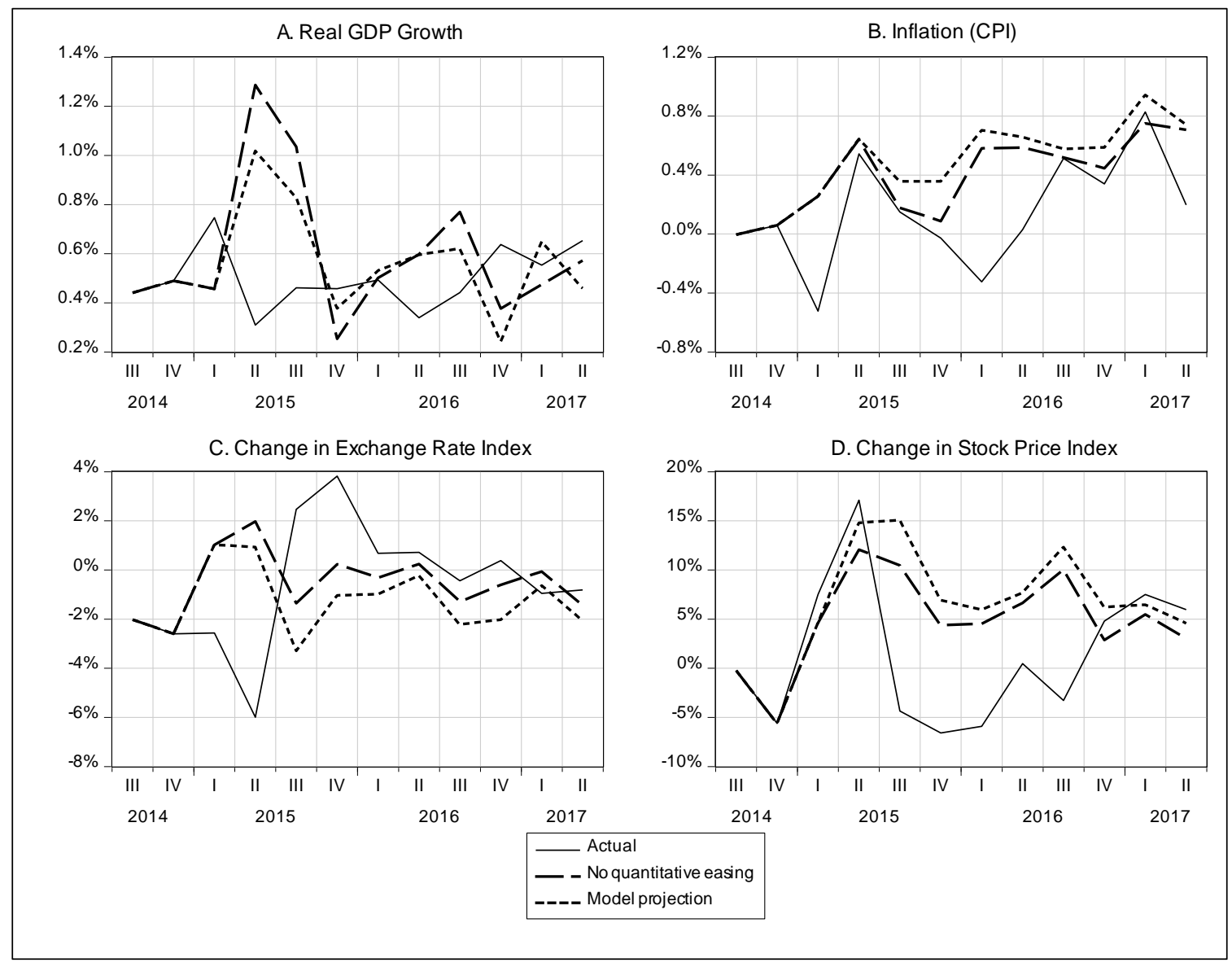

Figure 10: Simulations for Euro Area 
The effect of QE of ECB on stock market development is rather opposite as shown in panel D. Model projection of change in stock price index lies entirely above the no-QE simulation which suggests that stock market development would have been lower if QE had not been implemented by ECB.

Overall, while the impact of ECB's QE is uncertain on real GDP growth and adverse on CPI inflation and exchange rate, it is found to be favorable for the development of stock market of euro area.

\section{Conclusion}

The study examines the impact of UMP or QE announcements of major central banks of advanced economies on major economic indicators, namely output growth, inflation, exchange rate indices and stock market indices. Simulation results of the study suggest that QE was supportive for real GDP growth of USA. But the impact QE had on output growth was inconclusive for euro area and not supportive for the UK and Japan. However, the overall impact of QE on CPI inflation of these advanced economies was not found to be conducive. Except from euro area, QE weakened the domestic currencies and stock market development of USA, UK and Japan. One of the reasons for such results might be that the recessionary forces were strong enough to offset the forces of QE. Or, it might be due to inadequate scale of QE to address the recession of these advanced economies. At the same time, policy makers should think over other supplementary measures that can support and expedite the impact of QE in favourable directions to achieve the desired goals of the UMP.

\section{References}

- Baumeister, C., and L. Benati. (2013). Unconventional Monetary Policy and the Great Recession: Estimating the Macroeconomic Effects of a Spread Compression at the Zero Lower Bound. International Journal of Central Banking, 9(2), 165-211.

- $\quad$ Bhar, R., Malliaris, A. G. and Malliaris, M. (2015). The Impact of Large-Scale Asset Purchases on the S\&P 500 Index, Long-Term Interest Rates and Unemployment. Applied Economics. 47 (55), 6010-6018.

- Bouraoui, T. (2015). The effect of reducing quantitative easing on emerging markets. Applied Economics, 47(15), 1562-1573. https://doi.org/10.1080/00036846.2014.1000524

- $\quad$ Bridges, J. and Thomas, R. (2012). The Impact of QE on the UK Economy - Some Supportive Monetarist Arithmetic, Bank of England Working Paper No. 442. http://dx.doi.org/10.2139/ssrn.1992942

- Bundesbank, D. (2016). The macroeconomic impact of quantitative easing in the euro area. Deutsche Bundesbank Monthly Report, 29-53.

- Chen, H., V. Cúrdia, A. Ferrero (2012). The Macroeconomic Effects of Large-scale Asset Purchase Programmes, Economic Journal, 122(564), F289-F315. https://doi.org/10.1111/j.1468-0297.2012.02549.x

- $\quad$ Chung, H., Laforte, J. P., Reifschneider, D., \& Williams, J. C. (2012). Have we underestimated the likelihood and severity of zero lower bound events? Journal of Money, Credit and Banking, 44(s1), 47-82. https://doi.org/10.1111/j.1538-4616.2011.00478.x

- Clouse, James, Dale Henderson, Athanasios Orphanides, David Small, and Peter Tinsley, (2000). Monetary Policy when the Nominal Short-Term Interest Rate is Zero. The B.E. Journal of Macroeconomics, 3(1), https://doi.org/10.2202/1534-5998.1088.

- $\quad$ De Graeve, F., K. Theodoridis (2016). Forward guidance, quantitative easing, or both? National Bank of Belgium, Working Paper 305.

- $\quad$ Eggertsson, G. B. (2003). Zero bound on interest rates and optimal monetary policy. Brookings papers on economic activity, 2003(1), 139-233.

- Eggertsson, G. B. (2006). The Deflation Bias and Committing to Being Irresponsible. Journal of Money, Credit, and Banking, 38(2), 283-321. https://doi.org/10.1353/mcb.2006.0031

- $\quad$ Faust, J., Rogers, J. H., Wang, S. Y. B., \& Wright, J. H. (2007). The high-frequency response of exchange rates and interest rates to macroeconomic announcements. Journal of Monetary Economics, 54(4), 1051 1068. https://doi.org/10.1016/j.jmoneco.2006.05.015

- $\quad$ Fratzscher, M., Lo Duca, M., \& Straub, R. (2018). On the international spillovers of US quantitative easing. The Economic Journal, 128(608), 330-377. https://doi.org/10.1111/ecoj.12435

- Gagnon, J., Raskin, M., Remache, J., \& Sack, B. (2011). The Financial Market Effects of the Federal Reserve's Large Scale Asset Purchases. International Journal of Central Banking, 7(1), 3-43.

- $\quad$ Gertler, M. \& Karadi, P. (2013). QE 1 vs. 2 vs. 3: A Framework for Analyzing Large-Scale Asset Purchases as a Monetary Policy Tool, International Journal of Central Banking, 9(1), 5-53.

- Giannone, D., Lenza, M., Pill, H. and Reichlin, L. (2012). The ECB and the interbank market, The Economic Journal, 122(564), F467-86. https://doi.org/10.1111/j.1468-0297.2012.02553.x 
- Glick, R., \& Leduc, S. (2012). Central bank announcements of asset purchases and the impact on global financial and commodity markets. Journal of International Money and Finance, 31(8), 2078-2101. https://doi.org/10.1016/j.jimonfin.2012.05.009

- Haldane, A. G., Roberts-sklar, M., Wieladek, T., \& Young, C. (2016). QE: the story so far. Bank of England Working Paper No. 624. https://ssrn.com/abstract=2858204

- Hamilton, J. D., \& Wu, J. C. (2012). The effectiveness of alternative monetary policy tools in a zero lower bound environment. Journal of Money, Credit and Banking, 44(s1), 3-46. https://doi.org/10.1111/j.15384616.2011.00477.x

- Hausken, K., \& Ncube, M. (2013). Quantitative Easing and Its Impact in the US, Japan, the UK and Europe. London: Springer.

- Hohberger, S., Priftis, R., \& Vogel, L. (2017). The macroeconomic effects of quantitative easing in the Euro area: evidence from an estimated DSGE model. European University Institute, Economics Working Paper No ECO2017/04. http://cadmus.eui.eu/bitstream/handle/1814/45726/ECO_2017_04.pdf

- Joyce, M., Lasaosa, A., Stevens, I., \& Tong, M. (2011). The financial market impact of quantitative easing in the United Kingdom. International Journal of Central Banking, 7(3), 113-161.

- Joyce, M., Miles, D., Scott, A., \& Vayanos, D. (2012). Quantitative Easing and Unconventional Monetary Policy - An Introduction. The Economic Journal, 122(1), 45-64. https://doi.org/10.1111/j.14680297.2012.02551.x.

- $\quad$ Kapetanios, G., Mumtaz, H., Stevens, I. and Theodoridis, K. (2012). Assessing the economy-wide effects of quantitative easing, The Economic Journal, 122(564), F316-47. https://doi.org/10.1111/j.14680297.2012.02555.x

- Kenourgios, D., Papadamou, S., \& Dimitriou, D. (2015). On quantitative easing and high frequency exchange rate dynamics. Research in International Business and Finance, 34, 110-125. https://doi.org/10.1016/j.ribaf.2015.01.003

- Lenza, M., Pill, H. and Reichlin, L. (2010). Monetary policy in exceptional times, Economic Policy, 25(62), 295-339. https://doi.org/10.1111/j.1468-0327.2010.00240.x

- Maggio, D. M., Kermani, A., \& Palmer, C. (2016). How Quantitative Easing Works: Evidence on the Refinancing Channel. NBER Working Paper No. 22638. https://doi.org/10.3386/w22638

- Michaelis, H., \& Watzka, S. (2017). Are there differences in the effectiveness of quantitative easing at the zero-lower-bound in Japan over time? Journal of International Money and Finance, 70, 204-233. https://doi.org/10.1016/j.jimonfin.2016.08.008

- Mishkin, F. (1996). The Channels of Monetary Transmission: Lessons for Monetary Policy. NBER Working Papers No. 5464. Cambridge, MA: NBER.

- Neely, C. (2012). The large-scale asset purchases had large international effects. Federal Reserve Bank of St. Louis, Working Paper Series No. 2010-018D.

- Sahuc, J.-G. (2016). The ECB's asset purchase programme: A model-based evaluation, Economics Letters 145(C), 136-140. https://doi.org/10.1016/j.econlet.2016.06.009

- $\quad$ Schenkelberg, H. and Watzka, S. (2013). Real Effects of Quantitative Easing at the Zero Lower Bound: Structural VAR-Based Evidence from Japan. Journal of International Money and Finance, 33 (Mar), $327-$ 357. doi:10.1016/j.jimonfin.2012.11.020.

- Steeley, J. M., \& Matyushkin, A. (2015). The effects of quantitative easing on the volatility of the gilt-edged market. International review of financial analysis, 37, 113-128. https://doi.org/10.1016/j.irfa.2014.11.004

- Tobin, J. (1969). A General Equilibrium Approach to Monetary Theory. Journal of Money, 1(1), 15-29. https://doi.org/10.2307/1991374

- Ueda, K. (2012). The effectiveness of non-traditional monetary policy measures: the case of the Bank of Japan. The Japanese Economic Review, 63(1), 1-22. https://doi.org/10.1111/j.1468-5876.2011.00547.x 


\title{
Blockchain Technology and its Impact on the Global Economy
}

\author{
Dr. Burcu Sakız (Istanbul Aydın University, Turkey) \\ Prof. Dr. Ayşen Hiç Gencer (Beykent University, Turkey)
}

\begin{abstract}
The world's most valuable resource is no longer oil, but data. Smartphones and the internet have made data abundant, ubiquitous and far more valuable. Modern algorithms can predict when a customer tends to buy, a car needs servicing or a person is at risk of a disease. Meanwhile, artificial intelligence techniques extract more value from data. As individuals accumulate information which transforms into knowledge, entrepreneurs will want to use and/or share that knowledge. It is the sharing of knowledge that needs a decentralized, autonomous mechanism so that knowledge can be shared fairly amongst all peoples of the world, not just within corporations. Blockchain technology gives us that mechanism. Blockchain is one of a kind decentralized technology and it is distributed as well as decentralized ledger. Blockchain is the answer to a lot of obstacles the world has to go through today. Before today, nobody could think of transferring money from one account to another safely without any financial institution in the middle, like a bank. Blockchain technology presents a radical and disruptive new way of conducting all manner of transactions over the Internet. The advent of Bitcoin and the blockchain has brought a lot of change to the world of finance even the world economy was formerly run using fiat currencies. Introducing the blockchain environment will actually enhance the economics because in blockchain, all transactions are recorded right from the manufacturer to the buyer. This paper explores the emerging landscape for blockchain technology focusing on the economics.
\end{abstract}

\section{Introduction}

Blockchain is one of the hottest topics almost all around the world. Especially with the beginning of the 21 st century, there are many major developments and changes seen in financial technologies like blockchain. What it really means and what it stands for in the global economy today is very important. Blockchain technology and distributed database technologies becomes the key technological enablers of recent developments in distributed transaction and ledger systems. These technologies cause opening of new gates for opportunities based on open sources especially new types of digital platforms and services (Lindman vd., 2017). We can define open source as they refer to any program whose source code is made available and open source software is usually developed as a public collaboration and made freely available (Url-1,2019). Usually new technologies attract a wide variety of developers especially in IT (information technologies) industry, including many freelancers from around the world. At the elementary stage of blockchain solutions, it is likely to be in a developer's best interest to develop, or monitor the development of, blockchain applications on open source. And it is going to change the way applications and users interact with the internet.

Blockchain is touted as one of the most significant technical innovations in digitalization of asset ownership in this century. The most impactful blockchain applications will require tight collaboration between developers, incumbents, innovators, and regulators, adding complexity and delaying implementation (Url-2, 2016). Blockchain environment refers to a fully distributed system for cryptographically capturing and storing a, immutable, consistent and linear event log of transactions between networked actors. It is similar to a distributed ledger that is consensually kept, updated, not deleted and validated by the parties involved in all the transactions within a network (Risius, Shoprere, 2017). Blockchain technology currently receives a lot of academic and public attention. It has an aim to constitution of the foundation for truly trust-free economic transactions (Glaser 2017). Normally blockchain systems can not only process monetary transactions but can also ensure that transactions comply with programmable rules in the form of "smart contracts" (Tschorsch, Scheuermann 2016), it allows even parties to conduct and reliably control mutual transactions without requiring of any trusted middle-men.

Blockchain can be described as "the trust machine," indicating that it takes care of trust issues between individuals (Url-3, 2019). It is an open source ledger that is visible to users across the network brings a level of security that is unmatched. Blockchain puts the trust in its users and their ability to maintain the ledger. In other words, blockchain technology built economic system runs without people, thus making a transaction "trust-free". This technology provides a viable alternative to eliminate middle-mans, thereby lowering operational costs and increasing the efficiency of a sharing service. Blockchain is a platform where people are allowed to carry out transactions of all sorts without the need for a central or trusted arbitrator. With blockchain technology, the world's most fundamental commercial interactions can be re-imagined. That causes many opportunities to invent new styles of digital interactions in trust-free sharing services (Sun et al., 2016).

The blockchain, the ledger that underlies the famous cryptocurrency Bitcoin, has huge implications for many industries. The advent of Bitcoin and the blockchain has brought a lot of change to the world of finance. Also it is kind a financial tool that can potentially play an important role in the sustainable development of the global 
economy. That's why this paper focuses on the emerging landscape for blockchain technology in terms of economics.

\section{History of Blockchain Technology}

The blockchain technology promises to revolutionize the way of business. It has effects on various sectors, from financial to manufacturing as well as education. Satoshi Nakamoto released the well-known whitepaper about the technology in 2009. In the paper, he provided details of how the technology was well equipped to enhance digital trust given the decentralization aspect that meant nobody would ever be in control of anything. Ever since Satoshi Nakamoto exited the scene and handed over Bitcoin development to other core application developers, the digital ledger technology has evolved resulting in new applications that make up the blockchain history (Url-4, 2018). The evolution of Bitcoin and other cryptocurrencies have both drawn significant attention and also threatened the very foundations of the financial system. After all, this was the intention of Satoshi Nakamoto when the global financial crisis hit not only USA but also the global economy harder than any crisis in history.

But after the global financial crisis, the year 2009 is not the exact date that blockchain concept revealed. Blockchain was invented in 1991. Blockchain history dates back to early 1990's by two researchers: Stuart Haber and W. Scott Stornetta. They both touted as the co-inventor of the blockchain technology. Several aspects of the Bitcoin blockchain architecture are based on Stornetta's work. They described the concept of a cryptographically secured network of blocks.

The first mention of blockchain architecture was held in a publication that Stornetta coauthored described a digital hierarchy system known as a "block chain" that utilized digital time-stamps for ordering transactions. They worked on a cryptographically secured chain of blocks whereby no one could tamper with timestamps of documents. Afterwards they upgraded block chain system to incorporate Merkle trees that enhanced efficiency thereby enabling the collection of more documents on a single block in 1992 (Url-5,2019).

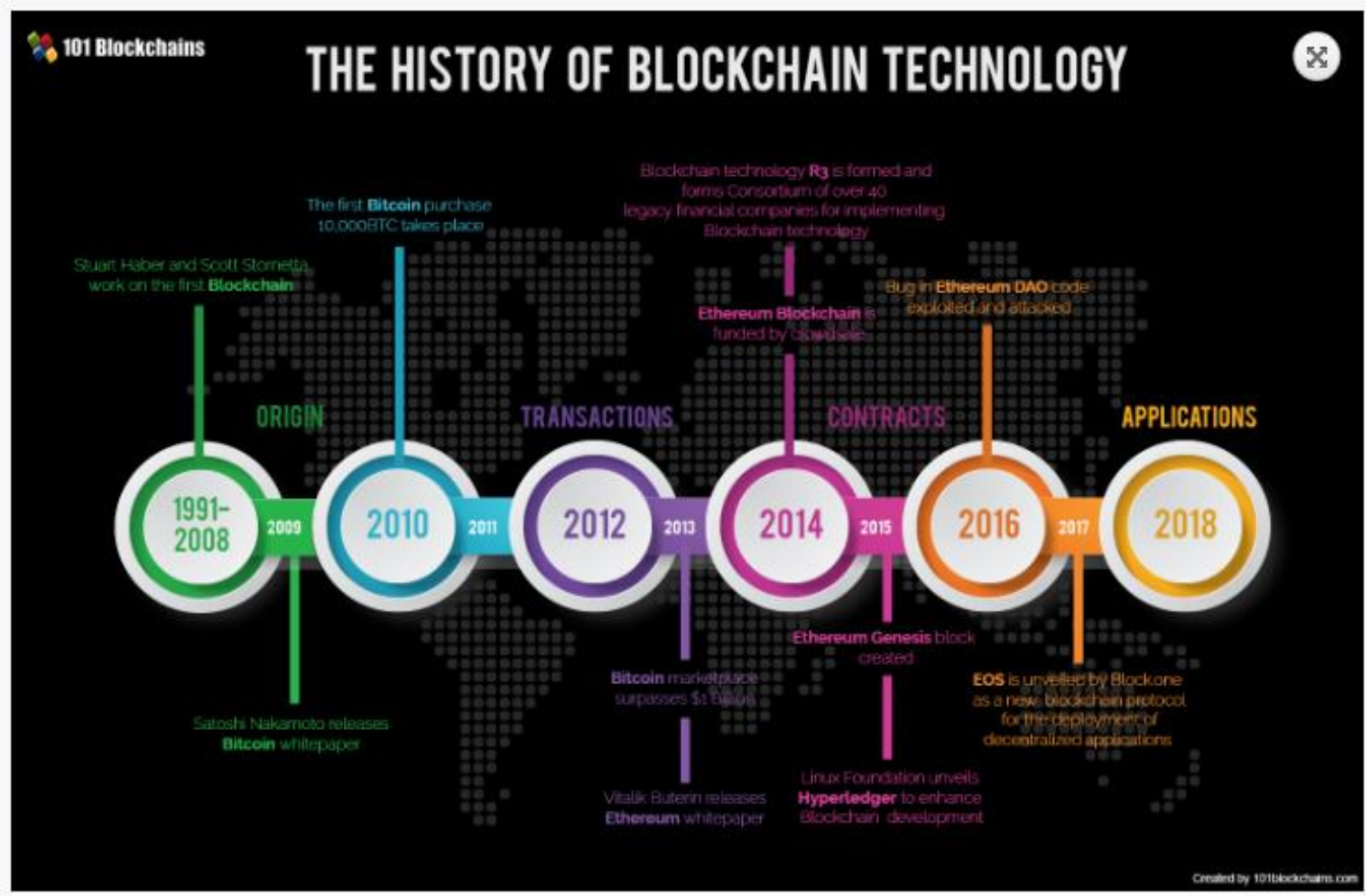

Figure 1. The History Of Blockchain Technology Source: Url-4, 2018.

Additionally, by 1998 Nick Szabo had begun working a decentralized digital currency which was called as Bit Gold. It wasn't until 2009 that developer Satoshi Nakamoto implemented the first blockchain. Nakamoto is known for creating the world's first digital currency called Bitcoin. Nakamoto is a group of developers who collaborated in order to use blockchain technology to create Bitcoin. Bitcoin utilized blockchain technology on a peer-to-peer network as a ledger for any transactions made with Bitcoin, (Url-6, 2019). Very little is known about Nakamoto as people believe whether he or she could be a person or a group of people that worked on Bitcoin, which was accepted as the first application of the digital ledger technology. Figure 1 above Blockchain history is illustrated.

Moreover, blockchain technology has several essential features developed in time. One is that it allows a deep transition from a centralized transactional model, which until today has prevailed, to a decentralized one. 
distributed system should turn out to be a more robust and reliable solution than is usually provided by a centralized authority to its stakeholders - such as a government to its citizens (Collomb, Sok, 2016 ). Table below summarized standard transactions versus blockchain ones.

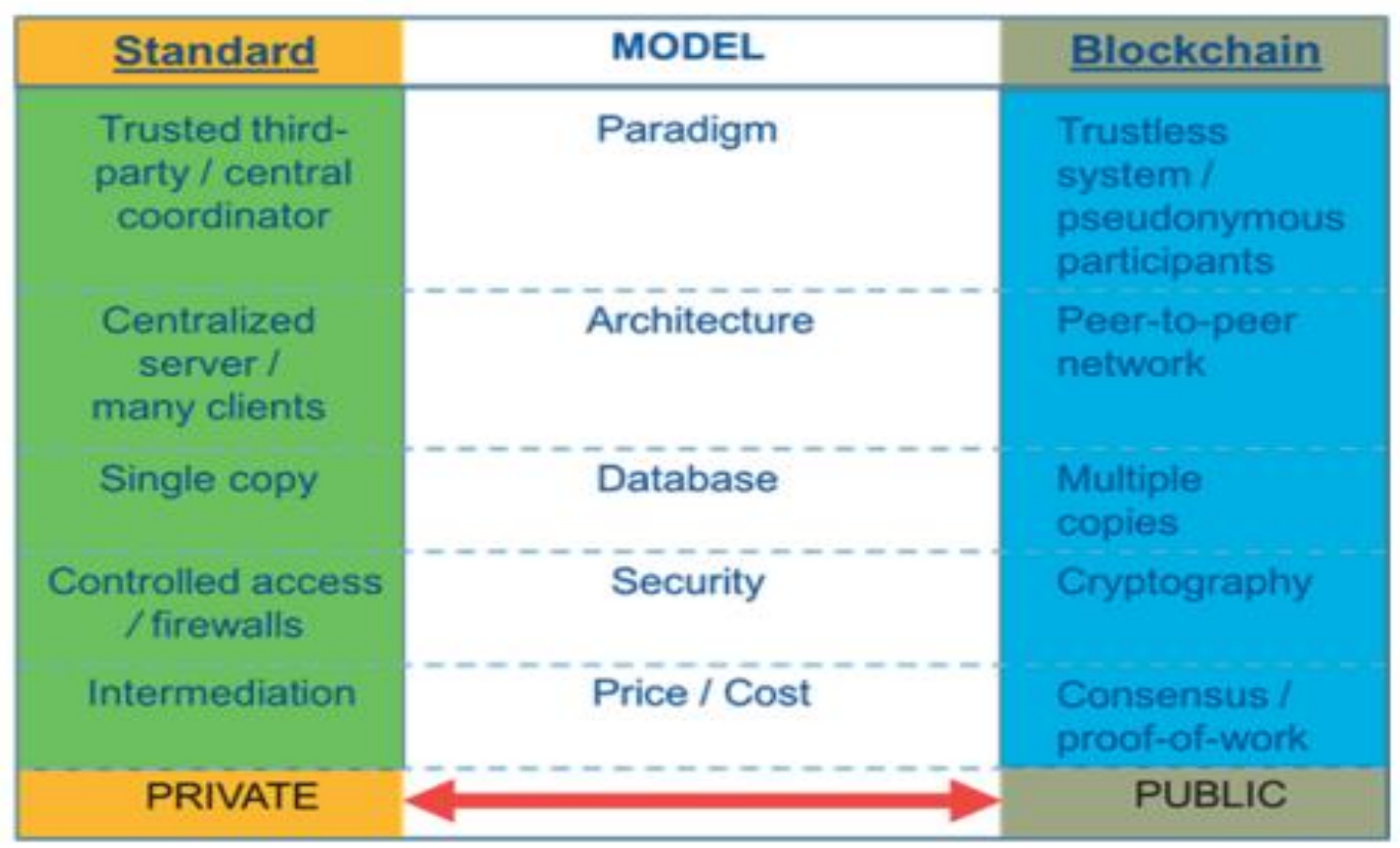

Table 1. Standard Versus Blockchain based Transactional Models Source: Collomb, Sok, 2016.

\section{Blockchain Evolution}

A blockchain's three main benefits are that it provides transparency, authentication and auditing abilities and generally evolution of blockchain technology can be held in two phases. First phase consists of years between 1991 and 2013. Actually the cost of the bankruptcy of Lehman Brothers in 2008 to the USA is estimated in trillions and unfortunately it triggered a chain of events that sent several countries into economic recession or depression. Bitcoin came into being in 2008 as the first application of Blockchain technology. One contributor to the crisis was the centralized payment and monetary system based on clearinghouses that act as intermediaries between buyers and sellers and take on the risk of defaults. Bitcoin is an innovative technology that may allow banks to settle accounts among themselves without relying on centralized entities. Based on Blockchain technology, Bitcoin is considered the first decentralized currency system that works on a global scale. It relies on cryptographic proofs of work, digital signatures, and peer-to-peer networking in order to provide a distributed ledger containing transactions (Ateniese et al, 2017). Ever since Bitcoin number of applications have cropped all of which seek to leverage the principles and capabilities of the digital ledger technology. Consequently, blockchain history contains a long list of applications that have come into being with the evolution of the technology (Url-4, 2018).

Blockchain phase 2 is called Contracts and consist of years between 2013 and 2015. Developed by Vitalik Buterin, Ethereum was born out as a new public blockchain in 2013 with extended functionalities compared to Bitcoin, a development that has turned out to be a pivotal moment in Blockchain evolution timeline. He differentiated Ethereum from Bitcoin Blockchain by enabling a function that allows people to record other assets such as contracts. With his development new features expanded Ethereum functionalities from being a cryptocurrency to be a platform for developing decentralized applications as well. In 2015, Ethereum blockchain has launched and become one of the biggest applications of blockchain technology given its ability to support smart contracts used to perform various functions (Url-4, 2018).

Also in 2015, In 2015, the Linux Foundation unveiled an Umbrella project of open source blockchain called Hyperledger. Hyperledger does not support Bitcoin or any other cryptocurrency. Hyperledger focus is to encourage the use of blockchain technology to improve performance and reliability of current systems to support global business transactions. It is something like a hub for open industrial blockchain development. (Url-7, 2019).

In 2017, a company called Eos published a paper detailing a new blockchain protocol powered by an EOS as the native cryptocurrency. s main purpose is to encourage the deployment of decentralized applications through an autonomous decentralized corporation. Phase 3 of Blockchain began in 2018 and called applications. In recent years, a number of projects have cropped up all leveraging blockchain technology capabilities. Neo is one of the applications launched in China, billed as the first open source, decentralized and blockchain platform. Neo casts 
itself as the Chinese Ethereum having already received the backing of Alibaba CEO Jack Ma. Another cryptocurrency platform is optimized for the Internet of things (Iot) ecosystem as it strives to provide zero transaction fees as well as unique verification processes. Called IOTA. Than Monero Zcash and Dash blockchains came into being as a way of addressing some issues such as security and scalability (Url-4, 2018). Blockchain evolution and milestones summarized in table below.

\begin{tabular}{|c|c|c|c|c|}
\hline Timeline & Blockchain & Bitcoin & Ethereum & NEO \\
\hline 1991-2008 & $\begin{array}{l}\text { Stuart Haber and Scott } \\
\text { Stornetta Work on The } \\
\text { First Blockchain }\end{array}$ & & & \\
\hline 2009 & & $\begin{array}{l}\text { Satoshi Nakamoto } \\
\text { Releases Bitcoin White } \\
\text { Paper }\end{array}$ & & \\
\hline 2010 & & $\begin{array}{l}\text { The First Bitcoin } \\
\text { Purchase 10,000BTC } \\
\text { take place }\end{array}$ & & \\
\hline 2013 & & $\begin{array}{l}\text { Bitcoin Marketplace } \\
\text { Surpasses } \$ 1 \text { Billion }\end{array}$ & $\begin{array}{lr}\text { Vitalik } & \text { Buterin } \\
\text { Releases } & \text { Ethereum } \\
\text { White Paper } & \\
\end{array}$ & \\
\hline 2014 & & & $\begin{array}{l}\text { Ethereum Blockchain } \\
\text { Is Funded By } \\
\text { Crowdsale }\end{array}$ & \\
\hline 2014 & $\begin{array}{l}\text { Blockchain } \\
\text { Technology R3 is } \\
\text { Formed and forms } \\
\text { Consortium of Over } 40 \\
\text { Legacy financial for } \\
\text { implementing } \\
\text { Blockchain } \\
\text { Technology }\end{array}$ & & & \\
\hline 2014 & & & & $\begin{array}{l}\text { NEO Project Is } \\
\text { Launched as Antshares } \\
\text { by Da Hongfei and } \\
\text { Erik Zhang }\end{array}$ \\
\hline 2015 & & & $\begin{array}{lr}\text { Ethereum } & \text { Second } \\
\text { Blockchain } & \text { Is } \\
\text { Unveiled } & \\
\end{array}$ & \\
\hline 2015 & $\begin{array}{lr}\text { Linux } & \text { Foundation } \\
\text { Unveils } & \text { Hyperledger } \\
\text { To } & \text { Enhance } \\
\text { Blockchain } & \\
\text { development } & \\
\end{array}$ & & & \\
\hline 2017 & $\begin{array}{l}\text { EOS.IO is Unveiled by } \\
\text { block.one as a new } \\
\text { blockchain protocol for } \\
\text { the deployment of } \\
\text { decentralized } \\
\text { applications }\end{array}$ & & & \\
\hline 2015-2018 & \multicolumn{4}{|c|}{$\begin{array}{l}\text { Blockchain Technology Continues To Evolve Depicted by increased number of cryptocurrencies } \\
\text { as well as Companies leveraging the Technology To enhance Efficiency }\end{array}$} \\
\hline
\end{tabular}

Table 2. Blockchain Evaluation Source: Url-4,2019.

\section{Impacts on Global Economy and Economic Benefits of Blockchain}

Blockchain can be defined as a chain of blocks of information, called digital ledgers. These ledgers are chronologically linked and replicated not in a centralized database but in a distributed database. Information can be added as blocks and never deleted and also any change is monitored and validated by the chain Each block is protected by cryptographic algorithms, and only authorized ones can access the information. Although private blockchains exist, a typical blockchain is public and identified as "decentralized". The four main kinds of blockchain applications are money transfer and payments, property registries, contractual agreements, and identity confirmation. Replacing the dependency on trust with cryptography means that most verification, identification, 
authentication, and similar forms of assurance, accreditation, certification, and legalization of identity, origin, competence, or authority of persons or assets can be assured by mathematics (Ljutic, McPhee, 2017).

In another words, Blockchain (distributed ledger technology) is a network software protocol that enables the secure transfer of money, assets, and information via the Internet, without the need for a third-party intermediary such as a bank. A blockchain can be used as a digital registry to record, transfer, and verify asset ownership (such as home, auto, stocks, bonds, mortgages, and insurance etc.), and also can be used to preserve the integrity and authenticity of sensitive documents or records (e.g., passports, visas, driver's licenses, birth and death certificates, voter registration, contracts, wills, patents, and medical records). In a network economy with blockchain based asset transfer, personalized financial and government services might be better tailored to individual needs. With Blockchain technology, many daily operations involving money, assets, and documents could start to be conducted on digital networks with the help of cryptographic security algorithms. Given that less friction and human involvement may be needed to transfer goods and services, less physical infrastructure might be needed to make it happen (Swan, 2017).

It is widely accepted that the computational architecture of blockchain technology (distributed ledger technology) creates a wide range of potential uses. For instance, by providing an immutable, distributed ledger, it can help to facilitate not only peer-to-peer payments, but also manage records, track physical objects and transfer value via smart contracts, all without a third party or manual reconciliation. Developments in computer processing power and networked computer systems have facilitated advances in blockchain applications, while the domination of smartphones has made digital wallets possible and increasingly relevant. Additionally, there has been a proliferation of IoT (internet of things) and AI (artificial intelligence) applications that can automate bigdata collection and processing for use in blockchain platforms (Wef, 2018).

Blockchain applications are commonly used with cryptocurrencies i.e. currencies that use public-key cryptography as security measure and to prevent counterfeiting transactions. Blockchain technology can be seen both as a technical and as an economic innovation (Liebenau, Elaluf-Calderwood, 2016). Blockchain technology (distributed ledger) can be utilized as a transactional mechanism for "sharing economy" services, as it solves trusted recording of large-scale peer-to-peer activities naturally. Blockchain as an economic innovation offers solutions where there exists a need for a reliable record of transactions in a decentralized environment where not all parties can be fully trusted (Mainelli, Smith, 2015). And blockchain technology has created a global economy of immediate trust and value, built on an agreement and complex computer algorithms. Also digitized streaming money and payment channels could be techniques to quicken the 30-60-90 day terms and uncollectible debt problem in supply chain finance, and facilitate a just-in-time economy for money (Swan, 2017).

When it comes to Blockchain economy, it can be defined as a term for a move toward cryptocurrencies and digital ledger systems, and away from traditional national hard currencies and legacy, old fashioned ledger systems. In the blockchain economy, technologies like bitcoin and blockchain are the typical tools for financial management, rather than traditional software application programs managing existing national currencies. Also the blockchain economy is a scenario and potential future environment that cryptocurrencies will replace current monetary systems globally (Url-8, 2018). Also with blockchain-based asset transfer, personalized financial and government services might be better tailored to individual needs. Blockchain technology currently revolutionizes the storing, management and transfer of value between digital identities in many economic sectors.

The Future of the Blockchain Market Report revealed distributed ledger technology (DLT) named blockchain optimistically would have a positive economic impact. It will contribute as much as $\$ 120$ billion dollars worldwide between 2018 and 2024. Also the study revealed that the benefits offered by blockchain meant mainstream adoption was highly probable. They predicted that blockchain could contribute anywhere between $\$ 87$ billion to $\$ 120$ billion by 2024 , depending on which industries add it and the rate of adoption (Url-9, 2018).

Blockchain technology has been holding many promises for not only the financial sector, in particular its financial markets infrastructure, but also for the insurance industry. At the heart of this enthusiasm for blockchain lies the new decentralized transactional model that the technology permits, whose principles are based upon Satoshi's white paper about peer to peer communication (2008). Blockchain technology is very likely to have a very strong impact on the digital economy and global e-commerce, precisely because of this decentralized transactional model that it facilitates. And indeed, even if the share of e-commerce has been steadily rising since the age of the Internet, essentially over the last score of years, it remains that the main transactional paradigm is centralized (Collomb, Sok, 2016).

While blockchain technology is effecting financial sector heavily, with blockchain technology, new industry leaders are emerging. Financial services seem near term future leader of blockchain. Other sectors such as energy, industrial products, healthcare and utilities. Figure below, World Economic Report experts shows proportions of sectors effected by distributed ledger technology (blockchain) with the help of PwC Global Blockchain Survey in 2018 (Wef, 2018). 


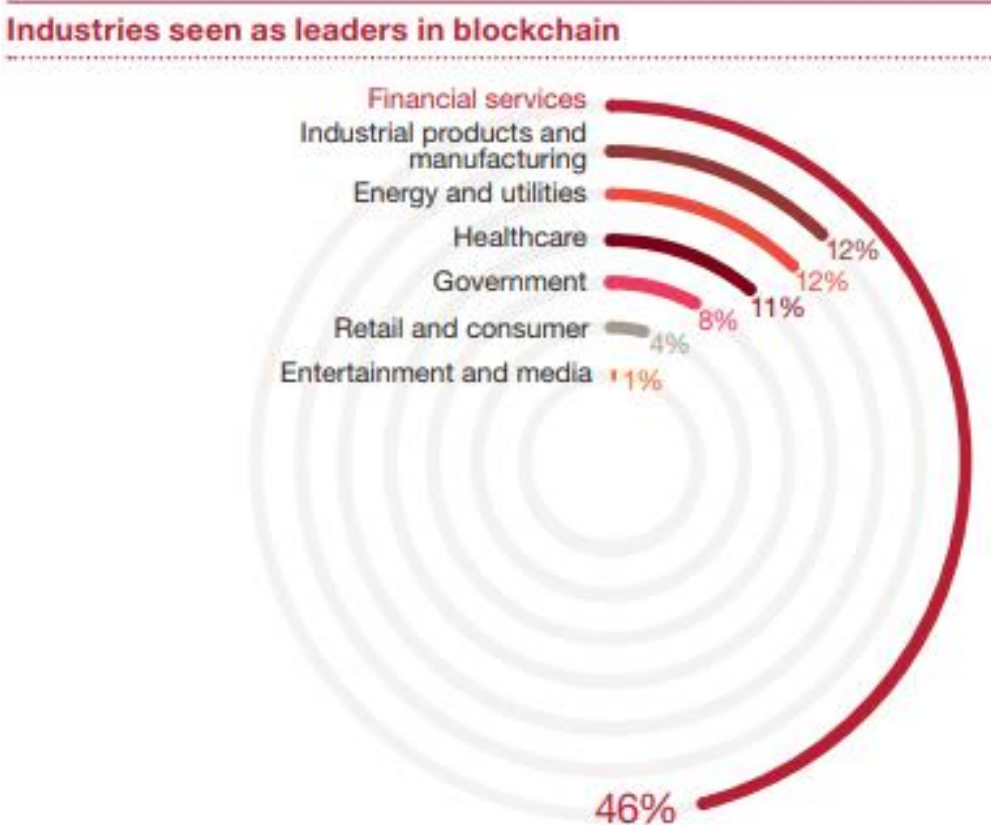

Note: Base: 600.

0 : Which of the following industries are the most advanced in developing blockchain today?

Source: PwC Global Blockchain survey, 2018

Figure 2. Industries Seen As Leaders in Blockchain Source: Wef, 2018.

According to some experts, there are four waves of anticipated blockchain deployments summarized in Table 2 below. They initially expect the first two waves to be focused on sharing and using data, before expanding to critical infrastructure once confidence in blockchain technology grows. The third wave involves the adoption of blockchain technology in major pieces of capital markets infrastructure. Truly decentralized financial ecosystem will arise in final wave, is perhaps the most ambitious and the most uncertain one (Url-10, 2019).

\begin{tabular}{|c|c|c|}
\hline Wave & Advancements & Examples in developmen \\
\hline $\begin{array}{l}1 \\
\text { Information sharing } \\
2016-19\end{array}$ & $\begin{array}{l}\text { - Blockchain used to share and communicate data } \\
\text { - Used internally and between trusted external organizations } \\
\text { - Distributed ledger solutions tested in parallel with current } \\
\text { workflows as proof of concept } \\
\text { - Augmentation of existing processes }\end{array}$ & $\begin{array}{l}\text { CDS trade } \\
\text { processing } \\
\text { Payment } \\
\text { messaging }\end{array}$ \\
\hline $\begin{array}{l}2 \\
\text { Data solutions } \\
2017-25\end{array}$ & $\begin{array}{l}\text { - Blockchain enables an environment to store and manipulate data } \\
\text { - Incorporation of distributed ledger technology as part of existing } \\
\text { solutions, supporting new efficiencies in operations and workflows } \\
\text { - Initial pilots may run in parallel with existing processes, } \\
\text { until user confidence is high enough to begin migrating volumes } \\
\text { - Users are faced with a choice of infrastructures developed by providers }\end{array}$ & $\begin{array}{c}\text { Transaction } \\
\text { management } \\
\text { Regulatory } \\
\text { reporting }\end{array}$ \\
\hline $\begin{array}{l}3 \\
\text { Critical infrastructure } \\
2020-30\end{array}$ & $\begin{array}{l}\text { - Blockchain adopted by market participants as main infrastructure } \\
\text { for critical functions } \\
\text { - Centralized authority still required for administrative functions } \\
\text { (e.g., granting access rights, setting industry standards) } \\
\text { - Replacement of existing asset, transaction and payments infrastructure } \\
\text { - Participants forced to adopt and integrate new blockchain-based infrastructure }\end{array}$ & $\begin{array}{l}\text { Custody and } \\
\text { settlement } \\
\text { Private } \\
\text { markets }\end{array}$ \\
\hline $\begin{array}{l}4 \\
\text { Fully decentralized } \\
\text { Uncertain }\end{array}$ & $\begin{array}{l}\text { - Blockchain replaces centrally controlled infrastructure with fully decentralized } \\
\text { solutions } \\
\text { - Direct engagement in digital asset transactions for organizations and individuals } \\
\text { - Legal and regulatory frameworks support asset ownership and transfers via } \\
\text { distributed ledgers } \\
\text { - Disintermediation of legacy infrastructure owners }\end{array}$ & $\begin{array}{c}\text { Open, P2P } \\
\text { blockchain-powered } \\
\text { economy } \\
\text { Digitally issued } \\
\text { fiat currency }\end{array}$ \\
\hline
\end{tabular}

Table 3. Blockchain Waves Source: Url-10, 2019 


\section{Conclusion}

Distributed ledgers named blockchain have the ability to securely digitize many current operations in economics and finance, and legal and government services. Blockchain can be defined as a decentralized public ledger, which records transactions between users in a permanent, secure and verifiable way. The important thing is that blockchain can be programmed to record not only financial transactions, but anything of value. There is a growing realization that blockchain technology will bring a radical shift of especially on financial assets. It is no doubt that the financial sector is at the forefront in adoption of blockchain technology. Blockchain is rapidly revolutionizing the global economy. The potential effect of blockchain technology - distributed ledgers - on the society and the global economy are hugely important, as they promise to always have an optimistic impact. Actually the potential benefits of the blockchain are more than just economic and the technological capacity of the blockchain is already being harnessed to address real world problems by specific groups.

Only nine years after the first Bitcoin white paper, blockchain technology is now studied by companies and governments to find possible use cases for efficiency and can possibly trigger the third industrial revolution. On the other hand, debate over blockchain's promise, as well as its limitations, is ongoing. Blockchain technology, in all its forms, continues to evolve rapidly. It is widely accepted that Blockchain technology future looks bright and attractive in part because of the way governments, developers, firms and investors are investing big as they seek to spur innovations and applications. The opportunities that blockchain offers need to be developed and governed wisely, with upfront and continual management of unintended consequences and downside risks. Blockchain is the kind of technological breakthrough that has the potential to make global changes. Its predicted impact on the world economy is big enough that some of the countries and biggest companies are already preparing for it.

\section{References}

- Ateniese G. Magri B., Venturi D., Andrade E., 2017. "Redactable Blockchain - or - Rewriting History in Bitcoin and Friends", 2nd IEEE European Symposium on Security and Privacy-EuroS\&P.

- Collomb A., Sok K., 2016. "Blockchain / Distributed Ledger Technology (DLT) What Impact On Financial Sector?", Digiworld Economic Journal no. 103, third quarter, p.93.

- Glaser F., 2017. "Pervasive Decentralisation of Digital Infrastructures: A Framework for Blockchain Enabled System and Use Case Analysis, Proceedings of the 50th Hawaii International Conference on System Sciences, Frankfurt.

- $\quad$ Liebenau, J., Elaluf-Calderwood, S.M., 2016. "Blockchain Innovation Beyond Bitcoin and Banking", Available at SSRN 2749890.

- $\quad$ Lindman J.,Rossi M.,Tuunainen V.K., 2017. "Opportunities and risks of Blockchain Technologies in Payments- a Research Agenda", Proceedings of the 50th Hawaii International Conference on System Sciences, pp 1533-1542.

- $\quad$ Ljutic A., McPhee C., 2017. "Editorial: Blockchain", Technology Innovation Management Review vol. 7 issue 10.

- Mainelli, M., Smith, M., 2015. "Sharing ledgers for sharing economies: an exploration of mutual distributed ledgers (aka blockchain technology) ", The Journal of Financial Perspectives 3, (3), pp. 38-69.

- Nakamoto, S., 2008. "Bitcoin: A Peer-to-Peer Electronic Cash System"

- $\quad$ Risius M., Shoprere K., 2017. "A Blockchain Research Framework: What We (don't) Know, Where We Go from Here, and How We Will Get There", Business \& Information Systems Engineering.

- Sun J. Yan J., Zhang K., 2016. "Blockchain-based sharing services: What blockchain technology can contribute to smart cities", Financial Innovation 2:26.

- Swan M., 2015. Blockchain: Blueprint For New Economy, O’reilly Media Inc.

- Swan M., 2017. "Anticipating the Economic Benefits of Blockchain", Technology Innovation Management Review vol. 7 issue 10.

- Tschorsch F., Scheuermann B., 2016. "Bitcoin and beyond: A technical survey on decentralized digital currencies", IEEE Communications Surveys \& Tutorials 18 (3):2084-2123.

- World Economic Forum (Wef), 2018. "Building Block (chains) For A Better Planet".

- Zimmermani 2016. The Evolution of Fintech, The New York Times, https://www.nytimes.com/2016/04/07/business/dealbook/the-evolution-of-fintech.html.

- Url-1, https://whatis.techtarget.com/definition/open-source, Alıntı Tarihi: 05.04.2019

- Url-2, https://www.weforum.org/reports/the-future-of-financial-infrastructure-an-ambitious-look-at-howblockchain-can-reshape-financial-services, 2016 
- Url-3, http://www.economist.com/news/leaders/21677198-technology-behind-bitcoin-could-transform-howeconomy-works-trust-machine, 2015

- Url-4, https://101blockchains.com/history-of-blockchain-timeline/\#prettyPhoto, Alıntı Tarihi: 03.04.2019

- Url-5, https://www.worldcryptoindex.com/creators/w-scott-stornetta/, Alıntı Tarihi: 04.04.2019

- Url-6, https://www.worldcryptoindex.com/blockchain/, Alıntı Tarihi: 05.04.2019

- Url-7, https://blockgeeks.com/guides/hyperledger/, Alıntı Tarihi: 06.04.2019

- Url-8, http://www.lteconomy.it/blog/2018/12/09/blockchain-economy-impact-and-future/, 2018

- Url-9, https://cryptobriefing.com/blockchain-adoption-study/, 2018

- Url-10, https://www.oliverwyman.com/content/dam/oliver-wyman/v2/publications/2016/jul/joint-report-byjp-morgan-and-oliver-wyman-unlocking-economic-advantage-with-blockchain-A-Guide-for-AssetManagers.pdf, Alıntı Tarihi: 06.04.2019 


\title{
Foreign Direct Investment as an Important Source of External Development Financing: New Evidence in Turkey
}

\author{
Mohamed Isse Ibrahim (İstanbul Commerce University, Turkey)
}

\begin{abstract}
Foreign direct investment is a critical source of external instruments for financing development for Turkey, FDI can contribute to technology diffusion, Economic growth, Employment generation and Sustainable development. However; the Objective of this research is to examine whether foreign direct investment as an external source of financing effects economic growth in Turkey, based on time series data from 2003 to 2016 during the Erdoğan administration. This study employed Harrod-domar growth model using under OLS method. The paper considerate main variables foreign direct investment, Exchange rate and labor force. Based on empirically investigated the study confirmed that foreign direct investment and Labor force has a positive significant relationship to economic growth in Turkey while exchange rate has a negative significant relationship to economic growth in Turkey. So this paper recommends that movement of Turkey should promote policies encourage and creation of a good microeconomic and macroeconomic a friendly environment and utilization of the careful of loose monetary policy to economic performance.
\end{abstract}

\section{Introduction}

The level of investment in a country is one of the main sources of economic development and growth. However, in most developing economies, actual foreign investment falls short of the preferred volume necessary to cause a significant raise in gross domestic product growth, a lot of developing economies depend on investment to resolve several economic problems and crisis. A large number of economists agreed that foreign direct investment plays main role in the development process of every country either high income, middle income or low income. For example (Zhang, 2001), confirmed that FDI led economic growth but concluded that its benefits are contingent upon certain characteristics of the host country. According to world development indicators point out that gross domestic product has been increased in overall GDI from $\$ 312$ billion to $\$ 860$ billion from 2003 to 2015 , the average economic growth is increasing annually more than $6 \%$ until 2008 , privatization program also to reduce state involvement in banking, basic communication, industry and transport. Before 1980s foreign investment inflows in Turkey was weak because of policy of import substitution that used to productions of domestic via nontariffs barriers and tariffs, foreign investors were subject government control to strict. The number operating of firms with FDI in 1980 was 78, which increased to 6584 as 2003 . When the FDI amount is compared number of firms was approximately 3 million USD. The trend of foreign direct investment towards sectors has given risen, the share of service sector was $28.5 \%$ during 1990 to 1995 , has increased to $52.7 \%$ in the $1996-2002$ period. By the mentioned period the share of industrial sector was $56.7 \%$. The share of agricultural sector was $1.4 \%$ between 1990 and 2002 (Alıc1\& Ucal, 2003). Last two decade Turkish economy perceived a rapid growth especially foreign direct investment considered the most powerful in the international economic relations. FDI inflow in Turkey represented by multinational and transnational companies. However, Turkey helped economic reform After Turkey a severe financial crisis in 2001, political stability, European Union accession process and privatizations to attract new investments and the levels of FDI net inflows has increased $0.5 \%$ of GDP in 2003 to 2\% in 2015. Similarly, GDP growth increased from $5 \% 2003$ to $6 \% 2015$ (Sirin, 2017). The overall foreign direct investment of net inflow has been increased very significantly from $\$ 2.8$ billion to $\$ 18$ billion from 2003 to 2015 .The main purpose of the research is to measure foreign investment on Economic Growth in Turkey, the paper specifically considering some important variables like foreign direct investment, labor force and exchange rate. The findings very interesting to policy makers and central banks in Turkey and developing economics because could be same case of other developing economics suggest should consider the level of effect of the foreign direct investment on economic growth. The rest of the research comprised as follows: section two discusses the empirical and theoretical literature on the foreign direct investment and economic growth. Section three describes data used and the methodology. Section four presents the empirical results and discusses of the finding. Section five offers managerial and policy implication and concluding remarks.

\section{Literature Review}

Several literates have been conducted the relationship among Economic growth and foreign direct investment in the literature. The studies rage forms a specific country to cross countries using different data source and type. The findings of individual studies were different which depends on Data, Period selected, model of the studies and also used various proxies for foreign direct investment and different methodologies. The study on cross countries analysis were done Alvarado, Ponce, \& Ponce, (2017) carried out the impact of foreign investment on economic growth in Latin American countries, the study used paned data from 1980 to 2014, the finding of the study based the development level reached by the countries, Foreign direct investment in lower middle counties is negative 
significant on economic growth, while upper middle income countries the is insignificant and uneven. Finally, FDI has a significant with positive effect on gross domestic product in high-income counties. The study suggested counties in medium low income of Latin American should promote fiscal instruments to attract foreign investors, as well as high income counties in the region can encourage foreign investment inflows to increase domestic production. Moreover Amin \& Khalid, (2014) conducted investigation the relationship between foreign direct investment and economic growth review of Literature over 1994-2012 period. The study reviewed 33 papers relating FDI and EG The finding reveals that most of the studies FDI that positive impact on the host country's productivity growth which mainly contributes well- development financial markets, Human capital, technology and open trade regimes. A few cases are negative or even null impact. Additionally Malikane \& Chitambara, (2017) examined the effect of foreign direct investment, technology and economic productivity in 45 African countries, the study used panel date over period 1980-2012, they applied the two-step systems GMM method and the fixedeffects to account for the issues of endogeneity. The result of the study revealed that generally weak but positive effect of foreign direct investment on total productivity growth because of the failure by many African counties to fully adopted foreign capital may cause the limited absorptive capacity. The paper stated that huge gap of technology is lead to catch-up and greater diffusion of knowledge, so the study suggested that African countries need to improve strengthen their institution to expend the capacity and close gap of the technology. Iamsiraroj, (2015) investigated the relationship between foreign investment and Economic growth nexus 124 cross country, the date over 1971-2010 period. The paper was applied simultaneous system of equations approach. The finding shows that foreign direct investment is highly associated with productivity of countries and vice versa, as well as the study stated trade openness, labor force and freedom of economic are keys determinants of foreign direct investment, the result indicate that consistently in favor of important gains to host countries from attract foreign direct investment inflow. Based results, the authors put forward of recommended that host counties should promote policy on attracting FDI to enhance productivity of country as well as to minimalize the volatility of total productivity. Maeseneire \& Claeys, (2012) carried out the investigation the relationship medium and small sized enterprises, FDI, and financial constraints in Belgium. The authors interviewed thirty-two Belgian medium and small sized enterprises five of them are banks and five venture capitalists. The found reported there is finance gab hinder development of small firms, leads to suboptimal and foreign investment hosting country development. Under the result of the paper the study suggested policy and recommendation to consider the barriers faced SMEs, Belgium government must make sure that restrictions the lending, investor, bankruptcy procedures and creditor protection. As an illustration, India and China have been largest recipient of foreign direct investment since 1990s. Kim, Lin, \& Suen, (2013) have assessed the impact of foreign direct investment and trade openness on Investment depend upon social capacity matters, the paper used cross-sectional data from 85 countries 1975 up to 2010 , applied regression analysis approach. The researchers have found that trade openness has positive effect on domestic investment when social capability such as political institutions, financial development and human capital have good performance a negative effect in countries with opposite attributes, while foreign direct investment has a positive impact domestic investment when social capability of countries have bad performance but positive effect with opposite attributes. The study suggested FDI is beneficial for domestic investment so low income counties should promote trade openness to attract foreign direct investment. As far as the effect of foreign direct investment on productivity growth Feeny, Iamsiraroj, \& Mcgillivray, (2014) have investigated role foreign direct investment on domestic production growth in 209 pacific island countriesfrom1971 to 2010, the result indicates that the FDI has positive associated with higher productivity growth in host pacific countries, on the other hand pacific region has given more positive assessments of aid and remittance because of poverty of the region, limit resource and small domestic market. Based on the result two policy: first movements in island find ways of increase the impact of foreign direct investment on economic growth, second movements should encourage firms from developed countries to invest the pacific region. Additionally Tahir, Khan, \& Shah, (2015) examined the effect external factors on productivity growth in Pakistan for period 1977 to 2013, the study applied ARDL approach to co-integration. The result of the study reveals remittance and foreign investment has positive associated and improve long run productivity growth in Pakistan economy while foreign import has negative effect one economic growth (Munemo, 2016). examine link between foreign direct investment and start-up of business depends upon financial market development for the panel of 92 developing economics for the period 2004 to 2012. The result reveals that foreign direct investment appears has effect on business start-ups with high level development of financial in the host economy, finally the paper suggested host counties should improve financial market will facilitate higher growth of capita income and important for encourage entrepreneurship. furthermore Makiela \& Ouattara, (2018) explored the impact of foreign direct investment on productivity growth in developed and developing countries for the period 1970 to 2007 . The empirical result of the study shows that in developing countries foreign direct investment has statistically significant with positive impact on productivity growth. Finally Sunde, (2017) empirically investigated the effect foreign direct investment on productivity growth in South Africa for the period 1990 up to 2014. The paper applied the autoregressive distributed model and VECM granger causality. The paper indicates foreign investment and export does not cause productivity growth in South Africa but the study confirmed that foreign investment led economic growth for South Africa. at the theoretical level is has been argued link between foreign direct investment and productivity growth, these recent studies have provided different influences of FDI 
on economic growth but all these confirmed FDI has beneficial the economy host country. Therefore this paper investigates foreign direct investment as an important source of external factor of development in Turkey.

\section{Data and Methodology}

\subsection{Harrod-Domar Growth Model}

Horrod-Domar clarified that equilibrium of economic growth is dictated by yearly investment returns and product of saving ratios. This implies economic growth will continue at rate of which society can mobilize saving of domestic resources combined with the production of investment. Realizing that the significant imperative with respect to developing countries is the capital shortage. Horrod-Domar Model explained the extension of open where investment can be financed both the flow foreign capital and Domestic. The model independently was developed by Roy Horrod in 1939 and Evsey Domar in 1996.

\subsection{Data}

The study uses the annual data economic growth and investment Time series during the Erdoğan administration from 2003 to 2016, obtained from World Bank. Gross domestic product is Nominal GDP at current price is GDP at price during a specified period. Official exchange rate is computed as an annual average based on monthly average of exchange rate determined by National Authorities. Foreign direct investment refers the net inflow of investment and components of the foreign direct investment are reinvested earning, equity capital and other capital. And Total labor force is all people who labor of supply for the production of services and good a certain period of time.

\subsection{Model Specification}

The study used OLS regression to estimate foreign direct effects on economic growth in Turkey. This article follows Harrod-Domar Growth Model:

$$
\mathrm{GDP}=\beta_{\mathrm{t}}+\beta_{1} \mathrm{FDI}_{\mathrm{t}}+\beta_{2} \mathrm{E}_{\mathrm{t}}+\beta_{4} \mathrm{~L}_{\mathrm{t}}+\varepsilon_{\mathrm{t}}
$$

Where GDP stands gross Domestic product, FDI is foreign direct investment inflow, E is official exchange rate, $\mathrm{L}$ is total labor force and $\varepsilon t$ is error term.

\section{Result and Discussion}

This study employed yearly data of Turkey, namely gross domestic product, foreign direct investment, Exchange rate and labor force. The statistical technique in used in this study is regression analysis using a time series data covering the period from 2003-2016 obtained from World Bank statistical report. First, the study use Summary Statistics and unit root test, to insure that the regression result would not be spurious. Second, the study uses correlation analysis to examine the relationship among the variables.

\subsection{Descriptive Statistics}

Present Summary Statistics which reveals that the stander deviation and mean.

\begin{tabular}{lclccc}
\hline Variable & Abr & Measurement & Obs & Mean & St. dev. \\
\hline Economic growth & GDP & Gross national product & 14 & 710000000000 & 202000000000 \\
$\begin{array}{l}\text { Foreign direct } \\
\text { investment }\end{array}$ & FDI & $\begin{array}{l}\text { Foreign direct } \\
\text { investment }\end{array}$ & 14 & 13000000000 & 6150000000 \\
$\begin{array}{l}\text { Labor force } \\
\text { Exchange rate }\end{array}$ & L & Total labor force & 14 & 25263778 & 3076695 \\
\hline
\end{tabular}

Table1. Summary Statistics of the Variables,

The result of descriptive statistics show that economic growth has the highest number of average while exchange rate has the lowest number of average mean as well as the standard deviation. 


\subsection{Correlation}

\begin{tabular}{llllll}
\hline & GDP & FDI & ER & L & TB \\
\hline GDP & 1 & & & & \\
EDI & $0.54 * *$ & 1 & & \\
ER & $0.57 * *$ & $0.12^{*}$ & 1 & 1 & \\
\hline
\end{tabular}

Note. $*$ indicates weak correlation, $* *$ indicates moderate correlation and $* * *$ indicates strong correlation

Table 2. Multicollinearity (Correlation Matrix)

It is evident from the correlation matrices of Table 2 reveals exchange rate and labor have the highest coefficient of the correlation is0.91, whereas foreign direct investment and exchange rate have The lowest coefficient of the correlation is 0.12 . All of the indicators have positive and weak relationship with dependent variable.

\subsection{Unit Root Test}

To test the data stationary is checked through Phillips-Perron and Augmented Dickey Fuller test are applied to trend and intercept. The results have showed that some variables are stationary at level while other non-stationary. However all variables became stationary at first difference, so all null hypotheses were not fail to rejected for every test at first difference.

\begin{tabular}{|c|c|c|c|c|c|}
\hline & Levels & $\begin{array}{l}\text { ADF } \\
\text { t-statistics }\end{array}$ & Prob. * & $\begin{array}{l}\text { PP } \\
\text { Adj. S-stat }\end{array}$ & Prob. * \\
\hline \multirow[t]{2}{*}{ GDP } & At Level & -1.394935 & -1.394935 & -0.724470 & 0.9462 \\
\hline & $1^{\text {st }}$ Difference & -4.193404 & 0.0316 & -7.903820 & 0.0003 \\
\hline \multirow[t]{2}{*}{ FDI } & At Level & -3.798013 & 0.0560 & -2.299713 & 0.4058 \\
\hline & $1^{\text {st }}$ Difference & -2.635106 & 0.2741 & -2.526040 & 0.3127 \\
\hline \multirow[t]{2}{*}{ ER } & At Level & 1.759423 & 0.9999 & 2.600927 & 1.0000 \\
\hline & $1^{\text {st }}$ Difference & -4.148955 & 0.0337 & -5.852614 & 0.0032 \\
\hline \multirow[t]{2}{*}{$\mathrm{L}$} & At Level & -2.352484 & 0.3822 & -4.518914 & 0.0174 \\
\hline & $1^{\text {st }}$ Difference & -3.238008 & 0.1241 & -3.238008 & 0.1241 \\
\hline
\end{tabular}

Table 3. Unit Root Test (Stationary Test at Level and at In Difference)

4.4 Estimation of the Model

\begin{tabular}{lllll}
\hline Dependent Variable: GDP & & & \\
\hline Variable & Coefficient & Std. Error & t-Statistic & Prob. \\
FDI & 8.426910 & 1.245585 & 6.765421 & 0.0000 \\
ER & $-3.81 \mathrm{E}+11$ & $3.39 \mathrm{E}+10$ & -11.21488 & 0.0000 \\
L & 111215.4 & 6023.334 & 18.46409 & 0.0000 \\
C & $-1.54 \mathrm{E}+12$ & $9.64 \mathrm{E}+10$ & -15.96717 & 0.0000 \\
R-squared & 0.987173 & Durbin-Watson stat & 2.288964 \\
\hline
\end{tabular}

Table 4. Regression Test

The result of the model shows that that FDI and labor force have positive effect and significant effect on economic growth in Turkey, exchange rate has negative and significant relationship to economic performance of Turkey. Furthermore, the study explains the foreign direct investment of Turkey has a positive relationship Productivity growth, this means that foreign investment has an important contribution in increasing the production level in country in the period 2003-2016. Investments play important role overall growth rate in Turkey economy because foreign inventors create new jobs, also well-develops markets of financials and the opens trade play important role in the production of the country and investment seems to great benefit economic growth rate most in the Electricity, Manufacturing, Wholesale and Retail Trade sectors and Gas and water. Exchange rate associates inversely rate to productivity of Turkey this implies asymmetric impact of the currency depreciation and appreciation on economic performance Turkey. The appreciation of exchange rate persuades that producer's losses of competitiveness and depreciation of Turkish currency increases the cost imports and discourage the foreign investors have an important role increasing the overall production levels. As the result indicates Labor force has positive impact to economic growth in Turkey this implies that increases labor productivity and skilled labors that will attract of foreign investors and creates economic stability.

\subsection{Model Stability}

The model stability is tested through CUSUM line. The following figure are obtained 


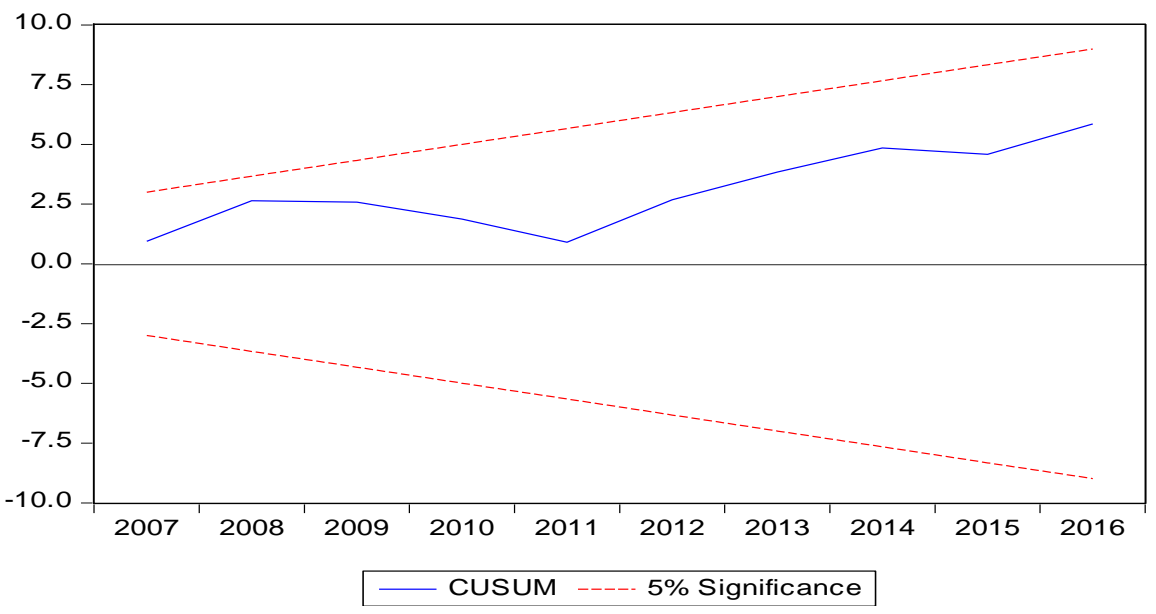

Figure 1. Cusum Line

The result of graph reveals that line of estimated is well within the 5 percent significant level, the model of estimated are stable and reliable.

\begin{tabular}{lll}
\hline Heteroskedasticity & Obs*R-squared 0.837912 & Prob. Chi-Square 0.3600 \\
serial correlation & Obs*R-squared 1.283447 & Prob. Chi-Square 0.5264 \\
Ramsey & T-statistic 0.780134 & Probability 0.4553 \\
Normality & Jarque-Bera 0.86 &
\end{tabular}

\section{Table 5. Diagnostic Checking}

The report of diagnostic checking reveals that the model is free form autocorrelation nor Heteroskedasticity which means the two tests are insignificants at significant level at 5 percent. Moreover Ramsey test and Normality reveal that are correct and the distributed is normal. Therefore model of choosing is best fit since DW is 2.28 and $\mathrm{R}$ square is $98 \%$.

\section{Conclusion and Policy Recommendations}

The paper empirically examined foreign direct investment as an external source of financing effects on economic growth in Turkey based on time series date from 2003 to 2016. The article applied Harrod-Domar Growth Model using MRA under the regression method, known as the OLS bounds testing approach to effect of foreign direct investment on economic growth. The Summary Statistics and unit root was tested to examine the existence of which could make the regression result spurious and Correlation approach was used to emanate the relationship among the variables. The findings confirmed foreign direct investment and labor force has a positive impact to economic growth in Turkey, this implies both contribute rate growth overall positive in Turkish economy and foreign direct investment and labor force spur economic growth. The OLS method found Exchange rate has a negative impact to productivity of Turkey this indicates the fluctuation Turkish currency may discourage the foreign investors play an important role in increasing production levels.

Based on the empirical result in this research and father to induce economic performance in Turkey. There is need for the government retain policies in order to accelerate the attraction of foreign inventories following policies are suggested: the Turkey government should encourage foreign direct investment through macroeconomic and microeconomic a friendly environment and utilization of the careful of loos monetary policy to economic performance. Central Bank of the Republic of Turkey should have important role to control volatility of exchange rate in a way that is prevented rising inflation without affecting productivity and investment adversely. We hope that this article will promote additional research on investigating the foreign direct investment as external source of financing effects on economic growth in Turkey. It should be very interesting to finding the relationship between foreign direct investment and economic performance in Turkey. Therefore, our results may need further analysis and additional empirical result by contributing economic performance and updated in Turkey.

\section{References}

- Alıcı, A. A., \& Ucal, M. Ş. (2003). "Foreign Direct Investment, Exports And Output Growth Of Turkey : Causality Analysis". In European Trade Study Group (ETSG) Fifth Annual Conference.

- $\quad$ Alvarado, R., Ponce, P., \& Ponce, P. (2017). "Foreign direct investment and economic growth in Latin America". Economic Analysis and Policy. https://doi.org/10.1016/j.eap.2017.09.006 
- Amin, M., \& Khalid, M. (2014). "Foreign Direct Investment and Economic Growth "Literature Review from 1994 to 2012. Procedia - Social and Behavioral Sciences, 129, 206-213. https://doi.org/10.1016/j.sbspro.2014.03.668

- $\quad$ Feeny, S., Iamsiraroj, S., \& Mcgillivray, M. (2014). "Growth and Foreign Direct Investment in the Paci fi c Island countries". Economic Modelling, 37, 332-339. https://doi.org/10.1016/j.econmod.2013.11.018

- Iamsiraroj, S. (2015). "The Foreign Direct Investment-Economic Growth Nexus". International Review of Economics and Finance. https://doi.org/10.1016/j.iref.2015.10.044

- $\quad$ Kim, D., Lin, S., \& Suen, Y. (2013). "Investment, trade openness and foreign direct investment : Social capability matters". International Review of Economics and Finance, 26, 56-69. https://doi.org/10.1016/j.iref.2012.08.008

- Maeseneire, W. De, \& Claeys, T. (2012). SMEs, "foreign direct investment and financial constraints : The case of Belgium". International Business Review, 21(3), 408-424. https://doi.org/10.1016/j.ibusrev.2011.03.004

- $\quad$ Makiela, K., \& Ouattara, B. (2018). "Foreign direct investment and economic growth : Exploring the transmission channels". Economic Modelling, (July 2017), 1-10. https://doi.org/10.1016/j.econmod.2018.02.007

- $\quad$ Malikane, C., \& Chitambara, P. (2017). "ScienceDirect Foreign direct investment ( FDI ), productivity and the technology gap in African economies". Journal of African Trade. https://doi.org/10.1016/j.joat.2017.11.001

- Munemo, J. (2016). "Foreign Direct Investment and Business Start-up in Developing Countries: The Role of Financial Market Development". Quarterly Review of Economics and Finance. https://doi.org/10.1016/j.qref.2016.08.010

- $\quad$ Sirin, S. M. (2017). "Foreign direct investments ( FDIs ) in Turkish power sector : A discussion on investments , opportunities and risks". Renewable and Sustainable Energy Reviews, 78(September 2016), 1367-1377A. https://doi.org/10.1016/j.rser.2017.05.160

- Sunde, T. (2017). "Foreign direct investment and economic growth: ADRL and causality analysis for South Africa". Research in International Business and Finance, 1-23. https://doi.org/10.1016/j.ribaf.2017.04.035

- $\quad$ Tahir, M., Khan, I., \& Shah, A. M. (2015). "Foreign Remittances , Foreign Direct Investment, Foreign Imports and Economic Growth in Pakistan" : A Time Series Analysis. Arab Economics and Business Journal, 10(2), 82-89. https://doi.org/10.1016/j.aebj.2015.06.001

- Zhang. (2001). "Does Foreign Direct Investment Promote Economic Growth? Evidence from East Asia and Latin America". Contemporary Economic Policy, 19(2), 175-185. https://doi.org/10.1111/j.14657287.2001.tb00059.x 


\title{
Highlighting Cross-cultural Differences as Rhetorical Strategies in Tourism Marketing for Eurasian Countries
}

\author{
Asst. Prof. Dr. Ayca Oralkan (Beykent University, Turkey)
}

\begin{abstract}
Today, tourism represents a large part of the global economy. Tourism, which has become a widespread activity of the modern world, has generated a diversified marketing sector with motivations such as experiencing different natural conditions and different cultures. In addition to its contribution to regional development, the marketing of cultural tourism promotes multidimensional cultural characteristics that have a positive impact on the welfare of society. Quality of life as an understanding of life satisfaction is increased by the standards offered by tourism. In this context, tourism marketing strategies designed according to intercultural differences provide mutual benefits. The aim of this paper is to highlight possible rhetorical approaches to the attractiveness of cultural diversity that accompany the welfare effect of cultural tourism.
\end{abstract}

\section{Introduction}

In the 21 st century, tourism is representing a large chunk of the global economy as a mechanism for generating income and employment. While the modern world's life strategy has transformed tourism into a common spare time activity, involuntary retreat from nature and social life has created a diverse range of tourism demand. According to UNWTO (World Tourism Organization) data, the number of international tourists around the world was around 1.4 billion in 2018. In line with this global demand, cultural tourism is a multidimensional economic sector that makes a significant contribution to the economy of Eurasia countries. While cultural elements and activities provide an important motivation for travel, the process itself is involved in shaping the cultural structure (Richards, 2018, p. 12). In cultural tourism categorization, the experience of cultural attraction in touristic travel is the primary objective; for instance, a museum visit is decided before arriving at the destination (Hughes, 2002, p. 170). Although the concept of culture can be defined in many different ways, it ultimately represents the common life strategy and common values of the majority of its members. A possible social contact between individuals from different cultures can lead to the development of positive attitudes through mutual understanding. On the other hand, the contact between individuals from different cultures can generate negative attitudes through stereotypes, which can eventually lead to loss of sense of security (Reisinger, 1998 p. 82). Under such circumstances, tourist-host interaction is only disappointing rather than satisfaction. Therefore, it is necessary for tourism centers to highlight a tolerant approach, which is based on understanding and appreciation to ensure harmony, as well as intercultural differences, which are the elements of attraction.

Urban culture and heritage assets, such as museums, art galleries, historic centers, squares, theaters, and architecture, offer a wide range of cultural tourism opportunities. In this conjuncture, there is increasing competition for cultural tourism among the well-known destinations of countries across the globe. It is crucial for tourism marketing strategies to highlight cultural attractions and favorable cross-cultural differences to generate interest among tourist candidates. Past values tend to be nostalgic and regarding rhetorical analysis, such engagements are also very effective in tourism advertising. In addition to its contribution to regional development, marketing of cultural tourism promotes multidimensional cultural characteristics, which leads to positive effects on society's wellbeing. Quality of life as an understanding of life satisfaction has a tendency to get increased by the standards offered by tourism. In order to achieve sustainable tourism, it is necessary to meet the short and longterm standards of quality-living requirements of the local population, which is part of the tourism resource due to the nature of this interaction (Andereck et al., 2007, p. 484). For sustainable tourism, there is a clear definition as, "Tourism that takes full account of its current and future economic, social and environmental impacts, addressing the needs of visitors, the industry, the environment, and host communities" (UNWTO, 2005). In many countries around the world, investing in infrastructure and promotion for tourism development is state policy (Nowak, 2003, p: 4). In this context, the tourism marketing strategies of national tourism administrations and ministries of tourism, which are designed in accordance with cross-cultural differences lead a mutually beneficial path.

\section{Background}

Cultural tourism is a type of tourism activity where the main motivation of the visitors is to experience the cultural elements of a tourism destination and to consume the related products. Culture and tourism, by their nature, are interactively intertwined, and in view of the distinct link between culture and tourism, cultural tourism has begun to be defined as a particular type of consumption (Richards, 2018; p. 01). As income and consumption continued to increase in the mid-twentieth century, international travel and culture consumption also increased, and eventually, by the end of the 20th century, with the prominence of the main destinations of international tourists, cultural tourism began to gain importance. The capacity in international and domestic travels has increased with the undeniable effect of cultural tourism, contributing to the interactive development of economy and culture 
(Richards, 2001). In the middle of the twentieth century, cultural tourism, which was accepted as an elite form of tourism, started to become more evident in the mass-market since the 1990s through the fruitful interaction based on mutual interest generated by the relatively increasing satisfaction of tourists and their contribution to local economies (Jovicic, 2016, p. 2). In the 21 st century, cultural tourism has become a deep-rooted phenomenon in many tourism regions, with a sense of orientation towards the mass market. World Tourism Organization (UNWTO), through its publicly announced statement as an agency of the United Nations, promotes responsible, sustainable and universally accessible tourism. Confirming the significance of cultural tourism among the general motives of visit, UNWTO report (2018) emphasizes that international tourism has progressed towards the field of cultural practice worldwide.

Cultural attractions are usually in the open-air category, and when that is the case, it is very difficult to find reliable information about the number of tourists visiting and their possible motivations on these visits. On the other hand, methods that allow tourists to be grouped according to their cultural motivations are very important for the efficiency of management in any cultural center (Gali-Espelt, 2012, p. 46). For example, as a popular component of cultural tourism, culinary tourism is a well-known motivation for tourists who travel to learn about food and beverages in a given destination (Benkhard, 2017, p.41). Another example of the main motivations for international touristic visits is music with growing demand. Music events that can offer a wide range of activities ranging from Mozart in Salzburg to opera festivals in Bayreuth can increase the attractiveness of tourism centers (Hjalager, 2009, p. 266). Food-based traditions, diversified in the local gastronomy category, provide another motivation for tourists in search of exotic experiences. Festivals are also multicolored tourist motivations and comprehensive planning is required to provide a unique experience for their desired impact (Fernandes, 2014, p. 289).

\section{Main Focus of the Paper}

Given the increasing importance of cultural elements in the marketing of tourism, this paper aims to identify the current and possible future rhetoric trends towards this broad topic. The research methodology involves theoretical evaluations of tourism marketing among cross-cultural differences. The purpose of this paper is to emphasize the possible rhetoric approaches towards the attraction of cultural diversity accompanying the welfare impact of cultural tourism. In addition, in accordance with rhetoric analysis, there is the evaluation of possible advantages of cross-cultural differences and the interactive contribution of the resident support for culture-based tourism. In this regard, this paper presents cross-cultural evaluations on how the quality of life of the people living in tourism centers is affected.

\section{Economic Aspects of Cultural Tourism}

The economic return of cultural tourism has long been evident; in fact, cultural heritage can be said to be better protected through supportive tourism policies and tourism revenues. Even though it cannot be exactly known how much the income from tourism is spent on preservation and improvement of the cultural heritage, even the provision of the minimum value requirements can provide significant advantages. Cultural tourism has a significant contribution to the expansion of potential customer base, diversification of touristic facilities, lengthening of stay of tourists and reduction of seasonality. For example, this seasonality constraint has an important place among the challenges facing Turkey tourism. The number of tourists visiting Turkey with the motivation of cultural tourism is not very high and focusing mostly on summer vacationers as the target audience is often defined as the main problem. In order to reduce the seasonal effect, Turkey needs to position itself with cultural assets and values, and therefore needs to be able to use its cultural resources efficiently and effectively (Okumus et al., 2012, p. 648).

Because of all these important economic advantages, governments are trying to obtain formal approvals for the historical and cultural values of favorite destinations from global organizations such as Cultural Organization (UNESCO) and World Heritage Sites (WHS) (Patuelli, 2016, p. 2). Historical towns and historical corners of city centers are the main components of cultural heritage for Eurasian countries. Most of these open-air exhibitions, which are the focus of tourists, take place as the heritage sites in the list of UNESCO.

In addition, in order to provide further development of tourism, it is possible to provide unique experiences by developing creative economic approaches and to contribute to making tourist regions more attractive. When the experiences in a tourism center are diversified, the satisfaction of tourists can be increased, and therefore, tourists can be expected to repeat the selection of the location. A positive destination experience is not only the emotional appreciation of past satisfaction but also a direct impact on destination loyalty. Despite the tendency to attract new tourists in tourism marketing strategies, the destination loyalty is considered to generate fruitful intentions of revisits and place recommendations (Correia, 2013, p. 238). In this context, highlighting cross-cultural differences and original cultural resources that can arouse interest among tourist candidates is advantageous in the competitive environment. While the residence requirement of the people in the heritage sites continues to be met, the authenticity of the region must be maintained in line with the expectations of the tourists. 
As an extreme cross-cultural tourism phenomenon, indigenous tourism refers to the destinations in which, the focus of direct interest is the culture of indigenous people itself. In such cases, there may be policies that support the utilization of indigenous culture in the provision of economic efficiency in tourism enterprises (Whitford et al., 2001, p. 176). However, this is usually the case for Aboriginal category or locals of exotic islands rather than Eurasian countries.

Creative tourism is another efficient tourism phenomenon with the potential of transforming tourism experience in destinations into an unforgettable experience by making them even more impressive. The combination of cultural tourism with creative tourism comprising social and physical enhancements has the potential to transform an ordinary town into an attractive tourist center. Creative tourism has various aspects like enhancing the tourism experience and developing new thematic tourism products. In this context, contributing to local economies, creative tourism appears to provide more active and longer-lasting experiences (Chang, 2014, p. 4).

\section{Managing Overcrowding in Tourism}

While tourism provides economic contributions to the region by generating various options like the job options, unplanned growth in the tourist attractions can result in over-tourism. While enhancing the standards of infrastructure and facilities, it is crucial to provide consistent dynamics for the sustainability of the sector. A successful tourism marketing has the power to turn unknown places into popular tourist attractions. However, excessive use of natural resources such as water, and insufficient waste-discharging methods can create short and long-term problems for the region. Besides, the crowd can cause routine actions of daily life and all kinds of social activities to become a source of stress because of the excessive number of people (Neuts \& Nijkamp, 2012, p. 2134). At this point, there is the inspiring limitation approach of the World Tourism Organization through the definition of carrying capacity as, "The maximum number of people that may visit a tourist destination at the same time, without causing destruction of the physical, economic, socio-cultural environment and an unacceptable decrease in the quality of visitors" (UNWTO, 2005). Besides, in the analysis of crowded perception, coping methods with possible negative effects should be taken into account. Tourism centers that comply with this limitation approach of the World Tourism Organization can maintain the general satisfaction with the help of appropriate crowd-management methods in the tourist-intensive centers (Popp, 2012, p. 52). The main source for the motivation of the tolerance on the negative side effects is the mutually beneficial nature of mass tourism. Destination safety is another vital component as the mutual benefits of cultural tourism. Disruption of destination trust can turn into an irreversible weakness over the perception of tourist candidates. Therefore, the perception of trust upon tourism centers and their countries should be clearly established. In particular, the locals in the locations where tourism has an economic contribution will be the protectors of security in order to prevent tourism from being interrupted.

\section{Rhetoric Approach for Cultural Tourism}

The rhetoric, which has been used for centuries, is obliged to ensure that the messages of tourism marketing, which has been shining with the socioeconomic contributions over the past few decades, reach the potential tourists effectively. The Rhetoric strategy, which is the persuasion method, has three main components as Logos for the information given in the name of logic, Ethos for the credibility, and finally Pathos for the emotional effect (Aristotle, 4th century BC). By benefiting from the advantages of social media in communication strategy, it is possible to promote tourism centers efficiently and to reveal their favorable differences. The main characteristics of social media, such as a high message rate on a global scale and high return on investment (ROI), are important reasons for preference. Moreover, the potential efficiency of these marketing strategies has increased even more with smartphones that boost the rate of user interaction on the Internet. However, it can be very difficult to draw attention due to the very high number of shares and over-intensive information flow. Therefore, the choice of communication methods that can attract attention and interest is as important as the content of the message to be delivered to the tourist candidates in the target audience. In this conjuncture, rhetoric strategies aim to make these messages more convincing to target groups and there are efficient platform options that social media provides in this regard.

\subsection{Logos for Rhetoric Approach}

Internet memes are not only entertaining tools but also communication tools that can contain persuasive texts (Huntigton, 2013, p. 3). A slogan is a very effective communication tool to spread the image of the destination as a brand positioning strategy, and in terms of the effectiveness of brand messages, how spreadable that content is decisive. A successful slogan can provide an advantage in the competitive environment by contributing to the formation of brand identity through a perceptual difference (Pike, 2005, p. 259). Tourism centers are aware of the impact of the memes that can spread in social media and this communication method is considered as an influential strategy in marketing. Social media enables tourism centers to interact directly with tourist candidates through various Internet platforms, and to monitor their assessments of experiences. While each network platform generates its own advantages, simplicity is a critical characteristic enhancing the chance of the content spread 
faster. For instance, a core destination message as a Twitter text gets spread easier, an attractive visual as Instagram photo becomes viral much easier and links of touristic web addresses involving more detailed information can more effectively be shared on Facebook. However, the general slogans that do not focus on certain destination characteristics or cultural experiences, such as "exploring the potential" or "There are many things to discover", may not provide the intended differentiation. When it is a case of the spread of information, more focused slogans are able to provide strategic contents as valuable building blocks for destination image. While it is beneficial to focus on the agencies in the promotion of destination in the countries where the travel agencies are preferred, it is strategically critical to developing web pages with comprehensive and compelling information for countries, where tourists travel more often through the researches on the internet. Besides, it is strategically critical that the positioning in tourism marketing should be developed in such a way as to address the possible needs of potential tourists by investigating the cultural tendencies in target countries. Even in the responses to the slogans and promotional images used, there may be differences, depending on the cultural tendencies of the target countries. For example, in advertisements that are focused on cultures dominated by longing for the sea, slogans and promotional images highlighting the seas and beaches would be advantageous.

\subsection{Ethos for Rhetoric Approach}

A critical point in an environment where exaggerated or even false information circulates in destination promotions is reliability. Trust itself is about meeting the promises. Basically, trust has a very important impact on how tourism-related information is perceived from the very beginning. In other words, tourist candidates need to have an adequate level of trust in the tourism center and information sources to be able to approach the promotional information positively. Consistency is very important for the long-term reputation of tourism centers. Regardless of the tourism centers, even the unpleasant news from the country of origin may have negative effects. The more strongly and permanently established trust, the more effective-responsive approaches that neutralize consumer perceptions against possible negative information. In this context, one of the best ways of securing trust is the delivery of messages about promoted destinations via popular social media accounts such as popular Instagram accounts or popular YouTube channels instead of advertising agencies.

For effective tourism marketing strategy, it would be appropriate to carry out market segmentation for the formation of target groups that would increase the efficiency of promotional messages. Presenting all the elements of cultural diversity to all potential tourists can lead to a decrease in effectiveness by causing excessive information intensity and complexity. Positioning options in the destination include global, local and foreign elements. When evaluated in the rhetorical perspective, the global values would contribute to an acceptable level of compliance, thus contributing significantly to the need for reliability in the Ethos component. Therefore, positioning with a hybrid approach can be an optimum strategy (Akaka \& Alden, 2010, p. 49). While the perception of harmony built with the highlight upon global values ensures reliability, highlighting cross-cultural differences can provide advantages in the competitive environment.

\subsection{Pathos for Rhetoric Approach}

Due to the high number of attraction centers of the countries, the presentations that can be effective in the destination decisions of tourists are vital for the marketing strategies in order to gain an advantage by enabling differentiation in the competitive environment. Although cultural differences provide a natural advantage, there may be some humanitarian characteristics or social values in the context of the expectations of tourists. In view of the selective perception, consumers pay attention to messages that already contain the features they are looking for. Emotional appeal is a crucial variable of rhetorical works (Huhmann, 2010, p.13). When the information is shared with an emotional attachment the information is more likely to be remembered. Destination personality is a crucial component of tourism marketing and directly related to emotional experiences at a particular tourism center. Analyzing the destination personality with a tourist perspective can provide an understanding of the emotional connection to a particular destination (Kim \& Stepchenkova, 2017, p. 416). Tourists who experience a perceptual harmony between that destination and their own self-image have a tendency to revisit that destination (Matzler et al., 2016, p. 516). With an effective rhetoric perspective, the development of destination personality can enable tourists to express themselves through specific social values and individual-based styles that reflect a particular lifestyle. Or, for tourists who are looking for a break in their stressful life, the intimate and peaceful characteristics can be very attractive. Aaker's well-known statement, "the set of human characteristics associated with a brand", refers to the tendency to associate brands with positive human characters as sincerity, competence, excitement, sophistication, and ruggedness (Aaker, 1997, p. 351). Highlighting a certain character such as sincerity or excitement in harmony with cultural values and national trends can increase the effectiveness of cultural marketing strategy. In addition, globally positioned locations can be preferred by tourists for their expectation of a social lifestyle enhancement or a desire to gain international status. In this context, in marketing strategies, if the differentiated social values in the touristic regions are properly highlighted, accommodation periods and repeated visits may increase in these attraction centers. 


\section{Conclusion}

The global contribution of communication technology nourishes intense demand for the exchange of goods, services, information and capital based on cultural tourism worldwide. In this regard, cultural tourism is potentially effective in terms of these contributions to the opportunities for sustainable socio-economic development in Eurasian countries regarding welfare elements. Studies on tourism motivation are focused on acquiring information about travel behavior and have been one of the main elements of tourism literature. Especially in recent years, examining the tourist behavior has gained high significance with the fact that tourism, which is a critical component of the global economy, has become a cross-cultural phenomenon. A successful positioning provides an effective differentiation through these cross-cultural differences in the audience perception, among competing destinations. Besides, there are critical advantages of cross-cultural differences and the interactive contribution of the resident support for culture-based tourism. Beyond the regional impact of tourist expenditures, marketing of cultural tourism amplifies the benefits of this interaction by emphasizing the cultural values among the prosperity of social life. A positive experience at the tourism center is not only an emotional assessment of past satisfaction but also a direct impact on destination loyalty. Therefore, it is advantageous in the competitive environment to highlight cross-cultural differences and unique cultural resources that may attract interest among tourist candidates. Advertising, which aims to shape a positive image of tourism destinations through these cultural differences, plays an important role in promotion. Ads that highlight places to see using attractive promotional materials motivate tourist candidates to travel to these destinations. Apart from such advertising, mouth-to-mouth communication, and social media platforms that provide interactive communication, contribute significantly to the formation and promotion of destination images. In any case, it is crucial for destination trust to exist in advance in order for tourist candidates to positively evaluate the message content. In this regard, awareness-oriented messages -like the prevention of water pollution- lead advertisements to be positively perceived. However, effective destination management comprises long-run tourism planning and in order to gain the long-run trust, the consistency in the content of the messages is crucial. The halo effect generated by a strong destination trust can eliminate the hesitations of tourist candidates during the region selection and may even make the possible inconveniences that occur during their travels invisible.

\section{References}

- $\quad$ Aaker, J. L. (1997). Dimensions of Brand Personality. Journal of Marketing Research, 34(3), 347-356.

- Akaka, M. A., \& Alden, D. L. (2010). Global Brand Positioning and Perceptions: International Advertising and Global Consumer Culture. International Journal of Advertising, 29(1), 37-56. http://Doi.Org/10.2501/S0265048709201026

- $\quad$ Andereck, K. L., Valentine, K. M., Vogt, C. A., \& Knopf, R. C. (2007). A Cross-Cultural Analysis of Tourism and Quality of Life Perceptions. Journal of Sustainable Tourism, 15(5), 483-502. http://doi.Org/10.2167/Jost612.0

- Benkhard, B., \& Halmai, M. (2017). Mouthful Hungary - Overview of Hungarian Cuisine and Culinary Tourism. Geography and Tourism, 5(1), 41-54. http://doi.org/10.5281/zenodo.83449

- Chang, L. L., Backman, K. F., \& Huang, Y. C. (2014). Creative Tourism: A Preliminary Examination of Creative Tourists' Motivation, Experience, Perceived Value and Revisit Intention. International Journal of Culture, Tourism, and Hospitality Research, 8(4), 401-419. http://doi.org/10.1108/IJCTHR-04-2014-0032

- Correia, A., Kozak, M., \& Ferradeira, J. (2013). From Tourist Motivations to Tourist Satisfaction. International Journal of Culture, Tourism, and Hospitality Research, 7(4), 411-424. http://doi.org/10.1108/ijcthr-05-2012-0022

- Fernandes, C., \& Rachao, S. (2014). Reinventing Tourism at A Traditional Cultural Tourism Destination: A Case Study of Viana Do Castelo (Portugal). International Journal of Business and Globalisation, 12(3), 281296. http://doi.org/10.1504/ijbg.2014.060213

- Galí-Espelt, N. (2012). Identifying Cultural Tourism: A Theoretical Methodological Proposal. Journal of Heritage Tourism, 7(1), 45-58. https://doi.org/10.1080/1743873x.2011.632480

- Hjalager, A. M. (2009). Cultural Tourism Innovation Systems - The Roskilde Festival. Scandinavian Journal of Hospitality and Tourism, 9(2-3), 266-287. https://doi.org/10.1080/15022250903034406

- Hughes, H. L. (2002). Culture and Tourism: A Framework for Further Analysis. Managing Leisure, 7(3), 164-175. http://doi.org/10.1080/1360671022000013701

- Huhmann, B. A. (2010). A Model of The Cognitive and Emotional Processing of Rhetorical Works in Advertising. Go Figure: New Directions in Advertising Rhetoric, (September 2007), 133-175. https://doi.org/10.3386/w19846 
- Huntington, H. E. (2013). Subversive Memes: Internet Memes as A Form of Visual Rhetoric. Selected Papers of Internet Research, (2009), 2002-2005. Retrieved From http://spir.aoir.org/index.php/spir/article/view/785

- $\quad$ Kim, H., \& Stepchenkova, S. (2017). Understanding Destination Personality Through Visitors' Experience: A Cross-Cultural Perspective. Journal of Destination Marketing and Management, 6(4), 416-425. https://doi.org/10.1016/j.jdmm.2016.06.010

- $\quad$ Matzler, K., Strobl, A., Stokburger-Sauer, N., Bobovnicky, A., \& Bauer, F. (2016). Brand Personality and Culture: The Role of Cultural Differences on The Impact of Brand Personality Perceptions on Tourists' Visit Intentions. Tourism Management, 52, 507-520. https://doi.org/10.1016/j.tourman.2015.07.017

- $\quad$ Neuts, B., \& Nijkamp, P. (2012). Tourist Crowding Perception and Acceptability in Cities. Annals of Tourism Research, 39(4), 2133-2153. https://doi.org/10.1016/j.annals.2012.07.016

- Jovicic, D. (2016). Cultural Tourism in The Context of Relations Between Mass and Alternative Tourism. Current Issues in Tourism, 19(6), 605-612. https://doi.org/10.1080/13683500.2014.932759

- $\quad$ Nowak, J. J., Sahli, M., \& Sgro, P. M. (2003). Tourism, Trade and Domestic Welfare. Pacific Economic Review, 8(3), 245-258. http://doi.org/10.1111/j.1468-0106.2003.00225.x

- $\quad$ OECD Tourism Trends And Policies 2018. (2018). Paris: OECD Publishing. Retrieved April 4, 2019, from https://doi.org/10.1787/tour-2018-en

- $\quad$ Okumus, F., Avci, U., Kilic, I., \& Walls, A. R. (2012). Cultural Tourism in Turkey: A Missed Opportunity. Journal of Hospitality Marketing and Management, 21(6), 638-658. https://doi.org/10.1080/19368623.2012.627231

- $\quad$ Patuelli, R., Mussoni, M., \& Candela, G. (2016). The Effects of World Heritage Sites on Domestic Tourism: A Spatial Interaction Model for Italy. Advances in Spatial Science, (9783319301945), 281-315. https://doi.org/10.1007/978-3-319-30196-9_13

- Pike, S. (2005). Tourism Destination Branding Complexity. Journal of Product and Brand Management, 14(4), 258-259. https://doi.org/10.1108/10610420510609267

- Popp, M. (2012). Positive and Negative Urban Tourist Crowding: Florence, Italy. Tourism Geographies, 14(1), 50-72. https://doi.org/10.1080/14616688.2011.597421

- $\quad$ Reisinger, Y., \& Turner, L. (1998). Cross-Cultural Differences in Tourism: A Strategy for Tourism Marketers. Journal of Travel \& Tourism Marketing, 7(4), 79-106. http://doi.org/10.1300/j073v07n04

- Richards, G. (2014). Creativity and Tourism in The City. Current Issues in Tourism, 17(2), 119-144. https://doi.org/10.1080/13683500.2013.783794

- Richards, G. (2018). Cultural Tourism: A Review of Recent Research and Trends. Journal of Hospitality and Tourism Management, 36, 12-21. http://doi.org/10.1016/j.jhtm.2018.03.005

- $\quad$ UNEP, WTO, Tourism More Sustainable A Guide for Policy Makers Making (2005). Retrieved April 4, 2019, from http://sdt.unwto.org/content/about-us-5

- Whitford, M., Bell, B., \& Watkins, M. (2001). Indigenous Tourism Policy in Australia: 25 Years of Rhetoric and Economic Rationalism. Current Issues in Tourism, 4(2-4), 151-181. https://Doi.Org/10.1080/13683500108667886 


\title{
The Comparative Advantage of Crude Oil in the Top 10 Oil- Producing Countries
}

\author{
Ph.D. Candidate Osama Elsalih (Eastern Mediterranean University, TR of Northern Cyprus) \\ Assoc. Prof. Dr. Kamil Sertoğlu (Eastern Mediterranean University, TR of Northern Cyprus) \\ Prof. Dr. Mustafa Besim (Eastern Mediterranean University, TR of Northern Cyprus) \\ Asst. Prof. Dr. Abdelhakim Embaya (Sabratha University, Libya)
}

\begin{abstract}
This paper investigates the comparative advantage of crude oil in the top 10 oil-producing countries over the period 1990-2016 through computing the Normalized Revealed Comparative Advantage (NRCA) index and further examines the determinants of this advantage using panel estimation technique. The results of the NRCA index showed that not all the top10 oil-producing countries have a comparative advantage in crude oil production during the study period. Countries like Iran, Iraq, Kuwait, Russia, Saudi, and UAE are found to have a comparative advantage in producing crude oil, while countries like Brazil, China, and the USA have no comparative advantage in producing crude oil. For Canada, its comparative advantage is only revealed just between 2006 and 2016 . The result of the Panel ARDL suggested that in the long run, crude oil price (COP) and daily average of crude oil production (DAP) are found to be positive and significantly related to NRCA, whereas proven reserve (PR) and domestic demand for oil (DDO) are negative and significantly related to NRCA. In the short run, COP, DAP, and DDO have the same effect as in the long run and significantly related to NRCA, while PR is statistically insignificant. Finally, a bidirectional Granger-causality is detected between the variables except for the PR and NRCA where a unidirectional causality runs from PR to NRCA.
\end{abstract}

\section{Introduction}

The global efforts to find clean and efficient alternative sources of energy started many decades ago. However, oil still remains the main source of energy with the highest share of consumed energy source compared to the other sources. Figure (1) shows that, despite the decline in the share of oil in the world's energy consumption, oil consumption is the highest with $39 \%$ in 1996 . This decreases to $36 \%$ in 2006 and $34 \%$ in 2016 . Thus, due to the importance of oil as a non-renewable energy source produced in around 100 countries (EIA, 2017) and utilizes all over the world, the competition in the world's oil market is raged as to whether to maximize profits or to secure the supply of energy sources. According to the statistics in Table (1), the top 10 oil-producing countries produce around 63 million barrels of crude oil per day and consume around 48 million barrels per day, with the USA and China as the biggest consumers of crude oil, respectively consume around 7 and 8 million barrels more than their native daily production in 2016 .
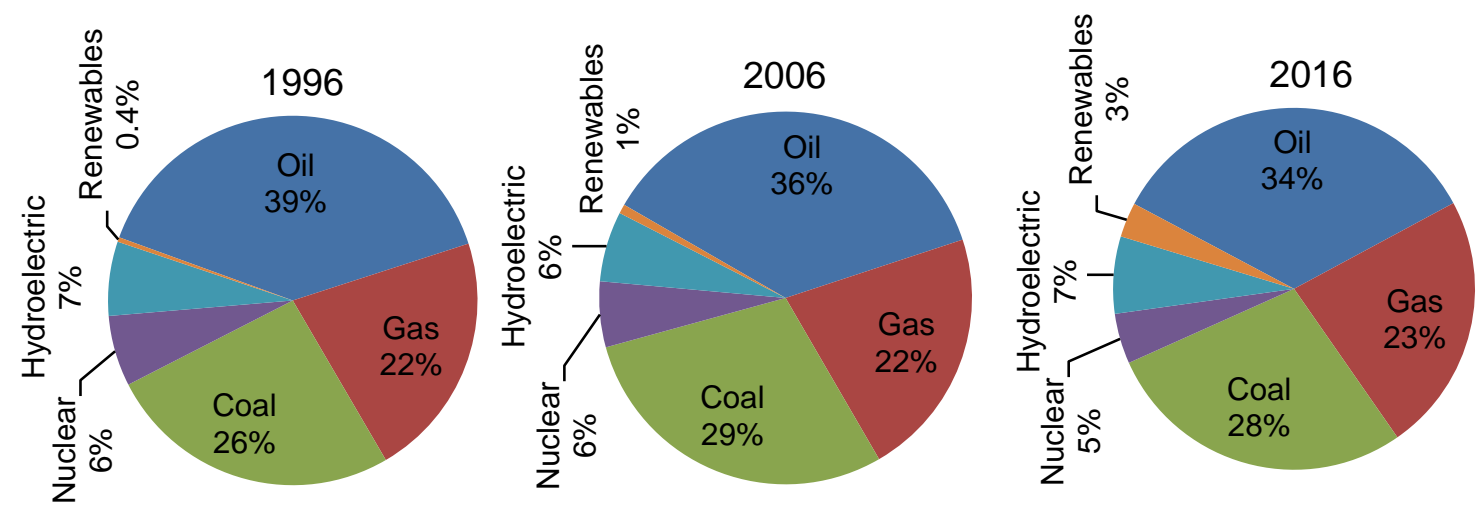

Figure 1. Energy Consumption by Fuel in 1996, 2006 and 2016 


\begin{tabular}{cccc}
\hline Production Rank & Country & $\begin{array}{c}\text { Production } \\
1000 \mathrm{~b} / \mathrm{d}\end{array}$ & $\begin{array}{c}\text { Consumption } \\
1000 \mathrm{~b} / \mathrm{d}\end{array}$ \\
\hline 1 & Saudi & $12,401.80$ & $3,938.60$ \\
2 & US & $12,365.80$ & $19,687.20$ \\
3 & Russia & $11,269.40$ & $3,193.20$ \\
4 & Iran & $4,602.40$ & $1,722.40$ \\
5 & Canada & $4,470.20$ & $2,400.60$ \\
6 & Iraq & $4,422.90$ & 758.00 \\
7 & UAE & $4,019.90$ & $1,002.60$ \\
8 & China & $3,999.20$ & $12,301.70$ \\
9 & Kuwait & $3,145.10$ & 452.80 \\
10 & Brazil & $2,607.80$ & $3,012.70$ \\
Total of the Top 10 countries & $63,304.30$ & $48,470.00$ \\
\hline
\end{tabular}

Table 1. Top 10 Oil-Producing Countries, Production and Consumption in 2016

In the context of international trade, the classical and neoclassical international trade theories argue that a country with a comparative advantage in producing specific commodity can export this commodity to another country produces the same commodity as long as the opportunity cost in the first country is lower than in the other country. However, it has been difficult to apply such a framework in an empirical analysis to measure the comparative advantage (Sanidas and Shin, 2010), until the time when Balassa (1965) proposed the first and the most widely used revealed comparative advantage (RCA) index. This index is based on the idea that the comparative advantage could be "revealed" through analyzing trade patterns of the specific country using post-trade variables. Later on, the Balassa index (BRCA) was revised and modified to several indices so as to address its shortcomings and develop alternative indices. Thus, the latest index in this scope is the Normalized Revealed Comparative Advantage index (NRCA) introduced by Yu et al., (2009). This index is developed to overcome the shortcomings of the other RCA indices and to provide a reliable and systematic tool for assessing the comparative advantage over space and time (Yu et al., 2009).

It is well established in the existed literature of the comparative advantage that the RCA indices could just identify whether a country has a comparative advantage through the consistency between production intensity and the export structures of a specific economy but are not able to identify the reason behind the change in comparative advantage (Batra and Khan, 2005). Therefore several empirical studies investigated the comparative advantage of a variety of economic activities using one of RCA indices with a different method of econometrics. For instance, Yeats (1985) used the BRCA index for the industrial sector. Similarly, Abidin and Loke (2008), Fertö and Hubbard (2003) and Bojnec (2001) used the BRCA index for agricultural and food agricultural sector; Nath et al., (2015), Seyoum (2007) and Langhammer (2004) for service sector; Chi and Kilduff (2006) and Havrila and Gunawardana (2003) for textile and clothing sector. Moreover, Ahrend, (2006), Utkulu and Seymen (2004) and Valentine and Krasnik (2000) used BRCA for the whole SITC-3 commodity classifications. More recently, the relatively new NRCA index was used to assess the comparative advantage in agriculture and some specific crops and life stock (see Hoang et al., 2017; Seleka and Kebakile, 2017; Sarker and Ratnasena, 2014; Sharma et al., 2014; Ndayitwayeko et al., 2014), also this index was used to measure the comparative advantage of cheese production (see Balogh and Jambor, 2017), and tourism and travel service sector (see Toit, et al., 2010; Fourie, 2009).

Following the existing literature on the comparative advantage, and recognizing the importance of oil as the main source of energy globally, the objectives of this paper are (a) to assess the comparative advantage of producing crude oil in the top10 oil-producing countries (Brazil, Canada, China, Iran, Iraq, Kuwait, Russia, Saudi, UAE, USA) over the period of 27 years (1990-2016); and (b) to investigate the determinants of the comparative advantage of producing crude oil in the sampled countries, in order to answer the following two crucial research questions:

Do all oil-producing countries have a comparative advantage in crude oil production?

What are the main factors that determine the comparative advantage of crude oil production?

The paper is organized as follows: Section two is methodology and data. Section three discusses the results and section four concludes the paper.

\section{Methodology and Data}

In this paper, we use NRCA index to quantitatively measure the comparative advantage of crude oil production in the top 10 oil-producing countries. We then employ a panel data technique through a Panel Autoregressive Distributive Lag (ARDL), proposed by Pesaran et al. (1999) to estimate the relationship between the comparative advantage (NRCA index) and four explanatory variables, which are crude oil price (COP), proven reserve (PR), daily average of crude oil production (DAP) and domestic demand for crude oil (DDO). These variables are selected so as to capture the effect of the exogenous shocks in oil prices, the endowed natural resource and the 
domestic supply and demand for crude oil on the comparative advantage of crude oil production. In terms of data, this paper mainly relies on secondary data, collected from the United Nation Com trade database, and the Organization of the Petroleum Exporting Countries (OPEC).

\subsection{Measuring revealed comparative advantages (RCA)}

The NRCA is a relatively new index possesses a group of favorable properties that make this index a superior, and most successful to overcomes the shortcomings of the alternative RCA indices, except the properties of normality of error terms assumption (Bebek, 2017; Sanidas and Shin, 2010). The NRCA index has a constant mean, symmetry, and distributed between -0.25 and +0.25 , which are the required properties for time-series econometric studies. Thus, the NRCA for a country $\mathrm{i}$ in commodity $\mathrm{j}$ can be calculated as follow:

$$
\operatorname{NRCA}_{j}^{i}=\frac{\Delta E_{j}^{i}}{E_{w}}=\frac{E_{j}^{i}}{E_{w}}-\frac{E_{w j} \cdot E^{i}}{E_{w} \cdot E_{w}}
$$

Where $E_{j}^{i}$ refers to the export of country $i$ from commodity $j$ which is crude oil in this study; $E^{i}$ is the total exports of the country $i$; $E_{w j}$ is the world's total export from the commodity $j ; E_{w}$ is the world's total export. Basically, the method of the NRCA index gauges the degree of deviation of actual $E_{j}^{i}$ from the neutral point of its comparative advantage $\widehat{E}_{j}^{i}$ in terms of its relative scale with respect to the world's export of the same commodity, where the neutral point of the comparative advantage $\widehat{E}_{j}^{i}$ of $E_{j}^{i}$ can be expressed as $\widehat{E}_{j}^{i}=\frac{E^{i} \cdot E_{j}}{E}$. Thus, a country can enjoy a comparative advantage in producing and exporting a commodity $\mathrm{j}$ when NRCA $>0$, this means the country's export from the commodity $\left(E_{j}^{i}\right)$ is greater than the natural point of its comparative advantage $\left(\widehat{E}_{j}^{i}\right)$. On the other hand, in case of where NRCA $<0$, the country has no comparative advantage, i.e. the country's export from the commodity $\left(E_{j}^{i}\right)$ is less than the natural point of its comparative advantage, ( $\left.\widehat{E}_{j}^{i}\right)$ (Yu et al., 2009).

\subsection{Panel Estimation}

As mentioned earlier, the RCA indices are unable to identify the sources of the comparative advantage. For this reason, several studies have used the comparative advantage indices with a variety of econometric models to identify the key drivers of the comparative advantage. Therefore, in this study, we employ a panel data technique to estimate the relationship between the comparative advantage and the explanatory variables. In order to employ a panel data framework, we need to address two main issues to determine whether to follow first- or secondgeneration panel estimation (Breitung and Pesaran, 2008). Thus, Breusch and Pagan (1980) test, Pesaran (2004) $\mathrm{CD}$ test and Pesaran and Ullah and Yamagata (2008) tests are used to investigate the presence of the cross-sectional dependency (CD) in the panel. Then Swamy (1970) test is employed to detect whether the slope in the panel data is homogeneous or not. Regarding the Unit root, we explored Pesaran CIPS (2007) unit root test for heterogeneous panels. This test augments the typical Augmented Dickey-Fuller test (ADF) with an average of the cross-section of the lagged level and the first difference of each time series. To detect the existence of the long-run cointegration relationship in the panel, we used Durbin-Hausman panel cointegration test developed by Westerlund (2008). This test is superior in panel data in the presence of heterogeneity, cross-section dependency, absence of stationarity, and mixed order of cointegration. This test is designed to exam the null hypothesis of no cointegration in group and panel at the same time using two subtests $-\mathrm{DH}_{\mathrm{g}}$ which denotes a test for group mean statistic and $\mathrm{DH}_{\mathrm{p}} \mathrm{which}$ denotes a test for panel statistic (Westerlund, 2008).

For estimating the coefficients of the relationship between comparative advantage and the explanatory variables as mentioned, we employed panel ARDL for large $\mathrm{T}$ and $\mathrm{N}$ panels. This mode is used in econometrics research due to its enviable advantages compared to other models that account for endogeneity, separately provides longrun and short-run coefficients as well as applicability for mixed order of integrated variables, i.e. whether I(0) or I(1) or partially integrated (Pesaran, et al. 1999). The Panel ARDL as an advanced version of the ARDL model works via three different methods, namely; Pooled Mean Group (PMG), Mean Group (MG), and Dynamic Fixed Effect (DFE). Specifically, this model is an intermediate procedure model, where the PMG works between MG and DFE functions. In more details, while the MG estimates both short-run and long-run coefficients and allows for heterogeneity, the DFE restricts homogeneity in both short run and long run, but PMG allows for heterogeneity in the short run and restricts homogeneity in the long run (Pesaran et al., 1999). The specification of the Panel ARDL model is given by the following equation:

$$
\mathrm{y}_{\mathrm{it}}=\sum_{\mathrm{j}=1}^{\mathrm{p}} \lambda_{\mathrm{ij}} \mathrm{y}_{\mathrm{i}, \mathrm{t}-\mathrm{j}}+\sum_{\mathrm{j}=0}^{\mathrm{q}} \delta_{\mathrm{ij}}^{\prime} \mathrm{x}_{\mathrm{i}, \mathrm{t}-\mathrm{j}}+\mu_{\mathrm{i}}+\varepsilon_{\mathrm{it}}
$$

Where $t$ is the time period $t=1,2, \ldots, T$; $i$ is the number of the group (countries) $i=1,2, \ldots, N ; y_{i t}$ is the dependent variable of the group $\mathrm{i}$ in time period $\mathrm{t}$; $\mathrm{x}_{\mathrm{it}}$ is the independent variables for group $\mathrm{i}$ in time $\mathrm{t} ; \delta_{\mathrm{ij}}$ is the coefficient of the independent variables; $\lambda_{\mathrm{ij}}$ is the coefficient of the lagged dependent variable $\mathrm{y}_{\mathrm{i}, \mathrm{t}-\mathrm{j}}$. Thus, specifying this model based on equation (2) for the panel yields:

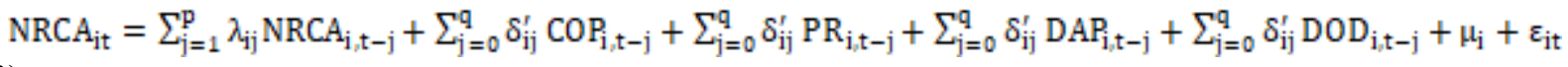


Finally, Dumitrescu and Hurlin in (2012) panel Granger non-causality test is used to understand the direction of the relationship between the variables. The null hypothesis for this test is that the independent variable does not Granger-cause the dependent variable.

\section{Empirical Results and Discussion}

\subsection{Measuring the NRCA for oil production}

Following the calculated scores of the NRCA of producing crude oil in the sampled countries in appendix (A), we can conclude that not all the top 10 oil-producing countries have a comparative advantage in producing crude oil. While Iran, Iraq, Kuwait, Russia, Saudi, UAE have a comparative advantage in crude oil production, on the other hand, the USA, China and Brazil have no comparative advantage in this industry. Whereas Canada's comparative advantage is revealed just between 2006 and 2016. Nonetheless, discussing these results in light of the Heckscher Ohlin (H-O) trade theory implies that, as oil production industry is a capital-intensive industry (Westney, 2011), our results for Canada Iran, Iraq, Kuwait, Russia, Saudi, UAE as capital-abundant countries (Bolbol and Young, 1992), therefore, support the H-O theory. However, our result for Brazil as a capital-abundant country (Muriel and Terra, 2009) and the USA as capital-abundant country as well (Krugman, 2008) does not support this theory.

\subsection{Panels estimation and empirical results}

Based on the results of the diagnostic tests, which are available to request, the panel data is facing the problems of cross-sectional dependence and heterogeneity of slope parameters. These problems mean that following the second-generation panel technique guarantees better and robust results. Furthermore, the result of CIPS panel unit root indicates a different order of variables cointegration, where the COP variable is stationary at level, I(0) and all the remaining variables are stationary at first difference I(1). Moreover, the results of the Durbin-Hausman cointegration test as shown in Table 2, presents evidence that the null hypothesis of no cointegration is perhaps rejected both in the panel and in the groups at 5\% level of significance when the test is carried out with constant and constant and trend. Therefore, we can conclude the existence of a valid long-run relationship between the variables captured in this study. Hence, we proceed to estimate our model.

\begin{tabular}{lcccccc}
\hline & \multicolumn{2}{c}{ Non } & \multicolumn{2}{c}{ Constant } & \multicolumn{2}{c}{ Constant \& trend } \\
\cline { 2 - 7 } & Statistic & P-value & Statistic & P-value & Statistic & P-value \\
$\mathrm{DHg}$ & -0.094 & 0.463 & -2.276 & 0.011 & -2.119 & 0.017 \\
$\mathrm{DHp}$ & -1.307 & 0.096 & -1.801 & 0.036 & -1.795 & 0.036 \\
\hline
\end{tabular}

Table 2. Durbin-Hausman Panel Cointegration Test

After estimating the coefficients of the long-run and short-run relationship among the variables investigated via PMG and MG methods of the Panel ARDL (1, 1, 1, 1, 1) model, we applied Hausman (1978) test for pairwise comparison between the MG and PMG estimations to decide which method is the most preferable and as such provide consistent and efficient results by testing the null hypothesis of homogeneity restrictions. The result of the Hausman test in the lower part of Table 3 shows that the null hypothesis cannot be rejected. This suggests that the $\mathrm{PMG}$ estimation is preferable to the MG estimation.

\begin{tabular}{|c|c|c|c|c|c|c|}
\hline & \multicolumn{3}{|c|}{ PMG } & \multicolumn{3}{|c|}{$\mathrm{MG}$} \\
\hline & Coefficients & $\mathrm{SE}$ & $\mathrm{P}>\mathrm{Z}$ & Coefficients & $\mathrm{SE}$ & $\mathrm{P}>\mathrm{Z}$ \\
\hline Speed of adjustment & -0.175 & 0.087 & 0.045 & -0.571 & 0.076 & 0.000 \\
\hline \multicolumn{7}{|l|}{ Long Run Coefficients } \\
\hline $\mathrm{COP}$ & 0.466 & 0.097 & 0.000 & 0.218 & 0.353 & 0.536 \\
\hline PR & -1.351 & 0.311 & 0.000 & -0.469 & 0.290 & 0.106 \\
\hline DAP & 1.699 & 0.275 & 0.000 & 0.675 & 0.313 & 0.031 \\
\hline DDO & -0.414 & 0.198 & 0.037 & -0.12 & 0.390 & 0.757 \\
\hline \multicolumn{7}{|l|}{ Short Run Coefficients } \\
\hline$\triangle \mathrm{COP}$ & 0.48 & 0.195 & 0.014 & 0.489 & 0.192 & 0.011 \\
\hline$\Delta \mathrm{PR}$ & -0.281 & 0.174 & 0.106 & -0.255 & 0.148 & 0.086 \\
\hline$\triangle \mathrm{DAP}$ & 0.816 & 0.417 & 0.050 & 0.799 & 0.380 & 0.036 \\
\hline$\triangle \mathrm{DDO}$ & -0.274 & 0.165 & 0.097 & -0.061 & 0.245 & 0.801 \\
\hline Constant & -0.010 & 0.040 & 0.795 & -0.038 & 0.032 & 0.242 \\
\hline \multicolumn{7}{|l|}{ Hausman test MG vs PMG } \\
\hline $\operatorname{chi} 2(10)$ & 13.79 & & & & & \\
\hline Prob>chi 2 & 0.1827 & & & & & \\
\hline
\end{tabular}

Table 3. Panel PMG and MG Estimation \& Hausman Test 
Regarding the results of the panel ARDL, based on the two estimation methods, there is evidence that the speed of adjustment coefficients are all negative and highly significant at 5\% and 1\% level of significance for PMG and MG respectively. This confirms the long-run relationship obtained through the panel cointegration test in Table 2.

Turning to the coefficients of crude oil price (COP) in Table 3, the estimation of the PMG show that, the effect of the COP on the comparative advantage of crude oil in the top 10 oil-producing countries is positive and statistically significant at $1 \%$ and $5 \%$ in both long run and short run respectively. This established relationship between COP and comparative advantage mainly reflects the relationship between COP, production, and exports of crude oil since the NRCA index is calculated by post-trade data. The implication for this result is that as the COP increases, it will lead to more oil production and exportation, which revealed the comparative advantage of the country. However, according to Cologni and Manera, (2014), oil-producing countries are characterized by different responses to exogenous shocks in world oil demand and oil prices. Conventionally, such relationships always investigate in the form of comparison between the reactions of OPEC and non-OPEC countries. Therefore, our result is in support of the positive relationship between the COP and crude oil production in OPEC countries based on the findings of Ratti and Vespignani (2015); Brémond, et al, (2012); Kaufmann, et al. (2004). In addition, this finding is congenial to Ramcharran (2002) who found a positive relationship between COP and crude oil production in non-OPEC countries. Conversely, our result is not consistent with a negative relationship between COP and crude oil production found by Ramcharran (2002) in OPEC countries, and in non-OPEC countries found by Ratti and Vespignani (2015).

The proven reserve variable (PR) represents the endowed natural resource of the crude oil that is already discovered and available for production. Basically, according to Harold Hotelling (1931), the price of depletable (non-renewable) natural resource tends to be higher than marginal cost or equal to the interest rate, in order to compensate stock resources exhausted, even in a perfectly competitive market. This is known as Hotelling rent or scarcity rent (Krautkraemer, 1998; Hamilton, 2008). Accordingly, the scarcity of crude oil as a depletable resource causes its price to rise (Frankel, 2010). Therefore, the established negative relationship between PR and the comparative advantage in this study is apparently due to the growth of PR, i.e. crude oil abundance, which in turn leads to growth in the supply of crude oil. Consequentially, this will lead to an inverse relationship between PR and comparative advantage. Our result further suggests that PR has a negative and significant relationship with the comparative advantage in the long-term based on the PMG estimation, while it is negative but statistically insignificant in the short run. This result agrees with the thought that natural resource is one of the determinants of comparative advantage, in addition to a number of socio-economic factors (Yeats, 1985). However, this result is inconsistent with the findings documented by Heller (1976); Gunton (2003); Svaleryd and Vlachos (2005); Fourie (2009); Toit, et al. (2010); Hoang, et al. (2017); Balogh and Jambor (2017) that natural resources are positively related to comparative advantage.

The daily average of crude oil production variable (DAP), which expresses the capacity of oil production per day, has a positive and statistically significant effect on the comparative advantage in both the long and short run. These results align with the finding of Yue and Hua (2002) that the rapid growth of domestic production capacity stimulates the value of export.

Lastly, the domestic demand for crude oil (DDO) has a negative and statistically significant effect on the comparative advantage in both the long run and short run. These results are in support of the idea documented by Bowen (1983) that the comparative advantage is a net trade concept where he proposed two alternative RCA indices. One of these indices is the production intensity index based on the relationship between domestic production and consumption, and net trade intensity index (Vollrath, 1991). This relationship has also been proved by Sharma et al., (2014) and Seleka and Kebakile, (2017). The implication for this relationship can be traceable to the fact that as the domestic demand for crude oil increases, it will lead to more crude oil production and less exportation. This may also lead to importing crude oil in some cases to cover the increasing domestic demand. The implication for this result can be seen clearly in the case of the USA and China as the biggest oil consumers. Although these countries are among the top 10 oil producers (see Table 1), but they have no comparative advantage in crude oil.

In terms of panel Granger non-causality test, the results shown in Table 4 present a bidirectional (two-way) causal relationship between all variables used except the causal relationship between PR and NRCA, which indicates a unidirectional (one-way) causality running from PR to NRCA. These results, therefore, support the earlier results of the panel ARDL model which show that the four dependent variables have a significant relationship with the comparative advantage. 


\begin{tabular}{ccc}
\hline Null Hypothesis & Statistic & P-Value \\
\hline COP does not Granger-cause NRCA & 5.8 & 0.000 \\
NRCA does not Granger-cause COP & 1.98 & 0.047 \\
PR does not Granger-cause NRCA & 8.82 & 0.000 \\
NRCA does not Granger-cause PR & 0.35 & 0.719 \\
ADP does not Granger-cause NRCA & 4.52 & 0.000 \\
NRCA does not Granger-cause ADP & 15.92 & 0.000 \\
NOD does not Granger-cause NRCA & 9.34 & 0.000 \\
NRCA does not Granger-cause NOD & 3.48 & 0.000 \\
\hline
\end{tabular}

Table 4. Granger Causality Test

\section{Conclusion}

This paper aimed to explore the comparative advantage of crude oil in the top 10 oil-producing countries and investigating the determinants of this advantage. To achieve these objectives, the NRCA index was used to compute the comparative advantage of crude oil and the panel data technique employed to estimate the relationship between the comparative advantage embodied in the NRCA index and four explanatory variables (COP, PR, DAP, and DDO). Consequently, the sample and the methodology used allowed us to derive meaningful and robust results. These results revealed that not all the top 10 crude oil-producing countries have a comparative advantage in crude oil production. In addition, the four explanatory variables (COP, PR, DAP, and DDO) have significant relationships with the comparative advantage in both long run and short run. Hence the paper concludes that these variables are among the main determinants of the comparative advantage of crude oil production in the sampled countries.

\section{References}

- $\quad$ Abidin, M. Z., \& Loke, W. H. (2008). Revealed comparative advantage of Malaysian exports: The case for changing export composition. Asian Economic Papers, 7(3), 130-147.

- Ahrend, R. (2006). Russian industrial restructuring: Trends in productivity, competitiveness and comparative advantage. Post-Communist Economies, 18(3), 277-295.

- Balassa, B. (1965). Trade liberalisation and "revealed" comparative advantage 1. The Manchester school, 33(2), 99-123.

- Balogh, J. M., \& Jámbor, A. (2017). Determinants of revealed comparative advantages: The case of cheese trade in the European Union. Acta Alimentaria, 46(3), 305-311.

- $\quad$ Batra, A., \& Khan, Z. (2005). Revealed comparative advantage: An analysis for India and China (No. 168). Working paper.

- Bebek, U.G. (2017). RCA: Choosing the Right Measure. Department of Economics, University of Birmingham.

- Bojnec, $\breve{S}$. (2001). Trade and revealed comparative advantage measures: regional and central and east European agricultural trade. Eastern European Economics, 39(2), 72-98.

- Bolbol, A. A., \& Young, L. (1992). Development with limited and unlimited supplies of capital. The Manchester School of Economic \& Social Studies, 60(3), 307-316.

- Breitung, J., \& Pesaran, M. H. (2008). Unit roots and cointegration in panels. In The econometrics of panel data (pp. 279-322). Springer, Berlin, Heidelberg.

- Brémond, V., Hache, E., \& Mignon, V. (2012). Does OPEC still exist as a cartel? An empirical investigation. Energy Economics, 34(1), 125-131.

- Chi, T., \& Kilduff, P. (2006). An assessment of trends in China's comparative advantages in textile machinery, man-made fibers, textiles and apparel. Journal of the Textile Institute, 97(2), 173-191.

- Cologni, A., \& Manera, M. (2014). On the economic determinants of oil production: Theoretical analysis and empirical evidence for small exporting countries. Energy Economics, 44, 68-79.

- Du Toit, L., Fourie, J., \& Trew, D. (2010). The sources of comparative advantage in tourism. Stellenbosch Economic working papers, 01/10.

- EIA (2017) U.S. Energy Information Administration. Where our oil comes from, https://www.eia.gov/energyexplained/index.php?page=oil_where.

- $\quad$ Fertö, I., \& Hubbard, L. J. (2003). Revealed comparative advantage and competitiveness in Hungarian agrifood sectors. World Economy, 26(2), 247-259.

- Frankel, J. A. (2010). The natural resource curse: a survey (No. w15836). National Bureau of Economic Research. 
- Gunton, T. (2003). Natural resources and regional development: An assessment of dependency and comparative advantage paradigms. Economic Geography, 79(1), 67-94.

- Hamilton, J. D. (2008). Understanding crude oil prices (No. w14492). National Bureau of Economic Research.

- Havrila, I., \& Gunawardana, P. (2003). Analysing comparative advantage and competitiveness: an application to Australia's textile and clothing industries. Australian Economic Papers, 42(1), 103-117.

- Hoang, V. V., Tran, K. T., Tu, B. V., Nguyen, V. N., \& Nguyen, A. Q. (2017). Agricultural Competitiveness of Vietnam by the RCA and the NRCA Indices, and Consistency of Competitiveness Indices. AGRIS on-line Papers in Economics and Informatics, 9(665-2018-3598).

- Kaufmann, R. K., Dees, S., Karadeloglou, P., \& Sanchez, M. (2004). Does OPEC matter? An econometric analysis of oil prices. The Energy Journal, 67-90.

- Krautkraemer, J. A. (1998). Nonrenewable resource scarcity. Journal of Economic literature, 36(4), 20652107.

- Krugman, P. R. (2008). International economics: Theory and policy, 8/E. Pearson Education India.

- Langhammer, R. J. (2004). Revealed comparative advantages in the services trade of the United States, the European Union and Japan: what do they tell us. J. World Investment \& Trade, 5, 887.

- Muriel, B., \& Terra, C. (2009). Sources of comparative advantages in Brazil. Review of Development Economics, 13(1), 15-27.

- Nath, H. K., Liu, L., \& Tochkov, K. (2015). Comparative advantages in US bilateral services trade with China and India. Journal of Asian Economics, 38, 79-92.

- $\quad$ Ndayitwayeko, W. M., Odhiambo, M. O., Korir, M., Nyangweso, P. M., \& Chepng'Eno, W. (2014). Comparative advantage of the eastern and central Africa in the coffee export sector: the case of Burundi. African Crop Science Journal, 22, 987-995.

- $\quad$ Pesaran, M. H., Shin, Y., \& Smith, R. P. (1999). Pooled mean group estimation of dynamic heterogeneous panels. Journal of the American Statistical Association, 94(446), 621-634.

- Ramcharran, H. (2002). Oil production responses to price changes: an empirical application of the competitive model to OPEC and non-OPEC countries. Energy economics, 24(2), 97-106.

- $\quad$ Ratti, R. A., \& Vespignani, J. L. (2015). OPEC and non-OPEC oil production and the global economy. Energy Economics, 50, 364-378.

- Sanidas, E., \& Shin, Y. (2010, June). Comparison of revealed comparative advantage indices with application to trade tendencies of East Asian countries. In 9th Korea and the World Economy Conference, Incheon.

- $\quad$ Sarker, R., \& Ratnasena, S. (2014). Revealed Comparative Advantage and Half-a-Century Competitiveness of Canadian Agriculture: A Case Study of Wheat, Beef, and Pork Sectors. Canadian Journal of Agricultural Economics/Revue canadienne d'agroeconomie, 62(4), 519-544.

- Seleka, T. B., \& Kebakile, P. G. (2017). Export Competitiveness of Botswana's Beef Industry. The International Trade Journal, 31(1), 76-101.

- Seyoum, B. (2007). Revealed comparative advantage and competitiveness in services: A study with special emphasis on developing countries. Journal of Economic Studies, 34(5), 376-388.

- Sharma, P. U. R. U. S. H. O. T. T. A. M., Patel, R. M., \& Srivastava, S. K. (2014). Comparative advantage of Indian soymeal vis-à-vis major exporters. Soybean Research, 12(1), 129-143.

- Svaleryd, H., \& Vlachos, J. (2005). Financial markets, the pattern of industrial specialization and comparative advantage: Evidence from OECD countries. European Economic Review, 49(1), 113-144.

- Utkulu, U., \& Seymen, D. (2004, September). Revealed Comparative Advantage and Competitiveness: Evidence for Turkey vis-à-vis the EU/15. In European trade study group 6th annual conference, ETSG (pp. 1-26).

- Valentine, N., \& Krasnik, G. (2000). SADC trade with the rest of the world: Winning export sectors and revealed comparative advantage ratios. South African journal of economics, 68(2), 114-124.

- Vollrath, T. L. (1991). A theoretical evaluation of alternative trade intensity measures of revealed comparative advantage. Weltwirtschaftliches Archiv, 127(2), 265-280.

- Westerlund, J. (2008). Panel cointegration tests of the Fisher effect. Journal of Applied Econometrics, 23(2), 193-233.

- Westney, R. (2011). Assessing the risk in capital-intensive opportunities. Oil \& Gas Financial Journal. 
- Yeats, A. J. (1985). On the appropriate interpretation of the revealed comparative advantage index: implications of a methodology based on industry sector analysis. Weltwirtschaftliches Archiv, 121(1), 61-73.

- Yu, R., Cai, J., \& Leung, P. (2009). The normalized revealed comparative advantage index. The Annals of Regional Science, 43(1), 267-282.

- Yue, C., \& Hua, P. (2002). Does comparative advantage explains export patterns in China?. China Economic Review, 13(2-3), 276-296.

\section{Citations}

- $\quad$ Figure (1) constructed by the authors using data from British Petroleum (BP) Statistical Review of World Energy (2018).

- Table (1) constructed by the authors using data from British Petroleum (BP) Statistical Review of World Energy (2018)

Appendix A

\begin{tabular}{ccccccccccc}
\hline Year & Brazil & Canada & China & Iran & Iraq & Kuwait & Russia & Saudi & UAE & USA \\
\hline 1990 & -6.4 & -12.1 & -3.5 & 45.1 & 25.8 & 17.1 & 16.9 & 108 & 38.5 & -79.2 \\
1991 & -5.3 & -6.0 & -3.5 & 41.5 & 0.9 & 2.3 & 17.2 & 119.7 & 37.8 & -70.3 \\
1992 & -3.6 & -2.5 & -3.6 & 38.9 & 1.2 & 16.1 & 17.8 & 120.5 & 35.7 & -57.8 \\
1993 & -3.5 & -2.7 & -4.4 & 32.8 & 1.1 & 25.4 & 21.0 & 100.7 & 30.4 & -55.2 \\
1994 & -3.8 & -5.1 & -8.5 & 30.9 & 1.0 & 24.2 & 23.3 & 88.1 & 25.4 & -55.1 \\
1995 & -3.2 & -2.0 & -8.3 & 28.9 & 0.9 & 23.5 & 20.1 & 84.4 & 23.6 & -49.3 \\
1996 & -3.5 & -3.5 & -9.0 & 36 & 1.3 & 26.3 & 20.9 & 100.6 & 26.1 & -58.9 \\
1997 & -3.4 & -3.0 & -10.6 & 27.8 & 8.7 & 24.2 & 20.6 & 95.6 & 25.9 & -57.6 \\
1998 & -1.4 & -1.6 & -8.2 & 18.5 & 9.5 & 15.7 & 13.8 & 60.1 & 19.5 & -39.7 \\
1999 & -1.6 & -6.3 & -14 & 28.1 & 21.3 & 19.4 & 19.1 & 79.0 & 24.9 & -53.4 \\
2000 & -2.6 & -5.3 & -19.8 & 37.4 & 29.2 & 26.8 & 27.6 & 104.3 & 36.5 & -71.7 \\
2001 & -2.1 & -4.9 & -20.1 & 33.0 & 24.2 & 23.1 & 30.2 & 92.0 & 35.0 & -60.9 \\
2002 & -2.3 & -2.9 & -24.8 & 27.7 & 18.6 & 20.7 & 34.4 & 93.7 & 31.4 & -56.9 \\
2003 & -2.6 & -0.5 & -30.2 & 32.5 & 9.5 & 24.0 & 39.6 & 103.4 & 34.2 & -53.3 \\
2004 & -3.6 & 0.3 & -37.8 & 34.8 & 18.3 & 27.5 & 48.6 & 113.8 & 36.7 & -53.5 \\
2005 & -4.5 & -1.9 & -52 & 46.8 & 21.1 & 37.8 & 59.5 & 143.3 & 44.8 & -63.9 \\
2006 & -3.4 & 2.3 & -61.7 & 43.1 & 23.4 & 40.7 & 60.7 & 145 & 48.9 & -67.8 \\
2007 & -2.4 & 5.2 & -65.2 & 44.7 & 26.3 & 39.2 & 63.3 & 135.8 & 43.6 & -63.1 \\
2008 & -2.6 & 14.1 & -78.7 & 50.4 & 36.1 & 46.7 & 68.4 & 157.9 & 50.3 & -71.8 \\
2009 & -1.0 & 12.8 & -65.0 & 40.0 & 29.5 & 36.4 & 58.7 & 119.6 & 44.1 & -57.2 \\
2010 & 0.8 & 14.3 & -76.9 & 42.2 & 31.5 & 37.6 & 65.1 & 129.7 & 38.8 & -62.0 \\
2011 & -0.4 & 16.7 & -90.7 & 56.5 & 41.9 & 48.6 & 70.1 & 159 & 47.2 & -70.5 \\
2012 & -1.0 & 18.4 & -102.1 & 49.4 & 47.2 & 54.2 & 73.5 & 166.9 & 29.4 & -76.5 \\
2013 & -4.0 & 22.1 & -100.1 & 27.1 & 44.3 & 53.0 & 69.9 & 157 & 29.4 & -69.3 \\
2014 & -0.4 & 27.8 & -95.4 & 24.5 & 41.7 & 46.4 & 62.1 & 138.4 & 33.6 & -59.6 \\
2015 & 0.4 & 18.4 & -68.4 & 14.4 & 28.8 & 28.1 & 44.5 & 87.7 & 23.9 & -40.4 \\
2016 & 0.6 & 14.9 & -54.2 & 23.6 & 26.7 & 25.1 & 39.4 & 80.7 & 21.1 & -31.9 \\
\hline & & & & & & & & & & \\
\hline
\end{tabular}

Table 1. NRCA Scores 


\title{
The Impact of Research and Development on Productivity: Case of Turkey
}

\author{
Prof. Dr. Muammer Tekeoğlu (Çukurova University, Turkey) \\ Prof. Dr. Neşe Algan (Çukurova University, Turkey) \\ Asst. Prof. Dr. Erhan İşcan (Çukurova University, Turkey) \\ Ph.D. Candidate Duygu Serin Oktay (Çukurova University, Turkey)
}

\begin{abstract}
Productivity is one of the major research topics in economic literature because of the importance of sustainable development and growth for the countries. Besides, many of the theories stated that technology is the major source of productivity growth in the long run. Especially the productivity acceleration of the countries draw the attention of the researchers after the 90's due to the changes in the technology. Also, these changes expanded the productivity gap between countries in the consequences of changing growth pattern and increasing the size and structure of the economy. Therefore understanding the linkage between research and development and productivity becomes the most important research topic in the economic literature. Due to this importance analyzing the characteristics of productivity become an important issue for the policymakers for setting new policies. By virtue of the growing importance of understanding productivity changes of countries, the aim of this paper is to investigate the interaction between the research and development spending and productivity for Turkey. We used various types of research and development spending and productivity indicators to estimate this linkage using data for the last three decades. The importance of this paper is to clarify the effect of research and development impact on the productivity of Turkey. The results of this paper will enlighten the details of the underlying variables that affect productivity.
\end{abstract}

\section{Introduction}

There is a remarkable increase in productivity for all developing and developed economies in the last three decades. As mentioned in Frascati Manual (1963) research and development activities increased over time rapidly and this increase induced the economic growth through productivity for OECD members. OECD (2003) stated that productivity induced economic growth especially through the rise of information and communication technology. Therefore, in the empirical literature, productivity growth is still the main issue of the economic growth literature within the debates about cross-country productivity differentials and long-lasting effects of R\&D. Debates in the economic theory about the effect of technological progression started with Schumpeter (1934) and defined in his study technology as an important source of economic growth. In his seminal paper Solow (1956) emphasized the technological progress as a major determinant of the economic growth in a neoclassical framework and this emphasize directed the literature to a new pathway. Solow described the technological progress as an exogenous variable and stated that technological advancements promoted the economic growth for some economies. Besides, Lucas (1988) established an economic growth model that is introducing technological change as a key determinant. Likewise, Romer (1990) introduced a growth model that is driven by technological change. These models created the endogenous economic growth theoretical framework for the many types of research that are investigating the effect of the technological change on economic growth. Grossman and Helpman (1991a, 1991b) and Aghion and Howitt (1992, 1998) have emphasized importance of the technological progress through R\&D in their papers for achieving a long-term economic growth with generating spillovers to economy. Especially $R \& D$ is the key for industrial innovation as the main promoter of economic growth and therefore $R \& D$ expenditures have a positive effect on economic progression with increasing output through increasing productivity.

Innovation and technology are very sensitive to R\&D expenditure for producing high value-added goods and services. Besides, innovation and technology is a key element to increase productivity for promoting economic growth. The strong economic growth of the developed and emerging countries after the 1990s showed us the importance of the effect of technology and innovation for productivity growth in the long run. Similarly, developing countries with lower technology that is a boundary for the productivity increase is decoupling from the others. Many researchers asserted that among the other reasons of low productivity like institutional framework, lower quality of the labor and lack of resources, lower technology with lower R\&D expenditure caused the low rate of economic growth.

In the current literature, many of the researchers' found that R\&D spendings as the main promoter for the productivity and cause of the cross-country differences by using various techniques with different country data. In this framework, the main aim of this study is to analyze the effect of R\&D spendings on productivity for Turkey. For this purpose, there will be a detailed analysis of the impact of R\&D on productivity with the R\&D and productivity dataset by using the ARDL technique. In the second section, there will be a view of R\&D spendings and productivity of Turkey. In the third section, the current literature will be analyzed. In the fourth section, 
method, model, and dataset will be introduced. Results will be given in the fifth section and there will be a conclusion in the last section.

\section{R\&D Expenditure and Productivity in Turkey}

Many of the researches in the literature pointed out the productivity changes in an economy induced by R\&D spendings and emphasized as a key component of technological progress for promoting economic growth. Especially the substantial increase in the productivity of European countries and the US drew attention to the impact of R\&D. The case is also similar for Turkey and the data showed a substantial increase in productivity after the 1990s. Besides, R\&D started to increase at the beginning of the 2000 s and reached to $1 \%$ of GDP while the average of OECD is about $2.5 \%$.

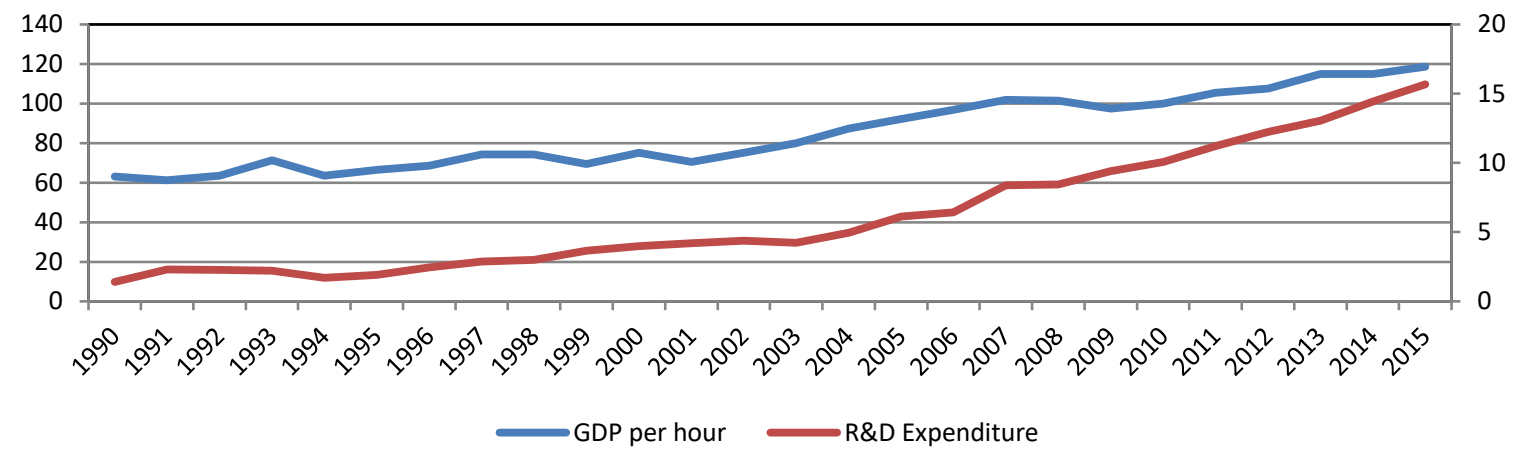

Graph 1: GDP per Hour Worked and Gross Domestic Expenditure on R\&D

R\&D investments are considered as one of the key criteria in evaluating the competitiveness and economic development of a country. Especially, one of the main factors that promote economic growth in developed economies is the innovation of new products and techniques. In this context, due to the importance of R\&D expenditure for the innovation gross domestic spending on R\&D as \%of GDP will reflect the decoupling of the developed countries. Share of the R\&D expenditure is very low from the OECD average in Turkey and implied the results.

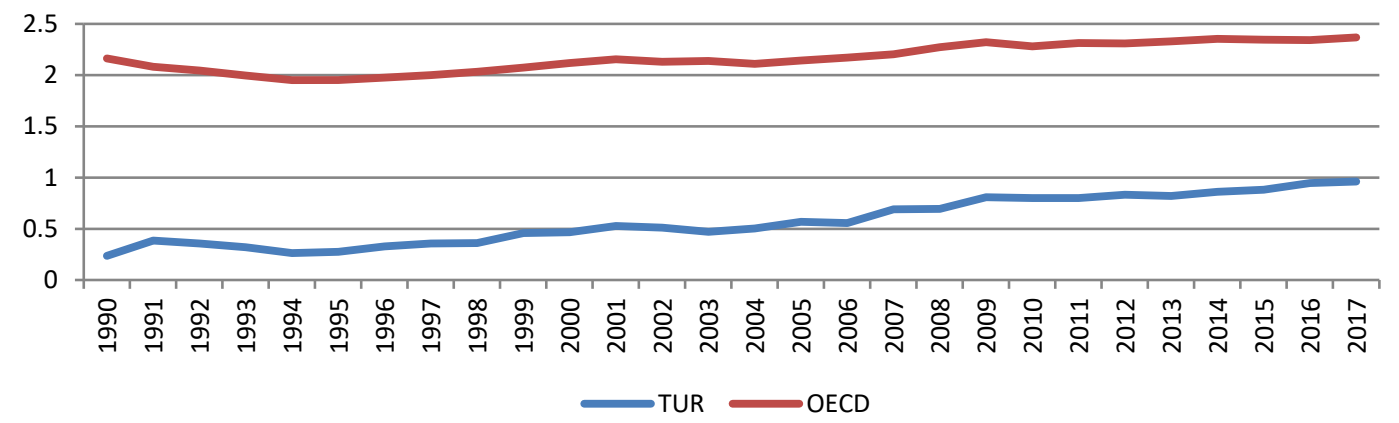

Graph 2: Gross Domestic Spending on R\&D as \% of GDP

\section{Literature Review}

There are a large number of studies in the literature on the analysis of causality and relations between R \& D, patent, innovation, export, and growth. These researches in the current literature have studied the effect of the R\&D on productivity by using various techniques and found different results. Although there is a wide difference between these results of the studies, they revealed the importance of the R\&D for the productivity growth and economic progress within the technological change. But, there is no consensus on the impact of R\&D thus explanations are quite ambiguous for this interaction. Different countries with different levels of $R \& D$ expenditures, different periods with different sectors and different models with variables brought the different results. The main line of the literature stated that technological development and innovation increase export growth and economic growth, while increasing profits and market share of firms. Therefore R\&D expenditures have indirect effect to affect economic growth.

Lichtenberg (1993) analyzed the relationship between private and public sector R\&D expenditures and economic growth and results showed that there is a relationship between R \& D expenditures and growth in the private sector and there is no such relationship in the public sector. Hall and Mairesse (1992) analyzed the relationship between 
R\&D and productivity in their paper and found a positive impact on R\&D expenditures. Griffith, Redding, and Van Reenen (2004) analyzed the impact of R\&D by using the data of 12 OECD countries and found that R\&D is the key to the innovation for economic progression. Rouvinen (2002) conducted research for the OECD countries and found a positive impact of R\&D expenditures. Fikirli and Çetin (2015) analyzed the relationship between $R \& D$ capital stock and total factor productivity and found that R\&D expenditure does not have statistically significant effects on TFP during the period of analysis. Edquist and Henrekson (2017) analyzed the effect of R\&D and ICT on total factor productivity for Sweden and found that R\&D is significantly associated with productivity growth. Besides, there is no significant short-run association between ICT and TFP but a positive association with a lag of seven to eight years. Castellani et. al (2019) investigates the sources of the US/EU productivity gap by using data on the US and EU R\&D expenditures from 2004 to 2012 and found that US firms have higher R\&D impact on productivity than EU firms.

\section{Dataset and Method}

The annual dataset in this analysis was gathered from OECD.stat and consists of Turkey's R\&D expenditure and GDP per hour worked as a proxy for productivity for the period between 1990 and 2015. ARDL bound test method is used to analyze the relationship between these two variables. The variables used in the model and their definitions are as follows.

RDEXP: Gross domestic expenditure on R\&D by sector of performance and type of expenditure. R\&D is in constant prices and PPPs.

GDPPHW: GDP per hour worked. This can be achieved if more capital is used in production or through improved overall efficiency with which labor and capital are used together, i.e., higher multifactor productivity growth (MFP). GDP per hour worked is an index and 2010 is the base year.

Logarithmic transformations of the data sets used in the study were made and conducted a unit root test to determine the order of integration for each variable. Then the ARDL method is employed to determine the relationship between the variables. ARDL method has two advantages for our study. First one is about the integration order of the variables and the second one is the size of the sample. Because of these two advantages, the ARDL method is employed in this study.

\section{Results}

In this study, it was determined that the series were stationary or not and KPSS test is used to investigate the stationary properties of the variables. KPSS test results are as follows. For the KPSS test, the lags were based on bandwidth Newey-West using Bartlett kernel. The critical values for the KPSS test are from Kwiatkowski et al. (1992). KPSS unit root test results indicated that the ARDL method can be used for analyzing the relationship. Even though ARDL method does not require testing for the unit root for stationary, variables must be analyzed for I(2) for using the ARDL method.

\begin{tabular}{|l|l|l|l|l|l|}
\hline \multicolumn{2}{|c|}{} & LM-Stat & $\begin{array}{l}\text { Asymptotic Critical } \\
\text { Values 1\% }\end{array}$ & $\begin{array}{l}\text { Asymptotic Critical } \\
\text { Values 5\% }\end{array}$ & $\begin{array}{l}\text { Asymptotic Critical } \\
\text { Values 10\% }\end{array}$ \\
\hline \multirow{2}{*}{ Level } & \multirow{2}{*}{ T } & 0.712651 & 0.739 & $0.463 *$ & 0.347 \\
\cline { 3 - 6 } 1. Difference & 0.200134 & 0.216 & $0.146^{*}$ & 0.119 \\
\hline \multirow{2}{*}{ Level } & \multirow{2}{*}{ T\&I } & 0.568075 & 0.739 & $0.463^{*}$ & 0.347 \\
\cline { 3 - 6 } 1. Difference & 0.065563 & 0.216 & 0.146 & 0.119 \\
\hline
\end{tabular}

Table 1: KPSS Unit Root Test Results for RDEXP

\begin{tabular}{|l|l|l|l|l|l|}
\hline \multicolumn{2}{|c|}{} & LM-Stat & $\begin{array}{l}\text { Asymptotic Critical } \\
\text { Values 1\% }\end{array}$ & $\begin{array}{l}\text { Asymptotic Critical } \\
\text { Values 5\% }\end{array}$ & $\begin{array}{l}\text { Asymptotic Critical } \\
\text { Values 10\% }\end{array}$ \\
\cline { 1 - 5 } Level & \multirow{2}{*}{$\mathrm{T}$} & 0.733047 & 0.739 & $0.463 *$ & 0.347 \\
\cline { 3 - 6 } 1. Difference & 0.140975 & 0.216 & 0.146 & $0.119^{*}$ \\
\hline \multirow{2}{*}{ Level } & \multirow{2}{*}{ T\&I } & 0.173010 & 0.739 & 0.463 & 0.347 \\
\cline { 3 - 6 } 1. Difference & 0.064856 & 0.216 & 0.146 & 0.119 \\
\hline
\end{tabular}

Table 2: KPSS Unit Root Test Results for GDPPHW

The first step of the ARDL model is to determine the appropriate lag length. In the study, since the number of observations was limited the maximum lag length was taken as three. For the ARDL boundary test, the F statistic was calculated to test the cointegration relationship. If the F statistic is greater than the critical upper limit, the cointegration relationship exists between the series and if it falls below the lower critical value, the cointegration relationship is decided. If the F statistic falls between the lower and upper critical values, then a final decision cannot be made. 


\begin{tabular}{|c|c|c|c|c|c|}
\hline \multirow[t]{2}{*}{ F-statistic } & \multicolumn{2}{|c|}{$\begin{array}{l}\text { Bound critical values (unrestricted } \\
\text { constant and no trend) }\end{array}$} & \multirow[t]{2}{*}{ F-statistic } & \multicolumn{2}{|c|}{$\begin{array}{l}\text { Bound critical values } \\
\text { (restricted intercept and trend) }\end{array}$} \\
\hline & $\mathrm{I}(0)$ & $\mathrm{I}(1)$ & & $\mathrm{I}(0)$ & $\mathrm{I}(1)$ \\
\hline 4.587632 & & & 2.249870 & & \\
\hline $1 \%$ & 6.84 & 7.84 & $1 \%$ & 6.1 & 6.73 \\
\hline $5 \%$ & 4.94 & 5.73 & $5 \%$ & 4.68 & 5.15 \\
\hline $10 \%$ & 4.04 & 4.78 & $10 \%$ & 4.05 & 4.49 \\
\hline
\end{tabular}

Table 3: F-Statistic of a Cointegration Relationship

The cointegration relationship between the variables was investigated and it was concluded that there is no longterm relationship between GDPPHW and RDEXP series. Therefore, the ARDL boundary test approach did not proceed to other stages where long and short term elasticities were obtained respectively.

\section{Conclusion}

The main aim of this study is to analyze the impact R\&D expenditures on the productivity that is essential for economic progression. Although many of the researchers have found a positive impact of R\&D on productivity, there is no such relationship for Turkey. The reason for this kind of result is in fact not a surprise. In the literature, many of the researches stated that import of technology, human capital or organizational and managerial innovations may be the main promoter of productivity growth. The main reason for this result may be the low R\&D expenditure of Turkey. The ratio of total R\&D expenditure is lower than OECD average and developed countries within the differences of characteristics that are promoting productivity.

\section{References}

- Aghion, Philippe, and Peter Howitt. "The Schumpeterian approach to technical change and growth." Economic Growth in the World Economy: Symposium. Vol. 1993. 1992.

- Castellani, Davide, et al. "R\&D and productivity in the US and the EU: Sectoral specificities and differences in the crisis." Technological Forecasting and Social Change 138 (2019): 279-291.

- Edquist, Harald, and Magnus Henrekson. "Do R\&D and ICT affect total factor productivity growth differently?." Telecommunications Policy 41.2 (2017): 106-119.

- Edquist, Harald, and Magnus Henrekson. "Swedish lessons: How important are ICT and R\&D to economic growth?." Structural Change and Economic Dynamics 42 (2017): 1-12.

- $\quad$ Fikirli, Özlem, and Ahmet Kibar Çetin. "Ar-Ge Sermaye Birikiminin Toplam Faktör Verimliliğine Etkisi: Türkiye Örneği." Girişimcilik ve İnovasyon Yönetimi Dergisi 4.2 (2015): 147-166.

- Griffith, Rachel, Stephen Redding, and John Van Reenen. "Mapping the two faces of R\&D: Productivity growth in a panel of OECD industries." Review of economics and statistics 86.4 (2004): 883-895.

- Grossman, Gene M., and Elhanan Helpman. "Trade, knowledge spillovers, and growth." European economic review 35.2-3 (1991): 517-526.

- Grossman, Gene M., and Elhanan Helpman. Innovation and growth in the global economy. MIT press, 1991.

- Hall, Bronwyn H., and Jacques Mairesse. "Exploring the Relationship Between R\&D and Productivity at the Firm Level in French Manufacturing." (1992).

- Howitt, Peter, and Philippe Aghion. "Capital accumulation and innovation as complementary factors in long-run growth." Journal of Economic Growth 3.2 (1998): 111-130.

- Lichtenberg, F.R. (1993), “R\&D Investment and International Productivity Differences”, NBER Working Paper Series, No. 4161.

- $\quad$ Lucas Jr, Robert E. "On the mechanics of economic development." Journal of monetary economics 22.1 (1988): 3-42.

- $\quad$ OECD. "Frascati Manual 1992." (1992).

- OECD (1993), The Measurement of Scientific and Technological Activities: Standard Practice for Surveys of Research and Experimental Development - Frascati Manual 1993, OECD, Paris.

- $\quad$ Romer, Paul M. "Endogenous technological change." Journal of political Economy 98.5, Part 2 (1990): S71S102.

- $\quad$ Rouvinen, Petri. "The existence of R\&D spillovers: A cost function estimation with random coefficients." Economics of Innovation and New Technology 11.6 (2002): 525-541.

- Schumpeter, J.A. (1934) The Theory of Economic Development: An Inquiry into Profits, Capital, Credits, Interest, and the Business Cycle. Transaction Publishers, Piscataway. 
- Solow, Robert M. "A contribution to the theory of economic growth." The quarterly journal of Economics 70.1 (1956): 65-94.

- Solow, Robert M. "A contribution to the theory of economic growth." The quarterly journal of economics 70.1 (1956): 65-94. 


\title{
The Impact of External Instability and Socio-economic Infrastructure on the Productivity Dynamics of North Cyprus
}

\author{
Prof. Dr. Mustafa İsmihan (Eastern Mediterranean University, TR of Northern Cyprus) \\ Prof. Dr. Mustafa Besim (Eastern Mediterranean University, TR of Northern Cyprus) \\ Assoc. Prof. Dr. Kamil Sertoğlu (Eastern Mediterranean University, TR of Northern Cyprus)
}

\begin{abstract}
This study aims to explore the long-term productivity dynamics of the economy of the Turkish Republic of Northern Cyprus by using a simple Autoregressive Distributed Lag (ARDL) Model. More specifically, we aim to analyze the impact of macroeconomic instability and socio-economic infrastructure on total factor productivity over the 1977-2017 period. Additionally, this study develops a socio-economic infrastructure index by combining information from communication, energy, education and health indicators. The main result of this paper is that while total factor productivity is positively and significantly affected by the improvements in socio-economic infrastructure it is negatively affected from the external macroeconomic instability.
\end{abstract}

\section{Introduction}

Productivity growth is of central importance to economic growth and development in every economy. More than half a century ago, Solow (1957) developed a method for decomposing economic growth based on the contribution of the primary factors of production (capital and labor) and the total factor productivity (TFP). In its basic form, neo-classical model postulates that in the long run two critical factors determining growth are exogenously given; respective rates of technological progress and population growth. And, in the medium-term, accumulation of not only labour force which depends on the rate of population growth but also that of physical capital will play a critical role in determining the growth rate of the economy as explained by Solow (1957) and Froyen (1998). In short, for the quantity of output to grow, either the quantity of inputs must grow or productivity must improve, or both.

The literature on definition, measurement and explanation of sources of growth of TFP are extensive. Weil (2005) defines TFP or 'Solow residual' as the multiplication of efficiency and technology. Literally, the growth in TFP measures the improvement of productivity in production function where the improvement can come from various sources including better utilization of tangible and intangible capital (human and organizational) (Jeong and Townsend, 2007).

In this study, we specifically aim to investigate the impact of external macroeconomic instability on TFP. In order to be able to identify a more solid impact of external macroeconomic instability, we add socio-economic infrastructure (by combining communication, energy, education and health indicators) as control variable to our analysis given the critical role of knowledge indicators on TFP -à la endogenous growth models (see, e.g., Chen and Dahlman, 2004, Froyen, 1998). As for the case study, we take North Cyprus economy which is a micro size economy producing approximately 4 billion USD of GDP a year (Besim and Sertoğlu, 2015). The case of North Cyprus is unique as it has very high level of economic relations with Turkey and the channels for instability are diverse and critical. These are both through financial markets as well as products markets. The volume of trade between North Cyprus and Turkey represents more than 80 percent of total trade of North Cyprus (SPO, 2019). The legal tender in North Cyprus is Turkish Lira (TL) which makes the economy to be functioning in the Lirazone with Turkey. So, changes in the value of TL against major hard currencies directly affect the trade and prices in North Cyprus. Monetary policy change by Central Bank of Turkey also has implication on the money market in North Cyprus with different levels of interest rates and amounts of money in the money market. Furthermore, the two leading sectors of North Cyprus, one being tourism and the other higher education, are also generating most of their incomes from Turkey. The other channel that stands as a potential instability channel is the fiscal assistance of Turkey to North Cyprus, though have been declining in the recent years, it varies from 20-30 percent of the budget. This fiscal dependence of North Cyprus, at times when Turkey faces financial difficulties, jeopardizes the flow of capital that is budgeted for infrastructure investments as well as for financing the deficit in the recurrent budget. All these explained channels are potential vehicles for the transmission of the instability to North Cyprus economy.

From an economic view point, our main motivation is to understand to what extent macroeconomic stability in Turkey has significant impact on the TFP in North Cyprus. In this respect, in the following section we introduce our model and then provide and interpret the preliminary empirical results. 


\section{The Model and Empirical Results}

In this study we follow Musolesi (2011) and utilize a TFP framework to analyze the impact of macroeconomic instability and socio-economic infrastructure on total factor productivity. In doing so, the following TFP model is considered:

$$
\operatorname{Ln} A_{t}=\beta_{0}+\beta_{1} \operatorname{Ln} S_{t}+\beta_{2} \operatorname{Ln} I_{t}
$$

where $A_{t}=$ TFP (Solow Residual), $S_{t}=$ Socio-economic infrastructure; $I_{t}=$ external macroeconomic instability and $\mathrm{Ln}=$ natural logarithm. [It should be noted that Equation (1) is derived from $A_{t}=\beta_{0}{ }^{\prime} S_{t}^{\beta_{1}} I_{t}^{\beta_{2}}$ ]

Before we estimate the above TFP equation with the yearly time series data from 1977 to 2017 (The data sources and definitions are provided in the appendix.), it is essential to determine the time-series properties (i.e. the presence of a unit root) in each series. Table 1 presents the ADF test results. When we consider the levels of all the variables ( $\mathrm{Ln}$ A50, LnA35, Ln I and Ln S), the null hypothesis of a unit root is not rejected at the 5\% significance level. Furthermore, the null of a unit root for the first differences of the variables are rejected at the $1 \%$ significance level. Thus, all of these variables seem to contain a unit root at the $5 \%$ significance level. However, the results are not clear at the $10 \%$ significance level for all variables except $\mathrm{Ln} \mathrm{S}$.

\begin{tabular}{|l|c|c|c|}
\hline \multirow{2}{*}{ Variables } & \multicolumn{3}{|c|}{ ADF Tests } \\
\cline { 2 - 4 } & \multicolumn{2}{|c|}{ Level } & First Difference \\
\cline { 2 - 4 } & Without Trend & With Trend & Without Trend \\
\hline Ln A50 & $-1.6090(1)^{\mathrm{b}}[0.4686]^{\mathrm{c}}$ & $-3.4422(1)[0.0604]$ & $-4.6027(0)[0.0007]$ \\
\hline Ln A35 & $-1.1924(1)[0.6681]$ & $-3.3224(1)[0.0704]$ & $-4.4377(0)[0.00010]$ \\
\hline Ln S & $-1.0835(0)[0.7130]$ & $-1.6851(0)[0.7394]$ & $-6.2711(0)[0.0000]$ \\
\hline Ln I & $-2.6269(0)[0.0961]$ & $-6.1906(0)[0.0000]$ \\
\hline
\end{tabular}

Table 1. ADF Tests

The dynamic empirical relationship between socio-economic infrastructure, external instability and TFP can be analyzed by using cointegration approach. However, when we take into account the possibility of the mix of $\mathrm{I}(0)$ and I(1) variables, the above TFP model is estimated with the ARDL technique. The long-run estimation result is as follows (ARDL Bounds test confirms the existence of cointegration relation):

$$
\begin{gathered}
\operatorname{Ln} A 35_{t}=4.547+0.777 \operatorname{Ln} S_{t}-0.549 \operatorname{Ln} I_{t} \\
{[0.0000] \quad[0.0030]}
\end{gathered}
$$

Note: $p$-values are provided in square brackets.

This equation indicates that while total factor productivity is positively and significantly affected by the improvements in socio-economic infrastructure it is negatively affected from the external macroeconomic instability. All these results are consistent with a priori expectations mentioned in Section 1 (It should be also noted here that we obtained similar results with Ln A50 used as a dependent variable and when we consider the inflation rate of North Cyprus as an additional control variable).

\section{Conclusion}

Our preliminary results indicate that external macroeconomic instability has detrimental effects on TFP whereas improvements in socio-economic infrastructure improve productivity. This results which are in line with the work of İsmihan and Özcan (2009), implies that, macroeconomic instability in Turkey distorts the resource allocation by creating uncertainty and has a negative impact on the TFP in North Cyprus -through various channels. The results also show that North Cyprus economy is highly fragile given the permanent negative impact of external instability on TFP. 


\section{Appendix}

\section{Data Definitions and Sources}

A refers to the estimated TFP (Solow residual) with $\alpha$ set at 0.50 and $0.35\left[\mathrm{~A}=\mathrm{Y} /\left(\mathrm{K}^{\alpha} \cdot \mathrm{L}^{1-\alpha}\right)\right]$ (see, İsmihan and Metin-Ozcan, 2006).

Y (output) is measured by GDP (at 1977 prices).

$\mathbf{K}$ (physical capital stock) is calculated by perpetual inventory method as in Ismihan and Metin-Ozcan (2006). Gross fixed capital investment is used in calculation of $\mathrm{K}$.

$\mathbf{L}$ (labor input) is measured by employment data.

The Socio-economic Infrastructure Index (S) is developed by combining information from communication, energy, education and health indicators. This index is calculated by using human development index (HDI) methodology and it is a weighted average of the four sub-indices obtained from those four indicator by using the principal components analysis.

Macroeconomic Instability Index (I or INSW) is developed by İsmihan $(2009,2012)$ and used as a proxy for macroeconomic instability. This index is calculated by using human development index (HDI) methodology and it is based on four macroeconomic instability indicators; namely, public deficit to GDP ratio, inflation rate, change in the current account balance to GDP ratio and change in exchange rate. Note that the absolute values of the last three indicators are used. INSW is a weighted average of the four sub-indices obtained from these four variables and the respective weights are determined by using the principal components analysis. Source: İsmihan (2012).

All the data for the North Cyprus economy are obtained from State Planning Organization.

\section{References}

- Besim, M. and Sertoğlu, K., 2015. Kuzey Kıbrıs Türk Cumhuriyeti’nde İstikrarlı ve Sürdürülebilir Ekonomik Büyüme: Sektör Temelli Analiz ve Politika Önerileri [Stable and Sustainable Economic Growth in the Turkish Republic of Northern Cyprus: Sectoral Analysis and Policy Recommendations], Report, Eastern Mediterranean University. Famagusta, North Cyprus.

- Chen, D. H. C. and Dahlman C. J., 2004."Knowledge and Development: A Cross-Section Approach", World Bank Research Working Paper 3366.

- Froyen, R., 1998. Macroeconomics, Prentice-Hall, London.

- İsmihan, M. (2009). The Role of Politics and Instability in Macroeconomic Performance: Theory and Lessons from the Turkish Experience. VDM Verlag Dr. Muller, Saarbrucken, Germany.

- İsmihan, M. and Metin-Ozcan, K., 2006. "Türkiye Ekonomisinde Büyümenin Kaynakları, 1960-2004", İktisat İsletme ve Finans, 241, pp. 74-86.

- İsmihan, M., 2012. "The Political Economy of Productivity Collapses and Accelerations: The Turkish Experience, 1950-2010", in Proceedings of ICE-TEA (Türkiye Ekonomi Kurumu, Uluslararası Ekonomi Konferans1 2012), 1-3 November 2012, İzmir, Türkiye.

- Jeong, H. and Townsend, R.M., 2007. "Sources of TFP Growth: Occupational Choice and Financial Deepening", Economic Theory, 32, p. 179.

- Musolesi, A., 2011. "On Public Capital Hypothesis with Breaks", Economics Letters, 110, pp. 20-24.

- Solow, R., 1957. "Technical Change and the Aggregate Production Function", Review of Economics and Statistics, 39, pp. 312-20.

- SPO, 2019. Statistical Year Book, State Planning Organization, Prime Ministry, Nicosia, North Cyprus.

- Weil, D., 2005. Economic Growth. Addison Wesley, Boston. 


\title{
Dünyadaki Ekonomik İşbirlikleri ve Ütopik Avrasya Economic Cooperation in the World and Utopian Eurasia
}

\author{
Assoc. Prof. Dr. Hakkı Çiftçi (Çukurova University, Turkey)
}

\begin{abstract}
In the first part of this study, Economic Cooperation and Utopian Eurasia, the main characteristics of the new collaborations in the world, the concept of economic cooperation, the effects of the elements, the economic cooperation, the characteristics of structural adjustment, the global market targets with the economic cooperation, the adaptation possibilities and problems of the economic cooperation will be explained. Based on the Eurasian concept, the basic population, economic structure and development potential of the Eurasian Economic Union will be discussed. In the third and the last part, together with the transformations in the world, which carry the confrontational processes, it will be included in the contemporary communication to achieve the success of the economic cooperation by means of the common communication network and the changes in the areas where the rapid change between the political, economic, cultural, technological and social decision-making centers become up-to-date. the necessity of being equipped with sufficient information about economic associations and developments, the success of the country in the field of economy, the changes and developments occurring in the world will be evaluated in the context of Eurasian economic cooperation and the results and suggestions will be made.
\end{abstract}

\section{Giriş}

Dünya ekonomisindeki gelişmeler dikkate alındığında ekonomik işbirliklerine dahil olmadan bugün artık hiçbir ülke kendi iç yapısı çerçevesinde oluşan, sosyo,ekonomik, politik, kültürel, ekonomik gelişmeler ve hatta bilim ve teknoloji ile gelişemez, kendi kendine yeter sandığı bir ekonomi kurup onun dar bilgi ve olanakları çerçevesinde yaşayamaz. Temelleri İkinci Dünya Savaşına kadar uzanan, ancak 1980'li yıllarda teknoloji ve iletişim alanındaki gelişmelerle adından sıkça söz ettirmeye başlayan Küreselleşme olgusuyla artık, ekonomik, sosyal, siyasal ve kültürel olarak bütünleşen ve homojenleşen bir dünya oluşmaktadır. Bu oluşum kendini zaman içinde iki yönde geliştirmiştir. Bunlardan biri; bütünleşme ve tek bir dünya olma amacını gerçekleştirmek için ülkeler arasındaki gümrük tarifeleri ve diğer ticaret kısıtlamalarının azaltılması ve kaldırılmasını öngören GATT Anlaşması tarzı anlaşmalar, yani evrenselleşme, diğeri ise birbirleriyle gerek ekonomik gerekse coğrafi olarak benzerlik gösteren ülkeler arasındaki ticaretin serbestleştirilmesi amacına yönelik ekonomik entegrasyonlar, yani bölgeselleşme hareketleridir. Bulunulan dönemin şartlarına göre küreselleşme, belli bir bölge ve ideolojiyi paylaşan ülkeler arasında olabileceği gibi, her bölgeyi ve ekonomik yapıyı kendisine yaklaştırarak belirli bir sistem ve düzen dahilinde işbirliklerini sağlamaya yönelik de olabilmektedir. Ülkeler, bugün kendilerinden geri olan ülkelere karş1 küreselleşmeyi kullanırken, kendilerine ekonomik, teknolojik bakımdan rakip olan kutuplara karşı birleşerek entegrasyonlar oluştur-maktadırlar. Küreselleşme yolunda da bu kutuplar arasında çeşitli temas ve anlaşmalar gerçekleşmektedir. Dünyanın tek süper gücü olan A.B.D. bile, İngiltere veya kendi bölgesindeki ülkelerle kültürel, ticari, ekonomik ve politik işbirliklerine gitme yoluyla yalnız kalmaktan kaçınmaktadır. Aynı zamanda diğer güçlü kutup olan Avrupa (AB) ile ve çıkarlarına uygun kaynakları sağlayacak veya stratejik önemi olan ülkelerle de küreselleşmeye yönelik ilişkiler kurmaktadır. Birbirine zit gibi gözüken bu iki gelişim, küreselleşme ve bölgeselleşme; genel görüş itibarıyla aslında birbirinin zıttı değil tamamlayıcısıdır. Bölgesel bir entegrasyona dahil olmak küreselleşme yolunda atılan ilk adımdır (Harman,1996:23).

Bu kapsamda eğitim, bilim ve teknoloji, sanayileşme, ticaret. rekabet ve işgücü piyasalarıyla ilgili politikaların yeniden düzenlenmesi önem taşımaktadır. Yapılan bu çalışma; dünyadaki işbirliklerinin Avrasya üzerindeki etkilerini ve dünya ülkelerinde ortaya çıkan radikal ekonomik ve teknolojik değişimlerin genel karakteristiklerini irdelemek ve bu kapsamda değişmeleri ortaya çıkaran global olguların ve ekonomik işbirliklerinin doğasına yönelik incelemelerde bulunmayı amaçlamakta ve dünyadaki ekonomik birliklerdeki gelişmeler karşısındaki durumu irdelenmeye çalışılmaktadır. Yine, bu kapsamda Avrasya'nın yeni sürece adapte olabilmesi için mevcut sanayi yapısı, bilim ve teknoloji politikası konularında neler yapması gerektiği hususu üzerinde durulmaktadır. Bu yapılırken çoğunlukla global bağlantıları çoğaltacak ekonomik faaliyet alanlarının hangileri olduğu ve bunların mevcut durumlarının bir dökümü yapılmaya çalışılacaktır.

\section{Dünyadaki Ekonomik İşbirlikleri}

Genel olarak, dünyadaki ekonomik işbirliklerinin politik ekonomik, sosyolojik, kültürel ve teknolojik açıdan yayılması, massedilmesi, benimsenmesi ülkelerin gelişmişliğinin boyutuyla da farklı anlamlar ve katkılar yükleyecektir. Söz konusu ekonomik birleşme hareketlerinden Gelişmiş Ülkelerin ve Gelişmekte Olan Ülkelerin bekledikleri faydalar, karşılaşacakları tehditler, sorunlar ve sonuçları farklı olabileceği gibi, eğer gelişmişlik düzeyleri farklı olan bu ülkeler aynı ekonomik entegrasyon içinde yer alırsa, gelişmişliklerin düzeyiyle alakalı 
kazanımları, güçlülükleri ve zayıflıkları da bu katılımdan doğacak sonuç ve beklentiler de farklı olacaktır (Ertürk, 1996: 169). Çünkü Gelişmekte Olan Ülkeler, bu değişime bünyevi olarak güçlü olan gelişmiş ülkelere göre entegrasyonu sanayileşmeyi başlatan bir araç olarak görürken; Gelişmiş Ülkeler, bir çok alanda kaynaklarını tam olarak etkin olarak yerinde kullandıkları için beklentilerinde sanayileşme hızını arttırmak kadar sanayileşmede ulaşılan düzeyi de koruma aracı olarak hegemonik entegrasyona yönelirler (İncekara, 1995:87). Dolayısıyla farklı gelişmişlik düzeyinde bulunan ülkelerin orantısız güç, imkan, firsat ve kaynak açısından oluşturulacak tehdit ve tehlikelere gögüs germe açısından aynı grup içinde yer alması gelişmişlik düzeyi düşük olan ülkelerin bu durumdan olumsuz etkilenmesine sebep olur (Tuna, 1995: 22).

Ekonomik Entegrasyon kuran blokların genişlemesi, gittikçe daha fazla ülkenin ekonomi alanındaki kapasitelerini birleştirmeleri, ancak blok dışına karşı kendi ortak ticari kurallarını koyarak kendilerini korumaları hem küreselleşmeyi hem de bölgeselleşmeyi birarada sağlayan durumu karşımıza çıkarmaktadır. Post modern politik ekonominin yaşandığ 1 bu dönemde enformasyon teknolojileri devrimi”nin başladığı süreçte yüksek teknolojileriyle beraber oluşan küresel sistemin ekonomi politiğinde katma değer ekonomisi yönüyle hem karşılıklı ekonomik bağımlılık hem de karlılık açısından ekonomik birliklerin kurulmasında önemli değişmeler meydana gelmiştir: bu değişimin neticesinde jeopolitik olarak doğu bloku çökmüş, soğuk savaş sona ermiş ve tek kutuplu bir dünya düzeni ortaya çıkmıştır.

Dünya, 1980' li yıllarla birlikte enformatik teknolojiler sayesinde her alanda radikal sayılabilecek dönüşümlerle bir hızlanma etkisi yaşamaktadır. 20.yy'dan ve 21.yy 'a doğru kabuksal dönüşüm ünitercilikten, federal konfederal yapılanmalara, merkeziyetçilikten, küresel ve yöresel anlayışa, merkez yönetimden merkez yönlendirime, bürokratik yoğunluktan katılımcılığa, emir ve kontrolden duyarlı ve hesap verebilirliğe, içe bağımlılıktan rekabetçi yapıya, kapalı ve yavaşlıktan açık ve hızlılığa geçiş, riskten kaçıştan riske açık olmaya varana kadar bir çok alanda yeni yapılanmalar ve değişimler. Bu hılanma etkisi, yeni servet yaratma sisteminin adı olmakta ve ekonomik ilerlemenin kaynağını oluşturmaktadır.(Dura,2000:8).

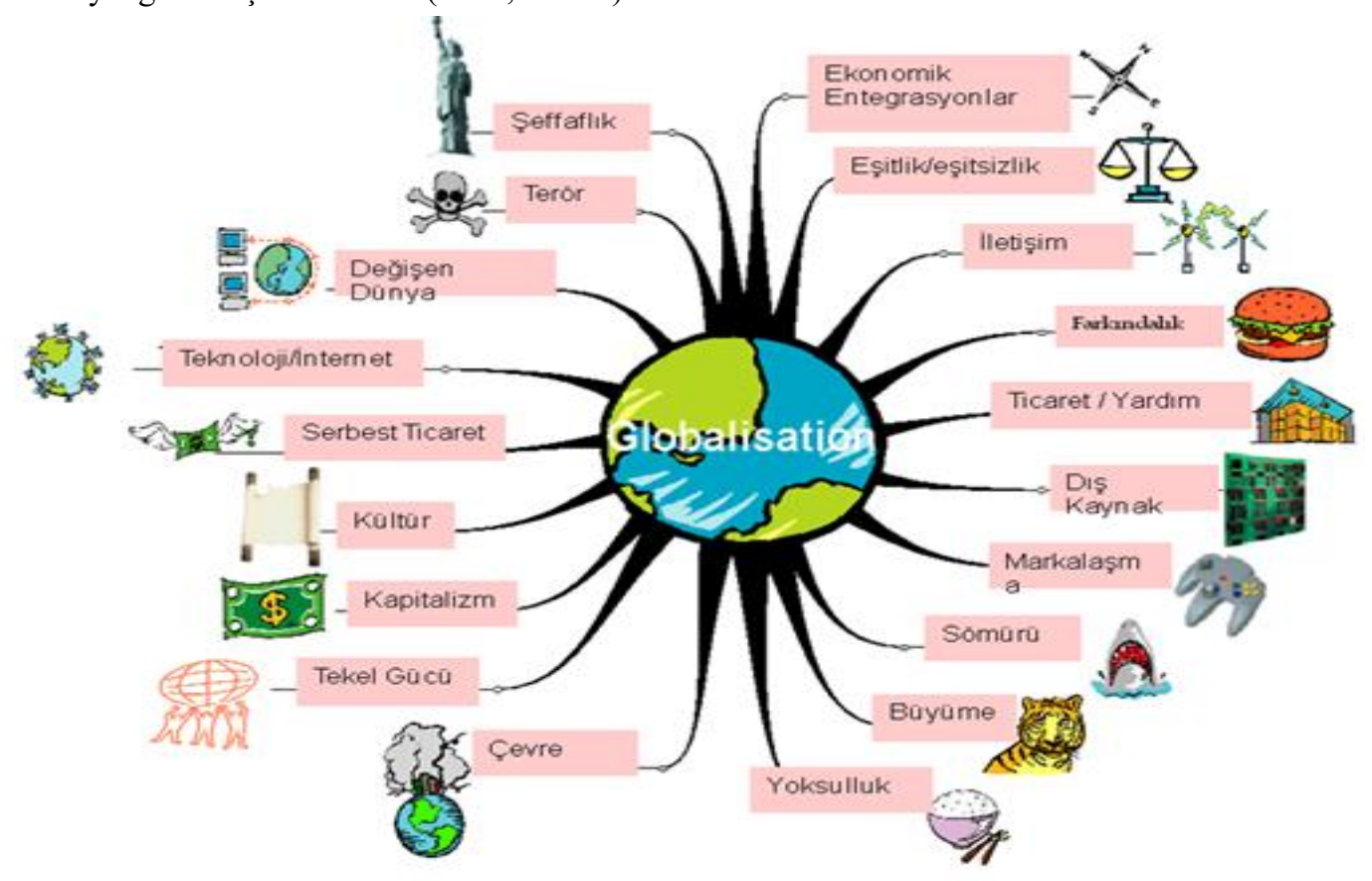

Şekil 1. Beşinci Küreselleşme Dalgasının Etkileri Kaynakça:

https://www.toppr.com/guides/economics/globalisation-and-the-indian-economy/globalisation-and-the-indianeconomy/

$\mathrm{Bu}$ dönüşümle birlikte ekonomik alanda da yeni servet yaratma sistemi içinde, rekabet etmek isteyen ülkeler. rekabet edenlerin temposunda hareket etmeye mecbur olacaklardır.. 21.yüzyıl sahnesi birleştirici ve çatışmacı süreçleri de bünyesinde taşıyan dönüşümlerle birlikte, dünyadaki kurulacak ekonomik birlikteliklerin verimliliğin ve etkinliğin arttırılması ölçütü yanında bilginin ortak iletişim şebekesi kanalıyla politik, ekonomik ve sosyal karar alma odakları arasındaki hızlı değişiminin güncellik kazandığı maliyetleri düşürücü, rekabet güçlerini arttırıcı, fiyatları kontrol edici düzgün işleyen ekonomik yapıya doğru bir perdeyle açılmaktadır. Yeni ekonomik birliktelikler, katma değer ekonomileri, maliyet avantajları, yüksek teknolojiler ve bunların etkisiyle ortaya çıkan yeni yaşam stilleri bilgi toplumu ve yeni ekonomi adıyla yeni bir ileri ve yüksek teknolojiye aşina bir toplum biçimini şekillendirmektedir(Şengönül A., İsmail,T 2004:5). 


\begin{tabular}{|l|l|l|}
\hline Fonksiyonel Sınıflandırma & Siyasi Sınıflandırma & Yükümlülük Sınıflandırması \\
\hline $\begin{array}{l}\text { Serbest Ticaret Bölgeleri } \\
\text { Ortak Pazar } \\
\text { Gümrük Birliği }\end{array}$ & $\begin{array}{l}\text { Saf Ekonomik Entegrasyonlar } \\
\text { (laissez-faire, laissez passer) }\end{array}$ & $\begin{array}{l}\text { Negatif Entegrasyonlar } \\
\text { Yapmama Yükümlülü̈̆̈̈ }\end{array}$ \\
\hline $\begin{array}{l}\text { Sosyo-politik Entegrasyonlara } \\
\text { Hazırlık Aşaması }\end{array}$ & $\begin{array}{l}\text { Sosyo-politik Entegrasyonlar } \\
\text { (Küreselleşme) }\end{array}$ & $\begin{array}{l}\text { Pozitif Entegrasyonlar } \\
\text { Yapma Yükümlülüğ̈̈ }\end{array}$ \\
\hline Ekonomik ve Parasal Birlik & & \\
\hline Tam Ekonomik Birlik & & \\
\hline
\end{tabular}

Tablo:1. Ekonomik Birliklerin Temel Sinıflandırılması

Tablo:1'de de görüldüğü üzere bu değişim ve dönüşüm sonucunda Serbest ticaret bölgeleri, ortak pazar, gümrük birliği, sosyo-politik entegrasyonlar, ekonomik ve parasal birlik ve tam ekonomik birlik şekliyle bazen de siyasi açıdan yükümlülük sınıflandırılması şeklinde ekonomik, siyasi, sosyal, kültürel ve politik birlikler tasnif edilebilir.

Soğuk savaş döneminin ve ulus devletlerin terminolojisi, yeni ekonominin ve bilgi toplumunun şekillendirdiği enformasyon teknolojileri devrimi ile bütünleşen bu yeni küreselleşme dalgasını ve bu dalganın ekonomik, sosyal ve politik yapılar üzerindeki etkilerini açıklamada yetersiz kalmıştır. soğuk savaş döneminin ve ulus devletlerin terminolojisi, enformasyon teknolojileri devrimi ile bütünleşen bu yeni küreselleşme dalgasını ve bu dalganın ekonomik, sosyal ve politik yapılar üzerindeki etkilerini açıklamada yetersiz kalmıştır. Dünyadaki ekonomik birliklerin nüvesi sanayi toplumunun çok boyutluluğu ve çeşitliliği bağımlılığı, bilgi iletişim ve yüksek teknoloji ile insanlığın yenilenmeye benzer biçimde bilgi toplumuyla da bir yenilenme süreci ve katma değer ekonomisi ekonomik birlikleri bazen karşılaştırmalı bazen mutlak üstünlük bazen de faktör donatımı ile rekabet gücünü arttırıcı etkiyi apaçık ortaya çıkmaktadır. Hatta bu sürecin, toplumları sanayi toplumundan çok daha köklü bir değişim, birliktelik, bağımlılık ve dönüşüme uğratması beklenmektedir Şengönül Ahmet, İsmail Tuncer;,2004:161. Ancak, bilgi teknolojisindeki hızlı gelişmelerin, sosyal, ekonomik, politik ve kültürel alanlarda ne tür değişmeler yaratacağını bugünden kestirebilmek güçtür. İki kutuplu dünya düzeni, Tek kutuplu dünya düzeni, Çok kutuplu ya da iki kutuplu dünya düzeni ve buna etki edecek güç merkezleri-ülkeler gibi kategoriler ölçütünde yakın geçmişten bugünümüze yaklaşı son yüzyılda 1950-1990 yılları arasında iki kutuplu dünya, Soğuk savaş dönemi - gerginliğe dayalı caydırıcı denge stratejisi, 1990-2018 yılına kadar hegamon - biçimlendirici devlet olarak ABD'nin tartışmasız üstünlüğü öngörülebilir, 2018'den sonra görünürde iki merkezli bir denge stratejisi ABD-ÇIN (uzlaştırıcı-dengeleyici işlev üstlenen güç merkezleri/LATİN AMERİKA-AB-JAPONYARUSYA (Avrasya vizyonu-İmparatorluk planları)-HINDİSTAN), Küresel ekonomi-sosyal liberalizm - uygar denge stratejisi (2018-2050 SÜRECI).

Bu tematik öğeler çerçevesindeki birlikteliklerden bazıları bölgelere göre sermayenin 20. yüzyılda oluşturduğu küresel boyuttaki önemli yapılanmaları arasında ICC - International Chamber of Commerce (Uluslararası Ticaret Odas1) Merkezi Paris 1918, 1945 sonras1 IMF -İnternational Monetary Found (Uluslararas1 Para Fonu), WB World Bank (Dünya Bankası), BM-GATT - The General Agreement on Tariffs And Trade (Tarifeler ve Ticaret Genel Anlaşmas1), OECD -Organisation for Economic Co-operation and Development (Ekonomik Kalkınma ve İşbirliği Teşkilatı) Merkezi Paris 1960, 1970'lerde WEF - World Economic Forum (Dünya Ekonomik Formu), 1994'teWTO -World Trade Organisation (Dünya Ticaret Örgütü) TABD - Transatlantic Business Dialog (Atlantik ötesi Sermaye Diyaloğu)1995 TAFTA - Transatlantic Free Trade Agreement/NTM - New Transatlantic Marketplace (Atlantik Ötesi Serbest Ticaret Anlaşmas1) TEP - Transatlantic Economic Partnership (Atlantik Ötesi Ekonomik Ortaklık) 1998 bulunmaktadır. Avrupa'da: Avrupa Serbest Ticaret Bölgesi (EFTA), Avrupa Birliği (AB), Kuzey Avrupa Ülkeleri Topluluğu (NC), Karadeniz Ekonomik İşbirliği Bölgesi (KEİB), Bağımsız Devletler Topluluğu ve Baltık Gümrük Birliği (BDT). Asya’da: Güney Doğu Asya Ulusları Birliği (ASEAN), Ekonomik İşbirliği Teşkilatı (ECO), Körfez İşbirliği Konseyi (GCC), Mısır, Suriye Ürdün ve Lübnan arasında ekonomik ve siyasal amaçlı (MAŞREK). Amerika'da: Latin Amerika Serbest Ticaret Bölgesi (LAFTA 1980 sonrasında LAIA adını almıştır.), Cartagena Anlaşması ile 1969'da kurulmuş olan (AND Paktı), Merkezi Amerika Ortak Pazarı (CACM), Karayip Ülkeleri Topluluğu (CARICON), Kuzey Amerika Serbest Ticaret Anlaşması (NAFTA), Brezilya, Arjantin, Paraguay ve Uruguay arasında 1991'de imzalanan (MERCOSUR). Afrika'da: Batı Afrika Ülkeleri Ekonomik Topluluğu (ECOWAS), Merkezi Afrika Gümrük ve Ekonomik Birliği (UDEAC), Fas, Tunus ve Cezayir arasında kurulan Siyasi ve Ekonomik İşbirliği Teşkilatı (MAGREB). Bu bağlamda konuya ilişkin analizlerin ve politik, ekonomik, sosyolojik, kültürel ve teknolojik birlikteliklerin çeşitli boyutlarda sürdürülmesi ve değerlendirilmesi gerekliliğinden söz edilebilir. Çalışmamız bu alandaki analizlere bir katkıda bulunabilmek üzere Avrasya'da oluşan birlikteliğin öneminin kavranılamadığı ve ihmal edildiği kanaatiyle Ütopik Avrasya bu birlikteliğin içinden adeta cımbızla çekilerek alınmıştır(İyibozkurt,2001:89).

\section{Dünyadaki Ekonomik Birliklerin Etkileri}

Günümüzde globalleşmenin önemini ve gerekliliğini anlayamamış ülkeler kendi pazar payını daha düşük maliyetlere, daha çok deneyime, daha iyi ürünlere ve tüketicilere daha fazla değer sunan rakiplerine karş1 kaybetmek zorunda kalmaktadır. işte böyle bir rekabetin çarkları arasında ezilmemek ve hatta başarıya ulaşabilmek 
için çağdaş gelişmeler hakkında yeterli bilgi ile donatılmış bulunmak zorunludur. Artık bir ülkenin ekonomi alanında başarıya ulaşması da, dünyada meydana gelen değişme ve gelişmeleri çok iyi izlemesine bağlıdır. Bu bağlamda. bugün artık hiçbir ülke kendi iç yapısı çerçevesinde oluşan, bilim ve teknoloji ile gelişemez, kendi kendine yeter sandığı bir ekonomi kurup onun dar bilgi ve olanakları çerçevesinde yaşayamaz. Ekonomik birlikler ile dünya ile bilgi alıverişine girmek. onlarla ekonomik ilişkiler kurmak zorundadır. Bir ekonominin öteki ekonomilerle kuracağı ilişki geçmiş yıllarda bile karmaşıktı. Günümüzde bir ülkenin ekonomi alanında başarıya ulaşabilmesi için dünyayı, dünyada meydana gelen değişme ve gelişmeleri çok iyi izlemesi, onları öğrenmesi, hatta sağlıklı tahminlerde bulunarak gerekli tedbirleri zamanında alabilecek bir uyanıklığa, bilgiye sahip olması zorunludur. Bu bütün yenilikleri devamlı olarak yakından izlemekle mümkün olabilir(Karluk,1991:37).Ekonomik birlikteliklerin ve bölgesel oluşumların küreselleşmeye bir alternatif olmadığı ve küreselleşmeyi besleyen yapılar olduğu konusunu kısa bir iki bilgi ile sunuşu tamamlayabiliriz. Post modern politik ekonomi ya da enformatik gelişmelerin hızla yaşandığı beşinci küreselleşme dalgası diye adlandırılan döneme varıncaya kadar son iki asır teknoloji, ekonomilerin büyümesi ve toplumsal dönüşümlerin gerçekleştirilmesinde güçlü bir araç rolünü üstlenmiştir(Yıldız, Ş. \&Künü, S. 2018:612.. Ekonomik birliklerde ekonominin. kurumların ve kişilerin amaçlarına uygun düşmek şartıyla, yeniliğe dönüştürülmüş her teknolojik aşama, toplumlara sağladığı faydalar, hız ve esneklik açısından oluşturduğu avantajlar sayesinde karşı çıkanları olsa bile, yine de içinde doğduğu toplumu veya sektörü etkilemiş ve de önemlilik derecesine bağlı olarak uluslararası bir yayılma etkisi göstermiştir(Tekeoğlu, 1993:.13\}. Özellikle post modern politik dönemde, teknolojinin etkisi ekonominin her sektör alanında daha çok artmış gözükmektedir. Günümüz gelişmiş sınai toplumlarında ortaya çıkan. ancak gelişmekte olan ülkelerin de kayıtsız kalamadığı hızlı teknolojik gelişmeler, üretim sistemlerinde ve ekonomik yapıların güçlenmesinde köklü bir değişime neden olmuştur. Teknolojinin massedilmesi, yayılması bilim ve ileri teknolojiye dayalı yöntemlerin üretim süreçlerine uygulanması ülkelerin kaynak dağılımı ve kullanımı, etkinlik, verimlilik, karlılık ile tercihlerini olduğu kadar, toplumsal sınıfların yapılarını ve bölüşüm ilkelerini de dönüştürmektedir. üretim sistemi, planı, denetimi, yönlendirilmesi, organizasyonu ve iş örgütlenmesinde ortaya çıkan yeni oluşumlar. emek-sermaye ilişsileri. para-kredi mekanizmaları. pazar yapısı ve rekabet biçimleri ile devletin rolü ve dünya ekonomisiyle birleşmenin globalleşmenin aldığı görünümler. bu değişim sürecinin oldukça geniş bir alanı içine aldığını göstermektedir (Eser, 1993:36). Post modern politik ekonomi diye adlandırılan beşinci küreselleşme dalgasında bilim ve teknoloji alanındaki gelişmeler, patentler, markalar, araştırma ve geliştirme, yeni ve ileri bir toplumsal dönüşüme geçişin temellerini de oluşturmakta ve "bilgi toplumu” olarak nitelendirilen yeni bir toplum yapısının nesnel koşullarını hazırlamaktadır. Yeni ekonomi alanında bilim ve teknoloji alanındaki gelişmeler sadece üretim sistemlerini değil, bölüşümü, dağıtımı, üretimi, tüketimi, yatırımı ve bir toplum düzenini oluşturan tüm kurumsal yapıları, toplumsal ilişkileri, kültürel, süreçleri, sistemi ve yapıyı, siyasal sistemleri, ekonomik yap1, süreç ve sistemleri de köklü değişikliğe uğratmaktadır. Bütün bu değişmelerin temelinde de teknolojinin yeni biçimi, bilgi tabanlı yeni enformatik teknoloji bulunmaktadır. Bu devasa etkileri de beraberinde getirmektedir (Mcpherson, M. A., Michael, R. R., \&Margie, A. T., 2001:657. Bu etkilerden başlıcaları; dinamik, statik, en çok kayrılan ülke ve fiyat sadakati şeklinde kendini göstermektedir. Dinamik Etkiler olarak; Dünyadaki Ekonomik Entegrasyonların, ülkelere sağladığı statik etkiler dışında verimliliğin artması, rekabetin artması (rekabet diğer taraftan kalkınma ve ileri teknoloji kullanımını teşvik eder.), kaynakların kullanımı ve etkinliği açısından pazarın genişlemesi sonucu ortaya çıkan ölçek ekonomilerinden faydalanma, rekabet ve genişleyen pazarın yatırımcılar için cazip hale gelmesi sonucu yatırımların artması, pozitif dışsal ekonomilerin oluşması (genellikle kamu kesiminde, herhangi bir iktisadi birimin, üretim faaliyetleri sırasında, maliyeti içinde yer almayan ekonomik faaliyetin sonuçlarından yararlanmasıdır.), verimlilik, rantabilite ile üretim faktörlerinin serbest dolaşımı sonucu kaynak etkinliğinin sağlanması(Entegrasyon içinde emek ve sermaye gibi üretim faktörlerinin serbestçe dolaşması, ekonomide kaynakların daha etkin kullanılmasını sağlar.), Döviz tasarrufu yaratması. iyi ikili siyasi ilişkiler, coğrafi yakınlık, ortak bir sınır, küçük ekonomik ölçek ve ticarette açıklık şeklinde sıralanabilir (İncekara, 1995: 54). - Statik Etkiler olarak ekonomik yapı ve teknolojinin değişmediği varsayımında, üretim faktörlerinin yeniden dağılımından doğacak etkilerle ilgilidir.(Ertürk, 1996: 217). GATT’’n bu konudaki prensibi, üye ülkeler arasındaki anlaşmazlık durumunda sert ticari önlemlere başvurulmadan arabuluculuk yolu ile dünya ticaretini serbestleştirmek ve refahı arttırmak olmaktadır (Seyidoğlu, 1993: 410). GATT çerçevesinde üye ülkelerin tamamını kapsayan ve tarife oranlarını aşağı çekmeyi hedefleyen görüşmeler, diğeri ise bölgesel entegrasyonlar yoluyla söz konusu bölgedeki ülkeler arasındaki kısıtlamaların kalkması ancak üçüncü ülkelere yeni kısıtlamaların getirilmesi şeklindedir. Eğer GATT üyesi ülkeler dış ekonomik ilişkilerde krize girmişlerse, kota uygulamasına başvurabilirler. Ancak "bu uygulama geçici olmak zorundadır ve amacına ulaştığında da bırakılmalıdır" ibaresi yer almaktadır (Ertürk, 1997: 181). 1980'li yılların başında teknoloji alanındaki hızlı gelişmelerle ortaya çıkan küreselleşme, kendini İkinci Dünya savaşı sırasında ideolojik bazda göstermeye başlamıştır. Savaş sonrasındaki süreçte ise, dünyadaki Komünizm tehdidi, Avrupa'nın tekrar sömürge imparatorluklarına dönmesini engellemiştir. 1940’lı yıllarda Komünizm'in Doğu Avrupa ve Çin'de kurulması ve Sovyetler Birliği ile birleşmesi, "Küresel Komünizm" karşısında Kapitalizmin de küreselleşmesi sorununu ortaya çıkarmıştır. Bu dönemde A.B.D. için diş ekonomik büyüme, iç ekonomik büyümeden daha önemli bir hale gelmiştir. Küreselleşme yolunda atılan adımlardan GATT (Gümrük Tarifeleri Ticaret Genel Anlaşması) - Bretton Woods Sistemi II. Dünya Savaşı'ndan 
önce ortaya çıkmakla birlikte, dünya ticaretini serbestleştirmek amacıyla başlatılan girişimler savaş sonrasında daha da hızlanmıştır (Thurow, 1997: 98).

\section{Avrasya Ekonomik Birliği}

Bugün gelişmiş ülkelerin dünya ekonomik hasılasından, pastasından aldıkları pay; ABD \%24.32, Kanada \%2.9, Meksika \% 1.54'tür. 510 milyonluk nüfuslu Avrupa'da Almanya \%4.54, Fransa \%3.26'dır.Şimdi bir tarafta ABD, bir tarafta Avrupa, bir tarafta Çin nüfusu yaklaşık 2 milyar civarıdır. Çin 1 milyar 300 milyon nüfusa sahip. Avrupa 510 milyon, ABD 320 milyon nüfusa sahip. Bu 2.100 milyonluk ülkeler dünya gelirlerinin çoğunluğuna sahipken, geriye kalan 5 milyarlık nüfus da arta kalanla yetinmek zorunda.18 trilyon Dolar ABD,11 trilyon Dolar Çin, 4.4 trilyon Dolar Japonya, 3.4 Almanya, İngiltere 2.9 trilyon dolar, Fransa 2.4 trilyon dolar sahibidirler. Türkiye 850 milyar dolar 1 trilyon dolara bile sahip değil. Bu hali ile ülkemiz dünyada ekonomik büyüklük olarak 17. sirada yer almaktadır.(Çiftçi, 2018:17). 4324 bin kilometre karelik alanı bulunan Avrupa; 9826 bin kilometre karelik ABD, 9706 bin kilometre karelik alanda Çin, 17098 bin kilometre karelik alanda Rusya, Eski Doğu Bloku 23574 bin kilometre karelik alanda, Avrasya Birliği 20000 bin kilometre karelik alanda Türk Birliği 10581bin kilometre karelik alanda, Turan Birliği ise 16697bin kilometre karelik alanda ve Ütopik Avrasya 54759 bin kilometre karelik alanda 4 milyar 620 milyon insanı barındırırken, Avrupa 506 milyon 913 bin kişi, ABD 320 milyon, Çin 1 milyar 357 milyon, Rusya 141 milyon 423 bin kişi, Avrasya 183 milyon 319 bin kişi, Türk Birliği 141 milyon 284 bin kişiden, Turan Birliği ise 395 milyon 844 bin kişiden müteşekkil. Nüfus ve alan itibariyle bölgenin ne kadar büyük öneme sahip olduğunu açıkça göstermektedir(Sümer,2018:5).

Avrasya Ekonomik Birliği Anlaşması 29 Mayıs 2014 tarihinde Beyaz Rusya, Kazakistan ve Rusya liderleri tarafından imzalanmış ve 1 Ocak 2015 tarihi itibarıyla yürürlüğe girmiştir. Ermenistan 2 Ocak 2015, Kırgızistan ise 6 Ağustos 2015 itibarıyla Birliğe katılmıştır. Birliğin fikir olarak Sovyetler sonrasında söz konusu ülkeler arasında ticari, ekonomik ve siyasi birliği sağlamak üzere gündeme geldiği, bu aşamada gümrük birliği ve ekonomik işbirliğini temel alan ve 2018 itibarıyla 5 ülkenin üye olduğu bir yapı olduğu görülmektedir. Parasal birlik ve benzer konuların ise zamana yayıldığı anlaşılmaktadır. Birlik diğer örneklerde olduğu gibi esas olarak malların, hizmetlerin, sermayenin ve emeğin serbest dolaşımı ilkesine dayanmaktadır. Ayrıca, ulaştırma, endüstri, tarım, enerji, dış ticaret, yatırım, gümrükler ve makroekonomik politikalarda ortak politika izlenmesini öngörmektedir(RTİB;2018:2).

\begin{tabular}{|l|l|l|l|l|}
\hline Üye Ülkeler & Katılış Tarihi & Nüfus(milyon) & Milli Gelir(Dolar) & Yüzölçümü \\
\hline Rusya & 1 Ocak 2015 & 144 & 1,5 trilyon & 17 milyon \\
Beyaz Rusya & 1 Ocak 2015 & 9 & 54 milyar & 207 bin \\
Kazakistan & 1 Ocak 2015 & 17 & 160 milyar & 2 milyon \\
Kırgizistan & 12 Ağustos 2015 & 6 & 7 milyar & 199 bin \\
Ermenistan & 2 ocak 2015 & 3 & 11 milyar & 29 bin \\
\hline
\end{tabular}

Tablo 2. Avrasya Ekonomik Birliği Üyeleri Kaynakça: Rus Türk Işsadamları Birliği (RTİB), 2018 Raporu, 2.11.2018 Sayl:D-1-2018

Birlik fikri ilk olarak Kazakistan Cumhurbaşkanı Nur Sultan Nazarbayev'in 1994 yılında Moskova'da yaptığı bir konuşmada gündeme gelmiştir. Birlik 183 milyonluk bir nüfus potansiyelini ve 2017 nominal rakamlarıyla yaklaşık 1,7 trilyon dolarlık bir milli gelir potansiyelini barındırmaktadır. Satın alma gücü paritesi (PPP) ile bakıldığında ise söz konusu Birlik yaklaşık 4,5 trilyon dolarlık bir büyüklüğe ulaşmaktadır.

\section{Sonuç}

Dünya ile bilgi alıverişine girmek. onlarla ekonomik ilişkiler kurmak zorundadır. Bir ekonominin öteki ekonomilerle kuracağı ilişki geçmiş yıllarda bile karmaşıktı. Bugün böyle bir ilişki daha karışık, daha büyük bir bilgiyi gerektiren bir niteliğe sahip olmuştur. Günümüzde bir ülkenin ekonomi alanında başarıya ulaşabilmesi için dünyayı, dünyada meydana gelen değişme ve gelişmeleri çok iyi izlemesi ve doğru ekonomik birlikler içerisinde yer alması ile mümkün olabilecektir(Söylemez Alev S.;2004:32).. Dünya ülkeleri, gözler önünde hızla global ekonomi düzenine doğru ilerlerken. Avrasya da bu gelişmelerden soyutlanmamalıdır. Bunun için de Avrasya ekonomisinin dünya ekonomisine entegre olma kararını bütünleşme bakımından bir yandan globalleşme hareketlerinin içinde yer alması ve . diğer taraftan da ekonomik güç odakları ile ticari ilişkilerini sürdürmesi ve dünya ekonomik entegrasyonu hareketine tam katılma iradesi doğrultusunda eğitim ve haberleşme altyapısı ile işgücü piyasası başta olmak üzere ekonomik ve sosyal altyapıda devletlerin ekonomideki rolü ve organizasyon yapısında köklü değişikliklerin yapılması gerekmektedir.

Dünyanın ağırlık merkezi doğuya doğru kayarken Uzakdoğu'dan esen sert rüzgarlar eşliğinde dünya yeni bir düzleme oturmakta ve bu düzlemde dünyadaki iktisadi ve politik gelişmeler, önümüzdeki 10-15 y1llı perspektifte ABD’nin politik ve iktisadi alandaki başat rolünü Çin'e devredeceğini, Hindistan ve Rusya'nın da Avrupa Birliği'nin etki gücüne erişebilecek bir potansiyele vurgu yapmaktadır. Avrasya Ekonomik Birliği bu kurulan birlikler içerisinde Ekonomik büyümeyi artırmak, bölgesel kalınmayı sağlamak, endüstriyel çeşitliliği artırmak 
gibi amaçlar ve yüklendiği politik, ekonomik, sosyolojik ve teknolojik açıdan belirgin olarak öne çıkmaktadır. kurulacak dengeler açısından dünyanın ekonomisine barındırdığı potansiyelleri itibariyle pozitif bir dışsallık sağlayacak hem Avrasya Ekonomisi kalkınacak hem de bu kalkınma dünyanın ekonomisine de olumlu katkıda bulunacaktır..

\section{Kaynakça}

- Dura, C. (2000). "Yeni Dış Ticaret Teoriler: Genel Bir Bakış”, E.Ü. İktisadi ve İdari Bilimler Fakültesi Dergisi, Say1:16, 1-16.

- $\quad$ Ertürk, E.(1996); "Uluslararası İktisat", 1.Baskı, Ekin Kitabevi, İstanbul, 1996 ss:3-7

- Harman, B(1996).,"Uluslararası Ekonomik Sistemi Biçimlendiren Yeni Olgular ve Türkiye'nin Uyum Sorunları", Çukurova Üniversitesi, Sosyal Bilimler Enstitüsü, Basılmamış Yüksek Lisans Tezi, Adana,1996, ss. 18-23

- İncekara,A.(1995); "Globalleşme ve Bölgeselleşme Sürecinde NAFTA ve Etkileri", İTO Yayınları, Yay.No:1995-14, İstanbul, 1995.

- $\quad$ İyibozkurt, E. (2001). “Uluslararası İktisat: Teori-Politika-Uygulama”, Ezgi Kitabevi Yayınlar, Bursa, s.9

- Karluk, Rıdvan; Uluslararası Ekonomi, 3.Baskı, Bilim Teknik Yayınevi, İstanbul, 1991.

- Mcpherson, M. A., Michael, R. R., \&Margie, A. T., (2001)."International Trade and Developing Countries: An Empiricalİnvestigation of The Linder Hypothesis", Applied Economics, Cilt: 33, Say1: 5, ss. 649-657.

- Seyidoğlu, Halil; Uluslararası İktisat, 9. Baskı, Güzem Yayınları, İstanbul, 1993.

- Söylemez Alev S.;(2004) "Küreselleşme, Yapısal Dönüşüm ve Büyüme: Bilgi Göstergeleri Işığında Türkiye Açısından bir Değerlendirme”, Ekonomik Yaklaşım, 15(51), ss.32-64.

- Sümer,K.K; 2018, Türk Dünyasının Ekonomik Gelişimi ve Türk Devletleri ve Halkları Arasında Ticari Perspektifler, Antalya Türk Dünyası Araştırmalar Kongresi

- S Şengönül Ahmet, İsmail Tuncer;(2004) “Dış Ticaret Politikaları ve Uzun Dönem Büyüme”, Ekonomik Yaklaşım, 15(52-53), ss.161-184.

- Tekeoğlu Muammer;(1993) “İktisadi Düşünceler Tarihi”, Çukurova Üniversitesi, Adana,

- Thurow, Lester C(1997).; "Kapitalizmin Geleceği", 1. Baskı, Sabah Yayınları, İstanbul, 1997

- Tuna, Y.(1995), “Dünya'da Globalleşme Eğilimleri ve Dengeler" Süreç Özel Sayı, ss. 17-18, İstanbul, 1995. 


\title{
Kuzey Kıbrıs Türk Cumhuriyetinin 36. Kuruluş Yıldönümünde Kıbris Sorunu
}

\section{The Cyprus Issue at the 36th Anniversary of the Turkish Republic of Northern Cyprus}

\author{
Asst. Prof. Dr. Çetin İlhan Akbulut (Kavram MYO, Turkey)
}

\begin{abstract}
Cyprus Issue is a still existing dispute, which have not been brought to a conclusion by the international society, continuing to be relevant. Purpose of this present article is the evaluation of the Cyprus Issue, an international process caused by the Cypriot Greeks' violation of constitution whose list of guarantors included Turkish Republic, which resulted in foundation of Turkish Republic of Northern Cyprus whom celebrated its 36 Anniversary of Foundation this year. For this purpose, with regards to related necessary scientific studies; geographical properties of Cyprus were referred, history of Cyprus was emphasized and importance of ethnic background of Cyprus were argued and effects of these were discussed. Legal process and also the international effects of Cyprus Issue was evaluated. Root of problems regarding this Issue, undoubtedly crucial to Turkish Republic were determined and solution proposals aimed at settlement were included.
\end{abstract}

\section{Giriş}

Kıbrıs, Doğu Akdeniz'de yer alan bir Adadır. Akdeniz'in doğu ucundadır. Yani Avrupa, Asya ve Afrika kıtalarının buluştuğu noktadadır. Kıbrıs'ın yüzölçümü 9251 km²'dir. Bunun yaklaşık 3242 km²'lik alanını Kuzey Kıbrıs Türk Cumhuriyeti (KKTC) toprakları, $256 \mathrm{~km}^{2}$ 'lik alanını İngiliz hâkimiyetindeki Dikelya ve Ağrotur üs bölgeleri, 244 km²'lik alanını sınır hattındaki kullanılmayan “Ara Bölge” (Tampon Bölge) ve yaklaşık 5509 km²'lik alanını da Kıbrıs Rum Kesimi toprakları oluşturur (Yorgancıoğlu, 1998), Akbulut, 1998).

Kıbrıs Adası, Türkiye’ye 71 km, Girit Adasına 550 km, Yunanistan'a 965 km, Suriye’ye 98 km, Misır'a 316 km, İngiltere'ye ise, 3000 km uzaklıktadır (Harp Akademisi Komutanlığı Yayınlarından, 1995).

Doğu ile batı arasındaki en uzak noktaları (Ada uzunluğu) 322 km, kuzey ile güney arası ise, (Ada genişliği) 96 km'dir. Dünya'nın çok haraketli bir bölgesinde bulunan Kıbrıs, Ortadoğu'nun zengin petrol yataklarına yakınlığı bakımından ayrı ve farklı bir özelliğe sahiptir. Kıbrıs, bir Ortadoğu ülkesidir; ancak toplumsal gelişmiş̧lik bakımından Asya'dan çok bir Avrupa ülkesi görünümündedir ve böyle kabul edilir. Aynı zamanda Akdeniz'in üçüncü büyük adasıdır.

\section{Kıbrıs Adasının Stratejik Önemi}

Bugün için Kıbrıs çoğunlukla bir uçak gemisi gibi tasvir edilir. Esasında uçak gemisinden daha önemlidir; çünkü uçak gemisi batabilir. Kıbrıs ise, her zaman deniz ve hava üssü olarak niteliğini korur. 16. yüzyılda, Akdeniz'in Türk gölü haline geldiği yıllarda, Kıbrıs’ta üslenmiş olan Cenevizli ve Venedikli korsanların bir kısmı Anadolu'nun güney sahillerini, Antalya bölgesini ve civarını yağmalamışlar ve bu şekilde Türkiye için bir tehdit oluşturmuşlardır. Bilindiği gibi Osmanlı İmparatorluğu, 1571 yılında stratejik önem arz eden Kıbrıs Adası'nı ele geçirerek topraklarına yapılan tehditleri önlemiştir.

\subsection{Kıbrıs Adasının Tarihsel Gelişimi}

Kıbrıs Adası, 1571'de Osmanlı İmparatorluğu tarafından fethedildiği zaman Ada'da yaşayan Hıristiyan olan Rumlar, Katolik Venedikliler' in zulmü altında ezilmekteydiler. Padişah II. Selim, Ada'da kalan yirmi bin askere ilaveten çoğunluğu Konya-Karaman'dan olmak üzere Anadolu'dan toplam beş bin yedi yüz yirmi bir evden Türk ailesini Kıbrıs’a göndermiştir. Rumlar, Türklerin üç yüz sekiz yıllık hoşgörülü yönetimi altında din, dil, eğitim, kültür ve ekonomi alanlarında gelişmişler, zenginleşmişler ve güçlenmişlerdir. 1820'li yıllarda Yunanistan'ın Türk yönetiminden ayrılıp bağımsızlığını kazanması ile Enosis (Kıbrıs'ın Yunanistan'a bağlanması) hareketi de başlamıştır. Rumlar Enosis'i gerçekleştirme faaliyetlerini, Ada'nın Türk yönetimi altında olduğu dönemde fiilen uygulamaya koydular (İsmail, 1988).

Osmanlı İmparatorluğu'nun 1878 Osmanlı-Rus savaşından yenik çıkmasından doğan siyasal koşullara bağlı olarak 4 Haziran 1878 tarihinde İngiltere ile imzalanan savunma antlaşması ve 1 Temmuz 1878 tarihinde yine aynı devletle imzalanan ek protokol ile geçici bir süre İngiltere'nin yönetimine devredilmiştir (Erim, 1953), (Gazioğlu, 1960).

1914 yılında Osmanlı İmparatorluğu’nun İngilizlere karşı harbe girmesiyle İngilizler, Ada’yı tek yanlı olarak ilhak etmiştir. Türkiye bu ilhakı dokuz sene sonra 1923 Lozan Barış Antlaşması'yla tanımak zorunda kalmıştır. 1920'li yıllar, binlerce Kıbrıslı Türk'ün Ada'dan göçtüğü yıllar olmuştur. Göç edenlerin büyük çoğunluğu anavatan Türkiye'ye yerleşmişlerdir. Türkiye'de halen beşyüz bin civarı Kıbrıs Türk'ü yaşamaktadır. 2017 yılı itibariyle 
tespit edilen sayılara göre, Kıbrıs'ın Güney kesiminde sekiz yüz elli dört bin sekiz yüz, Kuzey’de ise, yani KKTC'de üç yüz elli bir bin dokuz yüz altmış beş kişi yaşamaktadır.

\subsection{Kıbrıs Adasında Hak İddiasında Bulunan Ülkeler ile Yapılan Antlaşmalar}

Kıbrıs Cumhuriyeti Devleti'nin bağımsızlığını sağlama yolundaki ilk antlaşma, 11 Şubat 1959 tarihindeki Türk ve Yunan başkanlarının onayladığı Zürih Antlaşması'dır (Bilge, 1959).

Zürih Antlaşması ile Kıbrıs'ta iki toplumun ortaklığına dayanan Türkiye ve Yunanistan'la işbirliği yapacak bağımsızlığı garanti edilmiş bir çeşit federal (iki toplumlu) Cumhuriyet kuruldu. Garanti edilmiş bağımsızlık, yasaklı bir bağımsızlıktır. Garanti Antlaşması'nın birinci maddesine göre, "Kıbrıs Cumhuriyeti, bağımsızlığının, ülke bütünlügünün ve güvenliğinin devamını ve anayasasına saygıyı diğer ülkelerin nazarında sağlayacaktır. Hiçbir devlete siyasal veya ekonomik birliğe kısmen veya tamamen katılmayacaktır. Bir devletle doğrudan doğruya veya dolaylı olarak birleşmeyi veya Ada'nın taksimini destekleyen her hareketi yasak ilan edecektir." (Meray, 1975), (Pazarc1, 1999).

\section{Kıbrıs 1960 Anayasası ile Oluşturulan Hukuki Statü}

Zürih Antlaşması, Türkiye, Yunanistan, İngiltere, Kıbrıs Türk ve Rum cemaatleri liderlerinin katılması ile toplanan ikinci Londra Konferansı'nda, Makarios'un çıkarmaya çalıştığı güçlüklere karşın, 19 Şubat 1959 tarihinde onaylandı ve 23 Şubat 1959'da Ankara, Atina ve Londra'da aynı zamanda açıklandı. Antlaşmaların yürürlüğe konması için Londra ve Lefkoşa'da komisyonlar kuruldu. Komisyonlar, çalışmalarını yaklaşık bir yılda tamamladılar. Kıbrıs'ta İngiltere'ye bırakılacak üslerin yüzölçümü konusunda çetin pazarlıklar yapıldı. Bu nedenden dolayı Kıbrıs’ta 16 Ağustos 1960 tarihinde cumhuriyet ilan edilebildi (Bilge, 1996).

1960 Anayasası'nın kabulü ile Ada, bağımsızlığına kavuşmuştur. 1960 Anayasası, yeni Cumhuriyette bir Anayasa Mahkemesi ile bir Yüksek Adalet Mahkemesi'nin kurulmasını öngörmüştür. Anayasa Mahkemesi, Anayasa kurallarına göre tarafsız bir başkan, bir Kıbrıslı Elen yargıç ve bir Kıbrıslı Türk yargıçtan oluşmuştu. Yüksek Adalet Mahkemesi ise, tarafsız bir başkan, iki Kıbrıslı Elen yargı̨̧ ve bir Kıbrıslı Türk yargıçtan oluşmuştu. Her iki mahkemenin başkan ve diğer üyelerinin atamaları, Cumhurbaşkanı ve yardımcısı tarafından müştereken yapılmıştı. Alt düzeyde ise, kaza mahkemeleri kurulmuştu.

Anayasa, Türk davalarına, Türk yargıç veya yargıçlardan oluşan mahkemelerin, Elen davalarına Elen yargıç veya yargıçlardan oluşan mahkemelerin bakabileceğini öngörmüştür. Ayrıca her iki toplum üyelerinin neden oldukları davalara ise, karma mahkemelerin bakabileceğini öngörmüştür.

Anayasaya göre eğitim, aile hukuku ve belediye işlerinde her iki toplum özerkti. Rum Cumhurbaşkanı ve Türk Cumhurbaşkanı Yardımcısı, icrada eşit yetkilere sahipti.

1960 Anayasası'nın öngördüğü iki toplumlu düzen, 1963’ün Aralık ayında Türk toplumuna yapılan saldırı ve bu toplumun Cumhuriyet hükümetinden dışlanması ile son buldu. Bu tarihten sonra Kıbrıs'ta iki toplumun birbirlerinden kopması ile toplumların yargı sistemlerinde de farklılaşma baş göstermiş oldu.

Kıbrıs Türk toplumunun siyasal düzene alışması, geçen zaman içerisinde, toplum gereksinimlerine göre ayarlanan bünyesel ve biçimsel evrelerden geçmiştir. 1963-1976 döneminde Türk toplumu merkezi bir "Genel Komite" tarafından yönetilmekte idi. Bu evrede Kıbrıs Türk toplumunun yargı işlemleri "Genel Komite" tarafindan kurulan bazı komisyonlar tarafından görülmekte idi. İlk olarak "Ceza Komisyonu" ve "Kira Takdir Komisyonu" kurulmuştu.

1967 yılının Aralık ayında temel kuralların kabul edilmesi ile Kıbrıs Geçici Türk Yönetimi kuruldu. Temel kurallar, Geçici Türk Yönetimi'nin yargı işlerinin bağımsız Türk mahkemeleri tarafından görüleceğini, mahkemelerin teşkili ve yargıçların yetki, görev ve statülerinin yasa ile düzenleneceğini öngörmekte idi. Temel kurallara göre Türk yargıçlar, Türk yönetiminin yürütme kurulunun başkan yardımcısının önerisi üzerine başkan tarafından atanmaktaydılar. Bu yöntem, 1975 yılına kadar devam etmiştir.

\section{Barış Harekâtı ve Kıbrıs Türk Federe Devletinin Kuruluşu}

Kıbrıs sorununa çözüm bulmak için 1968 yılında başlayan toplumlararası görüşmeler belirli aralıklarla devam etmiş; ancak bir sonuç alınamamıştır. Toplumlararası görüşmeler devam ederken Yunanistan'da bir darbe ile Makarios devrilip yerine Samson getirilmiş ve böylelikle Rumlar da Enosis'i ilan etmeye hazırlanmıştır. Bu tehlikeyi sezen Türkiye, 1974 Temmuz'unda, Kıbrıs’ta kurulu yasal düzeni silah gücüyle bozmaya kalkışan Kıbrıs Rumlarına karşı 16 Ağustos 1960 tarihli Garanti Antlaşması'nın 4. maddesine dayanarak Kıbrıs'a asker çıarmıştır (Serter ve Fikretoğlu, Tarihsiz Yayın), (Fehmi, 1992).

Kıbrıs genelinde yaşayan tüm Türklerin kuzeyde toplanması sağlandıktan sonra 13 Şubat 1975 tarihinde "Kıbrıs Türk Federe Devleti” kurulmuştur. Kurulan bu devlet, uluslararası hukukun gerektirdiği bütün koşullara sahipti. Rumlar ve Yunanlar, Kıbrıs Türk Federe Devleti'ni tanımamış, Dünya çapında Türk halkı aleyhine kampanya açmış ve Birleşmiş Milletler'den 13 Mayıs 1983 tarihli kararın çıkmasını sağlamıştır. Bu karar, Kıbrıs Türk Federe Devleti'nin kaldırılması için bütün devletlerin Kıbrıs Rum Yönetimi’ne yardımını öngörüyordu. 


\section{Kuzey Kıbrıs Türk Cumhuriyeti'nin İlanı}

Kıbrıs Sorunu'nun çözümüne ilişkin çeşitli tarihlerde sürdürülen görüşmelerde, iki bölgeli, iki toplumlu ve iki toplumun eşitliği ilkeleri çerçevesinde bir federasyon (veya konfederasyon) oluşturulması konusunda mutabakata varıldı. Mutabakat sağlanan iki toplumlu, iki bölgeli federal sistemde Rumlar'ın Kıbrıs Türkleri'ne tekrar baskı ve terör hareketleri uygulamaması ve Kıbrıs Türkleri'nin Rumlar'ın insafina kalmaması için güvence içeren maddelere yer verilmediği belirlenmiştir. Kıbrıs Rumları'nın “Kıbrıs Hükümeti” olarak tüm Dünya'da tanınmalarının rahatlı̆̆ içinde hiçbir antlaşmaya yanaşmamaları ve Kıbrıs Türklerini her gün biraz daha fazla köşeye sıkıştırmak yönündeki çabalarını yoğunlaştırmaları karşısında, self-determinasyon (kendi kendini yönetme) hakkını kullanan Kıbrıs Türk halkı, 15 Kasım 1983’te Federe Meclis'in oybirliği ile aldığı bir kararla Kuzey Kıbrıs Türk Cumhuriyeti'ni ilan ettiğini tüm Dünya'ya duyurdu.

Kuzey Kıbrıs Türk Cumhuriyeti'nin 15 Kasım 1983’te ilanı, Kıbrıs’ta tarihin akışını geri dönülmez biçimde belirleyen, iki yüz yıllık “megalo idea” hayalinin ve bu hedef içindeki Enosis Rüyası'nın gerçekleşmesine kapıları kapayan bir tarihsel oluşumdur.

Kıbrıslı Türkler'in self-determinasyon hakkını kullanarak Türk Cumhuriyeti'ni kurmaları Kıbrıs Rumları'nı kızdırmıştı. Bundan hareketle Kıbrıslı Rumlar, Kuzey Kıbrıs Türk Cumhuriyeti'nin tüm Dünya Devletleri’nce tanınmasını engellemek amacıyla tüm siyasi güçlerini kullandılar. Güney Kıbrıs Rum yönetimi (GKRY), 4 Temmuz 1990 tarihinde Avrupa Birliği’ne (AB’ye) tam üyelik başvurusunda bulundu. Kıbrıslı Rumların, uluslararası hukuka aykırı olarak yaptıkları tam üyelik başvurusu, Kıbrıslı Türkler’i hiçe saymaktan başka bir şey değildi (Tamçelik, 1997).

Türkiye'nin 6 Mart 1995 tarihinde, AB ile Gümrük Birliği Antlaşması'nı imzalaması Kıbrıs meselesine dolaylı yoldan etkili olmuştur. Böylece AB, 1996 yılında yapılması tasarlanan hükümetler arası toplantıdan yaklaşık altı ay sonra Kıbrıs'la (Güney Kıbrıs Rum Yönetimi) tam üyelik müzakerelerine başlayacağını teyit etmişti. AB'nin bu husustaki teyidi Kıbrıs meselesinde birçok dengelerin değişmesine neden olmuştur (Tamçelik, 1997).

Kuzey Kıbrıs Türk Cumhuriyeti günümüzde bütün yaşanan bu süreçlerin sonunda 2017 yılı itibariyle yaklaşık üç yüz altmış bin kişilik bir nüfusa sahiptir. Üç yüz altmış bin kişinin yüz altmış bin kadarı Ada'da yaşayan Kıbrıs kökenli Türkler'dir. Geriye kalan iki yüz bin kadarı ise, Türkiye'de yaşayan Kıbrıs kökenli Türkler olup 1974 Kıbrıs Barış Harekatı'ndan sonra Türkiye Cumhuriyeti tarafından Kıbrıs'a yerleştirilmişlerdir.

Kuzey Kıbrıs Türk Cumhuriyeti'nde Barış Harekatı'ndan sonra geçen kırk beş yıl boyunca önemli bir ekonomik gelişme sağlanamamıştır. Bunda Ada’nın coğrafi konumu, iklimin çok sıcak olması, Türkiye ile ulaşımın zor olması, gümrük mevzuatının ithalat ve ihracata kolaylık getirmemesi gibi ekonomik tedbirlerin yeterince alınmamasının etkisi vardır.

Bugünkü siyasi ortama baktığımızda, Ada'da iki ayrı halk, iki ayrı dil, iki ayrı din ve iki ayrı ırk vardır. İnsan hakları savunucusu kesilen bazı Batılı devletler, suçlu arar gibi Kuzey Kıbrıs Türk Cumhuriyeti'ni suçlayarak, Kıbrıs'taki iki bölgeli, iki devletli statüyü kabul etmemektedirler. Bunun sebebi Rumların Ada'daki Türkleri yok etme, kaçırma ve Ada’yı Yunanistan’a bağlama gayretleri olan Enosis ve Akritas planıdır.

\section{Kuzey Kıbrıs Türk Cumhuriyetinin İlanından Sonra Uygulanan Ekonomik Geliş̧meler}

\subsection{Kamunun Etkinliğinin ve Özel Sektörün Rekabet Gücünün Artırılması Programı}

Kuzey Kıbrıs Türk Cumhuriyeti ile Türkiye Cumhuriyeti arasında 1986 yılından bu yana çeşitli tarihlerde ekonomik ve mali işbirliği protokolleri imzalanmıştır. Protokoller kapsamında KKTC'de uygulanan ekonomik programların amacı ülkenin içerisinde bulunduğu siyasi ve ekonomik izolasyonlara rağmen sürdürülebilir bir kalkınmanın tesis edilmesidir. KKTC tarafindan uygulanan protokoller içerisinde en kapsamlısı 20.07.2006 tarihinde imzalanan ve 2007-2009 yılları arasında uygulanan "Sürdürülebilir Kalkınma İçin Yapılandırma ve Destek Programı"na esas teşkil eden protokoldür. Söz konusu protokol ile ilk defa kredi desteklerine ek olarak hibe niteliğini taşıyan savunma ve yardım yatırımları dâhil T.C. tarafından 3 yıllık dönemde sağlanacak toplam yardım miktarı tespit edilmiş ve mahalli gelirler ile mahalli giderler arasındaki fark olarak tanımlanan KKTC'nin cari bütçe açığına sayısal bir sınırlama getirilmiştir. Diğer taraftan 26.06.2008 tarihinde imzalanan ek protokol ile 2009-2013 yıllarını kapsayan beş yıllık dönemde Bafra ve İskele bölgelerindeki turizm yatırımlarında kullanılmak üzere Türkiye Kalkınma Bankası tarafından üç yüz milyon TL'ye kadar finansman desteği sağlanması kararlaştırılmıştır. Ayrıca, 20.07.2009 tarihinde imzalanan ikinci ek protokol ile T.C. tarafından KKTC'ye, 20.07.2006 tarihli protokolde öngörülen tutara ilaveten üç yüz elli milyon TL'ye kadar ilave yardım sağlanması kararlaştırılmıştır. İleri tarihlerde uygulanacak programın temel hedefi kamunun ekonomi içerisindeki payının azaltılarak sürdürülebilir bir büyümeyi teminen özel sektöre dayalı rekabet gücü yüksek bir ekonomik ortamın oluşturulmasıdır (T.C. Lefkoşa Büyükelçiliği Yardım Heyeti, 2012).

\subsection{Kamu Maliyesi}

2000'li yılların başında yaşanan kriz ile bozulan ekonomik yapının uygulanan programlar neticesinde hızlı bir toparlanma sürecine girdiği gözlemlenmektedir. Özellikle 2003-2007 y1lları arasında yakalanan yüzde onüçlük 
ortalama büyüme oranı sayesinde milli gelirde ciddi oranda artışlar olmuştur; ancak büyümede yaşanan olumlu gelişmelere rağmen kamu maliyesinde beklenen yapısal dönüşüm tam anlamıyla sağlanamamıştır. Kamu mali yönetiminde beklenen adımların atılmamasından dolayı özellikle 2008 yılında başlayan ve hâlen etkilerini sürdürmekte olan küresel ekonomik krizin etkileri KKTC ekonomisinde daha derinden hissedilmektedir.

Kamu kesiminin toplam ekonomi içinde büyük bir paya sahip olması özel sektörün rekabet gücünün artırılmasında büyük bir engel oluşturmaktadır. Özel sektörün rekabet gücünün artırılması ve sürdürülebilir bir büyüme için kamu kesiminin toplam ekonomi içindeki payının azaltılması büyük önem arz etmektedir. Kamu, özel sektörü dışlayacak şekilde bir maliye politikası izlememeli, özel sektör için hayati önem taşıyan finansman ve personel kaynakları, kamu tarafindan kullanılmamalıdır.

\subsection{Reel Sektör}

KKTC ekonomisinin gelişmesinde potansiyel taşıyan alanlar incelendiğinde turizm ve eğitim sektörü öne çıkmaktadır. Belirli ölçüde katma değeri yüksek olan sanayi üretimi yapılması ve tarım sektörünün turizm ve eğitim sektörlerini destekleyecek şekilde geliştirilmesi potansiyeli de bulunmaktadır. Ayrıca Ada'nın deniz ticareti yolları üzerinde bulunması nedeniyle deniz taşımacılığının artması ve bu vesileyle gemi inşa sektörünün de gelişebilmesine imkân sağlayacağı düşünülmektedir.

KKTC bir yandan Türkiye ile yoğun ekonomik ilişkilerini yürütürken diğer taraftan GKRY ile de ticari faaliyet içerisindedir. Güney Kıbrıs Rum Kesimi'nden (GKRK) ve KKTC'den gelen her iki taraf vatandaşlarının karşılıklı ticaret yapması mal ve hizmet fiyatlarının karşılaştırılmasını sağlamaktadır. KKTC'deki fiyatlar Güney Bölgesindeki fiyatlarla rekabet etmek mecburiyetinde kalmakta ve yoğun ticaret kaymaları yaşanmaktadır. Ekonomiyi genel olarak etkileyen izolasyonların dışında çözümlenmesi gereken asıl sorun, üretim maliyetlerinin yapısal sorunlar nedeniyle girdi maliyetlerine ilişkin piyasalarda rekabetçi ortam olmaması sonucu yüksek oluşudur.

KKTC'de tarım sektörü önemli bir potansiyele sahip olup ülke ekonomisine değişik yollardan katkı sağlamaktadır. Tarım sektörü toplam istihdamın yaklaşık yüzde beşini oluşturmaktadır. Ülke ihracatının yüzde yetmiş kadarı tarım ürünleri ile tarıma dayalı sanayi ürünlerinden oluşmaktadır. KKTC kurak iklim etkisinde olup bitkisel üretim önemli ölçüde doğal yağışlara bağımlıdır. Türkiye'den borularla ülkeye su bağlantısı yapılmış olup tarım sahasına yönelik çalışmalar devam etmektedir. Suyun gelmesi Ada'ya büyük canlılık katacaktır; çünkü şimdiye kadar sulama suyunun yüksek tuz yoğunluğu nedeniyle sulanabilir alanların toprak kalitesinde bozulmalar başlamıştır. Hâlen büyük bir proje olarak Beşparmak Dağları'nın içinden tünel açılmaktadır. Bu tünel vasıtasıyla "Meserya Ovası"na sulama gelmiş olacaktır.

Hayvancılık faaliyetleri önemli oranda ithal girdi kullanımı ile yapılan entansif bir yapı göstermektedir. Yem hammaddesinin bir kısmı ülkede üretilen arpadan karşılansa da ağırlıklı olarak ithalat yoluyla karşılanmaktadır. Kırmızı et ve beyaz et üretimi yeter seviyede olup süt ürünleri önemli oranda ihraç edilmektedir; ancak balıkçılık ve arıcılık yeterince gelişme göstermemiştir.

Turizm sektörü KKTC'de istenilen başarıya ulaşamamasına rağmen hedeflenen amaca varmak için etkin çalışmalar yapılmaya devam edilmektedir. KKTC'de turizm, büyük otellerin yanı sıra ev pansiyonculuğu, özel ilgi turizmi ve eko turizme dayalı bir gelişim planı içermektedir. Ev pansiyonculuğu, özel ilgi ve eko turizmin geliştirilmesi amaciyla Karpaz pilot bölge olarak seçilmiştir. Hem büyük otellerde hem de ev pansiyonculuğu, özel ilgi turizmi ve eko turizmde önemli gelişmeler olmuştur. Yatak sayısı artmış, geceleme oranında kayda değer ilerlemeler olmuştur. Ev pansiyonculuğu, özel ilgi turizmi ve eko turizmin gelişmesi, az gelişmiş yörelerin ekonomik aktivitesinin artmasını sağladığı için ayrı bir öneme sahiptir. Son yıllarda özel sektörün gerçekleştirdiği oteller Avrupa'nın en lüks otelleri ile yarışacak durumdadır.

KKTC'deki yükseköğretim hizmeti son yıllarda önemli başarı kazanmıştır. Türkiye'den de birçok tanınmış üniversite kampüs açarak eğitim hizmetine destek vermektedir. KKTC'deki öğrenci yurt-yatak sayısı sağlanan teşviklerin de etkisi ile yeterli seviyeye getirilmiştir. Öğrencilerin, Ada ekonomisine büyük katkı sağladıkları gibi aldıkları kaliteli eğitim ile de iş hayatında büyük başarılar kazandıkları görülmektedir.

Enerji konusu KKTC için hayati öneme sahiptir. Doğu Akdeniz'de keşfedilen zengin kaynaklarda Türkiye'nin etkin olması için siyaseten İsrail, Lübnan ve Mısır ile ilişkilerin iyi olması gerekmektedir. Bugün İsrail açıklarında “Tamar ve Leviathan” bölgelerinde Kıbrıs'ın güneyindeki “Afrodit” bölgesinde ve Misır'ın “Zuhr” bölgesinde bulunan doğalgaz rezervleri hayati öneme sahiptir. "Afrodit” sahasında 200 milyar metreküp doğalgaz ve 3,7 milyar varil petrol olduğundan bahsedilmektedir.

Doğu Akdeniz havzası, 2000'li yıllardan sonra enerji konusunda faaliyet gösteren firmaların ilgisini çekmektedir. 2010 yılında İsrail'in Hayfa kenti açıklarında büyük doğalgaz rezervi tespit edildi; ancak Doğu Akdeniz'in enerji ihtilafı sadece GKRK ile KKTC-Türkiye arasında yaşanmıyor. Bölgenin Hidrokarbon zenginliği Lübnan ile İsrail arasındaki gerginliği yükseltirken İsrail ile Mısır'ı birbirine yaklaştırıyor. Diğer taraftan Mısır ile Türkiye arasındaki ilişkileri de bozuyor. Güney Kıbrıs'ın tek taraflı ilan ettiği "Münhasır Ekonomik Bölge" de doğalgaz ve petrol arama faaliyetlerine başlaması sıkıntıyı arttırmaktadır. 
KKTC'de elektrik enerjisi, fuel-oil yakıtla çalışan termik santrallerde üretilmektedir. KKTC'de elektrik iletim ve dağıtım işlemleri Kıb-tek tarafından yürütülmektedir. KKTC'nde elektrik enerjisi ağırlıklı olarak konutlarda kullanılmaktadır. Konutların ısıtma ve soğutma ihtiyaçlarına göre tüketim talebi gün içinde saatlere, yıl içinde aylara göre önemli ölçüde dalgalanma göstermektedir. Bu durum enerji üretim maliyetini artırmaktadır.

KKTC'de su problemi 2016 yılından itibaren çözümlenmiştir. Dünyada ilk kez deniz altından askılı boru sistemiyle KKTC'ye su sevkiyatı yapılmaya başlanmıştır. Türkiye tarafinda Alaköprü Barajı, KKTC tarafında ise Geçitköy Barajı su depolama mekânı olarak tutulmuştur. Dragos çayından Adaya gelen 75 milyon metreküplük suyun yaklaşık yarısı içme suyu olarak kullanılacak, geri kalan yarısı ise, tarımda değerlendirilecektir. Adaya ulaşan suyun KKTC'nin en az 50 yıllık su ihtiyacını karşılayacă̆ belirtilmektedir (Hürriyet Gazetesi, 08.08.201518.10.2015)

\section{Kuzey Kıbrıs Türk Cumhuriyetinde Mülkiyet Meselesi}

KKTC ve GKRY'nin uzlaşma konusunda en önemli problemlerin başında "Mülkiyet Meselesi” gelmektedir. KKTC vatandaşları arazisini, evini Rumlara bırakmak istememektedir. Başka bir yer gösterilse veya bunun karşılığı para olarak tazmin edilse bile evini terk etmek taraftarı değildir. Aynı şekilde Güneyde bulunan Rum vatandaşları da Kuzeyde bulunan toprağının veya evinin geri verilmesini değil, para olarak tazmin edilmesini istemektedir. Nitekim geçmiş senelerde önemli bir derginin yazarının özel izinle gelip iki kesimin vatandaşları ile yaptığı görüşme sonucunda iki kesimin vatandaşlarının birlikte yaşamasının mümkün olmadığı kanısına varılmıştır. $\mathrm{Bu}$ görüşmede Rum vatandaşları, hâkimiyetin Rumlarda olması gerektiğini iddia etmiştir. $\mathrm{Bu}$ düşünceyi iddia nedenleri olarak, kendilerinin Yunanistan'dan yaklaşık 3000 yll önce Ada'ya göç ettiklerini; ancak Kıbrıs'lı Türklerin 1878'de Ada'nın İngiliz hâkimiyetine devredildikten sonra Ada'da yaşam sürmeye başladıklarını ileri sürmüşlerdir (Szulc, 1993a).

Rum vatandaşlarının bu görüşmede ileri sürdüğü görüşlere katılmak mümkün değildir. Geçmişte Ada'da kimlerin hüküm sürdüğü tarihi vesikalarla sabittir. O dönemlerde Ada, Venedikliler'in işgalinde bulunuyordu. Akdeniz'de bulunan korsanlar, Ada sakinlerine tacizde bulunuyorlardı. Osmanlı bütün bu korsanlık faaliyetlerinin engellenmesi amacıyla 1571'de Kıbrıs'a çıktı ve düzeni sağladı. Bu konuda gerek Türk tarihçilerimiz gerekse tarafsız yabancı ülke tarihçileri geçmişten günümüze kadar uzanan Kıbrıs Tarihi ile ilgili birçok eser kaleme almışlardır. Bu eserlerde hiçbir tarihçi Ada'da üç bin yıllık bir Yunan yerleşiminin olduğunu ifade etmemiştir. Yukarıda da belirtildiği gibi önemli bir derginin yazarının özel izinle gelip yaptığı görüşmede Rahmetle andığımız KKTC Kurucu Cumhurbaşkanı Rauf R. Denktaş yazara kesin tavrını koyarak şöyle demiştir: "Rumlar ortaklığımızı yıllar önce bozdular. Hayvan muamelesi gördüğ̈̈müz ve isyancı olarak nitelendirildiğimiz 1974 öncesi döneme dönmeyeceğiz. Ellerimi kesseler de Kıbrıs'ı 1974 öncesine götüren antlaşma yapmayacağım." (Szulc, 1993b)

\section{Kuzey Kıbrıs Türk Cumhuriyetinde Toprak Paylaşımı ve Harita Pazarlığı}

Uzun yıllardır devam eden Kıbrıs görüşmelerinde birçok konuda uzlaşma sağlandığı; ancak mülkiyet ve haritanın nasıl olacağı üzerinde mutabakatın sağlanamadığı anlaşılmaktadır. Esasında Türkiye ve KKTC, 2004 yılında büyük bir haksızlığa uğratılmıştır; çünkü Annan Planı kabul edildiğinde AB üyeliğinin garanti olacağı düşünülerek Kıbrıs Türkleri Annan Planı'na "Evet" demiştir. Rum tarafı ise, "Hayır" demiştir. Annan Planı'na "Evet" demenin KKTC'ye de Türkiye'ye de bir faydası olmamıştır. Bu durumdan Rum tarafi kazançlı çıkmıştır; çünkü Güney Kıbrıs'ı AB'ye tam üye olarak kabul etmişlerdir.

Görüşmelerde Kıbrıs Rum tarafının KKTC'den Annan Planı'nda talep ettiği topraklara ilaveten Dipkarpaz, Güzelyurt'un kendilerine bırakılması ve Türk askerinin Ada'dan çekilmesi taleplerinin bulunduğu belirtiliyor. Bu taleplerin kabulü hâlinde, hiç kuşkusuz Türkiye'nin Doğu Akdeniz'de hiçbir gücünün kalmayacağı ve ileri aşamada Kıbrıs'ın Girit Adası gibi kaybedilebileceği ihtimalini daima göz önünde bulundurmak gerekmektedir.

Bugünkü durum itibariyle, 2 milyon 400.000 dönümden oluşan KKTC topraklarının, 1 milyon 550.000 dönümünü Rum mülklerinin oluşturduğu belirtiliyor. Bunun 30.000 dönümünün takas ve tazminatla el değiştirmesini isteyen Rum tarafı geri kalan 1 milyon 520.000 dönümünün doğrudan iadesini talep etmektedir. $\mathrm{Bu}$ da KKTC topraklarının yüzde yemişaltısına karşılık gelmektedir. Mülkiyet sonucunun çözümü için eğer mülklerin iadesi söz konusu olmazsa 25-30 milyar dolarlık bir tazminatın söz konusu olabileceği belirtiliyor. Yıllardır KKTC'de kurulan "Taşınmaz Mal Komisyonu"nun Takas, Tazminat ve İade yöntemlerini kullanarak çözüm üretmeye çalıştıkları belirtiliyor. Tabii bu Mülkiyet konusu KKTC'de mülkü bulunan herkesi ilgilendirmektedir. Dolayısıyla bu durum endişeye de sebep olmaktadır.

Mülkiyet konusunda Rum tarafının en çok güvendiği konu "Loizidou Davası"dır. Bilindiği üzere bu dava kısaca Girne'deki arsasına ev yapmayı düşünürken 1974 harekâtı yüzünden göç eden ve arazisine dönemeyen bir kadının davasıydı. Bu dava sonucunda Avrupa İnsan Hakları Mahkemesi (AİHM), 28.07.1998 tarihli kararıyla, Titina Loizidou adlı hanıma Türkiye'nin tazminat ödemesini hüküm altına almıştı (Akbulut, 2002). 


\section{Sonuç}

Geçtiğimiz Temmuz ayında, Kıbrıs Barış Harekatı'nın 44. Yıldönümü törenleri yapıldı. Geriye bakıldığında geçen 44 yılda çok şeyin değiştiğini görmekteyiz. Karşımızda artık sadece Rum Yönetimi değil; İngiltere, ABD, İsrail ve Fransa da vardır.

Kıbrıs’ta İngiltere'nin biri hava diğeri deniz olmak üzere toplam iki üssü bulunmaktadır. Türkiye ve Yunanistan ile birlikte Kıbrıs'ta garantör ülkelerden olan İngiltere'nin üsleri, kendi toprağı kabul edilmektedir ve AB sınırları dışında yer almaktadır. İngiltere, aktif olarak Ortadoğu'daki askeri operasyonlarının çoğunluğunu bu üsler vasıtası ile gerçekleştirmektedir. İngiltere, Ada'da ayrıca, Ortadoğu'da en büyük dinleme tesislerine de sahip bulunmaktadır. Kıbrıs Rum yönetiminin, ABD’yle de benzer bir askeri işbirliği antlaşması mevcuttur. Rum yönetimi ayrıca, son yıllarda İsrail ile işbirliği içinde bulunmaktadır.

Türkiye'nin Güney Kıbrıs Rum Kesimi’nin (GKRK) Doğu Akdeniz'de tek yanlı parsellediği alanlarda sondaj yapmaya kalkan yabancı enerji şirketlerinin gemilerini engellemesinin ardından Rumlar, Fransa ile askeri işbirliğini artırmaya gitti. Onbir yıl önceki Fransa-GKRK askeri antlaşması yenilendi. GKRK üslerini Fransızlara açarken Fransa'da sondaj çalışmalarının güvenliğini üstlenme taahhüdünde bulundu. Görüldüğü gibi artık Türk varlığı şart oluyor.

GKRK'nin, KKTC’yi yok edip Kıbrıs Türklerini egemenliği altına almasının önündeki en büyük iki engel; Türkiye'nin garantörlüğü ve Türk askerinin Adadaki varlığıdır. Kıbrıs Türk’ü Adada 1974'ten beri güven içerisinde yaşayabiliyorsa nedeni bu iki güvencedir. Kıbrıs Türkleri'nin Ada'da huzur ve barış içinde yaşayabilmesi için üç farklı çözüm önerisi geliştirilebilir:

1. KKTC'nin ekonomik hayatı iyileştirilmeli veya GKRY'nin ekonomik koşullarına denk bir hale getirilmelidir. Bunun içinde KKTC'den Türkiye'ye yapılan ihracattan her türlü vergi kaldırılmalı, iş Adamlarımızın Kuzey Kıbrıs Türk Cumhuriyeti’ne yapacağı yatırımlar teşvik edilmelidir. Bunun yanında turizm cenneti olan Kıbrıs'a ülkemize gelen turistlerin bir kısmının ortak turlarla gitmesi sağlanmalıdır. KKTC'nin su ihtiyacının çözülmesi için çalışmalar yapılmış ve sorun çözülmüştür.

2. KKTC'nin, toplumlararası görüşmelerin sonucunda, adil ve kalıcı antlaşma yapmasıdır. Kıbrıs'ta her iki tarafın sırf çözüm olsun diye devlet yaşantısından vazgeçmesi, geçmişte yaşanan acı olaylara ve güvensizliğe rağmen azınlık hakları gibi daha alt düzeyde bir statüyü kabul etmesi söz konusu değildir. Bu antlaşma; iki kesimli, iki bölgeli, konfederal bir çatı altında, zayıf bir üniter devlet modeli çerçevesinde, Türkiye'nin etkin garantörlüğü altında Konfederal Kıbrıs Cumhuriyeti'ni kuracak tez üzerinde durulmalıdır.

3. "Mülkiyet" ve "Harita" konusunda çok dikkatli ve hassas davranılarak çözüme varılmalıdır. Yer değiştirme konusu, her iki taraf maliklerini sıkıntıya sokabileceği gibi nefreti de artırır. Benzer şekilde "Tazminat" konusu da hem Türkiye hem de KKTC açısından büyük bir ekonomik buhran demektir. Dolayısıyla toprak verilmesi kesinlikle kabul edilmemelidir. Bu konuda pazarlık yapılacaksa sadece "Maraş Bölgesi”" iyi niyet göstergesi olarak verilebilir. Zaten bu bölge hiçbir zaman kullanıma açılmamış, bölgede bulunan ne evlere ne de dükkânlara bakmak amacı ile bile girilmemiştir.

Yukarıda sayılan üç farklı çözüm önerisinin yanı sıra aşağıdaki sonuçlara ulaşmak mümkündür:

1. 1960 yılında iki kesimli Kıbrıs Cumhuriyeti aslında bir konfederasyondu; çünkü sorunlar hakkında görüş birliği için iki tarafın da onayına ihtiyaç duyuluyordu.

2. Kıbrıslı Türkler için üyelikten ayrılma diye bir şey söz konusu değildi; çünkü Rumlar iki kesimli 1960 üyeliğinden ismini gasp ederek zaten ayrılmışlardı.

3. Güney Kıbrıs, AB üyeliğini sınırlarını genişletmek için bir faktör olarak kullanmakta ve AB üyeliği ile birlikte egemenliğini Kıbrıs Türk toplumu üzerinden kurmayı ümit etmektedir. Rumların tek taraflı olarak AB'ye üye olması, iki tarafın işbirliğine yönelik bütün şansları yok edecektir.

4. Kıbrıs meselesinin adli bir mesele olmadığının farkına varılmalıdır; çünkü iki bağımsız devletin varlığı tartışmanın ötesindedir ve ilgili politik meseleler bu yasal çerçevede olmak zorundadır.

\section{Kaynakça}

- Akbulut, 2002. “Kıbrıs ile İlgili Önemli Bir Karar: Loizidou Davası”, İstanbul Barosu Dergisi Yayını, 76, s 160-163.

- Akbulut, 1998. Kuzey Kıbrıs Tarihi ve Tarihi Eserleri, Sultan Ofset, Lefkoşa.

- Bilge, 1996. Ankara, Atina, Lefkoşa Üçgeni, İmge Kitabevi Yayınları, Ankara.

- Bilge, 1959. Kıbrıs Uyuşmazlığı, Siyasal Bilgiler Fakültesi Yayını. Ankara.

- Erim, 1953. Devletlerarası Hukuku ve Siyasi Tarih Metinleri, C.1: Osmanlı İmparatorluğu Andlaşmaları, Türk Tarih Kurumu Basımevi, Ankara.

- Fehmi, 1992. A'dan Z’ye KKTC, Sosyal Ansiklopedik Bilgiler, Lefkoşa.

- Gazioğlu, 1960. İngiliz İdaresinde Kıbrıs (1878-1960), Ekin Basımevi, İstanbul. 
- Harp Akademisi Komutanlığı Yayını, 1995. Kıbrıs'ın Dünü Bugünün Yarını, Harp Akademileri Basımevi, İstanbul.

- Hürriyet Gazetesi, 08.08.2015-18.10.2015.

- $\quad$ İsmail, 1998. 150 Soruda Kıbrıs Sorunu, Kastaş Yayınları, İstanbul.

- Meray, 1975. Devletler Hukukuna Giriş, 2. Cilt, Ajans Türk Matbaası, Ankara

- Pazarcı, 1999. Uluslararası Hukuk Dersleri, 2. Kitap, Turhan Kitabevi, Ankara.

- Serter, 1982. Kıbrıs Türk Mücadele Tarihi, Lefkoşa.

- Szulc, 1993a. “Cyprus A Time of Reckoning”, National Geographic, 184, p. 109.

- Szulc, 1993b. “Cyprus A Time of Reckoning”, National Geographic, 184, p. 125.

- Tamçelik, 1997. Avrupa Birliği Güney Kıbrıs Rum Yönetimi Münasebetlerinin Kuzey Kıbrıs Türk Cumhuriyeti'ne İktisadı, Siyasi ve Hukuki Tesirleri, Nil Yayınları, İzmir.

- T.C. Lefkoşa Büyükelçiliği Yardım Heyeti, 2012. 2012 KKTC Ekonomik Durum Raporu, T.C. Lefkoşa Büyükelçiliği Yardım Heyeti Yayını, Lefkoşa.

- Yorgancıoğlu, 1998. Kıbrıs Coğrafyası (Fiziki), Boğaziçi Yayınları, İstanbul. 


\title{
Ambargodan Ablukaya Doğru: Dış Politikada İktisadi Araçların Kullanımı Bağlamında Amerika Birleşik Devletleri’nin İran'a Yönelik İktisadi Yaptırımları Üzerine Bir Değerlendirme \\ From Embargo to Blockade: An Evaluation of the United States Sanctions against Iran in the Context of the Use of Economic Impact Tools in Foreign Policy
}

\author{
Asst. Prof. Dr. Nuri Gökhan Toprak (Kırklareli University, Turkey)
}

\begin{abstract}
The concept of influence can be defined as a tool of international actors, a form of power, the ability to overcome obstacles in order to achieve different purposes or the desired result in the process of power relations established between actors in international politics. According to the approach that aims to reach the concept of influence as the desired result, in the process of setting up influence states try to influence each other through different methods and tools in which can be used through states' own capacities. In addition to political and military tools, economic impact tools related to the field of foreign trade and finance are frequently used today. Economic impact tools, such as external aid, which may be positive or rewarding, may also be negative or punitive in a range from the boycott to the blockade. The study aims to provide a qualitative assessment of the United States' (US) economic sanctions against Iran in the context of the use of economic impact tools in international politics. In order to achieve this aim, 12 executive orders issued by the US on the grounds that Iran poses a threat to its national security, foreign policy and economy will be examined. In the conclusion of the study, the assumption that the US sanctions against Iran almost for 40 years has become a multilateral structure such as commercial and financial blockade from a structure related to bilateral relations such as boycott and embargo will be tested.
\end{abstract}

\section{Giriş}

Uluslararası ilişkiler çalışmalarında bireyden küresel sisteme kadar tüm aktörlerin davranışları farklı boyutlar ekseninde ele alınabilmektedir. "Psikolojik" gibi daha çok birey düzeyinde veya "askeri" gibi daha çok bireyden farklı düzeydeki aktör davranışlarının analizinde ve açıklamasında kullanılan tüm düzeylerden ziyade belirli düzeylerde ele alınması daha mümkün boyutlar bulunmaktadır. "Siyasi" ve "iktisadi" boyutlar ise uluslararası ilişkilerin herhangi bir düzeyindeki aktör davranışlarını açıklamada kullanılabilecek genel boyutlar arasında yer almaktadir.

XX. yüzyıldan itibaren iktisadi ve toplumsal yaşam üzerindeki etkisini arttıran küreselleşme süreci, uluslararası ilişkiler aktörlerinin davranışlarını, ister özgül isterse genel olsun, yalnızca bir boyut ekseninde değerlendirmeyi oldukça zorlaştırmıştır. II. Dünya Savaşı'nın sona ermesinin ardından özellikle devlet düzeyindeki uluslararası ilişkiler aktörlerinin birbirlerinin davranışlarını değiştirme çabaları noktasında askeri müdahalelerin meşruluğunu gittikçe yitirmeye başlamış; siyasi ve iktisadi hedeflerin askeri araçlardan daha çok yine siyasi ve iktisat boyutları ekseninde değerlendirilebilecek davranışlarla desteklenmeye başladığı görülmektedir. İster siyasi amaçları desteklemek ister yalnızca yine iktisadi amaçlarla gerçekleştirilmiş olsun, devlet düzeyindeki uluslararası ilişkiler aktörlerinin kullandıkları iktisadi etki araçları temel olarak iki başlık altında incelenebilmektedir. Bu etki araçlarından ilki boykot, ambargo ve abluka uygulamalarından oluşan dış ticarete ilişkin etki araçlarıdır. İkinci tür etki araçları ise küresel iktisadi yapının gittikçe karmaşıklaşan çeşitli düzeydeki finansal uygulamalarını içermektedir.

Amerika Birleşik Devletleri’nin (ABD) İran'ın başta siyasi, daha sonraki yıllarda ise askeri davranışlarına etki etmeye yönelik amaçlara ulaşmada iktisadi etki araçlarını kullandığı varsayımından hareketle bu çalışma ABD'nin kullanmış olduğu dış ticarete ilişkin etki araçlarına odaklanacaktır. Çalışmada sınanacak bir diğer varsayım ABD’nin İran'ın siyasi davranışlarını etkilerken daha çok ambargo olarak nitelendirilebilecek araçları kullandığı, ancak son yıllarda İran'a karşı kullanılan iktisadi etki araçlarının ablukaya doğru bir evrim geçirdiği olacaktır. Bu iki varsayımın sınabilmesi için öncelikle iktisadi bir etki kurma aracı olarak ambargo ve ablukanın kavramsal çerçevesi çizilecektir. ABD’nin 1979'dan itibaren İran'a yönelik uygulamaya koyduğu yaptırımlar tarihsel süreç takip edilerek gerekçeleri ile birlikte sunulduktan sonra çalışmanın sonuç bölümünde varsayımlar yeniden değerlendirilecektir.

\section{Dış Politikada İktisadi Etki Araçları}

II. Dünya Savaşı süresince devletlerin birbirlerine karşı kullanmış olduğu olağanüstü askeri gücün yüksek maliyeti, savaşın sonunda savaşan aktörlerin diğer aktörler üzerinde etki yaratma noktasında sağladıkları nihai başarıyı sorgulamalarına neden olmuştur. Devletlerarası düzeyde askeri güç kullanımın, Birleşmiş Milletler 
Antlaşması 1. Bölümü 2. Maddesinin 4. Fıkrasında da belirtildiği üzere (Birleşmiş Milletler Antlaşması ve Uluslararası Adalet Divanı Statüsü, 1945), uluslararası kamuoyu nezdindeki meşruluğunu yitirmeye başlaması, bu sorgulamanın en net örneği olmuştur.

Askeri güç kullanımın meşruluğunu yitirmesine paralel olarak gelişen iktisadi küreselleşme süreci, devletlerin birbirleri üzerinde dış ticaret ve uluslararası finansa ilişkin önlemler alarak etki kurma çabalarına da zemin hazırlamıştır. Devletlerin birbirleri üzerinde etki kurmaya yönelik kullandıkları dış ticarete ilişkin geleneksel uygulamalar arasında gümrük tarifelerini arttırmak, ticari ilişkilere kota koymak, aşırı fiyat yükseltme ya da azaltma, boykot, ambargo veya abluka gibi uygulamalar bulunmaktadır (Sönmezoğlu, 2014, s. 494). Ancak bu uygulamalardan boykot, ambargo ve abluka, bu uygulamaların nispeten daha geniş kapsamlı, siyasi yönü iktisadi yönüne daha baskın ve sonuçları itibariyle daha net bir görünüm sunmaları sebebiyle, uluslararası politika açısından daha etkin bir analizi mümkün kılmaktadır.

\subsection{Boykot ve Ambargo}

Boykot, devlet ya da halk düzeyinde bir toplumsal örgütlenmenin, yine aynı düzeylerdeki bir başka toplumsal örgütlenmenin mal veya hizmetlerinin ithalatını durdurmak suretiyle, ihracatçı konumda yer alan toplumsal örgütlenme üzerinde etki kurmaya çalışmasıdır. Dış ticarette özellikle ihracatçı konumda yer alan devletin ihracatta aşırı derecede boykotu gerçekleştiren devlete bağımlı olduğu ya da kısa süre içerisinde alternatif bir ithalatçı devlet bulamayacağı durumlarda boykot oldukça etkili bir diş ticaret etki aracı olmaktadır (Galtung, 1967, s. 384). 22 Eylül 1908 tarihinde Bulgaristan'ın bağımsızlı̆̆ını ilan etmesinin yanı sıra 08 Ekim 1908'de Bosna-Hersek'in Avusturya-Macaristan İmparatorluğu tarafından ilhakı üzerine Osmanlı halkının Avusturya-Macaristan İmparatorluğu'nda üretilen feslerin ithalatına karşı gerçekleştirdiği boykot (Çetinkaya, 2014), tarihte verilebilecek boykot örneklerinden biridir.

Etki aracını kullanan aktör açısından bakıldığında ithalatı odağına alan bir uygulama olan boykotun, ihracatı odağına alan uyarlaması ise ambargo olarak tanımlanmaktadır (Sönmezoğlu, 2014, s. 495). Tarihsel süreç içerisinde daha ziyade devlet düzeyindeki aktörler tarafindan uygulanan ambargo, bu çerçevede, bir devletin bir başka devlete mal veya hizmet ihracatını yine etki kurmak ya da arzu ettiği sonuca ulaşasıya kadar durdurmasıdır. İhracatçı konumdaki devletin mal veya hizmetlerini ambargo uyguladığı devlet dışındaki devletlere ihraç edebilecek olması ya da ithalatçı konumdaki devletin özellikle ambargoyu uygulayan devletin mal ve hizmetlerine bağımlılık oranı ambargonun etkisini belirlemektedir. 05 Şubat 1975 tarihinde ABD’nin, Türk Silahlı Kuvvetlerinin Kıbrıs Adası'ndaki varlığını gerekçe göstererek savunma ve tarım sanayini kapsayan mal ve hizmetlerin Türkiye'ye ihracatını durduran ambargo (U.S. Library of Congress, 1975), tarihte verilebilecek ambargo örneklerinden biridir.

Ambargo ve boykot, esas itibariyle iki devlet veya devletlerden oluşan iki farklı koalisyon arasında gerçekleşen bir uygulamadır. Bu bağlamda Osmanlı İmparatorluğu'nun 1908'de Avusturya Macaristan İmparatorluğu'na yönelik boykotu ya da ABD'nin 1975-1978 yılları arasında Türkiye'ye yönelik uyguladığı ambargo iki devlet arasında yaşanan uygulamalara örnek teşkil etmektedir. II. Dünya Savaşı Sırasında Müttefik Devletler ile Mihver Devletler arasında diş ticarete yönelik uygulamalar ya da 1973 yılında OPEC üyesi devletlerin başta ABD olmak üzere Batılı devletlere yönelik uyguladığı ambargo ise birden fazla devletin yine birden fazla devlete aynı zaman aralığında uyguladığı ambargo ve boykotlara verilebilecek örneklerdir.

Ambargo ve boykotun bir diğer özelliği amaçlanan etkinin yaratılması veya arzu edilen sonuçlara ulaşılması noktasında bu uygulamaları gerçekleştiren devletlere nispeten sınırlı bir kontrol imkanı sunmasıdır. Özellikle iktisadi küreselleşmenin sunmuş olduğu imkanların etkisiyle devletler veya devletlerden oluşan koalisyonlar, uluslararası ilişkilerin farklı düzeydeki aktörleriyle kolaylıkla alternatif ticari işbirliklerine gidebilmektedir (Sönmezoğlu, 2014, s. 487-488). Bu noktada ambargo veya boykot uygulayan devletlerin başvurdukları iki temel davranış bulunmaktadır. Bunlardan birincisi devletlerin doğrudan askeri etki araçlarını kullanmalarıdır. Ancak daha önceden belirmiş olduğumuz üzere bu uygulama hem uluslararası kamuoyu nezdinde meşruluğunu yitirmekte hem de askeri güce maruz kalan devletlerin kamuoyunda bu güce karşı bir direnişin örgütlenmesini kolaylaştırmaktadır. Öte yandan askeri güçle desteklenmesine rağmen temelde yine iktisadi bir etki kurma aracı olan abluka, dış ticarete ilişkin gerçekleştirilen uygulamalardan bir diğeri olmaktadır.

\subsection{Abluka}

Ambargo ve boykot haricinde dış ticarette kullanılan bir diğer etki aracı ablukadır. Ancak ambargo ve boykot yalnızca etki kurmaya çalışan ile üzerinde etki kurulmaya çalışan taraflar arasında gerçekleşen diş ticaret uygulamalarıyken, abluka sonuçları itibarıyla üçüncü tarafları da etkileyen bir dış ticaret uygulamasıdır. Devletlerin tarih boyunca daha çok savaş durumunda kullandıkları abluka, "hedef ülkenin tümünün veya belirli bir bölümünün dış ile olan bağlantısının kısmen veya tamamen denetim altına alınması, sınırlandırılması veya kesilmesidir" (Sönmezoğlu, 2014, s. 497). Bu bağlamda abluka ile kurulan kontrolün devamlılığını askeri etki araçları sağlamaktadır. I. Dünya Savaşı ile başlayıp 1919'a kadar Birleşik Krallığın Almanya'nın deniz ticaret yollarını (Osborne, 2004), 1941 ile 1945 yılları arasında ise Almanya'nın Sovyetler Birliği'nin Leningrad şehrinin kara ticaret yollarını keserek uygulamış olduğu ablukalar (Playsier, 2008, s. vii), askeri etki araçları ile desteklenen dış ticaret etki araçlarına örnek olarak verilebilir. 
Abluka yalnızca savaş hali içerisinde olan taraflar arasında gerçekleşen bir dış ticaret uygulaması değildir. Ambargo veya boykot ile arzu ettiği ölçüde etki yaratamayan devletler, XX. yüzyılın ikinci döneminden itibaren askeri güç kullanımının iktisadi, uluslararası hukuki ve dünya kamuoyu nezdindeki imajlarında yaşanacak bozulmanın maliyetini de hesaba katarak bu dış ticaret uygulamasının devamlılığını yoğun bir diplomasi ve küresel finansal sisteme ilişkin uygulamalarla desteklemektedir. 2017 yılının Haziran ayından itibaren, Katar'ın karadan tek komşusu olan, Suudi Arabistan'ın önderliğinde başlayıp 9 devletin tam, 4 devletin ise diplomatik düzeyde destek verdiği abluka (Reuters, 2017), askeri etki araçları yerine yoğun diplomasi ve finansal kısıtlama çalışmaları ile desteklenen uygulamalara örnek olarak verilebilir.

\section{ABD'nin İran'a Yönelik Yaptırımları ve Yaptırımların Değișen Niteliği}

Çalışmanın temelini oluşturan ABD’nin İran'a yönelik uyguladığı dış ticaret uygulamalarının ambargodan bir ablukaya dönüştüğü varsayımındaki "abluka", askeri etki araçları yerine diplomasi ve finansal kısıtlama çalışmaları ile desteklenen türden bir ablukadır. Bu varsayımı sınamak için, öncelikle ABD’nin İran'a karşı kullandığ 1 dış ticarete ilişkin etki araçlarının neden ve nasıl ortaya çıktığı sunulmalıdır. Daha sonra yaptırımların ilk başladığı 1979 tarihinden itibaren Amerika'nın kamuoyu ile paylaştığı çeşitli belgeler 1şığında bu uygulamaların niteliğindeki değişim ortaya konmaya çalışılacaktır.

\subsection{Yaptırımlar Öncesinde İran-Amerikan İlişkileri}

XIX. yüzyıl boyunca Britanya İmparatorluğu ve Rus Çarlığı arasında cereyan eden ve "Büyük Oyun” olarak da nitelendirilen emperyal çekişme, Merkezi Asya'da yer alan Hanlıklar, Hindistan veya Afganistan kadar İran tarihini de derinden etkilemiştir (Mojtahed-Zadeh, 2004). Britanya ve Rusya arasındaki çekişmenin İran'ın güvenliğine karşı oluşturduğu potansiyel tehdidin yanı sıra, 1804-1813 yılları arasında Rusya'yla, 1856-1857 yılları arasında ise Britanya ile savaşılması, İran'ın dönemin bu iki önemli gücüne karşı yaklaşımını olumsuz etkilemiştir. Öte yandan ABD ise uluslararası işbirliği kurulma noktasında nispeten daha güvenilir bir ortak olarak kabul edilmiştir. Bu durumun en önemli göstergelerinden biri, 1911 yılında William Morgan Shuster, 1922-1927 ve 1942-1945 yılları arasında ise Arthur Millspaugh isimli Amerikan vatandaşlarına İran'ın ekonomik durumunu düzeltmek için bakanlık seviyesinde yetkilerin bizzat İran yönetimleri tarafindan verilmesidir (Cottam, 1988, s. 53).

ABD-İran ilişskilerinin iktisadi alandan farklı alanlara doğru genişlemesi ve kurumsallaşması ise II. Dünya Savaşı'nın son yıllarından itibaren gelişen bir süreçtir. Bu süreç 1947'de ABD Başkanı Harry Truman ABD’nin komünizme karşı uluslararası politikada daha etkin bir rol oynayacağını ilan etmesiyle başlamıştır. Truman tarafından 20 Ocak 1949 tarihinde ilan edilen "Dördüncü Nokta Programı” doğrultusunda kurulan “Teknik İşbirliği İdaresi” (TCA) ve "Yedi Yıllık Plan” ile ABD’nin İran’a verdiği iktisadi danışmanlık hizmeti daha kapsamlı ve kurumsal bir nitelik kazanmıştır (Ricks, 1979, s. 176).

ABD'nin İran'a yönelik desteğinin askeri bir boyut kazanması ise 1943 yılında başlayan bir süreçtir. Bu süreçte ilk olarak 1943 yılında İran Jandarması (GENMISH), 1947 yılında ise İ́ran Ordusu'na destek ve danışmanlık yapması amaciyla Amerikan Ordusu Görev Merkezi (ARMISH) ABD’nin desteği ile kurulmuştur (Ricks, 1979, s. 173-174). 1950 yılında imzalanan “Karşılıklı Savunma Yardımı Anlaşması” kapsamında ABD’nin İran'a askeri yardımı yıllık ortalama 45 milyon Amerikan Doları olacak şekilde (bu tutarın 2019 yılındaki cari karşılığı yıllık ortalama 361 milyon Amerikan Dolarıdır (Official Data Foundation, 2019)) 1965 yılına kadar devam etmiş, 1958 yılında İran'daki “Askeri Yardım Danışma Grubu'nun” (MAAG) ARMISH ile birleştirilmesi sonucu askeri yardımlar da kurumsal bir seviyeye ulaşmıştır (Al-Saud, 2003, s. 68-69).

ABD-İran İlişkileri tesis edildiğinden İran İslam Devrimi’nin gerçekleştiği döneme kadar ilişkiler olumlu bir seyir izlerken, bu dönem içerisinde tek istisnai dönem 1951-1953 yılları arasında İran'da Başbakanlık görevini icra eden Muhammed Musaddık Dönemi olmuştur. Nitekim Musaddık’ın görevi süresince, başta İran enerji sektörünün millileştirilmesi olmak üzere, uygulamış olduğu pek çok politikanın ikili ilişkilere olumsuz yansıdığ gözlemlenmiştir (Blanchard, 1996, s. 15-17). Ancak Musaddık'ın askeri bir darbe sonrasında görevden uzaklaştırılmasının ardından ikili ilişkiler yeniden olumlu bir zemine dönmüş, 1957'de dönemin ABD Başkanı Dwight Eisenhower'in uluslararası komünizmle mücadele kapsamında, İran'ın da dahil olduğu, Orta Doğu coğrafyasındaki devletlere ABD’nin iktisadi ve askeri destek vereceğini açıklamasıyla yeniden gelişme eğilimi göstermiştir.

\subsection{ABD’nin İran'a Yönelik Yaptırımları ve Yaptırımların Değișen Niteliği}

İran-Amerikan ilişkileri başlangıcından İran İslam Devrimi'ne kadar, ABD’nin İran'a yönelik iktisadi ve askeri desteğiyle, devletler düzeyinde gelişmeyi sürdürürken, toplumlararası ilişkilerde benzeri bir gelişim gösterememiştir. Tahta çıktığı günden itibaren ABD ile ilişkileri geliştirmeye özen gösteren Şah Muhammed Rıza Pehlevi bu doğrultuda 1963 yılında “Ak Devrimi” ilan etmiş, fakat bu kapsamda gerçekleştirilmeye çalışılan reformlara karşı "Haziran Ayaklanması" olarak nitelenen, önderleri arasında Ayetullah Humeyni'nin de bulunduğu, milliyetçi ve muhafazakar nitelikte geniş katılımlı bir halk ayaklanması aynı yıl içerisinde başlamıştır (Ashraf, 1996, s. 37-40). Ayaklanmalar Pehlevi Yönetimi tarafından kısa süre içerisinde bastırılmış, Humeyni sürgüne gönderilmiştir. Ancak gerek İran kamuoyu nezdinde İran devletinin iktisadi ve askeriden sonra kültürel 
açıdan da ABD ile fazlaca yakınlaşmaya başlaması, gerekse Asyalı devletlerin kendi güvenliklerini sağlama noktasında daha fazla sorumluluk alması gerektiğini belirten Nixon Doktrini sonrası İran'ın askeri harcamalarında aşırı bir artış göstermesi 1970 li yıllar boyunca İran'daki toplumsal gerginliği gittikçe tırmandırmıştır (Ricks, 1979, s. 185).

1979 yılında İran'da gerçekleşen İslam Devrimi, İran-Amerikan İlişkilerinde bir kırılma olmuştur. Nitekim İslam Devrimi, bir açıdan, iktisadi ve askeri alanda teknik yardım ile başlayıp II. Dünya savaşı sonrasında bir tür bağımlılık ilişkisine dönüşen İran-Amerikan İlişkilerine yönelik toplumsal bir tepki olarak şekillenmiştir. Dönemin ABD Başkanı Jimmy Carter Devrim'in ilk aylarında ikili ilişkileri sürdürmeye çalışsa da Musaddık Dönemi'nden sonra ilk kez devlet ve halkın bir tür bütünleşme yaşadığı İran'da gerek yeni siyasi lider Humeyni gerekse Şah Pehlevi'nin ABD'ye iltica edeceğini düşünen halk ikili ilişkilerin mevcut haliyle devam ettirilemeyeceğinin kuvvetli sinyallerini vermiştir (Guerrero, 2016, s. 176-179). Nitekim tarihe "Rehine Krizi" olarak geçen olayda, Pehlevi'nin ABD'ye iltica edeceğini düşünen silahlı devrimci gruplar, bu durumu protesto etmek için Humeyni'nin "Casus Yuvası" olarak tanımladığı Tahran'daki Amerikan Büyükelçiliğini 04 Kasım 1979'da işgal etmiştir (Houghton, 2001, s. 62). ABD, Rehine Krizi'ni, 1961 yılında Viyana'da gerçekleştirilen “Birleşmiş Milletler Diplomatik İlişkiler ve Dokunulmazlıklar” konferansında alınan kararlar çerçevesinde hazırlanan, 1964 yılında yürürlüğe giren "Diplomatik İlişkiler Hakkında Viyana Sözleşmesi'nin” açık bir ihlali olarak yorumlamış, bu doğrultuda İran'ın hukuk dışı olduğunu iddia ettiği davranışlarını değiştirmek için dış ticarete ilişkin etki araçlarını kullanmaya başlamıştır.

ABD’nin İran'a yönelik ilk dış ticari yaptırımı bir boykot olmuş, 12 Kasım 1979'da ABD İran'dan petrol ithalatını durdurmuştur (Goshko \& Walsh, 1979). İkinci yaptırım, İran Hükümeti'nin ABD’deki tüm mal varlığının 14 Kasım 1979 tarihli 12170 Sayılı Başkanlık Emri ile dondurulması olmuştur (U.S. Department of the Treasury, 1979). ABD, 07 Nisan 1980'de İran ile tüm diplomatik ilişkilerini keserken (Department of State, 2019), 17 Nisan 1980 tarihinde yürürlüğe giren 12205 ve 12211 Sayılı Başkanlık Emirleri ile İran'a yönelik yaptırımlar geniş kapsamlı bir ambargoya dönüşmüştür (U.S. Department of the Treasury, 1979). Cezayir Hükümeti'nin ABD ile İran arasında arabuluculuk yapma girişimleri 19 Ocak 1981 tarihinde sonuç bulmuş, ABD yaptırım kararlarını, rehin alınan Amerikan vatandaşlarının serbest bırakılması karşılığında 12276, 12277, 12278, 12279,12280,12281, 12282, 12283, 12284, 11294 Sayılı Başkanlık Emirleri ile kaldırmıştır (U.S. Department of the Treasury, 2019).

ABD ile İran arasındaki ticaretin hacmi 1985-1987 yılları arasında toplam 3 milyar Amerikan dolarını aşan bir seviyeye ulaşmasını karşın ABD, İran'ın uluslararası teröre destek verdiği ve Basra Körfezi'nde seyreden Amerikan gemilerine yönelik hukuksuz ve saldırgan tavırlarını gerekçe göstererek 30 Ekim 1987 tarihinde yayımlanan 12613 Sayılı Amerikan Başkanlık Emri ile yeniden boykot uygulamasına başvurmuştur (U.S. Department of the Treasury, 1987). Ancak bu kez ABD'nin İran mallarına yönelik boykotu beraberinde bir ambargo kararını getirmemiş, 1989 yılındaki veriler ile karşılaştırıldığında ABD'nin İran'a yönelik yıllık ihracatı 1992'de 13,5 katına çıkmıştır (U. S. Census Bureau, 2018). ABD’nin İran'a yönelik uzun erimli ve kapsamlı ambargosu, 1995 yılında dönemin ABD Başkanı William J. Clinton tarafından yayımlanan 12957 (U.S. Department of the Treasury, 1995), 12959 (U.S. Department of the Treasury, 1995) Sayılı Başkanlık Emirleri ile başlatılmıştır. Gerekçeleri önceki Başkanlık Emirlerine kıyasla daha geniş tanımlamaları içeren bu Emirlerin açıklanmasına müteakip 4 yılda İran ve ABD arasında ticaretin hacmi toplam 46,7 milyon Amerikan Doları'na kadar düşmüştür (U. S. Census Bureau, 2018).

Ocak 1998'de İran'da Cumhurbaşkanlığı görevine gelen Muhammed Hatemi’nin ABD'ye yönelik nispeten daha 1lımlı bir politikayı benimsemesine ek olarak 31 Ağustos 2000'de New York'da ABD Kongresi üyelerinin, İran Meclis üyeleriyle gayri resmî bir şekilde bir araya gelmesi gibi gelişmeler İran-Amerikan İlişkilerinde bir yakınlaşma gibi algılansa da 11 Eylül Saldırıları ardından ikili ilişkiler yeniden gerilmiştir. Nitekim 29 Ocak 2002 tarihindeki konuşmasında dönemin ABD Başkanı George W. Bush İran'1, Irak ve Kore Demokratik Halk Cumhuriyeti ile birlikte, uzun menzilli füzeleriyle ABD'yi tehdit eden ve terörü destekleyen "Şer Ekseni" ülkeleri arasında saymıştır. Bu düşmanca söylem İran'da da karşı1ık bulmuş, 2005'de göreve başlayan İran Cumhurbaşkanı Mahmud Ahmedinejad da ABD’ye karşı toplumsal destek gören muhafazakar söyleme geri dönmüştür.

11 Eylül Olaylarının ardından ABD’nin uluslararası güvenlik söyleminin muğlak bir küresel terörle mücadele ekseninde yeniden şekillenerek Bush Doktrini kapsamında oldukça geniş bir karşı cephe yaratması, bu söylemde "Şer Ekseni" içerisinde yer alan devletler başta olmak üzere, pek çok devletle ABD arasındaki ilişkileri olumsuz etkilemiştir. Bu noktadan hareketle ABD’nin İran'a yönelik yaptırımlarının modern bir ablukaya dönüşmesinde de 11 Eylül Olaylarının önemli etkisi bulunmaktadır. Nitekim 11 Eylül Olaylarının ardından ABD’nin İran'a karşı yeniden geliştirdiği düşmanca bir tavır, Bush Doktrininin "vurulmadan önce vurma" anlayışı bağlamında İran nezdinde de ABD'den yoğun bir tehdit algısının yaratılmasına neden olmuştur.

İran ve ABD, 1981'de Cezayir'den sonra bu kez 2005'te Almanya'nın önderliğindeki Avrupa Birliği troykasının arabuluculuğu ile başlayan, devam eden süreçte Birleşmiş Milletler Güvenlik Konseyi'nin daimi üyesi Çin Halk Cumhuriyeti ve Rusya'nın desteğiyle güçlenen bir süreç içerisinde yeniden aynı masaya oturma imkanı yakalamışlardır. 2013'te resmiyet kazanan ve 14 Temmuz 2015 tarihinde Viyana'da imzalanan, İran'ın nükleer enerji çalışmalarını barışçıl bir nitelik kazandırmayı hedefleyen "Kapsamlı Ortak Eylem Planı'nın” imzalanmasıyla sağlam bir hareket noktası kazandığı düşünülen süreç aynı zamanda ABD’nin İran'a yönelik 
yaptırımlarını kaldırılmasını öngörmekteydi. Ancak ikili ilişkileri geliştirmesi öngörülen bu süreç ABD Başkanı Donald J. Trump'ın 06 Ağustos 2018 tarihli ve 13846 Sayılı Başkanlık Emri ile kesintiye uğramıştır (U.S. Department of the Treasury, 2018).

İran Hükümeti ve İran Devrim Muhafizları Ordusu'nun silahlanmaya ve füze geliştirmeye devam etmesinin yanı sıra Ortadoğu'daki terörist gruplara destek verdiği iddiasıyla İran'1 ABD'nin güvenliği için bir tehdit olarak tanımlayan Trump'ın Başkanlık Emrini yaptırım emri içeren diğer Başkanlık Emirlerinden ayıran özellik, 13846 Sayılı Başkanlık Emrinin 2. Bölümü’nde "yabancı finans kurumlarının” da bu yaptırımlara tabi tutulmuş olmasıdır. Nitekim 20 devletin ABD Başkanlık Emrinden sonra İran'dan petrol ithalatını kestiğine, Çin Halk Cumhuriyeti, Tayvan, Hindistan, Güney Kore, İtalya, Japonya ve Yunanistan'la birlikte Türkiye'ye yalnızca 6 ay süreyle ve yine yalnızca petrol ithalatı noktasında istisnai bir konum tanındığına dair açıklamalarıyla (U.S. Department of State, 2018) ABD Dışşşleri Bakanı Mike Pompeo, dış ticarete ilişkin yaptırımların artık iki taraf arasında cereyan eden nitelikten çok taraflı bir ablukaya dönüştürülmeye çalışıldığına dair varsayımımızı desteklemektedir.

\section{Sonuç ve Değerlendirme}

Devletlerarası ilişkilerde etki kurmak amacıyla askeri araçların kullanılması devletler tarafından tamamen terk edilen bir uygulama değildir. Ancak II. Dünya Savaşı ve Nükleer Caydırıcılık devletler arası çatışmaların çözümünde askeri güç kullanımının maliyetini pek çok yönden arttırmıştır. Öncelikle uluslararası çatışmaların barışçıl yollardan halledilmesi Birleşmiş Milletler Anlaşması da dahil olmak üzere pek çok uluslararası hukuk belgesinde kendine yer bularak, askeri etki araçlarının kullanımının siyasi ve hukuki maliyetini arttırmıştır. Bununla birlikte kültürel küreselleşme ve karşılıklı bağımlılık sonucunda toplumlar arası entegrasyonun artmasıyla askeri etki araçları uluslararası kamuoyunun nezdinde de meşruluğunu yitirmeye başlamış, dolayısıyla askeri araçların toplumsal ve psikolojik maliyeti de artmıştır.

Askeri etki araçlarının artan maliyetleri karşısında devletler, iktisadi küreselleşmenin de sağladığı imkanlar vasıtasıyla, iktisadi etki araçlarına daha fazla ağırlık verme eğilimi göstermiştir. Öte yandan yine iktisadi küreselleşmenin bir sonucu olarak devletlerarası ilişkilerde etki aracı olarak ambargo veya boykot gibi iki taraflı dış ticaret uygulamaların etkinliği küreselleşme öncesi dönemlere nispeten azalmıştır. Bu durumda devletler tüm askeri, iktisadi, toplumsal, hukuki ve psikolojik maliyetlerine rağmen askeri etki araçlarına yeniden başvurabilmekte ya da dış ticarete ilişkin geleneksel bir etki aracı olan ablukanın modern bir uyarlamasını uygulayabilmektedirler. Geleneksel olarak askeri araçlarla devamlılığı sağlanan abluka, modern haliyle, dış ticarete ilişkin uygulamaların küresel finansal sisteme ilişkin önlemlerle desteklenmesiyle devletlerarası ilişkilerde etki kurma noktasında yeniden işlevsel bir araç haline getirilmeye çalışılmaktadır.

ABD’nin İran'a yönelik yaptırımları ilk etapta Rehine Krizi'ne ilişkin tepkisel bir boykot, kısa süre sonrasında ise Carter Doktrini çerçevesinde sistematik bir ambargoya dönüşmüştür. Öte yandan İslam Devrimi İran'daki siyasal konsolidasyonunun ardından, İran'ın ABD tarafından desteklendiğini iddia ettiği Irak ile gerçekleştirdiği savaş sonrasında toplumsal konsolidasyonunu da sağlamıştır. ABD'nin İran'a yönelik yaptırımları bu gelişmeler neticesinde, Johan Galtung'un teorisiyle (Galtung, 1967, s. 388-390) örtüşecek şekilde, İran halkı üzerinde psikolojik bir kenetlenme yaratırken ABD'nin iki taraflı bir etki aracıyla arzu ettiği sonuçlara ulaşmasını gittikçe zorlaştırmıştır.

ABD’nin 1990'lar boyunca herhangi olumlu bir sonuç vermeyen İran politikası yukarıda sunmuş olduğumuz çerçevede ABD Başkanı Trump tarafından yeniden değerlendirilmeye tabi tutulmuştur. Bu yeniden değerlendirme sonucunda ise Trump Yönetimi İran'ın nükleer askeri kapasitesi ve Ortadoğu'daki ulusötesi terörist gruplara destek verdiği iddiaları yineleyerek yeni bir Başkanlık Emri yayınlamıştır. Bu Başkanlık Emrinde geçen ifadeler ve sonrasında ABD Dışişleri Bakanı Pompeo'nun açıklamaları ekseninde ABD’nin İran'a yönelik diplomatik ve finansal araçlarla desteklenen yaptırımlarını modern bir ablukaya dönüştürmeye çalıştığına dair varsayımımız doğrulanmıştır.

\section{Kaynakça}

- Al-Saud, 2003. Iran, Saudi Arabia and the Gulf: Power Politics in Transition. New York: I. B. Tauris.

- Ashraf, 1996. "From the White Revolution to the Islamic Revolution". S. Rahnema, \& S. Behdad (Dü) içinde, Iran After the Revolution: Crisis of an Islamic State (s. 21-44). London: I. B. Tauris.

- Birleşmiş Milletler Antlaşması ve Uluslararası Adalet Divanı Statüsü. 1945, Haziran 26. Nisan 7, 2019 tarihinde BM Enformasyon Merkezi: http://www.unicankara.org.tr/doc_pdf/chart_turkce.pdf adresinden alınd1

- Blanchard, 1996. Neocolonialism American Style, 1960-2000. Connecticut: Greenwood Press.

- Cottam, 1988. Iran and the United States: A Cold War Case Study. Pittsburgh: University of Pittsburgh Press.

- Çetinkaya, 2014. 1908 Osmanlı Boykotu: Bir Toplumsal Hareketin Analizi. İstanbul: İletişim Yayınları. 
- Department of State, 2019. A Guide to the United States' History of Recognition, Diplomatic, and Consular Relations, by Country, since 1776: Iran. Nisan 07, 2019 tarihinde Office of the Historian:

https://history.state.gov/countries/iran adresinden alınd1

- Galtung, 1967. "On the Effects of International Economic Sanctions: With Examples from the Case of Rhodesia”, World Politics, XIX(3), 378-416. Nisan 7, 2019 tarihinde https://www.jstor.org/stable/2009785 adresinden alınd

- Goshko, November 13 1979. “U.S., Iran Declare Halt to Oil Trade”. Nisan 07, 2019 tarihinde The Washington Post: https:/www.washingtonpost.com/archive/politics/1979/11/13/us-iran-declare-halt-to-oiltrade/0141298a-fe50-4fae-bc59-b71eb2614765/?noredirect=on\&utm_term=.f2babccf74da adresinden alınd

- Guerrero, 2016. The Carter Administration and the Fall of Iran's Pahlavi Dynasty: US-Iran Relations on the Brink of the Islamic Revolution. New York: Palgrave Macmillan.

- Houghton, 2001. US Foreign Policy and the Iran Hostage Crisis. Cambridge: Cambridge University Press.

- Mojtahed-Zadeh, 2004. Small Players of the Great Game: The Settlement of Iran's Eastern Borderlands and the Creation of Afghanistan. London: RoutledgeCurzon.

- Official Data Foundation 6 Nisan 2019. Calculating Inflation in the U.S. Inflation Calculator: http://www.in2013dollars.com/us/inflation/1965?amount= adresinden alınd1

- Osborne, 2004. Britain's Economic Blockade of Germany: 1914-1919. London: Frank Cass.

- Playsier, 2008. Frozen Tears: The Blockade and Battle of Leningrad. Lanham: University Press of America.

- Reuters, June 5 2017. “Arab Powers Sever Qatar Ties, Citing Support for Militants”. (N. Browning, Düzenleyen) Nisan 7, 2019 tarihinde https://www.reuters.com/article/us-gulf-qatar/arab-powers-sever-qatarties-citing-support-for-militants-idUSKBN18W0DQ adresinden alındı

- Ricks, 1979. "U.S. Military Missions to Iran, 1943-1978: The Political Economy of Military Assistance”, Iranian Studies, XII(3-4), 163-193.

- Sönmezoğlu, 2014. Uluslararası Politika ve Dış Politika Analizi (Gözden Geçirilmiş ve Genişletilmiş 6. Baskı b.). İstanbul: Der Yayınları.

- U. S. Census Bureau, December 18 2018. Trade in Goods with Iran. Nisan 7, 2019 tarihinde U. S. Census Bureau Web Sitesi: https://www.census.gov/foreign-trade/balance/c5070.html adresinden alındı

- U.S. Department of State, November 5 2018. Press Availability With Secretary of Treasury Steven T. Mnuchin. Nisan 7, 2019 tarihinde U.S. Department of State Web Sitesi: https://www.state.gov/secretary/remarks/2018/11/287132.htm adresinden alınd1

- U.S. Department of the Treasury, , November 14 1979. Executive Order No. 12170. Nisan 6, 2019 tarihinde U.S. Department of the Treasury Web Sitesi: https://www.treasury.gov/resourcecenter/sanctions/Programs/Documents/Executive\%20Order\%2012170.pdf adresinden alınd1

- U.S. Department of the Treasury, April 17 1979. Executive Order No. 12205. Nisan 7, 2019 tarihinde U.S. Department of the Treasury Web Sitesi: https://www.treasury.gov/resourcecenter/sanctions/Programs/Documents/Executive\%20Order\%2012205.pdf adresinden alınd1

- U.S. Department of the Treasury, October 30 1987. Executive Order No. 12613. Nisan 7, 2019 tarihinde U.S. Department of the Treasury Web Sitesi: https://www.treasury.gov/resourcecenter/sanctions/Documents/12613.pdf adresinden alınd1

- U.S. Department of the Treasury, March 171995. Executive Order No. 12957. Nisan 7, 2019 tarihinde U.S. Department of the Treasury Web Sitesi: https://www.treasury.gov/resourcecenter/sanctions/Documents/12957.pdf adresinden alındı

- U.S. Department of the Treasury, May 9 1995. Executive Order No. 12959. Nisan 7, 2019 tarihinde U.S. Department of the Treasury Web Sitesi: https://www.treasury.gov/resourcecenter/sanctions/Documents/12959.pdf adresinden alınd1

- U.S. Department of the Treasury, May 6 2018. Executive Order No. 13846. Nisan 7, 2019 tarihinde U.S. Department of the Treasury Web Sitesi: https://www.treasury.gov/resourcecenter/sanctions/Programs/Documents/08062018_iran_eo.pdf adresinden alınd1

- U.S. Department of the Treasury, March 14 2019. Iran Sanctions. April 7, 2019 tarihinde U.S. Department of the Treasury Web Sitesi: https://www.treasury.gov/resource-center/sanctions/Programs/pages/iran.aspx adresinden alınd 1

- U.S. Library of Congress, February 26 1975. S. 846: A Bill to Authorize the Further Suspension of Prohibitions against Military Assistance to Turkey and for Other Purposes. Nisan 7, 2019 tarihinde Congress.Gov: https://www.congress.gov/bill/94th-congress/senate-bill/846 adresinden alındı 


\title{
Ekonomik Karar Vermede Duyguların Rolü The Role of Emotions in Economic Decision Making
}

\author{
Asst. Prof. Dr. Aslı Öztopçu (Maltepe University, Turkey)
}

\begin{abstract}
Decision making points out to the consequences of past or future behaviors. An individual has to make decisions on all subjects throughout his life. An important part of these decisions are economic decisions. Individuals make decisions such as renting, buying, buying new goods, migrating, changing jobs, making investments, enterprise, choosing holidays, evaluating savings. Non-rational decisions are observed although individuals should make rational decision, according to mainstream economics.

In this study, the effects of the emotions that form the basis of psychology, such as time, option constraint, opportunities, risk taking, risk aversion, procrastination, rush, or uncertainty, inconsistency, intuitive movement, cognitive error in the decision-making process of individuals are discussed. For this purpose, the characteristics of decision-making process, individual effects of cognitive of emotions, individual decision making theorems in economic theory and behavioral economics literature are mentioned. It is thought that the role of emotions that shape behaviors should be known in the regulation of economic life that is determined according to human behavior.
\end{abstract}

\section{Giriş}

Davranışsal iktisat literatüründe yapılan çalışmalar, bireylerin ekonomik karar verme aşamasında rasyonel davranış teoremine uygun davranışlarla birlikte, rasyonel olmayan davranışları da sergilediklerini göstermektedir. Bilinen, tekrarlayan ya da tahmin edilen davranışlarda bile birey davranışlarının farklı biçimlere dönüştüğü, belirgin olmayan durumlar nedeniyle her defasında aynı olmayan sonuçlara neden olduğu anlaşılmaktadır.

Bireyin diğer bireylerden farklılığını ortaya koyan ilk durum fiziksel özellikleridir. Birey cinsiyeti, yaşı, boyu, cilt rengi, saçları, beden tipi, yüz şekli gibi birçok fiziksel özellikler aracılığıyla ayrım oluşmaktadır. Bununla birlikte bireyin yaşadığı yer, çevresel etkiler, toplumsal normlar, popüler kültür, eğitim, tutum, kişilik gibi unsurlardan dolayı daha karmaşık bir yapıdadır. Bu nedenle insanlar hakkında fikir sahibi olurken sözü geçen özellikler tek başına yeterli olmamaktadır.

Bu karmaşık yapıyı etkileyen ve ölçümü zor ya da belirsiz hale getiren diğer faktörler ise insani duygulardır. Duyguların kontrol edilmesindeki zayıflık ya da ani olaylar karşısındaki istemsiz tepkiler, birey davranışıyla ilgili belirsizliği de artırmaktadır. Örneğin çığlık sesinden hiç hoşlanmayan birinin bir çocuğun düşmesi sırasında aniden çı̆̆lık atması gibi.

Bu bağlamda, insanın zihinsel, fiziksel ve duygusal özellikleri sabit bir şekilde ilerlemez demek mümkündür (Aren ve Akgüneş, 2018: 363). Karar vericiler bazen akıldan uzak ya da tam tersi duygudan uzak kalabilmektedir. Bazen de durumların etkisine karşı bağışıklık kazanmaktadırlar. Bunun nedenini görmek için "beklenen" ve "acil" duygular arasındaki ayrımı görmek önemlidir (Loewenstein, Weber, Hsee, ve Welch, 2001). Örneğin Murat Bey hisse senedi alıp almama konusunda ikilem yaşamaktadır. Ĕger satın alır ve hisse senetlerinin fiyatı düşerse hayal kırıklığı yaşayacak ve maddi kayba uğrayacaktır. Bununla birlikte hisse senedini alır ve fiyatlarda artış olursa bu kez rahatlama, başarı, haz gibi duygular devreye girecektir. Bu ikilem ve kararsızlık sadece seçimin riski değil aynı zamanda gelecekteki duygularla ilgili bilişsel yaklaşımdır (Rick ve Loewenstein, 2008: 138). Burada oluşabilecek durumlarla karşılaşıldığında nasıl hissedilebileceğine dair beklentiler, gerçekte var olmayan duyguların oluşacağı varsayımıyla etki etmektedir. Hisse senedi alındıktan sonra fiyatlardaki artış ya da azalış sonucunda ortaya çıkabilecek ihtimal hislerle ilgili birey kendini sorgulamakta ve karar vermede farklı sonuçlara gitmektedir.

Oysaki genel akım iktisat anlayışında aniden oluşacak duygular, davranışları etkileyecek olsa bile gerçekte oluşacak sonucun bir parçası olmayacaktır. Çünkü karar vericilerin duygular değil akıl olduğu kabul edilmektedir (Şekil 1). 


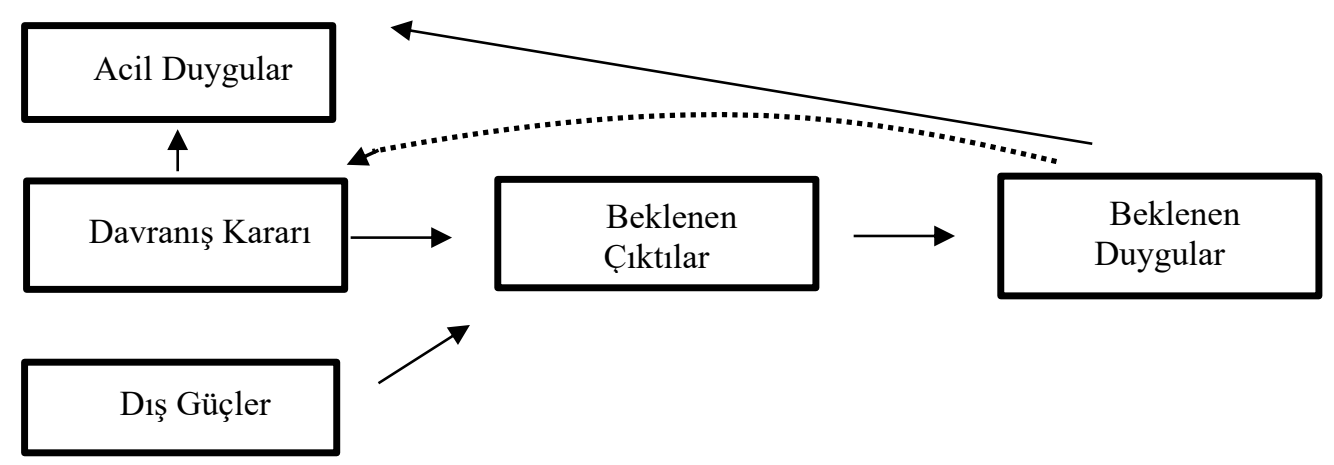

Şekil 1. Karar Vermede Sonuçcu Model Kaynak: Rick, S. ve Loewenstein, G. (2008: 139).

Geleneksel anlayıştan Neoklasik yaklaşıma geçildiğinde büyük değişiklik görmeyiz. Çünkü Neoklasik iktisatta insan davranışının tanımlanması, kısmen farklı olsa da rasyonel davranış teoreminden çok uzaklaşmamaktadır. Neoklasik yaklaşımda da birey davranışının hata yapma olasılığı ya da seçiminin o andaki en doğru karar olmayabileceği durumu yok sayılmıştır. Sadece kâr ve fayda maksimizasyonuyla hareket edeceği ön görülen insanın kişilik, tutum, duygu gibi insanı başkalaştıran özelliklerinin, birçok açıdan aynı olduğu varsayılmış ya da söz konusu unsurların oluşturabileceği farklılıklar önemsenmemiştir.

Gözden kaçan ya da dikkate alınmayan bu durum yeni iktisat alanının oluşmasına imkân sağlamıştır. Rasyonel insan davranışının beklenen biçimde gerçekleşmediği görüldükten sonra bu konudaki araştırmalarda da artış sağlanmıştır. Davranışsal iktisat anlayışının da ortaya çıkışında büyük etkisi olan gözlemler, rasyonel beklenti teoreminin doğru olmadığını göstermeye yetmiştir. Özellikle belirsizlik ya da riskin yüksek olduğu durumlarda bireylerin karar verme davranışlarında tutarsızlık ya da farklılık olduğu görülmektedir. Belirsizlik altında karar vermek değer teorisi ile açıklanmaya çalışırken iktisadi açıdan davranışsal iktisat perspektifinde alternatif beklenti teorisi (Kahneman ve Tvertsky, 1979) geliştirilmiştir.

Psikoloji bilimi, insan davranışlarındaki farklılığı araştırmak ve bunların altında yatan bilişsel süreçleri anlamak ya da açıklamak ve bazen de değiştirmekle ilgilenir. Davranışsal iktisat bu nedenle psikoloji bilimiyle birlikte çalışmaktadır. İnsan zihnindeki karmaşıklığın iktisat teorileri ya da diğer bilimlerde elde edilen sonuçlarla açılanması mümkün değildir. Bu bağlamda psikolojiden yararlanan iktisat çoğu zaman bireyin hangi davranışta bulunacağını belirleyemese de neden o davranışta bulunduğunu açıklayabilmektedir. Gözlenmesi zor olan zihinsel süreçler (duygular, tutum, güdüler vs.) iktisat biliminde tanımlanamıyorken, davranışlar somut biçimde gözlenebilmektedir.

Bu çalışmanın amacı, iktisat teoreminde insan davranışlarını açıklayan teoremlerin yerini alma çabasında olan davranışsal iktisat perspektifinde bireyin psikolojik açıdan hangi etkilerde kalarak nasıl farklı davranışlarda bulunduğuna dikkat çekmektir. İnsanın belirsizlik ortamında belirsiz davranışlarının açıklanması teorik olarak 1970'li yıllara kadar gitmektedir. Bununla birlikte ölçülmesi zor insan davranışının, neden her defasında farklılaştığının açıklanması için araştırmaların devamlılığı gerekmektedir. Buradan hareketle önce davranışsal iktisat literatürü değerlendirilecek daha sonra güncel olay ve örneklerle karşılaştırma yapılacaktır.

\section{Davranışsal İktisat Literatürüne Bakış}

Davranışsal iktisat Kahneman ve Tvertsky (1979) çalışmalarıyla dikkat çekmiş ve sonrasında iktisatçılar tarafından da izlenir, araştırılır bir duruma gelmiştir. Ancak daha önceki dönemlerde de birey davranışının açıklanmasında klasik ve neoklasik yaklaşımdaki rasyonel davranışın yetersizliği fark edilmiştir. Knight (1921) riskin bir yere kadar kontrol edilebilir bir durum olduğunu, belirsizliğin ise hiçbir durumda hesaplanamayacağını savunmaktadır. Benzer biçimde Knight'ın (1921) ki kadar net ifade edilmese de Keynes (1909)'in Olasılık üzerine hazırladığı tezinde de belirsizlik ortamındaki davranışı inanç ve sezgi ile açıklaması, davranışsal iktisat perspektifi için önemlidir.

Belirsizlik ya da risk olan durumlardaki ekonomik davranışı açıklamak için "beklenen fayda kuramı"nı ilk olarak fizikçi, matematikçi Daniel Bernoulli (1738) tarafından geliştirilmiştir. Daha sonra von Neuman ve Morgenstern (1944) "Theory of Games and Economic Behavior" adlı eserinde kuramı geliştirmiş ve daha formel bir yapıya dönüştürmüştür. Bununla birlikte yeni alanlardan biri olan oyun teorisinin ilk temelleri atılmış ve özellikle o dönem ki başkan adaylarının optimal politika seçimleri gibi kritik davranışların analizleri yapılmıştır. Beklenen değer teorisine de zamanla eleştiriler gelmiş ancak Kahneman ve Tversky (1979)'un beklenti teorisine kadar risk altında karar almayı açıklarken kullanılmıştır. Somut örneklerle açıklamak gerekirse örneğin, 1. Dünya savaşı sonrası belirsiz ekonomik durum, işsizlik gibi olumsuzluklarla birlikte Avrupa'da nazizmin (Nasyonel sosyalizm) artması ve barışçıl ortam oluşmasının zorlukları, o dönemki toplumsal ve politik hayattaki devam eden ve değişmeyen yapının sorgulanmasına neden olmuştur (Alada, 2000: 65). (Nasyonal Sosyalist ideolojide en yüksek değer ırktır, insanlar ve irklar eşit değildir. Büyük bir uygarlık ancak uygarlık kurma yeteneğine sahip üstün bir irk tarafindan kurulabilir). 
Beklenen fayda kuramında, insanlar sadece fiyat ya da maliyet üzerinden karar vermemekte, faydaya verilen değer üzerinden de hareket edilebilmektedir. Fayda, yine soyut bir kavram olarak kişi ve toplumlara bağlı olan değerlerin sınıflandırılması olarak belirlenir. Örneğin muz seven birisi için muz almak ya da yemek ne kadar önemliyse muzu sevmeyen biri için hiçbir ifadesi olmayacaktır. Dolayısıyla fayda ülkelere, normlara, inançlara, modaya, zamana göre de farklılık gösterecektir. von Neuman ve Morgenstern (1944) beklenen faydanın maksimize edilmesi ilkesiyle hareket etmiştir. Faydanın hesaplanması konusunda ise iki görüş hâkimdir. Faydanın ölçülebileceğini öngören "Kardinal Fayda Teorisi” ve faydalanın ölçülemeyeceğini ama kıyaslanabileceğini ön gören "Ordinal Fayda Teorisi”" arasında fayda ölçülmeyi beklerken "Modern fayda yaklaşımı” ile yeni bir boyut kazanmıştır. Burada kişi karar verirken rasyonel yaklaşımda bulunur, riski hesaplar gibi bir durum oluşur. Özetle, malın yerine parasal değerin, psikolojik tatmini ölçmek yerine risk karşısında belirlenen davranışın değer ölçüsü ele alınmaya başlamıştır. Bu yaklaşımı şu şekilde açıklamak mümkündür: İnsanlar az ama sürekliliği olan güvenilir bir gelir ve hesaplanır gideri yüksek kazançlı ama belirsiz bir gelir ya da gidere tercih etmektedirler. Modern fayda yaklaşımında Tedbir amaçlı, olup olmayacağı belirsiz ama küçük veya büyük riski olan şeyler içinde harcama yapmaya isteklidir. Örneğin sigorta bedelleri.

Bununla birlikte Markowitz'e (1952) göre, yatırımlarla ilgili kararların hepsi risk ortamında alınmaktadır. Böyle durumlarda yatırımcının temel davranışı da riskten kaçınma olmaktadır. Kararlarda subjektif olur demek mümkündür bu durumda. Markowitz; Modern Portfolyo teorisinde, çeşitlendirmenin sadece bir güvenlik riskini, değişkenliğini veya standart sapmasını azaltarak değil, aynı zamanda portföydeki iki veya daha fazla menkul kıymetin kovaryansını veya etkileşimli riskini azaltmayı da amaçlaması gerektiğini belirtmektedir. Çünkü farklı menkul kıymetlerin kombinasyonunda olduğu gibi, sıfırdan sonsuza kadar değişen bir risk yelpazesine sahip olmak teorik olarak mümkündür. Daha sonra Brainard'ın (1967) çarpımsal belirsizlik, parametre belirsizliği kavramları dikkat çekmektedir. Belirsizliğin bazen de kararsızlık olacağı varsayımıyla (örneğin politik bir kararın ekonomide etkisi konusunda belirsizlik oluşturması), diğer normal zamanlardan daha dikkatli ve ihtiyatlı davranılmasına yol açmaktadır (Aktaran: Aksoy ve Şahin, 2015: 4). Bu bağlamda bu ve benzer düşüncelere eleştiriler oluşmuştur. von Neuman ve Morgenstern (1944) beklenen değer teorisine yapılan ilk eleştiriler ise Allais ve Ellsberg paradoksları olmuştur.

Maurice Allais'in (1953) Econometrica'da yayınlanan Nobel ödüllü çalışması olan Allais paradoksu, literatürde önemli bir yer tutmaktadır. Buna göre bir kişiden A, B, C ve D gibi seçeneklerden birinin seçilmesi söylenir. Burada A, B, C ve D olasılıkları ve karşılığındaki pozitif değerler önceden belirlenmiştir ve tercihler arasında nasıl seçim yapıldığına bakılmıştır. Eğer kişi A'yı B'ye tercih ederken faydasını maksimize ediyorsa C'yi de D'ye tercih etmesi beklenmektedir. Ancak çalışmadaki sonuç A'yı B'ye tercih eden kişinin beklenenin aksine D'yi C olasılığına karşı tercih etmesidir. Elde edilen sonuç, beklenen değer teorisinin olası ihtimallerini ihlal eden bir durumu göstermiştir.

Daha sonra Daniel Ellsberg (1961) de Paul Samuelson ve Gerard Debreu gibi önemli iktisatçıların da yer aldığı bir denek grubu üzerinde hipotetik deney uygulamıştır. Bu uygulamada siyah ve kırmızı toplam 100 adet topun bulunduğu iki torba verilmiştir. Birinci torbadaki renk oranları bilinmemektedir. İkinci torbada ise 50 şer eşit sayıda kırmızı ve siyah top bulunmaktadır. Deneklere iki torbadan birinden top seçmesi istenmiştir. Daha sonra da çıkacak renk için fikir beyanında bulunacaklardır. Eğer rengi bilirlerse karşılığında 100\$ kazanmış olacaklardır. Bilinmediği durumda ise bir kazanç veya kayıp olmamaktadır.

Ellsberg paradoksu ise şöyle ifade edilebilir. Elimizde bir kupa olsun. Bu kupanın içinde 30'u kırmızı, 60'1 ise sarı ve maviden oluşan toplam 90 tane top olsun. Oyunculara şöyle bir teklif yapılsın; kupadan çekilen bir top mavi çıkarsa (1/3 olasılık) oyuncu $100 \$$ kazanır, kırmızı top çıkarsa $100 \$$ kazanır. Bu oyunda kırmızı top çekme olasılığı belirsizdir. Yani seçim olasılığı bilinen bir durumla, olasılığı bilinmeyen bir durum arasında yapılmaktadır.

Ellsberg, oyuncuların tipik olarak birinci durumu seçtiklerini belirtmiştir. Beklenen değer teorisine göre bu seçim ancak oyuncuların kupada 30'dan daha az kırmızı top olduğuna inanmaları durumunda mümkün olabilir (dolayısıyla sarı top sayısı 30'dan fazladır). Daha sonra, oyunculara ikinci bir teklif sunulmaktadır; mavi veya sarı top çekme durumunda oyuncu $100 \$$ kazanır, kırmızı veya sarı top çekme durumunda ise $100 \$$ kazanır. Oyuncuların bu durumda ikinci seçeneği seçtikleri gözlemlenmiştir. Ancak bu iki seçim arasında bir paradoks bulunmaktadır. Birinci oyunda, oyuncunun kırmızı top çekme olasılığına 1/3'den daha az bir oran atfetmesine rağmen (sarı top çekme olasılığı 1/3'den fazladır), ikinci oyunda çelişkili bir biçimde ikinci seçeneği seçmektedir. Dolayısıyla oyuncuların beklenen değer teorisine uygun hareket etmediği görülmektedir. İkinci seçeneğin daha mantıklı gelmesinin nedeni, insanların belirsizlikten kaçınma eğilimidir. Yapılan iki seçim de kırmızı topları yani kesin bir olasılığı içermektedir. Buradaki ihtimaller aşağıdaki gibidir:

1. A) Torba 1 den kırmızı top çekmek.

B) Torba 1 den siyah top çekmek.

2. A) Torba 2 den kirmızı top çekmek.

B) Torba 2 den siyah top çekmek.

3. A) Torba 1 den kırmızı top çekmek.

B) Torba 2 den kırmızı top çekmek.

4. A) Torba 1 den siyah top çekmek.

B) Torba 2 den siyah top çekmek. 
Birinci ve ikinci ihtimaldeki seçeneklerde kararsız kalınmasına karşın üçüncü ve dördüncü ihtimallerde A olasılığı tercih edilmiştir. Yani iki torbadan da aynı rengin seçilmesi ihtimali daha mümkün görülmüştür. Burada birinci torbada 50'den daha fazla sayıda kırmızı ya da siyah top olacağının düşünülmesi dikkat çekicidir. Önemli olan üçüncü ihtimalde A olasılığını seçen kişinin dördüncü durumda B ihtimalini seçmesi beklenmektedir. Oysaki tercihler bu şekilde olmamıştır. Dolayısıyla beklenen fayda açısından kaotik bir durum oluşmuş olduğu gözlenmiştir.

Sözü geçen Allais (1953) ve Ellsberg (1961) paradoksları sonrasında birçok araştırmacı bu konuda çalışmalar yapmaya başlamıştır. Bunlardan en dikkat çekeni ve Nobel ödülü getiren Kahneman ve Tvertsky (1979) çalışmasıdır. Gerçekleşen davranışların açıklanmasında beklenen fayda teorisinin yetersiz kaldığı ve risk altında alınan kararlarda bu teoridekinden daha farklı davrandıkları tespit edilmiştir (Kahneman ve Tversky, 1979: 263). "Prospect Theory" olarak açıklanan bu teori umut ya da beklenti kelimeleriyle de kullanılmaktadır. Stockholm Üniversitesi'nde ve Michigan Üniversitesi'nde öğrenci ve öğretim üyesinden oluşan gruplar üzerinde denenmiştir (Kahneman ve Tversky, 1979: 265). Bu model, "pi” olasılıkları dâhilinde gerçekleşmesi mümkün olan "xi” sonuçları olan bahis sözleşmesi üzerinden açıklamıştır (Kahneman ve Tversky, 1979: 263). Çalışmanın sonuçları şu şekilde özetlenmektedir: Çalışmada para konusu üzerinden deney yapılmış olsa da başka alanlarda da uygulanması mümkündür (Örneğin yaşam kalitesinin artıp azalması gibi bir belirsizlikte verilecek politik karar gibi). Burada sonuçlar tarafsız bir referansa göre kazanç ya da kayıp kodlamasındaki davranışların teorilerde ki gibi olmadığıdır (Kahneman ve Tversky, 1979: 288).

$\mathrm{Bu}$ çalışmalara öncülük eden bir araştırma da Langer (1975)'in irrasyonel davranış kalıplarını araştırdığı "Illusion of Control”" çalışmasıdır. 631 yetişkinle gerçekleştirdiği 6 çalışmada beceri durumlarından tesadüfi durumlara kadar 6 farklı durumla ilgili senaryolar yönelterek seçimleri gözlenmiştir. Kontrol yansıması olarak çevirebileceğimiz bu çalışmaya göre, bireylerin önyargıları sonucunda farklı davranışlar ortaya çıkmaktadır.

Finansal davranışlarda riskli durumların daha kolay oluşması nedeniyle finansal iktisat alanında bu konuyla ilgili araştırmalara sürekli yenisi eklenmektedir. Finansal konularla ilgili kararlarda da ortaya konan teorilerin yetersiz kaldığı görülmektedir. Finans teorileri açısından da gerçek yaşamda, kararlarla ilgili tahminler ile gerçekleşen kararlar birbirinden farklıdır (Jurevičienė ve Ivanova 2013: 54). Örneğin, genellikle sermaye yapısı ve kar dağıtım politikalarının temelinde yetersiz olduğu söylenmektedir. Hatta bu kararlar bazen bilmece gibi yorumuyla ifade edilebilmektedir (Myers, 1984). Bu bağlamda insanın en iyi tercihi yapması konusundaki çelişkili durum için yeni modellere ihtiyaç duyulmaktadır. Davranışsal iktisat alanında davranışsal finans konusu da bu bağlamda değerlendirilmelidir (De Bondt ve Thaler, 1994:387).

\section{Karar Verme Davranışı}

Her gün onlarca konuda karar veriyoruz. Kahvaltıda, akşam, öğle yemeğinde ne yesek, aracın bakımını ne zaman kime yaptırsak, çocukları hangi okulda okutsak, hafta sonu gezmeye nereye gitsek, tatil sürecini nasıl planlasak, hangi semtten ev alsak-taşınsak, kredi çeksek, nasıl nereden vs. derken çoğunda nelerden etkilendiğimizi bile fark etmeden birçok kararla hayatımıza yöne veriyoruz. Davranışlarımızın çoğu rasyonel kararlar gibi görünmekle birlikte bir başkası açısından irrasyonel davranış olarak algılanabilmektedir.

Rasyonellik kavramını tanımlamak, rasyonel ve rasyonel olmayan (irrasyonel) davranışın belirlenmesi açısından önemlidir. Etzioni'ye (1988) göre, bireyin hedefine ulaşmak için aklıyla en uygun alternatife yönelmesidir. Burada akla gelen ilk soru bireyin rasyonellik için tutarlı olması gerekmekte midir? Her davranışın bir tercih olduğunu da düşünürsek, tercihler konusunda her zaman en yüksek fayda beklentisi gerekli midir diye de düşünmek gerekecektir.

Dawes (2001) tutarsızlığın irrasyonel davranışın özü olduğu sonucuna varmıştır. Tutarlılık aynı zamanda aksiyomatik (Sosyolojik kuramların çoğu, bir ya da birkaç ispatlanmamış aksiyoma, örneğin insanın tüm eylemlerinin akılcı olduğu ya da sınıf mücadelesinin tarihin motoru olduğu aksiyomuna dayanır). Yaklaşımların rolünü anlamada da önemlidir. O zaman rasyonel davranışın temelinde tutarlılık vardır diyebiliriz. Bir problemin ifade ediliş biçimi kişinin kararlarında büyük değişiklikler yaratmaktadır.

Heracleous'a (1994) göre, Rasyonel karar verme, bir süreçtir. Önce bir problem oluşur, sonra problemle ilgili hedefler, sonra alternatiflerin oluşması için araştırma, alternatiflerin değerlendirilmesi, bir alternatifin seçilmesi, en akla yatkın rotanın uygulanması, elde edilen sonuçların değerlendirilmesi ve tatmin düzeyine göre sürecin yenilenmesi biçimindedir. Aslında pazarlamada tüketici satın alma kararı, fiyat belirleme süreci, işletme de kalite çözüm yöntemlerinden bazılarıyla hemen hemen aynı aşamaları içeren bir süreçtir. Bu bağlamda insanın her konuda davranışı belirlemede aynı süreçten geçtiğini söylemek de mümkündür.

Rasyonel davranışta tutarlı davranış sergilenmesinin önemini vurguladıktan sonra çoğu davranışımızın irrasyonel olduğunu söylemek mümkündür. Kahneman ve Tversky’ın (1979) çerçeveleme etkisi isimli teori, bu konuyu açıklamakta yardımcı olacaktır. Beklenti teorisinde, her birey kendisine farklı biçimlerde sunulan aynı durum için farklı seçim yapma eğilimindedir. Aynı bilginin farklı biçimlerde ifade edilmesi, farklı algı ve duygular nedeniyle kararını değiştirmesine neden olmaktadır. Bu duruma çerçeveleme etkisi denmektedir. Bu bağlamda 
tutarsızlık, bireyin her defasında çeşitli nedenlerle bilgiyi farklı algılaması biçiminde yorumlanabilmektedir (Kahneman, 2011: 88).

Alınan kararlar, herkes için doğru ve uygulanabilir olsaydı bugün pazarlama stratejileri, reklamlar, ürün çeşitliliği ya da rekabet koşulları çok daha farklı olurdu. Çeşitli nedenlerle her bireyin yaşam algısı, korku ve beklentileri, riski tanımlaması ve birlikte yaşadığı diğer bireylerin özellikleri birbirinden farklı olduğu için birbirine benzer gibi görünen ancak kendi içinde çok farklı özelliklere sahip bir yapı olarak kendini göstermektedir.

Fiziksel koşullar, demografik özellikler gibi somut unsurlar kadar inanç biçimleri, alışkanlıklar, ilgi alanları, deneyimler, algı ve ön yargılar gibi karmaşık psikolojik ve sosyolojik unsurlar birey düşünce ve davranışını etkilemektedir (Tekin, 2016: 83). Psikolojik unsurların birey üzerindeki etkisini objektif olarak tahmin etmek bile mümkün olamamaktadır. Örneğin New York Borsası üzerinde yapılan bir araştırmada (1993), hava durumuyla borsadaki hisse senetleri arasında ilişki olduğu görülmüştür. Kapalı havanın birey üzerindeki olumsuz etkisi fiyatların daha düşük seviyeye inmesine neden olmaktadır.

Örneğin, Eşinizin isteğiyle gerçekten çok ağır, edebi bir bale gösterisine gittiniz ve tahammülünüz kalmadığ1 için salondan ayrılmak istiyorsunuz. Eşinize fisıldayarak isteğinizi belirttiğinizde ağır bir tepkiyle karşılaşıyor ve biz bu biletlere kaç lira ödedik biliyor musun diye bir cevap veriyor. Siz ısrarla konuşmaya devam ediyor ve para gittiyse gitti, zamanım da boşa gidiyor, ne kadar çabuk ayrılırsak o kadar kar biçiminde söylenmeye devam ediyorsunuz. Burada dikkat çekilmesi gereken ana düşünce, birçoğumuzun, paramız boşa gitmesin diye sevmediğimiz ya da emin olmadığımız şeyi yarım bırakmaktan çekinmesi, onu bir süre daha kullanmaya devam etmesi ya da katlanmasıdır. Batık maliyet düşüncesi bizi istemediğimiz davranışlara sürüklemektedir. Sözü geçen olay, bazen mecbur kalarak fayda maksimizasyonu yerine canımızı sıkacak şeylere katlanmamıza bir örnektir. Bu bağlamda irrasyonel davranışların sergilenmesinde bazen mecbur kalıyoruz dememiz bile mümkündür.

Karar verme davranışında aynı konular karşımıza çıksa bile her defasında farklı bir davranışta bulunulmasının en temel nedeni duygu ve düşüncelerin değişmesidir. Değişimin neden olduğu sorusuna yanıt gerekmektedir. Bu değişimlere neden olan sebepleri belirlemek mümkündür. Belirsizlik ve riskli ortamlarda üç tip davranışla karşılaşılmaktadır (Camerar, 1999). Bunlardan biri "riskten kaçınma” davranışıdır. Riski en aza düşürmek ya da kaçmak adına alınan kararlardır. Diğeri “risk tarafsızlı̆̆ ”" davranışıdır. Buradaki davranışta ise riskin dağılımı göz ardı edilmekte ve daha çok kazanç üzerine odaklanılmaktadır. Üçüncü davranış tipi de "risk düşkünlüğü "'dür. Buna göre, risk tercih edilmektedir. Böyle durumların getirisinin yüksek olacağı varsayımının ön plana çıktığ anlaşılmaktadır.

\section{Nitel Araştırma}

Davranışsal iktisat literatüründeki çalışmalar doğrultusunda küçük bir araştırma yapılmıştır. Araştırmanın amacı, bireylerin karar verme davranışlarındaki durumları gözlemlemek ve literatürdeki çalışmalarla değerlendirmek. Bu amaçla belirsizlik ya da henüz oluşmamış olaylarla ilgili 2 farklı senaryo hazırlanmış ve senaryolardaki seçeneklerden hangisinin daha uygun olduğu sorulmuştur. Araştırmadaki örneklem kütlesi belirli istatistiklerin de uygulanabilmesi ve temsil yeteneği sağlayacak biçimde olması için otuz kişi olarak belirlenmiştir. Bu bağlamda çalışmaya 4-17 yaşlarında çocuğu/çocukları olan veya olmayan otuz kişi katılmıştır. Katılımcılara olasılığa dayalı (kolay) örnekleme ile ulaşılmıştır. Uygulama, yüz yüze ya da mesajla interaktif iletişimle yapılmıştır. Yanlış algılamayı engellemek için cevapları neden seçtikleri de sorulmuştur. Çalışma 15-19 Mart 2019 tarihleri arasında gerçekleştirilmiştir. Katılımcılara aşağıdaki seçenekler sunulmuştur: Burada 1 ve 2 arasından bir seçenek, X ve $Y$ arasından bir seçenek belirlenmesi istenmiştir.

\section{Birinci senaryo:}

1: Yaşadığınız evin site yönetimi, tüm daireleri sigortalatma kararı vermiştir. Hırsızlık, yangın, doğal afet gibi birçok oluşabilecek kaza ve olayı kapsamaktadır. Eğer buna katılmak isterseniz yıllık aidatı 100 liradır. Ayrıca yılda bir kez klima bakımı ve kuru temizleme hediyesi sunulmaktadır.

2: Site yönetimine başvurmadan benzer içerikli sigorta başvurusunda bulunduğunuzda sigorta firmalarının verdiği en düşük yıllık aidat 80 liradır. Önümüzdeki beş yıl aidat ücretinde değişiklik yapılmayacaktır. Ancak ek imkânları bulunmamaktadır.

İkinci senaryo:

X: Çocuklarımızın okullarında iş güvenliği kapsamında her öğrencinin de oluşabilecek kazalara karşı sigortalanması ön görülmüştür. Bu kapsamda bir öğrenci için sigorta bedeli yıllık 100 liradır.

Y: Okul içindeki oluşabilecek tüm riskler dışında okula gelip giderken (servis süresinde) oluşabilecek hasarlara karşı sigortalanma bedeli ise yıllık $100+25$ : 125 liradır. Birinci seçenekle birlikte sunulmaktadır.

Katılımcılara ait demografik özelliklerden bazıları aşağıdaki gibidir:

\begin{tabular}{|c|c|c|c|c|c|c|}
\hline Kadin & Erkek & 19-28 Yaș & 29-35 Yaş & 36-50 Yaş & Çocuk var & Çocuk yok \\
\hline 21 & 9 & 5 & 9 & 16 & 23 & 7 \\
\hline
\end{tabular}

Tablo 1. Katılımcıların Bazı Demografik Özellikleri 
Yukarıda da görüldüğü gibi birinci senaryoya ait iki seçenek sunulmuştur. Oluşabilecek bir risk üzerinden önlem alınması amacıyla alternatifli iki seçeneğin 1. si, hediyeleri olan, site yönetiminin önerdiği 100 liralık aidatı olan bir seçenek iken 2. si, herhangi bir sigorta firmasından hediyeleri olmayan 80 liralık aidatı olan seçenektir. Katılımcıların verdikleri cevaplar aşağıdaki gibidir:

Senaryo 1: 1. Seçenek: 9 kişi, 2. Seçenek: 21 kişi.

Senaryo 2: x seçeneği: 1 kişi, y seçeneği: 29 kişi.

Senaryo 1 için büyük çoğunluk "2” Seçeneği yani düşük aidatı seçmiştir. "1" Seçeneği tercih edenler klima bedelinin aidattan çok olduğunu ya da yönetimin dişında hareket etmek istemediklerini belirtmiştir. Burada ilk seçeneğin tercih edilmesinde dışlanma korkusu ya da klima bakım hizmetinin yüksek olduğu varsayımı bulunmaktadir.

Senaryo 2'de sadece bir kişi “ $x$ ” seçeneğini tercih ederken 17 kişi “ $y$ ” seçeneğini tercih etmiştir. Seçim nedeni olarak çocuklarının güvenlik ve sağlık durumu söz konusu olduğunda parasal değerin öneminin kalmadığ anlaşılmıştır. " $x$ ” seçeneğini seçen kişi ise çocuğum yok, o zaman düşünürüm cevabı vermiştir.

Teorik boyutuyla yapılan küçük araştırmada da diğer çalışmaların desteklendiği anlaşılmaktadır. Görüldüğü gibi birinci senaryoda seçeneklerde ilk olarak ödenecek bedelin az olması nedeniyle bireyler düşük aidatın bulunduğu seçeneğe yönelirken, birkaç kişi de fayda sağlayacak yan hizmetlerin bedelinin daha yüksek olacağını düşünerek yine fayda maksimizasyonu sağlanmaya çalışmıştır. İkinci senaryoda ise çocuğu olmayan çoğu kişi de dâhil olarak kaza oluşma ihtimali riskinin oluşabileceği korkusuyla daha fazla ödeyerek ikinci seçeneği tercih etmişlerdir. Birinci senaryoda hesaplama ve belirsizlikteki algıda farklılık oluşması nedeniyle ödenecek aidat tutarıyla ilgili iki bakış açısıyla karşılaşılmaktadır. Bununla birlikte oluşma ihtimali birinci senaryodan çok da farklı olmayan bir durum için herkes tek seçeneğe odaklanmıştır. Duygu ve düşüncenin çocuğa zarar gelmesi gibi rahatsız edici bir durum için değerlemenin parasal olmadığı anlaşılmaktadır.

Kahneman, Knetsch ve Thaler (1991) yaptıkları bir araştırma da bu çalışmayı desteklemektedir. Araştırmada katılımcılar iki gruba ayrılmış ve bir saat süren anketi cevaplamaları istenmiştir. Ancak çalışmanın esas amacı anket sonrasında başlamaktadır. Anket tamamlandıktan sonra ilk gruba bir bardak kahve hediye edilmiştir. Daha sonra kahveler geri alınmak istenmiştir. Kahveyi geri vermeleri için ne kadar istedikleri sorulmuştur. Diğer gruba ise kahveler gösterilerek bir bardak kahve için ne kadar ödeyecekleri sorulmuştur. İki grup arasında fark oluşmuştur. Kahveye para ödeyerek sahip olacaklar, makul fiyatlar belirtirken kahvesini geri vermek istemeyen grup neredeyse iki katını talep etmiştir. Çünkü kahveye sahip olma duygusu kahvenin değerini artırmıştır.

Yukarıda da görüldüğü gibi davranışsal iktisat alanında yapılan tüm çalışmalarda durum, kişi, olay, yer ve zamana göre kararlar değişkenlik göstermektedir. Geleneksel ekonomi yaklaşımının aksine rasyonel tanımı dışında kalan davranışlar tespit edilmektedir.

\section{Sonuç}

Davranışsal iktisat literatürü ve yapılan araştırma da görüldüğü gibi insan yapısı rasyonel davranış içinde olmaktan oldukça uzaktır. Geleneksel iktisat anlayışındaki literatürü takip ettiğimizde de ilk ortaya konulan teorilerden bugünlere kadar gelinen sonuç, insan davranışının irrasyonel olduğudur. Burada belki rasyonel kelimesinin yeniden tanımlanmaya da ihtiyacı olabilir.

Eğer fayda maksizimizasyonundan bahsediyorsak buradaki kriterlerin vurgulanması da önemli olacaktır. Örneğin değerli olduğunu düşündügüumüz ürün ve hizmetleri satın alırken yüksek bedel ödemeyi kabul ediyorken, sıradan ya da kolay ulaşılabilen herşey için çok daha düşük bedeller ödeme isteği içinde oluyoruz. Burada değerli tanımlaması küresel boyutta kabul edilebilirken (değerli taşlar, antikalar, vb.) bazen de göreceli olarak kişiye göre oluşabilmektedir (aile yadigarı eski bir saat gibi). Böyle durumlarda davranışlar herkesce beklenenden farklı gerçekleşebilmektedir. Bu davranış farklılığının temelinde kuşkusuz insan beyni ve psikoloji bulunmaktadır.

Beynin işlevlerini lobların görevleriyle açıklamak mümkündür. Frontal lob (sol arka) akıl yürütme, karar verme, duyguları kontrol etme, plan yapma gibi görevleri yürütmektedir. Parietal lob (să̆ arka), duyuları işleme, görme algıs1, aritmetik yetenekler gibi özellikleri yürütmektedir. Temporal lob (sol ön), konuşma ve duyma, işitsel öğrenme, dil öğrenimi, müzik farkındalığı gibi işlevleri yürütmektedir. Oksipital lob (sağ-ön), görsel bilgiyi işleme ve okuma işlevlerini yürütmektedir. Sol lobu somut bilgileri işlemektedir. Serebellum denilen öndeki kısım denge sağlayıcı iken beyin sapı da uyku, sinir sitemi düzenleyicisi, solunum, yutma gibi işlevleri yürütmektedir (Robert, 2002). Örneğin, matematiksel işlemler, analizler, bilgi alışverişi sol lob tarafından gerçekleştirilmektedir. Beynin sağ lobunda ise renkler, müzik, sanat, hayal kurma gibi soyut kavramlar işlenmektedir. Her iki lobun dengeli kullanıldığı durumlarda gerçek öğrenmenin gerçekleştiği belirtilmektedir. Karar verirken ise olaya bağlı duygusal ve hayali duygu düşünceler de entegre olmaktadır. Seçim yaparken geçmişte yaşanan olaylar ve bunlardan biriktirdiklerimizin etkisi oldukça fazladır. Bununla birlikte hava durumu, stres, ruh hali vb. birçok unsur bir araya gelince herkes farklı kararlar vermektedir. Dolayısıyla sözü geçen durumlarda beyin loblarının birbirlerine üstünlük sağladığı gibi bir varsayımı söylemek mümkündür. Bir karar verirken sezgilerin ve bazı davranış eğilimlerinin (aşırı özgüven, belirsizlikten kaçma gibi) de oluşturduğu etkiler sonucunda kararlar sorgulanırken 
cevaplarını bile bulamayabiliyoruz. Örneğin bir parayı $10 \mathrm{kez}$ yere attığında 8 defa tura, 2 defa yazı geldiyse 11 . kez denemede tura geleceği iddia edilebilmektedir. Oysaki bir para yere atıldığında yazı ya da tura gelme olasılığ $1 / 2$ oranında ve birbirine eşittir. Önceki yaşananların etkisi ve farklı bir algı oluşturması nedeniyle beklentiler de değişmektedir.

Örneğin, insanlar kazanç getireceğini düşündüğü işlerde riskten kaçınırken, kayıp oluşacak işlerde risk almayı uygun görebilmektedir. Bu tip benzer davranışların ve davranış nedenlerinin tespiti için psikoloji bilimiyle birlikte daha çok çalışmaya ihtiyaç vardır. Özetle, insan beyninin etkide kaldığı olaylar, kişilik-tutum gibi bireysel yaklaşımlar, psikoloji bilimindeki çalışmalar eşliğinde bireyin karar verme süreci ve sonuçlarının değerlendirilmesi daha sağlıklı sonuçlar elde edilmesini sağlayabilecektir. Bu çalışma da literatürdeki çalışmalara katkı sunması ve kaynak göstermesi beklentisiyle hazırlanmıştır.

\section{Kaynakça}

- Aksoy, T. ve Şahin, I. (2015). "Belirsizlik Altında Karar Alma: Geleneksel ve Modern Yaklaşımlar”. İktisat Politikası Araştırmaları Dergisi, 2(2), 1-28.

- Alada, D. (2000). İktisat Felsefesi ve Belirsizlik. Bağlam Yayınları, İstanbul.

- Allais, M. (1953). "Le Comportement de l'Homme Rationnel devant le Risque: Critique des Postulats et Axiomes de l'Ecole Americaine". Econometrica, 21 (4), 503-546.

- Bernoulli, D. (1738). "Specimen theoariae novae de mensura sortis. Commentarri Academiae Scientiarum Imperialis Petropolitanae, Tomus V, 175-192. Translated by Louise Sommer as "Expositions of a New Theory on the Measurement of Risk." Econometrica. vol.22, no.1:.23-36, Jan. 1954.

- Çalık, Ü. ve Düzü, G. (2009). “İktisat ve Psikoloji.” Akademik Bakış Dergisi, 18, s.3-9.

- Camerer, C. (1999). "Behavioral Economics: Reunifying Psychology and Economics". Proceedings of the National Academy of Sciences of the USA, 96, 10575-10596.

- De Bondt, W. F. ve Thaler, R. H. (1994). Chapter 13 Financial Decision-Making in Markets and Firms: A Behavioral Perspective. Handbooks in Operations Research and Management Science, 9, 385-410.

- Dekel, E. (1986). “An axiomatic characterization of preferences under uncertainty: Weakening the independence axiom”. Journal of Economic Theory, 40(2), 304-318.

- Etzioni, A. (1988). "Normative-affective factors: Toward a new decision-making model". Journal of Economic Psychology, 9(2), 125-150.

- Gül, F. (1991). “A theory of disappointment aversion”. Econometrica, 59(3), 667-86.

- Heracleous, L., Th., (1994). “Rational Decision Making: Myth or Reality?”. Management Development Review, 7(4), 16-23.

- Jurevičienè, D. ve Ivanova, O. (2013). "Behavioural Finance: Theory and Survey". Science-Future of Lithuania/Mokslas-Lietuvos Ateitis, 5(1), 53-58.

- Kahneman ve Tvertsky (1979). "Prospect Theory: An Analysis of Decision Under Risk". Econometrica, 47(2), 263-291.

- Kahneman, D. (2011). Thinking, fast and slow. New York: Macmillan.

- Langer, E. J. (1975). “The İllusion of Control”. Journal of Personality and Social Psychology, 32(2), 311328.

- Loewenstein, G., Weber, E. U., Hsee, C. K., ve Welch, N. (2001). "Risk as feelings". Psychological Bulletin, 127(2), 267-286.

- Markowitz, H. (1952). "Modern Portfolio Theory”. Journal of Finance, 7(1), 77-92.

- Myers, S. C. (1984). “The capital structure puzzle”. The journal of finance, 39(3), 574-592.

- Rick, S. ve Loewenstein, G. (2008). The Role of Emotion in Economic Behavior. Handbook of Emotions, Third Edition, edited by Michael Lewis, Jeannette M. Haviland-Jones, and Lisa Feldman Barrett.

- Roberts, J. W. (2002). "Beyond learning by doing: The brain compatible approach". The Journal of Experiential Education, 25 (2), 281-285.

- Tekin, B. (2016). "Beklenen Fayda ve Beklenti Teorileri Bağlamında Geleneksel Finans - Davranışsal Finans Ayrımı". Journal of Accounting, Finance and Auditing Studies, 2(4), 75-107.

- $\quad$ von Neuman, J. ve Morgenstern, O. (1944). Theory of Games and Economic Behavior. Published: Princeton University Press's Notable Centenary Titles. Resources ISBN 9781400829460. 


\title{
Kırgızistan'da Öğrencilerin Akademik Başarılarını Etkileyen Psikolojik Faktörler
}

\section{Psychological Factors Affecting Students Academic Performance in Kyrgyzstan}

\author{
Asst. Prof. Dr. Raziya Abdiyeva (Kyrgyzstan-Turkey Manas University, Kyrgyzstan) \\ Dr. Kadiyan Boobekova (Kyrgyzstan-Turkey Manas University, Kyrgyzstan)
}

\begin{abstract}
The quality of human capital plays decisive role in the social and economic development of the country. Education and its quality are essential issue to government. In the learning process the students' comprehension is important in achieving the determined goal. However there are various factors that affect the students' performance as socio-demographic, economic and psychologic factors. This paper is aimed to investigate the effect of psychologic factors on academic achievements of students in higher education in the case of the Kyrgyz Turkish 'Manas' University. Psychological factors were analyzed using ordered probit model and data that was obtained in 2014 by conducting a questionnaire to 3133 students. According to the results psychological factors significantly affect academic performance of students.
\end{abstract}

\section{Giriş}

Globalleşen dünyada eğitim kalitesi, özellikle yükseköğretimin kalitesi ve etkililiği ekonomik kalkınma ve büyümenin en önemli faktörlerinin biri haline gelmiştir. Böylece eğitim, günümüzde sosyal hayat, ekonomi ve iş çevresi için çok önemlidir. Üniversite eğitiminin kalitesi, girişimciliğin performansını ve verimliliğini, ekonominin kalkınmasını ve büyümesini, yaşam standartlarının yükselmesini doğrudan etkilemektedir.

Eğitimin kalitesi, onu sunan öğretim üyesi ile eğitimi alan öğrencinin tutum ve davranışları, potansiyeli ve isteklerine bağlıdır. Öğrencilerin eğitim kalitesi sadece eğitimi sunan tarafın performansı ve potansiyeli, fiziksel imkan ve koşullarına bağlı değildir. Eğitim sürecinde öğrencilerin psikolojik durumu, onların akademik başarılarını önemli ölçüde etkilemektedir. Diğer bir değişle, öğrencilerin sinirli olmaları, kaygı düzeleri, yalnızlık ve çaresizlik hissetmeleri, korkuları gibi psikolojik sorunları, onların performansını negatif yönde etkilemektedir.

Çalışmamızda Kırgızistan'da üniversite öğrencilerinin psikolojik sorunlarının onların akademik performansına olan etkileri incelenmiştir. Araştırma, Kırgızistan-Türkiye Manas Üniversitesi’nde 2014 yılında 3133 öğrenciye yapılan anket verileri analiz edilerek yapılmıştır. Girişi izleyen ikinci bölümde literatür taraması, üçüncü bölümde betimleyici istatistikler ve istatistiksel analizler, dördüncü bölümde ise ekonometrik analiz ve yöntem, son bölümde de sonuç ve değerlendirme sunulmuştur

\section{Literatür}

Bhattacharya ve Bhattacharya (2015:62) Hindistan'da yükseköğretimde eğitim gören öğrencilerin başarılarına psikolojik faktörlerin etkisini araştırmışlar. Neticede, psikolojik faktörler bilinçli ve bilinçsiz düzeyde öğrencilerin akademik başarılarını etkileyeceği bulunmuştur. Öğrencilerin yüksek başarısı, onların ileride iş hayatında başarılı olabilmesi için etken olup, düşük başarı onları strese soktuğu belli olmuştur. Öğrencilerin böyle duruma tepkileri çeşitli olmaktadır: duyuşsal (stres, kaygı, korku, suçluluk, keder, depresyon); bilişsel (stresle başa çıkma stratejileri); davranışsal (ağlama, kendine ve başkalarına kötü davranma, sigara kullanma, sinirlilik); psikolojik (terleme, kekeleme, kilo kaybı veya kilo alma, baş ağrısı, bedende ağrılar). Can sıkıntısı, motivasyon eksikliği, stresli olmaları onların derslerinde başarıyı düşürmektedir.

Yapılan ampirik araştırmalar, öğrencilerin akademik başarılarını psikolojik faktörlerin etkilediğini göstermiştir. Wondu (2018), Dire Dawa Üniversitesi'ndeki 16 birinci sınıf Psikoloji bölümü öğrencilerinin katılımı ile yapılan araştırma sonucunda, öğrencilerin öz yeterliği ile öz motivasyonları arasında, stres düzeyi ile içsel motivasyon arasında güçlü anlamlı ilişkiyi bulmuştur.

Habibian v.d. (2015), psikolojik faktörler okuryazarlık eğitimi ve okuma sürecine, etkin okuma üzerinde çok önemli olduğunu tespit etmişlerdir. Nijerya'da yapılmış bu araştırmada öğrencilerin özgüveni ile Matematik derslerinde başarı arasında anlamlı bir ilişki bulunmuştur (Wachikwu v. d., 2017). Bununla birlikte ailevi sorunlar da öğrencilerin psikolojik sorun ve kaygılarının nedenlerinden birini oluşturmaktadır (Захаров, 2002).

Volchik v.d. (2018) dünyada üniversitelerde yapılan reformları incelemişlerdir ve yükseköğretimin hem ülke çapında hem de kişisel düzeyde sosyal ve ekonomik performansı üzerinde olumlu etkide bulunduğunu açıklamışlardır. Ayrıca, yerli vatandaşlar, Avrupa Birliği vatandaşları ve üçüncü dünya vatandaşları için faydalı olduğunu Almaya örneğinde tespit etmişlerdir. Dolayısıyla, Avrupa Birliğinin göçmenlere açılması önerilmektedir. 
Günümüzde Kırgızistan'ın yüksek düzeyde ülke dışına göç vermesi, toplum için sosyal ve psikolojik sorunları ortaya çıkarmaktadır. Veliler, iş göçmeni olarak yurt dışında bulunmalarından dolayı çocuklarına istenilen derecede dikkat edip bakamamaktalar. Ailedeki işsizlik ve maddi sorunlardan ötürü çatışmalar ve geçimsizlik meydana gelmektedir. Aile içi iletişim zayıflamış ve bu durumda çocuğun gelişimine olumsuz etki etmektedir. Aile içi iletişim, çocuğun gelişimine kendini tanıma, değerlendirme, kabul etme ve özgüvenini geliştirme konusunda oldukça etkendir. Ancak, ailevi problemler çocukların gelişimine ve başarısına olumsuz etki edeceği, onlarda saldırganlık, sinirlilik, kaygı, durumu kabul etmeme, uyumsuzluk, derslerde zayıflama gibi problemleri beraberinde getirdiği tespit edilmiştir (Boobekova, 2018,238).

Kırgızistan'da yükseköğretim kurumlarında eğitim gören öğrencilerinin akademik başarısına anne-babasının ayrılmış olmasının negatif etkilediği bulunmuştur. Bunula birlikte ailenin gelir seviyesi ve annesinin çalışıp çalışmadığı da akademik performansını etkilediği tespit edilmiştir (Abdieva, 2016).

\section{Betimleyici İstatistikler}

Bu çalışmada Kırgızistan-Türkiye Manas Üniversitesinde 2014 y1lında öğrencilerin problemlerini inceleme amacıyla yapılan anket verileri kullanılmıştır. Ankete 3133 öğrenci katılmıştır.

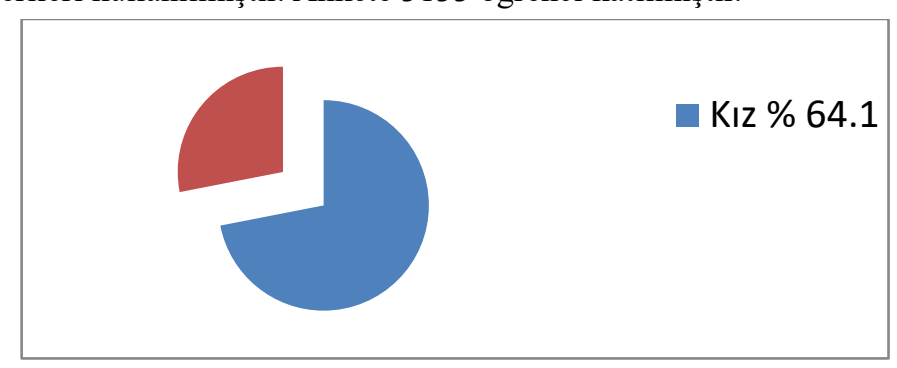

Şekil 1. Ankete Katılanların Cinsiyete Göre Dă̆ılımı

Ankete katılanların \% 64'ü kız ve \% 35'i erkek olduğu görülmektedir.

\begin{tabular}{|l|l|} 
& Kırgızistan $-\% 86.5$ \\
& Türkiye- \% 9.0 \\
& Kazakistan-\% 0.7 \\
& Çin-\% 0.3 \\
Özbekistan- \%1.1 & Rusya-\%0.2 \\
& \\
& \\
\end{tabular}

Şekil 2. Ankete Katılanların Uyruğuna Göre Dağılımı

Ankete katılanların \% 86,5'i Kırgızistan vatandaşı, \% 9'u Türkiye, \% 1,1'i Özbekistan, \% 0,7'si Kazakistan ve diğer ülkelerin vatandaşı olduğu görülmektedir.

\begin{tabular}{|l|l|l|}
\hline & Frekans & Oran1 \\
\hline Evet & 715 & 22,8 \\
\hline Bazen & 1148 & 36,6 \\
\hline Hayır & 1268 & 40,5 \\
\hline Cevapsiz & 2 & 0.1 \\
\hline Toplam & 3133 & 100.0 \\
\hline
\end{tabular}

Tablo: 1. Ankete Katılanların 'Her şeye fazla üzülüyorum' Ifadesine Verilen Cevaplarına Göre Dağılımı

Ankete katılanların \% 22,8'i her şeye fazla üzüldüklerini, \% 36,6'sı ise bazen fazla üzüldüklerini ve \% 40,5'i de fazla üzülmediklerini bildirmişlerdir. Bu sorun yaşa göre bakılınca tüm yaş grubunda aynı derecede olmakla birlikte 21 yaştakilerde manidarlık düzeyi yüksek çıkmıştır.

\begin{tabular}{|l|l|l|}
\hline & Frekans & Oran1 \\
\hline Evet & 756 & 24,1 \\
\hline Bazen & 904 & 28,9 \\
\hline Hayır & 1464 & 46,7 \\
\hline Cevapsiz & 9 & 0.3 \\
\hline Toplam & 3133 & 100.0 \\
\hline
\end{tabular}

Tablo: 2. Ankete Katılanların 'Psikolojik danışmaya ihtiyacım var' Ifadesine Verilen Cevaplarına Göre Dă̆llımı 
Ankete katılanların \% 24,1'i psikolojik danışmaya ihtiyaç duyduklarını, \% 28,9'u ise bazen ihtiyaç duyduklarını ve \% 46,7'si de psikolojik danışmaya ihtiyaç duymadıklarını bildirmişlerdir. Öğrencilerimizin yarısından fazlasının psikolojik danışmaya ihtiyaçları olduklarını ifade etmeleri, güzel bir şey olmanın yanı sıra, kişisel sorunlarını çözemeyecekmiş gibi görmeleri, dikkate değer bir durumdur. Neticede, güvenip danışacağı kimselerin olmadığını düşünmektedirler ve görülmeye, danışmaya ihtiyaçları vardır.

\begin{tabular}{|l|l|l|}
\hline & Frekans & Oran1 \\
\hline Evet & 756 & 24,1 \\
\hline Bazen & 904 & 28,9 \\
\hline Hayır & 1464 & 46,7 \\
\hline Cevapsiz & 9 & 0.3 \\
\hline Toplam & 3133 & 100.0 \\
\hline
\end{tabular}

Tablo: 3. Ankete Katılanların 'Okulda problemlerim ve üzüntülerim hakkında akıl danışabileceğim kimse yok' Ifadesine Verilen Cevaplarına Göre Dă̆ılımı

Okulda akıl danışabileceği kimsenin olmadığını düşünen öğrenci sayısı, yaklaşık olarak \% 55'i oluşturmaktadır. Okulda akıl danışabileceği kimsenin olmaması, öğrencilerin problem karşısında kendilerini yalnız hissetmelerine sebep olmaktadır. Bu konuda öğrencilerin sosyal uyum sorunları yaşadığı, psikolojik sorunlarının olduğu ve bunu birilerine söyleyince ne olabileceği konusunda bilgisi olmadığı durum, onları endişelendirmektedir diye yorumlanabilir.

\begin{tabular}{|l|l|l|}
\hline Çekingenim ve utangacım & Frekans & Oran1 \\
\hline Evet & 811 & 25,9 \\
\hline Bazen & 1092 & 34,9 \\
\hline Hayır & 1224 & 39,1 \\
\hline Cevapsiz & 6 & 0.2 \\
\hline Toplam & 3133 & 100.0 \\
\hline
\end{tabular}

Tablo: 4. Ankete Katılanların 'Çekingenim ve utangacım' Ifadesine Verilen Cevaplarına Göre Dă̆llımı

Ankete katılanların \% 25,9'u çekingen ve utangaç olduklarını, \% 34,9'u da bazen çekingen ve utangaç olduklarını ve \% 39,1'i de çekingen ve utangaç olmadıklarını belirtmişlerdir. Öğrencilerin çekingen olması veya kendilerini çekingen olarak görmeleri, uyruk ve cinsiyet olarak bakılınca Kırgızistanlı kız öğrencilerde yüksek çıkmıştır. 18-20 yaş arasında olan öğrencilerde önemli bir derecede kendisiyle çatışma var, kendilerini çekingen ve utangaç olarak hissediyorlar.

\begin{tabular}{|l|l|l|}
\hline $\begin{array}{l}\text { Bazen intihar etmeyi } \\
\text { düşünüyorum }\end{array}$ & Frekans & Oranı \\
\hline Evet & 191 & 6,1 \\
\hline Bazen & 360 & 11,5 \\
\hline Hayır & 2574 & 82,2 \\
\hline Cevapsız & 7 & 0.2 \\
\hline Toplam & 3133 & 100.0 \\
\hline
\end{tabular}

Tablo: 5. Ankete Katılanların 'Bazen intihar etmeyi düşünüyorum' Iffadesine Verilen Cevaplarına Göre Dă̆llımı

İntihar etme düşünceleri olanların sayısını inceleyince "evet" diyenlerin \% 6.1 olması ve "bazen" diyenlerin \%11.5 olması oldukça düşündürücüdür. Bu durum, öğrencilerin çoğunluğu türlü sebeplerden dolayı gizli ve açık depresyon yaşadıklarının, ancak duygularını güvenip paylaşacak birilerini bulamayacakları hissine kapıldıklarının veya sorunlarını çözülebileceklerine inanmadıklarının göstergesidir.

"Bazen intihar etmeyi düşünenler" yaş olarak 18, 19, 20 yaşındakiler olduğu, derslerdeki not ortalaması yükseldikçe intihar etmeyi düşünenlerin oranı azalmakta olduğu ve ailesi tarafından çok eleştirilenlerin intihar etme düşüncesi daha fazla olduğu saptanmıştır.

\begin{tabular}{|l|l|l|}
\hline Sik sık yalnızlı hissediyorum & Frekans & Oran1 \\
\hline Evet & 776 & 24,8 \\
\hline Bazen & 1129 & 36,0 \\
\hline Hayır & 1225 & 39,1 \\
\hline Cevapsiz & 3 & 0.1 \\
\hline Toplam & 3133 & 100.0 \\
\hline
\end{tabular}

Tablo: 6. Ankete Katılanların 'Sık sık yalnızlık hissediyorum' Ifadesine Verilen Cevaplarına Göre Dă̆llımı

Ankete katılanların \% 24,8'i sık sık yalnızlık hissettiklerini, \% 36'sı bazen yalnız hissettiklerini ve \%39,1'i de kendilerini yalnız hissetmediklerini bildirmişlerdir. Bununla birlikte, "Ailem beni çok eleştiriyor" diyen 
öğrencilerin \% 45,1'i kendilerini sık sık yalnız hissediyorlar. Bu durum, öğrencilerin uyum sorununun var olduğunun ve kaygı ve çekingenlik düzeylerinin yüksek olduğunun göstergesidir. Cinsiyete bakılınca, daha çok kız öğrenciler kendilerini yalnız hissettikleri tespit edilmiştir.

\section{Veri ve Yöntem}

Bu çalışmada Kırgızistan-Türkiye Manas Üniversitesinde 2014 yılında öğrencilerin problemlerini inceleme amacıyla yapılan anket verileri kullanılmıştır. Ankete 3133 öğrenci katılmıştır. Fakat bunların sadece 1932'u not ortalamalarını belirttikleri için analize not ortalamasını bildirmeyen öğrenciler dahil edilmemiştir. Not ortalaması 1 ile 5 arasında değişmektedir ve dağılımı Tablo. 1'de gösterilmektedir.

\begin{tabular}{|l|l|l|l|l|l|l|l|}
\hline Not Ortalamas1 & Bilmeyenler & 1 & 2 & 3 & 4 & 5 & Toplam \\
\hline Öğrenci sayıs1 & 17 & 8 & 188 & 959 & 487 & 290 & 1949 \\
\hline Yüzdesi, \% & 0,9 & 0,4 & 9,7 & 49,2 & 25 & 14,9 & 100 \\
\hline
\end{tabular}

Tablo 7. Ankete Katılanların Not Ortalamalarına Göre Dă̆ılımı

Ankete katılanların 17'si not ortalamalarını bilmediklerini, 8'inin ortalaması 1'dir. Katılımcıların \% 9,7'sinin ortalaması 2; \% 49,2'sinin 3; \% 25'inin 4; ve \% 14.9'unun not ortalaması 5 olduğu bilinmektedir.

\begin{tabular}{|l|l|}
\hline Değişkenler & \multicolumn{1}{|c|}{ Açıklama } \\
\hline Sinirli olmak & Bazen sinirli olanlar 1, diğerleri 0 \\
\hline Virtuel dünyada yaşayanlar & $\begin{array}{l}\text { İnsanlar arası iletişimde kendini bazen gerçek dünyaya göre virtüel dünyada } \\
\text { daha iyi hissedenler 1, diğerleri 0 }\end{array}$ \\
\hline $\begin{array}{l}\text { Okulda akıl danışabileceği } \\
\text { kimsenin olmaması }\end{array}$ & $\begin{array}{l}\text { Okulda problemleri ve üzüntüleri hakkında akıl danışabileceği kimsesi } \\
\text { olmayanlar 1, diğerleri 0 }\end{array}$ \\
\hline Psikolojik danıșmaya ihtiyaç & Psikolojik danıșmaya ihtiyacı olanlar 1, diğerleri 0 \\
\hline İntihar düşüncesi & Bazen intihar etmeyi düșünenler 1, diğgerleri 0 \\
\hline Suçluluk duygusu & Kendini suçluluk duygusu içinde hissetmeyenler 1, diğerleri 0 \\
\hline Fazla üzülmek & Her şeye fazla üzülmeyenler 1, diğerleri 0 \\
\hline Cekingenlik ve utangaçlık & Cok çekingen ve utangaç olanlar 1, diğerleri 0 \\
\hline Yalnızlık duygusu & Sik sık yalnı hissetmeyenler 1, diğerleri 0 \\
\hline Fazla alınganlık & Fazla alıngan olmayanlar 1, diğerleri 0 \\
\hline Zamanını hayalle geçirmek & Zamanının çoğunu hayal kurmakla geçirmeyenler 1, diğerleri 0 \\
\hline
\end{tabular}

Tablo 8. Bă̆ımsız Değişkenlerin Açıklamaları

\begin{tabular}{|l|l|l|}
\hline Değișkenler & Katsay1 & Marjinal Etkileri \\
\hline Sinirli olmak & $0.1403^{* *}$ & $0.0322^{* * *}$ \\
\hline Bazen virtuel dünyada yaşayanlar & $-0.1107^{*}$ & $-0.0241^{*}$ \\
\hline Okulda akıl danıșabileceği olmaması & $-0.2342^{* * *}$ & $-0.0504^{* * *}$ \\
\hline Psikolojik danıșmaya ihtiyaç & $-0.2410^{* * *}$ & $-0.0504 * * *$ \\
\hline İntihar düșüncesi & $-0.3017^{* * *}$ & $-0.0586^{* * *}$ \\
\hline Suçluluk duygusu & 0.0376 & -0.0084 \\
\hline Fazla üzülmek & $-0.1113^{*}$ & $-0.0247^{* *}$ \\
\hline Cekingenlik ve utangaçlık & 0.0303 & 0.0136 \\
\hline Yalnızlık duygusunu hissetmeyenler & 0.0319 & 0.0072 \\
\hline Fazla alıngan olmayanlar & $-0.1338^{*}$ & $-0.0301 * *$ \\
\hline Zamanını hayalle geçirmeyenler & $0.0941^{*}$ & $0.0214 *$ \\
\hline Her zaman virtuel dünyada yașayanlar & -0.0140 & -0.0031 \\
\hline Cut1 & -2.257752 & \\
\hline Cut2 & .1142334 & \\
\hline Cut3 & -1.00495 & \\
\hline
\end{tabular}

Tablo 9. Stralı Probit Modelinin Sonuçları

LR chi2 (13) $=87.50(0.0000) \quad$ Pseudo R2 $=0.0178 \quad$ Log likelihood $=-2411.3749$

Marjinal etki not ortalaması değişkeninin en yüksek değerine göre hesaplanmıştır (veya 5 'e göre). Not: *, ** ve *** $10 \%, 5 \%$ ve $1 \%$ düzeyinde anlamlllı derecesini göstermektedir.

Modelin sonuçlarına göre bazen sinirli olanların, her zaman sinirli olanlar ve hiç sinirli olmayanlara göre not ortalamaları \% 3'e yüksek olduğu ve bu farkın istatistiksel olarak anlamlı olduğu tespit edilmiştir. İnsanlar arası iletişimde kendini bazen gerçek dünyaya göre virtüel dünyada daha iyi hissedenlerin akademik performansı ise diğerlerine göre \% 2 oranında daha düşük olduğu saptanmıştır.

Okulda problemleri ve üzüntüleri hakkında akıl danışabileceği kimsesi olmadığını belirten ve psikolojik danışmaya ihtiyacı olan öğrencilerin akademik başarısı diğerlerine göre \% 5 oranında daha düşüktür. Bununla 
birlikte, bazen intihar etmeyi düşünen öğrencilerin de not ortalamaları diğerlerine göre $\% 5$ oranında daha düşük olduğu açıklanmıştır. Bu sonuçlar istatistiksel olarak \% 1 düzeyinde anlamlıdır.

Diğer yandan paradoksal olarak da görülebilen sonuç, her şeye fazla üzülenler ile fazla alıngan olmayanların akademik başarıları diğerlerine göre $\% 2$ ve $\% 3$ oranında daha düşük olduğu tespit edilmiştir. Bu sonuçlar \% 5 seviyesinde istatistiksel olarak anlamlıdır.

Bunun yanında suçluluk ve yalnızlık duygusunu hissetmeyen öğrencilerin not ortalamalarında diğerlerinden farkı ile ilgili istatistiksel olarak anlamlı sonuç bulunamamıştır. Aynı zamanda insanlar arası iletişimde kendini her zaman gerçek dünyaya göre virtüel dünyada daha iyi hissedenlerin not ortalamaları diğerlerine nazaran düşük olduğu görülmüştür. Fakat bu sonuç da istatistiksel olarak anlamsızdır.

\section{Sonuç ve Değerlendirme}

Eğitim kalitesi ekonomik kalkınma ve kişisel düzeyde yaşam kalitesinin yükselmesinde önemli rolü olan faktördür. Eğitimin etkinliği ve başarısı üzerinde psikolojik faktörlerin önemi büyüktür. Psikolojik faktörler öğrenme, eğitimin etkinliği ve akademik başarıyı etkilemektedir. Çalışmamızda Kırgızistan'da psikolojik faktörlerin üniversite öğrencilerinin akademik başarıları üzerindeki etkisi sıralı probit modeli ile incelenmiştir. Araştırma sonucuna göre insanlar arası iletişimde kendini bazen gerçek dünyaya göre virtüel dünyada daha iyi hisseden, okulda problemleri ve üzüntüleri hakkında akıl danışabileceği kimsesi olmayan ve psikolojik danışmaya ihtiyacı olan öğrencilerin akademik başarısı diğerlerine göre daha düşüktür. Ayrıca bazen intihar etmeyi düşünen öğrencilerin not ortalamaları diğerlerine göre \% 5 oranında daha düşük olduğu açıklanmıştır. Dolayısıyla, üniversitelerde psikolojik danı̧̧ma hizmetinin yaygınlaşması, öğrencilerin sosyalleşmesini sağlayan metod ve faaliyetlerin arttırılması öğrencilerin akademik başarıları açısından da önemi büyük olduğu görülmektedir.

Diğer yandan, her şeye fazla üzülenler ile fazla alıngan olmayanların akademik başarıları diğerlerine göre daha düşük olduğu tespit edilmiştir. Aynı şekilde bazen sinirli olanların, her zaman sinirli olanlar ile hiç sinirli olmayanlara göre not ortalamaları \% 3'e yüksek olduğu açıklanmıştır. Bu ise, öğrencilerin kaygı derecesinin orta seviyede olması, onların akademik başarıları üzerinde olumlu etkide bulunduğunu bildirmektedir.

\section{Kaynakça}

- Abdiyeva, 2016. Geçiş Ekonomilerinde Üniversite Öğrencilerinin Başarılarını Etkileyen Demografik Faktörler: Kırgızıstan Örneği, Manas Sosyal Araştırmalar Dergisi, Cilt 5, Sayı 1, s. 86-93.

- Anthonia ve Nwaukwu Chukwuemeka, 2017. Psychological Factors And Students' Academic Achievement In Mathematics In Ughell1-South Local Government Area Of Delta State, Nigeria, British Journal of Education, Vol.5, No.10, pp. 8-21, September, Published by European Centre for Research Training and Development UK

- Bhattacharya, R. ve Bhattacharya, B,. 2015. Psychological factors affecting student"s academic performance in higher education among students, International Journal For Research \& Development In Technology Volume-4,Issue-1, July- 2015 ISSN (O) :- 2349-3585: p.62-70;

- Habibian, Samsilah, Khairuddin, Jamilah,. 2015. The Role of Psychological Factors in the Process of Reading, Journal of Education and Practice www.iiste.org, Malaysia, Vol.6, No.29, 114-123.

- Volchik, Oganesyan ve Olejarz, 2018. Higher education as a factor of socio-economic performance and development, Journal of International Studies, 11(4), 326-340. doi:10.14254/2071-8330.2018/11-4/23

- Wondu, 2018. Psychological Factors Affecting Students Academic Performance Among Freshman Psychology Students in Dire Dawa University, Journal of Education and Practice, Vol.9, No.4, 59-65.

- Бообекова, К. С. 2018, Өлкөбүздө жогорку окуу жайларда билим алган студенттердин үй бүлөгө байланыштуу проблемалары, И.Арабаев ат. КМУ «Вестник» журналы, 2018, Май, 231-243-бб.

- Захаров А. И. 2002. Неврозы у детей и психотерапия. СПб.: Союз. 


\title{
Yöneticilerin Empatik Eğilim Düzeylerinin, Yönetsel Yetkinlikleri Üzerindeki Etkisi
}

\section{The Impact on the Managerial Competences of the Managers' Empathy Trends Levels}

\author{
Asst. Prof. Dr. Hilal Çelik (Beykent University, Turkey) \\ Ph.D. Candidate Ufuk Özen (Beykent University, Turkey) \\ Ph.D. Candidate Ebru Bağçı (Beykent University, Turkey)
}

\begin{abstract}
A large share of the concept of "human resource", which has a very important place in the working life, constitutes managers and their behaviors beside the rulers. There are many variables in the managerial competence of managers. In this study, the effects of empathic tendencies and empathic skills on their managerial competencies were investigated. In the economic process, which is the ultimate goal of working life, human resources are a great asset. For this reason, the managerial and employee behaviors will directly and indirectly affect this process, so the concept of empathic tendency is emphasized with the anticipation that the effect on manager performance will be great in this study. The survey found that the differences between managers with high empathy power and managers with less empathy power were not clear as to how their subordinates perceived this difference and reflected on their performance, what sort of consequences they had in solving individual problems of subordinates, job security and motivation and how they worked in the businesses they worked for.
\end{abstract}

\section{Giriş}

Yönetim kavramı, farklı bilim dallarında birbirine benzer olsa da farklı anlamlarda tanımlanmakla birlikte uluslararası bir değere sahiptir. Bu değer, yönetim kavramını bir tabanda topluyor gibi görünse de yönetim biçimlerindeki farklılık tabanda ayrılığa neden olmaktadır. Bunun nedeni ise yönetimin niteliğinin yöneticinin tarzına göre farklılık göstermesidir. Bireylerin sahip oldukları kişisel nitelikleri, yaşam tarzlarındaki farklılıklar hayattaki amaçları farklı olsa da ortak bir amaç için bir araya gelmeleri sadece onları yönlendiren ve ortak çalışmalarını düzenleyen bir unsur ile mümkündür. Bu unsur da "yönetim” kavramıyla açıklanmaktadır (Yıldırım, 2002).

Kurumlar ile ilgili düşünüldüğünde, kurumların yönetiminin sahip olması gereken birçok değer vardır. Bunlardan bazıları; çalışan ve diğer yöneticilerle empati kurabilme, etkili ve kaliteli iletişim çerçevesinde etkili konuşma ve dinleme, hiçbir çalışanı birbirinden ayırmama anlamında önyargısız bir yönetim, planlama, koordinasyondur (Katman, 2010). Kurumları bu değerlere ulaştırma ya da bu değerler çerçevesinde varlığının idamesini sağlamaya yönelik çalışan kişiler ise yöneticilerdir. Yani yönetici; bir amaç çerçevesinde bir araya gelmiş insanları, etkili ve işletme çıkarlarına yönelik verimli olarak yönetme bilinci ve aynı zamanda da yönetme zorunluluğu olan kişilerdir (Eren ve Güleç, 2018:839).

Yöneticiler, fikir öncülüğü etme, planlama, iş organizasyonunu yapma, çalışanları işe motive etme, haberleşme ve çalıştıkları alanı kontrol etme gibi görevlere sahip olmakla birlikte bulundukları alanda önderlik etme ve yol gösterme gibi görevleri de üstlenmişlerdir. Bu nedenle de yönetici; kendisine bağlı çalışan toplulukların başını çeken, kendisine bağlı çalışanlara destek veren, çalışanların iş motivasyonunu arttırmaya yönelik rahat ve huzurlu bir iş ortamı sağlayarak aynı zamansa iş verimlerini en üst seviyeye çıkaran kişilerdir (Erdoğan, 2008).

\section{Yönetici ve Empati}

Yönetici, belli bir zaman dilimi içinde ve değişen çevre koşulları altında belirli birtakım amaçları gerçekleştirmek üzere; maddî ve beşeri üretim faktörlerini uyumlu bir şekilde birleştiren ve çalıştıran kimsedir (Eren, 2013, s.8).

Empati, kişinin kendisini karşısındaki kişinin yerine koyarak olaylara onun bakış açısıyla bakması, o kişinin duygularını ve düşüncelerini doğru olarak anlaması, hissetmesi ve bu durumu ona iletmesi sürecidir (Dökmen, 2002, s. 135).

Başkalarının duygularını anlayabilen yöneticiler, onların beklentilerini ve hassasiyetlerini kavrayarak onlara esin kaynağı olabilirler. Bireylere önem veren ve sadece onlarla grupta değil, birebir ilişkiler de kurabilen ve empati yaparak kendini onların yerine koyan yöneticiler, ilişkilerini etkin yönetmektedirler.(Barling, Slatter ve Kelloway, 2000). İşyeri ortamında anlaşmazlıklar çıktığında, çatışmalar oluştuğunda çok dikkatli olunmalıdır. Anlaşmazlığa düşen kişilerin empati göstermeleri ortaya çıkacak anlaşmazlıkların ve çatışmaların daha kolay çözülmesini sağlayacaktır (Aquino, 2000). 


\section{Yetkinlik}

Yetkinlik kavramı insan kaynakları yönetimi planlamasında son derece önemli bir yere sahiptir. Bu kavram neredeyse her bilimdalı içerisinde kendine yer bulabildiği için tanımsal anlamda da bazı fikir ayrılıklarına sebep olmuştur.

Uluslararası kaynaklara göre bir görevi icra edebilmek için gerekli olan bilgi beceri ve güç anlamına gelmekteyken; ulusal kaynaklara göre ise bir işi yapmaya yeterli olmak anlamına gelmektedir. 5 temel özelliği bulunmaktadır. Bunlar; bilgi, beceri, tutum, gözlemlenebilir davranış ve üstün performanstır (Çetinkaya, 2009).

\section{Yönetsel Yetkinlik}

Yöneticiler çalışma yaşamında diğer iş görenlerle birlikte görevlerini ifa ettiklerinden, iş görenler yöneticileri ile aralarındaki hiyerarşi konusunda zaman zaman bocalama yaşayabilmektedirler. Bu durumda yöneticilerin iş görenler karşısında başarılı olabilmeleri için bazı temel yönetsel yetkinliklere sahip olmaları gerekir. Bu temel yönetsel yetkinlikleri üç başlık altında incelenebilir;

- Teknik yetkinlikler

- Beşeri yetkinlikler

- Kavramsal yetkinlikler (Pehlivanoğlu, 2018).

\section{Empatinin Ölçülmesi}

Literatürde, empatinin ölçülmesinde kullanılan farklı ölçekler bulunmaktadır. Dökmen (1988), empati ölçümlerine ilişkin empati ölçeklerini dört grupta toplamıştır. Erçoban 2003; s.29 da bu konuya değinmiştir.

- Kişilerarası Algıyı Ölçen Empati Ölçekleri: Kişilerin birbirlerini nasıl algıladıklarının ölçülmesinde kullanılan ölçeklerdir.

- Empati Kurma Becerisini Kişiliğin Bir Boyutu Olarak Ele Alan Ölçekler: Bu ölçekler günlük yaşamda empatik duyarlılığı olan kişilerin kişilik özellikleri dikkate alınarak hazırlanmıştır. Daha çok duygusal empatiyi ölçerler ve bir kişilik ölçeği özelliği taşırlar.

- Bir Başkasının Rolünü Alma. Onu Doğru Anlama Becerisini Ölçen Ölçekler: Bu ölçekler empatinin bilişsel bileşenini ölçer ve bireyin kendisine söylenen sözleri ne derece doğru anladığını belirlemeye çalışır.

- Belli Uyarıcılar Karşısındaki Empatik Tepkilerin Ölçüldüğü Ölçekler: Bu ölçekler ile bireylerin belli uyarıcılara gösterdiği sözel ya da davranışsal nitelikli empatik tepkileri ölçülür.

\section{Yazın Alanında Konuya İlişkin Yapılan Çalışmalar}

Genç ve Kalafat (2008); “Öğretmen adaylarının demokratik tutumları ile empatik becerilerinin değerlendirilmesi üzerine bir araştırma" isimli çalışmasında, öğretmen adaylarının demokratik tutumları ile empatik becerilerini farklı değişkenler açısından ele almışlardır. 360 öğretmen adayı örneklem grubuna alınmıştır. Öğretmen adaylarının öğrenim gördükleri anabilim dallarına göre empatik becerileriyle ilgili görüşleri arasında farklılığın olduğunu; cinsiyet, öğrenim gördükleri sınıf, öğrenim şekilleri, anne ve babalarının öğrenim durumlarına göre ise farklılığın olmadığını ortaya koymuştur.

Çiçek (2006); "Sağlık Çalışanlarının Empatik Eğilim ve Becerilerinin Değerlendirilmesi” isimli çalışmasında 546 sağlık çalışanı örneklem grubuna alınmıştır. Araştırmanın bulgularına göre; sağlık çalışanlarının empatik eğilim düzeylerinde çalışma yılı, yaş, eğitim durumu, çalıştıkları kurum, çocuk sayısı ve çalışma durumu değişkenlerine göre anlamlı farklılık bulunmadığını; kadınların empatik eğilim düzeylerinin erkeklerin empatik eğilim düzeylerinden yüksek olduğu, mesleği isteyerek seçenlerin empatik eğilimlerinin, mesleği istemeyerek seçenlerin empatik eğilimlerine göre yüksek olduğu ortaya koyulmuştur.

Çetinkaya (2009); "Yöneticilerin Yönetsel Yetkinlik Algllamalarına İlişkin Bir Araştırma ” isimli çalışmasında elde edilen bulgulara göre; yöneticilerin temelde benzer görevleri üstlenseler de bulundukları konuma özgü farklı yönetsel yetkinliklere sahip olmaları gerektiği, orta ve üst düzey yönetsel yetkinliklerin dört başlık altında incelenmesi gerektiği ve daha alt düzey yöneticilerin ise beş başlık altında incelenmesi gerektiği ortaya çıkmıştır.

Çetinkaya ve Özutku (2012); “Yönetsel performansa yetkinlik temelli yaklaşım: Türk otomotiv sektöründe bir araştırma" isimli çalışmada; otomotiv sektöründe yönetsel yetkiliklere verilen önem ve performans ölçümlerinde yönetsel yetkiliklerin bir etkisinin olup olmadığı araştırılmış ve yönetsel yetkinliklerin dikkate alınmadığı ortaya konmuştur. Üç ayrı düzeyde (üst, orta ve alt düzey yönetici) ele alınan yöneticilerin hepsine aynı sorular sorulmuş ve alınan cevaplarda yönetsel yetkinliklere verilen önem düzeyi ile performans değerlendirmede yetkinliklerin göz önünde bulundurulması arasında anlamlı farklar ortaya çıkmıştır. Ayrıca bu çalışmada yöneticilerin başarılı 
olmalarında hangi yönetsel yetkinliklerinin daha etkili olduğu konusunda işletmelerin tanımlamaya daha istekli olmaları gerektiği de ortaya çıkmıştır.

\section{Araştırmanın Yöntemi}

Yöneticilerin empatik eğilim düzeylerinin yönetsel yetkinlikleri üzerine etkilerini belirlemeye yönelik veriler anket tekniği ile toplanmıştır. Anket üç ana bölümden oluşmaktadır. Birinci bölümde, yöneticilerin özelliklerini sorgulayan sorular yer almaktadır. İkinci bölümde yöneticilerin yetkinliklerini ölçmeye yönelik 10 ifadeden oluşan ölçek yer almaktadır. Üçüncü bölümde ise; yöneticilerin empatik eğilimlerini ölçmeye yönelik 20 ifadeden oluşan empatik eğilim ölçeği yer almaktadır. Tüm ölçekler 5 noktalı olup, yöneticilerin yetkinlikleri ölçeği 1 hiç sahip değilim, 5 çok sahibim olacak şekilde sıralanmıştır. Empatik eğilim ölçeğinde ise; 1 tamamen aykırı, 5 tamamen uygun şeklinde sıralanmıştır. Ölçeklere verilen yanıtlar 5'e yaklaştıkça empatik eğilim düzeylerinin ve yönetsel yetkinliklerinin arttığını göstermektedir.

Ankette yer alan empatik eğilim ölçeği Dökmen (1988)' den, yönetsel yetkinlik ölçeği Boyatzis (1982)' den alınmıştır. Örneklem sayısı bakımından parametrik testlere uygun olmayan çalışmada bulgular non-parametrik testlerden Kruskal-Wallis testi ile elde edilmiştir.

\section{Anakütle ve Örneklem}

İstanbul ilinde bulunan üretim ve planlama hizmeti veren büyük ölçekli 50 Tekstil işletmesinin fason organizasyon, modelhane, üretim, planlama, depo, insan kaynakları ve muhasebe, sevkiyat, kesimhane, mamul depo(aksesuar), kumaş depo, idari, ütü-paket ve kalite kontrol bölümlerinde yönetici pozisyonunda bulunan toplam 650 kişi araştırmanın anakütlesini oluşturmaktadır.

İnternet tabanlı gönderilen anket formuna yapılan dönüşler ile İstanbul ili içerisinde bölüm yöneticisi konumunda bulunan yöneticilerden araştırmaya katılan 44 birey araştırmanın örneklemini oluşturmaktadır.

\section{Bulgular}

Ankete yanıt veren katılımcılara ilişkin demografik veriler Tablo 1'de verilmiştir.

\begin{tabular}{|c|c|c|}
\hline \multicolumn{2}{|c|}{ KATILIMCILARA İLIŞSİN BİLGİLER } & \multirow{2}{*}{$\begin{array}{c}\text { ORANLAR (\%) } \\
31,4\end{array}$} \\
\hline & Kadın & \\
\hline CINSIYET & Erkek & 65,9 \\
\hline \multirow{3}{*}{ MEDENİ DURUM } & Evli & 61,4 \\
\hline & Bekar & 36,4 \\
\hline & Boşanmış & 2,3 \\
\hline \multirow{3}{*}{ GELİR DÜZEYİ } & $0-5000 \mathrm{TL}$ & 43,2 \\
\hline & 5001-10000 TL & 50 \\
\hline & 10001 TL ve Üzeri & 6,8 \\
\hline \multirow{3}{*}{ YASS } & $18-25$ & 6,8 \\
\hline & $26-33$ & 38,7 \\
\hline & $34-42$ & 54,5 \\
\hline \multirow{4}{*}{ EĞíTİM DURUMU } & Lise ve Alt1 & 6,8 \\
\hline & Ön Lisans & 6,8 \\
\hline & \begin{tabular}{|l|} 
Lisans \\
\end{tabular} & 45,5 \\
\hline & Lisans Üstü & 40,9 \\
\hline \multirow{5}{*}{ İŞ TECRÜBESİ } & 1-5 Yil & 25 \\
\hline & 6-10 Y1l & 31,8 \\
\hline & 11-15 Y11 & 20,5 \\
\hline & 16-20 Y1l & 11,4 \\
\hline & 21 Yil ve Üzeri & 11,3 \\
\hline
\end{tabular}

Tablo 1. Katılımclların Demografik Verileri 


\begin{tabular}{|c|c|c|c|}
\hline $\begin{array}{c}\text { YÖNETSEL YETKİNLIIK } \\
\text { İFADELERİ }\end{array}$ & CINSIYYET & $\begin{array}{l}\text { KATILIMCILARIN CINSIIYETLERİNE } \\
\text { GÖRE DAĞILIMLARI }\end{array}$ & Ort. \\
\hline \multirow{2}{*}{ Liderlik } & kadın & 15 & 23,53 \\
\hline & erkek & 29 & 21,97 \\
\hline \multirow{2}{*}{ Motive Etme } & kadın & 15 & 23,10 \\
\hline & erkek & 29 & 22,19 \\
\hline \multirow{2}{*}{ Kararlık } & kadın & 15 & 25,50 \\
\hline & erkek & 29 & 20,95 \\
\hline \multirow{2}{*}{ Özgüven } & kadın & 15 & 22,70 \\
\hline & erkek & 29 & 22,40 \\
\hline \multirow{2}{*}{ Zaman Yönetimi } & kadın & 15 & 22,77 \\
\hline & erkek & 29 & 22,36 \\
\hline \multirow{2}{*}{ İnsan Odakl1lık } & kadın & 15 & 22,73 \\
\hline & erkek & 29 & 22,38 \\
\hline \multirow{2}{*}{ Risk Alma } & kadın & 15 & 21,33 \\
\hline & erkek & 29 & 23,10 \\
\hline \multirow{2}{*}{ Çalışma Azmi } & kadın & 15 & 22,17 \\
\hline & erkek & 29 & 22,67 \\
\hline \multirow{2}{*}{ Problem Çözme } & kadın & 15 & 18,97 \\
\hline & erkek & 29 & 24,33 \\
\hline \multirow{2}{*}{ Stratejik Düşünme Yeteneği } & kadın & 15 & 20,40 \\
\hline & erkek & 29 & 23,59 \\
\hline
\end{tabular}

Tablo 2. Yönetsel Yetkinlik Düzeylerinin Cinsiyete Göre Dă̆gllımı

Örneklem hacmi küçük olduğundan araştırmada Non-Parametrik testlerden Kruskal-Wallis Testi uygulanmıştır. Katılımcıların yönetsel yetkinliklerini ölçmeye yönelik 10 ifadelik soru sorulmuştur. Bu sorularda katılımcıların sahip oldukları yetkinlikleri 5 likert ölçek bağlamında değerlendirmeleri istenmiştir. Buna göre; "liderlik, motive etme, kararlılık, özgüven, zaman yönetimi, insan odakl1lık" yetkinliklerine kadınlar erkeklere oranla daha fazla sahip olduklarını belirtmişlerdir. Erkekler ise; "risk alma, çalışma azmi, problem çözme, stratejik düşünme yeteneği" yetkinliklerine kadınlara oranla daha fazla sahip olduklarını belirtmişlerdir. Sonuçlara iliş̧kin veriler Tablo 2.'de yer almaktadır. 


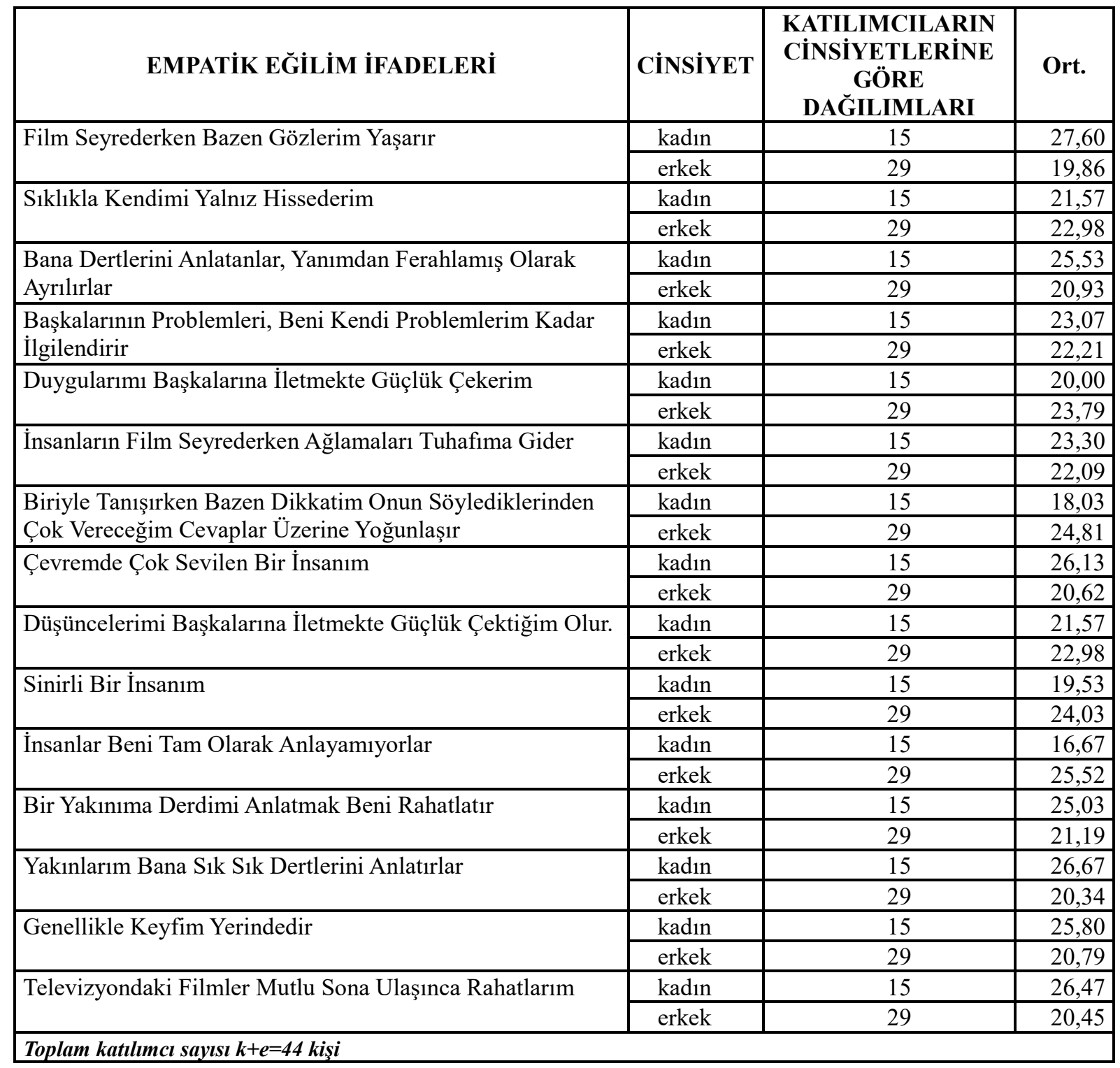

Tablo 3. Empatik Eğilim Düzeylerinin Cinsiyete Göre Dă̆ılımı

Katılımcıların empatik eğilim düzeylerini ölçmeye yönelik 20 ifadelik soru sorulmuştur. Bu sorularda katılımcıların ifadeleri 5 likert ölçek bağlamında değerlendirmeleri istenmiştir. Buna göre; "Film Seyrederken Bazen Gözlerim Yaşarır, Bana Dertlerini Anlatanlar Yanımdan Ferahlamış Olarak Ayrılırlar, Başkalarının Problemleri; Beni Kendi Problemlerim Kadar İlgilendirir, İnsanların Film Seyrederken Ağlamaları Tuhafıma Gider, Çevremde Çok Sevilen Bir İnsanım, Bir Yakınıma Derdimi Anlatmak Beni Rahatlatır, Yakınlarım Bana Sık Sık Dertlerini Anlatırlar, Genellikle Keyfim Yerindedir, Televizyondaki Filmler Mutlu Sona Ulaşınca Rahatlarım” ifadeler yer almaktadır. Kadınların erkeklere göre bu ifadelere daha fazla sahip oldukları sonucuna ulaşılmıştır. Erkekler ise; "Sıklıkla Kendimi Yalnız Hissederim, Duygularımı Başkalarına İletmekte Güçlük Çekerim, Biriyle Tanışırken Bazen Dikkatim Onun Söylediklerinden Çok Vereceğim Cevaplar Üzerine Yoğunlaşır, Düşüncelerimi Başkalarına İletmekte Güçlük Çektiğim Olur, Sinirli Bir İnsanım, İnsanlar Beni Tam Olarak Anlayamıyorlar” ifadelerine kadınlara oranla daha fazla sahip olduklarını belirtmişlerdir. Sonuçlara ilişkin veriler Tablo 2.'de yer almaktadır.

\section{Sonuç ve Öneriler}

Bu çalışmada üst düzey yönetimde bulunan bireylerin yönetsel yetkinlikleri ölçülmeye çalışılmıştır. Çalışmadan elde edilen bulgulara göre yöneticilerin bireysel olarak yetkinliklerini değerlendirmeleri neticesinde kendilerinde yetkinlik düzeylerini yeterli gördükleri sonucuna varılmıştır. Ancak daha kapsamlı yönetsel yetkinlik gereklerine ulaşabilmek için hem daha kapsamlı hem de daha fazla çalışmaya ihtiyaç vardır. Bu çalışma küçük bir örneklemdeki yöneticilerin yönetsel düzeylere yönelik yetkinlik algılamalarını ortaya koyduğu için elde edilen sonuçların tüm yöneticileri temsil etmesi beklenmemelidir. Yönetsel yetkinliklerin üst düzey yöneticiler açısından daha detaylı incelenmesi konusunda yeni boyutlar eklenebilir. 
İletişim, bireyler için ihtiyaç ve sosyal alanda yer edinebilmek için gerekliliktir. Çatışma çözümlemesinde önem arz etmesinin yanında çatışmaların temel nedeni de olabilmektedir. Çatışma noktasında empati, çatışmayı önlemek ve sağlıklı ilişskilerin kurulmasına neden olmaktadır. Organizasyonların, hedeflerine ulaşmalarında yönetici ve astların uyum içerisinde çalışması önemlidir. Bu noktada yöneticilerin empatik eğilimleri astlarına olan davranışları konusunda yönlendirici özellik taşımaktadır. Bu çalışmada, yöneticilerin empatik eğilim düzeyleri ölçülmüştür. Araştırmanın bulgularına göre, kadın yöneticilerin erkek yöneticilere oranla empatik eğilim düzeyleri daha yüksektir. Bu çalışma küçük bir örneklemdeki yöneticilerin empatik eğilim düzeylerine yönelik algılamaları ortaya koyulduğu için elde edilen sonuçların tüm yöneticileri temsil etmesi beklenmemelidir. Empatik eğilim düzeylerinin belirlenmesi için daha kapsamlı ve daha fazla çalışmaya ihtiyaç vardır.

\section{Kaynakça}

- $\quad$ Aquino, Karl, "Structural And Individual Determinants Of Workplace Victimization: The Effects Of Hierarchical Status And Conflict Management Style.” Journal Of Management, March, 2000

- Barling, J., Slatter F., \& Kelloway, E. K. (2000). "Transformational leadership and emotional intelligence: An exploratory study." Leadership and Organization Development Journal, 21(3), p.157-161.

- Çetinkaya, M. (2009). "Yöneticilerin Yönetsel Yetkinlik Algılamalarına İlişkin Bir Araştırma”. Afyon Kocatepe Üniversitesi, I.I.B.F. Dergisi,p.219-239.

- Çetinkaya, M. (2009). "Yönetsel Yetkinliklerin Analizi ve Yönetim Düzeyleri Açısından Yönetsel Yetkinliklere İlişkin Model Önerisi: Otomotiv Sektöründe Bir Uygulama.” Afyonkarahisar, Türkiye.

- Çetinkaya, M., \& Özutku, H. (2012). "Yönetsel performansa yetkinlik temelli yaklaşım: Türk otomotiv sektöründe bir araştırma.” İstanbul Üniversitesi İsletme Fakültesi Dergisi, p.142-161.

- Çiçek, A. (2006). “Sağlık Çalışanlarının Empatik Eğilim ve Becerilerinin Değerlendirilmesi.” Yüksek Lisans Tezi. Marmara Üniversitesi, Să̆lık Bilimleri Enstitüsü, İstanbul.

- Dökmen, Ü. (1988)," Empatinin yeni bir modele dayanılarak ölçülmesi ve psikodrama ile geliştirilmesi” A.Ü.Eğitim Bilimleri Fakültesi Dergisi, 2(1-2); p.155-190.

- Dökmen, Üstün,(2002) İletişim Çatışmaları ve Empati, Sistem Yayıncılık, İstanbul

- Empatik Yaklaşımlarının Kişilerarası İletişim Becerilerine Katkısının İncelenmesi”. Bursa Uludă Üniversitesi Eğitim Fakültesi Dergisi, p. 837-857.

- Erçoban, S. (2003). “İlköğretim II. kademesindeki branş öğretmenlerinin empatik eğilim düzeylerinin çeşitli değişkenler açısından incelenmesi.” Yayınlanmamış Yüksek Lisans Tezi, Uludă̆ Üniversitesi Sosyal Bilimler Enstitüsü

- $\quad$ Eren, S., \& Güleç, S. (2018, Kasım 1). “Okul Öncesi Eğitim Kurumlarındaki Yöneticilerin

- Eren,E. (2013).Yönetim Ve Organizasyon, Beta yayınevi, İstanbul

- Genç, S. Z ve Kalafat, T. (2008) “Öğretmen Adaylarının Demokratik Tutumları İle Empatik Becerilerinin Değerlendirilmesi Üzerine Bir Araştırma.” Manas Üniversitesi SBE Dergisi, 19, p.212-222.

- Katman, H. A. (2010). “Okul yöneticilerinin empatik eğilimlerinin incelenmesi : Isparta il merkezi örneği.” Isparta: Süleyman Demirel Üniversitesi SBE.

- Pehlivanoğlu, M. Ç. (2018). “Çok Uluslu Ve Ulusal İşletmelerde Örgütsel Yapıların Yöneticilerin Yönetsel Yetkinlik Kazanımı Üzerindeki Etkisi.” İstanbul, Türkiye.

- Yıldırım, H. A. (2002).” Eğitimde Toplam Kalite Yönetimi”. İstanbul: Nobel Akademik Yayıncılık. 


\title{
Gösterișçi Tüketim Üzerine Ampirik Bir Araştırma: Kırklareli Üniversitesi Örneği
}

\section{An Empirical Research on Empirical Consumption: Kırklareli University Case}

\author{
Asst. Prof. Dr. Aslı Okay Toprak (Kırklareli University, Turkey) \\ Prof. Dr. Zekai Özdemir (Istanbul University, Turkey)
}

\begin{abstract}
Consumption is defined as the use of goods and services produced in order to meet the needs and demands. However, the goods and services consumed are not only indicator of purchase power but also social status. At this point, the aim of conspicuous consumption comes to the fore. Conspicuous consumption for social status was first discussed by Thorstein Veblen in his book, The Theory of The Leisure Class, in 1899. According to Veblen, this kind of consumption is carried out in order to raise the social status by the upper social class and other classes trying to be similar to them rather than to the need. The views of Veblen are important when considered today's consumer society and constitute an important point of reference for gaining an insight into the world of overconsumption, especially for the younger generations. For this reason, in our study, we aim to conduct a questionnaire for Kurklareli University students in order to understand how the concept of conspicuous consumption has acquired dimension for university students. As a result of the study, it will be tried to determine whether the students have conspicuous consumption; which factors are affected if the students turn to conspicuous consumption and whether the students have loaded symbolic meanings to the commodities they purchased.
\end{abstract}

\section{Giriş}

Tüketim, bireyin ihtiyaçlarını karşılamak amacıyla yaptı̆̆ı tercihleri ile bireysel davranış ve sosyal etkileşim biçimlerini yansıtmaya katkı sağlayan bir olgudur. Günümüz tüketim toplumunda bireylerin sosyal statüleri ve ekonomik güçleri, tükettikleri metaların miktarı ve çeşidi ile ortaya konmaktadır. Bu noktada ürünün sadece tüketilmesi değil topluma sergilenmesi ihtiyacı da ortaya çıkmaktadır. Bu davranış biçimi tüketimin gösteriş amacını vurgulamaktadır. Bu davranış biçimini gösteriş̧̧i tüketim adıyla iktisat literatürüne kazandıran Thorstein Veblen, bu tür tüketimin esas itibariyle bireylerin maddi gücünü ve toplum içindeki statülerini göstermeye ve diğer kişilerde imrenme yaratmayı amaçladığını ifade etmektedir. Toplumun üst sınıfları, alt sınıflardan ayrışabilmek için bu tür tüketime yönelmektedir. Alt sınıflardaki bireyler ise kendi sınıfları içinde farklılaşabilmek için gösterişçi tüketim eğilimi içinde bulunup daha pahalı ürünlere yönelebilmektedirler. $\mathrm{Bu}$ şekilde üst kademelerdekiler kendilerini toplumun diğer kademelerinden soyutlarken, alt kademelerdekiler de sadece kendi sınıfları içinde farklılaşmak için değil aynı zamanda yüksek statülü sınıfların yaşama tarzına ulaşmak için de bu tarz tüketime yönelmektedirler (Koçak, 2017, s. 81). Diğer bir deyişle gösterişçi tüketim üst sınıfın saygınlık göstergesi olması ile birlikte toplumların geçişkenliği nedeniyle alt sınıflara da yansımaktadır (Özdemir, 2019).

Çalışmada Kırklareli Üniversitesi öğrencilerinin tüketim davranışlarında gösterişçi tüketimin etkisi ortaya koyulmaya çalışılmaktadır. Bu amaçla Kırklareli Üniversitesi öğrencilerinin gösteriş̧̧i tüketim eğilimine sahip olup olmadığını, lüks veya marka ürünlere sembolik anlam yükleyip yüklemedikleri ve gösteriş̧̧i tüketim ile toplumsal statüyü ilişkilendirip ilişkilendirmediğini anlamaya yönelik bir anket çalışması gerçekleştirilmiştir. Örneklem toplumun en dinamik kesimi olması ve geleceğin potansiyel karar vericileri olmaları nedeniyle üniversite öğrencileriyle sınırlandırılmıştır. Çalışmada tüketim tercihlerinin belirleyicileri; moda ve marka kavramlarının sembolik anlamları, internet, büyük alışveriş merkezlerinin, kent hayatının ve sosyal çevrenin etkileri üzerinde duran sorular yer almaktadır.

\section{Gösterişçi Tüketim Kavramı}

Gösterişçi tüketim kavramı iktisat literatürüne Veblen'in "Aylak Sınıfın Teorisi” adlı eseri ile dahil olmuştur. Gösterişçi tüketim kavramı, toplumun tüm kesimlerine ait tüketim davranışlarının ele alınmasında anahtar niteliği taşımaktadır. Gösterişçi tüketim, tüketicilerin olağan ihtiyaçlarını karşılamaktan ziyade kişilerin başkalarını etkileyerek toplumsal bir statü elde etmesini ve çevresine gösteriş yapmayı amaçlamasını ifade etmektedir. Veblen'e göre bu tür tüketim davranışı, aylak sınıfının ayırt edici özelliğidir. Gösterişli tüketim verimsiz bir tüketim davranışı olarak salt toplumdaki diğer bireyleri etkilemek için gerçekleştirilmektedir (Özdemir, 2019).Veblen'in aylak sınıfı tanımı soylular, rahipler ve onlara eşlik edenlerden oluşmaktadır. Söz konusu sınıfın uğraşları endüstriyel olmama niteliği taşımaktadır. Endüstriyel olmayan bu uğraşlar, yönetim, savaş, dinsel ve spor faaliyetlerini kapsamaktadır. Bununla birlikte endüstriyel faaliyetler, geçimlik her türlü iş alt sınıfların uğraşı olarak tanımlanmaktadır (Veblen, 2017, s. 9-10). Bununla birlikte Malların belirli bir amaç için tüketiminin maddi gücün bir göstergesi olarak değerlendirilmesi iktisadi evrimin en erken dönemlerine kadar dayanmaktadır. Veblen 
tüketimdeki bu farklılaşmada yaşam konforu sağlayan lüks malların aylak sınıfına ait olduğunu belirtmektedir. Bu tür lüks tüketim esas itibariyle erkek tüketicinin konforuna yönelik olup ve efendilik işareti olmaktadır. Toplumun diğer bireylerinin gerçekleştirdiği tüketim ise günlük yaşamın olağan tüketimlerini ifade etmektedir. Lüks malların tüketimi şüphesiz bir mal varlığı kanıtı olarak nitelendirilmektedir. Bu tür malların tüketilmemesi toplum içinde küçük düşmeye ve alt sınıfa tabi olmayı ifade etmektedir. Aylak sınıfta yer alan soylu erkek, doğru malları ve onları tüketim biçimini bilmek durumundadır. Asil yaşam biçimi, gösterişçi tüketim kuralına uyum göstermeyi gerekli kılmaktadır. Gösteriş̧̧i tüketim aylak soylu için saygınlık aracı sayılmaktadır. Bunun dışında festival ve davetler de gösteriş yapma amacına hizmet etmektedir. Ekonomik gelişmenin ilerleyen dönemlerinde malların özel mülkiyetin ve endüstriyel üretimin ücretli emeğe dayanması ile birlikte bu tür tüketim ayrımı ortadan kaybolmaya başlamıştır (Veblen, 2017, s. 67-74). Modern toplumlarda sınıflar kendilerinden sonraki daha yüksek tabakada moda olan yaşam tarzını kendilerine adapte ederek bu ideale uygun yaşamayı amaçlamaktadırlar. Maddi gücü sergilemenin ve nam kazanmanın yöntemi gösterişçi tüketimdir. Geleneksel anlamda zamanın ve çabanın boşa harcanması aylaklık durumunu ifade ederken, malların boşa harcanması gösterişçi tüketimi işaret etmektedir. Ancak modern zamanlarda gösterişçi tüketim aylaklıktan daha etkin bir role sahiptir. Modern çağda iletişimde gerçekleşen yenilikler ve popüler kültür bireylerin saygınlığının sınanmasında tüketilen malların teşhiri önemli bir araç haline gelmiştir. Bireylerin maddi imkânı çevresi tarafından izlenmekte ve bu söz konusu gözlemciler üzerinde olumlu bir intiba bırakabilmek için sosyal paylaşımların yoğun olduğu toplanmalara katılım önem kazanmaktadır. Bireyler topluluktaki diğer kişileri etkileyebilmek için maddi güçlerini en görünür halde sergilemek durumundadırlar. Dolayısıyla gösterişçi tüketimin gelişme trendi aylaklığa nazaran yükselmektedir. Bu noktada gösterişçi tüketimin en geniş popülasyona sirayet etmesi şüphesiz ki kentleşmenin yüksek olduğu bölgelerde olmaktadır. Şehir popülasyonu, tüketimi yaşam standardının önemli bir unsuru olarak değerlendirir ve gösterişçi tüketime daha heveslidir (Veblen, 2017, s. 79-82). Şehir hayatı, başkalarına kendini beğendirme, kanıtlama, maddi gücünü sergileme gibi psikolojik etkilerin daha görünür olduğu cezbedici bir atmosfere sahiptir. $\mathrm{Bu}$ doğrultuda günümüz popüler kültürü ve tüketim anlayışı kent hayatında uçsuz bucaksız bir alan yarattı̆̆ görünümünü sergilemektedir (Hız, 2011, s. 118). Bu alanda toplumdaki tüm aktörler meşgul oldukları mücadelenin doğasının bilincindedir. Gösterişçi tüketim, bireylerin bilinçli bir çaba ile belirli bir sonuç elde etmek için gösterdikleri faaliyettir. Bireylerin ortak teması maddi gücün tezahüründe üstünlük sağlamak, başkalarını etkilemek, başkalarının gözünde saygınlık kazanmak ve kıskanılmaktır. Gösterişçi tüketim başkalarının gözünde takdir kazanmaya dönük kasıtlı eylemlerin bir kategorisidir (Camphell, 1995, s. 39).

\section{Araştırmanın Yöntemi}

Bu çalışmada Kırklareli Üniversitesi öğrencilerinin tüketim davranışlarında gösterişçi tüketimin rolü ortaya konmaya çalışılmaktadır. Bu amaçla Kırklareli Üniversitesi bünyesinde yer alan Sosyal Bilimler Enstitüsü, Fen Edebiyat Fakültesi, İktisadi ve İdari Bilimler Fakültesi, Turizm Fakültesi, Mühendislik Fakültesi, Teknoloji Fakültesi, Hukuk Fakültesi, Mimarlık Fakültesi, Sağlık Yüksekokulu, Lüleburgaz Meslek Yüksekokulu ve Pınarhisar Meslek Yüksekokulu öğrencileri ile anket çalışması gerçekleştirilmiştir. Kırklareli Üniversitesi'nde toplam 26,643 öğrenci bulunduğundan, çalışmada 0,95 güvenilirlikle 384 örneğe ulaşılması yeterli görülmüşsür. Anketin örnek yeterliliğini ölçen KMO (Kaiser-Meyer-Olkin) örnekleme ölçüsüne bakıldığında bu oranın 0,786 olduğu tespit edilmiştir. Oran 0,50-0,90 aralığında yer aldığından örnekleme oranının yeterliliğe sahip olduğu görülmüştür. Bunun yanı sıra anketin güvenilirlik testi için bulunan Cronbach Alpha değerinin 0,730 olduğu bulunmuştur. Bu sonuca göre anketin güvenilir olduğu ileri sürülebilir.

\begin{tabular}{|c|c|}
\hline Cronbach's Alpa & $\begin{array}{c}\text { Kaiser-Meyer-Olkin Measure of } \\
\text { Sampling Adequacy }\end{array}$ \\
\hline 0,730 & 0,786 \\
\hline
\end{tabular}

Tablo 1. Güvenilirlik Testi ve Örnekleme Ölçüsü

Gösterişçi tüketimi gençler bağlamında ele alan çalışma sayısı oldukça azdır. Bu çalışmadaki anket soruları Pınar Güner Koçak tarafından Pamukkale Üniversitesi öğrencilerine uygulanan anket soruları ile Gülay Hız'ın Muğla'da hanehalkına uyguladığı anket sorularından derlenmiştir. Anket sorularının gruplandırılmasında 5'li likert ölçeğinden faydalanılmıştır. İlk 8 soru demografik özelliklere yönelik kapalı uçlu sorulardan, 9-17 arasındaki sorular satın alma alışkanlıkları, reklam, moda ve marka algılarına yönelik sorulardan, 18. Soruda yer alan 11 adet önerme likert ölçeğinde verilen değerlerden oluşmaktadır. Araştırmada anket yoluyla elde edilen veriler SPSS 21.0 sistem programında analiz edilmiştir. Ankette yer alan sorular için frekans dağılımı ve yüzde oranları incelenmiş ayrıca öğrencilerin gösterişçi tüketim ile ilgili ifadelere karşı tutumları chi square (ki-kare) yöntemiyle test edilmiştir. Araştırma kapsamında geliştirilen varsayımlar aşağıda yer almaktadır.

- “Gelir durumu bireylerin toplumsal statüsünü belirler” ifadesine katılma derecesi ile öğrencinin gelir durumu arasında ilişki vardır.

- Birçok ürün gösteriş amacıyla tüketilir" ifadesine katılma derecesi ile "ürünlerin faydasının yanında sembolik anlamı da önemlidir” ifadesine katılma derecesi arasında ilişki vardır. 
- “Sahip olduğum ürün ihtiyacımı karşılasa bile yeni modelini almayı tercih ederim” ifadesine katılma derecesi ile "kullandığım ürünlerin imajıma zarar vermemesini isterim" ifadesine katılma derecesi arasında ilişki vardir.

- "Sahip olmayı çok istediğim markalı/pahalı bir ürün için borçlanmaktan kaçınmam” ifadesine katılma derecesi ile "bir ürünü satın alırken çevremde örnek aldığım insanların tercihlerini de göz önünde bulundururum" ifadesine katılma derecesi arasında ilişki vardır.

\section{Araştırma Sonuçlarının Değerlendirilmesi}

Kırklareli Üniversitesi öğrencilerine yöneltilen anket soruları ile genel olarak tüketim davranışları ve gösterişçi tüketim eğilimleri değerlendirilmeye çalışılmıştır. Bu doğrultuda anket sorularının ilk kısmı demografik özelliklerin belirlenmesine yöneliktir.

Tablo 2'de araştırmaya katılan öğrencilerin demografik özellikleri yer almaktadır. Ankete yanıt verenlerin $\% 48,7$ 'si kadın, \%51,3'ü ise erkektir.

\begin{tabular}{|l|c|c|c|}
\hline & Frekans & Geçerli Yüzde & $\begin{array}{c}\text { Kümülatif } \\
\text { Yüzde }\end{array}$ \\
\hline Kadın & 187 & 48,7 & 48,7 \\
\hline Erkek & 197 & 51,3 & 100,0 \\
\hline Toplam & 384 & 100,0 & \\
\hline
\end{tabular}

Tablo 2. Araştırmaya Katılan Öğrencilerin Cinsiyet Bakımından Dă̆ılımı

Ankete katılan öğrenciler gelir durumlarına yönelik soruya \%39,1 oranında 0-500 TL aras1, \%30,7 oranında 5011000 TL arası, \%16,7 oranında 1001-1500 TL, \%6,8 oranında 1501-2000 TL yine \%6,8 oranında 2001-2500 TL olarak yanıt vermişlerdir.

\begin{tabular}{|l|c|c|c|}
\hline & Frekans & Geçerli Yüzde & $\begin{array}{c}\text { Kümülatif } \\
\text { Yüzde }\end{array}$ \\
\hline $0-500 \mathrm{TL}$ & 150 & 39,1 & 39,1 \\
\hline $501-1000 \mathrm{TL}$ & 118 & 30,7 & 69,8 \\
\hline $1001-1500 \mathrm{TL}$ & 64 & 16,7 & 86,5 \\
\hline $1501-2000 \mathrm{TL}$ & 26 & 6,8 & 93,2 \\
\hline 2001-2500 TL & 26 & 6,8 & 100 \\
\hline Toplam & 384 & 100 & \\
\hline
\end{tabular}

Tablo 3. Araştırmaya Katılan Öğrencilerin Gelir Bakımından Dă̆ılımı

Ankette tüketim tercihlerinde reklamların belirleyici etkisi olup olmadığına yönelik soruya öğrencilerin \%52,1’i evet etkili, \%47,9’u da hayır etkili değil şeklinde yanıtlamıştır.

\begin{tabular}{|l|c|c|c|}
\hline & Frekans & Geçerli Yüzde & $\begin{array}{c}\text { Kümülatif } \\
\text { Yüzde }\end{array}$ \\
\hline Evet & 200 & 52,1 & 52,1 \\
\hline Hayır & 184 & 47,9 & 100,0 \\
\hline Toplam & 384 & 100 & \\
\hline
\end{tabular}

Tablo 4. Araştırmaya Katılan Öğrencilerin Tüketim Tercihlerinde Reklamların Belirleyici Etkisinin Dă̆ılımı

Tablo 5'de çoklu yanıt verilen "tüketim tercihlerinizde reklamların belirleyici bir etkisi oluyor mu?" sorusuna verilen yanıtlar yer almaktadır. Ürüne ihtiyaç duymak seçeneği 267, ürünün kalitesi seçeneği 151, ürünün fiyatı seçeneği 122 ve ürünün markası seçeneği 36 yanıtlanma sayısına sahiptir. Yanıtlar arasında en yüksek yüzdeye sahip olan \%46,4 ile ürüne ihtiyaç duymak seçeneğidir. İkinci sırada ise \%26,2 ile ürünün kalitesi seçeneği gelmektedir.

\begin{tabular}{|l|c|c|}
\hline & Yanıt Sayıs & Yanıt Yüzdesi \\
\hline Ürüne ihtiyaç duymak & 267 & $\% 46,4$ \\
\hline Ürünün kalitesi & 151 & $\% 26,2$ \\
\hline Ürünün fiyatı & 122 & $\% 21,2$ \\
\hline Ürünün markası & 36 & $\% 6,3$ \\
\hline Toplam & 576 & $\% 100$ \\
\hline
\end{tabular}

Tablo 5. Araştırmaya Katılan Öğrencilerin Ürün Satın Alışındaki Belirleyicilerin Dă̆ılımı

Tablo 6'da çoklu yanıt verilen “Gösterişli/lüks ürün satın alma nedeniniz?” sorusuna verilen yanıtlar yer almaktadır. "Tarzımı yansıttığı için satın alıyorum” seçeneği 70, "Hususi pahalı ürün satın alma eğilimim yok" 
seçeneği 181, “Gösterişli/lüks ürün satın alabilecek gelire sahip değilim” seçeneği 58, "Gösterişli/lüks ürün satın almayı israf olarak görüyorum" seçeneği 92 ve "Gösterişli/lüks ürünlerin daha kaliteli olduğunu düşünüyorum" seçeneği 59 yanıtlanma sayısına sahiptir. Yanıtlar arasında en yüksek yüzdeye sahip olan \%39,3 ile "Hususi pahalı ürün satın alma eğilimim yok" seçeneğidir. İkinci sırada ise \%20 ile "Gösterişli/lüks ürün satın almayı israf olarak görüyorum" seçeneği gelmektedir.

\begin{tabular}{|c|c|c|}
\hline & Yanit Say1s1 & Yanıt Yüzdesi \\
\hline Tarzımı yansıttığı için satın alıyorum. & 70 & $\% 15,2$ \\
\hline Hususi pahalı ürün satın alma eğilimim yok. & 181 & $\% 39,3$ \\
\hline Gösterişli/lüks ürün satın alabilecek gelire sahip değilim. & 58 & $\% 12,6$ \\
\hline Gösterişli/lüks ürün satın almayı israf olarak görüyorum. & 92 & $\% 20$ \\
\hline Gösterişli/lüks ürünlerin daha kaliteli olduğunu düşünüyorum. & 59 & $\% 12,8$ \\
\hline Toplam & 460 & $\% 100$ \\
\hline
\end{tabular}

Tablo 6. Araştırmaya Katılan Öğrencilerin Gösterişli/Lüks Ürün Alma Nedeni Dă̆ılımı

Tablo 7'de “Gösterişli/lüks ürün satın alma nedeniniz?” sorusuna verilen çoklu yanıtların farklı gelir gruplarındaki dağılımı yer almaktadır. 1501-2000 TL gelir grubu dışındaki öğrenciler en yüksek düzeyde hususi pahalı ürün satın alma eğilimlerinin olmadığını belirtmişlerdir. 1501-2000 TL gelire sahip öğrenciler ise tarzımı yansıttığı için satın alıyorum ifadesine \%38,5 oranında katılmışlardır.

\begin{tabular}{|l|l|l|l|c|c|c|}
\hline & $\begin{array}{l}\text { Tarzımı } \\
\text { yansıttı̆̆1 } \\
\text { için satın } \\
\text { alıorum. }\end{array}$ & $\begin{array}{l}\text { Hususi pahalı } \\
\text { ürün satın } \\
\text { alma eğilimim } \\
\text { yok. }\end{array}$ & $\begin{array}{l}\text { Gösterişli/lüks } \\
\text { ürün satın } \\
\text { alabilecek } \\
\text { gelire sahip } \\
\text { değilim. }\end{array}$ & $\begin{array}{l}\text { Gösterişli/lüks } \\
\text { ürün satın } \\
\text { almayı israf } \\
\text { olarak } \\
\text { görüyorum. }\end{array}$ & $\begin{array}{l}\text { Gösterişli/lüks } \\
\text { ürünlerin daha } \\
\text { kaliteli } \\
\text { olduğunu } \\
\text { düşünüyorum. }\end{array}$ & Toplam \\
\hline $0-500 \mathrm{TL}$ & $\% 14,7$ & $\% 31,6$ & $\% 18,4$ & $\% 22,6$ & $\% 12,6$ & 190 \\
\hline $501-1000 \mathrm{TL}$ & $\% 9,9$ & $\% 41,8$ & $\% 12,1$ & $\% 22$ & $\% 14,2$ & 141 \\
\hline $1001-1500 \mathrm{TL}$ & $\% 13,3$ & $\% 58,7$ & $\% 4$ & $\% 14,7$ & $\% 9,3$ & 75 \\
\hline $1501-2000 \mathrm{TL}$ & $\% 38,5$ & $\% 26,9$ & $\% 7,7$ & $\% 15,4$ & $\% 11,5$ & 26 \\
\hline $2001-2500 \mathrm{TL}$ & $\% 28,6$ & $\% 39,3$ & $\% 3,6$ & $\% 10,7$ & $\% 17,9$ & 28 \\
\hline Toplam & 70 & 181 & 58 & 92 & 59 & 460 \\
\hline
\end{tabular}

Tablo 7. “Gösterişli/Lüks Ürün Satın Alma Nedeniniz?” Sorusuna Verilen Yanıtların Farklı Gelir Gruplarındaki Dağılımı

Tablo 8'da çoklu yanıt verilen "Moda sizin için ne ifade ediyor?" sorusuna verilen yanıtlar yer almaktadır. "Moda bana uyan ve yakışandır" seçeneği 258, "Toplumun geleneklerine ve sosyal yapısına uygun giyinmek modadan daha önemlidir" seçeneği 41, "Modayı takip edecek ekonomik güce sahip değilim” seçeneği 42, "Moda özgürce her istediğini giyinebilmektedir" seçeneği 85 ve "Modayı takip ederim ve yeni trendlere uyarım" seçeneği 25 yanıtlanma sayısına sahiptir. Yanıtlar arasında en yüksek yüzdeye sahip olan \%57,2 ile "Moda bana uyan ve yakışandır" seçeneğidir. İkinci sırada ise \%18,8 ile "Moda özgürce her istediğini giyinebilmektedir" seçeneği gelmektedir.

\begin{tabular}{|c|c|c|}
\hline & $\begin{array}{c}\text { Yanit } \\
\text { Sayis1 }\end{array}$ & $\begin{array}{c}\text { Yanıt } \\
\text { Yüzdesi }\end{array}$ \\
\hline Moda bana uyan ve yakışandır. & 258 & $\% 57,2$ \\
\hline $\begin{array}{l}\text { Toplumun geleneklerine ve sosyal yapısına uygun giyinmek modadan } \\
\text { daha önemlidir. }\end{array}$ & 41 & $\% 9,1$ \\
\hline Modayı takip edecek ekonomik güce sahip değilim. & 42 & $\% 9,3$ \\
\hline Moda özgürce her istediğini giyinebilmektedir. & 85 & $\% 18,8$ \\
\hline \multirow[t]{2}{*}{ Modayı takip ederim ve yeni trendlere uyarım. } & 25 & $\% 5,5$ \\
\hline & 451 & $\% 100$ \\
\hline
\end{tabular}

Tablo 8. Araştırmaya Katılan Öğrencilerin Moda İle İlgili Görüşlerinin Dă̆ılımı

Tablo 9'da çoklu yanıt verilen "Marka sizin için ne ifade ediyor?" sorusuna verilen yanıtlar yer almaktadır. “Kaliteli ürün demektir” seçeneği 193, "Hiçbir şey ifade etmez” seçeneği 86, "Pahalılığı ifade eder” seçeneği 106, “Tarzımı yansıtır" seçeneği 20, "Gösterişli olmamı sağlar" seçeneği 40, "Fark edilmemi sağlar" seçeneği 11, "Çevrem tarafından onaylanmamı sağlar" seçeneği 9 ve "Yaşam tarzımı yansıtır" seçeneği 26 yanıtlanma sayısına sahiptir. Yanıtlar arasında en yüksek yüzdeye sahip olan \%39,3 ile "Kaliteli ürün demektir" seçeneğidir. İkinci sırada ise \%21,6 ile "Pahalılığı ifade eder" seçeneği gelmektedir. "Gösterişli olmamı sağlar" seçeneğinin yüzdesi $\% 8,1$, "çevrem tarafından onaylanmamı sağlar” seçeneğinin yüzdesi \%1,8 ve "Fark edilmemi sağlar” seçeneği ise $\% 2,2$ düzeyindedir. 


\begin{tabular}{|l|c|c|}
\hline & $\begin{array}{c}\text { Yanıt } \\
\text { Sayıs1 }\end{array}$ & $\begin{array}{c}\text { Yanıt } \\
\text { Yüzdesi }\end{array}$ \\
\hline Kaliteli ürün demektir. & 193 & $\% 339,3$ \\
\hline Hiçbir şey ifade etmez. & 86 & $\% 17,5$ \\
\hline Pahalılığı ifade eder. & 106 & $\% 21,6$ \\
\hline Tarzımı yansıtır. & 20 & $\% 4,1$ \\
\hline Gösterişli olmamı sağlar. & 40 & $\% 8,1$ \\
\hline Fark edilmemi sağlar. & 11 & $\% 2,2$ \\
\hline Çevrem tarafından onaylanmamı sağlar. & 9 & $\% 1,8$ \\
\hline Yaşam tarzımı yansıtır. & 26 & $\% 5,3$ \\
\hline Toplam & 502 & $\% 100$ \\
\hline
\end{tabular}

Tablo 9. Araştırmaya Katılan Öğrencilerin Marka İle İlgili Görüşlerinin Dağıllımı

Öğrencilerin gösteriş̧̧i tüketimle ilgili ifadelere yönelik verdikleri yanıtlar gösteriş̧̧i tüketim anlayışları ile ilgili ipuçları vermektedir. "Markasız ürünleri kullanmamaya çalışıım" ifadesine verilen yanıtlar değerlendirildiğinde \%38 oranında kararsız kaldıkları görülmektedir. İkinci yüksek yüzdeye sahip olan ise \%21,6 ile katılıyorum yanitidir.

\begin{tabular}{|l|c|c|c|}
\hline & Frekans & Geçerli Yüzde & $\begin{array}{c}\text { Kümülatif } \\
\text { Yüzde }\end{array}$ \\
\hline Hiç Katılmyorum & 46 & 12,0 & 12,0 \\
\hline Katılmıorum & 75 & 19,5 & 31,5 \\
\hline Ne Kat1lıyorum Ne Katılmıorum & 146 & 38,0 & 69,5 \\
\hline Kat1l1yorum & 83 & 21,6 & 91,1 \\
\hline Tamamen katılyyorum & 34 & 8,9 & 100,0 \\
\hline Toplam & 384 & 100 & \\
\hline
\end{tabular}

Tablo 10. "Markasız Ürünleri Kullanmamaya Çalışırım” Iffadesiyle İlgili Soruya Verdikleri Cevapların Dağılımı

"Bir ürünün faydasının yanında sembolik anlamı da önemlidir" ifadesine verilen yanıtlar değerlendirildiğinde \%32,6 oranında kararsız kaldıkları görülmektedir. İkinci yüksek yüzdeye sahip olan ise \%26,8 ile katılıyorum yanitidir.

\begin{tabular}{|l|c|c|c|}
\hline & Frekans & Geçerli Yüzde & $\begin{array}{c}\text { Kümülatif } \\
\text { Yüzde }\end{array}$ \\
\hline Hiç Katılmıorum & 30 & 7,8 & 7,8 \\
\hline Katılmıorum & 85 & 22,1 & 29,9 \\
\hline Ne Kat1lıorum Ne Katılmıorum & 125 & 32,6 & 62,5 \\
\hline Kat1lıorum & 103 & 26,8 & 89,3 \\
\hline Tamamen kat1lyyorum & 41 & 10,7 & 100 \\
\hline Toplam & 384 & 100 & \\
\hline
\end{tabular}

Tablo 11. "Bir Ürünün Faydasının Yanında Sembolik Anlamı da Önemlidir” Ifadesiyle Illgili Soruya Verdikleri Cevapların Dağılımı

"Bir ürünü satın alırken çevremde örnek aldığım insanların tercihlerini de göz önünde bulundururum" ifadesine verilen yanitlar değerlendirildiğinde en yüksek orana sahip ifade \%37 ile katıllyorum ifadesidir.

\begin{tabular}{|l|c|c|c|}
\hline & Frekans & Geçerli Yüzde & $\begin{array}{l}\text { Kümülatif } \\
\text { Yüzde }\end{array}$ \\
\hline Hiç Katılmyorum & 56 & 14,6 & 14,6 \\
\hline Katılmıorum & 56 & 14,6 & 29,2 \\
\hline Ne Kat1lyorum Ne Katılmıyorum & 86 & 22,4 & 51,6 \\
\hline Katıllyorum & 142 & 37,0 & 88,5 \\
\hline Tamamen katıllyorum & 44 & 11,5 & 100 \\
\hline Toplam & 384 & 100 & \\
\hline
\end{tabular}

Tablo 12. "Bir Ürünü Satın Alırken Çevremde Örnek Aldı̆̆ım İnsanların Tercihlerini de Göz Önünde Bulundururum "Ifadesiyle Ilgili Soruya Verdikleri Cevapların Dağıllımı

"Beğenerek aldığım bir ürünün başkalarınca da satın alınmasından hoşlanmam” ifadesine verilen yanıtlar değerlendirildiğinde en yüksek orana sahip ifade \%26,6 ile hiç katılmıyorum ifadesidir. 


\begin{tabular}{|l|c|c|c|}
\hline & Frekans & Geçerli Yüzde & $\begin{array}{c}\text { Kümülatif } \\
\text { Yüzde }\end{array}$ \\
\hline Hiç Katılmıyorum & 102 & 26,6 & 26,6 \\
\hline Katılmıyorum & 67 & 17,4 & 44 \\
\hline Ne Kat1liyorum Ne Katılmıyorum & 75 & 19,5 & 63,5 \\
\hline Kat1liyorum & 57 & 14,8 & 78,4 \\
\hline Tamamen katıliyorum & 83 & 21,6 & 100 \\
\hline Toplam & 384 & 100 & \\
\hline
\end{tabular}

Tablo 13. “Bĕgenerek Aldı̆̆ım Bir Ürünün Başkalarınca da Satın Alınmasından Hoşlanmam” Iffadesiyle Ilgili Soruya Verdikleri Cevapların Dağılımı

“Gelir durumu kişilerin toplumsal statüsünü belirler” ifadesine verilen yanıtlar değerlendirildiğinde \%24,2 oranında katılıyorum; \%21,1 oranında tamamen katılıyorum şeklinde cevaplandığ 1 görülmektedir.

\begin{tabular}{|l|c|c|c|}
\hline & Frekans & Geçerli Yüzde & $\begin{array}{c}\text { Kümülatif } \\
\text { Yüzde }\end{array}$ \\
\hline Hiç Katılmıorum & 75 & 19,5 & 19,5 \\
\hline Katılmıyorum & 65 & 16,9 & 36,5 \\
\hline Ne Katıliyorum Ne Katılmıorum & 70 & 18,2 & 54,7 \\
\hline Katıllyorum & 93 & 24,2 & 78,9 \\
\hline Tamamen katıliyorum & 81 & 21,1 & 100 \\
\hline Toplam & 384 & 100 & \\
\hline
\end{tabular}

Tablo 14. “Gelir Durumu Kişilerin Toplumsal Statüsünü Belirler” İfadesiyle İlgili Soruya Verdikleri Cevapların Dağılımı

"Birçok ürün gösteriş amaçlı tüketilir" ifadesine verilen yanıtlar değerlendirildiğinde en yüksek orana sahip ifade $\% 31,8$ oranıla tamamen katılıorum ifadesidir.

\begin{tabular}{|l|c|c|c|}
\hline & Frekans & Geçerli Yüzde & $\begin{array}{c}\text { Kümülatif } \\
\text { Yüzde }\end{array}$ \\
\hline Hiç Katılmıyorum & 41 & 10,7 & 10,7 \\
\hline Katılmıyorum & 36 & 9,4 & 20,1 \\
\hline Ne Katıllyorum Ne Katılmıorum & 86 & 22,4 & 42,4 \\
\hline Katıliyorum & 99 & 25,8 & 68,2 \\
\hline Tamamen kat1lyyorum & 122 & 31,8 & 100 \\
\hline Toplam & 384 & 100 & \\
\hline
\end{tabular}

Tablo 15. “Birçok Ürün Gösteriş Amaçlı Tüketilir” İfadesiyle İlgili Soruya Verdikleri Cevapların Dă̆ılımı

"Kullandığım ürünlerin imajıma zarar vermemesini isterim" ifadesine verilen yanıtlar değerlendirildiğinde \%28,6 ile tamamen katılıyorum ifadesinin en yüksek orana sahip olduğu görülmektedir.

\begin{tabular}{|l|c|c|c|}
\hline & Frekans & Geçerli Yüzde & $\begin{array}{c}\text { Kümülatif } \\
\text { Yüzde }\end{array}$ \\
\hline Hiç Katılmıyorum & 61 & 15,9 & 15,9 \\
\hline Katılmıyorum & 51 & 13,3 & 29,2 \\
\hline Ne Katılıyorum Ne Katılmıyorum & 60 & 15,6 & 44,8 \\
\hline Katıliyorum & 102 & 26,6 & 71,4 \\
\hline Tamamen katıliyorum & 110 & 28,6 & 100 \\
\hline Toplam & 384 & 100 & \\
\hline
\end{tabular}

Tablo 16. “Kullandığım Ürünlerin İmajıma Zarar Vermemesini İsterim” İfadesiyle İlgili Soruya Verdikleri Cevapların Dă̆ılımı

“Sahip olmayı çok istediğim markalı/pahalı bir ürün için borçlanmaktan kaçınmam” ifadesine verilen yanıtlar değerlendirildiğinde \%38,8 ile hiç katılmıyorum ifadesinin en yüksek orana sahip olduğu görülmektedir. 


\begin{tabular}{|l|c|c|c|}
\hline & Frekans & Geçerli Yüzde & $\begin{array}{c}\text { Kümülatif } \\
\text { Yüzde }\end{array}$ \\
\hline Hiç Katılmıyorum & 149 & 38,8 & 38,8 \\
\hline Katılmıyorum & 111 & 28,9 & 67,7 \\
\hline Ne Katılıorum Ne Katılmıorum & 48 & 12,5 & 80,2 \\
\hline Katıliyorum & 34 & 8,9 & 89,1 \\
\hline Tamamen katıliyorum & 42 & 10,9 & 100 \\
\hline Toplam & 384 & 100 & \\
\hline
\end{tabular}

Tablo 17. “Sahip Olmayı Çok İstediğim Markalı/Pahalı Bir Ürün İçin Borçlanmaktan Kaçınmam” Ifadesiyle İlgili Soruya Verdikleri Cevapların Dă̆ılımı

"Sahip olduğum ürün ihtiyacımı karşılasa bile yeni modelini almayı tercih ederim" ifadesine verilen yanıtlar değerlendirildiğinde \%40,4 ile hiç katılmıyorum ifadesinin en yüksek orana sahip olduğu görülmektedir.

\begin{tabular}{|l|c|c|c|}
\hline & Frekans & Geçerli Yüzde & $\begin{array}{l}\text { Kümülatif } \\
\text { Yüzde }\end{array}$ \\
\hline Hiç Katılmıorum & 155 & 40,4 & 40,4 \\
\hline Katılmıyorum & 95 & 24,7 & 65,1 \\
\hline Ne Katıliyorum Ne Katılmıorum & 71 & 18,5 & 83,6 \\
\hline Katıllyorum & 41 & 10,7 & 94,3 \\
\hline Tamamen katıliyorum & 22 & 5,7 & 100 \\
\hline Toplam & 384 & 100 & \\
\hline
\end{tabular}

Tablo 18. “Sahip Olduğum Ürün İhtiyacımı Karşılasa Bile Yeni Modelini Almayı Tercih Ederim” İfadesiyle İlgili Soruya Verdikleri Cevapların Dă̆llımı

Araştırmanın varsayımları için yapılan chi-kare testi sonucunda,

1. “Gelir durumu bireylerin toplumsal statüsünü belirler” ifadesine katılma derecesi ile öğrencinin gelir durumu arasında bir ilişkinin olduğu p $>0,05$ düzeyinde olduğundan, varsayım reddedilmiştir.

\begin{tabular}{|l|c|c|c|}
\hline & $N$ & Değer & $P$ \\
\hline Pearson Chi-Kare & 384 & $25,974(\mathrm{a})$ & 0,054 \\
\hline
\end{tabular}

Tablo 19. “Gelir Durumu Bireylerin Toplumsal Statüsünü Belirler” Iffadesine Katılma Derecesi ile Öğrencinin Gelir Durumu Arasında Bir İlişkinin Dă̆llımı

2. “Birçok ürün gösteriş amacıyla tüketilir” ifadesine katılma derecesi ile "ürünlerin faydasının yanında sembolik anlamı da önemlidir” ifadesine katılma derecesi arasında bir ilişkinin olduğu $p<0,05$ düzeyinde olduğundan, varsayım kabul edilmiştir.

\begin{tabular}{|l|c|c|c|}
\hline & $N$ & Değer & $P$ \\
\hline Pearson Chi-Kare & 384 & $31,143(\mathrm{a})$ & 0,013 \\
\hline
\end{tabular}

Tablo 20. “Birçok Ürün Gösteriş Amacıyla Tüketilir” Iffadesine Katılma Derecesi ile “Ürünlerin Faydasının Yanında Sembolik Anlamı Da Önemlidir” Ifadesine Katılma Derecesi Arasında Bir İlişkinin Dă̆̆lımı

3. "Sahip olduğum ürün ihtiyacımı karşılasa bile yeni modelini almayı tercih ederim" ifadesine katılma derecesi ile "kullandığım ürünlerin imajıma zarar vermemesini isterim" ifadesine katılma derecesi arasında ilişki $\mathrm{p}<0,05$ düzeyinde olduğundan, varsayım kabul edilmiştir.

\begin{tabular}{|l|c|c|c|}
\hline & $N$ & Değer & $P$ \\
\hline Pearson Chi-Kare & 384 & $44,078(\mathrm{a})$ & 0,000 \\
\hline
\end{tabular}

Tablo 21. "Sahip Olduğum Ürün İhtiyacımı Karşılasa Bile Yeni Modelini Almayı Tercih Ederim” Ifadesine Katılma Derecesi ile "Kullandığım Ürünlerin Imajıma Zarar Vermemesini Isterim” Ifadesine Katılma Derecesi Arasında Bir İlişkinin Dă̆ılımı

4. "Sahip olmayı çok istediğim markalı/pahalı bir ürün için borçlanmaktan kaçınmam” ifadesine katılma derecesi ile "bir ürünü satın alırken çevremde örnek aldığım insanların tercihlerini de göz önünde bulundururum" ifadesine katılma derecesi arasında ilişki $\mathrm{p}<0,05$ düzeyinde olduğundan, varsayım kabul edilmiştir. 


\begin{tabular}{|l|c|c|c|}
\hline & $N$ & Değer & $P$ \\
\hline Pearson Chi-Kare & 384 & $55,391(\mathrm{a})$ & 0,000 \\
\hline
\end{tabular}

Tablo 22. "Sahip Olmayı Çok İstediğim Markalı/Pahalı Bir Ürün İçin Borçlanmaktan Kaçınmam” Ifadesine Katılma Derecesi ile "Bir Ürünü Satın Alırken Çevremde Örnek Aldı̆̆ım İnsanların Tercihlerini de Göz Önünde Bulundururum” Ifadesine Katılma Derecesi Arasında Bir İlişkinin Dağıllmı

\section{Sonuç}

Kırklareli Üniversitesi öğrencilerinin tüketim davranışlarında gösterişçi tüketim eğiliminin etkisinin araştırıldığı çalı̧̧mamızda gençler üzerinde yapılan az sayıda çalışmada bulunan gelir durumu bireylerin toplumsal statüsünü belirlediği görüşü ile öğrencilerin gelir durumu arasında ilişki bulunurken, bizim çalışmamızda aradaki ilişkinin varlığına dair varsayım reddedilmiştir. Diğer bir deyişle öğrencilerin gelir durumları ile gelirin toplumsal statüyü belirlediği görüşü arasında bir ilişki tespit edilememiştir. Bununla birlikte öğrencilerin gösteriş amaçlı tüketimin ürünlerin sembolik anlamlarıyla ilişkilendirdiği görülmüştür. Ayrıca bir ürünün satın alınması sürecinde öğrencilerin tarz, imaj, stil ve çevrede uyandırılan etkiyi göz önünde bulundurduğu da görülmektedir. Veblen'in gösteriş̧̧i tüketim kavramında ifade ettiği bireylerin çevrelerinde olumlu intiba bırakmak amacıyla gerçekleştirdiği kasttlı faaliyetlerin çalışmaya katılan öğrencilerin görüşlerinde karşılık bulduğu söylenebilir. Özellikle sosyal medyanın yaygınlaşması ve en çok genç kitleler tarafından kullanılması bu tür davranışların görünürlülüğünü de arttırmış durumdadır. Kırklareli Üniversitesi öğrencileri de tüketim davranışındaki çevre etkisinin olduğunu yanıtlarında belirtmişlerdir.

Kırklareli Üniversitesi öğrencilerinin moda ve marka anlayışları incelendiğinde markalı ürünlerin daha çok kalite ile ilişkilendirildiği görülmektedir. Marka gösteriş̧̧i tüketim aracı olmaktan ziyade daha kaliteli ürün tüketimi ile ilişkilendirilmektedir. Öğrenciler her ne kadar markasız ürün de kullandıklarını belirtseler de imaj konusunda duyarlı olduklarını da belirtmişlerdir. Ürün satın alma faaliyetinin temelinde ise isteklerden ziyade ihtiyaçlar ön plana çıkmaktadır. Sonuç olarak öğrenciler çevreden beğeni kazanma isteği içinde olmakla birlikte yoğun bir gösterişçi tüketim eğilimi içinde bulunmamaktadırlar. Bununla birlikte öğrenciler toplumda gösterişçi tüketim eğiliminin varlı̆̆ını kabul etmektedirler. Ayrıca gelir durumu ile toplumsal statü arasında ilişki olduğuna dair kanı gelir durumu ne olursa olsun öğrencilerin ortak kanısı durumundadır.

\section{Kaynakça}

- Camphell, 1995." Conspicuous Confusion? A Critique of Veblen's Theory of Conspicuous Consumption", Sociological Theory,13, p. 39.

- Hız, 2011."Gösterişçi tüketim eğilimi üzerine bir alan araştırması", organizasyon ve yönetim bilimleri dergisi,3, s. 118.

- Koçak, 2017." Gösterişçi Tüketim Üzerine Teorik ve Uygulamalı Bir Çalışma: Pamukkale Üniversitesi Örneği ", Erciyes Üniversitesi Sosyal Bilimler Enstitüsü Dergisi,43, s. 80-81.

- Özdemir, 2019. Veblen, Weber ve Cengiz Aytmatov'un Kahramanları, http://zekaiozdemir.com/2010/10/31/veblen-weber-ve-cengiz-aytmatovun-kahramanari/

- Veblen, 2077. Aylak Sınıfın Teorisi: Kurumların İktisadi İncelemesi. Heretik Yayınları, Ankara. 


\title{
The Effect of Technology Spillovers on Income Distribution: An Application on OECD countries
}

\author{
Teknolojik Yayılımının Gelir Dağılımı Üzerine Etkisi: OECD \\ Ülkeleri Üzerine Bir Uygulama
}

\begin{abstract}
Ensuring a fair income distribution to increase social welfare is one of the main objectives of economic policies. With the acceleration of innovations in information and communication technology in the 20th century, the developments in technology have been characterized as the main reason for growth, welfare and productivity growth. However, rapid technological developments have revealed that significant changes in the dynamics of income inequalities occur at the same time. The growth in income inequality has increased significantly in many countries recently. Accordingly, the notion that the spread of technology has led to growth in income inequality has attracted attention in recent years. In the light of this information, the aim of the study is to reveal the impact of the spread of new technologies on income inequality and the factors underlying the income inequality dynamics. Therefore, the purpose of this study is to examine the impact of technology spillovers on income inequality of selected OECD countries including Turkey using panel data analysis. The data for all countries obtained from the World Bank's Development Indicators and OECD. Stat. The empirical conclusion indicated the effect of the technology spillovers on income inequality. This empirical finding contributed to promote the existing literature, and also draws main attention of policymakers. Because, knowing the factors underlying income inequality, which is seen as an important economic and social problem, is important in determining effective policies to ensure a more equitable income distribution.
\end{abstract}

\section{Giriş}

Günümüzde iktisat politikalarının en temel hedeflerinden biri gelir dağılımının adil hale getirilmesidir. Ancak şunu belirtmek gerekir ki, gelir dağılımı iktisat literatüründe en tartışmalı alanlarından birini oluşturmaktadır. Bu durumun başlıca nedeni gelir dağılımı olgusunun normatif bir özellik taşımasıdır. Şöyle ki, piyasa işleyişi içerisinde gelir dağılımı eşitsiz olarak görülmektedir. $\mathrm{Bu}$ nedenle, gelir farklılıklarının yeniden dağılım kapsamında azaltılması veya gelir yönünden zayıf kesimlerin göreli olarak iyileştirilmesi gerekmektedir. Ancak iktisat politikasının gelir farklılıklarının düzeltilmesinde nasıl bir yön izlemesi gerektiği konusunda mevcut bir görüş birliği sağlanmamaktadır. Bunun nedeni gelir dağılımı eşitsizliğini belirleyen bir çok faktörün söz konusu olmasıdır.

Yakın zamana kadar, teknoloji ve eşitsizlik, birbiriyle bağlantısız iki kavram olarak düşünülmekteydi. Bunun nedeni teknolojinin, büyümenin ana motoru olarak kabul edildiği gelişmiş ülkelerin dünyasına ait olan; eşitsizliğin ise, temelde gelişmekte olan ülkelerin sorunu olduğu için gelişmekte olan ülkelere ait kavramlar olarak nitelendirilmesidir. Ancak bu durum son yıllarda önemli ölçüde değişmektedir. Bu gelişmenin arkasındaki motivasyon, ABD'de 1970'lerin başlarında ve İngiltere'de 1970'lerin sonlarında görülen gelir dağılımındaki eşitsizlik artışından kaynaklanmaktadır (Jenkins, 1995). Diğer taraftan, OECD tarafından yayınlanan raporların (2008, 2011, 2015) çoğu OECD ülkelerinde artan gelir eşitsizliği konusuna dikkat çekmektedir. Burada ilginç olan, büyümeyi ve refahı artırmak için önem kazanmış olan teknolojinin, aynı zamanda gelişmiş ülkelerde görülen eşitsizlikteki artışın temel nedeni olarak gösterilmesidir. Teknolojinin eşitsizliği arttırdığı konusunda önemli ölçüde bir görüş birliği söz konusudur (Berman vd, 1997). Bunun nedeni, bilgi ekonomisinin ortaya çıktığından beri gelir eşitsizliğinin de hızlı bir artış eğilimde olduğu gerçeğidir. Eşitsizlikteki bu artış hem gelişmekte olan hem de gelişmiş ülkelerde dikkat çekmektedir. OECD ülkelerinde en yüksek gelirli grubun \%10'un ortalama geliri 25 yıl öncesine kıyasla 9.5 kat artmıştır. Diğer taraftan en düşük gelirli grubun \%10'un ortalama gelirinde ise yalnızca 7 kat artış görülmüştür. 2008 yılında yaşanan küresel finans krizinden sonra gelir dağılımı eşitsizlikleri arasında bu fark son 25-30 yıl öncesine kıyasla hızla büyümüştür (OECD,2014).

Literatürde teknolojik yayılımının gelir eşitsizliğini arttırdığı ve dolayısıyla gelir eşitsizliği ve teknoloji arasındaki bağlantıyı dikkate almanın önemli olduğu tartışılmaktadır. Ayrıca, çok az çalışma OECD ülkeleri için gelir eşitsizliği-teknoloji arasındaki ilişkiyi araştırmıştır. $\mathrm{Bu}$ boşlukları doldurmak için, mevcut çalışma Türkiye'nin de içinde bulunduğu seçilmiş OECD ülkeleri için teknolojik yayılımın gelir dağılımı üzerine etkisini inceleyerek literatüre katkı sağlamaktadır. Çalışmanın geri kalan kısmı şu şekilde yapılandırılmıştır. İkinci bölümde gelir eşitsizliği ve teknoloji arasındaki ilişkinin teorik çerçevesi incelenmiştir. . Üçüncü bölümde ilgili literatür özeti yer almaktadır. Sonraki bölümde, Arellano ve Bover (1995) ve Blundell ve Bond (1998) tarafindan geliştirilen GMM-Sistem yöntemi ile teknolojik yayılım ve gelir eşitsizliği arasındaki ilişki ampirik olarak analiz edilmiştir. Son bölümde analiz bulgularına yer verilmiştir. 


\section{Teorik Çerçeve}

1990'lı yıllar itibariyle teknolojik gelişmeler büyüme ve verimliliğin başlıca nedeni olarak ifade edilmektedir. Ancak, yaşanan teknolojik gelişmeler ile ülkelerin gelir dağılımı dinamiklerinde görülen değişimlerin eş zamanlı olarak ortaya çıktığı dikkat çekmektedir. Gelir dağılımı eşitsizliğinin artması, ülkelerin çoğunda hızla büyüme göstermektedir. Bu kapsamda son yıllarda, teknolojik yayılımın gelir eşitsizliği artışına neden olduğunu ifade eden iki temel yaklaşım söz konusudur. Bunlar beceri yanlı teknolojik değişim ile görev yanlı teknolojik değişimdir.

Beceri yanlı teknolojik değişimde (skill-biased technological change), temel varsayım, teknolojik değişimin, yüksek vasıflara sahip bireyleri talep eden işler yaratması anlamında beceriye dayalı olduğu yönündedir. Teknolojinin eşitsizliğe yol açtığı mekanizma, teknolojik açıdan yüksek vasıflı işgücü talebindeki artışın, vasıfsız işgücüyle karşılaştırıldığında, yüksek vasıflı işçiler için daha yüksek bir ücrete yol açtığı varsayımına dayanmaktadır. Beceri yanlı teknolojik değişim, teknolojik yeniliklerin yükssek becerili işgücünü tamamlamasıdır. $\mathrm{Bu}$ yaklaşımda teknoloji ve emek arasında ikame yerine tamamlayıcılık ilişsisi vardır. Şöyle ki, yeni teknolojiler daha becerili işgücü sayesinde tamamlanmaktadır. Bu kapsamda, daha az becerili işgücüne olan talep azalmakta ve daha becerili işgücüne olan talep artmaktadır. $\mathrm{Bu}$ süreçte ücret farklılıkları da beceri seviyesine göre değişmektedir. Daha becerili işgücü verimlilik artışına katkı sağladığından dolayı daha yüksek ücret almakta ve bu grup lehine ücret primi yaratmaktadır (Weiss ve Garloff, 2005). Aksine düşük becerili işgücü daha az ücret aldığından dolayı iki kesim arasında ücret kutuplaşmasına neden olmaktadır. Literatürde becerili işgücü; yetenekli, eğitimli ve tecrübeli kesimi kapsamaktadır. Beceri yanlı teknolojik değişim hipotezi, yüksek teknoloji kapsamındaki endüstrilerin yeniliklere uyum sağlayacak daha becerili işgücüne ihtiyaç duymasını ifade etmektedir (Bartel ve Sicherman, 1998). Teknolojik gelişmeler yaşandıkça eski meslekler yerine daha yaratıcı ve daha yüksek beceri gerektiren istihdam alanları ortaya çıkmaktadır. Bu durumda, yeni buluşlar ve ürünler daha az becerili çalışanlar aleyhine mevcut işlerini yok ederken, çeşitli sektörlerde farklı becerilere ihtiyaç duyan istihdam alanları oluşturmaktadır (OECD,1998). Bu nedenle 20. yüzyıl beceri yanlı teknolojik değişim olarak nitelendirilmektedir. Çünkü nitelikli işçilerin arzındaki hızlı artış, beceri tamamlayıcı teknolojilerin gelişmesine neden olmaktadır. Beceri yanlı teknolojik değişim, son yıllarda gelir ve ücret eşitsizlikleri artışının temel belirleyicisi olduğu vurgulanmaktadır (Aghion, 2002; Acemoğlu, 2002).

Son yıllarda teknolojik yayılımın gelir eşitsizliğine neden olduğunu ifade eden diğer hipotez görev yanlı teknolojik değişim (Task-Biased Technology Change) yaklaşımıdır. Bu hipoteze göre, üretim süreci görevler açısından tanımlanmaktadır. İş görevleri şunlara bağlı olarak işçilere veya sermayeye (makineler) tahsis edilmektedir: 1) otomatikleştirilebilme derecesi açısından (kod ve makineler tarafından tekrarlanabilir ve değiştirilebilir olması); 2) diğer görevlerden ayrılabilir olması açısından; ve 3) insanlara karşı makineleri kullanmanın nispi maliyetleri açısından. Bu bağlamda, 'makineler' donanım, yazılım ve bu ikisinin kombinasyonu olan robotları içermektedir. Bu hipotezin temel özelliği, becerilerden daha çok rutine odaklanması ve bu iki kavramın zarif bir şekilde farklılaşmasıdır. Acemoğlu ve Autor'a göre (2011); görev, çıktı üreten (mal ve hizmetler) ekonomik etkinlik olarak tanımlanırken; beceri, işçinin çeşitli görevleri yerine getirme yeteneklerine sahip olması olarak ifade edilmektedir. Görevler, işçilerin işlerinde yaptıkları eylemlerdir ve teknik değişiklikler ile sermayeye karşı emeğin göreceli fiyatı nedeniyle değişebilmektedir. Şöyle ki, teknolojik değişimler insan işgücünü rutin olan bir çok görevde ikame edebilirler. Fakat teknolojilerin nitelikli olan rutin olmayan görevleri yerine getirmeleri oldukça güçtür. Teknolojik gelişmeler ücret eşitliğini etkileyen rutin olmayan işgücüne talebi arttırırken, rutin orta gelirli işgücüne talebi azaltmaktadır. Bunun nedeni, rutin olarak yapılan görevler gelişen teknolojiler ile yapılmasına olanak sağlarken, rutin olmayan görevlerin daha çok kişisel ve bilişsel beceri gerektirmesidir. Rutin olmayan görevler, bilginin üretimi, işlenmesi ile ilgili olarak tekrarlanmayan görevlerdir. Esas olarak yönetsel, profesyonel ve yaratıcı meslekler içinde gerçekleştirilen bu görevler genellikle yüksek becerili işgücü tarafından yerine getirilir. Bu gruba örnek olarak hakimler, psikologlar, avukatlar veya tıp doktorları verilebilir. Bu kapsamda orta seviyede beceri isteyen daha rutin istihdam alanları kaybolmakta veya azalmakta, diğer taraftan daha yukarda yer alan rutin olmayan görevler gelişmektedir. Bu durum emek piyasasının kutuplaşmasına neden olmaktadır (Autor, 2003).

Gelir dağılımı eşitsizliği çalışmalarında en çok kullanılan ölçüm yöntemlerinden biri İtalyan istatistikçi Corrada Gini tarafından geliştirilen gini katsayısıdır. Gini katsayısı eşitsizlik düzeyini bir sayı ile ifade etmesinden dolayı farklı gelir eşitsizlikleri karşılaştırmasının yapılmasını sağlamaktadır. Gini katsayısı "0" ve "1" arasında değişmektedir. Gelir dağılımı eşitsizliği azalma eğilimi gösterdikçe katsayı sıfıra, aksi halde bire yaklaşmaktadır. Gini katsayısının artması eşitsizliğin artışını ifade ederken, azalması gelir eşitsizliğinin azalışını ifade etmektedir. Gini katsayısı, sıfır ise gelir adil olarak dağılmaktadır. Eğer katsayı bir ise, gelir dağılımında tam eşitsizlik söz konusudur (Haughton ve Khandker, 2009). Şekil 1'de OECD ülkelerine ait gini katsayıları yer almaktadır. Geçtiğimiz on yılda, gelir eşitsizliği düzeyleri yüksek seviyelerde olduğu görülmektedir. OECD ülkeleri ortalaması 2016 yılında 0.318'e olarak gerçekleşmektedir. Bu katsayı 1980'lerin ortalarından bu yana kaydedilen en yüksek değerdir. Genel olarak OECD ülkeleri incelendiğinde, gelir eşitsizliğinin 2007'den itibaren arttığı görülmektedir. Slovakya, İspanya ve İsveç'te yaklaşık iki puandan fazla artış görülürken, İzlanda ve Litvanya'da azalma eğilimi görülmektedir. 


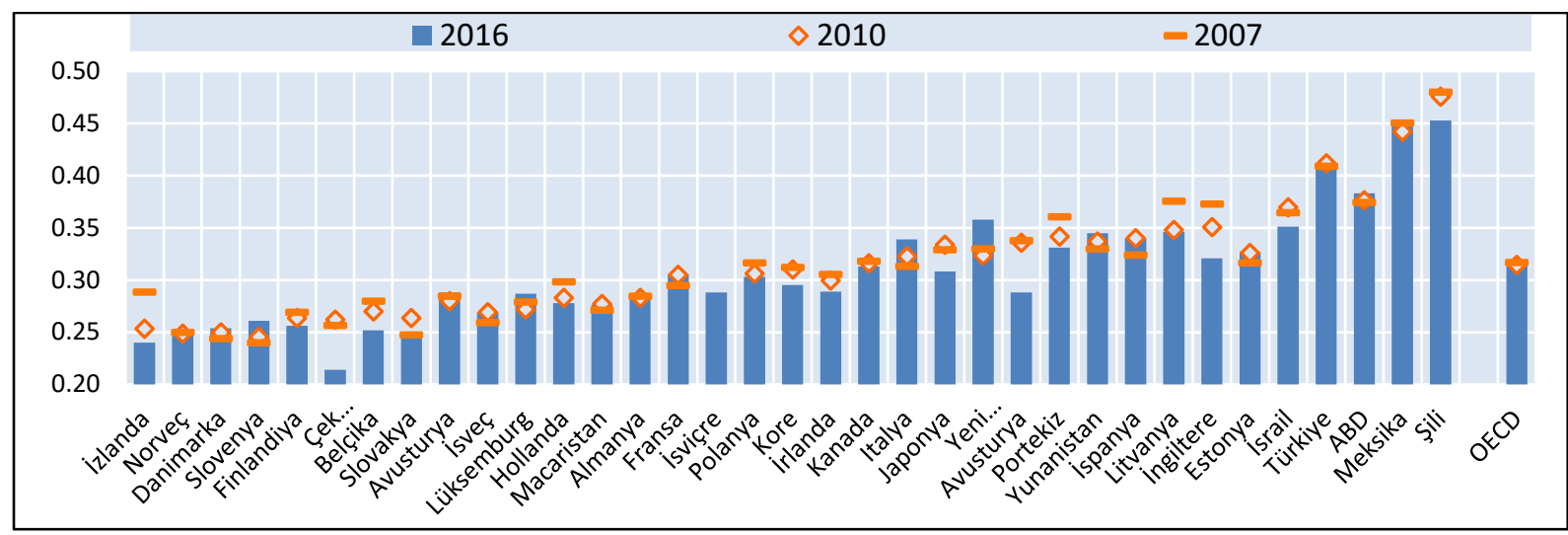

Şekil 1: Gini Katsayılart-OECD (2007-2016)

\section{Literatür}

Gelir dağılımı dinamiklerini araştıran literatür incelendiğinde geniş bir araştırma grubunun eşitsizliği araştırmış olmasına rağmen, az sayıda çalışma teknolojik yayılımı ve gelir eşitsizliği arasındaki bağlantılara odaklanmaktadır. Birçok araştırmacı, teknolojik gelişmelerin yaygın olarak benimsenmesinin, gelir eşitsizliğinde son yıllarda değişimlere neden olduğunu kabul etmektedir. Bu duruma paralel olarak son yirmi yılda ulusal düzeydeki eşitsizlik, birçok yüksek gelirli ülkede ve gelişmekte olan ekonomilerde artmaya başlamıştır (Atkinson, 2008; Bourguignon, 2015). Bu değişimlerin, gelir eşitsizliğinin temelini oluşturan dijital inovasyonu sağlayan, gelişmiş teknolojilerin benimsenmesiyle yakından ilişkili olduğu düşünülmektedir. Yeni teknolojilerin benimsenmesinin eşitsizlik üzerindeki rolüne ilişkin çalışmalarda farklı bulguların yer aldığı görülmektedir. Teknoloji iyimserleri gelir eşitsizliğini gelecekteki ileri teknoloji ekonomisine geçişte geçici bir olgu olarak görmektedir. Diğer taraftan kapitalizmin eleştirmenleri ise, bunu teknolojik işsizliğin ve dijital proletaryanın kademeli olarak ortaya çıkmasının sonucu olarak görmektedir (Bauer, 2018).

Literatür incelendiğinde, birçok çalışmada artan gelir ve ücret eşitsizliğini açıklamak için beceri yanlı teknolojik değişim kullanılmaktadır (Berman, 1998). Beceri yanlı teknolojik gelişme hipotezi hem gelişmiş hem de gelişmekte olan ülkelerde önemli bir olgudur. Yeni teknolojilerin (örneğin, mikrobilgisayarların) geliştirilmesinin, daha nitelikli işgücüne olan talebin artmasına neden olduğu ve böylece bu kesim lehine ücretlerin arttırdı̆̆ görülmektedir. Dolayısıyla nitelikli işgücü ile daha az nitelikli işgücü arasındaki ücret eşitsizliğine neden olmaktadır (Acemoglu, 2002; Chusseau vd, 2008). Literatürde gelişmiş ülkelerde beceri yanlı teknolojik değişimin nedenlerini ve ücret eşitsizliği etkilerini araştıran birçok teorik çalışma vardır. Örneğin, Acemoğlu (1998) bu konuyu incelemek için içsel teknik değişim ve büyüme modeli geliştirerek, nitelikli işgücü arzındaki artışın kısa vadede ücret eşitsizliğini azaltmasına rağmen, uzun vadede beceri yanlı teknolojik değişim yaşanmasına ve ücret eşitsizliğinin derinleşmesine neden olduğunu ifade etmektedir.

Haskel ve Slaughter (2002), beceri yanlı teknolojik değişimin ücret eşitsizliğini değiştirmede önemli bir rol oynadığını göstermek için bir model oluşturmaktadır. Weiss ve Garloff (2011) beceri yanlı teknolojik değişimin, sosyal faydalar endojen olarak belirlendiğinde niteliksiz işgücünün göreceli olarak işsizliğe ve artan ücret eşitsizliğine yol açtığını tespit etmektedir. Ancak, mevcut teorik çalışmalar gelişmiş ülkelerin yanı sıra, gelişmekte olan ülkelere de odaklanmaktadır. Şöyle ki, beceri yanlı teknolojik değişme, gelişmiş ülkelerde, gelişmekte olan ülkelere göre daha yaygın olarak ortaya çıksa da, gelişmekte olan ülkelerde de beceri yanlı teknolojik değişim bulunduğunu destekleyen birçok kanıt söz konusudur. Gelişmekte olan ülkeler ithal edilen teknolojiler ve diğer kanallar aracılığıyla bu tür bir değişim yaşayabilmektedir. Bekman, Bound ve Machin (1998), gelişmekte olan pek çok ülkede beceriye dayalı teknolojik değişime uygun bir ücret eşitsizliği olgusunun olduğunu göstermek için uluslararası kanıtlar sunmaktadır. Berman ve Machin (2000) beceri yanlı teknoloji transferinin orta gelirli ülkeler için önemli olduğunu, ancak düşük gelirli ülkeler için önemli olmadığını ortaya koymaktadır. Kijama (2006), Hindistan'da artan gelir eşitsizliğine endüstrilerdeki beceri yanlı teknolojik değişimlerin neden olduğunu göstermektedir. Li (2010), Çin'de beceri yanlı teknolojik değişimin var olduğunu tespit etmiştir. Rattsø ve Stokke (2013) Güney Afrika için beceri yanlı teknolojik değişim yoluyla gerçekleşen ticari etkilerin ücret eşitsizliğini artırmada önemli rol oynadığını ortaya koymaktadır. Schulte (2015), beceri yanlı teknolojik değişimin hem gelişmiş ülkelerde hem de gelişmekte olan ülkelerde var olan uluslararası bir olgu olduğunu tespit etmiştir.

\begin{tabular}{|l|l|l|}
\hline Yazar(lar) & Model - Yöntem & Bulgular \\
\hline
\end{tabular}




\begin{tabular}{|c|c|c|}
\hline Conceiçâo ve Galbraith (2000) & $\begin{array}{l}\text { 1970-1990 dönemi için OECD } \\
\text { ülkelerinde teknolojinin gelir } \\
\text { eşitsizliği üzerine etkisini panel } \\
\text { veri yöntemi ile analiz etmiştir. }\end{array}$ & $\begin{array}{l}\text { Çalışmada teknolojik yeniliklerin } \\
\text { yeni istihdam alanları yaratacağı, } \\
\text { becerili işgücü talebinin artacağı } \\
\text { ve ücretlerin daha az becerili } \\
\text { işgücünün aleyhine olacağını } \\
\text { tespit etmektedir. }\end{array}$ \\
\hline Lansing ve Markiewiez (2011) & $\begin{array}{l}\text { 1980-2007 yılları için ABD'nin } \\
\text { teknolojik yayılımının gelir } \\
\text { dağılımı eşitsizliği üzerine etkisini } \\
\text { iş çevrimleri kapsamında } \\
\text { incelemiştir. }\end{array}$ & $\begin{array}{l}\text { Analizde son } 30 \text { yılda ABD'de } \\
\text { becerili işgücü ile daha az becerili } \\
\text { olan işgücü arasındaki ücret } \\
\text { farklılığının gelir eşitsizliğinin } \\
\text { temel nedeni olduğu sonucuna } \\
\text { ulaşılmıştır. }\end{array}$ \\
\hline Jaumotte vd. (2008) & $\begin{array}{l}\text { Çalışmasında 1981-2003 yılları } \\
\text { için } 31 \text { gelişmekte olan ve } 20 \\
\text { gelişmiş ülkeyi incelemiştir. } \\
\text { Küreselleşme ve teknolojinin gelir } \\
\text { eşitsizliği üzerine etkisini analiz } \\
\text { etmiştir. }\end{array}$ & $\begin{array}{l}\text { İlgili ülke grubunda teknolojik } \\
\text { yeniliklerin, gelir eşitsizliği } \\
\text { üzerinde küreselleşmeden daha } \\
\text { çok etkili olduğu sonucuna } \\
\text { ulaşılmıştır. Teknoloji yoğun } \\
\text { sektörlerde becerili işgücüne olan } \\
\text { talebin arttığı ve ücretlerin } \\
\text { artacağı olgusuna dikkat } \\
\text { çekilmiştir. }\end{array}$ \\
\hline Hall (2009) & $\begin{array}{l}\text { 1980-1995 yılları kapsamında } \\
\text { gelişmekte olan ülkeler için } \\
\text { teknolojik yayılımın gelir dağılımı } \\
\text { eşitsizliği üzerine etkisi test } \\
\text { edilmiştir. Çalışmada gravity } \\
\text { modeli kullanılmştır. }\end{array}$ & $\begin{array}{l}\text { Çalışmada sonuçlar beceri yanlı } \\
\text { teknolojik değişimi destekler } \\
\text { niteliktedir. Eğitimin gelir } \\
\text { eşitsizliğini azaltan ve yeni } \\
\text { teknolojilere kolaylıkla uyum } \\
\text { sağlanmasını kolaylaştıran bir } \\
\text { faktör olduğu sonucuna } \\
\text { ulaşılmıştır. Buna bağlı olarak, } \\
\text { eğitim kalitesinin düşük olması ve } \\
\text { teknolojik yayılımının hızlı olması } \\
\text { durumunda gelir eşitsizliğinin } \\
\text { artacağı tespit edilmiştir. }\end{array}$ \\
\hline Perugini ve Pompei (2009) & $\begin{array}{l}\text { 1995-2001 dönemi için } 14 \text { Avrupa } \\
\text { ülkesinde teknolojik yayılım ve } \\
\text { gelir eşitsizliği arasındaki ilişkiyi } \\
\text { incelenmiştir. Analizde En Uygun } \\
\text { Genelleştirilmiş En Küçük Kareler } \\
\text { Yöntemi (FGLS) kullanılmıştır. }\end{array}$ & $\begin{array}{l}\text { Çalışmada incelenen } 8 \text { farklı } \\
\text { teknoloji yoğun sektörün beşinde } \\
\text { beceri yanlı teknolojik değişme ile } \\
\text { gelir dağılımı eşitsizliği arasında } \\
\text { simetrik olmayan bir ilişki olduğu } \\
\text { sonucuna ulaşılmıştır. }\end{array}$ \\
\hline Katz ve Murphy (1992) & $\begin{array}{l}\text { 1987-1993 yılları kapsamında } \\
\text { ABD'de beceri yanlı teknolojik } \\
\text { değişim ile gelir eşitsizliği } \\
\text { arasındaki ilişkiyi araştırmıştır. }\end{array}$ & $\begin{array}{l}\text { Çalışmada eğitimli ve yetenekli } \\
\text { işgücüne olan talebin ücret } \\
\text { yapısında değişime neden } \\
\text { olduğunu ve bu durumun gelir } \\
\text { eşitsizliklerinin temel nedeni } \\
\text { olduğunu tespit etmiştir. }\end{array}$ \\
\hline Goldin ve Katz (2008) & $\begin{array}{l}\text { 1890-2005 y1lları için ABD'de } \\
\text { eğitim ve teknolojinin gelir } \\
\text { eşitsizliği üzerine etkisini analiz } \\
\text { etmiştir. }\end{array}$ & $\begin{array}{l}\text { Analiz sonucunda teknolojik } \\
\text { değişimin daha becerili işgücüne } \\
\text { olan talebi arttırdığı, buna bağlı } \\
\text { olarak eğitimde arzın talebin } \\
\text { gerisinde kalmasından kaynaklı } \\
\text { olarak gelir eşitsizliğine neden } \\
\text { olduğuna ulaşılmıştır. }\end{array}$ \\
\hline
\end{tabular}

Tablo 1: Teknolojik Yayılımının Gelir Dağılımı Eşitsizliği Üzerine Literatür Özeti 


\section{Model ve Veri Seti}

Çalışmada teknolojik yayılımının gelir dağılımı üzerine etkisi dinamik panel veri analizi tekniği olan Sistem Genelleştirilmiş Momentler Metodu kullanılarak analiz edilmiştir. 2000-2016 dönemini kapsayan yıllık veriler kullanılmıştır. Çalışma, Türkiye'nin de içinde bulunduğu seçilmiş 28 OECD ülkelerini içermektedir. Bunun nedeni incelenen dönem için, değişkenlere ait verilerin her ülke ve yıl için düzenli olmamasıdır. Modele dahil edilen söz konusu ülkeler şu şekildedir: Avustralya, Avusturya, Belçika, Çek Cumhuriyeti, Kanada, Danimarka, Estonya, Finlandiya, Fransa, İzlanda, İrlanda, İsrail, Japonya, Slovakya, Güney Kore, Lüksemburg, Macaristan, Meksika, Yeni Zelanda, Norveç, Polonya, Portekiz, İspanya, İsveç, İsviçre, Türkiye, İngiltere ve Amerika Birleşik Devletleri'nden oluşmaktadır. Değişkenler ve açıklamaları Tablo 2'de verilmiştir. Analizde yer alan değişkenler logaritmik formda modele dahil edilmiştir. Teknolojik yayılımının ve gelir eşitsizliği arasındaki ilişkinin açıklanması için oluşturulan model aşağıdaki gibidir:

$$
\operatorname{GINI}_{\mathrm{i}, \mathrm{t}}=\alpha_{0}+\beta_{1} \mathrm{GINI}_{\mathrm{i}, \mathrm{t}-1}+\beta_{2} \operatorname{IND}_{\mathrm{i}, \mathrm{t}}+\beta_{2} \mathrm{AGR}_{\mathrm{i}, \mathrm{t}}+\beta_{3} \text { TECH }_{\mathrm{i}, \mathrm{t}}+\boldsymbol{\varepsilon}_{\mathrm{i}, \mathrm{t}}
$$

\begin{tabular}{lll}
\hline Değişken & Açıklama & Kaynak \\
\hline GINI & Gini katsayısı & SWIID 7.0 (Solt, 2017) \\
IND & Sanayide çalışan işgücü (toplam & WB Databank \\
& iş̧ücü içerisindeki payı) & \\
AGR & Tarım sektöründe çalışan işgücü & WB Databank \\
& (toplam işgücü içerisindeki payı) & \\
TECH & Yüksek teknoloji içeren ürün & OECD.Stat \\
& ithalatı & \\
\hline
\end{tabular}

Tablo 2: Analizde kullanılan değişkenler ve açıklamaları

Modelde, i ve t sirasıyla ülke ve zaman periyodunu, $\boldsymbol{\alpha}_{\mathbf{0}}$ sabit terimi ve $\varepsilon_{\mathbf{i}, \mathbf{t}}$ hata terimini ifade etmektedir. Analizde dinamik panel veri analizlerinde en etkili tahmin sonucunu veren GMM-Sistem metodu tercih edilmiştir. Dinamik modeller uygulama kolaylığı ve modellerin tahmin edilmesi için gereken araç değişkenlere kıyasla basit varsayımlara dayandığından literatürde çok sık karşılaşılmaktadır. Analizde dinamik modeller arasında yaygın olarak kullanılan Arellono ve Bover (1995) ve Blundell ve Bond (1998) tarafindan geliştirilen iki aşamalı GMM yöntemi kullanılmıştır. GMM yöntemleri bir aşamalı ve iki aşamalı olmak üzere ikiye ayrılmaktadır. Bir aşamalı tahminde hata terimlerinin zaman içinde ve gruplar arasında sabit varyanslı olduğu varsayılmaktadır. İki aşamalı tahmincide ise, hata terimlerinin sabit varyanslı olmadığı kabul edilmektedir. İkinci aşamada birinci aşamadan elde edilen hata artıkları da kullanılmakta bu nedenle iki aşamalı tahmin asimtotik olarak daha güçlü sonuçlar vermektedir (Khadraoui, 2012). Bu yüzden çalışmada diğer GMM yöntemleri ile kıyaslandığında daha iyi bir tahmin edici olan iki aşamalı GMM-Sistem yöntemi kullanılmıştır.

\section{Analiz Sonuçları}

Çalışmada seçilmiş OECD ülkeleri kapsamında teknolojik yayılımın gelir dağılımı üzerindeki etkilerinin araştırılması amacıyla incelenen modelin bulguları bu bölümde verilmiştir. Modele ilişkin iki aşamalı GMMSistem yöntemi analiz sonuçları Tablo 3'de yer almaktadır.

\begin{tabular}{|l|l|}
\hline Değiskenler & Katsaylar \\
\hline GINI $_{\mathrm{i}, \mathrm{t}-1}$ & .549772 \\
& $(0.142)^{*}$ \\
\hline $\mathrm{IND}_{\mathrm{i}, \mathrm{t}}$ & -.02999 \\
& $(0.012)^{*}$ \\
\hline $\mathrm{AGR}_{\mathrm{i}, \mathrm{t}}$ & .022225 \\
& $(0.005)^{*}$ \\
\hline TECH $_{\mathrm{i}, \mathrm{t}}$ & .00615 \\
& $(0.001)^{*}$ \\
\hline Wald Testi & $\chi^{2}(4)=151.70$ \\
& {$[0.0000]^{*}$} \\
\hline Sargan Testi & $\chi^{2}(151)=9.5555$ \\
& {$[1.0000]$} \\
\hline Spesifikasyon Testleri & \\
\hline AR(1) & -2.8276 \\
& {$[0.0047]^{*}$} \\
\hline AR(2) & .73047 \\
& {$[0.4651]$} \\
\hline
\end{tabular}


Not: * \%1 düzeyindeki anlamlılıkları ifade etmektedir. Parantez içindeki değerler standart sapmaları, köşeli parantezler ise testlerin olasılık değerlerini göstermektedir.

Teknolojik yayılımın gelir dağılımı üzerine etkisinin incelendiği analiz sonuçlarına göre, bağımlı değişken olan gini katsayısının gecikmesinin pozitif ve istatistiksel açıdan anlamlı olduğu tespit edilmiştir. Modelde teknolojik yayılımının gelir dağılımı eşitsizliği arttıracağı yaklaşımının temelinde beceri yanlı teknolojik değişim hipotezi yer almaktadır. Bu hipotez kapsamında, yüksek nitelikli işgücünün verimliliği artırmasından dolayı ücret artışına neden olarak, beceri primini bu grup lehine oluşturmasıdır. Yeni teknolojilere uyum açısından nitelikli işgücü daha değerli hale gelmektedir. Buna karşılık, nitelikli olmayan işgücü ise, daha değersiz olmaktadır. Dolayısıyla, nitelikli işgücünü temsil etmesi açısından toplam işgücü içinde sanayi sektöründe çalışan işgücü payı kullanılırken; daha düşük nitelikli işgücünü temsil etmesi açısından tarım sektöründe çalışan işgücü payı modele dahil edilmiştir.

Toplam işgücü içinde sanayi sektöründe çalışan işgücünün ücretleri göreceli olarak daha yüksek olmasından dolayı, sanayi sektöründe çalışan kesimin payı arttıkça gelir dağılımı eşitsizliğinin azalma göstermesi beklenmektedir. Bu duruma paralel olarak sanayi sektöründe çalışan işgücünü temsil eden katsayının beklentilere uygun olarak negatif ve istatistiksel açıdan anlamlı olduğu görülmektedir. Toplam işgücü içinde tarım sektöründe çalışanların payı arttıkça gelir dağılımı eşitsizliğinin artacağı beklenmektedir. Bunun nedeni nitelikli işgücü ile nitelikli olmayan işgücü ücretleri arasındaki farkın yüksek olmasında dolayı, gelir eşitsizliğini derinleştirmesidir. Tarım sektöründe çalışanların payını temsil eden katsayının pozitif ve istatistiksel açıdan anlamlı olduğu sonucuna ulaşılmıştır. Teknolojik yayılımı temsil etmesi amacıyla yüksek teknoloji içeren ürün ithalatı modelde yer almaktadır. Gelir eşitsizliğini temsil eden gini katsayısı ile teknolojik yayılım göstergesi olan yüksek teknoloji ürünlerin toplam ithalatı arasında ilişkinin pozitif ve istatistiki açıdan anlamlı olduğu görülmektedir. Buna bağlı olarak, teknolojik yayılımın artması gelir eşitsizliğini arttırmaktadır.

Wald testi, modelde yer alan değişkenlerin bir bütün olarak anlamlı olup olmadığını analiz etmektedir. Modelde hesaplanan Wald testi olasılık değeri incelendiğinde modelin bir bütün olarak anlamlı olduğu tespit edilmiştir. Analizde kullanılan araç değişkenlerin uygun olup olmadığının analizi için Sargan testinin yapılması gerekmektedir. Sargan test sonuçlarına göre, olasılık değeri beklenen şekilde araç değişkenlerin içsellik sorunu taşımadığını ve araç değişkenlerin tam ve doğru olduğunu göstermektedir. Dinamik panel veri analiz tekniği olan GMM-Sistem yönteminde birinci dereceden otokorelasyon olması modelin kendi yapısı gereği çoğunlukla karşılaşılan bir durum olduğundan önem arz etmemektedir. Fakat tahmin bulgularının tutarlı ve etkin olabilmesi için modelin ikinci dereceden otokorelasyon sorununun olmaması gerekmektedir. Tablo incelendiğinde, analizde beklenildiği gibi birinci dereceden otokorelasyonun var olduğu ancak ikinci dereceden otokorelasyon sorunun olmadığı görülmektedir. Bu nedenle GMM-Sistem tahmin sonuçları etkin ve tutarlıdır.

\section{Sonuç}

Günümüzde gelir dağılımı eşitsizlikleri hem gelişmekte olan hem de gelişmiş ülkelerde yaşanan temel sorunlardan biridir. Gelir dağılımında eşitliğin sağlanması demokratikleşmenin sürekliliği için önemli bir rol oynamaktadır. Sosyal devlet anlayışının sonucu olarak, gelir dağılımında eşitliğin sağlanmasını amaçlayan politikalar gelir dağılımının nispi olarak düzeltilmesinde etkili olabilmektedir. Sosyal huzurun sağlanması ve korunmasında, ekonomik büyümenin gerçekleştirilmesinde, üretkenliğin arttırılmasında, ekonomik ve siyasal istikrarın sağlanması için gelir dağılımında eşitliğin sağlanması önem arz etmektedir. Son yıllarda teknolojik yayılımların, gelir dağılımını etkileyen önemli bir faktör olması dikkat çekmektedir. Teknolojik gelişmeler verimlilik artışı yaratarak, yeni endüstrilerin, istihdam firsatlarının ve yüksek gelir potansiyeli olan mesleklerin oluşturulmasına neden olmaktadır. Teknolojinin olumlu etkilerinin yanı sıra, teknoloji yayılımı arttıkça beceri yanlı teknolojik gelişme hipotezinde ifade edilen daha becerili işgücünün beceri primi artarken, daha az becerili işgücünün ücreti göreceli olarak azalmakta ve mevcut yerini daha nitelikli işgücüne bırakmaktadır. Bu durum gelir dağılımı eşitsizliğini arttırarak, var olan eşitsizliğin daha da derinleşmesine neden olmaktadır. Teknolojik yayılımının gelir dağılımı eşitsizliğinde artışa yol açtığına dair bu görüşler, literatürde teknoloji ve gelir dağılımı arasındaki ilişkiye yönelik çalışmaların yapılmasına neden olmuştur.

Genel olarak, bu olumlu ve olumsuz etkiler göz önüne alındığında, teknolojik yayılımın gelir dağılımı üzerindeki net etkisinin dikkatlice değerlendirilmesi gerekmektedir. Dolayısıyla bu çalışmada teknolojik yayılımının gelir dağılımı üzerine etkisini ve gelir eşitsizliği dinamiklerinin incelenmesi amaçlanmaktadır. Çalışmada 28 OECD ülkesinin 2000-2016 dönemini kapsayan yıllık verileri analiz edilerek, teknoloji yayılımı ve gelir dağılımı arasındaki ilişki ampirik olarak incelenmiştir. Bu kapsamda gini katsayısı, toplam işgücü içerisinde sanayi ve tarım sektöründe çalışan işgücü payı ile teknolojik yayılım göstergesi olarak yüksek teknoloji içeren ürün ithalatı verileri kullanılmıştır. Analiz dinamik panel veri analiz yöntemlerinden biri olan GMM-Sistem yöntemi ile tahmin edilmiştir. Analiz sonuçlarına göre, beklentilere paralel olarak teknolojik yayılımın gelir dağılımı üzerinde etkili olduğu tespit edilmiştir. Şöyle ki, sonuçlar teknoloji yayılımının artması, gelir dağılımı eşitsizliğinde artışa neden olduğu hipotezini doğrulamaktadır. Teknoloji yayılımı arttıkça, beceri yanlı teknolojik değişme yaklaşımında sözü edilen daha yüksek nitelikli işgücüne yönelik beceri primini arttırmaktadır. Düşük nitelikli işgücünün ücretleri 
azalmakta veya mevcut yerini daha nitelikli işgücüne bırakmaktadır. Bu nedenle nitelikli ve düşük nitelikli işgücü arasında gelir eşitsizliği farkı zaman içerisinde artma eğilimi göstermektedir.

Teknolojik yayılımının önemli bir göstergesi olan yüksek teknoloji içeren ürün ithalatı da gelir dağılımı eşitsizliğini etkilemektedir. Bunun nedeni, teknoloji ürün ithalatı yapan ülkeler, teknolojik ürün bilgisine de sahip olmaktadır. Buna bağlı olarak, yüksek teknoloji ürün ithalatı teknolojik yayılımın artmasına ve dolayısıyla gelir dağılımı eşitsizliğinin artmasına neden olmaktadır.

Çalışmanın genel olarak sonuçları değerlendirildiğinde, teknolojik yayılımın gelir dağılımı eşitsizliğini arttırdığı gerçeği söz konusu olmasına rağmen, gelişen teknolojik yeniliklerden geri kalmak mümkün değildir. Çünkü teknoloji verimlilik ve büyümenin temel faktörü olarak nitelendirilmektedir. Bu nedenle gelişmiş ve gelişmekte olan ülkelerdeki hükümetlerin gelir dağılımı adaletsizliklerini azaltmak için etkili önlemler almaları gerekmektedir. Beceriye dayalı teknolojik değişimin arka planında, hükümetler ücret eşitsizliğini azaltmaya çalışarak, emeğin farklı sektörlerdeki dağıtım paylarını dikkate almalıdır. Özellikle emek sektörünün niteliksiz sektörlere kıyasla nitelikli sektördeki dağıtıcı payının oranına dikkat etmeleri önem arz etmektedir. Endüstriyel gelişim sürecinde hükümetler, karşılaştırmalı üstünlükleri olan ve daha az becerili işgücüne fayda sağlayan endüstrilerin gelişimini teşvik ederek ücret eşitsizliklerini azaltma eğilimi göstermelidir.

\section{Kaynakça}

- Acemoglu, D. (1998). Why do new technologies complement skills? Directed technical change and wage inequality. Quarterly Journal of Economics, 113(4), 1055-1089.

- Acemoglu, D. (2002). Technical change, inequality and the labor market. Journal of Economic Literature, 40(1), 7-72.

- Arellano, M., \& Bover, O. (1995). Another look at the instrumental variable estimation of errorcomponents models. Journal of econometrics, 68(1), 29-51.

- Atkinson, A. B. (2008). The changing distribution of earnings in OECD countries. Oxford, UK: Oxford University Press.

- $\quad$ Autor, D. H., Levy, F., and Murnane, R. J. (2003). "The Skill Content of Recent Technological Change: An Empirical Exploration”, Quarterly Journal of Economics, 118(4), 1279-1334.

- Bartel, A. and N. Sicherman 1998, “Technological Change and Skill Acquisition Young Workers”, Journal of Labor Economics, 16/4

- Bauer, J. M. (2018). The Internet and income inequality: Socio-economic challenges in a hyperconnected society. Telecommunications Policy, 42(4), 333-343.

- Berman, E., \& Machin, S. (2000). Skill-biased technology transfer around the world. Oxford Review of Economic Policy, 16(3), 12-22.

- Berman, E., Bound, J., \& Machin, S. (1998). Implications of skill-biased technological change: International evidence. Quarterly Journal of Economics, 113(4), 1245-1279.

- Blundell, R., \& Bond, S. (1998). Initial conditions and moment restrictions in dynamic panel data models. Journal of econometrics, 87(1), 115-143

- Bourguignon, F. (2015). The globalization of inequality. Princeton, NJ: Princeton University Press.

- Chusseau, N., Dumont, M., \& Hellier, J. (2008). Explaining rising inequality: Skill-biased technical change and north-south trade. Journal of Economic Surveys, 22(3), 409-457.

- Conceicao P. \& Galbraith J. (2000). Technology adoption and inequality: empirical evidence from a selection of OECD countries. 33rd Hawaii International Conference on System Sciences, vol. 7.

- Goldin, Claudia, Katz, Lawrence F., (2007), "The Race Between Education and Technology: The Evolution of U.S. Educational Wage Differentials, 1890 tO 2005”, NBER Working Paper Series, Working Paper 12984

- Hall, J. (2009). The diffusion of technology, education and income inequality: evidence from developed and developing countries.

- Haskel, J., \& Slaughter, M. J. (2002). Does the sector bias of skill-biased technical change explain changing skill premia? European Economic Review, 46(10), 1757-1783.

- Jaumotte F., S. Lall ve C. Papageorgiou (2008). Rising income inequality: technology, or trade and financial globalization? IMF Working Paper, WP/08/185.

- Jenkins, S. P. (1995). “Accounting for Inequality Trends: Decomposition Analysis for the UK, 1971-86," Economica 62(1), 29-63.

- Katz, Lawrence F., Murphy, Kevin M., (1992), “Chances In Relative Wages, 1963-1987; Supply and Demand Factors”, The Quarterly Journal of Economics, Vol. 107, No. 1, pp. 35-78. 
- Khadraoui, N. (2012). Capital Movements and Economic Growth Fluctuations: The Threshold Effect of Financial Development. International Journal of Economics and Finance, 4(4), p193.

- Kijama, Y. (2006). Why did wage inequality increase? Evidence from urban India 1983-99. Journal of Development Economics, 81(1), 97-117.

- Lansing K. \& Markiewicz A. (2011). Technology diffusion and income inequality.

- Li, B. (2010). Multinational production and choice of technologies: New evidence on skill-biased technological change from China. Economics Letters, 108(2), 181-183.

- OECD (2014). All on Board: Making Inclusive Growth Happen. OECD Publishing, Paris.

- Perugini C. ve F. Pompei (2009). Technological change and income distribution in Europe. International Labour Review, Vol. 148, No. 1-2, s. 123-148.

- $\quad$ Rattsø, J., \& Stokke, H. E. (2013). Trade, skill biased technical change and wage inequality in South Africa. Review of International Economics, 21(3), 419-431.

- Schulte, P. (2015). Does skill-biased technical change diffuse internationally? ZEW Discussion Paper No.15-088.

- Solt, Frederick. 2016. \The Standardized World Income Inequality Database." Social Science Quarterly 97. SWIID Version 7.0, July 2018.

- Weiss, M., \& Garloff, A. (2011). Skill-biased technological change and endogenous benefits: The dynamics of unemployment and wage inequality. Applied Economics, 43(7), 811-821.

- Weiss, Matthias. \& Alfred Garloff, "Skill Biased Technological Change and Endogenous Benefits: The Dynamics of Unemployment and Wage Inequality”, ZEW Discussion Paper No. 05-79 


\title{
Linder Hipotezinin Geçerliliğinin Çekim Modeli ile Test Edilmesi: Türkiye ve Seçilmiş Geçiş Ekonomileri \\ Testing the Validity of Linder Hypothesis Using Gravity Model: The Case of Turkey and Selected Transition Economies
}

\author{
Prof. Dr. Harun Bal (Çukurova University, Turkey) \\ Asst. Prof. Dr. Müge Manga (Erzincan Binali Yıldırım University, Turkey) \\ Ph.D. Candidate Esma Erdoğan (Çukurova University, Turkey)
}

\begin{abstract}
In this study, the validity of the Linder Hypothesis has been tested based on export and import intensity of foreign trade flows between Turkish economy and selected Transition Countries. According to this hypothesis, the more similar the demand structures and per capita income levels of countries, the more they will trade with one another. The hypothesis uses the difference between the per capita income of countries engaged in foreign trade as the main parameter and indicates that a fall in income difference between two countries increases the validity of the Linder hypothesis by increasing the intensity of foreign trade of the countries. The study considers selected Transition Countries having rising share of foreign trade with Turkey during the period 2001-2017 to examine the validity of Linder Hypothesis in the context of foreign trade flows employing Gravity Models that shows "Aggregate Linder Demand Effect" and panel data analysis. Test results does not support Linder hypothesis in terms of export and import intensity of foreign trade flows between Turkish economy and selected Transition Countries during 20012017 , rather factor endowment does matter for inter-industry foreign trade.
\end{abstract}

\section{Giris}

1970’li yıllara kadar uluslararası ticarette Karşılaştırmalı Üstünlükler Teorisi ve bu teorinin gelişmesine katkı sağlayan Heckscher (1919), Ohlin (1933) ve Samuelson'un (1949) "Faktör Donatım Teori” (H-O-S) ön planda olmuştur. Faktör Donatım Teorisi; ülkelerin dış ticaret yaparken birbirlerine göreceli olarak üstün oldukları üretim faktörlerini (işgücü-sermaye) yoğun olarak kullandıkları malların üretiminde uzmanlaşarak, bu malların ihracatçısı konumuna gelmelerini savunmaktadır. Leontief paradoksu ile birlikte H-O-S gibi arz yönlü diş ticaret teorileri artan oranda sorgulanmaya başlanılmış ve talep yönlü yeni dıș ticaret teorilerinin geliștirilmesine yol açmıştır. Bu teorilerden birisini de Staffan Burenstam Linder (1961), “An Essay on Trade and Transformation” isimli eserinde ülkelerin dış ticaret modellerini açıklayarak, uluslararası ticaretin yapısal yönü ve refah etkisine vurgu yaparak Leontief Paradoksu için bir çözüm önerisi sunmuştur. Linder (1961), dış ticaret modellerini açıklarken ülkelerin endüstri malları ticaretinde katlanılan üretim maliyetinden çok, dış ticarette benzer talep yapısına sahip ülkeler arasında gerçekleşeceğini savunmuştur (Linder, 1961: 16).

Çalışmamız bu hipotezi analiz eden çalışmalara bir katkıda bulunabilmek üzere seçilmiş on geçiş ekonomisi ile Türkiye arasındaki ticareti ele almaktadır. Çalışmamızın sonraki kısımları şu şekilde organize edilmiştir; Birinci kısımda, yeni dış ticaret teorilerinden olan ve dış ticaretin talep yönüne vurgu yapan Tercihlerde Benzerlik Teoremi (Linder Hipotezi veya Taleplerin Çakışması Teorisi)'nin teorik çerçevesi ve ilgili literartürdeki çalışmalar ele alınmıştır. İkinci kısımda, seçilmiş on geçiş ekonomisi ele alınarak bunların Türkiye ile karşılıklı dış ticaretinde Linder hipotezinin geçerliliği 'Toplam Linder Talep Etkisini’ gösteren Çekim Modeli (Gravity Models) ile analiz edilmiştir. Çalışmamız, analizlerden elde edilen bilgilerin değerlendirildiği sonuç bölümü ile tamamlanacaktır.

\section{Tercihlerde Benzerlik Teoremi (Linder Hipotezi- Talepleri Çakışması Teorisi)}

Yeni dıș ticaret teorileri arasında sayılan ve Staffan Burenstam Linder (1961) tarafindan ortaya atılan "Tercihlerde Benzerlik Teorisi - Taleplerin Çakışması Teorisi (overlapping demand)" dış ticarette talep vurgusunun ilk yapıldığı çalışmalardan biri olarak ifade edilir. Linder çalışmasında üç önemli noktaya değinir. Bunlardan ilki bir malın ihraç malı olabilmesi için öncelikle o ürünün iç piyasada talep görüyor olması gerekir. İkincisi; talebi belirleyen en önemli faktörlerden biri gelir unsurudur. Gelir düzeyi birbirine benzeyen ülkeler, benzer zevk ve tercihlere sahip olacağı için bu ülkelerin karşılıklı ticareti artacaktır. Üçüncü önemli husus ise; ürün farklılaştırılması ile birlikte ölçeğe göre artan getir kavramının söz konusu olmasıdır (Linder, 1961: 94). Böylece Linder'in teorisi, ticareti gerçekleştirecek ülkelerin zevk ve tercihlerinin yanı sıra ticarete konu olan ürünlerin de farklılaştırılmasına izin vermesi ve ölçeğe göre artan verimlerin geçerli olduğu varsayımları ile kendinden önceki arz yönlü dış ticaret teoremlerinden önemli ölçüde ayrışmaktadır (Hallak,2004:11-Arıca, 2014:29).

Linder Tercihlerde Benzerlik Teorisinde tüketicileri ve dış ticareti iki kısıma ayırmaktadır. Tüketiciler kendi içerisinde tercihlerdeki benzerlik yapılarına göre azınlık (ülke içerisinde yaşayan çok zengin veya çok fakir olan halk kesimi) ve çoğunluk (azınlık dışındaki tüm kesimler) olarak ayrışır iken dış ticarette ise sanayi ürünleri ticareti 
ve hammadde ticareti olarak iki kısımda incelenmektedir (Bukhari vd, 2005:11-Dura, 2000:10). Özellikle benzer talep yapısına ve gelir düzeyine sahip ülkeler sanayi ürünlerinin ticaretine odaklanır ve bu ülkeler arasında dış ticaret aktif olarak gerçekleşmektedir. Artan dış ticaretin temel nedeni ise ülkelerin "çakışan talepleri" dir (Borkakoti,1998:367- İyibozkurt, 2001:82).

\section{Literatür Taraması}

Ampirik literatür incelendiğinde dış ticarette talep yapılarındaki benzerliği test eden ilk çalışmanın bu alandaki teorinin kurucusu olan Linder (1961)'in kendisine ait olduğu görülmektedir. Linder çalışması sonucunda gelir düzeyi benzer olan ülkelerin birbiri ile daha yoğun ticari faaliyette bulunduklarını ve bu durumun da ülkelerin refah düzeylerinde de artışa yol açtığını tespit etmektedir. Literatürde Linder hipotezinin geçerliliğini test etmek için yapılan diğer çalışmalar incelediğinde uygulanan ekonometrik analiz yöntemine göre üç farklı kategoride yoğunlaşı̆ı̆ı görülmektedir. Birinci kategoride yer alan çalışmalar Linder Hipotezinin geçerliliğini korelasyon katsayısı ve regresyon analiz yöntemi ile tespit eden çalışmalardır. Bunlardan, Fortune (1971) çalışmasında, 50 ülke için Linder hipotezini test edilmesi amaçlanarak korelasyon analizinde faydalanmıştır. Hirsch ve Lev (1973) Hollanda, Danimarka, İsviçre ve İsrail için 1959-1966 dönemi verileri ile Linder Hipotezinin geçerliliğini regresyon analizi yöntemi ile test etmiş ve ilgili dönemde ülkeler arasında Linder hipotezinin geçerli olduğu sonucuna ulaşmıştır. İkinci kategoride yer alan çalışmalar ise daha çok zaman serisi ve Çekim Modeli (Gravity Model) ile analiz yapılan çalışmalardır. Hanink (1990), Francois vd (1996), Bernasconi (2009) vb. çalışmalarında Linder hipotezini çekim modeli yöntemi ile test etmiş ve analiz sonucunda edilen bulgular ilgili ülkelerde Linder Hipotezinin geçerli olduğunu göstermiştir Ü̧̧üncü kategorideki çalışmalar ise, yatay kesit ve zaman serisinin bir arada kullanımına olanak sağlayan panel veri yöntemi ile yapılan çalışmalardır. Choi (2002), Bukhari vd (2005), Hallak (2006), Keum (2010), Kumar Misra vd. (2015) çalışmalarında Linder hipotezinin geçerliliğini panel veri analiz yöntemini kullanarak test etmiştir. Analiz sonucunda elde ettikleri bulguların Linder (1961) çalışmasını destekler nitelikte olduğu görülmüştür.

Linder Hipotezinin geçerliliğini test eden Türkiye özelindeki çalışmaların ise sınırlı sayıda olduğu görülmüştür. Atik (2006) Türkiye özelindeki çalışmasında 1990-2000 dönemi için Türkiye ve yakın komşuları olan Yunanistan, İran ve Suriye arasında Linder hipotezinin geçerliliğini Panel veri seti ile oluşturulan Tobit yöntemi ile test etmiştir. Analiz sonucunda Linder hipotezinin geçerli olduğu bulgusuna ulaşmıştır. Bilgin vd (2011) çalışmasında ise 19892000 dönemi veri setinden faydalanarak Türkiye ile ticari ilişkilerde bulunan İran, Nepal, Hindistan, Pakistan ve Çin arasında arasındaki ticarette Linder hipotezinin geçerliliğini Panel EKK yöntemi ile test etmiştir. Analiz sonucunda elde edilen bulgular ilgili ülkelerle yapılan ticarette yine Linder hipotezinin destekleyen bulgulara ulaşmışlardır. Saygılı ve Manavgat (2014) çalışmasında 1995-2012 döneminde Türkiye'nin önemli ticari partneri olan 30 ülkeyle karşlıklı ticaretinde Linder hipotezinin geçerliliğini “Toplam Linder Talep Etkisini” gösteren çekim modeli (gravity type model) ve panel veri analizi yöntemi ile test etmiştir. Çalışmanın sonuçları Linder değişkeninin Türkiye'nin ithalat yoğunluğu üzerinde belirgin bir etkisi olduğunu ortaya koyarken, ihracat yönüyle hipotezi desteklemediğine işaret etmiştir. Yakın tarihlerde yapılan bir örnek olmak üzere Yıldız ve Künü (2018)'nin çalı̧̧masında 1996 - 2016 dönemi itibariyle Türkiye-BRICS ülkeleri (Brezilya, Rusya, Hindistan, Çin ve Güney Afrika) ile yaptığı ihracat ve ithalatta Linder hipotezinin geçerliliği panel veri analizi kullanılarak test etmiş ve analiz sonucunda Türkiye ile BRICS ülkeleri arasında ihracat açısından Linder hipotezi geçerli olduğu bulgusuna ulaşmışlardır. Konuya ilişkin ampirik çalışmalardan seçilen ve Tablo 1'de gösterilen literatür genel olarak teoriyi destekleyici olmakla birlikte aksi sonuçların da varlığına işaret etmektedir. Bu bağlamda konuya ilişkin analizlerin çeşitli boyutlarda sürdürülmesi ve değerlendirilmesi gerekliliğinden söz edilebilir. 


\begin{tabular}{|c|c|c|c|c|}
\hline Çalışmayı Yapan & Dönem & Ülke Grubu & $\begin{array}{l}\text { Ekonometrik } \\
\text { Yöntem }\end{array}$ & Çalışma Sonucu \\
\hline Linder (1961) & 1958 & 32 Ülke & $\begin{array}{l}\text { Korelasyon } \\
\text { Analizi }\end{array}$ & $\begin{array}{lcc}\text { Linder } & \text { Hipotezinin } & \text { Geçerli } \\
\text { Olduğu Tespit edilmiştir. } & \\
\end{array}$ \\
\hline Fortune (1971) & 1966 & 50 Ülke & $\begin{array}{l}\text { Korelasyon } \\
\text { Analiz }\end{array}$ & $\begin{array}{lcc}\text { Linder } & \text { Hipotezinin } & \text { Geçerli } \\
\text { Olduğu Tespit edilmiştir. } & \\
\end{array}$ \\
\hline Hirsch vd (1973) & $1959-1966$ & 4 Ülke & $\begin{array}{l}\text { Regresyon } \\
\text { Tahmini }\end{array}$ & $\begin{array}{ll}\text { Linder } & \text { Hipotezinin } \\
\text { Olduğu Tespit edilmiştir. }\end{array}$ \\
\hline Kennedy vd. (1980) & $1960-1975$ & 14 Ülke & $\begin{array}{l}\text { Korelasyon } \\
\text { Analizi }\end{array}$ & $\begin{array}{l}\text { Linder Hipotezinin } \\
\text { Olmadığı edilmiştir. }\end{array}$ \\
\hline Tursby vd (1987) & 1974-1982 & 17 Ülke & $\begin{array}{l}\text { Kesit Veri } \\
\text { Regresyon } \\
\text { Yöntemi }\end{array}$ & $\begin{array}{l}\text { Kanada ve Güney Afrika ülkeleri } \\
\text { dışında ele alınan ülkelerde Linder } \\
\text { Hipotezinin geçerli olduğunu } \\
\text { tespit etmiştir. }\end{array}$ \\
\hline Hanink (1988) & 1984 & 26 Ülke & $\begin{array}{l}\text { EKK } \\
\text { Yöntemi } \\
\end{array}$ & $\begin{array}{lcc}\text { Linder } & \text { Hipotezinin } & \text { Geçerli } \\
\text { Olduğu Tespit edilmiştir. } & \\
\end{array}$ \\
\hline Greytak vd (1990) & $1963-1980$ & $\mathrm{ABD}$ & $\begin{array}{l}\text { Regresyon } \\
\text { Tahmini }\end{array}$ & $\begin{array}{l}\text { Doğrusal olmayan tüketim } \\
\text { benzerlik fonksiyonu Linder } \\
\text { hipotezi açıklamada yetersidir. }\end{array}$ \\
\hline Hanink (1990) & 1984 & 26 Ülke & $\begin{array}{l}\text { EKK Logit } \\
\text { Yöntemi }\end{array}$ & $\begin{array}{l}\text { Linder Hipotezinin Geçerli } \\
\text { Olduğu Tespit edilmiştir. }\end{array}$ \\
\hline François vd. (1996) & 1973-1976 & 38 Ülke & $\begin{array}{l}\text { Regresyon } \\
\text { Analizi }\end{array}$ & $\begin{array}{l}36 \text { ülke için Linder Hipotezinin } \\
\text { Geçerli Olduğu Tespit edilmiştir. }\end{array}$ \\
\hline Chow vd. (1999) & $1965-1990$ & $\begin{array}{l}\text { Hong Kong-Singapur- } \\
\text { G.Kore ve Tayvan'in } \\
\text { OECD ile karşılaştırılmas1 }\end{array}$ & $\begin{array}{l}\text { EKK } \\
\text { Yöntemi }\end{array}$ & $\begin{array}{l}\text { Linder } \quad \text { Hipotezinin } \\
\text { Olduğu Tespit edilmiştir. }\end{array}$ \\
\hline McPherson vd. (2001) & 1989-1992 & 6 Ülke & $\begin{array}{l}\text { Panel Tobit } \\
\text { Modeli }\end{array}$ & $\begin{array}{l}\text { Tanzanya hariç, } 5 \text { ülkede Linder } \\
\text { Hipotezinin geçerli olduğunu } \\
\text { tespit etmiştir. }\end{array}$ \\
\hline Choi (2002) & 1970-1992 & 63 Ülke & $\begin{array}{l}\text { Panel Gravity } \\
\text { Modeli }\end{array}$ & $\begin{array}{l}\text { Linder Hipotezinin güçlü bir } \\
\text { şekilde geçerli olduğu sonucuna } \\
\text { ulaşmıştır. }\end{array}$ \\
\hline Castejon vd. (2004) & 1959-1986 & İspanya & $\begin{array}{l}\text { EKK } \\
\text { Yöntemi }\end{array}$ & $\begin{array}{l}\text { D1ş ticareti belirleyen en önemli } \\
\text { faktörün iç talep olduğu sonucuna } \\
\text { ulaşmıştır. }\end{array}$ \\
\hline Bukhari vd. (2005) & 1993-2002 & 3 Ülke & $\begin{array}{l}\text { Panel Tobit } \\
\text { Modeli }\end{array}$ & $\begin{array}{lcc}\text { Linder } & \text { Hipotezinin } & \text { Geçerli } \\
\text { Olduğu Tespit edilmiştir. } & \end{array}$ \\
\hline Hallak (2006) & 1995 & 65 Ülke & $\begin{array}{l}\text { Panel Tobit } \\
\text { Modeli }\end{array}$ & $\begin{array}{l}\text { Linder } \quad \text { Hipotezinin } \\
\text { Olduğu Tespit edilmiştir. }\end{array}$ \\
\hline Mohammed (2010) & $2003-2010$ & ABD ve Bangladeş & $\begin{array}{l}\text { Panel Gravity } \\
\text { Model }\end{array}$ & $\begin{array}{lll}\text { Linder } & \text { Hipotezinin } & \text { Geçerli } \\
\text { Olduğu Tespit edilmiştir. } & \end{array}$ \\
\hline Atik (2006) & $1990-2000$ & $\begin{array}{l}\text { Türkiye-Yunanistan-İran } \\
\text { ve Suriye }\end{array}$ & $\begin{array}{l}\text { Panel Tobit } \\
\text { Model }\end{array}$ & $\begin{array}{lll}\text { Linder } & \text { Hipotezinin } & \text { Geçerli } \\
\text { Olduğu Tespit edilmiştir. } & \\
\end{array}$ \\
\hline Bilgin vd. (2011) & $1989-2000$ & $\begin{array}{l}\text { Türkiye, İran, Nepal, } \\
\text { Hindistan, Pakistan ve Çin }\end{array}$ & $\begin{array}{l}\text { Panel EKK } \\
\text { Yöntemi }\end{array}$ & $\begin{array}{l}\text { Türkiye ile ticari ilişkilerde } \\
\text { bulunan İran, Nepal, Hindistan, } \\
\text { Pakistan ve Çin için Linder } \\
\text { hipotezini test etmiş ve geçerli } \\
\text { olduğu sonucuna ulaşmıştır. }\end{array}$ \\
\hline Sayg1l1 vd. (2014) & $1995-2012$ & Türkiye ve 30 Ülke & $\begin{array}{l}\text { Panel Gravity } \\
\text { Model }\end{array}$ & $\begin{array}{l}\text { Linder değişkeninin Türkiye'nin } \\
\text { ithalat yoğunluğu üzerinde } \\
\text { belirgin bir etkisi olduğunu ortaya } \\
\text { koyarken, ihracat yönüyle hipotezi } \\
\text { desteklemediğini göstermiştir. }\end{array}$ \\
\hline Y1ld1z vd. (2018) & 1996-2016 & $\begin{array}{c}\text { Türkiye ve BRICS üyesi } 5 \\
\text { Ülke }\end{array}$ & $\begin{array}{l}\text { Panel Gravity } \\
\text { Model }\end{array}$ & $\begin{array}{l}\text { Türkiye ile BRICS ülkeleri } \\
\text { arasında ihracat açısından Linder } \\
\text { hipotezi geçerli olduğu bulgusuna } \\
\text { ulaşmışlardır. }\end{array}$ \\
\hline
\end{tabular}

Tablo 1. Linder Teorisini Test Eden Çalışmaların Literatür Özeti

Çalışmamız bu alandaki analizlere bir katkıda bulunabilmek üzere 2001-2018 dönemi için Sovyetler Birliğinin dağılması sonrası oluşan ve son dönemlerde Türkiye'nin önemli dış ticaret partnerleri arasına giren seçilmiş on geçiş ekonomisini ele almıştır. Bu ülkelerin seçilme nedeni ilgili ülkelerin Tablo 2 ve 3 'ten de görüleceği üzere ülkemizle olan karşılıklı dış ticaretlerinde meydana gelen artışlardır. 


\begin{tabular}{|l|c|c|c|c|c|c|c|c|c|}
\hline Dönem & $\begin{array}{l}\text { Gürcistan } \\
- \text { Türkiye } \\
\text { İthalat }\end{array}$ & $\begin{array}{l}\text { Rusya- } \\
\text { Türkiye } \\
\text { İthalat }\end{array}$ & $\begin{array}{l}\text { Ukrayna- } \\
\text { Türkiye } \\
\text { İthalatı }\end{array}$ & $\begin{array}{l}\text { Kazakistan- } \\
\text { Türkiye } \\
\text { İthalat }\end{array}$ & $\begin{array}{l}\text { Kurgizistan- } \\
\text { Türkiye } \\
\text { İthalatı }\end{array}$ & $\begin{array}{l}\text { Azerbeycan } \\
- \text { Türkiye } \\
\text { Ithalatı }\end{array}$ & $\begin{array}{l}\text { Türkmenistan- } \\
\text { Türkiye } \\
\text { İthalatı }\end{array}$ & $\begin{array}{l}\text { Özbekistan- } \\
\text { Türkiye } \\
\text { İthalatı }\end{array}$ & $\begin{array}{l}\text { Moldova- } \\
\text { Türkiye } \\
\text { İthalatı }\end{array}$ \\
\hline 2001 & 106,905 & 521,012 & 138,098 & 136,889 & 15,773 & 148,167 & 105,278 & 89,725 & 19,684 \\
\hline 2002 & 89,216 & 728,857 & 195,305 & 173,620 & 17,006 & 156,219 & 118,493 & 93,473 & 32,745 \\
\hline 2003 & 111,617 & 927,988 & 312,299 & 208,976 & 25,989 & 195,132 & 170,347 & 138,422 & 48,249 \\
\hline 2004 & 201,365 & $1,231,149$ & 356,339 & 342,347 & 33,243 & 224,968 & 214,848 & 145,226 & 69,094 \\
\hline 2005 & 282,264 & $1,732,114$ & 607,701 & 399,737 & 33,699 & 313,002 & 180,635 & 151,071 & 93,034 \\
\hline 2006 & 519,370 & $2,722,646$ & 769,081 & 558,265 & 39,467 & 385,040 & 281,325 & 175,995 & 113,815 \\
\hline 2007 & 708,366 & $4,171,918$ & 972,254 & 958,803 & 50,919 & 624,692 & 339,989 & 225,612 & 166,769 \\
\hline 2008 & 916,168 & $6,141,305$ & $1,949,725$ & 970,750 & 91,111 & 807,343 & 662,933 & 337,130 & 231,877 \\
\hline 2009 & 786,909 & $3,221,933$ & 952,241 & 570,875 & 72,699 & 906,072 & 945,655 & 279,964 & 172,354 \\
\hline 2010 & 885,904 & $4,865,990$ & $1,298,282$ & 616,256 & 84,700 & 771,442 & $1,139,825$ & 282,666 & 205,822 \\
\hline 2011 & $1,278,677$ & $6,352,530$ & $1,481,219$ & 729,289 & 117,090 & $1,302,443$ & $1,493,336$ & 354,490 & 366,883 \\
\hline 2012 & $1,470,241$ & $6,840,000$ & $1,951,858$ & 786,138 & 178,519 & $1,520,405$ & $1,480,052$ & 449,884 & 388,193 \\
\hline 2013 & $1,410,197$ & $7,272,773$ & $1,852,897$ & 926,126 & 204,730 & $1,480,932$ & $1,957,484$ & 562,526 & 380,992 \\
\hline 2014 & $1,728,764$ & $6,654,286$ & $1,298,157$ & $1,019,387$ & 307,968 & $1,286,641$ & $2,231,246$ & 603,013 & 300,855 \\
\hline 2015 & $1,327,398$ & $4,068,852$ & 851,742 & 741,917 & 164,290 & $1,172,178$ & $1,857,964$ & 488,654 & 285,117 \\
\hline 2016 & $1,352,396$ & $2,147,525$ & $1,098,551$ & 618,147 & 190,776 & $1,262,580$ & $1,241,470$ & 533,018 & 271,986 \\
\hline 2017 & $1,372,803$ & $3,441,120$ & $1,261,187$ & 730,082 & 224,930 & $1,284,887$ & $1,037,980$ & 680,104 & 304,338 \\
\hline 2018 & $1,271,454$ & $4,215,914$ & - & - & - & - & 467,266 & 951,704 & - \\
\hline
\end{tabular}

Tablo 2. 2001-2018 Dönemleri Arasında Türkiye 'nin Seçilmiş Ülkelerle Olan İthalatı Verileri (Bin \$) Kaynak: ITC, Dış Ticaret İstatistikleri, www.trademap.org

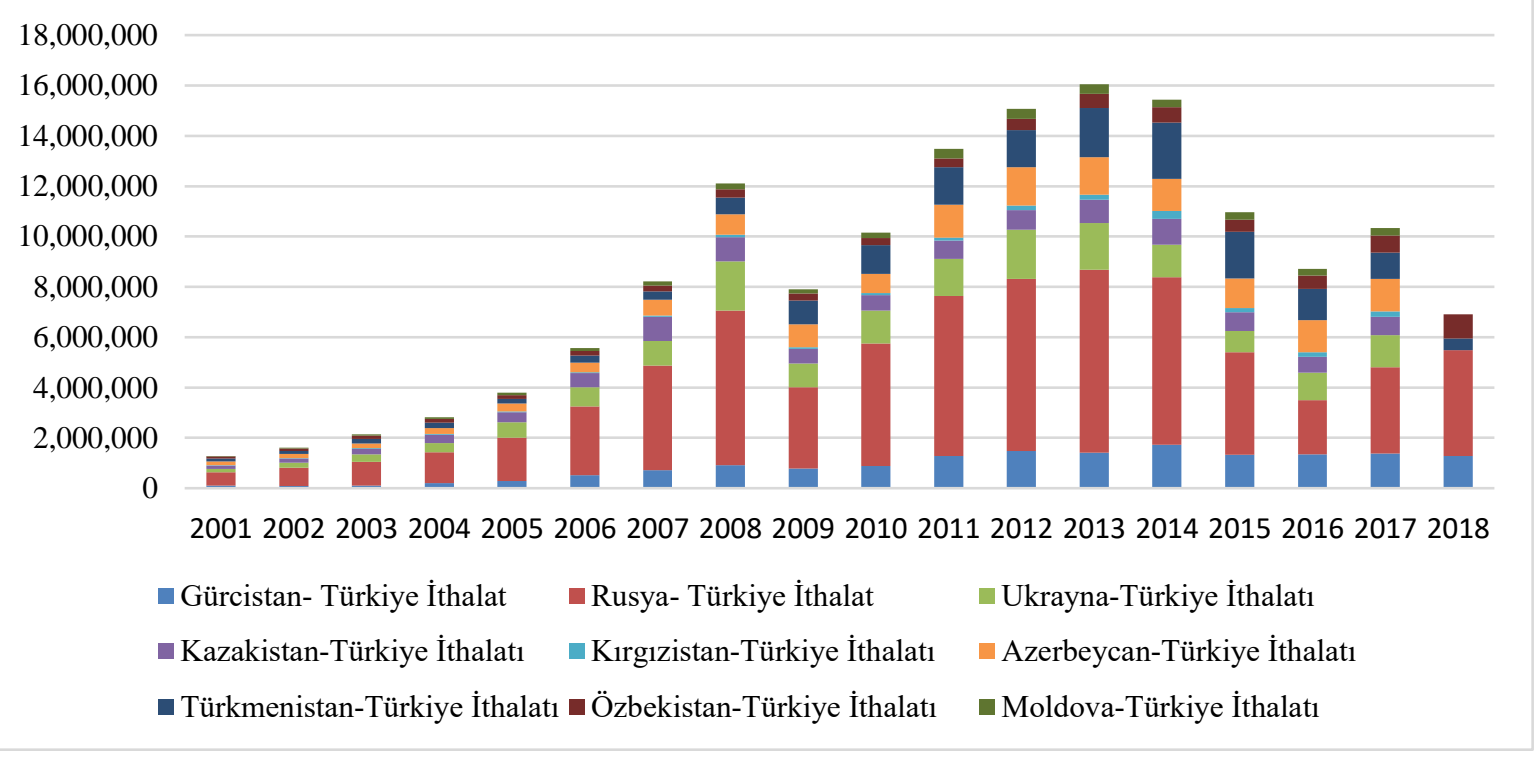

Şekil 1. Türkiye'nin Seçilmiş Ülkelerle Olan İthalatı (Bin \$)

Tablo 2,3 ve Şekil 1,2'den de görüleceği üzere ilgili ülkelerle olan 2001-2018 dönemine kadarki süreçte 2008 küresel kriz dönemi hariç seçilen 10 ülke ile olan dış ticaretimiz önemli ölçüde artışlar göstermiştir. Yıllar itibari ile bu 10 ülke içerisinde en çok ithalat yapılan ülkenin ise Rusya olduğu görülmektedir. Türkiye'nin Rusya'dan yaptığı en önemli ithalat kalemleri ise enerji ürünleri, mineral yakıtlar, demir çelik ve hububat sektörü olarak ön plana çıkmaktadır. Türkiye'nin Rusya'ya ihraç ettiği en önemli ürün kalemleri ise motorlu kara taşıtları, makinalar ve meyve ürünleri oluşturmaktadır (http://www.tim.org.tr). 


\begin{tabular}{|l|c|c|c|c|c|c|c|c|c|}
\hline Dönem & $\begin{array}{l}\text { Türkiye- } \\
\text { Gürcistan } \\
\text { İhracatı }\end{array}$ & $\begin{array}{l}\text { Türkiye- } \\
\text { Rusya } \\
\text { İhracatı }\end{array}$ & $\begin{array}{l}\text { Türkiye- } \\
\text { Ukrayna } \\
\text { İhracatı }\end{array}$ & $\begin{array}{l}\text { Türkiye- } \\
\text { Kazakistan } \\
\text { İhracatı }\end{array}$ & $\begin{array}{l}\text { Türkiye- } \\
\text { Kurgizistan } \\
\text { İhacatı }\end{array}$ & $\begin{array}{l}\text { Türkiye- } \\
\text { Azerbaycan } \\
\text { İhracatı }\end{array}$ & $\begin{array}{l}\text { Türkiye- } \\
\text { Türkmenistan } \\
\text { İhracatı }\end{array}$ & $\begin{array}{l}\text { Türkiye- } \\
\text { Ozzekistan } \\
\text { İhracatı }\end{array}$ & $\begin{array}{l}\text { Türkiye- } \\
\text { Moldova } \\
\text { İhracatı }\end{array}$ \\
\hline 2001 & 144,049 & 924,107 & 289,180 & 119,795 & 17,350 & 225,214 & 105,278 & 89,725 & 27,816 \\
\hline 2002 & 103,373 & $1,168,309$ & 310,450 & 158,655 & 23,967 & 226,865 & 118,493 & 93,473 & 39,453 \\
\hline 2003 & 155,070 & $1,367,591$ & 444,967 & 233,994 & 40,862 & 315,488 & 170,347 & 138,422 & 46,794 \\
\hline 2004 & 199,699 & $1,859,187$ & 575,827 & 355,590 & 74,702 & 403,942 & 214,848 & 145,226 & 66,352 \\
\hline 2005 & 271,828 & $2,377,050$ & 821,034 & 459,946 & 89,529 & 528,076 & 180,635 & 151,071 & 81,108 \\
\hline 2006 & 407,962 & $3,237,611$ & $1,121,364$ & 696,823 & 132,172 & 695,287 & 281,325 & 175,995 & 107,377 \\
\hline 2007 & 646,082 & $4,726,853$ & $1,481,156$ & $1,079,887$ & 181,311 & $1,047,668$ & 339,989 & 225,612 & 145,752 \\
\hline 2008 & 997,844 & $6,483,004$ & $2,187,675$ & 890,568 & 191,351 & $1,667,469$ & 662,933 & 337,130 & 198,468 \\
\hline 2009 & 762,977 & $3,189,607$ & $1,004,772$ & 633,417 & 140,002 & $1,400,446$ & 945,655 & 279,964 & 118,090 \\
\hline 2010 & 769,271 & $4,628,153$ & $1,260,423$ & 818,900 & 129,202 & $1,550,479$ & $1,139,825$ & 282,666 & 148,209 \\
\hline 2011 & $1,092,321$ & $5,992,633$ & $1,729,760$ & 947,822 & 180,241 & $2,063,996$ & $1,493,336$ & 354,490 & 208,885 \\
\hline 2012 & $1,253,309$ & $6,680,777$ & $1,829,207$ & $1,068,625$ & 257,470 & $2,584,671$ & $1,480,052$ & 449,884 & 224,464 \\
\hline 2013 & $1,245,917$ & $6,964,209$ & $2,189,245$ & $1,039,420$ & 388,336 & $2,960,371$ & $1,957,484$ & 562,526 & 275,971 \\
\hline 2014 & $1,443,790$ & $5,943,014$ & $1,729,294$ & 977,487 & 421,431 & $2,874,608$ & $2,231,246$ & 603,013 & 286,741 \\
\hline 2015 & $1,109,018$ & $3,589,464$ & $1,121,373$ & 750,157 & 294,702 & $1,898,715$ & $1,857,964$ & 488,654 & 201,645 \\
\hline 2016 & $1,176,634$ & $1,732,954$ & $1,253,155$ & 623,715 & 308,933 & $1,285,127$ & $1,241,470$ & 533,018 & 262,383 \\
\hline 2017 & $1,208,645$ & $2,734,316$ & $1,340,709$ & 746,244 & 343,600 & $1,356,999$ & $1,037,980$ & 680,104 & 284,649 \\
\hline 2018 & $1,315,583$ & $3,401,617$ & $1,467,390$ & 695,417 & 377,195 & $1,474,693$ & 467,266 & 951,704 & 266,321 \\
\hline
\end{tabular}

Tablo 3. 2001-2018 Dönemleri Arasında Türkiye ’nin Seçilmiş Ülkelerle Olan İhracat Verileri (Bin \$) Kaynak: ITC, Dış Ticaret İstatistikleri, www.trademap.org

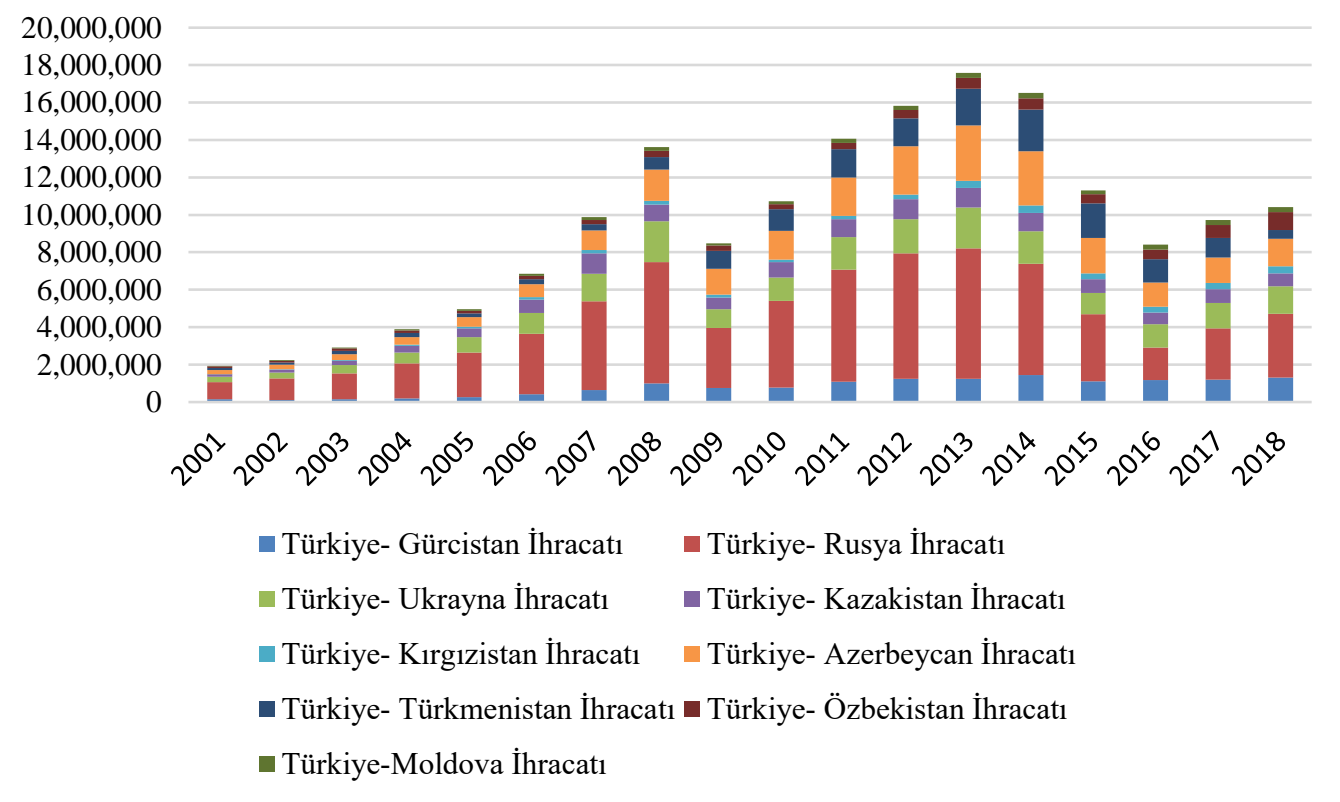

Şekil 2. Türkiye’nin Seçilmiş Ülkelerle Olan İhracatı (Bin \$)

\section{Model, Veri Seti ve Bulgular}

Bu çalışmada, ülkelerin gelir düzeyleri arasındaki farklılık ile yapılan ticaret arasındaki ilişki üzerine kurulmuş olan Linder hipotezinin test edilmesi amaçlanmış olup, 2001-2017 dönemi için Türkiye ekonomisi ile seçilmiş Bağımsız Devletler Topluluğu (BDT) ülkelerinden; Gürcistan Rusya Ukrayna Kazakistan Kırgızistan Azerbaycan Türkmenistan Özbekistan ve Moldova ülkeleri arasındaki dış ticaret analize konu olarak belirlenmiştir. Türkiye ekonomisi ile dış ticaret yapan BDT ülkelerinin seçilmesindeki amaç bu ülke grubuyla Türkiye arasındaki dış ticaretin yıllara bağlı olarak artış eğilimi göstermesidir. Linder hipotezi üzerine yapılmış çalışmaların ağırlıklı olarak gravity (çekim) modeli çerçevesinde ele alındığı görülmektedir. Gravity modeli, metodolojik olarak iki veya daha fazla mekânsal nokta arasındaki etkileşimin derecesi üzerine odaklı olan ilişkisel bir teori olarak kabul edilmektedir. Klasik Gravity modelinin merkezinde fiziksel kanun ve teoriler olmasına rağmen Carey (1858), 
Young (1924) ve Reiily (1931) gibi çalışmalarla birlikte Gravity modeli göç gibi sosyal değişsimlerdeki ilişkilerin ölçülmesinde de kullanılmaya başlanmıştır (Nijkamp ve Reggiani, 1992, s. 3-4).

Ticaret teorilerine göre, iki ülke arasındaki dış ticaret, teknoloji düzeyi ve faktör donatımında söz konusu olan farklılıklardan kaynaklı olarak ortaya çıkmaktadır. Ticaret teorilerine özgü olan gravity modelinde üç temel ana faktör dikkate alınmaktadır. Bunlar, bir ülke ekonomisinin diğer ülke ekonomileriyle yaptığı ihracat ve ithalat büyüklüğü ve ticaret yoğunluğu derecesidir. Karşılıklı iki ülke arasındaki dış ticareti Gravity modeliyle ele alan çalışmalar Tinbergen (1962), Poyhonen (1963), Linnemann (1966), Anderson (1979), Bergstrand (1985), Helpman and Krugman (1985), Deadorff (1995), Evenett ve Keller (1998), Eichengreen ve Irwin (1998) gibi çalışmalar tarafından ele alınmış̧ır. Uluslararası ticari işlemlerde geçerli olan gravity modelinin genel formu (Paas, 2000, s. 12-18);

$$
X_{i j}=b_{0} Y_{i}^{b 1} Y_{j}^{b 2} N_{i}^{b 3} N_{j}^{b 4} D_{i j}^{-b 5} P_{i j}^{-b 6}
$$

şeklinde ifade edilebilir. Modelde yer alan;

$X_{i j}$ :i ülkesi ile j ülkesi arasında gerçekleşen ticaret akımını

$b_{0}:$ Sabit bir sayiy1

$b_{1,2,3,4,5,6}$ : geometrik ortalamaların ağırlıklı katsayısını

$Y_{i}$ ve $Y_{j}$ : sırasıyla i ve j ülkelerinin kişi başına düşen yurtiçi harcamalarını

$N_{i}$ ve $N_{j}$ : srrasiyla i ve j ülkelerinin nüfusunu

$D_{i j}$ :i ve j ülkeleri arasındaki coğrafi uzaklıktan kaynaklanan ticaret direncini

$P_{i j}$ :i ve j arasındaki ticareti etkileyen faktörlerini ifade etmektedir.

Bu çalışmada, Türkiye ekonomisinin seçilmiş BDT ülkeleri ile yaptı̆̆ı dış ticarette Linder Hipotezinin geçerli olup olmadı̆̆ının tespit edilmesinde, kullanılan çekim modeli olarak belirlenmesinde Paas (2000), Hallak (2010) ve Saygılı ve Manavgat (2014) gibi çalışmalarda yer alan modellerden faydalanılmıştır. Linder hipotezinin tespit edilmesinde kullanılan modeller aşağıdaki şekilde belirlenmiş̧ir.

Model 1:

$\operatorname{Ln}\left(E X_{i j t}\right)=\beta_{0}+\beta_{1} \operatorname{Ln}\left(Y_{i t}\right)+\beta_{2} \operatorname{Ln}\left(Y_{j t}\right)+\beta_{3} \operatorname{Ln}\left(\right.$ Dist $\left._{i j}\right)+\beta_{4} \operatorname{Linder}_{i j}+\beta_{5}$ Dborder $+\epsilon_{i j}$

Model 2:

$$
\operatorname{Ln}\left(I M P_{i j t}\right)=\beta_{0}+\beta_{1} \operatorname{Ln}\left(Y_{i t}\right)+\beta_{2} \operatorname{Ln}\left(Y_{j t}\right)+\beta_{3} \operatorname{Ln}\left(\text { Dist }_{i j}\right)+\beta_{4} \text { Linder }_{i j}+\beta_{5} \text { Dborder }+\epsilon_{i j}
$$

Denklemde yer alan;

$E X_{i j t}$ : $\mathrm{t}$ dönemde, Türkiye'nin (i) seçilmiş ticaret ortağı ülkelere (j) yaptı̆̆ ihracatı

$I M P_{i j t}: \mathrm{t}$ dönemde, Türkiye'nin (i) seçilmiş ticaret ortağı ülkelerden (j) yaptı̆̆ı ithalatı

$Y_{i t}$ : $\mathrm{t}$ dönemde Türkiye'nin gayrisafi milli hasıla (cari fiyatlarla satın alma gücüne dayalı -ABD doları cinsinden)

$Y_{j t}$ : t dönemde Türkiye'nin seçilmiş ticaret ortaklarının (j) gayrisafi milli hasıla (cari fiyatlarla satın alma gücüne dayalı -ABD doları cinsinden)

Dist $_{i j}$ : Türkiye ile ticaret ortakları arasındaki coğrafi boyuttaki fiziki uzaklık $\left(\mathrm{km}^{2}\right)$

Linderij: t dönemde, Türkiye ile dış ticaret yapan ülkeleri arasındaki kişi başına düşen gelir farkının mutlak değeri

Dborder: Türkiye (i) ile seçilmiş ülkeler (j) arasında sınır komşuluğu olması durumunda 1, olmaması durumunda 0 verilerek oluşturulan kukla değişkenini ifade etmektedir.

2001-2017 yılları arasının analiz edilmesi için kurulan modelde yer alan değişkenlerden, i ve j ülkelerine ait olan gayrisafi milli hasıla veri setleri Dünya Bankası'ndan, $t$ dönemde $i$ ve $j$ ülkeleri arasında gerçekleşen ihracat ve ithalatın verileri (milyon \$) Trade Map (https://www.trademap.org/Index.aspx), ülkelerin başkentleri arasındaki uzaklık ise https://www.timeanddate.com/ veri tabanından elde edilmiştir.

Çalışmada, Türkiye ekonomisi ile seçilmiş BDT ülkeleri arasında yapılan ticarette Linder hipotezinin geçerli olup olmadığının sınanmasında, panel regresyon yönteminden faydalanılmıştır. Panel regresyon yöntemleri, Sabit etkili ve Rassal etkili modeller olmak üzere iki şekilde ele alınmaktadır. Her iki modelde çeşitli varsayımlara dayanmaktadır. Bu varsayımlara bağlı olarak yapılan model seçimleri, yapılan tahminlerin doğru bir şekilde analiz edilmesi için oldukça önemlidir. Sabit etkiler modelinin en temel özelliği, tüm veri setlerini etkileyebilecek ortak bir etki büyüklüğünün söz konusu olmasıdır. Rassal etkili modellerinde ise ortak etki (gerçek) büyüklüğü çalışmadan çalışmaya farklılık göstermektedir. Sabit etkili model altında, ortak etki tüm çalışmalarda geçerli olan bir etki iken, rassal etkili modelde oluşan ortak etki, gerçek etkiler dağılımı ortalamasının bir tahminidir. Ayrıca Rassal etkili modellerde, ortak oluşan etkinin standart hatasının güven aralığı sabit etkili modelin güven aralı̆̆ına göre daha geniştir (Borenstein vd., 2010). 
Yapılan çalışmanın ilk aşamasında, Panel veri regresyon analizinde söz konusu olan rassal ve sabit etkili modelleri arasında tercih yapılması gerekmektedir. Kurulan model için uygun panel veri modelinin belirlenmesini amaciyla uygulanan test sonuçlar Tablo 4'de yer almaktadır.

\begin{tabular}{|c|c|c|}
\hline \multicolumn{3}{|c|}{ Model 1 } \\
\hline \multicolumn{2}{|c|}{$\boldsymbol{x}_{\mathbf{2}}$ Test İstatistiği } & Olasılık Değeri \\
\hline $\begin{array}{c}\text { Hausman Test (Birimler aras1 Cross } \\
\text { Section) }\end{array}$ & 0.41 & 0.938 \\
\hline F testi & 209.85 & 0.000 \\
\hline \multicolumn{2}{|c|}{ Model 2 } \\
\hline Breusgh -Pagan Testi LM & $\boldsymbol{x}_{\mathbf{2}}$ Test İstatistiği & 0.027 \\
\hline \multicolumn{2}{|c|}{0.69} & 0.150 \\
\hline $\begin{array}{c}\text { Hausman Test (Birimler aras1 Cross } \\
\text { Section) }\end{array}$ & 67.58 & 0.000 \\
\hline F testi & 3.71 & 0.054 \\
\hline
\end{tabular}

Tablo 4. Panel Veri Regresyon Modellerinin Belirlenmesi

F testi, belirlenen model için Klasik modelin geçerliliğini test etmek için kullanılmaktadır. Bu teste göre, eğer elde edilen bulgular çerçevesinde veri birimlere göre farklılık göstermiyorsa modelin tahmin edilmesi için Klasik modelin uygulanmasi gerekmektedir. Sinanacak hipotez;

$H_{0}=\beta_{i}=\beta$ şeklindedir.

Buna göre, sıfır hipotezinin kabul edilmesi kurulan modelin tahmini için Klasik modelin, Havuzlanmış En Küçük Kareler Yönteminin uygulanması gerektiğin göstermektedir (Yardelen Tatoğlu, 2012, s. 46-47). Tablo 1'de her iki model için uygulanan $\mathrm{F}$ testi bulguları yer almaktadır. $H_{0}$ hipotezinin red edilmesi, kurulan modelin tahmininde birim ve/veya zaman etkilerinin söz konusu olduğunu ve Klasik modellerin kullanılmaması gerektiğini göstermektedir.

Ayrıca uygulanan Breusgh-Pagan LM testi ile belirlenen modelin tahmininin yapılmasında, rassal etkiler modeli ile Klasik modeller arasında da tercih yapılmaktadır. Tablo 1'de elde edilen sonuçlar, her iki model için panel etkisinin var olması dolayısıyla $\mathrm{H}_{0}$ hipotezinin red edildiğini, diğer bir ifadeyle, klasik modeller yerine panel veri regresyon modelinin kullanılması gerektiğini göstermektedir.

Tablo 4'te Sabit ve Rassal Etkili modeller arasında tercih yapılmasını sağlayan ve "rassal etkiler tahmincisi doğrudur" sıfır hipotezine sahip olan Hausman testi sonuçları yer almaktadır. Elde edilen test sonuçlarına göre, Model 1 ve Model 2 için uygulanması gereken panel veri regresyon modeli, $\mathrm{H}_{\mathrm{o}}$ hipotezi kabul edildiğinden, rassal etkiler modelidir. Kurulan modelde yer alan değişkenler için yapılan tanımlayıcı istatistikler Tablo 5'de yer almaktadır.

\begin{tabular}{|c|r|r|r|r|r|r|}
\hline & \multicolumn{1}{|c|}{ Ortalama } & \multicolumn{1}{c|}{ Medyan } & \multicolumn{1}{c|}{ Maximum } & \multicolumn{1}{c|}{ Minimum } & Standart Sapma & Olasıllkk \\
\hline $\operatorname{Ln}(E X)$ & 1038901.0 & 603013.0 & 6964209.0 & 17350.00 & 1324601.0 & 0.0000 \\
\hline Ln(IMP) & 951776.4 & 533018.0 & 7272773.0 & 15773.00 & 1335694. & 0.0000 \\
\hline$Y_{i t}$ & 9020.714 & 10546.15 & 12542.72 & 3119.606 & 2934.711 & 0.0000 \\
\hline$Y_{i t}$ & 3720.186 & 2243.990 & 16007.09 & 308.4088 & 3586.742 & 0.0000 \\
\hline Linderij $_{\text {int }}$ & 5511.753 & 5561.529 & 11260.28 & 2.587343 & 2947.245 & 0.0195 \\
\hline Dist $_{i j}$ & 2436.556 & 2080.000 & 3990.000 & 967.0000 & 1052.066 & 0.0007 \\
\hline
\end{tabular}

Tablo 5. Tanımlayıcı Ístatistikler

Kurulan model için uygun olduğuna karar verilen panel veri regresyon modeli tahmin sonuçları Tablo 6'da yer almaktadir.

\begin{tabular}{|c|c|c|}
\hline & Model 1 & Model 2 \\
\hline $\mathrm{Yi}$ & $0.377^{* * *}$ & $0.526^{* * *}$ \\
\hline $\mathrm{Yj}$ & $0.906^{* * *}$ & $0.902^{* * *}$ \\
\hline LnDistij & -0.986 & -0.324 \\
\hline Linderij & $0.067 * *$ & $0.064^{* *}$ \\
\hline Dborder & 0.262 & 0.097 \\
\hline $\mathrm{c}$ & 2.855 & 3.185 \\
\hline $\mathrm{R}^{2}$ & 0.8070 & 0.8469 \\
\hline$\overline{R^{2}}$ & 0.8005 & 0.8417 \\
\hline F istatistiği & $122.97 * * *$ & $162.66^{* * *}$ \\
\hline
\end{tabular}

Tablo 6: Panel Veri Regresyon Sonuçları

Not: *,**,**, \%10, \%5 ve \%1 düzeyinde anlamlılı̆̆ ifade etmektedir. 
Yapılan teşhis testleri ile öncelikle belirlenen model için Klasik modellerin uygulanmasından ziyade panel etkisinin ortaya konulduğu panel veri regresyon modellerinin uygulanması gerektiği ortaya çıkmıştır. Buna bağlı olarak yapılan Hausman testi ile kullanılması gereken panel veri regresyon modelinin Rassal Etkiler modeli olduğuna karar verilmiştir. Her iki modeli oluşturan değişkenlere yapılan model belirleme testleri sonrasında belirlenen modele uygulanan Rassal Etkiler modeli bulgularında Linderij değişkeninin katsayısının pozitif ve istatistiki olarak anlamlı olması Türkiye ile seçilmiş ülkeler arasında yapılan dış ticarette Linder hipotezinin geçerli olmadığı sonucuna ulaşılmıştır. Bu durum, seçilmiş BDT ülkeleri ile Türkiye arasında gerçekleşen ticarette gelir farklılığının azalmasının herhangi bir etkisi bulunmadığını göstermektedir. İhracat ve ithalat değişkeninin bağımlı değişken olarak kabul edildiği sırasıyla Model 1 ve Model 2 için elde edilen bulgular, Türkiye ile dış ticaret yapan ve analize konu olan seçilmiş ülkelerin kişi başına kişi başına düşen gelir düzeyindeki bir artışı Türkiye ile bu ülkeler arasında gerçekleşen ihracat ve ithalat hacmini pozitif yönde etkilediğini ortaya koymaktadır. Ayrıca modelde yer alan bir diğer değişken olan LnDistij katsayısının negatif yönlü olması ikili ülkelerin başkentleri arasında azalan uzaklığın başka bir ifade ile azalan ulaştırma maliyetlerinin Türkiye ile yapılan ihracat ve ithalatı artırdığını ortaya koymaktadır. Ancak elde edilen bu katsayı istatistiki olarak anlamlı değildir.

\section{Sonuç}

$\mathrm{Bu}$ çalışmanın temel amacı, teorik ve ampirik modelleri çerçevesinde dış ticaret kuramında görece yeni ve popüler bir model olan Çekim Modeli aracılığıyla, Türkiye ile seçilmiş bazı geçiş ekonomileri arası dış ticaretin analiz edilmesidir. Benzer tercihlere ve gelir düzeyine sahip ülkeler arasında sanayi ürünleri ticaretinin daha fazla yapıldığı, diğer bir ifade ile zevk ve tercihleri birbirine benzer ülkeler arasında daha fazla ikili ticaret ilişkileri kurulduğu bilinmektedir. Teoride taleplerin ya da tercihlerin benzerliğini (Linder Hipotezi) ölçmede, ülkelerin kişi başına düşen yurtiçi harcamaları, ülke nüfus sayıları ve ülke ticaret merkezlerinin birbirlerine olan uzaklık mesafesi değişkenleri kullanılmaktadır. Özellikle kişi başına düşen yurtiçi harcamalar değişkenin ele alınmasının sebebi, talebin kişi başına gelire bağlı olması ve kişi başına gelir düzeyleri birbirine yakın olan ülkelerin taleplerinin de benzer olmasıdır. Çalışmamızda, 2001-2017 dönemi için Türkiye'nin seçilmiş geçiş ekonomileri ile olan dış ticaretinin Linder hipotezinin geçerliliği bağlamında panel çekim modeli ile analiz edilmesi amaçlanmıştır. Yapılan analizler; Türkiye ile dış ticaret yapan söz konusu seçilmiş ülkelerin kişi başına düşen gelir düzeyindeki bir artışın Türkiye ile bu ülkeler arasında gerçekleşen ihracat ve ithalat hacmini pozitif yönde etkilediğini ortaya koymaktadır. Ayrıca modelde yer alan bir diğer değişken olan LnDistij katsayısının istatiksel olarak anlamlı olmamakla birlikte negatif yönlü olması ikili ülkelerin başkentleri arasında azalan uzaklığın Türkiye ile yapılan ihracat ve ithalatı artırdığını ortaya koymaktadır. Elde edilen bulgular sonucunda Türkiye ile söz konusu ülkeler arasındaki dış ticaretin Linder hipotezini desteklemediği ve dış ticaretin endüstriler arası faktör donatımından kaynaklandığını söyleyebiliriz.

\section{Kaynakça}

- Andersson, J.E. “A Theoretical Foundation for the Gravity Equation” American Economic Review, Vol. 69 (1), 1979, pp. 106-116

- Arıca, F. (2014). “Türkiye’nin Dış Ticaret Potansiyelinin Genişletilmiş Linder Hipotezi Çerçevesinde Değerlendirilmesi: Bir Panel Data Analizi”, Doktora Tezi.

- Atik, H. (2006) “Tercihlerde Benzerlik Teorisi: Türkiye ve Bazı Komşu Ülkelerin Dış Ticareti Üzerine Bir Analiz”, Ankara Üniversitesi SBF Dergisi, Ankara, 33-44.

- Baldwin, R., E. (1971). "Determinants of the Commodity Structure of U.S. Trade", American Economic Review, 61, 126-46.

- Borenstein M., Hedges, L.V., Higgins, J.P.T \& Rothstein, H.R. (2010), A basic introduction to fixed-effect and random-effects models for meta-analysis,

- Borkakoti, J. (1998). "International Trade: Causes and Consequences”, London: Macrnillan.

- Bukhari, S., Ahmad, M., Alam, S., Bukhari, S., Butt, M. (2005). "An Empirical Analysis of the Linder Theory of International Trade for South Asian Countries", The Pakistan Development Review, Vol. 44, No. $3,(307-320)$.

- Carey. H.C., (1858). Principles of Social Science. J.B. Lippincott, Philadelphia. PA.

- Choi, C. (2002). "Linder Hypothesis Revisited", Applied Economics Letters, 9(9):601-605.

- Chow, P., Kellman, M. ve Shachmurove, Y. (1999). "A Test of the Linder Hypothesis in Pacific NIC Trade 1965- 1990”, Applied Economics, 31(2):175-182.

- Davis, D. ve Weinstein, D. (2001). "An Account of Global Factor Trade", American Eco-nomic Review, 91,1424-1453.

- Deadorff Alan V. "Determinants of Bilateral Trade: Does Gravity Work in a Neoclassical World?" NBER Working Paper, No 5377, Cambridge Mass.: National Bureau of Economic Research, 1995 
- Dura, C. (2000). "Yeni Dıș Ticaret Teoriler: Genel Bir Bakış”, E.Ü. İktisadi ve İdari Bilimler Fakültesi Dergisi, Say1:16, 1-16.

- Eichengreen Barry, Irvin Douglas A. "The Role of History in Bilateral Trade Flows” J.A. Frankel ed. The Regionalization of the World Economy, The University of Chicago Press, Chicago, London, 1998, pp.33-64

- Evenett Simon J., Keller Wolfgang “On Theories Explaining the Success of the Gravity Equation” NBER Working Paper, No W6529, Cambridge Mass.: National Bureau of Economic Research, 1998

- $\quad$ Francois, J. \& Kaplan, S. (1996). “Aggregate Demand Shifts, Income Distribution, and the Linder Hypothesis" Review of Economics and Statistics, 78(2):244-250.

- $\quad$ Greytak, D. \& Ukrist, T. (1990). "The Composition of Consumption and Trade Intensities: An Alternative Test of the Linder Hypothesis", Weltwirtschaftliches Archiv, Cilt: 126, Say1: 1, ss. 50-58.

- Hallak, J. C. (2004). "Product Quality, Linder and the Direction of Trade," NBER Working Paper, 10877.

- Hallak, J. C. (2010). A product-quality view of the linder hypothesis. The Review of Economics and Statistics, 92(3), 453-466.

- Hallak, J.C. (2006). “A Product-Quality View of The Linder Hypothesis”, IPC Working Paper Series, No 24.

- Hanink, D. M. (1988).“An Extended Linder Model of International Trade”, Economic Geography, Cilt: 64, Say1: 4, ss. 322-334.

- Hanink, D. M. (1990).“ Linder, Again”, Weltwirtschaftliches Archiv, Cilt: 126 Sayı:2, ss. 257-267.

- Heckscher, E. F. \& Ohlin, B. G. (1991). "Heckscher-Ohlin Trade Theory”, The MIT Press.

- Heckscher, E. F. (1950) The Effect of Foreign Trade on the Distribution of Income, In American Economic Association (Chapter No. 13).

- Helpman Elhanang, Krugman Paul R. "Market Structure and Foreign Trade” MIT Press, 1985

- Hirsch, Z. \& Lev, B.(1973) "Trade And Per Capita İncome Differentials: A Test Of The Burenstam-Linder Hypothesis", World Development, Cilt: 1, Say1: 9, ss. 11-17.

- İyibozkurt, E. (2001). "Uluslararası İktisat: Teori-Politika-Uygulama”, Ezgi Kitabevi Yayınlar, Bursa, 569 s.

- Kennedy, T. E., \& Richard, M. (1980). "Taste Similarity and Trade Intensity: A Test of the Linder Hypothesis for United States Exports", Weltwirtschaftliches Archiv, Cilt: 119, Say1: 1, ss. 84-96.

- Leontief, W. W. (1953). "Domestic Production and Foreign Trade: The American Capital Position Reexamined”, In J. Bhagwati (ed.) International Trade: Selected Readings. Middlesex, England. Penguin Books.

- Linder, S., B. (1961). “An Essay on Trade and Transformation”, Stockholm: Almquist and Ohlin, B. (1933). "Interregional and International Trade", Cambridge: Harvard University Press.

- Linnemann, H. (1966). “An Econometric Study of International Trade Flows” Amsterdam: North-Holland Publishing Company.

- $\quad$ Mcpherson, M. A., Michael, R. R., \& Margie, A. T., (2001)."International Trade and Developing Countries: An Empirical İnvestigation of The Linder Hypothesis", Applied Economics, Cilt: 33, Say1: 5, ss. 649-657.

- Nijcamp,P., \& Reggiani, A. (1992).“Interaction, Evolution and Chaos in Space”, Springer Verlag, Berlin.

- $\quad$ Paas, T. (2000). "Gravity approach for modeling trade flows between Estonia and the main trading partners", University of Tartu, Economics \& Business Administration Working Paper.

- Poyhonen, P. (1963). “A Tentative Model for Volume in Trade Between Countries Weltwirtschaftliches Arhiv, Vol. 90, pp.91-113

- Reilly, W.J., (1931). “The Law of Retail Gravitation”, Knickerbocker Press, New York.

- Samuelson, P. A. (1949). “International Factor Price Equalisation Once Again”, Economic Journal 59:234, 181-97.

- Saygili, F., \& Manavgat, G. (2014). Linder Hipotezi:“Türkiye'nin Dış Ticareti için Ampirik Bir Analiz”. Ege Akademik Bakış Dergisi, 14(2), 261-270.

- Tatoğlu, F. Y (2012). “ İleri panel veri analizi”, Beta Yayıncılık, İstanbul.

- $\quad$ Thursby, J. G. \& Marie, C.T. (1987)."Bilateral Trade Flows, the Linder Hypothesis, and Exchange Risk", The Review of Economics and Statistics, ss. 488-495.

- Timeanddate, (2019), https://www.timeanddate.com/

- Tinbergen, J.(1962). "Shaping the World Economy: Suggestions for an International Economic Policy", New York, Twentieth Century Fund.

- $\quad$ Trademap, (2019), https://www.trademap.org/Index.aspx 
- Travis, W. P. (1964). “The Theory of Trade and Protection”, Harvard University Press, Cilt 121, 255-296.

- Yıldız, Ş. \& Künü, S. (2018). “Türkiye ile BRICS Ülkeleri Arasındaki Dış Ticaret Potansiyelinin Linder Hipotezi Çercevesinde Değerlendirilmesi”, Kafkas Üniversitesi, İktisadi ve İdari Bilimler Fakülte Dergisi, Cilt:9, Say1:18, 599-612.

- Young, E.C.(1924). “The Movement of Farm Population”, Ithaca, N.Y., Cornell Agricultural Experiment Station Bulletin, no. 426.

\section{Notlar}

* Bu Çalışma, Türkiye Bilimsel ve Teknolojik Araştırma Kurumu (TÜBİTAK) 2211-A Yurt İçi Doktora Burs Programı tarafından desteklenmiştir.

* $\quad$ Bu çalışma Bu Çalışma, Çukurova Üniversitesi BAP Birimi SBA-2018-10768 numaralı proje tarafindan desteklenmiştir. 


\title{
Kapsayıcı Büyüme ve Küreselleşme: Türkiye Örneği Inclusive Growth and Globalization: The Case of Turkey
}

\author{
Ph.D. Candidate Zeynep Gizem Can (Çukurova University, Turkey) \\ Ph.D. Candidate Ufuk Can (Çukurova University, Turkey) \\ Prof. Dr. Harun Bal (Çukurova University, Turkey)
}

\begin{abstract}
This study aims to determine the relationship between inclusive growth and globalization. Since both concepts are multidimensional and do not directly related data on these concepts, an inclusive growth index is formed which covers sixteen different data with the help of principal component analysis. The globalization data are compiled from the KOF Swiss Economic Institute and the relationship between them is determined by Engle-Granger cointegration, Granger causality and ARDL bounds tests. Econometric findings show that inclusive growth has accelerated in the period between 1991 and 2015, that there is a long-term relationship with the inclusive growth index and the globalization index. This situation is contradictory with the conclusion that the causality relationship in the literature is towards global growth through inclusive growth. Information, social, economic and financial globalizations are directly related to economic performance, education, health and infrastructure investments and its funding conditions.
\end{abstract}

\section{Giriş}

Çağımıza yön veren yoksullukla mücadele, cinsiyet eşitsizliği, çocuk ölümlerinin azaltılması, anne sağlığının geliştirilmesi, evrensel ilköğretimin gerçekleştirilmesi, çevresel sürdürülebilirliğin sağlanması, temel ihtiyaçlara ve altyapıya erişim gibi konularda 147 ülkenin katılımıyla Eylül 2000'de Birleşmiş Milletler Milenyum Deklarasyonu imzalanmış, hedefler yukarıdaki başlıklar altında kategorize edilse de temelinde yoksulluk odaklı olan bu bildirge literatüre yoksulluğu gidermek için yeni bir kavram olan kapsayıcı büyümeyi eklemiştir. Daha sonra kapsayıcı büyüme kavramının kullanımı yaygınlaşmış, Ekonomik İşbirliği ve Kalkınma Örgütü (OECD) toplumun tüm katmanlarına refahlarını yükseltebilme imkanı yaratılmasını, parasal ve parasal olmayan tüm refah bileşenlerinin toplumda adaletle dağıtılmasını; Asya Kalkınma Bankası (ADB) ise ekonomik büyüme ile yaratılan firsatların herkese, özellikle de yoksullara mümkün olan en yüksek düzeyde ulaşmasını kapsayıcı büyüme olarak tanımlamıştır (Özütler, 2018). Özellikle yoksulların durumlarının iyileştirilmesinin yanı sıra ekonomik büyümenin dinamiklerinin toplumun refahı için eşit olarak dağıtılmasını önermesi nedeniyle kapsayıcı büyüme adil kazanç ile yoksulluğun ve eşitsizliğin ortadan kaldırılmasını ifade etmektedir (Son ve Ali, 2007). Kapsayıcı büyümeyi mutlak ve nispi olmak üzere iki şekilde tanımlayan Anand vd. (2013) mutlak tanım olarak, yoksullar için kişi başına düşen gayri safi yurtiçi hasıla (GSYİH) tutarı mutlak olarak yükseldiğinde; nispi tanım olarak ise, yoksulların ortalama geliri toplumun ortalama gelirinden yüzde olarak daha fazla arttığında söz konusu büyümeyi yoksuldan yana yani kapsayıcı büyüme olarak nitelemektedir.

Kapsayıcı büyümenin düzeyi ile doğrudan ilişki verinin bulunmaması ve kapsayıcı büyüme düzeyinin ölçümünün zor olmasına rağmen, literatürde farklı yöntemler kullanılarak bu ölçüm yapılmaya çalışılmaktadır. Pasha (2007) büyümenin kapsayıcılık derecesini belirlemek için yoksulluk büyüme esnekliğini hesaplamaktadır. Ali ve Son (2007) büyüme, eşitsizlik, erişilebilirlik ve sosyal koruma boyutlarını tek bir kapsayıcı büyüme ölçütüne indirgemekte ve toplumun firsatlara erişim ve eşitlikle ilgili gözlenebilecek firsat endeksi olarak insani gelişme endeksinin (HDI) kullanılmasını önermektedir. McKinley (2010) ekonomik büyümeyi, verimli istihdamı, iktisadi altyapı göstergelerini, gelir ve cinsiyet eşitliği göstergelerini, beşeri sermaye göstergelerini ve sosyal güvenlik göstergelerini belirlediği ağırlıklar çerçevesinde kullanarak kapsayıcı büyüme ile ilgili bir endeks oluşturmaktadır. Chaudhary ve Sadaf (2012) Asya Kalkınma Bankası'nın benimsediği metodolojiyi izleyerek kapsayıcı büyüme ile ilgili farklı endeksler geliştirilmekte, temel aldığı endekste ise büyümeyi, istihdam yaratmayı ve ekonomik altyapıya erişimde başarıyı \%50, aşırı yoksulluğu, ılımlı yoksulluğu, eşitsizliği ve cinsiyet eşitsizliğini azaltmadaki başarıyı \%25, temel sosyal korumayı sağlamadaki başarıyı \%10, insan yeteneklerini (sağlık, eğitim, su vb.) artırmada başarıyı da \%15 olarak ağırlıklandırmaktadır. Anand vd. (2013) büyümenin kişi başına düşen milli gelir ve dengeli dağılım bileşenlerini bir arada incelemeye olanak tanıyan sosyal mobilite ve yoğunlaşma eğrileri ile büyümenin kapsayıcılığını incelemektedir. Khan vd. (2016) büyüme, eşitsizlik, erişilebilirlik ve yönetimi Asya Kalkınma Bankası'nın önerdiği metodolojiyi ve ağırlıkları kullanarak tek bir kapsayıcı büyüme boyutuna indirgemektedir. Bocutoğlu (2017) ise 7 ana ve 15 alt ölçüt yardımı ile 112 devletin ekonomilerinin sürdürülebilirliğini ve kapsayıcılığını sorgulamaktadır. Literatürde yapılan çalışmalarda genellikle birden çok boyutu tek bir boyuta indirgeyen faktör ve temel bileşenler analizi gibi yöntemlerin ve mobilite eğrilerinin sıklıkla kullanıldığı görülmektedir.

$\mathrm{Bu}$ çalışmada McKinley (2010) çalışması baz alınarak kapsayıcı büyümenin boyutları belirlenmektedir. Ekonomik aktivite, eğitim, sağlık, altyapı, yoksulluk ve eşitsizlik boyutları altında belirlenen değişkenler tek bir boyuta indirgenerek kapsayıcı büyüme endeksi oluşturulmaktadır. Belirlenen boyutlar ile kapsayıcı büyüme 
arasında literatürde birçok çalışma bulunmaktadır. Kapsayıcı büyümenin eğitim boyutu ile ilgili olarak Barro ve Lee (1997), Lal (2005) ve Tilak (2007), sağlık boyutu ile ilgili olarak Brenneman ve Kerf (2002) ve Yeravdekar vd. (2013), altyapı boyutu ile ilgili olarak Sanchez-Robels (1998), Roller ve Waverman (2001), Estache vd. (2002), Calderon ve Serven (2004) ve Ali ve Yao (2004), Calderon ve Chong (2004), yoksulluk boyutu ile ilgili olarak Palanivel (2003) ve Osmani (2008), eşitsizlik boyutu ile ilgili olarak Pasha (2007), Lin vd. (2008) ve Ali ve Son (2007) literatürde yer alan çalışmalar arasında yer almaktadır.

Türkiye'de kapsayıcı büyüme kavramı özellikle son dönemlerde önem kazanmakta ve literatürde yapılan çalışma sayısı gitgide artmaktadır. Taşkın (2014) Türkiye'nin son on yıldaki GSYİH büyümesini kapsayıcılık açısından incelemekte ve Türkiye'de büyümenin 2002-2011 dönemi için kapsayıcı olduğunu göstermektedir. Bölgesel ve dönemsel gelişmelere odaklanıldığında, büyüme performansı açısından bölgeler arasında ve alt dönemlerde farklılaşmalar dikkati çekmekte, Türkiye'de kişi başına düşen GSYİH büyümesinde bölgeler arasında eşbütünleşme olduğu görülmektedir. Bocutoğlu (2017) Dünya Ekonomik Forumu'nun verileri kullanarak yaptığ çalışmasında, farklı gelir gruplarında yer alan D-8 İktisadi İşbirliği Örgütü ekonomilerinin sürdürülebilir kapsayıcı büyüme bakımından, bazı ölçütlerde Malezya, Türkiye, Endonezya ve İran istisnaları dışında, genel olarak ortalamanın altında bir performans gösterdiği sonucuna ulaşmaktadır. Özütler (2018) Türkiye için 1997-2016 döneminde çalışmasında kapsayıcı büyüme ile cari denge arasındaki ilişkiyi incelemekte, başarılı yönetildiklerinde ulusal ve global cari denge kadar güvenlik ve göç hareketleri gibi parametrelerin de sosyal refah, adalet ve toplumsal barışa katkı sunarak kapsayıcı büyümenin ekopolitiğini ve sosyal refah fonksiyonunu pozitif etkiledikleri tespit etmektedir.

Kapsayıcı büyümenin farklı tanımları ve boyutları arasında dikkat çeken ekonomik büyüme, eşitlik ve yoksulluk kavramlarında özellikle 1990 ve sonrası dönemde görülen ciddi yapısal kırılmaların en önemli sebeplerinden birisi olarak kapsayıcı büyümenin tüm bileşenlerini etkileyen küreselleşme görülmektedir. Mal ve hizmet, faktör ve finans piyasalarında ülkeler arasındaki entegrasyon sürecinin hızlanması olarak tanımlanan küreselleşme neoliberal iktisat politikalarıyla ilişkili görülse de, kökenleri daha eski dönemlere dayanmaktadır. Neoklasik iktisat görüşüne göre küresel entegrasyon etkin kaynak kullanımını ve karşılaştırmalı üstünlükler bakımından uzmanlaşmayı sağlayarak düşük gelirli kesimlerin bu durumdan daha fazla kazançlı çıkmasına yol açmaktadır (Wade, 2004). Küreselleşme ile özdeşleşen dış ticarette serbestleşme eğiliminin yarattığı büyümenin kapsayıcılığı ile ilgili olarak, Dollar ve Kraay (2002) toplumdaki en yoksul kesimlerin ortalama gelirlerindeki artış ile diğer gelir gruplarının ortalama gelirlerindeki artışın eşit olduğunu, Fields (1989) ve Ravallion (2002) ise küreselleşmenin yoksulların aleyhine olduğunu ifade etmektedir. Ayrıca, küreselleşme sonucunda çok uluslu şirketlerin uluslararası bir mal ve hizmet arzı ve işgücü ve sermaye talebi yaratarak sağlık, eğitim ve altyapı olanaklarının iyileştirilmesine ve gelirlerin yükselmesine yol açması büyümenin kapsayıcılığı ile küreselleşme ilişkisinin bir başka boyutunu belirtmektedir. Bununla birlikte, kapsayıcı büyümenin boyutları arasında yer alan ekonomik aktivitelerin, sağlık, eğitim ve altyapı harcamalarının artması ve eşitsizlik ve yoksulluğun azalmasının ülkeler arasındaki farklılıkları azaltarak küreselleşmeye olumlu katkıda bulunduğu görülmektedir. Bu nedenle bu iki endeks arasında karşılıklı etkileşim bulunmaktadır.

\section{Veri ve Metodoloji}

$\mathrm{Bu}$ çalışmada kapsayıcı büyüme kavramını inceleyebilmek için McKinley (2010) çalışması baz alınarak ekonomik aktivite, eğitim, sağlık, altyapı, yoksulluk ve eşitsizlik boyutlarının altında Türkiye için 1991-2015 dönemi için yıllık olarak derlenen veriler kategorize edilmektedir. Dünya Bankası veri tabanları içerisinden Dünya Kalkınma Göstergeleri (WDI) ve kurumların yayınlarını temel alarak tüm ülkeler için GİNİ endeksi hesaplayan Solt (2016) veri kaynakları olarak seçilmektedir. Sanayi ve hizmet sektörlerinde istihdam edilen nüfus yüksek verimliliği nedeniyle ekonomik ve kapsayıcı büyümenin unsuru olarak değerlendirilmektedir.

\begin{tabular}{|c|c|c|}
\hline Boyutlar & Değişkenler & Kaynaklar \\
\hline & Ekonomik Büyüme (EB) & Dünya Bankas \\
\hline $\begin{array}{l}\text { Ekonomik } \\
\text { Aktivite }\end{array}$ & $\begin{array}{l}\text { Sanayi (Sİ) ve Hizmetler (Hİ) Sektöründeki İstihdamların Toplam İstihdam İçerisindeki } \\
\text { Payları }\end{array}$ & Dünya Bankas \\
\hline Ĕ̈itim & $\begin{array}{l}\text { Toplam Nüfusun İlköğretim (IM), Ortaöğretim (OM) ve Yükseköğretim (YM) } \\
\text { Eğitimlerini Bitirme Oranları }\end{array}$ & Dünya Bankası \\
\hline Sağlık & $\begin{array}{l}1000 \text { Canlı İçerisinde Yenidoğan (YÖ), Bebek (BÖ) ve } 5 \text { Yaş Altı (BEÖ) Ölüm Oranları } \\
\text { Kişi Başı Petrol Tüketimi (PT) } \\
\text { Toplam Nüfusun Su Kaynaklarına Erişim Olanakları (SK) }\end{array}$ & Dünya Bankas \\
\hline Altyapı & $\begin{array}{l}\text { Toplam Nüfusun Sağlık Olanaklarına Erişim Olanakları (SO) } \\
\text { Toplam Nüfus İçerisinde İnternet Kullananların Oranı (IK) } \\
\text { Toplam Nüfus İçerisinde Mobil Telefon Kullananların Oranı (MT) }\end{array}$ & Dünya Bankas \\
\hline Yoksulluk & GİNİ Endeksi (GE) & Solt (2016) \\
\hline Esitsizlik & İsgücüne Katılımda Kadınların Erkeklere Oranı (KO) & Dünya Bankası \\
\hline
\end{tabular}

Tablo 1. Kapsayıcı Büyüme Veri Seti 
Farklı birimler cinsinden ifade edilen, 6 boyuttan ve 16 değişkenden oluşan veri seti analizlerin güvenirliğini etkilemesi nedeniyle bu çalışmada çok sayıda birbiriyle ilişkili değişkenlerin oluşturduğu veri setinin varyasyonlarını korumak ve boyutsallığını azaltmak amacıyla Temel Bileşenler Analizi (PCA) kullanılmaktadır. Pearson (1901) ve Hotelling (1933) çalışmalarında orijinal " $z$ " değişkenini oluşturan daha küçük bağımsız değişkenler veri setinin olabileceğini, ana bileşenlerin toplam varyansı maksimize edecek şekilde belirlenmesi gerektiğini belirtmektedir. Temel Bileşenler Analizinde, “ $p$ ” tane değişkenin oluşturduğu veri seti, aralarında ilişki olmayan " $k$ " sayıda temel bileşen ile ifade edilebilmektedir $(k \leq p)$. Bu sayede, aralarında yüksek otokorelasyon ilişkisi bulunma ihtimali yüksek olan değişkenlerin oluşturduğu veri setleri birbiriyle ilişkisi bulunmayan ve boyut olarak indirgenmiş verilere dönüşmektedir. Bartlett (1950) küresellik testi ve Kaiser-Meyer-Olkin (1974) örneklem uygunluk ölçütü yardımıyla veri setinin Temel Bileşenler Analizine uygunluğu belirlenerek, ekonomik aktivite, eğitim, sağlık, altyapı, yoksulluk ve eşitsizlik boyutları ile ilgili birbirinden bağımsız on altı değişkeni tek bir endekse indirgemek için temel bileşen ağırlıkları hesaplanmaktadır.

$$
\left(\begin{array}{c}
Y_{1} \\
Y_{2} \\
\vdots \\
Y_{n}
\end{array}\right)=\left(\begin{array}{c}
a_{11} X_{1}+a_{12} X_{2}+\ldots .+a_{1 n} X_{n} \\
a_{21} X_{1}+a_{22} X_{2}+\ldots .+a_{2 n} X_{n} \\
\vdots \\
a_{n 1} X_{1}+a_{n 2} X_{2}+\ldots . .+a_{n n} X_{n}
\end{array}\right)
$$

$Y_{i(1,2, \ldots, p)}$ parametreleri $p$ tane temel bileşeni ve $a_{i j(1,2, \ldots, p)}$ katsayıları $i$. temel bileşen için $j$. değişkenin ağırlığını ifade etmektedir. Temel bileşen ağırlıkları $a_{i j(1,2, . ., p)}$ sırasıyla toplam varyansa azalan biçimde katkı sağlayacak şekilde belirlenmektedir. Ayrıca, her bir bileşenin analizde yer alan tüm bileşenlerin doğrusal bir fonksiyonu olması, varyanstan arındırılıp standartlaştırılan temel bileşenlerin karelerinin toplamlarının bire eşit olması ve yeni belirlenen değişkenlerin ağırlıklarını değiştirerek varyansı arttırmanın mümkün olması aşağıda gösterilmektedir.

$\sum_{j=1}^{n} a_{i j}^{2}=1$

$\sum_{k=1}^{n} a_{i k}^{2} a_{j k}^{2}=0$

Temel bileşenlerin toplam varyansa analize giriş sıraları ile paralel olarak katkı yapmaları nedeniyle McKinley (2010) ve Khan vd. (2014) çalışmalarında değişkenler için belirledikleri ağırlıkların büyüklüklerine göre değişkenler sıralanmaktadır. Bu çerçevede, ekonomik büyüme ve istihdam ilk iki temel bileşeni oluşturmaktadır. Değişkenler ortalama değer çıkarıldıktan sonra standart sapmaya bölünerek standardize edilmektedir. Aynı birimle ifade edilen bu değişkenler Temel Bileşenler Analizi ile belirlenen normalize edilmiş ağırlıklar ile çarpılmakta ve oluşturulan endeks tekrar standardize edilerek ortalaması sıfır ve varyansı bir olan kapsayıcı büyüme endeksi elde edilmektedir. Endeksin pozitif değer alması kapsayıcı büyümenin hızlanmasını, negatif endeks değerleri ise kapsayıcı büyümenin yavaşlamasını göstermektedir. Daha sonra, kapsayıcı büyüme endeksi ile aynı birim cinsinden ifade edilebilmesi için KOF İsviçre Ekonomik Enstitüsü tarafından yayınlanan küreselleşme endeksi verileri standardize edilerek bu iki endeks arasındaki ilişki incelenmektedir. Küreselleşme endeksi de kapsayıcı büyüme endeksine benzer biçimde ekonomi, sosyal ve politika boyutlarını ve ticari, finansal, bilgisel, politik, sosyal küreselleşmeyi kapsamaktadır (Gygli, Haelg ve Sturm, 2018).

\section{Ekonometrik Bulgular}

Temel bileşenler analizi çerçevesinde belirlenen ağırlıklar aşağıda verilmektedir. Seçilen ağırlıklar oluşturulan endeksin ortalamasını sıfır, standart sapmasını bir yapacak şekilde normalize edilmiştir. Böylelikle ağırlıklar ilgili değişkendeki bir standart sapma değişikliğin endeks üzerinde standart sapma cinsinden etkisini göstermektedir. Temel bileşenler analizi yapılırken sadece birinci temel bileşen ağırlıkları dikkate alınmaktadır ve analiz Stata 14.2 yardımıyla yapılmaktadır.

\begin{tabular}{llll}
\hline Değişkenler & Ağırlıklar & Değişkenler & Ă̆ırlıklar \\
\hline EB & 0.0745 & BEÖ & -0.2796 \\
Sİ & 0.2634 & BÖ & -0.2816 \\
HI & 0.2782 & YÖ & -0.2805 \\
GE & -0.2761 & PT & 0.2774 \\
KO & 0.0279 & IK & 0.2743 \\
IM & 0.2594 & MT & 0.2789 \\
OM & 0.2639 & SK & 0.2851 \\
YM & 0.0719 & SO & 0.2849 \\
\hline
\end{tabular}

Tablo 2. Temel Bileşenler Analizine Göre Belirlenen Ă̆ırlıklar

Toplam varyasyonu birinci bileşen tek başına \% 76.22, ilk üç bileşen ise \% 91.57 oranında açıklamaktadır. Bartlett küresellik testi ve Kaiser-Meyer-Olkin örneklem uygunluk ölçütü değerlerinin sırasıyla $\chi^{2}=1218.448$ (0.000) ve 0.754 olması verilerin temel bileşenler analizine uygun olduğunu göstermektedir. Grafik 1 ile temel 
bileşenler analizi ile belirlenen ağırlıklar çerçevesinde oluşturulan kapsayıcı büyüme endeksi (KBE) ve küreselleşme endeksi (KE) gösterilmektedir. Gini endeksinin ağırlığı dışındaki diğer bütün ağırlıklar beklentilerle uyumludur, fakat Gini endeksindeki azalmanın gelirin daha eşitlikçi dağılmasına ve bunun da sermaye birikim sürecine zarar vererek ekonomik büyüme kanalıyla kapsayıcı büyümenin varyasyonundaki değişimi olumsuz etkileyebileceği düşünülmektedir.

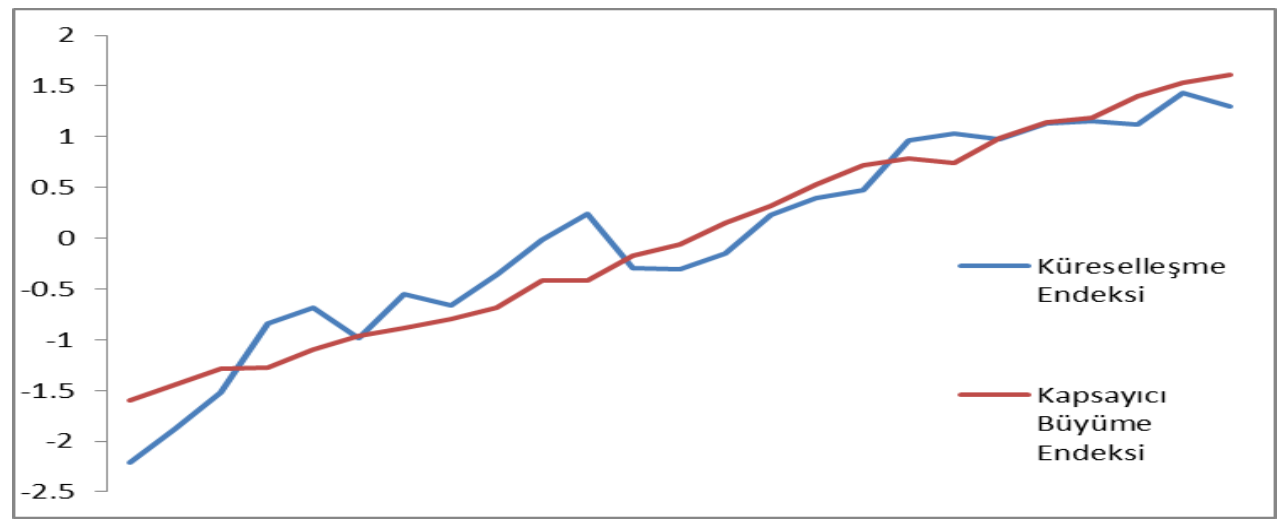

Grafik 1. Küreselleşme ve Kapsayıcı Büyüme Endeksleri

Türkiye'nin hızlanan bir kapsayıcı büyüme ve küreselleşme dönemi içerisinde olduğu ve her iki endeksin de benzer bir şekilde hareket ettiği görülmektedir. Ayrıca, bu iki endeks arasında çok yüksek korelasyon (0.953) bulunmaktadır. Endeksler arasındaki ilişkiyi inceleyebilmek için, öncelikle endekslerin durağanlık düzeyleri belirlenmektedir. Dickey ve Fuller (1979) tarafından formüle edilen Genişletilmiş Dickey-Fuller (Augmented Dickey Fuller, $A D F$ ) ve Kwiatkowski vd. (1992) tarafından geliştirilen Kwiatkowski-Phillips-Schmidt-Shin $(K P S S)$ testleri ile durağanlık sınamaları yapılmaktadır.

\begin{tabular}{llll}
\hline Testler & & KE & KBE \\
\hline \multirow{2}{*}{ ADF } & Sabit & $-4.774(0)$ & $-6.484(0)$ \\
& Sabit ve Trend & $-4.925(0)$ & $-6.345(0)$ \\
\multirow{2}{*}{ KPSS } & Sabit & $0.177(0)^{*}$ & $0.050(0)^{*}$ \\
& Sabit ve Trend & $0.052(0)^{*}$ & $0.049(0)^{*}$ \\
\hline
\end{tabular}

Tablo 3. Birim Kök Testi Sonuçları

Notlar: (1) ADF ve KPSS testlerinde \% 1 anlamlılık düzeylerinde kritik değerler sabit terim içeren modeller için, sırasıyla, 3.738 ve 0.739 iken, sabit ile birlikte trend içeren modeller için -4.394 ve 0.216 'dir. (2) Parantez içi değerler optimal gecikme sayısını temsil etmektedir. Maksimum gecikme sayısı 4 olarak alınmıştır. (3) * ve ** ve işaretleri, sırasılyla, boş hipotezin \% 1 anlamlılık düzeyinde reddedildiğini göstermektedir. KPSS testinde boş hipotez serinin durağan olduğunu belirtmektedir. (4) Testler EViews 10 yardımıyla yapılmaktadır.

Tablo 3 'te küreselleşme endeksi ve kapsayıcı büyüme endeksi serilerinin birinci fark durağan süreç olduğu belirlenmekte, farkı alınarak durağanlaştırılmaktadır. Daha sonra değişkenlerin düzey değerleri arasındaki ilişki tahmin edilerek, kalıntı serisi oluşturulmaktadır. Engle ve Yoo'nun (1987) tarafından önerilen ADF testi ile hata terimi serisinin durağanlığı test edilmekte, Granger (1969) tarafindan önerilen nedensellik testi ile iki seri arasındaki nedensellik ilişkisi belirlenmekte ve Pesaran, Shin ve Smith (2001) tarafından geliştirilen gecikmesi dağıtılmış otoregresif model (ARDL sınır testi) ile birlikte bu iki test çerçevesinde endekslerin eşbütünleşme ilişkisi araştırılmaktadır. Daha sonra, Akaike bilgi kriteri ile optimal gecikme uzunluğu belirlenerek ARDL sınır testi ile endeksler arasındaki uzun ve kısa dönemli ilişki ortaya konmaktadır.

Engle-Granger ve ARDL eşbütünleşme testi ile seriler arasındaki eşbütünleşme ilişkisi tespit edilmekte, Granger testi ile de nedenselliğin kapsayıcı büyüme endeksinden küreselleşme endeksine doğru olduğu belirlenmektedir. Tablo 4'te görüleceği üzere uzun dönemde kapsayıcı büyüme endeksinin istatistiksel olarak anlamlı olduğu ve beklentilerle uyuştuğu, ayrıca sabit terimin ve hata düzeltme katsayısının anlamlı olduğu görülmekte, kapsayıcı büyüme endeksinde yaşanacak şokların yaratacağı etkilerin küreselleşme endeksi tarafından yaklaşık iki dönemde absorbe edileceği belirlenmektedir. Katsayıların büyük ölçüde kararlı olduğu ve tanısal testler sonucunda otokorelasyon, model kurma, değişken varyans ve hata terimlerinin dağılımı ile ilgili herhangi bir problem olmadı̆̆ 1 belirlenmektedir. 


\begin{tabular}{llll}
\hline Test & Test İstatistiği & $\mathrm{KBE} \rightarrow \mathrm{KE}$ & $9.515(0.005)^{*}$ \\
Kalıntı ADF Testi & $-3.340(0)^{* *}$ & $\mathrm{KE} \rightarrow \mathrm{KBE}$ & $0.154(0.698)$ \\
\hline
\end{tabular}

Panel A. Engle-Granger Eşbütünleşme ve Granger Nedensellik Testleri

Notlar: (1) Kritik değerler Engle ve Yoo (1987) ve Granger (1969) çalışmasından alınmaktadır. (2) Engle-Granger eşbütünleşme testinde parantez içindeki değer Schwarz kriteri çerçevesinde belirlenen optimal gecikme uzunluğunu göstermektedir. Maksimum gecikme uzunluğu olarak 4 seçilmektedir. (3) Granger testinde VAR Modeli ile belirlenen optimal gecikme uzunluğu olan 1 seçilmektedir. (4) * işareti boş hipotezlerin \%1 anlamlılık düzeyinde reddedildiğini göstermektedir.

\begin{tabular}{cccccc}
\hline $\boldsymbol{p}$ & $\boldsymbol{S B C}$ & $\boldsymbol{X}_{L M_{(2)}(2)}^{2}$ & $\boldsymbol{X}_{L M_{(4)}}^{2}$ & $\boldsymbol{F}_{I}$ & $\boldsymbol{t}_{I}$ \\
1 & -2.389 & $3.24(0.20)$ & $8.22(0.08)$ & $7.689 * *$ & $-3.657^{* *}$ \\
\hline
\end{tabular}

Panel C: Panel B. ARDL Sınır Testi Çerçevesinde Seçilen Gecikme Uzunluğunun İstatistiksel Değerleri

Notlar: (1) $\boldsymbol{p}$ VAR modeli ile belirlenen gecikme uzunluğunu göstermektedir. (2) $\boldsymbol{S B C}_{\boldsymbol{p}}=\boldsymbol{L L}_{\boldsymbol{p}}-\boldsymbol{s}_{\boldsymbol{p}} / \mathbf{2}$ olarak hesaplanmaktadır. (3) $\boldsymbol{X}_{\mathbf{L M}}^{2} 2$ ve 4 gecikmede hata terimlerinin otokorelasyon problemi taşımadiğını sınayan LM istatistiğini belirtmektedir. (4) $\boldsymbol{F}_{\boldsymbol{I}}$ ve $\boldsymbol{t}_{\boldsymbol{I}}$ değerleri yalnızca kısa dönemde sabit terim içeren model tahminindeki $F$ ve $t$ istatistiğini yansitmaktadır. (5) [**] 0.05 alt sinırının üzerinde yer alan istatistik değerini ifade etmektedir.

\begin{tabular}{ll}
\hline Değişkenler & Katsayılar \\
KBE & $0.849^{*}$ \\
C & $0.252^{*}$ \\
D(KBE) & -1.466 \\
ECT & $-0.509^{*}$ \\
\hline
\end{tabular}

Panel C. ARDL $(1,1)$ Modeli Katsayllart

Notlar: (1) $\overline{\boldsymbol{R}}^{2}$ düzeltilmiş uyum ölçütünü, $\chi_{B P}^{2}, \boldsymbol{F}_{\boldsymbol{R}}, \chi_{J B}^{2}$ ve $\chi_{B P G}^{2}$ hata terimlerinin otokorelasyon (Breusch (1978) ve Godfrey (1978)), model kurma (Ramsey (1969)), normal dağılım (Jarque ve Bera (1980)) ve değişken varyans (Breusch ve Pagan (1980)) sinamaların ifade etmekte, [.] ise testlerin olastlık değerlerini göstermektedir. (2) * işareti \%1 kritik değerde boş hipotezin reddedildiğini göstermektedir. (3) Testler EViews 10 ile yapılmaktadır.

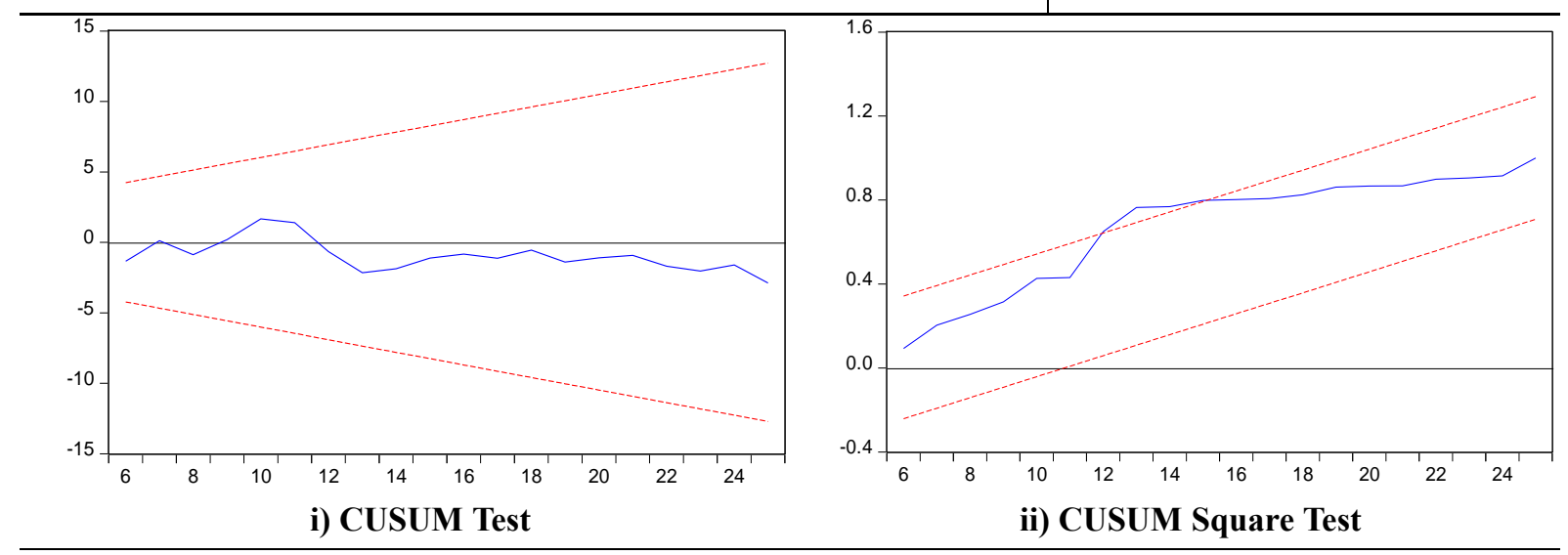

Panel D. Dură̆anlık Testi

Notlar: (1) CUSUM (Cumulative Sum of the Recursive Residuals) ve CUSUMQ (Cumulative Sum of Squares of the Recursive Residuals) testleri katsayıların durağanlığını test etmektedir.

Tablo 4. Eşbütünleşme, Nedensellik ve ARDL Sinır Testi Tahminleri

\section{Sonuç}

Bu çalışmada kapsayıcı büyüme ile küreselleşme arasındaki ilişkinin belirlenmesi amaçlanmaktadır. Her iki kavramın da çok boyutlu olması ve doğrudan bu kavramlarla ilgili verilerin var olmaması nedeniyle, öncelikle temel bileşenler analizi yardımıyla on altı farklı veriyi kapsayan kapsayıcı büyüme endeksi oluşturulmaktadır. Küreselleşme ile ilgili veriler ise KOF Enstitüsü'nden derlenmekte ve aralarındaki ilişki Engle-Granger eşbütünleşme, Granger nedensellik ve ARDL sınır testleri yardımıyla belirlenmektedir. 
Ekonometrik bulgular Türkiye'de 1991-2015 yılları arasını kapsayan süreçte kapsayıcı büyümenin hızlandığını, kapsayıcı büyüme endeksi ile küreselleşme endeksi ile uzun dönemli bir ilişsinin var olduğunu ve kapsayıcı büyümenin küreselleşmeyi olumlu etkilediğini göstermektedir. Bu durum literatürde nedensellik ilişkisinin küreselleşmeden kapsayıcı büyümeye doğru olduğu sonucu ile ters düşmekte, bunun nedenleri arasında ülkelerin büyümenin kapsayıcılığı için yaptıkları yatırımların iç ve dış finansmanın ekonomik ve finansal küreselleşme, eğitim, sağlık ve altyapı koşullarının iyileştirilmesinin politik ve bilgi küreselleşmesi ile doğrudan bağlantılı olduğu düşünülmektedir.

\section{Kaynakça}

- $\quad$ Ali, I., \& Son, H. H. (2007). Measuring Inclusive Growth. Asian Development Review, 24(1), 11.

- $\quad$ Ali, I., \& Yao, X. (2004). Pro-poor Inclusive Growth for Sustainable Poverty Reduction in Developing Asia: The Enabling Role of Infrastructure Development. ERD Policy Brief Series, (27).

- Ali, S., \& Ahmad, N. (2013). A Time Series Analysis of Foreign Aid and Income Inequality in Pakistan.

- Anand, R., Mishra, M. S., \& Peiris, S. J. (2013). Inclusive Growth: Measurement and Determinants (No. 13135). International Monetary Fund.

- Aschauer, D. A. (1989). Is Public Expenditure Productive?. Journal of Monetary Economics, 23(2), 177 200 .

- Barro, R. J., \& Lee, J. W. (1997). Determinants of Schooling Quality. Unpublished, Harvard University, March.

- Bartlett, M. S. (1950). Tests of Significance in Factor Analysis. British Journal of Statistical Psychology, 3(2), 77-85.

- Bocutoğlu, E. (2017) Kuruluşunun 20. Yılında Sürdürülebilir Kapsayıcı Büyüme Açısından D-8 İktisadi İşbirliği Örgütü Üye Devletlerinin Mevcut Durumu: Dünya Ekonomik Forumu Verileri İle Bir Değerlendirme.

- $\quad$ Brenneman, A., \& Kerf, M. (2002). Infrastructure \& Poverty Linkages. A Literature Review, The World Bank, Washington, DC.

- Breusch, T. S. (1978). Testing for Autocorrelation in Dynamic Linear Models. Australian Economic Papers, 17(31), 334-355.

- $\quad$ Breusch, T. S., \& Pagan, A. R. (1980). The Lagrange Multiplier Test and Its Applications to Model Specification in Econometrics. The Review of Economic Studies, 47(1), 239-253.

- Calderón, C., \& Chong, A. (2004). Volume and Quality of Infrastructure and the Distribution of Income: An Empirical Investigation. Review of Income and Wealth, 50(1), 87-106.

- Calderón, C., \& Servén, L. (2004). The Effects of Infrastructure Development on Growth and Income Distribution. The World Bank.

- Chaudhary, M. A., \& Sadaf, R. (2012). Poverty, Income Inequality and Inclusive Growth in Pakistan. University of Lahore.

- Dickey, D. A., \& Fuller, W. A. (1979). Distribution of the Estimators for Autoregressive Time Series with a Unit Root. Journal of the American Statistical Association, 74(366a), 427-431.

- Dollar, D., \& Kraay, A. (2002). Growth is Good for the Poor. Journal of Economic Growth, 7(3), 195-225.

- $\quad$ Engle, R. F., \& Yoo, B. S. (1987). Forecasting and Testing in Co-integrated Systems. Journal of Econometrics, 35(1), 143-159.

- $\quad$ Estache, A., Foster, V., \& Wodon, Q. (2002). Accounting for Poverty in Infrastructure Reform: Learning from Latin America's Experience. The World Bank.

- Fields, G. S. (1989). Changes in Poverty and Inequality in Developing Countries. The World Bank Research Observer, 4(2), 167-185.

- Godfrey, L. G. (1978). Testing against General Autoregressive and Moving Average Error Models when the Regressors Include Lagged Dependent Variables. Econometrica: Journal of the Econometric Society, 12931301.

- Gygli, S., Haelg, F., \& Sturm, J. E. (2018). The KOF Globalisation Index-Revisited. KOF Working Papers, 439.

- Hotelling, H. (1933). Analysis of a Complex of Statistical Variables into Principal Components. Journal of Educational Psychology, 24(6), 417.

- Jarque, C. M., \& Bera, A. K. (1980). Efficient Tests for Normality, Homoscedasticity and Serial Independence of Regression Residuals. Economics Letters, 6(3), 255-259. 
- $\quad$ Kaiser, M. O. (1974). Kaiser-Meyer-Olkin Measure for Identity Correlation Matrix. Journal of the Royal Statistical Society, 52, 296-298.

- $\quad$ Khan, A., Khan, G., Safdar, S., Munir, S., \& Andleeb, Z. (2016). Measurement and Determinants of Inclusive Growth: A Case Study of Pakistan (1990-2012). The Pakistan Development Review, 55(4 Part I \&), 455-466.

- $\quad$ Kwiatkowski, D., Phillips, P. C., Schmidt, P., \& Shin, Y. (1992). Testing the Null Hypothesis of Stationarity against the Alternative of a Unit Root: How Sure Are We that Economic Time Series Have a Unit Root?. Journal of Econometrics, 54(1-3), 159-178.

- Lal, M. (2005). Education-The Inclusive Growth Strategy for the Economically and Socially Disadvantaged in the Society. available online: dise. in/Downloads/Use\% 20of\% 20Dise\% 20Data/Meer\% 20Lal. pd.

- $\quad$ Lin, T., Zhuang, J., Yarcia, D., \& Lin, F. (2008). Income Inequality in the People's Republic of China and Its Decomposition: 1990-2004.

- McKinley, T. (2010). Inclusive Growth Criteria and Indicators: An Inclusive Growth Index for Diagnosis of Country Progress.

- Osmani, S. R. (2008). Achievements and Challenges of the Bangladesh Economy: An Overview. Emerging Issues in Bangladesh Economy, 1-23.

- Özütler, H. Ş. (2018). Kapsayıcı Büyümenin Kuramsal Çerçevesi Üzerine Bir Araştırma. Suleyman Demirel University Journal of Faculty of Economics \& Administrative Sciences, 23(4).

- Palanivel, T. (2003). Report of the Regional Workshop on Macroeconomics of Poverty Reduction.

- Pasha, A. K. (2007). India and West Asia: Past and Future. West Asia in Turmoil: Implications for Global Security, 441-70.

- Pearson, K. (1901). Principal Components Analysis. The London, Edinburgh, and Dublin Philosophical Magazine and Journal of Science, 6(2), 559.

- $\quad$ Pesaran, M. H., Shin, Y., \& Smith, R. J. (2001). Bounds Testing Approaches to the Analysis of Level Relationships. Journal of Applied Econometrics, 16(3), 289-326.

- Ramsey, J. B. (1969). Tests for Specification Errors in Classical Linear Least-squares Regression Analysis. Journal of the Royal Statistical Society. Series B (Methodological), 350-371.

- Ravallion, M. (2002). Have We Already Met the Millennium Development Goal for Poverty?. Economic and Political Weekly, 4638-4645.

- $\quad$ Roller, L. H., \& Waverman, L. (2001). Telecommunications Infrastructure and Economic Development: A Simultaneous Approach. American Economic Review, 91(4), 909-923.

- $\quad$ Sanchez-Robles, B. (1998). Infrastructure Investment and Growth: Some Empirical Evidence. Contemporary Economic Policy, 16(1), 98-108.

- Solt, F. (2016). The Standardized World Income Inequality Database. Social Science Quarterly, 97(5), $1267-$ 1281.

- Taskin, T. (2014). GDP Growth in Turkey: Inclusive or Not?/Türkiye'de GSYH Büyümesi: Kapsayı1 mı Değil mi?. Central Bank Review, 14(2), 31.

- Tilak, J. B. (2007). Inclusive Growth and Education: on the Approach to the Eleventh Plan. Economic and Political Weekly, 3872-3877.

- Wade, R. H. (2004). Is Globalization Reducing Poverty and Inequality?. International Journal of Health Services, 34(3), 381-414.

- Yeravdekar, R., Yeravdekar, V. R., Tutakne, M. A., Bhatia, N. P., \& Tambe, M. (2013). Strengthening of Primary Health Care: Key to Deliver Inclusive Health Care. Indian Journal of Public Health, 57(2), 59. 


\title{
İşsizlik ve Göç Arasındaki İlişki: OECD Ülkeleri Uygulaması (2008-2018)
}

\section{The Relationship Between Unemployment and Immigration: The Case of OECD Countries (2008-2018)}

\author{
Prof. Dr. Selahattin Sarı (Beykent University, Turkey) \\ Prof. Dr. Ahmet Ay (Selçuk University, Turkey) \\ Ph.D. Candidate Melike Köksal (Selçuk University, Turkey)
}

\begin{abstract}
In the broadest sense, immigration is defined as the change of places where people live, and it becomes a more complicated phenomenon when analyzed from the socio-economic, political and psychological aspects. The extent of the impact of migration in this context varies according to the conditions of each country, but it is also related to the number of migrants received and the many personal characteristics of immigrants, such as age, education level. Therefore, there is no unanimity on the subject in the literature. The total number of settled migrations of the 25 OECD countries in the last 10 years has been used. The effects of the migrants employed in the labor markets (registered) on the unemployment rates of the selected countries were investigated. The study period was selected as 2008-2018 years. The data was obtained from the OECD and World Bank databases. In this context, panel causality analysis was applied to investigate the short-term effects of the employed migrants on the unemployment rates of the selected countries. As a result of the analysis, in the short-term, no double or one-way relationship between unemployment and immigration was found. However, in the long run, the cointegration relationship between the variables was determined and the panel cointegration analysis revealed that long-term migration would affect unemployment in the same direction. So, according to the results of the analysis; for the countries examined, there is a long-term and similar relationship between unemployment and settled migrants who participate in labor force in the selected period.
\end{abstract}

\section{Giriş}

Ekonomik, siyasi ya da sosyal yönden incelendiğinde göç, hem göç eden ülke vatandaşlarının hem de göç alan ülke vatandaşlarının yaşamlarını her yönden etkilemektedir. Bu çalışmada göçün ekonomik etkileri incelendiği için, alınan göçün, bir makroekonomik gösterge olan iş gücü piyasaları üzerinde yarattığı kısa ve uzun dönemli etkilere de değinmek gerekir.

Tabi burada göç alan ülkelerin gelişmişlik ve refah düzeyleri önemlidir. Gelişmiş ülkelerin nüfus artış hızı az olduğu için genç iş gücüne daha fazla ihtiyaçları vardır. Gelişmiş ülkeler, sağladıkları bu genç iş gücü göçünün, eğitimle de destekleyerek, hem ülkelerinin hem de gelen göçmenlerin gelecek beklentileri adına doğru adımlar atmış olurlar. Diğer yandan gelişmiş ve gelişmekte olan ülke piyasalarının iş gücünü ise gelişmiş ülkelere oranla daha genç kesim oluşturmaktadır. Duruma böyle bakıldığında uluslararası iş gücü piyasalarında göç, göç alan ülkenin ekonomisine ve sosyal refahına faydalı olacağı gibi bireyler için de bir firsat olabilmektedir. Bunu firsata çevirmenin yolu, doğru bir şekilde yönetilmesidir. Bu doğru yönetim sağlanmazsa; piyasalarda ucuz iş gücü ön plana çıkarılırsa haksız rekabete sebebiyet vereceğinden toplum ve çalışan refahı için olumsuz bir durum olacaktır. Çünkü iş gücü göçünün temelinde; göçmenlerin göç ettikleri ülkede daha yüksek ücretlerle çalışma umutları vardır.

Diğer bir yandan küreselleşmenin iş gücü piyasalarına getirdiği teknolojik gelişme daha kaliteli üretim ve makineleşme, ülkelerin kendi içlerinde yaşadıkları işsizlik oranlarının artmasına sebep olmuştur. Bu çalışmada belirlenen 25 adet OECD ülkesindeki işsizlik ve göç ilişkisi incelenecektir. Çalışmanın birinci bölümünde göçün tanımlaması yapılmıştır. İkinci bölümünde; OECD ülkelerindeki göç ve işsizlik ilişkisinin incelendiği çalışmaların literatür taraması yer almıştır. Üçüncü ve son bölümde ise ampirik analize yer verilerek, analiz sonuçları tablolar yardımıyla yorumlanmıştır.

\subsection{Göçün Tanımlanması}

Göçün birçok alanda yer alması nedeniyle sosyoloji, psikoloji, ekonomi ve politika gibi alanlar kendilerine göre göç tanımlaması yapmışlardır. Bu yüzden göçün tanımlarken net bir çerçeve çizilemediği için literatürde dar ve geniş anlamda pek çok göç tanımı vardır. Bunlardan bazıları aşağıdaki gibidir.

OECD’ye göre göç: 'İnsanlık tarihinin vazgeçilmez unsurudur. İnsanların kendi ülkelerine kıyasla daha zengin (ama mutlaka “zengin” olması gerekmeyen) ülkelere taşınmasının hikayesidir' (OECD, 2009).

Uluslar Arası Göç Örgütü (IOM) 2015 raporuna göre göç tanımı, "Uluslararası bir sınırı geçerek veya devlet içerisinde yer değiştirmektir. Süresi, yapısı, nedeni ne olursa olsun insanların yer değiştirdiği nüfus hareketleridir. Buna mülteciler, yerinden edilmiş kişiler, yerinden çıkarılmış kişiler ve ekonomik göçmenler de dahildir” olarak yapılmıştır. 
Diğer bir tanımda göç, siyasi, dini, ekonomik, kültürel ve dini sebeplerden dolayı bir coğrafyadan diğerine yönelme işini olarak ifade edilir (Meral, 2016: 6).

Bir başka tanımda ise; sanayileşme ve küreselleşmenin etkileri sonunda topluluklar şeklinde ya da bireysel olarak sosyal, kültürel ve ekonomik açılardan daha rahat bir hayat yaşamak için ülke sınırlarında veya uluslararası sınırları aşarak gerçekleştirdikleri yer değiştirmedir. Bu yer değiştirme işi kimi zaman gönüllü kimi zaman zorunlu olarak meydana gelir (Akdoğan, 2019:6).

Yukarıda verilen göç tanımlarına ilaveten çalışmanın amacı gereği; yerleşik göçmen, mülteci ve sığınmacı kavramlarına da değinilmesi gerekmektedir. Bu bağlamda uluslararası hukukta; göçmen, 'mülteci tanımında bulunan nedenlerin dışında, çoğu zaman ekonomik gerekçelerle, ülkesini gönüllü olarak terk ederek başka bir ülkeye, o ülke yetkililerinin bilgi ve izni ile yerleşen kişidir'. Mülteci, 'vatandaşı olduğu ülke dışında olan ve ırkı, dini, tabiiyeti, belirli bir sosyal gruba mensubiyeti veya siyasi düşüncesi nedeniyle zulme uğrayacağından haklı sebeplerle korktuğu için vatandaşı olduğu ülkeye dönemeyen veya dönmek istemeyen kişiler' olarak tanımlamaktadır. Sığınmacı ise; 'mülteci statüsü almaya yönelik başvurularının hükümet ya da Birleşmiş Milletler Mülteciler Yüksek Komiserliği (BMMYK) tarafından karara bağlanmasını bekleyen kişiler' için kullanılır yani mülteci olarak uluslararası koruma arayan ancak statüleri henüz resmi olarak tanınmamış kişileri kapsar.

\subsection{Uluslararası Göç Kavramı ve Uluslararası Göçün Çeşitleri}

Uluslararası göç; dünyada meydana gelen değişim gelişmeler sonucunda uluslararası sınırlar boyunca yaptığı hareket olarak tanımlanabilir. Mülteciler, yerinden edilmiş halk gibi zaruri sebeplerden dolayı yaşadıkları yerleri değiştiren kesim de bu tanımın içerisinde yer almaktadır (Tokatlı, 2011: 21).

Uluslararası göçü incelerken gerçekleşen göçün zorunlu mu gönüllü mü olduğunun ayırdına varmak gerekir. Yukarıda da değinildiği üzere gönüllü göç, daha iyi imkanlarla hayat sürmek için yapılan yer değiştirme eylemidir. Zorunu göç ise savaş, doğal afet, hastalıklar ve gönü rızası olmadığı halde ülkesinden başka bir yerde yaşamaya mecbur edilmesi durumudur. Bu bağlamda uluslararası göç türleri aşağıdaki gibidir:

İlkel göç, ekonomik nedenlerle başa çıkılamaması sonucu meydana gelir. Cebri göç, şiddet, siyasi otorite veya daha güçlü bir grubun baskısı sonucu, bireylerin ve toplulukların zorunlu şekilde başka bölgelere göç etme suretiyle gerçekleşir. Zorunlu göç cebri göçe benzer gibi görünür ancak farklıdır. Burada şiddet ve sürgün söz konusu değildir. Etnik ve kültürel açıdan yakın iki ülkenin birey ve toplulukları (iradelerine dayalı şekilde) değiş tokuş etmeleridir. Grup göçü, zorunlu göçün aksine ülkeler arasında herhangi bir anlaşma bulunmadan, birey ve toplulukların uğradıkları baskıcı ve ayrımcı politikalar nedeniyle gerçekleşmektedir. Serbest göç, bireysel yapılan bir göç türüdür. Buradaki koşul, gidilmek istenen ülkenin kabul şartlarını sağlamaktır. Kabul edecek olan ülkenin temsilciliklerinin onay vermesinin ardından alınan "serbest göç vizesi”" ile gerçekleştirilmektedir. Mülteci göçü, bulundukları bölgede can güvenliği olmayan, baskı ve siyasi rejimle anlaşmazlığa maruz kalan bireyler ve toplulukların içinde bulundukları tehditten kaçmak için gerçekleştirdikleri göçtür. Geçici göç, işçi göçü kavramıyla aynı anlama gelmekle birlikte, göç eden birey ve topluluğa daimi ikamet statüsü kazdırmamaktadır. Belli bir zamanda belli bir süre ve belli bir amaçla gerçekleşir. Kalıcı göç geçici göçün tam zıttı olan göç türüdür. Göç eden birey ve topluluklara göç etikleri yerlerde sınırsız kalma hakkı tanır. Beyin göçü aldıkları eğitim ve kazandıkları tecrübeler sonucunda alanında uzman hale gelmiş bireylerin daha yüksek bir gelir seviyesi ve mesleki açıdan daha iyi bir konumda çalışmak istemeleri sonucunda gerçekleşmektedir (Çavuşoğlu, 2007:135).

\section{Uluslararası Göçün Gelişimi ve Nedenleri}

Uluslararası göçün temelinde ulus devlet yapısının kurulması yer almaktadır. Böylelikle ülkeler arasında sınırlar oluşturulmuştur. Özellikle II. Dünya Savaşı sonrasında devletlerinin birbirlerinin sınırlarından geçmeleri zorlaşmıştır. Uluslararası göç hareketliliğinin fazlalaşmasıyla yasal yollarla ülke sınırlarına giremeyenler yasal olmayan yollara başvurmaya başlamışlardır. $\mathrm{Bu}$ da devletlerin bu konuda yasal önlemler almalarına neden olmuştur (Kara, 2008:).

II. Dünya Savaşından sonra uluslararası göçün önemli bir unsuru olan mülteci hareketlere ilaveten sömürgeciliğin bitişiyle de 'ana' ülkelere doğru göç başlamıştır. Uluslararası göçün nedenlerini; ekonomik ve demografik, politik, sosyal ve kültürel olarak 3 ana başlıkta özetlenebilir. Ekonomik nedenler, göçün en büyük nedenlerinden biridir. İşsizlik oranının yüksek olması, gelecek kaygısı, yaşam kalitesini düşüklüğü, bireylerin düşük ücretleler çalıştırılmaları gibi sebeplerden kaynaklanmaktadır. Siyasal sebepler ise Orta Doğu örneğinde olduğu gibi siyasal istikrarsızlık sonucunda veya Balkanlar ve Kafkasya'nın birbirleriyle olan soğuk savaş1 sonrasında toplumsal refahın bozulmasından kaynaklı yaşanan göçlerdir. Siyasi sorunları sebep olduğu göçler genellikle mülteci akımları şeklinde gerçekleşir. Sosyal nedenlerin altında ise en bariz etken olarak bireylerin standartını arttırma isteği yatmaktadır. Son olarak demografik nedenler ise gelişmiş ülkelerde ki genç nüfusun nispeten daha az olması sebebiyle talep ettikleri emek arzıyla açıklanmaktadır (Çakırca, 2018:32).

\subsection{Uluslararası Göçü Açıklayan Teoriler}

Uluslararası göçün çıkışı ve sürekliliği ile ilgili genel bir teori olmamakla birlikte mevcut teoriler şu şekildedir:

1. Neoklasik göç kuramı 
Bu teoriye göre göç emeğin arz ve talebindeki ülkeler arasındaki farklılıklardan kaynaklanır. Ücret farklılıkları sonucunda yüksek ücretli ülkeler tercih edilir. Yani göç kararını alırken bireyler analiz yapar. Göç edilen yerde ki olumlu kazançlarla yeni alışkanlıklara adapte olmanın maliyetini kıyas ederek göç kararına varırlar (Tokatlı, 2001: 37).

2. Yeni göç ekonomisi teorisi

$\mathrm{Bu}$ yaklaşımda ise göç kararı sadece gelir seviyesini artırmak için değil aynı zamanda bazı riskleri de en aza indirgemek amaciyla bireysel tercihlerden ziyade aileler tarafindan alınmaktadır (Massey, vd: 1993, 436).

3. İlişkiler ağı teorisi

İlişkiler ağı teorisi; mevcut göçmenlerin bir süre sonra akrabalık ve dostluk ilişkileri ile yakın çevrelerinin de dahil olması üzerine kurulmuştur. Çünkü yeni bireyler için tanıdıkları birinin olduğu yere gitmek maddi ve manevi maliyet açısından daha düşük olacaktır (Abadan ve Unat, 2006: 34).

4. Dünya sistemleri teorisi

Göç kapitalizmin kaçınılmaz bir sonucudur. Yani kapitalist ülkelerin yüksek kar güdülemeleri ile kapitalist olmayan ülkelerden emek talebi etmesiyle göçün meydana geldiğini savunan teoridir (Gezgin, 1991: 48).

5. Parçalı emek piyasası teorisi

Göç edecek olan bireyler için göç kabul eden ülkelerin çekici ve itici faktörleri esastır. İtici faktörler mevcut durumdan tatmin olunmaması çekici faktörler ise başka yerlerde istenen koşullar ve tatminin sağlanacağı yönündedir. İtici ve çekici faktörlerin bir arada olması durumunda göç kuvvetlenecektir (Gözüm, 2017: 12).

\subsection{Uluslararası Göç ve İşgücü Piyasası}

On dokuzuncu yüzyıl sonları ve yirminci yüzyıl başları arasında dünyada büyük miktarda göç hareketleri gerçekleşmiştir. Dışa açık ekonomilerin bir getirisi olan uluslararası pazarlar, rekabeti artırarak ücret farklılıklarına ve emek gücü göçüne ortam hazırlamıştır.

Uluslararası Göç Örgütü(IOM) 2018 raporuna göre dünya genelinde 1990'da toplam 152.563.212 göç gerçekleşirken 2015'te bu rakam 243.700.236'a ulaşmıştır. Asya ve Avrupa 2015 yılından bu yana ayrı ayrı yaklaşık 75 milyon göçmen ağıllamışlardır. Bu toplam uluslararası göçün \%62'sine denk gelmektedir. 2. sırada Kuzey Amerika 54 milyonla, bu stoğun \%22'sini ve sırasıyla Afrika \%9, Latin Amerika \%4 olarak devam etmiştir.

Bu rakamların işgücü piyasalarına katılım oranları OECD verilerine göre bazı ülkeler için aşağıdaki gibidir:

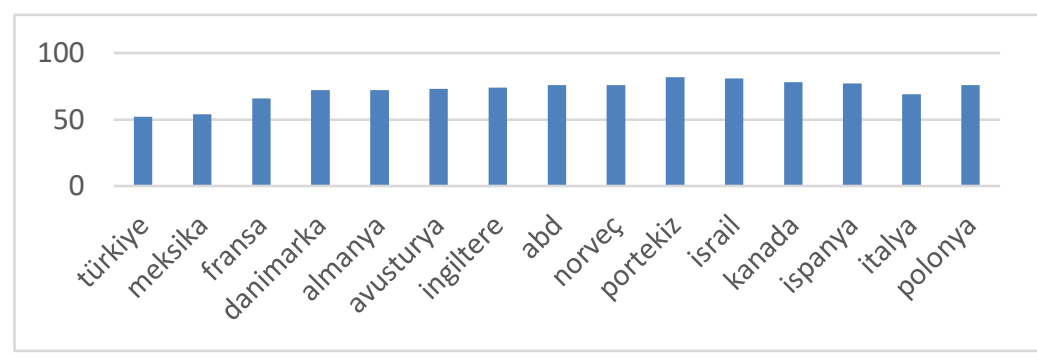

Tablo 1. Göçmenlerin İşgücüne Katıllım Oranları (2018)

Tablo 1'e bakıldığında 2018 yılı verilerine göre göçmenleri işgücüne katılım oranları oldukça yüksektir. Bu duruma göçmenler ve göç alan bölgeler açısından bakıldığında ortaya çıkan sonuçların olumlu ve olumsuz yanları sıklıkla tartı̧̧ılmaktadır. Yine IOM 2018 raporunda; yoğun göç alan ülkeler için, 2060'a kadar olan sürede işgücü becerisini teknolojiyle birleştirerek kullanmanın pozitif etkileri yanında nüfus artışıla ekonomilerindeki büyümenin eğitim kapasitesini ve şehirlerdeki alt yapı gereksinimlerini daraltacağına ve bu çerçevede yeterli kaynak sağlanmaması durumunda iş gücü piyasalar kadar sosyal hayatında etkileneceğine değinilmiştir.

\section{OECD Ülkelerinde Göç ve İşsizlik Arasındaki İlişki ve Literatür Taraması}

Göç ve işsizlik ilişkisinin literatür taramasına geçilmeden önce işsizliğin genel hatlarıyla tanımı aşă̆ıdaki gibi yapılmıştır.

İşsizlik; Uluslararası Çalışma Örgütü'ne (International Labour Office) göre üç unsurla ifade edilmiştir. Bunlardan ilki, İşi olmayan yani referans dönemde istihdam edilmeyen kısım, ikinci, iş arayan; son üç ay içerisinde iş arama kanalları aracılığıyla iş bulma girişiminde bulunan kısım ve üçüncü olarak da işe başlamaya hazır yani herhangi bir iş teklifi aldığında istihdam edilmeye hazır olan kısımdan meydana gelir.

OECD'ye göre ise işsizlik; son dört hafta içinde iş bulmak için aktif girişimlerde bulunan ve çalışmaya uygun olduğu halde iş bulamayarak, işgücünden dışlanan insanlar olarak tanımlanır. İşsizlik yaşı ise 15-64 olarak belirlenmiştir. 
Bu çerçevede, son 10 yılın OECD verilerine bakıldığında çalışmada ele alınan 25 ülkenin; yerleşik göçmenlerin istihdam oranları birbirine yakın seviyede devam etmiştir. Yine aynı yılların işsizlik oranlarıyla göçmenlerin istihdam oranlarının karşılaştırıldığında, alınan göçlerin işsizlik oranları üzerindeki etkileri fark edilmektedir. Ancak literatürde böyle bir etki olup olmadığı, var ise hangi yönde olduğu ile alakalı çeşitli görüşler vardır. Bu görüşlerden bazıları aşağıdaki gibidir.

\begin{tabular}{|c|c|c|c|}
\hline Yazar & $\begin{array}{l}\text { Ülke/ülkeler } \\
\text { alınan dönem }\end{array}$ & Yöntem & Analiz Sonucu \\
\hline Shan (1999) & $\begin{array}{l}\text { Avustralya ve yeni } \\
\text { Zelanda }\end{array}$ & VAR & İlişkisi bulunamamış. \\
\hline Bonin (2005) & $\begin{array}{l}\text { Alman ya } \\
1975-1997\end{array}$ & Panel Analizi & Göç işsizliği artırmaz. \\
\hline $\begin{array}{lll}\text { Jean ve Jimenez } \\
(2007)\end{array}$ & $\begin{array}{l}\text { OECD } \\
1984-2003 \\
\end{array}$ & $\begin{array}{l}\text { GMM (Generalized } \\
\text { Method of Moments) }\end{array}$ & $\begin{array}{l}\text { Göçün uzun dönemde işsizlik } \\
\text { üzerine etkisi yoktur. }\end{array}$ \\
\hline Feridun (2008) & $\begin{array}{l}\text { İsviçre } \\
1980-2004\end{array}$ & ARDL & İşsizlik göçün nedenidir. \\
\hline $\begin{array}{l}\text { Baubtane, Coulibaly, } \\
\text { Rault (2011) }\end{array}$ & $\begin{array}{l}22 \text { OECD ülkesi } \\
1980-2005\end{array}$ & $\begin{array}{l}\text { Granger Nedensellik } \\
\text { Testi }\end{array}$ & İlişki bulunamamıştır. \\
\hline Fromentin (2013) & $\begin{array}{l}\text { Fransa } \\
1970-2008\end{array}$ & VECM & $\begin{array}{l}\text { Uzun dönemde göç işsizliği } \\
\text { etkilemiştir. }\end{array}$ \\
\hline $\begin{array}{l}\text { Avila ve Bacarezza } \\
(2016)\end{array}$ & $\begin{array}{l}\text { ABD } \\
2001-2013\end{array}$ & Logit model & Kısa dönemde göç işsizliği artırır. \\
\hline $\begin{array}{ll}\text { Blanchflower } & \text { ve } \\
\text { Shadforth }(2017) & \end{array}$ & $\begin{array}{l}8 \text { AB ülkesi } \\
1971-2004\end{array}$ & Korelasyon Analizi & İlişki bulunamamıştır. \\
\hline $\begin{array}{l}\text { Esposito, Stefan ve } \\
\text { Sergio (2019) }\end{array}$ & $\begin{array}{l}15 \text { EU ülkesi } \\
1997-2016\end{array}$ & Panel ECM & Kısa dönemde göç işsizliği azaltır. \\
\hline
\end{tabular}

Tablo 1. Literatür Taramasl

\section{4 İşsizlik ve Göç Arasındaki İlişkinin Veri Seti ve Değişkenlerin Tanımlanması}

Bu çalışmada işsizlik ve göç ilişkisi seçilen 25 adet OECD ülkesi üzerinde incelenmiştir. Ekonomik yönden farklılık gösteren ülkelerin seçilmesi analizin sonucunu ve yorumunu etkileyeceği için. Söz konusu farklılık özellikle gözetilmiştir. Ülkeler analiz sıralarına göre; Avusturya, Avustralya, Belçika, Kanada, Şili, Danimarka, Finlandiya, Fransa, Almanya, Yunanistan, Macaristan, İsrail, İzlanda, İtalya, Lüksemburg, Meksika, Yeni Zelanda, Portekiz, Norveç, Polonya, Çek Cumhuriyeti, Türkiye, ABD, İspanya ve Estonya şeklindedir. Söz konusu ülkelere uygulanacak panel analizinde kullanılan verilerde göçün tanımlanmasında; seçilen ülkelerdeki toplam istihdam edilen nüfusun içindeki göçmenlerin oranları, işsizliğin tanımlanmasında ise ülkelerin yıllık işsizlik oranları kullanılmıştır. Veriler bir önceki yıla göre değişim yüzdesi şeklinde hesaplanarak, verilerin elde edilmelerinde OECD ve Dünya Bankası veri tabanlarından faydalanılmıştır.

\subsection{Yöntem}

Panel veri analizi, zamanlara göre yatay kesit verilerini kullanarak ekonomik ilişkileri tahmin etme yöntemidir. Bu bağlamda panel veri analizinin özelliği zaman serileri ve yatay kesit verilerinin bir arada kullanılmasıdır. Yatay kesit verilerine dayalı çalışmalarda sadece ekonomik birimlerin farklılıkları ortaya koyulurken, panel veri analizlerinde hem ekonomik birimler hem de zaman içinde meydana gelen değişimler ortaya koyulmaktadır. Ayrıca panel veri analizinde zaman serileri ve yatay kesit serilerine ait daha karmaşık modeller kurulabilmekte ve sonuçları daha kapsamalı, kesin ve gerçekçi olması sağlanmaktadır (Hsiao, 2003).

Panel veri yöntemini tercih etmenin avantajları Baltagi tarafından şöyle özetlenmiştir;

1.) Heterojenliğin kontrol edilmesi.

2.) Veriler hakkında daha fazla bilgiye, serbestlik derecesine ve etkinliğe ulaşılabilirken bunun sonucu olarak söz konusu değişkenler arasında daha az eş-doğrusallık sorunuyla karşılaşılmaktadır.

3.) Bu yol, etkilerin ölçülmesi ve tanımlanmasında zaman serisi ya da yatay kesit verilerine göre daha faydalıdır ve dinamik ayarlama yapmaya daha uygundur (Baltagi, 2005).

Özetle; Panel veri modellerinde; birimlerin eşit varyanslı olduğu (homoskedasite) ve birimler arasında korelasyon barındırmadı̆̆ı varsayımlarına dayanmaktadır. 
Ayrıca zaman serisi veya yatay kesit veri analizlerinde, bağımsız değişkenler tarafından gözlemlenemeyen birimlerin farklı özellikleri hata terimi içinde gösterilirken, panel metodunda ise her birim için ayrı ayrı sabit terimler tanımlanarak, bahsi geçen farklı özellikler hata teriminden ayrılmaktadır

Panel verilerinin basit yazılımı aşağıdaki gibidir:

$$
\begin{aligned}
& \mathrm{Y}_{\text {it }}=\alpha_{\mathrm{i}}+\beta \mathrm{X}_{\mathrm{it}}+\varepsilon_{\text {it }} \\
& \mathrm{i}=1, \ldots \ldots \ldots \ldots \ldots, \mathrm{N}
\end{aligned}
$$$$
\mathrm{t}=1, \ldots \ldots \ldots \ldots \ldots, \mathrm{T}
$$

Modelde; i hane halkı, bireyler, firmalar, hane, ülkeleri ifade ederken, t zamanı ifade etmektedir. Aynı zamanda $\mathrm{i}$ indisi yatay kesit boyutunu belirtirken, $\mathrm{t}$ indisi zaman serisi boyutunu belirtmektedir. Bireysel etkiyi gösteren $\alpha \mathrm{i}$; $\alpha, \mathrm{t}$ zaman ve i yatay kesitine özgü bireysel etkileri içeren sabittir.

Bu bilgilere göre çalışmada kullanılacak olan model aşağıdaki gibidir:

Analizde; göç: Mig ve işsizlik: Unp şeklinde yer almıştır. Tahmin edilecek model ise şekildedir:

$\mathrm{Unp}=\alpha+\beta_{\text {it }} \mathrm{Mig}+\mu_{\mathrm{it}}$

Burada i yatay kesit sayısını, t zamanı ve $\alpha$ ise sabit terimi göstermektedir.

Panel veri analizine durağanlık testleri ile başlanacaktır. Durağanlık analizi birim kök testleri yardımıyla gerçekleştirilmekte olup, panel metodu için birim kök testleri iki grupta incelenir. Bunlardan birincisi, birimler arasında korelasyon etkisinin olmadığını söylerken diğeri birimler arasındaki korelasyonun var olduğundan yanadir.

\subsection{Birim Kök Analizi}

Yukarıda da bahsedildiği üzere 2 grupta incelenen durağanlık sınaması, bu çalışmada birinci gruba göre test edilmiştir. Yani, genelleştirilmiş Dickey Fuller dinamik sabit etkiler modeli panel analizine uygun şekilde genişletilmiştir. Panel analizindeki değişkenlerin bazıları durağanken bazılarının durağan olmama durumuyla karşılaşılabilir. Bu da heterojenliğe yol açacaktır (Gujarati, 2006).

Panel veri analizine başlanmadan önce serilerin durağan olup olmadığına bakılır çünkü durağan olmayan serilerle yapılan çalışmalarda t istatistikleri anlamlı görünerek sahte regresyon sorununa neden olabilir (Sevüktekin ve Nargeleçekenler, 2005).

Durağanlık kavramı; serilerin zaman içerisinde ortalamasının ve varyansının sabit kalması durumudur şeklinde açıklanabilir. Durağanlık sınaması birim kök testleriyle gerçekleştirilmektedir. Birim kök sınamasına ait hipotezler şu şekildedir;

$\mathrm{H}_{0}$ : Seri birim kök içermektedir (Durağan değildir).

$\mathrm{H}_{1}$ : Seri birim kök içermemektedir (Durağandır).

Çalışmada kullanılan ve en yaygın birim kök testi olan Augmented Dickey Fuller Test (ADF) sonuçları aşağıdaki gibidir.

\begin{tabular}{|c|c|c|c|c|c|}
\hline \multicolumn{6}{|c|}{ Level } \\
\hline Yöntem & Değişken & T ist. & Olasılık* & Kesit Sayıs1 & Gözlem Sayıs1 \\
\hline \multirow{2}{*}{$\begin{array}{c}\text { Levin, Lin ve } \\
\text { Chu }\end{array}$} & Mig & -1.05835 & 0.1449 & 25 & 225 \\
\cline { 2 - 6 } & Unp & 0.59045 & 0.7226 & 25 & 225 \\
\cline { 2 - 6 } & \multicolumn{6}{|c|}{ Null: Unit root (assumes invidual unit root process) } \\
\hline \multirow{7}{*}{$\begin{array}{c}\text { ADF- Fisher } \\
\text { Cgi Square }\end{array}$} & Mig & 50.0623 & 0.4709 & 25 & 225 \\
\cline { 2 - 6 } & Unp & 37.9489 & 0.8944 & 25 & 225 \\
PP- Fisher & Mig & 67.8687 & 0.0470 & 25 & 225 \\
\cline { 2 - 6 } & Unp & 59.5714 & 0.1666 & 25 & \\
\hline
\end{tabular}

Tablo 2. Level Değerleri İle Panel Birim Kök Analizi Sonuçları

Tablo 2'de yer alan Levin, Lin Chu ve Fisher ADF, PP birim kök testlerinin sonuçları birbirlerine yakındır. Testler sonucunda değişkenlerin durağan olmadığı sonucuna karar verilmiştir. Değişkenlerin durağan hale gelmesi için birinci farklarını ya da logaritmik değerlerinin alınması gerekmektedir.

\section{Panel Veri Analizi}

Panel veri analizi, sabit (fixed) etki ve tesadüfi (random) etki modeli olmak üzere iki çeşit model önerir. Sabit etki modelinde, birimlerin farklılıkları sabit terime yansır ve sabit terim birimler için farklı değerler alır. Tesadüfi etkili modelinde ise bağımsız değişken ve hata terimi arasında bir ilişki olmadığı be bağımlı değişkeni etkileyen, ancak modelde yer almayan faktörlerin varlığına işaret eder (Ar1 ve Özcan, 2011). 
Analiz için uygun olan modelin, sabit etki modeli mi yoksa tesadüfi etki modeli mi olduğunu belirlemek için de Hausman Testi kullanılır. Hausman testi için hipotezler şu şekildedir:

$\mathrm{H}_{0}$ : Tesadüfi etki modeli uygun

$\mathrm{H}_{1}$ : Sabit etki modeli uygun

Bu çerçevede yapılan testler aşağıdaki tabloda yer almıştır.

\begin{tabular}{|c|c|c|c|c|}
\hline Değişken & \multicolumn{4}{|c|}{ Sabit Etki Modeli } \\
\hline $\mathrm{C}$ & Coefficients & Std. Error & t-ist. & Prob \\
\hline Mig & 17.74975 & 3.45864 & 5.13199 & 0.0000 \\
\hline R-squared & \multicolumn{4}{|c|}{0.771534} \\
\hline Prob (F-Statistic) & \multicolumn{4}{|c|}{0.000000} \\
\hline
\end{tabular}

\begin{tabular}{|c|c|c|c|c|}
\hline Değişken & \multicolumn{4}{|c|}{ Tesadüfi Etki Modeli } \\
\hline $\mathrm{C}$ & Coefficients & Std. Error & t-ist. & Prob \\
\hline Mig & 14.77277 & 3.16756 & 4.66376 & 0.0000 \\
\hline R-squared & \multicolumn{4}{|c|}{0.020007} \\
\hline Prob (F-Statistic) & \multicolumn{4}{|c|}{0.018938} \\
\hline
\end{tabular}

Tablo 3. Fixed ve Random Etki Sonuçlarl

Tablo 3 'te sabit ve tesadüfi etki sonuçlarına yer verilmiştir. Bu doğrultuda Hausman testine de bakıldıktan sonra, analiz için hangisinin uygun olduğuna karar verilecektir. Hausman testi aşağıdaki gibidir.

\begin{tabular}{|c|c|c|}
\hline Test Summary & Chi-statistic & Olas1lik \\
\hline Cross-section Random & 3.688641 & 0.0548 \\
\hline
\end{tabular}

Cross- section random effects test comparisons:

\begin{tabular}{|c|c|c|c|c|}
\hline Değişken & Sabit & Tesadüfi & Var(diff) & Olasılık \\
\hline Mig & -0.141235 & -0.100441 & 0.000451 & 0.0584 \\
\hline
\end{tabular}

Tablo 4. Hausman Test Sonuçlarl

Tablo 4'te ki sonuçlara bakıldığında, kurulan hipotezlerden tesadüfi etkini uygun olduğunu söyleyen $\mathrm{H}_{0}$ hipotezi reddedilmiştir. Sabit etki modelinin uygunluğunun belirlenmesiyle değişkenler arasındaki uzun dönemli ilişkilerin tespitinin yapıldığı eş bütünleşme analizine geçilecektir. Bu çerçevede çalışmanın amacını doğrultusunda ülkelere göçmen olarak gelen ve istihdam edilen göçmenlerin uzun dönemde işsizlik üzerine etkide bulunup bulunmayacakları araştırılacaktır.

\subsection{Eş Bütünleşme Analizi}

Panel veri analizinde uzun dönemli ilişkilere bakılmak için kullanılan Kao eş bütünleşme analizi denklemi aşağıdaki gibidir:

Kao testi, bireysel sabit varken Schwarz kriteri ve uzun dönem varyansı bulmak için kullanılır. Kao modeli aşağıdaki gibidir:

$\mathrm{Y}_{\mathrm{it}}=\beta^{\prime} \mathrm{X}_{\mathrm{it}}+¥^{\prime} \mathrm{Z}_{\mathrm{it}}+\mu_{\mathrm{it}}$

Ve hata terimi üzerinden:

$\hat{\mathrm{e}}_{\mathrm{it}}=\partial \hat{\mathrm{e}} \mathrm{i}_{\mathrm{t}-1}+\mathrm{V}_{\mathrm{it}}$

Burada test edilen hipotezler de:

$\mathrm{H}_{0}$ : Eş bütünleşme ilişkisi yoktur

$\mathrm{H}_{1}$ : Eş bütünleşme ilişkisi vardır şeklindedir ve aşağıdaki tabloda eş bütünleşme testi sonuçları yer almaktadır. 


\begin{tabular}{|c|c|c|c|c|}
\hline \multirow{2}{*}{\multicolumn{3}{|c|}{ ADF }} & t-Statistic & Prob. \\
\hline & & & -3.844526 & 0.0004 \\
\hline \multicolumn{3}{|c|}{ Residual variance } & \multicolumn{2}{|c|}{1.884625} \\
\hline \multicolumn{3}{|c|}{ HAC variance } & \multicolumn{2}{|c|}{2.350070} \\
\hline \multicolumn{3}{|c|}{ Augmented Dickey-Fuller Test Equation } & & \\
\hline Variable & Coefficient & Std. Error & t-Statistic & Prob. \\
\hline RESID(-1) & -0.270661 & 0.031572 & -8.572769 & 0.0000 \\
\hline $\mathrm{D}(\operatorname{RESID}(-1))$ & 0.449495 & 0.036777 & 12.22220 & 0.0000 \\
\hline
\end{tabular}

Tablo 5. Eş Bütünleşme Testi Sonuçlarl

Tablo 5'in olasılık değerine bakıldığında anlaşılacağı üzere, bu çalışma için, söz konusu ülkelerde, seçilen dönem aralığı itibariyle göç ve işsizlik arasında uzun dönemli bir ilişskiden bahsetmek mümkündür. Yani uzun dönemde istihdam edilen göçmen sayısının değişimine bağlı olarak, işsizlik oranları da aynı yönde değişiklik gösterecektir. Değişkenler arasında uzun dönemli bir ilişkinin tespitinden sonra, şimdide bu değişkenler arasında nedensellik ilişkisinin olup olmadığına ve eğer bir nedensellik ilişkisi varsa hangi yönde olduğuna bakılacaktır.

\begin{tabular}{|c|c|c|}
\hline Null Hypothesis: & F-istatistik & Olasılık \\
\hline Unp granger nedeni değildir Mig. & 1.93273 & 0.1073 \\
\hline Mig granger nedeni değildir Unp & 0.73743 & 0.5677 \\
\hline
\end{tabular}

Tablo 6. Nedensellik Testi Sonuçlarl

Tablo 6'da yer aldığ1 şekliyle işsizliğin göçün nedeni olmadığı ve göçün de işsizliğin nedeni olmadığg yönündeki iki hipotezde reddedilememiştir. Yani, bu çalışma için ele alınan 25 adet OECD ülkesinde alınan göçler işsizliğin bir nedeni değildir ve benzer şekilde göç de işsizliğin bir nedenidir değildir. Yani söz konusu ülkelerde kısa dönemde, işsizlik ve göç arasında herhangi bir nedensellik tespit edilememiştir.

\section{Sonuc}

İnsanların göç etmelerinin çeşitli sebepleri vardır. Bu sebeplerin en temel olanı ekonomik gerekçelere bağlıdır yani daha iyi yaşam koşulları aramaktır. Refah seviyesinin ve yaşam kalitesinin yüksek olduğu gelişmiş ülkelere bu çerçevede akım daha fazladır. Ancak göç bazen de savaş, doğal felaketler gibi zaruri sebeplerden dolayı gerçekleşir. Sebebi her ne olursa olsun göç alan ülkelerin ekonomisinde ve piyasalarında değişiklikler yaşanacağ 1 açıktır. Rekabetin ve ucuz işgücüne talebin artması ayrımcılığı da beraberinde getirecek ve toplumun huzuru da etkilenecektir.

OECD ülkelerine gelen işgücü göçünün büyük bir kısmı Asya, Afrika, Latin Amerika ve Orta Doğu'dan olmuştur. Kalıcı göçmen girişlerine bakıldığında göç oranlarının büyük ölçüde ailelere dayandığı görülmektedir. İtalya, İrlanda ve İspanya gibi ülkelerin de aralarında bulunduğu birçok OECD ülkesi işçi alan ülkeler olduğu için göçmenlerin kalıcı olma nedenlerinin yaklaşık \%30’luk kısmı iş ile ilgili nedenlerden kaynaklanıyor. Avusturya, Belçika, Danimarka ve Almayanda ise bu oran \%70’lere çıkmaktadır.

2018 OECD göç raporuna göre Avusturya haricinde, göçmenlerin ücretleri yerel halktan daha düşük oluyor. OECD ülkelerinde vasıflı işçileri toplama ve tutma bakımından rekabet halinde olsa da işgücü pazarındaki ihtiyaç çoğunlukla daha az vasıflı işçilere yönelik oluyor. Daha az vasıflı işçileri yönetmek, bu göçmenlerin ev sahibi ülkeye entegrasyonu ve uzun vadede istihdamı açısından bazı sorunlar oluşturabileceği için, ülkelerin göç politikalarının sağlam olmasını gerektiriyor. Bu bağlamda birçok OECD ülkesi hala geçici iş programlarına başvuruyor.

Bu çalışmada 2008-2018 yılları arasında 25 adet OECD ülkesine gelen göç içerisinde, işgücü piyasalarında istihdam edilen kısım ve söz konusu ülkelerdeki işsizlik oranları incelenmiştir. Panel Veri Analizi yardımıyla kurulan model sonunca göre, 25 ülke içinde kısa dönemde herhangi bir nedensellik ilişkisi bulunmamakla birlikte uzun dönemde ise, göçün işsizliği etkilediği ve nedenselliğin yönünün göçten işsizliğe doğru olduğudur.

\section{Kaynakça}

- Abandan, U. ve N. Unat 2006. “Bitmeyen Göç: Konuk İşçilikten Ulus Ötesi Yurttaşlığa” İstanbul: Bilgi Üniversitesi Yayınları.

- Avila ve Bacarezza, 2016. "Unemployed, Now What? The Effect of Immigration on Unemployment Transitions of Native-born Workers in the United States", Levy Economic Institue, 870, 30.

- Baltagi, 2005. Econometrics Analysis of Panel Data. John Wiley \& Sons, Ltd, İngiltere.

- Bonin, 2005. "Wage and Employment Effects of Immigration to Germany: Evidence from a Skill Group Approach”, IZA Discussion, p. 1875.

- $\quad$ Boubtane, vd, 2011. "Immigration, unemployment and GDP in the host country", CEPII, WP, 29, p. 16. 
- Blanchflower, vd, 2007. "Fear, Unemployment And Migration”, National, Bureau of Economic Research, 13506, p. 1.

- Çakırca 2018. "Uluslararası Göçü Dış Ticaret Üzerine Etkisi: Türkiye İçin Bir Ampirik Analiz”, Afyon Kocatepe Üniversitesi, Sosyal Bilimler Enstitüsü.

- Çavuşoğlu 2007. Yugoslavya - Makedonya Topraklarından Türkiye’ye Göçler ve Nedenleri, Bilig Dergisi, Bahar, Say1: 41.

- Chletsos ve Roupakias, 2012. "Immigration, Unemployment and Growth: Empirical Evidence from Greece", Munich Personal RePEc Archive, 39927, p. 2.

- Demir, vd, 2005. Sosyal Bilimler Sözlüğü, Adres Yayınları, Ankara.

- Esposito, vd, 2018. "Immigration and unemployment in Europe: does the core-periphery dualism matter?", GLO Discussion Paper, p. 310.

- Feridun, 2008. "Immigration, Income and Unemployment: An Application of the Bounds Testing Approach To Cointegration", Scholarly Journals Online, 41, p. 37.

- Fromentin, 2013. "The Relationship Between Immigration and Unemployment: The Case of France", Economic Analysis\&Policy, 40, p. 64.

- Gezgin 1991. “İşgücü Göçü Teorileri”, Dergi Park, Sosyoloji konferansları, sayı:23.

- Gözüm 2017. “Uluslararası Göç ve Gelişmekte Olan Ülkelere Etkisi: Türkiye Örneği”, Selçuk Üniversitesi Sosyal Bilimler Enstitüsü.

- Gujarati, 2006. Basic Econometri, McGraw- Hill Education, New York.

- Hsiao, vd, 2003. "Analysis of Panel Data", 2nd edition, Cambridge University Press, p. 348.

- Jean ve Jimenez, 2007. “The Unemployment Impact of Immigration in OECD Countries”, OECD Economics Department Working Paper, 563, p. 2.

- Massey, vd. 1993. “Theories of International Migration: A Review and Appraisal”, Population and Development Review, Vol 19, No 3.

- Meral, 2016. “Göçün Ekonomik Analizi: Niğde Uygulaması”, Niğde Üniversitesi Sosyal Bilimler Enstitüsü, p. 6.

- Miller, vd, 2008. , Göçler Çağı: Modern Dünyada Uluslararası Göç Hareketleri, İstanbul Bilgi Üniversitesi Yayınları, İstanbul.

- OECD, 2009. https://www.oecd.org/newsroom/43125523.pdf

- $\quad$ Özcan ve Ari, 2011. "Finansal Gelişme ve Ekonomik Büyüme Analizi İlişkisinin Ampirik Analizi: Türkiye Örneği”, Business and Economics Research Journal, 1, p. 108.

- Sevüktekin ve Nargeleçekenler, 2005. Zaman Serileri Analizi, Nobel Yayıncılık, Bursa.

- Shan, 1999. "Immigration and Unemployment: New Evidence from Australia and New Zealand", International Review of Applied Economics, 13, p. 254.

- Tokatlı, (2011). "Küreselleşme Sürecinde Uluslararası Göç Hareketlerinin İşgücü Piyasalarına Etkisi”, Dokuz Eylül Üniversitesi Sosyal Bilimler Enstitüsü.

- Uluslararası Göç Örgütü, 2015. http://www.gam.gov.tr/files/6-2015-Turkiye-Goc-Raporu.pdf 


\title{
Türkiye ve Rusya Ekonomilerinin Girdi-Çıktı Analizi Kullanılarak Karşılaştırılması
}

\section{Comparing the Turkish and Russian Economies by the Using of Input-Output Analysis}

\author{
Assoc. Prof. Dr. Tuncer Özdil (Manisa Celal Bayar University, Turkey) \\ Asst. Prof. Dr. Ainura Turdalieva (Kyrgyzstan-Turkey Manas University, Kyrgyzstan) \\ Prof. Dr. Cengiz Y1lmaz (Konya Food and Agriculture University, Turkey)
}

\begin{abstract}
Nowadays, progress in information technologies and globalization, influenced disappearing the borders between countries in economic terms; and the competition has spread worldwide and became influential on all countries and territories. In this process, countries have joined forces to create a stronger competitive environment. The results obtained from comparative study of the production structures is extremely important to countries for achieving economic cooperation to increase mutual economic interests, the relations between their countries' economies and planning.

The purpose of this paper is to describe the production structures of Turkey and Russian economies. The comparative analysis of the similarities and differences in the production structures of both countries made by input-output approach. Given research based on analysis of input-output tables prepared by the Statistics Committees of two countries. For the study purpose forward and backward linkages, key sectors, efficiency in intermediate product usage, production techniques, external trade and production structure were calculated and compared on sectoral and macro-level. The results, obtained from the analysis, allow giving recommendations to further development of economic relations between countries.
\end{abstract}

\section{Giriș}

Günümüzde küreselleşme ve bilişim teknolojilerindeki ilerlemeler ulusal ekonomileri doğrudan etkileyerek ekonomik üretim sektörleri arasındaki karşılıklı etkileşimi arttırmış, ülkeler arasındaki sınırlar ortadan kalkmış rekabet dünya geneline yayılmıştır. Benzer kültürel özelliklere ve ortak çıkarlara sahip ülkeler güçlerini birleştirerek rekabet güçlerini arttırabilmek için ekonomik ve siyasal yönden birlikte hareket etmeye başlamışlardır. Bu süreç ülkeler arasında ekonomik ilişkileri daha da arttırmıştır.

Son dönemlerde Türkiye'nin bulunduğu bölgede gerçekleşen çeşitli toplumsal olaylar, ekonomik ve siyasal konjonktür Türkiye ile Rusya'yı birbirine yakınlaştırmıştır. Türkiye, Rusya için tarım ürünleri ihracatçısı konumunda ve turizm açısından önemli bir ülkedir. Bu çalışmanın temel amacı; Türkiye ve Rusya ekonomilerinin üretim yapılarının karşılaştırmalı olarak incelenerek elde edilen sonuçlara göre taraflara aradaki ekonomik işbirliğini daha da arttıracak önerilerde bulunmaktır. Her iki ülke ekonomik yapılarının karşılaştırılması GirdiÇıktı analizi yaklaşımıyla yapılmaktadır. Araştırmada her iki ülke İstatistik Kurumu tarafından en son hazırlanan, 2012 yılı, Girdi-Çıktı sonuç tabloları kullanılmıştır. Ekonomik üretim yapılarının karşılaştırılması, her iki ülke için toplam ileri ve geri bağlantı endekslerinin incelenmesi, üretim tekniklerindeki değişmenin, aramalı kullanımındaki etkenliğin araştırılmasıyla gerçekleştirilmiştir.

\section{Girdi Çıktı Analizi Yaklaşımıyla Üretim Yapılarının İncelenmesi}

Girdi-Çıktı Analizi, bir ekonomide matematiksel ve istatistiksel teknikler yardımıyla, endüstrilerarası ilişkileri tutarlı olarak inceleyen bir modeldir. Bir ekonomik sistemin belirli yapısal özelliklerini tanımlayan bir veriler toplamı ve sistemin belirli bir zaman aralığı içinde belirli bir anındaki davranışını etkileyici ve açıklayıcı analitik bir teknik olarak tanımlanabilir (Todaro, 1987, s.17). Analizin temeli, herhangi bir ülke ekonomisinin kendi içerisinde homojen ya da birbirine benzer mallar üreten endüstrilere bölünebilmesi ve bu endüstrilerin birbirleriyle ve ekonomiyle olan etkileşimlerinin matematiksel ifadesine dayanır. Girdi Çıktı modelleri sektörel tutarlılık planlamasından dış ticaret teorilerinin sınanmasına, beşeri kaynak planlamasından bölgesel planlamaya yapısal değişim çözümlemelerinden endüstrilerarası bağınlaşma çözümlemelerine kadar çok çeşitli alanlarda yaygın olarak kullanılmaktadırlar.

Ekonomik yapının önemli bir unsurunu üretimde sektörler arasında ortaya çıkan karşılıklı bağımlılıklar oluşturur. Üretim sürecinde ekonomide hiç bir sektör birbirinden bağımsız, yalıtılmış durumda değildir. Ekonomik sektörler arasında mal ve hizmet alışverişlerinden kaynaklanan karşılıklı bağımlılıklar vardır. Bu karşılıklı mal ve hizmet alışverişi kısaca endüstriyel bağınlaşma olarak adlandırılmaktadır (Aydoğuş, 2010, s.125). Endüstriyel bağınlaşma iki şekilde ortaya çıkmaktadır. İlk olarak sektör kendi üretimini gerçekleştirmek için diğer sektörlerden kendi üretiminde kullanmak üzere aragirdi talep eder. Bu geriye bağlantı etkisi olarak bilinir. İkinci olarak sektör 
kendi çıktısını diğer üretim sektörlerine aragirdi olarak arzeder. Bu ise ileri bağlantı etkisi olarak tanımlanmaktadır. Ekonomik sektörler arasındaki ileri ve geri bağlantı etkileri; sektörel aragirdi kullanımının ve sektör malına olan aratalep toplamının sektör çıktısına bölünmesiyle oran olarak hesaplanabileceği gibi toplam etkileri vermesi bakımından ters matris satır ve sütun toplamları alınarak da hesaplanabilir. Burada sektör malına olan nihai talepteki 1 birimlik artışın (geri bağlantı) ve diğer sektörlerin nihai taleplerindeki 1 birimlik artışın (ileri bağlantı) sektörel üretime olan etkileri incelenmektedir. Burada endüstrilerarası bağınlaşma toplam etkileri yansıtması bakımından ters matris satır ve sütun toplamları alınarak hesaplanmıştır.

Girdi-Çıktı modelleri kapsamında üretim yapılarının karşılaştırılması genellikle endüstrilerarası bağınlaşma, üretim teknikleri, aragirdi kullanımları ve temel girdi kullanımları gibi konuları kapsar (Aydoğuş, 2010, s.137). Özellikle ülkelerarası yapılan karşılaştırmalarda ülkelerin doğal, coğrafik, gelişmişlik düzeyi, sosyo-kültürel özelliklerinin farklı olması üretim yapılarını da farklılaştıracaktır. Ancak bu farklılıkların nedenlerinden birisi de tabloların hazırlandıkları dönemden ve hazırlanış ilkelerinden kaynaklanan farklılıklardır. Kuşkusuz Girdi-Çıktı analizinin teorik varsayımlarından kaynaklanan sektör sayısı ve içerikleri, toplulaştırma, ekonomi genelindeki enflasyonist etkiler gibi benzer farklılıkların etkilerinin ülkelerarası karşılaştırmalarda hiç ya da çok az olacağı varsayılmaktadir.

Girdi-çıktı çözümlemesinde dar anlamda sektörel üretim tekniklerini, teknoloji (katsayı) matrisinin sütunları temsil eder. Ekonomide, r ve s gibi herhangi iki farklı dönemde veya ülkede “j”" sektöründeki üretim teknikleri aşağıdaki katsayı aracılığıyla karşılaştırılabilir;

$$
P T_{j}^{r s}=\frac{\sum_{i}\left|a_{i j}^{r}-a_{i j}^{s}\right|}{(1 / 2) \sum_{i}\left(a_{i j}^{r}+a_{i j}^{s}\right)}
$$

(1) no’lu denklemle tanımlanan söz konusu katsayı, iki ülkenin “j” sektörüne karşılık gelen girdi katsayıları arasındaki farkların mutlak değerlerinin toplamının, karşılıklı katsayılarının aritmetik ortalamalarının toplamına oranı $\mathrm{PT}_{\mathrm{j}}^{\text {rs }}$ şeklinde tanımlanmaktadır. $\mathrm{PT}_{\mathrm{j}}^{\text {rs }}$ katsayısı, saf bir katsayı olup 0 ile 2 arasında değerler alabilir (Aydoğuş, O. 2010, s.139). Ülkelere göre, teknik katsayılarda değişim, farklılık yoksa yani üretim teknikleri aynıysa payda yer alan mutlak farklar sıfır olacağından katsayı 0'a eşit çıkacaktır. Bunun anlamı ülkeler arasında ilgili sektörde üretim teknolojisinde hiç farklılığın olmadığı veya her iki ülke üretim tekniğinin aynı, benzer olduğudur. Eğer teknik katsayılar farklıysa, payda da yer alan 1/2 katsayısı nedeniyle bölüm sonucu en fazla iki çıkacaktır. Bunun anlamı da, farklılığın çok fazla olduğudur. Bu yönüyle katsayı ne kadar 0'a yakın çıkarsa farklılık az, ne kadar 2'ye yakın çıkarsa farklılık o kadar fazla demektir. Genel olarak 0.80'nin üzerindeki oranlar farklılığın çok olduğu yönünde değerlendirilmektedirler.

Farklı dönemler arasında çeşitli aramalların kullanımındaki etkenlik dereceleri ise aşağıdaki gibi karşılaştırılabilir:

$$
I U_{i}^{r s}=\frac{\sum_{j} a_{i j}^{r} x_{j}^{s}}{\sum_{j} a_{i j}^{s} X_{j}^{s}}
$$

(2) no'lu denklemdeki $I U_{i}^{r s}$ katsayısı r ve s ülkelerindeki $i$. malının aramalı olarak kullanımındaki etkenliğin benzerlik derecesini, $X_{j}^{s}$ ise diğer ülke üretim vektörünü göstermektedir. Katsayının payındaki terim r ülkesinde s ülkesinin üretim vektörünü gerçekleştirmek için ne kadar i malının aramalı olarak kullanılması gerektiğini, paydadaki terim ise s ülkesinde aynı üretim vektörünü gerçekleştirebilmek için ne kadar i malının aramalı olarak kullanılması gerektiğini göstermektedir (Aydoğuş, O. 2010, s.140). Burada doğal olarak bir oran söz konusudur. Oranın sonucu 1 ise, ülkelerde sektörel bazda aramalı kullanımında farklılığın olmadığı aramalı kullanım etkenliğinin değişmediği, aynı olduğu anlamına gelmektedir. Katsayının 1'den küçük çıkması karşılaştırma yapılan ülkede diğerine göre daha az kullanıldığı anlamına gelecektir.

\section{Girdi-Çıktı Analizi Yaklaşımıyla Rusya ve Türkiye Ekonomileri}

Girdi-çıktı tabloları Türkiye'de ekonomide planlı döneme geçişle birlikte belli aralıklarla hazırlanmaktadır. 1963 yılından beri tüm tablolar Türkiye İstatistik Kurumu tarafından hazırlanmıştır. 2016 yılında yayın haline getirilen son 2012 yılı Girdi-Çıktı Sonuç Tabloları, Birleşmiş Milletler Ulusal Hesaplar Sistemi (SNA) ve Avrupa Hesaplar Sistemi'nin (ESA) önerdiği şekilde hazırlanmıştır. Sanayi grupları için Avrupa Topluluğunda Ekonomik Faaliyetlerin İstatistikî Sınıflaması (Statistical classification of economic activities in the European Community, NACE Rev 2) ve ürün grupları için Avrupa Ekonomik Topluluğunda Faaliyete Göre Ürünlerin İstatistikî Sinıflamas1 (Statistical Classification of Products by Activity in the European Economic Community, CPA-2008) kullanılmıştır. Tablonun ayrıntı düzeyi, Avrupa Birliği ülkelerinde olduğu gibi 64 sektör üzerinden, 64 sanayi-64 ürün olarak oluşturulmuştur (http://www.tuik.gov.tr/PreTablo.do?alt_id=1021). 
Dağılma sonrası yeniden yapılanma sürecinde Rus İstatistik Enstitüsü (Rosstat) tarafından 1995 yılında, Birleşmiş Milletler Ulusal Hesaplar Sistemine (SNA) uygun olarak Girdi-Çıktı tablosu hazırlama çalışmaları başlatılmıştır. Bu çalı̧̧malar kapsamında 1996-2003 dönemi için cari fiyatlarla Girdi-Çıktı sonuç tabloları hazırlanmıştır. Ancak bu hazırlanan tablolar sektör sayıları, içerik ve kapsamları bakımından, eski Sovyet döneminden miras kalan "Ulusal Ekonomi Sektörleri ve Malların Genel Sınıflandırılması" sistemine uygun hazırlanmış tablolardır. Kuşkusuz, bu tabloların hazırlanmasında kullanılan sınıflandırma sisteminin gelişmiş batılı ülkelerde kullanılan sınıflandırmayla uyumlu olmayışı, uluslararası karşılaş̧ırmalara dayalı ekonomik analizleri zorlaştırmış ve bu alandaki etkin işbirliği olanaklarını da kısıtlamıştır (Baranov, E. vd. 2014, s.10).

Bu nedenle Rus hükümeti, 2004 yılından itibaren ülkedeki ekonomik faaliyetlerin sınıflandırılmasında; sektör sayısı, içerik ve kapsam bakımından Avrupa Topluluğunda Ekonomik Faaliyetlerin İstatistikî Sınıflaması (Statistical classification of economic activities in the European Community, NACE Rev 1) sistemine geçme, 2010 yılından itibaren ise ürün grupları için Avrupa Ekonomik Topluluğunda Faaliyete Göre Ürünlerin İstatistikî Sinıflamas1 (Statistical Classification of Products by Activity in the European Economic Community, CPA-2008) sistemine geçme kararlarını almıştır.

$\mathrm{Bu}$ alınan kararlarla 1995 yılında oluşturulan sistemle yeni tabloların hazırlanması olanaksız hale gelince, 2004 yılından itibaren tablo hazırlama çalışmalarına ara verilmiştir. Yeni sınıflama sistemine uyum süreci tamamlandıktan sonra 2011 yılında çalışmalar yeniden başlatılarak Federal Devlet İstatistik Kurumu tarafindan 2012 yılı tablosu hazırlanmışıır (Baranov, E. vd. 2014, s.11).

Söz konusu karşılaştırma Federal Devlet İstatistik Kurumu tarafından hazırlanan 2012 yılı Girdi-Çıktı Endüstrilerarası akım tablosu kullanılarak yapılmıştır. Her iki tabloda Avrupa Birliği ülkelerinde olan sektörel sınıflamaya uygun şekilde 64 sektörlüdür. Ancak her iki ülke tablosu ekonomik üretim sektörleri bakımından karşıllklı incelendiğinde; sektörlerin önemli bir kısmının tablodaki sıraları farklı olmakla birlikte birebir uyumlu olduğu ancak bazı üretim sektörlerinin daha ayrıntılı olarak alt sektörlerle verildiği görülmüştür. Örneğin madencilik sektörü Türkiye Girdi-Çıktı tablosunda Madencilik-taşocakçılı̆̆ı-petrol çıkarımı olarak tek bir sektör olarak görülürken, Rusya Girdi-Çıktı tablosunda aynı sektör; Madencilik, Taşocakçılığı, Petrol-doğal gaz çıkarımı, Uranyum-Toryum çıkarımı Kömür çıkarımı olarak beş alt sektörde tanımlanmaktadır. Benzer şekilde imalat sektörlerinde Gıda-İçki-Tütün Türk tablosunda tek sektör iken aynı sektör Rus tabloda tütünü ayıracak şekilde iki sektörde gösterilmektedir. Bu ve benzer nedenlerle tablolar arasında uyum sağlayabilmek için benzer sektörler biraraya getirilerek her iki tablo 46 sektöre göre toplulaştırılmıştır. Karşılaştırma işlemi 46 sektör üzerinden gerçekleştirilmiştir. Tüm hesaplamalarda; homojen üretim birimleriyle ilgili analitik amaçlı verimlilik, maliyet, işgücü gibi analizlerde kullanılan "temel fiyatlarla girdi-çıktı tablosu" kullanılmıştır.

\subsection{Türkiye ve Rusya'nın Toplam İleri ve Geri Bağlantı Etkilerine Göre Karşılaştırılması}

Ekonomide sektörler arası ilişkileri tanımlayan temel araçlardan birisi ters matris satır ve sütun toplamlarının alınmasıyla hesaplanan toplam ileri ve geri bağlantı etkileridir. Burada da, her iki ülke için toplam ileri ve geri bağlantı katsayıları hesaplanmış, bu katsayıların göreceli önemini açıklayabilmek için bağlantı endeksleri ve bunların diğer sektörlere olan yayılma dereceleri elde edilmiştir. İleri ve Geri Toplam Bağlantı etkileri bunları tanımlayan sektör ortalamasına göre hesaplanan endeks değerleri Tablo 1'de gösterilmiştir.

Ekonomide diğer sektörlerin nihai talebindeki 1 birimlik artışın sektörel üretime olan etkisini tanımlayan ileri bağlantı etkileri incelendiğinde, Türkiye için 46 ekonomik üretim sektöründen 16 tanesinde endeks değeri 1'den büyük çıkmıştır. Yani bu sektörler diğer sektörlere aragirdi arzında bulunma anlamında, diğer sektörlere göre ekonomiyi daha çok etkileme gücüne sahip olan sektörlerdir. Bu sektörlerde ileri bağlantı katsayıları da en yüksek değerlerdedir. İleri bağlantı endeks değerlerine göre, en yüksek endeks değeri Madencilik ve taşocakçılığı sektöründe elde edilmiştir. Bunu sırasıyla Kimya, elektrik üretimi, Ana metal, Rafine petrol ürünleri, Tarım, Tekstil, Kağıt ve Doğal su arıtımı imalat sektörleri izlemektedir. Rusya'da ise ileri bağlantı etkisi yüksek olan sektörler; Madencilik, Rafine petrol ürünleri, Kimya, Ana metaller, Elektrik-doğal gaz, Makine ekipman üretim ve onarımı olarak elde edilmiş̧ir. İleri bağlantı etkisi ortalamanın üzerinde olan bu sektörler içerisinde Türkiye'de etkili olup, Rusya'da etkisi az olan imalat sektörleri, tarım, tekstil, kağıt, doğal su arıtımı sektörleri olmuştur. Rusya'da etkili olup Türkiye'de göreli etkisi az olan sektörler ise, makine ve ekipmanların üretim, bakım ve onarımı sektörleri olmuştur. Hizmet sektörlerinde ise İnşaat ve mesleki bilişsel hizmetler olmak üzere iki sektör dışında ekonomiyi etkileme gücü diğerlerine göre daha yüksek olan hizmet sektörleri her iki ülke için aynı çıkmıştır. Bu sektörler; Toptan ticaret, Karayolu-Boru taşımacılığı, Bilimsel araştırma-ar-ge hizmetleri sektörleridir. İnşaat sektörü sadece Rusya'da 1'den büyük endeks değeriyle ileri bağlantı etkisi yüksek iken avukatlık, veterinerlik, doktorluk gibi Mesleki ve bilişsel hizmetler de sadece Türkiye'de ileri bağlantı etkisi yüksek olan sektör olmuştur (Tablo 1a ve 1b).

Sektörün nihai talebindeki 1 birimlik artışın diğer sektörlerin talebine etkisini tanımlayan geri bağlantı etkisi bakımından 46 sektörden Türkiye için 22 tanesinde, Rusya için, 24 tanesinde endeks değeri 1 'den büyük çıkmıştır. Bu sektörler birkaç hizmet sektörü dışında hemen hemen her iki ülke için de aynı sektörlerdir. Toplam 19 alt sektörden oluşan imalat sektörleri içinde Doğal su üretim ve arıtımı dışındaki tüm imalat sektörleri her iki ülke için geri bağlantı etkisi yüksek sektörler olarak çıkmışlardır. Hizmet sektörleri açısından ise, havayolu ve uzay 
taşımacılığı her iki ülke için geri bağlantı etkisi yüksek çıkarken, Deniz yolu taşımacılığı, Taşıma-depolama, lojistik Rusya için geri bağlantı etkisi yüksek çıkan hizmet sektörleri olmuşlardır. Sadece Türkiye için Geri bağlantı etkisi yüksek çıkan hizmet sektörleri ise, İnşaat, konaklama-yiyecek hizmetleri, sigorta-reasürans hizmetleri sektörleri olmuştur (Tablo 1a ve 1b).

İleri ve geri bağlantı etkilerine göre, her iki etkinin yüksek olduğu sektörler; Türkiye için, Tekstil, Kağıt-Basımyayım, Kok kömürü-Rafine petrol ürünleri, Kimya, Ana metal, Elektrik-doğal gaz üretimi imalat sektörleri olmaktadır. Aynı sektörler Rusya için ise, Rafine petrol ürünleri, Kimya, Ana metaller, Makine-Ekipmanların üretimi, montaj-bakım ve onarımı, Elektrik-doğal gaz üretimi, Ulaştırma-depolama hizmet sektörleri olarak elde edilmiştir.

İleri ve Geri bağlantı etkileri ekonomi genelinde toplam olarak değerlendirildiğinde, Türkiye için toplam etkisi 94,9411 milyon TL., ortalama etki 2,0639 milyon TL., Rusya için toplam etki 96,9288 milyon ruble, ortalama etki 2,1071 milyon ruble olmaktadır (Tablo 1b). Toplam ileri ve geri bağlantı etkilerinin daha sağlıklı değerlendirilebilmesi için bu katsayıların diğer sektörlere olan yayılma dereceleri de hesaplanmıştır (Tablo 2). Yayılma derecesi ne kadar küçük (sıfıra yakın) çıkarsa bu ilgili sektörün ekonomide o kadar çok sayıda sektörü etkilediği hatta sıfıra eşit çıkması halinde ekonomideki diğer tüm sektörleri etkilediği anlamına gelir.

Burada hesaplanan yayılma derecelerine bakıldığında her iki ülke için hem ileri hem geri bağlantı yayılma derecelerinin katsayılarının çoğunun sıfırdan çok büyük değerler olduğu görülmektedir. Rusya için yayılma dereceleri ileri bağlantıda, (toptan ticaret motorlu kara taşıtları hariç) 1,3265 ile (Bilimsel araştırma ar-ge hizmetleri) 6,7078 arasında değişirken geri bağlantı için bu değerler; (Mobilya ve diğer mamul eşyalar) 2,7182 ile (Kendi konutunda oturanlar için izafi kira) 5,6249 arasında değişmektedir. Türkiye için ise, yayılma dereceleri geri bağlantıda (elektrikli teçhizat) 2,7477 ile (Orman ürünleri) 5,2598 arasında değişirken, İleri bağlantı yayılma dereceleri, (madencilik taşocakçılığı) 1,6648 ile (Bilimsel araştırma ar-ge hizmetleri) 6,7082 arasında değişmektedir. Yayılma derecelerinin ortalamaları alındığında, bu değerler Türkiye için 4,1786, Rusya için 4,1112 olarak elde edilmiştir. Buradan her iki ülkenin yayılma derecelerinin yüksek olduğunu, sektörler arası teknik üretim ilişkilerinin zayıf olmakla birlikte benzer olduğunu söyleyebiliriz (Tablo 2).

\section{2 İki Ülke Üretim Tekniklerinin Karşılaştırılması}

Girdi-Çıktı Analizinde dar anlamda sektörel üretim tekniklerini teknik katsayı matrisinin sütunları temsil etmektedir. Ülkelerarası karşılaştırmalarda, her iki ülkenin denk gelen teknik katsayıları arasındaki farkın mutlak değerinin katsayıların aritmetik ortalamasına oranlanmasıyla elde edilen katsayılarla (PTj rs) üretim teknikleri birbiriyle karşılaştırılabilir. Katsayı 0 ile 2 arasında değer alabilir. Üretim tekniklerinin tamamen aynı olması durumunda teknik katsayılar birbirine eşit olacağından oran sıfır çıkacaktır. Teknik katsayılar arasındaki farklılık arttıkça oran 2'ye yaklaşacaktır. Genel olarak 0,8 civarı ve altındaki oranlarda üretim tekniklerinin benzer olduğu düşünülmektedir. Elde edilen sonuçlar Tablo 3 'te gösterilmiştir.

Tüm sektörler için hesaplanan etkenlik katsayıları 0,3364 (Gıda-İçki-Tütün) ile 1,3775 (Bilimsel araştırma arge hizmetleri) arasında değişmektedir. 46 üretim sektöründen kabul edilen teorik sınır olan 0,8097 ve daha küçük sektör sayısı 30’dur. Primer temel üretim sektörlerinden Orman ürünleri ve balıkçılık-Su ürünleri sektörleriyle imalat sektörlerinden Makine ve ekipmanların kurulum ve onarımı, Doğal su üretimi ve arıtımı sektörleri dışındaki tüm sektörlerde katsayılar teorik sınırın altındadır. Hizmet sektörleri bakımından ise, Toptan ve perakende ticaret, Karayolu-Boru taşımacılığı, Posta-Kurye Hizmetleri, Bilgisayar programlama-danışmanlık, Finansal hizmetler, Gayrımenkul hizmetleri, Bilimsel araştırmalar ar-ge hizmetleri, Eğitim, Kendi konutunda kalanlar için izafi kira hizmet sektörlerinde katsayılar teorik sınırın yani 0,8698 ve üzerinde çıkmışlardır. Makine ve ekipmanların kurulum ve onarımı dışındaki tüm imalat sektörlerinde katsayının teorik sınırdan küçük olması ve inşaat dahil 23 alt hizmet sektöründen 11 tanesinde yine küçük katsayı elde edilmesi iki ülke ekonomisinin oldukça birbirine benzer teknolojilerle üretim yaptığını, ekonomilerin üretim yapısı bakımından benzer olduğunu ifade etmektedir (Tablo 3).

\subsection{Aragirdi Kullanımı Etkenlik Derecelerinin Karşılaştırılması}

Endüstrilerarası analizde ekonomik sektörler aramalı kullanımları bakımından da incelenebilirler. Bu inceleme aynı ekonomik sektörlerin farklı ülkelere ait tablolarıyla yapılabilir. Burada da Rusya ve Türkiye ekonomileri aragirdi kullanımı açısından da değerlendirilmektedirler. Önce Türkiye ekonomisi üretim vektörü Türkiye ekonomisine ait teknik katsayı matrisiyle çarpılarak, Türkiye'deki üretimi gerçekleştirebilmek için gerekli sektörel aragirdi kullanımları hesaplanmıştır. Sonra aynı üretim Rusya'da yapılsaydı aragirdi kullanımı ne olurdu? sorusunun yanıtını verecek şekilde Türkiye ekonomisi üretim vektörü Rusya ekonomisi teknik katsayı matrisiyle çarpılarak sektörel aragirdi kullanımları hesaplanmıştır. Elde edilen aragirdi kullanımları birbirine oranlanarak etkenlik dereceleri elde edilmiştir (Tablo 4).

Burada hesaplanan etkenlik dereceleri 1'den küçük, 1'e eşit ya da 1'den büyük çıkabilir. Oranın 1'den küçük çıkması karşılaştırma yapılan ülke Türkiye'de aynı üretimin Rusya'ya göre daha çok aragirdi kullanımıyla yapıldığ 1,1 'e eşit çıkması her iki ülkede üretimin aynı miktar aragirdi kullanımıyla yapıldığg1, 1'den küçük çıkması ise, aynı üretimin Türkiye'de Rusya'ya göre daha az aragirdi kullanımıyla yapıldığı anlamına gelir. 


\begin{tabular}{|c|c|c|c|c|c|}
\hline \multirow{3}{*}{$\begin{array}{l}\text { Sira } \\
\text { No: }\end{array}$} & \multirow{3}{*}{ Ekonomik Sektörler } & \multicolumn{2}{|c|}{$\begin{array}{c}\text { Toplam İleri } \\
\text { Bağlantı Etkileri }\end{array}$} & \multicolumn{2}{|c|}{$\begin{array}{l}\text { İleri Bağlantı } \\
\text { Endeksleri }\end{array}$} \\
\hline & & Türkiye & Rusya & Türkiye & Rusya \\
\hline & & $\overline{\mathbf{R}_{\mathbf{i}}}$ & $\mathbf{R}_{\mathbf{i}}$ & $\mathbf{I R}_{\mathbf{i}}$ & $\mathbf{I R}_{\mathbf{i}}$ \\
\hline 01 & Tarım ve avcılık ürünleri ve ilgili hizmetler & 2,1721 & 2,0642 & 1,0524 & 0,9796 \\
\hline 02 & Orman ürünleri ve ilgili hizmetler & 1,2660 & 1,4301 & 0,6134 & 0,6787 \\
\hline 03 & Balıkçılık, su ürünleri, destekleyici hizmetler & 1,0366 & 1,0649 & 0,5023 & 0,5054 \\
\hline 04 & Madencilik ve Taşocakçılığı, petrol ve uranyum çıkarımı & 5,8312 & 4,2864 & 2,8253 & 2,0342 \\
\hline 05 & Gıda, İçki ve tütün ürünleri & 1,8071 & 1,7401 & 0,8756 & 0,8258 \\
\hline 06 & Tekstil, Deri ve Giyim eşyaları & 2,0720 & 1,5607 & 1,0039 & 0,7407 \\
\hline 07 & Kereste, ağaç, orman ürünleri (mobilya hariç) & 1,5742 & 1,3716 & 0,7627 & 0,6509 \\
\hline 08 & Kağıt ve kağıt ürünleri ve Basım yayın kayıt hizmetleri & 2,2296 & 1,5376 & 1,0803 & 0,7297 \\
\hline 09 & Kok ve rafine petrol ürünleri & 3,0886 & 4,0870 & 1,4965 & 1,9396 \\
\hline 10 & Kimyasallar ve kimyasal ürünler & 4,8120 & 3,7213 & 2,3315 & 1,7660 \\
\hline 11 & Kauçuk ve plastik ürünler & 2,0065 & 1,7333 & 0,9722 & 0,8226 \\
\hline 12 & Diğer metalik olmayan mineral ürünleri & 1,7422 & 1,7509 & 0,8441 & 0,8309 \\
\hline 13 & Ana metaller & 4,2205 & 4,0377 & 2,0449 & 1,9162 \\
\hline 14 & Fabrikasyon metal ürünleri, makine ve ekipmanlar hariç & 1,7359 & 1,8498 & 0,8411 & 0,8779 \\
\hline 15 & Bilgisayar, elektronik ve optik ürünler & 1,6125 & 1,5714 & 0,7813 & 0,7457 \\
\hline 16 & Elektrikli teçhizat & 1,6856 & 1,8742 & 0,8167 & 0,8894 \\
\hline 17 & Başka yerde sınıflandırılmamış makine ve ekipmanlar & 1,5610 & 2,3657 & 0,7563 & 1,1227 \\
\hline 18 & Motorlu kara taşıtları, treyler (römork) ve yarı treyler & 1,6475 & 2,0201 & 0,7982 & 0,9587 \\
\hline 19 & Diğer ulaşım araçları & 1,1981 & 1,7252 & 0,5805 & 0,8187 \\
\hline 20 & Mobilya ve diğer mamul eşyalar & 1,2317 & 1,1078 & 0,5968 & 0,5257 \\
\hline 21 & Makine ve ekipmanların kurulumu ve onarımı & 1,4778 & 2,3602 & 0,7160 & 1,1201 \\
\hline 22 & Elektrik, gaz, buhar ve iklimlendirme & 4,7331 & 5,7862 & 2,2932 & 2,7460 \\
\hline 23 & Doğal su; suyun arıtılması ve temini hizmetleri & 2,7248 & 1,1237 & 1,3202 & 0,5333 \\
\hline 24 & İnşaat & 1,9174 & 2,2881 & 0,9290 & 1,0859 \\
\hline 25 & $\begin{array}{l}\text { Toptan perakende ticaret, motorlu kara taşıtları ve } \\
\text { motosikletlerin bakım onarım hizmetleri }\end{array}$ & 1,5461 & 1,3962 & 0,7491 & 0,6626 \\
\hline 26 & Toptan ticaret, motorlu kara taşıtlar ve motosikletler hariç & 3,1574 & 5,2521 & 1,5298 & 2,4925 \\
\hline 27 & $\begin{array}{l}\text { Perakende ticaret (motorlu kara taşıtları ve motosikletler } \\
\text { hariç) }\end{array}$ & 1,7018 & 1,1794 & 0,8245 & 0,5597 \\
\hline 28 & Kara taşımacılığı ve boru hattı taşımacılığı hizmetleri & 3,7746 & 4,0404 & 1,8289 & 1,9175 \\
\hline 29 & Su yolu taşımacıllı̆̆ hizmetleri & 1,5112 & 1,1480 & 0,7322 & 0,5448 \\
\hline 30 & Hava yolu ve uzay taşımacıllı̆ı hizmetleri & 1,1821 & 1,2006 & 0,5728 & 0,5698 \\
\hline 31 & Ulaştırmayla ilgili depolama ve destek hizmetleri & 2,2795 & 2,7525 & 1,1045 & 1,3062 \\
\hline 32 & Posta ve kurye hizmetleri & 1,2009 & 1,7094 & 0,5819 & 0,8112 \\
\hline 33 & Konaklama ve yiyecek hizmetleri & 1,4704 & 1,1846 & 0,7125 & 0,5622 \\
\hline 34 & Bilgisayar programlama, danışmanlık ve ilgili hizmetler & 1,4222 & 1,7362 & 0,6891 & 0,8239 \\
\hline 35 & Finansal hizmetler (sigorta ve bireysel emeklilik hariç) & 2,2013 & 3,0071 & 1,0666 & 1,4271 \\
\hline 36 & Sigorta, reasürans ve emeklilik fonları hizmetleri, & 1,4676 & 1,3857 & 0,7111 & 0,6576 \\
\hline 37 & Finansal hizmetler, sigorta hizmetlerine yardımcı hizmetler & 1,5261 & 1,2716 & 0,7394 & 0,6035 \\
\hline 38 & Gayrimenkul hizmetleri & 2,3523 & 3,1661 & 1,1398 & $\mathbf{1 , 5 0 2 6}$ \\
\hline 39 & Bilimsel araştırma ve geliştirme hizmetleri & 1,0000 & 1,0545 & 0,4845 & 0,5005 \\
\hline 40 & Kamu yön. ve savunma; zorunlu sosyal güvenlik hizmetleri & 1,1079 & 1,1890 & 0,5368 & 0,5643 \\
\hline 41 & Eğitim hizmetleri & 1,1004 & 1,0698 & 0,5332 & 0,5077 \\
\hline 42 & Kendi konutunda ikamet edenler için izafi kira & 1,3968 & 1,8554 & 0,6768 & 0,8805 \\
\hline 43 & Sağlık ve sosyal hizmetler & 2,2762 & 3,4516 & 1,1029 & 1,6380 \\
\hline 44 & Dinlenme, eğlence, kültür ve spor organizasyon hizmetleri & 1,5421 & 1,2423 & 0,7472 & 0,5896 \\
\hline 45 & Mesleki Bilimsel Kişisel Hizmetler & 2,6710 & 1,0137 & 1,2941 & 0,4811 \\
\hline \multirow[t]{2}{*}{46} & Diğer hizmetler & 1,6668 & 1,1641 & 0,8076 & 0,5525 \\
\hline & Genel Toplam & \multicolumn{2}{|c|}{ Rusya : 96,9288 } & \multicolumn{2}{|c|}{ Ortalama : 2,1071 } \\
\hline
\end{tabular}

Tablo 1a: Türkiye ve Rusya Ekonomileri Toplam İleri ve Geri Bağlantı Etkileri Kaynak: TÜIK 2012 yılı Türkiye ve Rusya Girdi Çıktı Sonuç Tabloları Kullanılarak Yazarlar Tarafindan Hazırlanmıştır. 


\begin{tabular}{|c|c|c|c|c|c|}
\hline \multirow{3}{*}{$\begin{array}{l}\text { Sira } \\
\text { No: }\end{array}$} & \multirow{3}{*}{ Ekonomik Sektörler } & \multicolumn{2}{|c|}{$\begin{array}{c}\text { Toplam Geri } \\
\text { Bağlantı Etkileri }\end{array}$} & \multicolumn{2}{|c|}{$\begin{array}{l}\text { Geri Bağlantı } \\
\text { Endeksleri }\end{array}$} \\
\hline & & Türkiye & Rusya & Türkiye & Rusya \\
\hline & & $\mathbf{R}_{\mathbf{j}}$ & $\mathbf{R}_{\mathbf{j}}$ & $\mathbf{I R}_{\mathbf{j}}$ & $\mathbf{I R}_{\mathbf{j}}$ \\
\hline 01 & Tarım ve avcıllk ürünleri ve ilgili hizmetler & 1,7096 & 1,9866 & 0,8283 & 0,9428 \\
\hline 02 & Orman ürünleri ve ilgili hizmetler & 1,2967 & 2,0736 & 0,6283 & 0,9841 \\
\hline 03 & Balıkçıllk, su ürünleri, destekleyici hizmetler & 1,4975 & 2,0859 & 0,7255 & 0,9899 \\
\hline 04 & Madencilik ve Taşocakçıllğı, petrol ve uranyum çıkarımı & 1,8145 & 1,6590 & 0,8792 & 0,7873 \\
\hline 05 & Gıda, İçki ve tütün ürünleri & 2,3676 & 2,5892 & 1,1471 & 1,2288 \\
\hline 06 & Tekstil, Deri ve Giyim eşyaları & 2,5292 & 2,3319 & 1,2254 & 1,1067 \\
\hline 07 & Kereste, ağaç, orman ürünleri (mobilya hariç) & 2,3347 & 2,4508 & 1,1312 & 1,1631 \\
\hline 08 & Kağıt ve kağıt ürünleri ve Basım yayın kayıt hizmetleri & 2,4797 & 2,6047 & 1,2014 & 1,2361 \\
\hline 09 & Kok ve rafine petrol ürünleri & 2,4927 & 2,2797 & 1,2077 & 1,0819 \\
\hline 10 & Kimyasallar ve kimyasal ürünler & 2,5190 & 2,5243 & 1,2205 & 1,1980 \\
\hline 11 & Kauçuk ve plastik ürünler & 2,6837 & 2,8090 & 1,3003 & 1,3331 \\
\hline 12 & Diğer metalik olmayan mineral ürünleri & 2,3162 & 2,5060 & 1,1222 & 1,1893 \\
\hline 13 & Ana metaller & 2,7804 & 2,5742 & 1,3471 & 1,2217 \\
\hline 14 & Fabrikasyon metal ürünleri, makine ve ekipmanlar hariç & 2,4883 & 2,6739 & 1,2056 & 1,2690 \\
\hline 15 & Bilgisayar, elektronik ve optik ürünler & 2,4058 & 2,6142 & 1,1656 & 1,2406 \\
\hline 16 & Elektrikli teçhizat & 2,8918 & 2,6371 & 1,4011 & 1,2515 \\
\hline 17 & Başka yerde sınıflandırılmamış makine ve ekipmanlar & 2,6033 & 2,4173 & 1,2613 & 1,1472 \\
\hline 18 & Motorlu kara taşıtları, treyler (römork) ve yarı treyler & 2,9925 & 3,1513 & 1,4499 & 1,4955 \\
\hline 19 & Diğer ulaşım araçları & 2,3163 & 2,5229 & 1,1223 & 1,1973 \\
\hline 20 & Mobilya ve diğer mamul eşyalar & 2,4334 & 2,5639 & 1,1790 & 1,2168 \\
\hline 21 & Makine ve ekipmanların kurulumu ve onarımı & 2,0911 & 2,4571 & 1,0132 & 1,1661 \\
\hline 22 & Elektrik, gaz, buhar ve iklimlendirme & 3,0334 & 2,5332 & 1,4697 & 1,2022 \\
\hline 23 & Doğal su; suyun arıtılması ve temini hizmetleri & 1,9397 & 2,0785 & 0,9398 & 0,9864 \\
\hline 24 & İnşaat & 2,4197 & 2,0798 & 1,1724 & 0,9870 \\
\hline 25 & $\begin{array}{l}\text { Toptan perakende ticaret, motorlu kara taşıtları ve } \\
\text { motosikletlerin bakım onarım hizmetleri }\end{array}$ & 1,9357 & 1,7576 & 0,9379 & 0,8341 \\
\hline 26 & Toptan ticaret, motorlu kara taşıtlar ve motosikletler hariç & 1,7724 & 1,6962 & 0,8587 & 0,8050 \\
\hline 27 & $\begin{array}{l}\text { Perakende ticaret (motorlu kara taşıtları ve motosikletler } \\
\text { hariç) }\end{array}$ & 1,6786 & 1,6649 & 0,8133 & 0,7901 \\
\hline 28 & Kara taşımacılığı ve boru hattı taşımacıllı̆ı hizmetleri & 1,9318 & 1,9962 & 0,9360 & 0,9473 \\
\hline 29 & Su yolu taşımacıllı̆̆ hizmetleri & 1,9721 & 2,1955 & 0,9555 & 1,0419 \\
\hline 30 & Hava yolu ve uzay taşımacılığı hizmetleri & 2,2740 & 2,6118 & 1,1018 & 1,2395 \\
\hline 31 & Ulaştırmayla ilgili depolama ve destek hizmetleri & 1,7922 & 2,2264 & 0,8683 & 1,0566 \\
\hline 32 & Posta ve kurye hizmetleri & 1,8717 & 1,7440 & 0,9068 & 0,8277 \\
\hline 33 & Konaklama ve yiyecek hizmetleri & 2,1787 & 2,0452 & 1,0556 & 0,9706 \\
\hline 34 & Bilgisayar programlama, danışmanlık ve ilgili hizmetler & 1,3337 & 1,6527 & 0,6462 & 0,7843 \\
\hline 35 & Finansal hizmetler (sigorta ve bireysel emeklilik hariç) & 1,5159 & 1,4398 & 0,7345 & 0,6833 \\
\hline 36 & Sigorta, reasürans ve emeklilik fonları hizmetleri, & 2,2564 & 1,9048 & 1,0932 & 0,9040 \\
\hline 37 & Finansal hizmetler, sigorta hizmetlerine yardımcı hizmetler & 1,5388 & 1,4812 & 0,7456 & 0,7029 \\
\hline 38 & Gayrimenkul hizmetleri & 1,3890 & 1,3398 & 0,6730 & 0,6358 \\
\hline 39 & Bilimsel araştırma ve geliştirme hizmetleri & 1,3133 & 2,0249 & 0,6363 & 0,9610 \\
\hline 40 & Kamu yön. ve savunma; zorunlu sosyal güvenlik hizmetleri & 1,7209 & 1,6551 & 0,8338 & 0,7855 \\
\hline 41 & Ĕgitim hizmetleri & 1,3164 & 1,4312 & 0,6378 & 0,6792 \\
\hline 42 & Kendi konutunda ikamet edenler için izafi kira & 1,4424 & 1,2035 & 0,6988 & 0,5712 \\
\hline 43 & Sağlik ve sosyal hizmetler & 1,7254 & 1,6728 & 0,8360 & 0,7939 \\
\hline 44 & Dinlenme, eğlence, kültür ve spor organizasyon hizmetleri & 1,8812 & 1,7423 & 0,9115 & 0,8269 \\
\hline 45 & Mesleki Bilimsel Kișisel Hizmetler & 1,7933 & 1,2558 & 0,8689 & 0,5960 \\
\hline \multirow[t]{2}{*}{46} & Diğer hizmetler & 1,8702 & 1,9826 & 0,9061 & 0,9409 \\
\hline & Genel Toplam & \multicolumn{4}{|c|}{ Türkiye : 94,9411 } \\
\hline
\end{tabular}

Tablo 1b: Türkiye ve Rusya Ekonomileri Toplam İleri ve Geri Bağlantı Etkileri Devamı Kaynak: TÜIK 2012 yılı Türkiye ve Rusya Girdi Çıktı Sonuç Tabloları Kullanılarak Yazarlar Tarafından Hazırlanmıştır. 


\begin{tabular}{|c|c|c|c|c|c|}
\hline \multirow{3}{*}{$\begin{array}{l}\text { Sira } \\
\text { No: }\end{array}$} & \multirow{3}{*}{ Ekonomik Sektörler } & \multicolumn{2}{|c|}{$\begin{array}{l}\text { Toplam İleri Bağlantı } \\
\text { Yayılma Dereceleri }\end{array}$} & \multicolumn{2}{|c|}{$\begin{array}{c}\text { Toplam Geri Bağlantı } \\
\text { Yayılma Dereceleri }\end{array}$} \\
\hline & & Türkiye & Rusya & Türkiye & Rusya \\
\hline & & $\mathbf{R}_{\mathbf{i}}$ & $\mathbf{R}_{\mathbf{i}}$ & $\mathbf{R}_{\mathbf{i}}$ & $\mathbf{R}_{\mathbf{i}}$ \\
\hline 1 & Tarım ve avcılık ürünleri ve ilgili hizmetler & 4,0094 & 4,3494 & 4,8047 & 4,2983 \\
\hline 2 & Orman ürünleri ve ilgili hizmetler & 5,4422 & 5,1816 & 5,2598 & 3,5354 \\
\hline 3 & Balıkçılık, su ürünleri, destekleyici hizmetler & 6,6257 & 6,4528 & 4,5629 & 3,3612 \\
\hline 4 & Madencilik ve Taşocakçılığı, petrol ve uranyum çıkarımı & 1,6648 & 1,8103 & 4,2546 & 4,3687 \\
\hline 5 & Gıda, İçki ve tütün ürünleri & 4,4289 & 4,7532 & 3,5396 & 3,3213 \\
\hline 6 & Tekstil, Deri ve Giyim eşyaları & 5,0561 & 5,7487 & 4,1574 & 3,8578 \\
\hline 7 & Kereste, ağaç, orman ürünleri (mobilya hariç) & 5,3610 & 5,4480 & 3,6261 & 3,0848 \\
\hline 8 & Kağıt ve kağıt ürünleri ve Basım yayın kayıt hizmetleri & 4,1301 & 5,2463 & 3,7577 & 3,1428 \\
\hline 9 & Kok ve rafine petrol ürünleri & 2,3648 & 1,9312 & 3,6716 & 3,6401 \\
\hline 10 & Kimyasallar ve kimyasal ürünler & 2,3600 & 2,4926 & 4,2921 & 3,4806 \\
\hline 11 & Kauçuk ve plastik ürünler & 3,7819 & 4,1063 & 3,2000 & 2,8906 \\
\hline 12 & Diğer metalik olmayan mineral ürünleri & 4,4515 & 4,4275 & 3,4419 & 3,1490 \\
\hline 13 & Ana metaller & 2,3229 & 2,2777 & 3,3237 & 3,3763 \\
\hline 14 & Fabrikasyon metal ürünleri, makine ve ekipmanlar hariç & 4,1266 & 3,8316 & 3,1092 & 2,8811 \\
\hline 15 & Bilgisayar, elektronik ve optik ürünler & 5,6099 & 5,8128 & 3,7476 & 3,5269 \\
\hline 16 & Elektrikli teçhizat & 4,5048 & 4,0984 & 2,7477 & 3,0251 \\
\hline 17 & Başka yerde sınıflandırılmamış makine ve ekipmanlar & 4,8052 & 3,2240 & 2,9845 & 3,2399 \\
\hline 18 & Motorlu kara taşıtları, treyler (römork) ve yarı treyler & 5,5391 & 5,4008 & 3,0759 & 3,4553 \\
\hline 19 & Diğer ulaşım araçları & 6,2755 & 4,7636 & 3,2532 & 3,2811 \\
\hline 20 & Mobilya ve diğer mamul eşyalar & 5,8794 & 6,1887 & 2,9909 & 2,7182 \\
\hline 21 & Makine ve ekipmanların kurulumu ve onarımı & 4,5453 & 3,6785 & 3,2227 & 3,5402 \\
\hline 22 & Elektrik, gaz, buhar ve iklimlendirme & 2,8118 & 1,7981 & 4,5924 & 4,2234 \\
\hline 23 & Doğal su; suyun arıtılması ve temini hizmetleri & 3,0112 & 6,0690 & 4,0413 & 3,3923 \\
\hline 24 & İnşaat & 4,1534 & 3,0030 & 3,3215 & 3,3638 \\
\hline 25 & $\begin{array}{l}\text { Toptan perakende ticaret, motorlu kara taşıtları ve } \\
\text { motosikletlerin bakım onarım hizmetleri }\end{array}$ & 4,4886 & 5,0422 & 3,5855 & 3,9908 \\
\hline 26 & Toptan ticaret, motorlu kara tașitlar ve motosikletler hariç & 2,1152 & 1,3265 & 3,8446 & 4,1732 \\
\hline 27 & $\begin{array}{l}\text { Perakende ticaret (motorlu kara taşıtları ve motosikletler } \\
\text { hariç) }\end{array}$ & 3,9175 & 5,6914 & 3,9987 & 4,0489 \\
\hline 28 & Kara taşımacılığı ve boru hattı taşımacılığı hizmetleri & 2,1075 & 1,7910 & 4,2543 & 3,6843 \\
\hline 29 & Su yolu taşımacıllığı hizmetleri & 5,0003 & 5,9444 & 3,9487 & 3,1728 \\
\hline 30 & Hava yolu ve uzay taşımacılığı hizmetleri & 6,0679 & 5,7404 & 3,2835 & 2,7992 \\
\hline 31 & Ulaştırmayla ilgili depolama ve destek hizmetleri & 3,5183 & 2,8264 & 4,3864 & 3,4877 \\
\hline 32 & Posta ve kurye hizmetleri & 5,7894 & 4,9628 & 3,7107 & 4,8698 \\
\hline 33 & Konaklama ve yiyecek hizmetleri & 4,8810 & 5,6595 & 3,3586 & 3,3297 \\
\hline 34 & Bilgisayar programlama, danışmanlık ve ilgili hizmetler & 4,8891 & 4,4712 & 5,2296 & 4,7147 \\
\hline 35 & Finansal hizmetler (sigorta ve bireysel emeklilik hariç) & 3,3240 & 2,3653 & 4,8892 & 5,0740 \\
\hline 36 & Sigorta, reasürans ve emeklilik fonları hizmetleri, & 5,6772 & 5,6030 & 3,7882 & 4,1036 \\
\hline 37 & Finansal hizmetler, sigorta hizmetlerine yardımcı hizmetler & 4,7067 & 5,3610 & 4,4486 & 4,5891 \\
\hline 38 & Gayrimenkul hizmetleri & 2,8446 & 2,1549 & 4,8888 & 5,2376 \\
\hline 39 & Bilimsel araștırma ve geliștirme hizmetleri & 6,7082 & 6,7078 & 5,0788 & 3,4882 \\
\hline 40 & $\begin{array}{l}\begin{array}{l}\text { Kamu yön. ve savunma; zorunlu sosyal güvenlik } \\
\text { hizmetleri }\end{array} \\
\end{array}$ & 6,0817 & 5,6371 & 3,8833 & 4,0309 \\
\hline 41 & Eğitim hizmetleri & 6,1589 & 6,3567 & 5,1344 & 4,7392 \\
\hline 42 & Kendi konutunda ikamet edenler için izafi kira & 4,9345 & 3,6287 & 4,7838 & 5,6249 \\
\hline 43 & Sağlik ve sosyal hizmetler & 3,1883 & 2,0042 & 4,2580 & 4,2756 \\
\hline 44 & Dinlenme, eğlence, kültür ve spor organizasyon hizmetleri & 5,2597 & 5,8338 & 4,2913 & 4,1463 \\
\hline 45 & Mesleki Bilimsel Kişisel Hizmetler & 2,8440 & 6,6185 & 4,3109 & 5,3218 \\
\hline \multirow[t]{2}{*}{46} & Diğer hizmetler & 4,4043 & 5,9062 & 3,9248 & 3,4513 \\
\hline & & \multicolumn{4}{|c|}{$\begin{array}{l}\text { Ortalama Yayılma : 4,1786 (Türkiye) } \\
\text { (Rusya) }\end{array}$} \\
\hline
\end{tabular}

Tablo 2: Illeri ve Geri Bağlantı Yayılma Dereceleri Kaynak: TÜIK 2012 yılı Türkiye ve Rusya Girdi-Çıktı Sonuç Tabloları Kullanilarak Yazarlar Tarafindan Hazırlanmıştır. 


\begin{tabular}{|c|c|c|}
\hline $\begin{array}{l}\text { Sura } \\
\text { No: }\end{array}$ & Ekonomik Sektörler & $\begin{array}{r}\text { Etkenlik } \\
\text { Katsayısı }\end{array}$ \\
\hline 1 & Tarım ve avcılık ürünleri ve ilgili hizmetler & $\mathbf{0 , 4 1 2 7}$ \\
\hline 2 & Orman ürünleri ve ilgili hizmetler & 1,3166 \\
\hline 3 & Balıkçılık, su ürünleri, destekleyici hizmetler & 1,2338 \\
\hline 4 & Madencilik ve Taşocakçılığı, petrol ve uranyum çıkarımı & $\mathbf{0 , 5 6 3 0}$ \\
\hline 5 & G1da, İçki ve tütün ürünleri & $\mathbf{0 , 3 3 6 4}$ \\
\hline 6 & Tekstil, Deri ve Giyim eşyaları & $\mathbf{0 , 4 3 5 6}$ \\
\hline 7 & Kereste, ağaç, orman ürünleri (mobilya hariç) & 0,6145 \\
\hline 8 & Kağıt ve kağıt ürünleri ve Basım yayın kayıt hizmetleri & $\mathbf{0 , 7 7 3 4}$ \\
\hline 9 & Kok ve rafine petrol ürünleri & $\mathbf{0 , 7 5 7 0}$ \\
\hline 10 & Kimyasallar ve kimyasal ürünler & 0,7645 \\
\hline 11 & Kauçuk ve plastik ürünler & $\mathbf{0 , 4 4 5 7}$ \\
\hline 12 & Diğer metalik olmayan mineral ürünleri & $\mathbf{0 , 5 4 1 6}$ \\
\hline 13 & Ana metaller & 0,8097 \\
\hline 14 & Fabrikasyon metal ürünleri, makine ve ekipmanlar hariç & 0,3709 \\
\hline 15 & Bilgisayar, elektronik ve optik ürünler & $\mathbf{0 , 5 9 3 8}$ \\
\hline 16 & Elektrikli teçhizat & 0,4240 \\
\hline 17 & Başka yerde sınıflandırılmamış makine ve ekipmanlar & $\mathbf{0 , 5 3 9 7}$ \\
\hline 18 & Motorlu kara taşıtları, treyler (römork) ve yarı treyler & 0,5156 \\
\hline 19 & Diğer ulaşım araçları & 0,6481 \\
\hline 20 & Mobilya ve diğer mamul eşyalar & 0,5736 \\
\hline 21 & Makine ve ekipmanların kurulumu ve onarımı & 0,9636 \\
\hline 22 & Elektrik, gaz, buhar ve iklimlendirme & 0,6958 \\
\hline 23 & Doğal su; suyun arıtılması ve temini hizmetleri & 0,8658 \\
\hline 24 & İnşaat & 0,5682 \\
\hline 25 & Toptan perakende ticaret, motorlu kara taşıtları ve motosikletlerin bakım onarım hizmetleri & 0,7537 \\
\hline 26 & Toptan ticaret, motorlu kara taşıtlar ve motosikletler hariç & 0,9006 \\
\hline 27 & Perakende ticaret (motorlu kara taşıtları ve motosikletler hariç) & 0,6797 \\
\hline 28 & Kara taşımacılı̆̆ ve boru hattı taşımacılı̆̆ı hizmetleri & 0,9414 \\
\hline 29 & Su yolu taşımacıllı̆ı hizmetleri & $\mathbf{0 , 7 9 4 9}$ \\
\hline 30 & Hava yolu ve uzay taşımacılığı hizmetleri & $\mathbf{0 , 7 6 3 7}$ \\
\hline 31 & Ulaştırmayla ilgili depolama ve destek hizmetleri & 0,8068 \\
\hline 32 & Posta ve kurye hizmetleri & 1,2495 \\
\hline 33 & Konaklama ve yiyecek hizmetleri & 0,6248 \\
\hline 34 & Bilgisayar programlama, danışmanlık ve ilgili hizmetler & 1,2561 \\
\hline 35 & Finansal hizmetler (sigorta ve bireysel emeklilik hariç) & $\mathbf{0 , 7 2 0 2}$ \\
\hline 36 & Sigorta, reasürans ve emeklilik fonları hizmetleri, & $\mathbf{0 , 7 2 8 3}$ \\
\hline 37 & Finansal hizmetler, sigorta hizmetlerine yardımcı hizmetler & 1,0990 \\
\hline 38 & Gayrimenkul hizmetleri & 0,8698 \\
\hline 39 & Bilimsel araştırma ve geliştirme hizmetleri & 1,3775 \\
\hline 40 & Kamu yön. ve savunma; zorunlu sosyal güvenlik hizmetleri & 0,7895 \\
\hline 41 & Eğitim hizmetleri & 0,8365 \\
\hline 42 & Kendi konutunda ikamet edenler için izafi kira & 1,1816 \\
\hline 43 & Sağllk ve sosyal hizmetler & 0,6805 \\
\hline 44 & Dinlenme, eğlence, kültür ve spor organizasyon hizmetleri & $\mathbf{0 , 7 0 3 1}$ \\
\hline 45 & Mesleki Bilimsel Kişisel Hizmetler & 1,3740 \\
\hline 46 & Diğer hizmetler & 0,9343 \\
\hline
\end{tabular}

Tablo 3: Türkiye ve Rusya Ekonomilerinin Üretim Tekniklerinin Benzerliği Kaynak: TÜIK 2012 yılı Türkiye ve Rusya Girdi-Çıktı Sonuç Tabloları Kullanılarak Yazarlar Tarafından Hazırlanmıştır. 


\begin{tabular}{|c|c|c|c|c|}
\hline \multirow{2}{*}{$\begin{array}{l}\text { Sira } \\
\text { No: }\end{array}$} & \multirow{2}{*}{ Ekonomik Sektörler } & \multicolumn{3}{|c|}{ Aragirdi Kullanımları ve Oranı } \\
\hline & & Türkiye & Rusya & (TR/RU) \\
\hline 1 & Tarım ve avcılık ürünleri ve ilgili hizmetler & 97.048 .230 & 93.441 .876 & 1,0386 \\
\hline 2 & Orman ürünleri ve ilgili hizmetler & 2.325 .667 & 4.294 .551 & $\mathbf{0 , 5 4 1 5}$ \\
\hline 3 & Balıkçılık, su ürünleri, destekleyici hizmetler & 950.367 & 3.722 .958 & $\mathbf{0 , 2 5 5 3}$ \\
\hline 4 & Madencilik ve Taşocakçılığı, petrol ve uranyum çıkarımı & 94.735 .469 & 56.831 .160 & 1,6670 \\
\hline 5 & Gıda, İçki ve tütün ürünleri & 53.806 .928 & 58.600 .071 & 0,9182 \\
\hline 6 & Tekstil, Deri ve Giyim eşyaları & 64.212 .942 & 44.036 .114 & 1,4582 \\
\hline 7 & Kereste, ağaç, orman ürünleri (mobilya hariç) & 12.868 .821 & 11.951 .260 & 1,0768 \\
\hline 8 & Kağıt ve kağıt ürünleri ve Basım yayın kayıt hizmetleri & 27.299 .110 & 15.402 .535 & 1,7724 \\
\hline 9 & Kok ve rafine petrol ürünleri & 60.932 .680 & 71.080 .519 & $\mathbf{0 , 8 5 7 2}$ \\
\hline 10 & Kimyasallar ve kimyasal ürünler & 80.773 .018 & 73.462 .213 & 1,0995 \\
\hline 11 & Kauçuk ve plastik ürünler & 33.169 .956 & 28.643 .002 & 1,1580 \\
\hline 12 & Diğer metalik olmayan mineral ürünleri & 43.924 .047 & 41.770 .315 & 1,0516 \\
\hline 13 & Ana metaller & 95.898 .063 & 74.276 .858 & 1,2911 \\
\hline 14 & Fabrikasyon metal ürünleri, makine ve ekipmanlar hariç & 28.647 .667 & 30.933 .684 & 0,9261 \\
\hline 15 & Bilgisayar, elektronik ve optik ürünler & 8.702 .368 & 6.227 .131 & 1,3975 \\
\hline 16 & Elektrikli teçhizat & 20.493 .079 & 20.284 .126 & 1,0103 \\
\hline 17 & Başka yerde sınıflandırılmamış makine ve ekipmanlar & 14.488 .044 & 33.403 .906 & $\mathbf{0 , 4 3 3 7}$ \\
\hline 18 & Motorlu kara taşıtları, treyler (römork) ve yarı treyler & 19.435 .642 & 27.350 .545 & 0,7106 \\
\hline 19 & Diğer ulaşım araçları & 1.722 .016 & 12.094 .166 & 0,1424 \\
\hline 20 & Mobilya ve diğer mamul eşyalar & 9.380 .594 & 3.830 .865 & 2,4487 \\
\hline 21 & Makine ve ekipmanların kurulumu ve onarımı & 9.577 .776 & 17.881 .704 & 0,5356 \\
\hline 22 & Elektrik, gaz, buhar ve iklimlendirme & 98.369 .748 & 128.681 .658 & 0,7644 \\
\hline 23 & Doğal su; suyun arıtılması ve temini hizmetleri & 37.007 .929 & 3.947 .846 & 9,3742 \\
\hline 24 & İnşaat & 66.743 .517 & 51.962 .647 & 1,2845 \\
\hline 25 & $\begin{array}{l}\text { Toptan perakende ticaret, motorlu kara taşıtları ve } \\
\text { motosikletlerin bakım onarım hizmetleri }\end{array}$ & 15.783 .313 & 11.480 .921 & 1,3747 \\
\hline 26 & Toptan ticaret, motorlu kara taşıtlar ve motosikletler hariç & 71.891 .306 & 126.505 .213 & 0,5683 \\
\hline 27 & $\begin{array}{l}\text { Perakende ticaret (motorlu kara taşıtları ve motosikletler } \\
\text { hariç) }\end{array}$ & 23.300 .095 & 8.762 .760 & 2,6590 \\
\hline 28 & Kara taşımacılığ1 ve boru hattı taşımacıllı̆ı hizmetleri & 93.035 .989 & 73.534 .026 & 1,2652 \\
\hline 29 & Su yolu taşımacıllı̆ı hizmetleri & 10.110 .856 & 2.493 .920 & 4,0542 \\
\hline 30 & Hava yolu ve uzay taşımacılığı hizmetleri & 4.647 .592 & 5.061 .921 & 0,9181 \\
\hline 31 & Ulaştırmayla ilgili depolama ve destek hizmetleri & 25.472 .213 & 38.857 .794 & 0,6555 \\
\hline 32 & Posta ve kurye hizmetleri & 5.390 .907 & 11.283 .674 & 0,4778 \\
\hline 33 & Konaklama ve yiyecek hizmetleri & 16.720 .409 & 6.215 .781 & 2,6900 \\
\hline 34 & Bilgisayar programlama, danışmanlık ve ilgili hizmetler & 11.655 .058 & 14.192 .810 & $\mathbf{0 , 8 2 1 2}$ \\
\hline 35 & Finansal hizmetler (sigorta ve bireysel emeklilik hariç) & 33.086 .765 & 55.168 .518 & $\mathbf{0 , 5 9 9 7}$ \\
\hline 36 & Sigorta, reasürans ve emeklilik fonları hizmetleri, & 6.649 .744 & 7.310 .963 & 0,9096 \\
\hline 37 & $\begin{array}{l}\begin{array}{l}\text { Finansal hizmetler, sigorta hizmetlerine yardımc1 } \\
\text { hizmetler }\end{array}\end{array}$ & 5.748 .269 & 2.863 .911 & 2,0071 \\
\hline 38 & Gayrimenkul hizmetleri & 45.773 .226 & 79.043 .168 & $\mathbf{0 , 5 7 9 1}$ \\
\hline 39 & Bilimsel araştırma ve geliştirme hizmetleri & 46 & 630.371 & $\mathbf{0 , 0 0 0 1}$ \\
\hline 40 & $\begin{array}{l}\begin{array}{l}\text { Kamu yön. ve savunma; zorunlu sosyal güvenlik } \\
\text { hizmetleri }\end{array} \\
\end{array}$ & 2.340 .687 & 5.105 .190 & $\mathbf{0 , 4 5 8 5}$ \\
\hline 41 & Eğitim hizmetleri & 3.434 .876 & 2.755 .786 & 1,2464 \\
\hline 42 & Kendi konutunda ikamet edenler için izafi kira & 9.058 .616 & 23.356 .858 & $\mathbf{0 , 3 8 7 8}$ \\
\hline 43 & Sağlik ve sosyal hizmetler & 43.415 .496 & 72.429 .493 & $\mathbf{0 , 5 9 9 4}$ \\
\hline 44 & Dinlenme, eğlence, kültür ve spor organizasyon hizmetleri & 11.971 .637 & 8.342 .715 & 1,4350 \\
\hline 45 & Mesleki Bilimsel Kişisel Hizmetler & 48.390 .310 & 611.025 & 79,1953 \\
\hline \multirow[t]{2}{*}{46} & Diğer hizmetler & 20.456 .967 & 7.043 .566 & 2,9043 \\
\hline & Toplam & 1490848056 & 1.477 .162 .096 & 1,0092 \\
\hline
\end{tabular}

Tablo 4: Türkiye ve Rusya Ekonomilerinin Aramalı Kullanımı Etkenlik Dereceleri Kaynak: TÜIK 2012 yll Türkiye ve 2012 yılı Rusya Girdi-Çıktı Sonuç Tabloları Kullanılarak Yazarlar Tarafından Hazırlanmıştır. 
Örneğin, 1-Tarım ve avcılık ürünleri sektörü için hesaplanan oran 1,0386 (97.048.230/93.441.876=1,0386) çıkmıştır. Üretim Türkiye'de gerçekleştirildiğinde kullanılan aramalı miktarı 97.048 .230 olmaktadır. Aynı üretim Rusya'da gerçekleştirildiğinde kullanılan aragirdi miktarı 93.441.876 olmaktadır. Bu durumda Türkiye aynı üretimi daha çok ara girdi kullanımıyla gerçekleştirmekte dolayısıyla kaynakları Rusya, Türkiye'ye göre daha etkin kullanmaktadır.

Etkenlik derecelerine göre, 1'den küçük sonuçlar Türkiye'nin etkinliğinin Rusya'ya göre daha iyi olduğu, 1'den büyük sonuçlar ise, Rusya'nın etkinliğinin Türkiye'ye göre daha iyi olduğu anlamına gelmektedir. Ekonomi genelinde yer alan 46 sektörden 22 tanesinde oran 1'den küçük çıkmıştır.

Temel üretim-imalat sektörleri içerisinde, Ormancılık, Balıkçılık-su ürünleri, Gıda-İçki-Tütün, Rafine petrol ürünleri, Fabrikasyon metal ürünler, Makine-ekipman üretimi, Motorlu kara taşıtları treyler, Diğer ulaşım araçları, Makine ve ekipmanların kurulum ve onarımı, Elektrik-gaz sektörleri Türkiye'nin Rusya'ya göre daha etkin olduğu sektörlerdir. Hizmet sektörleri içerisinde ise, Toptan ticaret, Hava-uzay yolu taşımacılı̆̆ , Ulaştırma-depolama lojistik, Posta-kurye hizmetleri, Bilgisayar programlama-danışmanlık, Finansal hizmetler, Sigortacılık, Gayrımenkul hizmetleri, Bilimsel araştırmalar ar-ge hizmetleri, Kamu Yönetimi-Savunma-Zorunlu Sosyal Güvenlik hizmetleri, Sağlık ve sosyal hizmetlerle Kendi konutunda yaşayanlar için izafi kira sektörlerinde etkenlik derecesi 1'den küçük çıktığından Türkiye'nin Rusya'ya göre daha etkin olduğu anlaşılmıştır. Burada belirtilen sektörler dışında kalan 24 sektör ise, Rusya'nın daha etkin aragirdi kullanımı yönünden avantajılı olduğu sektörler olarak karşımıza çıkmıştır. Toplam değerler üzerinden yapılan incelemede ise oran 1,0092 olarak elde edilmiştir. $\mathrm{Bu}$ da aslında iki ülkenin benzer teknolojileri kullanarak hemen hemen aynı aragirdi kullanımıyla üretim yaptıklarını bize göstermektedir. Burada da üretim tekniklerinin benzerliğiyle ilgili elde edilen sonuç bir başka yoldan da teyit edilmiştir.

Ancak burada ülke ekonomilerini aragirdi kullanımları bakımından değerlendirirken sonuçların güvenilirliği bakımından iki ülke arasındaki sosyal, kültürel, coğrafi, ekonomik ve üretim koşullarındaki farklılıkların gözönünde tutulması gerektiğini de belirtmeliyiz. Herhangi bir ülkede herhangi sektörde diğer ülke sektörüne göre aragirdi kullanımının az olması her zaman o ülkedeki ilgili sektörün daha verimli olduğu anlamına gelmeyebilir. Sosyo-ekonomik koşullardan kaynaklanan farklılıklar, örneğin reel fiyat farklılıkları da buna neden olabilir.

\section{Sonuç}

Son dönemlerde dış ekonomik politik konjonktür, Türkiye ile Rusya arasında yakınlaşma ve ortak kararlar alarak birlikte hareket etme ortamı yaratmıştır. Rusya, hem dış ekonomik-politik konjonktür hem de tarihten gelen ortak bağlar nedeniyle dağılma sonrasında da Orta Asya Türk Cumhuriyetleri için uluslararası alanda önemli bir aktördür. Bu çalışmada Girdi-Çıktı Analizi Yaklaşımıyla Türkiye ve Rusya ekonomileri karşılaştırmalı olarak incelenmiştir. Kuşkusuz iki ülke arasındaki ekonomik işbirliğinin ve ticari ilişkilerin geliştirilmesi başta Türkiye dolaylı olarak da Orta Asya Türk Cumhuriyetleri için önemli kazançların ortaya çıkmasına yol açacaktır.

Elde edilen sonuçlara göre, sektörel ileri ve geri bağlantı etkilerinde, Rusya'dan farklı olarak tarım, tekstil, kağıt, avukatlık, veterinerlik, doktorluk gibi mesleki ve bilişsel hizmetler, endeks değeri 1'e çok yakın olmakla birlikte inşaat Türkiye için ileri bağlantı etkisi yüksek çıkan sektörler olmuşlardır. Geri bağlantı etkileri bakımından ise, Rusya'dan farklı olarak, sadece Türkiye için geri bağlantı etkisi yüksek olan sektörler; inşaat, konaklama-yiyecek hizmetleri, sigorta-reasürans hizmetleri sektörleri olmuştur. Hem ileri hem geri her iki etkinin yüksek olduğu sektörler ise, Türkiye için, Tekstil, Kağıt-Basım-yayım, Kok kömürü-Rafine petrol ürünleri, Kimya, Ana metal, Elektrik-doğal gaz üretimi imalat sektörleri olmaktadır. Aynı sektörler Rusya için ise, Rafine petrol ürünleri, Kimya, Ana metaller, Makine-Ekipmanlarının üretimi, montaj-bakım ve onarımı, Elektrik-doğal gaz üretimi, Ulaştırma-depolama hizmet sektörleri olarak elde edilmiştir. Bu sonuçlara göre, iki ülke arasındaki dış ticaretin ileri geri bağlantı etkilerine göre ülkelerin göreli olarak avantajlı olduğu sektörlere yönelik yapılması her iki ülke ekonomisi için fayda sağlayacaktır. Bu kapsamda, Türkiye için tarım, tekstil, turizm, kağıt ve kağıt ürünleri, inşaat, mesleki bilişsel faaliyetler, sigortacılık Rusya'ya ihracat bakımından Türkiye için önemli, avantajlı sektörler olarak ortaya çıkarken, Rusya'dan ithalat bakımından ise, makine-ekipman, enerji, kimya ve anametaller göreli olarak daha avantajlı sektörler olarak ortaya çıkmaktadır.

İki ülkenin üretim teknikleri bakımından incelenmesi sonucunda da, hem teknik katsayıların benzerliği hem de aragirdi kullanım etkinliği bakımından her iki ekonominin birbirine oldukça benzer teknolojileri kullandığı aralarında çok büyük farklılıkların olmadığı görülmüsşür. Ancak aragirdi kullanım etkinliklerinde, hizmet sektörlerinde; Toptan ticaret, Hava-uzay yolu taşımacılı̆̆ı, Ulaştırma-depolama lojistik, Posta-kurye hizmetleri, Bilgisayar programlama-danışmanlık, Finansal hizmetler, Sigortacılık, Gayrimenkul hizmetleri, Bilimsel araştırmalar ar-ge hizmetleri, Kamu Yönetimi-Savunma-Zorunlu Sosyal Güvenlik hizmetleri, Sağlık ve sosyal hizmetler sektörlerinde Türkiye'nin Rusya'ya göre daha etkin olduğu görülmüştür. Türkiye bakımından bu sektörlere yoğunlaşacak olan hizmet ihracatı her iki ülke için yararlı olacaktır. Elde edilen bu sonuçlar, iki ülke arasında yapılacak ortak çalı̧̧malar ve anlaşmalarla bir maliyet-fiyat avantajına dönüştürüldüğünde, iki ülke yararına ekonomik işbirliği ve ticaret de hızla gelişecektir. 


\section{Kaynakça}

- $\quad$ Aydoğuş, O. (2010) Girdi-Çıktı Modellerine Giriş, Efil Yayınevi, Ankara.

- $\quad$ Koyçuyev T., SSCB Ülkelerinde Dengeli Ekonomik Büyüme Özelliklerinin Analizi ve Teorik Problemler, Doktora Tezi, Moskova İktisat Enstitüsü, Moskova-1983.

- Todaro M.P. (1987) Kalkınma Planlaması (Modeller ve Yöntemler), (Çev. Orhan Sezgin), İstanbul.

- $\quad$ TÜİK, 2012 Yılı Girdi-Çıktı Sonuç Tabloları, Ankara-2016. http://www.tuik.gov.tr/PreTablo.do?alt_id=1021). Erişim tarihi: 04.09.2018.

- Баранов Э.Ф., Ким И.А., Пионтковский Д.И., Старицына Е.А. Вопросы построения таблиц «затратывыпуск» России в международных классификаторах. Экономический журнал ВШЭ, 2014, стр.7-40. (Baranov E., Kim I., Piontkovski D., Staritsyna E. (2014) Problems of Constructing Russian Input-Output Tables into the International Classifications. HSE Economic Journal, vol. 1, no 1, pp. 7-40) https://www.hse.ru/data/2015/03/10/1093904239/HSE2014-1.pdf. Erişim tarihi: 04.09.2018.

- Федеральная служба государственной статистики Российской Федерации. Таблицы «Затратывыпуск» за 2012 год. http://www.gks.ru/wps/wcm/connect/rosstat_main/rosstat/ru/statistics/accounts/\#. Erişim tarihi: 04.09.2018. 


\title{
Doğu Akdeniz'deki Mücavir Ekonomik Bölge Enerji Kaynaklarının AB, Türkiye ve Kıbrıs Yönünden Değerlendirilmesi
}

\section{The Evaluation of the Energy Resources of Exclusive Economic Zones in Eastern Mediterranean}

\author{
Assoc. Prof. Dr. Kamil Uslu (Kavram MYO, Turkey)
}

\begin{abstract}
The Eastern Mediterranean has attracted new attention on the gas potential in the world. In fact, overseas research in the eastern Mediterranean waters began in the late 1960s with a number of wells opened by Belpetco. With the overseas production of the region in recent years, it has entered the world agenda. However, these discoveries have triggered additional conflicts between the states on the establishment of sovereign rights and the limitation of the Exclusive Economic Zone (EEZ). In 2009, a large amount of energy was produced in the Eastern Mediterranean Region. The resulting supply, economic line in the westward movement, between Cyprus and Turkey, Turkey would reach out to EU countries. Arish-Ashkelon, which supplies gas to Israel, Jordan, Syria and Lebanon, has been identified as a pipeline. The other line is the Arab Gas Pipeline. The cooperation with the implementation of the line was met and accepted. But the Syrian civil war has postponed this view for now. When Cyprus joined the EU in 2004, the Sea of Levantine made the European Union a sea border for all practical purposes. In the early 2000s, Cyprus and Turkey's EU membership expectancy, could boost optimism about the possibility of a breakthrough. Turkey should not be admitted to the EU has prevented the solution of the Cyprus problem. Turkey and the Turkish Republic of Northern Cyprus (TRNC) and made clear that the agreement with the International Exclusive Economic Zone reached 200 Mile limits. The energy source derived from the region, the future of both Turkey and the TRNC will be able to improve the economic well-being. Thus, will contribute to peace in the region.
\end{abstract}

\section{Giriş}

Doğu Akdeniz Bölgesi, enerji çalışmaların 1970'lı yıllardan itibaren başlanmış ve Mısır, İsrail ve Güney Kıbrıs Rum Yönetimleri kendi Münhasır Ekonomik Bölgelerinde üretime başlamışlardır. Ortadoğu Enerji Üretiminde (Petrol ve Doğalgaz) dünya enerji üretimini yüzde 63 'üne sahipken, Doğu Akdeniz Denizaşırı (offshore) bölgelerinde tahmin edilen enerji kaynakları bugünkü değer üzerinden 1.5 Trilyon \$ olduğu tahmin edilmektedir.

Doğu Akdeniz, münhasır Ekonomik Bölge'de çıkartılan doğal kaynakların, Avrupa Birliği (AB) yönünden incelenmiştir. Bunun nedeni, bölgeden elde edilen enerji kaynağının en büyük pazarı $\mathrm{AB}$ olmasındandır. Diğer bir nedeni de AB'ne katılan Güney Kıbrıs Rum Yönetimi (GKRY), dolayısıyla Münhasır Ekonomik Bölge’ye de sınır olmuştur. Türkiye ve Kuzey Kıbrıs Türk Cumhuriyeti (KKTC) ile yapmış olduğu anlaşma ile Uluslararası Münhasır Ekonomik Bölge'nin 200 Millik sınıra ulaşmıştır. Bölgeden elde edilen enerji kaynağı, hem Türkiye'nin ve hem de KKTC'nin ekonomik refahına ve bölge barışına katkı sağlayabilecektir.

\section{Tarihi Yönü}

Doğu Akdeniz gaz potansiyeli üzerindeki yeni ilgiyi çekmiş̧ir. Aslında, Doğu Akdeniz sularındaki açık deniz araştırmaları 1960'ların sonunda Belpetco tarafından açılan bir dizi kuyu ile başlamıştır. Bu kuyular, İsrail ve kuzey Sina'nın sı ğ rafındaki yapısal dorukları kapsamaktadır. Ancak, açılan kuyuların hepsi kuru bulunmuştur. Hidrokarbon üretimi açısından başarısız olan bu ilk kuyular, önemli bilgiler sağladı ve Doğu Akdeniz bölgesinin ilk jeolojik modelini oluşturdu. 1970'lerin ortaları ile 1980'lerin ortaları arasında yapılan ikinci bir keşif kampanyası daha başarılı oldu. Ticari bir üretim yapılmamasına rağmen, Sina'da açık denizde birkaç kuyu açıldı ve çeşitli bölgelerde hafif petrol bulundu (http://www.europarl.europa.eu/RegData/etudes/STUD/2017/578044/EXPO_STU(2017)578044_EN.pdf,s.16 (09.04.2019)).

2010 yllında, ABD Jeolojik Etütleri (USGS), Doğu Akdeniz bölgesindeki sekiz havzadan biri olan Levant Havzasının, Irak rezervleriyle karşılaştırılabilecek 3455 milyar metreküp (bcm) doğal gaz kaynağı içerebileceğini tahmin edilmiştir. Son zamanlarda büyük hidrokarbon kaynaklarının keşfedilmesi Orta Doğu'daki enerji alanını yeniden tanımlamış ve 1990'dan 2009'a kadar bölgenin enerji karışımının \% 27'sinde doğal gaz artışı sağlamıştır (http://www.europarl.europa.eu/RegData/etudes/briefing_note/join/2014/522339/EXPO-

AFET_SP\%282014\%29522339_EN.pdf( 21.03.2019)). Levant'ı dönüştüren sırasıyla 2009 ve 2010 'da keşfedilen İsrail gaz sahaları Tamar ve Leviathan'dı. Havza, potansiyel bir ihracat bölgesidir. Levant Havzası'ndaki toplam kanıtlanmış doğal gaz üretim rezervlerinin toplamı $(515 \mathrm{bcm})$ küresel seviyelere göre önemsiz olmakla birlikte 
Kıbrıs ve İsrail'in Levant Havzası'ndaki son zamanlarda yapılan keşifler tahminleri zorlamıştır. Bölgedeki kazanılabilir doğal gaz kaynakları 1076 bcm'den fazladır. Gelecekteki araştırmalar kısa vadede gaz rezervlerini artırabileceği yönündedir.

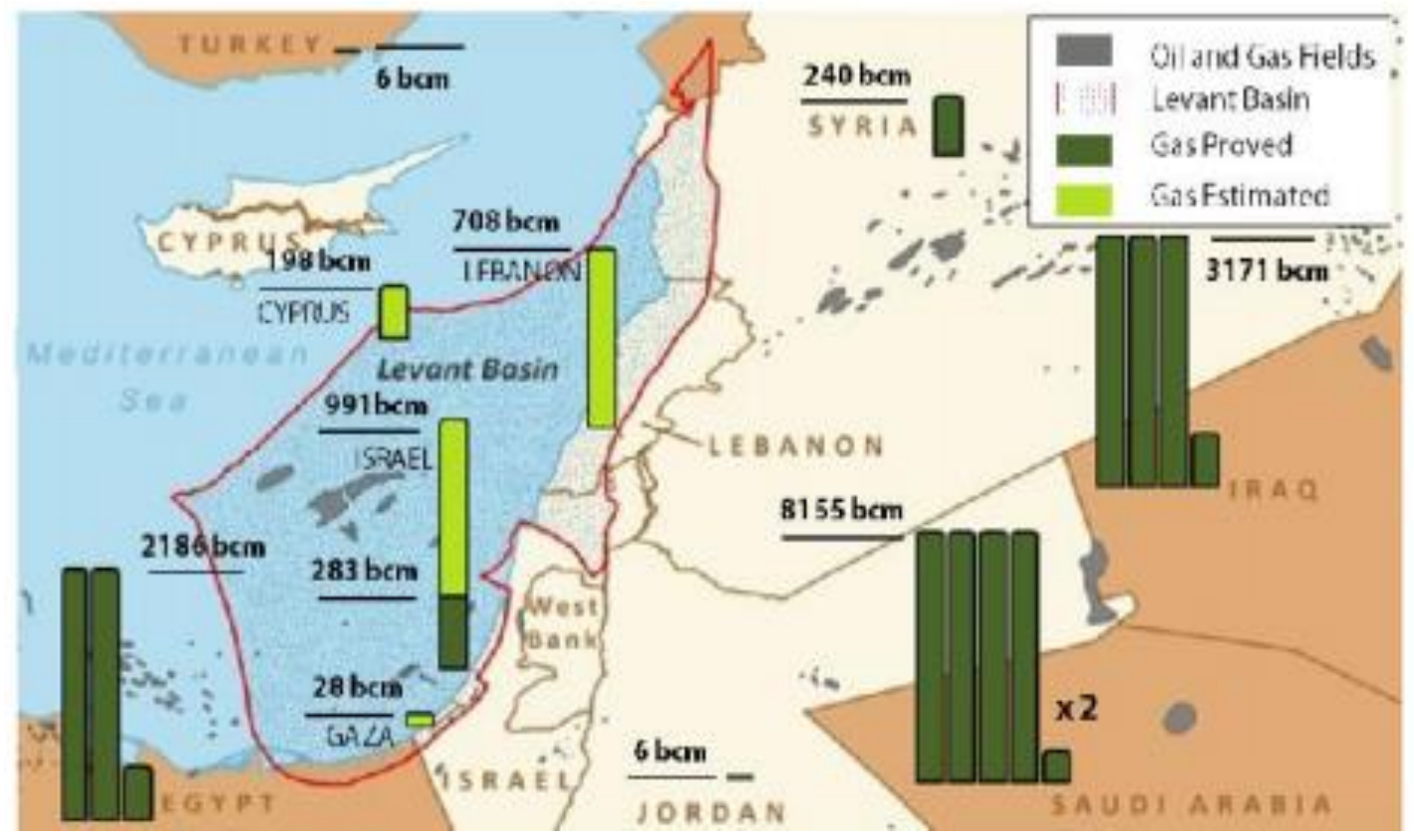

Şekil 1. Levant Havzası, Komşu Ülkelerin Kanıtlanmış Gaz Rezervleri İle İlgili Olarak Gaz Rezervleri Kaynak:http://www.europarl.europa.eu/RegData/etudes/briefing_note/join/2014/522339/EXPOAFET_SP\%2820 14\%29522339_EN.pdf_(21.03.2019)

Tarihsel açıdan bakıldığında, Doğu Akdeniz, özellikle komşu bölgeleriyle karşılaştırıldığında Orta Doğu ve Kuzey Afrika gibi enerji açısından hiçbir zaman büyük öneme sahip olmamıştır. Levanten Denizi ve Ege Denizi'ndeki deniz gelişiminin tarihi üç ana döneme ayrılabilir. Birincisi, 1970'lerden 1990'ların sonuna kadar, İsrail ve Mısır'ın Levantine Denizi'nde ve Yunanistan ve Türkiye tarafindan Ege Denizi'nde yapılan küçük denizaşırı (offshore) faaliyetleri ile nitelendirilir. Ege Denizi'nde, bu faaliyetler herhangi bir büyük keşifle sonuçlanmamıştır. Ancak, deniz sınırlarının sınırlandırılması konusundaki geniş çatışmalarının bir parçası olarak Atina ile Ankara arasında ciddi çatışmalara neden olmuştur. Yunanistan, 1981'de Avrupa Topluluğuna katılmış olmasına rağmen, Yunanistan ve Türkiye arasındaki rekabet esas olarak NATO güvenlik çerçevesi içinde kalınmıştır. Taraflar arasındaki Soğuk Savaş, daha geniş jeopolitik alanda, başta ABD olmak üzere, diğer dış aktörlerin müdahalesiyle ele alınmıştır. Bu dönemin bir diğer önemli siyasi gelişmesi de Kıbrıs sorununun yükselmesidir. Çözüme kavuşamayan Kıbrıs sorunu, 1983 'te ve yalnızca Türkiye tarafından tanınan Kuzey Kıbrıs Türk Cumhuriyeti'ne (KKTC) şeklinde bölünmesidir. Bu gelişme, önümüzdeki yıllarda Doğu Akdeniz denizaşırı siyasetini büyük ölçüde etkileyebilecektir.

Levanten Denizi'nde, 1960'ların sonunda ve 1970'lerin başında İsrail kıyılarında denizaşırı araştırması başlamıştır. Ancak, tarlaların ticari gelişimini haklı kılan keşifler ise yapılmamıştır. Bölgedeki ilk önemli gaz keşifleri, 1980'lerin ikinci yarısında Mısır sularında Nil Deltası, Alessandria'nın kuzeyi ve Port Said'in önündeki Mısır sularında yapılmıştır (Khadduri 2012). Mısır, aynı zamanda bölgede MEB (EEZ)'yi1983'te UNCLOS'a uygun olarak kuran ilk ülke olmuştur. 1980'lerde Kıbrıs ve Lübnan da UNCLOS'u (sırasıyla 1982 ve 1984'te) imzaladılar. Ancak, İsrail, Suriye ve Türkiye henüz sözleşmenin tarafları olmamıştır. 1990'ların başında, British Petroleum, ENI ve British Gas gibi bazı önemli uluslararası petrol şirketleri, Mısır'da denizaşırı yatııımlarını artırdılar. 1997 yılında önemli gaz keşifleri yapıldıktan sonra, son on yılın sonunda, doğalgaz üretimi ve yerel tüketimi çarpıcı bir şekilde artmıştır (Prontera, s. 9).

Íkinci dönem, (1990'ların sonundan 2009'a kadar) Levanten Denizi'nde denizaşırı faaliyetlerin artması ve Mısır'da ve Gazze Şeridi'ndeki bazı doğal gaz sahalarının keşfedilmesi ile başlamıştır. Bu keşifler, tüm Levanten havzası hakkında daha kesin veriler elde etmek için araştırma faaliyetlerinde ve uluslararası hukuk rejimini tamamlama çabalarını da hızlanmaya neden olmuştur. Bununla birlikte, keşifler, devletlerarasında denizde egemenlik haklarının oluşturulması ve Münhasır Ekonomik Bölge (MEB),(Exclusive Economic Zone EEZ),'lerinin sınırlandırılması konusundaki anlaşmazlıkları tetiklemiş̧tir. Özellikle Kıbrıs ile Türkiye arasında, Mısır'dan İsrail, Ürdün, Suriye ve Lübnan'a gaz sağlayan Arish-Ashkelon boru hattı ve Arap Gaz Boru Hattı'nın hayata geçirilmesi, karadaki işbirliğini oluşturmuştur. Daha da önemlisi, Kıbrıs AB'ye 2004'te katıldığında Levantine Denizi, tüm pratik amaçlar için, Avrupa Birliği'nin bir deniz sınırı haline gelmiş̧ir. AB daha sonra, Kıbrıs sorununu çözmede aktif hale gelmiştir. 2000'li yılların başlarında, AB'nin Kıbrıs ve Türkiye'ye üyeliği 
beklentisi, bir atılım olasılığı konusunda iyimserliği arttırdı. Ancak, 2004 tarihli BM Annan Planı referandumunda bir anlaşmaya varılmaması, Kıbrıs'ın AB üyeliğine ilişkin beklentilerinin anlaşmazlığın çözümünden ayrıldığı anlamına geliyordu. $\mathrm{O}$ zamandan beri, gerçek bir ilerleme kaydedilmedi ve Türkiye'nin AB'ye katılma olasılığı gittikçe daha uzaklaştığı için, AB'nin Kıbrıs-Türkiye anlaşmazlığ üzerindeki etkisi azalmıştır.

Üçüncü dönem, 2009-11'de, İsrail ve Kıbrıs sularında büyük keşiflerin gerçekleştiği ve çevresindeki alanlarda ek kaynakların beklentisinin arttığı 2009-11 yılında başladı. Bu keşifler, ilgili ülkelerin enerji güvenliği ortamını çarpıcı bir şekilde değiştirmiştir. Aynı zamanda, özellikle deniz sınırlarının çoktan tartışıldığı, yani İsrail-Lübnan ve Türkiye-Kıbrıs'ta, kaynakların mülkiyeti konusunda daha ciddi devletlerarası çatışmaları tetiklemiştir. Bununla birlikte, yeni gaz keşiflerinden - özellikle 2013 İsrail'in rezervlerinin bir kısmını ihraç etme kararından sonra - yeni gaz ihracatı yolları ve ilgili altyapıların inşası yoluyla para kazanma olasılığı, yeni işbirliği modellerinin de önünü açmıştır (Prontera, s. 10).

2010 yllında, ABD Jeolojik Etütleri (USGS), Doğu Akdeniz bölgesindeki sekiz havzadan biri olan Levant Havzasının, Irak rezervleriyle karşılaştırılabilecek 3455 milyar metreküp (bcm) doğal gaz kaynağı içerebileceğini tahmin etmiştir. Son zamanlarda büyük hidrokarbon kaynaklarının keşfedilmesi, Orta Doğu'daki enerji alanını yeniden tanımlamış ve 1990'dan 2009'a kadar bölgenin enerji karışımının \% 27'sinde doğalgaz artışı sağlamıştır (http://www.europarl.europa.eu/RegData/etudes/briefing_note/join/2014/522339/EXPO-

AFET_SP\%282014\%29522339_EN.pdf( 21.03.2019)). Levant'1 dönüştüren sirasıyla 2009 ve 2010 'da keşfedilen İsrail gaz sahaları Tamar ve Leviathan'dı. Levant Havzası'ndaki toplam kanıtlanmış doğal gaz üretim rezervlerinin toplamı $(515$ bcm) küresel seviyelere göre önemsiz olmakla birlikte Kıbrıs ve İsrail'in Levant Havzası'ndaki son zamanlarda yapılan keşifler tahminleri zorlamıştır. Bölgedeki geri kazanılabilir doğalgaz kaynakları 1076 bcm'den fazladır. Gelecekteki araştırmalar kısa vadede gaz rezervlerini artırabilir. “ABD Jeolojik Araştırmalar Merkezi'nin 2010 yılında yayımladığı raporlar dikkate alındığında;

- Kıbrıs Adası ile İsrail arasında kalan ve Leviathan olarak adlandırılan bölge,

- Misır ile Kıbrıs Adası arasında kalan ve Nil olarak adlandırılan bölge,

- Girit Adası'nın Güneydoğusunda kalan ve Heredot olarak adlandırılan bölge ile Kıbrıs Adası etrafındaki toplam enerji rezervi (petrol, doğalgaz ve sıvı doğalgaz) olan bölge.

Yukarıdaki coğrafi sınırlarda belirtilen bölgede yaklaşık olarak 30 milyar varil petrole eşdeğer bir rakama ulaşmaktadır. Bu rakamın piyasa değeri yaklaşık 1,5 trilyon dolar olarak hesap edilmektedir”'(Sandıklı, s. 7).

\section{$3 \quad$ Akdeniz Bölgesinin Jeopolitiği}

Akdeniz Bölgesinin Jeopolitiği, tarihin her döneminde önemini korumuştur. Kadim medeniyetleler, Akdeniz Havzasında oluşmuş, geçmişte ticaret merkezi haline gelmişti. Günümüzde de Akdeniz Havzası, bütünüyle jeoekonomik ve jeopolitik yönden, önemini artırarak gelecekte de artırarak devam edebilecektir. Akdeniz havzasının üç önemli faktörü vardır. Bunların; Birincisi: Avrupa, Asya ve Afrika kavşağındaki konumu; İkincisi: Uluslararası deniz yolları ve boğazı olan Cebelitarık, İstanbul Boğazı, Çanakkale Boğazı, Üçüncüsü: Süveyş Kanalı ve bir petrol ve doğalgaz kaynağı olma potansiyelidir.

Doğu Akdeniz yukarıdaki faktörlere göre, son doğalgaz keşifleri bu potansiyelini yeniden doğrulamıştır. Bu yönden borsalar, doğalgazı ticareti şeklinde gelişmesi ile ilgili bir dizi önemli jeoekonomik karar vermişlerdir. Literatürde jeoekonominin jeopolitik strateji ve ekonomi politikasını birbirine bağlayabildiği vurgulanmaktadır. Ancak, jeopolitik hedeflerin uygulanmasında genellikle ekonomik politika araçlarının kullanılması olarak algılanmaktadır. Jeopolitik amaçlara göre; Jeopolitik politikalar, çıkarların önceliği ve iktisadi durumun üstünlüğü anlamına gelir. Jeopolitik bir mercekle enerji ilişkilerini görmek, onları ekonomik değil, ulusal güvenlik ve dış politika çıkarları tarafından yönlendirilen devlet ilişkileri olarak analiz etmek anlamına gelirken, enerji ticaretini dış politika ve güvenlik hedeflerine ulaşmak için bir araç olarak değerlendirmek anlamına gelmektedir. Bununla birlikte, doğalgazın jeopolitiği oldukça karmaşıktır (Andrea Prontera, Mariusz Ruszel, https://www.mepc.org/journal/energy-security-eastern-mediterranean (20.04.2019)).

Petrolün aksine, doğalgaz, boru hattıyla veya sıvılaştırılmış biçimde (LNG) taşımayı pahalı yapan fiziksel özelliklere sahiptir. Bu gaz ticaretinin toplam ulaştırma maliyetinin önemli bir bölümünü oluşturur ve sektörün politik ekonomisinin önemli bir bileşenidir. Normal olarak gaz taşımacılığı; altyapı için büyük yatırımlar, uzun vadeli bir bakış açısı ve siyasi istikrar gerektirmektedir. Bu sabit altyapı bileşenleri nedeniyle, gaz sektörü ülkeler arasındaki politik ilişkilere özellikle duyarlıdır. Gaz geliştirme politikaları, içinde bulundukları güvenlik bağlamından özellikle etkilenmektedir (Andrea Prontera, Mariusz Ruszel, https://www.mepc.org/journal/energysecurity-eastern-mediterranean (20.04.2019)). 1990'ların sonundan bu yana, Doğu Akdeniz'in hidrokarbon kaynakları önemi büyük ölçüde artmıştır. Büyük gaz, 2009 ve 2011 yılları arasında İsrail ve Kıbrıs kıyılarını (Leviathan ve Afrodit alanlarında) ve 2015 yılında Mısır kıyılarını (Zohr alanında) keşfediyorsa, enerji güvenliği politikaları üzerinde önemli bir dönüştürücü etki yaratabilir. Aşağıdaki Tablo :1 de gösterilmiştir. 


\begin{tabular}{|l|l|l|l|l|c|}
\hline Alan Adı & Keşif Yılı & Ülke & $\begin{array}{l}\text { Tahmini } \\
\text { Rezervler } \\
\mathbf{B c m}\end{array}$ & Ana Ortaklar (Menşe Ülkeler) & $\begin{array}{l}\text { İlk Gaz } \\
\text { Üretimi/Planlaması } \\
\text { (2014 itibariyle) }\end{array}$ \\
\hline Mari-B & 2000 & İsrail & 42 & Soylu Enerji (ABD) Delek Grubu (İsrail) & 2004 \\
\hline Tamar & 2009 & İsrail & 283 & Delek Grubu (İsrail) & 2003 \\
\hline Dev gemi & 2010 & İsrail & 510 & Soylu Enerji (ABD) Delek Grubu (İsrail) & 2017 \\
\hline Afrodit & 2011 & Kıbrıs & 200 & Soylu Enerji (ABD) Delek Grubu (İsrail) & 2017 \\
\hline Tanen & 2012 & İsrail & 34 & Soylu Enerji (ABD) Delek Grubu (İsrail) & - \\
\hline Karish & 2003 & İsrail & 50 & Soylu Enerji (ABD) Delek Grubu (İsrail) & - \\
\hline Zohr & 2015 & Misır & 850 & Delek Grubu (İsrail) ENI (İtalya) & - \\
\hline
\end{tabular}

Tablo 1. Doğu Akdeniz'deki Büyük Gaz Keşifleri (2000-15) Kaynaklar: Yazarların H. Darbouche, L. El-Katiri ve B. Fattouh'tan derlemeleri, Doğu Akdeniz Gazl: Ne tür bir oyun değiştirici? (Oxford Enerji Araştırmaları Enstitüsü, 2012), http://www.oxfordenergy.org/wpcms/wp-content/uploads/2012/12/NG-71.pdf; ABD Enerji Bilgi İdaresi (ÇED), "Doğu Akdeniz Bölgesi, Tam Rapor", 15 Ağustos 2013; ve ENI Press Bülteni, "ENI, Akdeniz'de Bugüne Kadar Bulunan Mısır'ın Açık Denizindeki Süper Gaz Alanını Keşfeder", 30 Ağustos 2015. den Naklen ve Andrea Prontera, Mariusz Ruszel,https://www.mepc.org/journal/energy-security-easternmediterranean (20.04.2019).

Bölgede çıkan doğalgazın İhracat için, İsrail ve Güney Kıbrıs'tan Yunanistan'a oradan da Avrupa pazarlarına gaz taşımak için bir boru hattı (Doğu Med Gaz Boru Hattı) düşünülmektedir. Güney Kıbrıs kıyılarında, Vassilikos yakınlarındaki ortak bir İsrail-Güney Kıbrıs LNG üretim yeri olarak değerlendirmektedirler. Ancak, diğer doğalgaz boru hattı projeleri her hükümet tarafından kendi enerji güvenliği gündemine ve ulusal çıkarlarına göre değerlendirilmektedir. Bu projeler arasında bir LNG tesisi veya İsrail'de yüzen bir sıvılaştırılmış doğal gaz (LNG plant or a floating liquefied natural-gas FLNG) tesisi düşünülmektedir. Bunun yanında alternative olarak, İsrailKıbrıs-Türkiye boru hattı bir de İsrail-Türkiye boru hattı yer almaktadır. 2011'den 2014'e kadar, gaz kaynaklarından para kazanması için çeşitli rekabet seçenekleri değerlendirilmiştir (Andrea Prontera, Mariusz Ruszel,https://www.mepc.org/journal/energy-security-eastern-mediterranean (20.04.2019)). İki veya daha fazla ülkelerle, farklı seviyelerde işbirliği talebi, farklı fiyat yapılarına, aynı zamanda, farklı derecelerde politik desteğe de sahiptirler. Doğu Akdeniz'de çıkan gazın AB ve diğer ülkelere pazarlanması için alternatif yollar ve tahmini maliyetleri aşağıdaki Tablo 2 de görülmektedir.

\begin{tabular}{|c|c|c|c|c|}
\hline Projeler & $\begin{array}{c}\text { İlgili Devletler } \\
\text { (*Ana Destekçi) }\end{array}$ & $\begin{array}{c}\text { Gaz } \\
\text { Kapasitesi } \\
\text { (bcm / yıl) }\end{array}$ & $\begin{array}{c}\text { Tahmini Maliyet } \\
\text { (milyar ABD doları) }\end{array}$ & $\begin{array}{c}\text { Tahmini Faaliyet } \\
\text { Yılı (2014 } \\
\text { itibariyle) }\end{array}$ \\
\hline LNG Tesisi & Kıbrı * ve İsrail & $7-14$ & $10-15$ & 2020 \\
\hline Boru hattı & İsrail-Kıbrıs-Yunanistan * & $30-40$ & $17-20$ & 2020 sonrası \\
\hline Boru hattı & İsrail-Kıbrıs-Türkiye * & $5-11$ & $5-10$ & $2023-2025$ \\
\hline Boru hattı & İsrail-Türkiye * & $5-11$ & $5-10$ & $2023-2025$ \\
\hline
\end{tabular}

Tablo:2.Doğu Akdeniz Gaz Kaynaklarından Para Kazanmaya Yönelik Ortak Projeler (2011-14) Kaynaklar: Yazarların Avrupa Parlamentosundan derlenmesi, "Doğu Akdeniz Gaz Üretimi Beklentisi: AB için Alternatif Bir Enerji Tedarikçisi?" DG Dış Politikalar, Politika Bölümü, Nisan 2014. ve Andrea Prontera, Mariusz Ruszel,https://www.mepc.org/journal/energy-security-eastern-mediterranean (20.04.2019)

Doğu Akdeniz'deki gaz keşifleri, İsrail ve Kıbrıs için tamamen yeni imkanlar oluşturmuştur. İsrail, net bir enerji tüketicisinden potansiyel net bir ihracatçıya dönüşüm yaparken, enerji güvenliğini güçlendirip ve politik esneklik kazanabilmektedir. Bu gelişme, Hüsnü Mübarek'in düşmesi, Mısır doğalgaz arzının kesilmesine neden olmuştur. Bölgede, Arap Baharı'ndaki artan istikrarsızlık nedeniyle, enerji arz güvenliğini kaygılandırması önemlidir. Ayrıca, İsrail kaynaklarını daha geniş politika hedeflerine ulaşmak için kullanabilir. Ciddi bir finansal krizden, ortaya çıkan ve ekonomik krizin ortasında olan Kıbrıs, enerji güvenliğini artırabilir ve enerji rantını kullanmak için orta vadeli bir strateji planlayabilir. Özellikle Ürdün, Mısır ve Türkiye, artan enerji taleplerini, enerji güvenliğini artırarak ve yeni keşiflerden de faydalanabilirler. İsrail-Türkiye boru hattına yönelik müzakereler 
devam ederken, bir taraftan Tel Aviv-Ankara arasındaki siyasi ilişkilerini normalleştirme süreci karşılıklı olarak 2016 başında yeniden başlatılmıştır.

\section{Münhasır Ekonomik Bölge ve BM Deniz Hukuku Sözleşmesindeki Yeri}

\subsection{Münhasır Ekonomik Bölge Tanımı}

Münhasır Ekonomik Bölge (MEB),(Exclusive Economic Zone EEZ), belirli bir ülkenin kara denizlerinin ötesinde ve bitişiğindeki bir bölgedir. Bir ülkenin kendi kıyı şeridinden 200 deniz milinden (370 kilometre) daha fazla olmayan bir alandır. Eğer MEB üst üste binmişse ve hala 400 deniz milinden daha az ise, o zaman kıyı şeridinin gerçek sınırlarını belirlemek için ilgili devletlerin üzerine düştüğü görülmektedir. Bir devletin MEB'inin altındaki alan, bitişik kıta sahanlığındaki deniz kaynaklarını keşfetmek ve kullanmak için tam haklar sağlar (Münhasır Ekonomik Bölge,https://www.worldatlas.com/articles/what-is-an-exclusive-economic-zone-eez.html (23.04.2019)).

\subsection{Birleșmiş Milletler Deniz Hukukuna Göre: Münhasır Ekonomik Bölgenin (Meb) Özel Yasal Rejimi}

"Münhasır Ekonomik Bölge (MEB), karasal devletin haklarının ve yetkilerinin ve diğer devletlerin hak ve özgürlüklerinin ilgili hükümler tarafından yönetildiği, bu Bölümde belirlenen özel yasal rejime tabi, bölge denizinin ötesinde ve bitişiğindeki bir alandır. Bu Sözleşmenin;

Münhasır ekonomik bölgedeki klyı devletinin hakları, yargı yetkisi ve görevleri

(1). Münhasır ekonomik bölgede, kıyı Devleti

(a) Doğal kaynakları, ister yaşayan olsun ister olmasın, deniz tabanına ve onun alt topraklarına komşu olan suları ve diğer faaliyetlerle ilgili olarak araştırmak, kullanmak, korumak ve yönetmek amacıyla, egemen haklardır. Sudan, akıntılardan ve rüzgardan enerji üretimi gibi bölgenin ekonomik kullanımı ve keşfi;

(b) Aşağıdakilerle ilgili olarak bu Sözleşmenin ilgili hükümlerinde öngörülen yargı yetkisi:

(i) Yapay adaların, tesislerin ve yapıların kurulması ve kullanılması;

(ii) Deniz bilimsel araştırmaları;

(iii) Deniz ortamının korunması ve korunması;

(c) Bu Sözleşmede öngörülen diğer hak ve görevler.

(2). Kıyı Devleti, bu Sözleşme altındaki haklarını münhasır ekonomik bölgede kullanma hakkını kullanırken ve görevlerini yerine getirirken, diğer Devletlerin haklarına ve görevlerine saygılı olmalı ve bu Sözleşme hükümleriyle uyumlu bir şekilde hareket etmelidir.

\section{Münhasır ekonomik bölgenin genişliği}

Münhasır ekonomik bölge, kara denizinin genişliğini ölçen taban hatlarından 200 deniz mili (370 kilometre) ötesine geçemez."( https://www.un.org/Depts/los/convention_agreements/texts/unclos/part5.htm (23.04.2019))

\section{Münhasır Ekonomik Bölge’nin, Bilimsel Önemi (MEB), Sınırları ve Olumsuzlukları}

MEB veye EEZ'ler, sadece sınırları belirlemedikleri için ekonomik öneme de sahipler. Aynı zamanda balıkçılık, doğal gaz rezervleri ve turizm nedeniyle birçok ülke için geçim kaynağıdırlar. Deniz taşımacıllğ̆ bu bölgelerden diğer birçok ülkeden gerçekleştirilmektedir. EEZ'lerin bilimsel önemi, çeşitli deniz canlıları ile ilgili bilimsel araştırmaların yapılmasını ve bu sularda da gerçekleştirilebilecek petrol ve doğal gaz amaçlı deniz tabanlarının örneklenmesini içermektedir. Her ülkeye karasularını koruma hakkı verilmiştir. Ancak, bazı ülkeler kaynakları araştırmak isterse, o zaman ilgili komşu ülke ile ikili bir anlaşma yapmaları gerekir.

\subsection{Akdeniz'de Enerji Güvenliği AB İçin Deniz Așırı (Offshore) Sınırları}

Doğalgaz, $\mathrm{AB}$ için önemli bir enerji kaynağıdır. AB, özellikle doğalgaz ihtiyacını, bölgesinde bulunan denizaşırı (offshore) hidrokarbon üretimlerinden karşılamaktadır. 2012'de denizaşırı ham petrol üretimi, AB'nin brüt petrol ürün tüketiminin neredeyse \% 9'unu, denizaşırı gaz üretimi, AB'nin brüt enerji tüketiminin \% 13,8'ini karşılamıştır. AB'nin şu anki deniz aşırı (offshore) hidrokarbon üretiminin çoğu, Kuzey Denizi'nde, İngiltere, Danimarka ve Hollanda'ya ait sularda bulunmaktadır. AB doğalgaz ihtiyacının bir kısmını da Akdeniz'de, İtalya, çoğunlukla Adriyatik ve Ege Denizi'nde bulunan en fazla denizaşırı tesislerden sağlamaktadır (Prontera, s. 1). Güney Kıbrıs Rum Yönetimi (GKRY) AB'ye 1 Mayıs 2004'de tam üye olması ile AB'nin, sınırları genişlemiştir. AB, bir anda Akdeniz'deki hidrokarbon alanlarının içinde olduğunu açıklayarak Münhasır Ekonomik alanlarda hak sahibi olduğunu açıklamış ve son zamanlarda önemini daha da artırmıştır.

2000'li yılların başında, denizaşırı araştırmalarındaki teknolojik gelişmeler, yüksek petrol fiyatları ile birlikte, enerji şirketlerinin Akdeniz'e olan ilgisini artırmıştır. Bu gelişme, 2007-08 küresel finansal kriz ve Güney Avrupa'da ortaya çıkan ekonomik gerileme ile güçlendirildi. 2008'den sonra, Kıbrıs, Hırvatistan, Yunanistan ve İtalya gibi birçok AB Akdeniz ülkesi, yalnızca enerji bağımlılı̆̆ını azaltmak için değil, aynı zamanda yabancı yatıımları çekmek istemiştir. Bu şekilde, ekonomik kazanımı artırmak için denizaşıı hidrokarbon kaynaklarının araştırılması ve kullanılması için yeni planlar hazırlamıştır. Petrol ve doğalgaz rantının kullanılması, Akdeniz'in 
yeni bir AB enerji arz güvenliği sınırına dönüşmesi, (örneğin, Slovenya ve Hırvatistan) ve AB üyesi olmayan ülkeler (örneğin, Hırvatistan-Karadağ, Kıbrıs-Türkiye) arasındaki çözülmemiş deniz ihtilaflarını da canlandırmıştır (Prontera, s 1).

\subsection{Doğu Akdeniz'deki Doğalgaz ve Petrol Yönünden Olumsuzluklar}

Doğu Akdeniz'deki olumsuzluklara bir bütün olarak bakmak gerekir. Adriyatik, Ege ve Levantine Denizlerinde bulunan hidrokarbon kaynakları nedeniyle Orta ve Doğu Akdeniz hem AB hem de AB üyesi olmayan ülkelerin, son zamanlarda enerji gelişimi açısından daha fazla ilgi çekmiştir. Ortadoğu Osmanlı İmparatorluğu parçalanmadan önce batılı ülkelerin, özelikle İngiltere ve Fransa'nın enerji yönünden dikkati çekmiştir. 04 Aralık 2016, Sky Pique gizli anlaşması, ile paylaşılan Ortadoğu, o günkü paylaşımda olmayan ABD için bir bahane niteliğinde olup, demokratik olmayan Ortadoğu ülkelerine, demokrasi ve insan hakları gibi hoş söylemlerle dikkatleri çekmiştir. Asıl sebep, "parçala böl yönet” anlayışıyla petrol ve doğalgaz kaynaklarının sahibi olabilmektir. ABD, Bölge ülkelerinde marjinal unsurlar ve terör öğütleri destekleyip, karışıklıklar çıkartarak kendilerine bir alan oluşturmaktır. Suriye'nin kuzeyinde bulunan zengin enerji kaynaklarına oldu bitti politikasıyla yerleşmektir. Bu bölgede suni bir devlet kurdurma peşindedir. Böylelikle, Suriye iç Savaşı 15 Mart 2011'de ülkenin güneyindeki Deraa'da, komşu ülkelerdeki "Arap Bahar'ından esinlenen demokrasi yanlısı gösterilerin başlaması", DAEŞ'in yükselişi, İsrail - Lübnan Çatışması ve İsrail'in, Gazze Şeridi'nin bombalanması, Mısır'da Askeri darbe olması gibi olaylar enerji istikrarını da etkilemektedir. İstikrarsılaştırılan bu bölgede uzun süredir devam eden gerilimlere neden olmuştur. İstikrarsızlık, Suriye'nin Akdeniz hakimiyet sahasında da mevcuttur. Ortadoğu'da Büyük Ortadoğu Projesi (BOP) kurulmuştur. BOP, ilk kez 2000 yılındaki Davos Zirvesi'nde Dick Cheney, 2004'te ise Bush tarafından dillendirilmişse de öncesinin olduğu bilinmektedir. Fikri hazırlığını yapan isimler arasında Türkiye'de de yakından tanınan Bernard Lewis, Zbigniew Brzezinski gibi uzmanlar öne çıkmışlardır. BOP'un kapsama alanına 35 ülkenin girdiği, bunlardan 22'sinin Arap ülkesi, 5 'inin Arap olmayan Ortadoğu ülkesi, 5 'inin Orta Asya ülkesi, 3 'ünün ise Trans Kafkasya ülkesi olduğu çokça ifade edilmiştir (Köylü, ss. 85-100). Bu ülkelerin hepsi enerji zengini ülkelerdir. Doğu Akdeniz Bölgesinde ülkelerarasında da sınır çatışmaları mevcuttur. Mısır, İsrail, Filistin, Ürdün, Lübnan ve Suriye, GKRY Bu ülkelerin Akdeniz'de kıta sahanlığı problemleri ve KKTC problemler devam etmektedir.

\section{Doğu Akdeniz'de İstikrar İçin Bölgesel Bir Şekillendirme Enerji Faktörü}

2010'dan beri Doğu Akdeniz bölgesi, İsrail, Kıbrıs'ın açık denizindeki bir dizi gaz keşfi nedeniyle uluslararası enerji tartışmalarının sıcak noktası oldu. Mısır bu gaz potansiyelinden yararlanmak için, yeni bölgesel işbirliği senaryolarının yanı sıra, aşamalı olarak bir dizi ihracat seçeneği tartışılmıştır. Yeni gaz keşiflerinin bölgedeki potansiyel rolü hakkında umutlar da dile getirilmiştir. Sadece, bölgesel enerji işbirliğini değil, aynı zamanda genel bölgesel ekonomik ve politik istikrarı da güçlendirmektedir. Ancak, başlangıçtaki beklentiler büyük ölçüde soğumuş, zamanla özellikle İsrail'deki yatırım kararındaki gecikmeler ve Kıbrıs'taki gaz kaynaklarının aşağı doğru revize edilmesine neden olmuştur. Bu gelişmeler, Doğu Akdeniz'in büyük ölçüde gaz ihraç eden bir bölge haline gelme fikri konusunda şüphecilik bile yaratmıştır. Ancak, başlangıçtaki beklentiler, denizaşırı Mısır'daki büyük Zohr gaz sahasının keşfedilmesinden sonra, 2015 yılında yeniden canlanmıştır. Büyük resme bakıldığında, bu keşif bölgesel gaz görünümünü yeniden şekillendirmiş ve yeni bölgesel işbirliği umutları da yaratmıştır. Bununla birlikte, bölgedeki birçok çatışma çizgisi, gelecekteki Doğu Akdeniz gaz faaliyetlerini önemli bir jeopolitik sorun haline getirmeye devam edebilecektir. Bu çalışma, hem Doğu Akdeniz ülkeleri hem de AB için bölgesel gaz keşiflerinin gerçekçi etkilerini değerlendirmek amacıyla tüm bu gelişmelerin kapsamlı bir analizini yapmayı amaçlamaktadır

(http://www.europarl.europa.eu/RegData/etudes/STUD/2017/578044/EXPO_STU(2017)578044_EN.pdf,s.16 (09.04.2019)).

\subsection{Doğu Akdeniz Gazının AB ile Olan İlişkisi ve Enerjinin Dış Politikadaki Yeri}

Doğu Akdeniz gazındaki gelişmeler AB için neden ilgi çekicidir? Bu sorunun cevabı iki yönlüdür. Birincisi; $A B$ enerji politikasının yanı sıra $\mathrm{AB}$ dış politikası ile de ilgilidir. AB'nin enerji politikası, 2000'lerin başında önem kazanmıştır. Bazı ekonomik ve politik nedenlerden dolayı bu stratejinin uygulanması zor olmuştur. Tesadüfen değil, gaz arzının güvenliği konusu, 2014 yılında, Juncker Komisyonunun amiral gemisi girişimlerinden biri olmuştur. AB, Enerji Birliği'nin başlatılması için bir katalizör görevi görmüştür. Geniş, kullanılmayan gaz kaynakları ve Avrupa'ya olan coğrafi yakınlığından dolayı Doğu Akdeniz, AB enerji güvenliğine önemli bir katkı sağlayabilir ve Enerji Birliği gaz arzının çeşitlendirilmesini sağlayabilecektir. Íkincisi; dış politika görünümüne göre, Doğu Akdeniz, AB için kilit bir noktayı temsil etmektedir. 2015 yılında başlayan göç krizi, Doğu Akdeniz bölgesindeki gelişmelerin Avrupa'ya nasıl yayılabileceğinin açık bir örneğidir. Bu nedenle AB için Doğu Akdeniz'de ve tüm Güney Komşuluk Bölgesi'nde jeopolitik istikrar ve ekonomik kalkınmanın teşvik edilmesi bir önceliktir. $\mathrm{Bu}$ öncelik AB Komşuluk Politikası'nda özellikle 2015 gözden geçirmesinin ardından açıkça belirtilmiştir (http://www.europarl.europa.eu/RegData/etudes/STUD/2017/578044/EXPO_STU(2017)578044_EN.pdf,s.16 (09.04.2019)). 


\subsection{Enerji Birliği Girișimi}

"Avrupa Komisyonu 2008 y1lında “ikinci Stratejik Enerji İncelemesi - Bir AB Enerji Güvenliği ve Dayanışma Eylem Planı" olan ve aşağıdaki noktalara dayanarak bir eylem planı önerdiği, "Altyapı İhtiyaçları Eylemi" Tebliğini kabul etmiştir. Buna göre: "i) Altyapı ihtiyaçları ve çeşitlendirilmesi enerji kaynakları; ii) Dış enerji ilişkileri; iii) Petrol ve gaz stokları ile kriz müdahale mekanizmaları; iv) Enerji verimliliği; v) AB'nin yerli enerji kaynaklarını en iyi şekilde kullanmak ". Bu görünüm, 2011 yılında Komisyon tarafından, "AB Enerji Politikası: Sinırlarımız Dışında Ortaklarla İliş̧kilendirme" İletişimi ile geliştirildi ve bu, üç eksene dayanan yeni bir strateji önermiştir. Bunlar: “i) AB üyesi olmayan ülkelerle, Üye Devletlerarasında enerji anlaşmalarında şeffaflığı teşvik etmek. ii) Hem belirli ortak ülkelere yönelik politikaları, hem de alınacak pozisyonları koordine edecek uluslararası kuruluşlar; iii) Kilit ortak ülkelerle kapsamlı enerji ortaklıkları teşvik ederek, Yeni Juncker Komisyonu resmen Mart 2015'te Enerji Birliği giriş̧imini başlatmuşstr. İletişim ile İleriye Yönelik, Esnek bir Enerji Birliği için Çerçeve Strateji İklim Değiş̧ikliği Politikasının, birbirine bağlı beş bölümü vardır. Bunlar: "i) enerji güvenliği, dayanışma ve güven; ii) tamamen entegre bir Avrupa enerji pazarı; iii) talebin ölçülmesine katkıda bulunan enerji verimliliği; iv) ekonominin de karbonizasyonu; ve v) araştırma, yenilikçilik ve rekabet edebilirlik. Belgenin kökenleri göz önüne alındığında, önce enerji güvenliğinden bahsedilmesi şaşırtıcı değildir. Belgeye göre, enerji arzı tüketimini azaltarak ve iç enerji değişimi ve çeşitlendirmektir. Ayrıca, tüketimi azaltmak ve enerji piyasalarını iyileştirmektir"(

http://www.europarl.europa.eu/RegData/etudes/STUD/2017/578044/EXPO_STU(2017)578044_EN.pdf,s.16 (09.04.2019)).

\section{Mısır: Doğu Akdeniz Bölgesel Gaz Piyasaları}

Misır, 1980'lerde ve 1990'larda, 18 trilyon metreküp (Tcm) 18 olarak tahmin edilen büyük gaz rezervlerini giderek daha fazla kullanmış, ancak, yalnızca 2000'den sonra üretimini arttırmıştır. Önemli miktarda gaz ihracatı olması için yol açmak istemektedir. Arap Baharı sonrasında ortaya çıkan gaz ithalatı bağlamı, Mısır'ın önceki on yılda geliştirdiği ihracat altyapısını eski hale getirmiştir. Bu altyapı, Damietta ve Idku'da bulunan iki LNG tesisinden ve iki boru hattından - El Arish-Ashkelon Boru Hattı ve Arap Gaz Boru Hattı'ndan oluşturmaktadır. Aşağıda bu gaz boru hattı haritası görülmektedir.

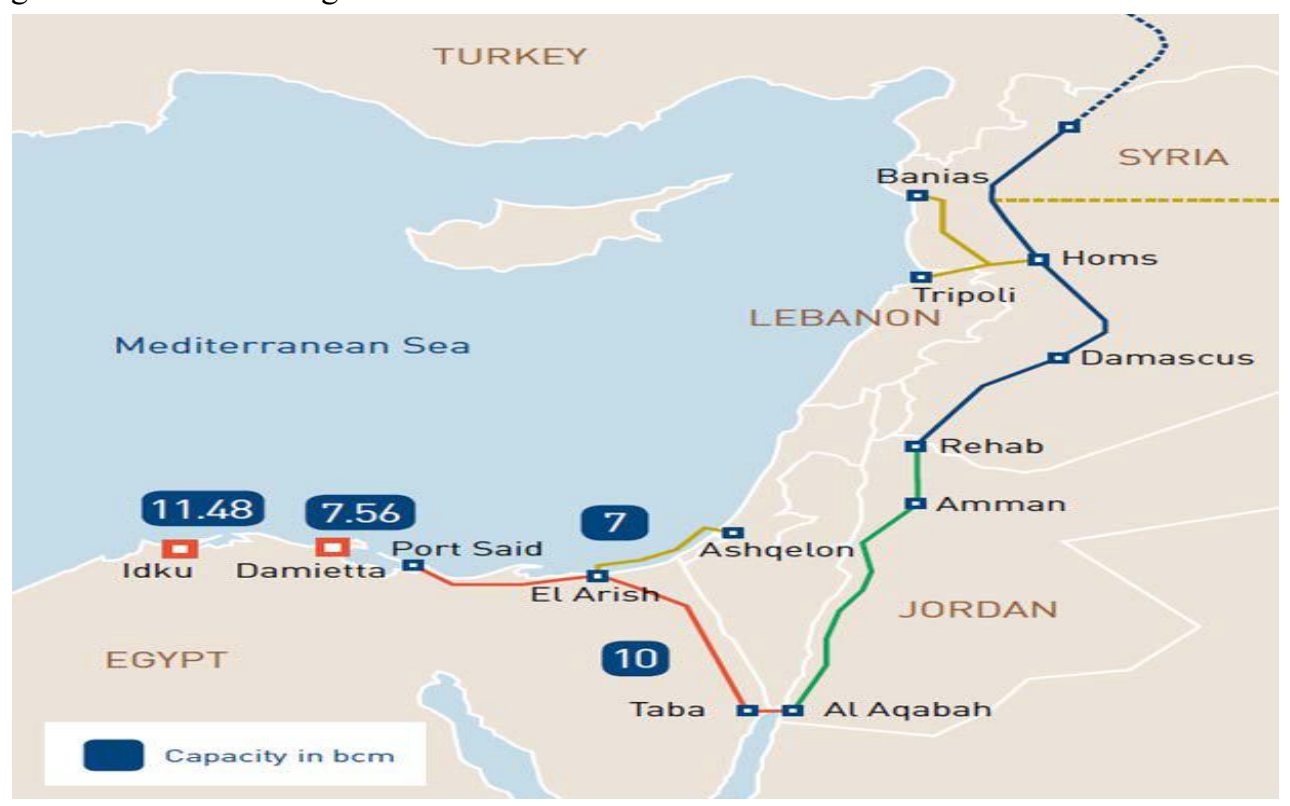

Şekil 2. Mısır'in Doğalgaz İhracat Altyapı Yolları

Kaynak:http://www.europarl.europa.eu/RegData/etudes/STUD/2017/578044/EXPO_STU(2017)578044_EN.pdf (09.04.2019)

El Arish-Ashkelon Boru Hattı 2008 yılında faaliyete geçmiş ve Mısır gazını İsrail'e yönlendirmiştir. 2010 yılında boru hattı İsrail'de tüketilen gazın yaklaşık yarısını tedarik etmiştir. Boru hattının toplam $9 \mathrm{Bcm} / \mathrm{y}$ l fiziksel kapasitesi ile Mısır ve İsrail arasında 7,5 Bcm / yıl'a kadar teslimat için anlaşmalar yapılmıştır. Arap Gaz Boru Hattı (Trans-Mashreq Gaz Boru Hattı olarak da bilinir), Misır' 10 Bcm / yıl kapasiteli Mısır, Ürdün, Lübnan, Suriye ve Türkiye'ye ile bağlayan 1200 km'lik bir altyapıdır. Gaz boru hattından 2003 yılında başlayıp Ürdün'e aktı ve ardından 2008'de Suriye'ye, 2009'da da Lübnan'a ulaşmıştır. Boru hattı henüz Türkiye'ye ulaşmamıştır.

\subsection{Yeni Denizaşırı Ufku: Jeoloji ve Yasal Yönler}

Dünyadaki öncelikli havzaların geri kazanılabilir petrol ve gaz kaynaklarını tahmin etmeyi amaçlayan bir programın bir parçası olarak, ABD (U.S. Geological Survey (USGS), Jeolojik Araştırmaları (USGS) 2010 yılında 
Nil Deltası Havzası ve Levant Havzası'nın keşfedilmemiş gaz kaynaklarını tahmin etmiştir. Gaz keşifleri açısından asıl dönüm noktası, 2009 yılında NobleEnergy'nin açık denizde İsrail'in Tamar sahasını keşfettiğini duyurmasıyla başlamıştır. Bu keşiften sonra NobleEnergy, Levant Havzasında iki önemli bulgu daha açıklamıştır. Açık denizdeki Kıbrıs'ın güneyinde Afrodit alanını keşfetmiştir. İtalyan derin deniz petrol şirketi Eni, 2015 yılında Mısır'ın kuzeyinde açık denizde dev Zohr gaz sahasının keşfedildiğini açıklamıştır.

\begin{tabular}{|l|c|c|}
\hline \multicolumn{1}{|c|}{ Gaz Sahası } & $\begin{array}{c}\text { Brüt ortalama kaynaklar } \\
(\mathrm{Bcm})\end{array}$ & Keşfi \\
\hline Tamar - Israel & 280 & 2010 \\
\hline Leviathan - Israel & 620 & 2011 \\
\hline Aphrodite - Kıbrıs & 140 & 2012 \\
\hline Zohr - Egypt & 850 & 2015 \\
\hline
\end{tabular}

Tablo: 3.Doğu Akdeniz'de Doğalgaz Sahalarının Keşfi ve Kaynak Miktarları

Kaynak:http://www.europarl.europa.eu/RegData/etudes/STUD/2017/578044/EXPO_STU(2017)578044_EN.pdf (09.04.2019) ve Noble Energy and Eni (officialwebsites, accessed in January 2017)'den Naklen,

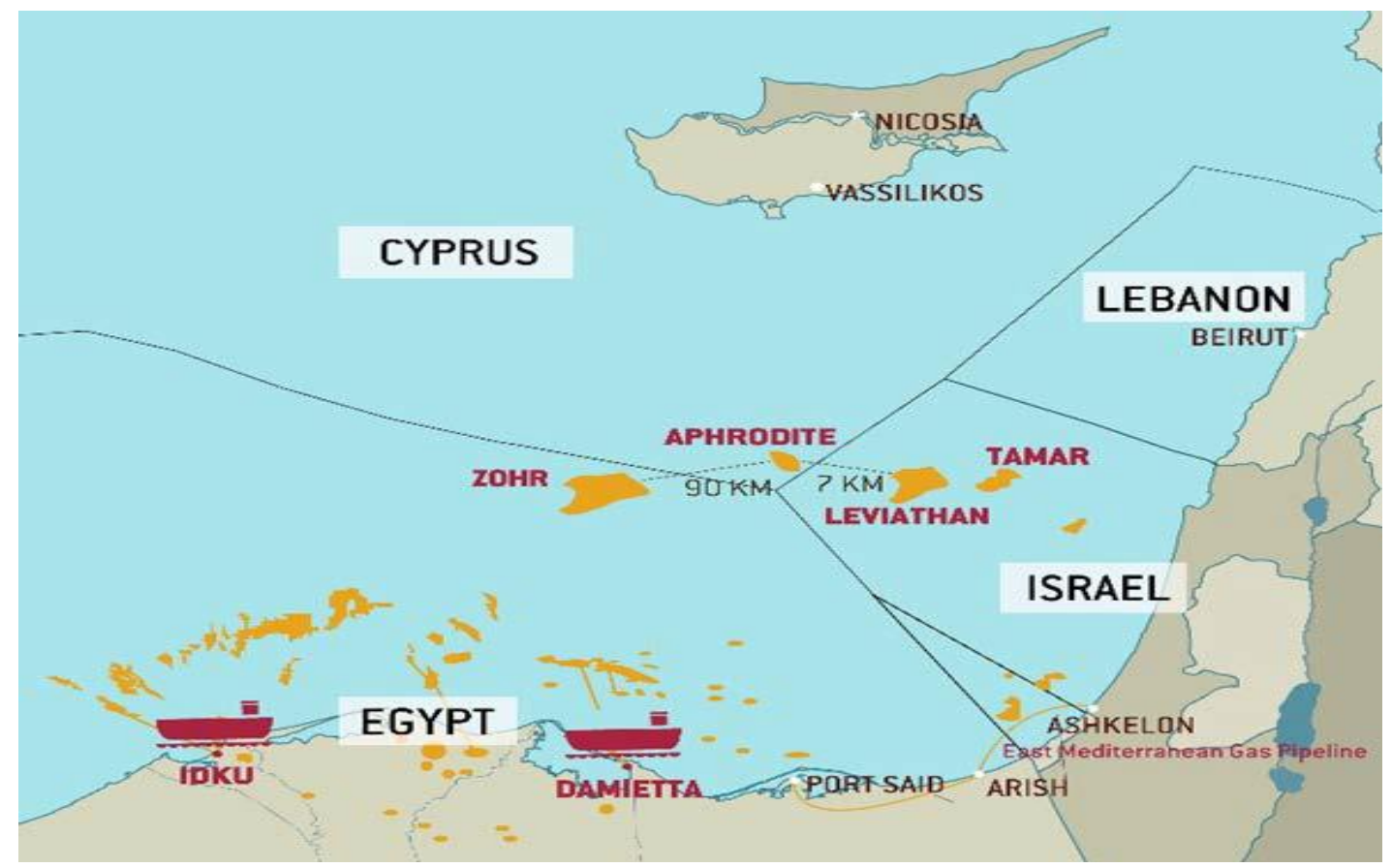

Şekil 3. Doğu Akdeniz'deki Denizaşırı Ana Gaz Keşiflerinin Coğrafi Konum

Kaynak:http://www.europarl.europa.eu/RegData/etudes/STUD/2017/578044/EXPO_STU(2017)578044_EN.pdf (09.04.2019) Ve author'selaboration on Middle East EconomicSurvey (2016)'den naklen.

Gaz keşif dalgası, Doğu Akdeniz'de deniz sınırı sorununu canlandırmıştır. Aslında, bölgede, özellikle Kıbrıs'ta ve İsrail ile Lübnan arasında, çeşitli sınırlandırma anlaşmazlıkları hala açıktır.

Dünyadaki öncelikli havzaların geri kazanılabilir petrol ve gaz kaynaklarını tahmin etmeyi amaçlayan programın bir parçası olarak, (U.S. GeologicalSurvey(USGS), ABD Jeolojik Araştırmaları 2010 yılında Nil Deltası Havzası ve Levant Havzası'nın keşfedilmemiş gaz kaynaklarını tahmin etmiştir. Aşağıdaki harita 4'de görülmektedir. 


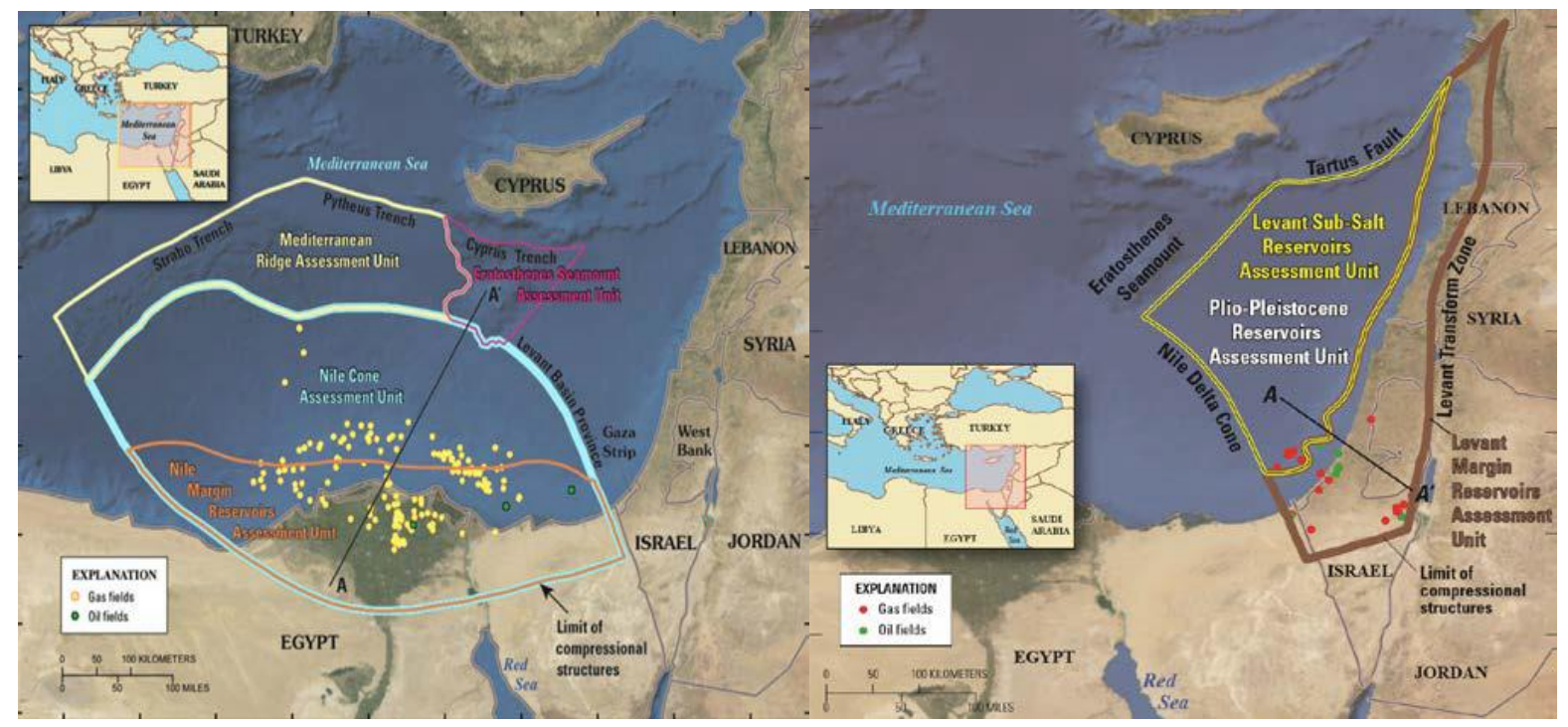

Şekil 4. USGS'nin Nil Deltası Havzası'nın ve USGS'nin Levant Havzası Değerlendirilmesi Kaynak:http://www.europarl.europa.eu/RegData/etudes/STUD/2017/578044/EXPO_STU(2017)578044_EN.pdf (09.04.2019)

USGS (U.S. Geological Survey (USGS), jeolojiye dayalı bir değerlendirme metodolojisi kullanarak, keşfedilmemiş teknik olarak geri kazanılabilir gaz kaynaklarını tahmin etmiştir. Tahmini keşfedilmemiş kaynakların belirli konumları henüz bilinmemekle birlikte, bunların jeolojik açıdan uygun ortamlarda bulunduğuna inanılmaktadır. "Kanıtlanmış rezervler", jeolojik ve mühendislik verilerinin, mevcut ekonomik ve işletme koşulları altında bilinen rezervuarlardan gelecek yıllarda geri kazanılabilir olduğunu makul bir şekilde kanıtladığı petrol ve gaz miktarlarıydı). USGS, jeolojiye dayalı bir değerlendirme metodolojisi kullanarak, Nil Delta Havzası'nın 6.3Tcm'de ve Levant Havzası'nın 3.5 Tcm'de keşfedilmemiş teknik olarak geri kazanılabilir gaz kaynaklarını tahmin (http://www.europarl.europa.eu/RegData/etudes/STUD/2017/578044/EXPO_STU(2017)578044_EN.pdf $(09.04 .2019))$.

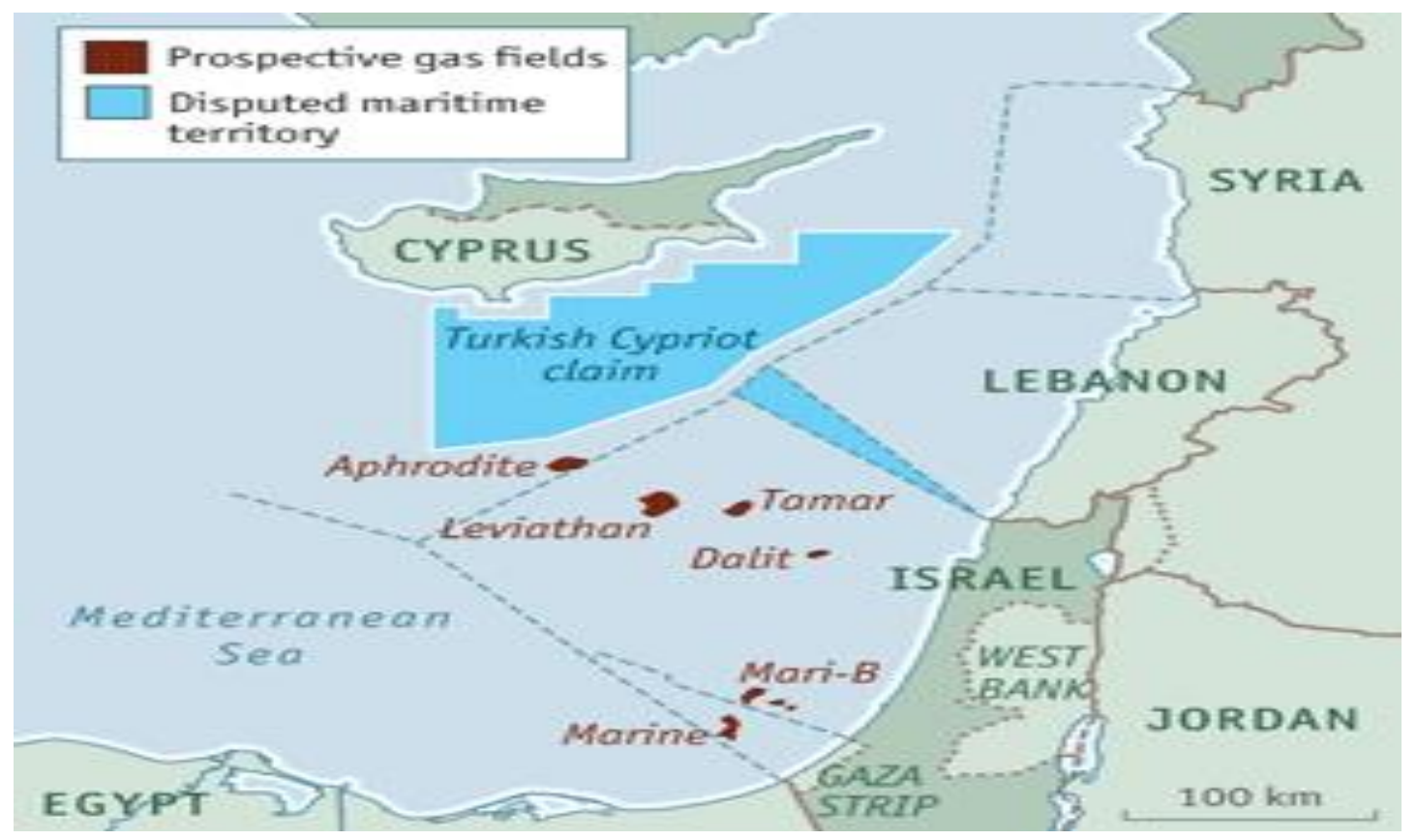

Şekil 5. Doğu Akdeniz'in Önemli Potansiyel Gaz Sahaları ve Tartışmalı Deniz Sınırları Bölgesi Kaynak:http://www.europarl.europa.eu/RegData/etudes/STUD/2017/578044/EXPO_STU(2017)578044_EN.pdf (09.04.2019)

Yukarıdaki Harita 6'da; Türkiye ve KKTC'inin Münhasır Ekonomi Bölge (MEB) de enerji çalışmaları devam etmektedir. Türkiye Cumhuriyeti ile KKTC’nin Arasındaki Mücavir Ekonomik Alan Anlaşmasına göre; “ KKTC ve Güney Kıbrıs Rum Yönetimi (GKRY) arasında Münhasır Ekonomik Bölge (MEB) sınırları açısından ihtilaf bulunmaktadır. KKTC yönetiminin iddia ettiği MEB sınırları GKRY tarafından tanınmamaktadır. Özellikle 
KKTC'nin $\boldsymbol{G}$ ve $\boldsymbol{F}$ Bloklarının bulunduğu bölge GKRY'nin iddia ettiği lisans alanları ile çakışmaktadır. 2011 yılında KKTC Ekonomi ve Enerji Bakanlığı ile TP arasında 1 kara ve 7 deniz bloğu için Üretim Paylaşım Anlaşması imzalanmış olup KKTC Bakanlar Kurulu'nun onayı sonrası KKTC Resmi Gazete'sinde 23 Kasım 2011'de ilan edilmiştir.

KKTC, Doğu Akdeniz bölgesinde süre-giden jeolojik olayların anlaşılmasında önemli ipuçlarının bulunduğu sınırlı ancak önemli bir kara parçasıdır. Ülkede üretilen maden ve mineraller, bakır, çimento, kil, jips, kireçtaşı, kum ve çakıl, amber ve boya taşıdır. Bu çerçevede "Türkiye Cumhuriyeti Hükümeti ile Kuzey Kıbrıs Türk Cumhuriyeti Hükümeti Arasında Enerji Alanında İşbirliğine İlişkin Anlaşma”(https://www.tbmm.gov.tr/sirasayi/donem26/yil01/ss516.pdf ( 21.04.2019)). “ 9-13 Ekim 2016 tarihlerinde İstanbul'da gerçekleştirilen 23. Dünya Enerji Kongresi sırasında, 11 Ekim 2016 tarihinde imzalanmıştır. Söz konusu Anlaşmayla; enerji alanında ikili bilimsel, teknik, teknolojik, yasal, idari ve ticari işbirliğinin geliştirilmesi ile enerji alanında faaliyet gösteren kamu ve özel kuruluşlar arasındaki ortaklığın güçlendirilmesi yoluyla bilgi ve uzmanlık değişimini teşvik etmek amaçlanmıştır. Anlaşmanın, Türkiye ile KKTC arasındaki mevcut ilişkileri ve dostluk bağlarını güçlendireceği, enerji alanındaki işbirliğini teşvik edeceği ve uzun yillardan bu yana kısıtlamalara maruz kalan KKTC'nin bu mağduriyetinin bir nebze de olsa giderilmesinin sağlanarak KKTC'yi uluslararası arenada destekleyeceği düşünülmektedir.”( https://www.tbmm.gov.tr/sirasayi/donem26/yil01/ss516.pdf(21.04.2019)). Türkiye ve KKTC, BM Deniz Hukuku Münhasır Ekonomik Bölgenin (MEB) Özel Yasal Rejimi’ne göre, kendi kıyı şeridinden 200 deniz milinden (370 kilometre) uygulamaya başlamıştır. Kıbrıs Adası çevresindeki haklarını da saklı tutmaktadır.

Deniz sınırlarıyla ilgili konular, Montego Bay Sözleşmesi (Birleşmiş Milletler Deniz Hukuku Sözleşmesi 10 Aralık 1982 tarihinde Jamaika'nın Montego Bay kentinde yapılmıştır), Birleşmiş Milletler Deniz Hukuku Sözleşmesi (UNCLOS) tarafından uluslararası olarak düzenlenmektedir. UNCLOS, ülkelerin dünya okyanuslarını ve denizlerini kullanmalarına, işletmelere, çevreye ve deniz doğal kaynaklarının yönetimine yönelik kılavuzlar oluşturmaya ilişkin hak ve sorumluluklarını tanımlamaktadır. UNCLOS deniz bölgelerini tanımlamakta ve ayrıca navigasyon, transit rejimleri, derin deniz dibi madenciliği, sömürü rejimi ve uyuşmazlıkların çözümü konularında net rehberlik sağlamaktadır. Deniz bölgeleri, Şekil 5'de bildirildiği gibi sözleşme ile tanımlanmaktadır(http:/www.europarl.europa.eu/RegData/etudes/STUD/2017/578044/EXPO_STU(2017)57804 4_EN.pdf (09.04.2019). Aşağıdaki harita, deniz tabanının nasıl kullanılacağını göstermektedir.

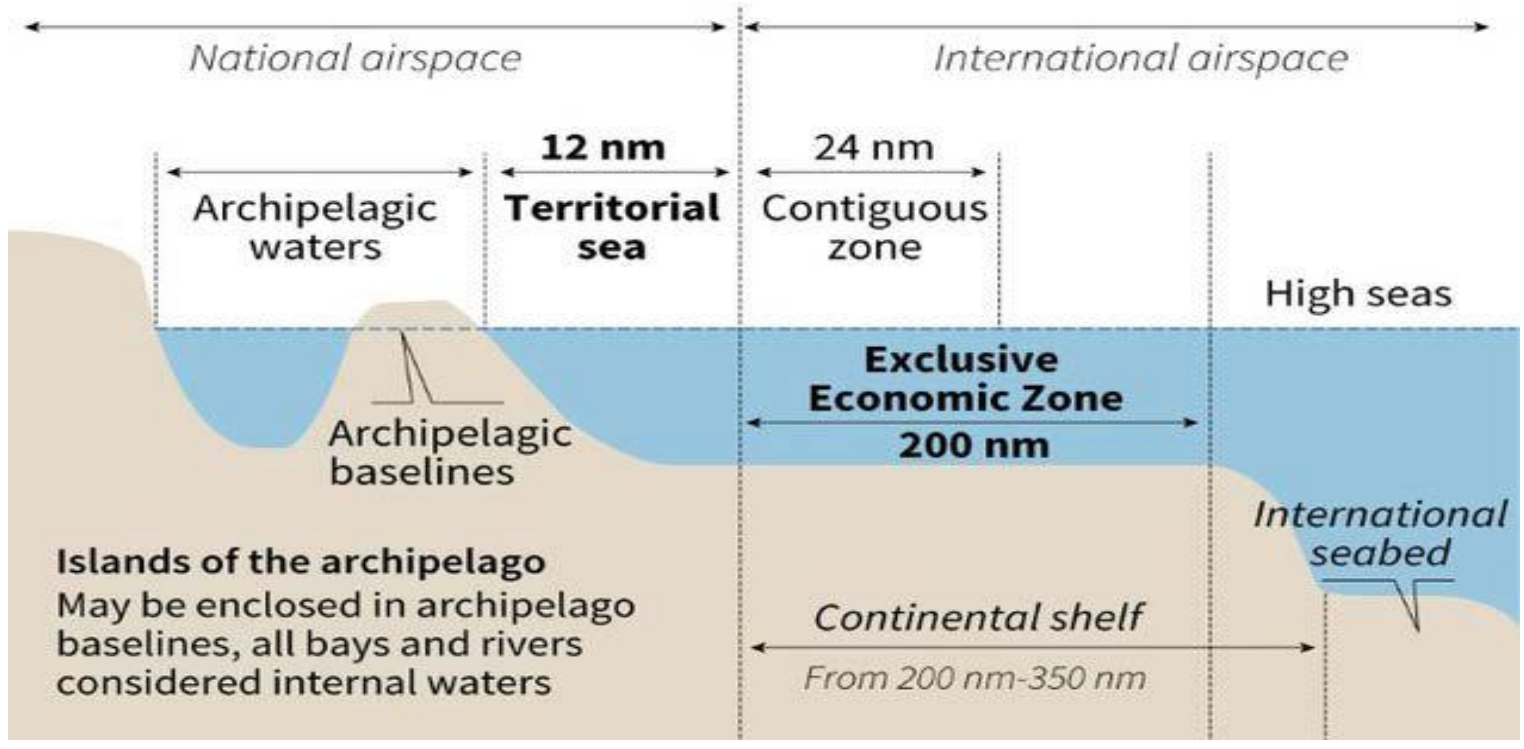

Şekil 6. UNCLOS Kapsamındaki Deniz Bölgeleri

Kaynak:http://www.europarl.europa.eu/RegData/etudes/STUD/2017/578044/EXPO_STU(2017)578044_EN.pdf (09.04.2019)

UNCLOS'a dayanarak şu ana kadar Doğu Akdeniz'de denizcilik sınırları oluşturmak için dört anlaşma imzalanmıştır.

“(i) Kıbrıs Cumhuriyeti-Birleşik Krallık: 1960 yılında Kıbrıs Cumhuriyeti, Yunanistan, Türkiye ve Birleşik Krallık tarafindan imzalanan bu özel anlaşma, Akrotiri ve Dhekelia'da bulunan iki Egemen Temel Alanın Birleşik Krallık'ın egemenliği altında tutulmasına yönelik;

(ii) Kıbrıs Cumhuriyeti-Mısır: 2003 yılında imzalanan anlaşma, iki ülkenin Münhasır Ekonomik Bölgelerini (EEZ) sinırlandırdı;

(iii) Kıbrıs Cumhuriyeti-Lübnan: 2007 yılında imzalanan anlaşma, iki ülkenin EEZ'lerini sınırlandırdı. Bu anlaşma Kıbrıs Cumhuriyeti tarafından onaylandı. Ancak, Lübnan tarafından imzalanmamıştır; 
(iv) Kıbrıs Cumhuriyeti - İsrail : 2010'da imzalanan anlaşma, iki ülkenin EEZ'lerini sınırlandırmıştır “( http://www.europarl.europa.eu/RegData/etudes/STUD/2017/578044/EXPO_STU(2017)578044_EN.pdf (09.04.2019). Ancak, KKTC tarafindan Anlaşma onaylanmamıştır.

“(i) Kıbrıs: 2004'te Türkiye, Birleşmiş Milletlere, EEZ'lerin sınırlandırılması konusunda Kıbrıs Cumhuriyeti ile Mısır arasında daha önce belirtilen 2003 tarihli anlaşmayı tanımadığını, Kıbrıs karasuları sınırlamalarının herkes tarafından kabul edilmesi gerektiğini bildirmiştir. Kıbrıs'ta iki toplumlu eşitlik ilkesine dayanan bölge oluşmuştur. Kuzey Kıbrıs Türk Cumhuriyeti'nin ('KKTC') 1983'te Birleşmiş Milletlerin yasal olarak geçersiz olduğunu ve yalnızca Türkiye’nin tanıdığını ilan etmesiyle ortaya çıkmıştır. Denizaşırı İsrail ve Kıbrıs'taki gaz keşiflerinin ardından Türkiye, 2011'de kıta sahanlığının sınırlandırılması için "KKTC" ile bir anlaşma imzalamıştır.

(ii) İsrail-Lübnan: Bu anlaşmazlık, Kıbrıs Cumhuriyeti ile Mısır arasında daha önce belirtilen anlaşmaların imzalanmasından sonra 2010 yılında ortaya çıkmıştır. Lübnan, anlaşmanın deniz dibi ve sular üzerindeki haklarını ihlal ettiğini iddia etmiștir." http://www.europarl.europa.eu/RegData/etudes/STUD/2017/578044/EXPO_STU(2017)578044_EN.pdf (09.04.2019).

Türkiye Doğu Akdeniz'deki Münhasır Ekonomik Bölge (MEB) de bulunan doğalgaz ve petrolün Doğu Akdeniz'de kıyısı bulunan devletlerin, katılımıyla kullanılması, elde edilen kanyağın boru hatlarıyla AB ülkelerine taşınmasında önemli bir konuma sahiptir. Bu avantajını iyi kullanması, bölge ülkelerinin lehine olabilecektir. Türkiye'nin enerji güzergâhlarının merkezi olma hedefiyle de uyumludur. Bunun yanında Türkiye artan enerji ihtiyacından dolayı Doğu Akdeniz gazı için de en uygun pazardır (Yılmaz, s. )

\section{2 İsrail Türkiye Stratejik Yolu}

Mavi Marmara saldırısı sonrası, Türk-İsrail ilişkilerinin kötüleşmesine rağmen, mağdurlara tazminat diplomatik görüşmeleri yakın zamanda bir uzlaşma yaratmıştır. Bu bağlamda, 2013'ün başlarında İsrail, Leviathan gaz sahasından Türkiye'nin güney sahiline ve güney-doğu Avrupa'ya boru hattı inşa etmek için bir teklifte bulunmuştur. Leviathan gaz sahalarından boru hattı inşa etme planı, Kıbrıs, Türk-İsrail ilişkilerini dengelemek ve Akdeniz maliyetini Avrupa'ya ihraç etmek için Türkiye tarafından kullanılmıştır. Türkiye-İsrail'in bir boru hattı inşa etme girişimleri, Kıbrıs'ın önerdiği LNG tesisinden daha kârlı olabilir. Ancak, gelecekteki arz güvenliği maliyeti büyüktür. Aslında, birkaç uluslararası ve Türk firması bu projenin finansmanında şimdiden bir ilgi göstermiş olup, tahmini maliyeti - 5 milyar dolar - LNG tesisi için 15 milyar dolar ile olumlu bir şekilde karşılaştırmıştır. Leviathan sahasından bir Türk boru hattının inşası düşünülebilecek gibi görünüyorsa da boru hattı projenin yürütülmesini imkansız kılan Kıbrıs'ın kıta sahanlığını geçmek zorunda kalacaktır. Alternatif olarak, boru hattı Lübnan ve Suriye kıta sahanlığı boyunca inşa edilebilir: Ancak, İsrail’in Lübnan ve Suriye'yle olan çatışmacı ilişkileri göz önüne alındığında, transit anlaşması gor gibi görünmektedir (http://www.europarl.europa.eu/RegData/etudes/briefing_note/join/2014/522339/EXPO-

AFET_SP\%282014\%29522339_EN.pdf ( 21.03.2019). Türkiye-İsrail ilişkileri, Avrupa doğalgaz pazarındaki tekelini korumak için iyi, ancak, Rusya tarafından olumsuz karşılanabilir.

İsrail'in 2009 ve 2010 yılındaki keşifleri, Doğu Akdeniz'i doğalgaz üreten bir bölgeye ve Avrupa ve Asya pazarları için potansiyel bir enerji ihracatçısı haline getirmiştir. Ancak, Mısır'daki çalkantılı siyasi durum, Suriye iç savaşı, İsrail ile Gazze arasındaki gerginlikler, Türkiye ile Kıbrıs arasındaki uzun süren anlaşmazlık ve deniz sınırındaki anlaşmazlıklar, bu ekonomik fırsata gölge düşürmüştür. Dahası, Doğu Akdeniz'deki gaz endüstrisi bebek aşamasındadır ve söz konusu ülkeler gelecekteki ihracat planlarını koordine edemiyor gibi görünmektedir. Küresel aktörler, Doğu Akdeniz'in stratejik etkilerinden yararlanmaya hazırdırlar. Rusya, gaz tekelini korumayı, $\mathrm{ABD}$ ise ticari çıkarlarının desteklenmesini, $\mathrm{AB}$ ise enerji güvenliğini arttırmayı ve Rusya'ya Kırım krizinin 1şığında gaz bağımlılığını azaltmayı hedeflemektedir. Bu bağlamda, İsrail'in Lübnan ve Avrupa Birliği, Doğu Akdeniz enerji koridorunun inşasına ilk adım olarak İsrail, Kıbrıs ve Türkiye'nin stratejik üçgenini desteklemelidir (http://www.europarl.europa.eu/thinktank/en/document.html?reference=EXPO-AFET_SP(2014)522339 (22.04.2019).

\section{Sonuc}

Doğu Akdeniz'deki Münhasır Ekonomik Bölgenin Enerji Kaynaklarında Dünya da yeni bir alan oluştuğu görülmüştür. Türkiye ve Kıbrıs için yeni bir ekonomik alan oluşması, çıkartılacak olan doğalgaz ve petrolün her iki ülke ekonomisine büyük katkı sağlayabilecektir. Tarihi yönden kökü 1960'lara dayanan Doğu Akdeniz'de ki münhasır ekonomik bölgelerde ilk çalışma İsrail tarafından yapılmıştır. 2009 yılında ise İsrail Mısır ve Güney Kıbrıs Rum yönetimi doğalgaz üretimlerine başlamıştır. Ancak Kuzey Kıbrıs Türk yönetiminin haklarına bir ihlal olduğundan Güney Kıbrıs’ın yapmış olduğu gaz elde etme potansiyelini benimsememiştir. Bununla ilgili anlaşmazlıklar devam etmektedir.

Münhasır ekonomik bölge AB yönünden değerlendirilmiştir. Bu konuda AB Komisyonlarında birçok kararlar da mevcuttur. Kararlar daha çok 2004 yılı sonrasına rastlamaktadır. Bununda sebebi Güney Kıbrıs'ın AB'ne 2004 yılında kabul edilmesi ile AB sınırları Doğu Akdeniz'de ki münhasır ekonomik bölgeye de ulaşmıştır. Kuzey Kıbrıs Türk Cumhuriyeti ve Türkiye'nin Kıbrıs ve civarındaki ekonomik kaynaklardan istifade edememesi 
yönündeki kaygıları gidermek için 11 Ekim 2016 yılında Türkiye ile KKTC'nin yapmış oldukları anlaşma her iki ülkenin mağduriyetini ortadan kaldırmıştır. Bunun da sebebi, Uluslararası Deniz Hukukuna göre münhasır ekonomik alanın BM Deniz Hukuku Sözleşmesine göre 200 mil' e çıkarılmasındandır. Böylelikle hem Türkiye hem de KKTC münhasır ekonomik bölgede ekonomik kaynak potansiyelini kullanabilme ehliyetine sahip olmuştur. Bu durum, Doğu Akdeniz'deki denizaşırı kaynakları elinde bulunduran ülkeler bakımından tedirginlik oluşturmuştur.

Doğu Akdeniz de münhasır ekonomik bölgeden istifade etmek isteyen Mısır, İsrail, Filistin Lübnan, Suriye, Türkiye, Güney Kıbrıs Rum Yönetimi ve KKTC istifade edebilirler. AB yönünden önemli görülen bu uzlaş1 anlayışı elde edilen doğalgaz ve petrolün pazarlanması da önemli bir yön teşkil etmektedir. Bunun için Mısır, İsrail, Ürdün, Lübnan, Suriye ve Türkiye'ye uzanacak olan boru hatları ile beraber AB ye pazarlanabilmesi daha olumlu bir yöndür. Ancak, Suriye'de ki çıkar çatışmaları ve iç savaş nedeniyle olumsuzluklar yaşanabileceği aşikârdır. Özellikle Suriye'nin kuzeyinde ve Türkiye sınırına yakın bölgede bulunan verimli petrol ve doğalgaz alanları ABD tarafindan taşeron terör örgütleri sayesinde başarıya ulaşması mümkün değildir. $\mathrm{Bu}$ da bölgedeki istikrarsızlı̆g tetikleyebilmektedir. ABD'nin dolaylı münhasır ekonomik bölge ülkeler üzerindeki etkisi açık olduğundan henüz bu ülkeler arasında bir enerji çatışması mümkün değildir. Doğu Akdeniz'de ki münhasır ekonomik bölgenin çatışmalardan uzak iş birliği anlayışı içinde yapılacak olan çalışmalar, münhasır bölge ülkelerinin lehine olabilecektir. AB'nin bu yöndeki düşüncesi daha ziyade Güney Kıbrıs Rum yönetimini destekler mahiyetinde görülmektedir. Bunun için Kıbrıs sorununun her iki toplumun menfaatleri göz önüne alınarak çözüme kavuşturulması, iki toplumun aynı zamanda Türkiye'nin ekonomik ve sosyal refahına da katkı sağlayabilecektir.

\section{Kaynakça}

- (09.04.2019) Ve author'selaboration on Middle East EconomicSurvey (2016)'den naklen.

- Andrea Prontera, Mariusz Ruszel, https://www.mepc.org/journal/energy-security-eastern-mediterranean (20.04.2019)

- Andrea Prontera, Routledge,The New Politics of Energy Security in the European Union and Beyond. States, Markets, Institutions,London, 2017

- Atilla Sandıklı, Türkan Budak, Bekir Ünal, Doğu Akdeniz'de Enerji Keşifleri ve Türkiye, Bilge Adamlar Kurulu Raporu, (Bilgesam) Rapor No:59,Aralık 2013,İstanbul

- Emre Yılmaz, Doğu Akdeniz'de Enerji Çıkmazı, https://setav.org/assets/uploads/2018/03/P188_AkdenizdeEnerji.pdf (22.04.2019)

- http://www.europarl.europa.eu/RegData/etudes/briefing_note/join/2014/522339/EXPOAFET_SP\%282014\%29522339_EN.pdf( 21.03.2019)

- http://www.europarl.europa.eu/RegData/etudes/STUD/2017/578044/EXPO_STU(2017)578044_EN.pdf,s.16 (09.04.2019)

- $\quad$ http://www.europarl.europa.eu/RegData/etudes/STUD/2017/578044/EXPO_STU(2017)578044_EN.pdf

- http://www.europarl.europa.eu/RegData/etudes/STUD/2017/578044/EXPO_STU(2017)578044_EN.pdf (09.04.2019) ve NobleEnergyand Eni (officialwebsites, accessed in January 2017)'den Naklen,Energy: a shaping factor for regional stability in the Eastern Mediterranean Directorate-General For External Polıcies Policy Department Eurupean,Parliment,s.14

- http://www.europarl.europa.eu/RegData/etudes/STUD/2017/578044/EXPO_STU(2017)578044_EN.pdf (09.04.2019)

- http://www.europarl.europa.eu/thinktank/en/document.html?reference=EXPO-AFET_SP(2014)522339 (22.04.2019)

- https://www.researchgate.net/publication/324808564_BUYUK_ORTADOGU_PROJESI_BOP_TURKIYE_ VE_SURIYE_GREATER_MIDDLE_EAST_PROJECT_GMEP_AND_SYRIA

- $\quad h t t p s: / / w w w . t b m m . g o v . t r / s i r a s a y i / d o n e m 26 / y i 101 / s s 516 . p d f(21.04 .2019)$

- https://www.un.org/Depts/los/convention_agreements/texts/unclos/part5.htm (23.04.2019)

- Murat Köylü, Büyük Ortadoğu Projesi (Bop), Türkiye ve Suriye,Euluslararası İktisadi Ve İdari Bilimler Dergisi 2 (1) 2015, s.s.85-100

- Münhasır Ekonomik Bölge,https://www.worldatlas.com/articles/what-is-an-exclusive-economic-zoneeez.html (23.04.2019) 


\title{
Girişimcilik Öykülerinden Rekabet Stratejisi Analizi Competitive Strategy Analysis from Entrepreneurship Stories
}

\author{
Asst. Prof. Dr. Şeyma Gün Eroğlu (Muğla Sitkı Koçman University, Turkey) \\ Prof. Dr. Ayşe İrmiş (Pamukkale University, Turkey)
}

\begin{abstract}
Organizations apply two basic competitive strategies in general. These are the cost leadership strategy and the differentiation strategy. The application of any of the mentioned strategies by focusing on a smaller field in the market is called a focus strategy. Companies gain value in the eyes of customer with the strategy they choose.

The aim of this study is to analyze the competitive strategies applied by the enterprises and the results of these strategies. A semi-configured interview on the entrepreneurs of two firms which open to a wider market from local market in Denizli with their own brands, was conducted. The first enterprise, which has been maintaining its existence for 80 years and has many branches in the different provinces, is a firm producing sugar and sugar products (Firm A). The second, which has been maintaining its existence for 84 years and has branches in close neighbor cities and provinces, is a firm producing soft drinks (Firm B).

The common feature of both firms is that they keep their local characteristics and take their competitive power from the local people. In the research, the competitive strategies of entrepreneurs have been defined and analyzed by benefiting from the entrepreneurship stories that have been brought up to the present day. It was concluded that firm A applied differentiation strategy in the product, production process, and market, while firm B differentiated in the production process without any differentiation in the product and used the focus strategy in the market.
\end{abstract}

\section{Rekabet Stratejileri}

Konumlandırma okulunun en önemli ismi olan Porter (1996) stratejiyi, farklı faaliyetler seti gerektirmesi sebebiyle benzersiz ve değerli bir konum yaratmakla ilgili görmektedir. Porter rekabet stratejilerinin farklı olmakla ilgili olduğunu öne sürmektedir. Bu ise bilinçli olarak benzersiz bir değer bileşimi ortaya koyacak farklı faaliyetler seti tercih etmeyi gerektirmektedir. Stratejik konumlandırma, bir şirket hakkındaki ayırt edici/farklı özelliklerini muhafaza ederek sürdürülebilir rekabet üstünlüğü elde etme çabasını ifade etmektedir. Başka bir anlatımla stratejik konumlandırmanın temeli rakiplerden farklı faaliyetler seçmektir.

Porter (1980) oluşturduğu modelde sektördeki rakipleri devre dışı bırakma yaklaşımından hareketle üç jenerik strateji ileri sürmektedir: Farklılaştırma stratejisi, maliyet liderliği stratejisi ve odaklanma stratejisi. İlki olan maliyet liderliği; kaliteyi, hizmeti ve diğer unsurları ihmal etmeksizin rakiplere göre daha düşük maliyetlerle faaliyette bulunmayı vurgulamaktadır. İkinci strateji farklılaştırmada, firmanın ya üründe ya da hizmette sektörde benzersiz olarak algılanan bir takım şeyler yaratması gerekmektedir. Bu sayede ortalama fiyattan daha yüksek fiyat uygulama imkânı doğmaktadır. Üçüncüsü odaklanma stratejisidir. Bu stratejide firma, ürün hattı bölümleri, coğrafik pazarlar ya da belirli bir müşteri grubu üzerine konsantre olur (Dess ve Davis, 1984). Porter'a göre (2008) bir firmanın, rakipleri karşısında pek çok üstünlüğe ve zayıflığa sahip olabilmesine rağmen, rekabet üstünlüğüne sahip olabileceği iki temel yol vardır ve bunlar düşük maliyet veya farklılaştırma stratejileridir. Buna göre bir firmanın sahip olduğu birtakım üstünlükler ve zayıflıkların önemi, nihayetinde onun nispeten maliyet ve farklılaştırma üzerindeki etkisinin bir fonksiyonu olarak değerlendirilmektedir. Porter'ın jenerik rekabet stratejisi tipolojisine göre, maliyet üstünlüğü ve farklılaştırma, sektörün yapısından ileri gelmektedir. Maliyet üstünlüğü ve farklılaştırma, bir firmanın rakiplerinden daha iyi bir şekilde beş zorlayıcı gücün üstesinden gelme yeteneği ile ilgilidir (Porter, 2008). Porter'a (1980) göre, bir firmanın rekabet üstünlüğü elde edebilmesi için maliyet liderliği ya da farklılaştırma jenerik stratejilerinden sadece birini tercih etmesi gerekmektedir. Her ikisinin aynı anda uygulanması durumunu Porter $(1980,2008)$ "arada sıkışıp kalma" (stuck in the middle) olarak tanımlamakta ve arada sıkışıp kalan bir firmanın ortalamanın altında performans göstereceğini ve bunun da bu tür firmalar için çoğu zaman hiçbir rekabet üstünlügü elde edememe anlamına geldiğini iddia etmektedir. Porter ve taraftarları, düşük maliyet stratejisi gerektiren değer zincirinin, bir farklılaştırma stratejisi gerektiren değer zincirinden nitelik olarak farklı olduğunu düşünmektedirler. Bir başka deyişle bu görüşü savunanlar, çoğu zaman farklılaştırma ve düşük maliyet stratejilerini aynı anda izlemeye, bu stratejilerin her birinin farklı kaynak setleri ve örgütsel düzenlemeler gerektirdiği temeline dayanarak karşı çıkmaktadırlar (Pertusa-Ortega vd., 2009: 509). Stratejik yönetim literatüründe Porter'ın bu jenerik strateji tipolojisine yöneltilen en önemli eleştirinin jenerik stratejilerden sadece birinin uygulandığı durumlarda rekabet üstünlüğünün elde edilebileceği görüşü olduğu görülmektedir. Bununla birlikte bazı ampirik araştırmalar, düşüşte olan endüstrilerde ve gerileyen firmalarda bile, rekabet üstünlügü elde etmenin en iyi yolunun jenerik stratejilerin bir kombinasyonunun olabileceğini göstermektedir (Tansey vd., 2014:708). Buna göre bir kısım araştırmacılar, "hibrit", "karma", "birleşik" veya "kombinasyon" olarak isimlendirdikleri bu stratejilerin izlenebileceğini ileri sürmektedirler (Pertusa-Ortega vd., 2009). Örneğin; Leitner ve Güldenberg, (2010), küçük ve orta ölçekli işletmeler üzerinde inceleme yaptıkları çalışmalarında, hibrit strateji 
izleyen firmaların uzun dönemli karlılık ve büyüme açısından en iyiyi başardıklarını bulmuşlardır. Bu anlamda karşıt görüşe göre, hem düşük maliyet hem de farklılaştırma stratejileri aynı anda ve karlı bir şekilde firmalar tarafından hayata geçirilebilmektedir. Bu görüşe göre, bir farklılaştırma stratejisini hayata geçirmek, birtakım fonksiyonel alanlarda daha yüksek maliyetlerle faaliyette bulunmayı gerektirebilir. Ancak yüksek kaliteli ürünler muhtemelen daha fazla pazar talebini beraberinde getirecektir. Bu durum bir şirketin giderek artan üretim hacmi ve daha yüksek pazar paylarını elde etmesi sayesinde düşük maliyet stratejisini uygulamasına izin verebilir (Yamin vd., 1999). Bununla birlikte Hill, (1988), Porter'ın sadece üç durumda her iki stratejinin birden uygulanmasının başarılı sonuçlar verebileceği görüşüne vurgu yaparak, bu üç durumu şu şekilde tarif etmektedir. Pazardaki tüm rakipler stratejik anlamda arada sıkışıp kalmışsa, karşılıklı ilişkilerin ve pazar payının maliyetleri güçlü bir şekilde etkilemesi söz konusuysa ve bir firma önemli inovasyonları gerçekleştirmede öncü konumundaysa, her iki strateji aynı anda başarılı olarak uygulanabilir.

\subsection{Maliyet Liderliği Stratejisi}

Toplam maliyet liderliği stratejisi, rakiplere göre daha düşük maliyetlere vurgu yaparak pazar payını artırma çabası ile ilgilidir (Miller ve Dess, 1993). Bu stratejide firmalar, endüstrideki/sektördeki en düşük maliyetle faaliyet gösteren üretici olmayı amaçlamaktadırlar (Miller ve Friesen, 1986:). Maliyet liderliği stratejisi, herkes için düşük fiyatlarla ürün sunmak ve oldukça standardize edilmiş ürünlerin üretilmesini içermektedir (Datta, 2010). $\mathrm{Bu}$ genellikle, etkin bir ölçek oluşturma, deneyimlerden kaynaklanan maliyet düşüşünü çok titiz bir şekilde gerçekleştirme, sıkı bir maliyet ve genel giderler kontrolü yapma, marjinal müşteri hesaplarından kaçınma ve arge, hizmet, satış ekibi ve reklam gibi alanlarda maliyet minimizasyonunu gerektirmektedir (Porter, 1980: 35). Maliyet liderliği stratejisi, ölçek ekonomisini artırmak için agresif bir fiyatlandırma yoluyla pazar payı elde etmeyi, imalatı kolay ürünler tasarlamayı, ileri teknoloji ekipmanlar kullanmayı ve imalat sürecindeki teknoloji için ar-ge faaliyetleri yapmayı gerektirebilmektedir (Miller ve Friesen, 1986). Maliyet liderliği stratejisinin başarısı için kitle üretim, kitle dağıtım (massdistribution) ölçek ekonomileri, teknoloji, ürün tasarımı, girdi maliyetleri, kaynaklardan tam kapasite yararlanmak ve hammaddelere erişmek gibi birçok konu vardır. Düşük maliyet ve maliyet üstünlüğü, süreç inovasyonu, öğrenme eğrisi faydaları, ölçek ekonomileri, ürün tasarımı için azaltılmış üretim zamanı ve maliyetleri ve süreç yenileme faaliyetlerinden kaynaklanmaktadır. Bir firma, daha düşük maliyetlere yardımcı olan hammadde ve üstün teknolojiye erişebilmelidir. Ayrıca örgütler, maliyet üstünlüğüne sahip olmadıkları bazı faaliyetleri sürdürmemeye razı olmalıdır ve maliyet üstünlügü için diğer örgütlerle outsourcing faaliyetlerini yürütmeleri konusunu göz önünde bulundurmalılardır (Allen ve Helms, 2006). Bununla beraber, bu stratejiyi izleyen firmalar için en az derecede çevresel belirsizlik ve değişimle karşılaşmak oldukça önemlidir. Bir maliyet liderliği stratejisi, müşserilerin fiyata duyarlı oldukları ve ölçek ekonomileri, sahip olunan teknoloji, ucuz malzeme, ulaşım veya dağıtım kanalları yoluyla maliyet üstünlüğünü sürdürmek için mücadeleci bir ortamın olduğu durumlarda son derece etkilidir (Miller, 1992). Dolayısıyla bu stratejiyi izleyen firmalar, imaj veya yenilikten çok, fiyatı daha fazla önemseyen müşterileri ararlar, bu yüzden de ürün inovasyonu çoğu zaman bu tür firmalar için gereksiz ve etkisiz kalacaktır (Miller, 1988). Pazarda maliyet liderliği stratejisini en başarılı şekilde uygulayan firmalardan biri Walmart'tır. Bu anlamda Walmart'ın dikkat çeken esneklik ve hızlı çözümlerle birlikte maliyet üstünlüğü yeteneği, çoğu zaman oldukça dikkat çekici bir örnek olmuştur. Walmart Mağazaları çoğu zaman indirim uygulamaları, maliyetlere dair oldukça zengin bir veri akışının sağlanması sebebiyle pazarda bu stratejiyi en iyi uygulan firmalar arasında gösterilmektedir (Grant, 2002).

Maliyet liderliği stratejisi, bu stratejiyi izleyen firmaların etkin rakiplerle yarışmak için daha düşük fiyatlar belirleyebilmesi ve bu durumda bile yüksek karlar elde edebilmesi sebebiyle ortalamanın üzerinde getiri sağlayabilmektedir. Bu strateji, müşterilerin ve tedarikçilerin pazarlık gücünden kaynaklanan tehlikeli fiyat düşüşleri karşısında bir güvenlik/emniyet marjı sağlar. Maliyet liderliği çoğu zaman giriş engeli oluşturacak büyük ölçekli tesisler ve ekonomiler gerektirmektedir (Miller ve Friesen, 1986). Maliyet lideri olan bir firma, pazara girmek için büyük miktarda sermayeye ihtiyaç duyan yeni firmalara karşı bir engel teşkil etmektedir. Bu durumda lider olan firma, endüstrideki geniş çaplı bir fiyat indiriminden bir dereceye kadar korunmaktadır. Bununla birlikte maliyet liderliği stratejisinin bazı dezavantajları da bulunmaktadır. Bu strateji, düşük müşteri sadakati yaratır ve eğer firma fiyatları çok fazla düşürürse, gelirlerini kaybetmeye başlayabilir (Allen ve Helms, 2006).

\subsection{Farklılaştırma Stratejisi}

1960'ların sonları ile 1970'lerde özellikle maliyet liderliği stratejisi oldukça popülerdi ve bu birçok üretim biriminin nispi pazar payı elde etme amacına odaklanmasına yol açmıştı (Kotha ve Orne, 1989). Ürün farklılaştırma, bir firmanın ürünlerinin başka satıcıların mal ve hizmetlerinden ayırt edilmesi ve bir tercihe neden olması olarak tanımlanmaktadır (Dickson ve Ginter, 1987). Farklılaştırma stratejisinin amacı, tüketicilerin özgün ve benzersiz olarak algıladıkları bir ürün yaratmak ve böylece firmaların ürün geliştirme esnasında ortaya çıkan ekstra maliyetlerinin toplamını aşan yüksek bir fiyatlandırma yapmalarını kolaylaştırmaktır (Wu vd., 2007). Bunun yanında, ürün ya da hizmetin özgün olması, bu stratejinin yüksek müşteri sadakati sağlamasına da neden olmaktadır. Farklılaştırma stratejisi ile işletmeye ürün kalitesi, ürün özellikleri ve satış sonrası hizmetler vasıtasıyla müşteri için benzersiz ve üstün bir değer yaratılmaktadır. Farklılaştırma stratejisi izleyen firmalar, dağıtım kanalları, hizmet kalitesi, teslimat sistemi ve ürün özelliklerini esas alan mal ve hizmetleri için daha yüksek fiyat isteyebilir. Kalite, gerçek ya da algılanan moda, marka adı ve imaja dayalı olabilir. Farklılaştırma stratejisi, özgün 
ve kaliteli ürünlerle ilgilenen ve daha yüksek fiyat ödemeye razı olan sofistike müşterileri cezbetmektedir (Allen ve Helms, 2006).

Farklılaşmayı yaratabilmek için gerekli bazı anahtar unsurlar vardır: Dergi ve haber bültenlerinde şirketi olumlu etkileyecek temel konuların yer alması, toplumda ilgilenilen bir firma olmak, yaratıcı olma, rakiplerin sunmadığ ya da sunamayacağı bazı şeylerin sunulması, e-ticareti tesis etmek, çabuk ve kolay bir şekilde ürünlere ve şirket hakkındaki bilgilere erişim sağlamak, çalışanlara ürün ve hizmet bilgisi hakkında geniş kapsamlı eğitimler vermek, geliştirilmiş ve inovatif ürünler sunmak (Allen ve Helms, 2006). Ayrıca rekabet üstünlügünü sürdürmek için bu firmalar, artan gelişmelerinin ötesine geçerek ve özgün dağıtım kanalları ya da korunan tescilli entelektüel özelliklere sahip olmak ve kendilerini radikal olarak inovasyon yapar hale dönüştürerek rakipleri için giriş engellerini yükseltmek durumundadırlar (Gehani, 2013). Porter, fiyat inelastikiyeti ve müşteri sadakati yaratarak, bu stratejinin giriş engellerini yükselteceğini, daha yüksek marjlar sağlayacağını ve kabul edilebilir ikame ürünlere sahip olmadığını düşünen müşterilerin gücünü azaltacağını ileri sürmüştür (Miller, 1988). Murray’e (1988) göre ise müşterilerin fiyattan çok ürün özelliklerinin önemine bağlılığı, ürün farklılaştırma stratejisinin başarısı için gerekli bir koşuldur fakat yeterli koşul değildir. Bir ürün farklılaştırma stratejisinin başarılı olabilmesi için bir firmanın ürün sunumlarında, marka imajında, ambalajlamada, satış öncesi ve sonrası hizmetlerde ve finansman düzenlemelerinde göze çarpan farklılıklar yaratabilmesi ve bunu devam ettirebilmesi gerekmektedir. Bununla birlikte, daha büyük bir farklılaştırmayı başarabilmek, çoğu zaman daha yüksek maliyetler anlamına gelir. Öyle ki, Porter'a (2015) göre farklılaştırmayı başarmak, bazen yüksek bir pazar payı elde etmeye engel bile olabilir.

Miller (1986) en az iki tip farklılaştırma stratejisi olduğuna işaret etmiştir. Bunlar ürün inovasyonu temelli olanlar ile imaj yönetimi ve yoğun pazarlamaya dayalı olanlardır. İlki, en yeni ve cazip ürünlerle kalitede, tasarım inovasyonunda veya stilde rakiplerin önüne geçme çabasıdır. İkincisi, pazarlama uygulamalarıyla bir ürün için benzersiz bir imaj yaratma girişimidir.

Bertozzi ve diğerlerine (2017) göre farklılaştırma stratejisi geliştirmenin iki temel yolu vardır; bunlar ar-ge faaliyetleri ve pazarlamadır. Bu yazarlara göre, bir farklılaştırma stratejisi izlenirken ar-ge faaliyetleri kapsamında şunlar yapılabilir: Firmanın teknolojisini geliştirmek, kaliteli hizmet veya benzersiz ürünler ortaya koymak, diğer şirketler tarafından taklit edilmesi zor ve sınırlı sayıda ürün ortaya çıkarmak, aynı ürünü müşterilere cazip gelecek yeni özelliklerle sunmak, şeffaf olmak. Bunun yanında yazarlar, farklılaştırma stratejisi konusunda izlenebilecek diğer bir yol olarak öne sürdükleri pazarlama faaliyetleri çerçevesinde şunların gerçekleştirilebileceğini belirtmektedirler: Kaliteli reklam kampanyaları başlatmak, fuar ve sergilerde ürün hakkında bilgi vermek, şirketteki yeni teknolojiler ve gelecek planları gibi yenilikler hakkında ve ürün hakkındaki haberlerle ilgili müşterileri bilgilendirmek için haber bültenlerinde yer almak, şirketin web sitesinin kalitesini artırmak, şirketin web sitesi üzerinden e-ticareti tesis etmek, müşterilerin bireysel isteklerine göre ürün uyarlama gibi çeşitli seviyelerde hizmet sağlamak ve online marka tanınırlığ 1 yaratmak, kurumsal sosyal sorumluluk etkinlikleri düzenleyerek toplumla daha bağlantılı hale gelmek, satış sonrası müşteri destek hizmetleri sağlayan ekipler kurmak ve ürün ve hizmet bilgisi ile ilgili derinlemesine eğitim faaliyetleri düzenlemek.

Porter (1980) tarafından birbirine alternatif ve zıt olduğu ileri sürülen maliyet liderliği ve farklılaştırma stratejileri arasındaki ayrımların ortaya konması açısından bu jenerik stratejilere ait önemli değişkenler Tablo 1'de yer almaktadır.

\begin{tabular}{|c|c|c|}
\hline & Maliyet Liderliği & Farklılaştırma \\
\hline Faktör Girdileri & $\begin{array}{l}\text { Düşük maliyetli hammadde } \\
\text { İşgücü verimliliği } \\
\text { Sürdürülebilir sermaye } \\
\text { Gerekli yatırmmlar }\end{array}$ & $\begin{array}{l}\text { Ürün teknolojisi } \\
\text { Yaratıcıllk / İnovasyon }\end{array}$ \\
\hline Süreç & $\begin{array}{l}\text { Verimli ölçekli tesisler } \\
\text { Süreç Mühendisliği becerileri } \\
\text { Minimum fire / Yüksek verim } \\
\text { Çalış̧anların verimliliği } \\
\text { Lojistik }\end{array}$ & $\begin{array}{l}\text { Esneklik } \\
\text { Kalite }\end{array}$ \\
\hline Ürün veya Hizmet & $\begin{array}{l}\text { Kolay bir şekilde üretim } \\
\text { Sermaye yoğunluğu }\end{array}$ & $\begin{array}{l}\text { Teknik hizmetler } \\
\text { Stil } \\
\text { Benzersizlik } \\
\text { Opsiyonlar } \\
\text { Kalite / Güven } \\
\text { İmaj } \\
\text { Ürün çeşitleri } \\
\end{array}$ \\
\hline Ürünle İlgili Diğer Hizmetler & & $\begin{array}{l}\text { Kolay bulunurluk / Teslimat } \\
\text { Finansman } \\
\text { Garantiler } \\
\text { İyileştirilmiş kullanım için yeni fikirler } \\
\text { Pazar arașırmaları }\end{array}$ \\
\hline Dağıtım & $\begin{array}{l}\text { Basit ürün hattı } \\
\text { Fiyat ayrımı yapma }\end{array}$ & $\begin{array}{l}\text { Kredi } \\
\text { Satış desteği } \\
\text { Satış sonrası hizmetler }\end{array}$ \\
\hline
\end{tabular}

Tablo 1. Maliyet Liderliği ve Farklılaştırma Stratejilerinin Önemli Değişsenleri Kaynak: White, 1986 
Tablo 1'den de görüldüğü üzere Maliyet liderliği stratejisi, çoğunlukla sermayenin ve insan kaynağının verimli bir şekilde kullanılması vurgusuna ve işletmenin iç işleyişine odaklanmaktadır. Tersine, bir farklılaştırma stratejisi, prensip olarak işletmenin dış çevresini ilgilendiren değişkenlerle daha ilgilidir (White, 1986).

\subsection{Odaklanma Stratejisi}

Üçüncü jenerik strateji odaklanmadır. Bu strateji diğerlerinden oldukça farklıdır, çünkü endüstri içindeki dar bir rekabet alanının seçimine dayanmaktadır. Odaklanma stratejisi izleyen bir firma, endüstrideki bir ya da birkaç pazar bölümünü seçer ve rakiplerinin yer almadığı bu pazar bölümlerine hizmet edecek şekilde stratejisini düzenler (Porter, 2008). Bu kapsamda Porter'ın jenerik tipi odaklanma stratejisi, belirli bir müşteri türü, sınırlandırılmış bir coğrafi alan veya dar bir ürün yelpazesi gibi farklı şekillerde sınırlandırılmış ve özelleştirilmiş bir pazar bölümüne hitap etmektedir (Miller, 1988: 285).

Porter, bu modelin (farklılaştırma, maliyet liderliği, odaklanma) hem büyük hem de küçük işletmelere uygulanabilir olduğunu ve daha küçük işletmelerin daha çok niş pazarlarda rekabet etmeyi seçebileceklerini ileri sürmektedir (Leitner ve Güldenberg, 2010: 171). Wright'a (1987: 94) göre ise küçük firmalar, sadece odaklanma stratejisiyle başarılı olarak rekabet etme seçeneğine sahiptirler. Firmaların büyüklükleri ve izledikleri rekabet stratejisi konusunda Leitner ve Güldenberg (2010: 171), bir kısım araştırmalarda küçük ve orta ölçekli işletmelerin öncelikle bir odaklanma stratejisi izlediklerinin tespit edildiğine ve bu araştırmalarda farklılaştırmanın niş pazarlardaki küçük ve orta ölçekli işletmeler tarafından en çok tercih edilen jenerik rekabet stratejisi olduğuna dikkat çekildiğini ifade etmektedirler.

Porter'a (1985:15) göre odaklanma stratejisinin iki değişik biçimi vardır. Odaklanmış farklılaştırma stratejisi benimseyen bir firma, hedef pazarda farklılık yaratma peşinde olmasına rağmen; odaklanmış maliyet liderliği stratejisi benimsemiş bir firma, hedef pazarda bir maliyet üstünlüğü elde etme arayışı içindedir. Odaklanma stratejisinin her iki farklı biçimi, endüstrideki diğer bölümler ile odaklanan firmanın hedef pazarı arasındaki farklılıklara dayanmaktadır. Odaklanmış farklılaştırma stratejisinde belirli bir pazar bölümündeki müşterilerin özel ihtiyaçlarından yararlanılırken, odaklanmış maliyet liderliği stratejisinde birtakım pazar bölümlerindeki maliyet farklılıklarından yararlanılır. Bu tür farklılıklar, bu pazar alanlarında geniş hedefli rakipler tarafından yetersiz hizmet verildiğini göstermektedir. Böylece odaklanmış firmalar, sadece bu pazar bölümlerine kendilerini odaklayarak rekabet üstünlüğü elde edebilirler (Wright, 1987: 96).

\section{Girişimcilik Öyküleriyle Rekabet Stratejileri Analizine Yönelik Alan Araştırması}

Yapılan alan araştırması rekabet analizlerinde en çok bahsi geçen Porter'in rekabet stratejilerinin Denizli'de markalarıyla yüzyıla yaklaşan bir zamandır varlıklarını devam ettiren iki yerel KOBİ işletmesindeki uygulamalarını analiz etmeye yöneliktir. Araştırmada nitel yöntem kullanılmış iki kişi A işletmesinden, bir kişi de $\mathrm{B}$ işletmesinden olmak üzere üç kişiyle mülakat yapılmış ve elde edilen veriler yorumlanmıştır.

\subsection{Araştırmanın Amacı}

Çalışmanın amacı, kendi markalarıyla yerelden ulusal ve/veya uluslararası pazarlara açılan işletmelerin kendi tarihsel girişimcilik süreçleri ve halihazırdaki girişimcilik süreçleri içerisinde çevresel unsurları dikkate alarak hangi rekabet stratejilerini uyguladıklarını ve uygulanan stratejilerin sonuçlarını girişimcilerin gözüyle analiz etmektir.

\subsection{Araştırmanın Kapsamı ve Yöntemi}

Kendi markalarıyla Denizli kapsamındaki yerel pazardan daha geniş pazarlara açılan iki firmanın girişimcileriyle yarı yapılandırılmış mülakat gerçekleştirilmiştir. Firmalardan ilki, 80 yıldır varlığını devam ettiren ve pek çok ilde şubesi bulunan, 'şeker ve şekerli ürünler' firmasıdır (A firması). İkinci firma ise Denizli'de 84 yıldır varlığını devam ettiren, yakın il ve ilçelerde bayii bulunan ve aile şirketi olan bir gazoz firmasıdır (B firması). A firmasından mülakata katılan kişilerden ilki 'şeker ve şekerli ürünler' firma sahiplerinden biri olan N.H, ikincisi ise N.H'nin oğlu Y.H'dir. B firmasından tek kişi ile mülakat yapılmış, Z.Y.Ö olarak ifade edilmiştir.

Mülakatlar kendilerinden izin alınmak suretiyle ses kaydına alınmış daha sonra ses kayıtları kelimesi kelimesine araştırmacılar tarafından yazıya dökülmüştür. Mülakatları yorumlamak için içerik analizi yapılmıştır. İçerik analizi kodlama yoluyla altta yatan kavramları ve bu kavramların ilişkilerini ortaya çıkarmaya yöneliktir (Sı̆ğı, 2018). Kodlama yapabilmek için bütün veriler alanında uzman üç araştırmacı tarafından okunmuş ve literatür kapsamında cümleler kodlanmıştır. Bir araya gelen kodlu veriler kendi içerisinde kontrol edilerek, farklılıklar ve benzerlikler dikkate alınarak kodlara son şekli verilmiş̧ir. Kodlama işlemi tamamlandıktan sonra mevcut kodlar daha önceden kodlama işlemini yapmış olan alanında uzman kişiler tarafından gruplandırılarak Porter'ın rekabet stratejileri bağlamında tema öbeklerinde toplanmıştır (Ek 1). Buna göre tema başlıkları Maliyet Liderliği Stratejisi, Farklılaştırma Stratejisi ve Odaklanma Stratejisi'dir. Maliyet Liderliği Stratejisi kapsamında üç kod, Farklılaştırma Stratejisi kapsamında yedi kod, Odaklanma Stratejisi kapsamında da üç kod mevcuttur. İlgili kodlar ve temalar araştırma bulgularının analizinde kullanılmıştır. 


\subsection{Araștırma Soruları}

Araştırmanın üç sorusu mevcuttur

1. İşletmeler maliyet liderliği stratejisi uygulamakta mıdır? Uyguluyorlarsa nasıl uygulamaktadırlar?

2. İşletmeler farklılaştırma stratejisi uygulamakta mıdır? Uyguluyorlarsa nasıl uygulamaktadırlar?

3. İşletmeler odaklanma stratejisi uygulamakta mıdır? Uyguluyorlarsa nasıl uygulamaktadırlar?

\subsection{Araştırma Bulgularının Analizi}

İlk kuruluş yeri Denizli'nin Babadağ ilçesi olan A firması 1938 yılından beri varlığını devam ettirmektedir. Bugün ikinci, üçüncü ve dördüncü neslin bir arada bulunduğu A firması, N.H'ye göre dördüncü nesil olan Y.H'nin yaratıcı fikirleriyle günümüzde önemli bir gelişme kaydetmiştir. 1957 yılında Denizli’ye taşınan A firması, 2011 yılında uluslararası bir fuarla beraber yurt dışı pazara açılmış (Omur, 2014), ancak ertesi yıl fuar organizasyonu tarafindan davet edilmediği için yurtdışı pazarda yer alma süreci çok kısa sürmüştür. Y.H yapılan görüşmede Dubai'de katıldığı bu fuarda çok başarılı olduklarını, ürünlerinin haricinde ürünlerini içerisine koydukları markalı poşet ve torbalarını dahi gelen talep üzerine sattıklarını ifade etmiş, buna rağmen fuar organizasyonu tarafından daha sonraki yıllarda davet edilmemesinin sebebini fuara giden kişilerin kendi fikir ve görüşleri doğrultusundaki gruplaşmaları olarak belirtmiştir. 2007 yılında ilk şubesini açan ve bugün 45 şubesi olan A firması Y.H'nin anlatımına göre "2011 yıllarında dedim ki ben güzel gidiyor biz bunu dedim neden franchise vermiyoruz. Franchise verip de insanlara bir çok kendimiz ulaşamadığımız yerlerde verebiliriz. Biz franchise verdik. Bu da radikal bir karardı bence yani kendi şubelerinizle uğraşıyorsunuz bir de franchise veriyorsunuz..... Neler yapılabilir işte dondurmalı helvayı insanlara daha çok nasıl satabiliriz. Buradaki AVM'lerde açmış olduğum tarzdaki bir kioskla orada nasıl üretim diye ona uğraştık. 2012 yılında da biz dedik ki franchise vereceğiz. Tabi bu birden bire eş dost sayesinde dükkânları soruyorlar aylık veriyorlar mı? Veriyorlar. Böyle uğraşmaya başladık. İlk Aydın'a verdik. Sonra işte İzmir'e bir tane. Sonra Eskişehir'e verdim. Eskişehir'de alan arkadaşlar da forumda yiyorlar beğeniyorlar sonra bayilik istiyorlar o şekilde veriyoruz.... Şu anda 15 tane Franchise var".

B firması 1934 yılında bir aile şirketi olarak bugünkü isminden farklı bir isimle Denizli'de gazoz üretimiyle işe başlamıştır. 1953 yılında çıkan yangından dolayı yine Denizli içerisinde farklı bir yere bugünkü ismiyle taşınmıştır. İki kardeşin ortaklığı şeklinde kurulan B firmasının ilk yıllarındaki pazar yeri Denizli'de o dönem çok yaygın olan gazinolar, kahvehaneler ve sinema büfeleri olmuştur. 1992 yılında kardeş ortaklığını bitiren B firması iki ayrı firma haline gelmiş olmakla beraber mülakatımıza katılan Z.Y.Ö nün yönetiminde daha önceki firma ismiyle devam etmekte, diğer firma ise eski isminin başına "Yeni ..."kavramını alarak üretimine devam etmektedir. Daha ziyade Denizli pazarına odaklanan B firması, yakın çevre illere ve bu illerin ilçelerine bayilik vermekte, bununla beraber az da olsa ağırlıklı olarak Almanya ve Avusturya olmak üzere, Hollanda, Fransa ve İngiltere'de ürünlerini satmaktadır. Avrupa'daki bayi sahipleriyle ilgili "Türk zaten benim onlardan duyduğum, gidip yerinde görmedim ama Türk malları satan marketler var orada, genelde Türklerin alışveriş ettiği Türk markalarını satan, buradan götürdükleri ürünleri oralarda satıyorlar diye biliyorum ben. Bölge Almanya'da. İlk önce şeyde başladı bu Ştutgard bölgesinde o mahalde başladı. Berlin'de düşünüyorlar. Berlin'de biliyorsunuz Türk nüfus çok fazla. İyi gidiyorlar yani, profesyonel insanlar, bekliyoruz”. Z.Y.Ö yurt içi bayiliklerinden şöyle bahsetmektedir: “...yakın illerde var bayiliklerimiz. İzmir'de başladık bu sene, şimdi bu sene orada baya iyi. Antalya'da var. Uşak, Aydın Nazilli, Muğla, Isparta, Burdur'da var. Isparta, Burdur çok küçük çapta ama isteyen bizden telefonunu alıp bayiden ürün bulabilir. Uşak baya iyidir. Dinar var”.

Yukarıda da ifade edildiği üzere Araştırma analizinde oluşturulan temalar kapsamındaki kodlar ve kodlarla ilgili ifadeler (Ek 1) yorumlanmıştır.

\section{Maliyet Liderliği Stratejisi}

Maliyet Liderliği teması başlığı altında Rakiplerin maliyeti düşürmesi, Teknoloji ile maliyetin düşmesi ve maliyet liderliğinin dezavantajları adlarıyla üç kod oluşturulmuştur. 'Rakiplerin maliyeti düşürmesi' koduna göre A firmasından N.H alışveriş merkezlerindeki büyük marketlere satış yapamadıklarını çünkü diğer firmaların marketlere toptan satış yapabildikleri halde kendilerinin toptan satış yapmadıklarını ifade etmiştir (İfade 1). Bunun sonucunda da AVM'lere toptan satış yapan firmaların daha düşük fiyatla mamul sattıklarını belirtmiştir. Y.H ise marketlere toptan satış yapamama sebeplerini "Hiç toptan mal veremiyoruz. Neden? Çünkü içine bir katkı maddesi ya da koruyucu madde koymadığımız için bizim de bunlar çabuk bozuluyor. Çabuk bozulduğu için de marketlere veremiyoruz. Market diyor ki 1 sene raf ömrü olması lazım. Ya bu lokum. İçinde çerez var, mısır nişastası şeker kaynamış bir şey. Evde yaptığınız bir şey gibi düşünün. Bir sene durma imkanı var mı? Mutlaka koruyucu madde koymak lazım. Biz toptan veremiyoruz o yüzden” (Marka ile farklılaşma kodu, İfade 2) şeklinde açıklamaktadır.

Maliyet Liderliği stratejisinin ikinci kodu Teknoloji ile maliyetin düşürülmesiyle ilgilidir. Daha önceden dededen kalan makinelerle çalıştıklarını, iki yıl önce son sistem makineler aldığını ve yükselttikleri teknoloji ile B firmasının kapasitesinin üçe katlandığını söyleyen Z.Y.Ö "Saatte 8000 bin ürettiğin aynı saatte daha fazla adam 8000 üretirken biz aynı saatte 24000 üretiyoruz atıyorum ve altı yedi alanda üretiyoruz tamamen şey düşüyor maliyet düşüyor (İfade 1) diyerek B firmasında yükselen teknoloji ile yapılan üretimin maliyetleri nasıl azalttığına vurgu yapmıştır. Maliyet Liderliğinin dezavantajı olarak ise N.H fiyat için kaliteden ödün verilmemesi gerektiğini (İfade 1), hatta bunun için paradan dolayı tedarikçi değiştirmediğini belirtmiştir (İfade 2). 


\section{Farklılaştırma Stratejisi}

İşletmelerin farklılaştırma stratejisi olarak, fiyatta, üründe, nostaljiye dayalı üründe, tedarik edilen üründe, markayla, pazarda ve pazarlama faaliyetlerinde, üretim sürecinde farklılaşma gerçekleştirdikleri görülmüştür. A firmasının sahiplerinden biri olan N.H fiyat üzerinden yapılan rekabette, rakiplerinin ucuz satmak için kaliteden ödün verdiklerini ve çok para batırdıklarını (Fiyatta farklılaşma, İfade 1) anlatırken Y.H fiyatlandırmanın müşteri türüne göre de yapıldığını şöyle anlatmaktadır "Biraz ileride H.M (İstanbul'daki rakip firma kodu) var. Dükkânı tıklım tıklım lokum satıyor. Ben dükkânımda lokumu onun gibi satamam Adam sırf sade lokuma yazmış 40 lira. Sade lokumu burada 10 liraya satacağız diye uğraşıyoruz.... Onlar Araplara hitap ediyorlar. Ben Eminönü'nde yaşayan ya da Eminönü'ne gelen yerli turiste, o yörenin insanına" (Fiyatta farklılaşma, İfade 2).

Üründe farklılaşma kodu; altı tanesi N.H'ye ait, üç tanesi de Y.H'ye ait toplam dokuz ifade A firmasına dair, iki ifade de B firmasının sahibi ve yöneticisi Z.Y.Ö’ye ait olmak üzere 11 ifade yer almaktadır. A firmasında üründe farklılaşma stratejisi birinci nesil olan dedeye kadar dayanmaktadır. N.H'nin anlatımına göre babası, daha Babadağ'dayken şeker üretiminin yanı sıra Denizli'den ve hatta İstanbul'dan farklı şeker ve çikolatalar getirmektedir. Aynı zamanda N.H’nin babası, ürünlerinin kalitelerinden dolayı rakip firmalardan ayrıştığını, kaliteli ürün üreterek uzun dönemde var kalmanın yolunun babaları tarafından kendilerine öğ̈̈tlendiğini ifade etmiştir. Bu nasihati N.H kaliteli üretim neticesinde 'Denizli’nin nüfusunun çok daha az olduğu 1950'li yıllarda 56 şekerci olmasına rağmen, 1990’lı yıllara gelindiğinde Denizli nüfusunun500 bin olduğu ve sadece 4-5 şekercinin kalıp, gerisinin pazardan silindiği' sözleriyle aktarmaktadır (İfade 2,3,4,5). Bugün A fïrmasının meyve tatlısının farklı türlerinden, şeker ve çikolata türlerine, lokum türlerine ve dondurmalı irmik helvasına kadar çok sayıda ürün türü mevcuttur. Y.H üründeki bu farklılaşmanın asıl 2000'li yıllardan sonar başladığını, bu gün dondurmalı irmik helvasında pazarda lider konumunda olduğunu, bu konuda taklit edildiklerini ve rakip tanımadıklarını vurgulamaktadır (İfade 7,8,9). B firmasında ise gazozun sadece iki türü üretilmektedir (Sade gazoz ve meyveli gazoz). Ancak, tamamen doğal şeker kullanılmakta ve mandalinalı gazoz için Bodrum'dan mandalina getirilip suyu çıkarılarak üretim yapılmaktadır. Aynı zamanda bazı firmalar marka değiştirip aromada farklılık yapınca gazoz formülüzasyonunda da ufak değişiklikler yapılabiliyor (İfade 10,11).

Nostaljiye dayalı ürün farklılaştırması kodunda N.H 1935'li yıllarda babasının yaptığı tulumba tatlısını aynı kalıpla tekrar üretmeye başlamalarının müşterilerin beğenisini kazandığını ve onları 1950'li yıllara götürdüğünü ifade ederken (İfade 1), Z.Y.Ö ürün tadının geçmişe yaptığı atfı "Tadını bozmamalısın. Şimdi zaten bunu içenler şöyle söylüyor....içiyor, çocukluğumdaki şeye gittim. Çünkü insanın o beyninde kalıyor o lezzetler. Unutmuyor beyin onu" (İfade 2) sözleriyle ifade etmektedir.

Tedarik edilen ürünlerde farklılaşma kodu altında İfade 1'e göre A firması yıllardır doğal ürün tedarik ettikleri firmalarla çalışmaktadır. İfade 2'ye göre ise B firmasının ürün tadı kadar şişelerle de pazarda farklılaştıkları, dedelerine bir Rum'dan kalan şişe kalıbıyla hâlâ üretimlerini gerçekleştirdikleri, bu şişeleri de 1930'lu yıllardan beri Denizli'deki aynı firmadan tedarik ettikleri görülmektedir.

Marka ile farklılaşma kodunda da görüldüğü üzere her iki firmanın da markası mevcuttur. Y.H "doğallıktan vazgeçmedik. ...... Markanızın bir özelliği olmalı ki geleceğe taşınabilsin" (İfade 1,2) sözleriyle pazarda markanın yarattığı farktan bahsetmektedir. Z.Y.Ö ise markanın önemini "bu markayı tamamen 80 yıldır bir marka yapabildiysek bölgesel de olsa, gazozu bilen insanlar Türkiye'nin her yerinde gazoz meraklısı bir adam bu markayı biliyor... Ürünün kalitesi olarak. ... benim şahsi fikrim marka olmanın tek şeyi istikrar” (İfade 4) sözleriyle anlatmaktadır.

Pazarlamada ve pazarda farklılaşma kodu altında Y.H şekerin sağlık açısından tehlikesine yapılan vurgudan dolayı gelecekte ilaç kutusu gibi üretmeyi düşündüğü çikolata dizaynını İfade 1'de anlatmaktadır. Keza A firmasının 15 Franchise (İfade 2) ve 45 şubesi mevcuttur. B firması ise Denizli'ye yakın illere ve ilçelere bayilik vermiştir. Aynı zamanda Avrupa'daki Türk bayilere de satış yapmaktadır (İfade 3).

Üretim sürecinde farklılaşmayı ise A firması yeni bir fabrika yapıp, orada makineleşmeyle üretime başlaması, B firması ise son teknolojiye geçişiyle gerçekleştirmiştir (İfade 1, İfade 3). Aynı zamanda A firmasından Y.H kendi buluşu olan dondurmalı irmik helvasının makinesini kendi tasarlayarak patentini almıştır (İfade 2).

\section{Odaklanma Stratejisi}

Odaklanma stratejisi teması altında coğrafi odaklanma, demografik odaklanma ve kültürel odaklanma olarak üç kod yer almaktadır. A firmasından Y.H odaklanmayı daha ziyade Ege Bölgesi ve Marmara Bölgesi olarak yapmaktadır hatta Y.H İstanbul, İzmir, Denizli ve Ankara'ya francising vermediğinin ve sadece kendi şubeleriyle büyümek istediğinin altını çizmektedir. B firmasının sahibi ve yöneticisi Z.Y.Ö ise pazardaki odaklanma stratejisini “önce bir merkezi sağlam tutmak lazım ...... merkezi sağlam tuttuktan sonra dışarıda yavaş yavaş artık” diyerek açıklamakta, dünya pazarına açılamamanın en büyük sebebi olarak, "bizim açılma olayımız zor. Neden? Karşıda koskoca dünya devi bir Coca-Cola var. Her gittiğin yerde o var” diyerek belirtmektedir.

Demografik farklılaşmada ise A firması bebek doğum oranlarındaki fazlalığı dikkate alarak bebek çikolatası üretimine geçmiş hatta bebek çikolatalarını kendi içerisinde farklılaştırmaya gitmiştir (İfade 1) Keza Y.H "sevgililer günü, evlilik y1l dönümleri, anneler günü öğretmenler günü bizim için çok önemli. İnternette inanamazsınız ya. Öğretmenler günü için çikolata yapıyoruz deli gibi gidiyor” diyerek kültürel odaklanmaya da 
vurgu yapmaktadır (Kültürel odaklanma kodu, İfade 1). B firmasından Z.Y.Ö ise gazozda demografik bir farklılaşmanın yapılamayacağını herkesin gazoz içtiğini belirtmektedir (İfade 2).

\section{Sonuç}

İşletmeler genellikle iki temel rekabet stratejisi uygularlar. Bunlardan ilki maliyet liderliği stratejisi, ikincisi ise farklılaştırma stratejisidir. Maliyet liderliği stratejisi değer zincirindeki her bir fonksiyonun analizi neticesinde maliyetlerin düşürülerek kâr marjının yükseltilmesini ve müşteri nezdinde değer kazanılmasını ifade eder. Farklılaşırıa stratejisi ise işletmenin fonksiyonlarında veya mamulün kendisinde yaptığı farklılaşma sonucunda, pazarda rakiplerine nispeten, müşteri nezdinde değer kazanmasıyla ilgili olan stratejidir. İki temel stratejiden herhangi birinin pazardaki daha küçük bir alana odaklanarak gerçekleştirilmesi odaklanma stratejisi olarak adlandırılır.

Bu çalışmada Denizli ilinde faaliyet gösteren iki firmanın rekabet stratejileri ortaya çıkarılmaya çalışılmıştır. Çünkü Denizli ilinde bu iki firmanın ürünlerine ve markalarına Denizli halkı tarafından bir bağlllık olduğu gözlenmiştir. A firmasının şeker ve şekerli ürün markası ile B firmasının gazoz markası Denizli ilinde bütün Denizliler tarafından bilinmekte ve her iki ürünün kullanımı bir Denizlililik göstergesi olarak algılanmaktadır. $\mathrm{Bu}$ iki firmayla yapılan mülakatlar neticesinde A firmasının üründe önemli ölçüde farklılaşma gösterdiği, bunu hem ürün çeşidi hem de ürün kalitesi olarak gerçekleştirdiği sonucuna varılmıştır. B firmasında ise ürün türlerinde herhangi bir farklılaşma yokken, ürün tadında pazardaki değişime göre çok düşük düzeyde bir farklılaşmaya gidilebilmektedir. Her iki firma da üretim süreçlerinde farklılaşma yaparak ölçek ekonomisinden yararlanma yoluna gitmiş̧lerdir. Ancak B firmasında, makineleşme yoluyla artan üretim neticesinde maliyetlerin azaldığı A firmasına göre daha açık görülebilmektedir. Aynı zamanda, A firması daha ziyade demografik, coğrafik ve kültürel odaklanma stratejisi uygulamakta, B işletmesi ise sadece coğrafik odaklanma stratejisi uygulamaktadır. Her iki firmanın da ortak yönü kaliteli ürünleri, tadları ve Denizli markası olarak tanınmalarıdır. Öyle ki, mülakatlarda belirtildiği üzere, başka illerde ikamet eden Denizlililer bile her iki markanın da hem müş̧erisidir hem de gönüllü temsilciliğini yapmaktadırlar. 
Ek 1

\begin{tabular}{|c|c|c|}
\hline Tema & Kod & İfade \\
\hline \multirow{6}{*}{ 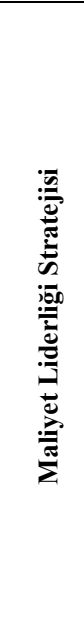 } & \multirow{3}{*}{ 急 } & $\begin{array}{l}1 \text { N.H Gidiyor geliyor firmalar, alış veriş merkezlerine diyorlar ki, biz size şu kadar şeker vereceğiz, şu kadar kârı } \\
\text { var. Onlar şekerleri veriyorlar, çok muazzam mal alıyorlar. Sonra onları bizden erken satıyor adamlar alışveriş } \\
\text { merkezleri. } 10 \text { ton alıyor } 20 \text { ton alıyor AVM'ler }\end{array}$ \\
\hline & & $\begin{array}{l}2 \text { N.H Onlara bizden daha aşağı veriyor. Biz meselâ } 10 \text { ton alıyorsak, o } 100 \text { ton alıyor... } 100 \text { ton alınca bizden } \\
\text { daha } 3 \text { lira } 5 \text { lira düşük fiyata alıyor. Yani kuruşla satıyor onlara. }\end{array}$ \\
\hline & & 3 Z.Y.ö burada tamamen az önce ilk anlattığınız strateji (Maliyet liderliği stratejisi) doğrudur. \\
\hline & 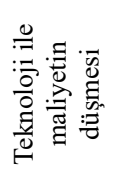 & $\begin{array}{l}1 \text { Z.Y.Ö Saatte } 8000 \text { bin ürettiğin aynı saatte daha fazla adam } 8000 \text { üretirken biz aynı saatte } 24000 \text { üretiyoruz } \\
\text { atıyorum. Ve altı yedi alanda üretiyoruz tamamen şey düşüyor maliyet düşüyor. E teknoloji yüksek olduğu için. } \\
\text { Atıyorum malı üretirken fire oranların düşüyor... günde } 7 \text { tır doldurabilirim burada. } 7 \text { tane tırı yükleyip } \\
\text { gönderebilirim. Bu şekilde yapıp artık satış artırı işçilik maliyetini düşürüp karı yükseltmeniz lazım. }\end{array}$ \\
\hline & \multirow{2}{*}{ 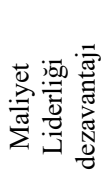 } & 1 N.H Kaliteden ödün vermemek. Fiyatı ne olursa olsun. Kaliteden ödün vermemek gerekiyor. \\
\hline & & 2 N.H Kolay kolay paradan dolayı tedarikçi değiştirmemeye çalışıyorum. \\
\hline \multirow{13}{*}{ 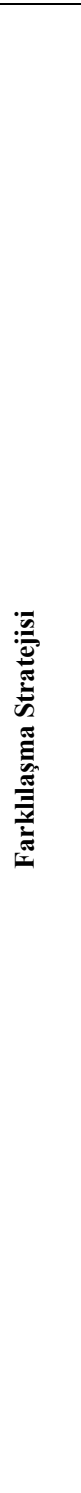 } & & $\begin{array}{l}1 \text { N.H. Rekabete girdiler, fiyat üstünden. Bizim öyle bir derdimiz yok. Biz, } 10 \text { liraya imal ederiz } 15 \text { liraya satarız. } \\
15 \text { liraya imal ederiz } 20 \text { liraya satarı. Bunlar bir şeker çuvalına mal satarlardı. Çok mal satarlardı, kamyonlar } \\
\text { yüklerlerdi, çok paraları battı. }\end{array}$ \\
\hline & & $\begin{array}{l}2 \text { Y.H Biraz ileride H.M (İstanbul'daki rakip firma kodu) var. Dükkânı tıklım tıklım lokum satıyor. Ben } \\
\text { dükkânımda lokumu onun gibi satamam Adam sırf sade lokuma yazmış } 40 \text { lira. Sade lokumu burada } 10 \text { liraya } \\
\text { satacağız diye uğraşıoruz. O tarz olmak için daha farklı bakmak lazım. Onlar Araplara hitap ediyorlar. Ben } \\
\text { Eminönü’nde yaşayan ya da Eminönü'ne gelen yerli turiste, o yörenin insanına hitap ettiğim için. }\end{array}$ \\
\hline & \multirow{11}{*}{ 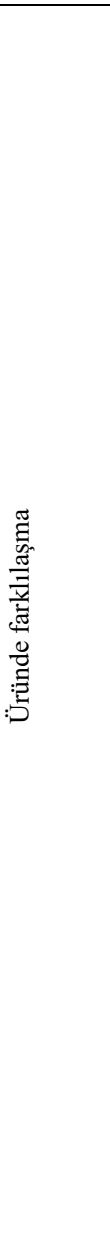 } & $\begin{array}{l}1 \text { N.H Hafız Mustafa var. Osman Nuri var. Şunlar bunlar var. Bunlar bizim rakibimiz olamaz. Neden olamaz? } \\
\text { Bütün şeyler farklı kulvarlar farklı ... Mesela ben lokumu } 35 \text { çeşit yapıyorum. Onun yaptığı } 10 \text { çeşidi geçmez. }\end{array}$ \\
\hline & & $\begin{array}{l}2 \text { N.H Babam askerden geliyor, Denizli’yle irtibatı var. 50’li yıllarda Denizli İstanbul'dan ürün alıp geliyor satıyor. } \\
\text { Dükkânı daha güzelleştiriyor. }\end{array}$ \\
\hline & & $\begin{array}{l}3 \text { N.H Şeker de alıp geliyor o zamanlarda Çikolata falan alıp geliyor.... Nestle çikolatası alıp geliyor. Babadağ'da, } \\
3 \text { liraya alıyor } 5 \text { liraya satıyor. }\end{array}$ \\
\hline & & $\begin{array}{l}\text { 4 N.H Ürünlerimiz orijinal, bizde her şey orijinal. Biz gece yatarız, sabah kalkarız, ne yapabiliriz acaba diye. Her } \\
\text { gün ürün çıkarmaya kafamız yatar. Her gün, çeşit bambaşka bir şeydir. }\end{array}$ \\
\hline & & $\begin{array}{l}5 \text { N.H } 1960 \text { 'lı senelerde buraya taşındığımızda Denizli'de } 56 \text { tane şekerci vardı. Denizli’nin nüfusu } 200 \text { bin....... } \\
56 \text { tane şekerci var... ama biz } 2 \text { çuval şekerle yapıyoruz. "Baba bunlar çok şeker yapıyorlar, çok şeker satıyorlar. } \\
\text { Biz az satıyoruz, biz de çok şeker yapalım, çok şeker satalım". "Oğlum, siz çok iyi yapın, çok güzel yapın, en } \\
\text { iyisini yapın, Bir çuval şekerden yapın ama çoka satın, fazlaya satın. Onlar on liraya verirler, biz } 20 \text { liraya veririz } \\
\text { ama biz az satıyoruz. Oğlum siz iyisi olun, güzel yapın, güzel satı̈". Sene 1990'lı seneler. Denizli’nin nüfusu } 500 \\
\text { bin oldu. Bir gün babam bizi topladı, } 90-95 \text { senesiydi, oğlum gelin bakiyim buraya dedi. "Denizli’nin nüfusu kaç } \\
\text { dedi, } 500 \text { bin. Denizli'de kaç tane şekerci var? } 4-5 \text { tane. Gerisi hep gitti”. }\end{array}$ \\
\hline & & $\begin{array}{l}6 \text { N.H (AVM'lerin fiyat tehdidine binayen) Bizim çeşide gitmemiz ondan dolayı. Bir meyve tatlısını koyamaz. } \\
\text { Bizde } 35 \text { çeşit lokum var. Orada 3-5 çeşit var. Bizde kalite de önemli. Biz malzemeyi de kısmıyoruz. Meselâ Antep } \\
\text { fistığıysa en iyisini kullanıyoruz. Bugün enteresandır. Çifte kavrulmuş lokum orda } 20 \text { liraya } 15 \text { liraya lokum var. }\end{array}$ \\
\hline & & $\begin{array}{l}7 \text { Y.H. } 2000 \text { yılında geldikten sonra dedim ki çeşit olması lazım. Cam kavanozlar aldım. Balık kavanozları } \\
\text { köşede... içine draje koydum. Ben dedim ki bu drajelerden satacağım. Dedem, babam, amcam dediler ki oğlum bu } \\
\text { burada gitmez satılmaz. Ya deneyelim satalım. O günlerde dört beş kavanozda satmak istediğimiz şey, bugün } \\
\text { çikolata üretiyoruz biz fabrikada çikolata üretiyoruz... } 2000 \text { senesinden sonra artık çeşitleri çoğaltmaya başladık } \\
\text { ne yaptık? Lokum yapıyoruz ama çifte kavrulmuş lokum da yapalım, antep fistıklı yapalım, antep fistıklı lokum } \\
\text { üzerine yeşil toz koyalım. Yeşil antep fistıklı lokum olsun. Şunu yapıyoruz şunu da yapalım. Sonra iş genişlemeye } \\
\text { başladı. }\end{array}$ \\
\hline & & $\begin{array}{l}8 \text { Y.H Dondurmalı helvada herkes beni taklit etti. Arkamda Rakip yok diyorum. İstanbul'da kime sorarsanız sorun } \\
\text { Eminönü’ne gidin helvacı varmış deyin kuyruk var önünde. O yüzden rakibim olduğunu düşünmüyorum. }\end{array}$ \\
\hline & & $\begin{array}{l}9 \text { Y.H Dondurmalı helvada Taklit ediliyorum çünkü İstanbul'da taklitlerim çıktı. Birçok yerde taklidim çıktı. } \\
\text { Taklitler aslında yaşatır yükseltir. Taklit edilmek güzel bir şey. }\end{array}$ \\
\hline & & $\begin{array}{l}10 \text { Z.Y.Ö Mesela mandalinanın konsantresini biz kendimiz Bodrumdan mandalina alıp yıllardır yaklaşık 30-35 } \\
\text { yıldır burada suyunu çıkarıp kaynatıp pastörize edip kendimiz depoluyoruz onu kullanıyoruz içinde. Gerçek } \\
\text { mandalina var yani bunun içerisinde. }\end{array}$ \\
\hline & & $\begin{array}{l}11 \text { Z.Y.Ö bazı ürünler marka değiştiriyor. Mesela atıyorum a aroması b firmasina satıllıor. Adam üzerinde bir } \\
\text { oynama yapıyor. Oynama yaptığı zaman sizin de burada formülasyonunuzda küçük dokunuşlar yapmanız } \\
\text { gerekebiliyor. }\end{array}$ \\
\hline
\end{tabular}




\begin{tabular}{|c|c|c|}
\hline \multirow{15}{*}{ 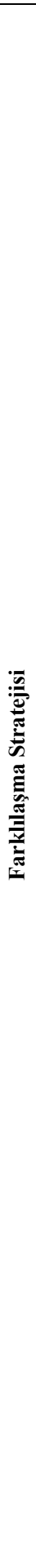 } & \multirow{2}{*}{ 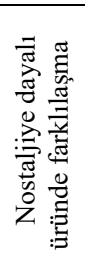 } & $\begin{array}{l}1 \text { N.H Bu (uzun bir tulumba tatlısı) daha yeni yapıldı da geldi, yeni çıktı. 1930-35'li senelerde, babamın } \\
\text { Babadağ'dan aldığı formüllerle, bize anlatırdı, tabi biz epeyden beri yapmıyorduk. Babadağ'da yapardı babam, } \\
\text { kalıbı da duruyordu Dedim baba bunun formülünü ver bize, kalıbı da var, küçücük bir kalıp. Verdi, biz yaptık. Biz } \\
\text { onu yapmaya başladık, Allah'ım her geçen gün daha güzelleşiyor. 1950'li senelere götürüyor. Herkes diyor çok } \\
\text { güzel. }\end{array}$ \\
\hline & & $\begin{array}{l}2 \text { Z.Y.Ö Tadını bozmamalısın. Şimdi zaten bunu içenler şöyle söylüyor....içiyor, çocukluğumdaki şeye gittim. } \\
\text { Çünkü insanın o beyninde kalıyor o lezzetler. Unutmuyor beyin onu. Ona yakın bir şey yakaladığı zaman, beni } \\
\text { diyor çocukluğuma götürdü. }\end{array}$ \\
\hline & 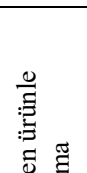 & $\begin{array}{l}1 \text { N.H S.D (firma ismi kodlanmıştır) diye bir firma, şu anda İzmir'deki. Bu Kemeraltın'da. Hâlâ devam ediyor } \\
\text { (alışverişi kastediyor). Bütün hammaddeleri veriyor bize. Bizim Hindistan cevizimizi verir. Bütün aromalarımızı } \\
\text { verir. Hâla çalışıyoruz. Yıllardan beri onlarla çalışıyoruz, direkt ithalatçı firma. Yurt dışından getiriyor, direkt bize } \\
\text { veriyor. Bizim ürünlerimiz Fransa'dan, İngiltere'den, Belçika'dan gelen var... Hammaddeler Çok pahalı tabi, } \\
\text { şimdi kaliteli alırsan, boyalar artık eskisi gibi değil, meyvelerden olan, doğal boya. Çok pahalı. }\end{array}$ \\
\hline & 竞 & $\begin{array}{l}2 \text { Z.Y.Ö Bu şişe aslen bu kalıp Niko Uludağ diye bir Rum. Niko Uludağ adamın adı.... adam Türkiye'yi terk ediyor. } \\
\text { Terk ederken dede bundan çok şişe alıyor. Bu şişeyi alıyor. Bu kalıbı dedeye devredip gidiyor. 56'larda falan bu } \\
\text { kalıp bize geçiyor. }\end{array}$ \\
\hline & & $\begin{array}{l}3 \text { Z.Y.Ö Biz şu anda Şişe Camla devam ediyoruz. Dediğim gibi bunlar hep özel kalıp... kalıp zaten onların kalıbı } \\
\text { bize devretti onlar kalıbı. Şimdi özel kalıp olduğu için makineler her şey mesela yeni yapılan hatlar bu şişenin } \\
\text { bütün çapı boyu posu İtalya'ya gitti şişeler numuneler ona göre yapıldı makinelerin. }\end{array}$ \\
\hline & & $\begin{array}{l}\text { 1 Y.H yani bir marka olmamız lazım dedim. Şekerciler olarak biliyorlardı. Ama bir marka olmazdı o. Bir logo } \\
\text { olması lazımdı bir isim olması lazımdı bir şeyle ilerlememiz lazım. O yüzden de .... (marka adı) insanın kulağına } \\
\text { takılmaya başladı. }\end{array}$ \\
\hline & 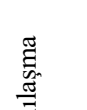 & $\begin{array}{l}2 \text { Y.H ..doğallıktan vazgeçmedik. Hiç toptan mal veremiyoruz. Neden? Çünkü içine bir katkı maddesi ya da } \\
\text { koruyucu madde koymadığımız için, bizim de bunlar çabuk bozuluyor. Markanızın bir özelliği olmalı ki geleceğe } \\
\text { taşınabilsin. }\end{array}$ \\
\hline & 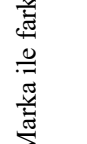 & $\begin{array}{l}3 \text { Z.Y.Ö Bu aspartam, sakarın o zaman müsaade edildi daha önce yasaktı bu. Bize çok ithalatçılar geldi bu } \\
\text { toptancılar ithal edenler. İlla kullanın... Ben o zaman daha } 24-25 \text { yaşındayım. Sen dedi boğazda akıntıya karşı } \\
\text { kürek çekiyorsun dedi, hiç unutmuyorum. Valla dedim abi o senin fikrin. Biz şekerle devam ettik hiç bozmadık. } \\
\text { Bunu tatlandırıcıyla çalışanların çoğu fabrikaları kapattı, o markalarda bitti. }\end{array}$ \\
\hline & & $\begin{array}{l}4 \text { Z.Y. Ö bu markayı tamamen } 80 \text { yıldır bir marka yapabildiysek bölgesel de olsa, gazozu bilen insanlar Türkiye'nin } \\
\text { her yerinde gazoz meraklısı bir adam bu markayı biliyor... geleneksel üretimi devam ettirmemizden de } \\
\text { kaynaklanan bir şey yani. Belirli bir standart yakalayıp belirli bir standartta gidiyoruz yani. Çok iniş çıkışlarımız } \\
\text { yok yani. Ürünün kalitesi olarak. ... benim şahsi fikrim marka olmanın tek şeyi istikrar. Çünkü marka olmak ne } \\
\text { bileyim reklamla parayla marka olunmuyor. }\end{array}$ \\
\hline & 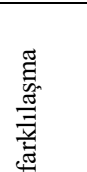 & $\begin{array}{l}1 \text { Y.H Şeker tehlikeli bir şey. Buna yapacak bir şey yok. Ama az yiyeceksin. İnsanlar az yiyecek yani ben çikolata } \\
\text { üreteceğim mesela artık koca koca tablet çikolatalar üretmeye gerek yok...şık bir çikolata yapacaksınız Pazartesi } \\
\text { Salı Çarşamba Perşembe Cuma Cumartesi Pazar yazacak hepsinin gramı olacak... günlük kaç gram çikolata } \\
\text { hakkınız var. } 25 \text { gramlık çikolatalardan } 7 \text { tane olacak } 6 \text { tanesi bitter olacak bir tanesi sütlü olacak... İlaç kutuları } \\
\text { gibi. Bunu yaparsanız koca tabletten daha pahalıya onu satarsınız. Güzel şık bir pakette. }\end{array}$ \\
\hline & $\underset{\Xi}{\tilde{\Xi}}$ & $\begin{array}{l}2 \text { Y.H } 2011 \text { yıllarında dedim ki ben güzel gidiyor biz bunu dedim neden franchise vermiyoruz. Biz franchise } \\
\text { verdik... Şu anda } 15 \text { tane Franchise var. }\end{array}$ \\
\hline & 芯 & $\begin{array}{l}3 \text { Z.Y.Ö Antalya'da var. Uşak, Aydın Nazilli, Muğla, Isparta, Burdur'da var. Isparta, Burdur çok küçük çapta ama } \\
\text { isteyen bizden telefonunu alıp bayiden ürün bulabilir. Uşak baya iyidir. Dinar var. Yavaş yavaş şehir dışı yurt dışı } \\
\text { başladı iki yıldır, hatta bu yıl çok iyi. Şimdi yakın illerde var bayiliklerimiz. İzmir'de başladık bu sene, şimdi bu } \\
\text { sene orada baya iyi Almanya, Hollanda, Fransa, bilhassa Almanya ağırlıklı iyi gidiyor. Avusturya. Avrupa yani. }\end{array}$ \\
\hline & 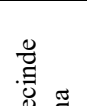 & $\begin{array}{l}1 \text { N.H Şimdi yeni fabrika yaptık. İzmir asfaltı } 8 \text {. Kilometreye } 5000 \mathrm{~m} \text { metre kapalı alan... Hepsi gitti oraya... } \\
\text { Burada } 3 \text { - } 5 \text { makine kaldı ama onda tahmin ederim önümüzdeki aylarda şeffaf bir cam yapacağı. Orada da } \\
\text { gelenlere göstereceğiz, helva nasıl yapılıyor, lokum nasıl yapılıyor. }\end{array}$ \\
\hline & 涪 & $\begin{array}{l}2 \text { Y.H Ben sadece makineyi tasarladım. Makineyi tasarlarken işte dondurmayı soğutan motor benmari usulüyle } \\
\text { helvayı ısıtıyordu, bunu çizdim... faydalı bir ürün olarak patentini aldım. }\end{array}$ \\
\hline & : & $\begin{array}{l}3 \text { Z.Y.Ö .....̇ki yıl önce son sistem makineler aldık. Kapasiteyi üçe katladı, teknoloji çok yükseldi, tam otomasyon. } \\
\text { Hiç eleman insan yok. Son teknoloji... Eski teknolojiyle olmuyor yani...Yani bayi gelmesin diye bakıyorsun. } \\
\text { Adam arıyor işte yarın gel bir gün sonra gel. Böyle olur mu? Sen daha gel diyeceksin adama. }\end{array}$ \\
\hline$: \overline{\frac{\pi}{2}}$ & $\widetilde{I}$ & $\begin{array}{l}1 \text { Y.H İstanbul, İzmir, Denizli, Ankara onları stratejik olarak vermiyorum. Ankara'da şuan bir tane bayimiz var ama } \\
\text { yine de büyümek istersem kendim büyümek isterim orada. }\end{array}$ \\
\hline 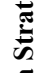 & 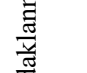 & $\begin{array}{l}2 \text { Y.H yani genelde ben franchise verirken de Ankara'dan diğer tarafa geçmemeye çalışırım. Kontrol edebileceğim } \\
\text { kadar. Ege bölgesi Marmara bölgesi daha çok odaklanıyorum, Akdeniz bile değil. }\end{array}$ \\
\hline 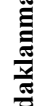 & 焉 & $\begin{array}{l}3 \text { Z.Y.Ö önce bir merkezi sağlam tutmak lazım. Çemberi dışına doğru büyütmek lazım. Burayı iyi yakaladıktan } \\
\text { sonra, merkezi sağlam tuttuktan sonra dışarıda yavaş yavaş artık o, pastanın kreması gibi verebildiğimiz kadar } \\
\text { veriyoruz. }\end{array}$ \\
\hline 0 & & $\begin{array}{l}4 \text { Z.Y.Ö bizim açılma olayımız zor. Neden? Karşıda koskoca dünya devi bir Coca-Cola var. Her gittiğin yerde o } \\
\text { var. }\end{array}$ \\
\hline
\end{tabular}




\begin{tabular}{|c|c|c|}
\hline \multirow{3}{*}{ 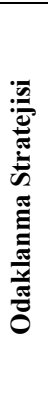 } & \multirow{2}{*}{ 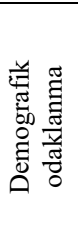 } & $\begin{array}{l}1 \text { Y.H En çok bebek doğuyor dimi? Bebek doğuyorsa biz bunlara çikolata satalım. Bebek çikolatası satalım. Herkes } \\
\text { bebek çikolatası satıyor. Biz üzerine etiket yapıştıralım. Farklı bir şey yapalım. Doğan çocuğun ismini yazalım öyle } \\
\text { gönderelim dedik. Sistemi oturttuk bebek çikolatasında günde } 500 \text { kargo gönderiyorsak } 400 \text { tanesi doğan bebeklere } \\
\text { çikolata gönderiyoruz. Bebek çikolatası verirken onu çeşitlendirebilirsiniz artık. Ayıcıklı yaparsınız yok işte biraz } \\
\text { daha büyük çikolata yaparsınız birazcık pahalısını yaparsınız azcık ucuzunu yaparsınız. }\end{array}$ \\
\hline & & $\begin{array}{l}2 \text { Z.Y.Ö gazozda bir hedef kitle zor. Niye hedef kitle zor? Bunu } 10 \text { yaşındaki çocuk da içiyor } 70 \text { yaşındaki amcada } \\
\text { içiyor. Yani bunda bir hedef kitle yakalamak zor. }\end{array}$ \\
\hline & 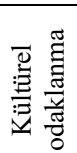 & $\begin{array}{l}1 \text { Y.H Sevgililer günü, evlilik yıl dönümleri, anneler günü öğretmenler günü bizim için çok önemli. İnternette } \\
\text { inanamazsınız ya. Öğretmenler günü için çikolata yapıyoruz deli gibi gidiyor. }\end{array}$ \\
\hline
\end{tabular}

Ek 1. Araştırma Tema ve Kodları

\section{Kaynakça}

- $\quad$ Allen, R. S., \& Helms, M. M. (2006). Linking strategic practices and organizational performance to Porter's generic strategies. Business Process Management Journal, 12(4), pp.435-436.Krugman, 1980. "Scale Economies, Product Differentiation, and the Pattern of Trade", American Economic Review, 70, p. 950.

- Bertozzi, F., Ali, C. M., \& Gul, F. A. (2017). Porter's five generic strategies; A case study from the hospitality industry. International Journal For Research In Mechanical \& Civil Engineering, 3(2), p.12

- Datta, Y. (2010). A critique of Porter's cost leadership and differentiation strategies. Chinese Business Review, 9(4), p.38.

- Dess, G. G., \& Davis, P. S. (1984). “Porter's (1980) generic strategies as determinants of strategic group membership and organizational performance". Academy of Management journal, 27(3), pp.469.

- $\quad$ Dickson, P. R., \& Ginter, J. L. (1987). Market segmentation, product differentiation, and marketing strategy. The Journal of Marketing, p.2.

- Gehani, R. (2013). Innovative strategic leader transforming from a low-cost strategy to product differentiation strategy. Journal of technology management \& innovation, 8(2), p.145.

- Grant, R. M. (2002). Contemporary strategy analysis: Text and cases edition. John Wiley \& Sons, p.36

- Hill, C. W. (1988). Differentiation versus low cost or differentiation and low cost: A contingency framework. Academy of management Review, 13(3), p.401.

- Kotha, S., \& Orne, D. (1989). Generic manufacturing strategies: a conceptual synthesis. Strategic management journal, 10(3), p.215.

- $\quad$ Leitner, K. H., \& Güldenberg, S. (2010). Generic strategies and firm performance in SMEs: a longitudinal study of Austrian SMEs. Small Business Economics, 35(2), pp.171-183.

- $\quad$ Miller, A., \& Dess, G. G. (1993). Assessing Porter's (1980) model in terms of its generalizability, accuracy and simplicity. Journal of Management Studies, 30(4), p.555.

- Miller, D. (1986). Configurations of strategy and structure: Towards a synthesis. Strategic management journal, 7(3), p.238.

- $\quad$ Miller, D. (1988). Relating Porter's business strategies to environment and structure: Analysis and performance implications. Academy of management Journal, 31(2), pp.283-285.

- $\quad$ Miller, D. (1992). The generic strategy trap. Journal of business Strategy, 13(1), p.40.

- Miller, D., \& Friesen, P. H. (1986). Porter's (1980) generic strategies and performance: an empirical examination with American data: part I: testing Porter. Organization studies, 7(1), p.38.

- Murray, A. I. (1988). A contingency view of Porter's "generic strategies". Academy of management review, 13(3), p.394.

- Omur M.T (2014), http://www.hurriyet.com.tr/yazarlar/mete-tamer-omur/dede-sekerinden-bir-tatli-hayat26892945, Erişim tarihi28.03.2019

- Pertusa-Ortega, E. M., Molina-Azorín, J. F., \& Claver-Cortés, E. (2009). Competitive strategies and firm performance: A comparative analysis of pure, hybrid and 'stuck-in-the-middle'strategies in Spanish firms. British Journal of Management, 20(4), p.509.

- $\quad$ Porter, M. E. (1980). Competitive Strategy, New York: Free Press, p.35

- Porter, M. E. (1985). Competitive Advantage Creating and Sustaining Superior Performance, The Free Press, New York. p.15

- $\quad$ Porter, M. E. (2008).The five competitive forces that shape strategy. Harvard business review, 86(1), p.1115. 
- $\quad$ Porter, M. E. (2015). Rekabet Stratejisi Sektör ve Rakip Analizi Teknikleri, Agora Kitaplığı, Çvr: Gülen Ulubilgen, s.46

- Porter, M.E. (1996). "What is Strategy?”, Harvard Business Review, November-December, pp.3-10.

- S Sı̆̆rı, Ü (2018). Nitel Araştırma Yöntemleri, Beta, İstanbul, s.280-285

- $\quad$ Tansey, P., Spillane, J. P., \& Meng, X. (2014). Linking response strategies adopted by construction firms during the 2007 economic recession to Porter's generic strategies. Construction management and economics, 32(7-8), p.708.

- White, R. E. (1986). Generic business strategies, organizational context and performance: An empirical investigation. Strategic Management Journal, 7(3), p.211.

- Wright, P. (1987). A refinement of Porter's strategies. Strategic Management Journal, 8(1), 94-96.

- Wu, H. L., Lin, B. W., \& Chen, C. J. (2007). Contingency view on technological differentiation and firm performance: Evidence in an economic downturn. R\&D Management, 37(1), p.77.

- Yamin, S., Gunasekaran, A., \& Mavondo, F. T. (1999). Relationship between generic strategies, competitive advantage and organizational performance: an empirical analysis. Technovation, 19(8), p.508 


\title{
Mizah Tarzları ile Girişimcilik Eğilimi Arasındaki İlişki Üzerine Bir Araştırma
}

\section{A Research on the Relationship between Humor Styles and Entrepreneurial Tendency}

\author{
Asst. Prof. Dr. Şeyma Gün Eroğlu (Muğla Sıtkı Koçman University, Turkey) \\ Merve Vural (Pamukkale University, Turkey) \\ Prof. Dr. Feyzullah Eroğlu (Pamukkale University, Turkey)
}

\begin{abstract}
Humor, which has a wide range of influences, has an important role in human life. Humor is regarded as an effective tool for transmitting a wide range of ideas, feelings, and thoughts and has long been seen as a coping strategy that is particularly healthy and effective. This is because humor is thought to be a strong antidote against negative emotions. In the previous studies, it was detected that the individuals who have a sense of humor also have high task motivation, cheerfulness, high self-esteem and social dominance, and more importantly, humor was found to be positively associated with the creative personality traits.

According to Humke and Schaefer (1996), humor and creativity involve both taking risks and generating unusual reactions. Moreover, entrepreneurship includes concepts such as innovation, risk-taking, tolerance to uncertainty, the need for achievement and locus of control. Likewise, entrepreneurial characteristics are defined by creativity, innovation, risk-taking, struggle and high motivation for success. In this respect, it is thought that there is a close relationship between entrepreneurial tendency and sense of humor.

This study aims to examine the relationship between individuals' humor styles and entrepreneurial tendencies. The sample of the study consists of students of the Faculty of Economics and Administrative Sciences of Pamukkale University and students of the Faculty of Engineering. We use the most preferred scales in the literature to measure humor styles and entrepreneurship tendency. We test the data through statistical methods and analyze the relationship between students' entrepreneurial tendencies and humor styles.
\end{abstract}

\section{Giriş}

Mizah kavramı, kendi içinde çok farklı anlam çeşitliliğine sahip olan geniş bağlamlı kavramlardan biridir. Mizah kavramı; şaka, gülmece, komedi, hiciv, ironi ve nükte gibi alt kavramların birbiriyle aynı anlam kümesine dahil olması nedeniyle zaman zaman birbirinin yerine kullanılmış olsa bile, gerçekte aralarında belirli bir anlam ve üslup farklılığı olan bir kavram bileşenidir. Mizah kavramı, içerdiği kavramlar ile en düşük yetenek ve zekaya sahip olan kişilerin keyif ve eğlenme eylemlerinden başlayarak, en yetenekli ve yüksek zekaya sahip olan kişilerin sorun çözücü ve yaratıcı zihinsel etkinliklerine kadar, geniş yelpazede bir anlam hiyerarşisine sahiptir. Yaratıcı zihinsel etkinliklerin ekonomik faaliyetler boyutu ile ilgili olan bir kavram olarak girişimcilik, her türlü mal ve hizmet üretimi için zorunlu olan bütün üretim faktörlerini ve bileşenlerini, tüketicilerin talep ve beklentilerine uygun düşecek nicelik ve nitelikte üretilmesini ve onlara ulaştırılmasını sağlayan işlem ve eylemlerin tümüdür. $\mathrm{Bu}$ çerçevede girişimcilik olgusu, kendi dışındaki diğer üretim faktörlerini (emek, toprak ve sermayenin) bir araya getirerek, bütün mal ve hizmet üretimi ile bunların nihai tüketiciye ulaştırıncaya kadar gerçekleştirilen tüm ekonomik ve işletmecilik işlevlerinin yerine getirilmesini sağlamak suretiyle çok geniş bağlamlı bir anlam kümesini temsil eden etkinlikler toplamını ifade etmektedir. Girişimcilik kapsamında bulunan tüm üretim faktörleri ve diğer işletmecilik işlevleriyle ilgili olarak ortaya çıkan ve son derece de karmaşık bir süreci temsil eden bütün etkinliklerin, belirli bir eşgüdüm ve düzen içerisinde gerçekleştirilmesi, büyük ölçüde çok yönlü ve dinamik bir yetenek sayesinde olabilmektedir. Bu bağlamda, önemli bir kişilik niteliği olarak mizahın, çok yönlü ve dinamik bir yetenek gerektiren nispeten olumlu boyutları ile yine çok yönlü ve dinamik bir yeteneği gerektiren girişimcilik eğilimleri arasında doğrusal bir ilişki olduğu öngörülmektedir. Bu çalışmanın amacı girişimcilik potansiyeli yüksek olan işletme ve endüstri mühendisliği bölümlerinde öğrenim gören üniversite son sınıf öğrencilerinin sahip oldukları mizah tarzları ile girişimcilik eğilimleri arasında ilişki olup olmadığını ve mizah tarzları düzeylerine göre girişimcilik düzeyinin farklılaşıp farklılaşmadığını tespit etmektir.

\section{Mizah Kavramı ve Mizah Tarzları}

Basit bir tanımlamayla mizah, güldürünün -nükte, eğlence, absürtlük, iğneleme, alay etme, hiciv veya ironi gibibir unsurudur ve temel olarak yaşama dair sorunlara karşı güler yüzlülüğü simgelemektedir (Ruch, 1998). Daha geniş bir tanımlamayla mizah; hiciv ( kişisel ya da toplumsal aksaklık ve yanlışlıkları, entelektüel bir tavır ve sanatkarane bir tarzda ortaya koyma), ironi ( temeli Sokrates'e dayanan, düşünsel tartışmaları yönlendirmek ve bilindiği iddia edilen konulardaki bilgisizliği ortaya çıkarmak maksadıyla konuyu bilmezlikten gelme üslubu 
dahilinde, karşıdaki kişinin çelişkiye düşürülüp gerçekle yüzleşmesinin sağlandığı zeka ürünü bir teknik) ve nükte ( yetenek ve zekanın katkısı ile entelektüel birikim aracılığıyla cinas, istiare, kinaye ve teşbih gibi edebiyat yöntemleriyle gerçekleştirilen zarif, etkili ve sanatkarca yapılan eleştiri) (Eker, 2014) gibi sosyal girişimciliği yüksek ve entelektüel yönleri baskın olan kişilerin söz ve eylemleridir. Aristo'dan bu yana gelen mizah geleneğine göre mizah, normalde birbirinden tamamen farklı olan iki fikrin, kavramın veya durumun şaşırtıcı veya beklenmedik bir şekilde bir araya gelmesini içermektedir (Ruch, 2001). Psikanalitik teorisyenlerden Freud'e göre ise mizah özellikle dünya üzerindeki sorunlara ve genel olarak insan doğasının zayıf yönlerine karşı anlayışll, hoşgörülü ve iyiliksever bir eğlenmeyi ifade etmektedir (Samson ve Gross, 2012). Bu çerçevede, fikirleri esprili bir şekilde manipüle etme ve fikirlere farklı bir açıdan bakabilme bilişsel yeteneği ile ifade edilen mizah anlayışı, bireylerin rahatsız edici olayları stresli, can sıkıcı veya korkutucu olarak görmek yerine, komik olarak algılamalarını mümkün kılmaktadır (Kelly, 2002). Mizah, pek çok yazarlar tarafından sadece gülmekle ilgili olumlu durumlarla sınırlı tutulmamıştır (Ruch, 2001). Özellikle çağdaş mizah araştırmacıları, mizahın heterojen olma özelliğine vurgu yapmaktadırlar. Freud'den günümüze kadar mizah biçimleri ile ilgili yapılan başlıca ayırımlardan biri, daha olumlu (iyi niyetli, yardımsever, düşmanca olmayan) ve daha olumsuz (saldırgan ve aşağılayıcı) mizah tarzlarıdır (Samson ve Gross, 2012). Mizah aynı zamanda birçok hedefe ulaşmak için kullanılabilecek çok işlevli bir araç olma niteliğine de sahiptir (Romero ve Cruthirds, 2006).

Thorson ve Powell (1991) mizah anlayışının çok boyutlu olduğunu ileri sürmüşler ve mizah anlayışının içinde yer aldığını iddia ettikleri altı unsurdan bahsetmişler ve bu unsurları şu şekilde sıralamışlardır: (1) Mizah üretimi aslında mizahi olabilme yeteneği, nükteli konuşma, herhangi bir durumdaki gülünç şeyleri tanımlama ve yaratma ve başkalarını eğlendiren unsurlarla bunu ilişkilendirme, (2) şakacılık anlayışı, iyi huylu olma ve iyi zaman geçirme yeteneği, (3) mizahı sosyal hedeflere ulaşmak için kullanabilme yeteneği, mizahı gergin bir durumu kolaylaştıracak bir araç olarak kullanma, sosyal normları güçlendirmek ve grup içi dayanışmayı artırmak, (4) mizahı kişisel olarak teşhis edebilme, mizahi olarak kendini tanımlama, (5) mizahı, mizahi insanları ve mizahi durumları değerlendirebilme (6) mizahın bir uyum mekanizması olarak kullanılması, sorunlara gülebilme veya mizah kullanımı yoluyla zor durumların üstesinden gelme. Martin ve diğerleri (2003) mizah anlayışını şu şekilde kavramsallaştırmaktadır: (1) Bilişsel yetenek (espri yapma, espriyi anlama ve yeniden üretme gibi), (2) estetik bir tepki, (3) sürekli bir davranış şekli, (4) duygularla ilişkili mizaç özelliği, (5) bir tutum, (6) bir başa çıkma stratejisi ya da savunma mekanizmasi.

Bununla birlikte son dönemdeki araştırmalar, mizahın hem uyumlu hem de uyumsuz tarzların içeren çok boyutlu bir yapı olduğunu ortaya koymuştur (Stieger vd., 2011). Chen ve Martin (2007) olumlu iki mizah tarzından katılımcı mizahı, komik şeyler söyleme, şaka yapma ve başkalarını eğlendirme, ilişkileri kolaylaştırma ve kişilerarası gerilimleri azaltmak için anında esprili şakalar yapma eğilimi olarak tanımlarken, kendini geliştirici mizahı ise yaşanan sorunlarla sıklıkla eğlenme, stres ve sıkıntı karşısında bile mizahi bakış açısını koruma ve mizahı bir duygu düzenleme mekanizması olarak kullanma eğilimi şeklinde izah etmişlerdir. Yazarlar, olumsuz iki mizah tarzından saldırgan mizahı, başkalarını eleştirmek ya da manipüle etmek amacıyla mizahı iğneleme, alay etme, hor görme ve aşağılama olarak kullanma eğilimi, kendini yıkıcı mizahı ise kendi aleyhine komik şeyler yaparak ya da söyleyerek başkalarını eğlendirme girişimleri, aşırı derecede kendini küçük düşürücü mizah, aşağılandığında ya da alay edildiğinde başkalarıyla birlikte gülme ve mizahı başkalarına yaranmak için kullanma şeklinde tanımlamışlardır.

Katılımcı mizah, bireyin hem kendini hem de başkalarını olumlu bir şekilde kabul eden kişilerarası ilişkilerin kurulmasını ve geliştirilmesini kolaylaştıran ve sosyal durumlarda kullanılan yararlı ve cana yakın bir mizah tarzı olarak tanımlanmaktadır (Kuiper ve Leite, 2010). Katılımcı mizah, muhtemelen kişilerarası birleştiriciliği ve çekiciliği artıran ve mizahın bireyin kendisi ve başkaları için olumlu olan ve esasen düşmanca olmayan kullanımıdır (Martin vd., 2003). Katılımcı mizah, kişilerarası ilişkileri kolaylaştırmak için dostça bir mizah kullanımını içerir (Veselka vd., 2010). Katılımcı mizah kullanan bireylerin sosyal etkileşimleri geliştirmeye çalıştıkları söylenebilir (Romero ve Cruthirds, 2006).

Kendini geliştirici mizah tarzı, yaşama mizahi bir perspektiften bakma yeteneğini içerir ve sıkıntılı veya stresli olaylara verilen olumsuz duygusal ve bilişsel tepkileri azaltarak kişisel stres ile başa çıkmak için kullanılmaktadır (Kuiper ve Leite, 2010). Kendini geliştirici mizah, hayatın stres yaratan faktörlerinde eğlenceli yönler bulma kabiliyeti ile karakterize edilmektedir (Veselka vd., 2010). Kendini geliştirici mizah sergileyen insanlar, mizahi bir yaşam görüşüne sahiptirler ve kaçınılmaz dertleri yüzünden çoğu zaman aşırı stresli değillerdir. Bu mizah tarzı, olumlu bir bakış açısını sürdürmeye yardımcı olan ve stresin üstesinden gelmek için bir başa çıkma mekanizmasıdır (Romero ve Cruthirds, 2006).

Uyumsuz mizah tarzlarından kendini yıkıcı mizah, bireyin başkalarının onayının kazanmak için kendisine yönelttiği, saldırgan mizah ise bireyin kendisi hakkındaki olumlu hisleri artırmak için başkalarına yönelttiği mizah tarzıdır (Kuiper ve Leite, 2010). Kendini yıkıcı mizah, bireylerin kendileri hakkında aşırı aşağılayıcı mizahi açıklamalar yaparak başkalarını eğlendirme çabalarını temsil etmektedir (Veselka vd., 2010). Kendini yıkıcı mizah, bireyin kendi aleyhine komik şeyler söyleyerek ya da yaparak diğer insanların onayını alma ya da kendini sevdirme çabalarını ifade eder (Martin vd., 2003). Kendini yıkıcı mizah tarzını kullanan bireyler, kendi zayıf yönleriyle dalga geçerek başkalarını eğlendirmeye çalışmakta ve diğer insanlara kendilerini sevdirme eğilimi içindedirler 
(Liu, 2012). Romero ve Cruthirds (2006), örgütlerde kendini yıkıcı mizah tarzını kullanan bireylerin, statü seviyelerini düşürme ve kendilerini daha yaklaşılabilir hale getirmeyi arzu ettiklerini ileri sürmüşlerdir. Kendini yıkıcı mizah tarzı, yalnızlık, utangaçlık, depresyon ile pozitif ilişkili ve görünür özsaygıyla negatif korelasyon gösterdiği bulunmuştur (Stieger vd., 2011). Stieger ve diğerleri (2011) zarar görmüş özsayg1 ile kendini yı1kı1 mizah arasında bir ilişki olduğunu ortaya koymuşlardır.

Genel olarak saldırgan mizah tarzı, başkaları üzerindeki olası etkilerini göz önüne almaksızın ve kişinin diğer insanları ötekileştirecek ve incitecek komik şeyleri söyleme dürtüsüne muhtemelen direnmekte zorlandığı mizah ifadelerini içermektedir. Bu mizah tarzına cinsiyetçi ya da ırkçı mizahı örnek olarak göstermek mümkündür (Martin vd., 2003). Saldırgan mizah, başkalarına zarar vermek ya da onları manipüle etmek için alay ve eleştirinin kullanılmasını içermektedir (Veselka vd., 2010). Saldırgan mizah tarzına sahip bireyler, genellikle örtülü bir alay etme tehdidi yoluyla başkalarını manipüle etmeyi amaçlamaktadırlar (Romero ve Cruthirds, 2006). Saldırgan mizah, kişilerarası ilişkiler üzerinde güçlü olumsuz etkiye sahiptir. Çünkü bu mizah tarzı, özellikle diğer insanlara hakaret etme ve onları küçümseme amacı taşımaktadır (Kuiper ve Leite, 2010).

\section{Girişimcilik ve Girişimci Kavramları}

Girişimcilik, daha önce mevcut olmayan örgütleme çabaları yoluyla, yeni mal ve hizmetleri, örgütlenme biçimlerini, pazarları, süreçleri ve hammaddeleri pazara sunma firsatlarının keşfedilmesi, değerlendirilmesi ve bunlardan yarar elde edilmesini içeren bir faaliyettir (Shane, 2003). Baumol (1968) girişimciliği, statü, güç ve zenginlik elde etme kararlılığıyla, hayal gücü, cesaret, yaratıcılık, liderlik ve azimli olmayı gerektiren ve sıra dışı bir tarzla gerçekleştirilen faaliyetler olarak tanımlamaktadır. Yeni ürün ve süreçlerin yaratılması, yeni girişimlerin meydana getirilmesi olarak kavramsallaştırılan girişimcilik Mcmullen ve Shepherd 'e (2006) göre eylem gerektirmektedir. Onlara göre girişimci olmak, takip etmeye değer bulunan bir firsat doğrultusunda hareket etmektir.

Shane ve Venkataraman (2000) farklı yazarların tanımlarından yola çıkarak girişimciliğin fonksiyonlarını şu şekilde tanımlamışlardır: (1) girişimcilik, teknik bilgiyi ürün ve hizmete dönüştürme mekanizmasıdır, (2) girişimcilik ekonomideki verimsizliklerin fark edilmesini ve azaltılmasını sağlayan bir mekanizmadır, (3) girişimcilik, ekonomideki ürün ve süreçlerdeki yeniliği ve değişim süreçlerini yönlendiren önemli bir motor güçtür. Robinson ve diğerleri (1991) girişimcilik ile ilgili olarak 4 alt tutum olduğunu ileri sürmüş ve bu tutumları şu şekilde ifade etmişlerdir: (1) İşteki başarı, bir iş girişiminin başlangıcı ve büyümesi ile ilgili somut sonuçları ifade etmektedir, (2) İște inovasyon, iş faaliyetlerinde yeni ve farklı yolları algılama ve buna göre hareket etmek ile ilgilidir, (3) İş sonuçları üzerinde algılanan bireysel kontrol, bireylerin işleri üzerindeki etkilerini ve kontrollerini algılama düzeyleri ile ilgilidir, (4) işle ilişkili algılanan özsaygı ise, bireylerin işlerindeki gidişat ile birlikte algılanan bireysel yetkinlik ve özgüven düzeylerini ifade etmektedir.

Girişimciler, serbest girişimci toplumların canlılığı için ağır sorumluluklar üstlenmektedirler (Baumol, 1968). Girişimciler, başkalarının kaos, çelişki ve karmaşa gördükleri yerde fırsatların farkına varan bireylerdir. Ayrıca girişimciler, pazarda değişim için önemli katalizörler olarak da tanımlanabilir (Kuratko, 2015). "Girişimci” ile ilgili yapılan tanımlar, inovasyon, proaktif davranış ve risk alma unsurları etrafında birleşmektedir (Raab vd., 2005). Ücretli çalışanların aksine, girişimciler kontrol altında olmaksızın karar almak, bağımsız olarak hedef belirlemek ve eylem planları hazırlamak ve başarı seviyelerini kendileri kontrol etmek isteyen bireylerdir ve özerk olma isteği yüksek bireyler, genel olarak girişimci olmaya çok uygun bulunmaktadır (Rauch ve Frese 2014).

Nispeten yeni ve gelişmekte olan girişimcilik literatüründe; eğitim, aile, iş tecrübesi ve finansal imkanlara erişim gibi daha geleneksel kabul edilen değişkenlere ek olarak bireylerin kişiliklerinin veya psikolojik özelliklerinin girişimciliğin önemli unsurlarından olup olmadığı da inceleme konusu haline gelmektedir (Fairlie ve Holleran, 2012). Aynı ekonomik, sosyal, kültürel, siyasi ve benzeri koşullar altında bireylerin girişimcilik faaliyetleriyle ilgili olarak neden farklı davranışlar sergilediklerini ve girişimciler ile girişimci olmayanlar arasındaki farklılıkları inceleyen yaklaşımların temel olarak kişilik özelliklerini bağlamında konuyu ele aldıkları görülmektedir (Aksay ve İplik, 2014). Girişimcilik ile ilgili psikolojik özellikler okulu, kişilik faktörüne odaklanmakta ve girişimcilerin işe ve hayata karşı özgün değerlere ve tutumlara sahip olduklarını düşünmektedir. Bu ekolden yola çıkarak Cunningham ve Lischeron (1991), (1) dürüstlük, görev, sorumluluk ve etik davranış gibi kişisel değerler, (2) risk alma eğilimi, (3) başarıya duyulan ihtiyaç olmak üzere üç kişilik özelliğinin dikkat çekici olduğunu ifade etmişlerdir. Girişimcilik bağlamında en çok çalışılan kişilik özelliği risk toleransıdır. İşletme sahipliği doğası gereği risklidir ve risk toleransı daha yüksek olan bireylerin girişimci olma ihtimallerinin daha yüksek olduğu sonucuna varılmaktadır (Fairlie ve Holleran, 2012). Risk alma eğilimi genel olarak, risk ve belirsizliğe katlanmaya hazır olma derecesi olarak tanımlanabilir (Raab vd., 2005). Raab ve diğerlerine (2005) göre girişimciliğe özgü bir özellik olarak görülen önsezi ve yeni şeyleri tanımlayabilme yeteneği, belirsizliğin yüksek olduğu çalışma ortamlarında, esnek ve başarılı problem çözme stratejileri sağlamaktadır.

\section{Araştırmanın Yöntemi}

Araştırmanın yöntemine ilişkin süreç aşağıdaki şekilde ele alınmıştır. 


\subsection{Araştırmanın Amacı}

$\mathrm{Bu}$ araştırmanın amacı, üniversite öğrencilerinin sahip oldukları mizah tarzları ile girişimcilik eğilimleri arasındaki ilişki olup olmadığını ve katılımcıların mizah tarzları düzeyleri ile girişimcilik davranışı düzeyleri arasında farklılık olup olmadığını incelemektir. Mizah kavramı ile ilgili öğrencileri kapsayan çok sayıda çalışma olmasına rağmen, bu çalışmalarda genellikle öğrencilerin girişimcilik eğilimlerinin ele alınmadığı görülmektedir. Mizah tarzları ile girişimcilik eğilimine ilişkin ampirik araştırmaların ilgili yazında bulunmaması dolayısıyla literatüre katkı sağlayacağı düşünülmektedir.

\subsection{Araştırmanın Hipotezleri}

Araştırmada bağımsız değişken olarak ele alınan mizah tarzları; olumlu iki mizah tarzını ifade eden katılımcı mizah ve kendini geliştirici mizah ile olumsuz mizah tarzlarını ifade eden saldırgan mizah ve kendini yıkıcı mizah olmak üzere dört boyutta incelenmektedir. Araştırmada bağımlı değişken olan girişimcilik eğilimi ise tek boyut olarak incelenmektedir. Kavramsal çerçeve doğrultusunda oluşturulan araştırma hipotezleri aşağıdaki gibidir:

H1a: Katılımcı mizah tarzı ile girişimcilik eğilimi arasında pozitif ve anlamlı bir ilişki vardır.

H2a: Kendini geliştirici mizah tarzı ile girişimcilik eğilimi arasında pozitif ve anlamlı bir ilişki vardır.

H3a: Saldırgan mizah tarzı ile girişimcilik eğilimi arasında negatif ve anlamlı bir ilişki vardır.

H4a: Kendini yıkıcı mizah tarzı ile girişimcilik eğilimi arasında negatif ve anlamlı bir ilişki vardır.

H1b: Yüksek seviyede katılımcı mizah tarzına sahip olma girişimcilik eğilimini artırmaktadır.

H2b: Yüksek seviyede kendini geliştirici mizah tarzına sahip olma girişimcilik eğilimini artırmaktadır.

H3b: Yüksek seviyede saldırgan mizah tarzına sahip olma girişimcilik eğilimini azaltmaktadır

H4b: Yüksek seviyede kendini yıkıcı mizah tarzına sahip olma girişimcilik eğilimini azaltmaktadır

\section{3 Örneklem ve Veri Toplama Yöntemi}

Araştırmanın örneklemini, Pamukkale Üniversitesi’nde işletme bölümü ile endüstri mühendisliği bölümlerindeki son sınıf öğrencilerinden oluşan kolayda örnekleme yolu ile belirlenen 264 öğrenci oluşturmaktadır. Veriler, anket tekniği kullanılarak elde edilmiştir. Anketler araştırmacılar tarafından ders saatlerinde öğrencilere dağıtılmış, cevaplamaya başlamadan önce araştırmanın amacı açıklanmış ve sonuçların üçüncü şahıslarla paylaşılmayacağı belirtilerek isimlerini yazmamaları istenmiştir. Son sınıf öğrencilerinin seçilme sebebi diğer öğrencilere göre nispi olarak çalışma hayatına yakın olmaları ve zorunlu olarak 'Girişimcilik' dersi almış olmalarıdır.

Araştırmaya katılan toplam 264 öğrenciden 143’ü (\% 54,2 ) kadın ve 121’i (\% 45,8) erkektir. Öğrenim gördükleri bölümlere göre katılımcıların \%63,3'ü işletme, \%36,7'si endüstri mühendisliği bölümlerinde öğrenim görmektedir. Katılımcıların \%50,4'ü bir süre başka bir iş yerinde çalıştıktan sonra kendi işini kurmak istediğini ve ayrıca katılımcıların \% 53’ü gelecekte kendi işini kurma ihtimallerinin yüksek ve çok yüksek olduğunu belirtmişlerdir. Araştırmaya katılan öğrencilerin demografik özelliklerine iliş̧in bilgiler Tablo-1'de yer almaktadır.

\begin{tabular}{|c|c|c|c|}
\hline & & Frekans & Yüzde \\
\hline \multirow{2}{*}{ Cinsiyet } & Kadın & 143 & 54,2 \\
\hline & Erkek & 121 & 45,8 \\
\hline \multirow{2}{*}{ Bölüm } & İşletme & 167 & 63,3 \\
\hline & Endüstri Mühendisliği & 97 & 36,7 \\
\hline \multirow{4}{*}{$\begin{array}{l}\text { Okulu bitirdikten sonraki } \\
\text { mesleki idealiniz nedir? }\end{array}$} & Daima kamu sektörü & 44 & 16,7 \\
\hline & Daima özel sektör & 65 & 24,6 \\
\hline & Hemen kendi İșimi kurmak & 22 & 8,3 \\
\hline & $\begin{array}{l}\text { Bir süre başka bir işyerinde çalıştıktan sonra } \\
\text { kendi işimi kurmak }\end{array}$ & 133 & 50,4 \\
\hline \multirow{5}{*}{$\begin{array}{l}\text { Gelecekte kendi işinizi } \\
\text { kurma ihtimaliniz nedir? }\end{array}$} & Çok Yüksek & 31 & 11,7 \\
\hline & Yüksek & 109 & 41,3 \\
\hline & Düșük & 84 & 31,8 \\
\hline & Çok Düşük & 33 & 12,5 \\
\hline & Yok & 7 & 2,7 \\
\hline \multicolumn{2}{|l|}{ Toplam } & 264 & 100 \\
\hline
\end{tabular}

Tablo 1. Katılımclları Demografik Özellikleri

Ölçme aracı olarak öğrencilerin girişimcilik davranışının saptanabilmesi için, Leroy, ve diğerleri (2009) tarafından oluşturulan ve Mert (2018) tarafından geçerliliği ve güvenilirliği test edilen ölçek kullanılmıştır. Araştırmada kullanılan girişimcilik eğilimi ölçeği 29 sorudan oluşmaktadır. Ölçeğe verilen yanıtlar güvenilirlik analizi ile test edildiğinde Cronbach Alfa değeri 0,909 olarak bulunmaktadır. Bu sonuca göre ölçeğin oldukça güvenilir olduğu görülmektedir. Girişimcilik eğilimi ölçeğine ilişkin olarak yapılan faktör analizinde KaiserMeyer-Olkin (KMO) örnekleme yeterliliği değeri 0,899 (p<.01), Barlett Küresellik Test değeri ise p<.01 olarak tespit edilmiştir. Söz konusu ölçeğin faktör analizine uygun olduğu görülmüştür. Mizah tarzlarını ölçmek için 
Martin ve diğerleri (2003) tarafından geliştirilen ve Yerlikaya (2003) tarafından Türkçeye uyarlanan mizah tarzları ölçeği kullanılmıştır. Ölçek, dört alt boyuttan ve 32 maddeden oluşmaktadır. Çalışmada bu ölçek için cronbach alfa değeri 0,802 olarak bulunmuştur. Mizah tarzları ölçeğine ilişkin olarak yapılan faktör analizinde KaiserMeyer-Olkin (KMO) değeri 0,791 ( $p<.01)$, Barlett Küresellik Test değeri ise $p<.01$ olarak tespit edilmiştir. Her iki ölçüm aracı için de beşli likert tipi ölçek kullanılmış olup " $1=$ Kesinlikle katılmıyorum” ve " $5=$ Kesinlikle katılıyorum" arasında değer almaktadır.

\section{Analiz ve Araştırma Bulguları}

Değişkenler arası korelasyon katsayıları Tablo 2'de sunulmuştur.

\begin{tabular}{|c|c|c|c|c|c|}
\hline & Girişimcilik & $\begin{array}{c}\text { Kendini Geliştirici } \\
\text { Mizah }\end{array}$ & $\begin{array}{c}\text { Katılımcı } \\
\text { Mizah } \\
\end{array}$ & $\begin{array}{c}\begin{array}{c}\text { Saldırgan } \\
\text { Mizah }\end{array} \\
\end{array}$ & \begin{tabular}{|c|}
$\begin{array}{c}\text { Kendini Yıkıcı } \\
\text { Mizah }\end{array}$ \\
\end{tabular} \\
\hline \multirow{5}{*}{$\begin{array}{l}\text { Girişimcilik } \\
\text { Kendini Geliştirici Mizah } \\
\text { Katılımcı Mizah } \\
\text { Saldırgan Mizah } \\
\text { Kendini Yıkıcı Mizah }\end{array}$} & 1 & & & & \\
\hline & ,092 & 1 & & & \\
\hline & $176^{* *}$ &, $360^{* *}$ & 1 & & \\
\hline &, 002 &, 006 &, 032 & 1 & \\
\hline &, 054 & $275^{* *}$ & $145^{*}$ & $380^{* *}$ & 1 \\
\hline
\end{tabular}

Tablo 2. Değişkenlere Ait Korelasyon Katsayıları

Yapılan analizler sonucunda bağımsız değişken olan mizah tarzları alt boyutlarından sadece katılımcı mizah ile bağımlı değişken olan girişimcilik eğilimi arasında pozitif ve anlamlı bir ilişki $(r=0,176 ; p<0,01)$ bulunmuştur. Tablo 2'deki korelasyon analizi sonucuna göre H2a, H3a ve H4a hipotezleri desteklenmemiştir.

\begin{tabular}{|c|c|c|c|c|c|}
\hline \multirow[t]{2}{*}{ Bağımlı Değişken: Girişimcilik } & \multicolumn{2}{|c|}{ EKK Katsayı Tahminleri } & \multirow{2}{*}{$\begin{array}{c}\begin{array}{c}\text { Standardize } \\
\text { Edilmiş } \\
\text { Katsayılar }\end{array} \\
\text { Katsayı }\end{array}$} & \multirow[b]{2}{*}{ t-istatistiği } & \multirow[b]{2}{*}{ p-değeri } \\
\hline & Katsayı & Std. Sapma. & & & \\
\hline Sabit terim & 3,118 &, 254 & & 12,294 &, 000 \\
\hline Kendini Geliştirici Mizah &, 022 &, 060 &, 025 & ,371 & ,711 \\
\hline Katılımcı Mizah &, 126 &, 051 & ,163 & $2,486^{*}$ &, 014 \\
\hline Saldırgan Mizah &,- 011 &, 049 &,- 015 &,- 220 &, 826 \\
\hline Kendini Yıkıcı Mizah &, 020 &, 047 & 029 & ,424 & ,672 \\
\hline F Değeri & 2,180 & p-değeri (F) & 0,072 & $\mathrm{R}^{2}$ & 0,033 \\
\hline
\end{tabular}

Tablo 3. Girişimcilik ile Mizah Tarzı Boyutları Arasındaki Regresyon Analizi

Araştırmada girişimcilik ile mizah boyutları arasında ki ilişkiyi daha iyi anlamak için regresyon analizi yapılmıştır. Bu regresyon analizini sonuçları Tablo 3'te görülmektedir. Tablo 3'e göre model uyum iyiliği düşük seviyededir, ayrıca model bütün olarak \%90 güvenlik seviyesinde anlamlı çıkmaktadır. Regresyon modelinde sadece katılımcı mizah boyutu ve sabit terimin istatistiki olarak anlamlı olduğu görülmektedir. Buna göre H1a hipotezi desteklenmiştir. Diğer mizah boyutlarının ise istatistiki olarak anlamlı olmadığı bulunmuştur. Anlamlı değişkenlerden sabit terimin katsayısı için şu şekilde yorum yapmak mümkündür: Hiç mizah anlayışı olmayan bireylerin ortalama girişimcilik seviyesi 3,118'dir. Bununla beraber, diğer mizah seviyeleri sabit iken katılımcı mizah seviyesinin bir birim artması, girişimcilik seviyesinde ortalama 0,126 birim artışa neden almaktadır.

Araştırmanın bir diğer amacı da mizah tarzları düzeylerine göre girişimcilik eğilimi düzeyinin farklılaşıp farklılaşmadığını incelemektir. Bu araştırma amacı doğrultusunda ölçekten alınan toplam puanların bağımsız değişkenlere göre farklılık gösterip göstermediğini belirlemek amacıyla parametrik analiz tekniklerinden bağımsız örneklemler için t-testi ve tek yönlü varyans analizi (ANOVA) uygulanmıştır (Dönmez ve Uslu, 2015).

Analiz sonucuna göre Tablo 4'te genel anlamda kendini geliştirici mizah tarzını üç seviyede (düşük, orta, yüksek) ele alınmıştır. Düşük seviyesindeki kendini geliştirici mizah tarzı aralığında yer alan katılımcı sayısı yetersiz $(n=10)$ bulunduğu için bu seviye analize dahil edilmemiştir. Tablo 4'te $\mathrm{p}$ değerinin 0,073 olduğu görülmektedir. Söz konusu değer \%95 güven seviyesinde ve 0,05 büyük olduğu için anlamlı bir farklılık olmadığ 1 görülmüştür. Ancak p değerinin 0,07 olması 0,05'e uzak bir rakam olmadığı için göz ardı edilmemelidir. Buna göre $\mathrm{H} 2 \mathrm{~b}$ hipotezi desteklenmemiştir.

\begin{tabular}{|l|l|l|l|l|}
\hline Kendini Geliştirici Mizah & $\mathrm{n}$ & Ortalama & p-değeri & anlamlılık \\
\cline { 1 - 3 } Orta & 86 & 3,5915 & \multirow{2}{*}{0,07} & \multirow{2}{*}{0,05} \\
\cline { 1 - 3 } Yüksek & 177 & 3,7155 & & \\
\hline
\end{tabular}

Tablo 4. Katılımcıların Kendini Geliştirici Mizah Tarzı Düzeylerine göre Girişimcilik Eğilimleri Ortalamalarının Karşılaştırılmasına Yönelik t-testi Sonuçları 
Analiz sonuçlarına göre Tablo 5'da katılımcı mizah tarzı üç seviyede (düşük, orta, yüksek) ele alınmıştır. Düşük seviyesindeki katılımcı mizah tarzı aralığındaki katılımcı sayısı yetersiz $(n=9)$ bulunduğu için analize dahil edilmemiştir. Tablo 5 'te p değerinin 0,007 olduğu görülmektedir. Söz konusu değer $\% 95$ güven seviyesinde ve 0,05 küçük olduğu için anlamlı bir farklılık olduğu görülmüştür. Tablo 5 'ten de görülebileceği gibi katılımcı mizah düzeyi yüksek olanlar orta düzeyde olanlarla karşılaştırıldığında, girişimcilik eğilimlerinin daha yüksek olduğu anlaşılmaktadır. Buna göre H1b hipotezi desteklenmiştir.

\begin{tabular}{|l|l|l|l|l|}
\hline Katılımcı Mizah & $\mathrm{n}$ & Ortalama & p-değeri & anlamlılık \\
\cline { 1 - 3 } Orta & 157 & 3,6021 & \multirow{2}{*}{0,007} & $<0,05$ \\
\cline { 1 - 3 } & 97 & 3,7838 & & \\
\hline
\end{tabular}

Tablo 5. Katılımcıların Katılımcı Mizah Tarzı Düzeylerine göre Girişimcilik Eğilimleri Ortalamalarının Karşılaştırılmasına Yönelik t-testi Sonuçları

Analiz sonuçlarına göre Tablo 6'da saldırgan mizah tarzı üç seviyede (düşük, orta, yüksek) ele alınmıştır. Yüksek seviyesindeki saldırgan mizah aralığındaki katılımcı sayıları yetersiz $(n=9)$ bulunduğu için analize dahil edilmemiştir. Tablo 6'da görüleceği üzere, $\mathrm{p}$ değeri 0,05 'ten daha fazla olduğu için saldırgan mizah tarzı düzeyleri ile girişimcilik düzeyi arasında anlamlı farklılık bulunmadığı anlaşılmıştır. Buna göre H3b hipotezi desteklenmemiştir.

\begin{tabular}{|l|l|l|l|l|}
\hline Saldırgan Mizah & $\mathrm{n}$ & Ortalama & p-değeri & anlamlılik \\
\cline { 1 - 3 } Düşük & 165 & 3,6775 & \multirow{2}{*}{0,68} & \multirow{2}{*}{$>0,05$} \\
\cline { 1 - 2 } Orta & 90 & 3,6498 & & \\
\hline
\end{tabular}

Tablo 6. Katılımcıların Saldırgan Mizah Tarzı Düzeylerine göre Girişimcilik Eğilimleri Ortalamalarının Karşılaştırılmasına Yönelik t-testi Sonuçları

Analiz sonuçlarına göre kendini yıkıcı mizah tarzı üç seviyede (düşük, orta, yüksek) ele alınmıştır. Fakat, yüksek seviyesindeki kendini yıkıcı mizah tarzı aralığındaki katılımcı sayıları yetersiz bulunduğu için bu düzey analize dahil edilmemiştir. Tablo 7'de görüleceği üzere, p değeri 0,05'ten daha fazla olduğu için kendini yıkıcı mizah tarzı düzeyleri ile girişimcilik düzeyi arasında anlamlı farklılık ortaya çıkmadığı anlaşılmıştır. Buna göre H4b hipotezi desteklenmemiştir.

\begin{tabular}{|l|l|l|l|l|}
\hline Kendini Yıkıcı & $\mathrm{n}$ & Ortalama & p-değeri & anlamlılık \\
\cline { 1 - 3 } Düşük & 94 & 3,6216 & \multirow{2}{*}{0,29} & \multirow{2}{*}{$>0,05$} \\
\hline Orta & 140 & 3,6962 & & \\
\hline
\end{tabular}

Tablo 7. Katılımcıların Saldırgan Mizah Tarzı Düzeylerine göre Girişimcilik Eğilimleri Ortalamalarının Karşılaştırılmasına Yönelik t-testi Sonuçları

Yapılan analizler neticesinde, mizah tarzlarından sadece katılımcı mizah tarzı alt boyutu ile katılımcıların girişimcilik eğilimleri arasında pozitif ve anlamlı bir ilişki olduğunu öne süren H1a hipotezinin desteklendiği tespit edilmiştir. Ayrıca olumlu mizah tarzlarını ifade eden katılımcı mizah ve kendini geliştirici mizah tarazlarının düzeyi arttıkça, girișimcilik eğiliminin artacağı, bununla birlikte olumsuz mizah tarzlarını ifade eden saldırgan ve kendini yıkıcı mizah tarzlarının düzeyi yükseldikçe de girişimcilik eğiliminin azalacağı öngörülmüş ve bu doğrultuda oluşturulan hipotezlerden sadece katılımcı mizah tarzı düzeyi arttıkça girişimcilik eğiliminin artacağını ifade edilen $\mathrm{H} 1 \mathrm{~b}$ hipotezinin desteklendiği bulunmuştur.

\section{Sonuç ve Öneriler}

Mizah olgusu, insanların bedensel yeteneği ile zihinsel zekasının her düzeyinde ve düzleminde, son derece farklı derecelerde ve davranış yansımalarında gerçekleşen bir söylem ve eylem şeklidir. Mizahın, insanların eğlenme ve dinlenme ihtiyaçları ile boş vakit geçirme amaçlarına uygun olarak gülme ve güldürme şeklinde bedensel gevşeme ve rahatlama yönü mevcuttur. Ayrıca, mizah başka bir bakış açısıyla zihinsel bir olgudur. Buna göre bireyler, içerisinde bulundukları çeşitli zorluk ve güçlükler karşısında zekice gerçekleştirdikleri mizahi eylemler sayesinde gerçeklik sınırlarını ve mevcut kalıplaşmış yargıları aşmak suretiyle özgün düşünce ve yaratıcılık kapasitelerini artırma imkanı bulmaktadırlar (Büyükyılmaz, 2018). Chen ve Martin (2007), mizah olgusunu, birisi olumlu (katılımcı ve kendini geliştirici mizah), diğeri ise olumsuz (kendini yıkıcı ve saldırgan mizah) olmak üzere yine iki zıt anlam bileşenlerine ayırmaktadır. Aslına bakılırsa, yetenek ve zeka düzeyi ile yüksek kültürel birikimi vasat ve vasatın üzerinde olan kişilerin, mizahın olumlu boyutu ile ilişkilerinin nispeten daha fazla olması beklenmektedir. Buna karşılık, yetenek ve zeka düzeyi ile yüksek kültürel birikimi vasatın altında olan kişilerin, mizahın olumsuz boyutu ile ilişskilerinin nispeten daha fazla olduğu söylenebilir. Benzer bir durumun, bir girişimcilik özelliği olarak kabul edilen yaratıcılık için de söz konusu olduğu söylenebilir. Yani yaratıcılık düzeyi daha yüksek olan ve standartların ötesine geçebilen bireylerin olumlu mizah tarzına nispeten daha fazla sahip oldukları ve bu anlamda başkalarını aşağılayarak ve küçük görerek ya da kendisini değersiz ve önemsiz görerek 
gelişen olumsuz bir mizah anlayışını daha az benimseyecekleri söylenebilir. Yaratıcılık kavramı, genel olarak düşünceler veya nesneler arasındaki ilişkinin algılanması veya tamamen yeni görünen ifade biçimleri olarak tanımlamaktadır (Cade, 1982). Mizah ve yaratıcılık ile ilgili bazı çalışmalarda, yaratııı insanların özelliklerine odaklanılmış ve mizahın yaratıcı kişilik özelliğiyle ilişkili olduğu bulunmuştur. Diğer bazı çalışmalarda ise mizahın, yaratıcılık sürecindeki kolaylaştırııı rolü incelenmiştir (Humke ve Schaefer, 1996). Genel yaratıcılığın hem mizahı anlama hem de mizah üretimi ile ne derecede ilişkili olduğunu inceleyen Babad'ın (1974) yaptığı araştırma bulgularına göre yaratıcılık düzeyi ile katılımcıların mizah üretme yetenekleri ilişkili bulunmasına rağmen, mizahı anlama düzeyi ile yaratıcılık arasında anlamlı bir ilişki ortaya çıkmamıştır (Akt. Martin, 1998). Bir başka araştırmada Humke ve Schaefer (1996) mizah ve yaratıcıllk arasında pozitif ve anlamlı bir iliş̧i olduğu bulgusuna ulaşmışlardır. Bu araştırmacılara göre mizah ve yaratıcılık, hem risk almayı hem de alışılmışın dışında tepkiler üretmeyi içerdiği için bu iki değişken ilişkili görülmektedir.

$\mathrm{Bu}$ çalışma özellikle girişimci bireylerin yaratıcılık, risk alma, firsatları görebilme, proaktif davranabilme, sosyal ağlarını geliştirebilme ve zorluklar karşısında dirençli olma gibi literatürde genel olarak kabul gören ortak kişilik özelliklerinden yola çıkarak, bireylerin olumlu mizah tarzlarının ağırlıklı olduğu bir mizah anlayışı ile girişimcilik eğilimleri arasında pozitif bir ilişki olacağı öngörülmüştür. Bununla birlikte bu çalışmada, bireylerin olumsuz mizah tarzlarının ağırlıklı olduğu bir mizah anlayışı ile girişimcilik eğilimi arasında ise negatif yönlü bir ilişki olacağı öngörülmüştür. Yapılan analizler neticesinde sadece olumlu mizah tarzlarından biri olan katılımcı mizah ile girişimcilik eğilimi arasında pozitif ve anlamlı bir ilişki tespit edilmiş̧ir. Diğer bir anlatımla kendini geliştirici, saldırgan ve kendini yıkıcı mizah tarzları ile katılımcıların girişimcilik eğilimleri arasında istatistiki olarak anlamlı ilişkiler olmadığı bulunmuştur. Diğer taraftan katılımcıların sahip oldukları mizah tarzı düzeyine göre girişimcilik eğilimlerinin farklılaşıp farklılaşmadığını tespit etmek amacıyla yapılan analizler neticesinde, katılımcıların sadece olumlu mizah tarzlarından katılımcı mizah düzeyleri ile girişimcilik eğilimleri düzeyleri arasında anlamlı farklılık saptanmıştır ve katılımcıların katılımcı mizah anlayışı düzeyi arttıkça, girişimcilik eğilimlerinin düzeyinin de ortalamada arttığ bulunmuştur. Bu çalışmada girişimcilik eğilimi ile arasında istatistiki olarak anlamlı ilişki ve fark bulunan tek mizah boyutu, etkileşimleri kolaylaştıran ve olumlu bir ortam yaratan sosyal bir kaynaştırıcı rolü olduğu ileri sürülen (Romero ve Cruthirds, 2006) katılımcı mizah tarzıdır.

$\mathrm{Bu}$ çalışmanın tek bir üniversitenin işletme ve endüstri mühendisliği bölümlerinde eğitim gören lisans öğrencileri üzerinde yapılmış olması, kısıtlarını teşkil etmektedir. Benzer çalışmaların daha farklı üniversitelerde ve bölümlerde de yapılmasına ihtiyaç vardır. Bununla birlikte hali hazırda girişimci olan ve girişimcilik faaliyetlerini devam ettiren örneklemler üzerinde de konunun incelenmesi gerekmektedir. Gelecekte yapılacak çalışmalarda mizah tarzları ile girişimcilik eğilimi ve girişimcilik davranışları incelenirken yaratıcıllğın aracı değişken olarak belirlendiği modeller kurulabilir. Bu çalışma ülkemizde mizah tarzları ile girişimcilik eğilimi arasındaki ilişkileri inceleyen öncü araştırmalardan biri olarak, literatüre katkı sağlayacağı ve gelecekte girişimcilik kavramı üzerine yapılacak yeni çalışmalara farklı bir perspektif kazandıracağı umulmaktadır.

\section{Kaynakça}

- Aksay, B., \& İplik, E., 2014. "Girişimcilik Eğilimi Ölçeğinin (GET 2) Türkiye Bağlamında Değerlendirilmesi”. Çukurova Üniversitesi Sosyal Bilimler Enstitüsü Dergisi, 23(2), 199-210.

- Rauch, A., \& Frese, M., 2014. "Born to Be an Entrepreneur? Revisiting the Personality Approach to Entrepreneurship". The Psychology of Entrepreneurship, 41.

- Baumol, W. J., 1968. "Entrepreneurship in economic theory". The American economic review, 64-71.

- Büyükyılmaz, Ozan, 2018. İş Hayatında Mizah Kullanımı, Mizahın Çalışan Tutum ve Davranışları Üzerindeki Etkileri. Ekin Yayınevi, Ankara

- Cade, B. W., 1982. "Humour and creativity”. Journal of Family Therapy, 4(1), 35-42.

- Chen, G. H., \& Martin, R. A., 2007. "A comparison of humor styles, coping humor, and mental health between Chinese and Canadian university students", Humor 20-3, 215-234.

- Cunningham, J. B., \& Lischeron, J., 1991. "Defining entrepreneurship", Journal of small business management, 29(1), 45-61.

- Dönmez C., Uslu S., 2015. “Sosyal Bilgiler Öğretmen Adaylarının Özel Alan Yeterliklerine İlişkin ÖzYeterlik İnançlarının Çeşitli Değişkenler Açısından İncelenmesi”, Dergipark, s. 461-482.

- Eker, Gülin Öğüt, 2014. İnsan, Kültür, Mizah, Eğlence Endüstrisinde Tüketim Nesnesi Olarak Mizah, 2. Bask1, Grafiker Yayınları Yayın No. 50, Ankara

- Fairlie, R. W., \& Holleran, W., 2012.” Entrepreneurship training, risk aversion and other personality traits: Evidence from a random experiment". Journal of Economic Psychology, 33(2), 366-378.

- Humke, C., \& Schaefer, C. E., 1996. "Sense of humor and creativity. Perceptual and motor skills", 82(2), 544-546. 
- Kelly, W. E., 2002. "An investigation of worry and sense of humor”. The Journal of psychology, 136(6), 657-666.

- $\quad$ Kuiper, N. A., \& Leite, C., 2010. "Personality impressions associated with four distinct humor styles", Scandinavian Journal of Psychology, 51(2), 115-122.

- Kuratko, D. F., 2016. Entrepreneurship: Theory, process, and practice. Cengage Learning

- Leroy, H., Maes, J., Sels, L., Debrulle, J., 2009 . “Gender Effects on Entrepreurial Intention: A TPB Multigroup Analysis at Factor and Indicator Level, In Paper presented at the Academy of Management Annual Meeting, Vol. 7, p. 11.

- $\quad$ Liu, K. W., 2012. "Humor Styles, Self-Esteem and Subjective Happiness", Discovery - SS Student EJournal, 1, 21-41.

- Martin, R. A., 1998. "Approaches to the sense of humor: A historical review”, The sense of humor: Explorations of a personality characteristic, 15.

- Martin, R. A., Puhlik-Doris, P., Larsen, G., Gray, J., \& Weir, K., 2003. "Individual differences in uses of humor and their relation to psychological well-being: Development of the Humor Styles Questionnaire", Journal of research in personality, 37(1), 48-75.

- $\quad$ Mert, M. 2018. "Kişilik Özellikleri İle Girişimcilik Davranışı Arasındaki İlişki: Denizli Meslek Yüksekokullarında Bir Araştırma”, Pamukkale Üniversitesi Sosyal Bilimler Enstitüsü, Basılmamış Yüksek Lisans Tezi, Denizli.

- $\quad$ Raab, G., Stedham, Y., \& Neuner, M., 2005. "Entrepreneurial Potential: An Exploratory Study of Business Students in the US and Germany", Journal of Business \& Management, 11(2). 71-88.

- $\quad$ Robinson, P. B., Stimpson, D. V., Huefner, J. C., \& Hunt, H. K., 1991. “An attitude approach to the prediction of entrepreneurship", Entrepreneurship theory and practice, 15(4), 13-32.

- $\quad$ Romero, E. J., \& Cruthirds, K. W., 2006. "The use of humor in the workplace", Academy of Management Perspectives, 20(2), 58-69.

- Ruch, W., 1998. "Foreword and overview. Sense of humor: A new look at an old concept"., The sense of humor: Explorations of a personality characteristic, 3-14.

- $\quad$ Ruch, W., 2001. "The perception of humor", In Emotions, qualia, and consciousness 410-425.

- Samson, A. C., \& Gross, J. J., 2012. "Humour as emotion regulation: The differential consequences of negative versus positive humour", Cognition \& emotion, 26(2), 375-384.

- Shane, S., \& Venkataraman, S., 2000. "The promise of entrepreneurship as a field of research", Academy of management review, 25(1), 217-226.

- $\quad$ Stieger, S., Formann, A. K., \& Burger, C., 2011. "Humor styles and their relationship to explicit and implicit self-esteem" Personality and Individual Differences, 50(5), 747-750.

- Thorson, J. A., \& Powell, F. C., 1991. "Measurement of sense of humor", Psychological Reports, 69(2), 691-702.

- Veselka, L., Schermer, J. A., Martin, R. A., \& Vernon, P. A., 2010. "Relations between humor styles and the Dark Triad traits of personality”, Personality and Individual Differences, 48(6), 772-774.

- Yerlikaya, E. E., 2003. Mizah Tarzları Ölçeği’nin Uyarlama Çalışması”, Çukurova Üniversitesi Sosyal Bilimler Enstitüsü Basılmamış Yüksek Lisans Tezi, Adana. 


\title{
Ăg ve Teknoloji Odaklı Uygulamalı Girişimcilik (ATOG) Programının Gençlerin Girişimcilik Bilgi ve Beceri Gelişimine Etkisi
}

\section{The Effect of the Network and Technology Oriented Applied Entrepreneurship Program on Entrepreneurial Knowledge and Skill Development of the Students}

\author{
Assoc. Prof. Dr. Ömer Lütfi Antalyalı (Kyrgyzstan-Turkey Manas University, Kyrgyzstan) \\ Dr. Pınar Göktaş (Süleyman Demirel University, Turkey)
}

\begin{abstract}
In the framework of Turkey Entrepreneurship Strategy and Action Plan, there is highlighted to the importance of education of entrepreneurship and there is a need for practical training programs. The Network and Technology Oriented Applied Entrepreneurship Program was carried out as an exemplary model to answer the purpose. The aim of this study is to examine the effect of entrepreneurship knowledge and skills on development. Data were collected with a questionnaire (Evans, 2009; Linan et al., 2008), pre and post-test were applied. There are 162 participants who answered both pre-test and post-test. Although the entrepreneurship information of the participants has been improved, there has not been a significant improvement in entrepreneurial skills. Similar to previous studies, this study also showed a strong relationship between entrepreneurial knowledge and entrepreneurship skill in both pre-test and post-test data. However, in the $\Delta$ test formed from the post-test pre-test difference, the relationship between the change of entrepreneurship knowledge and the change in entrepreneurship skills was found to be weak. It was found that the knowledge development provided by the trainings was weak in predicting skill development. It can be said that the entrepreneurship education carried out is not healthy enough and carries a risk of not leaving any permanent impact on the participants. As a result of the findings, revisions that need to be realized in the design of entrepreneurship trainings are discussed.
\end{abstract}

\section{Giriş}

Girişimcilik konusu dünya uygulamalarına bakıldığında kalkınma stratejileri içinde giderek daha önemli bir yere sahip olmaktadır. AB İlerleme Raporu, Küresel Girişimcilik Endeksi (GEM) ve benzeri uluslararası kuruluşların gerçekleştirdikleri araştırmaların sonuçları, Avrupa Küçük İşletmeler Yasası ve AB Komisyonu tarafından hazırlanan AB 2020 Girişimcilik Eylem Planı girişimcilikle ilgili yeni stratejilere vurgu yapmaktadır (GISEP, 2015-2018: 5-6). GEM 2000 raporunda girişimcilik sürecinde en önemli unsurun eğitim olduğu ve eğitimin girişimcilik kültürü, tutum ve becerilerinin yaygınlaştırılmasında kilit role sahip olduğuna dikkat çekilmektedir (Tanrıverdi vd., 2016: 11). Türkiye Girişimcilik Stratejisi ve Eylem Planı çerçevesinde girişimcilik eğitiminin önemi vurgulanarak yükseköğrenim dahil tüm eğitim aşamalarında girişimcilik dersinin müfredatta yer alması gerekliliği belirtilmektedir. Bunun için de uygulama ağırlıklı, öğrencinin aktif, bağımsız ve inisiyatif üstlenmesini sağlayacak onları iş dünyasıyla buluşturacak eğitim programlarına ihtiyaç bulunmaktadır (GİSEP, 2015-2018: 50). $\mathrm{Bu}$ bağlamda girişimciliğin girişimcilik eğitimi yoluyla teşvik edilebileceği vurgulanmaktadır (Krueger ve Brazeal, 1994: 102; Gorman ve meslektaşları, 1997). Girişimcilik eğitimiyle ilgili olarak bilimsel çalışmaların arttığını (Oosterbeek, Praag \& Ijsselstein, 2010), üniversitelerde girişimcilikle ilgili ders sayılarının arttığını (Sanchez, 2013) ve öğrencilerin girişimcilik potansiyellerini ortaya çıkarmak için girişimcilik eğitimi almanın önemli bir itici güç olduğunu belirten çalışmalar (Bozkurt, Aslan ve Göral, 2011; Ekici ve Turan, 2017) ile beraber girişimcilik eğitimi ile girişimcilik bilgi ve becerileri arasında ilişkiler bulunduğunu tespit eden çalışmalar da (Akmaliah vd., 2012; DeTienne ve Chandler, 2004; Gorman vd., 1997; Graevenitz vd., 2010; Hong vd., 2012; Jaafar ve Aziz, 2008; Oosterbeek vd., 2010; Uygun ve Güner, 2016) mevcuttur.

Bu çalışmanın amacı, Türkiye Girişimcilik Stratejisi ve Eylem Planı göz önüne alınarak üniversite öğrencilerinin aldıkları ATOG (A ̆̆ ve Teknoloji Odaklı Uygulamalı Girişimcilik) eğitiminin onların girişimcilik bilgi ve beceri gelişimine etkisinin incelenmesidir. Bu bağlamda Süleyman Demirel Üniversitesi'nin farklı fakülte, bölüm ve programlarında okuyan 2. 3. ve 4. sınıf genç girişimci adaylarının ATOG programı öncesi durumları da dikkate alınarak bir araştırma yapılımıştır. Çalışmada ayrıca katılımcı öğrencilerin demografik özellikleriyle beraber ailesinde girişimci olup olmadığı, daha önce iş deneyimi olup olmadığı, çocukluğunu geçirdiği çevrenin kent mi yoksa kırsal mı olduğu sorulmuş ve ATOG eğitiminin katkısını bu tür arka planların etkileyip etkilemediği araştırılmıştır. 


\section{Girişimcilik Ĕgitimi, Bilgi ve Becerisi}

Girişimciliğin ekonominin itici gücü olarak görülmesi ve önem kazanmasıyla beraber girişimcilik araştırmalarında artış olmuştur. $\mathrm{Bu}$ araştırmaların temel konularından biri girişimcilik eğitimidir. Girişimcilik becerilerinin doğuştan mı yoksa sonradan mı kazanıldığı sorusu girişimcilik eğitimlerinin başlangıç noktasını oluşturmuştur. Bu konuda farklı bakış açıları bulunmakla beraber kimi uzmanlar girişimciliğin öğretilebileceğini, kimileri ise doğuştan gelen bir yetenek ve bir kişilik özelliği olduğunu ve öğretilemeyeceğini savunmuştur (Özdemir, 2016:4). Son yıllarda yapılan çalışmalar sonrasında belirsizlik ortamında çalışmanın belli bir yöntemi olduğu ve bunun öğretilebileceği düşüncesi genel kabul görmeye başlamış (Elgin, 2014) ve yapılan araştırma bulguları da girişimciliğin öğretilebileceğini göstermektedir (Kuratko, 2003). Öğrencilerin girişimcilik farkındalıklarının oluşturulması ve girişimcilik özelliklerinin geliştirilmesine yönelik olarak eğitim kurumları tarafından eğitimlerin düzenlenmesi, öğrencilerin iş dünyası profesyonelleri ile bir araya gelebilecekleri ortamların oluşturulmasına yönelik veriler, girişimcilik ve eğitim arasında güçlü bir ilişki olduğunu göstermektedir (Yelkikalan vd., 2010: 53-54). Dolayısıyla günümüzde "girişimcilik öğretilebilir mi?" sorusu yerine "ne öğretilmeli ve nasıl öğretilmeli?" sorularına yanıt aranmaktadır. Bu bağlamda girişimcilik eğitim programları başlangıçta üniversitelerde teorik olarak gerçekleştirilmiş ve daha sonra üniversite dışı kurumlar da alana katkıda bulunmuşlardır. Zaman içerisinde teorik olarak gerçekleştirilen girişimcilik eğitimleri yeterli görülmeyerek çeşitli kurslar, enstitü programları ve uygulama programları ile teorik bilgi desteklenmiştir. Bunun sonucunda teorik olarak gerçekleştirilen eğitim programlarına uygulama programları da dâhil edilerek uygulama ağırlıklı girişimcilik eğitim programları yürürlüğe konulmuştur. Üniversitelerin teorik girişimcilik eğitiminin öğrenciye bilgiyi aktarmada yetersiz kalması ve dolayısıyla girişimcilik eğitimi konusunda oluşturulan teorik programların eğitimin etkinliği açısından tek başına yeterli olmaması sebebiyle üniversite ve mesleki eğitim merkezlerinin günümüz iş dünyası için daha fazla sayıda uygulamalı program oluşturmaları gerekmektedir (Binks vd., 2006: 1). Böylece eğitim programına katılanların teorik olarak aldıkları eğitim bilgisini destekleyecek uygulama programları ile girişimcilik becerisinin ortaya çıkarılması amaçlanmaktadır (Raichaudhuri, 2005: 73).

Girişimcilik eğitimi bireyin yaşına, eğitim durumuna, ilgilerine ve beklentilerine göre farklılık gösterebilen bir süreç olup farklı ortamlarda, farklı yöntemlerle öğretilebilmektedir (Valerio vd., 2014: 17). Dünyada girişimcilik eğitimleri üzerine yapılmış olan araştırmalardaki bazı öğretim metotları şunlardır (Mc Larty, 2005:223-243; Akt: Bozkurt, 2011:33-34): Konferans yoluyla öğretim (Haines, 1988), deneysel ve uygulama odaklı öğretim (Hills, 1977; Harwitz, 1977; McMullan ve Long, 1987), davranışsal eğitim (Rice, 1985; Ronstadt, 1985), yetenek pratikleri (Root ve Gall, 1981), bireysel analiz ve girişimcilerin gerçek sorun ve çözüm önerileri (Sexton ve Upton, 1987), ikili çalışma (Vesper, 1988), rol modelleri yaratma, girişimcilik yetenek pratikleri (Vesper ve McMullan, 1988) ve karar verme yeteneğini geliştirmedir (Whyte ve Braun, 1966; Zeithaml ve Rice, 1987). Girişimcilik eğitiminde uygulanan yeni metotlardan biri de oyun tabanlı uygulamalı programlardır (Efeoğlu vd., 2016: 17). Uygulamalı etkinliklerle eğitimin oyunlaştırılmasının öğrenci başarısı (Ar, 2016; Buckley ve Doyle, 2014; Faghihi vd., 2014; Rouse, 2013), derse yönelik tutumu (Harrold, 2015; Polat, 2014) ve motivasyonu (Measles ve AbuDawood, 2015; Rouse, 2013) üzerinde olumlu bir şekilde etki edeceğini belirten çalışmalar mevcuttur. Ancak her ne kadar teorik olarak eğitim sürecinde oyunlaştırmanın beklenen etkiyi gösterebileceği düşünülse de, pratikte işe yarayıp yaramadığına karar verecek olanlar şüphesiz öğrencilerdir (Yıldırım, 2017: 237). Genel itibariyle teorik olarak gerçekleştirilen girişimcilik eğitimlerini destekler nitelikte uygulama programları ile gençlerin girişimcilik davranışı kazanmalarında öneminin oldukça yüksek olduğunu söylemek mümkündür. Gençler örnek olaylar aracılığıyla, tecrübe ve gözlem yoluyla öğrenme sürecinde elde ettikleri bilgileri özümseyerek çalışmalarına aktarırlar (Tjan, 2004:71-72). Dolayısıyla girişimcilik eğitiminde teorik olarak verilen bilgilerin hızla değişen pazar koşullarıyla uyarlanarak uygulamalı etkinlikler aracılığıyla birbirini desteklemesi gerekmektedir (Bozkurt, 2011: 28).

Girişimcilik eğitiminin en sık kullanılan amaçları arasında Alberti ve arkadaşlarına (2004) göre şu maddeler yer almaktadır: Girişimcilikle ilgili bilgi, kavram ve teknikleri öğrenmek, iş durum analiz tekniklerinin uygulanması ve eylem planları çerçevesinde girişimcilik becerileri kazandırmak, girişimcilik ruhunu, yetenek ve becerilerini tanımlamak ve girişimcilik konusunda teşvik etmek. Tüm bu amaçlar 1şı̆̆ında eğitimin girişimcilik üzerinde oldukça büyük bir etkisi olduğunu söylemek mümkündür (Uğur, 2015: 22). Gençleri geleneksel bir kariyer için hazırlayan geleneksel eğitim programlarına karşı olarak girişimcilik eğitimi, girişimcilik için gerekli olan bilgi, beceri, tutum ve davranışların kazanılmasında önemli bir politika aracı haline gelmiştir. Bu durum girişimcilik becerilerinin öğretilebileceği varsayımına dayanmaktadır (Kuratko, 2003; Matlay, 2006: 293-295). Girişimcilik eğitimi ile bireylere bazı yetenekler kazandırılırken mevcut olan bazı yeteneklerin ise geliştirilmesi amaçlanmaktadır. Risk alma, sorumluluk üstlenme, yönetme becerileri ve mesleki eğitimle kazandırılacak beceriler, eğitimle geliştirilebilecek yeteneklerden bazılarıdır. Bunun yanında girişimcilik sürecinin farklı aşamalarında farklı beceriler ön planda olabilmektedir (Özdemir, 2016: 11).

Gençlerin girişimcilik becerisinin geliştirilmesi için onlara deneyimlerin gerçekte ya da kurguda bahsedildiği gibi olup olmadığını anlamaları, eylemlerle tepki gösterebilmeleri ve kendileriyle özdeşleştirme sağlamaları için çeşitli firsatlar sunulması gerekmektedir. Bu sebeple gençlerin beceri kazanacağı durumu yaşamasını, hissetmesini ve kendisi ile özdeşleştirmesini sağlayacak uygulamalı çalışmalar gerçekleştirilmelidir (Tahiroğlu ve Meydan, 
2017: 576). Bu bağlamda girişimcilik süreci ve başarı faktörleri gibi genel girişimcilik bilgilerini destekler nitelikte eğitim sürecinde tecrübeli ve başarılı girişimcilere eğitimci olarak yer verilerek onların bilgi ve deneyimlerinden yararlanılmalı, onların yanında çıraklık, stajyerlik uygulamaları geliştirilmeli ve özellikle üniversitelerde girişimcilikle ilgili ders sayısı artırılmalıdır (Ağca, 2007). Girişimcilik becerisinin gelişiminde önemli bir nokta da gençlere, ilgili becerilerin doğasının kazandırılmasını sağlayacak bir şekilde uygulanması gerektiğidir. Sadece beceri bilgisinin kazandırılması, sürekliliği sağlamada ve esas olan eylemlerin de kazanılmasında yeterli değildir. Bu bağlamda girişimcilik eğitim süreçlerinde girişimci, inisiyatif alan ve hedefler doğrultusunda öğrenci yetiştirme özelliklerine sahip eğitim programları, girişimciliğin oluşumunu ve gelişimini destekleyebilir. Ayrıca ders dışı etkinliklerle de bu sürecin desteklenmesi sağlanabilir (Tahiroğlu ve Meydan, 2017: 576). Girişimci adayının beceri ve yeteneklerini geliştirmeye yönelik olarak makro koşullar ve girişimcilik ortamının varlığı temel çerçeveyi oluşturmakla beraber sadece düzenleyici çerçevede yapılacak iyileştirmeler bu kapsamda yeterli değildir. Bu çerçeveyi tamamlayıcı nitelikte bir destek çerçeveye ihtiyaç bulunmaktadır. Böylece bilgi eksikliğinden kaynaklanan sorunların da çözülmesi sağlanabilir (GİSEP, 2015-2018: 49).

\section{Araştırma Sorusu ve Hipotezler}

Girişimcilik eğitiminin nasıl olması gerektiği konusunda ortak bir çerçeve veya üzerinde uzlaşılan kararlaştırılmış başarılı bir model henüz bulunmamaktadır (Rasmussen ve Sorheim, 2006: 186). Buna rağmen farklı ülkelerde ve bölgelerde uygulanan başarılı girişimcilik eğitim programları ile uzun vadede uygun modelin oluşturulması sağlanabilecektir (Volkmann, 2004: 177). Literatürde konuyla ilgili daha önce yapılan çalışmalardan (Akmaliah vd., 2012; DeTienne ve Chandler, 2004; Gorman vd., 1997; Graevenitz vd., 2010; Hong vd., 2012; Jaafar ve Aziz, 2008; Oosterheek vd., 2010, Uygun ve Güner, 2016) elde edilen bilgilere göre girişimcilik eğitimi ile girişimcilik bilgi ve becerileri arasında ilişkiler bulunmaktadır. Alanyazına dayalı olarak bu bilgiler ışığında geliştirdiğimiz modelde ATOG eğitiminin öğrencilerin girişimcilik bilgi ve becerisinde gelişim sağladığı, girişimcilik becerisinin gelişimini etkileyecek yönde bir girişimcilik bilgisi gelişimi sağladığı düşünülmektedir. $\mathrm{Bu}$ bağlamda araştırmada "Girişimci ekosistemin geliştirilmesini hedefleyen girişimcilik eğitim modelleri bulunmaktadır. Oyun tabanlı ve uygulamalı olarak gerçekleştirilen karma öğrenme yöntemine göre tasarlanan ATOG eğitimi, katılımcıların girişimcilik bilgi ve beceri düzeylerini geliştirmekte midir?" sorusuna yanıt aranmaktadır. Araştırma modeli Şekil 1'de sunulmuştur.

$\longrightarrow$ ATOG Eğitimi $\longrightarrow \longrightarrow$\begin{tabular}{l|}
$\longrightarrow$ \\
Girişimcilik Bilgisinde Gelişim \\
\hline $\begin{array}{l}\text { Girișimcilik Becerisinde Gelişim becerisinin gelişimini etkileyecek yönde bir girişimcilik } \\
\text { bilgisi gelişimi }\end{array}$ \\
\hline
\end{tabular}

Şekil 1. Araştırma Modeli

Şekil 1'de yer alan araştırma modeline dayalı olarak aşağıdaki hipotezler geliştirilmiş̧ir.

$\mathrm{H}_{1}$ : ATOG eğitimi, katılımcıların girişimcilik bilgisinde gelişim sağlar.

$\mathrm{H}_{2}$ : ATOG eğitimi, katılımcıların girişimcilik becerisinde gelişim sağlar.

$\mathrm{H}_{3}$ : ATOG eğitimleriyle, girişimcilik becerisinin gelişimini etkileyecek yönde bir girişimcilik bilgisi gelişimi sağlanmaktadır.

\section{Yöntem}

Nicel yaklaşımın uygulandığı bu araştırmada, değişkenleri inceleme biçimine göre "ilişkisel (bağıntısal) araştırma" türünden ve ön-deneysel araştırma deseninin "tek gruplu öntest sontest" türünden faydalanılmıştır. Yansız atamanın ve kontrol grubunun olmadığı, klasik tasarım kullanmanın zor olduğu durumlarda ön-deneysel tasarım kullanılmakta olup, bunun bir çeşidi olan tek gruplu öntest-sontest tasarımında ise tek bir gruba uygulama öncesi bir öntest, sonra bir uygulama ve ardından bir sontest yapılmakta (Neuman, 2007: 207-208) ve uygulamanın etkileri değerlendirilmektedir.

\section{1 İşlem}

Bu çalışma 2017-2018 güz eğitim öğretim döneminde Süleyman Demirel Üniversitesi’nin farklı fakülte, bölüm ve programlarından Üniversite Ortak Seçmeli Girişimcilik dersi kapsamında yürütülen ATOG programını seçen öğrencilerle gerçekleştirilmiştir. Dolayısıyla bu öğrenciler, geleceğin girişimci adayları olarak girişimcilik konusunda anahtar bireyler olup, sosyal yapı içerisinde girişimcilik eğitimine ilişskin ders alan hazır bir grubu temsil etmektedirler. Karma öğrenme yöntemine göre tasarlanan öğrenciyi merkeze alan ATOG programında sınıftaki yüzyüze öğretimle beraber web tabanlı sanal öğrenme biraraya getirilmiştir. Böylece web teknolojilerinin yüz yüze öğrenme ortamlarına entegrasyonuyla birlikte öğrencilerin daha fazla birlikte çalışma imkânına sahip olacakları ve böylelikle sosyal etkileşim alanlarının da genişleyeceği bir ortam yaratılması hedeflenmiş̧tir. Bununla beraber girişimcilik konusunda gerek temel düzeyde bilgi kazanmaları gerekse de uygulamalı olarak deneyim 
kazanmaları beklenmektedir. $\mathrm{Bu}$ hedeflere ulaşabilmek adına 10 modülden oluşan bir planlamayla teorik girişimcilik eğitimi sunulmuştur.

Gençlere öncelikle girişimcilik konusunda farkındalıklarının oluşumuna yönelik olarak teorik çerçevede bilgiler aktarılmıştır. Daha sonra öğrenciler; yönetimseverler, üretimseverler, icatseverler, finansseverler, pazarlamaseverler şeklinde her başlıkta en fazla üçer kişi olmak üzere; 10-12 kişilik gruplara ayrılmışlardır. Dolayısıyla iş alanlarını ve gruplarını kurmuşlardır. Eş zamanlı olarak gençler farklı fakültelerde olduğu için teknoloji temelli birlikteliklerini sürdürebilmeleri için aralarında WhatsApp grupları kurulmuş ve iletişime her an geçmeleri sağlanmıştır. Son olarak web sitesi tanıtılıp, eş zamanlı olarak da grupların kendilerine birer grup lideri seçilmesi istenmiştir. Web tabanlı olarak desteklenen programda öğrenciler edindikleri teorik bilgiler çerçevesinde oluşturdukları iş fikirlerini http://sdugirisimcilik.com adresine yüklerler ve çevrimiçi görüşmelerini gerçekleştirebilirler. Ancak sadece girişimcilik ve beceri bilgisinin kazandırılması, sürekliliğin sağlanmasında yeterli değildir. Dolayısıyla gençler, girişimcilik becerilerinin gelişimi için teorik çerçevede onlara aktarılan bilgilerin bahsedildiği gibi olup olmadığını anlamalarına ve kendileriyle özdeşleştirmelerine yönelik firsatlara ihtiyaç duymaktadırlar. Bu bağlamda iş dünyasından profesyonellerle gençlerin biraraya gelebileceği ortamlar oluşturularak, mentor buluşmaları ve 7 modül uygulamalı etkinliklerle gençlerin girişimcilik becerilerinin gelişimi beklenmektedir. Ancak planlanan bazı misafir konuşmacıların programları iptal edilmiş ve zaman ve imkan kısıtı sebebiyle bazı uygulamalı etkinlikler gerçekleştirilememiş ve ders dişı etkinliklerle sürecin desteklenmesi sağlanamamıştır. Ayrıca 4. hafta itibariyle 33 mentorun kendi alanlarına uygun 28 iş fikri grubuyla eşleşmeleri tamamlanmış ve ekiplerin her hafta mentorlarıyla düzenli olarak yüzyüze veya web üzerinden iş fikirlerini geliştirmelerine yönelik olarak görüşme yapmaları beklenmektedir. Ancak iş dünyasından katılan mentorların yoğun programı sebebiyle bu görüşmeler düzenli olarak gerçekleştirilememiştir. Yoğun emek sarfedilen dönemin sonunda düzenlenen 1. ATOG çalıştayında ekipler jüri karşısında iş fikirlerinin sunumunu gerçekleştirmiş ancak bütçe kısıtı sebebiyle kendilerine herhangi bir ödül sunulmamıştır. Üniversite Ortak Seçmeli Girişimcilik dersi, zorunlu olarak farklı eğitmenler tarafından sağlandığından, araştırma ATOG eğitimini veren eğitmenin rolünün homojen olduğu varsayımı ile sınırlıdır.

\subsection{Katılımcilar}

Süleyman Demirel Üniversitesinde öğrenim gören ve ATOG dersini alan 350 öğrenciye gönüllülük esasına göre araştırmaya katılmaları teklif edilmiştir. Öntest ve sontest eşleşmelerinin gerçekleştirilebilmesi için katılımcıların öğrenci numaralarını belirtmeleri istenmiştir. Çalışmada, planlanan haftalarda söz konusu olan derse gelerek o an sınıfta bulunan öğrencilerden veri toplandığı için toplam mevcudun ön testte \%64'üne ulaşılmış (224 katılımcıya); son testte \%67,7'sine ulaşılmış (237 katılımcıya), ulaşılan bu katılımcılar içerisinden de ön ve sontest verisi eşleşen analizlere esas teşkil eden kullanılabilir veri sayısı $161(\% 46)$ olmuştur.

Katılımc1lar 2017-2018 güz döneminde üniversitede bütün bölümlerdeki öğrencilerin seçebildiği girişimcilik dersini alan öğrencilerden oluşmuştur. Öntest ve sontestin gerçekleştirildiği derslerde mevcut olup her iki teste de katılan ve öntest-sontest eşleştirmesi yapılabilen öğrenci sayısı 161 olmuştur. Katılımcıların \%48,4'ü kadın, \%51,6'sı erkektir. 145 katılımcı (\%90,1) 19 ila 22 yaş aralığındadır. 13 katılımcı 23, 2 katılımcı 24 ve 1 katılımcı ise 28 yaşındadır. Katılımcıların \%48,4 İktisadi ve İdari Bilimler Fakültesinden, \%28,0'i Mühendislik Fakültesinden, \%6,2'si Fen Edebiyat Fakültesinden, \%5,6's1 Teknoloji Fakültesinden, \%3,1'i Hukuk Fakültesinden ve kalan \%8,7'si ise bahsedilen fakültelerin dışında kalan diğer 5 fakültedendir. \%23,6'sı 2. sınıf, \%64,0'ü 3. sınıf, $\% 12,4$ 'ü ise 4. sınıf öğrencisidir. \%49,1'i il merkezinde, \%50,9'u ise kırsalda büyümüştür.

\subsection{Veri Toplama Araçları}

Bu çalışmada, alanyazında belli amaçlarla geliştirilmiş, güvenirlik ve geçerliği sınanmış "girişimcilik bilgisi" ve "girişimcilik becerileri”" (Evans, 2009; Linan vd., 2008) ölçeklerinden ve demografik sorulardan oluşturulan bir anketle veri toplanmıştır. Ankette yer alan "girişimcilik bilgisi ölçeği”; (1) Hiç, (2) Düşük, (3) Orta, (4) Yüksek, (5) Çok Yüksek'e kadar uzanan, "girişimcilik becerisi ölçeği” ise, (1) Çok Zayıf, (2) Zayıf, (3) Orta, (4) İyi, (5) Çok İyi biçiminde beşli Likert tipi ölçeğe uygun olup her iki ölçek de 7 maddeden oluşmaktadır. Katılımcıların ATOG eğitimi sonrasında, öncesine göre girişimcilik bilgi ve becerilerinin betimsel olarak ne ölçüde etkilendiğini belirlemek için Uygun ve Güner'in (2016) çalışmasından yararlanılmıştır. Uygun ve Güner'in (2016) çalışmasına göre ilgili ölçeklerin güvenilirlik değerleri Tablo 1'de gösterilmiştir.

\begin{tabular}{lcc} 
Ölçekler & Cronbach's Alpha Katsayıları \\
\hline & Ön-Test & Son-Test \\
Girişimcilik Bilgisi Ölçeği &, 85 &, 88 \\
Girişimcilik Becerisi Ölçeği &, 81 &, 85 \\
\hline
\end{tabular}

Tablo 1. Girişimcilik Bilgi ve Beceri Ölçeklerine Yönelik Güvenilirlik Analizi Sonuçları Kaynak: Uygun, M. ve Güner, E. (2016). Girişimcilik Ĕ̆iliminin Gelişiminde Girişimcilik Eğitiminin Rolü, Manas Sosyal Araştırmalar Dergisi, 5(5): 37-57.

Katılımcıların ATOG eğitimi öncesine göre bir iş ya da proje yürütmeye ilişkin bir plan oluşturabilme, yenilikçi bir ürün ya da hizmet geliştirebilme, bir iş ya da proje için bütçe oluşturabilme ve yönetebilme, bir iş ya da proje 
için gerekli finansmanı bulabilme, bir ürün ya da hizmete yönelik bir pazar planı oluşturabilme, bir ürün ya da hizmeti pazarlayabilme ve bir işe / projeye başlamak için bir zaman çizelgesi oluşturabilme bilgilerinde eğitim sonunda değişiklik olup olmadığı merak edilmektedir. Benzer şekilde girişimcilik becerileri açısından ATOG eğitimi öncesinde katılımcıların problem çözme, parayı yönetme, işletme için sermaye sağlama, karar alma, liderlik, iş firsatlarının farkına varma ve insanları kendi fikrine ikna etme yeteneklerinde eğitim sonunda değişiklik olup olmadığı merak edilmektedir. Bu bağlamda verilerin analizinde SPSS programı kullanılmıştır.

\section{Bulgular}

Girişimcilik bilgisi ve girişimcilik becerisi ölçeklerinin güvenilirlik düzeylerini tespit etmek için Cronbach'ın Alfa katsayısı hesaplanmıştır. Girişimcilik bilgisi ölçeğinin Cronbach'ın Alfa katsayısı öntest için 0,847 , sontest için 0,869'dur. Girişimcilik becerisi ölçeğinin Cronbach'ın Alfa katsayısı ise öntest için 0,751, sontest için 0,791'dir. Her bir ölçeğin altında yer alan maddelerin aritmetik ortalaması alınarak öntest ve sontest için girişimcilik bilgisi ve girişimcilik becerisi değişkenleri oluşturulmuştur. Ayrıca her bir katılımcı için sontest ile öntestin farkı hesaplanarak girişimcilik bilgisi $\Delta$ test ve girişimcilik becerisi $\Delta$ test değişkenleri oluşturulmuştur. Bahsi geçen değiş̧kenlere ilişkin temel istatistikler Tablo 2'de sunulmuştur.

\begin{tabular}{lcccc} 
Değişken & Ortalama & $\begin{array}{c}\text { Standart } \\
\text { Sapma }\end{array}$ & $\begin{array}{c}\text { Çarpıklık/ } \\
\text { Standart Hata }\end{array}$ & $\begin{array}{c}\text { Basıklı/ } \\
\text { Standart Hata }\end{array}$ \\
\hline Girişimcilik bilgisi öntest & 3,356 & 0,675 & $-0,136$ & 0,626 \\
Girişimcilik bilgisi sontest & 3,600 & 0,661 & 0,979 & $-1,360$ \\
Girişimcilik bilgisi $\Delta$ test & 0,244 & 0,645 & 1,932 & 0,776 \\
Girişimcilik becerisi öntest & 3,766 & 0,611 & $-0,696$ & $-0,426$ \\
Girişimcilik becerisi sontest & 3,826 & 0,607 & $-0,131$ & $-1,734$ \\
Girişimcilik becerisi $\Delta$ test & 0,060 & 0,553 & 1,838 & 7,174 \\
\hline
\end{tabular}

\section{Tablo 2. Temel Istatistikler}

Veriler 5'li Likert ölçeği ile toplandığı için öntest ve sontest değişkenlerinin alabileceği maksimum değer 5, mimimum değer ise 1 'dir. Orta nokta ise 3 'tür. Katılımcıların eğitim öncesi girişimcilik bilgi ve beceri düzeyleri orta seviyenin üzerindedir $\left(\mu_{\text {bilgi }}=3,356, \mu_{\text {beceri }}=3,766\right)$. Eğitim sonrası ortalamalar sayısal olarak pozitif yönde artış göstermiştir. Bilgi ve beceri $\Delta$ test ortalamaları pozitiftir. Bununla beraber girişimcilik becerisi artışı oldukça düşük gözükmektedir $\left(\Delta\right.$ test $\left._{\text {beceri }}=0,060\right)$. Verilerin parametrik testlere uygunluğunu kontrol etmek için Field'ın (2005:88) önerdiği yöntem kullanılmışıtr. Çarpıklık ve basıklık değerleri standart hataya bölünerek $\mathrm{z}$ değerleri hesaplanmıştır. \%95 güven düzeyinde $\mathrm{z}$ değeri $-1,96$ ila 1,96 arasında olduğu durumda çarpıklık veya basıklığa ilişkin hipotez reddedilmemektedir. Sadece girişimcilik becerisi $\Delta$ test verilerinin basık olduğu sonucuna ulaşılmıştır. Diğer tüm verilerde herhangi bir çarpıklık veya basıklık bulgusuna rastlanmadığı ve verilerin parametrik testlere uygun olduğu sonucuna ulaşılmıştır. Girişimcilik becerisi $\Delta$ test değişkeninin yer aldığı analizlerde ise non parametrik testlerin alternatifi olarak kullanılan bootstrap prosedürü (DiCiccio \& Efron, 1996; Grunberg, 2001; Hayes \& Preacher, 2013:36-38) ile analiz bulguları kontrol edilmiştir.

Eğitimin katılımcıların gelişimine etkisini görmek için öntest sontest sonuçları karşılaştırılmıştır. Girişimcilik bilgisi ve girişimcilik becerisi öntest ve sontest sonuçları arasındaki farklar hem eşleştirilmiş̧ örneklemler $t$ testi (paired samples $t$ test) hem de tekrarlı ölçümler ANOVA testi (repeated measures ANOVA testi) ile incelenmiştir. Bulgular Tablo 3'te verilmiştir.

\begin{tabular}{lcccc} 
Değişken & $\Delta$ & $\mathbf{t}^{*}$ & $\mathbf{F}^{* * *}$ & $\mathbf{p}$ \\
\hline Girişimcilik bilgisi öntest - sontest & 0,244 & 4,808 & 23,117 & $<0,001$ \\
Girişimcilik becerisi öntest - sontest & 0,060 & 1,370 & 1,878 & 0,172 \\
\hline
\end{tabular}

\footnotetext{
"Paired-Samples t test

*** Repeated Measures, $N=161$
}

Tablo 3. Öntest Sontest Sonuçlarının Karşılaştırllması

Katılımcıların ortalama girişimcilik bilgi düzeyi 3,356'dan 3,600'e yükselerek 0,244'lük bir artış göstermiştir $(p<0,001)$. Bununla beraber katılımcıların girişimcilik beceri düzeyindeki değişim anlamlı düzeyde değildir $(\mathrm{p}=0,060)$. Eğitim, katılımcıların bilgi seviyesini yükseltme konusunda başarı sağlamış olup beceri gelişiminde herhangi bir etki göstermemiştir. " $\mathrm{H}_{1}$ : ATOG eğitimi, katılımcıların girişimcilik bilgisinde gelişim sağlar" hipotezi kabul edilmiş, " $\mathrm{H}_{2}$ : ATOG eğitimi, katılımcıların girişimcilik becerisinde gelişim sağlar" hipotezi ise reddedilmiş̧tir. Katılımcılara; ailesinde girişimci olup olmadığı, daha önce iş deneyimi olup olmadığı, çocukluğunu geçirdiği çevrenin kent mi yoksa kırsal mı olduğu sorulmuştur. Eğitimin katkısını bu tür arka planların etkileyip etkilemediği merak edilmiştir. Katılımcıların \%34,8'inin ailesinde girişimci vardır. \%74,5'inin iş deneyimi olmuştur. \%49,1'i çocukluğunu il merkezinde geçirmiştir. Eğitimin gelişime katkısı, tekrarlı ölçümler ANOVA testi 
ile bahsi geçen değişkenler (cinsiyet değişkeni de dahil edilerek) bağlamında incelenmiştir. Eğitimin gerek girişimcilik bilgisine gerek girişimcilik becerisine katkısında cinsiyetin, ailede girişimci olmasının ve iş deneyiminin herhangi bir etkisinin olmadığı sonucuna ulaşılmıştır ( $\mathrm{p}>0,05)$. Bununla beraber kişinin çocukluğunu geçirdiği çevrenin il merkezi veya kırsal olmasına göre eğitimin katkısı değişmektedir. Tekrarlı ölçümler ANOVA bulguları Tablo 4'de sunulmuştur.

\begin{tabular}{llccc} 
Değișken & Çevre & $\Delta$ & F $^{*}$ & p \\
\hline Girişimcilik bilgisi öntest - & Il merkez & 0,129 & \multirow{2}{*}{5,088} & \multirow{2}{*}{0,025} \\
sontest & Kirsal & 0,355 & & \\
\hline Girişimcilik becerisi öntest - & Il merkez & 0,078 & \multirow{2}{*}{0,175} & 0,677 \\
sontest & Kirsal & 0,042 & & \\
\hline
\end{tabular}

${ }^{*}$ (Repeated Measures) X (İl merkez / Kırsal), $N_{\text {il merkez }}=79, N_{\text {krral }}=82$

\section{Tablo 4. Ĕgitimin Katkısında Kişinin Çocukluğunu Geçirdiği Çevrenin Etkisi}

Girişimcilik becerisi gelişimi açısından, kişinin büyüdüğü muhitin il merkezi veya kırsal olmasının eğitimin katkısında herhangi bir etkisi bulunmamaktadır ( $>00,05)$. Girişimcilik bilgisi gelişiminde ise eğitimin katkısı, kırsalda büyüyenlerde il merkezinde büyüyenlere göre daha fazla olmuştur $(p<0,05)$. İl merkezinde büyüyenlerin girişimcilik bilgisi öntest ve sontest skorları eşleştirilmiş örneklemler t testi ile karşılaştırılmış ve bu kesimde anlamlı bir gelişim olmadığı sonucuna ulaşılmıştır $\left(\Delta_{\mu}=0,129, \mathrm{t}=1,715, \mathrm{p}=0,09\right)$. Yani çocukluğu il merkezinde geçenlerin girişimcilik bilgisi eğitimle beraber anlamlı düzeyde gelişim göstermemiştir. Kırsalda büyüyenlerin bilgi gelişimi ise anlamlı düzeydedir $\left(\Delta_{\mu}=0,355, \mathrm{t}=5,324, \mathrm{p}<0,001\right)$. Çocukluğu kırsalda geçenlerin, eğitimle beraber girişimcilik bilgisi artmıştır. Girişimcilik bilgisindeki gelişimde il merkezi - kırsal ayrımı Grafik 1'de gösterilmiştir.

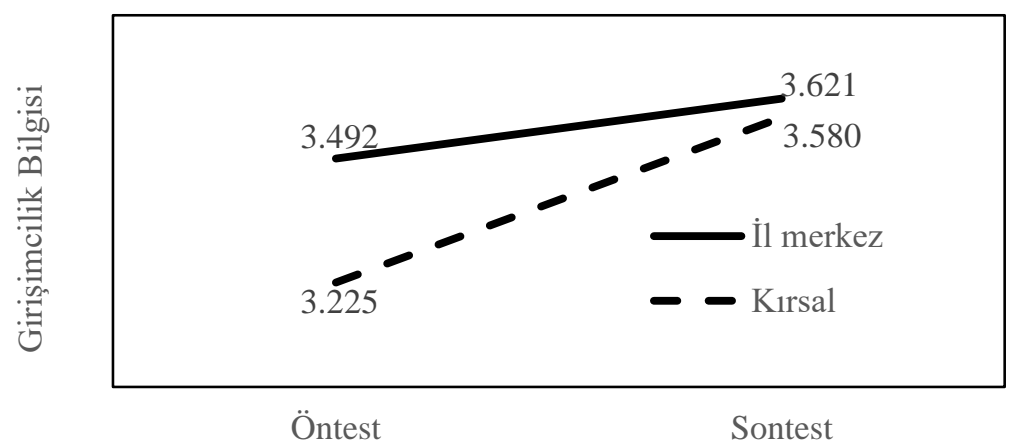

Grafik 1. Girişimcilik Bilgisi Gelişimine Kişinin Büyüdüğü Çevrenin Düzenleyici Etkisi

Grafikten de anlaşılacağı üzere, eğitimin girişimcilik bilgisi gelişimine etkisinde kişinin büyüdüğü çevrenin düzenleyici etkisi olduğu söylenebilir. Kırsalda büyüyenlerde girişimcilik bilgisi gelişimi daha fazla olmuştur. Burada öntest sonuçlarındaki il merkezi - kırsal ayırımına dikkat edilmesi gerekir. Eğitim öncesinde kırsalda büyüyenlerin girişimcilik bilgi düzeyi $(\mu=3,225)$ il merkezinde büyüyenlerin bilgi düzeyine $(\mu=3,492)$ göre daha düşüktür $(t=2,548, p<0,05)$. Eğitim sonrasında ise kırsalda büyüyenlerin girişimcilik bilgi düzeyi $(\mu=3,580)$ ile il merkezinde büyüyenlerin girişimcilik bilgi düzeyi $(\mu=3,621)$ arasında anlamlı bir fark söz konusu değildir $(\mathrm{t}=0,387, \mathrm{p}>0,05)$. Kırsalda büyüyenler eğitimlere daha düşük bir bilgi düzeyi ile başlamış, eğitimle beraber il merkezinde büyüyenlerin seviyesini yakalamıştır.

Normal şartlarda bireyin girişimcilik bilgisi ile girişimcilik becerisi arasında bir ilişki olduğu, önceki çalışmalarda yer almaktadır (Akmaliah vd., 2012; DeTienne ve Chandler, 2004; Gorman vd., 1997; Graevenitz vd., 2010; Hong vd., 2012; Jaafar ve Aziz, 2008; Oosterbeek vd., 2010; Uygun ve Güner, 2016). Bu çalışmada da bu ilişki incelenmiştir. Gerek öntest gerek sontest verilerinde girişimcilik bilgisi ile girişimcilik becerisi arasında bir korelasyon beklenmelidir. Bununla beraber sontest-öntest farkından elde edilen $\Delta$ test verilerinde nasıl bir ilişki olduğu önemlidir. $\Delta$ test verileri eğitimin sağladığı değişim verileridir. $\Delta$ test verilerindeki ilişkiler eğitimin yapısal değerini gözlemlemek açısından önemlidir. $\Delta$ test verilerinde de normal şartlardaki ilişkiler gözlemlenebiliyorsa, eğitimin yapısal anlamda nitelikli bir değişime katkı sağladığı söylenebilir. Öntest, sontest ve $\Delta$ test verilerindeki girişimcilik bilgisi ve girişimcilik becerisi arasındaki korelasyon bulguları Tablo 5 'te sunulmuştur. 


\begin{tabular}{lcccc} 
Değişkenler & & Öntest & Sontest & $\Delta$ test \\
\hline Girişimcilik Bilgisi X Girişimcilik & $r$ & 0,605 & 0,768 & $0,365^{*}$ \\
Becerisi $^{*}$ & $p$ & $<0,001$ & $<0,001$ & $<0,001$ \\
\hline "Hesaplanan katsayılar Pearson korelasyon katsayılarıdır. $N=161$ & & \\
"Girişimcilik Becerisi $\Delta$ test verileri normal dağılım göstermediği için korelasyon testi 1000 bootstrap ile tekrar \\
edilmiş, \%95 güven aralığının üst sınırı 0,548, alt sınırı 0,190 elde edilmiş, korelasyonun anlamlı olduğu sonucuna \\
ulaşılmıştır.
\end{tabular}

Tablo 5. Girişimcilik Bilgisi İle Girişimcilik Becerisi Arasındaki Korelasyon

Öntest ve sontest ölçümlerinde beklendiği gibi girişimcilik bilgisi ile girişimcilik becerisi arasında yüksek bir korelasyon gözlemlenmiştir $\left(\mathrm{r}_{\text {ötest }}=0,605, \mathrm{r}_{\text {sontest }}=0,768, \mathrm{p}<0,001\right)$. Bununla beraber $\Delta$ test için yapılan hesaplamada elde edilen korelasyon katsayısı anlamlı düzeyde olsa da düşüktür $\left(\mathrm{r}_{\Delta \text { test }}=0,365, \mathrm{p}<0,001\right)$. Eğitimin sağladığ 1 gelişimde çarpıklığın söz konusu olduğu söylenebilir. Eğitim, bilgi ve beceri gelişimini sağlamaya yönelik dizayn edilmiş olsa da önceki bulgularda belirtildiği üzere, bilgi gelişimine belli ölçü de katkı sağlamış olsa da beceri gelişimine anlamlı bir katkı sağlayamamıştır. Korelasyon bulguları ise, katılımcıların bilgi düzeylerindeki değişim ile beceri düzeylerindeki değişimin yeterince paralellik arz etmediğini göstermektedir.

Bilginin, beceri gelişiminin temelinde olması gerekir (Güneş, 2012: 6). Bu durumda girişimcilik becerisini belli ölçüde girişimcilik bilgisinin tahmin ediyor olması beklenir. Bu sebeple korelasyon bulgularının etki analizi ile gözden geçirilmesinin daha isabetli olacağı düşünülmüştür. Normal şartlarda girişimcilik bilgisi, girişimcilik becerisini hangi ölçüde tahmin etmektedir? Eğitimin sağladığı girişimcilik bilgisi değişimi, girişimcilik becerisi değişimini hangi ölçüde tahmin etmektedir? Bu sorulara cevap aramak için öntest, sontest ve $\Delta$ test verileri ile ayrı ayrı regresyon analizi gerçekleştirilmiştir. Analiz bulguları Tablo 6'da paylaşılmıştır.

\begin{tabular}{|c|c|c|c|c|c|}
\hline $\begin{array}{l}\text { Bağımlı } \\
\text { Değişken }\end{array}$ & $\begin{array}{l}\text { Bağımsız } \\
\text { Değişken }\end{array}$ & & Öntest & Sontest & $\Delta$ test \\
\hline \multirow{9}{*}{$\begin{array}{l}\text { Girişimcilik } \\
\text { becerisi }\end{array}$} & & $\mathrm{R}^{2}$ & 0,366 & 0,590 & 0,133 \\
\hline & & $\mathrm{F}(1,159)$ & 91,942 & 228,669 & 24,461 \\
\hline & & $\mathrm{p}(\mathrm{F})$ & $<0,001$ & $<0,001$ & $<0,001$ \\
\hline & \multirow{3}{*}{ Girişimcilik bilgisi } & $\beta$ & 0,548 & 0,705 & $0,313^{*}$ \\
\hline & & $S E$ & 0,057 & 0,047 & 0,063 \\
\hline & & $p(\beta)$ & $<0,001$ & $<0,001$ & $<0,001$ \\
\hline & \multirow{3}{*}{ Sabit } & $\beta$ & 1,929 & 1,288 & $-0,017$ \\
\hline & & $S E$ & 0,195 & 0,171 & 0,044 \\
\hline & & $p(\beta)$ & $<0,001$ & $<0,001$ & 0,700 \\
\hline
\end{tabular}

\section{Tablo 6. Girişimcilik Bilgisinin Girişimcilik Becerisine Etkisi}

Her üç regresyon testi de anlamlı sonuç vermiştir $(\mathrm{p}<0,001)$. Hem öntest hem de sontest ölçümlerinde girişimcilik bilgisi girişimcilik becerisini yüksek katsayılarla tahmin etmektedir $\left(\beta_{\text {öntest }}=0,548, \beta_{\text {sontest }}=0,705\right.$, $\mathrm{p}<0,001)$. $\Delta$ test skorlarına göre ise bu katsayı düşük kalmaktadır $\left(\beta_{\Delta \text { test }}=0,313, \mathrm{p}<0,001\right)$. Girişimcilik bilgisindeki değişim, girişimcilik becerisindeki değişimi düşük düzeyde tahmin etmektedir. Eğitim belirli ölçüde girişimcilik bilgisi gelişimi sağlamış olsa da bu gelişim girişimcilik becerisindeki gelişime yeterince etki edecek yönde olmamıştır. " $\mathrm{H}_{3}$ : ATOG eğitimleriyle, girişimcilik becerisinin gelişimini etkileyecek yönde bir girişimcilik bilgisi gelişimi sağlanmaktadır." hipotezi reddedilmemiştir fakat hipotezde bahsi geçen etkinin düşük düzeyde olduğu belirtilmelidir. Başka bir ifadeyle eğitimle beraber, büyük oranda beceri gelişiminden kopuk bir bilgi gelişimi söz konusu olmuştur. Eğitimdeki faaliyetler bilgi ve beceri gelişimine yönelik tasarlanmış olsa da eğitimin bazı yapısal sorunlar taşıdığı sonucuna ulaşılmıştır.

\section{Sonuç ve Tartışma}

Bu çalışmada Türkiye Girişimcilik Stratejisi ve Eylem Planı çerçevesinde başarılı girişimcilik eğitim modelleri esas alınarak teorik ve oyun tabanlı uygulamalı etkinliklerinin gerçekleştirildiği ATOG (Ă̆ ve Teknoloji Odaklı Uygulamalı Girişimcilik) eğitiminin gençlerin girişimcilik bilgi ve beceri gelişimine etkisi incelenmiştir. Bu bağlamda 2017-2018 güz eğitim öğretim döneminde Süleyman Demirel Üniversitesi'nin farklı fakülte, bölüm ve programlarından Üniversite Ortak Seçmeli Girişimcilik dersi kapsamında yürütülen ATOG programını seçen 2. 3. ve 4. sınıfta okuyan 350 öğrencinin ATOG programı öncesi durumları da dikkate alınarak bir araştırma yapılmıştır. ATOG programı gençlerin girişimcilik bilgi ve becerisini geliştirmeye yönelik olarak tasarlanmış olsa da araştırma bulgularına göre katılımcıların girişimcilik bilgisinde gelişim sağlanmasına rağmen, girişimcilik becerisinde 
gelişim sağlanmamış ancak girişimcilik becerisinin gelişimini düşük düzeyde etkileyecek yönde bir girişimcilik bilgisi gelişimi sağlanmıştır. Bu sonuçlara ulaşılmasında aşağıdaki maddelerin etki ettiği düşünülmektedir:

-Teorik girişimcilik eğitimi: Gençlerin girişimcilik konusunda farkındalık kazanmaları ve bilgi gelişimine yönelik olarak ATOG programında 10 modülden oluşan teorik çerçevede temel girişimcilik eğitimi sunulmuştur.

-Oyun tabanlı uygulamalı etkinlikler: Girişimcilik eğitimleri günümüzde artan bir ilgi görmektedir. Teorik eğitimi destekler nitelikte uygulamalı etkinliklerin gerçekleştirilmesinin hem teoriyi pekiştirici bir etki ortaya koyacağı hem de girişimci düşüncenin uygulamaya geçmesine ve kişinin öz yeterlilik algısına katkı sağlayacağ düşünülmektedir. Böylece oyun tabanlı uygulamalı etkinliklerle gençlerin "yaparak öğrenme"leri sağlanmaktadır (Efeoğlu, vd., 2016: 24). Uygulamalı etkinliklerle eğitimin oyunlaştırılmasının öğrenci başarısı (Ar, 2016; Buckley ve Doyle, 2014; Faghihi vd.,2014; Rouse, 2013), derse yönelik tutumu (Harrold, 2015; Polat, 2014) ve motivasyonu (Measles ve Abu-Dawood, 2015; Rouse, 2013) üzerinde olumlu bir şekilde etki edeceğini belirten çalışmalar mevcuttur. Ancak her ne kadar teorik olarak eğitim sürecinde oyunlaştırmanın beklenen etkiyi gösterebileceği düşünülse de, pratikte işe yarayıp yaramadığına karar verecek olanlar şüphesiz öğrencilerdir (Yıldırım, 2017: 237). ATOG programında 7 modül oyun tabanlı uygulamalı etkinlikler gerçekleştirilmiş, zaman ve imkan kısıtı sebebiyle planlanan 3 modül etkinlik gerçekleştirilememiştir. Gençlerin \%79’u eğitimin uygulama odaklı gerçekleşmesinden memnun olduğunu belirtmiştir.

-Web tabanlı destek: ATOG programı gençlerin iş fikirlerini yükleyebilecekleri çevrimiçi görüşmeleri gerçekleştirebilecekleri web tabanlı (http//sdugirisimcilik.com) olarak karma öğrenme yöntemine göre tasarlanmıştır. Ancak karma öğrenme yöntemine göre tasarlanan derslerde planlanan pedagojik yaklaşım olmadan basit ve yüzeysel bir şekilde yüz yüze ve çevrimiçi ortamların bir araya getirilmesi yeterli değildir. Başarılı eğitim ortamları oluşturmak için pedagojinin üzerinde durularak uygun teknolojilerle birlikte tasarlanması gerekmektedir (Dziuban \& Moscal, 2001). Oysa ATOG'da pedagojik yaklaşımın gözardı edilmesi, web sitesinin kullanıcı geri bildirimleriyle şekillenmesi sebebiyle web tabanlı sistem yeterince etkin şekilde kullanılamamıştır.

-Mentor buluşmaları: Gençlerin iş dünyasıyla buluşturulması hedeflenen ATOG programında iş dünyasından gönüllülük esasına göre seçilen 33 mentor gruplarla eşleşmiş ve ekiplerin mentorlarla iş fikirlerini geliştirmelerine yönelik düzenli olarak haftalık görüşme yapmaları beklenmektedir. Ancak çoğu mentorlar iş yoğunluğu veya farklı sebeplerle görüşmeleri gerçekleştirmemiştir.

-Misafir Konuşmacılar: Türkiye Girişimcilik Stratejisi ve Eylem Planı'nda da belirtildiği üzere gençlerin, girişimcilik becerilerinin gelişimi için teorik çerçevede onlara aktarılan bilgilerin bahsedildiği gibi olup olmadığını anlamaları ve kendileriyle özdeşleştirmelerini sağlayacak onları iş dünyasıyla buluşturacak eğitim programlarına ihtiyaç bulunmaktadır. ATOG programında planlanan bazı misafir konuşmacıların farklı nedenlerle gelememeleri sebebiyle 1'i yabancı olmak üzere 2 konuşmacı programda gençlerle deneyimlerini paylaşmıştır. Prof. Dr Walleck Dalpour'un sunumunu İngilizce gerçekleştirmesi sebebiyle gençlerin sunumu anlamada zorlandıkları görülmüştür.

Dolayısıyla gençlerin ATOG programında aldıkları 10 modülden oluşan teorik çerçevede temel girişimcilik eğitimi onların girişimcilik bilgisinde gelişim sağlamıştır. Girişimcilik becerisinin gelişiminde ise sadece teorik bilginin öğrencilere kazandırılmasının sürekliliğin sağlanmasında yeterli olmayacağı düşüncesiyle oyun tabanlı uygulamalı etkinlikler, karma öğrenme yöntemine göre web tabanlı destek, mentor buluşmaları ve misafir konuşmacıların sunumları planlanmıştır. Ancak yukarıda bahsedildiği üzere zaman ve imkan kısıtı sebebiyle planlanan 3 modül uygulamalı etkinliğin gerçekleştirilememesi, karma öğrenme yönteminde web tasarımında pedagojik yaklaşımın gözardı edilmesi, web sitesinin kullanıcı geri bildirimleriyle şekillenmesi ve etkin kullanılamaması, ekiplerin mentorlarıyla düzenli olarak görüşmelerinin gerçekleştirilememesinin gençlerin girişimcilik becerilerinde beklenen gelişimin sağlanamamasına neden olduğu düşünülmektedir. Öte yandan öğrenmenin anlam kazanabilmesi için bilgi becerileri geliştirmek için zihinde yapılandırılır, beceriyle ilişkilendirilir ve bilgiler uygulandıkça beceri geliştirilir (Güneş, 2012: 6). ATOG eğitimleriyle de, girişimcilik becerisinin gelişimini düşük düzeyde etkileyecek yönde bir girişimcilik bilgisi gelişimi sağlanmıştır.

Çalışmada ayrıca katılımcı öğrencilerin, çocukluğunu geçirdiği çevrenin kent mi yoksa kırsal mı olduğu sorulmuş ve ATOG eğitiminin katkısını bu tür arkaplanların etkileyip etkilemediği araştırılmıştır. Araştırma bulgularına göre ATOG eğitiminin girişimcilik bilgisi gelişimine etkisinde kişinin büyüdüğü çevrenin düzenleyici etkisi bulunmaktadır. Kırsalda büyüyenlerde girişimcilik bilgisi gelişimi daha fazla olmuştur. Daha önceki araştırma bulgularına göre (Kulak, 2011: 78; Fidan ve Nam, 2012: 56; Can ve Karataş, 2007: 253; Soysal, 2013:183) Türkiye'de kırsal alanda girişimcilik faaliyetlerini engelleyen unsurlar arasında eğitim düzeyinin düşüklüğü yer almaktadır. Bu çalışmada da kırsalda büyüyenler eğitimlere daha düşük bir bilgi düzeyi ile başlamış, eğitimle beraber il merkezinde büyüyenlerin seviyesini yakalamıştır.

Bu kapsamda ve yerelde ilk olarak gerçekleştirilen ATOG eğitiminin uzun vadeli etkileri araştırılmamıştır. Başka çalışmalarda uzun vadeli etkilerinin incelenmesi yerinde olacaktır.

\section{Kaynakça}

- Ağca, 2007. Avrupa Birliğinin Girişimcilik Politikası ve Türkiye’ye Yansımaları. Gazi Kitabevi, Ankara. 
- Akmaliah, Pihie ve Bagheri, 2012.” An Exploratory Study of Entrepreneurial Attributes Among Malaysian University Students". Life Science Journal. 9 (3), p.2358-2365.

- Alberti, Sciasci ve Poli, 2004. "Entrepreneurship Education: Notes on an Ongoing Debate”, 14th Annual Int. Ent. Conference, University of Napoli Federico II, 4-7 July, Italy.

- Ar, 2016. The Effects Of Gamification On Academic Achievement And Learning Strategies Usage Of Vocational High School Students, Yayımlanmamış Yüksek Lisans Tezi, Sakarya Üniversitesi, Bilgisayar ve Öğretim Teknolojileri Eğitimi, Sakarya.

- Binks, Starkey ve Chistopher, 2006. "Entrepreneurship Education and the Business School”, Technology Analysis and Strategic Management, 18(1), p. 1-18.

- Bozkurt Çetinkaya, 2011. Dünyada ve Türkiye'de Girişimcilik Eğitimi: Başarılı Girişimciler ve Öğretim Üyelerinden Öneriler, Detay Yayıncılık, Ankara.

- Bozkurt, Aslan ve Göral, 2011. "Yüksek Öğretimde Verilen Girişimcilik Eğitiminin Öğrencilerin Girişimcilik Eğilimine Etkisi: Teknik Program ve Sosyal Program Karşılaştırmalı Bir Araştırma”, İstanbul: Uluslararası Yönetim Kongresi: Yeni Yönelişler ve Sorunlar, 2.cilt, Bölüm VIII, 822-833.

- Buckley ve Doyle, 2014. “Gamification and Student Motivation”. Interactive Learning Environments, 24(6), p. 1162-1175.

- Can ve Karataş, 2007. "Yerel Ekonomilerde Kalkınmanın İtici Gücü Olarak Kadın Girişimcilerin Rolü ve Mikro Finansman: Muğla İli Örneği”, Selçuk Üniversitesi Karaman I.I.B.F. Dergisi, Mayıs, p.251-261.

- DeTienne ve Chandler, 2004.“Opportunity Identification And Its Role In The Entrepreneurial Classroom: A Pedagogical Approach And Empirical Test”. Academy of Management Learning and Edu. 3(3), p.242-257.

- DiCiccio ve Efron, 1996. Bootstrap Confidence Intervals(with Discussion). Statistical Science. 11, p.189228.

- Dilsiz ve Kölük, 2005. Girişimcilik. Detay Yayıncılık, Ankara.

- Dziuban ve Moscal, 2001. "Evaluating Distributed Learning At Metropolitan Universities". Educause Quarterly, 24(4), p. 60-61.

- $\quad$ Efeoğlu, Pekkan, Ciritci ve Çanşali, 2016. “Girişimcilik Eğitiminde Yeni Metotlar: Girişimcilik Oyunu Örneği”, Organizasyon ve Yönetim Bilimleri Dergisi, 8(2), p.17-26.

- $\quad$ Ekici ve Turan, 2017. "Üniversite Öğrencilerinin Girişmcilik Eğilimi: Planlanmış Davranışlar Teorisi ve Girişimcilik Eğitiminin Rolü”, Ç.Ü Sosyal Bilimler Enstitüsü Dergisi, 26(1), p. 201-215.

- Elgin, 2014. Girişimcilik Öğretilebilir mi?, Start Up. https://startup.capital.com.tr/kose-yazarlari/ihsanelgin/girisimcilik-ogretilebilir-mi.html (16.03.2019).

- Evans, 2009. The Psychology Of Entrepreneurial Intention in Black Adolescents: Racial Identity, Role Models And Self-Efficiency. San Francisco: Alliant International University, California School of Professional Psychology.

- $\quad$ Faghihi, Brautigam, Jorgenson, Martin, Brown, Measures, ve Maldonado-Bouchard, 2014. "How Gamification Applies For Educational Purpose Specially With College Algebra”. BICA2014, Procedia Computer Science, 41, p.182-187.

- Fidan ve Nam, 2012. "Kırsal Turizmde Yeni Dinamikler: Kadın Girişimciler- Taraklı Örneği”, KMÜ Sosyal ve Ekonomik Araştırmalar Dergisi, 14 (23), p. 51-57.

- $\quad$ Field, 2005. Discovering Statistics Using SPSS, 2.Bask1, Sage Publications, London, UK.

- GİSEP-Türkiye Girişimcilik Stratejisi Ve Eylem Planı 2015-2018

- Gorman, Hanlon ve King, 1997. “Some Research Perspectives On Entrepreneurial Education, Enterprise Education And Education For Small Business Management: A Ten Year Review". International Small Business Journal. 15 (3), p.56-77.

- Graevenitz, Hardoff ve Weber, 2010. “The Effects Of Entepreneurship Education”. Journal of Economic Behavior Organization. 76, p.90-112.

- Grunberg, 2001. "Bootstrapping And The Problem Of Testing Quantitative Theoretical Hypotheses". Philosophy Of Science, 10, p.143-150.

- Güneş, 2012. "Bologna Süreci İle Yükseköğretimde Öngörülen Beceri Ve Yetkinlikler, Yükseköğretim Ve Bilim Dergisi, 2(1), p.1-9.

- Harrold, 2015. Game On: A Qualitative Case Study On The Effects Of Gamified Curriculum Design On Student Motivational Learning Habits, Doktora Tezi, Robert Morris University. 
- Hayes ve Preacher, 2013. Conditional Process Modeling: Using Structural Equation Modeling To Examine Contingent Causal Processes. In G. R. Hancock And R. O. Mueller (Eds.) Structural Equation Modeling: A Second Course (2nd Ed). Charlotte, NC: Information Age Publishing.

- Hong, Hong, Cui ve Luzhuang, 2012. “Entrepreneurship Quality Of College Students Related To Entrepreneurial Education, Empirical Study On Psychological And Behavioral Characteristics". Energy Procedia. 17, p.1907-1913.

- Jaafar ve Aziz, 2008. "Entrepreneurship Education in Developing Country: Exploration On its Necessity in The Construction Program”. Journal Of Engineering, Design And Technology. 6 (2), p.178-189.

- Krueger ve Brazeal, 1994. "Entrepreneurial Potential And Potential Entrepreneurs". Entrepreneurship Theory And Practice. 18 (4), p.91-104.

- Kulak, 2011. Tarımsal Üretim Süreçlerindeki Değişimin Kırsal Alanda Kadın İstihdamına Etkileri: 1980 Sonrası Gelişmeler, T.C. Başbakanlık Kadının Statüsü Genel Müdürlüğü, Uzmanlık Tezi, Afşaroğlu Matbabas1, Ankara.

- Kuratko, 2003. Entrepreneurship Education: Emerging Trends And Challenges For The 21th Century. Muncie, IN : Coleman Foundation White Paper Series.

- Linan, Moriano ve Zarnowska, 2008. Stimulating Entrepreneurial Intentions Through Education. Madrid: Universidad Nacional De Educacion A Distanci.

- Matlay, 2006. "Entrepreneurship Education More Questions Than Answers?", Educational Training, 48(5), p.293 - 295 .

- Measles ve Abu-Dawood, 2015. “Gamification: Game-Based Methods And Strategies To Increase Engagement And Motivation Within An Elearning Environment”. Society For Information Technology \& Teacher Education International Conference içinde (p. 8319-8324).

- McLarty, 2005. “Entrepreneurship Among Graduates: Towards A Measured Response”, The Journal Of Management Development, 24(3), p. 223-243.

- Neuman, L.W. (2007). Basic Of Social Research Qualitative And Quantitative Approaches, 2nd Edt. Pearson Education, Inc.

- Oosterbeeg, Praag, ve Ijseelstein, 2010. “The Impact Of Entreprenurship Education On Entrepreneurship Skills and Motivation”, Europen Economic Review, 54, p. 442-454.

- Özdemir, 2016. “Girişimci Üniversiteler Ve Türkiye’de Girişimcilik Eğitimi”, Doktora Tezi, Marmara Üniversitesi, SBE, İşletme, İstanbul.

- Özdemir, Yılmaz, Arzu ve Polat, 2016. "Türkiye'de Girişimcilik Eğitimi Üzerine Bir İnceleme", International Journal Of Human Sciences. 13(1), p. 569-581.

- $\quad$ Polat, 2014. A Case Study: Gamification And Its Effect On Motivation Of Learners Of English, Yüksek Lisans Tezi, Çă̆ Üniversitesi, SBE, Mersin.

- Raichaudhuri, 2005. "Issues in Entrepreneurship Education”, Decision, 32(2), p.73-84.

- Rasmussen ve Sorheim, 2006. "Action Based Entrepreneurship Education", Technovation, 26(2), p.185-194.

- Rouse, 2013. Gamification In Science Education: The Relationship Of Educational Games To Motivation And Achievement (Doktora Tezi). The University Of Southern Mississippi, USA.

- Sanchez, 2013. "The Impact Of An Entreprenurship Education Program On Entreprenurial Competencies And Intention”, Journal Of Small Business Management, 51(3), p. 447-465.

- Soysal, A. 2013. "Kırsal Alanda Kadın Girişimciliği: Türkiye İçin Durum Değerlendirmesi”, Eskişehir Osmangazi Üniversitesi İ̈BF Dergisi, 8(1), p.163-189.

- Tahiroğlu ve Meydan, 2017. “Okul Kooperatifçilik Çalişmalarinin Öğrencilerin Girişimcilik Becerileri Ve Girişimci Kişilik Özellikleri Açisindan Değerlendirilmesi”, 3.Sektör Sosyal Ekonomi, 52, p.572-586.

- Tanrıverdi, Bayram ve Alkan, 2016. "Girişimcilik Eğitiminin Girişimcilik Eğilimi Üzerine Etkisinin İncelenmesi”. Girişimcilik Ve Kalkınma Dergisi, 11(1), p. 1-29.

- Tjan, 2004. "Education Entrepreneurs”, Innovation, 15(1), p.71-72.

- Uğur, 2015. Girişimcilik Eğitiminin İlköğretim Programlarına Konulmasına Yönelik Model Önerisi, Yüksek Lisans Tezi, Anadolu Üniversitesi, SBE, Eskişehir.

- Uygun ve Güner, 2016. “Girişimcilik Eğiliminin Gelişiminde Girişimcilik Eğitiminin Rolü”, Manas Sosyal Araştırmalar Dergisi, 5(5), p. 37-57.

- Valerio, Parton ve Robb, 2014. "Entrepreneurship Education and Training Programs Around The World: Dimensions For Success”, Washington DC, The World Bank 
- Volkman, 2004. "Entrepreneurship Studies- An Ascending Academic Discipline in The Twenty-First Century", Higher Education In Europe, 29(2), p. 177-185.

- Yelkikalan, Akatay, Yıldırım, Karadeniz, Köse, Koncagül ve Özer, 2010. "Dünya ve Türkiye Üniversitelerinde Girişimcilik Eğitimi: Karşılaştırmalı Bir Analiz”, KMÜ Sosyal ve Ekonomik Araştırmalar Dergisi, 12(19), p. 51-59.

- Yıldırım, 2017. "Eğitimin Oyunlaştırılmasına İlişkin Öğrenci Algıları: Bir Q Metodu Analizi, Eğitim Ve Bilim”, 42(191), p. 235-246. 


\title{
Kripto Para Bitcoin ve Türkiye' deki Bitcoin Piyasası Crypto Currency Bitcoin and Bitcoin Market in Turkey
}

\author{
Assoc. Prof. Dr. Hakan Acet (Selçuk University, Turkey) \\ Ph.D. Candidate Ayşe Özge Diken (Selçuk University, Turkey)
}

\begin{abstract}
Bitcoin, which emerged in 2008 and is now being used rapidly in various sectors, is a crypto currency. Bitcoin was revealed by Satoshi Nakamoto (who or who is not specific to the person or a group). An official or private regulator is exported independently of the institution and therefore has no guarantee. Bitcoin was first used in the market in 2009. Although more than one crypto currency has emerged, Bitcoin has maintained its leadership since its release. However, in the years ahead, another crypto currency, Ethereum, will also go ahead of Bitcoin. Although there are countries that are prohibited to be used in countries of the world, the number of countries in which it is used is increasing day by day. In Turkey, shipping fees, employee salaries, cost of books, such as food shopping are being used in many fields.
\end{abstract}

\section{Giris}

Teknolojinin hızla ilerlediği çağımızda paranın kullanım şekli de hızla değişim göstermektedir. İstenilen herhangi bir nesneye ulaşabilmek için malların değiş/tokuş yöntemi ile satın alınmasıyla başlayan para sistemi, sonralarında altın ve kâğıt paraların kullanımı ile değişimine devam etmiştir. Günümüze de ise para daha çok sanal bir sistemde varlığını sürdürmektedir. Bu sistem bankalar aracılığı ile havale, EFT, kredi kartları vb. araçlar ile yapılabilmektedir. Bankacılık sistemi ile yapılan bu işlemlerin daha da hızlanmasındaki etkenler, paranın taşınma maliyetinin azalması ve çok daha hızlı işlem yapılabilmesi olarak gösterilebilir.

2008 yılından sonra ise bankacılık sisteminden ayrılarak para, yeni bir değişim ile karşımıza çıkmıştır; kripto para Bitcoin. Satoshi Nakamoto (kim ya da kimler olduğu belirli olmayan kişi veya bir grup) tarafindan ortaya çıkarılan, resmi veya özel bir regülatör kurumdan bağımsız olarak ihraç edilen ve dolayısıyla güvencesi olmayan kripto para birimi Bitcoin, ilk olarak 2009 yılında piyasada kullanılmaya başlanmıştır. Piyasaya çıkışından bu yana kontrol edilebilir olmaması, hesapların gizliliği, yatırım aracı olabilirliği, kara para aklamaya sebep olması gibi birden fazla konuda tartışmalar yaşanmış ve eleştirilere maruz kalsa da Bitcoin kullanımı giderek yaygınlaşmaya devam etmektedir.

Bu çalışmada sanal bir para olan Bitcoin sisteminin ortaya çıkışı, işleyişi ve günümüzdeki durumu veriler üzerinden tartışarak Türkiye'deki konumunu incelemek amaçlanmaktadır. Böylelikle Türkiye'de hangi alanlarda kullanıldığı tespit edilmeye çalışılarak, yatırım amaçlı mı yoksa ödeme sistemi olarak mı kullanıldığı üzerine yapılan araştırma ile Bitcoin üzerine önerilerde bulunulacaktır.

\section{Kripto Para Bitcoin}

Cyripto ve currency kelimelerinin bir araya getirilmesiyle oluşturulan cryptocurrency şifreli para anlamına gelmektedir. Kriptonun şifre anlamında kullanılma nedeni, sanal cüzdanlardan şifre ile alınıp şifre ile çıkartılmasıdır (Turan, 2018). Başka bir ifade ile kripto para belirlenen bir şifre ile yerleştirildiği sanal cüzdandan aynı şekilde belirlenen bir şifre aracılığıyla çıkarılıp kullanılmaktadır. Kripto para birimleriyle kişi veya kurumlar gerçek para ile yapılan harcamaları gerçekleştirebilir dolayısıyla da para olarak kabul edilebilmektedir. Piyasada Kasım 2018 itibariyle anlık olarak 2.498 adet / 183 milyar dolar değerinde kripto para çeşidi bulunmaktadır (İnvesting, 2018). Bu paraların bazıları ve en popüler olanları şunlar: Bitcoin. Ethereum, Ripple, Bitcoin Cash, Stellar Lumens, EOS, Litecoin, Tether, Cardano, Monero. Sanal olarak adlandırılmalarının sebebi yalnız bilgisayar sisteminde kayıtlı olmalarından kaynaklanmaktadır. Yani bu sanal para birimleri Dolar/Euro/TL gibi basılı bir şekilde fiziksel olarak bulunmamaktadır (Eğilmez, 2017).

Kripto para çeşitlerinin ortak özellikleri şu maddeler ile sıralanabilir (Çarkacıoğlu, 2016):

- Merkezi bir yapıya bağlı olmadığından kripto paranın kontrolü Blok-Zincir işlemi veri tabanları tarafından gerçekleştirilir. Blok zinciri, hesap defteri girişini veya bir hesap hareketi kaydını temsil eden veri yapısıdır. Her hesap hareketi, gerçekliğini koruma altına almak için dijital olarak imzalanır ve kimse bu kayda müdahale edemez.

- Kripto-paralar, kamuoyuna açık ve herkesçe bilinen araçlarla merkezi bir yapıya bağlı olmayan bir kripto sisteminde kuruluş aşamasında belirlenen oranlarda üretilirler.

- Geleneksel elektronik para saklama ve transfer işlemlerinde güvenliği bulunan üçüncü bir kurum/kuruluş vardır. Oysa kripto para sistemlerinde üçüncü bir güvenli kurum/kuruluş yoktur. Güvenlik sistemi ve küresel hesap cüzdanının doğruluğu, birbirine güvenmeyen madenciler aracılığıyla karşılıklı gerçekleştirilir. 
- Sanal kripto paralara olan güvenin sağlanması, sanal paranın ihracına, dolaşım sistemine ve sistem kullanıcılarının çoğunluğunun yanlış yapmayacağına olan inanç ile gerçekleştirilir.

En iyi kripto para olarak adlandırılan sanal paralar ile ilgili temel bilgiler aşağıdaki tabloda yer almaktadır.

\begin{tabular}{|c|c|c|c|c|c|c|}
\hline & İsim & Sembol & Fiyat (USD) & Fiyat (TL) & Toplam Hacim & $\begin{array}{l}\text { Piyasa } \\
\text { Değeri }\end{array}$ \\
\hline$B$ & Bitcoin & BTC & $4.361,00$ & $22.534,10$ & $35,59 \%$ & $\$ 75,86 \mathrm{~B}$ \\
\hline$\asymp$ & Ripple & XRP & 0,40085 & 2,0741 & $3,93 \%$ & $\$ 16,09 \mathrm{~B}$ \\
\hline & Ethereum & ETH & 124,83 & 647,13 & $13,52 \%$ & $\$ 12,92 \mathrm{~B}$ \\
\hline 4 & Bitcoin Cash & $\mathrm{BCH}$ & 199,58 & $1.029,10$ & $0,65 \%$ & $\$ 3,44 \mathrm{~B}$ \\
\hline 19 & Stellar Lumens & XLM & 0,16599 & 0,85248 & $0,51 \%$ & $\$ 3,20 \mathrm{~B}$ \\
\hline & EOS & EOS & 3,3336 & 17,3271 & $4,25 \%$ & $\$ 3,02 \mathrm{~B}$ \\
\hline & Litecoin & LTC & 35,478 & 182,25 & $2,79 \%$ & $\$ 2,11 \mathrm{~B}$ \\
\hline $\mathcal{P}$ & Tether & USDT & 0,98887 & 5,173 & $23,24 \%$ & $\$ 1,85 \mathrm{~B}$ \\
\hline B & Bitcoin Cash SV [IOU] & BSV & 100,100582 & 541,1 & $1,68 \%$ & $\$ 1,71 \mathrm{~B}$ \\
\hline \% & Cardano & $\mathrm{ADA}$ & 0,043788 & 0,22273 & $0,22 \%$ & $\$ 1,13 \mathrm{~B}$ \\
\hline
\end{tabular}

Tablo 1. En Iyi Kripto Para Birimleri Kaynak: Investing, 2018

Kripto para piyasasında şu an 2498 sanal para mevcut olup Bitcoin en bilinen kripto para olarak piyasasında yaklaşık olarak \%36,5 payla en yüksek hacime sahiptir. Bitcoin'i takip eden an itibariyle kripto para birimi Tether olup \%23,17 paya sahip ikinci büyük kripto paradır (İnvesting, 2018). İlk çıktı̆̆ı zamanlarda yüksek fiyatlarla piyasaya giren Bitcoin'in sürekli genişleyen kripto sanal para piyasasında oluşan rekabet ile pazar payını düşürmektedir. Mevcut kripto paraların sıralamalarına bakıldığında fiyat hacim olarak ilk sırada Bitcoin'in yer aldığı görülmektedir. Bu sıralama zamanla değişebilmektedir. Fakat genel itibari ile bakıldığında Bitcoin diğer kripto paralara göre en yüksek hacim ve fiyata sahip olmuştur.

Bitcoin (BTC), son zamanlarda hacim ve gün geçtikçe kapsamı genişleyen bir sistemle yaygın bir alışveriş ortamı olarak meydana gelen ilk kripto para birimidir (Eyal ve Sirer, 2018). Bitcoin dünya çapında kullanılabilen ve merkezi bulunmayan rezervasyon sisteminin ilk örneği olarak gösterilebilir. İlk kripto para olan Bitcoin bu özelliklerinin yanı sıra kriptografik olarak yasal bir şekilde alınarak basitleştirilmesi anlamına gelen bir dijital para birimidir (Alpago, 2016).

\subsection{Bitcoin Üretimi ve İşleyişi}

En fazla kullanılan sanal para Bitcoin'in çalışma şekli kriptografi (şifreleme) yöntemi ile yapılmaktadır. Bitcoin'de para transferi diğer kripto para birimlerinin özelliğinde de olduğu gibi hiçbir merkezi otorite aracılığ ile yapılmamakta ve takip de edilmemektedir. Para transfer işlemi, merkezi bir sunucu olmadan bilgisayar sistemleri arasında dosya paylaşımı ile gerçekleşmektedir. Bu prensibin adı denkler arası/eşitler arası (peer to peer, P2P) elektronik para transferidir (Pirinçci, 2018).

Bitcoin üretimi teorik olarak bakıldığında herkes tarafından yapılabilir. P2P ağı içerisinde tamamlanan para transferleri diğer noktalara çok kısa sürede ulaşır ve böylece hangi hesaptan hangi hesaba ödeme yapıldı̆̆g kayıt altına alınmış olur. Bu sayede kayıt altına alınan ödemeler blok zinciri (block-chain) adı verilen yapıların içerisinde işlenir. İşlemlerin yer aldığı yeni bir blok yaratıldığında, madenciler bu bloktaki bilgileri işlemden geçirirler. Bu bilgiler üzerinde uygulanan matematiksel formüller ile blok içerisindeki işlemlerin yer aldığı uzun listenin rakamlar ile oluşturulan bir özeti çıkarılır. Buna "hash" adı verilir. Her bir blok üzerinde çok fazla sayıda işlem gerektiren bir sağlama olan hash algoritması uygulaması yapılarak, belli bir sıfır sayıyla başlayan ifadenin bulunması gerekmektedir. Bu şekilde karmaşık bilgisayar kümeleri kullanılır ve karmaşık matematiksel eşitliklerin çözülmesi sonrasında Bitcoin 'in piyasaya girişi gerçekleşmiş olmaktadır. Bu işlemlerin tamamına "madencilik" adı verilmektedir. Bu işlemleri yapmak için, sunulan Bitcoin yazılımı indirilmektedir. Donanımlar üzerinde yüksek işlemci gücü gerektiren işlemleri tamamlayan Bitcoin ağındaki kullanıcılara "Bitcoin Madencisi (Bitcoin Miner)" adı verilmektedir (Gültekin ve Bulut, 2016). 
Madenciler, bilgisayarlarının işlem gücü çerçevesinde Bitcoin Maden Yazılımı tarafından sunulan ve karmaşık işlem gerektiren eşitlikleri çözmeye çalışıp, ilk çözümü üreten kullanıcıya belirlenen miktardaki Bitcoin, otomatik olarak üretilerek ödül olarak verilmektedir. Bu üretim bilgisi P2P ağındaki bütün kullanıcılara iletilmektedir. Problemin çözümü sonrasında, söz konusu yazılım tarafından bir önceki problemden daha zor bir işlem çözülmek üzere madencilere verilmektedir. Bu süreç devam ettikçe, çok daha yüksek işlemciye sahip bilgisayarlara olan ihtiyaç artmakta ve günümüz ev kullanıcılarının donanım gücü yetersiz kalmaktadır. Bitcoin maden yazılımı daha önce belirlenen üretim eşikleri tamamlandıkça verilecek ödül miktarını yarıya indirecek şekilde tasarlanmıştır. Logaritmik bir yol izleyen bu üretim şeması, 21 milyon Bitcoin rakamına ulaştığında duracak ve yeni üretime izin verilmeyecektir. Geleceğin para birimi olarak görülen Bitcoin'in 21 milyon adet gibi belirli bir limitinin olması çelişki olarak görülebilmektedir. Fakat1 Bitcoin 'in, 108 değerine kadar bölünebildiği ve ağ sistemi içinde temsil edilebildiği hesaba katıldığında, dolaşımdaki limitin yeterli olacağı ve üretim sorunu yaşanmayacağı düşünülmektedir (Atik, vd, 2015).

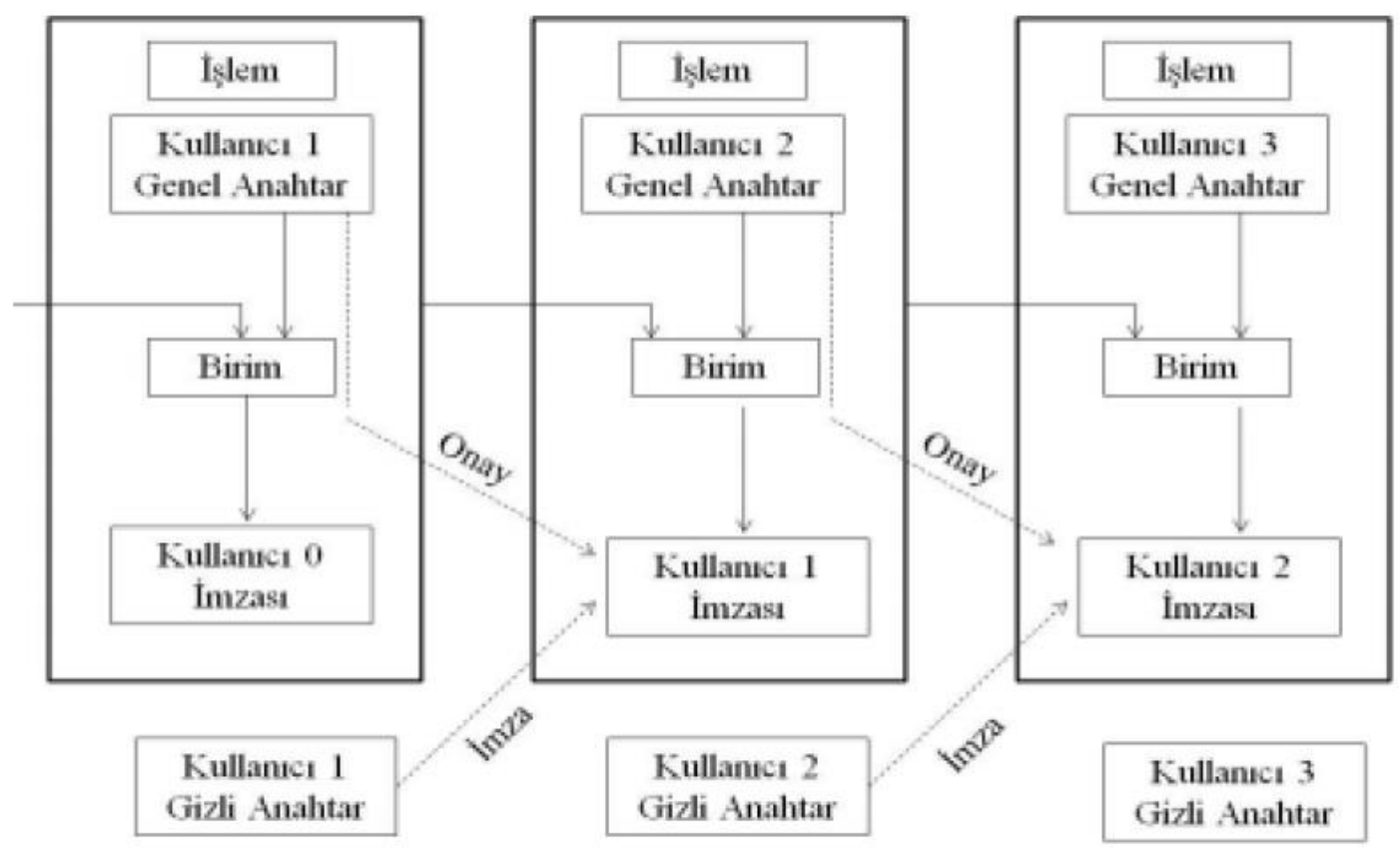

Şekil 1. Bitcoin İşlem Şeması Kaynak: Nakomato, 2008

Bitcoin cüzdanının yüklenmesi ile birlikte ilk Bitcoin adresi şekillenecek ve ihtiyaç olması halinde bir yenisi yaratılabilecektir. Bu cüzdanların adreslerinin herkesin görebilmesini sağlanmak, kullanıcı çevresinin kendisine ödeme yapmasını veya tam tersini sağlayabilmektedir. Bir başka ifadeyle e-posta sisteminin benzeri şekilde işleyişi bulunur fakat Bitcoin adreslerini yalnız bir işlem için kullanılması tavsiye edilir. Bütün onaylanmış işlemler blok zincirine eklenmektedir. Bu şekilde Bitcoin cüzdanlarında bulunan bakiyeyi hesaplayabilir ve yeni işlemler kullanıcıya ait olan Bitcoin harcamaları onaylanabilir. Blok zincirinin tamamı ve kronolojik sırası kriptografi ile desteklenir. Bitcoin cüzdanları, işlemleri gerçekleştirmek için kullanılan özel anahtar veya kaynak adı verilen bir parça bilgiyi saklar ve bu bilgi işlemlerin kullanıcı tarafından yapıldığına dair matematiksel bir kanıt niteliği taşır. İmza, işlem bir kez tanımlandıktan sonra herhangi başka bir kullanıcı tarafından değiştirilebilmesini engeller. Bütün işlemler kullanıcılar arasında görüntülenir ve çoğu kez 10 dakika içinde madencilik işlemi içerisinde ağ tarafından onaylanmaya başlar. Blok zincirinde kronolojik sıra bulunur, ağın tarafsızlığı korunur ve farklı bilgisayarların sistem içerisinde birleşmesini sağlar. Onaylanmaları için işlemler ağ tarafından belirlenen çok sıkı kurallar ile korunan bir bloğa yerleştirilir. Bu kurallar önceki blokların değiştirilmesini engeller çünkü değiştirilme durumunda bundan sonraki bloklar geçersiz olacaktır. Bunun yanı sıra madencilik, kimsenin kolayca üst üste yeni blokları blok zincirine eklemesini önler ve rekabet ortamı yaratılır. Bu şekilde hiçbir madenci, blok zincirine dâhil olan veya olmayanları kontrol edemez ve blok zincirinin parçalarını değiştirip harcanan paraları geri alamaz, sadece ödemeyi alan kullanıcı tarafindan geri ödeme yapılabilir. Bitcoin imla hatalarını tespit ederek genellikle geçersiz veya yanlış bir adrese para gönderilmesine de olanak sağlamaz (Bitcoin, 2018).

\subsection{Bitcoin Piyasası}

22 Mayıs 2010'da Laszlo takma isimli bir kullanıcı, Bitcoin karşılığında, 2 adet pizza satın almıştır. Pizzayı başka bir Bitcoin kullanıcısı, 10.000 Bitcoin karşılığında, Dominos'tan Laszlo adına satın alıp adresine yollatmıştır. 22 Mayıs 2010, Bitcoin'in tarihte ilk defa takas aracı olarak kullanıldığı gün olduğundan, dünyanın birçok bölgesinde 22 Mayıs Laszlo'nun Pizza Günü olarak kutlanmaktadır. Bitcoin'in değeri, bilinen her türlü mal, ürün, hizmet ve parada belirlendiği gibi, talep ve arzın bir araya geldiği ve dengede olduğu noktada belirlenir. Bu değer, 
coğrafi olarak kullanılabilirliği, yaygınlaşabilmesi, kabul edilebilmesi, yatırımcının güveni, gerçek hayatta ödeme aracı olarak kullanılabilmesi ve pazarın o anki esnekliği ile ilişkilidir (Çarkacıoğlu, 2016).

Çoğu ülkeler Bitcoin’i aktif olarak kullanmasına karşın bazı ülkeler tanımamıştır. Japonya, Kanada, ABD, Fransa, İngiltere, Almanya gibi ülkelerde Bitcoin kullanım alanı oldukça fazladır. Finlandiya Merkez Bankası Bitcoin'in elektronik bir ödeme aracı bile olamayacağını açıklamıştır. Norveç, Kore ve Almanya'nın devlet başkanları ise Bitcoin'in para tanımına uymadığını belirtmişlerdir. Çin Merkez Bankası Bitcoin'in gerçek para olmadığını açıklayarak 2014 yılında kullanımını yasak getirmiştir. Fakat Ocak 2016' da Çin Merkez Bankası kendi dijital parasını geliştirmek için bazı çalışmalara başlamıştır. Türkiye'de ise durum 2016'dan itibaren değişiklik arz etmiştir. Türk Lirası - Bitcoin paritesini düzenleyen BtcTürk ve Koinim borsaları, bu iki para değerleri arasında değişim yapmaktadır. Dünyadaki ilk Bitcoin ATM'si Kanada'da bulunmaktadır. Türkiye'deki ilk Bitcoin ATM'si ise İstanbul Atatürk havalimanında açılmıştır (Turan, 2018).

Bitcoin ile ilgili 2009 yılından 2018 Kasım ayı sonu itibariyle dolaşım hacmi, USD bazında değeri aşağıdaki grafiklerde gösterilmektedir.

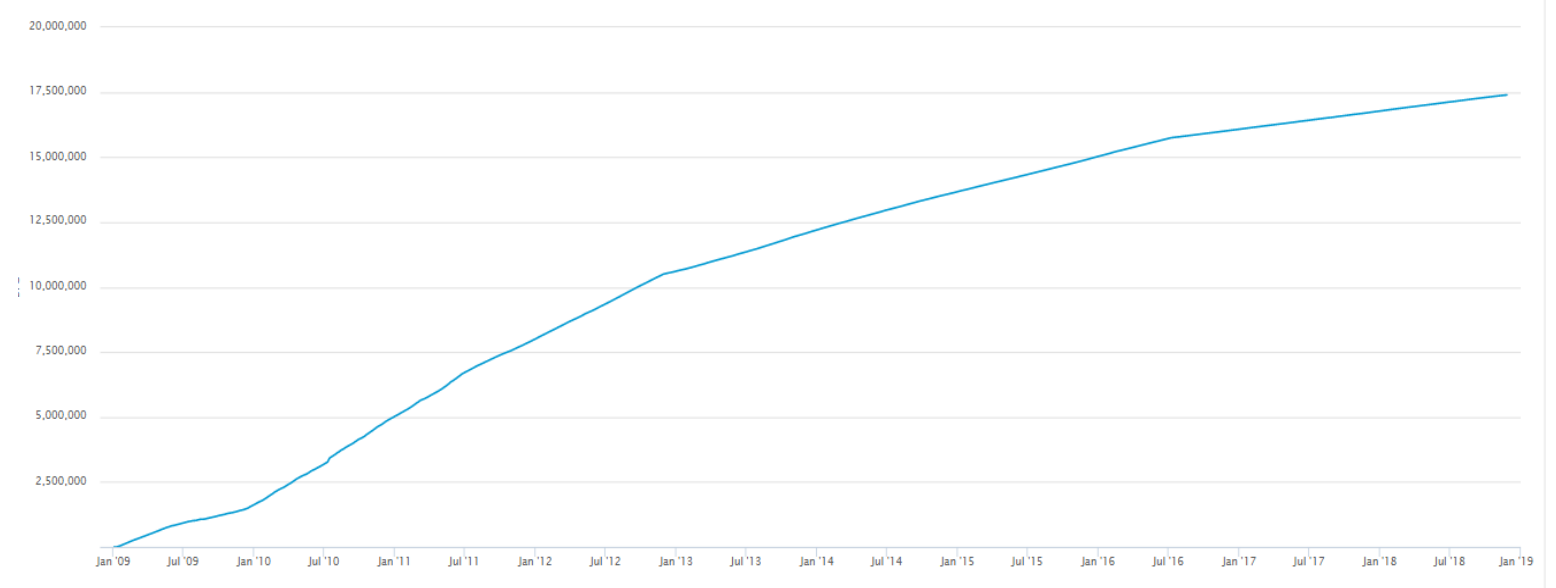

Şekil 2. Dolaşımdaki Toplam Bitcoinler Kaynak: Blockchain, 2018

2009 yılının Ocak ayı başlarında 50 BTC hacmi ile başlayan dolaşımdaki Bitcoin sayısı 26.11.2018 tarihi itibariyle 17.395.363 BTC sayısına kadar ilerlediği görülmektedir. Grafiğe bakıldığında Bitcoin’de, ortaya çıkışından bu yana her gün düzenli olarak artış olduğu anlaşılmaktadır.

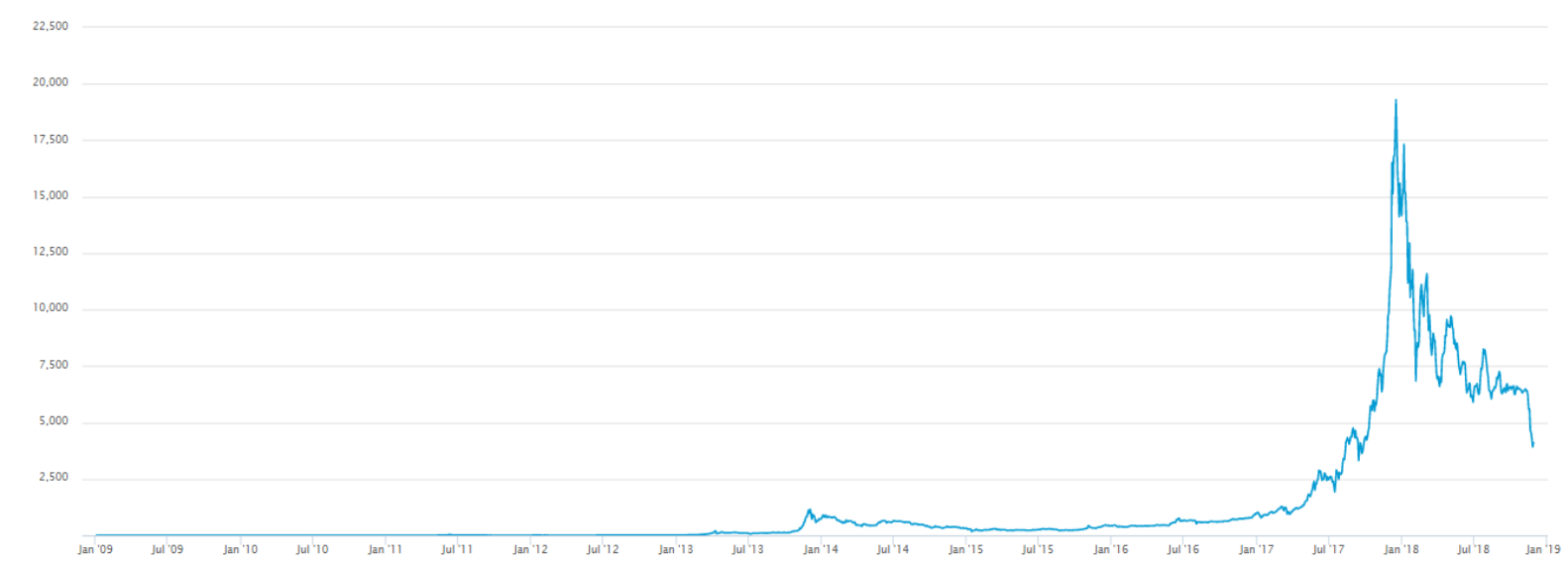

Şekil 3. Bitcoin Piyasa Fiyatı Kaynak: Blockchain, 2018

Bitcoin'in kripto para piyasalarında işlem görmeye başlamayıp kur değerinin ortaya çıtığı tarih olan 2010 yılından 01.04.2013 tarihi aralığında BTC/USD paritesi 100 USD fiyatının altında ve düz bir seyir izlemektedir. Fakat bu tarihten sonra o güne kadarki en yüksek USD değeri 17.12.2017 tarihinde 19.920 USD olmuş, 30.11.2018 tarihinde ise 4.107 USD değerine kadar gerilemiştir. Bitcoin kurunun bugün ulaştığı değere bakıldığında, Bitcoin kullanılarak küresel çapta yapılan ilk alışveriş olan 2009 yılındaki 10.000 BTC karşılığında satın alınan pizzanın neden "tarihin en pahalı pizzası” olarak söylendiğini de açıklamaktadır (Dulupçu, vd, 2017). 


\section{Türkiye'de Bitcoin}

Dünyada olduğu gibi ülkemizde de Bitcoin'in yaygınlaşması 2009'dan günümüze kadar sürekli olarak kullanımı her geçen gün daha da yaygınlaşmaktadır. Türkiye'de Bitcoin'in kullanımı farklı şehirlerde ve çeşitli sektörlerde görülmeye başlanmıştır: Avukatlık, danışmanlık, bilişim ve müteahhitlik ücretlerinden, futbolcu transfer bedeline, alışveriş merkezi veya havaalanında kurulan kiosklarda satın alıp anında harcamaya ve tatil rezervasyonu yapmaya kadar çok geniş bir çerçevede Bitcoin'in kullanımı mümkün olup hatta Türkiye'de çalışanlarına Bitcoin'le ödeme yapan firmalar bile bulunmaktadır. Türk Lirası ile Bitcoin alıp satma imkanının bulunduğu borsalar dahi sanal ortamda hizmet vermektedir (Dizkırıcı ve Gökgöz, 2018).

Ülkemizde Bitcoin'in yasal kullanımı hakkında Bankacılık Düzenleme ve Denetleme Kurumu (BDDK) 25 Kasım 2013'te Bitcoin ile ilgili yaptığı açılması şöyledir (BDDK, 2013). 'Herhangi bir resmi ya da özel kuruluş tarafindan ihraç edilmeyen ve karşılı̆̆ için güvence verilmeyen bir sanal para birimi olarak bilinen Bitcoin, mevcut yapısı ve işleyişi itibarıyla Kanun kapsamında elektronik para olarak değerlendirilmemekte, bu nedenle de söz konusu Kanun çerçevesinde gözetim ve denetimi mümkün görülmemektedir. Diğer taraftan, Bitcoin ve benzeri sanal paralar ile gerçekleştirilen işlemlerde tarafların kimliklerinin bilinmemesi, söz konusu sanal paraların yasadışı faaliyetlerde kullanılması için uygun bir ortam yaratmaktadır. Ayrıca Bitcoin, piyasa değerinin aşırı oynak olabilmesi, dijital cüzdanların çalınabilmesi, kaybolabilmesi veya sahiplerinin bilgileri dışında usulsüz olarak kullanılabilmesi gibi risklerin yanı sıra yapılan işlemlerin geri döndürülemez olmasından dolayı operasyonel hatalardan ya da kötü niyetli satıcıların suistimalinden kaynaklı risklere de açıtır.'

İlgili açıklamadan da anlaşılacağı üzere Türkiye'de Bitcoin elektronik para statüsünde değildir. Bununla birlikte Bitcoin kullanımı, alım veya satımı yasak olmadığı halde yasal bir çerçeve içerisinde yer almadığından vergilendirilme durumu da söz konusu değildir. Bunun yanı sıra Bitcoin'den para kazananların gelir vergisi ve KDV ödemeleri konusunda Gelir İdaresi, Maliye Bakanlığı ile Sermaye Piyasası Kurulu Merkez Bankası'na kazancın adının belirlenerek vergiye tabi tutulması adına çalışmalara da başlanmıştır.

Şubat 2018 de ise Ekonomi Bakanı yaptı̆̆ı açıklama da ise Türkiye'nin blockchain teknolojisi ile kendi sanal para birimini oluşturmasının sağlıklı olmadığını belirtmiştir. Ayrıca blockchain teknolojisi üzerinden oluşturulacak değerin bir para birimi anlamına gelmediğini de dile getirmiştir. Bunun sebebi olarak ise bilginin işlenmesi, saklanması, depolama ve güvenliğinden kaynaklandığını açıklamıştır. Daha önceleri ise 'saadet zinciri' olarak adlandırılan kripto paranın Türkiye'nin kendi kripto para birimini üretmeye girişmeyeceği de kamuoyuna sunulmuştur. Saadet zinciri ile ilgili Çarkacıoğlu' nun 2016 yılında yaptığı açıklaması ise şöyledir. Bitcoin kaldıraç etkisiyle işlem görmez, satın alınması tam finansmanla olur, bu sebeple balon değildir. Bitcoin'in sahibi yoktur, fiyatı tamamen piyasa koşullarında belirlenir, fiyatındaki oynaklık sebebiyle kar veya zarar edilmesi önceden tahmin edilemez. Bu sebeplerle, bir tür saadet zinciri de (Ponzi Scheme) değildir (Çarkacı̆̆glu, 2016).

Ülkemizde Bitcoin kullanımı ile yapılan araştırmada, çıkışından bu yana gün geçtikçe kullanım alanının çoğaldığı görülmektedir. Türkiye'de Bitcoin ile bir web sitesi üzerinden sanat eseri alınabilmektedir. Gıda mağazasından zeytinyağı, Aydın İlinde gayrimenkul satışı yapan bir emlakçıdan ev, yine online bir platformda ikinci el kitap alışverişi, İstanbul'da müzik şirketinden bir plak, Bilecik'te eczaneden bir ilaç alınabilir veya hukuk bürosundan bir avukat tutulabilmektedir (Listelist, 2018). Şirketlerin yanı sıra bireysel eşyaların satışı karşılığında Bitcoin kabul edenler de bulunmaktadır. Boğaziçi Üniversitesi öğrencilerinin kurduğu bir müzik grubu bilet satışlarını Bitcoin ile yaptığını açıklamıştır.

Kripto para birimleri gıda emtia ticaretinde de kullanılmaya başlamış ve ilk ticareti Türkiye'de gerçekleşmiştir. Rusya'nın Rostov limanından Türkiye'de Samsun limanına yapılan bir buğday ticaretinde taşıma masrafı ödemesi Bitcoin ile yapılmıştır. Böylelikle dünyada ilk kez bir navlun ücreti Bitcoin ile ödenmiştir (t24 haber, 2018).

Bunun yanı sıra kötü amaçlı kullanım yerleri de bulunmaktadır. Kaçak elektrik kullanımının yoğun olduğu Güneydoğu Anadolu Bölgesi’e Bitcoin madencilerinin yöneldiği, Diyarbakır İlinde yapılan yoğun şikâyet üzerinde yapılan araştırmada Kaçak Bitcoin madenciliği yapılan alanlarda bir fabrika kadar elektriğin tüketildiği tespit edilmiştir.

Herhangi bir yasak olmadığı sürece tüm bu gelişmeler kripto para Bitcoin' in Türkiye'de çeşitli sektörlere yayılacağını işaret etmektedir. Önemli olan bir kontrol mekanizması altında ilerleyebilmesini sağlamaktır. Ancak bu mekanizma sistemin ilerlemesine engel olmadan, mağduriyet veya ihlal yaşanmasına izin vermeden çalışmayı esas almalıdır.

\section{Sonuç}

Kripto para Bitcoin'in, yüzyıllardır kullanılan para sistemine göre oldukça yeni sayılacak bir tarihçesi bulunmaktadır. Tamamen teknolojik bir ürün olarak karşımıza çıktığından çağımıza getirdiği blokchain teknolojisi de farklı alanlarda kullanılmaya devam etmektedir. Bu özelliği ise gelişime ve geliştirmeye açık olduğunu göstermektedir. 
Bitcoin, denetime tabi olmayan, masraf ve komisyonların bulunmadığı, gün geçtikçe ödeme aracı olarak kullanılan sektörlerin artış gösterdiği bir kripto para birimidir. 2009 yılından beri gelişimine bakıldığında fiyatında iniş çıkışlar olmuş fakat hacmi düzenli olarak artış eğilimindedir. Bu durum Bitcoin'in dünyaca kabul edildiği ve gitgide yaygınlaştığını göstermektedir. Nitekim yaygınlaşması arttıkça sistemin güvenilirliği artacak ve spekülasyonlar karşısında dayanıklılık kazanacaktır.

Merkezi bir otoriteye bağlı olmaması Türkiye'de olduğu gibi birçok ülkede endişe yaratmaktadır. İzlanda, Bangladeş, Bolivya, Ekvador ve Tayland gibi ülkeler yasa bulunmadığı veya rekabet konusu gerekçeleriyle Bitcoin'i yasaklarken; ABD, Estonya, İsveç, Danimarka, Güney Kore, Hollanda, Finlandiya gibi ülkeler ise nakit kullanımı kaldırmak, dijitalleşme hedefleri doğrultusunda vergi ve KDV indirimleri uygulayarak teşvik vermektedir.

Bunların yanı sıra sistemde oluşan bir çökme ile ödenen paralar geri alınamayacaktır. Dahası kara para aklama, terörün finansmanı gibi kötü amaçlı kullanıma da açıktır. Merkezi bir kontrolün bulunmaması, işlem hatası veya itirazlarda muhatap bulunamayacağından ayrı bir güvenlik sorununu da beraberinde getirmektedir.

Bitcoin, hükümetler açısından endişe verici olsa da avantajları göz önüne alındığında bir firsat olarak değerlendirilebilir. Merkez Bankası, Sermaye Piyasası Kurulu bünyesinde yasal bir çerçeve içerisine alınarak geliştirilmesi, borsada işlem görmesi sağlanmalıdır. Güvenlik sorununun çözümlenmesi yatırım aracı olarak kullanılmasına teşvik sağlayacaktır. Bununla beraber dünya üzerindeki hacmi göz önüne alındığında, dış ticaret işlemlerinde olumlu bir etki yaratacağı düşülmektedir. Yatırım aracı olarak kullanılması, finansal hizmet sektöründe kullanılması ayrıca vergi geliri de sağlayacaktır.

\section{Kaynakça}

- Alpago, 2018. "Bitcoin'den Selfcoin'e Kripto Para”, Uluslararası Bilimsel Araştırmalar Dergisi, 3, p. 411428.

- $\quad$ Atik, vd, 2015. "Kripto Para: Bitcoin ve Döviz Kurları Üzerine Etkileri”, Bartın Üniversitesi İktisadi ve Idari Bilimler Fakültesi Dergisi, 6, p. 249.

- Çarkacıoğlu, 2016. "Kripto- Para Bitcoin”, Sermaye Piyasası Kurulu Araştırma Raporu, Ankara.

- Dizkırıcı ve Gökgöz, 2018. "Kripto Para Birimleri ve Türkiye’de Bitcoin Muhasebesi”, Journal of Accounting, Finance and Auditing Studies, 4, p. 92-105.

- Dulupçu, vd, 2017. "Dijital Ekonominin Yükselen Yüzü: Bitcoin'in Değeri İle Bilinirliği Arasındaki İlişkinin Analizi”, Süleyman Demirel Üniversitesi İktisadi ve İdari Bilimler Fakültesi Dergisi, 22, 2244.

- Eğilmez, 2013, Bitcoin, http://www.mahfiegilmez.com/2013/11/bitcoin.html.

- Eğilmez, 2017, Kripto Paralar, Bitcoin ve Blockchain, http://www.mahfiegilmez.com/2017/11/kriptoparalar-bitcoin-ve-blockchain.html.

- Gültekin, ve Bulut, 2016. “ Bitcoin Ekonomisi: Bitcoin Eko-Sisteminden Doğan Yeni Sektörler Ve Analizi”, Adnan Menderes Üniversitesi SBE Dergisi, 3, p. 82-92.

- http://www.bddk.org.tr/Duyurular/Bitcoin-Hakkinda-Basin-Aciklamasi/512

- https://bitcoin.org/tr/kelime-haznesi\#gizli-anahtar (Erişim tarihi: 28.11.2018)

- https://bitcoin.org/tr/nasil-calisir (Erişim Tarihi: 29.11.2018)

- https://bkm.com.tr/blok-zinciri-blockchain-nedir/ (Erişim Tarihi: 10.11.2018)

- https://listelist.com/bitcoin-ile-turkiyede-alisveris/ (Erişim Tarihi: 01.12.2018)

- https://t24.com.tr/haber/bitcoinle-ilk-uluslararasi-odeme-turkiyede-yapildi,543484 (Erişim tarihi: 04.12.2018).

- https://tr.investing.com/crypto/currencies (Erişim tarihi 14.11.2018)

- https://www.blockchain.com/charts

- https://www.coinkolik.com/bitcoin-rehberi/bitcoin-madenciligi-nedir, (Erişim Tarihi: 26.11.2018).

- Nakamoto, S., 2008, Bitcoin: A Peer-to-Peer Electronic Cash System, http://www.bitcoin.org/bitcoin.pdf.

- Pirinççi, 2018. "Yeni Dünya Düzeninde Sanal Para Bitcoin'in Değerlendirilmesi”, International Journal of Economics Politics Humanities and Social Sciences, 1, p. 48.

- Turan, 2018. "Kripto Paralar, Bitcoin, Blockchaın, Petro Gold, Dijital Para Ve Kullanım Alanları”, Ömer Halisdemir Üniversitesi İktisadi ve İdari Bilimler Fakültesi Dergisi, 11, p. 1-5. 


\title{
Avrasya Ekonomik Birliği’nde Döviz Kuru İşbirliği Perspektifi Prospects for Exchange Rate Cooperation in the Eurasian Economic Union
}

\author{
Asst. Prof. Dr. Junus Ganiev (Kyrgyzstan-Turkey Manas University, Kyrgyzstan) \\ Asst. Prof. Dr. Damira Baigonushova (Kyrgyzstan-Turkey Manas University, Kyrgyzstan)
}

\begin{abstract}
Foreign exchange risk is one of the main factors affecting foreign trade and foreign investment activities. The exchange rate instability in the Eurasian Economic Union members and in Turkey, which is one of the Union's major economic partners, constitutes one of the major economic problems. This situation inevitably affects the foreign economic relations of the countries. Therefore, the leaders of most countries such Turkey and Russia are encouraging to use national currencies in economic relations to reduce the dependence on the dollar, to provide stability in the foreign exchange market and to reduce the risk of exchange rate. One of the basic conditions for the success of these initiatives is the stability of exchange rates between national currencies. This study examines the fluctuations of exchange rates among national currencies of EAEU members and Turkey. The ERM implementation of the European Union and its applicability will be discussed as a solution.
\end{abstract}

\section{Giriş}

Döviz kuru riski dış ticaret ve dış yatırım faaliyetlerini etkileyen temel faktörlerden biridir. Avrasya Ekonomik Birliği üyelerinde ve Birliğin önemli ekonomik ortaklarından biri olan Türkiye'de son yıllarda döviz kuru istikrarsızlığı önemli iktisadi sorunların birini teşkil etmektedir. Bu durum ister istemez ülkelerin dış ekonomik ilişkilerini de etkilemektedir. Bundan dolayı Rusya, Türkiye gibi çoğu ülkelerin liderleri dolara olan bağımlılığ azaltmak, döviz piyasasında istikrarı sağlamak ve döviz kuru riskini azaltmak amacıyla ekonomik ilişkilerin ulusal paralarla yapılmasını teşvik etmektedirler. Belirtmek gerekirse, Türkiye Cumhurbaşkanı Sayın Recep Tayyip Erdoğan, Temmuz 2018'de "Kur baskısı denen olayı frenleyebilecek olan en iyi araçlardan biri, uluslararası platformda milli paralarla ticaret yapmaktır. Bunu Rusya ile konuştuk, kısmen başladık. İran ile kısmen başladık. Çin ile de konuşuyoruz. ... Alış verişi milli paralarla yaptığımız oranda kur baskısı da azalacaktır. Ama bunu tümüyle sıfırlamak tabii ki mümkün değildir” (https://www.timeturk.com/erdogan-cozum-milli-para-ileticaret/haber-930528, erişim tarihi: 13.02.2019) ifadelerini kullanmıştır. Benzer şekilde Rusya Cumhurbaşkanı Vladimir Putin de Eylül 2018'de Doğu Ekonomik Forumu'nda "Milli paralarla yapılan iki taraflı ticareti geliştirmek de doğru bir adımdır. Bu dünya finans sistemi ve dünya ekonomisi açısından doğrudur. Biz buna doğru aşamalı olarak ilerleyeceğiz" diye belirterek, diğer ülkelerle ödemelerin milli paralarla yapılmasının siyasi değil, iktisadi bir mesele olduğunu vurgulamıştır. Temmuz 2015'de ise Putin: "Tarafımızca iktisadi mübadelelerde milli paraları daha geniş kullanma kararı alınmıştır. Bazı ülkelerle özel döviz havuzları oluşturduk. Örneğin, Çin Cumhuriyeti ile birlikte merkez bankalarımız, takas düzenlemesi yaparak karşılık gelen miktarda kaynak alışverişinde bulundu. Ruble-yuan paritesi için vadeli işlemler yapıldı” açıklamasında bulunarak, benzer sistemlerin diğer BRICS ülkeleri ile yapılmasının “ilginç olacağını" ifade etmiştir (https://www.ntv.ru/novosti/1438918/, erişim tarihi: 13.02.2019). Kazakistan Cumhurbaşkanı Nursultan Nazarbayev ise 2003 'de Rusya, Belarus, Ukrayna ve Kazakistan ülkeleri arasında "altın" isimli ortak para birimi oluşturma önerisinde bulunmuştur (https://ria.ru/20030401/360448.html, erişim tarihi: 13.02.2019).

$\mathrm{Bu}$ inisiyatiflerin başarılı olmasının temel koşullarından biri kur riskinin düşük olması, yani ulusal paraların kendi aralarındaki döviz kurunun istikrarlı olmasıdır. Bu nedenle, AEB üyelerinin ve Türkiye'nin kendi aralarındaki döviz kurlarının istikrarlı olup olmadığını inceleyerek istikrarı ve güveni sağlamanın bir alternatifi olarak Avrupa Birliği'nin ERM uygulamasının ele alınması hedeflenmiştir. Bu doğrultuda önce ERM ve ERM II uygulamaları ile ilgili literatür taraması yapılacak, daha sonra AEB üyelerinin ve Türkiye'nin döviz kurlarının mevcut durumu incelenerek ERM gibi bir sistemin uygulanabilirliği tartışılacaktır.

\section{Literatür Taraması}

Avrupa ülkeleri, altı ülkenin 18 Nisan 1951 'de Avrupa Kömür ve Çelik Topluluğu anlaşmasını imzalaması ile başlayan sürecin sonucunda 1993 'de yürürlüğe giren Maastricht Anlaşması temelinde Avrupa Birliği'ne dönüşmüş, 2002'de Topluluğun ortak parası olan euro'yu dolaşıma sokmuştur. Bu bağlamda henüz ekonomik ve parasal birliğe tam katılmayan yada katılamayan üyelerden tam üyeliğe, yani euro'ya geçmesi için bazı yükümlülükleri yerine getirmesi talep edilmektedir. Avrupa Birliği'nin İşleyişi Hakkında Anlaşmada yakınlaşma kriterleri olarak dört temel gösterge belirlenmiştir (European Commission, 2018:4-5):

1. Fiyat istikrarı kriterine göre, ilgili ülkedeki enflasyon oranı, Avrupa Birliği üyeleri arasında fiyat istikrarı yönünden en iyi performansa sahip üç ülkenin ortalamasına yakın olmalıdır. 
2. Kamu maliyesiyle ilgili kritere göre, devlet bütçesi sürdürülebilir olmalıdır. Yani, bütçe açı̆̆ı Anlaşma'nın 126(6).maddesi çerçevesinde aşırı olarak bulunmamalıdır. Sözkonusu madde şu şekildedir: "Konsey, Komisyon'un önerisi üzerine ve ilgili üye devletin olası tespitlerini göz önünde tutarak, genel bir değerlendirme sonrasında, aşırı bir kamu açığı olup olmadığına karar verir."

3. Döviz kuru kriterine göre, ilgili ülke en az iki yıl süreyle euro karşısında kendi parasının değerini düşürmeyerek, ERM II ile öngörülen normal dalgalanma marjına uymalıdır.

4. Faiz oranı kriterine göre, derogasyonu bulunan üye devlet tarafından ulaşılan yakınsama sürekli olmalı ve üye devlet uzun vadeli faiz hadlerine yansıyacak şekilde döviz kuru mekanizmasına katılabilmelidir.

Örnek vermek gerekirse, 2018 'de fiyat istikrarı açısından en iyi performansa sahip üyeler olarak Kıbrıs $(\% 0,2)$, İrlanda $(\% 0,3)$ ve Finlandiya $(\% 0,8)$ ülkeleri; enflasyon oranının referans değeri olarak da \%1,9 (basit ortalama artı bir buçuk puan) belirlenmiştir. Faiz oranının referans değeri, Kıbrıs $(\% 2,2)$, İrlanda $(\% 0,8)$ ve Finlandiya'nın $(\% 0,6)$ ortalama uzun vadeli faiz oranlarının basit ortalaması, artı iki puan olarak hesaplanmış ve $\% 3,2$ olarak bulunmuştur.

Bunlardan üçüncü kriter olan döviz kuru kriterinde bundan kırk sene önce geliştirilip daha sonra bazı değişikliklere uğrayan Döviz Kuru Mekanizması (ERM) kullanılmaktadır.

Avrupa Birliği'nin ortak paraya geçişinin temelini oluşturan Avrupa Para Sistemi (EMS) Mart 1979'da yürürlüğe girmiştir. Bu sistem kapsamında değeri para sepeti yöntemine göre belirlenen Avrupa Para Birimi (ECU) ve Döviz Kuru Mekanizması oluşturulmuştur. Döviz Kuru Mekanizması'nın tarihi kısaca şu şekildedir:

- 13 Mart 1979'da Avrupa Para Sistemi kapsamında yürürlüğe girmiştir.

- Sisteme katılan ülke paraları (ilk başta Belçika, Fransa, Almanya, İrlanda, İtalya, Lüksemburg, Hollanda, Danimarka para birimleri) ECU'ye bağlanarak, $\pm \% 2,25$ 'lik bir dalgalanma marjı belirlenmiştir. İstisna olarak İtalyan lirası, İspanyol pezetası, Portekiz esküdosu ve İngiliz sterlini için $\pm \% 6,0^{\prime}$ 'lık bir dalgalanmaya izin verilmiştir.

- Eylül 1992'den sonra sistem baskı altına girerek döviz krizi yaşanmış ve bunun sonucunda Ağustos 1993'de dalgalanma marj1 $\pm \% 15$ 'e genişletilmiştir. Günümüzde ERM II'de $\pm \% 15$ 'e kadar izin verilmektedir.

- 1 Ocak 1999'da 1 ECU = 1 Euro kuruyla AB'nin ortak paras1 “euro" yürürlüğe girmiştir. Bu nedenle ERM'in yerini ERM II almış, sistemde o dönemde sadece Yunanistan ve Danimarka kalmıştır. ERM II sisteminde ulusal paralar para sepeti yerine euro'ya bağlanmaktadır.

- 2001'de Yunanistan'ın euro'ya geçmesiyle sadece Danimarka kalmış ve $\pm \% 2,25$ 'lik sınırı devam ettirmiştir. 2004'ten sonra Slovenya, Kibris, Malta, Slovakya, Estonya, Letonya ve Litvanya ERM II'ye katılarak gerekli şartları sağladıktan sonra, 2015'e kadar hepsi euro'ya geçmiştir. Günümüzde ERM II'yi sürdüren tek ülke Danimarka'dır.

- Konulan kriterlere göre, euro'ya geçebilmek için üye ülkeler iki sene ERM II'de "ciddi gerginlik" (severe tension) yaşamadan kalabilmelidir. Günümüzde AB'ne tam üye olmasına rağmen, kendi ulusal para birimlerini kullanan ve ERM II'yi uygulayarak euro'ya geçmesi beklenen 7 ülke (İsveç, Çek Cumhuriyeti, Polonya, Macaristan, Romanya, Bulgaristan ve Hirvatistan) bulunmaktadır.

AB'nin sözkonusu yeni üyeleri gerekli koşulları yerine getirdikten sonra, euro'ya geçeceğine dair resmi olarak yükümlülük almışlardır ve yeni üyelerin eskiler (Birleşik Krallık yada Danimarka) gibi katılmama (opt-out) konusunu görüşme imkanı da bulunmamaktadır (Coric ve Deskar-Skrbic, 2017:612). Fakat ekonomik durgunluk, istikrarsızlık gibi çeşitli nedenlerle ERM II uygulamasına halen resmi olarak geçmemişlerdir. Bundan dolayı ülkeler bazında çeşitli simülasyon ve tahmin araştırmaları yapılmaktadır. Örneğin, Coric ve Deskar-Skrbic (2017) Hırvatistan'1, Helisek ve Mentlik (2017) Çek Cumhuriyeti'ni incelemişlerdir.

Bazıları ise (Ciurlak, 2003; Wilson, 2006) Doğu Asya ülkelerine 1997-1998 Asya finansal krizinden sonra bir çözüm yolu olarak ERM uygulamasını önermişlerdir. Wilson (2006) mevcut seçeneklerin arasından ERM uygulamasının, ülkelere makroekonomik politika açısından yeteri kadar bağımsızlık sağlaması ve Avrupa deneyimine dayanması dolayısıyla siyasi olarak en cazip olabileceğini belirtmiştir. Ciurlak (2003) ise Avrupa tecrübesinin ders ve ilham kaynağı olabileceğini, fakat bunun doğrudan nakledilmesinin zor olduğunu ve Doğu Asya ülkelerinin muhtemelen kendi sistemlerini geliştirmek zorunda kalacaklarını ifade etmiştir.

Yukarıda da belirtildiği gibi, ERM uygulaması başlangıçta çok katı bir sistem olarak faaliyete geçmiştir, yani döviz kurlarının merkezi kur etrafinda toplam olarak sadece \%4,5 değişmesine izin verilmiştir. Fakat 1992'deki spekülasyon baskısı sonucunda mukayeseli olarak daha esnek bir sistem haline gelmiş̧ir.

Günümüzde Avrupa Komisyonu oy birliğiyle dar sınıra eğilim göstermekle beraber geniş sınırı da kabul etmektedir. Geniş sınırın amacı, döviz kurunun daha fazla değişmesine izin vermeyerek aynı zamanda ERM kapsamındaki spekülasyon baskısıyla baş edebilmektir (Helisek ve Mentlik, 2017:31). Bununla beraber, geniş sınır, bazı yazarlar (Dedek, 2014:146-147) tarafindan ulusal ekonomik politikaları ve özellikle devletin bütçe davranışını disipline etmek için aşırı geniş olarak nitelendirilmektedir. 
Bir diğer husus olarak bu sistemde döviz piyasasına yoğun müdahale kabul edilmemektedir. Sınır dışına biraz çıkan, fakat döviz piyasasına müdahale yapılmayan bir ülke parası yakınlaşma kriterini yerine getirmiş olarak kabul edilebilmektedir (Helisek ve Mentlik, 2017:32). Tersine, sınır dışına çıkmayan, fakat döviz piyasasına yoğun müdahalede bulunulan bir ülke parası da kriteri yerine getirmemiş sayılabilecektir. Fakat genel olarak her ülke ayrı ayrı, spesifik durumuna göre değerlendirilmektedir.

ERM II'de ulusal paranın değer kazanma yönünde \%15, değer kaybetme yönünde ise \%2,25 değişmesi gibi asimetrik bir sınır da daha sık rastlanan bir durum haline gelmektedir. Bu durum Schadler et al. (2005:7) tarafindan açıklanmışken, Komarek et al., 2005; Egert ve Kierzenkowski, 2003; Helisek ve Mentlik, 2017 gibi yazarlar tarafindan yapılan uygulamalı çalışmalarda kullanılmıştır.

Bu çalışmaların 1şı̆̆ında Avrasya Ekonomik Birliği (AEB) üyelerinde ve Türkiye'de son dönemlerde yaşanan döviz piyasasındaki istikrarsılıklara alternatif bir çözüm olarak ERM uygulaması ele alınmış ve altı ülke arasındaki dolaysız kurların seyri hem dar hem de geniş sınırlar çerçevesinde incelenmiştir.

\section{Veri, Yöntem ve Uygulama Sonuçları}

Çalışmanın uygulama kısmı iki kısımdan oluşmaktadır. Birinci kısımda Rusya rublesi ile AEB üyeleri ve Türkiye ulusal paralarının arasındaki kurların son iki senedeki, yani 2017-2018 dönemindeki dalgalanmaları ERM II uygulaması çerçevesinde ele alınmıştır. İkinci kısımda ise Avrupa Para Sistemi’nde kullanılan Avrupa Para Birimi (ECU) gibi bir hayali para sepeti oluşturularak 2015-2018 döneminde ulusal paraların bu hayali para birimine karş1 dalgalanmaları incelenmiştir. Kazakistan Cumhurbaşkanı Nursultan Nazarbayev’in 2003'deki “altın” isimli ortak para oluşturma fikrine (https://ria.ru/20030401/360448.html, erişim tarihi: 13.02.2019) dayanarak tarafımızca "altın" olarak isimlendirilmiştir.

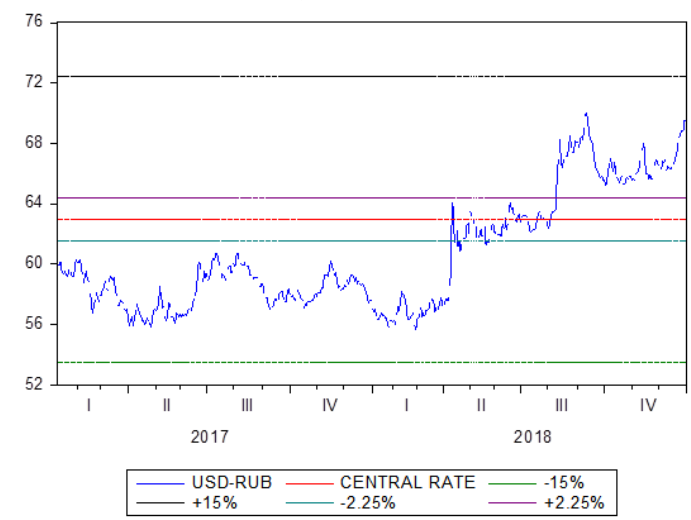

(a)

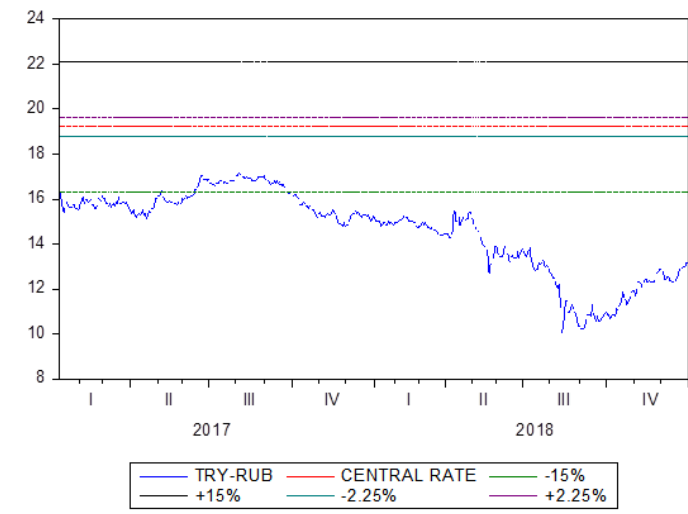

(a)

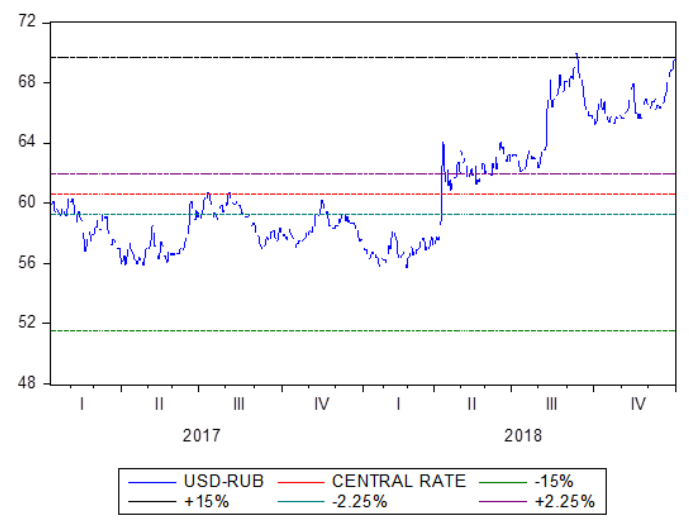

(b)

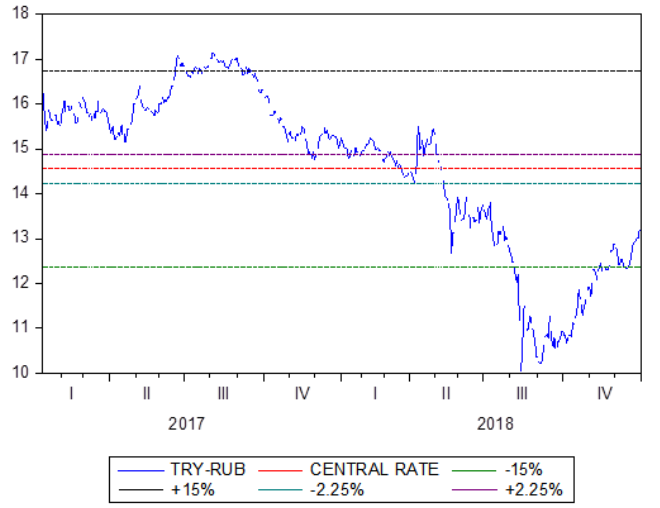

(b)

Şekil 1. Dolar-Ruble ve Lira-Ruble Kurlarındaki Dalgalanmalar

Verilerde standardı sağlamak ve aşırı detaydan kaçınmak amacıyla, sadece Rusya Merkez Bankası'nın verileri kullanılmıştır ve ancak diğer ülke paralarıyla ruble arasındaki kurlar incelenmiştir. Helisek ve Mentlik (2017:35) tarafından da belirtildiği gibi, ERM II sisteminde merkezi kur (central rate) uygulamaya "girişten" bir önceki çeyreğin ortalama kuruna eşit olarak belirlenmektedir. Bundan dolayı merkezi kuru ve dalgalanma sınırlarını belirlemede; (a) ERM II sisteminde öngörüldüğü gibi, uygulamaya geçmeden bir önceki çeyreğin ortalama kuru ve (b) iki senenin yani 2017-2018 döneminin ortalama kuru (sağ taraftaki şekiller) esas alınmıştır.

Öncelikle mukayese amacıyla ruble ile ABD doları arasındaki kurun dalgalanması ele alınmıştır. Şekilden görüldüğü gibi, son iki yılda dolar-ruble kurunun genelde $\pm \% 2,25^{\prime}$ 'lik dar sınırın dışında kaldığı, fakat $\pm \% 15^{\prime}$ lik 
geniş sınıın dışına çıkmadığı tespit edilmiştir. Buna karşılık, lira-ruble kurunun ise iki sınıın da dışına çıktığı, özellikle 2016'nın son çeyreğindeki ortalama kurdan çok fazla uzaklaştığı görülmektedir. Buna büyük ölçüde Türkiye'de 2018'de başlayan istikrarsızlıklar neden olmuştur.

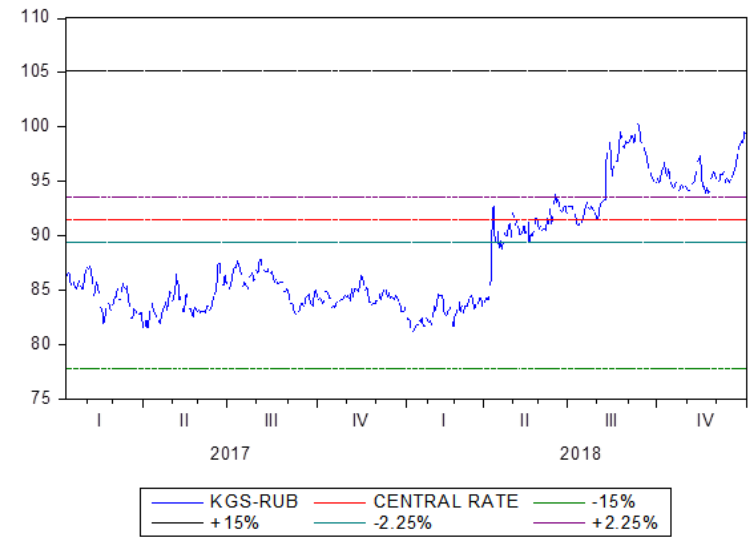

(a)

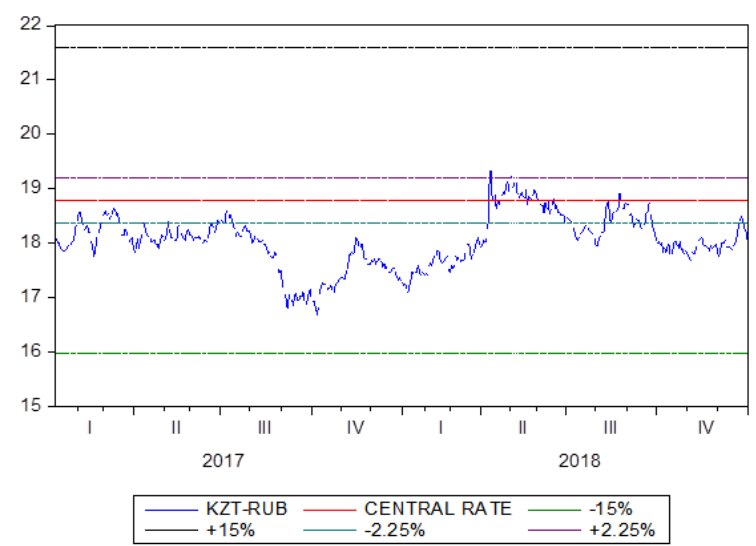

(a)

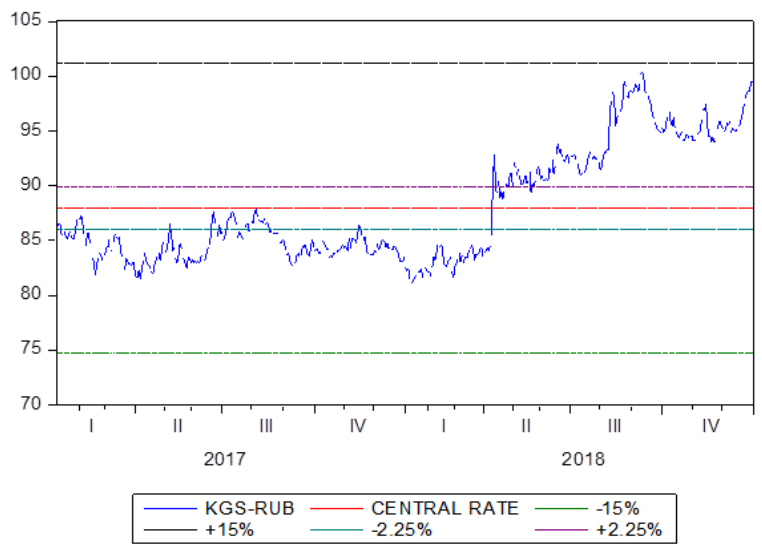

(b)

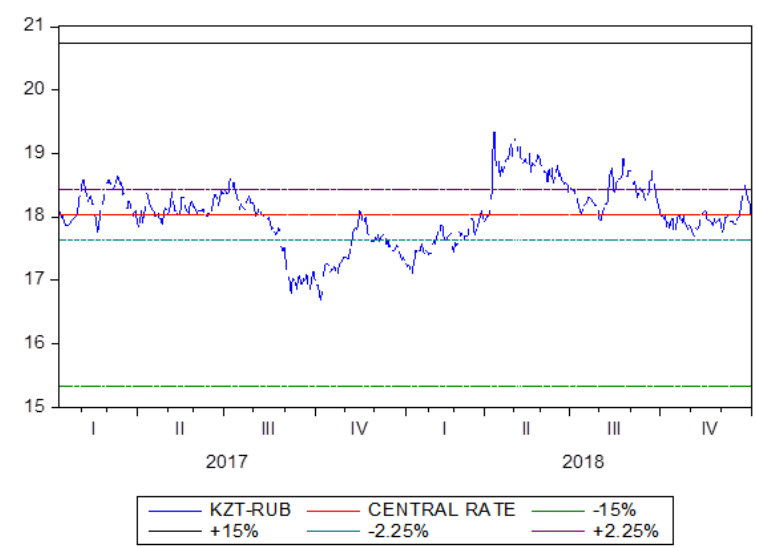

(b)

Şekil 2. Som-Ruble ve Tenge-Ruble Kurlarindaki Dalgalanmalar

Som-ruble (şekilde 100 som'a düşen ruble miktarı olarak alınmıştır) ve tenge-ruble (şekilde 100 tenge'ye düşen ruble miktarı olarak alınmıştır) kurlarının her iki yöntemde de dar sınııın dışına çıktığı, fakat geniş sınırın içinde kaldığı tespit edilmiştir. Bağımsızlık dönemi toplu olarak incelendiğinde genel olarak som-ruble kurunun istikrarlı bir seyir izlediği gözlemlenmektedir. Bundan dolayı bir çalışmada (Ganiev ve Emsen, 2008:106-107) “dolayısıyla Kırgız som'unun aldığı değerin belirlenmesinde, kendisinden daha güçlü ve kurumsal bir yapıya sahip olan Rusya'nın izlediği yolu takip ettiği söylenebilir ki, bu yönüyle Kırgızistan'da uygulanan kur politikasının (açıkça veya) zımnen ruble gölgesinde olduğu ileri sürülebilir” denmektedir. Burada elde edilen sonuçlar da bunu belirli düzeyde teyit eder niteliktedir. Şekilden gözlemlenen sekiz çeyreğin yaklaşı altı çeyreğinde som'un ruble karşısında daha değerli kaldığı, son dönemlerde de önemli oranda değer kaybına uğrayarak merkezi paritenin ve dar sınırın üstüne çıktığı görülmektedir. Diğer taraftan, incelenen dönemde tenge-ruble kurunun som-ruble kuruna göre daha istikrarlı dalgalanma yaşadığı söylenebilir. Sınırların açık olması nedeniyle rekabette kayba uğramamak amacıyla Kazakistan yönetimi tenge'nin ruble karşısında fazla değer kazanmasına yol vermemeye çalışmaktadır. Bunun tenge-ruble kurunun istikrarına önemli ölçüde katkı sağladığı söylenebilir.

Belarus devleti diğer ülkelere mukayeseli olarak çok daha yumuşak bir para politikası uygulamıştır. Aralık 2014'teki nominal para hacmi Aralık 2000'deki nominal hacmine oranlandığında para arzı Belarus'ta 145 kat; Rusya'da 28 kat; Kazakistan'da 27 kat; Kırgızistan'da 11 kat ve Ermenistan'da 10 kat artmıştır. Bu durum doğal olarak enflasyon oranlarına da yansımış ve diğer ülkelerde bu dönemde fiyatlar yaklaşık 3-5 kat artmışken, Belarus'ta 40 kat artmıştır. Bunun sonucunda Belarus yönetimi 1 Ocak 2000'de 1:1000 oranında ve 1 Temmuz 2016'da 1:10000 oranında denominasyon uygulamıştır. Dolayısıyla bugünlerde 1 Belarus rublesi 30 ruble civarındadır. Denominasyondan sonra Belarus rublesinin de ruble karşısında istikrarlı bir seyir izlediği, $\pm \% 15^{\prime}$ 'lik geniş sınırın dışına çıkmadığı görülmektedir. 


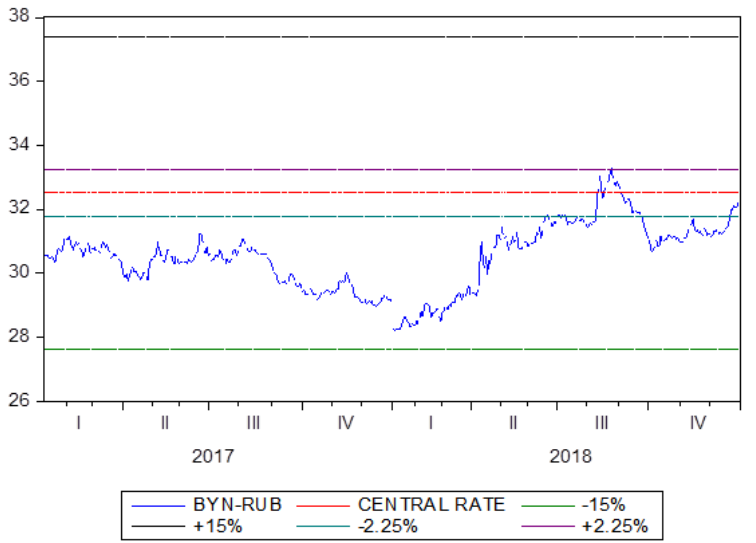

(a)

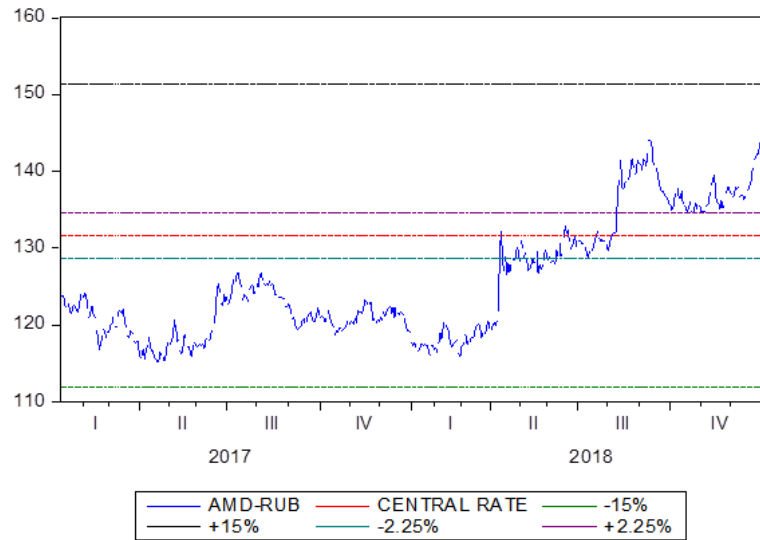

(a)

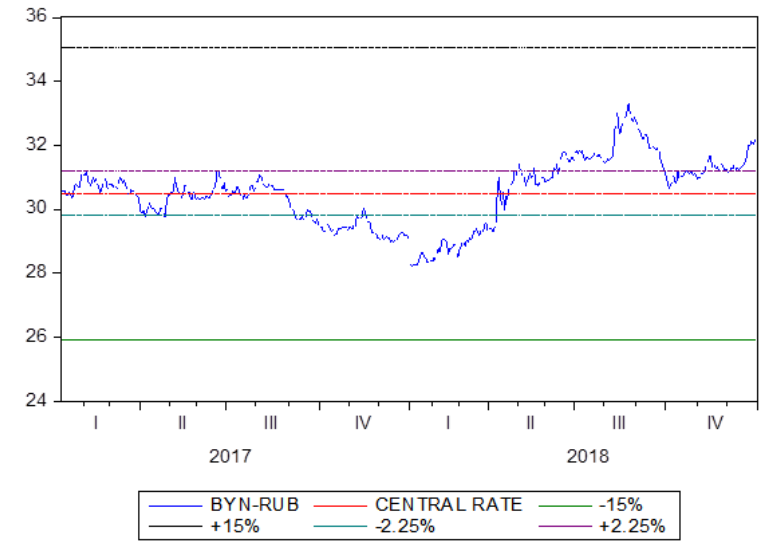

(b)

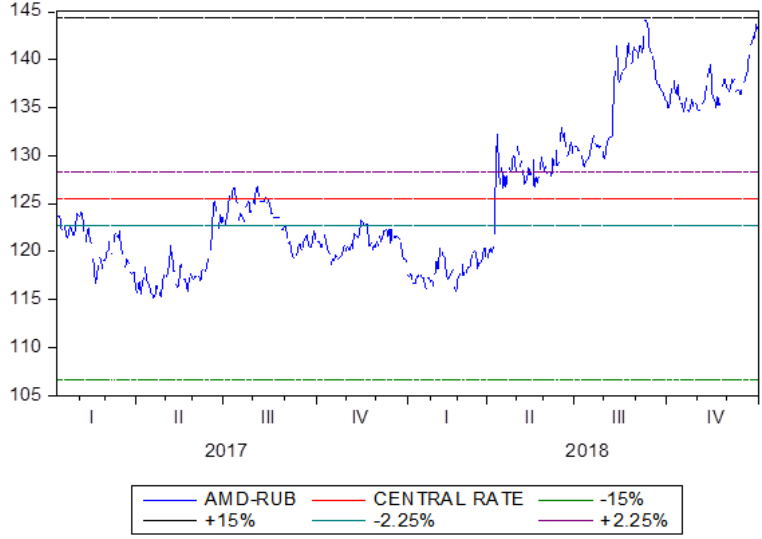

(b)

Şekil 3. Belarus Rublesi-Ruble ve Dram-Ruble Kurlarındaki Dalgalanmalar

Ermenistan dramı-ruble kuru (şekilde 1000 dram'a düşen ruble miktarı olarak alınmıştır), merkezi kur 2016'nın son çeyreğinin ortalaması olarak alındığında diğer ülke paraları gibi geniş sınırın dışına çıkmamıştır. Fakat ortalama kura göre bakıldığında 2018'in sonlarına doğru üst sınıra ulaştığı tespit edilmiştir.

Genel olarak, lira-ruble kuru hariç, tüm diğer ülke paralarının ruble karşısındaki kurunun \pm \%2,25 'lik dar sınırın dışına çıktığı, fakat $\pm \% 15^{\prime}$ 'lik geniş sınırın dışına çıkmadığı görülmüştür.

İkinci aşamada yukarıda değinildiği gibi, Avrupa Para Sistemi’nde kullanılan Avrupa Para Birimi (ECU) gibi bir hayali para sepeti oluşturularak buna "altın" ismi verilmiştir. Bu hayali para sepetinde ülkelerin ekonomik büyüklüğü kabaca dikkate alınarak altı ülke büyük, orta ve küçük ekonomi gibi üç sınıfa ayrılmış ve sırasıyla $\% 25$ 'er, \%15'er ve \%10'ar pay ayırılmıştır.

\begin{tabular}{|c|c|c|c|c|}
\hline Para Cinsi & $\begin{array}{c}\text { Hayali } \\
\text { Sepetteki Ăğırlı̆̆ı } \\
\text { (yüzde) }\end{array}$ & $\begin{array}{c}\text { Ulusal Para } \\
\text { Miktarı }\end{array}$ & $\begin{array}{c}\text { Döviz Kuru } \\
\text { (Ruble Kuru) }\end{array}$ & Ruble Karşılı̆̆ı \\
\hline Belarus rublesi (BYN) & 15,0 & 0.0935 & 38.7846 & 3.6268 \\
\hline Ermenistan dramı (AMD) & 10,0 & 20.3792 & 0.1186 & 2.4179 \\
\hline Kazakistan tengesi (KZT) & 15,0 & 11.7700 & 0.3081 & 3.6268 \\
\hline Kırgız somu (KGS) & 10,0 & 2.5318 & 0.9550 & 2.4179 \\
\hline Rusya rublesi (RUB) & 25,0 & 6.0447 & 1.0000 & 6.0447 \\
\hline Türk lirası (TRY) & 25,0 & 0.2500 & 24.1789 & 6.0447 \\
\hline I $A L T Y N=R U B L E$ & & & & 24.1789 \\
\hline
\end{tabular}

Tablo 1. Hayali Para Sepeti Kaynak: Yazarlar Tarafindan Oluşturulmuştur.

Hayali sepetin kuru 1 Ocak 2015'te 1 ALTYN = 1 Türk lirası olarak belirlenmiştir. Sepetteki ulusal paraların payları tabloda görüldüğü gibi, Türk lirası ve Rusya rublesi için \%25, Belarus rublesi ve Kazakistan tengesi için \%15, Kırgız somu ve Ermenistan dramı için \%10 olarak belirlenmiştir. Buna göre, eğer ulusal paralar bu hayali sepete bağlansaydı Ocak 2015'ten Ocak 2019'a kadar döviz kurları ERM II gibi bir sistemi başarabilir miydi sorusunun cevabı araştırılmıştır. 

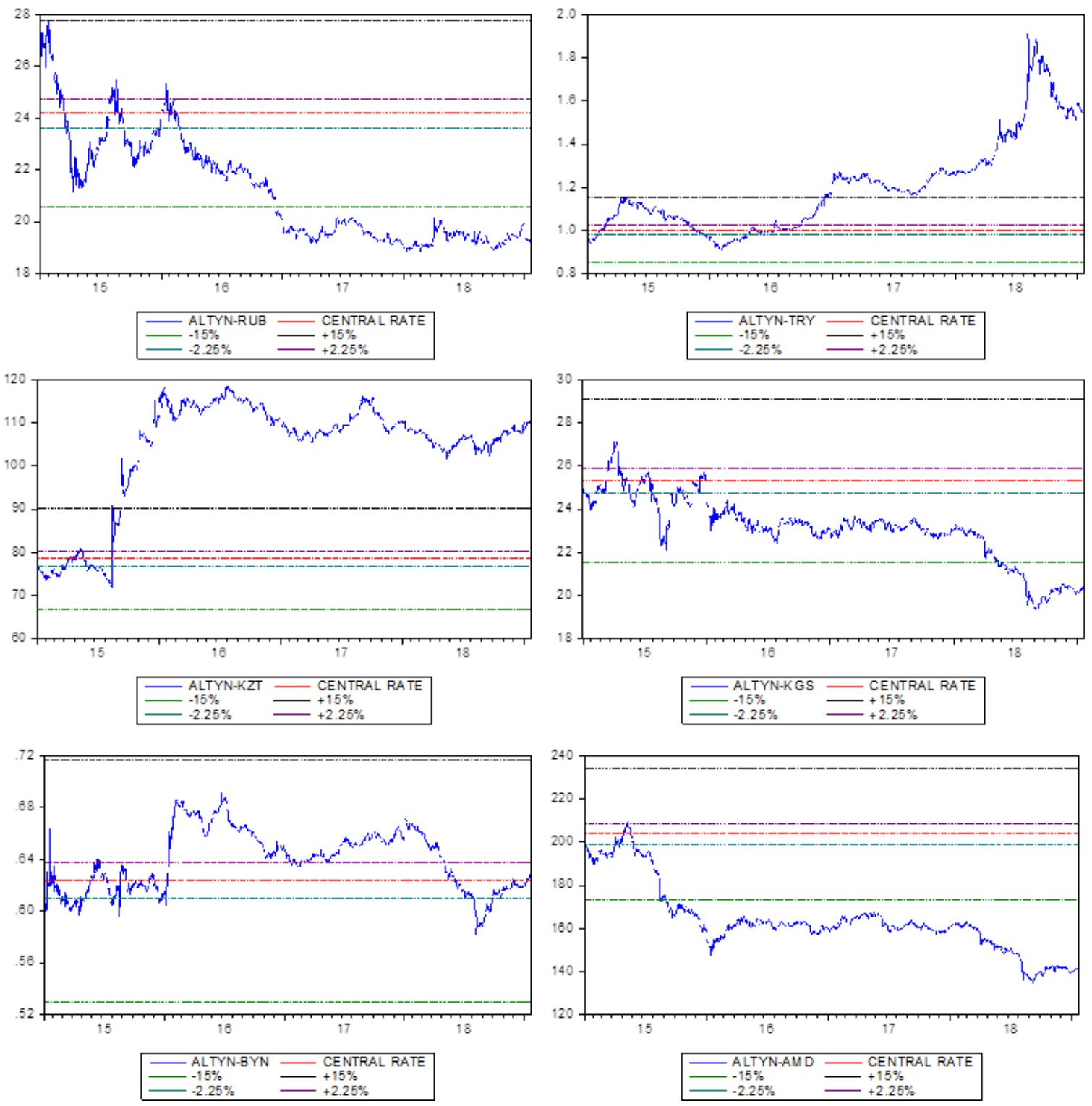

Şekil 4. Milli Paraların Para Sepeti Karşısındaki Dalgalanmaları (2015-2019)

Şekilden görüldüğü gibi, Belarus rublesi dışında hiçbir ülke parası $\pm \% 15$ 'lik geniş sınırın içinde de kalamamıştır. Bunun belki önemli bir nedeni dört yıllık bir sürenin alınmış olmasıdır. Bunu tespit etmek amacıyla ayrıca Ocak 2017'den Ocak 2019'a kadarki dönem incelenmiştir.

Son iki senede Rusya rublesi’nin yaptırımların ilk başladığ görülmektedir. Şekile göre, hayali para sepetine dayanarak belirlenen merkezi kurun etrafındaki dar sınırın da dışına pek çıkmadığı söylenebilir. Türk Lirası'nın para sepetine karşı kuru ise 2018'in ikinci çeyreğinden itibaren geniş sınırın da dışına çıkarak üçüncü çeyrekte en yüksek seviyesine ulaşmıştır. Fakat daha sonra değer kazanarak yavaşça geniş sınırın üst değerine doğru yaklaşmaktadır. Kazakistan tengesi'nin de genelde dar sınırın içinde seyrettiği, ancak geçici olarak bazı dönemlerde sınırın dışına çıktığı görülmektedir. Kırgız somu, Belarus rublesi ve Ermenistan dramı 2018'in ikinci çeyreğine kadar gayet istikrarlı gelmişken, o dönemden itibaren para sepetine karşı değer kazanmaya başlamıştır. Bunun önemli bir nedeni sözkonusu paraların dolar kurlarının istikrarlı tutulmaya çalışılmasıdır. Dolayısıyla Türk lirası değer kaybettiği dönemlerde sözkonusu ülke paraları para sepetine karş1 değer kazanmıştır. Hatta 2018'in üçüncü çeyreğinde kısa süreliğine Kırgız somu ile Ermenistan dramı $\% 15$ 'lik sınırın da dişına çıkmıştır.

Genel olarak, dört senelik bir süre incelendiğinde altı ülke paralarının tümünün para sepetine göre belirlenen merkezi kur istikrarını sağlayamadığı tespit edilmiştir. Fakat iki senelik bir süre dikkate alındığında ise Rus rublesi, Kazakistan tengesi ve Belarus rublesi'nin $\pm \% 15^{\prime}$ 'lik geniş sınırın dışına çıkmadı̆̆ tengesi'nin $\pm \% 2,25$ 'lik dar sınırın etrafında seyrettiği görülmüştür. Türk lirası Türkiye'de yaşanan olumsuz ekonomik gelişmeler nedeniyle önemli değer kaybına uğrayarak üst sınırın da üzerine çıkmışken, Kırgız somu ve Ermenistan dramı para sepetine karşı ciddi oranlarda değer kazanmıştır. 

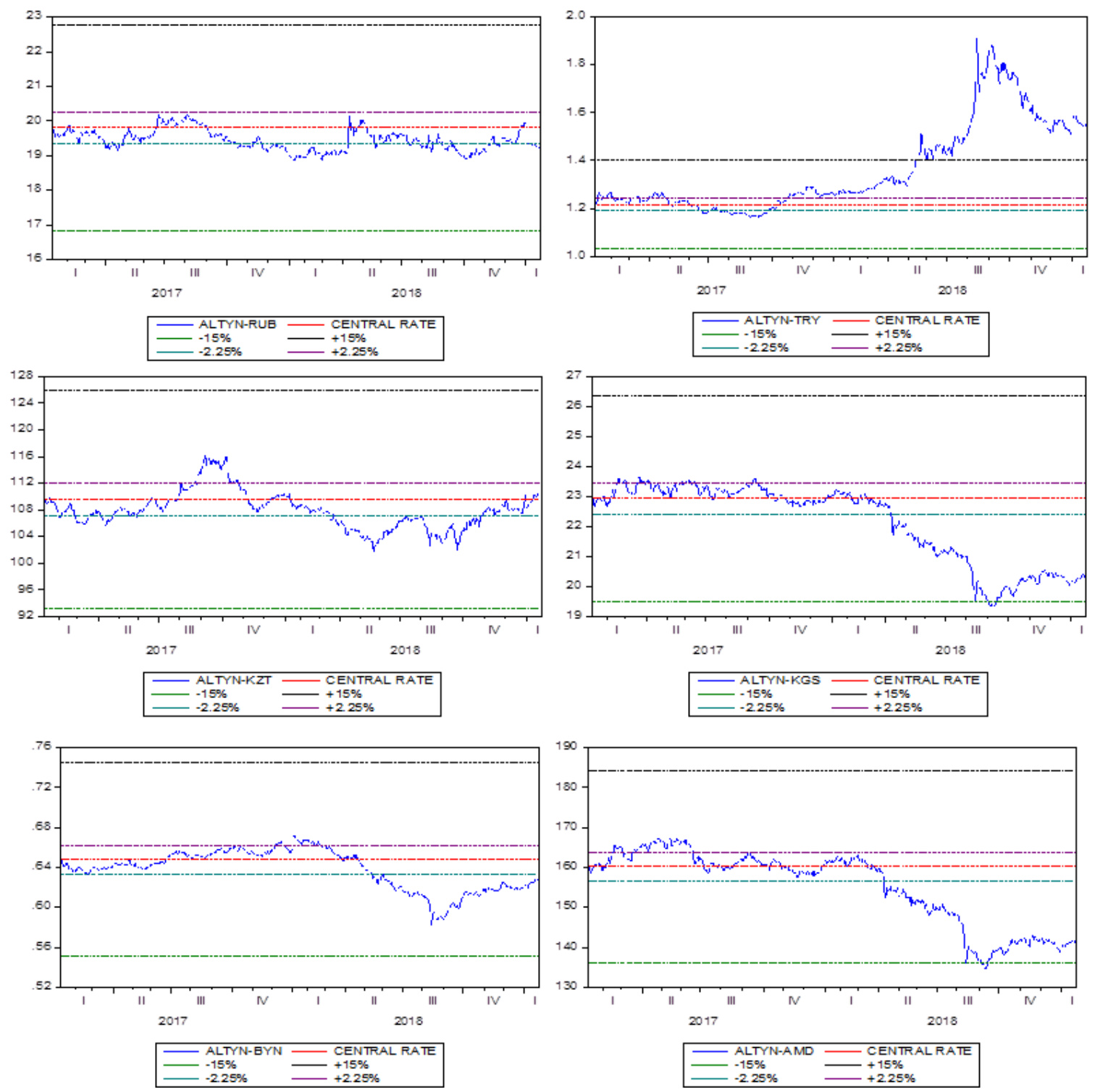

Şekil 5. Milli Paraların Para Sepeti Karşısındaki Dalgalanmaları (2017-2019)

Özetlersek, günümüzde AEB üyeleri ve Türkiye'nin milli paralarının kendi aralarındaki kurlarında önemli istikrarsızlıklar yaşanmaktadır. Bu ülkeler kendi aralarında ERM uygulamasında olduğu gibi bir para sepeti oluştursaydı, bazı ülkelerin $\pm \% 15$ 'lik sınırın dışına çıktığı görülecekti yada bu ülkelerin merkez bankaları buna izin vermemek için gerekli önlemleri alacaktı.

Sözkonusu ülkelerin kendi aralarındaki ticari ilişkilerine baktığımızda, 2018 y1lı verilerine göre (www.eaeunion.org, erişim tarihi: 04.03.2019), Birliğin toplam ihracatının \%89,1'i AEB dış1 ülkelere, \%10,9'u AEB ülkelerine yapılırken, ithalatın \%81,7'si birlik dışı, kalan \%18,3'ü de birlik içi ülkelere denk gelmektedir. Yani birlik içi ticaret çok düşük oranlarda kalmaktadır. AEB üyelerinin dış ticaretteki entegrasyon derinliğine bakıldığında, 2017 verilerine göre ihracatta \%46,5 ile ilk sırada Belarus'un geldiği görülmektedir. Yani Belarus ihracatının yarısına yakını AEB üyelerine yapılmaktadır. Kırgızistan ihracatının üçte biri, Ermenistan'ın dörtte biri AEB ülkelerine yönelik iken, Rusya ile Kazakistan ihracatının sadece \%10’u AEB ülkelerine düşmektedir. Diğer bir ifadeyle, diğer üç ülke için AEB önemli bir pazar iken, Kazakistan ve Rusya için önemli bir pazar durumunda değildir. İthalatta da yaklaşık aynı durum sözkonusu iken, önemli bir istisna olarak Kazakistan'ı belirtmek mümkündür. Kazakistan ithalatının \%41,8’i AEB ülkeleri tarafından karşılanmaktadır.

Birliğin Türkiye ile dış ticaretine bakıldığında, Türkiye İstatistik Kurumu'nun (www.tuik.gov.tr, erişim tarihi: 04.03.2019) verilerine göre, 2018 'de Türkiye'nin toplam ihracatındaki AEB üyelerinin toplam payı \%2,9; toplam ithalatındaki payı ise \%10,6 olarak gerçekleşmiştir. Payının büyüklüğüne göre ülkelerin sıralaması şöyledir: ihracatta ilk sirada Rusya (\%2,02), sonra Kazakistan (\%0,41), Belarus $(\% 0,26)$, Kirgizistan $(\% 0,22)$ gelirken; ithalatta gene ilk sırada Rusya $(\% 9,86)$, sonra Kazakistan $(\% 0,66)$, Belarus $(\% 0,09)$, Kırgızistan $(\% 0,02)$ gelmektedir. Ermenistan'ın payı ise yüzde sıfır denecek kadar çok küçüktür. 


\section{Sonuç ve Öneriler}

İstatistiki verilerden de görüldüğü gibi, hem AEB üyelerinin kendi aralarındaki ticarette hem de Türkiye ile olan ticari ve ekonomik ilişkilerinde önemli bir potansiyel vardır. Bunu etkileyen faktörlerden biri de döviz kuru istikrarıdır.

Mevcut durum incelendiğinde, genel olarak lira-ruble kuru hariç, tüm diğer ülke paralarının ruble karşısındaki kurunun $\pm \% 2,25^{\prime}$ lik dar sınırın dışına çıktığı, fakat $\pm \% 15^{\prime}$ lik geniş sınırın dışına çıkmadığı görülmüştür.

Hayali para sepeti oluşturularak yapılan analizlerde ise dört senelik bir süre incelendiğinde altı ülke paralarının tümünün para sepetine göre belirlenen merkezi kur istikrarını sağlayamadığı tespit edilmiştir. Fakat iki senelik bir süre dikkate alındığında Rus rublesi ile Kazakistan tengesi'nin $\pm \% 2,25$ 'lik dar sınırın etrafında seyrettiği, Belarus rublesi'nin $\pm \% 15$ 'lik geniş sınırın dışına çıkmadığı görülmüş̧ür. Türk lirası Türkiye'de yaşanan olumsuz ekonomik gelişmeler nedeniyle önemli değer kaybına uğrayarak üst sınırın üzerine çıkmışken, Kırgız somu ve Ermenistan dramı para sepetine karşı ciddi oranlarda değer kazanmıştır. Yani günümüzde AEB üyeleri ve Türkiye'nin milli paralarının kendi aralarındaki kurlarında önemli istikrarsızlıklar yaşanmaktadır. Bu ülkeler kendi aralarında ERM uygulamasında olduğu gibi bir para sepeti oluştursaydı, bazı ülkelerin $\pm \% 15$ 'lik sınırın dışına çıktığı görülecekti yada bu ülkelerin merkez bankaları buna izin vermemek için gerekli önlemleri alacaktı.

Özetlemek gerekirse, AEB üyeleri ve Türkiye ulusal paralarının arasındaki döviz kurlarında özellikle son dönemlerde büyük istikrarsızlıklar yaşanmaktadır. $\mathrm{Bu}$ nedenle bu konuda daha sıkı işbirliği yapılarak reel adımların atılması gerekmektedir. Bunları gerçekleştirmede Avrupa Birliği'nin ERM tecrübesinden de yararlanılabilir.

\section{Kaynakça}

- Avrasya Ekonomik Birliği resmi sitesi, http://www.eaeunion.org/

- Ciuriak D., 2003. "Is the European Exchange Rate Mechanism a Model for East Asia?”. Asian Affairs: An American Review 30:1, pp. 3-34. doi: 10.1080/00927670309603939

- Coric T. \& Deskar-Skrbic M., 2017. “Croatian path towards the ERM2: why, when and what can we learn from our peers?” Ekonomski Pregled 68(6), pp. 611-637.

- Dedek O., 2008. "Historie evropské měnové integrace. Od národních měn k euru” (The History of European Monetary Integration. From National Currencies to the Euro). Praha, C. H. Beck.

- $\quad$ Egert B. \& Kierzenkowski R., 2003. “Asymmetric Fluctuation Bands in ERM and ERM II: Lessons from the Past and Future Challenges for EU Acceding Countries”. William Davidson Institute WP 597, July 2003.

- European Commission, 2018. Convergence Report 2018, Institutional Paper 078, Retrieved from https:/ec.europa.eu/info/publications/economy-finance/convergence-report-2018_en

- Ganiev C. \& Emsen Ö.S., 2008. “Kırgızistan'da Döviz Kurlarının Yönü: Satın Alma Gücü Paritesi Yaklaşımı”. KTMÜ Sosyal Bilimler Dergisi 20, ss. 95-113.

- Helisek M. \& Mentlik R., 2017. “Simulation of the Czech koruna's participation in ERM II - alternative approaches. Journal of International Studies 10(2), pp. 28-45. doi:10.14254/2071-8330.2017/10-2/2

- https://ria.ru/20030401/360448.html, erişim tarihi: 13.02.2019

- https://www.ntv.ru/novosti/1438918/, erişim tarihi: 13.02.2019

- https://www.timeturk.com/erdogan-cozum-milli-para-ile-ticaret/haber-930528, erişim tarihi: 13.02.2019

- Komarek L. et al., 2005. "Kurzové aspekty v procesu přistoupení České republiky k eurozóně” (Exchange Rate Problems in the Process of the Czech Republic's Accession to the Euro Area). Studie Národohospodářského ústavu J. Hlávky 1/2005. Praha.

- Rusya Merkez Bankası resmi sitesi, http://cbr.ru/

- Schadler S. et al., 2005. “Adopting the Euro in Central Europe”. Washington DC, International Monetary Fund.

- Türkiye İstitastik Kurumu resmi sites, http://www.tuik.gov.tr/

- Wilson P., 2006. "Prospects for Asian Exchange Rate Cooperation: Why an ERM Solution Might be the Most Palatable". Journal of the Asia Pacific Economy 11(1), pp. 1-34. doi: 10.1080/13547860500347737 


\title{
Kurala Dayalı ve İhtiyari Para Politikası Tartışmaları Kapsamında Türkiye Ekonomisi İçin Taylor Kuralının Analizi An Analysis of Turkey to Taylor Rule in the Context of Rule-
Based and Discretionary Monetary Policy Debate
}

\author{
Prof. Dr. Harun Bal (Çukurova University, Turkey) \\ Asst. Prof. Dr. Mustafa Ildırar (Çukurova University, Turkey) \\ Ph.D. Candidate Esma Erdoğan (Çukurova University, Turkey)
}

\begin{abstract}
The readiness of central bank to adhere to a rule of monetary policy has always been one of the topics discussed in the economic literature. Policy decisions undertaken by monetary authorities in uncertain and unpredictable environments are the main reason for this debate. According to the Taylor Rule, that holds the rules and discretionary policies, the policy rate of the central bank is necessary to be determined in such a way that it provides a balance between the financial and the real sector that will increase foreign exchange inflows and not reduce investment expenditures. Therefore, the study examines the validity of the extended Taylor Rule for Turkish economy using the GMM method for the period 2001: 08-2017: 09. This method is preferred because its advantage to achieve strong and consistent coefficients even under weak assumptions, is based on strong assumptions that depend on the consistency of estimators. Findings obtained as a result of Taylor rule analysis support the studies in the literature and suggest that the rule is apparently valid in economies with low inflation rates and stable growth rates. In this context, in the absence of support for the Taylor rule, the TCMB should determine a policy rate that will provide internal and external equilibrium, and in doing so, the inflation-deficit variable should be used as an indicator.
\end{abstract}

\section{Giriş}

1970’ler başlayan ve güzümüze kadar devam eden süreçte para otoritelerinin uygulayacakları politikalar da kural politika mı yoksa ihtiyari politika mı uygulayacağı konusu tartışmalı bir konudur. Kurala dayalı ve ihtiyari politika nedir ve bu iki politika arasındaki fark nelerdir diye bakıldığında ise literatürde bu sorulara verilen cevapların, içinde bulunan döneme göre farklılık gösterdiği tespit edilmiştir. İhtiyari politika uygulamalarında MB'ları ekonominin içinde bulunduğu duruma göre, en uygun para politikası araçlarını seçerek uygulamaktadır. Kural politika uygulamasında ise MB'nin kamuoyu tarafında kolayca anlaşılabilen somut görevler üstlenmesini ifade etmektedir. İktisatçılar ve politika uygulayıcıları para politikasının bir kural çerçevesinde uygulanması gerektiği ve ihtiyari politikaların ekonomide zaman tutarsızlığı problemine yola açabileceği konusunda hem fikirlerdir. Fakat literatür de uygulanacak kuralın ne olması gerektiği konusunda halen bir fikir birliği sağlanamamıştır. Ayrıca MB'nin uygulayacağı kural politika uygulamaları konusunda da literatür de farklı uygulamalar mevcuttur. Bu farklı uygulardan biri de Taylor kuralıdır. Söz konusu kural, MB’nin ekonominin kurala bağlı olarak kısa dönemli nominal faiz oranı düzeyini belirlenmesini gerektiğini ifade etmektedir. Konu ile ilgili literatür incelendiğinde 1990'lı yıllardan itibaren para otoritelerinin kural politika uygulamalarını daha çok tercih ettikleri gözlemlenmiştir. MB'nin uyguladığı para politikasının kamuoyu tarafında tahmin edilebilir olması önemlidir. Bu durum ise basit bir para kuralı sayesinde mümkün kılınabilmektedir.

Bu çalışma dört kısımdan oluşmaktadır: Birinci kısımda, Kurala dayalı ve ihtiyari para politikaları tartışmaları teorik çerçevede ele alınmıştır. İkinci kısımda Taylor kuralı olarak bilinen faiz haddi kuralının açıklanmaya çalışılmıştır. Üçüncü kısımda konu ile ilgili teorik ve ampirik literatür ele alınmıştır. En son olarak da 2001:082017:09 dönemi için ekonomik aktörler tarafından anlaşılması kolay ve uygulama açısından basit bir kuralı temsil eden döviz kuru değişkenin modele dâhil edildiği genişletilmiş Taylor Kuralının Türkiye ekonomisi için geçerliliği test edilmiştir. Çalışmada analiz yöntemi olarak GMM yöntemi tercih edilmiştir. Söz konusu yöntemin tercih edilme sebebi, zayıf varsayımlar altında dahi güçlü ve tutarlı katsayılara ulaşılmasını mümkün kılarak, tahmin edicilerin tutarlılığına bağlı güçlü varsayımlarda bulunmasıdır

\section{Kurala Dayalı ve İhtiyari Para Politikaları Tartışmaları}

Merkez bankalarının uygulayacakları para politikalarında bir kurala bağlı kalıp kalmayacağı, iktisat literatüründe her zaman tartışılan konular arasında yer almıştır. Bu tartışmanın asıl sebebini para otoritelerinin, belirsiz ve öngörülemeyen ortamlarda politika kararları almak zorunda olmaları oluşturmaktadır. Geleneksel teori MB'lerin piyasa hakkında tam bilgi koşulunun sağlandığı ortamlarda politika kararlarını aldıklarını ve uyguladıklarını varsayarken, oysaki MB'leri eksik bilgiye sahip ortamlarda politika kararlarını alırlar, bu nedenle para politikası karar alma süreci ve uygulanma aşamaları karmaşıktır. MB'nin uygulayacağı politika stratejisini 
seçerken; hangi aracı ve ne kadar süre ile kullanacağını belirlemesi kurala dayalı politikalar (rules-based policy) ve duruma göre (ihtiyari, takdire dayalı) (discretionary policy) politika tercihini yansitmaktadır.

Kural politika kavramı literatürde ilk olarak klasik alın standardı uygulaması ile yer almıştır. Altın standardı döneminde uygulanan para politikası ülkelerin para birimlerini standart olarak altına bağlandığı katı bir kural olarak nitelendirilebilir. İkinci dünya savaşından sonra ise Keynesyen politikaları takip etme eğiliminde olan politika yapıcılar, duruma göre (ihtiyari) politika uygulamalarını tercih etmiştirler. Fakat ihtiyari para politikası uygulamaları 1970'lerde başlayıp 1980'ler boyunca devam eden yüksek enflasyon olgusuna yol açmıştır. Bu süreçte yaşanan yüksek enflasyon oranları 1974 ve 1980-1982 yıllarında derin resesyona neden olmuştur. Ekonomide meydana gelen resesyon olgusundan sonra politika yapıcılar ve iktisatçılar kural politikaların faydalarını düşünüp tekrardan tartışmaya başlamıştır (Adema \& Sterken, 2004, s. 3).

İktisat yazınında kurala dayalı politikalar üzerine ilk akademik çalışma ise Kydland ve Prescott (1977) ile Barro ve Gordon (1983)'in çalışmaları olarak karşımıza çıkmaktadır. Her iki çalışmanın da ortak noktası herhangi bir kural olmadığında politikacıların işsizliği doğal oranının altına çekmek isteyeceklerini ve bunu gerçekleştirmek için de sürpriz şoklara başvurmaktan kaçınmayacaklarını vurgulamalarıdır. Kurala dayalı politikaları savunanlara göre kural nedir ve ne olmalıdır? Bu sorunun cevabına bakıldığında ise literatürde birkaç tanım ile karşılaşılmaktadır. Poole (1993) çalışmasında kuralı "bilgileri tutarlı ve öngörülebilir bir şekilde kullanan sistematik bir karar süreci" olarak betimlemiştir. Ayrıca Poole (1993) para politikası kuralını, para politikasının uygulanmasında bu ilkenin Merkez bankası tarafindan gerçekleştirilmesi olarak ifade etmiştir. Svensson (1998b) çalışmasında kuralı kavramlar bütünü olarak ele almış ve MB'lerin para politikası uygulamalarında kolaylıkla başvurabileceği rehber olarak ifade etmiştir. Taylor (1993) ise kuralı belirli bir sistem dâhilin de yürütülen uzun süreli politikalar bütünü olarak tanımlamaktadır. Taylor (1993)'e göre politika yapıcılar ekonomide istikrarlı bir ortam ve kuralın sağlayacağı avantajlardan faydalanmak istiyorsa kurala sadık kalacaklarına dair taahhüt altına girmelidirler (Taylor, 1993, s. 200).

Kurala dayalı politikaları savunan iktisatçıların ortak noktası, kuralın güvenirlilik ve disiplinle ekonomide istikrara yol açtığını vurgulamalarıdır. Kurala dayalı politikaları savunanlara göre, MB'si ekonomide oluşacak her türlü beklenmedik olay karşısında duruma müdahaleden kaçınılmalıdır. Belirli bir kurala bağlılık, dikkatli bir şekilde uygulandığında, kamuoyunda enflasyonist politikalarla ilgilenilmeyeceğine dair beklenti oluşturarak para otoriterine duyulan güveni arttıracaktır. Tersi bir durum ise politika uygulayıcılarının ellerindeki gücü kötüye kullanmaları sonucunu doğuracaktır. $\mathrm{Bu}$ bağlamda kurallar tarafindan oluşturulan disiplinin maliyeti, beklenilmeyen ve olağan olmayan koşullarla karşılaşılması durumunda MB'yi itibarsızlaştırmak olacağı için söz konusu maliyetin çok yüksek olacağı şeklinde eleştirilere de maruz kalmaktadır.

Kural politikalara karşı görüş olarak savunulan duruma göre politikalar MB'lerin özgürce politikalarını uygulama imkânı sunan esnek politikalardır. Archer (1997) ihtiyari politikayı "insiyatif" kavramı ile açıklamaktadır. Bu kavram MB'lerin politikalarını kurallara bağlı kalmadan serbest bir şekilde belirlemesini ifade eder. Duruma bağlı politikalar kural politikalardaki gibi amaçlarını ve bu amaçları gerçekleştirmek için kullanacağı araçları belirlerken kararsızlıkla karşı karşıya kalabilirler. Turnovsky (1997), ihtiyari politikaları "politika uygulayıcıları her bir dönem için o an en iyi sonuç verecek politikaları uygulaması gerekmektedir" diyerek desteklemiş̧tir. Dwyer (1993) çalışmasında ise; duruma göre politikalar uygulandığında politika yapıcılar ellerindeki gücü kullanarak para politikası uygulayıcılarına sadece ekonomik büyümeyi gerçekleştirme görevi verebileceklerini ifade etmiştir. Ayrıca MB'leri kullanabilecekleri araçları kendileri belirleme imkânını sunduğunda, MB ihtiyari politikalar uygulayarak sadece ekonomik büyümeyi hedefleyecektir. Böyle bir durumda ekonomide sadece ekonomik büyümeyi dikkate alınıp diğer dinamikleri yok saymak, ekonomiyi açık risk konumuna getirecektir (Dwyer, 1993, s. 3-11).

Peki ekonomide uygulanan politikanın kural politika mı yoksa ihtiyari politika mı olduğunu nasıl anlayacağız? Bu sorunun cevabı; eğer politika uygulayıcıları başlangıçta, uygulanan politikanın çeşitli ekonomik koşullara nasıl cevap vereceğine ilişkin öncesinde kamuoyuna bir açıklamada bulunup ve bu yönde bir taahhüt belirtmiş iseler uygulanan politika kural politikadır. Fakat ekonomik koşullar değiştikçe uygulanan politikayı da istediğimiz şekilde değiştirebiliyorsak uygulanan politika ihtiyari politikadır (Mankiw, 1992, s. 331). İhtiyari politikaların sonucunun her zaman kötü olacağı anlamı çıkmamalıdır. Çünkü MB'nin ihtiyari para politikası uygulamalarında da gerçekleştirmeyi planladığı hedefleri vardır. Bu nedenle kural politikalardan tek farkı MB'nin amaç fonksiyonu olmasına rağmen uyguladığı politika kısa dönemler şeklinde gerçekleşmektedir. Kural politikada ise uygulama süresi daha uzun olmaktadır. Bu anlamda McCallum (1998) kural politikayı "sonsuz bakış açısı" olarak tanımlar (McCallum, 1998, s. 50).

\section{Taylor Kuralı}

İktisatçılar ve politika yapıcılar her zaman ekonominin mümkün olduğunca bir modelini oluşturmaya çalışmaktadırlar. Stanford Üniversitesi ekonomi profesörü John Taylor (1993) tarafından, ABD ekonomisi için önerilen Taylor kuralı (Taylor Rules) ihtiyari kararların alındığı kurala dayalı bir politika türüdür (Taylor, 1993, s. 7-8). Taylor Kuralı, kısa vadeli nominal faiz oranı ile enflasyon ve çıktı açığı arasındaki ilişkiye dayanmaktadır. 
Ayrıca literatürde kural Merkez Bankası Faiz Reaksiyonu olarak da yer almaktadır. Merkez bankasının ekonomide para arzını etkileyebileceği en güçlü yöntemlerden biri faiz oranını belirlemektir. Bu sebeple Taylor kuralı, MB'nin belirlediği faiz oranına giden karar verme sürecini açıklamaya çalışır.

Taylor ekonomide belirli ilkeler çerçevesinde kurala dayalı politikaların uygulanması gerektiğini savunarak, özellikle ekonomide başarılı bir dönem olan Greenspan döneminde alınan temel kurallara odaklanılması gerektiğini belirtmiş ve bu ilkeleri aşağıdaki maddeler halinde sıralamıştır (Overtveldt, 2008, s. 76);

- Para politikasının temelinde fiyat istikrarı yer almalı ve para politikası uygulayıcıları bu politika amacını gerçekleştirilmeye çalışılmalıdır.

- Ekonomide gerçekleşen enflasyon artışı faiz oranlarındaki artıştan daha düşük olmalıdır.

- Reel ekonomide para politikasının etkileri görülmelidir.

- MB piyasalarda bir likidite sıkışıklığı olması durumunda piyasaya likidite enjekte etmeli veya politika faizini düşürme yolunu seçmelidir.

- Para otoriteleri tarafından ekonomik performansın artırılması için gelecekteki belirsizlikler dikkate alınmalıdır.

- MB'leri para politikası için oluşturulan ekonometrik modelleri ve verileri kontrol ettikten sonra uygulama aşamasına geçmelidir.

MB'nin uyguladığı para politikasının ekonomide etkili sonuçlar vermesi için diğer merkez bankaları ve uluslararası finansal kuruluşlar ile ilişki içinde olması gerektiğini ifade etmiştir.

Taylor (1993) kuralında, para piyasasında kısa vadeli nominal faiz oranında meydana gelen değişim; enflasyonun hedeflenen değerinden, üretimin ise potansiyel düzeyinden sapmasına göre belirlenmektedir. Taylor'a göre, enflasyonun hedeflenen değerini, çıktının ise potansiyel düzeyini aşmasının temel nedeni talep baskısı olarak ifade edilmektedir. Ekonomide meydana gelen talep baskısının önlenmesi konusunda ise nominal faiz oranlarının bir politika aracı olarak kullanılmasını tavsiye etmektedir (Astar, 2009, s. 17). Ayrıca ekonomide enflasyon oranı ve çıktı düzeyinde bir artış yaşanması durumunda MB politika faiz oranını arttırarak daraltıcı para politikası uygulaması gerektiğini savunur. Nitekim MB'nin böyle bir uygulamayı tercih etmesi ekonomide harcama ve yatırım oranlarını azaltırken, tasarruf oranlarında bir artışa yol açacaktır. Ekonomide yaşanan bu durum toplam talebi baskılayarak enflasyonist eğilimi azaltacaktır.

Hem enflasyon hem de üretim istikrarına yönelen MB'ler için en uygun para politikası kuralının, Taylor kuralıdır olduğu düşünülmektedir. Taylor'un reaksiyon fonksiyonunda yer alan enflasyon açığı katsayısı, enflasyon hedefi ile para politikası aracı olarak kullanılan değişken arasındaki ilişkiyi göstermektedir. Nitekim üretim açı̆̆ı katsayısı da nominal faiz oranı ile potansiyel üretim düzeyi arasındaki ilişkileri ortaya koymaktadır (Aklan \& Nargeleçekenler, 2008, s. 28).

Taylor (1993) çalışmasında, para politikasının ekonomide etkin işleyebilmesi için oluşturduğu modelde fiyatlar genel düzeyi ve üretim düzeyini bir fonksiyon şeklinde ifade ederek bu değişkenlerde yaşanan sapmaların ekonomide olumsuz sonuçlara yol açmadan nasıl işleyeceğini açıklamaya çalışmıştır. Taylor kuralı aşağıdaki şekilde formülüze edilmiştir (Taylor, 1993, s. 202);

$$
\begin{aligned}
& r=\pi_{t}+0.5 y+0.5\left(\pi_{t}-2\right)+2 \\
& i_{t}=r+\pi_{t}+\alpha\left(\pi_{t}-\pi_{t}^{*}\right)+\beta\left(y_{t}-y_{t}^{*}\right)
\end{aligned}
$$

(1) nolu denklemde $r$ Federal faiz oranını (Federal Funds Rate), $p$ dört çeyrek önceki enflasyonun oranını ve $y$ ise gerçekleşen GSYİH'nin hedef veya potansiyel düzeyinde sapmasını ifade etmektedir. Taylor kuralında yer alan değişkenlerin açık bir şekilde ifade edildiği (2) nolu denklemde yer alan $i_{t}$ ver sirasıyla nominal ve reel faiz oranını, $\pi_{t}$ ve $\pi_{t}^{*}$ sırasıyla t dönemdeki gerçekleşen ve hedeflenen enflasyon oranını, $y_{t}$ ve $y_{t}^{*}$ sırasıyla t dönemdeki gerçekleşen ve potansiyel büyüme oranını, $\alpha(0.5)$ enflasyon tepki katsayısını ve $\beta(0.5)$ çıktı açığı tepki katsayısını ifade etmektedir. Taylor (1993) oluşturduğu kuralda katsayı olarak Federal faiz oranını \%2 ve enflasyon hedefinin $\% 2$ olduğu varsayımında bulunmuştur. Nitekim kuralda yer alan üretim açığı ve enflasyon açığının ABD ekonomisi için eş değer öneme sahip olduğunu belirterek kuraldaki iki değişkenin katsayılarını 0,5 olarak belirtmiştir. Özellikle kuraldaki 0,5 katsayısı Taylor tarafından büyük zaman simülasyon modellerinden çıkarılmış olup, daha sonraki araştırmalar daha büyük katsayıların kuralı daha istikrar sağlayıcı yapacağını göstermiştir. Ayrıca düzenleme katsayıları ile Taylor kuralı istikrar sağlayıcı özelliklere sahip olmuştur. Enflasyon yükselirse, kural reel faiz oranının yükseltilmesi gerektiğini ve GSYİH düşerse ise de reel faiz oranının düşürülmesi gerektiğini ifade etmektedir(Atılgan, 2009, s. 31).

Taylor kuralını incelediğimizde kuralın diğer para politikaları gibi karmaşık modellerin aksine basit bir para politikası kuralı olduğu gözlemlenmektedir. Basit bir para politikası olan ve daha çok MB'lerin üzerine odaklandıkları temel araçları arz etmesi Taylor kuralının en büyük avantajlıdır (Plantier \& Scrimgeour, 2002, s. 34). Ayrıca iktisat yazınında Taylor Kural'ının bu avantajına ilave olarak toplam talep eğrisinin temel eksikliklerinden birini de çözüme ulaştırdığı bilinmektedir. Faiz oranı aracılığı ile oluşan parasal çapa, Taylor'a geleneksel toplam arz-toplam talep (AD-AS) analizini yeniden tanımlama imkânını sunmuştur. Geleneksel analizde, toplam talep eğrisi para arzının (ya da iskonto oranının) sabit olduğu varsayımı ile çizilmekte, dolayısı 
ile para arzında yaşanan her bir değişim karşısında toplam talep eğrisi kaymakta ve bu durum yeni bir toplam talep eğrisinin oluşmasına yol açmaktadır. Lakin, para politikasının temel enstrümanı olan nominal faiz oranındaki değişmelerin, toplam talep eğrisinde kaymaya yol açmadan aynı toplam talep eğrisi üzerinde izlenebilmesi, analizi çok daha gerçekçi bir hale getirecektir. Bu durumu Taylor (1993) faiz haddi kuralı ile mümkün kılmaktadır. Ayrıca Taylor kuralının toplam arz eğrisi üzerindeki etkisi ise çok daha radikaldir. Bunun sebebi olarak ise; artık toplam arz etkisine ihtiyaç duyulmaması gösterilmektedir.

Taylor (1993) çalışmasında kapalı ülke modelini ele aldığı için çalışmaya döviz kuru değişkenini eklememiştir. Fakat Taylor dış ticaretin milli gelir içindeki payının göreceli olarak yüksek olduğu düşünülen ekonomilerde, kurda meydana gelen dalgalanmalar ile enflasyon arasında daha güçlü bir nedensellik ilişkisi tespit edilebileceğinden, döviz kurunun formülde yer almasının uygulamada bazı avantajlar sağlayacağını kabul etmektedir. Kuralın dışa açık ekonomilerde uygulanabilmesini sağlamak amacı ile ilk olarak Ball (1999a) çalışmasında modele bağımsız değişken olarak döviz kuru değiş̧kenin eklemiştir. Ball çalışmasında, açık ekonomilerde de Taylor kuralının geçerli olabileceğini göstermiştir. Döviz kuru değişkenin eklediği modeli incelediğimizde;

$$
i_{t}=r+\pi_{t}+\alpha\left(\pi_{t}-\pi_{t}^{*}\right)+\beta\left(y_{t}-y_{t}^{*}\right)+\gamma\left(e_{t}-e_{t}^{*}\right)
$$

(3) nolu denklemde $e_{t}$ ve $e_{t}^{*}$ sirasılyla t dönemdeki gerçekleşen ve denge döviz kurunu, $\gamma$ ise kur tepki katsayısını temsil etmektedir. Genişeltilmiş Taylor kuralı olarak ifade edilen bu denklemde kur tepki katsayısı, enflasyon ve çıktı açığından farklı özelliklere sahiptir. Ülke parasının değerinide yaşanan bir artış enflasyonist baskıları azaltacağından faiz oranları düşürülmekte, ülke parası değer kaybettiğinde ise enflasyonist baskıların artmasına bağlı olarak yükseltilmektedir. Ayrıca döviz kurunda yaşanan bir artış ulusal paranın aşırı değerlenmesi olarak kabul edildiğinde, politika faiz oranının $\mathrm{t}$ dönemindeki döviz kuruna vereceği tepki katsayısının sıfırdan küçük olması beklenilir $((y\langle 0))$. Nitekim ulusal paranın değer kazanması durumunda, enflasyon oranı ve buna bağlı olarak da faiz oranı düşmektedir.

$\mathrm{Bu}$ bağlamda açık ekonomi, kapalı ekonomiden farklı olduğu bilinir. Açık ekonomide döviz kuru davranışı, dışsal şokların etkilerini içerdiği için önemlidir (Clarida vd.,1998, s. 5; Ball, 1999, s. 13). Dahası, dışa açık ekonomiler de tüketici fiyatlarına göre enflasyonu, enflasyon ölçümünde üretim deflatörünün değişiminden daha iyidir. Fakat uygulamada, enflasyon hedeflemesini uygulayan merkez bankaları, tüketici fiyatları üzerindeki farklılığa bağlı olan enflasyonu ölçmeyi seçmiştir (Leith \& Wren-Lewis, 2009, s. 45).

Obsfeld ve Rogoff (2005) çalışmalarında döviz kuru değişkenini faiz oranı tepki fonksiyonuna dâhil ederken döviz kuru için belirlenen hedef değeri satın alma gücü paritesi (purchasing power parity) ile temsil etmiş ve kurda meydana gelen hareketlerin politika faiz oranı üzerindeki etkilerini incelemişlerdir. Çalışma sonucunda elde ettiği verilerden hareketle döviz kurunun satın alma gücü paritesinden sapması durumunda faiz oranında değişiklik yapılmamasını, bir değişiklik yapılması durumunda ise enflasyon ve çıktı düzeyinde bozulmalar meydana geleceğini savunmuşlardır.

Ayrıca Chicago FED Başkanı Charles Evans Taylor kuralının temelde enflasyonu düşürmeye yönelik bir para politikası olduğu ve bugünkü resesyon döneminde bu kuralı tekrardan revize edilmesi gerektiğini gündeme getirmiştir. Evans, ekonomideki 'Okun Yasası'na atıfta bulunarak (çıktı açığındaki 1 puanlık fark, işsizlik ve doğal işsizlik oranı arasındaki 1 puanlık farka eşittir) esasında yola çıkarak, dışa açık ekonomiler için revize edilen Taylor kuralına çıktı açığı yerine işsizlik oranının dâhil edilmesini önermektedir.

\section{Taylor Kuralı ve Seçilmiş Ülke Ekonomilerini Ele Alan Literatür Taraması}

Literatürde Taylor kuralının ülkelere göre geçerliliğini test etmek amacı ile yapılmış çeşitli ampirik çalışmalar bulunmaktadır. 1990'lı yıllardan başlayarak günümüze kadar devam eden süreçte Taylor kuralı iktisat yazını için önemli olmuştur. Taylor (1993) çalışmasında $a$ ve $\beta$ katsayılarını belirlemek için ekonometrik bir yöntem kullanmamış, sadece öngörüleri ile bu katsayıları belirlemiştir. 1993 yılından günümüze kadar yapılan çalışmalarda bu katsayıların ülkelere, kullanılan veri ve yönteme göre değiştiği gözlemlenmiş̧tir. Taylor politika kuralı denklemi $\mathrm{ABD}$ ekonomisi için uygulandı̆̆ında ise kuraldaki katsayıların ilgili dönemdeki cari para politikasına şaşırtıcı bir şekilde uyarak para politikası kuralını makul bir şekilde açıkladığını göstermiştir (Taylor, 1993:202).

Taylor (1998) yılında ABD ekonomisi için politika kuralının geçerliliğini 1879-1914, 1960-1979 ve 1986-1997 dönemi olmak üzere üç farklı gruba ayırarak test etmiştir. Çalışmada enflasyon, GSYİH ve federal fon oranı verilerinden faydalanarak EKK tahmini yapmıştır. Tahmin sonucunda elde ettiği katsayılar, 1879-1914 dönemi için kuralın geçerli olmadığını, 1960-1979 döneminde ise elde ettiği katsayıların 1'den küçük olduğu yani politika faiz oranının enflasyon ve çıktı açı̆̆ından çok az etkilendiği sonucuna ulaşmıştır. Ayrıca 1986-1997 döneminde elde ettiği katsayılar politika faiz oranının enflasyon ve çıktı açığında meydan gelen hareketliliklere karşı duyarlı olduğunu ortaya koymuştur.

Taylor kuralının Türkiye ekonomisi içinde uygulanabilir bir kural olduğunu gösteren birçok çalışma iktisat yazınında yerini almaktadır. Konu ile ilgili yapılan yerli çalışmalara Kesriyeli ve Yalçın (1998), Ongan (2004), 
Kaytancı (2005), Erdal ve Güloğlu, (2005), Çağlayan (2005), Zortuk (2007), Ertuğ (2007), Onur (2008), Aklan ve Nargeleçekenler (2008), Omay ve Hasanov (2010), Lebe ve Bayat (2011), Demirbaş ve Kaya (2012), Ardor ve Varlık (2014), Songur (2016), Gögül ve Songur (2016), Bal, Tanrı̈̈ver ve Erdoğan (2016) literatüre katkı sağlayan çalışmalar olarak örnek verilebilir.

\begin{tabular}{|c|c|c|c|c|c|}
\hline Yazar & Dönem & $\begin{array}{c}\text { Bağımlı } \\
\text { Değişsen }\end{array}$ & $\begin{array}{l}\text { Bağımsız } \\
\text { değişken }\end{array}$ & Model & Sonuç \\
\hline $\begin{array}{l}\text { Kaytanc1, B.G. } \\
(2005)\end{array}$ & $1990-2003$ & $\begin{array}{l}\text { Gecelik } \\
\text { Faiz Oranı }\end{array}$ & $\begin{array}{l}\text { Enflasyon Açı̆̆ı, } \\
\text { Üretim Açı̆̆ı, } \\
\text { Döviz Kuru }\end{array}$ & VAR & $\begin{array}{l}\text { İncelenen dönemde VAR analizi } \\
\text { sonucunda ortaya çıkan } \\
\text { bulgular yorumlandığında, bir } \\
\text { para politikası aracı olarak kısa } \\
\text { dönemli faiz oranının, yüksek } \\
\text { ve kronik enflasyona sahip } \\
\text { Türkiye'de fiyat istikrarın } \\
\text { sağlanmasında ve istikrarlı bir } \\
\text { üretim düzeyinin } \\
\text { oluşturulmasın da tek basına } \\
\text { etkili olmadığ sonucuna } \\
\text { ulaşılmıştır. }\end{array}$ \\
\hline $\begin{array}{l}\text { Zortuk,M. } \\
\text { (2007) }\end{array}$ & 2001-2006 & $\begin{array}{l}\text { Mevduat } \\
\text { Faiz Oran1 }\end{array}$ & $\begin{array}{l}\text { Enflasyon Açı̆̆ı, } \\
\text { Üretim Açı̆̆ı, } \\
\text { Nominal Döviz } \\
\text { Kuru Açığı }\end{array}$ & SINIR TESTİ & $\begin{array}{l}\text { Taylor kuralı Türkiye için analiz } \\
\text { edilmiş ve analiz sonucunda } \\
\text { Taylor kuralını söz konusunu } \\
\text { değişkenlerin kısa vadeli faiz } \\
\text { oranları üzerinde anlamlı } \\
\text { olduğu gözlemlenmiştir. }\end{array}$ \\
\hline $\begin{array}{l}\text { Aklan, N.A. ve } \\
\text { Nargeleçekenler, M., } \\
\text { (2008). }\end{array}$ & 2001-2006 & Faiz Oranı & $\begin{array}{l}\text { Enflasyon, } \\
\text { Döviz Kuru, } \\
\text { Üretim Düzeyi }\end{array}$ & GMM & $\begin{array}{l}\text { Çalışmanın } r \text { sonucunda, } \\
\text { TCMB'nin fiyat istikrarını } \\
\text { sağlama temel amacına uygun } \\
\text { olarak, uyumcu politikalar } \\
\text { izlemediğini gösteren bulgular } \\
\text { elde edilmiştir. }\end{array}$ \\
\hline $\begin{array}{l}\text { Omay,T. ve } \\
\text { Hasanov,M. } \\
(2010)\end{array}$ & $1990-2003$ & $\begin{array}{l}\text { İnterbank } \\
\text { Faiz Oranı }\end{array}$ & $\begin{array}{l}\text { Enflasyon, } \\
\text { Üretim Açı̆̆ı, } \\
\text { Bütçe Açığı } \\
\text { Reel Döviz } \\
\text { Kuru }\end{array}$ & STR & $\begin{array}{l}\text { Çalışmada kullanılan dört } \\
\text { modelden elde edilen sonuçlar, } \\
\text { TCMB'nin üretim istikrarına } \\
\text { genişleyici para politikas1 } \\
\text { yaparken dikkat ettiğini (katsayı } \\
\text { tahminleri sıfirdan oldukça } \\
\text { büyük çıkmıştır); daraltıcı para } \\
\text { politikası yaparken ise, aynı } \\
\text { önemi vermediğini göstermiştir. }\end{array}$ \\
\hline $\begin{array}{l}\text { Lebe, F.ve Bayat, T. } \\
\text { (2011) }\end{array}$ & $1986-2010$ & $\begin{array}{l}\text { İnterbank } \\
\text { Faiz } \\
\text { Oranı, } \\
\text { Mevduat } \\
\text { Faiz } \\
\text { Oran1, } \\
\text { Reeskont } \\
\text { Faiz Oranı }\end{array}$ & $\begin{array}{l}\text { Sanayi Üretim } \\
\text { Endeksi, } \\
\text { Enflasyon, } \\
\text { Döviz Kuru }\end{array}$ & VAR & $\begin{array}{l}\text { Bu çalışmada ele alınan dönem } \\
\text { itibari ile } 3 \text { model kurulmuştur } \\
\text { fakat çalışma bir bütün olarak } \\
\text { ele alınıp değerlendirildiğinde } \\
\text { genelde Türkiye'de faiz } \\
\text { oranlarının Taylor kuralına } \\
\text { bağlıymış gibi hareket ettiği } \\
\text { sonucuna varılmıştır. }\end{array}$ \\
\hline $\begin{array}{l}\text { Demirbaş, E. ve } \\
\text { Kaya, M. V. } \\
\text { (2012) }\end{array}$ & 2001-2012 & $\begin{array}{l}\text { Gecelik } \\
\text { Faiz Oranı }\end{array}$ & $\begin{array}{l}\text { Üretim Açı̆̆ı, } \\
\text { Enflasyon Açığı, } \\
\text { Reel Döviz } \\
\text { Kuru }\end{array}$ & ARDL & $\begin{array}{l}\text { Çalışmada yapılan analizin } \\
\text { sonuçları, Türkiye için seçilen } \\
\text { dönemlerde oluşturulan iki adet } \\
\text { modelin Taylor kuralına } \\
\text { uyduğunu göstermektedir. }\end{array}$ \\
\hline $\begin{array}{l}\text { Bal, H., Tanriöver, B. } \\
\text { ve Erdoğan, E. } \\
(2016)\end{array}$ & $\begin{array}{l}2001: 08- \\
2016: 06\end{array}$ & $\begin{array}{l}\text { Mevduat } \\
\text { Faiz } \\
\text { Oran1, }\end{array}$ & $\begin{array}{l}\text { Tüfe serisi, Cari } \\
\text { Ayın Enflasyon } \\
\text { Beklentisi, } \\
\text { Sanayi Üretim } \\
\text { Endeksi, TÜFE } \\
\text { Bazlı Reel } \\
\text { Efektif Döviz } \\
\text { Kuru }\end{array}$ & $\begin{array}{l}\text { BN } \\
\text { TREND } \\
\text { AYRIŞTIRMA } \\
\text { YÖNTEMI }\end{array}$ & $\begin{array}{l}\text { Elde edilen ampirik bulgular } \\
\text { sonucunda, enflasyon, çıktı ve } \\
\text { döviz kuru açığı değişkenlerine } \\
\text { ait tepki katsayılarının teoriyi } \\
\text { destekler nitelikte pozitif yönde } \\
\text { olduğu tespit edilmiştir. }\end{array}$ \\
\hline
\end{tabular}

Tablo 1: Türkiye Ekonomisi İçin Yapılan Taylor Kuralı Çalışmaları 


\section{Veri Seti ve Yöntem}

Çalışmada Kurala bağlı para politikası uygulamalarından biri olan Taylor kuralının geçerliliği, kurulan GMM modeli çerçevesinde 2001:08-2017:09 dönemi için aylık veriler yardımı ile E-Views 9 programı kullanılarak tahmin edilmiştir. Ele alınan modelde bağımlı değişken olarak kullanılan kısa vadeli nominal faiz oranlarını temsil etmek amacı ile Uluslararası Finans İstatistik raporlarından (IFS) elde edilen interbank faiz oranları kullanılmıştır. Ayrıca çalışmada açıklayıcı değişkenler olarak enflasyonun hedeflenen enflasyon değerlerinden sapması, sanayi üretim endeksinin ve reel efektif döviz kurunun trendin den sapmasının gecikmeli değerleri tercih edilmiştir.

Çalışmada enflasyon açığını hesaplanmak için TCMB'den alınan 2010=100 bazlı TÜFE verisinin aylık değişim oranı ile TCMB beklenti anketlerinde yer alan enflasyon beklenti oranı kullanılmıştır. Modelimizde yer alan ve Taylor kuralının tahmininde önemli bir değişken olan üretim açığının hesaplanmasında IMF (IFS) den alınan 2010=100 baz y1llı sanayi üretim endeksi verisi kullanılmıştır. E-Views 9 programında sanayi üretim verisi, tüfe verisi ve döviz kuru verisine TROMA/SEATS yöntemi ile mevsimsellikten arındırma işlemi uygulanmıştır. Daha sonra ise elde edilen seriden HP (Hodrick-Prescott) filtreleme yöntemi kullanılarak elde edilen seriden potansiyel üretim serisinin çıkartıldığı çıktı açığı (HGAP) serisi elde edilmiştir.

\begin{tabular}{|c|c|c|c|}
\hline Değişken & Açıklama & Dönemi & Veri Kaynağı \\
\hline $\mathrm{i}$ & İnterbank Faiz Oranları & 2001M08-2017M09 & IMF-IFS \\
\hline$\left(\pi_{v}\right)$ & Tüfe Aylık Oran Verisi & 2001M08-2017M09 & TCMB-EVDS \\
\hline$\left(\pi_{\pi}^{\frac{\pi}{\pi}}\right)$ & $\begin{array}{l}\text { Beklenti Anketi-12 Ay Sonrasının Yillık TÜFE } \\
\text { Beklentisi (Aritmetik Ortalama) }\end{array}$ & 2001M08-2017M09 & TCMB-EVDS \\
\hline$y$ & $\begin{array}{c}\text { Sanayi Üretim Endeksi (GSYİH verileri aylık } \\
\text { yayımlanmadığı için y ile proxsilenmiştir) }(2010=100)\end{array}$ & 2001M08-2017M09 & IMF-IFS \\
\hline$\theta$ & Reel Efektif Döviz Kuru (TÜFE bazlı 2010=100) & 2001M08-2017M09 & FRED \\
\hline
\end{tabular}

Tablo 2. Çalışmada Kullanılan Değişkenler ve Açıklamaları

Ekonomik modellerde kurulan regresyonun doğru bir ilişkiyi mi yoksa sahte bir ilişkiyi mi gösterdiği, zaman serisinin durağanlık özelliğine bağlıdır. Çalışmada kullanılan değişkenlerin istatistiksel açıdan anlamlı olabilmesi için modelde kullanılan ilgili değişkenlerin durağan olması gerekmektedir. Durağan olmayan seriler ile analiz yapılması modelde sahte ilişkiye sebep olup $\mathrm{R}^{2}$ değerinin yükselmesine neden olmaktadır. Çalışmada kullanılan serilere ait durağanlık analizleri Genişletilmiş Dickey-Fuller (ADF) ve Phillips-Perron (PP) birim kök testleri ile geçikme uzunluğu ise Swarz bilgi kriterine (SIC) göre yapılmıştır. ADF ve PP brim kök testinde hipotez şu şekilde kurulmaktadir;

\section{"Ho: Seri Brim Köke Sahiptir." \\ "H1: Seri Brim Köke Sahip Değildir."}

Bu hipotez çarcevesinde ADF ve PP test istatistiski sonucunun mutlak değeri tablo kritik değerinin mutlak değerini aşması durumunda $\mathrm{H}_{0}$ hipotezi red edilmekte ve $\mathrm{H}_{1}$ alternatif hipotezi kabul edilmektedir. Böyle bir durumda seri brim kök içermemektedir. Çalışmada kullanılan değişkenlere ait ADF ve PP Birim Kök testi sonuçları Tablo 3'de yer almaktadır.

\begin{tabular}{|c|c|c|c|c|c|c|c|c|c|}
\hline \multirow[b]{2}{*}{ Değişkenler } & \multicolumn{6}{|c|}{ ADF } & \multicolumn{3}{|c|}{ PP } \\
\hline & $\begin{array}{c}\text { Sabitsiz ve } \\
\text { Trendsiz }\end{array}$ & $\mathbf{L}$ & Sabitli & $\mathbf{L}$ & $\begin{array}{c}\text { Sabitli ve } \\
\text { Trendli }\end{array}$ & $\mathbf{L}$ & $\begin{array}{c}\text { Sabitsiz ve } \\
\text { Trendsiz }\end{array}$ & Sabitli & $\begin{array}{c}\text { Sabitli ve } \\
\text { Trendli }\end{array}$ \\
\hline$\left(e_{L}-e_{L}\right)$ & $\begin{array}{l}-6.492^{\mathrm{b}} \\
(0.0000)\end{array}$ & 1 & $\begin{array}{l}-6.477^{b} \\
(0.0000)\end{array}$ & 1 & $\begin{array}{l}-6.467^{\mathrm{b}} \\
(0.0000)\end{array}$ & 1 & $\begin{array}{l}-5.023^{c} \\
(0.0000)\end{array}$ & $\begin{array}{l}-5.011^{\mathrm{b}} \\
(0.0000)\end{array}$ & $\begin{array}{l}-4.995^{b} \\
(0.0003)\end{array}$ \\
\hline$\left(y_{r}-y_{r}\right)$ & $\begin{array}{l}-3.927^{\mathrm{b}} \\
(0.0001)\end{array}$ & 2 & $\begin{array}{c}-3.912^{\mathrm{b}} \\
(0.0024)\end{array}$ & 2 & $\begin{array}{c}-3.901^{\mathrm{b}} \\
(0.0138)\end{array}$ & 2 & $\begin{array}{l}-12.539^{b} \\
(0.0000)\end{array}$ & $\begin{array}{l}-12.520^{\mathrm{b}} \\
(0.0000)\end{array}$ & $\begin{array}{l}-12.501^{\mathrm{b}} \\
(0.0000)\end{array}$ \\
\hline $\mathrm{i}$ & $\begin{array}{c}-4.186^{b} \\
(0.0000)\end{array}$ & 0 & $\begin{array}{c}-2.708^{b} \\
(0.0744)\end{array}$ & 0 & $\begin{array}{c}-1.534^{b} \\
(0.8144)\end{array}$ & 0 & $\begin{array}{c}-4.519^{b} \\
(0.0000)\end{array}$ & $\begin{array}{c}-2.863^{\mathrm{b}} \\
(0.0516)\end{array}$ & $\begin{array}{c}-1.464^{\mathrm{b}} \\
(0.8385)\end{array}$ \\
\hline$\Delta \mathbb{i}^{*} * *$ & $\begin{array}{l}-14.491^{\mathrm{b}} \\
(0.0000)\end{array}$ & 0 & $\begin{array}{c}-15.270^{\mathrm{a}} \\
(0.0000)\end{array}$ & 0 & $\begin{array}{r}-15.701 \\
(0.0000)\end{array}$ & 0 & $\begin{array}{l}-14.657^{b} \\
(0.0000)\end{array}$ & $\begin{array}{c}-15.200^{\mathrm{b}} \\
(0.0000)\end{array}$ & $\begin{array}{c}-15.679^{b} \\
(0.0000)\end{array}$ \\
\hline$\left(\pi_{\tau}\right)$ & $\begin{array}{l}-6.105^{b} \\
(0.0000)\end{array}$ & 12 & $\begin{array}{l}-7.204^{b} \\
(0.0000)\end{array}$ & 12 & $\begin{array}{l}-6.172^{b} \\
(0.0000)\end{array}$ & 12 & $\begin{array}{l}-6.449^{b} \\
(0.0000)\end{array}$ & $\begin{array}{l}-9.726^{b} \\
(0.0000)\end{array}$ & $\begin{array}{l}-6.366^{\mathrm{a}} \\
(0.0000)\end{array}$ \\
\hline$\left(\pi_{\mathrm{L}}\right)$ & $\begin{array}{l}-3.922^{\mathrm{b}} \\
(0.0000)\end{array}$ & 1 & $\begin{array}{l}-5.312^{\mathrm{b}} \\
(0.0000)\end{array}$ & 1 & $\begin{array}{l}-5.991^{\mathrm{b}} \\
(0.0000)\end{array}$ & 1 & $\begin{array}{l}-7.461^{\mathrm{b}} \\
(0.0000)\end{array}$ & $\begin{array}{l}-12.270^{\mathrm{b}} \\
(0.0000)\end{array}$ & $\begin{array}{l}-9.843^{\mathrm{b}} \\
(0.0000)\end{array}$ \\
\hline$\theta$ & $\begin{array}{c}-6.477^{b} \\
(0.0000)\end{array}$ & 1 & $\begin{array}{c}-6.492^{b} \\
(0.0000)\end{array}$ & 1 & $\begin{array}{c}-6.467^{b} \\
(0.0000)\end{array}$ & 1 & $\begin{array}{l}-5.023^{b} \\
(0.0000)\end{array}$ & $\begin{array}{c}-5.011^{\mathrm{b}} \\
(0.0000)\end{array}$ & $\begin{array}{c}-4.995^{\mathrm{b}} \\
(0.0003)\end{array}$ \\
\hline
\end{tabular}

Tablo 3. ADF ve PP Birim Kök Testi Sonuçları 
Tablo 4'de yer alan Taylor Kuralı GMM tahmin sonuçlarına baktığımızda katsayılar literatürde beklenilen şekilde bulunmuştur. MB'nin uzun dönem denge faiz oranın (politika faiz oranı) tahmin katsayısı 5.96, enflasyon açığı katsayısı 1.031 , çıktı açı̆ı̆ katsayısı 0.80 ve döviz kuru açığı katsayısı -0.03 olarak tespit edilmiştir. Tablo 4 'de tahmin edilmiş olan tüm parametreler $\% 1$ ve $\% 5$ anlamlılık düzeylerinde anlamlı bulunmuştur. Tahmin sonuçlarında düzeltilmiş R2 katsayısının \%97 bulunması faiz oranlarındaki değişimlerin çok yüksek oranda bağımsız değişkenler tarafından açıklandığını belirtmektedir. Ayrıca model tahmin sonucun da elde edilen Hansen (1982) J-istatistik değeri modelde aşırı belirleme probleminin olmadığını gösteren H_0 hipotezini kabul etmektedir.

Gerçekleşen enflasyonun hedeflenen enflasyondan sapmasını gösteren enflasyon açı̆̆ı katsayısı $(\alpha) 1.031$ olarak tahmin edilmiştir. MB ekonomide diğer değişkenler sabit iken enflasyonun hedeflenen değerinde 1 puanlık bir sapma gerçekleştirmesi durumunda politika faiz oranını 1.031 arttırmalıdır. MB'nın enflasyon oranını düşürmek için kullandığı temel araçlardan birisi faiz oranı değişkenidir. Faiz ve enflasyon arasındaki ilişki Irving Fisher'ın ünlü varlık fiyatlaması denklemine dayanmaktadır. Denklemde nominal faiz oranı i, denge durumunda, reel faiz oranı $r$ ve enflasyon oranı $\pi$ 'nin toplamına eşittir $(i=r+\pi)$. Denklem enflasyon oranında meydana gelen bir birimlik artışın faiz oranı üzerinde artışa yol açacağını ifade etmektedir. Özellikle bireyler yüksek enflasyonist ortamlarda tasarruflarını enflasyonun olumsuz etkilerinden korumak için daha yüksek faiz talep edeceklerdir. Sonuçta olarak gerçekleşen enflasyon oranının hedeflenen enflasyon oranının üzerinde gerçekleşmesi durumunda MB sıkı para politikası uygulayarak politika faiz oranını arttırmaktadır.

Son yıllarda para politikası uygulamalarında yakından izlenen bir değişken olan çıktı açığı, ekonominin arz ve talep cephesine yönelik taşıdığı bilgi sebebi ile özellikle enflasyon hedeflemesi uygulayan ülkeler için önemli bir değişken haline gelmiştir. Çalışmada diğer değişkenler sabitken gerçekleşen çıktının potansiyel çıktıdan sapmasını gösteren çıktı açığı katsayısı 0.08 olarak bulunmuştur. Bu durumda gerçekleşen üretim düzeyinin potansiyel üretim düzeyini 1 birimlik aşması durumunda MB politika faiz oranını yaklaşık olarak 0.08 birim arttıracaktır. Çıktı açığı katsayısı Taylor kuralı katsayısı ile işaret ve büyüklük olarak uyumludur fakat tahmin sonucunda elde edilen değerin politika faiz üzerinde etkisi yok denilecek kadar az olmaktadır. Bu nedenle MB bankası politika faiz oranını belirlerken tek başına ekonomideki üretim düzeyine göre hareket etmemelidir.

Ayrıca model tahmin sonucundan reel efektif döviz kurunun trendinden sapmasını gösteren döviz kuru açığının katsayısı -0.07 olarak tespit edilmiştir. Buna göre ulusal paranın dolar karşısında değer kazanması (kaybetmesi) merkez bankasının genişlemeci (sıkı) para politikaları uygulayarak faiz oranlarını 0.07 oranında düşürmesine (yükseltmesine) neden olmaktadır. Esnek kur sistemi uygulanan ekonomilerde döviz kuru açı̆̆ı katsayısının sıfira yaklaşması beklenirken, Türkiye ekonomisi için yapılan analizde çok yüksek bulunmuştur. Bu durumun oluşmasındaki temel sebebi olarak küresel finansal kriz sonrasında ekonomide yaşanan kısa vadeli sermaye girişlerinin cari işlemler dengesinde bozulmaya yol açması söylenebilir.

Model sonuçlarımızı değerlendirdiğimizde enflasyon açığı, çıktı açığı ve döviz kuru açığının politika faiz oranı üzerindeki etkisi katsayı işareti olarak Taylor (1993) kuralı ile benzer sonuçtadır. Fakat katsayı büyüklüklerini incelediğimizde üç değişkeninde katsayıları Taylor (1993) kuralında elde ettiği katsayılarda uzak değerler olduğu görülmektedir. Çalışmada elde edilen katsayıların etkilerini büyüklük olarak sıraladığımızda ise MB'nin faiz kararlarında enflasyon açı̆̆ının etkisi nispeten diğer değişkenlerden daha yüksek olduğu görülmektedir. $\mathrm{Bu}$ kapsamda $\mathrm{MB}$ iç ve dış dengeyi ve özellikle fiyat istikrarını sağlayacak olan politika faizlerini hangi düzeyde belirlemesi gerektiğini, enflasyon açığı değişkenini bir gösterge olarak kullanmasıyla tespit edebilir.

\section{Sonuç ve Öneriler}

Merkez bankalarının, temel amacı olan fiyat istikrar ve ekonomik büyümeyi sağlamak için nasıl bir para politikası izlemesi gerektiği sorusu kurala dayalı ve ihtiyari para politikaları tartışmaları kapsamında ele alınmaktadır. Kurala dayalı politika argümanını savunanlara göre, kurala bağlı politika uygulamaları ekonomide bir disiplin sağlayarak, MB'na duyulan güvenilirliği arttıracağını ifade ederler. Kural politikanın zıttı olan ihtiyar politika ise MB'nin bir kurala bağlı kalmadan içinde bulunduğu şartlar göre istediği politikayı özgürce seçebilmesini ifade etmektedir. Bu politika uygulamasını savunanlara göre ekonomide beklenmeyen bir durum ile karşılaşıldığında MB duruma anında müdahale ederek çözüme kavuşturabilmektedir. Fakat ihtiyari politika savucunuların unuttuğu bir nokta vardır. O da zaman tutarsızlığı olgusudur.

Çalışmada 2001:08-2017:09 dönemi için interbank faiz oranı, sanayi üretim endeksi, tüfe, tüfe beklenti serisi ve reel efektif döviz kuru aylık verilerinde yararlanılmıştır. Taylor kuralı modelinde kullanılan tüm değişkenlere yönelik yapılan durağanlık analizleri, interbank faiz oranı serilerinin birinci derecen I(1) iken diğer tüm değişkenlerin seviyesinde durağan I (0) olduğu tespit edilmiştir. Analizde kullanılan değişkenler Genelleştirilmiş Momentler Metodu (GMM) ile tahmin edilmiştir. Kurulan model spesifikasyonu aracilığıyla kısa vadeli faizlerin, enflasyon açı̆̆ı, çıktı açığı ve döviz kuru açığına olan duyarlılı̆̆ incelenmiştir. Analiz sonucunda kısa vadeli faiz oranlarının enflasyon açı̆̆ı ve çıktı açığına verdiği tepki katsayılarının, Taylor (1993) kuralındaki katsayılardan uzak değerler olduğu tespit edilmiştir. Ayrıca reel efektif döviz kurunda meydana gelen bir sapmanın da faiz oranları üzerinde negatif yönde güçlü bir etkiye yol açtığı tespit edilmiştir. Analiz sonucunda elde edilen katsayılar Türkiye ekonomisi için yapılan çalışmaları destekler niteliktedir. 
Sonuç olarak TCMB'nin kurala dayalı ve ihtiyari para politikası tartışmaları kapsamında fiyat istikrarı ve ekonomik büyüme hedefini sağlamak amacı ile kural politika uyglamalarını tercih ettiği tespit edilmiştir. Fakat kural politika uygulamalarından biri olan Taylor kuralının Türkiye ekonomisindeki yüksek enflasyon oranı, finasal piyasalarda yaşanan kırılganlık ve döviz kurlarında meydana gelen aşırı hareketlilikten dolayı geçerli olmadığı görülmmektedir.

\section{Kaynakça}

- $\quad$ Aklan, N.A. ve Nargeleçekenler, M., (2008). Taylor Kuralı: Türkiye Üzerine Bir Değerlendirme, Ankara Üniversitesi SBF Dergisi.

- $\quad$ Ardor, H. M. ve Varlık, S., (2014). İleriye Dönük Yeni Keynesyen Para Politikası Reaksiyon Fonksiyonunun Tahmini: Taylor Kuralı'nın, Mccallum Kuralı'nın, Taylor-Mccallum Melez Kuralı'nın Türkiye Ekonomisinde Geçerliliği, Ekonomik Yaklaşım.

- Atılgan, H. (2009). Parasal Anayasa, Hukuk Ve İktisat Araştırmaları Dergisi Cilt 1, No 1, ISSN: 2146-0817, Ankara.

- $\quad$ Bal, H., Tanrı̈ver, B. ve Erdoğan, E. (2016). Taylor Kuralı Kapsamında Merkez Bankası Politika Faiz Oranlarının Belirlenmesi: Stokastik Trend Yaklaşımı, Journal of Academic Values Studies (JAVS), ISSN: 2149-8598, Volume, Issue 6.

- Ball, L., (1999). Policy Rules For Open Economies in John Taylor (eds), Monetary Policy Rules, NBER Working Paper, 6760.

- Batini, N., Harrison R. and Millard S., (2001). Monetary Policy Rules For An Open Economy, Bank of England Working Papers.

- Bernanke, B. S. and Mishkin, F. S. (1997). Inflation Targeting: A New Framework for Monetary Policy?, Journal of Economic Perspectives, 11 (2).

- Chevapatrakul, T., Mizen, P. ve Kim, T., (2002). Predicting Changes in The Interest Rate: The Performance of Taylor Rules Versus Alternatives For The United Kingdom, http//repec.org./res2016/kimTH.pdf.

- Clarida, R., J. Gali ve M. Gerdler, (1998). Monetary Policy Rules in Practice: Some International Evidence, European Economic Rewiev, 42.

- Clark, E. (1994). Nominal GDP Targeting Rules: Can They Stabilize the Economy? Federal Reserve Bank of Kansas City.

- Çağlayan, E., (2005). Türkiye'de Taylor Kural'ının Geçerliliğinin Ekonometrik Analizi, Marmara Üniversitesi İktisadi ve İdari Bilimler Fakültesi Dergisi.

- Drew, A. and B. Hunt. (1998). Efficient Simple Policy Rules and The Implications of Potential Output Uncertainty, Journal of Economics and Business, Elsevier, vol. 52, Elgar Publishing Inc.

- $\quad$ Erdal, F., ve Güloğlu, B. (2005). Modelling Real Exchange Rate Behaviour With The Taylor Rule: An Empirical Analysis, Proc. The International Conference on Policy Modeling, EcoMod, İstanbul.

- Ertuğ, D., (2007). Türkiye İçin Faiz Oranı Reaksiyon Fonksiyonu ve Taylor kuralı: Eşbütünleşme Yaklaşımı. Gazi Üniversitesi SBE, Yüksek Lisans Tezi.

- $\quad$ Evans, C. L. (1998). Real-time Taylor Rules and the Federal Funds Futures Market, Federal Reserve Bank of Chicago Economic Perspectives, Third Quarter, September.

- Fung, J. (2005). Estimating a Monetary Policy Reaction Function for the Dominican Republic, International Economic Journal, Korean International Economic Association, vol. 19.

- Gerlach, S. and G. Schnabel. (2000). The Taylor Rule and Interest Rates in the EMU Area, Economics Letters, vol. 67.

- Gögül, P.K. ve Songur, M., (2016). “Türkiye'de Enflasyon Hedeflemesi Stratejisinde Araç Kural "Taylor Kuralı” Mı?, Maliye Araştırmaları Dergisi, Yıı:2, Cilt:2, Sayı:1.

- Greenspan, A. (1994). Subcommittee on Economic Growth and Credit Formulation of the Committee on Banking, Finance and Urban Affairs, U.S.

- Gujarati, D. N. (1999). Temel Ekonometri, Literatür Yayınevi, İstanbul,

- Güçlü Ekonomiye Geçiş Programı (GEGP). (2002) TCMB. 05.06.2017 tarihin de http://www.tcmb.gov.tr.

- Hansen, L. P. (1982). Large Sample Properties of Generalized Method of Moments Estimators. Econometrica, Journal of the Econometric Society, 1029-1054.

- Hodrick, R. J. and Prescott, E. C. (1197).Postwar U.S. Business Cycles: An Empirical Investigation, Journal of Money, Credit and Banking, Vol.29, No.1. 
- Holtrop, W. M. (1963). Monetary Policy in an Open Economy:It's Objecives, Instruments, Limitations, and Dilemmas. Essays in International Finance, No.43.

- Hsing, Y. (2009). Is the Monetary Policy Rule Responsive to Exchange Rate Changes? The Case of Indonesia, Malaysia, the Philippinnes and Thailand, International Review Economics, vol. 56.

- http://www.tcmb.gov.tr/wps/wcm/connect/TCMB+TR/TCMB+TR/Main+Menu/Para+Politikasi/Finansal+Is tikrar (Erişim_Tarihi 04.06.2017)

- https://www.tbb.org.tr/Content/dijitalkitaplar/istikrar/tbbfiyatistikrari.html (Erişim saati: 01.05.2017 02:45).

- Iklaga, F. O. (2008). Estimating a Monetary Policy Reaction Function For The Central Bank of Nigeria (1999-2007), Unpublished Paper, Columbia University.

- Kaytancı, B. G., (2005). “Merkez Bankası Para Politikası Tepki Fonksiyonu: 1990-2003 Türkiye Uygulaması. Doktora Tezi, Eskişehir, Anadolu Üniversitesi Sosyal Bilimler Enstitüsü.

- Kesiyerli, M., Koçaker, İ.İ. (1999). Monetary Conditıons Index: A Monetary Policy Indicator For Turkey, CBRT Discussion Paper, 9908.

- $\quad$ Kesriyeli, M. ve Yalçın, C., (1998). Taylor Kuralı ve Türkiye Uygulaması Üzerine Bir Not, TCMB Araştırma Genel Müdürlüğü, Tartışma Tebliği, No:9802.

- $\quad$ Kozicki, S., (1999). How Useful Are Taylor Rules for Monetary Policy, Federal Reserve Bank of Kansas City Economic Review, Second Guarter.

- Kydland, F. and Prescott, E. C. (1977). Rules Rather Than Discretion: The Inconsistency of Optimal Plan, Journal of Political Economy, Vol. 85, No. 3, Jun.

- $\quad$ Lebe, F., ve Bayat, T., (2011). Taylor kuralı: Türkiye için Bir Vektör Otoregresif Model Analizi, Ege Akademik Bakış.

- McCallum, B. T., (2002). The Use of Policy Rules in Monetary Policy Analysis, Shadow Open Market Committee Speech, U.S.A.

- Meltzer, Allan H., (1995). Monetary, Credit and (Other) Transmission Processes: A Monetarist Perspective, Journal of Economic Perspectives, Volume 9, Number 4.

- Monticelli, C. and O. Tristani. (1999). What Does the Single Monetary Policy Do?, A SVAR Benchmark for the European Central Bank, European Central Bank Working Paper Series, vol. 2.

- Moura, M. L. and A. D. Carvalho. (2010). What can Taylor Rules Say About Monetary Policy in Latin America, Journal of Macroeconomics, vol. 32 (1).

- Omay, T., ve Hasanov, M., (2010). Türkiye için Reaksiyon Fonksiyonunun Doğrusal Olmayan Modelle Tahmin Edilmesi, Çankaya University Journal of Humanities and Social Sciences, 467-490.

- Ongan, T. H., (2004). “Enflasyon Hedeflemesi ve Taylor kuralı: Türkiye Örneği”. Maliye Araştırma Merkezi Konferans1, Kirk besinci Seri, 1-12.

- $\quad$ Onur, S., (2008). Türkiye Ekonomisinde Faiz Oranlar1-Enflasyon İlişkisi Üzerine Bir Model Denemesi (1980- 2005). Journal of Qafqaz University, 123-145.

- Plantier L.C. and Scrimgeour, D. (2002). Estimating Taylor Rule for a New Zealand with a Time-Varying Neutral Real Rate, Reserve Bank of New Zealand Discussion Paper Series, DP: 2002/06.

- Poole, W. (1993). Monetary Policy Rules. Federal Reserve Bank of Saint Louis

- Svensson, L.E.O. (1998). Open Economy Inflation Targeting, NBER Working Paper Series: 6545.

- Taylor, J.B., (1993). Discretion Versus Policy Rules in Practice. Carnegie-Rochester Conference Serieson Public Policy, 195-214.

- Taylor, J.B., (2001). The Role of the Exchange Rate in Monetary Policy Rules, The American Economic Review, 263-268.

- Taylor, J. B. (1998a). An Historical Analysis of Monetary Policy Rules, National Bureau of Economic Research Working Paper, vol. 6768.

\section{Notlar}

* Bu çalışma Kurala Dayalı ve İhtiyari Para Politikası Tartışmaları Kapsamında Taylor Kuralının Analizi: Teori ve Türkiye Örneği isimli Yüksek Lisans Tez çalışmasından üretilmiştir.

* Bu Çalışma, Çukurova Üniversitesi BAP Brimi SBA-2018-10768 numaralı proje tarafından desteklenmiştir.

* $\quad$ Bu Çalışma, Türkiye Bilimsel ve Teknolojik Araştırma Kurumu (TÜBİTAK) 2211-A Yurt İçi Doktora Burs Programı tarafından desteklenmiştir. 


\title{
İkili Uyarlanma Yaklaşımı: Türkiye için Yatırım Fonksiyonu Uygulaması (1963-2017)
}

\section{The Dual Adjustment Approach with an Application to the Investment Function for Turkey (1963-2017)}

\author{
Prof. Dr. Mustafa İsmihan (Eastern Mediterranean University, TR of Northern Cyprus) \\ Dr. Mustafa Can Küçüker (Atılım University, Turkey)
}

\begin{abstract}
The dual adjustment approach enables us to consider separate dual co-movements of permanent and transitory components of time series variables and hence the possibility of dual adjustment. The common \{filtered\} trend concept is developed within the framework of dual adjustment approach and a simple test for the existence of such relationship is suggested for nonstationary macroeconomic variables. This paper investigates the dual adjustment with an application to the private sector fixed capital investment function by using the Turkish data over the 19632017 period. Our results indicated that private sector fixed capital investment and income, public sector fixed capital investment and macroeconomic instability are not cointegrated and hence they have spurious relationship. In contrast, according to the dual adjustment approach, these variables have a long run relationship. Additionally, it is shown that there are dual relationships between permanent and temporary components of private sector fixed capital investment and income. Furthermore, it is shown that there is no long run relationship between private sector fixed capital investments and public sector fixed capital investments but they are negatively related in the short run. In addition, it is concluded that macroeconomic instability is detrimental for private sector fixed capital investments only in the long run.
\end{abstract}

\section{Giriş}

Teorik ve istatistiksel sebepler dolayısıyla bazı zaman serisi verilerinin geçici ve kalıcı bileşenlerine ayrılması, bu bileşenlerin ikili ortak hareketlerini anlayabilmek için oldukça önemlidir. Ancak standart eşbütünleşme ilişkisi, geçici bileşenlerin, kalıcı bileşenlere özgü ilişkilere sahip olduğunu yani tekil uyarlanmayı örtük olarak empoze etmektedir. Dolayısıyla ikili ortak harekete sahip olan değişkenleri, tekil uyarlanma kısıtına sahip olan eşbütünleşme testleri ile sınamak mümkün değildir.

İsmihan (2019) İkili Uyarlanma adını verdiği bir yaklaşım geliştirerek, zaman serilerinin geçici ve sürekli bileşenlerinin ikili uyarlanmasının analiz edilebileceğini ortaya koymuş ve eşbütünleşme testlerine alternatif bir bakış açısı getirmiştir. İsmihan'ın çalışmasında ortak Hodrick-Prescott (HP) trend kavramı ortaya konulmuş ve HP filtresi ile bileşenlerine ayrıştırılmış zaman serilerinin sürekli ve geçici bileşenlerinin ilişkilerinin ayrı ayrı incelenebileceği bir yaklaşım oluşturulmuştur.

$\mathrm{Bu}$ çalışmada HP dışında Baxter King (BK), Christiano-Fitzgerald (CF) gibi literatürde sıklıkla kullanılan filtreme yöntemleriyle İkili Uyarlanma yaklaşımı çerçevesinde ortak filtrelenmiş trend kavramı ortaya konulmuş ve serilerin bu tip bir ilişkiye sahip olup olmadıklarının sınanabilmesi için kolayca uygulanabilecek bir test önerilmiştir. Bu bağlamda bu çalışmada 1963-2017 döneminde özel kesim sabit sermaye yatırımlarının (IP), gelir (Y), kamu kesimi sabit sermaye yatırımları (IG) ve makroekonomik istikrarsızlık (INSW) ile olan ilişkisi İkili Uyarlanma yaklaşımı ile incelenmiştir.

Bölüm 2'de İkili Uyarlanma Yaklaşımı'ndan kısaca bahsedilecek, bölüm 3'te bu çalışmada kullanılacak olan modelin temellerinden bahsedilecek ve analiz sonuçları ile bu çalışmada kullanılan trend ayrıştırma yöntemlerinin karşılaştırmalı performansları verilecek ve bölüm 4'te bu çalışmadaki bulguların bir özeti bulunacaktır.

\section{2 İkili Uyarlanma}

Bu yaklaşımın temellerini atabilmek için ilk olarak Friedman’ın Sürekli Gelir Hipotezi’nin güçlü versiyonu düşünülecek olursa Y kişisel tüketim harcamalarını, X harcanabilir geliri simgelemek üzere zaman serileri aşağıdaki şekilde sürekli ve geçici bileşenlerine HP filtresi veya diğer zaman serisi filtreleme yöntemleri ile ayrilabilirler;

$$
\begin{aligned}
& Y_{t} \equiv Y_{t}^{P}+Y_{t}^{T}, \\
& X_{t} \equiv X_{t}^{P}+X_{t}^{T},
\end{aligned}
$$

Sürekli Gelir Hipotezinin güçlü versiyonuna göre sürekli tüketim ile sürekli gelir arasında uzun dönemli bir ilişki olmalıdır. Bu durumda İkili Uyarlanma yaklaşımında test edilecek olan iddia aşağıdaki gibidir:

$$
Y_{t}^{P}=\beta_{0}+\beta_{1} X_{t}^{P}
$$

Bu aşamada bu ifade (iddia) $Y_{t} \equiv Y_{t}^{P}+Y_{t}^{T}$ ifadesi içine konulursa bu iddia aşağıdaki şekilde ifade edilebilir: 


$$
Y_{t}=\beta_{0}+\beta_{1} X_{t}^{P}+Y_{t}^{T}
$$

Bağımlı değişkenin geçici bileşeninin teorik olarak durağan, yani I(0), olduğu düşünülürse uzun dönemli birlikte hareketin varlığı $Y_{t}^{T}=Y_{t}-\left(\beta_{0}+\beta_{1} X_{t}^{P}\right)$ ifadesinin I( 0$)$ olup olmamasının testi ile sinanabilir.

Yani yukarıda bulunan iddiayı test edebilmek için aşağıdaki model tahmin edilir;

$$
Y_{t}=\beta_{0}+\beta_{1} X_{t}^{P}+u_{t}
$$

Ampirik uygulamalarda (5) numaralı denklemden elde edilen kalıntılar $\mathrm{I}(0)$ ise $\mathrm{Y}$ ve $\mathrm{X}$ değişkenleri ortak HP trende sahiptirler (İsmihan, 2019).

İkili Uyarlanma Yaklaşımı'nda ayrıca geçici bileşenlerin birbirleri ile ilişkilerinin sınandığı ikinci bir aşama bulunmaktadır. Bu aşamada aşağıdaki modelin katsayısı EKK ile tahmin edilir:

$$
Y_{t}^{T}=\beta_{2} X_{t}^{T}+v_{t}
$$

Bu aşamada $\beta_{2}$ geçici bileşenlerin ilişkisini simgelemektedir. Eğer bu ilişki kalıcı bileşenlerin katsayısı ile aynı ise $\left(\beta_{2}=\beta_{1}\right)$ "tekil uyarlanma", farklı ise "ikili uyarlanma" vardır denilir.

Engle-Granger İki Aşamalı Eşbütünleşme Analizi literatürde ilk aşamadaki katsayıların ve standart hataların oldukça sapmalı tahmin edilebileceği konusunda eleştirilmektedir (örneğin Bannerjee, Dolado, Hendry ve Smith, 1986). Bu problemin üstesinden gelebilmek amaciyla Engle ve Yoo (1991) 3 aşamalı bir tahmin yöntemi önermiştir. Bu yöntem sayesinde katsayılar ve bu katsayıların standart hataları sapmasız bir şekilde tahmin edilebilmektedir. Bu çalışmada bu yöntemin İkili Uyarlanma Yaklaşımı'na dahil edilmesi ile sürekli bileşenlerin sapmasız bir şekilde tahmin edilmesi sağlanmış ve dolayısıyla bu katsayılar geçici bileşenlerin katsayıları ile karşılaştırılabilir hale gelmiştir.

\section{Model ve Analiz Sonuçları}

\section{Tekil ve İkili Uyarlanma}

Mevcut literatür dikkate alındığında IP'nin Y'den olumlu bir şekilde etkilendiği (İsmihan, 2009; Guncavdi ve McKay, 2013), INSW den olumsuz etkilendiği (Bleaney, 1996; İsmihan ve diğerleri, 2005; Günçavdi ve Küçük, 2013) ve IG’den ise farklı şekillerde etkilendiği söylenilebilir (Taylor, 1993; Cavallo ve Daude, 2011).

Geleneksel yaklaşım takip edilirse, yani ikili yerine tekil uyarlanma varsayılırsa, IP'nin Y, IG ve INSW ile olan ilişkisini analiz etmek için aşağıdaki matematiksel model kurulabilir:

$$
I P_{t}=\beta_{0}+\beta_{1} Y_{t}+\beta_{2} I G_{t}+\beta_{3} I N S W_{t}
$$

Yukarıdaki model bağlamında ikili uyarlanmanın teorik gerekçelerinin daha iyi anlaşılabilmesi için ilgili literatürün daha dikkatli okunmasıyla bahsedilen değişkenlerin sürekli ve geçici bileşenlerinin farklı şekillerde birbirleriyle uyarlanabilecekleri görülebilir.

\section{IP ve Y İlişkisi}

Firmalar, artan büyüme nedeniyle mevcut sermaye stokunu artırmak istediklerinde, yeni makineler ve binalar için yatırım akımı başlar ve sermaye stokuna olan yeni talep ile mevcut sermaye stoku arasındaki boşluk hızla kapanma eğilimine girer [bkz. Dornbusch ve diğerleri (2007)]. Dolayısıyla, yatırımlardaki kısa dönemli artış büyümeden daha çok olur. Tersi durumlarda ise, örneğin ciddi bir kriz karşısında, yatırımlarda daha sert düşüşler beklenmektedir. Çünkü hızlandıran prensibinin işleyişi zamana göre asimetriktir. Buna göre bu mallara olan talep, gelirdeki kısa dönemli değişimlere karşı oldukça sert bir şekilde cevap vermektedir. Dolayısıyla sabit sermaye yatırımlarının gelirin bir fonksiyonu olduğu, ancak bahsi geçen asimetri nedeniyle Y'nin devrevi bileşeni IP'nin geçici bileşenini, Y'nin sürekli bileşeninin IP'nin sürekli bileşenini etkilediğinden daha fazla etkileyecektir (Pindyck ve Rubinfeld, 2018).

\section{IP ve INSW İlişkisi}

Oldukça büyük batık maliyetlere sahip olan ve geri dönülmesi oldukça zor olan sabit sermaye yatırımları (Pindyck ve Rubinfeld, 2018) makroekonomik istikrarsızlığın yarattığı belirsizlik ortamından oldukça kötü bir şekilde etkilenmektedir (Pindyck, 1991). Ancak belirsizlik ortamında yatırım kararlarını bekletmenin de bir maliyeti bulunmaktadır ve bu sebepten ötürü iktisadi aktörler karşılaşacakları firsat maliyetlerini düşünerek istikrarsızlıkta yaşanılacak kısa dönemli değişiklik durumlarında yatırım kararlarını devam ettirebilirler. Yani INSW'nin sürekli bileşeninin, IP'nin sürekli bileşenini negatif bir şekilde etkileyeceği ancak bu değiş̧kenlerin geçici bileşenlerinin birbirlerini etkilemeyebileceği veya etkilese bile bu etkinin sürekli bileşenlerin etkisine nazaran daha düşük olacağı kolaylıkla söylenebilir.

IP ve IG İlişkisi 
Yatırımların (kamu ve özel) bugün maliyet yaratan ancak gelecekte fayda sağlayan bir eylem olduğu düşünüldüğünde kamu yatırımlarının özel yatırımlar üzerindeki etkisi kısa vadede, finansal dışlama etkisinden dolayı, olumsuz olabilmektedir. Ayrıca, kamu yatırımlarının özel yatırımlar üzerindeki uzun dönemli net etkisini belirlerken finansal dışlama ve içerileme etkilerinin görece büyüklüğünün de önemli bir rol oynayacağını unutmamalıyız. Yani kamu kesimi yatırımları ve özel kesim yatırımları tamamlayıcı olsalar bile kamu yatırımlarının uzun vadede net etkisi tam tersi nitelikte (olumsuz) ya da nötr olabilir.

İkili Uyarlanma yaklaşımında, eşbütünleşim analizleri çerçevesinde uygulanan geleneksel modelleme yaklaşımının doğasında bulunan sürekli ve geçici bileşenlerin birbirlerini aynı katsayı üzerinden etkilemelerini gerekli kılan kısıtın önüne geçilmiş olmaktadır. Buna göre bu yaklaşımda, geleneksel eşbütünleşme yaklaşımının şart koştuğu, aynı değişkenin sürekli ve geçici bileşenlerinin katsayılarının aynı olması durumuna izin verildiği gibi bu katsayıların birbirinden farklı olması veya bu katsayılardan birinin istatistiksel olarak anlamsız olması durumlarının test edilmesine de olanak sağlanmaktadır.

\section{İkili Uyarlanma}

Yukarıdaki bilgiler ışığında ve İkili Uyarlanma yaklaşımı'na dayanarak, bu çalışmada değişkenlerin sürekli ve devrevi bileşenlerinin birbirlerini farklı biçimlerde etkilemesine izin veren aşağıdaki ikili teorik model geliştirilmiştir.

$$
\begin{aligned}
& I P_{t}^{P}=\beta_{0}+\beta_{1} Y_{t}^{P}+\beta_{2} I G_{t}^{P}+\beta_{3} I N S W_{t}^{P} \\
& I P_{t}^{T}=\beta_{4} Y_{t}^{T}+\beta_{5} I G_{t}^{T}+\beta_{6} I N S W_{t}^{T}
\end{aligned}
$$

Sürekli bileşenlerin birbirleri ile ilişkisinin incelendiği ilk modelde katsayıları sırasıyla Y'nin, IG'nin ve INSW'nin sürekli bileşenlerinin, IP'nin sürekli bileşeni üzerindeki etkilerini gösterirken, katsayıları bu değişkenlerin geçici bileşenlerinin IP'nin geçici bileşeni üzerindeki etkilerini göstermektedir. Yukarıdaki teorik bilgiler ışı̆̆ında geçici ve kalıcı bileşenlerin katsayılarının farklı olduğu söylenebilir ve bunların aynı olduğunu örtük olarak iddia eden geleneksel (tekil) yaklaşımın kısıtlayıcı bir yaklaşım olduğu söylenebilir.

Bu bölümün geri kalan kısmında Türkiye için 1963-2017 dönemi dikkate alınarak oluşturulmuş olan özel kesim sabit sermaye yatırımları fonksiyonu tahmin edilecektir. Bu analiz yapılırken HP filtresi ile birlikte literatürde sıklıkla kullanılan BK ve CF filtreleri de İkili Uyarlanma Yaklaşımına dahil edilmiştir ve bütün sonuçlar EngleGranger eşbütünleşme testi ile karşılaştırmalı olarak Tablo 1'de verilmiştir. Bununla birlikte kullanılmış olan filtrelerin bu çalışma dahilindeki uygunluklarının sınanabilmesi yani kullanılan filtreleme yöntemleri arasında seçim yapılabilmesi amacıyla bilgi kriterlerine yer verilmiş ve son olarak veri setinin sonundan önceden belirlenmiş sayıda gözlem atarak (bu çalışmada 10 gözlem) analiz yapılmasını ve her defasında bu atılan gözlemlerden bir tanesinin veri setine tekrar eklenilerek analizin tekrar edilmesi temeline dayanan kırılganlık analizi sonuçlarına yer verilmiştir.

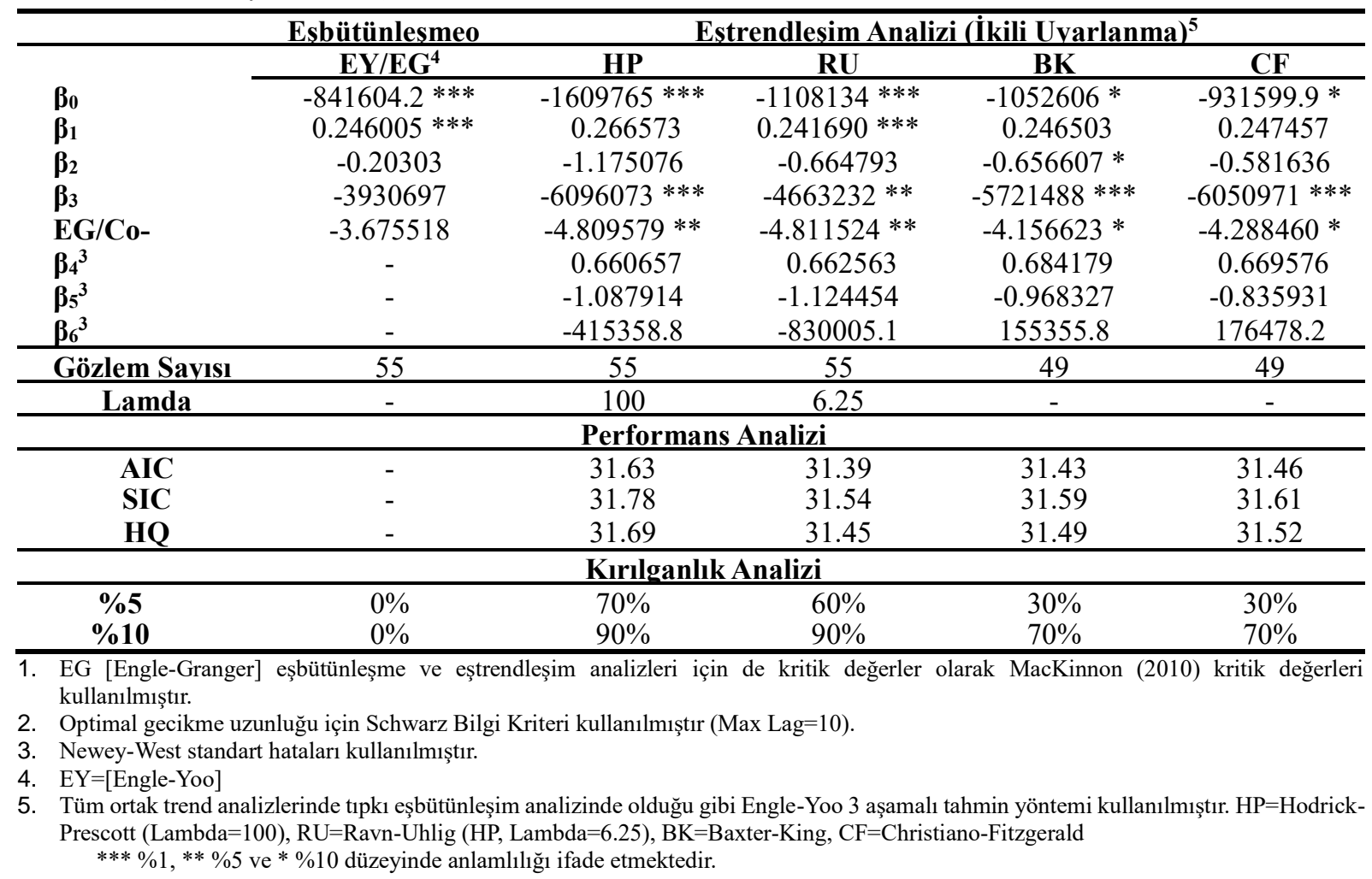

Tablo 1. Eştrendleşim ve Eşbütünleşim Analiz Sonuçları 
Tablo 1'de raporlanan sonuçlara göre Standart Engle-Granger yaklaşımını uyguladığımızda herhangi bir eşbütünleşim ilişkisine rastlanılmamıştır. Bu durum seriler arasındaki ilişkinin "sahte" olduğunu söylemekte ve eşbütünleşim analizi ile bu serilerin arasındaki ilişkiyi analiz edemeyeceğimiz manasına gelmektedir. Eştrendleşim (Co-Trending) analizine baktığımız zaman ise serilerin sürekli ve devrevi bileşenlerine ayrılması için kullanılan filtreleme yöntemi ne olursa olsun, seriler arasında uzun dönemli bir ilişki bulunduğu sonucuna ulaşılmaktadır. Genel olarak konuşulacak olursa parametre tahminlerinin tüm analizlerde birbirine oldukça yakın değerlerde alması bu sonuçların "dirençli” (robust) olduğunu göstermektedir. Performans analizlerine göre CO-RU analizi her 3 kritere göre en performanslı analiz olarak görülmektedir. Bununla birlikte kırılganlık analizlerine göre ise CO-HP analizi $\% 90$ oranında $\% 10$ anlamlılık düzeyinin, $\% 70$ oranında ise $\% 5$ anlamlılık düzeyinin altında kalarak en az kırılgan analiz durumundadır.

Analizde kullanılan değişkenlerin sürekli ve geçici bileşenlerinin birbirlerine eşit olup olmamasına yani uyarlanmanın tekil mi yoksa ikili mi olduğuna karar verilebilmesi için bu çalışmada t testlerinin kullanılması önerilmektedir. $\mathrm{Bu}$ işlem iki aşamada gerçekleştirilecektir. İlk aşamada sürekli katsayının, geçici (devrevi) katsayıya eşit olup olmadığı sınanacak, ikinci aşamada ise bu sınamayı desteklemek amacıyla geçici katsayının, sürekli katsayıya eşit olup olmadığı sınanacaktır. Bu sınamalar ile ilgili hipotezler aşağıda verilmiştir.

$$
\begin{array}{ll}
{\left[\begin{array}{l}
H_{0}: \beta_{1}=\widehat{\beta_{4}} \\
H_{A}: \beta_{1} \neq \widehat{\beta_{4}}
\end{array}\right]} & {\left[\begin{array}{l}
H_{0}: \beta_{4}=\widehat{\beta}_{1 E Y} \\
H_{A}: \beta_{4} \neq \widehat{\beta}_{1 E Y}
\end{array}\right]} \\
{\left[\begin{array}{l}
H_{0}: \beta_{2}=\widehat{\beta}_{5} \\
H_{A}: \beta_{2} \neq \widehat{\beta_{5}}
\end{array}\right]} & {\left[\begin{array}{l}
H_{0}: \beta_{5}=\widehat{\beta}_{2 E Y} \\
H_{A}: \beta_{5} \neq \widehat{\beta}_{2 E Y}
\end{array}\right]} \\
{\left[\begin{array}{l}
H_{0}: \beta_{3}=\widehat{\beta_{6}} \\
H_{A}: \beta_{3} \neq \widehat{\beta_{6}}
\end{array}\right]} & {\left[\begin{array}{l}
H_{0}: \beta_{6}=\widehat{\beta}_{3 E Y} \\
H_{A}: \beta_{6} \neq \widehat{\beta}_{3 E Y}
\end{array}\right]}
\end{array}
$$

Burada karar kuralı olarak her iki sınamada da boş hipotez reddedilir ise ikili uyarlanma, her iki sınamada reddedilemez ise tekil uyarlanma söz konusudur. Sınamalardan birinde boş hipotez reddedilirken diğer sınamada reddedilemiyor ise belirsizlik durumu geçerlidir yani değişkenlerin sürekli ve devrevi bileşenlerinin ikili mi yoksa tekil mi uyarlandığ konusunda karar verilemez. Bu hipotezler için hesaplanan değerler Tabl0 2'de verilmiştir.

Tablo 2'ye bakıldığı zaman Y değişkeninin sürekli ve devrevi katsayılarının birbirine eşit olduğunu iddia eden boş hipotez tüm analizlerde \%1 düzeyinde reddedilmektedir. Dolayısıyla bu analizlere göre bu değişkenin bileşenlerinin ikili uyarlandığı sonucuna varılmaktadır. Kamu kesimi sabit sermaye yatırımlarının sürekli ve devrevi bileşenleri Co-RU analizi dışındaki tüm analizlerde tekil uyarlanmakta ancak Co-RU analizine göre uyarlanmanın tekil mi yoksa ikili mi olduğu belirsizlik göstermektedir. Makroekonomik istikrarsızlık değişkenine bakıldığında ise tüm analizlerde ikili uyarlanma olduğu görülmektedir. Özetlemek gerekirse bu sonuçlar yukarıda bahsedilen teorik sonuçlar ile uyum içerisindedir.

\begin{tabular}{lllll}
\hline Boş Hipotez & HP & RU & \multicolumn{1}{c}{ BK } & CF \\
\hline$\beta_{1}=\widehat{\beta_{4}}$ & $-21.93^{* * *}$ & $-19.26^{* * *}$ & $-31.02^{* * *}$ & $-19.27^{* * *}$ \\
$\beta_{4}=\widehat{\beta}_{1 E Y}$ & $6.07^{* * *}$ & $8.15^{* * *}$ & $9.23^{* * *}$ & $8.28^{* * *}$ \\
$\beta_{2}=\widehat{\beta_{5}}$ & -0.23 & 1 & 0.95 & 0.51 \\
$\beta_{5}=\widehat{\beta}_{2 E Y}$ & 0.37 & $-2.35^{* *}$ & -1.37 & -1.15 \\
$\beta_{3}=\widehat{\beta}_{6}$ & $-3.72^{* * *}$ & $-2.11^{* *}$ & $-4.75^{* * *}$ & $-3.30^{* * *}$ \\
$\beta_{6}=\widehat{\beta_{3 E Y}}$ & $3.69^{* * *}$ & $3.37^{* * *}$ & $5.06^{* * *}$ & $6.14 * * *$ \\
\hline$* * * \% 1,{ }^{* *} \% 5 \mathrm{ve} * \% 10$ düzeyinde anlamlilığı ifade etmektedir.
\end{tabular}

Tablo 2. t Sinamalart 


\section{Sonuç}

Türkiye için incelenen dönemde bir eşbütünleşme ilişkisine rastlanamamışken İkili Uyarlanma Yaklaşımı uygulandığında tüm analizlerde (Co-HP ve Co-RU için \%5 düzeyinde, Co-BK ve Co-CF için \%10 düzeyinde) uzun dönemli ilişkinin bulunduğu ortaya çıkmıştır. Bu sonuç uzun dönemli ilişkilerin incelenmesi esnasında eğer serilerin birbirleriyle ikili uyarlanması söz konusuysa bu ilişkinin geleneksel eşbütünleşme yaklaşımıyla incelenmesinin bir kurgu hatası yaratarak sonuçların yanlış tahmin edilmesini sağlayacağını ve bu tip durumlarda İkili Uyarlanma kullanılması gerekliliğini göstermiştir. Bu çalışma ile İkili Uyarlanma Yaklaşımına ortak BK trend ve ortak CF trend kavramları dahil edilmiş ve bu eştrendleşim analizlerinin analiz edilen konu ve kullanılan veriyle uyumluluklarının sınanabilmesi için performans analizi ve kırılganlık analizi adı verilen 2 yöntem önerilmiştir. Ayrıca yine bu çalışmada İkili Uyarlanma Yaklaşımı'nda sürekli ve geçici bileşenlerin birbirlerine eşit olup olmadığına karar verebilmek için t testleri önerilmiş ve bu literatürün sınırları genişletilmiştir.

\section{Kaynakça}

- $\quad$ Banerjee, A., Dolado, J. J., ve Hendry, D. F. ve Smith, G. W., 1986. "Exploring Equilibrium Relationships in Econometrics Through Static Models: Some Monte Carlo Evidence", Oxford Bulletin of Economics and Statistics, 48, pp. 253-277.

- Bleaney, M. F., 1996. "Macroeconomic Stability, Investment and Growth in Developing Countries". Journal of Development Economics, 48, pp.461-477.

- Cavallo, E., ve Daude, C. (2011). "Public Investment in Developing Countries: A Blessing or a Curse?", Journal of Comparative Economics, 39, pp.65-81.

- Dornbusch, R., Fischer, S., ve Startz, R., 2007. Macroeconomics. McGraw-hill.

- $\quad$ Engle, R. F., ve Yoo, B. S., 1991. "Cointegrated Economic Time Series: An Overview With New Results". R.F. Engle and C.W.J. Granger (eds.), Long-run Economic Relationships: Readings in Cointegration içinde, Oxford University Press, New York.

- Friedman, M., 1957. A Theory of the Consumption Function. Princeton University Press, Princeton,.

- Günçavdi, Ö., ve Küçük, A. E., 2013. "Investment Expenditure and Capital Accumulation in an Inflationary Environment: The Case of Turkey". Journal of Policy Modeling, 35, pp.554-571.

- Günçavdi, Ö., ve McKay, A., 2003. "Macroeconomic Adjustment and Private Manufacturing Investment in Turkey: A Time-series Analysis." Applied Economics, 35, pp.1901-1909.

- İsmihan, M., 2009, The Role of Politics and Instability in Macroeconomic Performance, VDM Verlag Muller.

- İsmihan, M., 2019. "The dual adjustment approach with an application to the consumption function". Central Bank Review, pp.1-8.

- İsmihan, M., Metin-Ozcan, K., ve Tansel, A., 2005. "The Role of Macroeconomic Instability in Public and Private Capital Accumulation and Growth: the Case of Turkey 1963-1999". Applied Economics, 37, pp.239-251.

- $\quad$ Pindyck, R., 1991. "Irreversibility, Uncertainity, and Investment", Journal of Economic Literatüre, 29, pp.1110-48.

- $\quad$ Pindyck, R., ve Rubinfeld, D., 2018. Microeconomics. Pearson.

- Taylor, L. 1993. A Three-Gap Analysis of Foreign Resource Flows and Developing Country Growth. In The Rocky road to reform : adjustment, income distribution, and growth in the developing world. MIT Press. 


\title{
Ziraat Fakültesi Öğrencilerinin Tarımın Geleceğine Yönelik Bakış Açıları: Tekirdă̆ İli Örneği
}

\section{Agricultural Faculty Students' Perspectives on the Future of Agriculture: Tekirdag Case}

\author{
Asst. Prof. Dr. Burçin Başaran (Namık Kemal University, Turkey) \\ Ph.D. Candidate Zehra Meliha Tengiz (Namık Kemal University, Turkey) \\ Prof. Dr. Yasemin Oraman (Namık Kemal University, Turkey)
}

\begin{abstract}
In spite of technological developments today, agriculture is still among the priority of all countries. The fact that the agricultural areas cannot be increased and the required nutritional needs of the growing population needed to be met, it makes agriculture strategic case for the countries. The continuity of agricultural activities has become dependent on the wishes of future generations to work in this sector in all countries.

Agricultural Faculties' students do not look positively in the agricultural sector in Turkey. Youths are directed to non-agricultural sectors due to low income in agriculture. However, students should be encouraged and supported in order for agricultural activities can be practiced by conscious and enthusiastic young people. The sustainability of agriculture depends on young's willingness to participate in the sector.

The aim of the study is to determine perspective of students in Faculty of Agriculture of Tekirdağ Namık Kemal University about future of agriculture. The data was obtained from 175 students in the 3 . and the 4 . classes. The data were analyzed statistically with SPSS 23.0 in terms of descriptive and inferential statistics. According to the results of the study; a significant difference was observed between girls and boys in terms of evaluating the current state of Turkish agriculture. $67.5 \%$ of students expect their future pessimistic and uncertain. The rate of those who expect their future as hopeful and optimistic was found to be $32.5 \%$ respectively.
\end{abstract}

\section{Giriş}

Tarım ülkelerin kalkınmaları ve gelişmeleri için önemli sektörlerden biridir. Tarım sektörünün Türkiye içerisindeki önemi sürekli gündeme gelmekte gerek yurt içindeki pazar hacmi gerek ihracattaki önemi her geçen gün artmaktadır. Ancak tarıma yönelik politikalar, desteklemeler ve kırsal kalkınma projeleri mevcut tarım sektörünün geliştirilmesinde yetersiz kalmaktadır. Türkiye ekonomisi içinde Gayrisafi Yurtiçi Hasıla'da (GSYH) tarımın payı 2010 yılında \% 9.0, 2018 yılında ise \%5.8 olarak gerçekleşmiştir (TÜİK, 2019).

Tarımsal üretim girdilerinin yurtdışı tedarikli olması, maliyetlerin döviz kurlarına bağlı olarak artış göstermesine sebep olmaktadır. Bunun yanında devletin ürün ve girdi piyasalarından çekilmesi ile küçük üreticilerin, çoğunlukla büyük işletmelerin belirlediği fiyatlara razı gelmesine neden olmuştur (Koyubenbe, vd, 2006). Çiftçilerin eline geçen fiyatlar ile girdi maliyetlerinin arasındaki makasın açılması üretimi daha da zorlu hale getirmiştir. Bu durum tarım kesiminde çalışanların artan maliyetler karşısında faaliyetlerini azaltmalarına, geçimlik üretim yapılmasına veya tarımı tamamen terk etmelerine sebep olmaktadır.

Tarım sektöründe çalışanların yaşları 50 yaş üstü olarak yoğunlaşmaktadır. İstihdam edilen gençlerin \%18'i tarım sektöründe yer almaktadır (TÜİK, 2018). Kırsal kesimdeki gelirin düşük, eğitim ve alternatif iş olanaklarının yetersiz olmasından dolayı genç nüfus köyünü terk etmektedir. Kırsal alanda kalan gençlerin, özel bir istihdam alanı olmaksızın tarım veya tarım dışı köye yakın sanayi veya hizmet işletmelerinde çalıştığı bilinmektedir. Ancak tarımın geleceği açısından sektörde gençlerin varlığı önem arz etmektedir.

Bir ülkenin tarımsal kalkınmasında ve güvenilir bir şekilde beslenmesinde tarımsal eğitim-öğretimin yeri oldukça önemlidir. Yapılan çalışmalarda çiftçilerin üretim yaparken geleneksel davranış sergiledikleri görülmektedir. Bu davranış sonraki nesillere de aktarılmaya çalışılmaktadır. Ancak geleneksel davranış gösteren, yeniliklere açık olmayan üreticiler üretimlerini etkin ve verimli bir şekilde gerçekleştirememektedir. Birim alandan alınan verim, kullanılan girdinin zamanı ve miktarı, yapılan işlemlerin kayıt altına alınmaması gibi faktörler tarımı etkin ve verimli olmaktan uzaklaştırmaktadır. Üretimin güncel teknolojik gelişmelere adapte olabilmesi, etkin ve verimli bir şekilde gerçekleştirilebilmesi için bu alanda yetişmiş insan gücüne ihtiyacı vardır. Bunu sağlayabilecek en önemli kurumlardan biri de Ziraat Fakülteleridir.

Ziraat fakülteleri son yıllarda ziraat ve doğa bilimleri fakültesi, tarım bilimleri ve teknolojileri fakültesi gibi farklı fakülte isimleriyle de açılmaktadır. Bu fakültelerden mezun olanlar da ziraat mühendisi unvanını alabilmektedir. 2017 yılında ÖSYM (Öğrenci Seçme ve Yerleştirme Merkezi) tarafından yayınlanan yükseköğretim tercih kılavuzuna göre Türkiye'de ziraat fakülteleri 40 farklı üniversitede bulunmaktadır (Tablo 1). Bu üniversitelerden Kilis 7 Aralık ve Muğla Sıtkı Koçman üniversiteleri 2017-2018 eğitim öğretim yılında ilgili fakültelere öğrenci almamıştır. 


\begin{tabular}{|c|c|c|c|}
\hline Üniversite & Fakülte & Bölümler & $\begin{array}{l}\text { Toplam } \\
\text { Kontenjan }\end{array}$ \\
\hline $\begin{array}{l}\text { Abant İzzet } \\
\text { Baysal } \\
\text { Üniversitesi }\end{array}$ & $\begin{array}{l}\text { Ziraat ve Doğa } \\
\text { Bilimleri } \\
\text { Fakültesi }\end{array}$ & $\begin{array}{l}\text { Bahçe Bitkileri, Bitki Koruma, Kanatlı Hayvan Yetiştiriciliği, Tarla } \\
\text { Bitkileri, Yaban Hayatı Ekolojisi ve Yönetimi }\end{array}$ & 115 \\
\hline $\begin{array}{l}\text { Adıyaman } \\
\text { Üniversitesi }\end{array}$ & $\begin{array}{l}\text { Tarım Bilimleri } \\
\text { ve Teknolojileri } \\
\text { Fakültesi } \\
\end{array}$ & Bitki Koruma, Tarım Makineleri ve Teknolojileri Mühendisliği & 20 \\
\hline $\begin{array}{l}\text { Adnan Menderes } \\
\text { Üniversitesi }\end{array}$ & Ziraat Fakültesi & $\begin{array}{l}\text { Bahçe Bitkileri, Bitki Koruma, Biyosistem Mühendisliği, } \\
\text { Peyzaj Mimarlığı, Tarım Ekonomisi, Tarımsal Biyoteknoloji, Tarla } \\
\text { Bitkiler, Toprak Bilimi ve Bitki Besleme, Zootekni }\end{array}$ & 355 \\
\hline $\begin{array}{l}\text { Ahi Evran } \\
\text { Üniversitesi }\end{array}$ & Ziraat Fakültesi & Bahçe Bitkileri, Bitki Koruma, Tarım Ekonomisi, Tarla Bitkiler & 110 \\
\hline $\begin{array}{l}\text { Akdeniz } \\
\text { Üniversitesi }\end{array}$ & Ziraat Fakültesi & $\begin{array}{l}\text { Bahçe Bitkileri, Bitki Koruma, Tarım Ekonomisi, Tarım } \\
\text { Makineleri ve Teknolojileri Mühendisliği, Tarımsal } \\
\text { Biyoteknoloji, Tarımsal Yapılar ve Sulama, Tarla Bitkileri, Toprak } \\
\text { Bilimi ve Bitki Besleme, Zootekni }\end{array}$ & 280 \\
\hline $\begin{array}{l}\text { Ankara } \\
\text { Üniversitesi }\end{array}$ & Ziraat Fakültesi & $\begin{array}{l}\text { Bahçe Bitkileri, Bitki Koruma, Peyzaj Mimarlığı, Su } \\
\text { Ürünleri Mühendisliği, Süt Teknolojisi, Tarım Ekonomisi, } \\
\text { Tarım Makineleri ve Teknolojileri Mühendisliği, } \\
\text { Tarımsal Yapılar ve Sulama, Tarla Bitkileri, Toprak Bilimi ve Bitki } \\
\text { Besleme, Zootekni }\end{array}$ & 465 \\
\hline $\begin{array}{l}\text { Atatürk } \\
\text { Üniversitesi }\end{array}$ & Ziraat Fakültesi & $\begin{array}{l}\text { Bahçe Bitkileri, Bitki Koruma, Gıda Mühendisliği, } \\
\text { Tarım Ekonomisi, Tarım Makineleri ve Teknolojileri Mühendisliği, } \\
\text { Tarımsal Biyoteknoloji, Tarla Bitkileri }\end{array}$ & 175 \\
\hline $\begin{array}{l}\text { Bilecik Şeyh } \\
\text { Edebali } \\
\text { Üniversitesi }\end{array}$ & $\begin{array}{l}\text { Ziraat ve Doğa } \\
\text { Bilimleri } \\
\text { Fakültesi }\end{array}$ & Bahçe Bitkileri, Bitki Koruma, Tarla Bitkileri & 30 \\
\hline $\begin{array}{l}\text { Bingöl } \\
\text { Üniversitesi } \\
\end{array}$ & Ziraat Fakültesi & Bitki Koruma, Tarla Bitkileri & 40 \\
\hline $\begin{array}{l}\text { Bozok } \\
\text { Üniversitesi }\end{array}$ & Ziraat Fakültesi & Bitki Koruma & 30 \\
\hline $\begin{array}{l}\text { Çanakkale } \\
\text { Onsekiz Mart } \\
\text { Üniversitesi }\end{array}$ & Ziraat Fakültesi & $\begin{array}{l}\text { Bahçe Bitkileri, Bitki Koruma, Tarım Ekonomisi, Tarım } \\
\text { Makineleri ve Teknolojileri Mühendisliği, Tarımsal } \\
\text { Biyoteknoloji, Tarla Bitkileri, Zootekni }\end{array}$ & 246 \\
\hline $\begin{array}{l}\text { Çukurova } \\
\text { Üniversitesi }\end{array}$ & Ziraat Fakültesi & $\begin{array}{l}\text { Bahçe Bitkileri, Bitki Koruma, Gıda Mühendisliği, Peyzaj } \\
\text { Mimarlığı, Tarım Ekonomisi, Tarım Makineleri ve } \\
\text { Teknolojileri Mühendisliği, Tarımsal Yapılar ve Sulama, Tarla } \\
\text { Bitkileri, Toprak Bilimi ve Bitki Besleme, Zootekni }\end{array}$ & 445 \\
\hline $\begin{array}{l}\text { Dicle } \\
\text { Üniversitesi }\end{array}$ & Ziraat Fakültesi & Bahçe Bitkileri, Bitki Koruma, Tarla Bitkileri, Zootekni & 140 \\
\hline $\begin{array}{l}\text { Düzce } \\
\text { Üniversitesi }\end{array}$ & $\begin{array}{l}\text { Ziraat ve Doğa } \\
\text { Bilimleri } \\
\text { Fakültesi }\end{array}$ & Bitki Koruma & 25 \\
\hline Ege Üniversitesi & Ziraat Fakültesi & $\begin{array}{l}\text { Bahçe Bitkileri, Bitki Koruma, Peyzaj Mimarlığı, Süt } \\
\text { Teknolojisi, Tarım Ekonomisi, Tarım Makineleri ve } \\
\text { Teknolojileri Mühendisliği, Tarımsal Yapılar ve Sulama, Tarla } \\
\text { Bitkileri, Toprak Bilimi ve Bitki Besleme, Zootekni }\end{array}$ & 360 \\
\hline $\begin{array}{l}\text { Erciyes } \\
\text { Üniversitesi }\end{array}$ & $\begin{array}{l}\text { Seyrani Ziraat } \\
\text { Fakültesi }\end{array}$ & $\begin{array}{l}\text { Bahçe Bitkileri, Bitki Koruma, Biyosistem Mühendisliği, } \\
\text { Tarmsal Biyoteknoloji, Tarla Bitkileri, Zootekni }\end{array}$ & 170 \\
\hline $\begin{array}{l}\text { Eskişehir } \\
\text { Osmangazi } \\
\text { Üniversitesi } \\
\end{array}$ & Ziraat Fakültesi & Bahçe Bitkileri, Tarımsal Biyoteknoloji, Tarla Bitkileri, Zootekni & 140 \\
\hline $\begin{array}{l}\text { Gaziosmanpaşa } \\
\text { Üniversitesi }\end{array}$ & Ziraat Fakültesi & $\begin{array}{l}\text { Bahçe Bitkileri, Bitki Koruma, Biyosistem Mühendisliği, } \\
\text { Tarım Ekonomisi, Tarla Bitkileri }\end{array}$ & 120 \\
\hline $\begin{array}{l}\text { Harran } \\
\text { Üniversitesi }\end{array}$ & Ziraat Fakültesi & Bahçe Bitkileri, Bitki Koruma, Tarım Ekonomisi, Tarla Bitkiler & 140 \\
\hline $\begin{array}{l}\text { Iğdır } \\
\text { Üniversitesi }\end{array}$ & $\begin{array}{l}\text { Iğdır Ziraat } \\
\text { Fakültesi }\end{array}$ & Tarım Ekonomisi & 35 \\
\hline $\begin{array}{l}\text { İnönü } \\
\text { Üniversitesi }\end{array}$ & Ziraat Fakültesi & Bahçe Bitkileri, Bitki Koruma & 75 \\
\hline $\begin{array}{l}\text { Kahramanmaraş } \\
\text { Sütçü İmam } \\
\text { Üniversitesi }\end{array}$ & Ziraat Fakültesi & $\begin{array}{l}\text { Bahçe Bitkileri, Bitki Koruma, Biyosistem Mühendisliği, } \\
\text { Tarım Ekonomisi, Tarla Bitkileri }\end{array}$ & 145 \\
\hline
\end{tabular}

Tablo 1. ÖSYS 2017 Tercih Kılavuzuna Göre Bölüm ve Kontenjanlar Kaynak: ÖSYM (2017) 


\begin{tabular}{|c|c|c|c|}
\hline Üniversite & Fakülte & Bölümler & $\begin{array}{l}\text { Toplam } \\
\text { Kontenjan }\end{array}$ \\
\hline $\begin{array}{l}\text { Konya Gıda ve } \\
\text { Tarım } \\
\text { Üniversitesi } \\
\end{array}$ & $\begin{array}{l}\text { Tarım ve Doğa } \\
\text { Bilimleri } \\
\text { Fakültesi }\end{array}$ & Genetik ve Yaşam Bilimleri Programları & 20 \\
\hline $\begin{array}{l}\text { Mustafa Kemal } \\
\text { Üniversitesi }\end{array}$ & Ziraat Fakültesi & $\begin{array}{l}\text { Bahçe Bitkileri, Bitki Koruma, Biyosistem Mühendisliği, } \\
\text { Gıda Mühendisliği, Tarım Ekonomisi, Tarla Bitkileri }\end{array}$ & 175 \\
\hline $\begin{array}{l}\text { Namık Kemal } \\
\text { Üniversitesi }\end{array}$ & Ziraat Fakültesi & $\begin{array}{l}\text { Bahçe Bitkileri, Bitki Koruma, Biyosistem Mühendisliği, } \\
\text { Gıda Mühendisliği, Tarım Ekonomisi, Tarımsal Biyoteknoloji, Tarla } \\
\text { Bitkileri }\end{array}$ & 245 \\
\hline $\begin{array}{l}\text { Niğde Ömer } \\
\text { Halisdemir } \\
\text { Üniversitesi }\end{array}$ & $\begin{array}{l}\text { Tarım Bilimleri } \\
\text { ve Teknolojileri } \\
\text { Fakültesi }\end{array}$ & Bitkisel Üretim ve Teknolojileri, Tarımsal Genetik Mühendisliği & 60 \\
\hline $\begin{array}{l}\text { Ondokuz Mayıs } \\
\text { Üniversitesi }\end{array}$ & Ziraat Fakültesi & $\begin{array}{l}\text { Bahçe Bitkileri, Bitki Koruma, Tarım Ekonomisi, } \\
\text { Tarım Makineleri ve Teknolojileri Mühendisliği, } \\
\text { Tarımsal Biyoteknoloji, Tarla Bitkileri, Zootekni }\end{array}$ & 230 \\
\hline $\begin{array}{l}\text { Ordu } \\
\text { Üniversitesi }\end{array}$ & Ziraat Fakültesi & $\begin{array}{l}\text { Bahçe Bitkileri, Bitki Koruma, Gıda Mühendisliği, } \\
\text { Peyzaj Mimarlığı }\end{array}$ & 115 \\
\hline $\begin{array}{l}\text { Recep Tayyip } \\
\text { Erdoğan } \\
\text { Üniversitesi }\end{array}$ & $\begin{array}{l}\text { Ziraat ve Doğa } \\
\text { Bilimleri } \\
\text { Fakültesi }\end{array}$ & Bahçe Bitkileri, Tarla Bitkileri & 30 \\
\hline $\begin{array}{l}\text { Selçuk } \\
\text { Üniversitesi }\end{array}$ & Ziraat Fakültesi & $\begin{array}{l}\text { Bahçe Bitkileri, Bitki Koruma, Gıda Mühendisliği, Peyzaj } \\
\text { Mimarlığı, Tarım Ekonomisi, Tarım Makineleri ve } \\
\text { Teknolojileri Mühendisliği, Tarımsal Yapılar ve Sulama, Tarla } \\
\text { Bitkileri, Toprak Bilimi ve Bitki Besleme, Zootekni }\end{array}$ & 404 \\
\hline Siirt Üniversitesi & Ziraat Fakültesi & $\begin{array}{l}\text { Bahçe Bitkileri, Bitki Koruma, Biyosistem Mühendisliği, } \\
\text { Tarım Ekonomisi, Tarımsal Biyoteknoloji, Tarla Bitkileri }\end{array}$ & 115 \\
\hline $\begin{array}{l}\text { Süleyman } \\
\text { Demirel } \\
\text { Üniversitesi }\end{array}$ & Ziraat Fakültesi & $\begin{array}{l}\text { Tarla Bitkileri, Bahçe Bitkileri, Bitki Koruma, Tarım Ekonomisi, } \\
\text { Zootekni, Tarımsal Biyoteknoloji, Toprak Bilimi ve Bitki Besleme, } \\
\text { Tarımsal Yapılar ve Sulama, Tarım Makineleri ve Teknolojileri } \\
\text { Mühendisliği }\end{array}$ & 80 \\
\hline $\begin{array}{l}\text { Şrnak } \\
\text { Üniversitesi }\end{array}$ & Ziraat Fakültesi & Bahçe Bitkileri & 10 \\
\hline $\begin{array}{l}\text { Uludağ } \\
\text { Üniversitesi }\end{array}$ & Ziraat Fakültesi & $\begin{array}{l}\text { Bahçe Bitkileri, Bitki Koruma, Biyosistem Mühendisliği, } \\
\text { Gida Mühendisliği, Tarım Ekonomisi, Tarla Bitkileri, Toprak Bilimi } \\
\text { ve Bitki Besleme, Zootekni }\end{array}$ & 336 \\
\hline $\begin{array}{l}\text { Uşak } \\
\text { Üniversitesi }\end{array}$ & $\begin{array}{l}\text { Ziraat ve Doğa } \\
\text { Bilimleri } \\
\text { Fakültesi }\end{array}$ & Bitki Koruma, Tarla Bitkileri & 70 \\
\hline $\begin{array}{l}\text { Van Yüzüncü Y1l } \\
\text { Üniversitesi }\end{array}$ & Ziraat Fakültesi & Bitki Koruma, Tarla Bitkileri, Zootekni & 65 \\
\hline
\end{tabular}

Tablo 1. ÖSYS 2017 Tercih Kllavuzuna Göre Bölüm ve Kontenjanlar (Devam) Kaynak: ÖSYM (2017)

Tablo 2'de son 6 yılda öğrenci alan Ziraat Fakültesi sayısı, kontenjanı ve doluluk oranları verilmiştir. Ülkemizde 2013 yılından itibaren öğrenci alan ziraat fakültesi sayısının giderek arttığı görülmektedir. Ancak 2013-2018 yılları arasında kontenjan, yerleşen öğrenci sayısı ve doluluk oranı dalgalanma göstermiş; 2018 yılında bir önceki yıla göre düşüşler yaşanmıştır. Kontenjan sayısı artmasına rağmen yerleşen öğrenci sayısında azalma görülmüştür. Bu durum ziraat mühendisliğinin tercih edilen meslekler arasından giderek uzaklaştığını göstermektedir.

\begin{tabular}{lllllll}
\hline Yerleşim Durumu & $\mathbf{2 0 1 3}$ & $\mathbf{2 0 1 4}$ & $\mathbf{2 0 1 5}$ & $\mathbf{2 0 1 6}$ & $\mathbf{2 0 1 7}$ & $\mathbf{2 0 1 8}$ \\
\hline Öğrenci Alan Ziraat Fakültesi & 30 & 33 & 34 & 34 & 35 & 35 \\
\hline Kontenjan Açan Toplam Program Sayıs1 & 165 & 170 & 142 & 169 & 145 & 169 \\
\hline Kontenjan & 5842 & 5485 & 4797 & 5350 & 4791 & 5498 \\
\hline Yerleşen Ö̆ğrenci Sayısı & 4839 & 4153 & 4332 & 4446 & 4730 & 4081 \\
\hline Doluluk (\%) & 83 & 76 & 90 & 83 & 93 & 74 \\
\hline
\end{tabular}

Tablo 2. 2013-2018 Yılları Arasında Ziraat Fakültesi Yerleşme Durumu Kaynak: ZMO (2018)

Yeterli donanıma sahip olmadan açılan üniversite sayısındaki artış, eğitim kalitesinde düşüşe neden olmuş, ziraat mühendislerinin yapacağı işlerin diğer meslek gruplarının eline geçmesine neden olmuştur. Bu bölümleri tarımın içerisinden gelmiş veya tarım sektörüne meraklı gençler tercih etmektedir. Bir dönemin popüler mesleği olan ziraat mühendisliğinin halk ve öğrencilerin gözünde uğradığı değer kaybı iş bulma problemiyle doğrudan ilişkilidir. Demir vd. (2006) tarafından Ziraat Fakülteleri öğrencilerinin mesleğe bakış açıları ve eğilimlerini belirlemeye yönelik 10 üniversitede gerçekleştirilen çalışmaya göre, öğrencilerin Ziraat Mühendisliğini seçme nedenleri arasında en büyük payı \%75'ile açıkta kalmamak seçeneği almıştır. Atatürk Üniversitesi Ziraat Fakültesinde yapılan bir çalışmaya göre ise öğrencilerin büyük bir kısmının fakülteye istemeyerek geldiklerini ve ideallerindeki 
meslek olmadığını belirtmiştir (Sezgin, vd, 2008). Tarımsal üretime destek sağlayan ziraat mühendislerinin eğitim sürecindeki motivasyonları tarıma yönelik tutum ve davranışlarını etkilemektedir. Özellikle son sınıf öğrencilerin kısa zamanda hayata atılarak bir gelir elde edebilecekleri işi seçecek olan gençlerde kararsızlık ve kaygı yüksek olmaktadır (Karadaş, vd, 2016).

Öğrencilerin tarıma ve ziraat mühendisliğine karşı tutumu ülke tarımının geleceğini etkilemektedir. Tarımın sürdürülebilirliği tarım politikasının varlığı yanında gençlerin tarımın içinde yer alma isteklerine bağlıdır. Bu doğrultuda hazırlanan çalışmada gençlerin tarımın geleceğine yönelik beklentilerini belirlemek amaçlanmıştır.

\section{Materyal ve Metod}

Çalışmanın popülasyonunu Tekirdağ Namık Kemal Üniversitesi Ziraat Fakültesi 3. ve 4. sinıf öğrencileri oluşturmuştur. Veriler 2017-2018 yılında Ziraat Fakültesi'nin farklı bölümlerinde okuyan 3. ve 4 . sınıf öğrencilerinin mevcut sayılarına göre tabakalı örnekleme ile 175 anket yapılarak toplanmıştır. Elde edilen verilere SPSS 23.0 paket programı yardımıyla Ki- kare bağımsızlık analizi yapılmıştır.

\begin{tabular}{|c|c|c|c|c|}
\hline & & \multicolumn{2}{|c|}{ Sinif } & \multirow[b]{2}{*}{ Toplam } \\
\hline & & $3 . \sin 1 \mathrm{f}$ & 4.sinif & \\
\hline \multirow{9}{*}{ 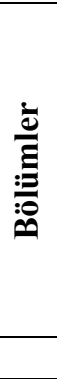 } & Bahçe Bitkileri & 8 & 15 & 23 \\
\hline & Bitki Koruma & 12 & 17 & 29 \\
\hline & Biyosistem Mühendisliği & 8 & 11 & 19 \\
\hline & Tarım Ekonomisi & 9 & 14 & 23 \\
\hline & Tarımsal Biyoteknoloji & 8 & 20 & 28 \\
\hline & Tarla Bitkileri & 21 & 21 & 42 \\
\hline & Toprak Bil. ve Bitki Besleme & 0 & 4 & 4 \\
\hline & Zootekni & 1 & 6 & 7 \\
\hline & Toplam & 67 & 108 & 175 \\
\hline
\end{tabular}

Tablo 3. Tekirdă̆ Namık Kemal Üniversitesi Ziraat Fakültesi Örnek Dă̆ılımı

\section{Bulgular}

Araştırmaya katılan gençlerin \%35,4’ü kız, \%64,6’sı erkek öğrencilerden oluşmaktadır. Ziraat Fakültesi 3. ve 4. sınıf öğrencilerinin yaşları 20 ile 35 yaş arasında değişmekle beraber en fazla 22 ile 24 yaş arasında $(\% 61,7)$ öğrenci bulunmaktadır. Öğrencilerin ailelerinin \%25,7'si çiftçi, \%20,0'si emekli ve \%18,9'u memurdur. Öğrencilerin aile aylık geliri dikkate alındığında; ailelerinin \%43,4’ü 3500 TL ve altında gelir elde etmektedir. Bu durum öğrenci ve ailelerinin yoksulluk sınırı altında yaşadıklarını göstermektedir. Bu durum öğrencilerin mezuniyet sonrası kendi işleri yerine diğer işlere yönelmek zorunda bırakmaktadır (Tablo 4).

\begin{tabular}{|c|c|c|c|}
\hline Demografik özellikler & & Frekans & Yüzde \\
\hline \multirow{2}{*}{ Cinsiyet } & $\mathrm{K}_{1 \mathrm{Z}}$ & 62 & 35,4 \\
\hline & Erkek & 113 & 64,6 \\
\hline \multirow{3}{*}{ Yaş } & 21 ve alt1 & 31 & 17,7 \\
\hline & $22-24$ & 108 & 61,7 \\
\hline & 25 ve üzeri & 36 & 20,6 \\
\hline \multirow{7}{*}{ Aile mesleği } & Çiftçi & 45 & 25,7 \\
\hline & Emekli & 35 & 20,0 \\
\hline & Memur & 33 & 18,9 \\
\hline & İşçi & 14 & 8,0 \\
\hline & Özel Sektör & 24 & 13,7 \\
\hline & Serbest Meslek & 21 & 12,0 \\
\hline & Diğer & 3 & 1,7 \\
\hline \multirow{6}{*}{ Aile aylık geliri } & 1600 ve alt1 & 14 & 8,0 \\
\hline & $1601-2800$ & 39 & 22,3 \\
\hline & $2801-3500$ & 23 & 13,1 \\
\hline & $3501-5000$ & 43 & 24,6 \\
\hline & 5001 ve üstü & 25 & 14,3 \\
\hline & Kayıp veri & 31 & 17,7 \\
\hline
\end{tabular}

Tablo 4. Demografik Özellikler

Gelişen bilişim çağında bilgi internet aracılı̆̆ı ile her zaman ulaşılabilir hale gelmiştir. İnternet kaynakları içerisinde günümüzde en yaygın kullanılan sosyal medyadır. Sosyal medya aracılığı ile ilgilenilen konulara yönelik bütün yenilikler, gelişmeler, haberler anında takipçisine ulaşmakta; zamandan ve paradan tasarruf sağlanmaktadır. 
Araştırmaya katılan gençler de tarımsal yenilikleri takip etmek için öncelikle sosyal medyayı $(\% 27,2)$ ve interneti $(\% 18,0)$ kullandıklarını belirtmişlerdir. Diğer kaynakları \%14,8 ile televizyon, \%13,3 ile tarım fuarları, \%8,9 dersler ve \%6,4 ile üyesi olunan siteler izlemiştir (Şekil 1).

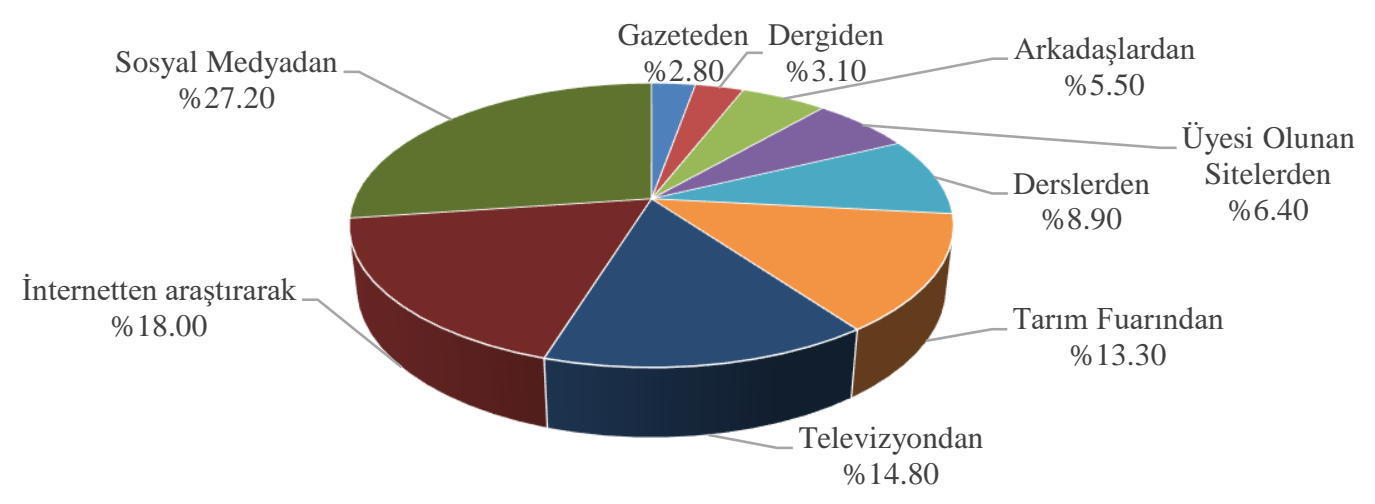

Şekil 1. Gençlerin Tarımsal Yenilikleri Takip Ettiği Kaynaklar

Tarımsal nüfus gençlerin çok önemli bir kısmı tarafından $(\% 84,0)$ yeterli görülmemektedir. Kırsal alanlardan kente göçün fazla olması, gelirin ve sosyal yaşamın kısıtlı olması çiftçileri kırsal alanlardan uzaklaştırmıştır. Kentlerde ya da kent merkezine yakın yerlerde yaşayan çiftçiler meslekleri dışında ek gelir de elde edebilmektedirler. Çiftçilik meslek olarak önemsenmemekte, ek gelir kaynağ 1 meslek olarak kabul edilebilmektedir. Tarımsal nüfus çiftçiliği meslek olarak gören, kırsal alanda yaşayan ve ekonomik işletme ölçeğine göre faaliyet gösteren tarımsal işletmeleri yönetenlerden oluşmalıdır. Bugün köylerde nüfusun azalması, sadece yaşı ıireylerin yaşaması, tarımsal faaliyetlerin bu bireyler üzerinden gerçekleştiği algısını yaratmaktadır. Ayrıca tarım ürünlerine yönelik ithalatın giderek artması da bu algıyı güçlendirmektedir. Gençlerde bu algı sonucunda ülkemizdeki tarımsal nüfusun yeterli olmadığı yönünde bir düşünce oluşmuştur.

Tarımda gençlerin tarımdan uzaklaşmaları ülkemiz dışında diğer ülkelerin de önem verdiği konular arasındadır. Çünkü gençler tarımsal faaliyetlerin geleceği ve devamlılığı açısından önemlidir. Her ne kadar teknolojik gelişmeler yaygınlaşsa da tarımsal işletmenin yönetimi için birey gereklidir. Avrupa Birliği başta olmak üzere ülkeler tarımı gençler açısından cazip hale getirecek destekler vermektedirler. Bu destekler hem maddi teşvik hem de yayım faaliyetleri aracılığı ile yapılmaktadır. Gençlere "sizce tarım sektöründe gençlere destek veriliyor mu?" sorusu yöneltilmiş; \% 71,4'ü destek verilmediği, \%28,6’s1 verildiği yönünde fikir beyan etmiştir. Gençlere verilen destekler daha çok eğitim faaliyetleri şeklinde gerçekleşmektedir. Maddi destek sağlayan ve tamamen tarıma ve gençlere yönelik olan Genç Çiftçi Projesi uygulanma süresinin kısalığı (2016-2018 yılları arasında) gibi bazı kısıtlar nedeniyle tarımla ilgilenmek isteyen gençleri kapsamaktan uzak kalmıştır.

Tarım ile ilgili kuruluşların özelleştirilmesi konusu son yıllarda sürekli gündeme gelmektedir. Konu ile ilgili öğrencilerin düşünceleri de önem arz etmektedir. Öğrencilerin büyük bir kısmı $(\% 79,0)$ tarımsal kuruluşların özelleştirilmesini doğru bulmadıklarını, \%12'si doğru bulduğunu, geriye kalanı ise bu konu hakkında fikrinin olmadığını belirtmiştir.

\begin{tabular}{|c|c|c|c|c|c|c|c|c|c|c|}
\hline & \multicolumn{10}{|c|}{ Yatırım yapılmak istenen sektör } \\
\hline & & & Tarım & Sanayi & Hizmet & Finans & Eğitim & Bilişim & Diğger & Toplam \\
\hline \multirow{6}{*}{ 苛 } & \multirow{2}{*}{ Kiz } & Kişi & 30 & 5 & 3 & 4 & 8 & 5 & 7 & 62 \\
\hline & & $\%$ & 48,4 & 8,1 & 4,8 & 6,5 & 12,9 & 8,1 & 11,3 & 100 \\
\hline & \multirow{2}{*}{ Erkek } & Kiși & 62 & 7 & 9 & 5 & 2 & 10 & 18 & 113 \\
\hline & & $\%$ & 54,9 & 6,2 & 8 & 4,4 & 1,8 & 8,8 & 15,9 & 100 \\
\hline & \multirow{2}{*}{ Toplam } & Kişi & 92 & 12 & 12 & 9 & 10 & 15 & 25 & 175 \\
\hline & & $\%$ & 52,6 & 6,9 & 6,9 & 5,1 & 5,7 & 8,6 & 14,3 & 100 \\
\hline & \multicolumn{3}{|c|}{ Pearson Chi-Square: 10,730} & \multicolumn{2}{|c|}{ df: 6} & \multicolumn{5}{|c|}{ P- Value: 0,097} \\
\hline
\end{tabular}

Tablo 5. Yatırım Yapılmak İstenen Sektörün Cinsiyete Göre Dă̆ılımı

\section{$H_{o}$ : Yatırım yapılmak istenen sektör ile cinsiyet birbirine bă̆ımlı değildir.}

$H_{1}$ : Yatırım yapılmak istenen sektör ile cinsiyet birbirine bağımlıdır.

Öğrencilere maddi kaynakları olduğu takdirde hangi sektöre yönelecekleri konusunda düşünceleri sorulmuş; \%52,6's1 tarım sektörüne, \%8,6's1 bilişim sektörüne, \%6,9'u sanayi ve hizmet sektörlerine, \%5,7'si eğitim sektörüne ve $\% 5,1$ 'i de finans sektörüne yatırım yapabileceğini belirtmiştir. Bu sektörler dışında diğer seçeneği içinde gayrimenkul, medya, taşımacılık, peyzaj gibi tercihler \% 14,3 oranında pay almıştır. Yapılan Ki kare testi ile maddi kaynakların olması durumunda yatırım yapılmak istenen sektör ile cinsiyetler arasında anlamlı bir farklılık belirlenmiştir $(p<0,10)$. Cinsiyetlere göre değerlendirildiğinde Ziraat Fakültesi’nde okuyan kız öğrencilerin 
\%48,4'ü, erkek öğrencilerin \%54,9’u tarım sektörüne yatırım yapabileceklerini ifade etmişlerdir. Bu durumda alternatif hipotez kabul edilmiştir (Tablo 5).

Tarımın şu an ki durumunun değerlendirilmesi

\begin{tabular}{|c|c|c|c|c|c|c|}
\hline & & & Negatif düşünenler & Fikri olmayanlar & Pozitif düşünenler & Toplam \\
\hline \multirow{6}{*}{ 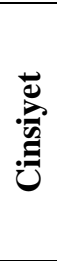 } & \multirow{2}{*}{$\mathrm{K}_{1 \mathrm{Z}}$} & Kişi & 40 & 10 & 12 & 62 \\
\hline & & $\%$ & 64,5 & 16,1 & 19,4 & 100 \\
\hline & \multirow{2}{*}{ Erkek } & Kişi & 99 & 4 & 10 & 113 \\
\hline & & $\%$ & 87,6 & 3,5 & 8,8 & 100 \\
\hline & \multirow{2}{*}{ Toplam } & Kişi & 139 & 14 & 22 & 175 \\
\hline & & $\%$ & 79,4 & 8,0 & 12,6 & 100 \\
\hline & \multicolumn{3}{|c|}{ Pearson Chi-Square: 14,134} & df: 2 & P- Value & \\
\hline
\end{tabular}

Tablo 6. Tarımın Şu Anki Durumunun Cinsiyete Göre Değerlendirilmesi

$H_{0}$ : Tarımın mevcut durumunun değerlendirilmesi ile cinsiyet birbirine bă̆ımlı değildir.

$H_{1}$ : Tarımın mevcut durumunun değerlendirilmesi ile cinsiyet birbirine bağımlıdır.

Öğrencilerin önemli bir oranı Türkiye tarımının şu an ki durumuna yönelik negatif düşünc eye sahiptir $(\% 79,4)$. Tarımın şu an ki durumuna dair düşünceleri ile cinsiyet arasında ki kare testi yapılmış ve cinsiyetler arasında önemli derecede fark belirlenmiştir $(\mathrm{p}<0,01)$. Tarımın mevcut durumunun değerlendirilmesinde erkek öğrenciler $(\% 87,6)$ k1z öğrencilere $(\% 64,5)$ göre daha fazla negatif düşünceye sahiptirler. Sonuç olarak alternatif hipotez kabul edilmiştir (Tablo 6).

\begin{tabular}{|c|c|c|c|c|}
\hline \multicolumn{5}{|c|}{ Mezuniyet sonrası tarımla ilgilenme düşüncesi } \\
\hline \multirow{9}{*}{ 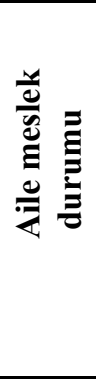 } & & Ort. & $\mathrm{n}$ & Std. Hata \\
\hline & Çiftçi & 4,36 & 45 & 1,048 \\
\hline & Emekli & 3,89 & 35 & ,867 \\
\hline & Memur & 3,61 & 33 & ,998 \\
\hline & İşçi & 4,36 & 14 & ,633 \\
\hline & Özel Sektör & 4,33 & 24 & ,702 \\
\hline & Serbest Meslek & 3,90 & 21 & ,995 \\
\hline & Diğer & 4,67 & 3 & 577 \\
\hline & Toplam & 4,07 & 175 & ,956 \\
\hline & \multicolumn{2}{|c|}{ Pearson Chi-Square: 46,731} & & P- Value: 0,015 \\
\hline
\end{tabular}

Tablo 7. Mezuniyet Sonrası Tarımla İlgilenme Düşüncesinin Aile Mesleğine Göre Dă̆glımı

$H_{o}$ : Aile mesleği ile mezuniyet sonrası tarımla ilgilenme düşüncesi birbirine bağımlı değildir.

$H_{1}$ : Aile mesleği ile mezuniyet sonrası tarımla ilgilenme düşüncesi birbirine bă̆ımlıdır.

Öğrencilerin \%25,7'sinin (n=45) ailesi çiftçilikle uğraşmakta, \%20,0'si emekli ve \%18,9'u da memurdur. Mezuniyet sonrasında tarımla ilgilenmeyi düşünme durumları beşli likert tipi ölçekleme ile tespit edilmiş, verilerin daha anlaşılabilir olması için ortalamaları tabloda gösterilmiştir. Aile mesleği ile mezuniyet sonrası tarımla ilgilenme düşüncesi arasındaki ilişki belirlenmeye çalışılmış ve ki kare testi sonucuna göre aralarında önemli derecede fark belirlenmiştir $(\mathrm{p}<0,05)$. Bu durumda alternatif hipotez kabul edilmiştir. Aile meslek gruplarına göre öğrencilerin tarım sektörü ile ilgilenme düşüncelerine dair katılım sıralamaları değişmektedir. Ailesi çiftçilikle uğraşan gençlerin $\% 57,8$ 'i, işçi olanların \%42,9'u ve özel sektörde çalışanların \%45,8'i gelecekte kesinlikle tarımla ilgilenmek isterken; ailesi emekli $(\% 48,6)$, memur $(\% 48,5)$ ve serbest meslekte $(\% 47,6)$ çalışan öğrenciler sadece düşündüklerini belirtmiştir (Tablo 7).

Uluslararası bir gıda ve içecek firması tarafından yapılan "Yeni Nesil Tarımcılarda Çiftçilik Algısı ve Motivasyon Unsurlarını Belirleme” araştırması sonuçlarına göre gençlerin \%65,5’i üreticilik yapma konusunda kararsızdır. Yorucu bir iş olması, gelir düzeyinin yüksek olmaması, sosyal olmayan bir iş olması, itibarının yüksek olmaması ve kırsal bölgelerde ikamet edilmek istenmemesi nedeniyle gençlerin \%28,2'si üreticiliğe olumsuz bakmaktadır. Üreticilikle ilgilenmek isteyenlerin büyük bir kısmı da ya alternatifleri olmadığından ya da aile mesleği olduğundan bu alanda devam etmekten yana olduklarını belirtmişlerdir. Gençlerin farklı arayışlar içerisinde olmasının temel sebepleri arasında üreticiliğin sabit bir gelirinin olmaması, yorucu bir iş alanı olması, 7/24 ilgi gerektirmesi, özellikle kırsal alanlarda sosyal yaşamın kısıtlı olması ve prestij anlamında güçlü bir alan olmaması yer almaktadır (Anonim, 2018).

Tarım ülkeler açısından önemli bir sektör olmanın yanında stratejik bir sektördür. Yaşamsal gıdalar başta olmak üzere tarıma dayalı sanayiye hammadde sağlama, istihdam, çevre ve daha birçok konuda katkı sağlayan bu sektörün geleceği bu konuda yetişmiş ve istekli gençlere bağlıdır. Tarım konusunda gençler ziraat mühendisi olduklarında bu mesleğin uzmanı olarak çalışabilirler. Çalışmada öğrencilerin ziraat mühendisi olarak kendi 
geleceklerini nasıl gördükleri sorulmuş; $\% 67,5$ 'i geleceklerinin karamsar ve belirsiz gördüklerini; geriye kalan öğrenciler $(\% 32,5)$ ise geleceklerini umutlu ve aydınlık gördüklerini belirtmişlerdir.

Trakya Kalkınma Ajansı tarafından yapılan Çiftçi Algısı Analizi'nde de gençlerin tarımı tercih etmeme nedenleri arasında tarımın eskisi gibi gelir getirmemesi, kırsal yaşamın kent yaşamına göre külfetli olması ve daha az prestijli bir iş olarak görülmesi yer almaktadır. Gençlerin tekrar tarıma yönelmelerinin koşulu, tarımın sanayiden daha iyi gelir getirmesi olarak görülmektedir (Trakyaka, 2018).

Sunar ve ark. tarafından yapılan "Türkiye'de Çalışma Yaşamı ve Mesleklerin İtibarı" isimli araştırmada deneklerin iyi bir işte en fazla aradıkları ilk üç özellik sırasıyla iyi bir ücret, iş garantisi ve iş güvenliği olarak ifade edilmiştir. Araştırma sonuçlarına göre Türkiye'de insanların toplumsal yaşamdaki konumları açısından mesleklere hala ciddi bir önem verildiği görülmektedir. Mesleklerin itibarları ile kazançları arasında yakından bir ilişki gözlemlenmiştir. Araştırmada TÜiK'in Standart Meslekler Sınıflamasının 3. düzey meslek gruplarından seçilen 126 tekil meslek içerisinde Çiftçi 53. sırada yer almıştır (TYAP, 2014).

Gençlerin kendi gelecekleri yanında tarımın geleceğini nasıl gördükleri yargıları öncelik sırasına göre seçmeleri istenmiş; sırasıyla mevcut politikalarla tarım sektörünün devamlılı̆̆ıın olmayacağını, desteklerin ve hibelerin siyasi çıkarlar doğrultusunda verildiğini, girdi fiyatları arttığı sürece tarım sektörünün biteceğini ve tarımsal nüfusun azalacağını, gençlerin tarımdan uzaklaşacağını ve üreten kimsenin kalmayacağını ifade eden görüşler tercih edilmiştir. Bu olumsuz görüşlerin yanında tarımın stratejik sektör olduğu ve bizim gibi alanında uzman gençler sayesinde tarım yeniden önem kazanacağı görüşü de tercihler arasında yer almıştır.

\section{Sonuc}

Ziraat fakülteleri tarımsal üretimin etkin, verimli ve bilinçli şekilde gerçekleştirilmesi için gerekli insan gücünü sağlar. Ülkemizde ziraat fakülteleri ve bu fakültelerde açılan programlar sektörün ihtiyacı olan işgücünü yetiştirmektedir. Ancak bu durum sektör ve sektörde yer alan diğer aktörler için yeterli görülmemektedir.

Tarım sektöründe eğitim ve yayım hizmetlerinin etkinleştirilmesi "Ulusal İstihdam Stretejisi 2014-2023" hedefleri arasında yer almaktadır. Bu amacı gerçekleştirmek için tarım sektörüne ilişkin yükseköğretim programlarının müfredatlarının sektörün ihtiyaçları doğrultusunda güncellenmesi ve Ziraat Fakültelerinde uygulama ağırlıklı eğitimin teşvik edilmesi yer almaktadır (ÇSGB, 2017).

Tarımın sosyal ve ekonomik özellikleri yanında, doğal koşullara bağlı üretimin gerçekleştiriliyor olması, kırsal alanlarda yaşamın zorlukları, uygulanan politikalar, uluslararası rekabet gibi unsurlar tarımın geleceğini etkilemektedir. Bu unsurların yanında tarımsal işgücü üretimin devamlılı̆̆ için gereklidir. Ülkede tarımsal nüfusun yaşlanıyor olması, gençlerin tarımdan uzaklaşması tarımın geleceği için tehdit oluşturmaktadır. Yapılan çalışmalarda çiftçiliğin zorlukları, bu zorluklara karşın getirisinin düşük olması, toplum nezdinde itibar gören mesleklerden uzak bir meslek olması gençleri ve bu konuda yetişmiş ziraat mühendislerini tarımdan uzaklaştırmaktadır. Gençler kazanç elde edebilecekleri başka sektörlere yönelmektedirler.

Gençlerin farklı arayışlar içerisinde olmasının temel sebepleri arasında üreticiliğin sabit bir gelirinin olmaması, yorucu bir iş alanı olması, 7/24 ilgi gerektirmesi, özellikle kırsal alanlarda sosyal yaşamın kısıtlı olması ve prestij anlamında güçlü bir alan olmaması yer almaktadır (Anonim, 2018).

Araştırmaya katılan ziraat mühendisi adayı gençlerin \%61,7'si 22-24 yaş aralığında ve ailelerinin \%25,7'si çiftçilikle uğraşmaktadır. Ailelerin aylık geliri alt düzey gelir grubuna giren öğrencilerin oranı $\% 43,4$ 'tür. Gençler tarımsal yenilikleri daha çok digital kaynaklardan takip etmektedirler. En çok tercih edilen kaynaklar sosyal medya ve internettir.

Aile mesleği ile mezuniyet sonrası tarımla ilgilenme düşüncesi arasında bir bağımlılık bulunmuş̧tur. Ailesi çiftçilikle uğraşan $(\% 57,8)$, iş̧i $(\% 42,9)$ ve özel sektörde $(\% 45,8)$ bulunan öğrenciler kesinlikle tarımla ilgilenmek isterken; ailesi emekli $(\% 48,6)$, memur $(\% 48,5)$ ve serbest meslekte $(\% 47,6)$ çalışan öğrenciler sadece düşündüklerini belirtmiştir.

Ailesi çiftçilikle uğraşan gençler üretimi devam ettirmek, daha bilinçli yaparak geliri artırmayı hedeflemektedirler. Ancak mesleğin getirisinin az olması, güncel politikaların uygulanması, girdilerde dışa bağımlılık, kırsal alanda yaşamın zorluğu ziraat mühendisi olacak gençleri meslekten uzaklaştırmaktadır.

Araştırmaya katılan öğrenciler mevcut politikaların yeterli olmadığını, verilen desteklemelere ve hibelere siyasetin karıştırıldığını ve girdi fiyatlarındaki artışın sektörün geleceğini tehlikeye attığını ifade etmişlerdir. Gençlere göre bu sorunlar devam ettiğinde gençlerin tarımdan tamamen uzaklaşacağını ve uzun dönemde üretim yapan üretici kalmayabileceğini belirtmişlerdir.

Gençler tarım sektörünün geleceğini kendilerinde görmektedirler. Alanında uzman ziraat mühendisleri aracıllğı ile tarımın topraktan-tüketiciye her aşamada bilinçli ve etkin yapılabilecek olması yanında kaynakların doğru kullanılması sağlanabilecektir. Yapısal politikaların doğru ve zamanında uygulanması, ziraat mühendisleri gençlerin sektörde istihdamına öncelik verilmesi, ziraat mühendisi gençlerin tarımdan elde ettiği gelirin diğer sektörlere yakın olması gençleri tarıma özendirebilecek unsurlar arasındadır. 


\section{Kaynakça}

- Anonim, 2018. Tarla Sera Dergisi, Tarımda Z Kuşağı. Tarla Sera Dergisi, Mart 2018, s.66-67.

- CSGB, 2017. Ulusal İstihdam Stratejisi 2014-2023; Tarım Sektörü, http://www.uis.gov.tr/media/1444/tar\%C4\%B1m_sektoru_2017.pdf (erişim tarihi: 03.04.2019)

- Demir A., Pala A., Baytekin H. (2006) Ziraat Fakülteleri Öğrencilerinin Sosyal Yapıları, Eğilimleri ve Sorunları Üzerinde Bir Araştırma. Tekirdağ Ziraat Fakültesi Dergisi, Sayı 3 (3), 259-267.

- Karadaş K., Ertürk Y.E., Şahin K., Kardağ Gürsoy A. (2016) Iğdır Üniversitesi Ziraat Fakültesi Tarım Ekonomisi Bölümü Öğrencilerinin İşsizlik Kaygıları Üzerine Bir Araştırma. XII. Ulusal Tarım Ekonomisi Kongresi, Isparta, 25-27 Mayis 2016, 1635-1642.

- Koyubenbe N, Uzmay A, Candemir M (2006). Avrupa Birliği ve Türkiye'de Organik Süt Üretimindeki Gelişmeler ve Fiyat Oluşumu: İzmir Örneği. Türkiye VII. Tarım Ekonomisi Kongresi, Cilt 2, 757-765, Antalya.

- Sezgin A., Erem T., Aksoy A. (2008) Atatürk Üniversitesi Ziraat Fakültesi Öğrencilerin Sosyo-Ekonomik Durumları ve Genel Eğilimlerinin Belirlenmesi Üzerine Bir Araştırma. Atatürk Üniversitesi Ziraat Fakültesi Dergisi, ISSN: 1300-9036 Say1 39 (1), 1-8.

- ÖSYM, 2017. 2017 ÖSYS Yükseköğretim Programları ve Kontenjanları Kılavuzu, https://dokuman.osym.gov.tr/pdfdokuman/2017/OSYS/LYS/KONTENJANKILAVUZ18072017.pdf (erişim tarihi: 08.11.2018)

- Trakyaka, 2018. Trakya Kalkınma Ajansı. Çiftçi Algısı Analizi, https://www.trakyaka.org.tr/upload/Node/33084/xfiles/Ciftci_Algisi_Analizi_Kalitatif_Rapor2.pdf (erişim tarihi: 27.11.2018)

- TYAP, 2014. Toplumsal Yapı Araştırma Programı, Mesleki İtibar Araştırması, https://tyap.net/mediaf/T\%C3\%BCrkiye-Mesleki-\%C4\%B0tibar-Skalas\%C4\%B1-Sunumu-Son.pdf (erişim tarihi: 03.04.2019)

- TÜIK, 2018. İstatistiklerle Gençlik, 2017, http://www.tuik.gov.tr/PdfGetir.do?id=27598 (erişim tarihi: 13.02.2019)

- TÜIK, 2019. Gayrisafi yurtiçi hasıla, iktisadi faaliyet kollarına (A21) göre cari fiyatlarla (değer, pay, değişim oranı), http://www.tuik.gov.tr/PreIstatistikTablo.do?istab_id=2513 (erişim tarihi: 14.03.2019)

- ZMO, 2018. 2018 Yılı Üniversite Yerleştirme Sonuçları Üzerine Bir Değerlendirme, http://www.zmo.org.tr/genel/bizden_detay.php?kod=30170\&tipi=5\&sube=0 (erişim tarihi: 05.03.2019) 


\title{
Devlet Hastanelerinin Hizmet Performansı Service Performance of State Hospitals
}

\author{
Dr. Seniha Avcil (Memorial Şişli Hospital, Turkey)
}

\begin{abstract}
Developments in health sector increased the expectations of patients. In order to meet these expectations, hospitals attach importance to their service quality. Although hospitals increase the quality of service, the perceptions of service users become more important. It was aimed to determine the quality of service and expectation of patients and their relatives who applied to four state hospitals in Istanbul by Servqual Scale.

In accordance with this purpose, the relationship between the dimensions of "physical properties", "reliability", "willingness - enthusiasm", "assurance" and "cross-empathy" quality of service and socio - demographic characteristics of participants were statistically analyzed. During sampling process, 358 participants who applied to physical therapy rehabilitation, surgery and internal medicine departments were reached via randomized sampling method.

One-way ANOVA and independent sample t-test and chi-square test were applied to analyze the differences in satisfaction level. As a result of the evaluations, it was determined that four state hospitals did not meet the expectations in terms of both the total service quality and service quality sub-dimensions of the patients and their relatives.
\end{abstract}

\section{Giriş}

Üretim imkanlarının son yıllarda artmasıyla aynı ürün pek çok firma tarafından aynı kalitede üretilmektedir. Bu bakımdan bir firmayı diğerlerinden ayıran en önemli unsur müşterinin memnuniyetidir. Rekabet koşullarının oldukça sertleştiği sektörlerde müşterilerinin isteklerini bilen ve ona göre ürün veya hizmet üreten firmalar hem müşterilerinin memnuniyet düzeylerini artırmakta hem de içinde bulundukları sektörün liderliğini ele geçirmektedirler.

Müşteri memnuniyeti, bir kişinin bir ürünün ya da hizmetin beklentileriyle ilgili algılanan performansı veya sonucunu karşılaştırmasından kaynaklanan zevk veya hayal kırıklığı hissidir. Bu tanımın açıkça ortaya koyduğu gibi, memnuniyet algılanan performans ve beklentilerin bir işlevidir. Performans beklentilerin altında kalıyorsa, müşteri memnuniyetsizdir. Performans beklentilere uygunsa, müşteri memnun olur. Performans beklentileri aşarsa, müşteri memnuniyet düzeyi daha da artar.

Hizmet sektöründe müşterilerin memnuniyetinin artması ve sadık birer müşteri olmalarını etkileyen faktörlerden biri de hizmet kalitesidir. Hizmet üretim kalitesini sürekli olarak artırmak zorunda olan sektörlerden biri de sağlık sektörüdür. Hizmet kalitesi göstergeleri arasında hasta memnuniyeti en çok kullanılan göstergelerden birisidir (Bahrampour, vd, 2018). Hasta memnuniyeti, hastanın hastanedeki tüm deneyimlerinin bir özetidir.

Hastaları diğer sektörlerin müşterilerinden ayıran en önemli unsur hastaların müşteri olmak istemediğidir (Mohapatra, vd, 2018). Bir hastanenin müşterisi, diğer hizmet sektörlerinin müşterilerinden tamamen farklıdır. Sağlık ve rahatsızlıklarından dolayı hizmete olan ihtiyaçları isteğe bağlı değildir. Hastanın isteksizce para harcıyor olması gözden kaçırılmaması gereken en önemli unsurdur. Hizmet sağlayıcılar, hasta ve hasta yakınlarının memnuniyetlerinin kazanmaları gerektiğini bilmelidir. Bunun rekabet koşulları içinde hayatta kalabilmeleri için ana faktör olduğunu anlamalıdır. Bu nedenle, bir hastanenin hizmetlerinin daha iyi sunulması için hasta memnuniyetini etkileyen belirli boyutların bilinmesi çok yararlı olacaktır.

Ülkemizde artan talebe bağlı olarak gün geçtikçe hastane sayısı artmaktadır. Hastane sayısı arttıkça ortaya çıkan rekabet koşulları sebebiyle hastaneler hizmet kalitesini artırmak, hastalarını ve hasta yakınlarını memnun etmek zorundadir.

Bu çalışmanın amacı İstanbul'da faaliyet gösteren dört devlet hastanesine başvuran hasta ve hasta yakınlarının bekledikleri ve algıladıkları hizmet kalitesinin Servqual Ölçeği ile belirlenmesidir.

$\mathrm{Bu}$ araştırmada İstanbul ilinde faaliyet gösteren dört devlet hastanesinin fizik tedavi rehabilitasyon (FTR), genel cerrahi ve dahiliye bölümlerine başvuran hasta ve hasta yakınlarının bekledikleri ve algıladıkları hizmet kalitesi "fiziksel özellikler", "güvenirlik", "isteklilik - heveslilik", "güvence" ve "empati” boyutları Servqual Ölçeği ile analiz edilmiş ve katılımcıların sosyo-demografik özellikleri ve hastaneye ait bazı özellikler arasındaki ilişki istatistiksel olarak tespit edilmiştir.

\section{Literatür}

Hizmet kalitesi ve hasta memnuniyeti sağlık sektörü üzerine yapılan çalışmalarda henüz yeni denecek bir aşamadadır. Ancak dünyanın pek çok yerinde artan rekabet koşulları sebebiyle hastaneler ve hükümetler hizmet 
kalitesi ve hasta memnuniyeti ile ilgili araştırmalar yaptırmıştır. Aynı zamanda bilim insanları bağımsız olarak kendileri de çalışmalar yapmışlardır. Yapılan çalışmalar hizmet sağlayan firmanın performansıyla hizmet kalitesinin birbiriyle ilişkisini (Zeithaml, vd, 2000; Boulding, vd, 1993) ortaya koymuştur. Bir başka açıdan hizmet kalitesinin hizmet alan müşterilerin memnuniyetiyle (Taylor ve Baker, 1994; Caruana, vd, 2000) bağlantılı olabileceğini gösteren çalışmalar da vardır. Hastanelerin kar sağlamaları ve hastaların memnun olarak hastaneden ayrılmaları hastanelerin hizmet kalitesiyle (Koska, 1990; Donabedian, 1996) ve müşteriyi elde tutmaya (Steenkamp, 1989) bağlıdır.

Dünyanın hemen her coğrafyasında hizmet kalitesi ve hasta memnuniyeti alanında pek çok çalışma yapılmıştır. Yapılan çalışmalarda varılan sonuçlar için genel geçer bir hükme varmak imkansız görünmektedir. Hasta memnuniyetini ya da algıladığı hizmet kalitesini hizmet alınan kuruluşun kamu ya da özel olması, hastanın demografik yapısı, hastalığı, hizmet aldığı kurumun fiziki ve teknik imkanları, hastane personelinin hastaya karşı kullandığı üslup, personelin hastaya karşı ilgi ve alakası, hizmet alınırken ve hizmetin bedeli ödenirken geçen zaman etkilemektedir. Bilim insanlarının yaptıkları çalışmalar ülke bazında aşağıda yer almaktadır.

Dubai'de yapılan bir çalışma özel hastanelerin tercih edilme sebebinin devlet hastanelerinde yaşanan zaman kaybı ile ilgili olduğu, ayrıca özel hastanelerde doktor ve hemşirelerin hastalarla iletişimindeki üslubun hastane seçiminde etkili olduğu (Bassam, vd, 2018),

Gana'nın sağlık sektöründeki hizmet kalitesinin, müşteri memnuniyetinin ve müşteri sadakatinin rolünü ve özel ve kamu hastanelerinin hizmet kalitesinin Wilcoxon-Mann-Whitney testi kullanılarak karşılaştırmalı bir şekilde incelendiği araştırmada özel hastanelerden hastaların daha memnun olduğu (Anabila, 2018),

Güney Afrika'da yapılan çalışmada hemşirelerin ilgisi ve yemek kalitesinin hastaların firmaya olan sadakatini ve memnuniyetini artırdığı (Gray ve Boshoff, 2004),

Hindistan'da yapılan çalışmada kamu hastanelerinden hizmet alan hastaların memnuniyet düzeylerinin yüksek olduğu, ayrıca doktorların aldıkları ücretin fazla olması, emeklilik imkanlarının varlığı ve esnek çalışma saatlerinin hastaya olan yaklaşımında etkili olduğu ve böylece hastaların memnuniyet düzeylerinin yüksek olduğu kamu hastanelerinde hastaların birçok hizmet için ödeme yapmamaları nedeniyle doktor ve klinik destek personelinin yaklaşımının memnuniyeti önemli derecede etkilediği (Mekoth, vd, 2012), özellikle yaşlı hastaların doktor ile olan etkileşiminin önemli olduğu (Chahal ve Kumari, 2012),

İran'da üroloji bölümünde yatan hastaların ayakta tedavi gören hastalara nazaran memnuniyet düzeylerinin yüksek olduğu (Golshan, vd, 2019),

İtalya'da pediatri kliniğine gelen hastaların ebeveynleri ile yapılan çalışmada hasta ve hasta yakınlarının memnuniyet düzeylerini etkileyen en önemli unsurun zaman ve mekan olduğu, hizmet alımında ve hizmet bedelinin ödenmesinde geçen zamanın kısa olması ve hizmet alımı esnasında bekleme salonlarının ferahlığı hasta yakınları memnun ettiği (Ierardo, vd, 2008).

Kanada'da yapılan bir çalışmada hastaların memnuniyet düzeylerinin olumlu yönde artmasında hastaların duygularının da önemli olduğu, algılanan hizmet kalitesinin yüksek olmasında hastaların hastaneden memnun ayrılmaları arasında dolaylı ve doğrudan ilişki bulunduğu (Ladhari ve Rigaux-Bricmont, 2013),

Katar'da sağlık çalışanlarının büyük çoğunluğunun göçmenlerden oluşmasının hastaların memnuniyet düzeylerini nasıl etkilediği (Abujaber ve Katsioloudes, 2015),

Mısır'da özel ve kamu hastanelerinin hasta memnuniyeti açısından ele alındığı çalışmada özel hastanelerin kamu hastanelerine göre daha çok tercih edildiği (Mostafa, 2005),

Pakistan'da özel ve kamu hastanelerinde hasta beklentileri ve memnuniyetleri üzerine yaptıkları çalışmada empati boyutunda kamu sektörü, duyarlılık boyutunda ise özel hastanelerde hasta memnuniyetinin yüksek olduğu (Javed ve Ilyas, 2018),

Suudi Arabisan'da üniversite hastanelerinde hastaların memnuniyet düzeylerinin artırılması için doktorlar, hemşireler ve hasta bakıcıların hastalarla iletişim becerilerini geliştirmesi gerektiği (Aljuaid, vd, 2016) kadın ve az eğitimli kişilerin algıladıkları memnuniyetin erkek ve eğitimli kişilere göre daha yüksek olduğu (Al Doghaither, 2004),

Suudi Arabistan'da bulunan özel ve kamu hastanelerinde SERVQUAL ölçeği kullanılarak yapılan çalışmada hastaların cinsiyet, eğitim ve mesleklerinin hastane tercihi konusunda etkili olduğu (Al-Borui ve Damanhouri, 2013),

Türkiye'de özel hastanelerin kamu hastanelerine göre hastaları daha da memnun ettiği, doktorların ve hemşirelerin hastalara yaklaşımında bu memnuniyetin belirleyici faktör olduğu (Taner ve Abtony, 2006),

Yunanistan'da yapılan bir çalışmada hasta memnuniyetinde eğitim durumu, hastanın sahip olduğu sigorta çeşidi ve acil kabulünün önemli olduğu, genç ve erkek hastalar yaşlı ve kadın hastalara göre aldıkları hizmetten daha fazla memnun olduğu (Priporas, vd, 2008) sonucuna varmıştır. 


\section{Araştırmanın Yöntemi}

\subsection{Araștırmanın Metodu ve Örneklemi}

$\mathrm{Bu}$ araştırma İstanbul ilinde bulunan dört devlet hastanenin hizmet kalitesinin düzeyini ölçmek ve hizmet kalitesinin hastanelere ait belli bazı özelliklere ve hastaların sosyo-demografik özelliklerine göre değişip değişmediğinin belirlenmesinin amaçlaması yönüyle ilişkisel tarama modelinde bir araştırmadır ve nicel araştırma yöntemi kullanılmıştır.

İstanbul ilinde bulunan dört devlet hastanesinde 1-30 Mart 2019 aralığında tedavi gören hasta ve hasta yakınları araştırmanın evrenini oluşturmaktadır. Hasta ve hasta yakınlarının seçiminde kolay ulaşılabilirlik esas alınmıştır. $\mathrm{Bu}$ nedenle örnekleme yöntemi, olasılıklı olmayan örnekleme türlerinden, uygun örnekleme yöntemine göre belirlenmiştir. Hastanelerin fizik tedavi polikliniği, dahiliye ve genel cerrahi polikliniğinden hasta ve hasta yakını toplam 358 kişi araştırmanın örneklemini oluşturmaktadır. Katılımcıların 120'si FTR, 120'si dahiliye ve 118'i ise genel cerrahi bölümünden araştırmaya katılmıştır. Araştırmaya dahil edilen bireylerin 180'i hasta, 178'i hasta yakınıdır.

Veri toplama aracı olarak Kişisel Bilgi Formu, Hastane Bilgi Formu ve Servqual Ölçeği kullanılmıştır.

Kişisel Bilgi Formu ile hasta ve hasta yakınlarının cinsiyet, yaş, medeni durum, meslek, eğitim durumu, hastanede bulunma nedeni ve hastaneden alınan servis türüne ait veriler toplanmış; Hastane Bilgi Formu ile hastanenin yatak sayısı, kurulduğu yıl, doktor sayısı belirlenmiş; beklenen ve algılanan hizmet kalitesini ölçmek için Servqual Ölçeği kullanılmıştır. Hastane Bilgi Formu ile elde edilen veriler hastanelerin paylaştıkları bilgiler ile sınırlı kalmıştır. Araştırmaya dahil olan hastanelerin herhangi bir akreditasyonu olmayıp, 2015 y1lında yürürlüğe giren 29399 sayılı "Sağlıkta Kalitenin Geliştirilmesi ve Değerlendirilmesine Dair Yönetmelik" kapsamında her yıl Sağlıkta Kalite Standartları kapsamında Sağlık Bakanlığı tarafından denetlenmektedir.

Servqual ölçeği boşluk modelini kendine temel almaktadır. Bir kişinin hizmet tüketimi sonucu edindiği deneyim ile hizmet sunumu öncesindeki beklentilerinin karşılaştırılması sonucu oluşan büyüklük ve bu büyüklüğün yönüyle alakalı olan tatmin boşluk modelini oluşturur (Parasuraman, Zeithaml, Berry, 1985). Hizmet sunumuyla ortaya çıkan tatmin düzeyi müşterinin hizmete yönelik bir tutum oluşturmasına neden olacaktır.

Servqual ölçeği “fiziksel özellikler”, “güvenirlik”, “isteklilik-heveslilik”, "güvence” ve "empati” den oluşan beş alt boyut ve 22 sorudan oluşacak şekilde daraltılarak kullanılmıştır (Parasuraman, vd, 1988). Servqual Ölçeği’nin bu formunun geçerlik ve güvenirlik analizleri Avcıl (2018) tarafından yapılmıştır. Açımlayıcı faktör analizi sonucunda ölçeğin beş faktörlü yapı gösterdiği ve beş faktörün ölçeğe ait varyansın \%70,65'ini açıkladığı görülmüştür. Ölçeğin güvenirliğini kanıtlamak adına her bir alt boyut ve ölçeğin tamamı için Cronbach alfa içtutarlılık katsayıları hesaplanmıştır. Ölçeğin alt boyutları için en düşük Cronbach alfa katsayısı 0,83 ve ölçeğin tamamına ait Cronbach alfa katsayısı 0,95 olarak elde edilmiştir.

Hastanelerin hizmet kalitesi puanlarının karşılaştırılması yapılmış, hizmet kalitesi puanlarının katılımcılara ait cinsiyet, hastanede bulunma nedeni ve medeni durum değişkenlerine göre anlamlı fark gösterip göstermediği bağımsız örneklem t testiyle, katılımcılara ait tedavi görülen klinik, eğitim düzeyi ve hastaneden alınan hizmetin türü değişkenlerine göre anlamlı fark gösterip göstermediği Tek Yönlü ANOVA testi ile, hastanelerin hizmet kalitesi puanları ile yaş değişkeni, hastanenin yatak kapasitesi, doktor sayısı ve hastane yaşı arasındaki ilişki Ki Kare testi ile incelenmiştir.

\section{Bulgular}

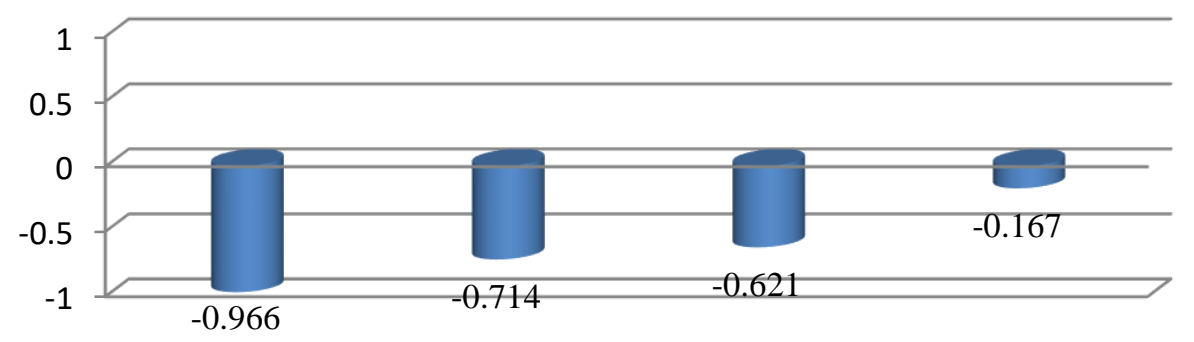

Şekil 1. Hastanelerin Ă̆ırlıklandırılmış Hizmet Kalitesi (Fiziksel Özellikler) Puanları

Araştırmada yer alan hastanelerin hizmet kalitesi (fiziksel özellikler) puanlarının -0,966 ile -0,167 arasında değiştiği görülmektedir. Araştırmada yer alan dört hastaneye ait hizmet kalitesi (fiziksel özellikler) puanlarının da negatif olduğu görülmektedir. Tüm hastanelerin ortalama hizmet kalitesi (fiziksel özellikler) puanı ise -0,617'dir. Buna göre, araştırmada yer alan hastanelere ait fiziksel özelliklerin hasta ve hasta yakınlarının beklentisini karşılamadığı ifade edilebilir. 


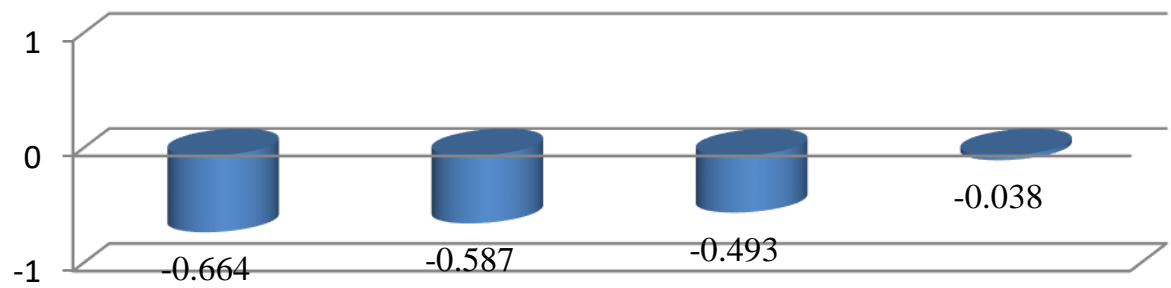

Şekil 2. Hastanelerin Ă̆ırlıklandırılmış Hizmet Kalitesi (Güvenirlik) Puanları

Araştırmada yer alan hastanelerin hizmet kalitesi (güvenirlik) puanlarının -0,664 ile -0,038 arasında değiştiği görülmektedir. Araştırmada yer alan dört hastaneye ait hizmet kalitesi (güvenirlik) puanlarının negatif olduğu görülmektedir. Tüm hastanelerin ortalama hizmet kalitesi (güvenirlik) puanı ise -0,446'dır. Buna göre, araştırmada yer alan hastanelerin güvenirliğinin hasta ve hasta yakınlarının beklentisini karşılamadığı söylenebilir.

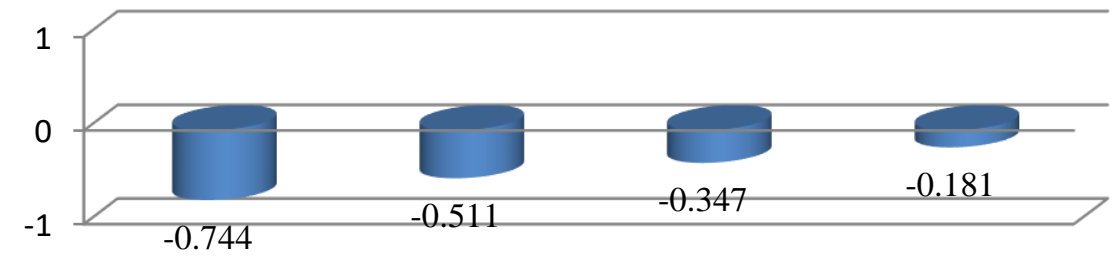

\section{Şekil 3. Hastanelerin Ağıllıklandırllmış Hizmet Kalitesi (İsteklilik-Heveslilik) Puanları}

Araştırmada yer alan hastanelerin hizmet kalitesi (isteklilik-heveslilik) puanları $-0,744$ ile $-0,181$ arasında değişmektedir. Araştırmada yer alan dört hastaneye ait hizmet kalitesi puanlarının negatif olduğu görülmektedir. Tüm hastanelerin ortalama hizmet kalitesi puanı (isteklilik-heveslilik) ise -0,446'dır. Buna göre, araştırmada yer alan hastanelerin isteklilik ve hevesliliğinin hasta ve hasta yakınlarının beklentisini karşılamadan uzak olduğu söylenebilir.

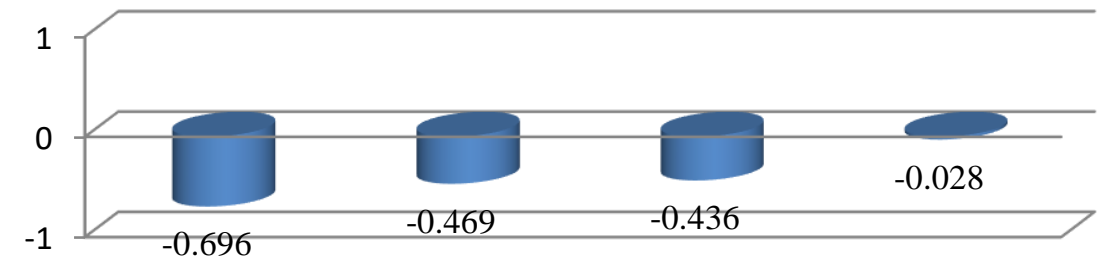

Şekil 4. Hastanelerin Ă̆ırlaklandırılmış Hizmet Kalitesi (Güvence) Puanları

Araştırmada yer alan hastanelerin hizmet kalitesi (güvence) puanlarının -0,696 ile -0,028 arasında değiştiği görülmektedir. Araştırmada yer alan dört hastaneye ait hizmet kalitesi (güvence) puanlarının negatif olduğu görülmektedir. Tüm hastanelerin ortalama hizmet kalitesi (güvence) puanı ise -0,407'dir. Buna göre, araştırmada yer alan hastanelerin verdikleri güvencelerin hasta ve hasta yakınlarının beklentisini karşılamadığı ifade edilebilir.

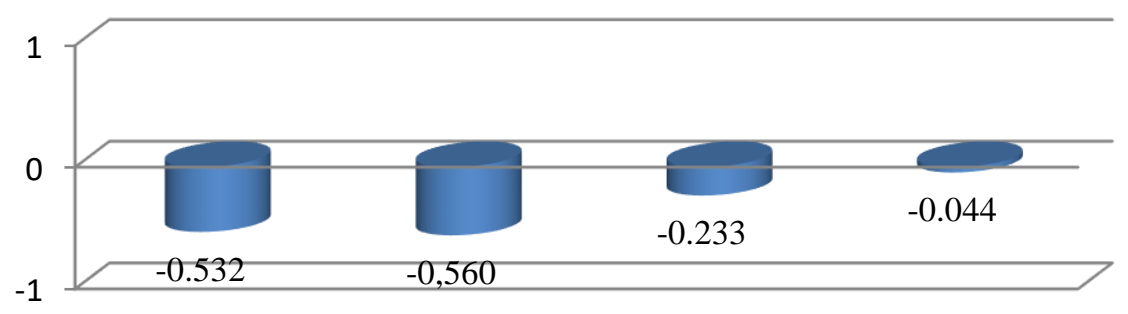

Şekil 5. Hastanelerin Ağırlaklandırllmış Hizmet Kalitesi (Empati) Puanları

Araştırmada dahil edilen hastanelerin hizmet kalitesi (empati) puanları -0,532 ile -0,044 arasında değişmektedir. Araştırmada yer alan dört hastaneye ait hizmet kalitesi (empati) puanlarının da negatif olduğu görülmektedir. Tüm hastanelerin ortalama hizmet kalitesi (empati) puanı ise - 0,342 'dir. Buna göre, araştırmada yer alan hastanelerin sahip oldukları empati düzeyinin hasta ve hasta yakınlarının hastanelerden beklediği empati düzeyinden uzak olduğu söylenebilir. 
Katılımcıların hastaneler için belirledikleri hizmet kalitesi puanlarının cinsiyete göre anlamlı fark gösterip göstermediğinin belirlenmesi amacıyla yapılan bağımsız örneklem $t$ testinin sonuçları Tablo 1 'de verilmiştir.

\begin{tabular}{|c|c|c|c|c|c|c|}
\hline Hizmet Kalitesi & Cinsiyet & $\mathrm{n}$ & $\overline{\bar{x}}$ & $\mathrm{~s}$ & $\mathrm{t}$ & $\mathrm{p}$ \\
\hline \multirow{2}{*}{ Fiziksel Özellikler } & Kadın & 214 & $-0,59$ & 0,95 & \multirow{2}{*}{$-1,827$} & \multirow{2}{*}{0,069} \\
\hline & Erkek & 144 & $-0,41$ & 0,83 & & \\
\hline \multirow{2}{*}{ Güvenirlik } & Kadın & 214 & $-0,55$ & 0,87 & \multirow{2}{*}{$-2,955$} & \multirow{2}{*}{$0,003 *$} \\
\hline & Erkek & 144 & $-0,28$ & 0,77 & & \\
\hline \multirow{2}{*}{ İsteklilik-Heveslilik } & Kadın & 214 & $-0,51$ & 0,90 & \multirow{2}{*}{$-1,803$} & \multirow{2}{*}{0,072} \\
\hline & Erkek & 144 & $-0,34$ & 0,87 & & \\
\hline \multirow{2}{*}{ Güvence } & Kadın & 214 & $-0,48$ & 0,84 & \multirow{2}{*}{$-2,141$} & \multirow{2}{*}{$0,033 *$} \\
\hline & Erkek & 144 & $-0,29$ & 0,80 & & \\
\hline \multirow{2}{*}{ Empati } & Kadın & 214 & $-0,41$ & 0,91 & \multirow{2}{*}{$-2,242$} & \multirow{2}{*}{$0,026^{*}$} \\
\hline & Erkek & 144 & $-0,20$ & 0,82 & & \\
\hline \multirow{2}{*}{ Toplam Hizmet Kalitesi } & Kadın & 214 & $-0,51$ & 0,73 & \multirow{2}{*}{$-2,745$} & \multirow{2}{*}{$0,006^{*}$} \\
\hline & Erkek & 144 & $-0,30$ & 0,65 & & \\
\hline
\end{tabular}

Tablo 1. Katılımcıların Hastaneler İçin Belirledikleri Hizmet Kalitesi Puanlarının Cinsiyete Göre Karşılaştırılması

Katılımcıların Servqual Ölçeği'nin fiziksel özellikler ve isteklilik-heveslilik alt boyutlarından aldıkları puanlar cinsiyete göre anlamlı fark göstermemektedir ( $p>0,05)$. Katılımcıların Servqual Ölçeği'nin güvenirlik, güvence, empati alt boyutundan aldıkları puanlar cinsiyete göre anlamlı fark göstermektedir $(\mathrm{p}<0,05)$. Katılımcıların Servqual Ölçeği’nden aldıkları toplam puanlar cinsiyete göre anlamlı fark göstermektedir $(\mathrm{p}<0,05)$. Erkeklerin ölçekten aldıkları toplam puanların ortalaması (-0,30) kadınların ölçekten aldıkları toplam puanların ortalamasından $(-0,51)$ anlamlı bir şekilde daha yüksektir. Buna göre, erkeklerin hastanelerin hizmet kalitesinden daha fazla memnun oldukları ifade edilebilir.

Katılımcıların hastaneler için belirledikleri hizmet kalitesi puanlarının tedavi gördükleri kliniğe göre anlamlı fark gösterip göstermediğinin belirlenmesi amacıyla yapılan Tek faktörlü ANOVA testinin sonuçları Tablo 2'te verilmiştir.

\begin{tabular}{|c|c|c|c|c|c|c|c|}
\hline Hizmet Kalitesi & Klinik & $\mathrm{n}$ & $\bar{x}$ & $\mathrm{~S}$ & $\mathrm{~F}$ & $\mathrm{p}$ & Fark \\
\hline & FTR & 120 & $-0,73$ & 1,03 & & & \\
\hline \multirow[t]{3}{*}{ Fiziksel Özellikler } & Dâhiliye & 120 & $-0,53$ & 0,89 & 6,869 & 0,001 & $1-3$ \\
\hline & Genel Cerrahi & 118 & $-0,30$ & 0,74 & & & \\
\hline & FTR & 120 & $-0,60$ & 1,07 & & & \\
\hline \multirow[t]{3}{*}{ Güvenirlik } & Dâhiliye & 120 & $-0,46$ & 0,74 & 5,208 & 0,006 & $1-3$ \\
\hline & Genel Cerrahi & 118 & $-0,25$ & 0,60 & & & \\
\hline & FTR & 120 & $-0,72$ & 1,08 & & & \\
\hline \multirow[t]{3}{*}{ İsteklilik-Heveslilik } & Dâhiliye & 120 & $-0,43$ & 0,82 & 11,849 & 0,000 & $1-2$ ve $1-3$ \\
\hline & Genel Cerrahi & 118 & $-0,17$ & 0,63 & & & \\
\hline & FTR & 120 & $-0,68$ & 0,89 & & & \\
\hline \multirow[t]{3}{*}{ Güvence } & Dâhiliye & 120 & $-0,37$ & 0,84 & 13,331 & 0,000 & $1-2$ ve $1-3$ \\
\hline & Genel Cerrahi & 118 & $-0,15$ & 0,65 & & & \\
\hline & FTR & 120 & $-0,51$ & 1,06 & & & \\
\hline \multirow[t]{3}{*}{ Empati } & Dâhiliye & 120 & $-0,45$ & 0,76 & 11,682 & 0,000 & $1-3$ ve $2-3$ \\
\hline & Genel Cerrahi & 118 & $-0,01$ & 0,70 & & & \\
\hline & FTR & 120 & $-0,65$ & 0,87 & & & \\
\hline \multirow[t]{2}{*}{ Toplam Hizmet Kalitesi } & Dâhiliye & 120 & $-0,45$ & 0,65 & 14,715 & 0,000 & $1-3$ ve $2-3$ \\
\hline & Genel Cerrahi & 118 & $-0,17$ & 0,43 & & & \\
\hline
\end{tabular}

Tablo 2. Katılımcıların Hastaneler İçin Belirledikleri Hizmet Kalitesi Puanlarının Kliniğe Göre Karşılaştırılması

Katılımcıların Servqual Ölçeği'nin fiziksel özellikler alt boyutundan aldıkları puanlar kliniğe göre anlamlı fark göstermektedir $(\mathrm{p}<0,05)$. FTR kliniklerinde $(-0,73)$ tedavi gören hasta veya hasta yakını olan katılımcıların fiziksel özellikler alt boyutundan aldıkları puanların ortalaması genel cerrahi kliniğinde tedavi gören hasta veya hasta yakını olan katılımcıların fiziksel özellikler alt boyutundan aldıkları puanların ortalamasından $(-0,30)$ anlamlı bir şekilde daha düşüktür. Buna göre, FTR kliniklerinde tedavi gören hasta veya hasta yakını olan katılımcıların, hastanelerin fiziksel özelliklerinden genel cerrahi kliniğinde tedavi gören hasta veya hasta yakını olan katılımcılara göre daha az memnun oldukları ifade edilebilir.

Katılımcıların Servqual Ölçeği’nin güvenirlik alt boyutundan aldıkları puanlar kliniğe göre anlamlı fark göstermektedir $(\mathrm{p}<0,05)$. Genel cerrahi kliniklerinde $(-0,25)$ tedavi gören hasta veya hasta yakını olan katılımcıların güvenirlik alt boyutundan aldıkları puanların ortalaması FTR kliniklerinde tedavi gören hasta veya hasta yakını olan katılımcıların güvenirlik alt boyutundan aldıkları puanların ortalamasından $(-0,60)$ anlamlı bir 
şekilde daha yüksektir. Buna göre, genel cerrahi kliniklerinde tedavi gören hasta veya hasta yakını olan katılımcıların, hastanelerin güvenirliğinden FTR kliniklerinde tedavi gören hasta veya hasta yakını olan katılımcılara göre daha fazla memnun oldukları ifade edilebilir.

Katılımcıların Servqual Ölçeği'nin isteklilik ve heveslilik alt boyutundan aldıkları puanlar kliniğe göre anlamlı fark göstermektedir $(\mathrm{p}<0,05)$. FTR kliniklerinde $(-0,72)$ tedavi gören hasta veya hasta yakını olan katılımcıların isteklilik ve heveslilik alt boyutundan aldıkları puanların ortalaması dahiliye $(-0,43)$ ve genel cerrahi $(-0,17)$ kliniklerinde tedavi gören hasta veya hasta yakını olan katılımcıların isteklilik ve heveslilik alt boyutundan aldıkları puanların ortalamasından anlamlı bir şekilde daha düşüktür. Buna göre, dahiliye ve genel cerrahi kliniklerinde tedavi gören hasta veya hasta yakını olan katılımcıların, hastanelerin isteklilik ve hevesliliğinden FTR kliniklerinde tedavi gören hasta veya hasta yakını olan katılımcılara göre daha fazla memnun oldukları ifade edilebilir.

Katılımcıların Servqual Ölçeği’nin güvence alt boyutundan aldıkları puanlar kliniğe göre anlamlı fark göstermektedir $(\mathrm{p}<0,05)$. FTR kliniklerinde $(-0,68)$ tedavi gören hasta veya hasta yakını olan katılımcıların güvence alt boyutundan aldıkları puanların ortalaması dâhiliye $(-0,37)$ ve genel cerrahi $(-0,15)$ kliniklerinde tedavi gören hasta veya hasta yakını olan katılımcıların güvence alt boyutundan aldıkları puanların ortalamasından anlamlı bir şekilde daha düşüktür. Buna göre, dâhiliye ve genel cerrahi kliniklerinde tedavi gören hasta veya hasta yakını olan katılımcıların, hastanelerin verdikleri güvenceden FTR kliniklerinde tedavi gören hasta veya hasta yakını olan katılımcılara göre daha fazla memnun oldukları ifade edilebilir.

Katılımcıların Servqual Ölçeği'nin empati alt boyutundan aldıkları puanlar kliniğe göre anlamlı fark göstermektedir $(\mathrm{p}<0,05)$. Genel cerrahi kliniklerinde $(-0,01)$ tedavi gören hasta veya hasta yakını olan katılımcıların empati alt boyutundan aldıkları puanların ortalaması FTR $(-0,45)$ ve dahiliye $(-0,51)$ kliniklerinde tedavi gören hasta veya hasta yakını olan katılımcıların empati alt boyutundan aldıkları puanların ortalamasından anlamlı bir şekilde daha yüksektir. Buna göre, genel cerrahi kliniklerinde tedavi gören hasta veya hasta yakını olan katılımcıların, hastanelerin gösterdikleri empatiden FTR ve dâhiliye kliniklerinde tedavi gören hasta veya hasta yakını olan katılımcılara göre daha fazla memnun oldukları ifade edilebilir.

Katılımcıların Servqual Ölçeği’nden empati alt boyutunda aldıkları toplam puanlar kliniğe göre anlamlı fark göstermektedir $(p<0,05)$. Genel cerrahi kliniklerinde $(-0,17)$ tedavi gören hasta veya hasta yakını olan katılımcıların toplam puanların ortalaması FTR $(-0,45)$ ve dâhiliye $(-0,65)$ kliniklerinde tedavi gören hasta veya hasta yakını olan katılımcıların toplam puanların ortalamasından anlamlı bir şekilde daha yüksektir. Buna göre, genel cerrahi kliniklerinde tedavi gören hasta veya hasta yakını olan katılımcıların, hastanelerin hizmet kalitesinden FTR ve dâhiliye kliniklerinde tedavi gören hasta veya hasta yakını olan katılımcılara göre daha fazla memnun oldukları ifade edilebilir.

Katılımcıların hastaneler için belirledikleri hizmet kalitesi puanlarının eğitim düzeyine göre anlamlı fark gösterip göstermediğinin belirlenmesi amacıyla yapılan Tek faktörlü ANOVA testinin sonuçları Tablo 3'da verilmiştir. 


\begin{tabular}{|c|c|c|c|c|c|c|c|}
\hline Hizmet Kalitesi & $\begin{array}{l}\text { Eğitim } \\
\text { Düzeyi }\end{array}$ & $\mathrm{n}$ & $\bar{x}$ & $\mathrm{~s}$ & $\mathrm{~F}$ & $\mathrm{p}$ & Fark \\
\hline \multirow{5}{*}{ Fiziksel Özellikler } & Okur-Yazar & 17 & $-0,70$ & 0,96 & \multirow{5}{*}{2,015} & \multirow{5}{*}{0,092} & \multirow{10}{*}{$\begin{array}{l}4-1,4-2, \\
4-3,5-1, \\
5-2,5-3\end{array}$} \\
\hline & İlkokul & 129 & $-0,52$ & 0,97 & & & \\
\hline & Ortaokul & 114 & $-0,35$ & 0,77 & & & \\
\hline & Lise & 81 & $-0,69$ & 0,95 & & & \\
\hline & Lisans & 17 & $-0,70$ & 0,88 & & & \\
\hline \multirow{5}{*}{ Güvenirlik } & Okur-Yazar & 17 & $-0,23$ & 0,66 & \multirow{5}{*}{3,106} & \multirow{5}{*}{0,016} & \\
\hline & İlkokul & 129 & $-0,39$ & 0,90 & & & \\
\hline & Ortaokul & 114 & $-0,32$ & 0,75 & & & \\
\hline & Lise & 81 & $-0,64$ & 0,84 & & & \\
\hline & Lisans & 17 & $-0,84$ & 0,92 & & & \\
\hline \multirow{5}{*}{ İsteklilik-Heveslilik } & Okur-Yazar & 17 & $-0,38$ & 0,75 & \multirow{5}{*}{0,932} & \multirow{5}{*}{0,445} & \multirow{10}{*}{$\begin{array}{l}4-1,4-2, \\
4-3,5-1, \\
5-2,5-3\end{array}$} \\
\hline & İlkokul & 129 & $-0,40$ & 0,81 & & & \\
\hline & Ortaokul & 114 & $-0,37$ & 0,87 & & & \\
\hline & Lise & 81 & $-0,57$ & 0,99 & & & \\
\hline & Lisans & 17 & $-0,66$ & 1,21 & & & \\
\hline \multirow{5}{*}{ Güvence } & Okur-Yazar & 17 & $-0,38$ & 0,70 & \multirow{5}{*}{3,970} & \multirow{5}{*}{0,004} & \\
\hline & İlkokul & 129 & $-0,38$ & 0,81 & & & \\
\hline & Ortaokul & 114 & $-0,21$ & 0,76 & & & \\
\hline & Lise & 81 & $-0,61$ & 0,89 & & & \\
\hline & Lisans & 17 & $-0,83$ & 0,82 & & & \\
\hline \multirow{5}{*}{ Empati } & Okur-Yazar & 17 & $-0,52$ & 0,85 & \multirow{5}{*}{0,596} & \multirow{5}{*}{0,666} & \multirow{10}{*}{$\begin{array}{l}4-3,5-1 \\
5-2,5-3\end{array}$} \\
\hline & İlkokul & 129 & $-0,33$ & 0,93 & & & \\
\hline & Ortaokul & 114 & $-0,24$ & 0,82 & & & \\
\hline & Lise & 81 & $-0,38$ & 0,91 & & & \\
\hline & Lisans & 17 & $-0,38$ & 0,82 & & & \\
\hline \multirow{5}{*}{ Hizmet Kalitesi } & Okur-Yazar & 17 & $-0,44$ & 0,60 & \multirow{5}{*}{2,475} & \multirow{5}{*}{0,044} & \\
\hline & İlkokul & 129 & $-0,41$ & 0,75 & & & \\
\hline & Ortaokul & 114 & $-0,30$ & 0,62 & & & \\
\hline & Lise & 81 & $-0,58$ & 0,73 & & & \\
\hline & Lisans & 17 & $-0,68$ & 0,71 & & & \\
\hline
\end{tabular}

Tablo 3. Katılımcıların Hastaneler İçin Belirledikleri Hizmet Kalitesi Puanlarının Eğitim Düzeyine Göre Karşılaştırılması

Katılımcıların Servqual Ölçeği’nin fiziksel özellikler, isteklilik ve heveslilik ve empati boyutlarından aldıkları puanlar eğitim düzeyine göre anlamlı fark göstermemektedir ( $\mathrm{p}>0,05)$.

Katılımcıların Servqual Ölçeği'nin güvenirlik, güvence alt boyutundan aldıkları puanlar eğitim düzeyine göre anlamlı fark göstermektedir $(\mathrm{p}<0,05)$. Katılımcıların Servqual Ölçeği'nden aldıkları toplam puanlar eğitim düzeyine göre anlamlı fark göstermektedir $(\mathrm{p}<0,05)$. Eğitim düzeyi lise olan $(-0,58)$ katılımcıların ölçekten aldıkları toplam puanların ortalaması eğitim düzeyi ortaokul $(-0,30)$ olan katılımcıların ölçekten aldıkları toplam puanların ortalamasından anlamlı bir şekilde daha düşüktür. Buna göre, eğitim düzeyi lise olan katılımcıların hastanelerin hizmet kalitesinden, eğitim düzeyi ortaokul olan katılımcılara göre daha az memnun oldukları ifade edilebilir. Benzer şekilde, eğitim düzeyi lisans olan $(-0,68)$ katılımcıların ölçekten aldıkları toplam puanların ortalaması eğitim düzeyi okur-yazar $(-0,44)$, ilkokul $(-0,41)$ ve ortaokul $(-0,30)$ olan katılımcıların ölçekten aldıkları toplam puanların ortalamasından anlamlı bir şekilde daha düşüktür. Buna göre, eğitim düzeyi lisans olan katılımcıların hastanelerin hizmet kalitesinden, eğitim düzeyi okur-yazar, ilkokul ve ortaokul olan katılımcılara göre daha az memnun oldukları ifade edilebilir.

Katılımcıların hastaneler için belirledikleri hizmet kalitesi puanlarının hastaneden alınan hizmetin türüne göre anlamlı fark gösterip göstermediğinin belirlenmesi amacıyla yapılan Tek faktörlü ANOVA testinin sonuçları Tablo 4'de verilmiştir. 


\begin{tabular}{|c|c|c|c|c|c|c|c|}
\hline Hizmet Kalitesi & Hizmet Türü & $\mathrm{n}$ & $\bar{x}$ & $\mathrm{~S}$ & $\mathrm{~F}$ & $\mathrm{p}$ & Fark \\
\hline \multirow{3}{*}{ Fiziksel Özellikler } & Poliklinik & 237 & $-0,62$ & 0,96 & \multirow{3}{*}{4,450} & \multirow{3}{*}{0,012} & \multirow{3}{*}{$1-2$ ve $1-3$} \\
\hline & 1-7 Yatan & 84 & $-0,33$ & 0,78 & & & \\
\hline & 8 Gün Üstü Yatan & 37 & $-0,30$ & 0,70 & & & \\
\hline \multirow{3}{*}{ Güvenirlik } & Poliklinik & 237 & $-0,51$ & 0,90 & \multirow{3}{*}{3,546} & \multirow{3}{*}{0,030} & \multirow{3}{*}{$1-2$ ve $1-3$} \\
\hline & 1-7 Yatan & 84 & $-0,23$ & 0,61 & & & \\
\hline & 8 Gün Üstü Yatan & 37 & $-0,44$ & 0,86 & & & \\
\hline \multirow{3}{*}{ İsteklilik-Heveslilik } & Poliklinik & 237 & $-0,56$ & 0,95 & \multirow{3}{*}{6,672} & \multirow{3}{*}{0,001} & \multirow{3}{*}{$1-2$ ve $1-3$} \\
\hline & 1-7 Yatan & 84 & $-0,15$ & 0,57 & & & \\
\hline & 8 Gün Üstü Yatan & 37 & $-0,35$ & 0,93 & & & \\
\hline \multirow{3}{*}{ Güvence } & Poliklinik & 237 & $-0,52$ & 0,88 & \multirow{3}{*}{7,631} & \multirow{3}{*}{0,001} & \multirow{3}{*}{$1-2$ ve $1-3$} \\
\hline & 1-7 Yatan & 84 & $-0,19$ & 0,65 & & & \\
\hline & 8 Gün Üstü Yatan & 37 & $-0,12$ & 0,68 & & & \\
\hline \multirow{3}{*}{ Empati } & Poliklinik & 237 & $-0,46$ & 0,91 & \multirow{3}{*}{9,141} & \multirow{3}{*}{0,000} & \multirow{3}{*}{$1-2$ ve $1-3$} \\
\hline & 1-7 Yatan & 84 & $-0,05$ & 0,64 & & & \\
\hline & 8 Gün Üstü Yatan & 37 & $-0,04$ & 0,97 & & & \\
\hline \multirow{3}{*}{$\begin{array}{l}\text { Toplam Hizmet } \\
\text { Kalitesi }\end{array}$} & Poliklinik & 237 & $-0,54$ & 0,77 & \multirow{3}{*}{0,462} & \multirow{3}{*}{0,000} & \multirow{3}{*}{$1-2$ ve $1-3$} \\
\hline & 1-7 Yatan & 84 & $-0,19$ & 0,43 & & & \\
\hline & 8 Gün Üstü Yatan & 37 & $-0,25$ & 0,63 & & & \\
\hline
\end{tabular}

Tablo 4. Katılımcıların Hastaneler İçin Belirledikleri Hizmet Kalitesi Puanlarının Hizmet Türüne Göre Karşılaştırılması

Katılımcıların Servqual Ölçeği'nin tüm alt boyutlarından aldıkları puanlar alınan hizmetin türüne göre anlamlı fark göstermektedir $(\mathrm{p}<0,05)$. Poliklinik hizmetinden yararlanan katılımcıların ölçeğin alt boyutlarından aldıkları puanların ortalaması, diğer hizmetlerden yararlanan katılımcıların ölçeğin alt boyutlarından aldıkları puanların ortalamasından anlamlı şekilde düşük bulunmuştur. Buna göre, poliklinik hizmetinden yararlanan katılımcıların hastanelerin hizmet kalitesinden (fiziksel özellikler, güvenirlik, isteklilik ve heveslilik, güvence, empati) diğer hizmetlerden yararlanan katılımcılara göre daha az memnun oldukları ifade edilebilir. Ek olarak, katılımcıların Servqual Ölçeği’nden aldıkları toplam puanlarında alınan hizmetin türüne göre anlamlı fark gösterdiği belirlenmiştir. Buna göre, poliklinik hizmetinden yararlanan katılımcıların hastanelerin hizmet kalitesinden diğer hizmetlerden yararlanan katılımcılara göre daha az memnun oldukları ifade edilebilir.

Katılımcıların, hastaneler için belirledikleri hizmet kalitesi puanları ile yaşları arasındaki ilişkinin belirlenmesi amacıyla yapılan Ki Kare analizinin sonuçları Tablo 5'de verilmiştir.

\begin{tabular}{lllllll}
\hline Yaş/Hizmet Kalitesi & Negatif & Nötr & Pozitif & Toplam & $\mathrm{X}^{2}$ & $\mathrm{p}$ \\
\hline $18-25$ aras1 & 45 & 3 & 9 & 57 & & \\
$26-30$ aras1 & 35 & 0 & 16 & 51 & & \\
$31-40$ aras1 & 40 & 6 & 16 & 62 & 24,308 & 0,007 \\
$41-50$ aras1 & 60 & 9 & 13 & 82 & & \\
$51-60$ aras1 & 34 & 4 & 15 & 53 & \\
60 ve üzeri & 29 & 1 & 23 & 53 & \\
Toplam & 243 & 23 & 92 & 358 & & \\
\hline
\end{tabular}

Tablo 5. Katılımcıların, Hastaneler İçin Belirledikleri Hizmet Kalitesi Puanları ile Yaşları Arasındaki İlişki

Katılımcıların hastaneler için belirledikleri hizmet puanları ile yaşları arasında anlamlı bir ilişki bulunmuştur $(\mathrm{p}<0,05)$. Tablo 8 incelendiğinde, bu ilişkinin üst yaş gruplarındaki katılımcıların hastanelerin hizmet kalitesinden alt yaş gruplarındaki katılımcılara göre fazla memnun olmasından kaynaklandığı görülmektedir. Özellikle 60 ve üzeri yaş grubu katılımcılarda hizmet kalitesinden memnuniyet diğer yaş gruplarına göre daha fazla bulunmuştur.

Katılımcıların, hastaneler için belirledikleri hizmet kalitesi puanları ile yatak kapasitesi arasındaki ilişkinin belirlenmesi amacıyla yapılan Ki Kare analizinin sonuçları Tablo 6'da verilmiştir.

\begin{tabular}{lllllll}
\hline Yatak kapasitesi /Hizmet Kalitesi & Negatif & Nötr & Pozitif & Toplam & $\mathrm{X}^{2}$ & $\mathrm{p}$ \\
\hline 0-100 arası & 133 & 14 & 31 & 178 & & \\
$101-200$ arası & 49 & 1 & 40 & 90 & 26,256 & 0,000 \\
201 ve üzeri & 61 & 8 & 21 & 90 & & \\
Toplam & 243 & 23 & 92 & 358 & & \\
\hline
\end{tabular}

Tablo 6. Katılımcıların, Hastaneler İçin Belirledikleri Hizmet Kalitesi Puanları ile Hastane Yatak Kapasitesi Arasındaki İlişki

Katılımcıların hastaneler için belirledikleri hizmet puanları ile hastane yatak kapasitesi arasında anlamlı bir ilişki bulunmuştur $(\mathrm{p}<0,05)$. Buna göre, hastanelerdeki yatak kapasitesi 0-100 arasında iken hizmet kalitesi memnuniyeti 
diğer durumlara göre oldukça azdır. En yüksek hizmet kalitesi algısının yatak kapasitesinin 101-200 arasında olduğu durumda olduğu görülmüştür.

\section{Sonuç}

Doktor ve hemşirelerin hastalar ile iletişim üslubu ve ilgisi memnuniyet düzeyini etkilemektedir (Bassam, vd, 2018; Aljuaid, vd, 2016; Gray ve Boshoff, 2004) özel hastanelerden hastaların daha çok memnun olduğu (Anabila, 2018; Taner ve Antony, 2006; Mostafa, 2005) belirlenmiştir. Bu araştırmanın sonuçları da bu görüşleri desteklemektedir. Yapılan değerlendirmeler sonucunda devlet hastanelerinde hem toplam hizmet kalitesi hem de hizmet kalitesi alt boyutlarında hasta ve hasta yakınlarının beklentilerini karşılamadığı görülmüştür.

Erkek hastaların memnuniyetlerinin kadınlardan daha yüksek olduğu belirlenmiştir (Priporas, vd, 2008). Bu araştırma da hizmet kalitesi cinsiyet değiş̧kenine göre güvenirlik, güvence, empati alt boyutlarında anlamlı farklılık göstermekte, fiziksel özellikler ve isteklilik-heveslilik alt boyutlarında ise anlamlı farklılık göstermemektedir. Erkeklerin hastanelerin hizmet kalitesinden kadınlara göre daha memnun oldukları belirlenmiş̧ir.

Üroloji bölümünde yatan hastaların ayakta tedavi gören hastalara göre memnuniyetlerinin yüksek olduğu (Golshan, vd, 2019) belirtmişlerdir. Bu araştırma sonucunda da kliniğe göre hastane hizmet puanı anlamlı farklılık göstermektedir. FTR kliniklerinde tedavi gören hasta ve hasta yakınları devlet hastanelerinin fiziksel özellikler, güvenirlik, isteklilik-heveslilik, güvence, empati alt boyutlarında diğer kliniklerden hizmet alan katılımcılara göre daha az memnun oldukları, genel cerrahi kliniğinden hizmet alan katılımcıların hastanelerin hizmet kalitesinden daha çok memnun oldukları belirlenmiş̧ir. Katılımcıların aldığı hizmet türü ile hizmet puanları arasında anlamlı farklılık bulunmaktadır. Poliklinik hizmetlerinden yararlanan katılımcılar hastanelerin hizmet kalitesinden daha az memnunken, yatan hasta ve hasta yakınlarının memnuniyet düzeyi daha yüksektir.

Eğitim seviyesi az olan hastaların hastanelerden daha memnun oldukları belirlenmiştir (Al Doghaither, 2004). $\mathrm{Bu}$ araştırma sonucunda katılımcıların eğitim düzeyi değişkenine göre fiziksel özellikler, isteklilik-heveslilik ve empati boyutlarında anlamlı farklılık göstermezken, güvenirlik ve güvence boyutlarında anlamlı farklılık göstermekte olduğu belirlenmiştir. Eğitim düzeyi arttıkça hastanelerin güvenirlik ve güvence boyutlarındaki memnuniyetin azalmakta olduğu görülmektedir.

Hastane hizmetlerinde isteklilik-heveslilik, güvence ve empati alt boyutları memnuniyeti özellikle etkilediği belirlenmiştir (Golshan, vd, 2019). Bu araştırma da katılımcıların güvenirlik, güvence ve empati alt boyutlarında farklılaştı̆̆ dikkat çekmektedir.

60 yaş ve üstü grupta yer alan katılımcıların hastanelerin hizmetlerinden memnun olma düzeyleri artmaktadır. Yatak kapasitesinin 101-200 arasında olan hastanelerden daha memnun oldukları belirlenmiştir. Katılımcıların hastanede bulunma sebebi, medeni durum, hastanenin kuruluş yılı (hastanenin yaşı) ve doktor sayısı arasında anlamlı farklılık bulunmamıştır.

Devlet hastanelerinden hasta ve hasta yakınlarının memnuniyet düzeylerini etkileyen değişkenlerin ve memnuniyet düzeylerinin ortaya konması hem sağlık politikalarının geliştirilmesinde hem hastane yönetimi hem de sağlık çalışanlarının eğitiminden sorumlu tarafların sağlık sektöründeki hizmet kalitesinin artırılmasını ve hizmet alanların memnuniyetlerinin artırılmasında yol gösterici olacağı düşünülmektedir. Analiz kapsamında ulaşılan sonuçlara göre devlet hastanelerin hizmet kalitelerini arttırabilmeleri için; hastane yönetimi ve personelinin hizmet alan hasta ve hasta yakınlarına karşı empati temelli iletişim geliştirmelerine dikkat edilmesi, hasta ve hasta yakınlarının beklentilerinin cinsiyete göre farklılaştığının dikkate alınarak hizmet sunumunun farklılaştırılması, hasta ve hasta yakınlarının eğitim seviyelerine göre güvenirlik ve güvence boyutlarında beklentilerin farklılaşması dikkate alınarak sunulan hizmetlerde güvenirlik ve güvence boyutlarının iyileştirilmesi, hasta ve hasta yakınlarına hizmet verirken yaş gruplarının ve hizmet alınan klinikten beklentilerinin farklılaşmasına uygun hizmet sunumunun dikkate alınması, hizmet alan kişilerden geri besleme alarak yaşadığı sorunlar tespit edilmeli ve bir daha sorun yaşamayacağı belirtilerek memnuniyetlerinin artırılması hedeflenmelidir.

\section{Kaynakça}

- Abujaber ve Katsioloudes, 2015. "Impact of HR retention strategies in healthcare: The case of Qatar" Avicenna Healthcare Devolopment and innovation in the Arabian Golf, 2015, 1, p. 6.

- Al Doghaither, 2004. "Inpatient satisfaction with physician services at King Khalid University Hospital, Riyadh, Saudi Arabia". EMHJ - Eastern Mediterranean Health Journal, 10 (3), pp. 358-364

- Al-Borie ve Damanhouri, 2013 "Patients' satisfaction of service quality in Saudi hospitals: a SERVQUAL analysis", International Journal of Health Care Quality Assurance, 26 (1), pp. 20-30.

- Aljuaid, Mannan, Chaudhry, Rawaf, Majeed, 2016. "Quality of care in university hospitals in Saudi Arabia: a systematic review" BMJ Open, 6 (2), p. 88.

- Anabila, 2019."Patients' Perceptions of Healthcare Quality in Ghana: A Review of Public and Private Hospitals". International Journal of Health Care Quality Assurance, 32 (1), pp. 176-190. 
- Avc11, 2019. Türkiye’deki JCI Akreditasyonuna Sahip Özel Hastanelerin Hizmet Performansı. Yayınlanmamış Doktora Tezi. Beykent Üniversitesi Sosyal Bilimler Enstitüsü, İstanbul.

- $\quad$ Bahrampour, Bahrampour, Amiresmaili, Barouni, 2018. "Hospital service quality - patient preferences - a discrete choice experiment", International Journal of Health Care Quality Assurance, 31(7), pp. 676-683.

- $\quad$ Bassam, Ahmad, Souzan, Chiara, 2018. "Patients' satisfaction as a dimension of quality: a survey on outpatients' care in Dubai", International Journal of Health Care Quality Assurance, 31 ( 8), pp. 1030-1043.

- Boulding, Karla, Staelin, Zeithaml, 1993. “A Dynamic Process Model of Service Quality from Expectations to Behavioral Intentions”, Journal of Marketing Research, 30 (1), pp. 7-27.

- Caruana, Money, Berthon, 2000. "Service Quality and Satisfaction-the Moderating Role of Value", European Journal of Marketing, 34 (11/12), pp. 1338-1352.

- Chahal ve Kumari, 2012. "Service Quality and Performance in the Public Health-Care Sector", Health Marketing Quarterly. 29 (3), pp. 181-205.

- Donabedian, 1996, “The Effectiveness of Quality Assurance”, International. Journal Quality of Health Care, 8 (4), pp. 401-407.

- Golshan, Feizy, Tavasoli, Basiri, 2019. "Service quality and urolithiasis patient adherence", International Journal of Health Care Quality Assurance, 32 (1), pp. 2-10.

- Gray ve Boshoff, 2004. "The Relationships Between Service Quality, Customer Satisfaction and Buying Intentions in the Private Hospital Industry". South African Journal of Business Management, 35 (4), pp. 27 37.

- Ierardo, Luzz1, Vestr1, Sfasciott1, Polımen1, 2008. "Evaluation of customer satisfaction at the Department of Paediatric Dentistry of "Sapienza" University of Rome". European Journal Of Paediatric Dentıstry, 9 (1), pp. 30-36.

- Javed ve Ilyas, 2018. "Service quality and satisfaction in healthcare sector of Pakistan — the patients' expectations", International Journal of Health Care Quality Assurance, 31 (6), pp. 489-501.

- Koska, 1990. "High Quality Care and Hospital Profits: is There a Link?”. Hospitals, 5 (March), pp. 62-63.

- Ladhari ve Rigaux-Bricmont, 2013. "Determinants of Patient Satisfaction With Public Hospital Services". Health Marketing Quarterly, 30 (4), pp. 299-318.

- Mekoth, George, Dalvi, Rajanala, Nizomadinov, 2012. "Service Quality in the Public Sector Hospitals: A Study in India", Hospital Topics, 90 (1), pp. 16-22.

- Mohapatra, Ganesh, Punniyamoorthy, Susmitha, 2017. Service Quality in Indian Hopitals, Perspectives from an Emerging Market, Springer, Switzerland.

- Mostafa, 2005. "An empirical study of patients' expectations and satisfactions in Egyptian hospitals". International Journal of Health Care Quality Assurance, 18 (6-7), pp. 516-532.

- Parasuraman, Zeithaml, Berry, 1988. "SERVQUAL: A Multiple Item Scale for Measuring Consumer Perceptions of Service Quality”, Journal Retailing, 64 (Spring), pp. 12-37.

- $\quad$ Priporas, Laspa, Kamenidou, 2008. "Patient Satisfaction Measurement for In-Hospital Services: A Pilot Study in Greece". Journal of Medical Marketing, 8(4), pp. 325-340.

- Steenkamp, 1989. Product Quality: An Investigation into the Concept and how it is Perceived by Consumers. Van Gorcum, Holland.

- $\quad$ Taner ve Antony 2006. "Comparing public and private hospital care service quality in Turkey", Leadership in Health Services, 19 ( 2), pp. 1-10.

- Taylor ve Baker, 1994. “An Assessment of the Relationship Between Service Quality and Customer Satisfaction in the Formation of Consumers' Purchase Intentions”, Journal of Retailing, 70 (2), pp. 163 - 178.

- Zeithaml, 2000.“Service Quality, Profitability, and the Economic Worth of Customers: What We Know and What We Need to Learn", Journal of the Academy of Marketing Science, 28 (1), pp. 67-85. 


\title{
Eğitim Kalitesini Etkileyen Faktörlerin PISA Tabanlı Test Puanları Kullanılarak Değerlendirilmesi: Asya Ülkeleri Örneği Evaluation of Factors Affecting Quality Education Using PISA- Based Test Scores: A Case of Asian Countries
}

\author{
Prof. Dr. Ebru Çağlayan Akay (Marmara University, Turkey) \\ Asst. Prof. Dr. Zamira Oskonbaeva (Kyrgyzstan-Turkey Manas University, Kyrgyzstan)
}

\begin{abstract}
Education is very important research subject in the field of economy. It is a major determinant of economic development and a central factor to human capital capacity-building. It is very common that the studies which focus on the examine the relationship between educational inputs and outputs generally analyze this relationship by Educational Production Function which connects a variety of input types to a given output. Following to this function, the aim of this study is to give a better understanding of the PISA-participating Asian countries' success analysing the importance of the economic/socio-economic and educational factors on the quality of education, using Panel Data methods. These economic and non-economic variables give us a good mix of data to regress upon and make our determinations about the relationship between educational output and inputs.

Since the quality of education is measured by student's average performance on standardized international test, we focus on the PISA-based test scores in the study. PISA was developed by OECD in order to determine how efficiently the students at the 15 year-old age group are educated and trained. It was first performed in 2000 and then repeated every three years. Its aim is to provide comparable data with a view to enabling countries to improve their education policies and outcomes.

In general, the implication of these findings can serve as a guideline for teachers, politicians, governments and give a light to educational policies and methodologies which help countries improve their quality on education.
\end{abstract}

\section{Giriş}

Eğitim hem gelişmiş hem de gelişmekte olan ülkelerde bireylerin gelişmelerine katkıda bulunan son derece önemli uzun vadeli bir yatırımdır. Günümüzde nitelikli insan kaynağı bir ülkenin en önemli serveti olarak değerlendirilebilmektedir. Globalleşen, sınırların kalktığı bir dünyada insan yetiştiren yani eğitime önem veren ülkeler gelişmişlik düzeyi bakımından üst sıralarda yer almaktadırlar. İnsan bilgi ve becerilerine yatırım yapmamanın maliyeti büyük olabilir. Bu durum ekonomileri işsizlik, daha fazla sosyal dışlanma, beceri uyumsuzluğu ve boşa harcanan ekonomik firsat riskine maruz bırakabilir (UNESCO/OECD, 2000). Dolayısıyla insana yatırım önem kazanmakta ve her geçen gün önemi daha da artmaktadır. Bir ülkenin iktisadi gücünü oluşturan insan varlığının en iyi şekilde yetiştirilmesi ancak eğitimle mümkündür.

Eğitim iktisadi üretim fonksiyonu bağlamında ele alınabilir. Tıpkı malların üretiminde olduğu gibi eğitimde üretim fonksiyonu eğitim girdileri ile eğitimsel çıktılar arasındaki ilişkileri gösterir. Diğer bir deyişle herhangi bir okul çıktısını (örneğin, test puanlarını) elde etmede kullanılan girdilerin tüm kombinasyonları olarak tanımlanır (Harris, 2010). Burada çıktı kavramını eğitimsel başarı olarak da tanımlamak mümkündür.

Ülkeler için eğitimin kalitesi ve bu kaliteyi arttırmak büyük önem taşımaktadır. Literatürde yer alan çoğu çalışmada eğitimin kalitesinin bir göstergesi olarak PISA Programme for International Student Assessment, Uluslararası Öğrenci Değerlendirme Programı), TIMSS (Trends in International Mathematics and Science Study, Uluslararası Matematik ve Fen Eğilimleri Araştırması) gibi uluslararası test skorlarının ele alındığı görülmektedir. $\mathrm{Bu}$ uluslararası test skorları incelenen ülkelerdeki öğrenci başarı performanslarının karşılaştırılmasında kullanılan eğitim çıktılarından biridir. Bu eğitim çıktılarını etkileyen faktörlerin incelenmesi eğitim kalitesi üzerindeki etkili olan faktörlerin belirlenmesi için önemli bir yoldur. Bu faktörler çoğunlukla eğitim girdileri olarak ele alınmaktadır. Bunların yanında ülkelerin eğitim sistemleri, ülkelerin ekonomik ve sosyo-ekonomik durumları, öğrencilerin aile yapıları da eğitimin kalitesi üzerinde önemli faktörler olarak karşımıza çıkmaktadır.

$\mathrm{Bu}$ çalışmanın amacı, seçilen Asya ülkeleri için eğitim kalitesini etkileyen faktörlerin incelenmesidir. Bu amaç için 2006, 2009, 2012 ve 2015 yılları için 10 Asya ülkesine (Hong Kong, Endonezya, Japonya, Singapur, Makao, Kore, Türkiye, İsrail, Katar, Tayland) ait PISA skorları ele alınarak, bu skorlar üzerinde hem eğitim girdilerinin hem de ekonomik ve sosyo-ekonomik değişkenlerin etkisi incelenmiştir. Okul başarısının göstergesi olarak ülkelerin PISA puanları ele alınmıştır. Okul çıktısının elde edilmesinde odaklandığımız girdiler ise öğrencilerin bireysel özellikleri, ailenin sosyo-ekonomik durumu, okul-öğretmen nitelikleri ve iktisadi faktörlerdir. Uygulamada 10 ülke için 4 dönemlik veriler ele alınmıştır. Ancak ülkeler PISA sınavlarına farklı yıllarda katılmaya başladıklarından değişkenler için farklı ülkelerde ve farklı zaman dilimlerinde gözlem değerlerinde eksiklikler meydana gelmiştir. Bu nedenle çalışmada dengesiz panel modelleri kullanılacaktır. 
Çalışmamız 6 bölümden oluşmaktadır. Girişi takip eden, ikinci bölümde Asya ülkelerinin PISA puanları OECD ülkelerinin puan ortalamasıyla karşılaştırılmıştır. Daha sonra bu konuda yapılan çalışmalar üzerinde durulmuştur. Dördüncü bölümde veri seti ve değişkenler ele alınmıştır. Çalışmanın metodolojisi ve elde edilen bulgular beşinci bölümde tartışılmıştır. Çalışmamız sonuç bölümüyle sona ermektedir.

\section{Asya Ülkelerinin PISA Puanlarının Karşılaștırılması}

PISA üç yılda bir OECD (İktisadi İşbirliği ve Kalkınma Teşkilatı) tarafından düzenlenen uluslararası bir sınav türüdür. Söz konusu sınava dünya ekonomisinin \% 90'ını oluşturan OECD üye ülkeleri ile ortak ülkelerdeki 15 yaşındaki okul öğrencileri katılabilmektedirler (OECD, 2006). PISA gençlerin bilgi ve becerilerini gerçek hayattaki zorlukları aşmak için kullanabilme yeteneklerine odaklanmakta ve zorunlu eğitimin sonundaki öğrencilerin okuma, matematik ve fen alanındaki bilgi ve becerilerini ölçmektedir. İlk PISA sınavı 2000 yılında 28 OECD üye ülkedeki ve 4 ortak ülkedeki 6000 okuldaki 172000 öğrencinin katılımıyla gerçekleşmiştir (Marks vd., 2006). Öğrenciler ve eğitim ortamları hakkında toplanan bilgi sayesinde, PISA öğrenci performansını etkileyen sosyal, kültürel, ekonomik ve eğitim faktörlerinin tanımlanmasına olanak sağlamaktadır.

Asya ülkelerinin (Singapur hariç) 2006 ve 2015 yılındaki her matematik, fen ve okuma alanlarındaki başarı performansları Grafik 1., Grafik 2. ve Grafik 3.'de gösterilmiştir. Singapur PISA sınavlarına 2009 yılından itibaren katılmaya başladığı için analiz dışı bırakılmıştır. Ülkelerin bazıları OECD ortalamasının üzerindeyken bazıları ilerleme kaydedememişlerdir. Genel olarak Kore Makao, Japonya ve Hong Kong'un her üç alanda yıllar itibariyle OECD ortalamasının çok üzerinde yer aldıkları söylenebilir.

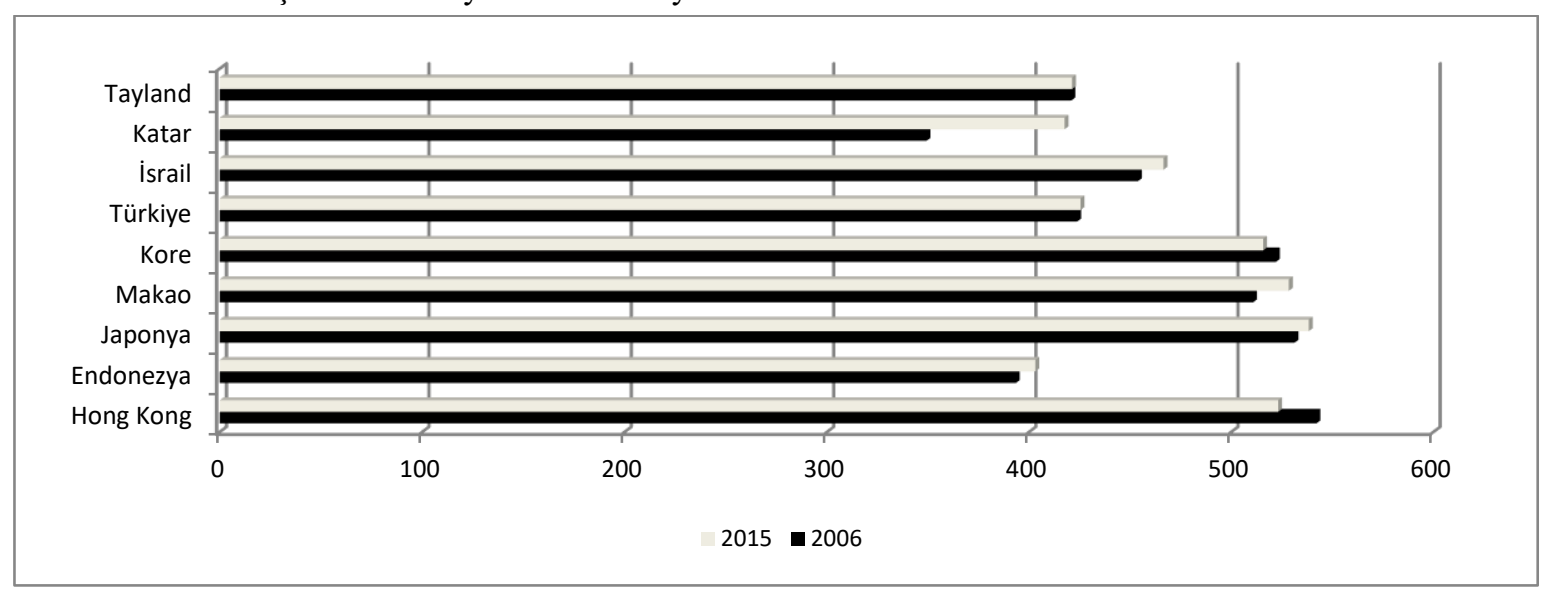

Grafik 1. Asya Ülkelerinin Fen Alanında PISA Puan Ortalamaları

Japonya, Makao, Endonezya, Katar ve İsrailli öğrencilerin fen alanında 2015 yılında 2006 yılına göre daha başarılı oldukları göze çarpmaktadır. Hong Kong ve Kore öğrencilerinin ise 2015 yılında 2006 yılındaki performansı gösteremedikleri, ayrıca Tayland ve Türkiye'de öğrencileri başarı ortalamalarının hemen hemen aynı düzeyde kaldığı söylenebilir.

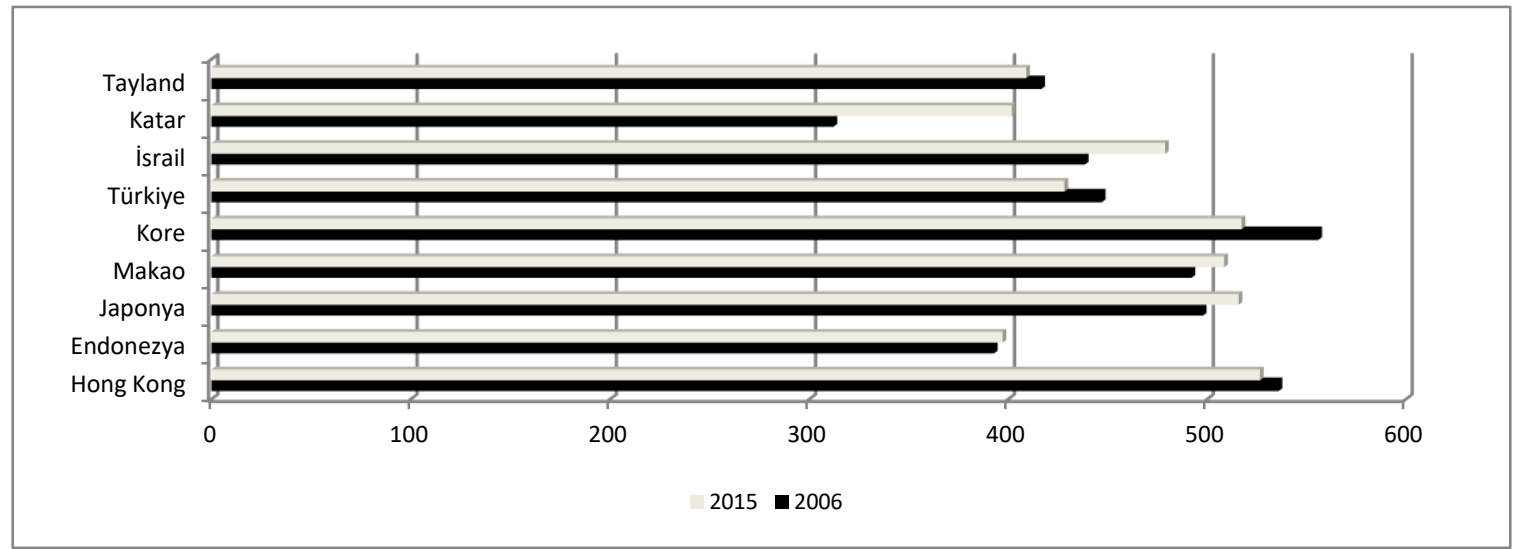

Grafik 2. Asya Ülkelerinin Okuma Alanında PISA Puan Ortalamaları

Tayland, Türkiye, Hong Kong ve Koreli öğrencilerin okuma alanında 2015 yılında 2006 yılındaki performans düzeylerini yakalamayı başaramamışlardır. Katar, İsrail, Makao, Japonya ve Endonezya'da sınava katılan öğrencileri 2015 yılında okuma alanında 2006 yılına göre daha yüksek performans göstermişlerdir. 


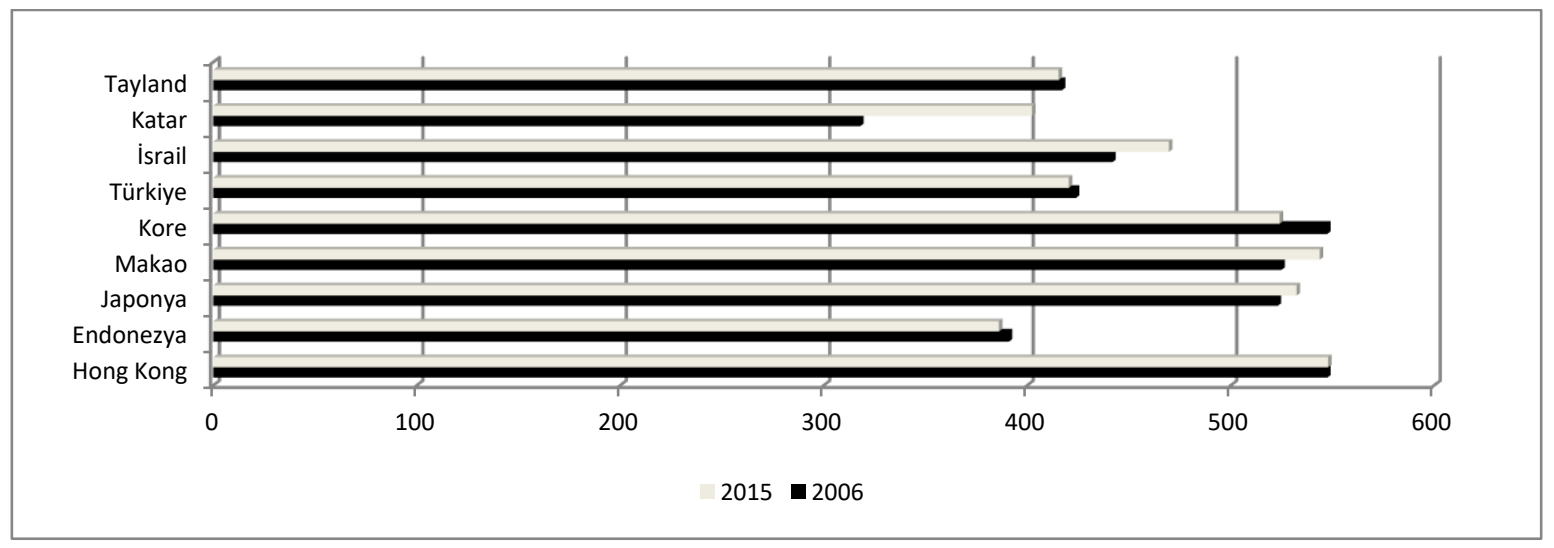

Grafik 3. Asya Ülkelerinin Matematik Alanında PISA Puan Ortalamaları

Türkiye, Kore ve Endonezya'da sınava katılan öğrencilerin matematik alanında 2015 yılında 2006 yılındaki performansı yakalayamadıkları, ayrıca Hong Kong ve Tayland'da öğrencilerin ortalamasının hemen hemen aynı düzeyde seyrettiği gözlemlenmektedir. Katar, İsrail Makao ve Japonyalı öğrenciler 2015 yılında 2006 yılına göre daha iyi performans gösterebilmişlerdir.

\section{Literatür}

Ülkelerin uluslararası sınavdaki başarılarını (eğitim performanslarını) dolayısıyla eğitim kalitesini etkileyen faktörleri ortaya koymak amacıyla farklı ülkeler için farklı yöntemleri kullanarak pek çok araştırma yapıllmıştır. Öğrenci başarısını etkileyen faktörler öğrencinin bireysel özellikleri, aile kaynaklı ve okul-öğretmen faktörleri olmak üzere üç başlık altında toplanabilmektedir (Hanushek ve Woessmann, 2011a, 2011b). Elde edilen bulgular incelendiğinde öğrencinin özelliklerinin (Clark, 2010; Kotte, vd., 2005; Kush, Watkins ve Brookhart, 2005; Unrau ve Schlackman, 2006), ailenin sosyo-ekonomik durumu Caldas ve Bankston, 1997; Ma ve Klinger, 2000; Jones ve White, 2000; Orr, 2003), okul ortamı (Wößmann, 2001, 2003) ve öğretmen niteliklerinin (Fidler, 2001; Ma ve Williams, 2004; Maslowski, Scheerens ve Luyten, 2007;) öğrencilerin akademik başarılarını etkileyen belli başlı faktörler olarak görülmüştür.

Öğrencinin bireysel özelliklerinin başarı üzerindeki etkisini inceleyen çalışmaların çoğunda öğrencinin okula başlama yaşı, cinsiyeti, ögrencinin öz güveni, motivasyonu ve okula karşı tutumları ve diğer faktörler ele alınmıştır (Karakolidis vd., 2016; Pitsia vd., 2017). Erkek öğrencilerin kızlara göre matematik okuryazarlığının ve kızların erkeklere göre okuma becerilerinin daha üst düzeyde olduğunu ortaya koyan çalışmalar da bulunmaktadır (Pitsia vd., 2017; Rajchert vd., 2014). Puhani ve Weber (2007) okula başlama yaşının öğrenci başarısı üzerinde etkili olduğunu savunurken, Fertig ve Kluve (2005) okula başlama yaşı ile eğitim arasında herhangi bir ilişki bulamamıştır. Ailenin sosyoekonomik durumunun akademik başarı üzerindeki etkisini ele alan ilk araştırmacı olarak Coleman vd., (1966) karşımıza çıkmaktadır.

Ailenin sosyoekonomik statüsü ne kadar yüksekse (Davis-Kean, 2005; Halle vd.,1997) ve kültürel açıdan ne kadar zengin ise (Davis-Kean, 2005; Feldman ve Wentzel, 1990) o denli öğrenci başarılı olacaktır. Bazı araştırmaların bulguları ebeveynlerin eğitim düzeyi yüksek olan öğrencilerin, ebeveynlerin eğitim düzeyi düşük olan öğrencilere göre daha iyi sonuçlar elde ettiklerini göstermiştir (Häkkinen vd., 2003; Woßmann 2003; Bouhlila, 2017). Ancak genel görüşün aksine öğrenci başarısının aile geliri veya sosyo-ekonomik durumu ile güçlü bir bağlantısı olmadığını gösteren çalışmalara da rastlanmaktadır (Marks, 2016). Son dönemlerde yapılan araştırmalar ise bu iki değişken arasında ilişkinin yönü doğrusal olmayıp kuadratik biçimde olduğunu göstermiştir (Zhao, vd., 2012). Bunun yanı sıra Reparaz ve Sotés-Elizalde (2019) aile katılımının akademik başarı üzerindeki etkisini inceleyen çalışmasında ebeveynlerin çocukları ile konuşmak için ayırdığı zaman ile performans arasında ilişkinin söz konusu olduğunu ileri sürmüşlerdir. Bir diğer araştırmacılar tarafından aile yapısının (ebeveyn ve kardeşlerin sayısı) öğrencinin akademik başarısını önemli ölçüde etkilediği ortaya konulmuştur (Pong, 1997, 1998; Manning,1998).

Öğrenci performansı ile okul ve öğretmen faktörleri arasındaki ilişkileri inceleyen çalışmalarda okul büyüklüğü, sınıf büyüklüğü, öğretmen becerisi, tecrübesi gibi değişkenlere yer verilmiştir. Okul büyüklüğünün ne ölçüde öğrenci performansını etkilediğine dair yapılan çalışmalar hala fikir birliğine ulaşmış değillerdir. Bazı çalışmalar küçük okulların başarıyı arttırıcı etkisinin olduğunu savunurken, diğer çalışmalar büyük okulların daha etkili olduğunu vurgulamaktadırlar. Son dönemlerde yapılan araştırmalar bu iki değişken arasında doğrusal olmayan ilişkinin söz konusu olduğunu ileri sürmektedirler (Giambona ve Porcu, 2018). Aynı şekilde sınıf büyüklüğünün öğrenci akademik başarısı üzerindeki etkisi de tartışmalıdır. Wilson (2011) sınıf büyüklüğünün öğrenci akademik başarısı ile hiçbir ilişkisi olmadığını tespit ederken, Bosworth (2014) küçük sınıfların öğrencilerin akademik başarısını olumlu yönde etkilediğini ortaya koymuştur. 
Bir diğer araştırmacılara göre sınıf büyüklüğü gibi diğer koşullar elverişli olmasa bile, kaliteli eğitim yoluyla başarı arttırılabilmektedir (Ngware, vd., 2014). Meroni vd., (2015) öğretmen becerilerinin öğrenci başarısını olumlu yönde etkilediğini vurgularken, Azigwe vd., (2016) öğretmen ve okulların gelişmiş ülkelerden ziyade gelişmekte olan ülkeler için daha önemli olduğunu ileri sürmektedir.

Yukarıda özetlenen araştırmalar göz önünde bulundurularak bu çalışmada diğer çalışmalardan farklı olarak başarının açıklayıcı değişkenleri arasında iktisadi değişkenlere de yer vermenin uygun olacağı kanaatine varılmıştır.

\section{Veri Seti ve Değişkenler}

Literatürdeki çoğu çalışmada eğitim kalitesini belirlemede kullanılan bir gösterge olan ve eğitimin çıktısı olarak değerlendirilen uluslararası test skorları ele alınarak öğrenci performansları incelenmiştir. Bu çalışmada eğitimin kalitesinin göstergesi olarak önerilen uluslararası test skorları arasında en çok bilinen PISA skorları 10 Asya ülkesi için ele alınmış ve bağımlı değişken olarak kullanılmıştır. Ele alınan bu ülkeler için eğitimin kalitesini yani eğitim performansını etkileyen faktörler ise model tahminlerinde açıklayıcı değişkenler olarak belirlenerek bu faktörlerin Asya ülkelerinin her üç alandaki (okuma, matematik ve fen) eğitim performansları üzerindeki etkileri incelenmiştir. Bu açıklayıcı değişkenler eğitim girdi faktörleri (sertifikalı öğretmen sayısı, öğretmen başına öğrenci sayısı, bilgisayar kullanımı), aile kaynaklı faktörler (ebeveynlerin mesleki statüsü gibi), ülkelerin eğitim sistemleri (okula başlama yaşı, zorunlu eğitim süresi), ülkelerin ekonomik gelişmeleri, yapıları ve performanslarını gösteren faktörler (kişi başına GSYIH, yüksek/düşük gelirli ülke durumu), ülkelerin sosyo-ekonomik yapılarını gösteren faktörler (insani gelişme endeksi) olarak ele alınmıştır. Bu değişkenlere ait 2006, 2009, 2012 ve 2015 dönemine ait veriler Dünya Bankası, OECD PISA ve UIS (UNESCO İstatistik Enstitüsü) ve Birleşmiş Milletler Kalkınma Programı veri tabanlarından elde edilmiştir. Tablo 1.'de çalışmada ele alınan değişkenlerin tanımı ve veri kaynakları yer almaktadır.

\begin{tabular}{|c|c|c|}
\hline Değişken & Tanımı & Kaynak \\
\hline PISA puanları & $\begin{array}{l}\text { Uluslararası PISA sınavında ülkelerin okuma, matematik ve fen } \\
\text { alanında aldıkları not ortalamalarıdır. }\end{array}$ & OECD PISA \\
\hline Ebeveynlerin mesleki statüsü & $\begin{array}{l}\text { Ebeveynlerin mesleki statüsü 0'dan 100'e doğru değerler alan } \\
\text { değişkendir. 100'e yaklaştıç̧a mesleki statünün yükseldiğini ifade } \\
\text { etmektedir. }\end{array}$ & OECD PISA \\
\hline Sertifikalı öğretmen sayısı & Sertifikalı öğretmen sayısını gösteren değişkendir. & $\begin{array}{l}\text { UNESCO İstatistik Enstitüsü } \\
\text { (UIS) }\end{array}$ \\
\hline $\begin{array}{l}\text { Eğitim amaçlı bilgisayar } \\
\text { kullanımı }\end{array}$ & Eğitim amaçlı kullanılan ortalama bilgisayar adedi. & OECD PISA \\
\hline $\begin{array}{l}\text { İlk okulda öğrenim görme } \\
\text { süresi beklentisi }\end{array}$ & $\begin{array}{l}\text { Bir okula giriş çă̆ındaki bir öğrencinin belirtilen eğitim süresi } \\
\text { içerisinde geçirmeyi bekleyebileceği yıllar. }\end{array}$ & $\begin{array}{l}\text { UNESCO İstatistik Enstitüsü } \\
\text { (UIS) }\end{array}$ \\
\hline $\begin{array}{l}\text { Öğretmen başına düşen } \\
\text { öğrenci sayısı }\end{array}$ & Öğretmen başına düşen öğrenci sayısını gösteren değişkendir. & $\begin{array}{l}\begin{array}{l}\text { UNESCO İstatistik } \\
\text { (UIS) }\end{array} \\
\end{array}$ \\
\hline Okula başlama yaşı & Öğrencilerin yasal olarak zorunlu eğitime kayıt oldukları yaş. & $\begin{array}{l}\text { UNESCO İstatistik Enstitüsü } \\
\text { (UIS) }\end{array}$ \\
\hline Zorunlu eğitim süresi & $\begin{array}{l}\text { Öğrencilerin yasal olarak okula gitmek zorunda kaldığı yıl veya yaş } \\
\text { aralığı. }\end{array}$ & $\begin{array}{l}\text { UNESCO İstatistik Enstitüsü } \\
\text { (UIS) }\end{array}$ \\
\hline Kişi başına GSYİH & $\begin{array}{l}\text { Satın alma gücü paritesine göre hesaplanmış kişi başına GSYİH } \\
\text { değişkenidir. }\end{array}$ & $\begin{array}{l}\text { UNESCO İstatistik Enstitüsü } \\
\text { (UIS) }\end{array}$ \\
\hline Yüksek/düşük gelirli ülke & $\begin{array}{l}\text { Eğer ülke yüksek gelirli ülke ise } 1 \text { değerini, değilse } 0 \text { değerini alan } \\
\text { kukla değişkenidir. }\end{array}$ & Dünya Bankası veri tabanı \\
\hline İnsani gelişme endeksi & İnsani gelişme endeksi 0 ile 1 arası değerler alan değişkendir. & $\begin{array}{l}\text { Birleşmiş Milletler Kalkınma } \\
\text { Programı veri tabanı }\end{array}$ \\
\hline
\end{tabular}

Tablo 1. Değişkenlerin Tanımı

\section{Metodoloji ve Bulgular}

Ampirik uygulamada kullanacağımız model aşağıdaki gibi yazılabilmektedir:

$$
Y_{i t}=\alpha+\beta X_{i t}^{\prime}+\varepsilon_{i t} \quad i=1,2, \ldots, N \quad t=1,2, \ldots, T
$$

Burada; $Y_{i t}$ değişkeni, öğrenci başarısını ifade eden PISA puanlarını göstermektedir. $X_{i t}$ ise Tablo.1'de açıkladığımız açıklayıcı değişkenler, $\varepsilon_{i t}$ ise hata terimi ifade etmektedir. Çalışmada ele alınan Asya ülkeleri PISA sınavlarına farklı yıllarda katılmaya başladıklarından değişkenler için farklı ülkelerde ve farklı zaman dilimlerinde gözlem değerlerinde eksiklikler meydana gelmiştir. Bu nedenle dengesiz panel veri modelleri yardımı ile tahminler yapılmıştır.

Çalışmada dengesiz panel veri modellerinin tahmini için Havuzlanmış En Küçük Kareler (HEKK) ve Genelleştirilmiş En Küçük Kareler (GEKK) yöntemleri kullanılmıştır. HEKK tahmincileri,

$\hat{\delta}_{E K K}=\left(X^{\prime} X\right)^{-1} X^{\prime} Y$ 
olarak elde edilmektedir. Havuzlanmış EKK yönteminde birim ve zaman etkilerinin olmadı̆̆ı varsayılmaktadır (Gujarati, 2016). Birim etkinin varyansı sıfıra eşit olduğunda en iyi doğrusal sapmasız tahminci elde edilmektedir, ancak birim etkinin varyansı sıfira eşit olmadığı durumda parametre tahminleri sapmasız ve tutarlı olmakla beraber, standart hatalar sapmalı tahmin edilmektedir.

Genelleştirilmiş En Küçük Kareler (GEKK) tahmincileri ise,

$$
\hat{\delta}_{\text {GEKK }}=\left(X^{\prime} \Omega^{-1} X\right)^{-1} X^{\prime} \Omega^{-1} Y
$$

olarak elde edilebilir. Burada, $\Omega, v_{i t}{ }^{\prime}$ nın varyans kovaryans matrisidir ve

$\Omega=E\left(v_{i} v_{i}^{\prime}\right)=\sigma_{u}^{2} I_{t}+\sigma_{u}^{2} e e^{\prime}$

olarak hesaplanır (Yerdelen Tatoğlu, 2018).

Dengesiz panel modellerinde GEKK uygulanırken verilerde bir dönüştürme işlemi yapılır. Dengeli panel modellerinden farklı olarak bu dönüştürme işlemi ile her bir birim için var olan gözlem sayısı dikkate alınmaktadır. $\mathrm{Bu}$ dönüştürülen veriler ile EKK yöntemi uygulanır. Genelleştirilmiş EKK yöntemi ile rassal etkiler modellenmiştir (Güriş ve Kızılarslan, 2018).

$\mathrm{Bu}$ yöntemler kullanılarak, matematik, fen ve okuma skorlarını etkileyen faktörler ayrı ayrı tahmin edilerek Tablo 2.'de özetlenmiştir.

\begin{tabular}{|c|c|c|c|c|c|c|}
\hline & \multicolumn{3}{|c|}{ Genelleştirilmiş EKK } & \multicolumn{3}{|c|}{ Havuzlanmış EKK } \\
\hline & Fen & Matematik & Okuma & Fen & Matematik & Okuma \\
\hline Sabit & $\begin{array}{c}7.6393 * * * \\
(0,3693)\end{array}$ & $\begin{array}{c}7,8728 * * * \\
(0,4563)\end{array}$ & $\begin{array}{l}5.3027 * * * \\
(0,9287)\end{array}$ & $\begin{array}{c}7,6393 * * * \\
{[0,3504]}\end{array}$ & $\begin{array}{c}7,8728 * * * \\
{[0,4655]}\end{array}$ & $\begin{array}{c}5.3027 * * * \\
{[0,6796]}\end{array}$ \\
\hline $\begin{array}{l}\text { Ebeveynlerin } \\
\text { mesleki statüsü }\end{array}$ & $\begin{array}{c}-0,0158 * * * \\
(0,0020)\end{array}$ & $\begin{array}{c}-0,0180 * * * \\
(0,0025)\end{array}$ & $\begin{array}{c}-0,0127 * * * \\
(0,0026)\end{array}$ & $\begin{array}{c}-0,0158 * * * \\
{[0,0023]}\end{array}$ & $\begin{array}{c}-0,0180 * * * \\
{[0,0029]}\end{array}$ & $\begin{array}{c}-0,0127 * * * \\
{[0,0026]}\end{array}$ \\
\hline $\begin{array}{l}\text { Eğitim amaçlı } \\
\text { bilgisayar } \\
\text { kullanımı }\end{array}$ & $\begin{array}{c}0,0009^{* *} \\
(0,0003)\end{array}$ & $\begin{array}{c}0,0011 * * \\
(0,0004)\end{array}$ & $\begin{array}{c}0,0020 * * * \\
(0,0006)\end{array}$ & $\begin{array}{l}0,0009 * * \\
{[0,0003]}\end{array}$ & $\begin{array}{l}0,0011^{* *} \\
{[0,0004]}\end{array}$ & $\begin{array}{c}0,0020 * * * \\
{[0,0004]}\end{array}$ \\
\hline $\begin{array}{l}\text { İlk okulda } \\
\text { öğrenim görme } \\
\text { süresi beklentisi }\end{array}$ & $\begin{array}{c}-0,0785 * * * \\
(0,0230)\end{array}$ & $\begin{array}{c}-0,0811 * * * \\
(0,0284)\end{array}$ & $\begin{array}{l}-0,0638 * \\
(0,0367)\end{array}$ & $\begin{array}{c}-0,0785^{* * * *} \\
{[0,0208]}\end{array}$ & $\begin{array}{c}-0,0811 * * * \\
{[0,0201]}\end{array}$ & $\begin{array}{c}-0,0638 * * \\
{[0,0296]}\end{array}$ \\
\hline $\begin{array}{l}\text { Kişi başına } \\
\text { GSYİH }\end{array}$ & $\begin{array}{c}-0,1208 * * * \\
(0,0274)\end{array}$ & $\begin{array}{c}-0,1429 * * * \\
(0,0339)\end{array}$ & $\begin{array}{c}-0,0989 * * * \\
(0,0348)\end{array}$ & $\begin{array}{c}-0,1208 * * * \\
{[0,0299]}\end{array}$ & $\begin{array}{c}-0,1429 * * * \\
{[0,0415]}\end{array}$ & $\begin{array}{c}-0,0989 * * * \\
{[0,0270]}\end{array}$ \\
\hline $\begin{array}{l}\text { Yüksek/düşük } \\
\text { gelirli ülke } \\
\text { olmaları }\end{array}$ & $\begin{array}{c}0,3672 * * * \\
(0,0504)\end{array}$ & $\begin{array}{c}0,4286^{* * * *} \\
(0,0623)\end{array}$ & $\begin{array}{c}0,5210 * * * \\
(0,0919)\end{array}$ & $\begin{array}{c}0,3672 * * * \\
{[0,0509]}\end{array}$ & $\begin{array}{c}0,4286^{* * *} * \\
{[0,0628]}\end{array}$ & $\begin{array}{c}0,5210 * * * \\
{[0,0743]}\end{array}$ \\
\hline $\begin{array}{l}\text { İnsani gelişme } \\
\text { endeksi }\end{array}$ & $\begin{array}{c}0,8188 * * * \\
(0,1611)\end{array}$ & $\begin{array}{c}0,8434 * * * \\
(0,1990)\end{array}$ & $\begin{array}{l}0,4300 * \\
(0,2340)\end{array}$ & $\begin{array}{c}0,8188 * * * \\
{[0,1099]}\end{array}$ & $\begin{array}{c}0,8434 * * * \\
{[0,1633]}\end{array}$ & $\begin{array}{l}0,4300 * * \\
{[0,1840]}\end{array}$ \\
\hline $\begin{array}{l}\text { Sertifikalı } \\
\text { öğretmen sayısı }\end{array}$ & $\begin{array}{c}0,0023 * * * \\
(0,0008)\end{array}$ & $\begin{array}{c}0,0029 * * * \\
(0,0010)\end{array}$ & & $\begin{array}{l}0,0023 * * \\
{[0,0009]}\end{array}$ & $\begin{array}{l}0,0029 * * \\
{[0,0012]}\end{array}$ & \\
\hline $\begin{array}{l}\text { Öğretmen başına } \\
\text { düşen öğrenci } \\
\text { sayısı }\end{array}$ & $\begin{array}{c}-0,0109 * * * \\
(0,0039)\end{array}$ & $\begin{array}{c}-0,0112 * * \\
(0,0048)\end{array}$ & & $\begin{array}{c}-0,0109 * * * \\
{[0,0022]}\end{array}$ & $\begin{array}{c}-0,0112 * * * \\
{[0,0030]}\end{array}$ & \\
\hline $\begin{array}{l}\text { Okula başlama } \\
\text { yaşı }\end{array}$ & & & $\begin{array}{l}0,1992 * * \\
(0,0798)\end{array}$ & & & $\begin{array}{l}0,1992 * * * \\
{[0,0486]}\end{array}$ \\
\hline \multirow[t]{2}{*}{$\begin{array}{l}\text { Zorunlu eğitim } \\
\text { süresi }\end{array}$} & & & $\begin{array}{l}0,0772 * * \\
(0,0324)\end{array}$ & & & $\begin{array}{l}0,0772 * * \\
{[0,0313]}\end{array}$ \\
\hline & $\begin{array}{l}\text { Wald chi2 }(8) \\
=278,32 * * * \\
\mathrm{R}^{2}=0,9298\end{array}$ & $\begin{array}{l}\text { Wald chi2(8) } \\
=240,82 * * * \\
\mathrm{R}^{2}=0,9198\end{array}$ & $\begin{array}{l}\text { Wald chi2(8) } \\
=131,09 * * * \\
\mathrm{R}^{2}=0,8619\end{array}$ & $\begin{array}{l}\mathrm{F}=52,06 * * * \\
\mathrm{R}^{2}=0,9298 \\
\text { chi2 }(1)=5,93 \\
\text { Prob > chi } 2= \\
0.0148\end{array}$ & $\begin{array}{l}\mathrm{F}=43,12 * * * \\
\mathrm{R}^{2}=0,9198 \\
\text { chi2 } 2(1)=6,75 \\
\text { Prob }>\text { chi } 2= \\
0.0094\end{array}$ & $\begin{array}{l}\mathrm{F}=28,79 * * * \\
\mathrm{R}^{2}=0,8619 \\
\text { chi2 }(1)=7,79 \\
\text { Prob }>\text { chi } 2= \\
0.0052\end{array}$ \\
\hline
\end{tabular}

Not: *, **ve *** sirastyla \%10, \%5 ve \%1 anlamlılık düzeylerini göstermektedir.

Köşeli parantez içerisinde robust standart hatalar verilmiştir.

\section{Tablo 2. Tahmin Sonuçları}

Tablo 2.'deki tahmin sonuçları incelendiğinde, incelenen ülkeler için PISA'nın fen, matematik ve okuma skorları için tahmin edilen modellerin tümünde eğitim girdisi (sertifikalı öğretmen sayısı, öğretmen başına öğrenci sayısı, bilgisayar kullanımı), aile kaynaklı faktörler (ebeveynlerin mesleki statüsü gibi), ekonomik (kişi başına GSYIH, yüksek/düşük gelirli ülke durumu) ve sosyo-ekonomik (insani gelişme endeksi) faktörlerin katsayılarının istatistiksel olarak anlamlı olduğu görülmektedir. Bunlardan farklı olarak okuma skorları ele alındığında eğitim sistemi faktörlerinin (okula başlama yaşı ve zorunlu eğitim süresi) de sırasıyla \%1 ve \%5 hata payına göre istatistiksel olarak anlamlı olduğu bulunmuştur. Wald ve F test sonuçlarına göre her iki modelin genel olarak anlamlı olduğu söylenebilir.

İki tahminci arasında seçim yapabilmek için Breusch-Pagan Lagranga Çarpanı (LM) testi kullanılmıştır. Breusch-Pagan (1980) yaklaşımına göre tahmin edilen modelin birim etkilerinin varyansı sıfıra eşit ise en küçük kareler yöntemi kullanılabilmektedir. Aksi durumda rassal etkili modelin kullanılması uygundur (Güriş, 2015). 


\begin{tabular}{|l|l|l|}
\hline Fen & Matematik & Okuma \\
\hline chi2 $(1)=1.65$ & chi2 $(1)=0.69$ & chi2 $(1)=1.71$ \\
Prob $>$ chi $^{2}=0.1985$ & Prob $>\operatorname{chi}^{2}=0.4067$ & Prob $>\operatorname{chi}^{2}=0.1916$ \\
\hline
\end{tabular}

Tablo 3. Breusch-Pagan Lagrange Çarpanı Testi

Tablo 3.'te özetlenen sonuçlara göre birim etkinin varyansının sıfıra eşit olduğu sıfır hipotezi reddedilememiştir. Dolayısıyla birim etkileri anlamsızdır ve havuzlanmış En Küçük Kareler (POLS) yönteminin kullanılması uygundur. F testi sonucunda model genel olarak anlamlı ve belirlilik katsayısı sırasıyla Tablo 2.'de görüldüğü gibi $\% 92, \% 91$ ve $\% 86$ civarında bulunmuştur.

Havuzlanmış modelde değişen varyans sorunun olup olmadığını analiz etmek için Breusch Pagan (1979) ve Cook Weisberg (1983) tarafından önerilmiş Breusch-Pagan/Cook-Weisberg değişen varyans testi kullanılmıştır. Test istatistikleri (ve olasılık değerleri) sirasıyla $5,93(0,0148), 6,75 \quad(0,0094)$ ve $7,79 \quad(0,0052)$ olarak hesaplanmıştır. Bu testin sonucunda sabit varyansın varlığını gösteren temel hipotez reddedilmiştir. Çalışmada robust standart hatalar hesaplanarak bunlar tabloda köşeli parantez içinde raporlanmıştır.

Tahmin sonuçlarını yorumlayacak olursak ebeveynlerin mesleki statüsü her üç alanda PISA puanlarını negatif yönde etkilediği görülmektedir. Ebeveynlerin mesleki statüsündeki bir birimlik artış öğrenci performanslarında 0,02 birim düşüşe neden olmaktadır. Diğer bir deyişle ele alınan Asya ülkelerinde düşük statülü ailelerin çocukları da yüksek performans gösterebileceğini ifade etmektedir. Çin, Singapur ve Japonya'da mesleki statünün düşük olması öğrencilerin yüksek performans yakalayabilmeleri için bir engel yaratmadığını PISA araştırmaları göstermiştir (OECD, 2014). Sertifikalı öğretmen sayısındaki bir birimlik artış fen ve matematik alanında PISA puanlarını olumlu yönde etkilemektedir. Bu bulgu öğrencinin başarısı için öğretmenin mesleki gelişimine vurgu yapan Myrberg (2007), Kaplan ve Owings (2001) ve Hammond ve Bransford (2005)'un çalışmalarıyla paralellik arz etmektedir. Eğitim amaçlı bilgisayar kullanımının fen okuryazarlığı; matematik okuryazarlığı ve okuma becerileri üzerindeki etkisi pozitif yönlü ve istatistiki açıdan anlamlı bulunmuştur. Bu bulgu Anil (2009), Anil ve Ozer (2012), Ozer ve Anil (2011)’’n çalışmalarıyla örtüşmektedir.

İlk okulda öğrenim görme süresi beklentisindeki bir birimlik artış PISA puanlarını 0,08 birim azaltmaktadır. İlk okulda öğrenim görme süresi öğrencilerin sınıfı tekrarlamalarından dolayı da artmış olabilir. Bu ise çocukların eğitimde daha fazla yıl geçirme olasılığını artırmaktadır. Yani başarısız öğrenciler sınıfı tekrar okumak zorunda kalırlar. Bu da öğrenim görme süresindeki artışa sebep olur. Bu değişken öğrenci performansını azaltıcı yönde etkilemektedir.

Öğretmen başına düşen öğrenci sayısı fen ve matematik alanında öğrencilerin başarısını azaltıcı yönde etkilemektedir. Yani öğretmen başına düşen öğrenci sayısındaki bir birimlik artış PISA puanlarını 0,01 birim azaltmaktadır. Diğer bir deyişle kalabalık sınıfların öğrencilerin performans düzeylerinin düşmesine neden olabileceğine işaret etmektedir (Özberk vd., 2017). Bu bulgu Arum (2000), Fidler (2001), Nye vd., (2001), Ehrenberg vd., (2001) ve Krueger (2003)'in çalışmalarıyla örtüşürken, Hanushek (2003) ve Rivkin vd., (2005) bu değişkenin öğrenci performansı üzerinde etkisinin anlamlı olmadığını vurgulamışlardır.

İktisadi değişkenlerin öğrenci başarısı üzerindeki etkileri ise farklılık göstermektedir. Kişi başına GSYİH değişkeni PISA puanları ile negatif yönde anlamlı ilişkiye sahiptir. Araştırmalar, bazı ekonomik açıdan dezavantajlı öğrencilerin, maddi yoksunluğun yol açtığı tüm zorluklara ve sorunlara rağmen, eğitimde başarıyı yakalayabilme yeteneğine sahip olduğunu göstermiştir. Farklı bir yaklaşımda, yoksul ailelerden gelen çocukların kendilerini bu tür koşullardan kurtarmaları için çok çalıştıkları ve bu nedenle akademik olarak iyi performans göstermeye daha fazla çaba harcadıkları anlamına gelmektedir. Diğer bir deyişle ele alınan Asya ülkelerinde de kişi başına gelirin düşük olması öğrencilerin başarı durumlarını engellemeyen bir etmen olarak karşımıza çıkmaktadır. Ülkelerin yüksek gelirli ülke grubuna girmesi PISA puanlarını sırasıyla 0,37, 0,43 ve 0,52 birim arttırmaktadır. İnsani gelişme endeksindeki bir birimlik artış öğrenci başarılarını sırasıyla 0,82, 0,84 ve 0,43 birim arttıracağ gözlemlenmektedir. Okuma becerileri üzerinde etkili olan iki değişken daha vardır. Bunlar okula başlama yaşı ve zorunlu eğitim süresi değişkenleridir. Okula başlama yaşındaki bir birimlik artış öğrencilerin başarılarını 0,2 birim ve zorunlu eğitim süresindeki bir birimlik artış ise öğrencilerin başarılarını 0,1 birim arttıracağ gözlemlenmektedir. Okula başlama yaşı ile öğrenci başarıları arasındaki pozitif yönlü ilişkinin varlığı Bedard ve Dhuey (2006), Fredriksson ve Öckert (2005)'in çalışmalarıyla benzerlik arz etmektedir.

\section{Sonuç}

Bu çalışmada öğrenci başarılarının bir ölçüsü olan PISA puanları ile onları etkileyen faktörler incelenmeye çalışılmıştır. Bu amaç doğrultusunda seçilmiş Asya ülkelerinin 2006, 2009, 2012 ve 2015 dönemlerine ait yıllık verilerine dengesiz panel veri modeli uygulanmıştır.

Eğitim karmaşık bir süreçtir ve öğrencinin başarısını doğrudan veya dolaylı olarak etkileyen birçok faktör söz konusudur. Dolayısıyla çalışmamızda ülkelerin başarısını daha iyi anlayabilmek için hem ekonomik hem de eğitimsel değişkenlerin öğrencilerin akademik performansı üzerindeki etkisi incelenmeye çalışılmıştır. 
Tahmin sonuçlarına göre tüm açıklayıcı değişkenler ile PISA puanları arasında istatistiksel açıdan anlamlı bir ilişkinin varlığı söylenebilir. İktisadi değişkenlerin öğrenci performansları üzerinde etkisinin daha yüksek olduğu gözlemlenmektedir.

Öğretmenlere ve okullara yönelik politikalar geliştirilmedikçe, öğrencilerin akademik başarılarının arttırılmasında kalıcı çözümler üretme olanaklarının azaldığı ifade edilebilir. Genel olarak, bu çalışmadan elde edilen bulgular öğretmenlere, politikacılara ve araştırmacılara eğitimde kaliteyi artırmalarına yardımcı olacak eğitim politikalarını geliştirmelerine 1şık tutabilir.

\section{Kaynakça}

- Arum, R.2000. Schools and communities: Ecological and institutional dimensions. Annual Review of Sociology 26, 395-418.

- Anil, D. 2009. Factors effecting science achievement of science students in programme for international students' achievement (PISA) in Turkey. Education and Science, 34 (152), 87-100.

- Anil, D. ve Ozer, Y. 2012. The effect of the aim and frequency of computer usage on student achievement according to PISA 2006. Procedia-Social and Behavioral Sciences, 46, 5484-5488.

- $\quad$ Azigwe, J.B. Kyriakides, L., ve Panayiotou, A., Creemers, B.P.M. 2016. The impact of effective teaching characteristics in promoting student achievement in Ghana, International Journal of Educational Development, 51, 51-61.

- Baltagi, B., H. 2005. Econometric Analysis of Panel Data. John Wiley \& Sons Ltd, p. 314.

- $\quad$ Bedard, K. ve Dhuey, E. 2006. The Persistence of Early Childhood Maturity: International Evidence of LongRun Age Effects. Quarterly Journal of Economics, 121(4), 1437-1472.

- Bosworth, R. 2014. Class size, class composition, and the distribution of student achievement, Education Economics, 22(2), 141-165, DOI: 10.1080/09645292.2011.568698.

- Bouhlila, D., S. 2017. Parents' education and literacy skills: Evidence on inequality of socioeconomic status in Arab countries, World Development Perspectives, 5, 34-43

- $\quad$ Breusch, T.S., ve Pagan, A. R. 1980. The Lagrange Multiplier Test and its Applications to Model Specification in Econometrics, The Review of Economic Studies, 47(1) 239-253.

- Breusch, T.S., ve Pagan, A. R.1979. A Simple Test for Heteroscedasticity and Random Coefficient Variation, Econometrica, 47(5), 1287-1294.

- Caldas, S. J. ve Bankston, C. L.1997. The effect of school population socioeconomic status on individual student academic achievement, Journal of Educational Research, 90, 269-277.

- Clark, C. (2010). Linking School Libraries and Literacy: Young People's Reading Habits and Attitudes to Their School Library, and an Exploration of the Relationship between School Library Use and School Attainment, Research Report, London: National Literacy Trust.

- Coleman, J. S., Campbell, J. S., Campbell, E. Q., Hobson, C. J., McPartland, J., Mood, A. M., Weinfeld, F. D., York, R. L., 1966. Equality of Educational Opportunity. Washington, D.C.: US Department of Health, Education, and Welfare, US Government Printing Office.

- Cook, R.D., ve Weisberg, S.1983. Diagnostics for Heteroscedasticity in Regression.Biometrika,70 (1),1-10.

- Davis-Kean, P. E. 2005. The Influence of Parent Education and Family Income on Child Achievement: The Indirect Role of Parental Expectations and the Home Environment. Journal of Family Psychology, 19(2), 294-304.

- $\quad$ Ehrenberg, R.G., Brewer, D.J., Gamoran, A. and Willms, J.D. 2001. Class Size and Student Achievement. Psychological Science in the Public Interest, 2, 1-30.

- $\quad$ Fredriksson, P. ve Ockert, B. 2005. Is Early Learning Really More Productive? The effect of School Starting Age on School and Labour Market Performance, IZA Discussion Paper no. 1659.

- Fertig, M. and Kluve, J. 2005. The Effect of Age at School Entry on Educational Attainment in Germany, Discussion Paper No. 1507, Institute for the Study of Labor (IZA), Bonn.

- $\quad$ Feldman, S. S., ve Wentzel, K. R. 1990. Relations among family interaction patterns, classroom selfrestraint, and academic achievement in preadolescent boys. Journal of Educational Psychology, 82(4), 813819.

- $\quad$ Fidler, P. 2001. The Impact of Class Size Reduction on Student Achievement. Los Angeles, CA: Los Angeles Unified School District, Program Evaluation and Research Branch.

- Giambona, F., ve Porcu, M. 2018. School size and students' achievement. Empirical evidences from PISA survey data, Socio-Economic Planning Sciences, 64, 66-77. 
- Güriş, S. 2015. Stata ile Panel veri Modelleri. Der Yayınları s.318.

- Güriş, S. ve Kızılarslan, Ş. 2018. Uygulamalı Panel Veri Ekonometrisi, Der Yayınları.

- Hammond, D., L., ve Bransford, J. 2005. Preparing Teachers For a Changing World: What Teachers Should Learn and Be Able to Do. San Francisco:Jossey-Bass.

- Harris, D.N. 2010. Education Production Functions: Concepts. International Encyclopedia of Education (Third Edition) p.412-422, 10.1016/B978-0-08-044894-7.01230-6.

- Häkkinen, I., Kirjavainen, T., ve Uusitalo, R. 2003. School resources and student achievement revisited: new evidence from panel data. Economics of Education Review, 22, 329-335.

- Hanushek, E. A. 2003. The failure of input based schooling policies. The Economic Journal,113, 64-98.

- Hanushek, E. A., Woessmann, L. 2011a. How much do educational outcomes matter in OECD countries? Economic Policy, 26 (67), 427-491.

- Hanushek, E. A., Woessmann, L. 2011b. The Economics of International Differences in Educational Achievement, in Handbook of the Economics of Education, 3, 89-200.

- Halle, T. G., Kurtz-Costes, B., ve Mahoney, J. L. 1997. Family influences on school achievement in lowincome, African American children. Journal of Educational Psychology, 89(3), 527-537.

- Jones, I. ve White, S. 2000. Family Composition, Parent Involvement, and Young Children's Academic Achievement. Early Child Development and Care, 161, 71-82.

- $\quad$ Karakolidis, A., Pitsia, V., Emvalotis, A., 2016. Examining students' achievement in mathematics: A multilevel analysis of the Programme for International Student Assessment (PISA) 2012 data for Greece. International Journal of Educational Research, 79, 106-115.

- Kaplan, L. S., ve Owings, W.A. 2001. Teacher Quality and Student Achievement: Recommendations For Principals. NASSP Bulletin, 85 (628), 64-73.

- Kotte, D., Liez, P. ve Lopez, M. M. 2005. Factors Influencing Reading Achievement in Germany and Spain: Evidence From PISA 2000, International Education Journal, 6 (1), 113-124.

- Kush, J. C., Watkins, M. W. ve Brookhart, S. M. 2005. The Temporal-Interactive Influence of Reading Achievement and Reading Attitude. Educational Research and Evaluation, 11 (1), 29-44.

- $\quad$ Krueger, A. B., 2003. Economics considerations and class size. Economic Journal, 113, 34-63.

- Lee, J., ve Stankov, L., 2018. Non-cognitive predictors of academic achievement: Evidence from TIMSS and PISA, Learning and Individual Differences, 65, 50-64.

- Ma X. ve D. A. Klinger 2000. Hierarchical linear modeling of student and school effects on academic achievement, Canadian Journal of Education, 25(1), 41-55.

- $\quad$ Ma. X. ve Williams, J. D. 2004. School Disciplinary Climate: Characteristics and

- Effects on Eighth Grade Achievement. Alberta Journal of Educational Research, 2 (50), 169-188.

- Manning, M. L. 1998. Gender differences in young adolescents' mathematics and science achievement. Childhood Education, 74, 168-171.

- Marks , G. N., Cresswell, J., ve Ainley, J. 2006. Explaining socioeconomic inequalities in student achievement: The role of home and school factors, Educational Research and Evaluation, 12(02), 105-128.

- Marks G. N. 2016. The relative effects of socio-economic, demographic, non-cognitive and cognitive influences on student achievement in Australia, Learning and Individual Differences 49, 1-10.

- Maslowski, R., Scheerens, J. and Luyten, H. 2007. The Effect of School Autonomy and School Internal Decentralization on Students' Reading Literacy. School Effectiveness and School Improvement, 18 (3), 303 334.

- $\quad$ Meroni, E. C., Vera-Toscano, E., ve Costa, P. 2015. Can low skill teachers make good students? Empirical evidence from PIAAC and PISA, Journal of Policy Modeling, 37(2), 308-323

- Myrberg E. 2007. The Effect of Formal Teacher Education on Reading Achievement of 3rd- Grade Students in Public And Independent Schools in Sweden. Educational Studies, 33 (2), 145-162.

- $\quad$ Ngware, M.W., Oketch, M., ve Mutisya, M. 2014. Does teaching style explain differences in learner achievement in low and high performing schools in Kenya? International Journal of Educational Development, 36, 3-12.

- $\quad$ Nye, B., Hedges, L. V. ve Konstantopoulos, S. 2001. The Long-Term Effects of Small Classes in Early Grades: Lasting Benefits in Mathematics Achievement At Grade 9. Journal of Experimental Education, 69, 245-257. 
- Orr, A. 2003. Black-White Differences in Achievement: The Importance of Wealth. Sociology of Education, 76 (4), 281-304.

- Ozer, Y. ve Anil, D. 2011. Examining the factors affecting students' science and mathematics achievement with structural equation modeling. Hacettepe University Journal of Education, 41, 313-324.

- $\quad$ Özberk E.H., Kabasakal K.A. ve Boztunç Öztürk, N. 2017. Investigating the Factors Affecting Turkish Students' PISA 2012 Mathematics Achievement Using Hierarchical Linear Modeling, Hacettepe Üniversitesi Eğitim Fakültesi Dergisi (H. U. Journal of Education) 32(3), 544-559 doi: 10.16986/HUJE.2017026950

- $\quad$ OECD, 2006. Assessing Scientific, Reading and Mathematical Literacy. A Framework for PISA 2006.

- OECD, 2014. PISA in Focus 2014/02.

- OECD PISA veri taban1. http://www.oecd.org/pisa/data/

- $\quad$ Pong, S. 1997. Family structure, school context, and eighth-grade math and reading achievement. Journal of Marriage and the Family, 59, 734-746.

- $\quad$ Pong, S. 1998. The school compositional effect of single parenthood on 10th-grade achievement. Sociology of Education, 71, 23-42.

- $\quad$ Pitsia, V., Biggart, A., ve Karakolidis, A. 2017. The role of students' self-beliefs, motivation and attitudes in predicting mathematics achievement: A multilevel analysis of the Programme for International Student Assessment data. Learning and Individual Differences, 55, 163-173.

- $\quad$ Puhani, P., ve Weber, A. 2007. Does the Early Bird Catch the Worm? Instrumental Variable Estimates of Educational Effects of Age of School Entry in Germany, Empirical Economics, 32(2-3), 359-386.

- Reparaz, C., ve Sotés-Elizalde, M.A. (2019). Parental involvement in schools in Spain and Germany: Evidence from PISA 2015. International Journal of Educational Research, 93(1), 33-52.

- $\quad$ Rivkin, S. G., Hanushek, E. A., Kain, J. F., 2005. Teachers, Schools and Academic Achievement. Econometrica, 73(2), 417-458.

- $\quad$ Rajchert, J.M., Żółtak, T., ve Smulczyk, M. 2014. Predicting Reading Literacy and its Improvement in the Polish National Extension of the PISA Study: The Role of Intelligence, Trait- and State-Anxiety, SocioEconomic Status and School-Type, Learning and Individual Differences, 33, 1-11

- UNESCO/OECD 2000. World Education Indicators Programme Investing in education : analysis of the 1999 world education indicators. Paris, OECD.

- Unrau, N., ve Schlackman, J. 2006. Motivation and Its Relationship with Reading Achievement in an Urban Middle School. Journal of Educational Research, 100, 81-101.

- UIS UNESCO İstatistik Enstitüsü http://data.uis.unesco.org

- UNDP Birleşmiş Milletler Kalkınma Programı veri tabanı. http://hdr.undp.org/en/data

- Wilson, C. 2011. The Effects of Class Size on Students' Academic Achievement, ProQuest LLC, Ed.D. Dissertation, University of Phoenix.

- Wößmann, L. 2001. Why Students in Some Countries Do Better: International Evidence on the Importance of Education Policy, Education Matters, 1 (2), 67-74.

- Woßmann, L. 2003. Schooling resources, educational institutions and student performance: the international evidence. Oxford Bulletin of Economics and Statistics, 65 (2), 117-170.

- World Bank, 2018. database https://databank.worldbank.org/data/reports.aspx?source=world-developmentindicators

- $\quad$ Yerdelen Tatoğlu, F. 2018. İleri Panel Veri Analizi Stata Uygulamalı. Düzenlenmiş ve yenilenmiş 3. Bask1, İstanbul

- Zhao, N., Valcke, M., Desoete, A., ve Verhaeghe, J., P. 2012. The quadratic relationship between socioeconomic status and learning performance in China by multilevel analysis: Implications for policies to foster education equity, International Journal of Educational Development, 32 (3), 412-422. 


\title{
Gıda Atıklarının Tarımda Gübre Olarak Kullanılabilme Olanakları
}

\section{Possibilities of Using Food Waste as Fertilizer in Agriculture}

\author{
Asst. Prof. Dr. Müjgan Hacıoğlu Deniz (İstanbul University, Turkey) \\ Assoc. Prof. Dr. Özlen Hiç (İstanbul University, Turkey)
}

\begin{abstract}
It is among the targets of sustainable agriculture to develop and maintain quality agricultural land and an efficient soil structure. Due to the interest in sustainable agriculture, the addition of organic wastes to promote the physical, chemical and biological characteristics of the soil will strengthen the soil structure and will play an important role in efficient agricultural activities in the future. Agricultural waste, which is a sustainable problem for the future generations, and which is a significant problem for the farmers, constitutes an important field of application for the solution of the waste problem of farmers and the solution of the efficiency problem of farmlands. Another benefit of using food waste is its economic potential to contribute to the reduction of costs significantly in agricultural production.
\end{abstract}

\section{Giriş}

Hızla artan dünya nüfusu karşısında, insanların metrekare başına tarım arazisinden aldıkları verim miktarını arttırmak önemli bir hedef haline gelmiştir.

$\mathrm{Bu}$ konuda bitkisel veya tarımsal atıkların tarımda tekrar kullanılabilirliği ve yeniden kazandırılması pek çok çalışmayla kanıtlanmıştır. Atıkların yapısının ayrıştırılarak sonraki süreçlerde de tekrar değerlendirilmesi dünyada giderek azalmakta olan verim arttırılmasında önemli bir rol oynayacaktır. Özellikle, organik maddenin ayrışmasını hızlandırarak toprak verimliliğini olumsuz etkileyen küresel ısınma probleminin olumsuz etkilerini minimize etmek ve organik maddece nispeten fakir olan Türkiye'deki tarım arazilerinin yapısını muhafaza etmek amacıyla besleyici organik maddeler kullanılmaya başlanmıştır.

Türkiye'de toprağın fiziksel, kimyasal ve biyolojik yapısına olumlu katkı yapabilecek ve kalitesini iyileştirecek organik madde kaynaklarının kısıtlı ve pahalı olması üreticileri yeni arayışlara itmiş ve bu süreçte son yıllarda organik madde kaynağı olan tarıma dayalı endüstri atıklarının kullanılmasına yönelik çalışmalar artmıştır. Hızla artan nüfus beraberinde gıda işleyen fabrikaların sayısının da artması gıda atık miktarının artmasına ve aynı zamanda sınırlı olan su ve toprak kaynaklarının ise kirlenmesine neden olmaktadır. Ortaya çıkan bu atık sorunu karşısında, bilim insanları, tarım endüstrisindeki girişımci ve işletmeciler yeni bir arayışa girmişlerdir. Nitekim bu arayış gıda artığı ve atık miktarının azaltılmasına, gıda atıklarının değerlendirilmesine ve bu sayede verimliliğin arttırılmasına ve kaynakların etkin kullanılmasına yönelik çalışmaları hızlandırmıştır.

Tarımın gelecek nesiller için sürdürülebilir hale gelmesi, aynı zamanda çiftçiler için önemli bir sorun olan tarımsal atıklar bu yeni ve bilimsel yaklaşımla hem çiftçilerin atık probleminin giderilmesi hem de tarım arazilerinin verimlilik sorunun çözümü adına önemli bir uygulama alanı teşkil etmektedir. Bir başka faydası da ekonomik açıdan maliyetlerin düşürülmesine ciddi oranda katkı sağlama potansiyeli bulunmaktadır. Gübre ve ilaç fiyatlarının artması tarımda maliyet artışını da beraberinde getirmektedir, işte bu sebepten gıda atıklarının gübreye dönüştürülerek gübre fiyatlarının düşürülmesi paralelinde tarımsal üretimdeki girdi maliyetlerini de aşağı çekecek ve bu da tarımdan geçimini sağlayan tüm çiftçi ve üreticilerin lehine bir durum ortaya koyacaktır.

\section{Organik Maddelerin Yeniden Dönüştürülmesi}

Kaliteli tarım arazisi ve verimli bir toprak yapısını geliştirmek, onu muhafaza etmek sürdürülebilir tarımın hedefleri arasındadır. Sürdürülebilir tarıma duyulan ilgiden dolayı, toprağın fiziksel, kimyasal ve biyolojik özelliklerini teşvik etmek için organik atıkların ilavesi yapılarak toprak yapısının güçlendirilmesi gelecekteki etkin tarımsal faaliyetlerde önemli bir yer tutacaktır.

Çevreye atıldıklarında kirliliğe yol açan, oksijeni azaltan, doğal yaşamı olumsuz şekilde etkileyebilen organik maddeler, gübreleme amacıyla kullanıldıkları zaman toprağa olumlu katkıları olacaktır. Bu organik maddeleri aşağıda iki başlık altında incelenecektir. İlk olarak, peynir altı suyu ve zeytinyağı posasının gübre yapımında kullanılması. İkinci olarak da tarımsal atıkların enerjiye dönüştürülmesi süreci ve bu faaliyetlerin olumlu yanları ve ekonomiye yapmış oldukları katkı ele alınacaktır. Bu başlık altında tarımsal atık kavramı sadece bitkileri ağaçları kapsamamakta aynı zamanda hayvansal atıklar da göz önünde bulundurulmaktadır.

\subsection{Atıkların Gübre Yapımında Kullanılması}

Organik maddelerin tarım arazilerinin ve toprakların fiziksel, kimyasal ve biyolojik özellikleri üzerine olan olumlu etkileri yapılan pek çok çalışma ile belirlenmiştir (Kacar, 1986). Türkiye ekonomisinde süt artıkları 
içerdikleri inorganik maddeler (laktoz, mineraller, proteinler, yağlar) nedeniyle akarsulara göllere hatta denizlere atıldığında çok ciddi kirliliğe yol açmaktadır (Konar ve Arıŏglu, 1987). Oysa gübreleme amacıyla kullanıldığında peynir altı suyunun toprağa olumlu faydaları yapılan çalışmalarda kanıtlanmıştır (Ocak ve Demir, 2012). Yine zeytin yağı üretimi esnasında çıkan yüksek fenolik maddeler ve bu maddelerin fitotoksik etkilerinin doğal çevre ve tarımsal araziler açısından zararı olsa da (Başkan, 2010) bunların kompostlaştırma işlemi ile fitotoksik etkisi olmaksızın gübreleme amaçlı kullanımının sağlanması tarımsal üretim için önemli fayda sağlamaktadır (Monteoliva-Sanchez, 1996). Gübreleme amacıyla kullanıldığında toprağa olumlu katkılarının olduğu tespit edilen peynir altı suyu artık gıda atı̆̆ı olarak değil arazilerin verimliliğini arttıracak ve tarımsal çıktıyı yükseltecek tarımsal katkı maddesi olarak görülmektedir.

\subsubsection{Peynir Altı Suyu}

Peynir altı suyu sütün peynire çevrilirken ardında bıraktığı renkli sıvıdır. Bu sıvının içerisinde toprağı besleyecek çok çeşitli maddeler vardır; laktoz, protein, yağ, kalsiyum, fosfat, laktat, klorür. Bu maddeler doğrudan doğaya atıldığında yüksek kirliliğe neden olur, oysa gübre amaçlı dönüştürüldüğünde olumlu etkisi ortaya çıkarılmış olacak (Ocak ve Demir 2012). Aynı zamanda, peynir altı suyundan çok sayıda yan ürün de elde edilmektedir (ilaç sanayi, etil alkol üretimi, laktoz üretimi, yem sanayi gibi). Yine peynir altı suyunun başlı başına besin değeri de bulunmaktadır. Sütçülük artığı içerdiği mineral maddeler ve süt şekeri (laktoz) ile protein ve yağ gibi inorganik maddeler nedeniyle akarsulara, göllere ve hatta denizlere boşaltıldığında çevrede ortamın oksijenini tükettiği için yaşamı olumsuz etkilediği üzerinde durarak, çevre kirlenmesine neden olduğu üzerinde durmuşlardır (Konar ve Arıŏglu, 1987). Öte yandan, bazı akademisyenlere göre, peynir altı suyunun bitki besin maddesi olarak bir değerinin bulunduğu ve özellikle gübreleme amacıyla kullanıldığında tarımsal üretime değer katacağıdır (Ocak ve Demir, 2012).

\subsubsection{Zeytinyağı Atıkları}

Zeytinler yağa dönüştürülürken altta kalan katı alt ürüne prina denmektedir, (Göçmez, 2013 ve Öcal 2005) ayrıca zeytinyağı işlevi sırasında yine zararlı bir madde olarak kara su denilen bir madde çıkmaktadır. Bu atık siyah bir su şeklindedir ve taşıdığı fenolik maddeler ve fitotoksik etkilerden dolayı tarım alanlarına zarar vermektedir. Yine atıldıkları çevredeki suları yüksek oranda kirletmektedir. Dolayısıyla çevre açısından da ciddi bir sorun teşkil etmektedir (Şengül ve Oktav, 2013). Bu konuyla ilgili çevre bakanlıkları bir takım yasal düzenlemeler yoluna gitmişlerdir (Göçmez, 2013). Bu çok yüksek kirliliğge sahip kara sudan kompost hazırlanarak içerisinde faydalı organik maddeler ve mineraller ile birlikte herhangi bir fitotoksik etki kalmaksızın organik gübre olarak kullanılması sağlanmıştır (Sanchez, 1996).

Ortalama $100 \mathrm{~kg}$ zeytinden $35-45 \mathrm{~kg}$ arası prina çıkmakta, karasu ise zeytin meyvesinin \%45 - \%50'sini oluşturmaktadır. Dolayısıyla, Türk zeytinyağı üretiminde hem prina hem de karasu karışık olarak çıkmakta (Oruç, 2012) olup, bunların gerek ayrıştırılarak gerek de bir arada kompost işlemiyle tekrardan kazanılarak gübreye dönüştürülmesi önem arz etmektedir.

\subsection{Tarımsal ve Hayvansal Atıkların Enerji Üretiminde Kullanılması}

Kullanılmayan tarımsal atıklardan elde edilecek enerji özellikle yöresel sanayi tesislerinde tarımsal gıda sanayiinde, KOBI'lerde birincil enerji kaynağı olarak değerlendirilmesi sonucu, enerjide dışa bağımlılığımızın önemli oranda azaltılması hedefiyle değerlendirilmesi gereken bir alandır. Bu konuda, tarımsal ürünler adeta enerji deposu görevi görmektedirler. Nitekim, bitkiler karbondioksit su ve güneş enerjisini fotosentez yoluyla karbonhidrata çevirerek depolarlar ve atık haline geldiklerinde de dahi bu enerji bünyelerinde barınır. İşte bu atıklardaki enerji dahi ülkenin sahip olduğu linyitlerden daha yüksek enerji değerine sahiptir. Son yıllarda yapılan çalışmalarla bu atıklar uygun prosesler sonucunda enerjiye dönüştürülebilmektedir. Örneğin, doğrudan yakılarak ısınma amaçlı kullanılması, elde edilen ısıdan buhar aracıllğıyla elektrik üretilebilmesi, modern tekniklerle kömür ve odunun kullanıldığı her alanda bir kaynak haline getirilmesi. Aynı zamanda bu süreçten biyogaz dışında biyoetanol ve biyodizel türünde yakitlar da elde edilebilmektedir.

Sonuç olarak, tarımsal atıklar farklı teknolojilerle katı sıvı ve gaz yakıtlara dönüştürülebilmekte ve bu sayede farklı sektörlerde istihdam oluşturulmakta, özellikle kırsal kesimlerde sosyo-ekonomik düzey artmaktayken, pek çok farklı alanda katma değer üretilebilmektedir. Bu konuda yenilenebilir Enerji Genel Müdürlüğü Biyokütle Atlası'ndan detaylı bilgi elde edilebilir.

\section{Sonuç}

Özetle denilebilir ki, bitkisel atıklar veya tarımsal endüstri atıklarının tarımda etkin bir şekilde kullanılabilir olduğu yapılan pek çok çalışmayla ortaya konmuştur. Nitekim, bitkisel kökenli atıkların organik madde kaynağı olmanın ötesinde içermiş oldukları kimi bitki besin maddeleri yönünden de önemli bir potansiyele sahip oldukları yapılan zirai çalışmalarla ortaya konmuştur. Dolayısıyla, bu atıkların tarımda kullanılması ile ülke ekonomisine önemli bir katkı sağlayabileceği aşikardır. Bu çalışmada, Türkiye'de önemli bir çevre problemini oluşturan zeytinyağı atıklarının yani karasu ve prinanın kompostlaştırılarak organik gübreye dönüştürülmesi ve peynir altı suyunun toprak yapısını güçlendirecek ve besleyecek gübre yapımında kullanılmasının etkileri ve tarımsal 
üretimdeki çıktılara etkisi incelenmiştir. Aynı zamanda, bin kişinin bir günde meydana getirdiği evsel atık suya eşdeğerde organik kirlilik içeren karasu kompostlaştırma ile fitotoksik etkisi ortadan kaldırılarak tarımsal üretimde kullanılabilir hale getirilmesi üzerinde durulmuştur.

\section{Kaynakça}

- Bakırcı İ. Ve Kavaz, A. (2006), Peynir Suyunun Değerlendirme Olanakları, Türkiye Gıda Kongresi 2006 Mayis 24-26, Bolu: 77-80.

- Başkan, E. A. (2010), Zeytinyağı işletmelerinin atıkları ve değerlendirme yolları; http://geka.org.tr/yukleme/dosya/50922ee05dd057dd5408ad2290aafa79.pdf,

- Bayındır, Ş., Şahin, S., Uysal, F. (2004), Türkiye'de Çiftlik Gübresi Kullanım Potansiyeli, Türkiye 3. Ulusal Gübre Kongresi, Tarım-Sanayi-Çevre, 11-13 Ekim, 2004, s.735.

- Kacar, B. (1986), Gübreler ve Gübreleme Tekniği, T.C. Ziraat Bankası Kültür Yayınları, No: 20.

- Konar, A ve Arıŏglu, H. (1987), Peynir Suyunun Soya Üretiminde Gübre Olarak Kullanılma Olanakları Üzerinde Bir Ön Araştırma, Çukurova Üniversitesi Ziraat Fakültesi Dergisi, 2(2): 14-18.

- Monteoliva-Sanchez, M. (1996), The Study of the Aerobik bacterial microbiota and biotoxity in various sample of olive mill wastewater (alpechin) during their composting process. International Biodeterioration \& Biodegradation, 53: 211-214.

- Ocak, E. ve Demir, S. (2012), Toprak Verimliliği ve Bitki Gelişiminde Peyniraltı Suyu ve Arbusküler Mikorhizal Fungus (AMF)'un Önemi, Yüzüncü Yı1 Üniversitesi Tarım Bilimleri Dergisi, 22 (1): 48-55.

- Oruç N. (2012), Zeytinyağı Fabrikası Atığı Karasu Ekolojik Kirlilik Yerine Toprak Düzenleyici Olabilir, SAÜ Fen Edebiyat Dergisi, 2012-1: 35-45.

- Göçmez, S. (2013), Karasu Kekinin Vermikompost Üretiminde Kullanım Olanakları, Tema Vakfı Ulusal Vermikültür Çalıştayı, 16 Nisan 2013, Ankara, Bildiri Kitabı: 40-51.

- Şengül F. ve Oktav, E. (2000), Zeytinyağı Üretimi Atıklarının Artırım Alternatifleri, 1. Ulusal Çevre Kirliliği Kontrolü Sempozyumu Bildiri Kitabı; 4- 6 Ekim 2000, Ankara, ss. 224-231. 


\title{
Türkiye Arıcılı̆ğının İleriye Yönelik Projeksiyonu Forward Projections of Turkey's Beekeeping
}

\author{
Dr. Yusuf Ziya Tengiz (Kadir Has University, Turkey) \\ Ph.D. Candidate Zehra Meliha Tengiz (Namık Kemal University, Turkey)
}

\begin{abstract}
Beekeeping is one of the most common agricultural activities in the world. In addition to the world and human life, it is very important in the pollination and the efficiency of the plants. Beekeeping activities have been done since ancient times as the tradition of Anatolian people. In Turkey grows $75 \%$ of the honey plants species determined in the world. This provides a variety of honey in different aroma and flavors. Turkey with 7796666 beehives is in 3rd rank, with 114471 tons of honey production is in 2nd rank and with 4488 tons of beeswax production in 2017 is in 4th rank in the world bee products have an important role.

It is important to determine future trends in developing appropriate policies for our country, which is one of the leading countries in beekeeping activities. The main aims of this study are to forecast honey and beeswax product in Turkey for 2019-2025. Arima model, which is one of the time series analysis, was used in this study.

According to the results, it is expected that honey production will increase in these years. However, it is expected the increase in the production of beeswax until 2021. After 2021 year is expected to decrease a little. In our country which has great potential for beekeeping, it will be able to take place among the countries which have a significant influence in foreign trade with the effective use of production resources in the realization of activities.
\end{abstract}

\section{Giriş}

Arıcılık faaliyetlerinin insanlık için önemi büyüktür. Arıların dünyadaki gıda üretiminin 1/3'üne katkı sağladığı, bitki tozlaşmasının da yaklaşık \% 90’nını gerçekleştirdiği tahmin edilmektedir (Çevik, 2018; Tepge, 2019). Ülkemiz coğrafyası, iklimi, bitki çeşitliliği, ekonomik ve kültürel faktörler arıcılığın yüzyıllardır bu topraklarda uygulanabilmesini sağlamaktadır. Arıcılık uygulamalarında yatırım ve işletme maliyetlerinin düşük olması, en az maliyetle en fazla getirinin sağlanması bu yetiştiriciliği çekici hale getirmektedir.

Bal arılarının sağladığı katkılar; bal, balmumu, arı sütü, polen, arı zehiri ve propolis üretiminin yanında, bitkilerde tozlaşmayı sağlayarak tarımsal üretimin artması şeklinde sıralanabilir (Tarımorman, 2019). Gıda ve Tarım Örgütünün (FAO) verilerine göre dünyada Türkiye, 2017 yılı itibari ile 7991000 adet kovan varlığı ile 3. ,114 471 ton bal üretimi ile 2. , 4488 ton bal mumu üretimi ile de 4. sırada yer almaktadır (FAO, 2019).

$\mathrm{Bu}$ bildiride ülkemizin 2019-2025 yılları itibariyle bal ve balmumu üretim miktarlarının tahmin edilmesi amaçlanmıştır. Ayrıca, bu ürünlerde ülkemiz üretiminin dünya ölçeğinde karşılaştırılmasına ve dış ticaretine yer verilmiş, Türkiye için bazı sonuçlara ulaşılması ve önerilerde bulunulmasına çalışılmıştır.

\section{Dünyada ve Türkiyede Arıcılık}

Dünyada arıcılık farklı amaçlara yönelik gerçekleştirilmektedir: bu Polonya, İspanya, Yunanistan, Macaristan ve Türkiye gibi ülkelerde kırsal gelir sağlama, Orta Doğu, Orta ve Güney Amerika ülkelerinde önemli düzeyde ihracat geliri oluşturma, Amerika Birleşik Devletleri, Kanada, Japonya gibi ülkelerde bitkilerde tozlaşmayı sağlayarak verim arttırma şeklindedir (Uzundumlu, vd, 2011).

2011-2017 yılları ve önemli üretici ülkeler itibariyle dünya bal üretimini sağlayan kovan sayısında yükselme görülmüştür (Tablo 1).

\begin{tabular}{lrrrrrrr}
\hline Ülkeler & 2011 & 2012 & 2013 & 2014 & 2015 & 2016 & 2017 \\
\hline Hindistan & 11500 & 11550 & 11600 & 11800 & 11949 & 12469 & 12764 \\
Çin & 8954 & 8987 & 9020 & 9075 & 9131 & 9148 & 9157 \\
Türkiye* & 6011 & 6348 & 6641 & 7082 & 7748 & 7900 & 7991 \\
İran & 5172 & 5613 & 6644 & 6996 & 7408 & 7062 & 7272 \\
Etiyopya & 4994 & 5207 & 5124 & 5885 & 5916 & 6189 & 6140 \\
Rusya Fed. & 3049 & 3250 & 3284 & 3341 & 3474 & 3458 & 3350 \\
Arjantin & 2970 & 2970 & 3000 & 2980 & 2959 & 3014 & 3003 \\
Tanzanya & 2800 & 2820 & 2850 & 2900 & 2942 & 2995 & 2999 \\
İspanya & 2440 & 2429 & 2444 & 2557 & 2730 & 2810 & 2905 \\
ABD & 2491 & 2539 & 2640 & 2740 & 2660 & 2775 & 2669 \\
Diğer & 30023 & 31346 & 31652 & 31907 & 32095 & 32745 & 32749 \\
\hline Dünya & 80404 & 83059 & 84899 & 87263 & 89012 & 90565 & 90999 \\
\hline
\end{tabular}

Tablo 1. Dünya Kovan Varlığı (Bin Adet) Kaynak: FAO, 2019; *TÜIK, 2019. 


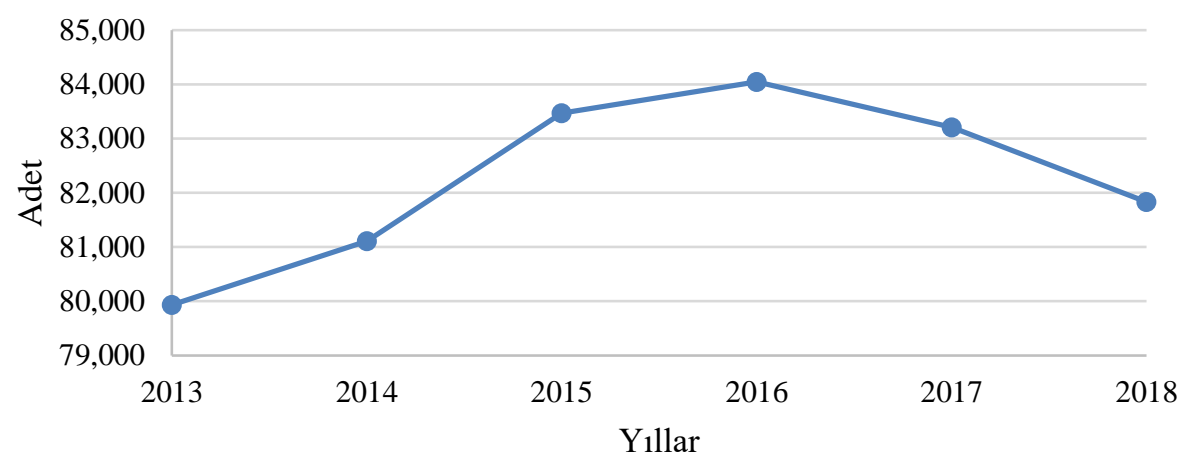

Şekil 1. Türkiye'de Arlcılık Yapan Işsletme Sayısı (Adet) Kaynak: TÜIK, 2019.

Türkiye'de arıcılık yapan işletme sayısı son iki yılda düşme göstermiş ve 2018 yılında 81830 adet olarak belirlenmiştir (Şekil 1). Bu işletmelerdeki kovan (koloni) varlığı 2017 yılında 7991072 adet, 2018 yılı itibariyle ise toplam 8108000 adete yükselmiştir (TÜİK, 2019).

Ülkeler bazında dünya yıllık bal üretimi, 2011-2017 dönemleri için, artış göstermiş rakam 2017’de 1860712 ton olarak gerçekleşmiştir (Tablo 2).

Ülkemizde 1990 yılından sonra arıcılıkta üreticilerin eğitim düzeylerinin yükselmesi, modern yöntem ve ekipmanların kullanılmasıyla önemli düzeyde kovan sayısı, bal ve balmumu üretimi artışı gerçekleşmiştir (Saner, vd, 2018). Bal üretimi 2018 yılında 114471 tondan 108000 tona, balmumu üretimi ise 4488 tondan yaklaşık 4000 tona gerilemiştir (TÜİK, 2019).

\begin{tabular}{lrrrrrrr}
\hline Ülkeler & 2011 & 2012 & 2013 & 2014 & 2015 & 2016 & 2017 \\
\hline Çin & 446089 & 462203 & 461431 & 474786 & 488726 & 502614 & 551476 \\
Türkiye* & 94245 & 89162 & 94694 & 103525 & 108128 & 105727 & 114471 \\
Arjantin & 72000 & 76000 & 67500 & 60000 & 52600 & 68123 & 76379 \\
İran & 50700 & 71100 & 74600 & 77800 & 73014 & 67783 & 69699 \\
ABD & 67294 & 64544 & 67812 & 80862 & 71007 & 73428 & 66968 \\
Ukrayna & 70300 & 70134 & 73713 & 66521 & 63615 & 59294 & 66231 \\
Rusya Fed. & 60010 & 64898 & 68446 & 74868 & 67736 & 69764 & 65678 \\
Hindistan & 60000 & 60000 & 61000 & 61046 & 61074 & 61335 & 64981 \\
Meksika & 57783 & 58602 & 56907 & 60624 & 61881 & 55358 & 51066 \\
Etiyopya & 39892 & 45905 & 48941 & 50000 & 59161 & 47706 & 50000 \\
Diğer & 597432 & 587183 & 561824 & 522079 & 718810 & 675864 & 683763 \\
\hline Dünya & 1615745 & 1649731 & 1636868 & 1632111 & 1825752 & 1786996 & 1860712 \\
\hline
\end{tabular}

Tablo 2. Dünya Bal Üretimi (Ton) Kaynak: FAO, 2019; *TÜIK, 2019.

Dünyada kovan başına ortalama bal verim miktarları 2011-2017 yıllarında inişli çıkışlı seyir izlemiş, bu 2017 yılında $20.44 \mathrm{~kg} /$ kovan olarak gerçekleşmiştir (Şekil 2). Ülkemizde ortalama verim $15 \mathrm{~kg} / \mathrm{kovan}$ olup dünya ortalamasının artındadır. Bu rakam Kanada, Arjantin, Çin, Meksika, Brezilya ve Avustralya gibi ülkelerde 30-60 $\mathrm{kg} / \mathrm{kovan}$ düzeyindedir (Uzundumlu, vd, 2011).

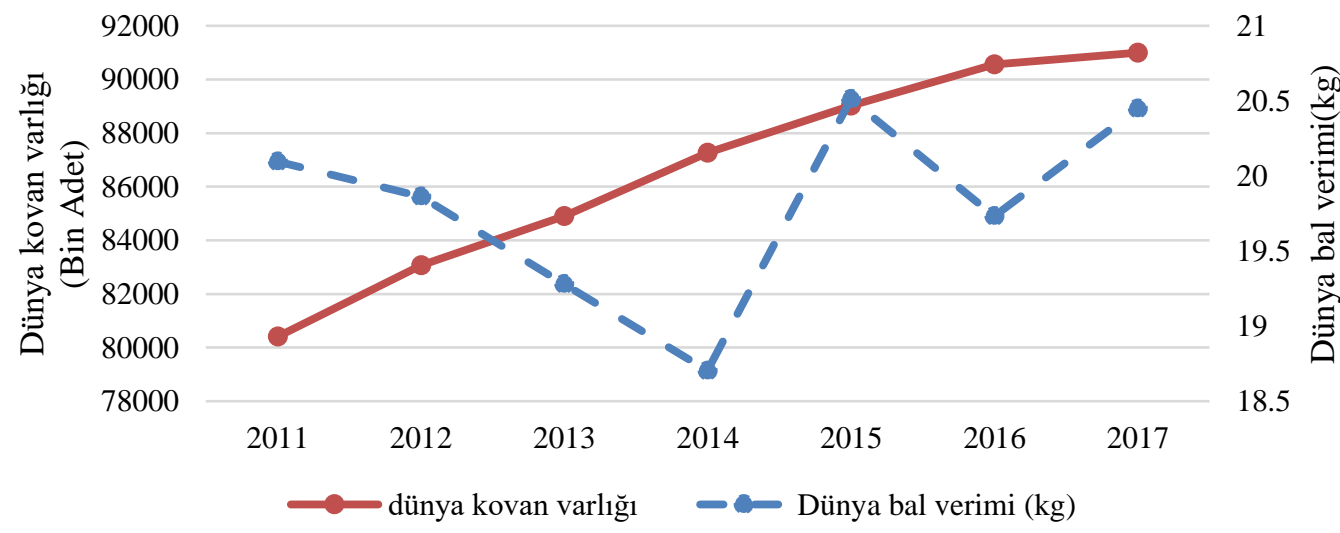

Şekil 2. Dünya Kovan Başına Bal Verimi (kg) Kaynak: FAO (2019) Verileri Kullanılarak Hesaplanmıştır. 
Arıcılık ürünlerinde baldan sonra gelen en önemli ürün balmumudur. Bu ürün yoğunluklu olarak bal peteği yapımında, ilaç ve kozmetik endüstrilerinde, çeşitli alanlarda su yalıtımı sağlamada, kalıp ve dişçilikte, malzemelerin cilalanması ve parlatılmasında kullanılmaktadır (Tarımorman, 2019). Dünya balmumu üretimi söz konusu dönemde hafif değişim gösterse de genelde hemen hemen düzgün bir seyir izlemiştir (Tablo 3).

\begin{tabular}{|c|c|c|c|c|c|c|c|}
\hline Ülkeler & 2011 & 2012 & 2013 & 2014 & 2015 & 2016 & 2017 \\
\hline Hindistan & 23000 & 23100 & 23200 & 23300 & 23400 & 23500 & $* * 23500$ \\
\hline Etiyopya & 5000 & 5000 & 5000 & 5310 & 5523 & 5542 & 5626 \\
\hline Arjantin & 4700 & 4700 & 4794 & 4897 & 4863 & 4880 & 4942 \\
\hline Türkiye* & 4235 & 4222 & 4241 & 4053 & 4756 & 4440 & 4488 \\
\hline Kore Cum. & 3063 & 3063 & 3063 & 4018 & 3620 & 3456 & 3449 \\
\hline Kenya & 2500 & 2500 & 2500 & 2500 & 2506 & 2504 & 2503 \\
\hline Angola & 2300 & 2300 & 2300 & 2303 & 2318 & 2313 & 2307 \\
\hline Meksika & 1966 & 1868 & 2010 & 1862 & 1439 & 1844 & 1618 \\
\hline Tanzanya & 1830 & 1850 & 1870 & 1881 & 1844 & 1842 & 1843 \\
\hline Brezilya & 1850 & 1650 & 1650 & 1700 & 1746 & 1761 & 1769 \\
\hline Diğer & 14451 & 14230 & 14398 & 14563 & 14577 & 14581 & 13762 \\
\hline Dünya & 64895 & 64483 & 65026 & 66387 & 66592 & 66663 & 65807 \\
\hline
\end{tabular}

Tablo 3. Dünya Balmumu Üretimi (Ton) Kaynak: FAO, 2019; *TÜIK, 2019.

Dünya arıcılık ürünleri dış ticaretinde en fazla ticareti yapılan ürün baldır. Dünya bal ithalatı miktar olarak 2011 y1lında 497472 tondan, 2017 yılında 689095 tona yükselmiş, ihracatta ise aynı yıllar için rakamlar 484876 tondan 651220 ton olarak gerçekleşmiştir (UN Comtrade, 2019). Ülkemiz bal uluslararası ticareti ürün bazında süzme ve petek bal şeklindedir. Üretimin büyük bir kısmı yurt içi piyasada tüketildiği için üretimin düşük bir kısmı ihraç edilmektedir. Dünya bal ihracatçı ülkeler arasında Türkiye 2017 yılında 6448 tonla ancak 23. sırada yer almıştır. 2018 yılında ise toplam bal üretiminin ancak \% 5,5 oranı, 5912 tonu ihraç edilmiş, bundan 23 milyon ABD doları gelir sağlanmıştır (TÜIKK, 2019). Ülkemizde bal ihracatını arttırmaya yönelik $160 \mathrm{TL} /$ ton olarak destekleme yapılmaktadır (Çevik, 2018). Türkiye'nin bal ithalatı ise 2017 yılında gerçekleşen 267 ton düzeyinde olduğu gibi oldukça düşüktür (TÜİK, 2019).

\begin{tabular}{lrrrrrrrr}
\hline & 2011 & 2012 & 2013 & 2014 & 2015 & 2016 & 2017 & 2018 \\
\hline Petek Bal & 400 & 400 & 356 & 566 & 528 & 849 & 953 & 1064 \\
Süzme Bal & 702 & 862 & 3206 & 4402 & 6664 & 2773 & 5495 & 4848 \\
\hline Toplam & 1102 & 1263 & 3563 & 4969 & 7192 & 3622 & 6448 & 5912 \\
\hline
\end{tabular}

Tablo 4. Türkiye Bal İhracatı (Ton) Kaynak: TÜIK, 2019.

\begin{tabular}{lrrrrrrr}
\hline & 2011 & 2012 & 2013 & 2014 & 2015 & 2016 & 2017 \\
\hline Petek Bal & 0 & 0 & 0 & 0 & 0 & 0 & 0 \\
Süzme Bal & 0 & 37 & 0 & 11946 & 90 & 1020 & 267 \\
\hline Toplam & 0 & 37 & 0 & 11946 & 90 & 1020 & 267 \\
\hline
\end{tabular}

Tablo 5. Türkiye Bal Ithalatı (Ton) Kaynak: Tepge, 2018.

Dünya balmumu uluslararası ticareti 2016 yılında miktar olarak toplam 25897 ton ithalat değeri, 19444 ton ihracat değeri olarak gerçekleşmiştir. Türkiye 2016 yılında 109 ton ithalat miktarı ile dünyada sıralamasında 24. olmuştur (FAO, 2019). Türkiye'nin balmumu ithalatı 2018 yılında 182 tondan 397 tona yükselmiş olup, ihracat ise hemen hemen yapılmamaktadır (TÜIK, 2019).

\section{Materyal ve Metod}

Çalışmada kullanılan veriler 1960-2018 yıllarını kapsamaktadır. Bu veriler FAO, TÜİK ve UN Comtrade kurumlarından alınmıştır. Ayrıca konu ile ilgili çalışmalar, kitaplar ve literatür taraması yoluyla elde edilen verilerde kaynaklar arasındadır.

Çalışmada, Türkiye'nin bal ve balmumu üretim miktarları 2019-2025 yılları için ARIMA(Otoregresif Tümleşik Hareketli Ortalama (Autoregressive Integrated Moving Average)) modeli ile tahmin edilmiştir. Bu yöntem tek değişkenli zaman serilerinde gelecek tahmini yapmak için yaygın olarak kullanılmaktadır (Duru, 2007). Yapılan analizlerde Eviews 4 paket programı kullanılmıştır.

Box-Jenkins yöntemini kullanan zaman serisi modelleri; otoregresif AR(p) (Auto Regressive), hareketli ortalama MA(q) (Moving Average), otoregresif hareketli ortalama ARMA(p,q) ve ARIMA(p,d,q) modelleridir (Kutlar, 2017). Yöntem geçmiş değerlerini açıklayıcı değişkenmiş gibi modele dahil eder. Bu modelin diğer BoxJenkins yöntemlerinden farkı, durağan olmayan serinin d'inci mertebede farkı alınarak durağan hale getirilmesidir ve bu süreç I(d) olarak belirtilir. Seri ayrıca p dereceden kendisinin gecikmesi ile ilişkisini ifade eden AR(p) ve $q$ 
ile ifade edilen ve herhangi bir dönemdeki gözlem değerleri ile hata terimlerinin doğrusal bir bileşimi olan MA(q) süreçlerinden oluşur (Hanedar, vd, 2015).

ARIMA modelinde öncelikle verilerin logaritması ya da farkı alınarak hangisinin kullanılacağına karar verilir. Verilerin durağan olup olmadığı Augmented Dickey Fuller birim kök testi ile belirlenir. Eğer seri durağan değilse yöntem kullanılmadan önce serinin d'inci farkı alınmalıdır. Elde edilen ADF değerinin mutlak değerce kritik değerlerden büyük olması gerekmektedir. AR ve MA terimlerinin seviyesinin belirlenmesinde Akaike bilgi kriteri (AIC), Schwarz kriteri (SIC) ve Hannan-Quinn kriterlerine bakılmaktadır. AR ve MA terimlerinin seviyeleri denenerek bu değerlerin minimuma sahip model belirlenir. Modelleme aşamasında modelde otokorelasyon olup olmadığını test etmek amaciyla LM testi uygulanmaktadır. Bu değerin $\% 5$ den büyük olması gerekmektedir. Uygun modeller arasında tahmin gücü yüksek olan modele karar verirken MAPE (Ortalama Mutlak Yüzde Hata), Theil eşitlik katsayısı değeri, Akaike criterion, Hannan-Quinn, Schwarz criterion değerleri dikkate alınarak en uygun model seçilmiştir. MAPE değeri \%10'un altında olan modeller çok iyi, \%10-20 arasında olan modeller iyi, \%2050 arasında olan modeller kabul edilebilir. Theil eşitlik katsayısının sıfır çıkması modelin öngörü gücünün en iyi olduğu durumu gösterirken, bu değerin mümkün olduğunca 1'den küçük çıkması gerekmektedir (Özer ve İlkdoğan, 2013; Kutlar, 2017; Yücesan, 2018).

\section{Bulgular}

Bal ve balmumu üretim miktarlarına ilişkin modelleme yapmadan önce serilerin durağan olup, olmama durumları test edilmiştir. Serilenin durağanlığına sağlayabilmek için logaritmaları alınmıştır. Sabit katsayılı ve trendli ADF testine göre bal ve balmumu üretim miktarları düzeyde $\% 1, \% 5$ ve $\% 10$ anlamlılık seviyesinde durağan olmayıp, buna karşılık birinci dereceden farkları alındığında durağan hale getirilmiştir. Verilerin \%1 düzeyinde istatistiksel olarak anlamlı olduğu görülmektedir (Tablo 6).

\begin{tabular}{|ccccc|}
\hline ADF Test İstatistiği & -7.734500 & $1 \%$ & Kritik Değeri* & -3.5547 \\
& & $5 \%$ & Kritik Değeri & -2.9157 \\
& $10 \%$ & Kritik Değeri & -2.5953 \\
\hline \multicolumn{5}{|c|}{ Bal Üretimi 1. Sıra Farkı Test İstatistiği } \\
\hline ADF Test İstatistiği & -6.503765 & $1 \%$ & Kritik Değeri * & -3.5745 \\
& $5 \%$ & Kritik Değeri & -2.9241 \\
& $10 \%$ Kritik Değeri & -2.5997 \\
\hline \multicolumn{4}{|c}{ Balmumu Üretimi 1. Sıra Farkı Test İstatistiği } \\
\hline
\end{tabular}

Tablo 6. Türkiye Bal ve Balmumu Üretimi ADF Birim Kök Testi Sonucu

ARIMA tahminlemesinde ACF (otokorelason fonksiyonu) ve PACF (kısmi otokorelasyon fonksiyonu) değerleri üzerinden AR ve MA değerleri belirlenmiştir. PACF, AR için p değerini, ACF ise MA için q değerini vermektedir. Bal üretim serisi için AR için 3. gecikme, MA için 2. gecikme olarak alınmıştır. Balmumu üretim serisi için AR için 2. gecikme, MA için 2. gecikme olarak alınmıştır (Tablo 7).

\begin{tabular}{|c|c|c|c|c|c|c|}
\hline \multicolumn{7}{|c|}{ Bal Üretimi } \\
\hline $\mathrm{ACF}$ & PACF & & $\mathrm{AC}$ & PAC & Q-istatistiği & p-değeri \\
\hline$* * * \mid$. & $* * * \mid$. & 1 & -0.350 & -0.350 & 7.2475 & 0.007 \\
\hline.$* 1$. & $* * \mid$. & 2 & -0.085 & -0.237 & 7.6816 & 0.021 \\
\hline. $\mid$ & $.^{*} \mid$. & 3 & 0.014 & -0.127 & 7.6942 & 0.053 \\
\hline.$\left.\right|^{*}$ &.$\left.\right|^{*}$. & 4 & 0.119 & 0.069 & 8.5732 & 0.073 \\
\hline$. * \mid$. &. $\mid$. & 5 & -0.067 & 0.009 & 8.8573 & 0.115 \\
\hline$*$. & $*$ & 6 & -0.064 & -0.064 & 9.1215 & 0.167 \\
\hline \multicolumn{7}{|c|}{ "Balmumu Üretimi } \\
\hline $\mathrm{ACF}$ & PACF & & $\mathrm{AC}$ & PAC & Q-istatistiği & p-değeri \\
\hline$* * \mid$ & $* * \mid$. & 1 & -0.305 & -0.305 & 4.6464 & 0.031 \\
\hline$* \mid$ & $*$. & 2 & -0.078 & -0.188 & 4.9548 & 0.084 \\
\hline.$\left.\right|^{*}$. & .1. & 3 & 0.078 & -0.008 & 5.2757 & 0.153 \\
\hline$. * \mid$ & $* * \mid$. & 4 & -0.184 & -0.197 & 7.0852 & 0.131 \\
\hline.$\left.\right|^{* *}$ &.$\left.\right|^{* *}$ & 5 & 0.305 & 0.226 & 12.197 & 0.032 \\
\hline$* *|. \quad|$ & $*{ }^{*}$ & 6 & -0.268 & -0.183 & 16.221 & 0.013 \\
\hline
\end{tabular}

Tablo 7. Bal ve Balmumu Üretimi 1. Dereceden Farkı için ACF ve PACF Dağılımı

Bal üretimi tahmini için AR(3) hariç MA(1) ve Trend değişkenleri \%1 düzeyinde, MA(2) \%5 düzeyinde anlamlı bulunmuştur. F test istatistik değerine göre yapılan tahmin anlamlı bulunmuştur $(p<0,01)$. Theil, Bias ve Variance Proportion değerleri 0'a yakın, Covariance 1'e yakındır. Bu değerler uygun bir model olduğunu göstermektedir. 
Oto korelasyon probleminin tespitinde LM test istatistiği değeri dikkate alınmaktadır ve bu değerin \%5'den büyük olması gerekmektedir. Buna göre $\% 5$ 'de oto korelasyon problemi ortaya çıkmamıştır. Modelin MAPE değeri \%0.68 olarak hesaplanmıştır. Elde edilen değer modelin uygun olduğunu göstermektedir. Theil eşitlik değeri ise 0.004 olarak hesaplanmış olup, bu değerin birden küçük olması, öngörü için bu modelin uygun bir model olduğunu göstermektedir.

\begin{tabular}{ccrrr} 
Değișken & Katsayı & Std. Hata & t-istatistiği & p-değeri \\
\hline C & 0.082550 & 0.003075 & 26.84599 & 0.0000 \\
@TREND & -0.001161 & 0.000151 & -7.685875 & 0.0000 \\
AR(3) & 0.057777 & 0.145085 & 0.398227 & 0.6922 \\
MA(1) & -0.894867 & 0.173575 & -5.155513 & 0.0000 \\
MA(2) & -0.415311 & 0.173302 & -2.396453 & 0.0205 \\
\hline \hline Akaike bilgi kriteri (AIC) & -2.368556 & & 0.516 \\
Schwarz kriteri (SIC) & -2.182680 LM testi p-değeri & 0.682749 \\
F-istatistiği & 12.45119 MAPE & 0.004410 \\
p (F-istatistiği) & 0.000001 Theil's U & & \\
\hline
\end{tabular}

Tablo 8. ARIMA(3,1,2) Modeline Ait Dĕ̌gerler (Bal Üretimi)

\begin{tabular}{crrrr} 
Değișken & Katsayı & Std. Hata & t-istatistiği & p-değeri \\
\hline \hline C & 0.059444 & 0.006821 & 8.714849 & 0.0000 \\
@TREND & -0.000968 & 0.000178 & -5.453624 & 0.0000 \\
AR(1) & -0.516429 & 0.149722 & -3.449246 & 0.0013 \\
AR(2) & 0.211868 & 0.152586 & 1.388515 & 0.1723 \\
MA(2) & -0.991156 & 0.031677 & -31.28940 & 0.0000 \\
\hline \hline Akaike bilgi kriteri (AIC) & -1.907732 & & 0.287 \\
Schwarz kriteri (SIC) & -1.710908 LM testi p-değeri & 0.952528 \\
F-istatistiği & 7.050301 MAPE & 0.006068 \\
p (F-istatistiği) & 0.000195 & & \\
\hline
\end{tabular}

Tablo 9. ARIMA $(2,1,2)$ Modeline Ait Değerler (Balmumu Üretimi)

Balmumu üretim tahmini için Trend ve MA(2) \%1 düzeyinde, AR(1) \%5 düzeyinde istatistiksel olarak anlamlıdır. AR(2) değişkeni anlamlı bulunmamıştır. LM testi istatistiğine göre \%5'de oto korelasyon problemi ortaya çıkmamıştır. Modelin MAPE değeri \%0.95 olarak hesaplanmıştır. Theil eşitlik değeri ise 0.006 olarak hesaplanmış olup, öngörü için bu modelin uygun bir model olduğunu göstermektedir.

Şekil 3 ve 4'te gerçekleşen ve ARIMA modeli sonucu tahmin edilen bal ve balmumu üretim miktarlarına ilişkin veriler sunulmuştur. Verilerin yorumlanabilmesi için başta logaritması alınan değerler farka dönüştürülmüştür.

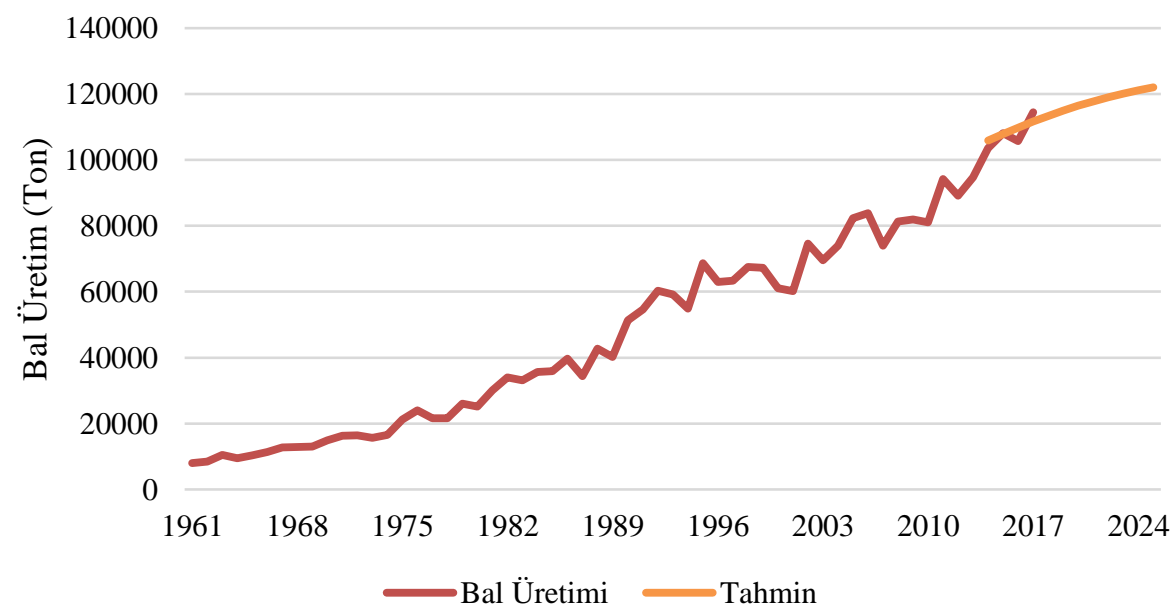

Şekil 3. Türkiye 2019-2025 Yılları Bal Üretim (Ton) Tahmin Sonuçları 


\begin{tabular}{|c|c|c|c|c|c|c|c|c|c|c|}
\hline & \multicolumn{10}{|c|}{ Yillar } \\
\hline & 2016 & 2017 & 2018 & 2019 & 2020 & 2021 & 2022 & 2023 & 2024 & 2025 \\
\hline Gerçekleşen & 105727 & $\begin{array}{l}114 \\
471\end{array}$ & $\begin{array}{l}107 \\
920\end{array}$ & & & & & & & \\
\hline Tahmin & 109803 & $\begin{array}{l}111 \\
616\end{array}$ & $\begin{array}{l}113 \\
328\end{array}$ & $\begin{array}{l}114 \\
931\end{array}$ & $\begin{array}{l}116 \\
424\end{array}$ & $\begin{array}{l}117 \\
798\end{array}$ & $\begin{array}{l}119 \\
050\end{array}$ & 120176 & 121172 & 122035 \\
\hline
\end{tabular}

Tablo 10. Türkiye 2019-2025 Yılları Bal Üretim (Ton) Tahmin Rakamlarl

Tahmin sonuçlarına göre Türkiye bal üretiminde 2018 yılından itibaren artış beklenmektedir. Türkiye'de 2025 yılında, bal üretiminin 2018 yılına oranla \%11.5 oranında artarak 122 bin ton olacağ tahmin edilmektedir.

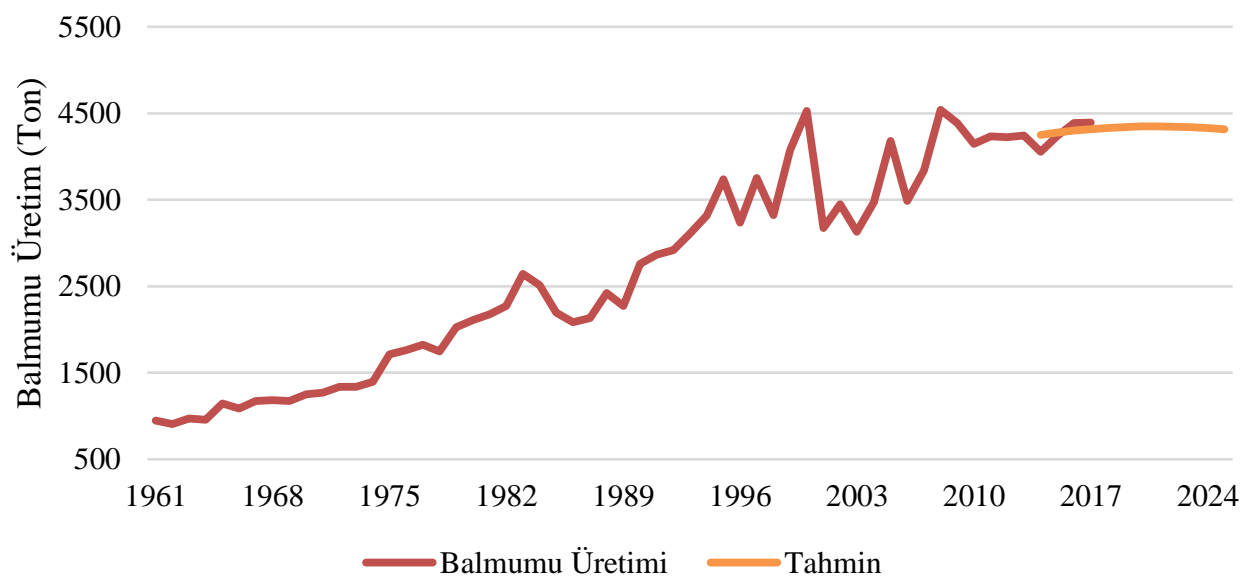

Şekil 4. Türkiye 2019-2025 Yllları Bal Üretim (Ton) Tahmin Sonuçları

\begin{tabular}{lcccccccccc}
\hline & \multicolumn{10}{c}{ Yıllar } \\
\hline & $\mathbf{2 0 1 6}$ & $\mathbf{2 0 1 7}$ & $\mathbf{2 0 1 8}$ & $\mathbf{2 0 1 9}$ & $\mathbf{2 0 2 0}$ & $\mathbf{2 0 2 1}$ & $\mathbf{2 0 2 2}$ & $\mathbf{2 0 2 3}$ & $\mathbf{2 0 2 4}$ & $\mathbf{2 0 2 5}$ \\
\hline Gerçekleşen & 4389 & 4393 & 3987 & & & & & & & \\
\hline Tahmin & 4299 & 4317 & 4331 & 4341 & 4347 & 4349 & 4346 & 4339 & 4328 & 4313 \\
\hline
\end{tabular}

Tablo 11. Türkiye 2019-2025 Yılları Balmumu Üretim (Ton) Tahmin Rakamları

Türkiye balmumu üretiminde tahmin edilen sonuçlara göre 2018 ile 2021 yılları arasında artış beklenmekte, 2021 yılından itibaren ise düşüş meydana gelmesi beklenmektedir. Türkiye'de 2025 yılında, balmumu üretiminin 2018 yılına oranla \%7,6 oranında düşerek 4313 ton olacağı tahmin edilmektedir.

\section{Sonuç}

Türkiye'nin 2019-2025 yılları itibarıyla bal ve balmumu üretimi ARIMA tahmin modeli kullanılarak öngörüde bulunulmaya çalışılmıştır. ARIMA modelleme sürecinde AR ve MA terimlerinin seviyesinin belirlenmesinde Akaike bilgi kriteri ve Schwarz kriterine bakılmıştır. AR ve MA terimlerinin seviyeleri denenerek bu değerlerin minimuma sahip modeller en uygun modeller olarak seçilmiştir. Elde dilen bulgulara göre 2025 y1lında bal üretiminin 122000 ton, balmumu üretiminin ise 4313 ton olacağı öngörülmüştür. Bu değerler 2018 yılına göre sıra ile balda \%11,5 artış ve balmumunda ise \%7,6 oranında azalış anlamına gelmektedir. Çerçeveli kovan sayısındaki artış temel petek kullanımını da arttırmış, dolayısıyla balmumuna olan talep artmıştır. Öte yandan, sanayide ucuz ve kullanım kolaylığından dolayı balmumuna alternatif ikame ürünlerin kullanımı söz konusudur. Neticede, bu durum balmumu talebinin düşmesine ve bu üründe üretimin azalmasına neden olabilir.

Arıcılıkta en önemli işletme özelliği üretimde doğaya bağlılığın çok yüksek olduğudur. Tarım alanlarının daralması, biyolojik, kimyasal ve fiziksel kirlenmesi, kuraklık, çevre kirliliği ve iklim değişikliğinin çeşitli etkileri üretimi olumsuz etkilemektedir. Arıcılık ve bal arıları söz konusu değişikliklerden hem biyolojileri gereği doğrudan, hem de yararlandıkları nektar ve polen kaynaklarının değişimi nedeniyle çok fazla etkilenmektedir. Bu durum ülkemiz arıcılığı açısından olduğu gibi dünya arıcılığı açısından da önemli bir sorun olarak karşımıza çıkmaktadır.

Bal üretiminde beklenen pozitif yönlü artımın gelecekte Türkiye nüfus artışının doğuracağı talebi karşılaması beklenir. Ülkemizde son yirmi yılda arıcılığa yönelik iyileştirici ve geliştirici politikalar ve destekler neticesinde işletmeci ve kovan sayısı artmış, fakat bu artış üretimin istenen seviyeye çıkmasını sağlayamamıştır. Mevcut durumda dünya ile kıyaslandığında ülkemizin kovan başına bal üretimi ve bal ürünleri uluslararası ticaret düzeyi oldukça düşüktür. Üretimin arttırılması için arı 1slah çalışmaları yoğunlaştırılmalı, üreticilerin ve paydaşların 
eğitimine önem verilmeli, verimli ırklardan yararlanılmalı, bakım teknikleri kalite olarak arttırılmalı, yöntem ve ekipmanlar iyileştirilmeli, iç ve dış pazarlamaya ağırlık verilmeli ve devletin üretim odaklı destekleri sürekli ve etkin halde sağlanmalıdır. Ayrıca, arıcılığın uygulamasında çeşitli safhalarda kooperatifleşmeye önem verilmeli, mevcut kooperatifler ihtiyaçlara cevap verebilecek etkinlikte rehabilite edilerek daha güncel hale getirilmelidir. Yine üretici birliklerinin yapısı, işlevleri ve sayısı ihtiyaçlara cevap verecek hale getirilmelidir. Bununla beraber, sektörle ilgili diğer akademik ve sivil toplum örgütleri üretime yönelik gerekli yapı ve ağırlıkta bulunmalıdırlar.

Arıcılık ürünleri konusunda tüketicilerin bilinçlendirilmesi de geleceğe yönelik olumlu tüketim kalıplarının oluşması için önemlidir. Bal üretimi yanında arıcılık yan ürünlerine de yönelimin arttırılması sağlanmalıdır. Bu bal veriminde yaşanacak düşüşle oluşacak riskleri azaltmak ve üreticilerin zarara uğramalarını önlemek adına bir gerekliliktir.

\section{Kaynakça}

- Çevik M (2018). “Bal Üretiminde Dünya İkincisiyiz”. Türk Tarım Orman Dergisi. Eylül-Ekim 2018, Sayı: 249, 10-14.

- Duru Ö (2007). “Zaman Serileri Analizinde ARIMA Modelleri ve Bir Uygulama”, Yüksek Lisans Tezi, İstanbul Üniversitesi Sosyal Bilimler Enstitüsü, İstanbul.

- $\quad$ FAO (2019). http://www.fao.org/faostat/en/\#data (Erişim Tarihi: 10.05.2019).

- Hanedar AÖ, Akkaya O, Bizim Ç (2015). "Durağanlık Analizi, Birim Kök Testleri ve Trend”, 14s. http://debis.deu.edu.tr/userweb//onder.hanedar/dosyalar/Metin.pdf (Erişim Tarihi: 20.05.2019).

- Kutlar A (2017). Eviews ile Uygulamalı Zaman Serileri. Umuttepe Yayınları. Kocaeli. s194.

- Özer O, İlkdoğan U (2013). “Box-Jenkins Modeli Yardımıyla Dünya Pamuk Fiyatının Tahmini”. Tekirdağ Ziraat Fakültesi Dergisi. 10(2): 13-20.

- Saner G, Adanacıoğlu H, Naseri Z (2018). “Türkiye'de Bal Arzı ve Talebi için Öngörü”. Tarım Ekonomisi Dergisi. 24(1): 43-52.

- Tarımorman (2019). “Arı Yetiştiriciliği”. Gıda Tarım ve Hayvancılık Bakanlığı, GTHB http://www.tarim.gov.tr/HAYGEM/Belgeler/Hayvancılık/KüçükEvcilYetiştiriciliği/Arıcılık/Arı Yetiştiriciliği.docx (Erişim Tarihi: 09.05.2019).

- Tepge (2019). "Tarım Ürünleri Piyasaları: Arıcılık”. Tarımsal Ekonomi ve Politika Geliştirme Enstitüsü. https://arastirma.tarimorman.gov.tr/tepge/Belgeler/PDF $\% 20 \mathrm{Tar} \% \mathrm{C} 4 \% \mathrm{~B} 1 \mathrm{~m} \% 20 \% \mathrm{C} 3 \% 9 \mathrm{Cr} \% \mathrm{C} 3 \% \mathrm{BC}$ leri $\%$ 20Piyasalar\%C4\%B1/2019Ocak\%20Tar\%C4\%B1m\%20\%C3\%9Cr\%C3\%BCnleri\%20Raporu/2019Ocak\% 20Ar\%C4\%B1c\%C4\%B11\%C4\%B1k.pdf (Erişim Tarihi: 07.05.2019).

- $\quad$ TÜİK (2019). http://tuik.gov.tr/Start.do (Erişim Tarihi: 10.05.2019).

- UN Comtrade (2019). https://comtrade.un.org/data/ (Erişim Tarihi: 12.05.2019).

- Uzundumlu AS, Aksoy A, Işıı HB (2011). “Arıcılık İşletmelerinde Mevcut Yapı ve Temel Sorunlar; Bingöl İli Örneği”. Atatürk Üniversitesi Ziraat Fakültesi Dergisi. 42 (1): 49-55.

- Yücesan M (2018). "YSA, ARIMA ve ARIMAX Yöntemleriyle Satış Tahmini: Beyaz Eşya Sektöründe Bir Uygulama”. İşletme Araştırmaları Dergisi. 10(1): 689-706. 


\title{
Yabancıların Türkiye'de Sınırlı Ayni Haklardan Yararlanmaları Limited Real Rights of Foreigners in Turkey
}

\author{
Prof. Dr. Adnan Deynekli (Bahçeşehir University, Turkey)
}

\begin{abstract}
Foreigner is a person who does not have any citizenship with the Republic of Turkey. According to the third paragraph of Article 35 of the Deed Law, the Council of Ministers/President of the Republic, in the interests of the country, is entitled to define, limit and prohibit, the limited real rights of the foreign real persons and foreign trade companies, in terms of country, person, geographical region, time, number, rate, type, quality, square measurement and amount.

To entitle the Council of Ministers/President of the Republic to limit and prohibit the use of limited rights of the foreigners, may be contrary to Article 16 of the Constitution.

The limited real rights are the usufruct rights (TCC 794), the right of residence (TCC 823), the right of construction (TCC 837) and the right of pledge and immovable load (TCC 839).

It may be established the right of usufruct, right of construction and immovable load in favor of foreigners in Turkey who can acquire real estates.

It may be established pledge rights without being subject to restrictions in favor of foreign real and legal persons.
\end{abstract}

\section{Giriş}

Türkiye son yıllarda komşu ülkelerde meydana gelen karışıklıklar nedeniyle göç almıştır. Yabancıların ülkemizde çalışmaları ve yaşamalarının sonuçlarından biri de taşınmaz mal edinmeleri ve sınırlı ayni haklardan yararlanmalarıdır. Kendi ülkelerindeki belirsizlikler nedeniyle de Türkiye'de taşınmaz mal edinenlerin sayısında artışlar gözlenmiştir. Yabancıların ülkemizde taşınmaz mal edinme ve sınırlı ayni haklardan yararlanma taleplerindeki artışlar nedeniyle inceleme gereği hissedilerek çalışma konusu yapılmıştır.

\section{Yabancıların Sınırlı Ayni Haklardan Yararlanmasına İlişkin İlke}

Yabancıların sınırlı ayni haklardan yararlanmaları, yabancıların Türkiye'deki taşınmaz mallar üzerinde sınırlı ayni hak sahibi olmaları anlamına gelir.

Türk pozitif hukukunda yabancıların sınırlı ayni haklardan yararlanmalarına ilişkin ilkeyi belirleyen açık bir hüküm bulunmamaktadır.

Anayasanın 35. maddesinde herhangi bir ayırım yapmaksızın ülkede bulunan herkesin mülkiyet ve miras hakkına sahip olduğu belirtildiğinden sınırlı ayni haklar da ayni hak olması nedeniyle Anayasanın 35. maddesi ile sağlanan güvenceden yararlanır. $\mathrm{Bu}$ nedenle yabancıların sınırlı ayni haklardan yararlanmalarının pozitif dayanağının Anayasanın 35. maddesi hükmü olduğu söylenebilir.

Anayasanın 35. maddesinin üçüncü fikrasında Bakanlar Kurulunun, Cumhurbaşkanının ülke menfaatlerinin gerektirdiği hallerde yabancı gerçek kişiler ile yabancı ticaret şirketlerinin sınırlı ayni hak edinmelerini sınırlandırabileceği ve yasaklayabileceği hükme bağlanmıştır. Sınırlandırma ve yasaklama ülke yönünden olabileceği gibi coğrafi bölge, kişi, sayı, oran, tür, nitelik, yüz ölçüm ve miktar yönünden de olabilir.

Anayasanın 16. maddesinde ise, temel hak ve özgürlüklerin yabancılar açısından milletlerarası hukuka uygun olarak ve kanunla sınırlanabileceği belirtilmiştir. Yabancıların sınırlı ayni haklardan yararlanmalarının sınırlandırılması ve yasaklanması yetkisinin Bakanlar Kurulu, Cumhurbaşkanına verilmesi Anayasanın 16. maddesine aykırılık teşkil edebilir. Zira bu düzenlemeye göre sınırlandırma ve yasaklama kanun hükmü ile yapılmamaktadir.

\section{Sınırlı Ayni Hak Türlerine Göre Yabancıların Bu Haklardan Yararlanmaları}

Türk hukukunda sınırlı ayni haklar, taşınmaza bağlı irtifak hakkı (TMK m.779), kişiye bağlı irtifak hakkı olan intifa hakkı (TMK m.794), oturma hakkı (TMK m.823 vd.), üst hakkı (TMK m.826) ile rehin hakkı (TMK m. 850 vd.) ve taşınma yüküdür (TMK m.839). Bu haklardan yabancıların yararlanıp yararlanamayacağını her bir hak yönünden ayrı ayrı değerlendireceğiz.

\subsection{Taşınmaza Bağlı İrtifak Hakları}

İrtifak hakkı, hak sahibine, konusu olan eşya üzerinde yararlanma veya kullanma hakkı veren ya da hem yararlanma hem de kullanma yetkisi veren bir sınırlı ayni haktır. İrtifak hakkı kişilik göz önünde tutularak tanınmışsa kişiye bağlı irtifak hakkı söz konusu olur. İrtifak hakkı bir taşınmaz üzerinde diğer bir taşınmaz lehine tanınmışsa taşınmaza bağlı irtifak hakkı söz konusu olur. 
Taşınmaza bağlı irtifak hakkı TMK'nın 779. maddesinde düzenlenmiştir. Taşınmaza bağlı irtifak hakkının söz konusu olabilmesi için iki taşınmaz bulunmalıdır. Bu taşınmazlardan biri üzerinde diğer taşınmaz lehine konulmuş olan yüke taşınmaza bağlı irtifak hakkı denilmektedir. Bu taşınmazlardan birisi yükümlü taşınmaz, diğeri ise yararlanan taşınmazdır. Taşınmaza bağlı irtifaklar müspet (olumlu) irtifak hakkı veya menfi (olumsuz) irtifak hakkı şeklinde kurulabilir. Geçit ve mecra geçirme hakkını olumlu irtifak hakkına taşınmaz malikinin mülkiyet hakkına bağlı bu haklardan vazgeçebilmesini olumsuz irtifak hakkına örnek gösterebiliriz.

Yabancılar bir taşınmaz maliki ise bu taşınmaz mala bağlı irtifak hakkının sahibi olabilirler. Taşınmaza bağlı irtifak hakkının konusu, kural olarak arazilerdir.

\subsection{Kişiye Bağı İrtifak Hakkı}

Kişiye bağlı irtifak, bir taşınmaz malın maliki adına değil, herhangi bir kişi lehine kurulan ve lehine kuruldukları kişi ile var olan bir sınırlı ayni haktır. Kişiye bağlı irtifakta hak sahibinin kişiliği önemlidir. Kişiye bağlı irtifakları devredilemeyen kişiye bağlı irtifak hakkı ve devredilebilen kişiye bağlı irtifak hakkı olarak ikiye ayırabiliriz. Devredilemeyen kişiye bağlı irtifak hakları intifa hakkı ve oturma (sükna) hakkıdır. Devredilebilen kişiye bağlı irtifaklar ise üst hakkı ve kaynak hakkıdır.

\section{i. Intifa Hakkı}

İntifa hakkı, bir başkasına ait taşınmazlar ve taşınırlar üzerinde kurulan üzerinde kurulan ve hak sahibine kullanma ve yararlanma yetkisi veren sınırlı bir ayni haktır (TMK m.794). İntifa hakkı sahibi, gerçek veya tüzel kişi olabilir. İntifa hakkı niteliği bakımından devredilebilen bir haktır. Sözleşmeyle kurulabileceği gibi kanunla da kurulabilir. İntifa hakkı sahibinin zillet olma, taşınır ve taşınmaz maldan yararlanma ve kullanma, yönetme, korunma hak ve yükümlülüğ̈̈ vardır.

Yabancıların intifa hakkından yararlanmalarını engelleyen bir düzenleme bulunmamaktadır.

\section{ii. Oturma (Sükna) Hakkı}

Oturma (sükna) hakkı, sahibine, bir binadan veya binanın bir bölümünden tek başına oturma veya işgal etme yetkisi veren başkasına devredilemeyen, miras yoluyla geçmeyen bir sınırlı ayni haktır. Sükna hakkı bir binada veya bir kısımda oturma hakkı verir.

Yabancılar lehine belli bir taşınmaz mal üzerinde oturma (sükna) hakkı tesis edilmesi mümkündür. Ancak Askeri Yasak Bölgeler ve Güvenlik Bölgeleri Kanunu’nun 7. maddesine göre yabancıların oturmasına izin verilmeyen askeri yasak bölgelerde bu kişiler lehine oturma (sükna) hakkı tesis edilemez.

\section{iii. Üst Hakkı}

Üst hakkı, sahibinin başkasına ait bir arazinin üstünde veya altında yapı inşa etmek veya mevcut olan bir yapıyı yerinde bırakma yetkisi veren, kural olarak devir ve temlik edilebilen, miras yoluyla geçebilen, kişiye bağlı bir irtifak hakkıdır (TMK m.826).

Üst hakkı sahibi yapı üzerinde mülkiyet hakkına sahip olur. Taşınmaz mal edinmesi mümkün olan yabancılar lehine üst hakkı da tesis edilebilir. Üst hakkı en az 30 yıl en fazla 100 yıl için kurulabilir. Bakanlar Kurulu/Cumhurbaşkanı yabancılar lehine kurulacak üst hakkının süresini kısaltabilir.

\section{iv. Kaynak Hakkı}

Kaynak hakkı, hak sahibine başkasının arazisi üzerinde bulunan kaynaktan su almak ve suyu akıtmak yetkisi veren bir sınırlı ayni haktır (TMK m.837). Kaynak hakkı kişiye sıkı sıkıya bağlı olmadığından aksi kararlaştırılmamışsa, başkasına devredilebilir ve mirasçılarına geçebilir. Kaynak hakkı en az 30 yıl için kurulmuşsa tapu kütüğüne taşınmaz olarak kaydedilebilir.

Kaynak hakkı bir taşınmaz mal lehine tesis edilmişse haktan yararlanacak olan yabancının malik olduğu bir taşınmazı bulunmalıdır.

Kaynak hakkı kişiye bağlı olarak kurulacaksa, yabancı lehine sınırlamaya tabi olmadan kaynak hakkı tesis edilebilecektir.

\subsection{Rehin Hakkı}

Rehin hakkı, bir alacağın tahsil edilememesi durumunda, hak sahibine, rehin konusu taşınmaz veya taşınır malın paraya çevrilmesini istemek ve elde edilen paradan alacağını elde etme yetkisi veren bir sınırlı ayni haktır. Rehin taşınmaz rehni (ipotek, ipotekli borç senedi ve irat senedi), taşınır rehni (teslime bağlı taşınır rehni, hayvan rehni, hapis hakkı) şeklinde kurulabilir.

Bir yabancının alacağını teminat altına almak için lehine rehin hakkı tesis edilmesinde yasal bir engel bulunmamaktadır. Rehin hakkı sahibi alacağı ödenmediği takdirde o rehin konusu malı iktisap etmesi yasaktır. Buna lex commissoria yasağı denilmektedir. Ancak rehin konusu malın cebri icra yoluyla satılması halinde yabancı alacaklı alacağına mahsuben bu malı ihalede alabilir. Bu durumda ise yabancının Türkiye'de mal edinmesine engel bir hal olmaması gerekir. Türkiye'de taşınmaz mal elde edinmesi yasak olan yabancı, cebri icra yoluyla ihaleye katılıp ipotekli alacaklı olarak alacağına mahsuben taşınmazı satın alamaz. İpotek yabancı para üzerinden 
kurulabilir. Yabancıların sınırlı ayni haklardan en önemlisi olan rehin hakkından yararlanabilmesi için karşılıklılık ilkesinin uygulanması yerinde olur.

\subsection{Taşınmaz Yükü}

Taşınmaz yükü, taşınmaz mala veya kişiye bağlı olarak kurulabilir. Taşınmaz yükü kural olarak başkasına devredilebilir ve mirasçılara geçer. Taşınmaz yükünün kurulabilmesi için tescil gereklidir. Taşınmaz yükü belirli bir kişi lehine kurulacaksa bu kişinin yabancı olup olmamasının bir önemi bulunmamaktadır. Ancak taşınmaz yükü, bir taşınmaz mal yararına kuruluyorsa, yabancının bu taşınmaza malik olması gerekir. Zira bu durumda taşınmaz yükünün hak sahipliği, yararlanan taşınmazın mülkiyetine bağlanmış olur. Bu nedenle Türkiye'de taşınmaz mal edinmesi mümkün olmayan yabancılar lehine taşınmaz yükü de tesis edilemeyecektir.

\section{Sonuç}

Türkiye Cumhuriyeti ile vatandaşlık bağı bulunmayan kişilerin (yabancıların) sınırlı ayni haklardan yararlanmaları Bakanlar Kurulu/Cumhurbaşkanı tarafından ülke menfaatinin gerektirdiği durumlarda sınırlandırılabilir veya yasaklanabilir. Yasaklama veya sınırlandırma yetkisinin Bakanlar Kurulu/Cumhurbaşkanına verilmesi Anayasanın 16. maddesinde yer alan temel hak ve özgürlüklerin ancak kanunla sınırlandırılabileceğine ilişkin düzenlemeye aykırıdır.

Türkiye'de taşınmaz mal edinmesi mümkün olan yabancıların sınırlı ayni haklardan yararlanmaları kural olarak mümkündür.

Ülkemizin menfaatlerinin gerektirdiği durumlarda yabancıların sınırlı ayni haklardan yararlanmaları kanunla sınırlandırılmalı veya yasaklanmalıdır. Sınırlı ayni haklar yönünden karşılıklılık esası getirilmelidir.

\section{Kaynakça}

- Akipek/Akıntürk, 2009, Eşya Hukuku, Beta Yayınevi, İstanbul.

- Çelikel/Gelgel, 2017, Yabancılar Hukuku, 23. Bası, Beta Yayınevi, İstanbul.

- $\quad$ Ertaş, 2011, Eşya Hukuku, Bilge Yayınevi, İzmir.

- Obut, 1956, Türk Hukukunda Yabancı Hakiki ve Hükmi Şahısların Ayni Haklardan İstifadesi, Ankara.

- Oğuzman/Seliçi/Özdemir, 2012, Eşya Hukuku, Beta Yayınevi, İstanbul.

- Sargın, 1997, Yabancı Gerçek ve Tüzel Kişilerin Türkiye’de Taşınmaz Mal Edinmeleri ve Sınırlı Ayni Haklardan Yararlanmaları, Yetkin Yayınevi, Ankara.

- Yarar, 2018, Yabancılar Türkiye'de Taşınmaz Mal Edinmeleri, Onikilevha Yayınevi, İstanbul 


\title{
Kamu Denetçiliği Kurumu Kararlarının İnsan Hakları Bakımından Değerlendirilmesi
}

\section{Evaluation of the Decisions of the Ombudsman Institution According to Human Rights}

\author{
Asst. Prof. Dr. Ezgi Cankurt (Beykent University, Turkey)
}

\begin{abstract}
Alternative solutions have come to the fore in recent years. In our country, the new Ombudsman Institution is; Upon the operation and complaint of the administration, it is responsible for examining and conducting all kinds of actions and operations of the administration and its attitudes and behaviors within the understanding of justice based on human rights, in terms of compliance with law and equity, and to make recommendations to the administration. Therefore, it offers alternative solutions for these issues.

In the first part, general information about the functioning of the Ombudsman Institution and the application standards will be given. In observing the decisions of the institution, reference is made to international conventions for examination. Because of this reason, in the second part, the decisions given by the ombudsman institutions will be evaluated for compliance with international conventions and the constitution.

Recommendations made by the Agency also help to increase the total quality of public institutions. The decisions of the Ombudsman institution should be made in accordance with the international conventions and the constitution. Because without reference to human rights, there will be problems in terms of binding decisions. Therefore, facilitator methods should be followed in terms of application criteria.
\end{abstract}

\section{Giriș}

Son yıllarda alternatif çözümler ön plana çıkmıştır. Ülkemizde yeni Ombudsman Kurumu; İdarenin işleyişi ve şikayeti üzerine, idarenin her türlü eylem ve işleyişini, insan haklarına dayalı adalet anlayışı içinde, hukuka ve hakkaniyete uyumu bakımından tutum ve davranışlarını incelemek ve yürütmek; İdareye önerilerde bulunmak. Bu nedenle, bu konular için alternatif çözümler sunmaktadır.

Birinci bölümde, Kamu Denetçiliği Kurumu'nun işleyişi ve uygulama standartları hakkında genel bilgi verilecektir. Kurumun kararlarını gözlemlerken, inceleme için uluslararası sözleşmelere atıfta bulunulur. Bu nedenle, ikinci bölümde, kamu denetçiliği kurumlarının verdiği kararlar uluslararası sözleşmelere ve anayasaya uygunluk açısından değerlendirilecektir.

Kurum tarafindan yapılan tavsiyeler, kamu kurumlarının toplam kalitesini arttırmaya yardımcı olmaktadır. Ombudsmanlık kurumunun kararları uluslararası sözleşmelere ve anayasaya uygun olarak alınmalıdır. Çünkü insan haklarına atıfta bulunmadan, bağlayıcı kararlar açısından sorunlar olacaktır. Bu nedenle, uygulama kriterleri açısından kolaylaştırıcı yöntemler izlenmelidir.

\section{Genel Olarak Kamu Denetçiliği}

Türkiye'de akademik metinlerde "ombudsmanlık kurumu" ve "kamu denetçiliği" terimlerinin kullanıldığını görmekteyiz. Doktrinde ombudsmanlık kurumu için, karmaşık ve ağır işleyen bürokrasinin vatandaşların taleplerini karşılama noktasında hak olası hak kayıplarının önüne geçmek için var olduğu da savunulmaktadır (Gökçe, 2012). "Kamu hakemi”" olarak da adlandırılan bu kurum, "idarenin yargı dışı denetim yolları" arasındadır (Tezcan/Erdem/Sancakdar/Önok, 2016).

Kamu Denetçiliği Kurumu'nın amacı, vatandaş ile idare arasında çıkan temel hak ve özgürlüklere ilişkin sorunları çözüme kavuşturmaktır (Tezcan/Erdem/Sancakdar/Önok, 2016). Kamu Denetçiliği Kurumu, bağlayıcı karar verme yetkisi yoktur. Vermiş olduğu kararlar birer öneri niteliğindedir (Yaşar, 2013). Kamu denetçiliği kurumunun tarihçesine baktığımızda İsveç oldukça önemli bir yer teşkil etse de, söz konusu kurumun köklerinin Osmanlı Devleti’nde Şeyhülislamlık kurumuna dayandığı da doktrinde öne sürülmektedir (Kalabalık, 2015).

Ülkemizde 2010 yılındaki referandum ile Anayasal hayata giren Kamu Denetçiliği Kurumu, Anayasa m. 74'de şöyle düzenlenmiştir: "(Ek fikra: 7/5/2010-5982/8 md.) Herkes, bilgi edinme ve kamu deneţisine başvurma hakkına sahiptir (Ek fikra: 7/5/2010-5982/8 md.). Türkiye Büyük Millet Meclisi Başkanliğına bağll olarak kurulan Kaтu Denetçiliği Kurumu idarenin işleyişiyle ilgili şikâyetleri inceler." (1982 Anayasası).

29.06.2012 tarih 28338 sayılı Resmi Gazetede yayınlanan Kamu Denetçiliği Kurumu Kanunu'nun amac1; “..kamu hizmetlerinin işleyiş̧inde bağımsız ve etkin bir şikâyet mekanizması oluşturmak suretiyle, idarenin her türlü eylem ve işlemleri ile tutum ve davranışlarını; insan haklarına dayalı adalet anlayıı̧ı içinde, hukuka ve 
hakkaniyete uygunluk yönlerinden incelemek, araştırmak ve önerilerde bulunmak üzere Kamu Denetçiliği Kurumunu oluşturmaktır.” (Kamu Denetçiliği Kurumu Kanunu 1. Madde).

Kamu Denetçiliği Kurumu 'nın görev alanı, ilgili kanunda, “ idarenin işleyişi ile ilgili şikâyet üzerine, idarenin her türlü eylem ve işlemleri ile tutum ve davranışlarını; insan haklarına dayalı adalet anlayışı içinde, hukuka ve hakkaniyete uygunluk yönlerinden incelemek, araştırmak ve idareye önerilerde bulunma" olarak belirtilmiştir (Kamu Denetçiliği Kurumu Kanunu 5. Madde 1. F1kra). Öte yandan denetimde bulunamayacağı alanlar ise; "Yasama yetkisinin kullanılmasına ilişkin işlemler, Yargı yetkisinin kullanılmasına ilişkin kararlar, Türk Silahlı Kuvvetlerinin sırf askerî nitelikteki faaliyetleri" olarak belirtilmiştir (Kamu Denetçiliği Kurumu Kanunu 5. Madde 2. F1kra).

Kamu Denetçiliği Kurumundaki başdenetçiye ve denetçilere, hiç kimse veya organ görevleriyle ilgili olarak emir ve talimat veremez, genelge gönderemez, tavsiye ve telkinde bulunamayacaktır ve kamu denetçiliği kurumu, tarafsızlık ilkesine riayet ederek kararlarını vermek zorundadır (Kamu Denetçiliği Kurumu Kanunu 12. Madde).

Kamu Denetçiliği Kurumu, yaptığı çıkarımları ve gözlemleri ilgili idareye bildirdikten sonra, onlardan bu tutumlarından vazgeçmesini istemek yetkisine sahiptir. Bu nedenle temel hak ve özgürlüklere ilişkin vatandaş ve idare arasındaki uyuşmazlıklarda, insan haklarını koruyucu fonksiyonu olduğu da ortadadır (Kalabalık, 2015).

İdarenin, Kamu Denetçiliği Kurumu kararlarına uyma zorunluluğu bulunmamaktadır. İdare, kendisine Kamu Denetçiliği Kurumu tarafından önerilen çözüme ilişkin olarak itirazlarını da belirten raporunu 30 gün içerisinde Kamu Denetçiliği Kurumu'na bildirmelidir. Bu aşamadan sonra başvurucu sadece idari yargıda dava açacaktır (Yaşar, 2013).

\section{Kamu Denetçiliği Kararlarındaki İyi Yönetişim İlkeleri ve İnsan Hakları Açısından Önemi}

Kamu yönetiminin denetimini sağlamaya yönelik olarak kurulan Kamu Denetçiliği Kurumu, vermiş olduğu kararlarda iyi yönetişim ilkelerine vurgu yapmakta ve özellikle de temel haklar, sosyal haklar vb alanlarda özellikle uluslararası sözleşmeler kapsamında düzenlenmiş temel hak ve özgürlüklere dolayısıyla insan haklarına vurgu yapmaktadir.

Özellikle Kamu Denetçiliği Kurumu kararlarında, iyi yönetişim ilkeleri bakımından da değerlendirme yapıldığ görülmektedir. Özellikle de, insan hakları bakımından kararların ele alınması açısından iyi yönetişim ilkeleri, katılımcı ve ileri seviyede gelişmiş bir idari anlayışın oluşturulabilmesi açısından önem taşımaktadır.

Kamu Denetçiliği Kurumu’nın varlığı, yönetenlerin “çoğunluktan ve güçlüden ziyade azınlıkta kalan ve güçsüz olanlara da eşit davranmaları gerekliliğini” de vurgulamakta ve varlık sebebi olan yönetilenlerin taleplerini ve isteklerini gözardı etmeme imkanı getirmektedir. Hesap sorulabilirliğin yargı merci dışında da bulunması, dava açmanın önündeki çeşitli engellerin bulunması sebebiyle, kamu eylemlerinin sorgulanmasının da önünü açmaktadır (Gökçe, 2012).

Dünyada farklı ombudsmanlık örnekleri görülmektedir. Elbetteki yönetim sistemleri benzese de, kültürel farklılıklar gibi sebepler ile her ülkede farklı uygulamalar gösterebilir. Ancak ortak noktalar aslında idarenin hesap verilebilirliğine yönelik kurumlar olmasıdır.

Örneğin İsveç’teki Meclis Ombudsmanlığ1; “ombudsman mahkeme ve idari mercilerin görevlerini “nesnel ve tarafsız” bir şekilde ve "yurttaşların temel hak ve özgürlüklerine tecavüz etmeksizin” yerine getirmelerini sağlamakla görevlidir" ve sadece hukukilik denetimi değil bir anlamda yerindelik denetimi de yaparak, idarenin takdir yetkisini değerlendirmektedir (Ekiz, 2018).

Yönetişim kavramının, kamu yönetiminin içerisinde sivil unsurlar barındırması daha doğru bir anlatımla sivilleşmesi anlamına geldiğini vurgulamaktan çekinmiyoruz. Çünkü, iyi yönetişim sayesinde, "Devletin yönetimi, devletin ve siyasal iktidarların faaliyetleri ile sınırlı kalmamakta, bunun yanında özel sektör ve sivil toplum kuruluşlarını da idarenin vazgeçilmez aktörleri olarak görülmektedir”' (Şahin, 2018).

İyi yönetişim ilkeleri, hiyerarşik yapıda kalan ve rüşvet, görevin kötüye kullanılması gibi suçların da ortadan kalkmasına ve yönetimin şeffaflaşmasına yol açacaktır. Çünkü vatandaşların, yönetimin aldığı kararlara etkin katılım sağlaması sebebiyle sivil bir denetim kendiliğinden oluşacaktır (Şahin, 2018).

İyi yönetişim ilkelerini 7 başlık içerisinde inceleyenler; bunları, “AB'nin ortaya koyduğu ilkelerden açıklık, katılım, hesap verebilirlik, etkinlik, uyum” dışında "hukukun üstünlüğü, denetim, yönetim ahlakı" olarak kabul etmektedir (Şahin, 2018).

Doktrinde bizim de katıldığımız görüşe göre; insan haklarının korunması başı başına iyi yönetişim ilkeleri arasındadır (Karakul, 2018). 1982 Anayasası'nın 90. Maddesinin son fikrası, temel hak ve özgürlüklere ilişkin olarak uluslararası sözleşmelerin kanunlara olan üstünlügünü düzenlemiştir. Bu nedenle idare, kararlarında ve eylemlerinde, temel hak ve özgürlüklere ilişkin konularda muhakkak uluslararası sözleşmeleri iç hukuk metni olarak uygulamak zorundadır. Bu nedenle de, Kamu Denetçiliği Kurumu'nın vermiş olduğu kararlarda insan hakları metinlerine uygunluğun tartışılması da oldukça yerindedir. 
İyi Yönetim/Yönetilme Hakkı, “kamu hizmetlerinden yararlananlar açısından öngörülmüş” bir haktır (Sancakdar/Us/Kasapoğlu Turhan/Önüt/Seyhan,2018). İyi Yönetilme Hakkı'nı düzenleyen 41. Maddede; "1.Herkes, konu ve işlerini Avrupa Birliği kurum ve organları tarafindan tarafsı ve adil bir şekilde ve makul bir zaman süresi içerisinde ele alınması hakkına sahiptir. 2. Bu hakka: Kendisi ile ilgili olarak olumsuz bir etki yaratacak herhangi bir önlem gerçekleştirilmeden herkesin ifadesinin alınmasi hakkı; Herkesin, gizlilik konusundaki yasal çıkarlarına ve meslek ve işi ile ilgili gizlilik hususlarına saygl duyularak kendisine ilişkin bilgilere erişebilme hakkl; İlgili idarelerin de verdiği kararların nedenlerini açıklama yükümlülüğ̈̈ dahildir. 3. Herkes, üye ülkeler yasalarının ortak genel ilkelerine uygun olarak Topluluk kuruluşlarının veya görevlilerinin neden olacăg zararların topluluk tarafindan giderilip düzeltilmesi hakkına da sahiptir. 4.Herkes, Avrupa Birliğ kurumlarına Antlaşmalarda belirtilen dillerden birisi ile yazılı başvuruda bulunabilir ve aynı dilden yanıt alır." (Avrupa Birliği Temel Haklar Şartı, 2000/C 364/01, madde 41). İyi yönetilme hakkı olarak kullanmayı tercih ettiğimiz bu hak oldukça geniş alt başlıkları kapsamaktadır. Bunlar arasında vatandaşın hukuki açıdan meramını anlatabilme ve idare tarafından dinlenilebilme hakkı, dosyalara erişim hakkı, işlemlerin gerekçeli yapılması zorunluluğu gibi alt başlıklar esasında bizi iyi yönetilme hakkından daha da ileri bir aşamaya taşımaktadır. Birlikte yönetmek, vatandaşın yönetime katılmasını da sağlayabilecek; iletişim ve etkileşim kavramlarını da bünyesinde barındıran yönetişim günümüzde idare hukuku açısından da ele alınmaktadır (Sancakdar/Us/Kasapoğlu Turhan/Önüt/Seyhan,2018).

Avrupa Konseyi AK Bakanlar Komitesi’nin iyi yönetim hakkında üye devletlere yönelik CM/Rec (2007) sayılı tavsiye kararında, özellikle Avrupa İnsan Hakları Sözleşmesi'nin gözardı edilmemesine vurgu yapmış ve Avrupa İnsan Hakları Mahkemesi kararlarında da özel kişilerin idare ile olan ilişkilerinde korunması gerektiğini tavsiye etmiştir (Karakul, 2018).

Kamu Denetçiliği Kurumu'na yapılan 01.2013/289 nolu başvuruda; kurum “Kamu Denetçiliği Kurumu Kanununun Uygulanmasına İlişkin Usul ve Esaslar Hakkında Yönetmeliğin "İyi yönetim ilkeleri "başlıklı 6 nc1 maddesinde "Kurum, inceleme ve araştırma yaparken idarenin, insan haklarına dayalı adalet anlayışı içinde; kanunlara uygunluk, ... ölçülülük, ... hesap verilebilirlik, haklı beklentiye uygunluk, ... savunma hakk, bilgi edinme hakkl, makul sürede karar verme, kararların gerekçeli olması, karara karşı başvuru yollarının gösterilmesi, kararın geciktirilmeksizin bildirilmesi, ... gibi iyi yönetim ilkelerine uygun işlem ve eylem ile tutum veya davranışta bulunup bulunmadı̆̆ını gözetir ve iyi yönetim ilkelerine uyar. “ hükmü yer almaktadır. ................. adı geçen İdare ve şirket bilgi ve belge istemimize ilişkin genel cevaplar vermiştir. Bu durum, istenen bilgilere ulaşılamamasına, konuyla ilgili tekrar yazışma yapılmasına ve yazışma sürecinin uzun sürmesine sebebiyet vermiştir. Söz konusu hususlar dikkate alındı̆̆ında; ilgili İdarenin, "bilgi edinme hakkl "ve "haklı beklentiye uygunluk "ilkelerine daha duyarlı davranacağı beklenmektedir.” Şeklinde karar vermiştir (Kamu Denetçiliği Kurumu, Sosyal Haklar Ve Alanlar, 2016).

Kamu Denetçiliği Kurumu kararlarında, İyi Yönetişim İlkelerine Uygunluk Yönünden Değerlendirme alt başlığı bulunmaktadır. Söz konusu değerlendirmenin oldukça yerinde olduğunu ve özellikle idarenin karar alma sürecinde vatandaşın katılımının sağlanması noktasında da kilit önem taşıdığını vurguluyoruz. Çünkü yönetim anlayışının yönetişim noktasında ilerlemesi, bağlayıcı karar vermediği ve tavsiye kararı verdiği noktasında dahi oldukça önem taşımaktadır. İdarenin amacı, iyi hizmet vermektir. Bunu da hukuku yok sayarak yerine getirmesi mümkün değildir. Söz konusu tavsiye kararları sayesinde, benzer konularda oluşacak olan içtihat, idarenin de eylemleri ve kararları noktasında geliştirici ve yol gösterici olacaktır.

Öte yandan söz konusu tavsiye kararları doktrinde de haklı olarak belirtildiği üzere; ,, ilgili idarenin de 30 günlük süre içerisinde hukuka uygun gerekçeler ileri sürmeli “dir (Derin/Coşkun, 2017).

\section{Sonuç ve Değerlendirme}

Kamu yönetiminin denetimini sağlamaya yönelik olarak kurulan Kamu Denetçiliği Kurumu, vermiş olduğu kararlarda iyi yönetişim ilkelerine vurgu yapmakta ve özellikle de temel haklar, sosyal haklar vb alanlarda özellikle uluslararası sözleşmeler kapsamında düzenlenmiş temel hak ve özgürlüklere dolayısıyla insan haklarına vurgu yapmaktadir.

Günümüzde idarelerin, sadece hukuka uygun davranmaları değil, aynı zamanda iyi yönetişim ilkelerini de hayata geçirmeleri beklenmektedir. Zaten daha önce de vurguladığımız üzere, esasında hukuka uygun davranmak özünde iyi yönetişim ilkesidir. Yani hukuka uygun davranmanın kapsamına iç hukuk metni haline gelen uluslararası sözleşmelerin de bulunduğu açıktır. Bireyi merkeze koyan ve hatta bireyi üstün değer kabul eden yönetim anlayışının dışında bulunmak mümkün değildir. Bu durumda Kamu Denetçiliği Kurumu'nın tavsiye kararları oldukça önemlidir.

Uluslararası Sözleşmeler ve İHAM kararlarına atıf yapılması, özellikle hukuki gerekçe ile ilgili başlık altında değerlendirilmektedir.. Her karar içerisinde ilk olarak ilgili mevzuat belirtilmekte, ardından somut olay açısından değerlendirme yapılmaktadır. Bu da kararın taraflar nezdinde tatmin edici olmasına yardımcı olduğu gibi, çeşitli hakların yasal dayanakları açısından içtihadi anlamda da yol gösterici olmaktadır. Bazı hukuksal kurumların tanımlandığı da, kararlarda görülmektedir. 
Kamu Denetçiliği Kurumu; tanık dinleme, bilirkişi incelemesi yaptırma, mukayeseli hukuktan faydalanmanın yanısıra ilgili idarenin uhdesindeki her türlü bilgi ve belgeye de ulaşabilmektedir. Her ne kadar yargı kararı olarak kabul edilmese de, Kamu Denetçiliği Kurumu önemli yetkilere sahip bir kurumdur ve verdikleri tavsiye kararlarında ilgili idare aleyhine kamu oyu oluşturabilme yetkisini de elinde bulundurmaktadır. Bu "ben yaptım, $o l d u$ ” anlayışı içerisinde olan bir idarenin, geleceğine ilişkin olarak ciddi bir kamu oyu oluşturmaya yetecektir. Bu nedenle kararların uygulanması açısından da etkilidir.

\section{Kaynakça}

- 1982 Anayasas1, http://www.mevzuat.gov.tr/MevzuatMetin/1.5.2709.pdf.

- Avrupa Birliği Temel Haklar Şartı, https://eyh.aile.gov.tr/uploads/pages/abtemelhaklarsarti-25b3a31ec6cfe6.doc.

- Derin/Coşkun, 2017. "Kamu Denetçiliği Kurumunun Tavsiye Kararı Üzerine Disiplin Cezasının Geri Alınması", Ombudsman Akademik. YIL: 4 SAYI: 7, Temmuz/Aralık 2017 SS: 173-195.

- Ekiz, 2018. “İsveç Anayasası Üzerine Notlar”, Dokuz Eylül Üniversitesi Hukuk Fakültesi Dergisi, Cilt: 20, Sayı: 1, 2018, s. 63-124.

- Gökçe, 2012. "Çağdaş Kamu Yönetiminde Kamu Denetçiliği (Ombudsmanlık) Ve Türkiye İçin Askeri Ombudsman Önerisi”, Süleyman Demirel Üniversitesi İktisadi ve İdari Bilimler Fakültesi Dergisi, C.17, S.2, s.203-227.

- Kalabalık, 2015. İnsan Hakları Hukuku. Seçkin Yayıncılık, Ankara.

- Kamu Denetçiliği Kurumu Kanunu, http://www.mevzuat.gov.tr/MevzuatMetin/1.5.6328.pdf.

- Kamu Denetçiliği Kurumu, Sosyal Haklar Ve Alanlar, 2016. Kamu Denetçiliği Kurumu Kararları, Sosyal Haklar Ve Alanlar. Kamu Denetçiliği Kurumu Yayınları, Ankara.

- Karakul ,2018 .’İyi Yönetim Ve İnsan Hakları İlişkisi Üzerine Değerlendirmeler”, Ombudsman Akademik • Özel Sayı 1 / Special Issue 1, Kamu Hizmetlerinde İyi Yönetim İlkeleri, Aralık /December 2018 SS: 27 55.

- Sancakdar/Us/Kasapoğlu Turhan/Önüt/Seyhan,2018. İdare Hukuku Teorik Çalışma Kitabı. Seçkin Yayınc1lık, Ankara.

- Şahin, 2018. "İyi Yönetişimin Türk Kamu Yönetiminde Uygulanması Ve Kamu Denetçiliği Kurumu”, Ombudsman Akademik • Özel Sayı 1 / Special Issue 1, Kamu Hizmetlerinde İyi Yönetim İlkeleri, Aralık /December 2018 SS: 99-139.

- Tezcan/Erdem/Sancakdar/Önok, 2016. İnsan Hakları Eı Kitabı. Seçkin Yayıncılık, Ankara.

- Yaşar, 2013. İdare Hukuku -Genel Esaslar-. Der Yayıncılık, İstanbul. 


\title{
Yabancı Yatırımcıların Türkiye'de Şirket Kurması ve Hisse Devralması
}

\section{Establishment of a Company and Share Acquisitions in Turkey by Foreigner Investors}

\author{
Prof. Dr. Mustafa Topaloğlu (Özyeğin University, Turkey)
}

\begin{abstract}
Relating to the establishment and acquisition of a company in Turkey by foreign investors, Foreign Direct Investments Law No.4875, FDI has entered into force on 17.06.2003. FDI formed a notification-based system rather than an approval-based system for foreigners to establish a new company and to take over company shares. Accordingly, company information regarding foreign investors will be notified to the General Directorate of Incentive Implementation and Foreign Capital via "Electronic Incentive Implementation and Foreign Capital Information System". Foreign investment means establishment of a new company by a foreign investor or share acquisitions of an existing company, any percentage of shares acquired outside the stock exchange or 10 percent or more of the shares/voting power of a company acquired through the stock exchange, by means of the following economic assets: assets acquired from abroad by the foreign investor which are capital in cash in the form of convertible currency bought and sold by the Central Bank of the Republic of Turkey, stocks and bonds of foreign companies excluding government bonds, machinery and equipment, industrial and intellectual property rights; or assets acquired from Turkey by foreign investor which are reinvested earnings, revenues, financial claims, or any other investment-related rights of financial value, rights for the exploration and extraction of natural resources. According to Article 4 of the Regulation for Implementation of Foreign Direct Investment Law, the Ministry of Economy shall provide information on the companies within the scope of foreign direct investments from Trade Registry Offices and related public institutions and organizations.
\end{abstract}

\section{Giriş}

Ülke ekonomilerinin kalkınma için sermayeye ihtiyacı vardır. Özellikle Türkiye gibi emek bol sermayenin kıt olduğu ülkelerde yabancı sermaye daha fazla önem kazanmaktadır. Yabancı sermaye, uygulamada "sıcak para" olarak ifade edilen finansal yada "doğrudan" olarak tanımlanan fiziksel olarak bir ülkeye girer. Doğrudan yabancı sermayenin de Türkiye'de mevcut bir şirketi yada tesisi satın almak yada sıfirdan sanayi yatırımı yapmak şeklinde iki ayrı türü söz konusudur (Cansen, 2019). Şirket satın alma veya birleşme şeklindeki birinci tür değil de daha çok istihdam ve katma değer sağlayan, yeni teknoloji getiren yeni yatırım şeklindeki ikinci tür Türkiye ekonomisine daha çok yarar sağlar (Ekinci, 2011).

Uzun dönemde ekonomik istikrarı yakalayacağı tahmin edilen ülkeler, yabancı sermayeyi daha çok çeker. $\mathrm{Ne}$ var ki, Avrupa, Ortadoğu ve Orta Asya arasındaki eşsiz jeopolitik konumu ve dünya enerji merkezlerine yakınlığı ile "bölgesel bir merkez" olma niteliğine; geniş iç pazarı, maliyet-etkin ve eğitimli iş gücü ve güçlü yerli sermayesine sahip Türkiye'nin doğrudan yabancı yatırımlar alanında hiçbir dönem kendisinden beklenen performansı sergilediği söylenemez. Doğrudan yabancı yatırımların ekonomik kalkınma stratejisinin temel bileşeni haline getirilmesi için ülke çıkarları ile yatırımcının çıkarları arasında akılcı bir dengenin sağlanması ve bu yönde stratejik politikaların izlenmesi gerekmektedir.

\section{Yabancı Yatırımlar ve Mevzuatın Gelișim Süreci}

Sadece ekonomik değil aynı zamanda uygun bir hukukî bir iklimi gerektiren yatırım iklimi nedeniyle yabancı yatırımcıların ihtiyaç ve beklentilerini dikkate alan, açık, anlaşılır ve şeffaf bir doğrudan yatırım mevzuatının varlığı zorunludur. 18 Ocak 1954 tarihinde yürürlüğe giren 6224 sayılı Yabancı Sermayeyi Teşvik Kanunu, dönemin doğrudan yabancı yatırımları için gerekli kanunî alt yapıyı sağlayan, oldukça liberal bir mevzuat olarak kabul edilmektedir. 6224 sayılı Kanunun isminde "Teşvik" ibaresinin yer almasının nedeni, o yıllar için teşvik unsuru olarak kabul edilebilecek kâr transferi, eşit muamele gibi hususları içermesi idi.

Ancak yatırım ortamının geliştirilmesine yönelik olarak gösterilen reform çabalarına karşın, 6224 sayılı Kanunun yürürlüğe girdiği tarihten bu yana doğrudan yatırımlara ilişkin olarak ortaya çıkan kavram ve uygulama farklılıklarını karşılamadaki ve yatırımcıların haklarını uluslararası standartlarda korumadaki eksikliği, yeni bir kanunun hazırlanması ihtiyacını doğurmuştur. Bu nedenle 4875 Sayılı Doğrudan Yabancı Yatırımlar Kanunu (DYYK) 17.06.2003 tarihinde yürürlüğe sokulmuştur. Uluslararası tanımlamalara da uygun olarak yeni kanunun ismi "Doğrudan Yabancı Yatırımlar Kanunu" olarak belirlenmiştir. DDYK ile doğrudan yatırımlara ilişkin temel kanun olarak dizayn edilerek Türkiye'nin uluslararası yatıımlara yönelik eşitlikçi ve liberal yaklaşımı yansıtmaya çalışılmıştır. Ayıca yeni Kanun'a yabancı yatırımcının değişik mevzuatlar gereği sahip olduğu haklar ve tâbi olduğu yükümlülükleri gösteren "yasal bir rehber" niteliği kazandırılmak istenmiştir (4875 Sayılı Kanunun 
Gerekçesi). Buna paralel olarak DYYK ile Mülga 6224 sayılı Kanun döneminde şirket kurmak, hisse devralmak, sermaye artışı için öngörülmüş bulunan formaliteler kaldırılmıştır.

\section{Yeni 4875 Sayılı DYYK ile Bilgilendirme Sistemine Geçiş}

Mülga 6224 sayılı Kanun sisteminde Türkiye'de yabancıların şirket kurması ve hisse devralmaları yada birleşmeler izne tabi idi. Ayrıca şirket ana sözleşmelerinde bir kısım kayıtların bulunması gerekiyordu. Yabancıların belirli miktarda döviz bloke etmeleri şart olduğu gibi kurulacak şirket türü bakımından bazı sinırlamalar öngörülmüştü.

DYYK ile, yabancıların şirket kurması ve şirket hissesi almalarında, izin-onay sisteminden "bilgilendirme" sistemine dönüş olmuştur. Buna göre, yabancı yatırımcılarla ilgili şirket bilgileri "Elektronik Teşvik Uygulama ve Yabancı Sermaye Bilgi Sistemi-E-TUYS” üzerinden Teşvik Uygulama ve Yabancı Sermaye Genel Müdürlüğü’ ne bildirilmesi gerekli ve yeterlidir. Bu bildirim dışında yabancılar Türkiye Cumhuriyeti vatandaşları ile eşit muameleye tabi tutuldukları için ayrıca bir izin veya onay süreci söz konusu değildir.

\subsection{Yabancı Yatırımeı - Yabancı Ortak Kavramları}

DYYK m.2 hükmünde Türkiye'de şirket kurmak isteyen yabancılar, yabancı yatıımcı kavramı altında gerçek kişi veya tüzel kişi olmalarına göre ayrı ayrı düzenlenmiş̧ir. Yabancı yatırımcı sayılma bakımından, gerçek kişiler yabancı ülke vatandaşları, Türkiye'de ikamet etmeyen Türkiye Cumhuriyeti vatandaşları gösterilmiştir. 5901 sayılı Türk Vatandaşlık Kanunu m.3 (1-d) hükmüne göre, Türkiye Cumhuriyeti Devleti ile vatandaşlık bağı bulunmayan kişi, Türk hukuku açısından yabancı sayılır (Aybay ve Kibar, 2010). 6458 sayılı Yabancılar ve Uluslararası Koruma Kanunu m. 3 (1-ş) hükmüne göre, hiçbir devlete vatandaşlık bağ ile bağlı bulunmayan vatansızlar, yabancı hükmündedir. Yine özel durumları nedeniyle Türkiye'de bulunan henüz Türkiye Cumhuriyeti vatandaşlığına geçmemiş, sığınmacılar, mülteciler ve göçmenler de yabancı olarak kabul edilirler.

Uygulamada Kuzey Kıbrıs Türk Cumhuriyeti vatandaşları, dayanağını ikili anlaşmadan alan Bakanlar Kurulu'nun 06.01.2001 gün ve 23928 sayılı kararıyla Türk soylu yabancı statüsünden çıkarılarak Türkiye Cumhuriyeti vatandaşlarına tanınan ikamet, çalışma, mülk edinme, ekonomik ve sosyal diğer bütün haklardan yararlanma hakkına sahip kılınmışlardır (Çiçekli, 2016).

DDYK, Türkiye Cumhuriyeti vatandaşlarını Türkiye'de ikamet etmiyorlarsa yabancı yatırımcı statüsünde görmektedir. DYYK Yönetmeliği m.18 hükmünde, Türkiye Cumhuriyeti vatandaşlarının yurt dışında ikamet ettiklerini ikamet veya çalışma izniyle ispat etmeleri halinde yabancı yatırımcı olarak kabul edilecekleri belirtilmektedir. Bunun yanında Türk vatandaşlığının yanında yabancı devlet vatandaşlığına sahip çifte vatandaşlar, Türk vatandaşı sayıldıklarından, Türkiye'de ikamet koşulunu sağlamaları halinde yabancı yatırımcı tanımına girmezler (Doğan, 2018).

DDYK m.2 hükmünde tüzel kişileri yabancı ülkelerin kanunlarına göre kurulmuş tüzel kişiler, uluslararası kuruluşlar, yabancı yatırımcı saymaktadır. Buna karşıslık, Türk Ticaret Siciline kayıtlı ve merkezi Türkiye'de bulunan bir şirket, ortakları yabancı olsa bile "Türk Şirketi” kabul edilir (Doğan 2018). Yabancı yatırımcı sayılmak için bir şirketin, vakfin, derneğin veya başka bir tür tüzel kişinin Türkiye dışında başka bir ülke kanunlarına göre kurulmaları yeterli olup, Türkiye'de faaliyette bulunmasının yada şubesinin bulunmasının önemi yoktur. Ayrıca Doğrudan Yabancı Yatırımlar Kanunu Uygulama Yönetmeliği m.6 hükmüne göre yabancı yatırımcıların Türkiye'de irtibat bürosu açmaları birtakım ön koşulların yerine gelmesine ve izin alınmasına bağlıdır.

\subsection{Yabancı Yatırım Sayılan Șirket İșlemleri}

DYYK m.2, yabancı yatırımcıların şirket kurmalarını, şube açmalarını veya hisse devralmalarını konulacak yada getirilecek sermaye niteliğine göre "yabancı yatırım" olarak tanımlamıştır. Birleşme veya bölünme yoluyla şirket kurmak yada hisse devralmak da aynı kurallara tabidir. Ancak oranı ne olursa olsun BİST dışında hisse edinmek veya BİST üzerinden en az \% 10 hisse oranı ya da aynı oranda oy hakkı sağlayan edinimler yoluyla mevcut bir şirkete hissedar olmak yabancı yatırım kapsamındadır. Bir işlem tanımlanan şekilde yabancı yatırım tanımına giriyorsa DYYK ve ilgili mevzuatına göre yürütülecektir.

Yabancı yatırım olarak tanımlanan bir işlemin kaynağı yurt dışından getirilebilir veya yurt içinden temin edilebilir. Yabancı yatırımcılar bu amaçla yurt dışından Türkiye Cumhuriyeti Merkez Bankası'nın alım satımını yapığı konvertibl para şeklinde nakit sermaye, şirket menkul kıymetleri (Devlet tahvilleri hariç), makine ve teçhizat, sınai ve fikri mülkiyet hakları getirebilirler.

Yabancı yatırımcının yurt içinden sağladığı yeniden yatırımda kullanılan kar, hasılat, para alacăğ, doğal kaynakların aranması ve çıkarılması haklarının sermaye olarak kullanılması da şirket kurma veya hisse devralma işlemini yabancı yatırım işlemi niteliğine büründürür. Maden ruhsatnamelerinin sermaye olarak kullanılması halinde yabancı yatırımcılar da Türkiye Cumhuriyeti vatandaşları gibi 2018/8 sayılı Cumhurbaşkanlığı Genelgesine göre izin almaları gerekir (Topaloğlu, 2018). Hatta Maden Yönetmeliğinin m.82(11) hükmüne göre maden ruhsatına sahip bir şirketin \%10'dan fazla oranda hisse devri, Enerji ve Tabi Kaynaklar Bakanlığının iznine tabidir. 


\subsection{Yabancı Yatırımcıların Kuracakları Şirket Türleri}

DYYK ile Türkiye'de yabancı yatırımcılar ile ilgili şirket tipi ile ilgili sınırlamalar da kalkmıştır. Daha önceki mevzuata göre yabancılar sadece sermaye şirketi (anonim ve limited şirket) kurabiliyorlar veya ortak olabiliyorlardı. Yeni düzenlemeyle şirket türü ile ilgili sınırlandırmalar kalkmıştır.

Doğrudan Yabancı Yatırımlar Kanunu Uygulama Yönetmeliği m.17 "Yabancı yatırımcıların kurabilecekleri veya iştirak edebilecekleri şirketler, Türk Ticaret Kanunu'nda düzenlenen şirketler ile Borçlar Kanunu'nda düzenlenen adi şirketlerdir. Adi ortaklık, konsorsiyum, iş ortaklı̆̆g, ortak girişim gibi isimler altında sözleşmeye dayalı olarak kurulan ve Türk Ticaret Kanunu'nda düzenlenen şirketlerin belirgin niteliklerini taşımayan ortaklıklar, Kanun 'un uygulanması bakımından adi şirket sayılırlar. " hükmünü öngörmektedir. Buna göre, yabancı yatırımcılar, TTK'da düzenlenen ticaret şirketlerinden birini veya TBK hükümlerine tabi adi şirket yapılanmalarından birini seçebilirler.

TTK m.124 hükmüne göre ticaret şirketleri; kollektif, komandit, anonim, limited ve kooperatif şirketlerden ibarettir. Ticaret şirketlerinden kollektif, komandit, limited ve anonim şirketler bakımından herhangi bir duraksama yoktur. Tartışmalı olmakla birlikte ayrı bir kanunla Kooperatifler Kanunu ile düzenlenen kooperatifler de ticaret şirketi sayılmaktadır (Bahtiyar, 2019). DYYK Yönetmeliği 17.maddesinde "Türk Ticaret Kanununda düzenlenen" ibaresini kullandığından TTK m.124 hükmü gereği yabancı yatırımcıların kooperatif kurmaları veya kooperatif üyeliği devralmaları mümkündür. Ancak nihai olarak bireysel ilişkiye geçerek taşınmaz mülkiyeti edinmeyi amaçlayan yapı kooperatifi üyeliği, yabancıların Türkiye'de taşınmaz mal edinmelerine ilişkin kurallara bağlıdır (Çalışkan, 2010).

Adi şirketler esasen Türk Borçlar Kanunu m.620 ve devamında düzenlenmiştir. Buna göre iki veya daha fazla kişi ortak bir amaca ulaşmak için emek ve sermayelerini birleştirmeleri halinde adi şirket kurulmuş olur. Adi ortaklığın birçok türü bulunmakta ve herhangi bir kanunda düzenlenen ortaklığın ayırt edici niteliğini taşımayan ortaklıklar adi ortaklık sayılmaktadır. DYYK Yönetmeliği 17.maddesinde adi ortaklığın türleri olan konsorsiyum, iş ortaklığı ve ortak girişim gibi ortaklıklar yabancı yatırımcı kavramına dahildirler. Yurt dışında mevcut fakat Türk Ticaret Kanunu'nda öngörülen unsurları taşımayan ortaklık tipleri de DYYK'nın uygulanması açısından adi ortaklık olarak kabul edilirler.

\subsection{Kurulacak Şirketlerde Sermaye Miktarı}

DYYK sisteminde, istisnası kanunla öngörülmedikçe, yabancılar, yerli yatırımcılarla eşit muameleye tabi tutulurlar. Yeni sistemle Mülga 6224 sayılı Kanun döneminde ortak başına 50.000.-ABD Doları getirme şartı kaldırılmıştır. TTK uyarınca TC vatandaşları gibi yabancı yatırımcıların kuracakları yada hisse sahibi anonim şirketler için 50.000-TL, limited şirketlerde 10.000-TL asgari sermaye gerekir. Ayrıca özel kanunlarında halka açık şirketler ve finansman şirketleri gibi konularına göre bazı anonim şirketlere daha yüksek sermaye oranıyla kurulma şartı getirilmiştir. Bunun dışında Kollektif ve Komandit şirketler için asgari sermaye öngörülmemiştir (Bahtiyar, 2019). TBK'ya tabi adi şirketler ve türleri olan konsorsiyum, iş ortaklığ ve ortak girişim vb için de asgari sermaye aranmaz. Dolayısıyla yabancı yatırımcılar, sadece anonim ve limited şirketler için TC vatandaşları için öngörülen asgari sermaye şartına onlarla eşit olarak tabi bulunmaktadırlar. Yabancı yatırımcılar için ayrıca bir sermaye oranı ve bloke şartı söz konusu değildir.

\subsection{Yabancı Yatırımcılardan İstenen Özel Belgeler}

Yabancı yatırımcılar, şirket kuruluşunda ve DYYK'a tabi hisse devirlerinde, Türkiye Cumhuriyeti vatandaşlarından ayrı olarak birtakım ek belge sunmaları gerekmektedir:

Yabancı yatırımcı sayılan gerçek kişiler;

- tercüme edilmiş noter onaylı pasaport sureti,

- potansiyel vergi numarası dökümü,

sunmaları gerekir.

Yabancı yatırımcı tüzel kişiler;

Türk Konsolosluğundan veya şirketin kayıtlı bulunduğu sanayi ve/veya ticaret odasınca veya yetkili mahkemelerce tanzim edilmiş faaliyet belgesi aslı (apostil şerhli) ve noter onaylı tercümesini ibraz etmek zorundadirlar.

\section{Yabancı Yatırımcıların Bilgilendirme Yükümlülüğü}

Doğrudan yabancı yatırımlarla ilgili mevzuatta bir yandan eşitlikçi ve liberal bir sistem getirilirken diğer yandan yabancıların ekonomik aktivitelerini izleyecek bir mekanizma oluşturulmuştur.

\subsection{E- TUYS Yetkilendirmesine Sahip Kullanıcı Ataması}

DYYK Yönetmeliğinde 1 Haziran 2018 tarihinde yapılan değişiklikle E-TUYS Sisteminde işlem yapacak "Kullanıcı" lar düzenlenmiştir. Yönetmeliğe göre, yabancı yatırımcıların bir ya da birkaç kişinin şirket adına kullanıcı olarak atanması için Teşvik Uygulama ve Yabancı Sermaye Genel Müdürlüğü’ne başvurmaları gerekir. 
Genel Müdürlük tarafından bildirilen kişiye kullanıcı yetkisi verilir. Kullanıcı, yabancı yatırımcı sayılan şirketle ilgili Yönetmelikte belirtilen bilgileri nitelikli elektronik imza kullanarak E-TUYS sistemine yükler.

\subsection{Yabancı Yatırımcılarla İlgili E-TUYS'a Yüklenecek Bilgiler}

DYYK Yönetmeliği kullanıcılara yabancı yatırım kapsamındaki şirketlerle ilgili bilgileri E-TUYS sistemine yükleme zorunluluğu getirmektedir.

Yabancı yatırımcılar, kullanıcı vasıtasıyla E-TUYS Sistemine;

- kullanıcının yetkilendirilmesini müteakip 1 ay içinde "Yatırımcı", "Ortak Listesi”" ve varsa "Bağlı İștirakleri" alanlarındaki bilgileri,

- yıllık bazda ve her yıl en geç Mayıs ayı sonuna kadar Faaliyetlerine ilişkin EK-1 Doğrudan Yabancı Yatırımlar İçin Faaliyet Bilgi Formunda yer alan bilgileri,

- sermaye artışı veya azalışı gerçekleşmesi durumunda en geç 1 ay içinde, E- "Ortaklar Listesi" alanındaki bilgileri,

- sermaye artışı veya hisse devrine istinaden ödemeyi takip eden 1 ay içinde EK-2 Doğrudan Yabancı Yatırımlar İçin Sermaye Bilgi Formundaki alanına ödeme bilgisini,

- mevcut yerli veya yabancı ortakların kendi aralarındaki veya şirket dışındaki herhangi bir yerli veya yabancı yatırımcıya yaptıkları hisse devirleri sonrasında "Ortaklar Listesi" alanını, hisse devrinin gerçekleşmesini müteakip en geç 1 ay içinde,

elektronik ortamda doldurarak kaydedilmesini sağlarlar.

\subsection{Yerli Şirkete Yabancı Yatırımcının Ortak Olması ve Bildirim}

Yabancı yatırım niteliği bulunmayan tamamen yerli sermayeli şirketlere, yabancı bir yatırımcının; hisse devri veya sermaye artışına iştirak yoluyla ortak olması halinde, şirket 4875 sayılı Kanun'a tabi olur. Böyle bir durumda, şirket, bir kullanıcı atanmasını sağlayarak, E-TUYS'ta yer alan "Yatırımcı", "Ortak Listesi" ve varsa "Bağlı İştirakleri”" alanlarındaki bilgileri, hisse devrinin gerçekleşmesini müteakip en geç 1 ay içinde, kullanıcı vasıtasıyla elektronik ortama kaydettirmek zorundadır.

\subsection{Ekonomi Bakanlığının Bilgi Toplaması}

DYYK Yönetmeliği m.4 uyarınca Bakanlık, ilgili kamu kurum ve kuruluşlardan doğrudan yabancı yatırımlar kapsamında şirketlerle ilgili bilgi temin eder. Bu çerçevede; ilgili Ticaret Sicil Memurlukları, DYYK kapsamındaki şirket ve şubelerle ilgili;

- $\quad$ kuruluş aşamasında ilgililerce doldurulacak "Şirket ve Şube Kuruluş Bildirim Formu ve Dilekçesi"nin bir nüshasını;

- bu şirketlerin tescil ve ilana tabi her türlü ana sözleşme değişikliklerinin bir nüshasını;

- bu şirketlerce ilgili Ticaret Sicil Memurluğuna iletilen "Ortaklar Listesi” veya "Hazirun Cetveli"nin bir nüshasını, Ekonomi Bakanlığına gönderirler.

Ayrıca, ticaret siciline tescil olunan adi şirket ticari işletmesine ait bilgiler de aynı şekilde gönderilir.

\subsection{Yabancı Yatırımlarla İlgili Bilgi Toplama ve Kullanımı}

Yabancı yatırımlarla ilgili istatistiki bilgilerin toplanması makro ekonomik politikalar açısından çok önemlidir. Bu hususu düzenleyen DYYK’nun 4. maddesine göre, Hazine Müsteşarllğı, (Maliye ve Hazine Bakanlığı), yabancı yatırımlar hakkındaki istatistiki bilgileri, her türlü kamu kurum ve kuruluşları ile özel kesim meslek kuruluşlarından istemeye yetkilidir.

Yabancı yatırımcılar, yatırımları ile ilgili istatistiki bilgileri Müsteşarlıkça hazırlanacak yönetmelikle belirlenen usul ve esaslar çerçevesinde Müsteşarlığa (Maliye ve Hazine Bakanlığı) bildirirler. Söz konusu bilgiler istatistik amaçları dışında ispat aracı olarak kullanılamaz.

\section{Sonuç}

Türkiye'ye istihdam sağlayan ve katma değer yaratan ve yeni teknolojiler getiren yabancı sermayenin ülke kalkınmasında önemli rol oynayacağı açıktır. İşte bu tür yabancı sermayeyi doğrudan yatırım yoluyla çekecek hukuk ikliminin ve uygulamasının uluslararası gelişmelere uygun inşa edilmesi gerekir. DYYK, bu amaçla çıkarılmış liberal ve eşitlikçi bir kanun olmasına karşın yürürlüğe girdiği 15 yıldan bu yana doğrudan yabancı yatırımlarda büyük artı̧̧a sebep olamamıştır. Maalesef idari uygulamalar Kanun'un gerisinde kalmış, teşvik edici olmaktan ziyade bazı durumlarda caydırıcı bir etki göstermiştir.

DYYK, sistematik olarak eksiklikleri olsa da yabancı yatırımcıların şirket kurmaları ve hisse devralmaları konusunda genel hükümler getirmiştir. DYYK'da yeterli hüküm olmadığı için yabancı yatırımlarla ilgili birçok husus Uygulama Yönetmeliğine bırakılmıştır. Uygulama Yönetmeliği ile getirilen Elektronik Teşvik Uygulama ve Yabancı Sermaye Bilgi Sistemi-E-TUYS son derece modern ve yenilikçi bir uygulamadır. 


\section{Kaynakça}

- Aybar ve Dardağan Kibar, 2010. Yabancılar Hukuku. İstanbul Bilgi Üniversitesi Yayınları, İstanbul.

- Bahtiyar, 2019. Ortaklıklar Hukuku. Beta, İstanbul.

- Barlas, 2016. Adi Ortaklık Temeline Dayalı Sözleşme İlişkileri. Vedat Kitapçılık, İstanbul.

- Cansen, 2019. "Yabanc1 Sermaye ile Kalkınma ve Döviz Fiyatları”, Sözcü, p.6.

- Çalışkan, 2010. "Yapı Kooperatiflerinde Yabancıların Ortaklığı”, Mali Çözüm, 2010, p.163.

- Çiçekli, 2016. Yabancılar ve Mülteci Hukuku. Seçkin, Ankara.

- Doğan, 2018. Türk Yabancılar Hukuku. Savaş Yayınevi, Ankara.

- Ekinci, 2011. "Doğrudan Yabancı Yatırımların Ekonomik Büyüme ve İstihdama Etkisi: Türkiye Uygulaması (1980-2010)”, Eskişehir Osmangazi Üniversitesi İ̈BF Dergisi, 6(2), p.71.

- Topaloğlu, 2018. "Madencilik İzinleriyle İlgili Cumhurbaşkanlığı Genelgesi Uygulaması”, Sektör Maden, 69, p.34 


\title{
Türk ve Fransız Anayasalarında Laiklik İlkesi Principle of Laicity in Turkish and French Constitutions
}

\author{
Assoc. Prof. Dr. Ebru Karaman (Beykent University, Turkey)
}

\begin{abstract}
To be assumed as a truly democratic state of law; the state should not make law according to a religion and not have a religion-based structure. Turkey and France are two countries different from others being in the discussions on secularism examining the relationship between religion and state. Because the laicity is one of the foundations of the regime and takes part in the legal system as a constitutional principle.

In the first chapter the provisions on laicity in the Turkish Constitutions before the date 1982 and in the Turkish Constitution dated 1982 are going to be explained then the discussions in Turkey are going to be evaluated according to the Turkish Constitutional Court's approach to the principle of laicity. In the second part the provisions on the principle of laicity in the French Constitution dated 1958 are going to be explained, afterwards the discussions on laicity in France is going to take place.

State and religion relations continue to be relevant a subject. That is why it still gives form to Turkish political life. The freedom of religion and the separation of religious and state relations are the requirements of the laic state. For a state these includes not to have an official religion, be impartial to all the religion and to treat equal to all the believers to different religions, to distinguish the religious institutions and state institutions and not to have an accordance between the rules of and the rules of religion.
\end{abstract}

\section{Giriş}

"Lâiklik" dilimize Fransızca "laïc" sıfatından girmiştir. Bu kelime de Latince "laicus" kelimesinden gelmektedir. Bu kelime din adamları sınıfina ait olmayan demektir (Robert, 1991). Dilimize bu kelime ilk defa meşrutiyet yıllarında girmiş ve "lâdini”" olarak Türkçeye tercüme edilmiştir. "Ladinî” Devellioğlu'nun OsmanlıcaTürkçe Sözlüğüne göre "dindışı” demektir (Gözler, 2018). Türkçede kullanılan "lâiklik” terimi Fransızca, "laïcisme"in değil, "laïcité"nin karşılığıdır. Laïcisme, "lâiklik" değil, "laikçilik" demektir. Laïcité, "sivil toplum ile dinsel toplumun ayrılığı ilkesi" demektir. Laïcisme ise, "kurumlara dinsel olmayan bir nitelik vermeyi amaçlayan doktrin" demektir (Robert, 1991). Lâiklik yerine bazen "sekülarizm” teriminin kullanıldı̆̆g da görülmektedir. Sekülarizm, "dinin toplumsal hayattaki öneminin azalması ve dindarlığın zayıflaması demektir". Dolayısıyla bu kavram hukukî değil, sosyolojik bir kavramdır (Gözler, 2018). 1982 Anayasası'nda "laikçilik (laïcisme)" kelimesi kullanılmamakta, "lâiklik" ve "lâik Cumhuriyet" ifadeleri kullanılmaktadır.

Lâikliğin çok çeşitli tanımları yapılmıştır. Laiklik, kamusal siyasi yaşamda din kurallarından arınmış, insanların eşitliğini, akıl ve bilimi temel almış bir yaşam biçimidir (Saylan, 2001). Başgil'e göre laiklik, din ile devletin birbirinden ayrılması ve devletin din, dinin de devlet işlerine karışmaması, memlekette mevcut ve maruf din ve mezheplere karşı devletin tarafsız vaziyet alması, bunlardan hiçbirini, diğeri aleyhine olarak, hususi surette imtiyazlandırmaması; buna mukabil dinin de devlete karşı nisbi de olsa, bir muhtariyet içinde ahlaki ve manevi hayatın nizamı olarak hüküm sürmesidir (Başgil, 1998). Sağlam, konuya farklı bir yaklaşım getirerek, her ülkenin farklı siyasi, ekonomik ve tarihsel koşullara, farklı bir din anlayışına sahip olduğundan yola çıkarak, laiklik tanımının da ülkeden ülkeye değişebileceğini ve bu sebeple genel bir tanım vermenin doğru olmayacağını düşünmektedir (Sağlam, 2009). Kanadoğlu ise, hem bir ideoloji hem de bir aksiyon olarak kabul edilmesi gereken laikliğin anlam ve tanımının, onun ait olduğu dildeki işlevine bakılarak yapılmasının en sağlıklı yol olduğunu düşünmektedir (Kanadoğlu, 2013).

Anayasa Mahkemesi kararlarında, laikliğin hukuki, sosyal ve siyasi tanımlarına değindikten sonra özenle korunması gereken çok önemli bir anayasal ilke olduğu üzerinde durmuştur. Anayasa Mahkemesine göre laiklik, Ortaçağ dogmatizmini yıkarak aklın öncülüğünü, bilimin aydınlığı ile gelişen demokrasi ve özgürlük anlayışını, uluslaşmayı, bağımsızlığı, ulusal egemenliği ve insanlık idealini temel kılan uygar bir yaşama biçimidir. Laiklik egemenliğe, demokrasiyle birlikte özgürlüğe, bilgi bileşimine dayanan toplumsal bir atılım, siyasal, kültürel ve sosyal yaşamın çağdaş düzenleyicisidir. Anayasa Mahkemesi bazı kararlarında, laikliğin her ülkenin kendi şartlarına göre farklılık arz edebileceğini belirterek, özellikle İslam Dini ile Hıristiyanlık arasındaki farklılıklara değinmiş ve Türkiye şartlarına uygun bir laiklik anlayışı belirleme yoluna gitmiştir (E.1971/53, K.1971/76, KT.21.10.1971; E.1980/19, K.1980/48, KT. 03.07.1980; E.1982/3, K.1983/1, KT.25.10.1983; E.1986/11, K.1986/26, KT.04.11.1986; E.1989/1, K.1989/12, KT.07.03.1989).

Laikliğin tanımından daha ziyade, doğrudan laikliğin gerekleri veya lâik bir devletin taşıması gereken nitelikler üzerinde durmak daha yerinde olacaktır. Bir devletin lâik olabilmesi için taşıması gerekli olan şartlar vardır. Laikliğin birinci cephesi din hürriyetidir. Bir devletin laik olabilmesi için, o devlette din hürriyetinin tanınmış ve güvence altına alınmış olması gerekmektedir. Din hürriyeti de kendi içinde "inanç hürriyeti" ve "ibadet hürriyeti" olarak ikiye ayrilır. 
İnanç hürriyeti, kişinin istediği dini seçebileceği anlamına gelir. Keza bir dini seçmekte hür olan kişi, herhangi bir dini seçmeme hakkına da sahiptir. Bir devletin lâik olabilmesi için, o devlette inanç hürriyeti tanınmış olmalıdır.

Anayasa'nın 24. maddesinin ilk fikrasında "herkes, vicdan, dinî inanç ve kanaat hürriyetine sahiptir" diyerek "inanç hürriyeti”ni tanımıştır. "İnanç hürriyeti"ne maddenin kendisinde bir özel sınır da getirilmemiştir. Keza, Anayasa "kimse... dinî inanç ve kanaatleri açılamaya zorlanamaz; dinî inanç ve kanaatlerinden dolayı kınanamaz ve suçlanamaz" (m.24/3) diyerek, inanç hürriyetine bir ek güvence de getirmektedir. Anayasamız olağanüstü hallerde dahi dinî inanç hürriyetini özel olarak korumaktadır. Anayasa'nın 15. maddesinin 2. fikrasına göre; savaş, seferberlik veya olağanüstü hallerde bile, "kimse din, vicdan, düşünce ve kanaatlerini açıklamaya zorlanamaz".

Anayasa Mahkemesi de 4 Kasım 1986 tarih ve K.1986/26 sayılı kararında inanç hürriyeti konusunda şöyle demiş̧ir: "Lâik devlette herkes dinini seçmekte ve inançlarını açığa vurabilmekte, tanınmış olan din ve vicdan özgürlüğünün sınırları içinde serbesttir. Hiçbir dine itikadı olmayanlar için de durum aynıdır. Lâik bir toplumda herkes istediği dine veya inanca sahip olabilir. Bu husus yasa koyucunun her türlü etki ve müdahalesinin dışındadır".

Anayasa'nın 24. maddesinde ifadesini bulan ve Anayasa güvencesinde olan din ve vicdan özgürlüğü sadece semavî dinlere inananlara özgü değildir. Ülke toprakları üzerinde yaşayan herkes bu özgürlüğe sahiptir”. Keza inanç hürriyeti bakımından bir din içinde mezhepler ve tarikatlar bakımından ayrım yapılamaz. Lâik devlet, kişinin anladığı anlamda dinin gerçekten bir "din" oluşturup oluşturmadığını veya oluşturuyorsa hangi dini oluşturduğunu araştıramaz.

Din hürriyetinin ikinci veçhesini "ibadet hürriyeti” oluşturur. İbadet en geniş anlamda bir dinin gereklerini yerine getirmek demektir. O halde ibadet hürriyeti, kişinin inandığı dinin gereklerini, özellikle ayin ve törenlerini serbestçe yerine getirebilmesi demektir. Bir devletin lâik olabilmesi için, o devlette ibadet hürriyetinin de tanınmış olması gerekir. Anayasa, ibadet hürriyetini "14'üncü madde hükümlerine aykırı olmamak şartıyla ibadet, dinî ayin ve törenler serbesttir" (m.24/2) diyerek tanımıştır. İbadet hürriyeti, inanç hürriyeti gibi mutlak bir şekilde değil, 14. madde ile sınırlı olarak tanınmıştır. İbadet hürriyeti, ibadet etmeme hürriyetini de içerir. Lâik bir devlette kişilere zorla ibadet ettirilemez. Anayasa "kimse, ibadete, dinî ayin ve törenlere katılmaya... zorlanamaz" (m.24/3) diyerek, ibadet etmeme hürriyetini de güvence altına almıştır.

Anayasa Mahkemesi, 1982 Anayasası döneminde verdiği kararlarında da ibadet hürriyetinin sınırlandırılabileceği görüşünü sürdürmüştür: 4 Kasım 1986 tarih ve K.1986/26 sayılı Kararında Anayasa Mahkemesi, "Türkiye Cumhuriyeti Anayasasında kabul edilmiş lâiklik ilkesinin esaslarından" birinin "dinin bireyin manevî hayatını aşarak toplumsal hayatı etkileyen ve davranışlara ilişkin bölümlerinde, kamu düzenini, güvenini ve çıkarlarını korumak amacıyla, sınırlamalar kabul etme ve dinin kötüye kullanılmasını ve sömürülmesini yasaklama" olduğuna işaret etmiştir.

Laikliğin ikinci cephesi din ve devlet işlerinin ayrılığıdır. Bir devlette, din ve devlet işlerinin birbirinden ayrılmış olduğunu söyleyebilmek için aşağıdaki şartların yerine getirilmesi gerekir.

Devletin Resmî Bir Dini Olmamalıdır: Din kurallarının muhatabı gerçek kişilerdir. Sevap ve günah ancak gerçek kişiler tarafından işlenebilir. O halde bir tüzel kişi olan devletin zaten bu anlamda bir dininin olması düşünülemez. Ancak buna rağmen, tarihsel olarak birçok anayasa, devlet-din ilişkileri konusunda hüküm getirmektedir. Bir anayasa dört şekilde din-devlet ilişkilerini düzenleyebilir: a) Resmi din; Anayasa açıç̧a devletin resmî bir dininin olduğunu belirtebilir. Bu ihtimalin tipik örneği 1876 Kanun-i Esasî'dir. b) Hâkim din; devletin resmî bir dininin olduğunu açıkça belirtmemekle birlikte, anayasa dinlerden birine üstünlük tanımış olabilir. Keza anayasada, belirli bir dinin veya mezhebin ismi zikredilir; Tanrının varlığına atıfta bulunulur. Bu ihtimalin örneği, Yunan Anayasası'dır. c) Hüküm İçermeme; Anayasa devletin dini konusunda hiçbir hüküm içermez. Lâiklik ilkesi açıkça kabul edilmese bile böyle bir anayasa, diğer şartları taşıyorsa lâik olarak kabul edilebilir. Bu ihtimale 1928-1937 arasında 1924 Teşkilât-1 Esasîye Kanunu örnek gösterilebilir. d) Lâiklik; Anayasa açıcça devlet-din ilişkileri konusunda "lâiklik" ilkesini kabul edebilir. Böyle bir devlette resmî bir devlet dini de yoktur. Diğer şartları taşımak kaydıyla böyle bir devleti lâik olarak kabul etmek gerekir. Bu ihtimale 1937'den bu yana Türk Anayasaları örnek gösterilebilir.

Devlet Bütün Dinler Karşısında Tarafsız Olmalıdır: Bir devletin lâik olabilmesi için, o devletin bütün dinler karşısında tarafsız olması, bu dinlerden birini himaye etmemesi veya bu dinlerden bazıları üzerinde baskı uygulamaması gerekir. Şüphesiz ki, toplumda birçok din olabilir. Toplumsal olarak bu dinlerden biri diğerlerine nazaran daha yaygın olabilir. Ancak devlet, yaygın olan dine üstünlük tanıyamaz. Dolayısıyla devlet, belirli bir dinin toplumda benimsenmesi, o dinin kurallarının toplumda öğrenilmesi için faaliyette bulunamaz. Bunun doğal sonucu olarak, devlet vatandaşlarına belirli bir dinin eğitim ve öğrenimini zorunlu kılamaz.

Bu bakımdan 1982 Anayasası'nın 24. maddesinin 4. fikrasında yer alan "din kültürü ve ahlâk öğretimi ilk ve ortaöğretim kurumlarında okutulan zorunlu dersler arasında yer alır" hükmünün lâiklik ilkesiyle bağdaştırılması oldukça güçtür. Burada her halükârda Anayasada zorunlu tutulan şeyin "din öğretimi” değil, "din kültürü ve ahlâk öğretimi” olduğunun altı çizilmelidir. Eğer uygulamada verilen "din kültürü ve ahlâk dersleri” genel bir din kültürüne ilişkin değil, belli bir dinin eğitimine ilişkin ise, bu lâiklik ilkesine aykırı olur. 
Devlet Bütün Din Mensuplarına Eşit Davranmalıdır: Lâikliğin gereklerinden biri de devletin bütün din mensuplarına eşit davranmasıdır. Bu ilke temelini ayrıca Anayasanın "kanun önünde eşitlik" ilkesini düzenleyen 10. maddesinden de almaktadır: "Herkes... din, mezhep ve benzeri sebeplerle ayırım gözetilmeksizin kanun önünde eşittir... Devlet organları ve idare makamları bütün işlemlerinde kanun önünde eşitlik ilkesine uygun olarak hareket etmek zorundadırlar".

Din Kurumları ile Devlet Kurumları Birbirinden Ayrı Olmalıdır: Lâik bir devlette din kurumları ile devlet kurumları birbirinden ayrı olmalıdır. Ergun Özbudun'un ifadesiyle, "lâik bir devlette din kurumları devlet fonksiyonlarını göremeyeceği gibi, devlet kurumları da din fonksiyonlarını ifa edemez. Diğer bir ifadeyle, lâik devlet, gerek 'dine bağlı devlet', gerek 'devlete bağlı din' sistemlerini reddeden, din ve devlet işlerini alan olarak birbirinden tamamen ayıran bir yönetim sistemidir”.

Hukuk Kuralları Din Kurallarına Uymak Zorunda Olmamalıdır: Lâik bir devlette hukuk kurallarının kaynağı beşerî iradedir. Lâik bir sistemde, hukuk kurallarını koyan beşerî iradenin din kurallarına uymak zorunda olmaması gerekir. Eğer bir devlette hukuk kurallarının din kurallarına uyma zorunluluğu varsa, o devlet lâik bir devlet değildir. Örneğin 1876 Kanun-u Esasîsine göre, Heyet-i Âyan, Heyet-i Mebusan tarafindan kabul edilen kanun tekliflerini “umuru diniye'ye" uygunluk açısından denetlemekle görevliydi (m.64). Oysa 1982 Anayasasında hukuk kurallarının din kurallarına uyma zorunluluğunu getiren herhangi bir hüküm yoktur. Bu anlamda 1982 Anayasası lâik bir hukuk sistemi öngörmektedir.

\section{Türk Anayasası’nda Laiklik İlkesi}

Lâiklik ilkesini benimsemiş olan Türkiye'de, 1924 Anayasası'na 1937 yılında yapılan bir değişiklikle laiklik ilkesi Anayasal bir hüküm haline gelmiştir. Türk pozitif hukuku açısından "laiklik" üzerinde durulması gereken önemli bir ilkedir. Laik ya da seküler devlet dine dayanmaz. Bu kural laiklik ilkesi için önkoşul olarak karşımıza çıkmaktadır (Tanör, Yüzbaşıŏlu, 2018).

1982 Anayasası'nın, 1961 Anayasası'na nazaran daha kısıtlayıcı olduğu iddia edilse de, 1982 Anayasası'nda laiklik konusunda, 1961 Anayasası'nda kabul edilen değerlerin korunmaya çalışıldığı görülmektedir. 1982 Anayasası'nda, Atatürk ilke ve inkılâplarından olan "laikliğin" özel bir yeri vardır. 1982 Anayasası birçok hükmünde cumhuriyetin laik niteliğine atıfta bulunmakta ve "laik cumhuriyetin", Türkiye'nin önemli unsurlarından biri olduğunun altını çizmektedir. Zira laiklik ilkesi, Türkiye Cumhuriyeti'nin temelini oluşturmaktadır. Bu nedenle, 1982 Anayasası'nda laiklik ilkesine Anayasa'nın Başlangıç bölümünde, 2, 4, 13, 14, 24, 42, 58, 68, 81, 103, 136, ve 174. maddelerinde yer verilmiştir.

1982 Anayasası'nın başlangıç bölümü 03.102001 tarih ve 4709 sayılı Kanunla değiştirilmiş ve Anayasa’ya "Hiçbir faaliyetin Türk milli menfaatlerinin, Türk varlığının, Devleti ve ülkesiyle bölünmezliği esasının, Türklüğün tarihi ve manevî değerlerinin, Atatürk milliyetçiliği, ilke ve inkılâpları ve medeniyetçiliğinin karşısında korunma göremeyeceği ve laiklik ilkesinin gereği olarak kutsal din duygularının, Devlet işlerine ve politikaya kesinlikle karıştırılmayacağı” şeklinde bir paragraf eklenmiştir (prg.4).

Anayasa'nın başlangıcı laiklik ilkesinin gereği olarak kutsal sayılan din duygularının, devlet işlerine ve politikaya karıştırılmasını yasaklamaktadır. Anayasa, bireysel-vicdani bir mesele olmak ve devlet işlerine, kamusal hayata karıştırılmamak kaydıyla din duygularını kutsal saymaktadır.

Cumhuriyetin niteliklerinin düzenlendiği Anayasa'nın 2. maddesi; Türkiye Cumhuriyeti'ni, toplumun huzuru, millî dayanışma ve adalet anlayışı içinde, insan haklarına saygıll, Atatürk milliyetçiliğine bağlı, başlangıçta belirtilen temel ilkelere dayanan, demokratik, lâik ve sosyal bir hukuk Devleti olarak tanımlamıştır. Söz konusu maddede sayılan Cumhuriyet'in nitelikleri ise, Anayasa'nın 4. maddesi ile koruma altına alınmıştır. Değiştirilemeyecek hükümler başlığını taşıyan bu madde, Cumhuriyet olan devletin şekli ile Cumhuriyetin niteliklerinin değiştirilmesinin teklif dahi edilemeyeceğini hükme bağlamıştır.

Anayasa'nın eşitliğe ilişkin 10. maddesinin 4. fikrasında da "Hiçbir kişiye, aileye, zümreye veya sınıfa imtiyaz tanınamaz." hükmü ile Devlet organlarının din ve inanç ayrımı gözetmeksizin herkese eşit mesafede durması gerektiğine vurgu yapılmıştır.

Laik devletin yer aldığı diğer iki madde ise; temel hak ve hürriyetlerin sınırlanmasını düzenleyen Anayasa'nın 13 maddesi ile temel hak ve hürriyetlerin kötüye kullanılmamasını düzenleyen Anayasa'nın 14. maddesidir. 2001 Anayasa değişiklikleri ile değiştirilen Anayasa'nın 13. maddesi uyarınca; temel hak ve hürriyetler, özlerine dokunulmaksızın yalnızca Anayasanın ilgili maddelerinde belirtilen sebeplere bağlı olarak ve ancak kanunla sınırlanabilir. Bu sınırlamalar, Anayasanın sözüne ve ruhuna, demokratik toplum düzeninin ve lâik Cumhuriyetin gereklerine ve ölçülülük ilkesine aykırı olamaz.

Anayasa'nın 14. maddesi ise; "Anayasada yer alan hak ve hürriyetlerden hiçbiri, Devletin ülkesi ve milletiyle bölünmez bütünlüğünü bozmayı ve insan haklarına dayanan demokratik ve lâik Cumhuriyeti ortadan kaldırmayı amaçlayan faaliyetler biçiminde kullanılamaz." şeklindedir. Anılan maddeye göre, temel hakkını kullanan bir kişi, din veya mezhebe dayanan bir devlet düzeni kurmak istediği takdirde hakkını kötüye kullanıyor olacaktır. 
Dolayısıyla bu doğrultuda, sivil ve kamusal hayatta ortaya çıkan dini saikli eylemler yasal şartların oluşması halinde laiklik karşıtı kabul edilecektir.

1982 Anayasası'nın laiklikle ilgili önemli maddelerinden birisi de 24. maddede yer alan düzenlemedir. Din ve vicdan hürriyetini düzenleyen Anayasa'nın 24. maddesinin ilk iki fikrası; herkesin, vicdan, dinî inanç ve kanaat hürriyetine sahip olduğunu; ancak 14. maddede belirtilen temel hak ve hürriyetlerin kötüye kullanılmaması şartıyla ibadet, dinî ayin ve törenlerin serbest olduğu hükme bağlanmıştır. Bu hüküm uyarınca; ibadet hürriyeti, Anayasada devletin ülkesi ve milletiyle bölünmez bütünlüğünü bozmayı ve insan haklarına dayanan demokratik ve lâik Cumhuriyeti ortadan kaldırmayı amaçlayan faaliyetler biçiminde kullanılamaz.

Laiklik ilkesi ile bağlantılı bir diğer madde ise; eğitim ve öğretim hak ve ödevini düzenleyen Anayasa'nın 42. maddesidir. Bu maddeye göre; "kimse, eğitim ve öğrenim hakkından yoksun bırakılamaz. Eğitim ve öğretim, Atatürk ilkeleri ve inkılâpları doğrultusunda, çağdaş bilim ve eğitim esaslarına göre, Devletin gözetim ve denetimi altında yapılır. Bu esaslara aykırı eğitim ve öğretim yerleri açılamaz."

Gençliğin korunmasına ilişkin Anayasa'nın 58. maddesi de Atatürk ilke ve inkılaplarından bahsetmektedir. Buna göre; "devlet, istiklâl ve Cumhuriyetimizin emanet edildiği gençlerin müsbet ilmin ışığında, Atatürk ilke ve inkılâpları doğrultusunda ve Devletin ülkesi ve milletiyle bölünmez bütünlüğünü ortadan kaldırmayı amaç edinen görüşlere karşı yetişme ve gelişmelerini sağlayıcı tedbirleri alır." Bu madde de laikliğe dolaylı olarak vurgu yapmaktadır.

Siyasi partilere ilişkin Anayasa'nın 68. maddesine göre; siyasî partilerin tüzük ve programları ile eylemleri, Devletin bağımsızlı̆̆na, ülkesi ve milletiyle bölünmez bütünlüğüne, insan haklarına, eşitlik ve hukuk devleti ilkelerine, millet egemenliğine, demokratik ve lâik Cumhuriyet ilkelerine aykırı olamaz; sınıf veya zümre diktatörlüğünü veya herhangi bir tür diktatörlüğü savunmayı ve yerleştirmeyi amaçlayamaz; suç işlenmesini teşvik edemez.

$\mathrm{Bu}$ düzenleme, laiklik açısından siyasi partilerin faaliyetlerine yönelik ciddi bir güvence oluşturmaktadır. Nitekim bu maddeyi izleyen 69. maddenin 5. fikrası uyarınca yasağa aykırı hareket eden siyasi partiler Anayasa Mahkemesi tarafından kapatılacaktır. Burada doğrudan doğruya siyasi faaliyetle ilgili ve laik cumhuriyetin korunması amaçlı bir kısıtlama yer almaktadır. 68. maddede işaret edilen "lâik Cumhuriyet ilkeleri”" formulü Anayasa'nın anlatım biçimi olduğu için, herhangi bir şekilde laiklik anlayışına aykırı amaçlar güden bir parti, laiklik karşıtı sayılarak kapatılma tehdidi altında kalabilecektir.

TBMM üyelerinin göreve başlama anında içtikleri andı düzenleyen Anayasa'nın 81. maddesi ise; "Devletin varlı̆ğ ve bağımsızlığını, vatanın ve milletin bölünmez bütünlüğünü, milletin kayıtsız ve şartsız egemenliğini koruyacağıma; hukukun üstünlüğüne, demokratik ve lâik Cumhuriyete ve Atatürk ilke ve inkılaplarına bağlı kalacağıma; toplumun huzur ve refahı, millî dayanışma ve adalet anlayışı içinde herkesin insan haklarından ve temel hürriyetlerden yararlanması ülküsünden ve Anayasaya sadakattan ayrılmayacağıma; büyük Türk milleti önünde namusum ve şerefim üzerine and içerim.” şeklindedir.

Aynı şekilde, Cumhurbaşkanının görevine başlarken Türkiye Büyük Millet Meclisi önünde edeceği andı düzenleyen Anayasa'nın 103. maddesi ise; "Cumhurbaşkanı sıfatıyla, Devletin varlığı ve bağımsızlığını, vatanın ve milletin bölünmez bütünlüğünü, milletin kayıtsız ve şartsız egemenliğini koruyacağıma, Anayasaya, hukukun üstünlüğüne, demokrasiye, Atatürk ilke ve inkılâplarına ve lâik Cumhuriyet ilkesine bağlı kalacağıma, milletin huzur ve refahı, millî dayanışma ve adalet anlayışı içinde herkesin insan haklarından ve temel hürriyetlerinden yararlanması ülküsünden ayrılmayacağıma, Türkiye Cumhuriyetinin şan ve şerefini korumak, yüceltmek ve üzerime aldığım görevi tarafsızlıkla yerine getirmek için bütün gücümle çalışacağıma Büyük Türk Milleti ve tarih huzurunda, namusum ve şerefim üzerine and içerim." şeklindedir.

Diyanet İşleri Başkanlığını düzenleyen Anayasa'nın 136. maddesi uyarınca; Genel idare içinde yer alan Diyanet İşleri Başkanlığı, lâiklik ilkesi doğrultusunda, bütün siyasî görüş ve düşünüşlerin dışında kalarak ve milletçe dayanışma ve bütünleşmeyi amaç edinerek, özel kanununda gösterilen görevleri yerine getirir.

1961 Anayasası'nda olduğu gibi 1982 Anayasası'nda da devrim kanunlarının korunması kabul edilmiş ve İnkılâp kanunlarının korunmasına ilişkin Anayasa'nın 174. maddesine göre; "Anayasanın hiçbir hükmü, Türk toplumunu çağdaş uygarlık seviyesinin üstüne çıkarma ve Türkiye Cumhuriyeti'nin lâiklik niteliğini koruma amacını güden, aşağıda gösterilen inkılâp kanunlarının, Anayasanın halkoyu ile kabul edildiği tarihte yürürlükte bulunan hükümlerinin, Anayasaya aykırı olduğu şeklinde anlaşılamaz ve yorumlanamaz..."

3 Mart 1940 tarihli ve 430 sayılı Tevhidi Tedrisat Kanunu; 25 Teşrinisâni1341 tarihli ve 671 sayılı Şapka İktisâsı Hakında Kanun; 30 Teşrinisâni 1341 tarihli ve 677 sayılı Tekke ve Zaviyelerle Türbelerin Seddine ve Türbedarlıklar ile Bir Takım Unvanların Men ve İlgasına Dair Kanun; 17 Şubat 1926 tarihli ve 743 sayılı Türk Kanunu Medenisiyle kabul edilen, evlenme akdinin evlendirme memuru önünde yapılacağına dair medenî nikah esası ile aynı kanunu 110 uncu maddesi hükmü; 20 Mayıs 1928 tarihli ve 1288 sayılı Beynelmilel Erkamın Kabulü Hakkında Kanun; 1 Teşrinisâni 1928 tarihli ve 1353 sayılı Türk Harflerinin Kabul ve Tatbiki Hakkında Kanun; 26 Teşrinisâni 1934 tarihli ve 2590 sayılı Efendi, Bey, Paşa Gibi Lâkap ve Unvanların Kaldırıldığına Dair Kanun; 3 Kânunevvel 1934 Tarihli ve 2596 sayılı Bazı Kisvelerin Giyilemeyeceğine Dair Kanun. 
Anayasa'nın geçici 2. maddesinde, Cumhurbaşkanlığı Konseyi’nin görevleri sıralanırken düzenlenmiş olan, "Türkiye Büyük Millet Meclisince kabul edilerek Cumhurbaşkanlığına gönderilen, Anayasada yazılı temel hak ve hürriyetlere ve ödevlere, lâiklik ilkesine, Atatürk inkılâplarının, millî güvenliğin ve kamu düzeninin korunmasına, Türkiye Radyo-Televizyon Kurumuna, milletlerarası andlaşmalara, dış ülkelere silahlı kuvvet gönderilmesine ve yabancı kuvvetlerin Türkiye'ye kabulüne, olağanüstü yönetime, sıkıyönetim ve savaş haline dair kanunlar ile Cumhurbaşkanınca gerekli görülen diğer kanunları Cumhurbaşkanına tanınan onbeş günlük sürenin ilk on günü içinde incelemek;" hükmünde de laiklik ilkesine vurgu yapılmıştır.

Söz konusu düzenlemelerden anlaşılacağı üzere, 1982 Anayasası din özgürlükleri karşısında ihtiyatlı bir tutum sergilemiş, kutsal din duygularının devlet işlerine ve politikaya karıştırılmaması için tedbirler almıştır. Laiklik ilkesi 1982 Anayasası'nda modern, çağdaş devletin önemli bir unsuru olarak kabul edilmiş ve ilkenin etkisini azaltacak veya değiştirecek girişimlere karşı koruma altına alınmaya çalışılmıştır. 1982 Anayasası din ve devlet ayrılığın kabul eden, ancak din alanına giren konularda devlete geniş bir müdahale yetkisi tanıyan, dolayısıyla dinin özerk olarak örgütlenmesine ve faaliyetlerine sınırlı olanak tanıyan bir anlayış yansıtmaktadır. Bu anlayış, bir yandan dinin devlet ve toplum üzerindeki etkisini azaltmak, diğer yandan da dinin kolektif vicdan ve kimlik düzeyinde oynadığ rolü ikame etmek olarak da değerlendirilmiştir.

Ülkemizin laiklik anlayıșının kendine özgü bir niteliği vardır. 1982 Anayasası ile her şeyden önce din ile devlet işleri birbirlerinden ayrılmaya çalışılmış ve laikliğe toplumsal bir proje olarak ulaşılmak amaçlanmıştır. Din, kişisel tercih ve eylem alanına bırakılması gereken bireysel ve özel bir mesele olarak kabul edilmekte, bu ayrılıktan dolayı da devletin din karşısında tarafsız olacağı varsayılmaktadır.

Türk Anayasa Hukuku doktrininde, laikliğin demokrasinin bir önkoşulu olduğu yönünde yaygın bir kanı vardır. Buna göre, bir devlet lâik olmadan demokratik olamaz. Türkiye'de demokrasinin yerleşebilmesi için öncelikle laikliğin yerleşmesi gerekmektedir. Laikliğin demokrasinin önkoşulu olduğu yolundaki düşünceler Anayasa Mahkemesi'nin çeşitli kararlarında da ifade edilmiştir. Örneğin Anayasa Mahkemesi, "türban kararı" diye bilinen 7 Mart 1989 tarih ve K.1989/12 sayılı kararında şöyle demiştir: "Demokrasiye geçişin de aracı olan lâiklik, Türkiye'nin yaşam felsefesidir". "Demokratik düzen, dinsel gerekleri egemen kılmayı amaçlayan şeriat düzeninin karşıtıdır. Dinsel gereklere yönetimde ağırlık veren bir düzenleme demokratik olamaz. Demokratik devlet ancak lâik devlettir".

Ancak doktrinde lâiklik ile demokrasi arasında hiçbir ilişkinin olmadığını söyleyen görüşler de mevcuttur. Lâik bir devlet, demokratik olabileceği gibi, anti-demokratik de olabilir. Örneğin Fransa lâik ve demokratik; eski Sovyetler Birliği ise lâik, ama anti-demokratik bir devlettir. Demokratik bir devlet de, lâik olabileceği gibi lâik olmayabilir de. Laikliğin demokrasinin bir şartı olmadığını söyleyenlerin verdiği tipik örnek ise; İngiltere'dir. İngiltere'de Anglikan Kilisesi ve Presbiteryan Kilisesi "devlet kilisesi" statüsündedir. Keza İngiltere'de din kurumlarıyla devlet kurumları arasında ayrılık da yoktur. Kral veya Kraliçe aynı zamanda Anglikan Kilisesinin başıdır. Keza, bazı din adamları da Lordlar Kamarası'nın üyesidirler. Bunlara "ruhanî lordlar" denir. Dolayısıyla, lâik olmayan İngiltere; dünyanın en eski demokrasilerinden biridir. O halde lâik olmak, demokratik olmak anlamına gelmediği gibi, lâik olmamak da demokrasiye engel değildir. Lâiklik ve demokrasi birbirinden farklı iki kavramdır. Ne birincisi ikincisini ne de ikincisi birincisini gerektirir (Gözler, 2018).

Laiklik ilkesi, Anayasa Mahkemesi'nin kamuoyunda ses getiren önemli kararlarına konu olmuştur. Anayasa Mahkemesi'nin 21 Ekim 1971 tarih ve 1971/76 sayılı kararı, Diyanet İşleri Başkanlığının mevcudiyetini tartışılır hale getirmiştir. Söz konusu karara göre; "Batı devletlerinde dinin kötüye kullanılması ve sömürülmesi bizdeki şekilde bir sonuç doğurmadığından din ve devlet işlerinin birbirine karışmaması yönünden kabul edilen kilisenin bağımsızlığı durumu, devlet düzeni bakımından bir tehlike göstermemektedir. Oysa İslamlık bireylerin yalnız vicdanlarına ilişkin olan dini inanç bölümünü düzenlemekle kalmamış, aynı zamanda bütün toplum ilişkilerini, devlet faaliyetlerini ve hukuku da tanzim etmiştir... Böyle bir tutumun ve sınırsız, denetimsiz bir din hürriyeti ve bağımsız bir dini örgütlenme anlayışının ülkemiz için pek ağır tehlikelerle yüklü olduğu uzak ve yakın tecrübelerle anlaşılmıştır... Diyanet İşleri Başkanlığının Anayasa'da yer almasının ve mensuplarının memur niteliğinde sayılmasının... Birçok tarihî nedenlerin, gerçeklerin ve ülke koşullarıyla gereksinimlerinin doğurduğu bir zorunluluk olduğundan kuşku yoktur”.

Anayasa'nın 136. maddesine göre, Diyanet İşleri Başkanlığı genel idare içinde yer almaktadır. Türkiye'de din hizmetleri bir kamu hizmeti olarak kabul edilmiş ve bu hizmetin yürütülmesi görevi Diyanet İşleri Başkanlığına verilmiştir. Ülkemizde imamlar ve diğer din adamları Diyanet İşleri Başkanlığına bağlıdır. Dolayısıyla ülkemizde İslam dininin din adamları, maaşlarını merkezî idareden almaktadırlar; keza, merkezî idarenin hiyerarşik denetimine de tâbidir. Türkiye'de devlet dine bağlı olmasa da, din tamamıyla merkezî idareye bağlıdır. Eğer lâik devlet, gerek "dine bağlı devlet", gerekse "devlete bağlı din” sistemlerini reddeden bir devlet anlayışı ise, Diyanet İşleri Başkanlığının merkezî idare içinde varlığını bu ilke ile bağdaştırmak hiçbir şekilde mümkün değildir. Bu nedenle Türk anayasa hukuku doktrininde, Diyanet İşleri Başkanlığı'nın varlığıyla lâiklik ilkesini uzlaştırmaya çalışan hâkim görüşü kanımızca kabul etmek mümkün değildir.

Göz önünde bulundurulması gereken bir başka husus da Anayasa'nın 24. maddesinin 4. fikrasında düzenlenen eğitim-öğretim hakkıyla ilgili olan, devletin gözetim ve denetimi altında yapılan zorunlu din kültürü öğretimidir. 
Anayasa'nın 24. maddesinin 4. fikrasında yer alan "Din ve ahlâk eğitim ve öğretimi Devletin gözetim ve denetimi altında yapılır. Din kültürü ve ahlak öğretimi ilk ve orta-öğretim kurumlarında okutulan zorunlu dersler arasında yer alır. Bunun dışındaki din eğitim ve öğretimi ancak, kişilerin kendi isteğine, küçüklerinde kanunî temsilcilerinin talebine bağlıdır." şeklindeki düzenleme, kimi kesimlerce eleştirilmektedir. Bu düzenleme ile laik bir devlette olmaması gereken zorunlu din eğitimi bir anayasal emir haline getirilmektedir. Bu maddenin anlamı, Türkiye'de özel din kurumlarına yer olmadığılır. Dinsel eğitim alma zorunluluğunun, dinsel referansı eğitim sistemine dâhil etmesi sebebiyle laiklik ilkesine aykırılık oluşturulduğu ileri sürülmektedir.

Anayasa Mahkemesine göre, dini eğitimin laik devlet anlayışına uygun şekilde yapılması gerekmektedir. Tüm devlet kuruluşlarında ve işlemlerinde olduğu gibi öğretim ve eğitimin her düzeyinde laiklik ilkesine özenle uyulmalıdır. Tevhid-i Tedrisat Kanunu da bu gereğin belgesidir (E.1989/1, K.1989/12, KT.07.03.1989; E.1990/36, K.1991/8/, KT.09.04.1991).

Anayasa Mahkemesi bazı kapatma davalarında, siyasi partilerin faaliyetlerinde laiklik ilkesine uygun davranmak zorunda olduklarını özellikle belirtmiş̧tir (E.1983/2, K.1983/2, KT.25.10.1983; E.1997/1, K.1998/1, KT.16.01.1998; E.1999/2, K.2001/2, KT.22.06.2001). Anayasa Mahkemesi, Atatürk devrimlerinin hareket noktasında laiklik ilkesinin yattığını ve devrimlerin temel taşını bu ilkenin oluşturduğunu, laiklik ilkesi açısından verilecek en küçük bir ödünün, Atatürk devrimlerini yörüngesinden saptırarak yok olması sonucunu doğurabileceğini, bu nedenle hiçbir düşünce ve mülahazanın Atatürk milliyetçiliği, ilke ve inkılapları ve medeniyetçiliğin karşısında koruma göremeyeceğini ve laiklik ilkesi gereği kutsal din duygularının devlet işlerine ve politikaya kesinlikle karıştırılamayacağını beyan ederek, Atatürk devrimleri ile laikliğin birbirlerinden ayrı düşünülemeyeceğini vurgulamıştır (Kanbur, 2003).

Anayasa Mahkemesi, laik devlette herkesin dinini seçmekte ve inançlarını açığa vurabilmekte, tanınmış olan din ve vicdan özgürlüğünün sınırları içerisinde kalma şartıyla serbest olduğu üzerinde özellikle durmuştur. AYM'ye göre hiçbir dine itikadı olmayanlar için de durum aynıdır; laik bir toplumda herkes istediği dine veya inanca sahip olabilir. Bu husus yasa koyucunun her türlü etki ve müdahalesi dışındadır. Yüksek Mahkeme bir kararında semavi olmayan dinlere inananların inanç hürriyetlerinin de anayasal konuma altında olduğunu belirtmiştir (E.1986/11, K.1986/26, KT.04.11.1986).

Laiklik ilkesine hem Fransız hem de Türk Anayasasında yer verilmiştir. 1958 tarihli halen yürürlükteki Fransız Anayasası'nın 1. maddesi, Fransa Cumhuriyetinin laik bir cumhuriyet olduğunu açıkça belirtmekte; 1982 Türk Anayasası'nın 2. maddesinde de Türkiye Cumhuriyeti'nin "laik ve sosyal bir hukuk devleti” olduğu vurgulanmaktadır. Böylece laiklik ilkesi her iki ülkede de pozitif bir hukuk kuralı olarak ortaya çıkmakta ve hatta pozitif hukuk kurallarının hiyerarşik olarak en üst normu olan anayasal bir hüküm olma özelliği taşımaktadır.

\section{Fransız Anayasası'nda Laiklik İlkesi}

Fransa'da laiklik diğer ülkelere bakıldığında, ideal şekline ulaşmış olmasa da en ileri evrededir. Fransa, Cumhuriyeti'nin laiklik etrafinda kurulduğunu kabul eder. Fransa, laikliği cumhuriyetin temel prensipleri arasında görür. Kişisel tanımlamalar, yorumlamalar çeşitlidir. Ancak laiklik, bugün Fransa'da geniş bir anlaşma konusudur. Fransa kendini onunla ispatlamakla beraber, herkesin yaklaşım şekli ve kavrayışı farklılık gösterir. Böyle olunca da tartışmaya açık, çok bakışlı, yumuşak ya da sert bir laiklik algısı ortaya çıkmaktadır.

Aslında Fransa dışındaki Batı ülkelerinin hukuklarında teknik anlamda laiklik ilkesine yer verilmemektedir. Bu ülkeler tarihsel olarak bu ilkeyi tanımadıkları gibi ihtiyaç da duymamıştır. Sekülerleşme evrimsel bir süreçle oluşurken laiklik, ortaya çıkışı açısından devrimsel bir nitelik taşır. Diğer batı ülkeleri bu sekülerleşme sürecinden geçmiş, ancak yalnızca Fransa laiklik ilkesini kullanarak bu sekülerleşme sürecini devrimsel bir yöntemle hızlandırma yoluna gitmiştir. Bunun nedeni ise Fransa'da Kilisenin, aşırı tutucu yapısı yüzünden siyasal iktidarı dolaylı olarak kullanmaktan vazgeçmemiş olması ve bunun sonucu olarak Fransız devrimcilerinin, Fransa'nın sekülerleşme sürecinde geri kalması yüzünden modern gelişmelere uyum sağlayamamasıdır (Ulusoy, 2019).

Fransa'da Katolik Kilisesi, 1905 tarihli Devlet ve Kiliselerin Ayrılması Yasası'nı ancak 1924 yılında tanımıştır. Buna rağmen, laiklik ilkesi Fransız Anayasası'na 1946 yllında girebilmişken, Türkiye'de Fransa'dan daha önce, 1937 yılında Anayasa'ya girdiği de unutulmamalıdır. 1905 tarihli Yasa, Rouvier Hükümeti tarafindan kabul edildiğinde, dine karşı saldırgan bir yasa olması istenmemiş; aksine yatıştırıcı olması istenmiştir. Söz konusu Yasa hakkında şu şekilde yorumlar yapılmıştır: "Cumhuriyetçiler hiçbir dinin Devletten daha imtiyazlı olmaya hakkı olmadığını hep hatırlarlar. Yurttaşların inanma ya da inanmama, ibadet etme ya da etmeme hakkı vardır. Meclis, Kilise ile Devlet'in Ayrılma yasasını yüz gibi bir oy çoğunluğuyla oyladı. Meclisin oyladığg yasa bütün dinlere özgürlük vermektedir; her yurttaşın istediği şekilde, bir dine inanmasına ve ibadetine izin verir. Birkaç ay geçmeden Devletin laikliği yasasının bir özgürlük yasası olduğunu göreceksiniz, bizzat siz, Kilise papazlarının, dini ortadan kaldırmak için yapılmış zulüm yasası olduğu yalanını utanmadan söylediklerini göreceksiniz. İnanç özgürlüğü güven altındadır, tam ve eksiksizdir” (Yazıcıoğlu, 2014).

IV. Cumhuriyet, Cumhuriyetin laik olduğunu 1946 Anayasası'na koymuştur. Bu metin, Başlangıç bölümünde, dinle ilgili bütün olarak ayrımcılığı yasaklamayı hatırlatır, her seviyede parasız ve laik kamu eğitimi düzenlemenin, devletin görevi olduğunu belirtir. 1946 Anayasası'nın 1. maddesinde, "Fransa bölünmez, laik, demokratik bir 
Cumhuriyettir" ifadesi yer almaktadır. İkinci Kurucu Meclis Komisyonu'nda yapılan tartışmalarla da Cumhuriyetin laik özelliği teyit edilmiştir. Piskoposlar tarafından tartışılan ve kaldırılması istenen laiklik ilkesi 1958 Anayasası'nda da yerini korumuştur. Katolik hiyerarşisinin yaşadığı bu korku üzerine ilgili maddeye, laiklik kavramının dini inançlara saygı şeklinde yorumlanmasını sağlamaya yönelik bir ilave yapılmıştır (Rivero, 2011).

$\mathrm{Bu}$ ilave 1946 yılında getirilen ilkeyi açıklamakla birlikte, onun yerini sağlamlaştırmıştır. Fransa'nın laik bir cumhuriyet olduğunu belirten cümleye "(Cumhuriyet) menşe, ırk ya da din ayrımı yapılmaksızın bütün vatandaşların kanun önünde eşitliğini sağlar. Tüm inançlara saygı duyar." ifadesi eklenmiştir. Bundan böyle laikliği bu iki ilkenin (eşitlik ve dini inançlara sayg1) 1şı̆̆ında yorumlamak; diğer bir ifade ile temel olarak laikliği devletin din konusunda tarafsızlığı olarak düşünmek doğru olacaktır. Laiklik devletin ideolojik tarafsızlığını yansıtır. Laiklik ilkesi, cumhuriyetin tüm inançlara saygı duyduğunu ve bütün vatandaşların... din ayrımı yapmaksızın kanun önünde eşitliğini sağladığını beyan eden Anayasada açıkça ifade edilmiştir (Prélot, 2011).

1958 Fransız Anayasası'nda dinler konusu sadece 1. maddede alınmıştır: "Fransa bölünmez, laik, demokratik ve sosyal bir cumhuriyettir." Bu maddenin devamı "Cumhuriyet, köken, ırk ya da din ayrımı gözetmeksizin bütün vatandaşların kanun önünde eşitliğini güvence altına alır. Bütün inançlara saygı duyar." şeklindedir. Anayasaların dini meselelerle ilgilenmek için değil, devletin genel teşkilat yapısının nasıl olacağı ve kamu gücünün nasıl işleyeceği ile ilgili kuralların belirlenmesi için hazırlandığı ilkesinden yola çıkıldığında, Anayasada bu hükmün dışında dinden bahsedilmemiş olması aslında hiç de şaşırtıcı değildir. Bu nedenle din ya da ibadet özgürlüğü gibi ilkelerin birinci maddenin yapıcı bir şekilde yorumlanması dışında Anayasada yer almaması normaldir (Prélot, 2011).

1958 Fransız Anayasası'nda laiklik ilkesinin çift anlamlı olduğu görülmektedir. Bu ilke bir taraftan devletin inançsal statüsü olarak adlandırılabilir ve devletin artık tüm dinlere karşı ideolojik ve organik tarafsızlığıyla belirginleşen durumunu tanımlamaktadır. Devletin dini yoktur, devlet hiçbir dine iltimas geçmediği gibi hiçbir dinin desteğini de talep etmez. Laiklik ilkesi diğer taraftan, 1905 tarihli yasayla düzenlendiği şekliyle "Fransız Hukukunda dinlerin tabi olduğu hukuki rejimin temel ilkelerini" ortaya koymaktadır. 1946 yılında İkinci Kurucu Meclisteki tartışmalarda belirtildiği üzere "devletin hiçbir inancı ya da dini tanımaması ve korumaması ilkesini" dile getirmektedir. Dinlerin tabi olduğu bu hukuki rejim ile artık hiçbir din herhangi bir şekilde özel bir kamu statüsünden faydalanmayacaktır (Prélot, 2011).

Başka bir deyişle, Anayasada yazılan "laiklik" kelimesi cumhuriyetçi devletin anayasal statüsünün tanımı açısından tıpkı devletin üniter yapısı, sosyal bir cumhuriyet olması ve kuvvetler ayrılığı ilkesi gibi temel bir öneme sahiptir (Prelot, 2011). Örneğin Conseil d'Etat, "İslami türban" davasındaki kararlarında laikliğe gönderme yapmıştır. Bir anayasal değerde hüküm olan laiklik, zorlayıcı bir kural olmaktan daha çok devletin anlayışının bir ifadesi olarak görünmektedir. Sadece eğitim konusunda yasa, zorlamaya yer vermektedir.

Laiklik her iki ülkede de, bir yandan diğer ülkelerden farklı olarak teknik bir hukuksal kurum olarak kabul edilmekte, diğer yandan ideolojik anlamda geçmişte cumhuriyeti kurma ve yerleştirme, günümüzde ise cumhuriyet ideolojisini (hayat ve düşünce tarzını) koruma misyonuyla görevlendirilmektedir. Örneğin; özellikle Arap, Afrika ve Ortadoğu kökenli göçmen kültürü, kimi çevrelerce cumhuriyet ideolojisi/hayat tarzı için bir tehdit olarak algılanmaktadır. Bunun sonucu olarak, laiklik bu tehdide karşı cumhuriyet ideolojisini koruyucu tedbirleri meşrulaştırıcı bir araç olarak kullanılmaktadır. Bu bağlamda Fransa'da çıkarılan bir sirkülerde, laikliğin milli birlik ve beraberliğin sağlanması ve dolayısıyla bir millet oluşturmak için gerekli bir araç olduğunu, zira inanç birliği olmayan bir toplumda değişik dinsel inanca mensup gruplar kendi inançları yönünde kendilerine özgü kurallar ve kültürlerle yaşayarak sadece basit bir birlikte yaşama amacı güderek yaşarlarsa o toplumda kader birliği olamayacağını ve o toplumun bir millet oluşturamayacağını belirtmiş ve bunun için laikliğin özellikle okullarda bu farklı dinsel grupların birbirleriyle tarafsızlık kuralları içinde kaynaşmaları yönünde bir araç olması gerektiğine işaret edilmiştir (Ulusoy, 2019).

Fransız yargısı, din ve vicdan özgürlüğünün tek sınırının kamu hizmetlerinin düzgün işleyişinin engellenmesi ve kamu düzeninin sağlanması olduğunu benimsemekte ve örneğin, bir dini inanca aidiyeti sembolize eden bir işaretin salt taşınması fiilinin, bu taşıma somut olayda kamu hizmetini aksatmıyorsa ve kamu düzenini bozmuyorsa, laikliğe aykırı olmadığına hükmetmektedir. Türk yargısı, Fransız yargısının aksine, okullarda türbanın salt taşınması fiilinin, somut olayda kamu düzenini bozucu ve kamu hizmetini aksatıcı olarak kullanılmasa bile, laiklik ilkesine aykırı olduğuna hükmetmekte ve böylece dini bir inancın sırf ifade edilmesini, bu ifade etmenin sonuçlarının hukuka aykırı olup olmadığını dikkate almadan, laikliğe aykırı bularak daha sert bir laiklik anlayışını benimsemektedir (Ulusoy, 2019) .

Laik Fransa'da İslam inancı sorunsalının nasıl ortaya çıktığını incelemek için, öncelikle bu konunun bir matematik denklemine benzediğini belirtmek gerekmektedir. Bu denklemde, kamu yetkilileri gibi devletin ulusal aktörleri ve Müslüman devletler ve Müslüman dernekler gibi devlet dışı aktörler ile bireyler daha belirleyici bir rol oynamaktadır. Burada ilk rol kaçınılmaz olarak İçişleri Bakanlığına ve Bakanlığın siyasi (İslami meseleleri ile ilgili teknik danışmanları) ve idari (inanç ofisleri) birimlerine düşmektedir (Frégosi, 2011). İslam'ın yasal olarak yönetilmesi, Fransa'da İslam olgusunun yerleşmesiyle ortaya çıkan sorunlara cevap verecek yasal normların oluşturulması şeklinde tezahür etmektedir. 
Siyasiler arasında İslam Dini uygulamalarının ulusal ölçekte düzenlenmesi yönünde varılan görüş birliği karşısında, Müslümanlar, bütün gözlerin İslam'a çevriliş olmasını kendi yararlarına kullanmak niyetindedir. Kendilerini "laik Müslümanlar" olarak sunmaları, açıkça bağdaşmayan iki kimliği (Müslümanlığı ve laikliği) terminolojik olarak bir arada kullanmaları cesaretini göstermeleri takdir edilmelidir. Kamuoyunun gözünde, bu iki kelimenin bir arada kullanılması İslam'ın endişe kaynağı olarak görüldüğü bir dönemde rahatlatıcıdır.

"Laik Müslüman" etiketi, bu tabiri kullananları tek cumhuriyetçi Müslümanlar, tek gerçek modern Müslümanlar; kısaca dini gericiliği savunduğu düşünülen diğerleri karşısında saygı duyulacak tek Müslümanlar haline getirecektir. Müslüman laikler, başörtüsü tartışmalarında da okullarda dini sembolleri yasaklayan yasanın en kararlı savunucuları arasında yer alacaktır. Onların talep ettiği İslam, kabul edilen belirli bir dini uygulamaya bağlılıktan ziyade belirsiz bir kültürel hatta etnik kimlik olarak özetlenmektedir. Dini cemaatçiliğe karşı olduklarını iddia eden laik Müslümanlar, bu şekilde İslami referansın etkinleşmesi üzerine kurulmuş bir karşı cemaatçilik yaratmaktadır.

Kelimelerin bu şekilde akıllıca birlikte kullanılması aynı zamanda laik Müslümanları İslam'ın cumhuriyetçileşmesinin ve laikçileşmesinin aracısı, temsilcisi haline getirmektedir. Bu tartışma bizi aslında evrensellik adı altında tamamen Fransa'ya özgü olan bir başka tartışmaya, dinle olan bağlarını kopartma ve modernlik arasındaki bağlantıya götürmektedir. Laikleşmiş bir İslam'ın çerçevesinin ne olması gerektiği konusundaki bu tartışma aracılığıyla Fransa'daki bazı Müslümanlar İslam'la olan bağlarını kültürel ve tarafsız hale getirerek dinle olan bağların düzgün bir şekilde koparmak niyetindedir (Frégosi, 2011).

Türk ve Fransız laiklik anlayışları arasında laikliğin her iki ülkede de teknik bir hukuksal kurum olması ve her ikisinde de ideolojik bir araç olarak kullanılması açısından benzerlikler bulunmaktadır. Fakat bu kavramın hem hukuksal yorumunda hem de ideolojik işlevindeki uygulama yöntemlerinde her iki ülke arasında farklar olduğu da gözlemlenmektedir. Hangi ülkedeki laiklik anlayışının daha iyi olduğu konusunda bir değer yargısında bulunmak ise, kuşkusuz oldukça güçtür. Laikliğin getirilme amacı her iki ülkede de aynı olduğuna göre (cumhuriyeti korumak için ideolojik ve hukuksal bir araç), hangi ülkedeki anlayışın bu amaca daha iyi hizmet ettiği üzerine düşünülmelidir.

\section{Sonuç}

Din ile siyaset, bireylerin davranışlarını ve toplumun işleyişini düzenleyen otorite sistemleri olarak insanlık tarihi boyunca iş birliği yapmıştır. Laikleşme her ne kadar bu iki öğeyi birbirinden ayırmış olsa da günümüzde kamusal dinin geri dönüşü laikliğin sorgulanmasına yol açmaktadır. Böyle bir atmosferde ise laikliği dışlayan dinsel anlayışların laik devlet ile bir arada var olup olamayacağı tartışılmaktadır (Joppke, 2015).

"Laiklik" çağdaş demokrasilerin olmazsa olmaz önkoşuludur. Laiklik din, ifade ve vicdan özgürlüğü demektir. Aklı ve bilimsel hayatı özgürleştirir. Laiklik, demokrasiyi egemen kılan ana devrimdir; sosyal, siyasal ve kültürel hayatı hukuk korumasına alır. Atatürk'ün de dediği gibi "Laiklik yalnız din ve dünya işlerinin ayrılması demek değildir. Tüm yurttaşların vicdan, ibadet ve din özgürlüğü de demektir." Laik toplumu germek ve kutuplaşmayı artıracak söylemlerde bulunmak yerine hoşgörülü, ifade özgürlüğünün korunduğu, akıl ve bilim yolunda çağdaş nesillerin yeşerdiği ülkede birbirine saygıllı yurttaşlar demektir (Akatlı, 2018).

En önemlisi laikliğin devlet ve hukuk sistemi haline getirilmesi ve uygulanmasıdır. Avrupa yaklaşık 400 yıl süren bir mücadele sonrası laik devlet düzenine kavuşmuş ve bu sayede de eğitimde, sanatta, ekonomide, sosyal yaşamda çağdaş seviyeye yükselmiştir. Böylece Batı toplumları kendilerini baskı altına almak isteyen dinsel ve siyasi oluşumları kontrol ve denetim altına almışlar; bilim, akıl, eşitlik ve özgür düşünce önündeki oluşumlara dur diyerek medeniyette ve yaşam kalitesinde en üst seviyelere çıkmışlardır.

Laikliği, devletin toplumun belirli bir dinsel/mezhepsel grubu temsil etmediği, inançlar arasında ayrım yapmadığı, özellikle eğitim ve adaletin her türlü dinsel tahakküm ve simgeden arındırıldığı, dinin siyaseten istismarının önlendiği siyasi bir ilke olarak tanımlamak gerekmektedir. Bu bağlamda tek bir laiklik vardır. LaiklikSekülerlik ayrımları yapaydır ve kafa karıştırıcıdır (Oyan, 2018).

Laiklik, Türkiye Cumhuriyeti'nin kuruluş felsefesi olan halkçıllk ve devrimciliğin daha ileriye götürülmesi olup vatandaşların egemenlik alanının da sigortasıdır. Türkiye'yi bölgede yaşanan dinsel ve mezhepsel çatışmalardan uzak tutarak bütün vatandaşları barış içinde ayrımsız bir şekilde ortak paydada buluşturan ana etken laikliktir. Dolayısıyla ürkek ve savunmacı bir laiklik çizgisi kaybetmeye mahkûm olacağından, Türkiye Cumhuriyeti'nin temelini teşkil eden laikliğin kaybedilmemesi için etkin bir mücadele gerekmektedir.

\section{Kaynakça}

• Akatl1, 2018. "Demokrasi Maskeli Dönüşüm", İçi Boşaltılan Cumhuriyet ve Laiklik, Tekin Yayınevi, İstanbul.

- Akgönül, 2011. "Giriş", Tartışılan Laiklik: Fransa ve Türkiye'de İlkeler ve Algılamalar, İstanbul Bilgi Üniversitesi Yayınları, İstanbul.

- Başgil, 1998. Din ve Laiklik, Kubbealtı Neşriyatı, İstanbul. 
- Frégosi, 2011. "Fransa'da Devlet-Dini Azınlıklar İlişkisinde İslam'la Gelen Değişiklik", Tartıșılan Laiklik: Fransa ve Türkiye'de İlkeler ve Algılamalar, İstanbul Bilgi Üniversitesi Yayınları, İstanbul.

- Gözler, 2018. Türk Anayasa Hukuku, Ekin Yayınları, Bursa.

- Joppke, 2015. Laik Devlet Kuşatma Altında, Çev.: İbrahim Kaya, Say Yayınları, Ankara.

- Kanadoğlu, 2013. "Laiklik ve Din Özgürlüğü”, Türkiye Barolar Birliği Dergisi, S.109, Ankara.

- Kanbur, 2003. Anayasa Mahkemesi’ne Göre Laiklik, Yayımlanmamış Yüksek Lisans Tezi, Hacettepe Üniversitesi, Ankara.

- Oyan, 2018. "Laiklik Yeniden Kazanılmalıdır", İçi Boşaltılan Cumhuriyet ve Laiklik, Tekin Yayınevi, İstanbul.

- Prélot, 2011. "Fransız Anayasalarında Din: Ruhbanların Sivil Anayasası'ndan, Anayasal Laikliğe Uzanan Yol (1789-1958)", Tartışılan Laiklik: Fransa ve Türkiye'de İlkeler ve Algılamalar, İstanbul Bilgi Üniversitesi Yayınları, İstanbul.

- $\quad$ Robert, 1991. Dictionnaire de la langue française, Paris.

- Sağlam, 2009, “Laiklik İlkesine Bağlı Güncel Anayasal Sorunlar”, Mümtaz Soysal'a Armağan, Mülkiyeliler Birliği Vakfı Yayınları, N.32, Ankara.

- Saylan, 2001. “Laiklik ve Demokrasi’ Kolokyumu”, Laiklik ve Demokrasi, Der.: İbrahim Ö. Kaboğlu, İmge Kitabevi, Ankara.

- Tanör, Yüzbaşığlu, 1982. Anayasasına Göre Türk Anayasa Hukuku, 12.bs., Beta Yayıncılık, İstanbul.

- Ulusoy, 2019. "Fransız ve Türk Laiklik Anlayışlarının Karşılaştırılması", http://www.libertedownload.com

- Yazıcıŏ̆lu, 2014. "Fransa'da Laikliğin Tarihi", http://sunar.canalblog.com/archives/2014/04/09/29629081.htm 


\title{
Kümülâtif Etki Değerlendirmesinin Yargısal Denetimi Judicial Review of Cumulative Impact Assessment
}

\author{
Assoc. Prof. Dr. Gürsel Özkan (Turkish State Council, Turkey)
}

\begin{abstract}
In our country, there is not any domestic or international regulation regarding assessment of cumulative impacts of air pollution caused by thermal power stations in the region or environment in where the station is established. According to the Article 56 of the Constitution, everyone has the right to live in a healthy and balanced environment and it is the duty of the State and citizens to protect the environmental rights. These rights include right to live in an environment which is protected and is not damaged or polluted, in addition to social and cultural development, and the efficient use of national resources for in particular the rapid, balanced and harmonious development of industry and agriculture throughout the country, which is stated in the Article 166 of the Constitution. Cumulative impact assessment is evaluation of the effects caused by the combined results of a project or a certain project action and foreseeable past, current and future human actions. Cumulative impact assessment of thermal power stations could be possible with the determination of the combined effects of existing and licensed power stations while licensing process of a new stations. There should be an assessment regarding the place, location and type of other power stations which are already established or are planned to establish in the same city or geographic area. This requirement is crucial in terms of judicial review of licensing of new power stations which are planned to establish upon Environment Impact Assessment is Positive decision.
\end{abstract}

\section{Giriş}

Ekonomik faaliyetlerin yapılması ile sağlanacak yarar ile doğal kaynaklar üzerindeki teknolojik etkisi diğer bir ifadeyle çevrenin korunması ile ekonomik ve sosyal kalkınma gerçekleştirilirken çevreye verilecek zarar arasındaki dengenin sağlanması önem taşımaktadır. Çevre ile ekonomik ve sosyal kalkınma arasındaki denge, aslında bir çelişkiyi ifade etmektedir. Çünkü kalkınma çevreyi tüketerek gerçekleştirilecek bir amaç olmadığı gibi kalkınma da sadece çevreden yararlanılarak gerçekleştirilecek ekonomik kalkınmadan ibaret değildir. Bu anlamda, mevcut ihtiyaç ve beklentileri geleceğin ihtiyaçlarından ödün vermeksizin gerçekleştirmenin yöntemlerini belirlemek mümkündür.

Nitekim çevreyi doğrudan ya da dolaylı olarak, olumlu ya da olumsuz yönde etkileyebilecek bir ya da birden fazla faaliyete ait bir projenin yapılması için alınacak karara esas olmak üzere, proje konusu faaliyetlerin bütün çevresel etkilerinin bilimsel yöntemler ve tekniklerle incelenmesi, ortaya çıkabilecek olumsuz etkileri önlemek ya da çevreye zarar vermeyecek ölçülerde en aza indirmek için alternatif çözümlerin belirlenmesi, belirlenen önlemlerin izlenip denetlenmesi sonucunu doğuran çevresel etkilerin değerlendirmesi yolu ile çevrenin korunması suretiyle ekonomik kalkınmayı gerçekleştirecek projeler yapılabilmektedir. Ancak sadece bir proje ile sınırlı olarak çevresel etkilerinin belirlenmesi yetmemekte aynı bölgede aynı nitelikteki çok sayıda projenin bir bütün olarak (birikmiş-kümülatif) çevreye olan toplam etkisinin belirlenmesi ve çevreye zarar verilmesi aşamasına gelinceye kadar bu tür projelerin gerçekleştirilmesine izin verilmesi uygun ve gerekli bulunmaktadır. Ancak çevreye zarar verilmesi aşamasına geçilince artık yeni projelere izin verilmemesinin sağlanması önem taşımaktadır.

$\mathrm{Bu}$ makalede, çevre hakkı, çevreninin korunmasına ilişkin uluslararası ve ulusal düzenlemeler ve ekonomik kalkınma ile ilgili yapılması gereken projelerin çevresel etkilerinin belirlenmesi ve çevreye zarar verilmesinin önlenmesi bakımından yargısal denetiminin önemi ve bu denetimin nasıl yapılması gerektiği üzerinde durulacaktır.

\section{2 Çevre Hakkı}

İnsan faaliyetleri ve canlı varlıklar üzerinde hemen ya da zaman içinde doğrudan ya da dolaylı olarak bir etkide bulunabilecek fiziksel, kimyasal, biyolojik ve toplumsal etkenler çevreyi oluşturmaktadır. "Çevre”nin, insanlığın ortak malvarlığının bir parçası olduğu düşüncesiyle korunması, iyileştirilmesi ve gelecek kuşaklara aktarılması gereken bir değer olarak kabul edilmesi, anayasal düzeyde bir insan hakkı olarak düzenlenmesine bağlıdır. Sağlıklı ve düzenli bir çevrede yaşamak anayasal bir hak olarak tanındığı ve koruma altına alındığı takdirde, doğal çevrenin kendisi de korunması gereken bir varlık ve değer olarak kabul edilecektir (Turgut, 2001, s.613). Bunun sonucu olarak, çevre unsurlarına yönelik olumsuz etki ve zararları önlemek, çevreye karşı suç teşkil eden fiilleri cezalandırmak amacıyla gerekli düzenlemeleri yapmak ve önlemleri almak devletin yükümlülüğü (Kantar, 1984, s.20) olarak kabul edilmektedir.

Çevre hakkı, mülkiyet hakkı ile çatışma halinde bulunmasına karşılık yaşama hakkı ve sağlık hakkı ile birbirini bütünleyici ve tamamlayıcı ilişki içerisindedir. Çevre hakkı, yaşama hakkı bakımından vazgeçilmez nitelikte olup yaşama hakkının güvencesini oluşturmaktadır. Çünkü çevre hakkının konusu, hayatın içinde gerçekleştiği "çevre"dir; amacı da insanoğlunun ve tüm canlı varlıkların hayatını sürdürdükleri yer olan çevrenin korunması ve iyileştirilmesidir. Yaşama hakkı, ancak insanın maddi ve manevi varlığını geliştirebileceği, hayatını sağlıklı bir 
şekilde sürdürebileceği koşullara sahip bir çevrede anlam ifade etmektedir. Bu bakımdan çevreye yönelik her tehdit aynı zamanda yaşama hakkını da tehdit etmektedir. Bu nedenle çevre hakkı, yaşama hakkının gerçekleşebilmesi için bir ön koşul olarak kabul edilmekte (Kaboğlu, 1998, s.296), çevre hakkı yaşama hakkının bir türevi olarak (Gemalmaz, 1987, s.240) değerlendirilmektedir.

Anayasanın 17. maddesinde, herkesin, yaşama, maddi ve manevi varlığını koruma ve geliştirme hakkına sahip olduğu, 56. maddesinde ise; herkesin, sağlıklı ve dengeli bir çevrede yaşama hakkına sahip olduğu, çevreyi geliştirmek, çevre sağlığını korumak ve çevre kirlenmesini önlemenin devletin ve vatandaşların ödevi olduğu düzenlenmiştir. Belirtmek gerekir ki çevre hakkı ve koruması, Anayasanın 90. maddesi ek fikrasında belirtilen "temel hak ve özgürlüklere ilişkin milletlerarası sözleşmeler" kapsamında bulunmaktadır. Nitekim çevre hakkı, “ister kişisel ve siyasal hakları, ister ekonomik, sosyal ve kültürel hakları, isterse üçüncü ya da/hatta dördüncü kuşak olarak nitelenen görece yeni insan hakları olsun, onayladığımız ve onaylayacağımız tüm sözleşmelerde güvenceye bağlanan tüm insan haklarını kapsamaktadır" (Gülmez, 2004, s.94).

Çevre hakkı, pozitif statü hakkı niteliğinde olmakla birlikte; insan haklarının negatif statü hakkı (koruyucu), pozitif statü hakkı ve aktif statü hakkı şeklinde tasnif edilmesinin artık geçerliliğini kaybettiği, insan haklarının her birinin devlete mutlaka olumlu bir edim yüklemekte, ancak bu olumlu edimlerin derecesi yere ve zamana bağlı olarak değişmektedir. Bu kapsamda, çevre kirliliğinin çok ileri boyutlara ulaştığı bir coğrafyada, devlete düşen kirliliği giderme yönündeki olumlu edimin, daha yoğun (daha pozitif) bir nitelik göstereceği kuşkusuzdur. Çevre hakkı bu anlamda, devlete yüklenen ödevler bakımından, bir pozitif statü hakkı niteliği taşımaktadır.

Günümüzde insan hakları, birinci kuşak, ikinci kuşak, üçüncü kuşak ayrımı yapılmak suretiyle incelenmektedir. Birinci kuşak insan haklarının, 18. yüzyıldan itibaren tanınan medeni ve siyasal haklara karşılık geldiği; ikinci kuşak hakların ise 20. yüzyılın başında ortaya çıkan sosyal, ekonomik ve kültürel haklara karşılık geldiği kabul edilmektedir (Kaboğlu, 1998, s.10).

Çevre hakkı ise tıpkı barış hakkı ve kalkınma hakkı gibi üçüncü kuşak haklar arasında yer almaktadır (Ertan, 2013, s.38). Üçüncü kuşak insan hakları, dayanışma hakları olarak da isimlendirilmektedir. Dayanışma haklarının gerçekleşmesi için birden fazla öznenin aynı amaç için birlikte çaba göstermesi gerekmektedir. Çevre hakkı da bir dayanışma hakkı olmakla, bu hakkın gerçekleşmesi devletlerin, bireylerin, kamu tüzel kişilerinin ve özel hukuk tüzel kişilerinin dayanışmasına bağlı bulunmakta, çevre hakkının korunması ortak sorumluluk altında olumlu ve olumsuz edimlerin bir arada olmasına bağlı bulunmaktadır.

Çevrenin korunması, ekonomik kalkınma amacıyla çevreye yapılacak teknolojik etkilerin çevreye zarar verilmeden ekonomik ve sosyal kalkınmanın gerçekleştirilmesinin önemini ortaya koymaktadır.

\section{Kümülatif Etki Değerlendirmesi}

Kümülâtif kelime olarak toplu veya birikmiş, kümelenen, birbirine eklenerek büyüyen, yığılarak biriken, katlanmış ve kümeli birikmiş gibi anlamlar taşımaktadır.

03.10.2013 tarih ve 28784 sayılı Resmi Gazetede yayınlanan Çevresel Etki Değerlendirmesi (ÇED) Yönetmeliği'nin 3 nolu ekinde; ÇED raporlarında projenin çevreyi etkileyebilecek olası sorunların belirlenmesi, kirleticilerin miktarı, alıcı ortamla etkileşimi, kümülâtif etkilerin belirlenmesi gerektiği açıklanmıştır.

Çevre ve Şehircilik Bakanlığı, Kümülatif Çevresel Etki Değerlendirmesine (KÇED) ilişkin olarak Dünya Bankası tarafından desteklenen KÇED teknik yardım çalışması kapsamında projelerin kümülâtif etkilerinin değerlendirilmesi ihtiyacına dayalı olarak Orman ve Su İşleri Bakanlığı'nın (OSİB) ilgili birimleri ile koordinasyon ve işbirliği içerisinde bir kılavuz hazırlatmıştır. KÇED Kılavuzunun temel amacı, ÇED sürecinin ve uygulamasının iyileştirilmesi/güçlendirilmesi, doğal kaynakların sürdürülebilir bir şekilde geliştirilmesine yönelik çalışmaların teşvik edilmesi ve havza yönetim planlamasının geliştirilmesi olarak açıklanmış ve KÇED kılavuzu içerisinde ele alınan ve ÇED süreci içerisinde değerlendirilmesi gereken temel kavramlar, rehber dokümanlar içerisinde belirtilmiştir. ÇED rehberleri ve KÇED Kılavuzu bir birini tamamlayıcı nitelikte dokümanlar olup, ÇED süreci içerisinde birlikte göz önünde bulundurulması gerekmektedir (ÇED Rehberi, 2014).

Kümülâtif etki değerlendirmesi, bir proje yahut proje faaliyetinin, geçmişte, günümüzde mevcut ve gelecekte makul olarak öngörülebilen insan faaliyetleri ile birlikte çevrede meydana getireceği değişikliklerin incelenmesidir.

Münferit bir projenin etkileri kabul edilebilir olarak değerlendirilebilse de, bir projenin etkilerinin diğer faaliyetlerin neden olduğu etkilerle karşılıklı etkileşime girerek "kümülatif etkiler” yaratma potansiyelinin de göz önünde bulundurulması gerekmektedir.

Ekonomik kalkınma amacıyla yapılmak istenen bir projenin kümülâtif etki değerlendirmesi; - Fiziksel özellikler, - Yaban hayatı popülasyonları, - Çevresel süreçler, - Ekosistem koşulları (biyolojik çeşitlilik), - Sosyal koşullar (sağlık, ekonomi) ve - Kültürel özellikler yönlerinden ayrı ayrı etkilerinin değerlendirilmesi demektir. Ancak kümülatif etkinin belirlenmesi için bu yetmemekte; mevcut, planlanmakta ve ya makul olarak tanımlanmış olan diğer faaliyetlerin, proje tarafından kullanılan veya projeden doğrudan etkilenen alanlar veya kaynaklar üzerine eklenerek artan değişimlerin neden olduğu etkilerin de değerlendirilmesinin yapılması önem taşımaktadır. 
Dolayısıyla bir proje'nin etkilerinin, potansiyel, çevresel ve sosyal etkileşimleri Proje ile birlikte toplam etki oluşturabilecek ş̧ekilde bir coğrafi alan içerisinde planlanan ve makul olarak tanımlanan, gelecekteki başka projelerden veya faaliyetlerden kaynaklanacak potansiyel etkilerle birlikte değerlendirilmesi gerekmektedir.

\subsection{Uluslararası Düzenlemeler}

Çevre sorunlarının sanayileșme ve kentleșme sürecine bağlı olarak küresel bir boyut kazanması ile birlikte bu sorunların çözümünde ulusal düzeydeki çabalar giderek yetersiz kalmış, bu yetersizlik ulusların çok yönlü işbirliğini ve çevre hakkının ayrı bir hak olarak kabul edilerek, düzenlenmesini gerektirmiştir.

Çevre hakkı, uluslararası alanda ilk defa 1972 'de Stockholm'de yapılan Birleşmiş Milletler Çevre ve İnsan Konferansı'nda gündeme gelmiştir (Güneş ve Coşkun, 2004, s.56).

Konferans sonucunda yayınlanan Stockholm Bildirisinin birinci maddesinde; insanın, onurlu ve iyi bir yaşam sürdürebilmesi için sağlıklı/elverişli bir çevrede yaşama hakkına sahip olduğu, bu hakka sahip olan insanların aynı zamanda hem bugünkü hem de gelecek kuşaklar için çevreyi koruma sorumluluklarının bulunduğu açık bir şekilde vurgulanmıştır.

Bu Konferans sonunda yayınlanan "İnsan ve Çevresi Deklarasyonu" doğrultusunda, Birleşmiş Milletler (BM) bünyesinde, çevre ile ilgili çalışmaları sürdürmek ve koordinasyonu sağlamak üzere Birleşmiş Milletler Çevre Programı (UNEP: United Nations Environmental Program) nın kurulması ve doğal kaynakları ve tabi varlıkları tahrip etmeden, çevreyi ön plana çıkararak kalkınmayı hedefleyen bir anlayış olan "sürdürülebilir kalkınma" anlayışının gündeme getirilmiş olması önem taşımaktadır (Bilir ve Hamdemir, 2011, s.144).

Çevresel Etki Değerlendirmesi ilk kez ABD'de Ulusal Çevre Politikası Yasası (National Environmental Policy Act - NEPA) ile yasal bir uygulama olarak 1 Ocak 1970'de yürürlüğe girmiştir. Çevresel Etki Değerlendirmesi yıllar içinde bilimsel ve teknik yönlerden geliştirilmiş, pek çok ülkenin çevre mevzuatında yerini almış, uluslararası kuruluşların karar metinlerine konu olmuştur.

Günümüzde teknolojik (ekonomik) faaliyetlerin çevresel etkileri ülkelerin sınırlarını aşmakta, çevre sorunları ile mücadelede uluslararası çabalara ihtiyaç göstermektedir. Uluslararası boyutta ele alınan çevre yönetim araçlarının başında ÇED gelmektedir. Genel olarak çevreye ilişkin uluslararası belgeleri şu şekilde belirtebiliriz.

3.1.1. "Ekonomik Kalkınma ile İlgili Çevresel Politikalar ve Kurallar Hakkında Bildirge" (the Déclaration of Environmental Policies and Procédures Relating to Economic Development) - 1 Şubat 1980

3.1.2. "Bazı Kamu ve Özel Sektör Projelerinin Çevresel Etkilerinin İrdelenmesi Hakkında 27 Haziran 1985 tarihli Konsey Direktifi" (Council Directive of 27 June 1985 on the Assessment of the Effects of Certain Public and Private Projects on the Environment) - Avrupa Topluluğu Resmi Gazetesi'nde yürürlük tarihi ve sayısı: 5 Temmuz 1985, No 1 175/40; Direktif no: 85/337/EEC

3.1.3. "Çevresel Etki Değerlendirmesinin Amaçları ve Esasları" (Goals and Principles of Environmental Impact Assessment) -UNEP Yönetim Konseyi'nin 17 Haziran 1987 tarih ve 14/25 sayılı "Sinırötesi Çevresel Etki Değerlendirmesi Sözleşmesi” (Convention on Environmental Impact Assessment in A Transboundary Context) Birleşmiş Milletler Avrupa Ekonomik Komisyonu'nca (AEK) üye ülkelerin imzasına açılış tarihi ve yeri: 25 Şubat 1991, Espoo/Finlandiya.

3.1.4. "Birleşmiş Milletler Çevre Kalkınma RİO Deklarasyonu (1992), Birleşmiş Milletler Çevre Kalkınma Konferansı", 3-14 Haziran 1992 tarihleri arasında Rio da Jenerio'da toplanarak 16 Haziran 1972 tarihinde Stockholm'de kabul edilen Birleşmiş Milletler İnsan Çevresi Konferansı Deklarasyonu'nu teyit edilmiştir. Yeni ve tarafsız küresel bir ortaklığın kurulabilmesi için devletler, toplumun anahtar sektörleri ve insanlar arasında yeni işbirliği düzeylerinin yaratılması hedefiyle bütün toplumların kendi ilgi alanlarını dikkate alan küresel çevre ve kalkınma sistemini koruyan Uluslararası antlaşmalar için çalışarak; dünyanın birbirinden ayrılmayan ve bir bütün olan doğasını tanıdıkları belirtilmiş ve 27 madde halinde deklarasyon ilkelerinin uygulanmasında ve sürdürülebilir kalkınma alanında uluslararası hukukun daha da geliştirilmesinde devletlerin ve insanların iyi niyet ve ortaklık ruhu ile işbirliği yapacakları açıklanmıştır. 172 devletin katıldığı Rio'da gerçekleştirilen Konferans sonucunda yayınlanan Deklarasyon uluslar arası anlaşma niteliğinde bağlayıcı olmamakla birlikte, siyasal olarak uyulması, belirlenen ilkelere uygun davranılması uluslararası hukukun gereğidir.

3.1.5. "Avrupa Parlamentosu ve Konseyi'nin Belli Kamu ve Özel Projelerin Çevreye Olan Etkilerinin Değerlendirilmesine İlişkin 31 Aralık 2011 tarihli 2001/92/EU sayılı Direktifi (Avrupa Parlamentosu ve Konseyi'nin 16 Nisan 2014 tarihli 2014/52/EU Direktifi İle Değiştirilmişs)'nin EK III. Maddesinde”, projelerin çevresel etki değerlendirmesinin yapılıp yapılmayacağının tespitine ilişkin kriterler belirlenmiş bulunmaktadır (https://eur-lex.europa.eu/legal content/EN/TXT/PDF/?uri= CELEX: 02011L0092- 20140515\&rid=2).

Buna göre, projelerin özellikleri belirlenen kriterlere uygunlukları yönünden; - Tüm projenin büyüklüğü ve tasarımı, - Mevcut ya da onaylanan diğer projeler ile kümülatif etkisi (kümülasyonu-birikmesi), - Özellikle bio çeşitlilik, su, toprak ve arazı gibi doğal kaynakların kullanımı, - Atık üretimi, - Kirlilik ve çevreye verilen zarar, Bilimsel veriler uyarınca iklim değişikliklerinin sebep oldukları da dâhil olmak üzere proje ile ilgili başlıca kaza ve afet riskleri ve - İnsan sağlığına tehlikeleri (örneğin su kirliliği ya da hava kirliliği nedeniyle) yönlerinden ayrı ayrı değerlendirme yapılması gerekmektedir. 
Yine bir Projenin çevreye olan önemli etkilerinin, projenin belirtilen unsurlara olan etkisi bakımından, yer verilen kriterlere göre potansiyel etkinin türü ve niteliği-mevcut ya da onaylanan proje etkileri ile olan kümülatif etkisi değerlendirilmek durumundadır.

3.1.6. “Avrupa Parlamentosu ve Konseyi’nin Belli Kamu ve Özel Projelerin Çevreye Olan Etkilerinin Değerlendirilmesine İlişkin Direktifin EK IV. Maddesinde” de, Çevresel Etki Değerlendirme için gerekli bilgi olarak "diğerlerinin yanı sıra, projenin çevreye olası önemli etkilerinin" ve "doğal kaynakların kullanımı ya da özellikle ekolojik önemi olan alanlarla ilgili mevcut çevresel problemler de göz önüne alınarak, mevcut ya da onaylanmış projeler ile kümülatif etkileri”nin dikkate alınarak yapılacağı açıklanmıştır. Ayrıca belirtilen unsurlara olası önemli etkilere ilişkin açıklamada, "projenin doğrudan etkileri ile dolaylı, ikincil, kümülatif, sınır ötesi, kısaorta-uzun vadeli, geçici, kalıcı olumlu veya olumsuz etkilerini içermesi” gerektiği belirtilmiş, açıklamanın ilgili projeye ilişkin Birlik ve Üye Devlet düzeyinde belirlenen çevresel koruma hedeflerini dikkate alması düzenlenmiştir.

\subsection{Ulusal Mevzuat}

\subsection{1. Çevre Kanunu}

2872 sayılı Çevre Kanunu'nun 1. maddesinde kanunun amacı, bütün canlıların ortak varlığı olan çevrenin, sürdürülebilir çevre ve sürdürülebilir kalkınma ilkeleri doğrultusunda korunmasını sağlamak olarak açıklanmıştır. Kanun; çevrenin, canlıların yaşamları boyunca ilişkilerini sürdürdükleri ve karşılıklı olarak etkileşim içinde bulundukları biyolojik, fiziksel, sosyal, ekonomik ve kültürel ortamı, çevre korunmasını ise çevresel değerlerin ve ekolojik dengenin tahribini, bozulmasını ve yok olmasını önlemeye, mevcut bozulmaları gidermeye, çevreyi iyileştirmeye ve geliştirmeye, çevre kirliliğini önlemeye yönelik çalışmaların bütününü, çevre kirliliğinin de çevrede meydana gelen ve canlıların sağlı̆̆ını, çevresel değerleri ve ekolojik dengeyi bozabilecek her türlü olumsuz etkiyi ifade ettiğini belirtmiştir.

Yine sürdürülebilir çevrenin, gelecek kuşakların ihtiyaç duyacağı kaynakların varlığını ve kalitesini tehlikeye atmadan, hem bugünün hem de gelecek kuşakların çevresini oluşturan tüm çevresel değerlerin her alanda (sosyal, ekonomik, fiziki vb.) 1slahı, korunması ve geliştirilmesi sürecini, sürdürülebilir kalkınmanın ise bugünkü ve gelecek kuşakların, sağlıklı bir çevrede yaşamasını güvence altına alan çevresel, ekonomik ve sosyal hedefler arasında denge kurulması esasına dayalı kalkınma ve gelişmeyi ifade etiği açıklanmıştır.

Sürdürülebilir kalkınmanın çevre hakkı ile doğrudan ilişkilendirilmesi, "şimdiki ve gelecek kuşaklar” ibaresi ile sağlanmıştır. Sürdürülebilir kalkınmanın özünde her iki kuşağın da ihtiyaçlarının karşılanması bulunmaktadır. Kaynakların sınırlılı̆̆ı ve çevreye baskı olgusu ise bunların temel ihtiyaçlar olduğunu göstermektedir. Böylece şimdiki kuşaklar hem hak sahibi, hem kendi nesline hem de gelecek nesle karşı ödevlerle yükümlüdürler. Burada da, sürdürülebilir kalkınmanın anlam ve amacında var olan, kuşaklar içi ve kuşaklararası hakkaniyet (ya da adalet) ilkeleri ortaya çıkmaktadır (Turgut, 2010, s.6).

\subsection{2. Çevresel Etki Değerlendirmesi (ÇED) Yönetmeliği}

ÇED ile ilgili ilk düzenleme ÇED Yönetmeliği adı altında ilk olarak 07/02/1993 tarihinde yürürlüğe girmiştir. Buna göre, çevresel etki değerlendirmesi, çevreyi doğrudan ya da dolaylı olarak, olumlu ya da olumsuz yönde etkileyebilecek bir ya da birden fazla faaliyete ait bir projenin yapılması için alınacak karara esas olmak üzere, proje konusu faaliyetlerin bütün çevresel etkilerinin bilimsel yöntemler ve tekniklerle incelenmesi, ortaya çıkabilecek olumsuz etkileri önlemek ya da çevreye zarar vermeyecek ölçülerde en aza indirmek için alternatif çözümlerin belirlenmesi, belirlenen önlemlerin izlenip denetlenmesi sürecini ifade etmektedir. Diğer bir anlatımla, ÇED; ekonomik ve sosyal gelişmeye engel olmaksızın çevre değerlerini ekonomik politikalar karşısında koruyarak, yeni proje ve gelişmelerin çevreye olabilecek sürekli veya geçici potansiyel etkilerinin sosyal sonuçlarını ve alternatif çözümlerini, ilgili tüm tarafların görüş, kaygı ve önerilerini de dikkate alarak işletme öncesi, işletme sırası ve işletme sonrasını da içine alarak değerlendirilmesinin, izlenmesinin ve denetlenmesinin yapıldı̆̆ı bir süreçtir.

Proje planlama aşamasında çevresel etki değerlendirmesinin yapılması için; başvuru, inşaat öncesi, inşaat, işletme ve işletme sonrası çalışmaları kapsayan süreçte çok yönlü bir araştırma ve inceleme yapılmasını gerektirmektedir. Çünkü gerçekleştirilmesi planlanan projenin çevreye, sosyal hayata, projenin gerçekleşeceği yerdeki yaşam tarzına ve gelecekteki yatırımlara etkilerinin belirlenmesi önem taşımaktadır. Yatırımların geleceğe dönük etkisi kaçınılmaz olarak çevreyi de etkileyecektir.

\section{4 Çevre Hakkı ve Ekonomik Kalkınma İlişkisi}

\section{1 İhtiyat İlkesi (Precautionary Principle)}

Çevre hukukunun, ekonomi, sosyoloji, ekoloji, fizik, kimya, biyoloji gibi diğer sosyal, teknik ve tabiat bilimleriyle bağlantısı bulunmaktadır. İhtiyat ilkesi, çevrenin korunması bakımından aslında bilimsel risklerin yönetimi ile ilgili bir kavramdır. Genelde çevre koruma politikasının ve bu arada çevre hukukunun bilimsel verilere bağımlılı̆̆ gerçeği, "bilimin birtakım sorunlar karşısında beklenen cevapları verememesi”yle birlikte düşünüldüğünde, çözümü güç ama zorunlu sorun kendini göstermektedir. 
Hukukun istediği belirgin verilerin bilim tarafından ortaya konulamadığı alanlarda ve durumlarda, çevrenin korunması mümkün olamayacak mıdır? İşte ihtiyat ilkesi bu sorunun cevabı çerçevesinde getirilmiş bir çözüm yoludur (Turgut, 1995, s.68). İhtiyat ilkesinin uygulanması belirsizlik ve risk derecesinin yüksek olduğu konularda önem ve duyarlılık kazanmaktadır. İhtiyat kelime anlamı olarak, herhangi bir konuda ileriyi düşünerek ölçülü davranma, sakınma demektir (Türk Dil Kurumu, Güncel Türkçe Sözlük).

İhtiyat ilkesinde iki ana unsur bulunmaktadır. Birincisi, bilimsel belirsizlik olgusu ikincisi ise potansiyel çevresel zarar riskidir. Bunlardan riskin varlığı bir kez saptandıktan sonra, çevre üzerinde oluşabilecek zararlarla bunlara sebep olarak gösterilen etkinlikler (veya kirleticiler) arasındaki sebep-sonuç ilişkisini gösterecek açık ve belirgin verilerin olmamasına karşın, sonucun gerçekleşmesi olasılığını önlemek için gerekli tedbirler alınmak durumundadır. Başka bir ifadeyle, bilimsel açıdan belirgin sonuçların elde edilmesini beklemektense, potansiyel zararın oluşmaması için ilk planda (çok geç olmadan) tedbirli hareket edilmesi gerekmektedir. Bu anlamda, risk ile ihtiyat arasında bir seçim yapılması söz konusu olmaktadır. Riskin tercih edilmesinin sonucu çevrede geri döndürülemez büyük bir zarar ya da umulandan daha küçük bir zarar ortaya çıkabilir. Tercihin ihtiyattan yana yapılması halinde ise, zararın ortaya çıkması önlenebilir ya da beklenenden çok düşük olması sağlanabilir. Bunun maliyeti ihtiyat için alınacak önlemin niteliğine göre değişik olacaktır.

İhtiyat ilkesi, Rio Deklarasyonu'nun 15. maddesinde (1992) tanımlanmıştır. Buna göre; “çevreyi korumak için ihtiyatlı yaklaşım devletlerin kendi imkânlarına göre en etkili biçimde uygulanacaktır. Ciddi ve geri dönüştürülemez hasar tehlikesi olan yerlerde tam bilimsel kesinlik eksikliği çevresel kirlenmenin önlenmesi için gecikmenin sebebi olarak kullanılamayacaktır." Bu ilke, gerek uluslar arası sözleşmelerde gerekse iç hukukumuzda yer almamaktadır. Rio'da gerçekleştirilen Konferans sonucunda yayınlanan Deklarasyon bağlayıcı nitelikte olmamakla birlikte, BM düzeyinde siyasal olarak etkisi bulunmakta ve uyulması uluslararası hukukun gereği olmaktadır.

Ayrıca belirtildiği gibi Avrupa Parlamentosu ve Konseyi’nin Belli Kamu ve Özel Projelerin Çevreye Olan Etkilerinin Değerlendirilmesine İlişkin 31 Aralık 2011 tarihli 2001/92/EU sayılı Direktifi'nin EK III. Maddesinde ve EK IV. Maddesi uyarınca projenin doğrudan etkileri ile dolaylı, ikincil, kümülatif, sınır ötesi, kısa-orta-uzun vadeli, geçici, kalıcı olumlu veya olumsuz etkilerini içermesi gerektiği belirtilmiş olduğundan, açıklamanın ilgili projeye ilişkin Birlik ve Üye Devlet düzeyinde belirlenen çevresel koruma hedeflerinin dikkate alınması gerekliliği nedeniyle ülkemiz bakımından da önemi kuşkusuzdur.

Nitekim Danıştay, ihtiyatilik ilkesini “Anayasa'da yer alan sağlıklı ve dengeli bir çevrede yaşama hakkı, geleceğe yönelik bilimsel belirsizliklerin bulunduğu hâllerde gelecek nesillerin yaşam hakkının korunmasına ilişkin gerekli tedbirlerin alınmasını öngören ihtiyat ilkesini içinde barındırmaktadır” şeklinde değerlendirme yapmak suretiyle karara yansıtmıştır (Danıştay Onüçüncü Daire, E:2011/2352, K:2015/1943, K.T. 22.05.2015). Bu karar Danıştay İdari Dava Daireleri Kurulunca da onanmıştır (Danıştay İDDK E. 2015/3645, K. 2016/2089, K.T. 18.05.2016).

\section{2 Çevrenin Geleceği Üzerine Yaklaşımlar}

Çevrenin geleceği üzerine üç temel yaklaşım söz konusudur. Bunlar, sürdürülebilir kalkınma, derin ekoloji ve yetinme yaklaşımlarıdır (Bilir ve Hamdemir, 2011, s.146-147).

\subsubsection{Sürdürülebilir Kalkınma Yaklaşımı}

Sürdürülebilir kalkınma yaklaşımı, bugünün ihtiyaçlarını ve beklentilerini, geleceğin ihtiyaçlarından ödün vermeksizin tedarik etmenin yöntemlerini ortaya koymak düşüncesini esas almaktadır (Dünya Çevre ve Kalkınma Komisyonu Raporu, 1991, s. 73). Bu yaklaşım, ekonomik ve sosyal gelişme gerçekleştirilirken, doğal dengenin de gözetilmesini esas almaktadır. Bu nedenle sürdürülebilir kalkınma dengeli kalkınma ile eş anlamlı olarak şu şekilde tanımlanabilir: Sürdürülebilir kalkınma, "şimdiki kuşakların ihtiyaçlarının gelecek kuşakların kaynaklarını tehlikeye atmadan karşılanmasına imkân veren ekonomik büyüme politikalarıdır.” (Güler, 1994, s. 362).

\subsubsection{Yetinme Seviyesi Yaklaşımı}

Kalkınmanın sürdürülebilir olması için her şeyden önce kaynakların da sürdürülebilir olması gerekmektedir. Kaynaklar; ormanlar ve deniz ürünleri gibi canlı doğal kaynaklar, madenlerden oluşan cansız doğal kaynaklar ve enerji kaynakları olmak üzere kabaca üç kategoriye ayrılmaktadır. Canlı doğal kaynaklar, her ne kadar kendini yenileyebiliyorsa da bunları tüketme hızı, kendilerini yenileme hızıyla orantılı olmak durumundadır. Aksi halde tamamen tükenmeleri söz konusu olacaktır. Cansız doğal kaynakların kendilerini yenilemeleri mümkün olmadığ için ne kadar yavaş tüketilirse tüketilsinler bir gün tamamen tükeneceklerdir. Dolayısıyla cansız doğal kaynakları özenle kullanmak gerekmektedir. Günümüzde kullanılan fosil yakıtlardan oluşan enerji kaynakları da bir gün tükenecektir. Bu nedenle yenilenebilir enerji kaynaklarına yönelmek, enerji konusunda uzun vadede sorunu çözecek tek yol gibi gözükmektedir (Gökdayı, 1997, s. 175).

Kaynaklarla ilgili bu durum, sürdürülebilir kalkınmanın, mevcut şartların devam etmesi durumunda bile "kaçınılmaz sonu önlemeyeceği”" sonucunu ortaya koymaktadır. Buna duruma göre aslolan gelişmiş ülkelerdeki tüketim düzeyinin “yetinme seviyesine” çekilmesinin sağlanmasıdır (Gökdayı, 1997, s. 175). İşte yetinme seviyesi yaklaşımı olarak da adlandırılan bu yaklaşım, kalkınmanın ve canlı yaşamının sürdürülebilmesi için sürdürülebilir 
kalkınma yaklaşımının yetersiz ve aldatıcı olduğu değerlendirilmektedir. Dolayısıyla yetinme seviyesi yaklaşımı, insanların temel ihtiyaçlarını gidermeye yönelik bir tüketim anlayışının benimsenmesinin daha gerçekçi ve kalıcı bir çözüm olacağı fikrine dayanmaktadır (Gökdayı, 1997, s. 179).

\subsubsection{Derin Ekoloji Yaklaşımı}

Derin ekoloji anlayışı, doğayı merkez olarak almaktadır. Biyosantrik düşünüş yerine ekosantrik düşünüşün hakim olduğu bu yaklaşıma göre, yeryüzünde değerli olan tek şey insan değildir; ekosistemin tümü değerlidir ve türlerin sürdürülmesi gereklidir. İnsanlar yaşamak için çevreyi yok etmeden ihtiyaçları kadar olanı doğadan almalı; ekosistemdeki tüm yaşam dengeli bir şekilde muhafaza edilmelidir (Yaren, 1995, s. 99-101).

\section{5 Çevrenin Korunması ve Yargısal Denetim}

Çevre sorunlarının çözümünde yargısal denetimin önemi kuşkusuzdur. Gerek ulusal yargı makamlarının gerek uluslarüstü yargı mercilerinin çevre hakkı ve çevre sorunlarına yönelik yaklaşımının bilinmesi önem taşımaktadır.

\subsection{Adalet Divanı ve Avrupa İnsan Hakları Mahkemesi (AİHM)}

Uluslararası Adalet Divanı (ICJ) Gabcikovo-Nagymaros davasında, (25 Eylül 1997) çevrenin korunmasının çağdaş insan hakları doktrininin çok önemli bir parçası olduğuna dikkat çekerek; yaşama ve sağlık hakkı gibi sayılı insan haklarından (sine qua non) ayrılmaz bir hak olduğunu belirtilmiştir. Kararın 52. Paragrafında; Mahkeme, çevreye saygının gereğini belirtmiş ve "çevrenin, bir soyutlama değil doğmamış nesilleri de kapsamak üzere, yaşam kalitesi ve insanların, sağlı̆̆ını ve yaşam alanını ifade ettiği açıklanmıştır. Devletlerin kendi yargısal alanındaki faaliyetleri ve diğer devletlerin çevreye saygısını veya kendi ulusal etkileri dışındaki alanın kontrolünü sağlamanın uluslararası çevre hukuku birikiminin bir parçası" olduğu şeklindeki açıklama ile sadece devletler için değil, bütün insanlık bakımından çevrenin önemini vurgulamıştır.

AİHM, Taşkın ve Diğerleri- Türkiye davasında; çevre sorunları üzerinde etkili olan devlet tasarrufları sonucunda oluşan uyuşmazlıklara ilişkin davalarda gerçekleştireceği incelemenin iki farklı temeli olduğunu belirtmiştir. Ulusal mercilere ait kararların maddi içeriğinin Sözleşmenin 8. maddesine uygunluğunu değerlendirebileceği ve ulusal makamlarca tesis edilen işlemlerde uygulanan karar alma sürecinde, bireylerin menfaatlerinin usule uygun olarak dikkate alınıp alınmadığını inceleyebileceğini açıklamıştır (https://hudoc.echr.coe.int/eng\#\{\%22itemid\%22:[\%22001-125031\%22]\},paragraf115). Kararın 116. Paragrafinda ise, çeşitli kararlarında, çevre ile bağlantılı uyuşmazlıklarda devletin geniş bir değerlendirme yetkisine sahip olduğu belirtilmiştir.

Yine Giacomelli v. İtalya davasında olduğu gibi AİHM; birçok kararında, çevre ile bağlantılı uyuşmazlıklarda devletin geniş bir değerlendirme yetkisine sahip olduğunu belirtmiştir. Anılan Kararın 84. Paragrafında AİHM, davalı devletin takdir yetkisinin kapsamının belirlenmesinde başvurucunun menfaatlerinin usulüne uygun olarak dikkate alınıp alınmadığı ve yeterli usuli güvencenin bulunup bulunmadığının incelenmesi gerektiğini (https://hudoc.echr.coe.int/eng\#\{\%22itemid\%22:[\%22001-77785\%22]\}) vurgulamıştır.

AİHM, her bir somut olayda ciddi endüstriyel kirliliğin etkilerini ölçmenin ve bu etkileri yaş, meslek veya bireysel yaşam tarzı gibi diğer faktörlerin etkilerinden ayırmanın çoğu zaman imkânsız olduğunu belirtmekte ve ispatta bulunmanın zorluklarını göz önüne alarak büyük ölçüde yerel mahkemelerin ve diğer yetkili mercilerin davanın maddi koşullarına ilişskin tespitlerini göz önüne almaktadır (Jugheli ve Diğerleri Gürcistan davası; https://hudoc.echr.coe.int/eng\#\{\%22itemid\%22:[\%22001-175153\%22]\}).

AİHM, termik santralin "ölçekleri, konumları ve içerikleri nedeniyle çevre, doğal kaynaklar ve insan sağlı̆̆ üzerinde ciddi olumsuz ve geri döndürülemez etkilere neden olabilecek" olarak tanımlanan bu tür faaliyetlerin tehlikeli doğaları, Tiflis Belediyesi tarafından da açık bir şekilde belirtildiği halde konunun özünü santralin özelleştirilmeden önce veya sonraki tehlikeli faaliyetleri için uygulanabilir bir mevzuat çerçevesinin gerçekten var olmaması ve başvuruların Sözleşmenin 8. maddesi kapsamındaki haklarını olumsuz etkileyen santralden kaynaklanan hava kirliliğinin giderilmemesi olarak kabul etmektedir. Özellikle tehlikeli faaliyetler açısından, Devletlerin, söz konusu faaliyetlerin belirgin özelliklerine bağlı olarak, özellikle de potansiyel risk seviyesine ilişkin olarak mevzuatı oluşturma yükümlülüğü bulunduğu, mevzuatın, faaliyetlerin ruhsatlandırılması, kurulması, işletilmesi, güvenliği ve faaliyetin denetlenmesini kapsaması ve işbu faaliyetlerin doğasından kaynaklanan riskler yüzünden hayatları tehlike altında olabilecek vatandaşların etkili bir şekilde korunmasını sağlamak üzere ilgili tüm taraflar için pratik önlemleri almalarının zorunlu olduğunu belirtmektedir (Di Sarno ve Diğerleri İtalya, No. 30765/08, § 106, 10 Ocak 2012).

\subsection{Anayasa Mahkemesi}

Anayasa Mahkemesi, çevre hakkının, bir pozitif statü hakkı olduğuna ve devlete birtakım ödevler yüklediğine vurgu yapmaktadır. Anayasa Mahkemesi bir kararında, Anayasa'nın 56. ve 63. maddelerine değinildikten sonra "bu hükümlere göre, çevrenin geliştirilmesi, çevre sağlığının korunması ve çevre kirlenmesinin önlenmesine; tarih, kültür ve tabiat varlıklarının ve değerlerinin korunmasına yönelik her türlü tedbiri almak Devletin temel ödevlerindendir. Bu amaçla Devlet, çevrenin ve kültür ve tabiat varlıklarının korunmasını sağlamak için etkili bir maddi hukuk düzeni oluşturmak ve öngörülen maddi hukuku uygulamak üzere gereken teşkilatı kurmakla 
yükümlüdür”(AYMK E. 2001/106, K. 2012/192, K.T. 29.11.2012; Resmi Gazete: 02.04.2013, 28606 (mükerrer) şeklinde açıklama yapmışıtır.

Başka bir kararında da, Anayasa'nın 56. maddesinde belirtilen ödevlerin somut tedbirlerle nasıl yerine getirileceği hususunun yasa koyucunun takdirinde olduğu ifade edilmiştir (AYM, E. 2011/110, K. 2012/79, K.T. 24.05.2012, RG: 21.07.2012, 28360.). Dolayısıyla Anayasa Mahkemesi, çevre hakkının gerçekleştirilmesi için devletin olumlu edimlerde bulunması ve somut önlemler alması gerektiğini kabul etmiş bulunmaktadır. Yine Anayasa Mahkemesi, 2634 sayılı Turizmi Teşvik Kanunu'nun 8. maddesinin bazı hükümlerinin Anayasa'ya uygunluk denetimini yaptığı kararında "ormanların turizm yatırımlarına tahsisini zorunluluk veya kaçınılmazlık hallerine özgüleyen belli ölçüt ve sınırlamalara yer verilmemesi” nedeniyle düzenlemeyi Anayasa'nın 169. maddesine aykırı bulmuştur (AYM, E. 2006/169, K. 2007/55, K.T. 07.05.2007, RG: 24.11.2007, 26710).

Bir diğer kararı ise Ereğli Kömür Havzası'ndaki madencilik faaliyetlerini 3213 sayılı Maden Kanunu'nun 7. maddesinde yer alan düzenlemelerden bağışık tutan, anılan Kanun'un ek 1. maddesinin 4. fikrasının Anayasaya aykırılı̆ıını incelerken, madencilik faaliyetinin çevreyle uyumlu bir şekilde yürütülmesi gerektiğine hükmetmiş; önemli bir ekonomik faaliyet olan madenciliğin, çevrenin korunması gerekliliğinden bağımsız olarak gerçekleş̧irilemeyeceğini ortaya koymuştur. Anayasa Mahkemesi kararda, sağlıklı ve dengeli bir çevrede yaşama hakkının, getirilecek kuralın ekonomik, bürokratik ve fiili yükümlülüklere yol açacağı ve üretim faaliyetlerinin etkileneceği gerekçeleriyle vazgeçilecek haklardan olmadığını belirtmiştir (AYM, E. 2011/110, K. 2012/79, K.T. 24.05.2012, RG: 21.07.2012, 28360).

Anayasa Mahkemesi başka bir kararında da, petrol, jeotermal kaynaklar ve maden arama faaliyetlerini, çevresel etki değerlendirmesi kapsamı dışında tutan düzenlemeyi Anayasa'nın 56. maddesine aykırı bularak iptal etmiştir. Gerekçede çevresel etki değerlendirmesinin, kalkınma ve ekonomik gelişme için yapılacak yatırım ve faaliyetlerin, doğayı tahrip etmeden ve çevreyi kirletmeden gerçekleştirilmesinde kullanılan bir yöntem olduğu belirtilmiştir. Kararda, ÇED ile korunmaya çalışılan temel unsurun çevre ve bu çevre içindeki varlıklar olduğu açıklanmış, arama faaliyetlerinin biyolojik çeşitlilik üzerinde ya da doğada değiş̧iklikler meydana getirebileceğine dikkat çekilmiştir (AYM, E.2006/99, K.2009/9, K.T. 15.01.2009, RG: 08.07.2009, 27282).

\subsection{Danıștay}

Çevre sorunlarının çözümünde etkili yargısal denetim asıl olarak Danıştay tarafından yapılmaktadır. Kümülatif etki değerlendirmesinin yargısal denetimi gerçekleştirilirken Danıştay'ın tutumunun bilinmesi önem taşımaktadır.

\subsubsection{Tek Tek Projelerin Çevresel Etkileri Değil Kümülatif Etkileşimin Belirlenmesi Gerekliliği}

Yargısal denetimde kümülatif etkiler araştırlırken, "bölgede faaliyet gösteren diğer kirletici tesisler (termik santral, haddane, demir-çelik, rafineri, petrokimya vb) de hesaba katılmalı, mevcut diğer santrallerin hava kalitesine (hava modellemesi ve atık ısı modellemesi), yüzey sularına (deniz deşarjı noktasında termal modelleme) olası etkilerinin planlanan faaliyet ile etkileşimi ortaya konulması gerekmektedir.

Danıştay, bir entegre proje kapsamında birden fazla tesis için ayrı ayrı alınan ÇED olumlu raporlarının tek başına değil, bir bütün halinde değerlendirilmesi” gerektiğine karar vermiştir (Danıştay Ondördüncü Dairesi, E.2018/2806, K.2018/8205, K. T. 26.12.2018).

Yine yapılan etki araştırmasının aynı bölgede daha önceden gerçekleştirilmiş projeler ile yapılacak sonraki projelerin birlikte çevresel etkilerinin belirlenmesi gerekmektedir. Belirtildiği gibi ihtiyat ilkesi uyarınca, risk ile ihtiyat arasında bir seçim yapılması söz konusu olmaktadır. Riskin tercih edilmesinin sonucu çevrede geri döndürülemez büyük bir zarar ya da umulandan daha küçük bir zarar ortaya çıkabilir. Tercihin ihtiyattan yana yapılması halinde ise, zararın ortaya çıkması önlenebilir ya da beklenenden çok daha düşük olması sağlanabilir.

Nitekim Danıştay; "Çevresel etki değerlendirmesi; işletme izni verilen alanda (işletme ruhsatı verilen alanın tamamında değil) gerçekleştirilmesi planlanan projenin, çevreye olabilecek olumlu ya da olumsuz etkilerinin belirlenmesi, olumsuz yöndeki etkilerin önlenmesi ya da çevreye zarar vermeyecek ölçüde en aza indirilmesi için alınacak önlemlerin belirlenerek değerlendirilmesi amacıyla yapıldığından, süreç içerisinde işletmenin faaliyeti aşamasında 25 hektar sınırlamasına ve çevre mevzuatında yer alan diğer kurallara riayet edilmediğinin tespiti halinde yetkili idare tarafından yasada öngörülen tedbirlerin alınarak gerekli yaptırımların uygulanabileceği tartışmasız olup, aynı maden işletme ruhsatı alanında işletme izni verilen alan dışında yeni bir maden işletme projesi için başvuruda bulunulması halinde ise, bu projelerin birbirinden bağımsız olarak kabul edilemeyeceği ve toplam proje sahaları üzerinden kümülatif olarak çevresel etki değerlendirmesine tabi tutulacağ 1 tabiidir." (Danıştay Ondördüncü Daire, E. 2018/ 2676, K. 2018/7082, K.T. 20.12.2018) şeklinde açıklama yapmıştır.

Kümülatif etki değerlendirmesinin nasıl yapılması gerektiği konusunda Danıştay, yol gösterici nitelikte bir karar vermiştir. Kararda, “...kümülatif etki değerlendirmesi için çalıştırılan modelde incelenen yaklaşık $2500 \mathrm{~km}^{2}$ 'lik alan için sadece Erdek ve Bandırma Meteoroloji İstasyonlarına ait verilerin kullanıldığı, bu istasyonların incelenen saha dışında olduğu, topoğrafyası ve bitki örtüsü sıklıkla değişkenlik gösteren ve içerisinde farklı mikro klimalar barındıran bölgenin tek bir meteoroloji istasyonu ile ifade edilmesinin mümkün olmadığı, bu istasyonların inceleme sahasının dışında kaldığı ve bölgeyi temsil konusunda şüphe yaratacağı, meteorolojik veriler kapsamında 2012 tarihli ÇED raporunda hava kalitesi değerlendirmesi ve modellemesi çalışmalarında mevcut hava kalitesi 
tespit çalışmalarının tüm mevsimleri kapsamadı̆̆ı ve kullanılan meteoroloji veri setinin tam olarak bölgeyi yansıtmadığının tespit edildiği, mevcut hava kalitesi tespit ve hava kalitesi modelleme çalışmalarının yukarıda anlatılan yöntemlerle hesaplanacak şekilde tekrarlanması gerektiği, ÇED raporunda kazı, dolgu, nakliye, kömür depolama ve yükleme benzeri faaliyetlerden dolayı baca dışı kaynaklı toz emisyonları ile ilgili bir araştırma ve raporun bulunmadığı görüldüğünden, belirtilen eksikliklerin ÇED raporunu dolayısıyla ÇED olumlu kararını sakatlayıcı, önemli nitelikte eksiklikler olduğu, söz konusu eksikliklerin ÇED raporu hazırlanmak suretiyle giderilmesi gerektiği anlaşılmakla aktarılan hususlarda eksik hazırlandığı anlaşılan ÇED raporu dayanak alınarak tesis edilen dava konusu ÇED olumlu kararında belirtilen yönlerden hukuka uyarlık bulunmadığı" (Danıştay Ondördüncü Daire, E.2019/263, K.2019/2052, K.T. 13.3.2019) belirtilmiştir.

Danıştay başka bir kararında ise, üretim lisansının kümülatif etki değerlendirme süreci izlenmeden alınan ÇED Olumlu kararına dayanarak verilmesini hukuka uygun bulmuştur. Kümülatif etki değerlendirmesi ihtiyat ilkesinin ve çevre hakkının bir gereği olmasına rağmen, “...kurulan ya da kurulacak santrallerin de dikkate alınarak bölgenin bir bütün olarak değerlendirileceği kümülatif etki değerlendirmesi yapılmış olmasının aranması hukuki güvenlik ilkesinin bir gereği olan "belirlilik" ve "öngörülebilirlik ilkesi" karşısında mümkün değildir" (Danıştay Onüçüncü Daire, E.2012/1154, K. 2018/4374, K.T. 25.12.2018) gerekçesine yer verilerek dava reddedilmiştir.

\subsubsection{Bilirkişi İncelemesi Yapılması Gerekliliği}

Danıştay ÇED sürecine bağlı olarak verilecek kararlarda bilirkişi incelemesi yaptırılması suretiyle düzenlenecek raporu esas almak suretiyle karar vermektedir. "ÇED süreci sonunda verilecek kararların yargısal denetimi yapılırken, seçilecek bilirkişiler arasında bir çevre mühendisinin bulunması, diğer bilirkişilerin ise projenin ve bulunduğu çevrenin özelliklerine göre ve nihai ÇED raporunu hazırlayan kişilerin uzmanlık alanları da dikkate alınmak suretiyle seçilmesi gerekmektedir" (Danıştay Ondördüncü Daire, E. 2018/ 2252, K.2018/8057, K.T. 25.12.2018)

Danıştay, ÇED raporunu düzenleyenlerin uzmanlık alanları ile bir denge kurularak bilirkişilerin uzmanlık alanları bakımından da yetkin olmalarına önem vermektedir. "Nihai ÇED raporunda onlarca uzmanın imzası bulunabildiğinden, birebir aynı sayıda ve aynı uzmanlık alanında olmasa dahi, yargılama usulü kurallarının elverdiği ölçüde, usul ekonomisi de gözetilerek bir denge kurulması, seçilecek bilirkişilerin projenin bulunduğu alana ve projeye yapılan itirazlara göre, değerlendirilmesi zorunlu olan ana konu başlıkları bakımından yeterli uzmanlığa sahip olması, tarafları tatmin edici ve adil bir yargılama yapılması açısından gerekliliktir" (Danıştay Ondördüncü Daire, E. 2018/ 5638, K.2019/876, K.T. 6.2.2019). "Dava konusu işlemin gerekçesi, davacının iddiaları ve nihai ÇED raporunu hazırlayanların uzmanlık alanları da dikkate alınmak suretiyle, dava konusu "ÇED Olumsuz" kararına konu faaliyetin, alanın niteliğine, tarım alanları, su kaynakları, ormanlık alanlar ve duyarlı yörelere etkisinin değerlendirilmesi ile nihai ÇED raporunun ve alınacak önlemlerin teknik ve bilimsel açıdan yeterliliğinin tespiti amacıyla üniversitelerin ilgili bölümlerinden seçilecek biri çevre mühendisi olmak üzere, kimya mühendisi, maden mühendisi, ziraat mühendisi, orman mühendisi, hidrojeoloji mühendisi gibi uzmanlardan oluşturulacak yeni bir heyet ile keşif ve bilirkişi incelemesi yaptırılması ve bunun sonucunda düzenlenecek raporun incelenmesi suretiyle karar verilmesi gerekmektedir" (Danıştay Ondördüncü Daire, E. 2018/ 3465, K.2019/88, K.T. 15.1.2019).

Yine Danıştay bilirkişi incelemesi bakımından da kümülatif etki değerlendirmesini önemsemekte, gerekmesi halinde ek rapor alınmak suretiyle karar verilmesi yoluna gitmektedir.

Nitekim “...Bilirkişi raporunda "Çevresel etkilerin değerlendirilmesi için Süreyyabey Barajı da dahil olarak çekerek çayının bir bütün olarak ele alınması yerinde olacaktır. Tek tek az/ve yönetilebilir olarak ortaya konan çevresel etkiler birlikte ele alınınca "kümülatif" olarak tanımlanan toplanmış etki bütün Çekerek Çayı havzasının özgünlüğünü tehdit edebilir." yönündeki tespite yer verilmiş ise de, bu hususun ÇED raporunun ekindeki "Kümülatif Etki Raporunun" dikkate alınarak değerlendirilmesi" (Danıştay Ondördüncü Daire, E. 2017/ 2648 K.T. 20.12.2018; Danıştay Ondördüncü Daire, E. 2017/ 1729, K.T. 20.12.2018) amacıyla ek rapor alınmasına karar vermiştir.

Bilirkişi raporu alınması bir projenin çevresel etkilerinin belirlenmesi amacı taşımakla birlikte, projenin yapılması öncesinde gerekli teknik bilgileri içermemesi durumunda çevresel etkilerinin belirlenmesine yetecek derecede eksik bilgiler anlamına geldiğinden Danıştay bu yönüyle de denetim yapmaktadır.

Nitekim, “...seçme eleme kriterlerine tabi olan dava konusu projenin mevcut arazi kullanımı ve kalitesi yönünden etkileri değerlendirilirken, sondaj noktalarına olan ulaşımın projeden bağımsız ele alınamayacağı, nitekim sondaj faaliyetiyle sondajlara ulaşım yolları açılmasının kümülatif etki oluşturacağı dolayısıyla Proje Tanıtım Dosyası (PTD) hazırlanırken bu hususlara da yer verilmesi gerektiği sonucuna varılmış olup, yapılan bu tespitler yönünden bilirkişi raporu hükme esas alınmıştır. Bu durumda; ormanlık alanda gerçekleştirilecek dava konusu proje için hazırlanan PTD'de sondaj noktalarına ulaşımın nasıl sağlanacağı, yol güzergahının nereden geçeceği ve genişliğinin ne kadar olacağı, ortaya çıkacak hafriyatın çevreye zarar vermeden nasıl uzaklaştırılacağı veya depolanacağı, bu kapsamda ağaç kesilip kesilmeyeceği hususlarına ve ağaç kesilecekse sayısına yer verilmediği görüldüğünden, belirtilen yönlerden eksik olan PTD esas alınarak tesis edilen dava konusu ÇED Gerekli Değildir kararında hukuka uyarlık bulunmamaktadır” (Danıştay Ondördüncü Daire, E. 2016/ 2561, 
K.2018/8325, K.T. 27.12.2018; Danıştay Ondördüncü Daire, E. 2018/ 1884, K.2018/8324, K.T. 27.12.2018). gerekçesiyle dava konusu işlemi iptal etmiştir.

Danıştay, kümülatif etki değerlendirmesi yapılmadan verilen Çevresel Etki Değerlendirme raporları esas alınarak verilen lisans işlemlerinin yargısal denetiminde, lisans verme işleminin dayanağı Çevresel Etki Değerlendirme raporunun dışında kümülatif etki değerlendirmesi yapılmasına ilişkin bilimsel, teknik ve hukuki açıdan çevre hukuku ile ilgili mevzuata uygun olup olmadığının araştırılması ve bu konularda uzman kişilerin görüşlerine başvurulması yoluna gitmemektedir. Nitekim Danıştay, kümülatif etki değerlendirmesinin ne anlama geldiğini belirtmiş ve "bir proje yahut proje faaliyetinin, geçmişte, günümüzde mevcut ve gelecekte makul olarak öngörülebilen faaliyetler ile birlikte çevrede meydana getireceği değişikliklerin incelenmesidir" şeklinde değerlendirmede bulunmuş ancak bilirkişi incelemesi yapılmasına gerek görmemiş̧ir (Danıştay Onüçüncü Daire, E.2012/1154, K. 2018/4374, K.T. 25.12.2018).

Ancak Osmaniye ilinde kurulmak istenen termik santral için verilen üretim lisansının iptali istemiyle açılan davada, Ankara 7. İdare Mahkemesince yaptrrılan bilirkişi incelemesi sonucunda düzenlenen rapor hükme esas alınmak suretiyle davanın reddine karar verilmiştir (Ankara 7. İdare Mahkemesi E. 2014/1874, K. 2017/32, K.T. 12. 01. 2017). Raporda “... tesisin ileri teknoloji kullanan, doğalgaz çevrim santrali olması nedeni ile çevre üzerinde düşük seviyeli bir yük oluşturacağı, Çukurova bölgesinde bulunan diğer tesislerden yeterince uzak olduğu için o tesislerin yarattığı etkiye bir katkısı olmasının beklenmediği, mevcut durumda, insan sağlığı, deniz, hava ve su ekosistemleri üzerinde kalııı bir etki/zarar oluşturmayacağı" görüş ve kanaatine yer verilmiştir. Davanın reddine ilişkin karara karşı yapılan istinaf başvurusunu raddeden Ankara 7. İdari Dava Dairesinin E. 2017/388, K.2017/572, K.T. 29.11.2017 sayılı kararına karşı yapılan temyiz başvurusu; bilirkişi incelemesi sonucunda düzenlenen rapora dayalı olarak karar verilmiş olmasına rağmen reddedilerek karar onanmıştır (Danıştay Onüçüncü Daire E. 2018/1198, K. 2018/4377, K.T. 25.12.2018).

Yine Danıştay, "Göle, Ardahan ve Çıldır Ovası'ndan geçerek, Gürcistan ile Azerbaycan üzerinden Hazar Denizi'ne dökülen Kura Nehri'nin, hidroelektrik santralleri kurmak amacıyla doğal mecrasından alınarak vadi atlatması yapılmak suretiyle Köprüler Deresi yoluyla Çoruh Nehri üzerinden Karadeniz'e aktarılmasına ilişkin Kura-Çoruh Enerji Grubu adı verilen proje işlemi ile bu projenin özel sektör tarafindan gerçekleştirilmesine ilişkin işlemin iptali istemiyle açılan davayı reddeden İdare Mahkemesi kararını; davacının ve davacı yanında müdahilin temyiz dilekçesinde ileri sürdüğü, Kura-Çoruh Enerji Grubu Projesinin bilimsel, teknik ve hukuki açıdan çevre hukuku ile ilgili mevzuata uygun olup olmadığının araştırılmadığı, bu konularda uzman kişilerin görüşlerine başvurulmadığı, projenin hayata geçmesi ile Ardahan ilinde ekolojik dengenin bozulacağı, tarım ve hayvancıllğın yok olacağı yönündeki iddialarına; söz konusu projenin taslak bir proje olması, projeye talep olması halinde projeyi üstlenen firmanın gerekli fizibilite çalışmalarını yapacak olması, projenin teknik verilerinin ve çevresel etkisinin bu aşamadan sonra ayrıntılarıyla değerlendirilecek olması, tüm bu safhaların ayrıca dava konusu edilebilecek olması hususları dikkate alınarak itibar edilmemiştir." (Danıştay Onüçüncü Daire, E. 2015/2753, K. 2015/ 2713, K. T. 29.06.2015) gerekçesiyle mahkeme kararını onamıştır.

\section{Sonuç}

Termik santrallerin kümülatif etkisinin değerlendirilmesi, yeni yapılacak santrallere lisans verilmesi aşamasında çevre üzerindeki mevcut ve önceden lisans verilmiş santrallerin bütünsel olarak etkilerinin belirlenmesi yolu ile mümkün olabilecektir. Aynı şehir veya coğrafi bölgede kurulan ya da kurulacak olan diğer santrallerin yeri, konumu ve yakıt türleri bakımından bölgenin bir bütün olarak değerlendirilmesi suretiyle santrallerin bölgesel ölçekte çevreye olan etkilerinin neler olacağı konusunda bir değerlendirme yapılması gerekmektedir.

ÇED; gerçekleştirilmesi planlanan projenin, çevreye olabilecek olumlu ya da olumsuz etkilerinin belirlenmesi, olumsuz yöndeki etkilerin önlenmesi ya da çevreye zarar vermeyecek ölçüde en aza indirilmesi için alınacak önlemlerin belirlenerek değerlendirilmesi amacıyla yapılmaktadır. Dolayısıyla, ÇED sürecinde verilen kararların iptali istemiyle açılacak davalarda keşif ve bilirkişi incelemesinin ayrı bir önemi bulunmaktadır. Danıştay kararları üzerinden verilen örnekler değerlendirildiğinde görüleceği gibi Danıştay çevre uyuşmazlıklarının çözümünde gerek çevresel etki değerlendirmesi gerekse kümülatif etki değerlendirmesinde bilirkişiye başvurmaktadır. Dolayısıyla Danıştay daireleri arasında keşif yapılmak suretiyle hazırlatılacak bilirkişi raporu incelenerek karar verilmesi yoluna gidilmesi konusunda istikrar sağlanması önem taşımaktadır.

Günümüzde gelişen teknoloji sayesinde bilgisayar programları yardımıyla simülatörler ve uydudan hava fotoğraflarıyla hava kirliliğinin sınır ötesi etkisinin dahi hesaplandığı bilinmektedir. Bu yöntemle her bir tesis için veriler toplanarak ölçümlerin yapılabilmesi teknik olarak mümkün olduğu gibi, henüz işletmeye geçmemiş tesisler bakımından mevcut kirlilik seviyesine katkı oranı da hesaplanabilecektir.

Bu itibarla, kümülatif etki değerlendirmesi üretim lisansının santrallerin bölgesel bazda çevreye olan etkilerinin neler olacağı konusunda hava modellemeleri yardımıyla bilimsel bir çalışmaya dayalı olarak hazırlanacak analiz süreci sonucunda düzenlenecek bilirkişi raporu uyarınca karar verilmesi gerekmektedir.

İhtiyat ilkesi gereğince, riskin varlığı bir kez saptandıktan sonra, çevre üzerinde oluşabilecek zararlarla bunlara sebep olarak gösterilen etkinlikler (veya kirleticiler) arasındaki sebep-sonuç ilişkisini gösterecek açık ve belirgin 
verilerin olmamasına karşın, sonucun gerçekleşmesi olasılığını önlemek için gerekli tedbirler alınmak durumundadır. Başka bir ifadeyle, çevreye zarar vereceği bilinebilir durumda olan potansiyel zararın meydana gelmemesi için çok geç olmadan tedbirli hareket edilmesi gerekmektedir.

Termik santrallerin, kurulduğu bölge ya da çevre üzerinde oluşturduğu hava kirlenmeleri sebebiyle ortaya çıkan etkilerini "kümülatif etki değerlendirmesi" adı altında düzenleyen doğrudan bağlayıcı nitelikte ulusal veya uluslararası herhangi bir kural bulunmadığı değerlendirmesi yapılarak, çevreye verilecek zararların önlenmemesi yolu seçilemez. Hatta hukuk devleti ilkesi olan öngörülebilirlik ve belirlilik, hukuk güvenliği gibi kavramlar çevre hakkının ihlaline gerekçe yapılamaz.

\section{Kaynakça}

- Bilir, Faruk ve Hamdemir, Berkan, 2011. Çevre Hakkı ve Uygulaması, International Conference on Eurasian Economies, Bishkek- Kyrgyzstan, 12-14 October 2011.

- ÇED Rehberi, 2014. Termik Enerji Santralları, Mayıs.

- $\quad$ Çevresel Etki Değerlendirmesi (ÇED) El Kitabı, Ocak - 2009

- Dünya Çevre ve Kalkınma Komisyonu, 1991. Ortak Geleceğimiz, 3. Baskı, (Çeviren Belkıs Çorakçı),Türkiye Çevre Sorunları Vakfı Yayını.

- Ertan, Birol, 2013. "Yeni İnsan Hakları”, Yeni Kuşak İnsan Hakları içinde (Editör: Kıvılcım Akkoyunlu Ertan), TODAİE Yayınları, Ankara.

- Gemalmaz, Mehmet Semih, Bir İnsan Hakkı Olarak Çevre Hakkı ve Türk Düzenlemesi, İÜHF Mecmuası, Cilt 52, Say1 1-4.

- Gökdayı, İsmail, 1997. Çevrenin Geleceği, (Yaklaşımlar ve Politikalar), Türkiye Çevre Vakfı Yayını, Ankara.

- Gülmez, Mesut, Anayasa 90 Uygulaması Panel, TBB Yayınları, 5.11.2004

- Güneş, Yusuf, / A. Aydın, Coşgun, 2004. Çevre Hukuku, Kazancı Hukuk Yayınları, İstanbul.

- Kaboğlu, İbrahim Ö., 1998. İnsan Haklarının Hukuksal Yapısı, (Özgürlükler Hukuku) Afa Yayınları, İstanbul

- $\quad$ Kantar, H. Elvend, 1984. “Çevre Hukukunda Sorumluluk Kavramı”, IBD, C. 58, S. 1-2-3, İstanbul, OcakŞubat-Mart.

- $\quad$ Turgut, Nükhet Yılmaz, 2010. Çevre Hakkı - Kuramsal ve Ampirik Çerçeve, İlgili Temel Kavram ve İlkeler: Yargının Rolü, Danıştay ve İdari Yargı Günü, Ankara.

- $\quad$ Turgut, Nükhet, 2001. Çevre Hukuku, Yenilenmiş 2. Bası, Savaş Yayınevi, Ankara.

- Turgut, Nükhet: İhtiyat İlkesi, http://dergiler.ankara.edu.tr/dergiler/38/297/2735.pdf (Erişim Tarihi:02.03.2019)

- Türkiye'deki Hidroelektrik Santralleri İçin Örnek Kümülatif Çevresel Etki Değerlendirmesi Klavuzu, 2012, Ankara.

- Vatansever Boşça Aysun-Şahin Hamamcı Nihan, 2013. Kümülatif Çevresel Etki Değerlendirmesi, Uluslararası ÇED Kongresi Bildiri Kitabı, Ankara.

- Yaren, F. Bülent, 1995. Yaşamı Kavrayış Üzerine Yapılanan Sorun: Çevre Sorunu, Değişen Dünya Görüşü Ekonomi-Ekoloji İlişkileri Bağlamında Ekolojik Kalkınma, Yeni Türkiye Dergisi - Çevre Özel Sayısı, Temmuz-Ağustos, Ankara. 


\title{
Varlık Yönetim Şirketleri ve Türkiye Ekonomisindeki Yeri Asset Management Companies and the Place in the Turkish Economy
}

\author{
Ph.D. Candidate Ayşe Özge Artekin (Selçuk University, Turkey) \\ Prof. Dr. Haldun Soydal (Selçuk University, Turkey)
}

\begin{abstract}
With the crisis that started in our country in 2000 s, those who owe the bank could not complete their payment obligations, the collection process was damaged and thus the number of problematic loans increased. However, as a result of structural deterioration, bank mergers were experienced, banks' capital was strengthened and many of them were seized by TMSF. This situation has created a distrust of the banking system. In order to change the negative perception, problematic loans which prevent the flow of funds should be solved. At this stage, Asset Management Company has become a need and started to operate in the financial markets of our country. The Asset Management Companies were established in the 1930s to solve the financial problems arising from the global economic crisis. Nowadays, these companies are formed according to the needs and shortcomings and become legal institutions which are effective in eliminating the negative effects of problem loans on banks.

In this study; the effects of problem loans, solutions, the process of emergence of companies in the world and in our country, its importance, aims, types, positive and negative aspects of banks and credit customers are examined. As a method of the study, domestic and foreign literature has been utilized and as a result of the study, it has been concluded that this problem has a positive effect on credit customers and banking system upon the transfer of problem loans to asset management companies.
\end{abstract}

\section{Giriş}

Bankacılık sektörünün ana faaliyet alanlarından biri olan krediler beraberinde kredi riskini de ortaya çıkarmaktadır. Kredi riski, banka müşterilerinin kredi talepleri neticesinde almış oldukları kredilerin kapsamında geri ödemeleri gereken anapara ve faizin bir kısmını ya da tamamını ödeyemeyerek yükümlülüklerini yerine getirmemeleri durumunu ifade etmektedir. $\mathrm{Bu}$ süreçten sonra bankanın takip altına aldığı ve sorunlu krediler kapsamı altına giren alacaklar, bankaların risk seviyesini artırarak verebilecekleri kredi hacmini negatif yönde etkilemektedir. Ayrıca sorunlu krediler; bilançoya, sermaye yeterliliğine, karlılığa, likiditeye ve reel sektöre de etki etmektedir. Bu yüzden sorunlu kredilerin çözümlenmesi gerekmekte ve bu noktada da Varlık Yönetim Şirketleri (VYŞ) devreye girmektedir.

Varlık Yönetim Şirketleri, bankaların kredi kullanan banka müşterilerinden tahsil edemedikleri varlıklarını pazarlık ya da ihale yöntemi ile belirli bir iskonto kullanarak devralmakta ve bu alacakların takibini ve tahsilini gerçekleştirmektedirler. Çalışmada finansal piyasalarda faaliyet göstererek finansal bir aktör haline gelen ve giderek daha da profesyonelleşen varlık yönetim şirketlerinin rolleri ayrıntılı olarak açıklanmaya çalışılacaktır.

\section{Sorunlu Krediler ve Etkileri}

Kredi kelimesi Türk Dil Kurumu sözlüğünde “Güven, Saygınlık ve İtibar” olarak ifade edilmektedir. Literatürde kredi ile ilgili;

- Bir mevcudun belirli bir sürenin sonunda geri ödenmesi kaydıyla verilmesi ya da verilmiş bir varlığın ödenmesine veya bir taahhüdün yerine getirilmesine kefil olunmasıdır (Tokel, 2004:4).

- Bankaların kredi değerliliği konusunda bir karara ulaşabilmek için gerekli ve ilgili görülen çeşitli bilgi ve etkenlerin değerlendirilmesi sonucunda kredi talebinde bulunan bir gerçek ya da tüzel kişiye yasalar ve banka kredi politikası göz önünde bulundurularak, ihtiyaca uygun düşecek tutar ve vadede para, garanti veya kefalet vermek şeklinde tanınan olanak ve limittir (Parasız, 2007:331).

- $\quad$ Komisyon ve faiz almak suretiyle belirlenen bir vade için ödünç para vermektir (Öztürk, 2014:20).

- Bankaların kişi veya kuruluşlara, vadesi olan ve bir maliyet karşılığında geri ödemek üzere verdikleri borçtur (Black vd, 2009:39) gibi tanımlar bulunmaktadır.

Kredi, borçlanan açısından bir yükümlülük banka açısından ise bir varlıktır. Gelir düzeyleri bazı mal ve hizmetleri almaya yetmeyen tüketiciler ya da hammadde, bina, arsa ve makina vb. üretim yapmaya olanak sağlayan araçlara ihtiyaç duyan üreticiler bankalardan belirli bir faiz ve vade karşılığında kredi kullanmaktadırlar. Bu vade kısa, orta veya uzun olabilir. Bu bağlamda kredi, satın alma gücünün belirli bir süre için kiralanması olarak düşünülebilir (Öztürk, 2014:20-21).

Normal işlemlerde kredi vermemek satışları kısıtlar, satış hacmini düşürür ve birim maliyetleri arttırır. Tüketicilere doğrudan satış yapan birçok işletme genellikle bunu nakit olarak yaparlar. Örneğin; süpermarketler, 
fast food mağazaları, kafeler gibi... Bununla birlikte, işletmeler arası satışlarda nakit ticaretin uygulanamaz olduğunu düşünülür ve bu durum çoğunlukla satış hacminin büyümesi için bir engel oluşturmaktadır (Edwards, 2004:6).

En büyük aracı kurum olan bankalar, topladıkları fonları ağırlıklı olarak ihtiyaç sahibi olanlara kredi verirler. Ancak bu kredilerin zamanında geri ödenmemesi durumu sorunlu kredilerin (takipteki krediler) varlığını ortaya çıkarmaktadır. Kredi tam olarak vade gününde ödenmediğinde ya da bu ödemenin birkaç gün gecikmesi halinde kredi sorunlu krediler kapsamına girmemektedir. Bu ödememenin veya anlaşmanın "önemli şekilde” bozularak tahsilatın gecikmesi gerekmektedir. Ancak bu önem kredi türüne, gecikme süresine, firmanın birden fazla onaylı kredisinde aynı anda veya birinde gecikme olmasına göre değişebilir. Örneğin; bireysel kredilerde 1 taksitin gecikmesi, ticari kredilerde anaparanın vadesinden itibaren 30 gün gecikmesi bu kredileri sorunlu krediler sınıfına dâhil etmemektedir. Ancak, ticari kredilerde anaparanın vadesinden itibaren 90 gün geçmesi bu krediyi sorunlu kredi haline getirmektedir (Selimler, 2004: 11).

Kredilendirme bankaların en çok gelir elde ettiği faaliyet olmakla birlikte, bu süreçte ortaya çıkan sorunlu krediler bankalar için ciddi bir problem teşkil etmektedir. Bu yüzden bankaların sıklıkla karşılaştığı ve yönetmek durumunda olduğu risk, kredi riskidir. Kredi riski, en basit şekilde, bir banka borçlusu veya karşı tarafinın, yükümlülüklerini kararlaştırılan şartlara uygun olarak yerine getirememesi potansiyeli olarak tanımlanmaktadır (Basel, 2000:1). Kredi riski aynı zamanda varsayılan risk, performans riski veya karşı taraf riski olarak da adlandırılmaktadır. Kredi de geri kazanılabilecek tutar arttıkça, risk de azalmaktadır (Brown and Moles, 2016:2).

Bankalar tarafından kullandırılan kredilerin vadeleri gelmesine rağmen anapara ve faizinin ödenmemesi durumunda kredi takibe düşerek sorunlu bir kredi haline gelmektedir. Şekil 1'de 2007-2018 y1lları arasında Türkiye'deki bankalar tarafından verilmiş tüm kredilerinin takipteki alacaklara yüzdesel olarak oranı gösterilmektedir.

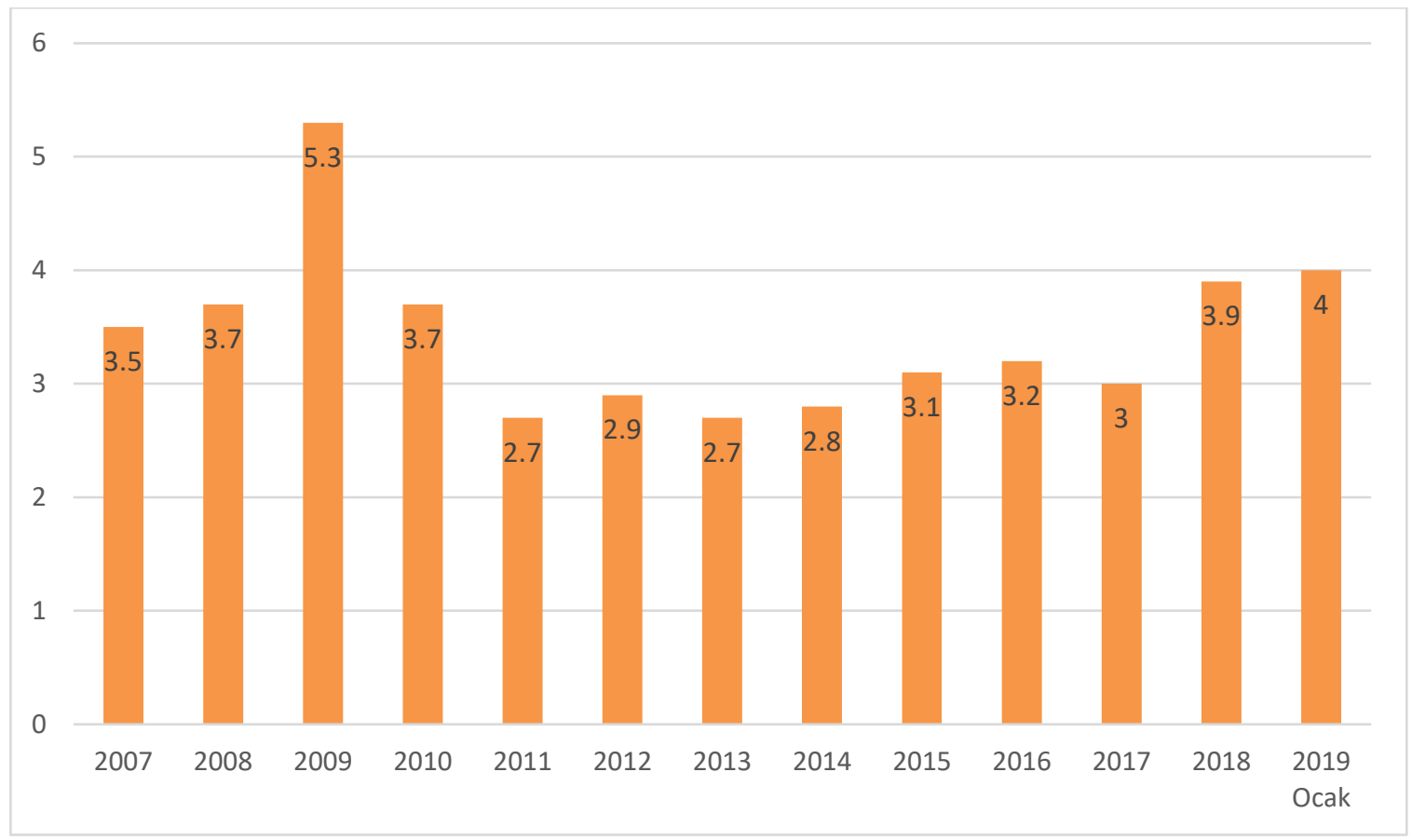

Şekil 1. Türk Bankacılık Sektöründe Takipteki Kredilerin Toplam Krediler Iç̧erisindeki Oranı (\%) Kaynak: TC. Hazine ve Maliye Bakanlı̆̆l, 2019.

Türkiye'de 2007-2018 yılları için ortalama değer yüzde 3.3 olup en yüksek oranın 2009 yılında yüzde 5.3 olarak gerçekleştiği görülmektedir. Kriz dönemlerinde Türk bankacılık sektöründe takipteki krediler oranı artış göstermektedir. 2009 yılındaki artışın sebebi de 2008 yılında gerçekleşen ve etkisi tüm dünyada hissedilen küresel ekonomik krizdir. 2010 yılında krizin etkilerinin azalması ile birlikte bu düzey gerilemiştir. 2019 Ocak ayında ise bu oran artış göstererek yüzde 4 olmuştur.

Bankalarda yeterli derecede bir müşteri değerlendirmesi yapılmaması durumunda yanlış kredilendirme ve fiyatlandırma ile birlikte risk oluşmuş olur. Diğer taraftan bankalar kredi vermeden önce ne kadar da doğru müşteri kredi değerlik incelemesi yaparlarsa yapsınlar birçok nedenden dolayı sonradan da kredi riski oluşabilmektedir. Bu nedenle bankalar her türlü kötümser senaryoları, koşullardaki olası değişmeleri ve bunun kredi alan müşteri üzerindeki etkilerini değerlendirmelidir. Kredi müşterisinin mali gücü ne kadar yüksek olursa olsun her kredi verilirken, gelecekte ortaya çıkması muhtemel bozulmalardan kaynaklanabilecek bir risk mutlaka bulunmaktadır (Koçyiğit ve Demir, 2014:224). 
Müşteriler için risk politikaları iki türlü olabilir:

1. Maksimum satış ve kredi kontrolünün olmaması: Daha yüksek satış yapılması ve dolayısıyla daha yüksek karlar elde edilmesi kesinlikle mümkündür ancak müşterilerin portföyleri burada önem taşımaktadır. Daha yüksek satış yaparak kar eden şirket; fazladan kaynak kullanan, önceden tecrübesi olmayan, bilgisiz ya da daha az bilgi sahibi sayısız bilinmeyen müşteriyle uğraşmanın maliyetinin ve riskinin daha yüksek olduğunu görmektedir.

2. Selektif satışlar ve kredi kontrolü: Satışlar düşük olabilir, ancak bu satışlardan elde edilen kazanç çok daha güvenilir olacaktır. Kötü kredilerin zararı daha az olacak ve vade zamanlarında daha fazla faiz ödenecektir. Satışları olabildiğince geniş bir alana yaymak yerine, daha iyi bilinen müşterileri hedeflemek ve sonuçta satışlardan doğan riskleri en aza indirmektir(Edwards,2004:47).

Bir banka, kredi tahsis ederken daima çok yüksek ve çok düşük risk arasında bir orta yol bulması gerekmektedir. Eğer banka çok düşük düzeyde risk üstlenmeyi tercih ediyorsa doğal olarak pazardaki önemli pek çok firsatı elinden kaçıracaktır. Öte yandan pazarda kaçırılan firsatların maliyeti batan bir krediden çok daha az soruna neden olacaktır. Yüksek riskli ve sorunlu kredilerin bankaya olan maliyetleri şöyle sıralanabilir (Ağaoğlu, 1989: 286, İnkaya ve Şahbaz, 2014: 72):

- Banka bilançosunun aktif kalitesi ve kompozisyonu bozulur,

- Bankanın likiditesi bozulur,

- Sorunlu krediler nedeniyle banka özel karşılık ayırır,

- Karlılık ve sermayede olumsuz etki yaratır,

- Şube karlılığını olumsuz etkiler,

- Bankanın aktif-pasif yönetimi olumsuz etkilenir

Bahsedilen bu durumların yanı sıra aşağıdaki gibi olumsuzluklar da söz konusu olabilmektedir (Kavcıoğlu, 2003: 49):

- Sorunlu krediler nedeniyle ayrılan fonların, daha yüksek getirili alternatif alanlara yönlendirilmesi mümkün olmayacaktır.

- Sorunlu kredilerin daha yakın takibi gerektiğinden, idari giderlerin artmasına neden olacaktır.

- Sorunlu krediler, yöneticilerin zamanlarını daha verimli alanlara yönlendirmelerine engel olacaktır.

- Sorunlu kredilerin hukuki konularda önemli bir uzmanlığı gerektirmesi, yüksek düzeyde hukuki giderlere neden olacaktır.

- Bankalarda sorunlu kredilerin miktarı arttıkça, düşük getiri ve sınırlı büyümeden dolayı bankada çalışanların morali de olumsuz yönde etkilenecektir.

Bankalarda sorunlu kredilerin artması bankacılık sektörünü olumsuz etkilemesinin yanı sıra ülke ekonomisi üzerinde de olumsuz etkilere neden olmaktadır. Bu etkileri aşağıdaki gibi sıralamak mümkündür (Sipahi,2003:21 22).

- Maliyet enflasyonu yükselir: Bankalar, kar oranında bir düşüş yaşanmasına sebep olan sorun krediler yüzünden kredi faiz oranlarını yükseltmek durumunda kalırlar. Bazen kaynak maliyeti düşmüş olsa bile kredi faizlerini düşüremezler. Dolayısıyla bu durum maliyet enflasyonunda bir artışa neden olmaktadır.

- Vergi gelirleri düşer: Sorunlu krediler sebebiyle kârları azalan ve kredi maliyetlerinin yüksek olması nedeniyle de kârlarında bir eksilme söz konusu olan firmalardan devlet, daha az vergi almak durumunda kalmaktadır.

- Piyasa olumsuz etkilenir: Sorunlu kredilerin oranında görülen artış, bankaların iflası sonucunu doğurabilir. Piyasa üzerinde görülmesi olası bir şok etkisi, finansal açıdan sorunsuz olan bankalarda bile sorun yaşanmasına yol açabilir.

- Üretim ve istihdam konularında sıkıntı yaşanır: Sorunlu kredilerin artması sonucu banka, üretim, istihdam gibi konularda kredi kullanmak için piyasadan gelen talebi karşılamakta güçlük çekecektir. Böylelikle de ülke ekonomisi zarar görecektir.

Sorunlu krediler, görüldüğü üzere hem bankacılık sektöründe hem de ülke ekonomisinde birçok olumsuz sonuca neden olmaktadır. Bu yüzden sorunlu krediler üstesinden gelecek çözümlerin araştırılması gereklidir. Sorunlu kredilerin başka bir şirkete devredilmesi de bu yöntemlerden biridir. Bu aşamada "Varlık Yönetim Şirketleri" adı altındaki bu kuruluşlar sorunlu kredilerin çözümlenmesinde belirgin rol oynamaktadırlar.

\section{Varlık Yönetim Şirketleri ve Günümüzdeki Faaliyetleri}

Bankalarının bilançolarında tutulan takipteki kredi stoklarının yüksek oluşu, ülkeler için önemli bir finansal istikrar sorunudur. Banka kredi verme kanalındaki aksaklıklar uygulanan para politikasını etkilemektedir. Para politikası sistemde bir tekerlek olarak düşünülürse kredi verme kanalındaki sıkıntı o tekerlekteki kum olarak düşünülebilir. Yani tekerlekteki kum miktarı ne kadar artarsa etkin politikaların uygulanması da o kadar zor 
olacaktır (Fell vd, 2017:71). Banka kredileri kanalına göre uygulanan bir para politikası banka rezervlerini değiştirerek bankaların kredi verme yeteneğini etkilemektedir. Bu kanal para politikalarıyla bankaların kredi imkanlarını genişletip daraltarak ekonomik aktörlerin yatırım ve harcama kararlarını ve nihayet hasılayı etkilemektedir(Belke ve Kaya, 2017:187). Bu perspektifte sorunlu kredilerin çözümlenmesi başta ekonomi açısından büyük önem teşkil etmektedir.

Her ülke, sorunlu kredilerin çözümlenmesinde ülkelerindeki sosyal politikalara, bankacilık düzenlemelerine ve makroekonomik konjonktürdeki değişimlerine göre farklı yöntemler tercih edebilmektedir. Türkiye'de sorunlu kredilerin çözümü için farklı kanallardan bazı yöntemler denenmiştir. Bunlardan ilki, 1990’lı yıllarda reel sektörün yaşadığı ekonomik krizin aşılması amacına yönelik olarak geliştirilen ve dünyada geliştirilen yeni yöntemlere temel olarak alınan Londra Yaklaşımı, yine Londra Yaklaşımı'ndan türetilen İstanbul Yaklaşımı ile onu takip eden Anadolu Yaklaşımı ve son olarak tüm dünyada bu alanda uzmanlaşan ve Türkiye'de de etkinlikleri hızla artan Varlık Yönetim Şirketleri'dir (Oy, 2009:63).

Birçok ülkede Varlık yönetim şirketleri, sistemik finansal sektör stresinden kaynaklanan sıkıntılı varlıkları yönetmek için kullanılmıştır ve takipteki alacak sorunlarından muzdarip bankacılık sektörünün tasfiyesinde önemli katkılarda bulunmuştur. İsveç'te (1990'ların başlarında), Kore'de (1990'ların sonlarında) ve daha yakın zamanlara bakıldığında İrlanda (2010), İspanya (2012) ve Slovenya (2013)'da bankacılık krizlerinin ortasında kurulan Varlık Yönetim Şirketleri bu duruma örnek olarak gösterilebilir. Buradaki şirketlerin ortak özelliklerinden biri, hükümetlerin, bu şirketlerin kuruluşlarında sermaye sağlayarak, fonlamayı kolaylaştırarak ve yasaları geçirerek onların yaratılmasında güçlü bir şekilde yer almalarıdır (Fell vd, 2017: 73).

Varlıkyönetimşirketleri faaliyet gösterdiği ülkenin ekonomik ve politik şartlarına göre farklı uygulamalara tabi olabilmektedir. Ülkelerde sorunlu varlıkların yönetimi için merkezi varlık yönetim şirketleri ve merkezi olmayan varlık yönetim şirketleri olmak üzere iki tür alternatif strateji mevcuttur.

Merkezi Varlık Yönetim Şirketleri; Merkezileştirilmiş varlık yönetim şirketleri, bir kurumda borç yeniden yapılandırılmasında iş gücü becerilerinin ve bilgi teknolojisinin merkezileştirilmesi becerilerinin ve kaynaklarının birleştirilmesine izin verir ve bu nedenle merkezileştirilme mümkün olan maksimum değerin elde edilmesinde daha verimli olabilir (Kliengebiel, 2000:5).

Merkezi Olmayan Varlık Yönetim Şirketleri; Genel olarak üç tür merkezi olmayan varlık yönetim şirketi vardır. Bunlar;

- Bankanın sahip olduğu ayrı bir varlık yönetim şirketleri: Kötü aktiflerin yönetilmesinde uygulanan yöntemlerden birisi de banka içinde sadece kötü aktiflerin yönetimi ile ilgili bir birim oluşturulması veya bankanın iştiraki olarak bankaya özel bir aktif yönetim şirketinin kurulmasıdır.

- Mevcut bankanın sorunlu varlıkları toplayıcı bir banka olarak yapılandırılması şeklindeki varlık yönetim şirketi: Örgütlenme konusunda diğer bir yöntem tahsilatçı banka yöntemidir. Söz konusu banka iyi banka ve kötü banka olmak üzere ikiye ayrılır. Kötü banka yani tahsilatçı banka yalnızca kalitesi düşük olan aktiflerin yönetimi ve tasfiyesi ile görevlendirilmektedir.

- Yapılandırma ve tasfiye işlemlerini birlikte yürüten varlık yönetim şirketleri: Bu yöntemde kamu otoritesinin idaresine geçmiş olan sorunlu bankanın varlıkları bu amaç için kurulmuş VYŞ tarafından yönetilmektedir. VYŞ kendi bünyesine almış olduğu sorunlu varlıkları tasfiye eder (Erarslan vd, 2018.309).

Türkiye'de Varlık yönetim şirketleri resmi olarak “Tasarruf Mevduatı Sigorta Fonu (TMSF), bankalar ve diğer mali kurumların alacakları ile diğer varlıklarının satın alınması, tahsili, yeniden yapılandırılması ve satılması amacına yönelik olarak faaliyet göstermek üzere bu Yönetmelik hükümlerine göre izin alarak kurulan şirketlerdir." şeklinde ifade edilmektedir (1 Kasım 2006 tarihli 26333 sayılı Resmi Gazete).

Varlık yönetim şirketleri; ödeme kabiliyeti bulunmayan ve/veya kısmen bulunan ve/veya tahsilatın olması gerekenden daha ileri bir tarihte yapılacağının anlaşıldığı ancak tüm bu olumsuzluğa rağmen kısmi de olsa tahsilat imkânı olan ve/veya varlıkları para eden şirketlerin borçlarını bankalara oranla daha uygun bir fiyatla satın alarak bu yolla bankalara belli bir kaynak aktarımı yapan ve daha sonra da söz konusu alacağın tahsilatını gerçekleştirmeye çalışan kuruluşlardır (Oy, 2009:66).

Varlık yönetim şirketlerinin kurulabilmesi için başta kuruluş işleminin Bankacılık Denetleme ve Düzenleme Kurulu (BDDK) tarafından uygun görülmesi şartıyla;

- Anonim ortaklık şeklinde kurulması,

- Ödenmiş sermayesinin yirmi milyon Türk Lirasından az olmaması,

- Hisse senetlerinin tamamının nama yazılı ve nakit karşılı̆̆ı çıkarılması,

- Ticaret unvanında "Varlık Yönetim Şirketi" ibaresinin bulunması,

- Kurucularının ilgili yönetmelikte sayılan şartları taşıması gerekmektedir (Çelik, 2017:8).

Varlık yönetim şirketleri sadece TMSF, bankalar, faktoring ve leasing şirketleri gibi finansal kuruluşların gecikmiş alacaklarını satın alabilmekte, bankacılık dışındaki sektörlerin (örneğin reel sektörün) tahsili gecikmiş 
alacaklarını ise satın alamamaktadırlar. Bahsi geçen süreçte varlık yönetim şirketinin bu faaliyeti gerçekleştirmekteki amacı ise, ilgili kurumlardan daha düşük bedel ödeyerek devir aldığ 1 alacakları, borçlulardan daha yüksek bir bedelle tahsil ederek, oluşacak fark ölçüsünde kazanç elde etmektir. Diğer taraftan bu şirketler alacak veya diğer varlıkları satın alabilmek amacıyla, bu satın alımı yapacakları banka veya diğer mali kurumlardan kredi kullanamazlar (Çelik, 2017:7-8). Tablo 1'de belli dönemlerde bazı bankalar tarafından tahsili gecikmiş bazı alacakların satış örnekleri gösterilmektedir.

\begin{tabular}{|l|c|c|l|}
\hline Banka Adı & $\begin{array}{l}\text { Tahsili Gecikmiş } \\
\text { Alacak Miktarı (TL) }\end{array}$ & Satış Bedeli (TL) & Satılan Varlık Yönetim Şirketi \\
\hline Garanti Bankası (20.11.2018) & $337.188 .588,73$ & $17.550 .000,00$ & Güven Varlık Yönetim AŞ. \\
\hline Akbank (26.12.2018) & $446.000 .000,00$ & $19.400 .000,00$ & $\begin{array}{l}\text { Arsan Varlık Yönetim A.Ş., İstanbul } \\
\text { Varlık Yönetim A.Ş. ve Sümer Varlık } \\
\text { Yönetim A.Ş }\end{array}$ \\
\hline Yapı Kredi Bankası (19.03.2019) & $396.328 .632,09$ & $24.040 .000,00$ & $\begin{array}{l}\text { Gelecek Varlık Yönetimi A.Ş., ve Efes } \\
\text { Varlık Yönetim A.Ş. }\end{array}$ \\
\hline
\end{tabular}

Tablo 1. Tahsili Gecikmiş Alacakların Satış Örnekleri Kaynak: Kamuyu Aydınlatma Platformu (KAP).

Örneklere bakıldığında; tahsili gecikmiş alacakların Varlık Yönetim Şirketlerine satış bedellerinin asıl alacak miktarına göre epey düşük olduğu görülmektedir. Ancak bankalar bu alacaklardan ortalama 2-3 yıl süresince yaptıkları tahsilat işlemlerine rağmen borçları tahsil edemediklerinden ve bu kredilerin büyük bir kısmının hiç tahsil imkanı olmaması ya da kısmen tahsil imkanı olmasından dolayı satış işlemini gerçekleştirmektedirler. Böylelikle bankalar önemli bir işletme yükünden kurtulmaktadırlar. Şekil 2'de kurulduğu günden bu yana Varlık Yönetim Şirketlerine devredilen tahsili gecikmiş alacaklar gösterilmektedir.

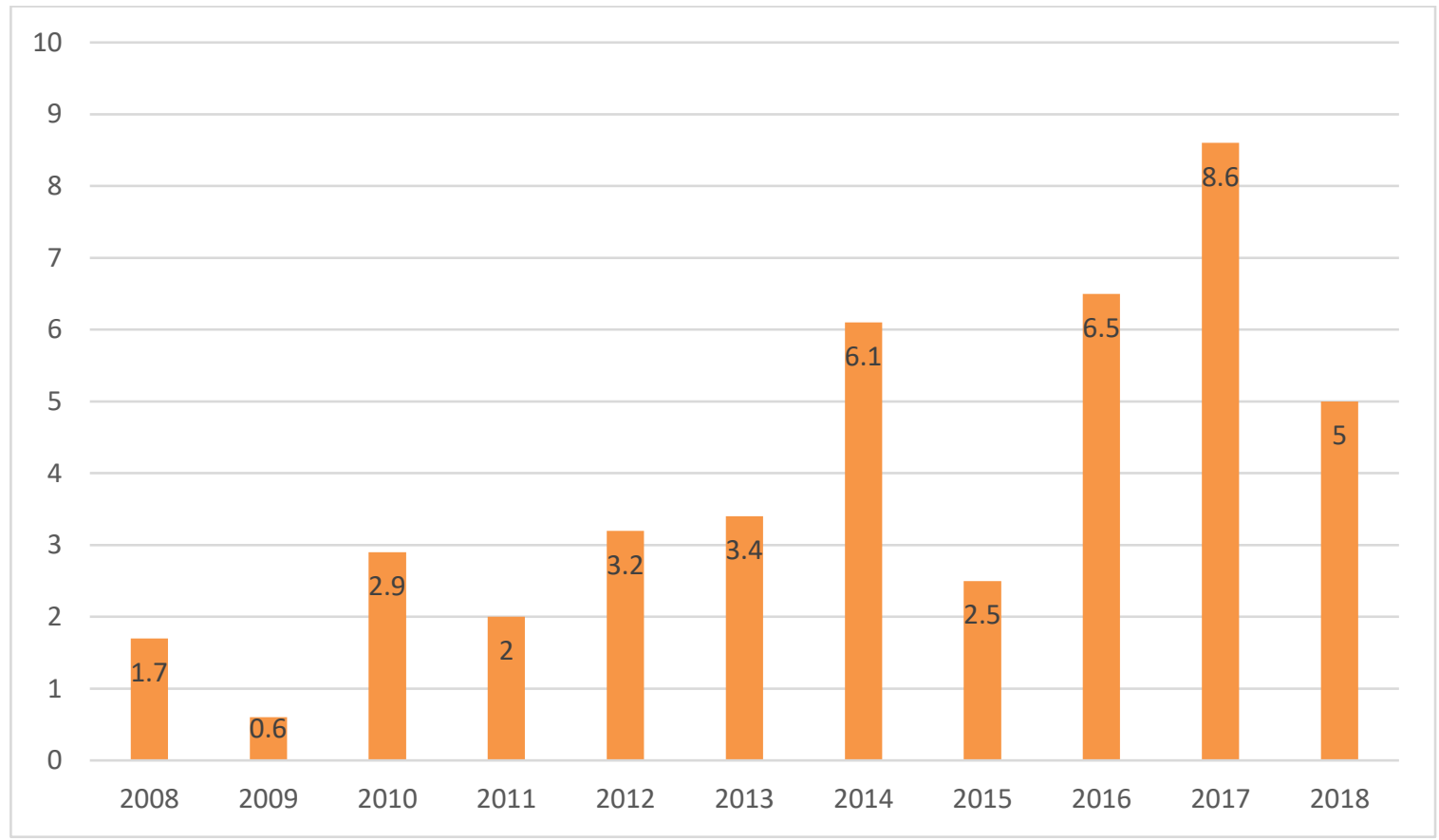

Şekil 2. Yıllara Göre Varlık Yönetim Şirketlerine Devredilen Tahsili Gecikmiş Alacaklar (Milyar TL) Kaynak: Tarmur ve Cı̆̆̆zoğlu,2018:11. ve Varlık Yönetim Şirketleri Derneği.

Türkiye'de Varlık Yönetim Şirketleri faaliyete geçtikleri 2008 yılından beri en yüksek satış seviyesine 2017 yılında ulaşmıştır. Bu şirketler 2017 yılında finansal kurumlardan anapara tutarı 8,6 milyar TL olan tahsili gecikmiş alacak satın almışlardır. 2018 yılında ise bu rakam 5 milyar TL olarak gerçekleşmiştir. 2018 yılında batık kredi satışlarının daralması bazı bankaların o yıl içerisinde satış gerçekleştirememesi, kredi büyümesinde zayıflama ve yüksek faiz oranları ile ifade edilebilir.

Kuruldukları günden bu zamana kadar portföyünü satan banka sayısında ve piyasaya yeni giren varlık yönetim şirketlerinin sayısında belirgin bir artış görülmektedir. BDDK verilerine göre şu anda Türkiye'de aktif olarak faaliyet içerisinde olan 20 tane Varlık Yönetim Şirketi bulunmaktadır. Portföylerin bankalardan devralınmasıyla birlikte Varlık Yönetim Şirketlerinin çatısı altında borçlarını yapılandırma firsatı elde eden borçlu sayısı 3.5 milyona ulaşmıştır. Bu süreçte 800 bini aşkın kişinin ise sorunlu kredileri Varlık Yönetim Şirketleri tarafından çözümlenmiştir(VŞYD,2019). Tablo 2'de Varlık Yönetim Şirketlerinin avantajları ve dezavantajları belirtilmektedir. 


\begin{tabular}{|c|c|}
\hline Avantajlar & Dezavantajlar \\
\hline $\begin{array}{l}\text { - Uygulama becerisi ve kaynakların bir acentede } \\
\text { birleştirilerek ölçek ekonomisi oluşturulması, } \\
\text { - Varlıkların büyük bir havuzda toplanarak menkul } \\
\text { kıymetleştirilmesinin daha kolay hale gelmesi, } \\
\text { Teminatların merkezileşmesi ile borçluların } \\
\text { üzerinde ve yönetimde (potansiyel olarak) daha } \\
\text { çok etkin olması, } \\
\text { Bankalar ve şirketler arasındaki bağlantının } \\
\text { kopması ve böylece kredi tahsilatının potansiyel } \\
\text { olarak iyileşmesi, } \\
\text { Bankaların temel işlerine odaklanmalarının } \\
\text { sağlanmasına imkan tanıması, } \\
\text { Ekonominin düzenli bir şekilde sektörel } \\
\text { yapılanması ihtimalinin artması, } \\
\text { Tek tip çalışma yöntemi uygulamalarına izin } \\
\text { vermesi, } \\
\text { Kredilerin geri kazandırılması ve bankaların } \\
\text { yeniden yapılanmasını hızlandırmak için özel } \\
\text { yetkiler verilebilmesi. }\end{array}$ & 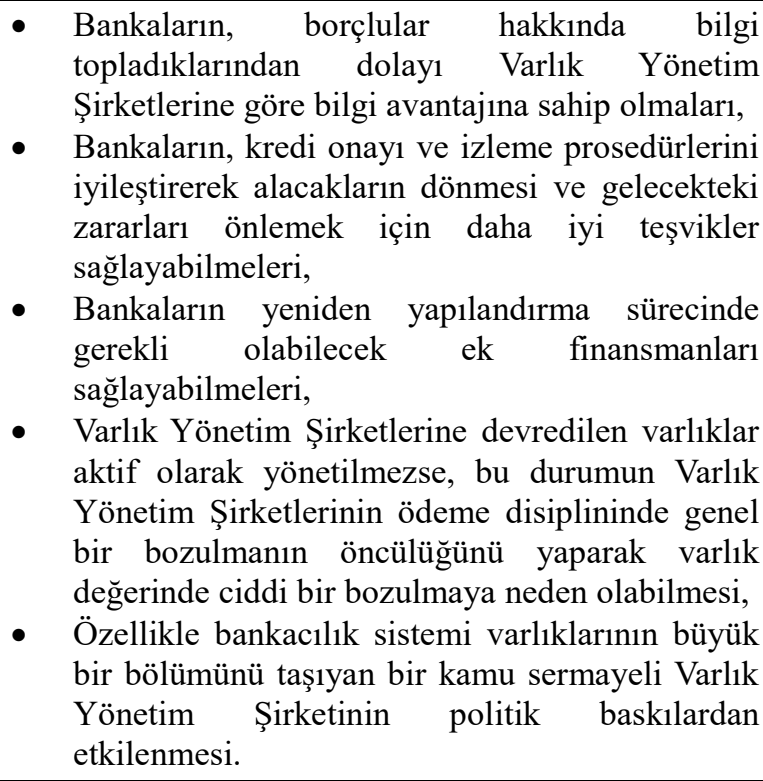 \\
\hline
\end{tabular}

Tablo 2. Varlık Yönetim Şirketlerinin Avantajları ve Dezavantajları Kaynak: Kliengebiel, 2000:6.

Bahsedilen avantajların yanı sıra zamanla kendi teknolojisini geliştiren ve kendi insan kaynağını yaratan Varlık Yönetimi Şirketleri, sektörde doğrudan ve dolaylı yaklaşı 5.000 kişiye istihdam sağlayarak ekonomik anlamda bir firsat yaratmışlardır (VŞYD, 2019).

\section{Sonuç ve Değerlendirme}

Finansal sistemin en büyük aracı kurumu olan bankacılık sektöründe, istikrarsız ekonomik yapı ve risk yönetiminde etkinsizlik gibi sebeplere bağlı olarak bazı dönemlerde tıkanmalar yaşanmaktadır. Bu durum, sadece bankacılık sektörünü değil aynı zamanda ülke ekonomisini de etkilemektedir. Kredi müşterilerinin bankalardan aldıkları borçları geri ödeme yükümlülüklerini yerine getiremeyip, kredi tahsilatının yapılamaması durumunda ortaya çıkan sorunlu krediler için bankalar belirli bir karşılık ayırmaktadırlar. Bu durum bankaların bilançolarını olumsuz etkileyerek banka karlılığını düşürmekte hatta sorunlu kredilerin toplam krediler içindeki payının giderek artmasının etkisi banka iflaslarına kadar gitmektedir.

Bankacılık temelli bir finansal sisteme sahip olan Türkiye'de, sorunlu kredilerin artışı ekonominin geneli üzerinde bir tahribata neden olmaktadır. Üretimin başlıca finansman kaynağı olan kredi akışında bir sıkıntı yaşamamak için banka bilançolarının sorunlu kredilerden arındırılması gerekmektedir. Bu süreçte gelinen son noktada Varlık Yönetim Şirketleri önemli bir misyon üstlenerek bankaların ve kredi borçlularının yükünü hafifletmektedirler. Varlık Yönetim Şirketleri, bankaların tahsili gecikmiş alacaklarını ihale ile belirli bir iskonto karşılığında alıp, borçlunun durumuna göre yapılandırarak borçların yeniden ekonomiye kazandırılmasını amaçlamaktadır. Bankalara kredi borcunu ödeyemeyen borçlular, daha esnek ödeme planı ve hatta bazen borçlulara yönelik yapılan faiz indirimleri ile kredi borcunu ödemediği takdirde maruz kaldığı kötü kredi sicilinden, finansal ve hukuki sınırlamalardan kurtulabilmektedirler. Varlık Yönetim Şirketleri Derneği'nin açıklamasına göre; tahsili gecikmiş alacakların bankalardan devralınmasıyla birlikte Varlık Yönetim Şirketlerinin çatısı altında borçlarını yapılandırma firsatı elde eden borçlu sayısı 3.5 milyona ulaşmıştır. Bugüne kadar ise 800 bin kredi borçlusu, borçlu konumundan, dolayısı ile finansal ve hukuki sınırlandırmalarından kurtulmuştur.

Varlık Yönetim Şirketleri, bankalardan sorunlu kredilerin yükünü alarak, bankaların kredi verme ve mevduat toplama gibi asli görevlerine odaklanabilmelerine imkan sağlamaktadır. Bu sayede ekonominin ihtiyaç duyduğu kaynak akışı da daha etkin hale gelecektir.

\section{Kaynakça}

- Ağaoğlu, A. E. (1989), Türkiye’de Banka İşletmelerinin Ekonomik Analizi ve Gelişme Eğilimleri, Yayımlanmamış Doktora Tezi, Ankara: Ankara Üniversitesi.

- Basel (2000), Principles for the Management of Credit Risk, Basel Committee on Banking Supervision https://ms.hmb.gov.tr/uploads/2019/03/temelekonomikgostergeler-1.pdf Erişim Tarihi: 09.03.2019.

- Belke, M. ve Kaya, H. (2017), Türkiye'de Para Politikalarının Kredi Kanalı Aktarımı: Var Yaklaşımı, Finans Ekonomi ve Sosyal Araştırmalar Dergisi, 2/3 ISSN : 2602-2486.

- Black, J., Hasminzade, N ve Myles, G. (2009), Dictionary of Economics, Third Edition, USA: Oxford. 
- $\quad$ Brown, K. Ve Moles P. (2016), Credit Risk Management, Edinburgh Business School Heriot-Watt University Edinburgh. https://www.ebsglobal.net/EBS/media/EBS/PDFs/Credit-Risk-Management-CourseTaster.pdf Erişim Tarihi: 08.03.2019.

- Çelik, O. (2017), Bankacılık Sektörünün Son Yıllardaki Vazgeçilmezi: Varlık Yönetim Şirketleri Ve Türkiye Ekonomisindeki Yerleri, Vergi Sorunları Dergisi 350/1

- $\quad$ Edwards, B. (2004), Credit Manegement Handbook, Gower Publishing Limited. http://cybercfo.net/creditmgt/Credit\%20Managment\%20Handbook.pdf Erişim Tarihi: 08.03.2019.

- $\quad$ Eraslan, S., Önal,S. ve Gürsoy, O. (2018), Varlık Yönetim Şirketlerinde Birleşme Örneği Ve Muhasebe Uygulamaları, TESAM Akademi Dergisi , 5(2). 299 - 324 ISSN: 2148 - 2462.

- $\quad$ Fell, J., Grodzicki, M., Martin, R. ve O’Brien, E.,(2017), A Role for Systemic Asset Management Companies in Solving Europe's Non-Performing Loan Problems, European Economy: Banks, Regulation and the Real Sector, 17(1).

- Kavcıoğlu, Ş. (2003), Ticari Bankalarda Sorunlu Kredilerin Yönetimi, Çözüm Yolları ve Takibi, Türkmen Kitabevi, İstanbul.

- Klingebiel, D. (2000), The Use of Asset Management Companies In The Resolution of Banking Crisis, World Bank Policy Research Working Paper, WPS/2284.

- Koçyiğit, S.Ç. ve Demir,A. (2014), Türk Bankacılık Sektöründe Kredi Riski ve Yönetimine İlişkin Bir Uygulama: Türkiye Garanti Bankası Örneği İşletme Araştırmaları Dergisi, 6/3 222-246.

- Oy, O.(2009), Varlık Yönetim Şirketleri, Beta Yayınevi, İstanbul.

- Öztürk, N. (2014), Para Banka Kredi, Ekin Yayınevi, İstanbul.

- Parasız, M.İ. (2000), Para, Banka ve Finansal Piyasalar, Bursa, Ezgi Kitabevi Yayınları.

- Resmi Gazete, (2006), 1 Kasım 2006 tarihli 26333 sayılı Resmî Gazete, Varlık Yönetim Şirketlerinin Kuruluş Ve Faaliyet Esasları Hakkında Yönetmelik, http://www.mevzuat.gov.tr/Metin.Aspx?MevzuatKod=7.5.10744\&sourceXmlSearch=\&MevzuatIliski=0 Erişim Tarihi: 10.03.2019.

- $\quad$ Selimler, H. ve Eken, M.H. (2004), Banka Muhasebesi, No: 375, Der Yayınları, İstanbul.

- Sipahi, N. (2003), Problemli Kredilerin Yeniden Yapılandırılması Uluslar Arası Uygulamalar Ve Türkiye Örneği, TCMB Yayınları.

- Şahbaz, N. ve İnkaya, A. (2014), Türk Bankacılık Sektöründe Sorunlu Krediler ve Makro Ekonomik Etkileri, Optimum Ekonomi ve Yönetim Bilimleri Dergisi 1/1.

- Tarmur, S. ve Ciğızoğlu, O. (2018), Turkish NPL Purchasing Market, Overview and the Way Forward, https://www.pwc.com.tr/tr/sektorler/yatirim-yonetimi/turkiye-tahsilli-gecikmis-alacaklar-satis-piyasasiraporu-final.pdf Erişim Tarihi: 02.04.2019.

- TC. Hazine ve Maliye Bakanlığı, (2019), https://ms.hmb.gov.tr/uploads/2019/03/temelekonomikgostergeler1.pdf Erişim Tarihi: 12.03.2019.

- Tokel, Ö. E. (2004),Kredi Risk Modelleri Kullanılarak Kredi Taleplerinin Değerlendirilmesi” Ankara Üniversitesi Sosyal Bilimler Enstitüsü İşletme Ana Bilim Dalı Yüksek Lisans Tezi, Ankara.

- https:/www.dunya.com/finans/haberler/5-milyarlik-batik-kredi-satildi-ozel-haberi-435822 Erişim Tarihi: 03.04.2019.

- http://www.varlikyonetim.org.tr/Pagedetail.aspx?Id=7_Erişim Tarihi: 29.03.2019.

- $\quad$ http://www.kap.org.tr Erişim Tarihi: 20.03.2019. 


\title{
İtibar Katsayısı Ölçeğinin Geçerlik ve Güvenirliğinin Bankacılık Sektöründe İncelenmesi
}

\section{Investigation of the Validity and Reliability of Reputation Quotient Scale in the Banking Sector}

\author{
Prof. Dr. Lutfiye Özdemir (İnönü University, Turkey) \\ Dr. Uyum Elitok (Batman University, Turkey) \\ Asst. Prof. Dr. Yavuz Elitok (Batman University, Turkey)
}

\begin{abstract}
According to data of The Banks Association of Turkey 2017; In Turkey, the banking sector occupies an important place in the country's economy due to the fact that banks employ approximately 200,000 people and foreign capital and partnerships are increasing in this sector. However, there is an intense competition environment in which all instruments in this sector are used. It is necessary to differentiate to achieve a competitive advantage and to achieve sustainable growth. Differentiation can be realized with abstract values rather than tangible values, which are generally not shown in the balance sheet. Corporate reputation holds a strategic place in relations with stakeholders and is placed in an important position in the eyes of stakeholders. In the study, it is aimed to make a structure analysis of the Reputation Coefficient Scale analysis which can be used to measure the corporate reputation. The data obtained from 185 people working in the banking sector in Batman province and analyzed with SPSS 23.00 and AMOS 24.00 programs. As a result of the analysis, Cronbach's alpha value was 0.924 and it was found to be highly reliable. According to the confirmatory factor analysis performed with the Maximum Likehood method, the results of the fit indexes of the model were well and found as $\mathrm{X} 2 / \mathrm{df}=1,788$, RMSEA $=0,065$, GFI $=0,903$, $\mathrm{CFI}=0,945$, TLI $=0,926$ and IFI $=0,946$. 'Reputation Coefficient Scale' used in the banking sector in Batman province has been determined as reliable and valid in terms of structure.
\end{abstract}

\section{Giriș}

Kurumsal itibar, işletmelere farklılaşma ve rekabet avantajı sağlaması sebebi ile son yıllarda üzerinde çok tartışılan konulardan birisi haline gelmiştir. İşletmelerde taklit edilmesi zor, işletmeye değer katan ve nadir bulunan bir kaynak olduğundan kurumsal itibar hakkında birçok kitap, makale yazılmış hatta konuya özel dergi (Corporate Reputation Review) yayınlanmaya başlamıştır. Ancak üzerinde çok fazla çalışılan bir konu olmasına rağmen kavramın tanımı hakkında henüz tam bir netlik oluşmamıştır. Bunun en önemli sebeplerinden biri kavramın soyut ve algıya yönelik olmasıdır. Kurumsal itibar, profesyonel yöneticiler ve konuya ilgi duyanlar için farklı anlamlar içerebilmektedir. Kurumsal itibarı ekonomistler, "belli durumlarda, kurumun yapabileceklerinin sinyalleri", stratejistler, "maddi olmayan, rakiplere karşı rekabet avantajı sağlayan, taklit edilmeyi engelleyen, hareketli bariyerler", muhasebeciler, "ölçümlenmesi zor olan birçok soyut varlık, ama şirket için değer yaratan, kişilerin şirketlerin ismiyle kurduğu, kurumları ifade eden ve sadık müşteriyi çeken, algısal bir güç", iletişimciler, "şirketin paydaşlarıyla, arasındaki iletişimin sonucunda gelişen, toplam değer", yönetim ve organizasyoncular, "şirketin kimliği, nasıl yaptığını, ne yaptığını, şirket ve paydaşları arasında yapılan kurumsal faaliyetler sonucu gelişen, şirketin bilişsel temsilleri" ve sosyologlar da itibar, "firmanın yapısıyla ilişkili olarak, paydaşları ile kurduğu, sosyal ilişkilerdir” şeklinde tanımlamaktadırlar (Fombrun vd., 2000). Kurumsal itibar hakkında yapılan tanımların hepsinin temelinde, rekabet avantajı yarattığı, işletmeye özgü bir değer olduğu ve paydaşların zihninde oluştuğu bulunmaktadır. En genel anlatımıyla kurumsal itibar, bir kurumun tüm paydaşları tarafından ne derece güvenilir, saygın ve değerli algılandığına dair, zaman içinde oluşmuş değerlendirmelerin bütünsel bir ifadesidir (Gotsi ve Wilson, 2001).

Kurumsal itibarı ölçmek için birçok metod geliştirilmiştir ancak çalışmada kurumsal itibarı kurum ile farklı ilişkiler içinde olan farklı özellik ve beklentilere sahip paydaşlar için farklı bileşenler açısından değerlendiren 'İtibar Katsayısı Ölçeği' (Reputation Quotient-RQ) kullanılmıştır. Hizmet sektöründe kurumsal itibarın oluşturulması özellikle çalışanlar ile müşteriler birebir iletişim kurduklarından ve bu iletişimin niteliğinden önemli bir rol oynar (Çekmecelioğlu ve Dinçel, 2013). Çalışmada bu durum göz önünde bulundurularak, hizmet sektöründen biri olan bankacılık sektöründe, banka çalışanları üzerinde yapılmış, 'İtibar Katsayısı Ölçeği’nin (Reputation Quotient-RQ) yapısal olarak geçerlik ve güvenirliği test edilmesi amaçlanmıştır.

\section{Kavramsal Çerçeve}

Kurumsal itibar, kurumun bir bütün olarak ortaya koyduğu değerlerin, tüm paydaşlar üzerinde yarattı̆ğ etki bir başka ifade ile paydaşların zihninde kurum ile ilgili oluşan algıların toplamıdır. İtibar yalnız müşterilerin gözünde değil, kurum çalışanları, tüketiciler, yatırımcılar, tedarikçiler ve yerel toplulukların da gözünde kurumun ne denli çekici olduğunu ortaya koymaktadır (Fombrun, 1996). Kurumsal itibarın hesaplanabilmesi için, paydaşların 
zihninde, kurum hakkında oluşan soyut algının ölçümlenebilir somut verilere dönüştürülmesi gerekir. Kurumsal itibarın ölçülmesi için iş çevrelerinde ve akademik alanda birçok yöntemler ve araçlar ortaya konulmuştur. Literatürde birçok araştırmacı tarafından kullanılan "İtibar Katsayısı" (Reputation Quotient) ölçeği (Fombrun, 2000), kurumsal itibarı çok boyutlu bir yapı olarak ele alan, maddi veriler yanında maddi olmayan verileri de değerlendiren, kurumun çeşitli paydaş grupları (çalışanlar, müşteriler, yatırımcılar) tarafından değerlendirilmesine olanak sağlayan ve metodolojik temellere dayanan bir ölçektir (Chun, 2005). Ölçek, kurumun itibarı üzerinde etkisi olan farklı faktörleri de değerlendirmeye alan, sektör ya da tek bir paydaş grubundan bağımsız genel bir ölçüm aracıdır (Fombrun vd. 2000, Barnett vd., 2006).

Ölçek kurumun itibarını pek çok farklı paydaşın (çalışanlar, müşteriler yatırımcılar, toplumun geneli) gözünden ölçebilmesi ve kurumsal itibarı oluşturan bileşenlerin hangilerinin kurum ve paydaş için önemli olduğunu belirlemeyebilme özelliğine sahip olması nedeniyle önemlidir. Örneğin; kurumsal itibar, hissedarlar için, iyi bir finansal performans ve yüksek kârlılık, çalışanlar için iyi bir çalışma ortamı, doyurucu finansal ve sosyal olanaklar, müşteriler için ise ürün ve hizmetin kalitesi olabilmektedir (Tolbert, 2000; Dentchev ve Heene, 2004). Ölçek bu ihtiyacı karşılayan nitelikte olduğu için yaygın şekilde kullanılmaktadır.

İtibar katsayısı ölçeğinde kurumsal itibar; duygusal çekicilik (güvenilir, dürüst, iyi hisler duyulur), ürün ve hizmet (yüksek kaliteli ürün ve hizmet sunar, paranın karşılığını verir, yenilikçi ve ürünlerinin arkasında durur), vizyon ve liderlik (pazar firsatlarını yakalar, gelecek için açık bir vizyona sahip, mükemmel liderlik vardır), çalışma ortamı (çalışılacak güzel bir yer, iyi çalışanlara sahiptir), kurumsal sosyal sorumluluk (çevreye karşı duyarlı, çevreye zarar vermez, iyi şeyleri destekler) ve finansal performans (güçlü bir karlılık, düşük risk, güçlü büyüme potansiyeli, rakiplerinden daha iyi performans sergiler) olarak altı boyuttan ve yirmi alt bileşenden oluşmaktadır (Fombrun vd.,2000; Fombrun vd., 2004).

Fombrun ve arkadaşları (2000) kurumsal itibarı oluşturan altı bileşeni şu şekilde tanımlamaktadır:

Duygusal çekicilik, paydaşların kuruma karşı ne derece olumlu hisler beslediğinin, kuruma ne kadar saygı ve hayranlık duyduğunun ve güvendiğinin bir ifadesidir. Duygusal çekim bir kurumun tüm paydaşları için önemli bir itibar bileșenidir.

Ürün ve hizmetler, kurumun yüksek kaliteli, yenilikçi, harcanan paranın karşılığını tam olarak veren ürün ve hizmetler sunması ve bunların arkasında sonuna kadar durmasını ifade etmektedir. Ürün ve hizmet kalitesi, müşteriler için önemli bir itibar bileşenidir.

Vizyon ve liderlik, kurumda mükemmel liderlik gösteren, geleceğe dair net bir vizyonu olan ve pazardaki gelişmeleri yakından takip edip firsatları iyi değerlendiren yönetim kadrosunu ifade etmektedir. Yönetim kalitesi hem paydaşlar hem de çalışanlar için önemli bir itibar bileşenidir.

Çalışma ortamı ve iş çevresi, kurumun iyi ve nitelikli çalışanlara sahip olması ve çalışanlara, zevkle çalışabilecekleri ideal bir ortam sunmasını ifade etmektedir. Çalışanlar için önemli bir itibar bileşenidir.

Kurumsal sosyal sorumluluk, kurumun çevreye karşı duyarlı olması ve toplumsal ve sosyal içerikli konulara önem vermesi ve bu yönde sosyal sorumluluk projeleri geliştirmesini ifade etmektedir. Hem işletme içinde hem de işletme dışındaki paydaşlar için önemli bir itibar bileşenidir.

Finansal performans, kurumun rakiplerine üstünlük sağlaması, yatırım yapmak için riski düşük, getirisi yüksek bir seçenek olması ve geleceğe yönelik güçlü beklentilerinin olmasını ifade etmektedir. Yatırımcılar ve ortaklar açısından önemli bir itibar bileşenidir.

\section{Araştırmanın Metodolojisi}

Araştırmanın amacı Fombrun (2000) tarafından geliştirilen İtibar Katsayısı Ölçeği'nin (Reputation QuotientRQ) yapısal olarak geçerliği ve güvenirliğini test etmektir.

Araştırmanın evrenini Batman ilinde bankacılık sektöründe faaliyet gösteren 316 banka çalışanı oluşturmaktadır. Anketin uygulanacağı örneklem sayısının belirlenmesi için örneklem hesaplama formülü kullanılmıştır. Basit tesadüfî örnekleme formülü evren büyüklüğünün bilindiği çalışmalarda kullanılmaktadır. $\% 95$ güvenilirlik düzeyi ve $\% 5$ örnekleme hatası kullanılan formüle göre (Kalayc1, 2015);

$$
\text { N. Z2.P. Q }
$$

$\mathbf{n}=$

$$
d^{2} \cdot(N-1)+Z^{2} \cdot P . Q
$$

$\mathrm{n}=$ Örneklem büyüklüğü

$\mathrm{N}=$ Ana kütle hacmi (evren)

$\mathrm{Z}=$ Belirli serbestlik derecesinde ve saptanan yanılma düzeyinde $\mathrm{z}$ tablosunda bulunan teorik değer

$\mathrm{P}=$ Olayın gerçekleşme olasıllı̆ 1

$\mathrm{Q}=$ Olayın gerçekleşmeme olasılığ 1

$\mathrm{d}=$ Hata payını temsil etmektedir. 
$\mathrm{Bu}$ formüle göre örneklem sayısı:

$$
\mathbf{n}=\frac{316 \cdot(1,96)^{2} \cdot(0,5) \cdot(0,5)}{(0,05)^{2} \cdot(316-1)+(1,96)^{2} \cdot(0,5) \cdot(0,5)}
$$$$
\mathrm{n}=173,629155
$$

$$
\mathrm{n} \cong 174
$$

Çalışma için gerekli olan örneklem sayısının hesaplandığı formüle göre, 174 örneklemin anakütleyi temsil etme gücüne sahip olduğu söylenebilir. Araştırmada ise 185 katılımcının anket formu geçerli kabul edilmiştir. Bu katılımcı sayısı gerekli olan örneklem sayısını karşılamaktadır.

Araştırma verileri anket yöntemiyle toplanmıştır. Sorularda katılımcıların ifadelere ne oranda katıldıkları sorularak beşli Likert ölçeği kullanılmıştır. Katılımcıların, 1 'kesinlikle katılmıyorum', 2 'katılmıyorum', 3 'kararsızım', 4 'katılıyorum', 5 'tamamen katılıyorum' şıklarından, kendi görüşlerini en iyi yansıtan şıkkı işaretlemeleri istenmiştir.

Ankette Fomburn (2000) tarafindan geliştirilen İtibar Katsayısı Ölçeği'nin (Reputation Quotient-RQ) orjinali Türkçe'ye çevrilerek kullanılmıştır. Ölçekte kurumsal itibar altı boyuttan oluşmakta olup duygusal cazibe boyutu üç soru, ürün ve hizmetler boyutu dört soru, vizyon ve liderlik boyutu üç soru, çalışma ortamı ve iş çevresi boyutu üç soru, kurumsal sosyal sorumluluk boyutu üç soru ve finansal performans boyutu dört soru şeklindedir. Ölçek toplam 20 sorudan oluşmaktadir.

Anket sorularına yönelik örneklem verilerinin analizinde SPSS 23.0 ve AMOS 24.0 programları kullanılmıştır. Ölçeğe güvenirlik analizi ve doğrulayıcı faktör analizi (DFA) uygulanmıştır.

\section{Bulgular}

Araştırmada kullanılan ölçekle elde edilen verilere ait güvenirlik analizi sonuçları Tablo 1'de bulunmaktadır.

\begin{tabular}{lcl} 
& N(Soru Sayısi) & Cronbach Alfa \\
Kurumsal İtibar & 20 & 0,924 \\
Duygusal Cazibe & 3 & 0,783 \\
Ürün ve Hizmetler & 4 & 0,800 \\
Vizyon ve Liderlik & 3 & 0,754 \\
Çalışma Ortamı ve İş Çevresi & 3 & 0,736 \\
Kurumsal Sosyal Sorumluluk & 3 & 0,702 \\
Finansal Performans & 4 & 0,758 \\
\hline
\end{tabular}

Tablo 1: Güvenirlik Analizi Sonuçları

Tablo 1'de görüldüğü üzere analiz sonuçları incelendiğinde elde edilen Cronbach Alfa değerlerinin itibar katsayısı ölçeği için $\alpha=0,924$ olduğu görülmektedir. İstatistiki değerlendirmelere göre elde edilen bu skor kullanılan ölçeğin $0,80 \leq \alpha \leq 1.00$ aralığında olduğunu ve çok yüksek güvenirlikte olduğunu göstermektedir. Ayrıca kurumsal itibarın alt boyutları olan duygusal cazibenin $\alpha=0,783$, ürün ve hizmetler $\alpha=0,800$, vizyon ve liderlik $\alpha=0,754$, çalışma ortamı ve iş çevresi $\alpha=0,736$, kurumsal sosyal sorumluluk $\alpha=0,702$ ve finansal performans $\alpha=$ 0,758 güvenirlik seviyesinde olduğu görülmektedir.

Araştırmanın ölçeği olan itibar katsayısı ölçeğine doğrulayıcı (confirmatory) faktör analizi uygulanmıştır. Analiz Maksimum Olabilirlik Metodu (Maximum Likehood) ile yapılmıştır. Doğrulayıcı faktör analizi model diyagramı Şekil 1'de gösterilmiştir. 


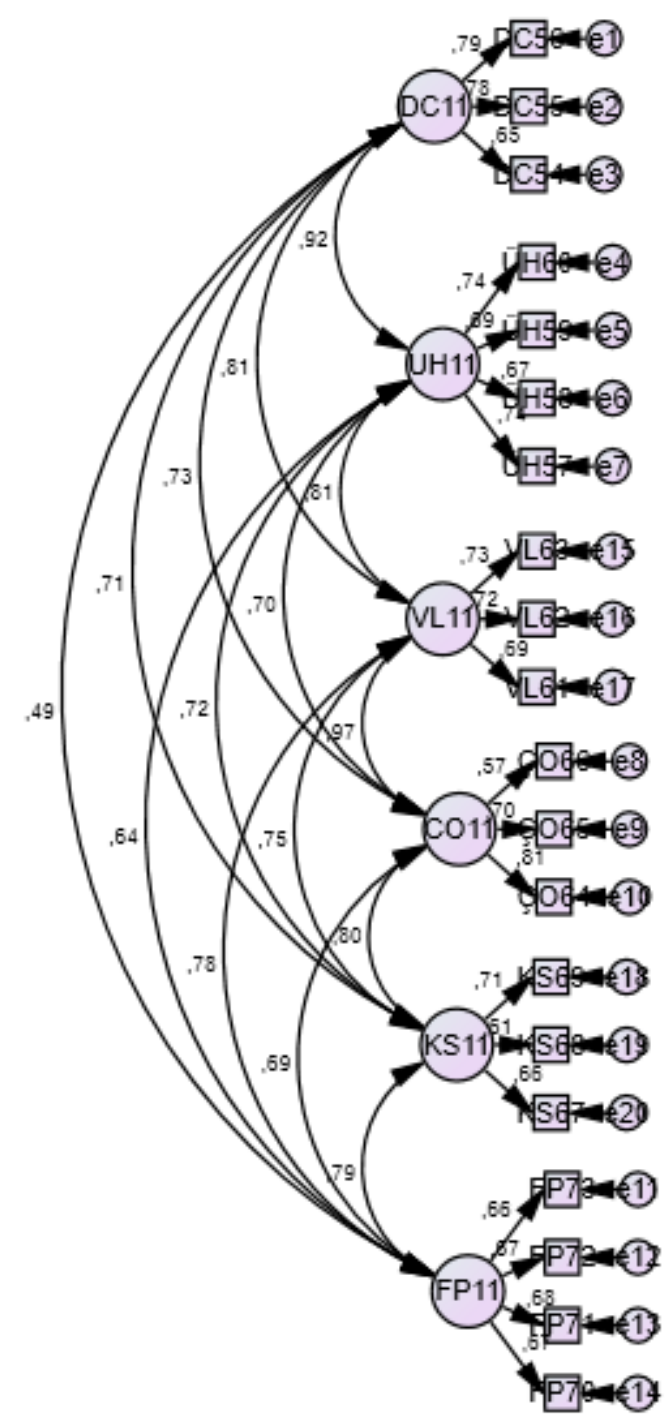

Şekil 1: İtibar Katsayısı Ölçeği DFA Model Diyagramı

Şekil 1'de gösterilen modelin uyum iyilik indeksleri incelendiğinde $\mathrm{X}^{2} / \mathrm{df}=2,192<3$, RMSEA $=0,08=0,08$, GFI= $0,846<0,90, \mathrm{CFI}=0,891<0,90, \mathrm{TLI}=0,866<0,90$ ve $\mathrm{IFI}=0,893<0,90$ olarak tespit edilmiş olup, modelin kabul edilebilir uyum göstermediği sonucuna ulaşılmıştır. Modelde revize yapılarak doğrulayıcı faktör analizi sonucunda faktör yükü düşük olan dört soru ('bankamız yüksek kalitede ürün ve hizmetler sunar', 'işletmemiz iyi ve yetenekli çalışanlara sahip bir firmadır', 'işletmemiz sosyal içerikli olayları destekler ve yardımseverdir (yardım kampanyaları gibi)', 'işletmemiz rakiplerinden önde ve üstündür') analizden çıkarılmıştır. Bu şekilde tekrar yapılan analiz sonucunda elde edilen uyum indeksleri değerleri Tablo 2'de verilmiştir.

$\begin{array}{cccccc}\mathrm{X}^{2} / \mathrm{df} & \text { RMSEA } & \text { GFI } & \text { CFI } & \text { TLI } & \text { IFI } \\ 1,788 & 0,065 & 0,903 & 0,945 & 0,926 & 0,946\end{array}$

Tablo 2: İtibar Katsayısı Ölçeği Doğrulayıcı Faktör Analizi İçin Uyum İndeksleri

Tablo 2 incelendiğinde $\mathrm{X}^{2} / \mathrm{df}=1,788<3$, RMSEA $=0,065<0,08, \mathrm{GFI}=0,903>0,90, \mathrm{CFI}=0,945>0,90$, TLI $=0,926>0,90$ ve IFI $=0,946>0,90$ uyum iyilik indeksleri değerlerine göre model iyi uyuma sahiptir. Dolayısiyla itibar katsayısı ölçeğinin geçerliği, doğrulayıcı faktör analizi ile teyit edilmiştir.

Doğrulayı Faktör Analizi (DFA) ile elde edilen revize modelin diyagramı Şekil 2'de verilmiştir. 


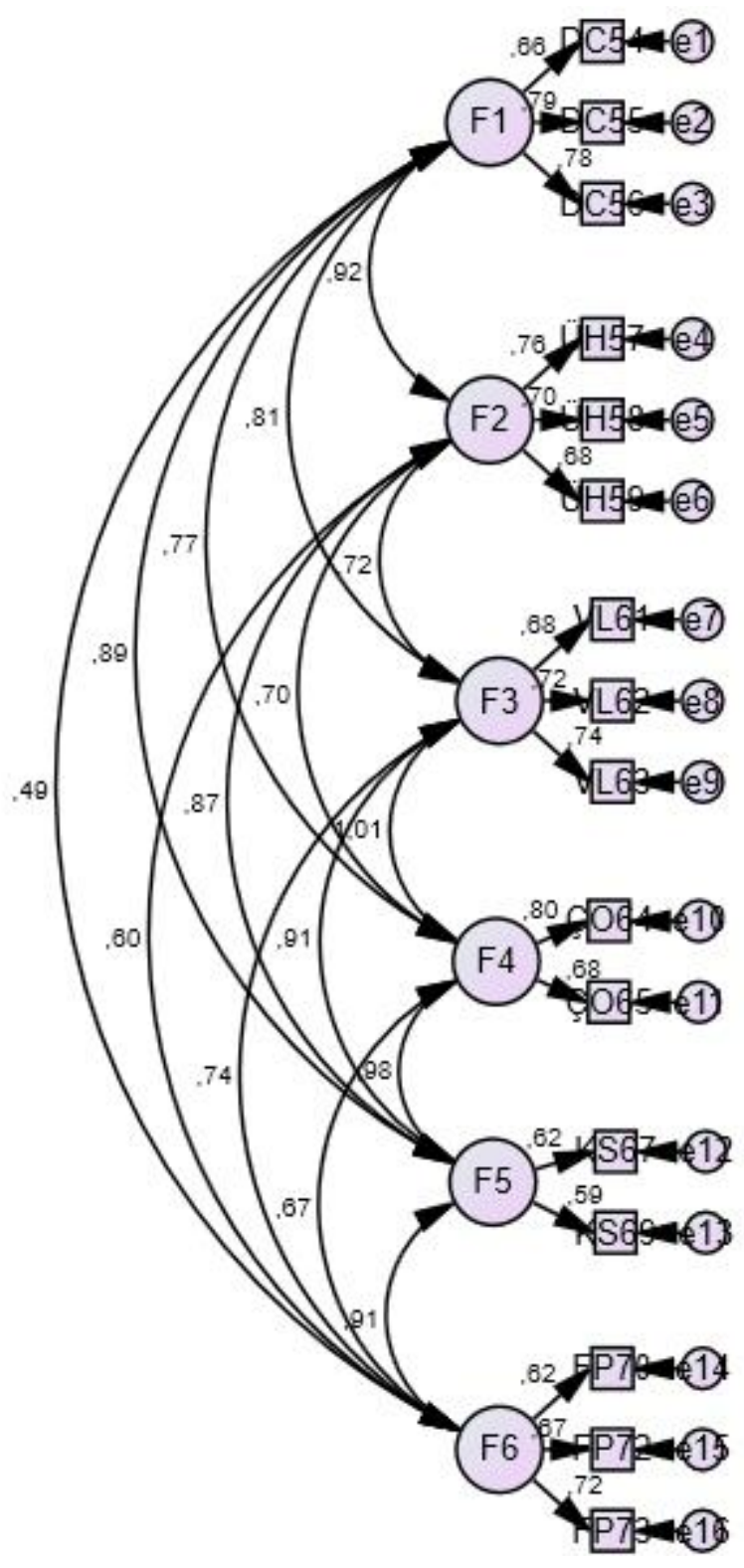

Şekil 2: İtibar Katsayısı Ölçeği DFA Revize Model Diyagramı

Regresyon değerleri, gözlenen değişkenlerin, gizli değişkenleri tahmin etme gücünü, yani faktör yüklenimlerini gösterir. Faktör yüklenimlerinin yüksek çıkması maddelerin, faktörlere doğru yüklendiğini göstermiştir. Tablo 3 'de standardize edilmiş regresyon katsayıları (standartized regression weights) verilmiştir. 
Bankamiza güvenirim

Bankamıza hayranlık ve saygı duyarım.

Bankamız hakkında iyi duygulara sahibim.

İşletmemiz mal ve hizmetlerinin arkasında durur.

Bankamız ödenen paranın karşılığını veren ürün ve hizmetler sunar.

Bankamız yenilikçi ürün ve hizmetler sunar.

İşletmemiz pazar fırsatlarını çabucak fark edip avantaj olarak kullanır.

İşletmemizde yönetim kademesinin gelecek için net bir vizyonu vardır.

İşletmemizde yönetim kademesi mükemmel liderliğe sahiptir.

İşletmemiz iyi yönetilmektedir.

İşletmemiz çalışanların zevkle çalıştığı, iyi bir firmadır.

İşletmemiz çevresine karşı sorumluluk sahibi olup, çevresel sorumluluk kampanyaları yürütmektedir.

İşletmemiz insanlara iyi davranır, ihtiyaç sahibi insanlara yardım eder. İşletmemiz güçlü bir kârlılığa sahip olup, kârlılık düzeyi yüksektir.

İşletmemiz yatırım yapmak için (örn: hisselerini almak için) riski düşük, getirisi yüksek bir seçenektir.

İşletmemizin geleceğe yönelik güçlü beklentileri vardır. (büyüme, yeni yatırımlar vb.)
Standartlaştırılmış

Regresyon Yükleri

\begin{tabular}{|c|c|c|}
\hline$\leftarrow$ & F1 & ,657 \\
\hline$\leftarrow$ & F1 & ,792 \\
\hline$\leftarrow$ & F1 &, 778 \\
\hline$\leftarrow$ & F2 &, 764 \\
\hline$\leftarrow$ & F2 & 695 \\
\hline$\leftarrow$ & $\mathrm{F} 2$ & 677 \\
\hline$\leftarrow$ & F3 & 683 \\
\hline$\leftarrow$ & F3 &, 724 \\
\hline$\leftarrow$ & F3 &, 735 \\
\hline$\longleftarrow$ & F4 & ,799 \\
\hline$\leftarrow$ & F4 & ,682 \\
\hline$\longleftarrow$ & F5 & ,623 \\
\hline$\leftarrow$ & F5 & 593 \\
\hline$\leftarrow$ & F6 & 620 \\
\hline$\leftarrow$ & F6 & ,674 \\
\hline & F6 &, 721 \\
\hline
\end{tabular}

Tablo 3: İtibar Katsayısı Ölçeği’nin Standardize Edilmiş Regresyon Yükleri

Tablo 3 incelendiğinde kurumsal itibar ölçeğinin altı faktörden oluştuğu görülmektedir. F1: Duygusal cazibe, F2: Ürün ve hizmetler, F3: Vizyon ve liderlik, F4: Çalışma ortamı ve iş çevresi, F5: Kurumsal sosyal sorumluluk ve F6: Finansal performans faktörlerini temsil etmektedir.

\section{Sonuç}

Çalışma, Fombrun'un (2000) İtibar Katsayısı Ölçeği'ne (Reputation Quotient-RQ) yeniden geçerlilik ve güvenilirlik analizi yapmayı amaçlamaktadır. Araştırmada anket yoluyla veri toplama yöntemi kullanılmış olup 185 banka çalışanının katılımıyla gerçekleştirilmiştir. Güvenilirlik analizi sonucu Cronbach Alfa değeri 0,924 şeklinde bulgulanmış olup ölçeğin güvenirliğinin yüksek olduğu tespit edilmiştir. Ölçeğe daha sonra doğrulayıc1 faktör analizi (DFA) uygulanmıştır. Doğrulayıcı faktör analizi sonucu elde edilen uyum indeksleri sonucu $\mathrm{X}^{2} / \mathrm{df}$ $=1,788<3, \mathrm{RMSEA}=0,065<0,08, \mathrm{GFI}=0,903>0,90, \mathrm{CFI}=0,945>0,90, \mathrm{TLI}=0,926>0,90$ ve $\mathrm{IFI}=0,946>0,90$ şeklinde hesaplanmıştır. Uyum indeksleri sonuçları modelin iyi bir uyuma sahip olduğunu ortaya koymuştur.

Fombrun'un (2000) İtibar Katsayısı Ölçeği'nin 2018 yılında Batman ili bankacılık sektöründe faaliyet gösteren banka çalışanları üzerinde geçerliği ve güvenirliği test edilmiş ve iyi uyuma sahip olduğu sonucuna ulaşılmıştır.

\section{Kaynakça}

- Barnett, M. L., Jermier, J. M., ve Lafferty, B. A. (2006). 'Corporate Reputation: The Definitional Lanscape’. Corporate Reputation Review, 9(1), 26-38.

- Chun, Rosa, (2005). 'Corporate Reputation: Meaning and Measurement'. International Journal of Management Reviews, 7(2): 91-109.

- Çekmecelioğlu, H. G., Dinçel, G. (2013). 'Çalışanların İş Tutum ve Davranışlarının Kurumsal İtibar Üzerine Etkisi’. Elektronik Sosyal Bilimler Dergisi, 12(47): 125-139.

- Dentchev, Nikolay A. ve Aime Heene, (2004). 'Managing The Reputation of Restructuring Corporations: Send The Right Signal to The Right Stakeholder'. Journal of Public Affairs, 4(1): 56-70.

- Fomburn, C.J. (1996). Reputation: Realizing Value From The Corporate Image. Boston: Harvard Business School Press.

- $\quad$ Fombrun, C.J. (1998). 'Indices of Corporate Reputation: An Analysis of Media Rankings and Social Monitors' Ratings'. Corporate Reputation Review, 1(4), 327-339.

- Fombrun, C. J. (2005). 'The Leadership Challenge: Building Resilient Corporate Reputations'. Handbook on ge Delahaye Medialink's Newsletter of Worldwide Communications Research, 14(3), 1-4.

- $\quad$ Fombrun, C. J, Gardberg, N. A., Sever, J. M. (2000). 'The Reputation Quotient: A Multi-Stakeholder Measure of Corporate Reputation'. The Journal of Brand Management, 7(4), 241-255.

- $\quad$ Fombrun, C., J., Gardberg, N. A., Barnett, M. L. (2007). 'Opportunity Platforms and Safety Nets: Corporate Citizenship and Reputational Risk’. Business and Society Review, 105(1), 85-106. 
- Fombrun, C.J., Rindova, V. (1998). 'Reputation Management In Global 1000 Firms: A Benchmarking Study'. Corporate Reputation Review, 1(3), 205-212.

- Fombrun, C. J., Shanley, M. (1990). 'What's In A Name? Reputation Building and Corporate Strategy'. Academy of Management Journal, 33(2), 233-258.

- Fombrun, C.J., Van Riel, C. B.M. (2004). Fame and Fortune: How Successful Companies Reputations.New York: Financial Time.

- Gotsi M. ve Wilson A. (2001). 'Corporate Reputation Management: "Living The Brand”, Management Decision, 39(2), 99-104.

- Kalaycı, Ş. (2015). Spss Uygulamalı Çok Değişkenli İstatistik Teknikleri. Ankara: Asil Yayınevi.

- Tolbert, S. L., (2000). 'A Conceptual Framework and Empirical Test of The Antecedents and Consequences of Corporate Reputation'. Unpublished doctoral dissertation, Ohio State University. 


\title{
Türkiye'de Konut Piyasası Dinamikleri Dynamics in Turkish Housing Market
}

\begin{abstract}
The recent economic crises of the summer 2018 has led to hiking foreign currency prices and an increased risk perception. Moreover, promising returns of alternative investments has convinced investors to refrain from the housing market and the demand in real estate market has fallen significantly. Measuring the demand for housing precisely is crucial for overcoming economic difficulties as well as understanding the profitability, liquidity and the future of construction sector in Turkey. In this study, significant factors that have impact on the demand for real estate market are assumed to be dynamic. Different regimes are formed based on interest rates and factors like housing prices, location, mortgage rates, bond rates, foreign currency returns, gold returns and iron prices are used to test the changes in the demand for real estate.
\end{abstract}

\section{Giriş}

Küreselleşen dünyada, sanayileşme ve toplumsal değişimle şekillenen Türk aile yapısı yerini daha çok kırsalda görülen geniş aile yapısından çekirdek aile yapısına bırakmakta böylelikle insanların bağımsız bir konuta olan ihtiyacı artmaktadır (Balc1, 2011). Konut edinme hakkı, Türkiye Cumhuriyeti Anayasasının 57. Maddesinde; "Devlet, şehirlerin özelliklerini ve çevre şartlarını gözeten bir planlama çerçevesinde, konut ihtiyacını karşılayacak tedbirleri alır, ayrıca toplu konut teşebbüslerini destekler.” ve İnsan Hakları Evrensel Beyannamesinin 25. maddesinde; "insanların konuta sahip olmaları yiyecek, giyim ve sağlık ihtiyaçları gibi yaşam standartlarının bir gereğidir.” hükümleriyle de güvence altına alınarak temel ihtiyaç olarak kabul edilmiştir (Aydoğdu, 2007).

Konutun; sosyal, kültürel, ekonomik, hukuki, teknolojik olmak üzere birçok farklı boyutu bulunmakta olup, yaşam alanı olma, üretim ve tüketime tabi bir mal olma, yatırım aracı olma, ekonomik güvence sağlama, sosyal ilişkilerde araç olma, şehirleşmenin oluşumunda yer alma gibi oldukça farklı fonksiyonları da bulunmaktadır. Konut talebi, bireylerin konut ihtiyaçlarını karşılamak amacıyla konut satın alabilmek veya konutun kirasını ödeyebilmek için yeterli mali güce sahip olması şeklinde tanımlanabilmektedir. Konuta olan ihtiyaç ve talep düzeyi hane halkının gelirinde meydana gelen değişimler, tasarruf ve yatırımların genel düzeyi, istihdam ve emek hareketlilik ile şekillenmekte, diğer birçok ülkede olduğu gibi Türkiye'de de makroekonominin önemli bir kalemini oluşturarak konut piyasasında ki dalgalanmalar tüm ekonomiyi etkisi altına alabilmektedir (Uysal ve Yiğit, 2016).

Gelişmiş ülke faiz oranlarının düşmesiyle Türkiye gibi gelişmekte olan ülkelerdeki yatırım araçlarının getirisinin görece artışı, gelişmekte olan ülkelere yönelik sermaye hareketlerinin artmasına imkân tanımış, artan yabancı sermaye girişi likidite artışına neden olurken, bir yandan faiz oranlarının düşmesine diğer taraftan iç talebin ve bu arada konut talebinin genişlemesine neden olmuştur. Konut sektörünün yüksek oranda yerli sermayeden oluşması, istihdam sağlama gücünün yüksek olması ekonomide canlanma sağlarken katma değer oluşturmakta ve başta imalat sektörü olmak üzere diğer sektörlerle bağlantılı yapısı konut sektörünün önemini artırmaktadır. Konut harcamalarının çarpan etkisinin yüksek olması sebebiyle konut harcamalarında meydana gelen artış, beyaz eşya, ev tekstili, mobilya gibi konutla ilgili diğer mallara olan talebi de etkilemektedir (Uysal ve Yiğit, 2016).

Konut sektörü, inşaat sektörünün bir bileşeni olmakla emek-yoğun ve kalifiyesiz işgücüne dayalı, ithalat bağımlılığı düşük, diğer sektörler (demir-çelik, çimento gibi yan sanayiler) üzerinde uyarıcı etkisi olan, üç ana ekonomik sektörün (tarım, sanayi ve hizmetler) konusu (neredeyse tüm sektörleri besleyen ve o sektörlerden beslenen) ve hem de tüm üretim faktörlerinin (sermaye, toprak, emek ve girişimcilik, vb) aynı anda ancak farklı düzeylerde kullanılmasının bir ürünüdür. Konut, (mal piyasası için) bir nihai maldır. Özellikle az gelişmiş ülkelerde ve enflasyonist yapılarda yüksek kâr beklentilerini doğurmaktadır (Özkurt, 2007).

Konut yatırım kararlarında birçok faktörle beraber faiz oranları dikkate alınmakta olup, düşük faiz oranları, kiracıları kira ödemek yerine kredi ödemeleri yaparak kendi konutlarını satın almaya teşvik etmekte, ödenen kira miktarı ile kredi ödemesi arasındaki fark azaldıkça konut satın almak rasyonel hale gelmektedir (Öztürk ve Fitöz, 2009). Konut talebindeki eğilimleri görebilmek için konut kredileri faiz oranları, tüketici güven endeksleri, kur, altın fiyatları, inşaat sektörüne ait maliyetler ile demografik değişkenler dikkate alınmalıdır (Kıral ve Cahit, 2018).

Konutlar yapıları gereği uzun vadeli yatırım aracı olmakla beraber finansman kaynaklarından olan Mortgage (ipotekli konut kredisi) finansman kaynaklarının başında gelmektedir. Mortgage piyasaları sermaye piyasasının önemli bir parçasını meydana getirdiğinden, bu piyasalarda ortaya çıkan mortgage faizi diğer uzun dönemli faizlerden ve merkez bankası para ve faiz politikalarından etkilenmektedir. Faizlerde meydana gelen değişiklikler de konut talebini ve değerini değiştirmektedir. Bu da konut fiyatlarının yükselme eğilimine girmesine sebep olmaktadır. Mortgage faizlerinde meydana gelen bir değişiklik konut finansman maliyetini değiştireceğinden hane halkları hem tüketim hem de yatırım amacıyla daha fazla (ya da daha az) konut talep edecek, böylelikle konut fiyatlarının yükselme (düşme) eğilimine girmesine yol açacaktır. Konut arzının önemli faktörlerinden olan inşaat 
maliyetleri de konut fiyatlarını etkileyen faktörler arasında yer almakta, faizlerde meydana gelen bir değişiklik şirketlerin inşaat finansman maliyetlerinin değişmesine yol açarak yeni konutların inşaat hızını olumlu (ya da olumsuz) yönde etkileyecektir. Konut inşası için gerekli olan yapı malzemeleri ve emek maliyetlerinde oluşan artış konut arzını azalan karlar nedeniyle olumsuz etkileyecektir. Konut fiyatlarının bu duruma tepkisi artış yönünde olacaktır (İslamoğlu ve Buluş, 2018).

\section{Literatür taraması}

Ülkemizdeki araştırmalar incelendiğinde, Durukaya ve Yamak'ın araştırmasında fiyatlar genel düzeyindeki artışların talep edilen konut miktarının azaltııı etkileri bakımından kişilerin hem reel gelirindeki azalışları hem de faiz oranlarındaki yükselmeler karsısında kullanabilecekleri konut kredilerinin daraldığı tespit edilmiştir (Durukaya ve Yamak, 2004).

Güler tarafindan Kırıkkale ilinde yapılan analizde İpotekli konut kredisinin düşük ve orta gelirli kesime etkisi araştırılmış, çalışma sonucunda; düşük ve orta gelir gurubunun ipotekli konut kredilerinden yüksek düzeyde yararlanamayarak konut sahibi olamadıkları belirtilmiştir. Araştırmada İpotekli Kredi Sisteminin başarılı olması düşük faiz oranları, ekonomik istikrar ve zaman koşuluna bağlanmıştır (Güler, 2007). Öztürk ve Fitöz, 2009, Türkiye konut piyasasında konut arz ve talebinin belirleyicilerini regresyon analizi ile araştırmış ve kişi başına milli gelir, konut fiyatları ve faiz oranları ile konut talebi arasında pozitif yönlü bir ilişki; demografik faktörler ile konut talebi arasında ise önemsiz bir ilişki elde etmiştir.

Lebe ve Akbaş, 2014, Türkiye'deki konut talebini etkileyen faktörleri Johansen\&Juselius eşbütünleşme ve VECM metoduyla ele almış ve analiz sonucunda kişi başı gelir, sanayileşme, konut fiyatı, tarım sektöründe istihdam, faiz oranı ve medeni durum gibi değişkenlerle konut talebi ve dolayısıyla konut satı̧ı arasında uzun dönemli bir ilişkinin olduğu tespit edilmiştir. Kişi başı gelir, medeni durum ve sanayileşmenin konut talebini arttırıcı yönde; konut fiyatları, tarım sektöründe istihdam miktarı ve faizin ise olumsuz yönde etkilediği tespit edilmiş̧tir. Bununla birlikte Türkiye'nin konut talebini uzun dönemde en fazla etkiyen faktörün konutu talep edecek olan kişilerin geliri olduğu belirlenmiştir.

Bekmez ve Özpolat (2013) tarafından yapılan araştırmada; 1986 yılı ile 2009 yılları arasında tahmin edilen VAR modelinde konut talebi göstergesi olarak kullanılan yapı kullanım belgeleri ve kişi başına milli gelir, faiz oranları, enflasyon oranı, borsa endeksi ve işsizlik oranlarını incelemiş, analiz sonuçlarına göre, konut talebini etkileyen en önemli değişkenin kişi başına milli gelir olduğu ve konut talebi ile doğru orantılı olduğu, işsizlik oranı ile konut talebi arasında kısa dönemde doğru orantı bulunduğu, ancak uzun dönemde aradaki ilişkinin değişerek konut talebini negatif yönde etkilediği, enflasyon oranı ile konut talebi arasında pozitif yönlü ilişki bulunduğu, borsa endeksinin kısa vadede talep üzerinde önemli bir etki yaratmadığı, uzun dönemde etkisini arttırdığı ve borsa endeksi ile konut talebi arasında negatif bir ilişki bulunduğu, faiz oranının konut talebi üzerinde önemli bir etkisi bulunmamakla beraber faiz oranı konut talebini negatif etkilediği tespit edilmiş̧ir. Faiz oranlarının talep üzerinde beklenenden az etkisinin bulunması analizde 1986- 2002 yılları arasında Mortgage oranlarının henüz Türkiye'de kullanılmamasına bağlanmıştır(Bekmez ve Özpolat, 2016).

İslamoğlu ve Buluş tarafından yapılan araştırmada ipotekli konut kredi faizleri, kişi başına düşen gelir ve inşaat maiyetlerinin konut fiyatları üzerindeki etkisi, TCMB gecelik borç verme faiz oranı, enflasyon oranı, döviz kuru ve ekonomik büyüme oranında meydana gelen değişmelerin konut finansman faizleri üzerindeki etkisi araştırılmıştır. Araştırma sonucunda merkez bankası tarafından hedeflere ulaşmak için kullanılan kısa vadeli faiz oranları ile ipotekli konut kredisi faiz oranları arasında pozitif yönlü bir ilişki bulunduğu konut talebinin merkez bankası para ve faiz politikalarından etkilendiği, yüksek reel faizlerin konut gibi uzun vadeli yatırımları olumsuz etkilediği tespit edilmiştir (İslamoğlu ve Buluş, 2018).

\section{Veri, Yöntem ve Uygulama Sonuçları}

Bu çalışmada; Konut kredi faizlerinin düşük olduğu dönemler, aylık \%1 seviyesinin altına düştüğü dönemler olarak belirlenmiş ve \% 1 'in üzerine çıktı̆̆ dönemler farklı bir rejim olarak kabul edilmiştir. Bahsi geçen iki dönemin kıyaslanılması sonucunda hane halkı alternatif yatırım araçlarından Dolar/TL kuru, BİST 30 endeks getirisi, Gram Altın getirisi değişkenleri ile konut maliyet kalemlerinden TÜFE oranları, Konut Kredisi Faiz Oranları ve Tüketici Güven Endeksi, Konut Birim Fiyatları, Hedonik Konut Fiyat Endeksi değişkenleri odağında konut talebinin nasıl şekilleneceği ortaya konulmaya çalışılmıştır. İncelenen dönemde konut satışına etki eden faktörlerin sadece belirtilen değişkenlere duyarlı olduğu varsayımı ile hareket edilmektedir. Bazı verilerin yayınlanma periyotları aylık bazda olduğu için zaman serileri aylık olarak ele alınmıştır. 2013 Ocak-2019 Ocak ayları arasındaki aylık verilerin kullanıldığı çalışmada her bir değişken için 73 adet gözleme yer verilmiştir. Kullanılan veriler TÜiK ve TCMB-EVDS'ye ait açık kaynaklardan elde edilmiştir. Analizlerde kullanılan değişkenlerle ilgili açıklamalar aşağı da belirtilmiştir.

İpotekli Konut Satış Verileri; Borçlanarak satın alınan konutun kredi teminatını oluşturmak için, yine aynı konutun teminat olarak gösterildiği ve bu şekilde kredi kullanılarak satışı sağlanan Türkiye'deki tüm yerleşim 
yerlerini kapsayan satış verileridir. Veriler TCMB-EVDS açık kaynağından alınmışır ve çalışmada bağımlı değişken olarak kullanılmıştır. Çalışmada (KSATIS) olarak isimlendirilmiştir.

Konut Kredi Faiz Oranları; Konut kredi faizleri konut kredisi talep edenler için önemli bir maliyet oluşturmaktadır. Faizlerdeki artışlar kredi kullananların geri ödemelerinde artışa yol açacağı gibi faiz oranlarındaki azalışta ödemeleri ve maliyeti azaltacaktır. Tüketici talepleri üzerinde belirleyici bir etki oluşturması beklenen konut kredi faizleri bu çalışmada bağımsız değişken olarak ele alınmıştır. Kredi Faiz Oranları için TCMB-EVDS sistemindeki mevduat bankalarınca açılan konut kredilerindeki ağırlıklandırılmış konut kredi faiz oranları kullanılmıştır. Çalışmada (KKREDI) olarak isimlendirilmiştir.

Reel Külçe Altın Getiri Oranı; Altın, Türkiye'de yatırımcıların güvenli liman olarak gördüğü ve uzun vadeli geleneksel yatırım aracı olarak kullanılan bir yatırım aracıdır. Altın verisi için TCMB-EVDS Külçe Altın (TL/Gr) kullanılmıştır ve çalışmada (ALTIN) olarak isimlendirilmiştir.

Reel Amerikan Doları Getiri Oranı; Amerikan Doları, enflasyon etkilerinin kuvvetli şekilde görüldüğü Türkiye'de Türk Lirası değerinde oluşabilecek kayıplardan korunmak veya getiri elde etmek için tercih edilen önemli bir yatırım aracıdır. Bu sebeple Amerikan Doları aylık reel getiri oranları çalışmada bağımsız değişken olarak kullanılmıştır. Veriler TCMB-EVDS Usd/Try getiri tablosundan elde edilmiştir. Amerikan Doları aylık reel getiri oranları çalışmada (USDTRY) olarak ifade edilmiştir.

Tüketici Fiyat Endeksi (TÜFE); Enflasyon oranları bir ülkedeki önemli makroekonomik göstergelerdendir. Türkiye'de Tüketici Fiyat Endeksi (TÜFE) ve Üretici Fiyat Endeksi (ÜFE) verileri enflasyon göstergesi olarak kabul edilmektedir. Bu çalışmada bağımsız değişken olarak Tüketici Fiyat Endeksi verileri tercih edilerek (TÜFE) kısaltmasıyla kullanılmıştır. Veriler TÜIKK sitesinden elde edilmiştir.

Hedonik Konut Fiyat Endeksi Türkiye'deki konutların gözlemlenebilen özelliklerinin zaman içinde kontrol edilerek kalite etkisinden arındırılmış fiyat değişimlerini izlemek amacıyla hesaplanan Hedonik Fiyat Endeksi çalışmada bağımsız değiş̧en olarak (HKFE) koduyla kullanılmıştır. Veriler TÜíK sitesinden elde edilmiştir.

Konut Birim Fiyatları; Konut Birim Fiyatları çalışmada (TLM2) koduyla gösterilmiş bağımsız olup veriler TCMB-EDS sisteminden elde edilmiştir.

Tüketici Güven Endeksi; Tüketici güven endeksi, tüketicilerin gelecek beklentilerini ölçümleyen önemli bir endeks olup, konut kredi kullanımı ile tüketicilerin bu beklentileri arasındaki ilişkinin ölçülmesi amacıyla çalışmaya eklenmiştir. Veriler TCMB-EVDS sisteminden elde edilmiştir. Çalışmada (TGE) koduyla kullanılmışırı.

Reel BİST30 Getiri Oranı; Hisse senetleri tasarruflarını değerlendirmek isteyen yatırımcıların alternatif yatırım seçeneklerinin başında gelmektedir. Borsa İstanbul pazarlarında işlem gören, piyasa değeri ve işlem hacmi en yüksek 30 hisse senedinin ortak performansının ölçülmesi amacıyla oluşturulan BİST30 endeksi çalışmada bağımsız değişken olarak kullanılmıştır. Veriler İnvesting.com sitesinden elde edilmiştir. Çalışmada (BIST30) koduyla kullanılmıştır.

$\mathrm{Bu}$ çalışmada önce birim kök testleri gerçekleştirilmiş, birinci farklar alındıktan sonra seriler durağan hale getirilmiştir. Birincil farklara ait veriler veri kodunun başına FARK kelimesi getirilerek belirtilmiştir. Gecikme seçimleri de yapıldıktan sonra, Johansen Eşbütünleşme testi ile eşbütünleşme seviyesi belirlenmiş ve eşbütünleşme seviyesi bir bulamadığından VAR analizi gerçekleştirilmiş̧ir.

Zaman serisi verilerinin yer aldığı çalışmalarda serilerin durağan olmaları çok önemlidir. Zaman serileri analizinde seriler durağan olmazsa oluşturulacak regresyonun sonuçları gerçekçi olmamakta ve regresyona tabi tutulan değişkenler arasında sahte ilişki bulunmaktadır. Bir değişkenin durağan olup olmadığını veya durağanlık seviyesini belirlemede kullanılan en geçerli yöntem birim kök testidir. Çalışmada Genişletilmiş Dickey-Fuller (ADF) Testi kullanılmış ve verilerin birincil farkları alınarak seriler durağan hale getirilmiştir. Çalışmada kullanılan serilerin durağanlık grafik ve test sonuçları aşağıya çıkarılmışıır.

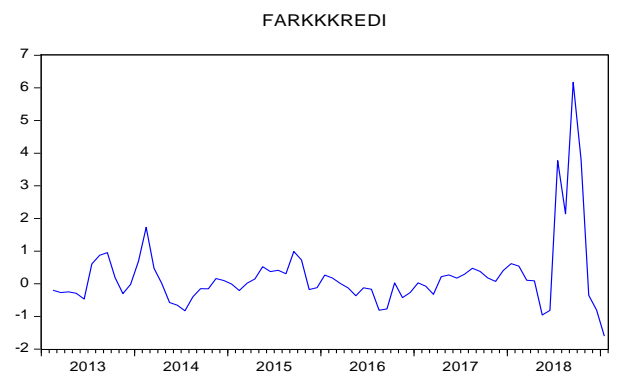

Grafik 1. Konut Kredi Faiz Oranlarının Durağanlık Grafiği

\begin{tabular}{llll} 
& t-Statistic & Prob. $^{*}$ \\
\hline \hline Auamented Dickev-Fuller test statistic & -4.195321 & 0.0001 \\
\hline Test critical values: & 1\% level & -2.597939 & \\
& $5 \%$ level & -1.945456 & \\
& $10 \%$ level & -1.613799 & \\
\hline \hline
\end{tabular}

"Mackinnon (1996) one-sided p-values.

Tablo 1. Konut Kredi Faiz Oranlarının Durağanlık Değerleri 


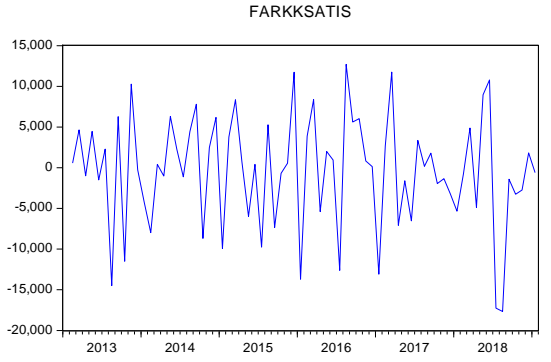

Grafik 2. İpotekli Konut Satış

Oranlarının Durağanlık Grafiği

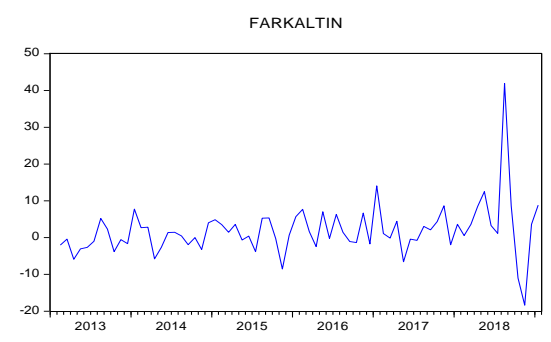

Grafik 3. Gram Altın Fiyatlarının Durağanlık Grafiği

FARKUSDTRY

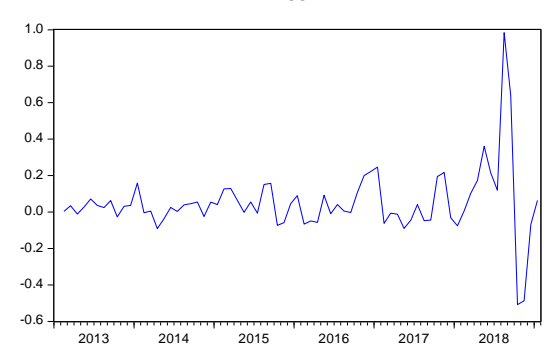

Grafik 4. USDTRY kurunun

Durağanlık Grafiği

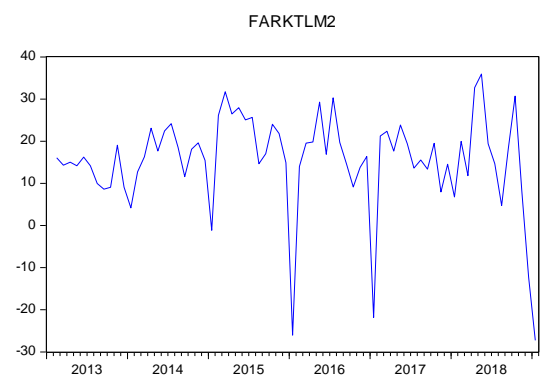

Grafik 5. Konut Birim Fiyatlarının Durağanlık Grafiği

\begin{tabular}{llll} 
& t-Statistic & Prob. $^{*}$ \\
\hline \hline Augmented Dickev-Fuller test statistic & -10.20507 & 0.0000 \\
\hline Test critical values: & $1 \%$ level & -2.597939 & \\
& $5 \%$ level & -1.945456 & \\
& $10 \%$ level & -1.613799 & \\
\hline
\end{tabular}

*Mackinnon (1996) one-sided p-values.

Tablo 2. İpotekli Konut Satış Oranlarının Durağanlık Değerleri

\begin{tabular}{lccc} 
& t-Statistic & Prob. $^{*}$ \\
\hline \hline Augmented Dickev-Fuller test statistic & -6.695009 & 0.0000 \\
\hline Test critical values: & 1\% level & -2.597939 & \\
& $5 \%$ level & -1.945456 & \\
& $10 \%$ level & -1.613799 & \\
\hline \hline
\end{tabular}

*MacKinnon (1996) one-sided p-values.

Tablo 3. Gram Altın Fiyatlarının Durağanlık Değerleri

\begin{tabular}{llll} 
& t-Statistic & Prob. $^{*}$ \\
\hline \hline Augmented Dickev-Fuller test statistic & -3.539478 & 0.0006 \\
\hline Test critical values: $\quad$ 1\% level & -2.598907 & \\
& $5 \%$ level & -1.945596 & \\
& $10 \%$ level & -1.613719 & \\
\hline \hline
\end{tabular}

*Mackinnon (1996) one-sided p-values.

Tablo 4. USDTRY kurunun

Durağanlık Değerleri

t-Statistic Prob.*

\begin{tabular}{lccc}
\hline & t-Statistic & Prob. $^{*}$ \\
\hline \hline \multicolumn{2}{l}{ Augmented Dickev-Fuller test statistic } & -2.903642 & 0.0042 \\
\hline Test critical values: & 1\% level & -2.597939 & \\
& $5 \%$ level & -1.945456 & \\
& $10 \%$ level & -1.613799 & \\
\hline \hline
\end{tabular}

*Mackinnon (1996) one-sided p-values.

Tablo 5. Konut Birim Fiyatlarının Durağanlık Değerleri 


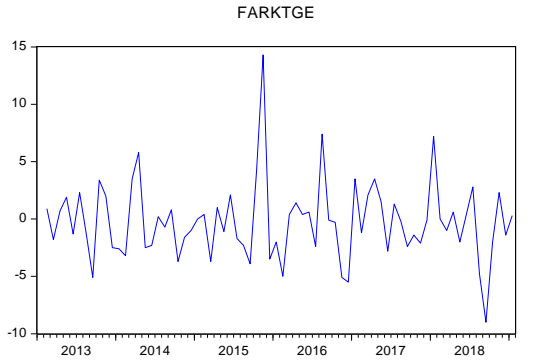

Grafik 6. Tüketici Güven Endeksinin

Durağanlık Grafiği

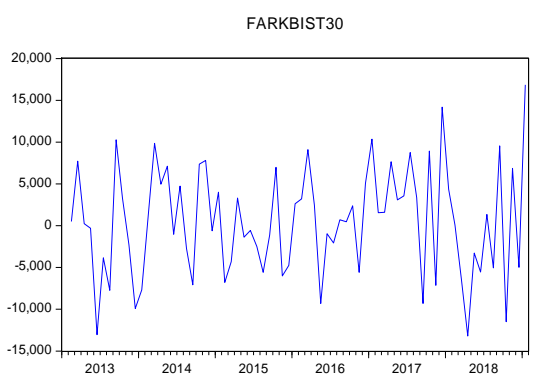

Grafik 7. BIST100 Endeksinin

Durağanlık Grafiği

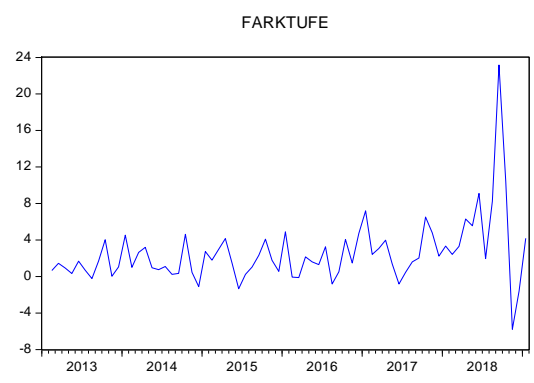

Grafik 8. Tüketici Fiyat Endeksinin Durağanlık Grafiğgi

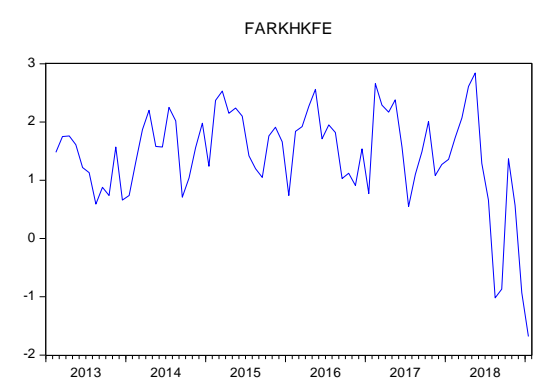

Grafik 9. Hedonik Konut Fiyat Endeksinin Durağanlık Grafiği

\begin{tabular}{|c|c|c|c|}
\hline & & t-Statistic & Prob.* \\
\hline Auamented Dickey & er test statistic & -7.592874 & 0.0000 \\
\hline Test critical values & $\begin{array}{l}1 \% \text { level } \\
5 \% \text { level } \\
10 \% \text { level }\end{array}$ & $\begin{array}{l}-2.598416 \\
-1.945525 \\
-1.613760\end{array}$ & \\
\hline
\end{tabular}

*Mackinnon (1996) one-sided p-values.

Tablo 6. Tüketici Güven Endeksinin Durağanlık Değerleri

\begin{tabular}{lccc} 
& t-Statistic & Prob. $^{*}$ \\
\hline \hline Aumented Dickev-Fuller test statisicic & -8.169923 & 0.0000 \\
\hline Test critical values: & 1\% level & -2.597939 & \\
& $5 \%$ level & -1.945456 & \\
& $10 \%$ level & -1.613799 & \\
\hline \hline
\end{tabular}

"Nackinnon (1996) one-sided p-values.

Tablo 7. BIST100 Endeksinin Durağanlık Değerleri

\begin{tabular}{llll} 
& t-Statisicic & Prob. $^{*}$ \\
\hline \hline Auamented Dickev-Fuller test statistic & -4.662775 & 0.0019 \\
\hline Test critical values: & $1 \%$ level & -4.098741 & \\
& $5 \%$ level & -3.477275 & \\
& $10 \%$ level & -3.166190 & \\
\hline \hline
\end{tabular}

*Nackinnon (1996) one-sided p-values.

Tablo 8. Tüketici Fiyat Endeksi Verilerinin Durağanlık Değerleri

t-Stailisic Prob.

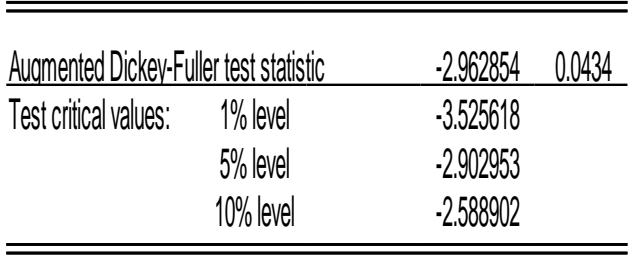

*Nackinnon (1996) one-sided p-values.

Tablo 9. Hedonik Konut Fiyat Endeksinin Durağanlık Değerleri

Durağan hale getirilen veriler gecikme seçimleri de yapılarak Johansen Eşbütünleşme testi ile eşbütünleşme seviyesi belirlendikten sonra VAR analizi gerçekleştirilmiştir. Johansen Eşbütünleşme Test sonuçları aşağıdaki gibidir. 
Sample (adjusted): 2013M04 2019M01

Included observations: 70 after adjustments

Trend assumption: No deterministic trend (restricted constant)

Series: FARKALTIN FARKBIST30 FARKHKFE FARKKKREDI FARKKSATIS FARKTGE FARKTLM2 FARKTUFE FARKUSDTRY

Lags interval (in first differences): 1 to 1

Unrestricted Cointegration Rank Test (Trace)

\begin{tabular}{|c|c|c|c|c|}
\hline $\begin{array}{l}\text { Hypothesized } \\
\text { No. of CE(s) }\end{array}$ & Eigenvalue & $\begin{array}{l}\text { Trace } \\
\text { Statistic }\end{array}$ & $\begin{array}{c}0.05 \\
\text { Critical Value }\end{array}$ & Prob. ** \\
\hline None * & 0.834438 & 419.2822 & 208.4374 & 0.0000 \\
\hline At most 1 * & 0.711200 & 293.3937 & 169.5991 & 0.0000 \\
\hline At most 2 * & 0.613776 & 206.4521 & 134.6780 & 0.0000 \\
\hline At most 3 * & 0.403225 & 139.8584 & 103.8473 & 0.0000 \\
\hline At most 4 * & 0.374101 & 103.7234 & 76.97277 & 0.0001 \\
\hline At most 5 * & 0.302349 & 70.92373 & 54.07904 & 0.0008 \\
\hline At most 6 * & 0.254992 & 45.72119 & 35.19275 & 0.0026 \\
\hline At most $7^{*}$ & 0.229125 & 25.11599 & 20.26184 & 0.0099 \\
\hline At most 8 & 0.093868 & 6.899956 & 9.164546 & 0.1318 \\
\hline
\end{tabular}

Trace test indicates 8 cointegrating eqn(s) at the 0.05 level

* denotes rejection of the hypothesis at the 0.05 level

**MacKinnon-Haug-Michelis (1999) p-values

Unrestricted Cointegration Rank Test (Maximum Eigenvalue)

\begin{tabular}{|c|c|c|c|c|}
\hline $\begin{array}{l}\text { Hypothesized } \\
\text { No. of CE(s) }\end{array}$ & Eigenvalue & $\begin{array}{l}\text { Max-Eigen } \\
\text { Statistic }\end{array}$ & $\begin{array}{l}0.05 \\
\text { Critical Value }\end{array}$ & Prob. ${ }^{* *}$ \\
\hline None * & 0.834438 & 125.8885 & 59.24000 & 0.0000 \\
\hline At most 1 * & 0.711200 & 86.94157 & 53.18784 & 0.0000 \\
\hline At most 2 * & 0.613776 & 66.59366 & 47.07897 & 0.0002 \\
\hline At most 3 & 0.403225 & 36.13503 & 40.95680 & 0.1579 \\
\hline At most 4 & 0.374101 & 32.79966 & 34.80587 & 0.0851 \\
\hline At most 5 & 0.302349 & 25.20255 & 28.58808 & 0.1275 \\
\hline At most 6 & 0.254992 & 20.60519 & 22.29962 & 0.0847 \\
\hline At most 7 * & 0.229125 & 18.21604 & 15.89210 & 0.0212 \\
\hline At most 8 & 0.093868 & 6.899956 & 9.164546 & 0.1318 \\
\hline
\end{tabular}

Max-eigenvalue test indicates 3 cointegrating eqn(s) at the 0.05 level

* denotes rejection of the hypothesis at the 0.05 level

**MacKinnon-Haug-Michelis (1999) p-values

Tablo 10. Johansen Eşbütünleştirme Test Sonuçlarına göre koentegrasyon durumu

Var analizi sırasında bütün verilerin durağanlık seviyeleri tekrar sınanmış ve aşağıdaki grafikle durağanlıkları teyit edildikten sonra VAR analizi gerçekleştirilmiştir. VAR analizi sonuçları aşağıdaki gibidir.

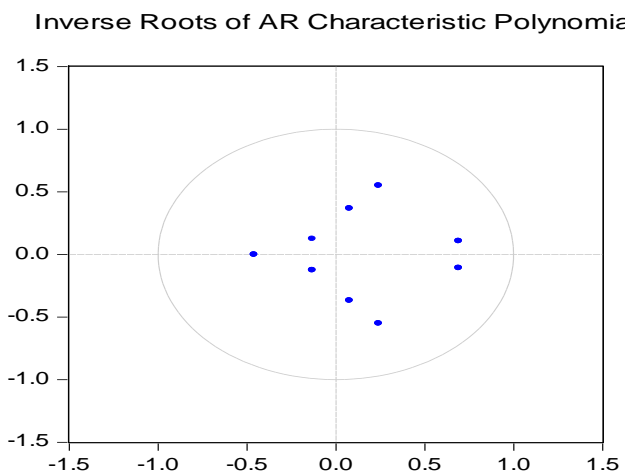

Grafik 10. VAR analizi yapılan verilerin durağanlık teyit grafiği 
Vector Autoregression Estimates

Sample (adjusted): 2013M03 2019M01

Included observations: 71 after adjustments

Standard errors in ( ) \& t-statistics in [ ]

\begin{tabular}{|c|c|c|c|c|c|c|c|c|c|}
\hline & $\begin{array}{c}\text { FARK } \\
\text { KSATIS }\end{array}$ & $\begin{array}{l}\text { FARK } \\
\text { ALTIN }\end{array}$ & $\begin{array}{c}\text { FARK } \\
\text { BIST30 }\end{array}$ & $\begin{array}{l}\text { FARK } \\
\text { HKFE }\end{array}$ & $\begin{array}{c}\text { FARK } \\
\text { KKREDI }\end{array}$ & $\begin{array}{l}\text { FARK } \\
\text { TGE }\end{array}$ & $\begin{array}{l}\text { FARK } \\
\text { TLM2 }\end{array}$ & $\begin{array}{l}\text { FARK } \\
\text { TUFE }\end{array}$ & $\begin{array}{c}\text { FAR } \\
\text { KUSDTRY }\end{array}$ \\
\hline FARK & $\begin{array}{r}-0.414089 \\
(0.13194) \\
{[-3.13840]}\end{array}$ & $\begin{array}{r}-0.000236 \\
(0.00013) \\
{[-1.85604]}\end{array}$ & $\begin{array}{r}-0.027799 \\
(0.12573) \\
{[-0.22111]}\end{array}$ & $\begin{array}{r}-1.32 \mathrm{E}-05 \\
(1.2 \mathrm{E}-05) \\
{[-1.06093]}\end{array}$ & $\begin{array}{r}1.37 \mathrm{E}-06 \\
(1.4 \mathrm{E}-05) \\
{[0.09574]}\end{array}$ & $\begin{array}{r}-1.70 \mathrm{E}-06 \\
(6.2 \mathrm{E}-05) \\
{[-0.02728]}\end{array}$ & $\begin{array}{r}-0.000279 \\
(0.00020) \\
{[-1.37221]}\end{array}$ & $\begin{array}{r}6.16 \mathrm{E}-05 \\
(4.3 \mathrm{E}-05) \\
{[1.43856]}\end{array}$ & $\begin{array}{r}-7.10 \mathrm{E}-06 \\
(2.9 \mathrm{E}-06) \\
{[-2.45423]}\end{array}$ \\
\hline $\mathrm{F}$ & $\begin{array}{r}271.2708 \\
(220.974) \\
{[1.22761]}\end{array}$ & $\begin{array}{r}-0.426557 \\
(0.21287) \\
{[-2.00382]}\end{array}$ & $\begin{array}{r}594.6020 \\
(210.561) \\
{[2.82389]}\end{array}$ & $\begin{array}{c}0.010824 \\
(0.02084) \\
{[0.51941]}\end{array}$ & $\begin{array}{r}0.013286 \\
(0.02390) \\
{[0.55586]}\end{array}$ & $\begin{array}{r}0.147539 \\
(0.10462) \\
{[1.41023]}\end{array}$ & $\begin{array}{r}0.407220 \\
(0.34106) \\
{[1.19398]}\end{array}$ & $\begin{array}{r}0.126975 \\
(0.07176) \\
{[1.76948]}\end{array}$ & $\begin{array}{r}-0.005161 \\
(0.00484) \\
{[-1.06535]}\end{array}$ \\
\hline FAF & $\begin{array}{r}0.047640 \\
(0.12910) \\
{[0.36902]}\end{array}$ & $\begin{array}{r}-0.000170 \\
(0.00012) \\
{[-1.36553]}\end{array}$ & $\begin{array}{c}0.0 \\
(0.1 \\
{[0.3}\end{array}$ & $\begin{array}{r}1.40 \mathrm{E}-05 \\
(1.2 \mathrm{E}-05) \\
{[1.14866]}\end{array}$ & $\begin{array}{r}-5 . \\
(1 . \\
{[-0 .}\end{array}$ & $\begin{array}{l}0.0 \\
(6 . \\
{[2 .}\end{array}$ & $\begin{array}{l}8 . \\
10 \\
{[0}\end{array}$ & $\begin{array}{r}5 . \\
(4 \\
{[0}\end{array}$ & $\begin{array}{r}-5.6 \\
(2 . \\
{[-1 .}\end{array}$ \\
\hline $\mathrm{FAl}$ & $\begin{array}{r}-918.0979 \\
(1734.12) \\
{[-0.52943]}\end{array}$ & $\begin{array}{r}2.887260 \\
(1.67053) \\
{[1.72835]}\end{array}$ & $\begin{array}{r}-2894.987 \\
(1652.40) \\
{[-1.75199]}\end{array}$ & $\begin{array}{r}0.996218 \\
(0.16354) \\
{[6.09163]}\end{array}$ & $\begin{array}{r}-0.409021 \\
(0.18757) \\
{[-2.18065]}\end{array}$ & $\begin{array}{r}-0.039025 \\
(0.82101) \\
{[-0.04753]}\end{array}$ & $\begin{array}{r}6.902032 \\
(2.67652) \\
{[2.57874]}\end{array}$ & $\begin{array}{r}-0.763853 \\
(0.56313) \\
{[-1.35644]}\end{array}$ & $\begin{array}{r}0.034328 \\
(0.03801) \\
{[0.90304]}\end{array}$ \\
\hline $\mathrm{F}$ & $\begin{array}{r}-3634.713 \\
(1157.64) \\
{[-3.13975]}\end{array}$ & $\begin{array}{c}2.135984 \\
(1.11520) \\
{[1.91534]}\end{array}$ & $\begin{array}{r}-1399.327 \\
(1103.09) \\
{[-1.26855]}\end{array}$ & $\begin{array}{r}-0.082385 \\
(0.10917) \\
{[-0.75462]}\end{array}$ & $\begin{array}{r}0.370206 \\
(0.12521) \\
{[2.95656]}\end{array}$ & $\begin{array}{r}-0.728451 \\
(0.54809) \\
{[-1.32908]}\end{array}$ & $\begin{array}{r}0.664981 \\
(1.78676) \\
{[0.37217]}\end{array}$ & $\begin{array}{r}0.664384 \\
(0.37593) \\
{[1.76732]}\end{array}$ & $\begin{array}{r}0.022846 \\
(0.02538) \\
{[0.90026]}\end{array}$ \\
\hline FA & $\begin{array}{r}122.3555 \\
(253.713) \\
{[0.48226]}\end{array}$ & $\begin{array}{c}0.043974 \\
(0.24441) \\
{[0.17992]}\end{array}$ & $\begin{array}{r}-453.6929 \\
(241.758) \\
{[-1.87664]}\end{array}$ & $\begin{array}{r}-0.015982 \\
(0.02393) \\
{[-0.66793]}\end{array}$ & $\begin{array}{r}0.036174 \\
(0.02744) \\
{[1.31817]}\end{array}$ & $\begin{array}{r}-0.097652 \\
(0.12012) \\
{[-0.81295]}\end{array}$ & & $\begin{array}{r}0.053544 \\
(0.08239) \\
{[0.64989]}\end{array}$ & $\begin{array}{r}0.007062 \\
(0.00556) \\
{[1.26984]}\end{array}$ \\
\hline & $\begin{array}{r}211.3397 \\
(116.385) \\
{[1.81587]}\end{array}$ & $\begin{array}{r}-0.214347 \\
(0.11212) \\
{[-1.91181]}\end{array}$ & $\begin{array}{l}65 . \\
(11 \\
{[0.5}\end{array}$ & $\begin{array}{r}-0.022709 \\
(0.01098) \\
{[-2.06899]}\end{array}$ & $\begin{array}{r}0.014913 \\
(0.01259) \\
{[1.18465]}\end{array}$ & & & $\begin{array}{r}0.031934 \\
(0.03779) \\
{[0.84493]}\end{array}$ & $\begin{array}{r}4.13 E-05 \\
(0.00255) \\
{[0.01618]}\end{array}$ \\
\hline FA & $\begin{array}{r}574.4951 \\
(328.994) \\
{[1.74622]}\end{array}$ & $\begin{array}{r}-1.240126 \\
(0.31693) \\
{[-3.91292]}\end{array}$ & $\begin{array}{r}8.346746 \\
(313.491) \\
{[0.02663]}\end{array}$ & $\begin{array}{c}0.092535 \\
(0.03103) \\
{[2.98246]}\end{array}$ & $\begin{array}{r}-0.018391 \\
(0.03559) \\
{[-0.51682]}\end{array}$ & $\begin{array}{r}0.323411 \\
(0.15576) \\
{[2.07632]}\end{array}$ & $\begin{array}{r}0.827074 \\
(0.50778) \\
{[1.62879]}\end{array}$ & $\begin{array}{r}-0.209743 \\
(0.10684) \\
{[-1.96322]}\end{array}$ & $\begin{array}{r}-0.034659 \\
(0.00721) \\
{[-4.80572]}\end{array}$ \\
\hline USDTI & $\begin{array}{r}-14985.76 \\
(9069.43) \\
{[-1.65234]}\end{array}$ & $\begin{array}{r}32.36901 \\
(8.73690) \\
{[3.70486]}\end{array}$ & $\begin{array}{r}-24168.75 \\
(8642.05) \\
{[-2.79664]}\end{array}$ & $\begin{array}{r}-0.440670 \\
(0.85531) \\
{[-0.51522]}\end{array}$ & $\begin{array}{r}3.061198 \\
(0.98098) \\
{[3.12055]}\end{array}$ & $\begin{array}{r}-12.19967 \\
(4.29391) \\
{[-2.84116]}\end{array}$ & $\begin{array}{r}2.320136 \\
(13.9982) \\
{[0.16575]}\end{array}$ & $\begin{array}{r}12.66589 \\
(2.94517) \\
{[4.30057]}\end{array}$ & $\begin{array}{r}0.906740 \\
(0.19881) \\
{[4.56077]}\end{array}$ \\
\hline C & $\begin{array}{r}-2851.054 \\
(2032.86) \\
{[-1.40248]}\end{array}$ & $\begin{array}{r}2.675167 \\
(1.95833) \\
{[1.36605]}\end{array}$ & $\begin{array}{r}4055.931 \\
(1937.07) \\
{[2.09385]}\end{array}$ & $\begin{array}{c}0.106304 \\
(0.19171) \\
{[0.55450]}\end{array}$ & $\begin{array}{r}0.382999 \\
(0.21988) \\
{[1.74185]}\end{array}$ & $\begin{array}{r}-2.057261 \\
(0.96245) \\
{[-2.13751]}\end{array}$ & $\begin{array}{c}0.185799 \\
(3.13761) \\
{[0.05922]}\end{array}$ & $\begin{array}{r}2.697343 \\
(0.66014) \\
{[4.08601]}\end{array}$ & $\begin{array}{r}0.044028 \\
(0.04456) \\
{[0.98799]}\end{array}$ \\
\hline n-squareu & & $0.3<6 / 15$ & & & & & & & 4598 \\
\hline Adj. R-squared & 0.159297 & 0.227447 & 0.132640 & 0.500194 & 0.607524 & 0.205777 & 0.277762 & 0.661940 & 0.420031 \\
\hline Sum sq. resids & $2.51 \mathrm{E}+09$ & 2333.900 & $2.28 \mathrm{E}+09$ & 22.36732 & 29.42315 & 563.7327 & 5991.166 & 265.2084 & 1.208529 \\
\hline E. equation & 6420.942 & 6.185519 & 6118.372 & 0.605539 & 0.694512 & 3.039987 & 9.910391 & 2.085109 & 0.140755 \\
\hline F-statistic & 2.473740 & 3.289851 & 2.189411 & 8.783808 & 13.03945 & 3.015160 & 3.991215 & 16.22930 & 6.632890 \\
\hline Log likelihood & -717.8353 & -224.7325 & -714.4082 & -59.73933 & -69.47275 & -174.2971 & -258.2000 & -147.5278 & 43.85666 \\
\hline Akaike AIC & 20.50240 & 6.612183 & 20.40586 & 1.964488 & 2.238669 & 5.191468 & 7.554929 & 4.437403 & -0.953709 \\
\hline & 20.82109 & 6.930870 & 20.72455 & 2.283176 & 2.557356 & 5.510155 & 7.873616 & 4.756091 & -0.635021 \\
\hline Mean dependent & -431.1690 & 1.859437 & 466.1911 & 1.424225 & 0.234401 & -0.256338 & 15.43592 & 2.544789 & 0.050747 \\
\hline S.D. dependent & 7002.893 & 7.037396 & 6569.560 & 0.856527 & 1.108596 & 3.411147 & 11.66140 & 3.586177 & 0.184825 \\
\hline
\end{tabular}

Determinant resid covariance (dof adj.)

$3.92 \mathrm{E}+16$

Determinant resid covariance

$1.00 \mathrm{E}+16$

Log likelihood

$-2214.584$

Akaike information criterion

64.91787 
Tablo 11. VAR Analizi Sonuçları

Var analizi sonrasında bağımlı değişken olarak kabul edilen FARKKSATIS verisinin diğer bağımsız değişkenlerle arasındaki nedensellik ilşkisinin bulunabilmesi için VAR Granger Nedensellik Analizi yapılmıştır. Test sonuçları aşağıdaki tabloda çıkarılmıştır.

Dependent variable: FARKKSATIS

\begin{tabular}{cccc}
\hline \hline Excluded & Chi-sq & df & Prob. \\
\hline \hline FARKALTIN & 1.507035 & 1 & 0.2196 \\
FARKBIST30 & 0.136172 & 1 & 0.7121 \\
FARKHKFE & 0.280299 & 1 & 0.5965 \\
FARKKKREDI & 9.858029 & 1 & 0.0017 \\
FARKTGE & 0.232574 & 1 & 0.6296 \\
FARKTLM2 & 3.297399 & 1 & 0.0694 \\
FARKTUFE & 3.049284 & 1 & 0.0808 \\
FARKUSDTRY & 2.730220 & 1 & 0.0985 \\
\hline \hline All & 18.91667 & 0.0153 \\
\hline \hline
\end{tabular}

Tablo 12. Granger Nedensellik Analizi Sonuçları

\section{Sonuç ve Öneriler}

Test Sonuçlarına göre Konut Kredi Oranlarının (FARKKKREDİ) tekbaşına değerlendirildiğinde Konut Satış Miktarına (FARKKSATIS) doğrudan etki ettiği, diğer verilerin tek başına Konut Satış Miktarına doğrudan etki etmediği fakat bütün bağımsız değişkenler birlikte değerlendirildiğinde bağımsız değişkenlerin toplam olasılık değerinin Konut Satış Miktarını etkilediği tespit edilmiştir.

Var analizinin yorumlanmasının devamında Etki-Tepki Fonksiyonları kullanılmıştır. Etki-Tepki Fonksiyonları VAR analizi ile bulunan ve rassal hata terimlerinden birindeki bir standart sapmalık şokun, içsel değişkenlerin şimdiki ve gelecekteki değerlerine olan etkisini gösteren fonksiyonlardır. Değişkenlere ait EtkiTepki değerleri aşağıdaki grafikte gösterilmiştir. Bu analiz gerçekleştirilirken sadece Konut Kredi Oranları ve Konut Satış Miktarları kullanılmış, diğer değişkenler inceleme dışı bırakılmıştır. Granger nedensellik analizinde Konut Kredi Oranları haricinde hiçbir seri ile Konut Satış Miktarları arasında doğrudan bir nedensellik ilişkisi bulunamamıştır.

Response to Cholesky One S.D. (d.f. adjusted) Innovations \pm 2 S.E.

Response of FARKKKREDI to FARKKSATIS

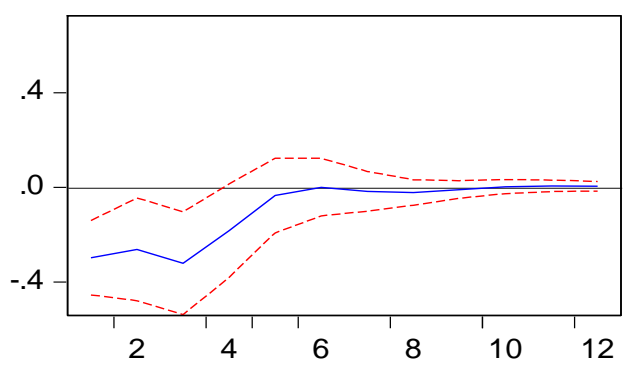

Garfik 11. Konut Kredi Oranlarının ve Konut Satış Rakmalarının Etki-Tepki Grafiği 
Yukarıda verilen Konut Kredi Oranları ile Konut Satış Miktarları arasındaki etki tepki grafiğinde Konut Kredi Oranlarında meydana gelen şoklara karşı 12 dönemlik zaman içinde Konut Satış Miktarlarının yaklaşık 6 ayda dengeye geldiği gözlenmektedir.

\begin{tabular}{|c|c|c|c|c|c|c|c|c|c|}
\hline \multicolumn{10}{|c|}{ Response of FARKKSATIS: } \\
\hline Period & FARKKS... & FARKALTIN & FARKBIST30 & FARKHKFE & FARKKK... & FARKTGE & FARKTLM2 & FARKTUFE & FARKUS... \\
\hline 1 & $\begin{array}{l}6420.942 \\
(538.833)\end{array}$ & $\begin{array}{l}0.000000 \\
(0.00000)\end{array}$ & $\begin{array}{l}0.000000 \\
(0.00000)\end{array}$ & $\begin{array}{l}0.000000 \\
(0.00000)\end{array}$ & $\begin{array}{l}0.000000 \\
(0.00000)\end{array}$ & $\begin{array}{l}0.000000 \\
(0.00000)\end{array}$ & $\begin{array}{l}0.000000 \\
(0.00000)\end{array}$ & $\begin{array}{l}0.000000 \\
(0.00000)\end{array}$ & $\begin{array}{l}0.000000 \\
(0.00000)\end{array}$ \\
\hline 2 & -1395.208 & 284.1958 & 212.6272 & 1183.073 & $\begin{array}{r}-2201.774 \\
\end{array}$ & 317.2060 & 1081.286 & 604.8077 & -1058.110 \\
\hline 3 & $\begin{array}{l}(836 . \\
1183\end{array}$ & $\begin{array}{l}(81 \\
-56\end{array}$ & $\begin{array}{l}\text { 70) } \\
87\end{array}$ & 6) & $\begin{array}{l}\text { 29) } \\
11\end{array}$ & $\begin{array}{r}(7 \\
-27\end{array}$ & $326)$ & $\begin{array}{l}65.298) \\
6.36812\end{array}$ & $\begin{array}{l}6.498) \\
6408\end{array}$ \\
\hline & (663.164) & (653.429) & (497.521) & (527.336) & (481.789) & (471.834) & $(518.865)$ & $.675)$ & (479.290) \\
\hline 4 & $\begin{array}{r}-66.74138 \\
(501.268)\end{array}$ & $\begin{array}{l}269.6694 \\
(445.405)\end{array}$ & $\begin{array}{l}277.7585 \\
(307.230)\end{array}$ & $\begin{array}{l}214.0492 \\
(472.167)\end{array}$ & $\begin{array}{r}-491.3768 \\
(366.233)\end{array}$ & $\begin{array}{r}-155.8473 \\
(253.061)\end{array}$ & $\begin{array}{r}-238.9960 \\
(366.610)\end{array}$ & $\begin{array}{l}379.5020 \\
(227.728)\end{array}$ & $\begin{array}{r}-357.1274 \\
(345.298)\end{array}$ \\
\hline 5 & $\begin{array}{l}231.3040 \\
(322.821)\end{array}$ & $\begin{array}{l}147.3814 \\
(236.836)\end{array}$ & $\begin{array}{l}112.2400 \\
(187.586)\end{array}$ & $\begin{array}{r}-90.40971 \\
(399.290)\end{array}$ & $\begin{array}{l}57.19433 \\
(243.544)\end{array}$ & $\begin{array}{r}-147.2049 \\
(136.255)\end{array}$ & $\begin{array}{r}-298.4928 \\
(262.996)\end{array}$ & $\begin{array}{r}-1.911918 \\
(146.661)\end{array}$ & $\begin{array}{l}33.10359 \\
(262.980)\end{array}$ \\
\hline 6 & $\begin{array}{r}-73.51947 \\
(183.682)\end{array}$ & $\begin{array}{l}31.02363 \\
(136.961)\end{array}$ & $\begin{array}{r}-53.96184 \\
(116.474)\end{array}$ & $\begin{array}{r}-73.95218 \\
(336.651)\end{array}$ & $\begin{array}{r}-90.61282 \\
(149.913)\end{array}$ & $\begin{array}{r}-36.50649 \\
(85.5907)\end{array}$ & $\begin{array}{r}-48.00351 \\
(210.642)\end{array}$ & $\begin{array}{r}-21.08194 \\
(108.319)\end{array}$ & $\begin{array}{l}32.67708 \\
(177.558)\end{array}$ \\
\hline 7 & 79.80501 & -106.4835 & -22.77630 & -33.86115 & $\begin{array}{l}2.373324 \\
(853065)\end{array}$ & $\begin{array}{r}-5.906363 \\
\end{array}$ & $\begin{array}{r}-37.80260 \\
(170862)\end{array}$ & $\begin{array}{r}-36.80871 \\
(73.9974)\end{array}$ & $\begin{array}{l}7.851817 \\
(106706)\end{array}$ \\
\hline & $(108$. & $(84$. & $(75$. & $(263$ & & & & 974) & 706) \\
\hline 8 & $\begin{array}{l}46.47091 \\
(72.2513)\end{array}$ & $\begin{array}{r}-46.57618 \\
(57.5511)\end{array}$ & $\begin{array}{l}18.03537 \\
(54.1880)\end{array}$ & $\begin{array}{l}1.602111 \\
(203.570)\end{array}$ & $\begin{array}{r}-50.52165 \\
(60.0468)\end{array}$ & $\begin{array}{l}2.232436 \\
(45.0233)\end{array}$ & $\begin{array}{l}9.631425 \\
(143.131)\end{array}$ & $\begin{array}{l}22.38318 \\
(54.7976)\end{array}$ & $\begin{array}{r}-55.28033 \\
(69.2300)\end{array}$ \\
\hline 9 & $\begin{array}{l}42.55880 \\
(46.2445)\end{array}$ & $\begin{array}{l}3.800383 \\
(37.6961)\end{array}$ & $\begin{array}{l}30.24848 \\
(38.1111)\end{array}$ & $\begin{array}{r}-12.22778 \\
(156.220)\end{array}$ & $\begin{array}{r}-16.96134 \\
(44.8255)\end{array}$ & $\begin{array}{r}-7.887471 \\
(35.7155)\end{array}$ & $\begin{array}{r}-1.391899 \\
(117.316)\end{array}$ & $\begin{array}{l}16.23496 \\
(42.9905)\end{array}$ & $\begin{array}{r}-41.68544 \\
(47.5858)\end{array}$ \\
\hline 10 & $\begin{array}{l}2.620598 \\
(33.6394)\end{array}$ & $\begin{array}{l}20.14170 \\
(25.7396)\end{array}$ & $\begin{array}{l}9.850555 \\
(28.6054)\end{array}$ & $\begin{array}{r}-25.53782 \\
(118.344)\end{array}$ & $\begin{array}{r}-7.682777 \\
(34.9751)\end{array}$ & $\begin{array}{r}-6.665726 \\
(27.3683)\end{array}$ & $\begin{array}{l}3.594264 \\
(93.0474)\end{array}$ & $\begin{array}{l}3.382400 \\
(33.3556)\end{array}$ & $\begin{array}{r}-16.55011 \\
(32.1930)\end{array}$ \\
\hline 11 & $\begin{array}{r}-2.274387 \\
(26.3791)\end{array}$ & $\begin{array}{l}4.325365 \\
(18.0907)\end{array}$ & $\begin{array}{r}-4.573480 \\
(23.0871)\end{array}$ & $\begin{array}{r}-27.10059 \\
(86.6506)\end{array}$ & $\begin{array}{l}4.996908 \\
(28.6428)\end{array}$ & $\begin{array}{r}-1.698220 \\
(20.8468)\end{array}$ & $\begin{array}{l}5.005291 \\
(72.2892)\end{array}$ & $\begin{array}{r}-8.216397 \\
(25.1383)\end{array}$ & $\begin{array}{l}0.304594 \\
(21.8736)\end{array}$ \\
\hline 12 & $\begin{array}{r}-2.204187 \\
(21.4855)\end{array}$ & $\begin{array}{r}-5.270929 \\
(12.4715)\end{array}$ & $\begin{array}{r}-6.699705 \\
(18.8780)\end{array}$ & $\begin{array}{r}-18.46377 \\
(61.6807)\end{array}$ & $\begin{array}{l}2.692963 \\
(23.4631)\end{array}$ & $\begin{array}{l}2.595784 \\
(16.8774)\end{array}$ & $\begin{array}{l}9.754127 \\
(55.8707)\end{array}$ & $\begin{array}{r}-6.412706 \\
(18.3010)\end{array}$ & $\begin{array}{r}-0.184079 \\
(14.8014)\end{array}$ \\
\hline
\end{tabular}

Tablo 13. Meydana gelen şoklarda İpotekli Konut Satış Rakamlarının tepkisi.

Analiz sonuçlarına göre Konut Kredi Oranlarında meydana gelen 1 birim şoka 12 periyotluk dönemde İpotekli Konut Satış rakamları pozitif yönde 2,692963 birimlik tepki vermektedir.

\begin{tabular}{|c|c|c|c|c|c|c|c|c|c|c|}
\hline \multicolumn{11}{|c|}{ Variance Decomposition of FARKKSATIS: } \\
\hline Period & S.E. & FARKKS... & FARKALTIN & FARKBIST30 & FARKHKFE & FARKKK... & FARKTGE & FARKTLM2 & FARKTUFE & FARKUS... \\
\hline 1 & 6420.942 & 100.0000 & 0.000000 & 0.000000 & 0.000000 & 0.000000 & 0.000000 & 0.000000 & 0.000000 & 0.000000 \\
\hline 2 & 7232.132 & 82.54688 & 0.154420 & 0.086438 & 2.676026 & 9.268569 & 0.192376 & 2.235366 & 0.699362 & 2.140567 \\
\hline 3 & 7459.184 & 80.11442 & 0.713949 & 0.675378 & 2.937717 & 9.024023 & 0.318826 & 3.374459 & 0.670840 & 2.170390 \\
\hline 4 & 7512.256 & 78.99434 & 0.832758 & 0.802577 & 2.977543 & 9.324816 & 0.357376 & 3.428162 & 0.916599 & 2.365830 \\
\hline 5 & 7526.296 & 78.79436 & 0.868001 & 0.821825 & 2.980874 & 9.295835 & 0.394298 & 3.572676 & 0.913189 & 2.358947 \\
\hline 6 & 7528.163 & 78.76481 & 0.869268 & 0.826556 & 2.989046 & 9.305712 & 0.396454 & 3.574970 & 0.913521 & 2.359661 \\
\hline 7 & 7529.641 & 78.74512 & 0.888926 & 0.827146 & 2.989895 & 9.302068 & 0.396360 & 3.576087 & 0.915552 & 2.358843 \\
\hline 8 & 7530.362 & 78.73385 & 0.892582 & 0.827561 & 2.989326 & 9.304788 & 0.396293 & 3.575565 & 0.916260 & 2.363780 \\
\hline 9 & 7530.710 & 78.72976 & 0.892525 & 0.829098 & 2.989314 & 9.304435 & 0.396366 & 3.575238 & 0.916640 & 2.366626 \\
\hline 10 & 7530.814 & 78.72760 & 0.893215 & 0.829246 & 2.990381 & 9.304282 & 0.396433 & 3.575162 & 0.916635 & 2.367043 \\
\hline 11 & 7530.874 & 78.72636 & 0.893234 & 0.829270 & 2.991629 & 9.304179 & 0.396432 & 3.575150 & 0.916739 & 2.367006 \\
\hline 12 & 7530.912 & 78.72558 & 0.893274 & 0.829341 & 2.992200 & 9.304098 & 0.396440 & 3.575282 & 0.916803 & 2.366982 \\
\hline
\end{tabular}

Tablo 14. Varyans Ayrıştırması Sonuçları.

Varyans Ayrıştırması sonuçlarına göre 12 periyotluk dönemde İpotekli Konut Satış Oranlarındaki değişimin \% 78,72’si kendisinden kaynaklanırken, \% 9,30’u İpotekli Konut Kredi Oranlarından kaynaklanmıştır.

Sonuç olarak; diğer faktör birleşimlerinin konut satış miktarlarını etkilediği anlaşılmakla birlikte özellikle konut faiz oranlarında meydana gelecek faiz indiriminin konut sektöründe talep yönlü artış meydana getireceği, bu talebin konut stoğunu eriterek, yeni yapılacak konutlarda satış miktarlarını arttıracağı, konut harcamalarının çarpan etkisinin yüksek olması sebebiyle konut harcamalarında meydana gelen artışın beyaz eşya, ev tekstili, mobilya gibi konutla ilgili diğer mallara olan talebi de etkileyeceği değerlendirilmektedir. 


\section{Kaynakça}

- Aydoğdu M., 2007. "Konut Finansman Sistemi (Mortgage) ve Sözleşmeleri”. Dokuz Eylül Üniversitesi Hukuk Fakültesi Dergisi, 9, ss. 1-52.

- Balcı Y., 2011. "Türkiye'de Konut Sorunu”. İstanbul Üniversitesi İktisat Fakültesi Mecmuası 46(0)

- Bekmez S. \& Özpolat A., 2016. "Türkiye'de Konut Talebinin Belirleyenleri: Dinamik Bir Analiz”. TISK Akademi 8(16), ss. 170-187.

- Durkaya M. \& Yamak R., 2004. "Türkiye"de Konut Piyasasının Talep Yönlü Analizi”. Iktisat Isletme ve Finans 19(217), ss. 75-83.

- Güler Y. B., 2007. "İpoteğe Dayalı Konut Finansman Sisteminin (Mortgage) Tüketicilerin Konut Talebine Olası Etkileri”. Atılım Üniversitesi Sosyal Bilimler Enstitüsü Finans Anabilim Dalı Yüksek Lisans Tezi. Ankara.

- İslamoğlu B. \& Buluş A., 2018. "Mortgage Piyasası ve Para Politikasının Konut Fiyatlarına Etkisi: Türkiye Üzerine Bir Uygulama”. Süleyman Demirel Üniversitesi İktisadi ve İdari Bilimler Fakültesi Dergisi (23), ss. 455-466.

- Kıral G. \& Cahit Ç., 2018. "Panel Veri Analizi ve Kümeleme Yöntemi ile Türkiye'de Konut Talebinin İncelenmesi”. Atatürk Üniversitesi İktisadi ve İdari Bilimler Dergisi (32), ss. 1009-1026.

- Lebe F. \& Akbaş Y., 2014. “Türkiye’nin Konut Talebinin Analizi: 1970-2011”. Atatürk Üniversitesi İktisadi ve İdari Bilimler Dergisi 28(1), ss. 57-83.

- Özkurt H., 2007. “Türkiye Ekonomisinde Konut Sektörü: Gelişimi ve Alternatif Finansman”. Sosyal Bilimler Dergisi (1), ss. 159-173.

- Öztürk N. \& Fitöz E., 2009. "Türkiye'de Konut Piyasasinin Belirleyicileri: Ampirik Bir Uygulama”. ZKÜ Sosyal Bilimler Dergisi (5), ss. 21-46.

- Uysal D. \& Yiğit M., 2016. "Türkiye'de Konut Talebinin Belirleyicileri (1970-2015): Ampirik Bir Çalışma". Selçuk Üniversitesi Sosyal Bilimler Meslek Yüksekokulu Dergisi (19), ss. 185-209. 


\title{
Kredi Kartı Kullanımı: Üniversite Öğrencileri Üzerine Amprik Bir Araştırma
}

\section{The Usage of Credit Cards: An Empirical Analysis on Turkish College Students}

\author{
Asst. Prof. Dr. Aslı Okay Toprak (Kırklareli University, Turkey) \\ Asst. Prof. Dr. Canan Özge Eğri (Kırklareli University, Turkey) \\ Asst. Prof. Dr. Güldenur Çetin (İstanbul Ticaret University, Turkey
}

\begin{abstract}
In recent years, there has been a dramatic increase in the number of credit card usage among university students. Credit cards can be a convenient payment tool that gives university students a number of advantages and benefits to learn financial responsibility when it can be used in a controlled and responsible manner. On the other hand, using credit cards also have serious financial consequences when mismanagedly used. The excessive credit card debt and overdue payments give burden on university students' shoulders before starting their full-time jobs. Besides that, when the other debts such as education credits are added, inevitable stress and anxiety make negative impacts on their newly started adult life. Also, lack of experience on using credit cards and personal financial information, tend to put some students at a higher financial risk due to a large and perhaps unmanageable debt burden. Therefore, rising number of students who use credit cards increases the concern for these long-term negative results of the credit card. In this context, we aim to evaluate the basic demographic and socio-economic factors that affect the attitudes of Kurklareli University students towards credit card ownership, credit card usage, and to evaluate the students' ability to manage their financial situation.
\end{abstract}

\section{Giriş}

1950 yılında Amerika Birleşik Devletleri’nde misafirlerini şık bir restoranda ağırlayan bir işadamının, cüzdanını diğer takım elbisesinde unutmasıyla başlayan kredi kartı fikrinin ortaya çıkış serüveni, Türkiye'ye bu buluşun, ilk kez Koç Grubuna ait Servis Turistik AŞ tarafından 1968 yılında getirilmesiyle ülkemizde devam etmiştir. Bir başka kaynağa göre; 1887 yılında kredi kartı ile ilgili fikirler öne sürülmüştür. Ancak 1894 yılında Amerika Birleşik Devletleri'nde Hotel Credit Letter Company, dünyanın ilk ödeme kartını kullanıma sunmuştur. Yalnız bu kart sadece belirli otellerde geçerli olmuştur. 1914 yılında Western Union Bank, "şimdi al, sonra öde" sloganı ile dünyanın ilk "kredili ödeme kartını" tanıtmıştır (İstinlice, 2017). 1988 yılında kredili kartlarının piyasaya çıkışına kadar, bahsi geçen kartlar daha çok seçkin sınıfın kullandığı bir finansal araç olmuştur (Koç Holding AŞ, 2018). Günümüzde ise, kredi kartları nakit para yerine kullanılan yaygın bir işlem ve mübadele aracı haline gelmişlerdir. Bununla beraber kayıt dışı ekonominin önlenmesinde katkıda bulunmaktadır. Bankalararası Kart Merkezinin 2017 yılı Aralık ayı faaliyet raporuna göre Türkiye'de; 58,6 milyonunu bireysel, 3,8 milyonu ticari olmak üzere toplam 62,4 milyon adet kredi kartı vardır (Bankalararası Kart Merkezi, 2017). Aynı kurumun verilerine göre, toplam kredi kartlı ödemeler 2018 yılında bir önceki yıla kıyasla \% 18 artmış ve banka kartı ile yapılan her beş işlemden üçü alışveriş olarak gerçekleşmiştir (Bankalararası Kart Merkezi, 2019). Kredi kartları, tüketiciye alışverişlerinde kolaylık sağlayabileceği gibi, bilinçsiz ve yanlış kullanım sonucu, borçlanmalar ve alınan yüksek riskli finansal kararlar sebebiyle yük de olabilmektedir (Akbulut \& Özbolat, 2015).

\section{2 Çalışmanın Amacı}

Kredi kartı başvuruları artık banka şubelerine gitmeden mobil uygulamalar vasıtasıyla telefondan, bankaların web siteleri üzerinden internetten, kısa mesaj veya telefon bankacılığı yoluyla kolaylıkla yapılabilen işlemlere dönüşmüştür. Kredi geçmişi ve geliri olmayan bir bireyin düşük limitli de olsa kredi kartı edinmesi kolay olmamaktadır. Ancak, sorumluluk sahibi bir tüketici olarak piyasada kendine yer edinmeye çalışan kredi kartı sahibi üniversiteli bir gencin; tüketim harcamaları, borçları ve gelirleri arasında iyi bir denge kurması, uzun dönemde kredi kartının olumsuz etkilerini yetişkinlik döneminde yüklenmemesi hem mikro hem makro düzeyde önemlidir. Bu sebeple üniversite öğrencilerinin sosyo-ekonomik durumları ve kredi kartı sahipliğine ve harcama alışkanlıklarına dair tutumları hakkında bilgi sahibi olmak adına Kırklareli Üniversiteli öğrencilerine yapılacak analiz ehemmiyet teşkil etmektedir. Geniş bir literatüre sahip alandaki bilgilerin güncellenmesi için çalışmanın bir katkı sağlayacağına inanılmaktadır.

\section{Yöntem}

2018-2019 Eğitim-Öğretim yılında, birinci ve ikinci öğretim programlarında, son güncellenen verilere ve aktif olarak öğrencilik statüsünü koruyan 20.000 öğrenci üzerinde örneklem evreni oluşturulmuştur. \% 95 güven 
düzeyinin sağlanması için minimum 377 anket formunun cevaplanması gerektiği hesaplanmıştır. Aşağıdaki tabloda Kırklareli Üniversitesi öğrencilerinin dağılımı görülmektedir.

\subsection{Veri Toplama Aracı}

Tüm Kırklareli nüfusu ya da farklı seviyelerdeki öğrenciler yerine yine aynı ilde yaşayan fakat üniversiteye giden öğrencilerin seçilmiş olması nüfustan rastgele seçilen çeşitli kademelerdeki öğrencilere ya da mukimlere kıyasla davranış şekli açısından daha benzer bir davranış kalıbı sunması açısından önemlidir (Schnell \& Kreuter, 2005). Farklı gelir düzeyleri, yaş ve sınıflarda dahi olsalar öğrencilerin benzer davranış göstereceği beklenmiştir. Öğrencilere üç bölümden oluşan bir anket uygulanmıştır. Anketin ilk bölümü demografik sorulardan oluşmuş, ikinci bölümü ise tüketim alışkanlıklarını anlamaya yönelik soruları içermiştir. Üçüncü bölümde ise, Yılmaz, Çatalbaş ve Çelik'in (2008) ile Akbulut ve Özbolat'ın (2015) çalışmalarından yararlanılarak hazırlanan kredi kartı tutum ölçeği (KTÖ) dikkate alınmıştır (Akbulut \& Özbolat, 2015). Ancak, oniki önerme yerine ondört önermeden oluşan ölçeğe, öğrencilerin kredi kartı kullanımına karşı tutumlarını, davranışlarını ve alışkanlıklarını tespit etmek için yer verilmiştir. Tamamen Katılıyorum (1), Katılıyorum (2), ne Katılıyorum ne Katılmıyorum (3), katılmıyorum (4) ve hiç katılmıyorum (5) seçeneklerinden oluşan likert tipi ölçek soruları öğrencilere, gönüllülük esası üzerine yöneltilmiştir.

\subsection{Araștırmanın Kriter Değișkenleri ve Araștırma Soruları}

Araştırmanın amaçları doğrultusunda öğrencilerin kredi kartı sahipliğine ve kullanımına etki eden değişkenler bağımlı (yaş, cinsiyet, gelir durumu, ikamet durumu, öğrenim gördüğü program, bursluluk) ve bağımsız değişken olarak (kredi kartı sahipliği, kredi kartı kullanımı) iki grupta incelenmiştir. “Öğrencilerin kredi kartı sahipliği, kullanımı ve tutumları ile demografik ve sosyo-ekonomik özellikleri arasında bir ilişki var mıdır veya farklılık göstermekte midir?” sorusuna çalışmada cevap aranmıştır (Akbulut \& Özbolat, 2015).

\subsection{Araştırmada Kullanılan İstatistiki Yöntemler}

Anketten elde edilen verilerle ilgili tüm analizler, SPSS 21.0 (Statistical Programming for Social Sciences 21.0) paket programıyla yapılmıştır. Çalışmaya katılan öğrencilerin demografik ve sosyo ekonomik durumlarına ilişkin frekans ve \% dağılımları tablolar şeklinde sunulmuştur. Araştırmanın amaçlarından biri olan öğrencilerin kredi kartı sahipliği ile kredi kartı kullanım durumlarının, cinsiyet, burs alma durumu ve gelir düzeyi gibi demografik ve sosyo-ekonomik özellikler ile ilişkisinin belirlenebilmesi amacıyla, değişkenler arasındaki ilişkiler Chi-kare testiyle analiz edilmiştir (Akbulut \& Özbolat, 2015).

\section{Bulgular}

Analizde kullanılan anketler, çevrimiçi olarak ve sınıf ortamında paylaşılmış, gönüllülük esası ile sorular cevaplanmıştır. Soruyu idrak etme, zihindeki gerekli bilgilere erişme, muhakeme etme ve cevap verme sürecini takip edebilmek ve soruların doğru silsile ile anlaşıldığına kanaat getirebilmek için pilot uygulama yapılmıştır (Jabine vd., 1984, p. 73). Pilot uygulama fiziki ortamda gerçekleştirilmiş, sonuçta bazı ifadeler daha anlaşılır hale getirilmiş, bazı sorular ve şıklar bu bilgiler 1şı̆̆ında tekrar düzenlenmiştir. Demografik soruları yanıtlayıp likert ölçekli soruları yanıtlamayan iki adet anket analizin dışında bırakılmıştır. Likert sorulara Cronbach'ın güvenilirlik testi sonucunda katsayı 0,735 bulunmuş ve değer 0,6 ile 0,8 arasında olduğu için sonuç güvenilir çıkmıştır.

\subsection{Katılımcıların Demografik Özelliklerine Ait Bulgular}

Soruları yanıtlamayı seçen öğrencilerin önemli görülen, seçili demografik ve sosyo-ekonomik özellikleri frekans ve yüzde tabloları aşağıda yer almaktadır. Tablo 1'de katılımcıların cinsiyet, Kredi Yurtlar Kurumu'ndan öğrenim kredisi ve diğer kurum, kuruluş ya da sivil toplum örgütlerinden burs alma durumları yer almaktadır.

\begin{tabular}{|l|l|l|l|c|c|c|c|c|}
\hline \multicolumn{3}{|c|}{ Cinsiyet } & \multicolumn{3}{c|}{$\begin{array}{c}\text { Kredi Yurtlar Kurumundan Öğrenim } \\
\text { Kredisi Alma Durumu }\end{array}$} & \multicolumn{3}{c|}{ Burs Alma Durumu } \\
\hline & Frekans & Yüzde & & Frekans & Yüzde & & Frekans & Yüzde \\
\hline Kadın & 187 & 49 & Evet & 227 & 59,4 & Evet & 78 & 20,4 \\
\hline Erkek & 195 & 51 & Hayır & 155 & 40,6 & Hayır & 304 & 79,6 \\
\hline Toplam & 382 & 100.0 & Toplam & 382 & 100.0 & Toplam & 382 & 100.0 \\
\hline
\end{tabular}

Tablo 1. Katılımclların Cinsiyet, KYK Kredisi ve Burs Alma Bilgileri

Yukarıda yer alan Tablo 1'de soruları cevaplayan öğrencilerin \% 49'unun kadın, \% 51'inin erkek olduğu görülmektedir. Bu öğrencilerin \% 59,4'ü geri ödemeli KYK öğrenim kredisi alıyorken, sadece \% 20,4'ü karşıllısız burs almaktadır. Aşağıda yer alan Tablo 3 'te tekrar görüleceği üzere Kırklareli Üniversitesi'nde öğrenim gören öğrencilerin çoğunun aylık gelirleri 1.000 TL'yı geçmemektedir. Söz konusu dilimde yer alan öğrencilerin kümülatif yüzdesi de 72,3 oranıyla bu durumu desteklemektedir. Katılımcıların en çok yer aldıkları gelir dilimi birinci kategori olan 1-500 TL arası miktarı temsil eden kısımdır. Bu durum kredi kartı sahipliğinin neden düşük olduğunu da açıklamaktadır. 


\begin{tabular}{|l|c|c|c|c|c|c|c|}
\hline \multicolumn{4}{|c|}{ Yarı-Zamanlı ya da Tam-Zamanlı Çalışma Durumu } & \multicolumn{4}{c|}{ Aile Yanında İkamet } \\
\hline & Frekans & Yüzde & Kümülatif Yüzde & & Frekans & Yüzde & Kümülatif Yüzde \\
\hline Evet & 51 & 13,4 & 13,4 & Evet & 79 & 20,7 & 20,7 \\
\hline Hayır & 331 & 86,6 & 100,0 & Hayır & 303 & 78,7 & 100 \\
\hline Toplam & 382 & 100,0 & & Toplam & 382 & 100 & \\
\hline
\end{tabular}

Tablo 2. Katılımcıların Çalışma ve İkamet Bilgisi

Yukarıda yer alan Tablo 2'de katılımcıların çalışma durumları ve aile yanında ikamet edip etmedikleri bilgileri vardır. Bu tabloya göre öğrencilerin \% 13,4'ü yarı-zamanlı ya da tam zamanlı çalışarak ek gelir elde etmektedir. Çalışan sayısının az olması kredi kartı sahipliğini de olumsuz yönde etkilemektedir. Gelir düzeyi düşük öğrencilerin kendi adlarına kredi kartına sahip olmaları zorlaşmaktadır. Zaten öğrenciler gelirlerini en çok, temel ihtiyaçları olan gıda ve barınma harcamalarına ayırmaktadırlar. Uygulama sırasında bu durum ayrıca öğrenciler tarafından dile getirilmiştir. Daha önce bahsedildiği gibi çalışan sayısının az olması, bursluluk oranının düşük olması ve öğrencilerin genellikle KYK kredisi ile desteklenmeleri aylık gelir miktarını düşük tutmaktadır.

\begin{tabular}{|c|c|c|c|c|c|c|c|c|c|}
\hline \multicolumn{5}{|c|}{ Aylık En Çok Harcama Yapılan Alan } & \multicolumn{5}{|c|}{ Aylık Gelir Miktarı } \\
\hline & & Frekans & Yüzde & $\begin{array}{l}\text { Kümülatif } \\
\text { Yüzde }\end{array}$ & & & Frekans & Yüzde & $\begin{array}{l}\text { Kümülatif } \\
\text { Yüzde }\end{array}$ \\
\hline \multirow{5}{*}{$\begin{array}{l}\text { Harcama } \\
\text { Çeşitleri }\end{array}$} & Gida & 233 & 61,0 & 61,0 & \multirow{5}{*}{ Miktar } & $1-500 \mathrm{TL}$ & 121 & 31,7 & 31,7 \\
\hline & Giyim & 18 & 4,7 & 65,7 & & 501-1000 TL & 155 & 40,6 & 72,3 \\
\hline & Barınma & 105 & 27,5 & 93,2 & & $1001-1500$ & 69 & 18,1 & 90,3 \\
\hline & Eğlence & 26 & 6,8 & 100,0 & & 1501 ve üzeri & 37 & 9,7 & 100,0 \\
\hline & Toplam & 382 & 100,0 & & & Toplam & 382 & 100,0 & \\
\hline
\end{tabular}

Tablo 3. Katılımclların Harcama Alanlart ve Gelir Aralıkları

\subsection{Katılımcıların Kredi Kartı Sahiplikleri ile İlgili Bulgular}

Çalışmada yer alan öğrencilerin sadece \% 57,1'inde kredi kartı bulunmaktadır. Kredi kartına sahiplik oranı cinsiyetler arasında neredeyse eşit olarak paylaşılmışken, erkek öğrencilerin yaklaşık \% 45'i kadın öğrencilerin ise yaklaşık \% 56'sı kredi kartına sahip değildir.

\begin{tabular}{|l|l|c|c|c|}
\hline \multicolumn{5}{|c|}{ Kredi Kart1 Sahiplï̆i } \\
\hline \multirow{3}{*}{ Durum } & Frekans & Yüzde & Kümülatif Yüzde \\
\hline & Evet & 218 & 57.1 & 57.1 \\
\cline { 2 - 5 } & Hayır & 164 & 42.9 & 100.0 \\
\cline { 2 - 5 } & Toplam & 382 & 100.0 & \\
\hline
\end{tabular}

Tablo 4. Katılımcıların Kredi Kartı Sahipliği

Çalışmanın başlangıcında, elektronik işlemlerin yaygınlaştığı günümüz dünyasında, öğrencilerin düşük limitli ya da kendisi dışında birinin adına olan kredi kartlarına, daha yüksek oranlarda sahip olacağı öngörülmüş, bunun dışında bir sonuçla karşılaşılmıştır. Yukarıda bahsedilen durum, Tablo 4'te ve 5'te görülmektedir.

\begin{tabular}{|l|c|c|c|c|}
\hline \multicolumn{5}{|c|}{ Cinsiyet ve Kredi Kartı Sahipliği } \\
\cline { 3 - 4 } \multicolumn{2}{|c|}{} & \multicolumn{2}{c|}{ Kredi Kartı Sahipliği } & \multirow{2}{*}{ Toplam } \\
\hline \multirow{2}{*}{ Cinsiyet } & Kadın & Evet & Hayır & 218 \\
\cline { 2 - 5 } & Erkek & 96 & 73 & 164 \\
\hline \multicolumn{2}{|c|}{ Toplam } & 91 & 195 & 382 \\
\hline
\end{tabular}

Tablo 5. Katılımcıların Cinsiyetleri ve Kredi Kartı Sahiplik Durumları

Kredi kartına sahip olan öğrencilerin tamamına yakını (yaklaşık \% 92'si) kendi adına olan kredi kartını kullanmaktadır. Ek kart ya da başkasına ait olan kartı kullananların oranı \% 8 ile oldukça düşüktür. Aşağıda yer alan Tablo 6'da da bu bilgiler görülmektedir.

\begin{tabular}{|l|c|c|c|}
\hline \multicolumn{4}{|c|}{ Sahip Olunan Kredi Kartı Üzerindeki İsim } \\
\hline Durum & Frekans & Yüzde & Kümülatif Yüzde \\
\hline Kendi adına & 202 & 52,9 & 52,9 \\
\hline Anne ya da babanın ek kartı & 12 & 3,1 & 56 \\
\hline Anne ya da babanın kendi kartı & 2 & 0,5 & 56,5 \\
\hline Diğer akrabalarının /arkadaşlarının kartı & 2 & 0,5 & 57,1 \\
\hline Kredi kartı yok & 164 & 42,9 & 100.0 \\
\hline Toplam & 382 & 100.0 & \\
\hline
\end{tabular}

Tablo 6. Katılımcıların Sahip Oldukları Kredi Kartının Üzerindeki İsim 


\subsection{Kredi Kartı Kullanım Davranış ve Alışkanlıklarına Dair Bulgular}

Tablo 3'te de bahsedildiği gibi öğrenciler aylık harcamalarını en çok gıda kalemine yapmaktadırlar. Aynı şekilde, kredi kartı ile öncelikli olarak yapılan harcama türü de gıdadır, ardından ikinci sırada giyim ve üçüncü sırada ise barınma harcamaları yer almaktadır. Buradan da anlaşılacağı üzere katılımcılar, temel ihtiyaçlarını kredi kartı vasıtasıyla yapmaktadırlar. Bu davranış şekli iki biçimde açıklanabilir: Bunlardan ilki, kredi kartının kullanımının her alana yayılarak para benzeri gibi kullanabildiği; ikincisi ise, gelirlerini sadece temel ihtiyaçlara ayıran öğrencilerin para benzeri olan kredi kartını da yine bu ihtiyaçlara yönelik kullanabildikleridir.

\begin{tabular}{|l|c|c|c|}
\hline \multicolumn{1}{|c|}{ Kredi Kartı ile Yapılan Öncelikli Harcama Türü } \\
\hline Garcama Türü & Frekans & Yüzde & Kümülatif Yüzde \\
\hline Giyim & 108 & 28,3 & 28,3 \\
\hline Barınma & 53 & 13,9 & 42,1 \\
\hline Eğlence & 13 & 3,4 & 45,5 \\
\hline Diğer & 15 & 3,9 & 49,5 \\
\hline Kredi kartım yok & 29 & 7,6 & 57,1 \\
\hline Toplam & 164 & 42,9 & 100,0 \\
\hline
\end{tabular}

Tablo 7. Kredi Kartı ile Yapılan Öncelikli Harcama Türü

Katılımcılara yöneltilen ne miktarda kredi kartı ile harcama yaptıkları ve yaptıkları bu harcamalarının ne kadarını geri ödedikleri hem alım güçlerini hem de bu işlem ve mübadele aracını ne kadar bilinçli kullandıklarını göstermektedir. Aşağıda yer alan Tablo 8'de söz konusu miktar ve durum yer almaktadır. Çalışmaya göre, katılımcılardan "kredi kartı sahibi olanların" \% 68'i kredi kartı ile aylık en fazla 500 TL harcamaktadırlar. Kredi kartı ile harcama yapan katılımcıların yaklaşık \% 38'i kredi kartı harcamalarının hepsini öderken, \% 43'ü ise harcadıkları miktarın banka tarafından belirtilen asgari ve zorunlu miktarını ödeyerek harcama yapmaya devam ettiklerini belirtmişlerdir. Geri kalan çok az orandaki katılımcı ise, ödemeleri gereken miktarın ya büyük bir kısmını ödediklerini ya da harcamalarını karşılayamadıklarını belirtmişlerdir.

\begin{tabular}{|l|c|c|c|l|c|c|c|}
\hline \multicolumn{4}{|c|}{ Kredi Kartı ile Yapılan Aylı Harcama Miktar1 } & \multicolumn{3}{c|}{ Kredi Kartı ile Yapılan Harcamanın Geri Ödeme Durumu } \\
\hline \multicolumn{1}{|c|}{ Miktar } & Frekans & Yüzde & Kümülatif Yüzde & \multicolumn{1}{|c|}{ Miktar } & Frekans & Yüzde & Kümülatif Yüzde \\
\hline $1-500$ TL & 149 & 39,0 & 39,0 & Hepsini & 84 & 22,0 & 22,0 \\
\hline $501-1.000$ TL & 49 & 12,8 & 51,8 & Asgari Miktarın1 & 94 & 24,6 & 46,6 \\
\hline $1.001-1500$ TL & 14 & 3,7 & 55,5 & Büyük Bir Kısmın1 & 27 & 7,1 & 53,7 \\
\hline $1501-2000$ TL & 5 & 1,3 & 56,8 & Öde(ye)miyorum & 13 & 3,4 & 57,1 \\
\hline 2001 TL ve üstü & 1 & 0,3 & 57,1 & Kredi kart1 yok & 164 & 42,9 & 100,0 \\
\hline Kredi kart1 yok & 164 & 42,9 & 100.0 & & & & \\
\hline Toplam & 382 & 100.0 & & Toplam & 382 & 100.0 & \\
\hline
\end{tabular}

Tablo 8. Kredi Kartı ile Yapılan Aylık Harcama Miktarı ve Bu Harcamanın Geri Ödeme Durumu

\section{4 Öğrencilerin Demografik ve Sosyo-Ekonomik Özellikleri İle Kredi Kartı Sahiplikleri Arasındaki İlişskiler}

Öğrencilerin demografik ve sosyo-ekonomik özellikleri ile kredi kartı sahiplikleri arasındaki ilişki ki kare (chisquare) yöntemiyle analiz edilmiştir. Yapılan analiz sonucunda cinsiyetin, bursluluk durumunun ve kredi kartı sahipliği ile ilişkili olduğu görülmüştür. Ancak, katılımcıların verdikleri yanıtlara göre öğrencinin ailesinin yanında ikamet etmesi ile Kredi Yurtlar Kurumu'ndan alınan öğrenim kredisinin ve aylık gelir düzeyinin, çalışma tam zamanlı veya yarı zamanlı durumunun kredi kartına sahip olma durumu arasında bir ilişsi tespit edilememiştir. Ki kare testi sonucunda aylık gelir düzeyi ile çalışma durumunun ilişkisiz çıkması ilginç bir sonuçtur. Bu durum, ancak elde edilen gelirin kredi kartı sahipliği için yeterli bir zemin oluşturmadığı sonucu ile yorumlanabilir. Aşağıda yer alan Tablo 9'da ki kare analizlerinin sonuçları yer almaktadır.

\begin{tabular}{|c|c|c|c|c|}
\hline & & Value & df & $\begin{array}{r}\text { Asymp. Sig. } \\
\text { (2-sided) }\end{array}$ \\
\hline Kredi Kartı Sahipliği ve Cinsiyet & $\begin{array}{l}\text { Pearson Chi- } \\
\text { Square }\end{array}$ & $4.911^{\mathrm{a}}$ & 1 & .027 \\
\hline Kredi Kartı Sahipliği ve Bursluluk Durumu & $\begin{array}{l}\text { Pearson Chi- } \\
\text { Square }\end{array}$ & $1.980^{\mathrm{a}}$ & 1 & .159 \\
\hline Kredi Kartı Sahipliği ve KYK Kredisi & $\begin{array}{l}\text { Pearson Chi- } \\
\text { Square }\end{array}$ & $46.678^{\mathrm{a}}$ & 1 & .000 \\
\hline Kredi Kartı Sahipliği ve Aylık Gelir Düzeyi & $\begin{array}{l}\text { Pearson Chi- } \\
\text { Square }\end{array}$ & $15.622^{\mathrm{a}}$ & 5 & .003 \\
\hline Kredi Kartı Sahipliği ve Aile Yanında İkamet & $\begin{array}{l}\text { Pearson Chi- } \\
\text { Square }\end{array}$ & $.369^{\mathrm{a}}$ & 2 & .832 \\
\hline Kredi Kartı Sahipliği ve Çalışma Durumu & $\begin{array}{l}\text { Pearson Chi- } \\
\text { Square }\end{array}$ & $5.757^{\mathrm{a}}$ & 1 & .016 \\
\hline
\end{tabular}

Tablo 9. Öğrencilerin Demografik ve Sosyo-Ekonomik Özellikleri İle Kredi Kartı Sahiplikleri Arasındaki İlişkiler 


\section{5 Öğrencilerin Kredi Kartı Kullanımına Karşı Tutumları}

Öğrencilerin kredi kartı kullanımına karşı olan tutumlarını ölçmek amacıyla hazırlanan 14 maddelik ölçeğe güvenirlik analizi uygulanmıştır. anketin içsel tutarlılığının bir ölçüsü olan Cronbach $\alpha$ katsayısı hesaplanmış ve bu değer 0,735 olarak bulunmuştur. Cronbach $\alpha$ katsayı 0,60'dan büyük olduğu için ölçek güvenilir kabul edilmiştir. Aşağıda yer alan Tablo 10'da kredi kartının kişiye verdiği güveni temsil eden önermeler ile katılımcıların bu önermelere verdikleri cevaplar yer almaktadır. Verilen cevapların çoğunluğuna göre katılımcılara için kredi kartı sahipliği kişiye güven vermemektedir. Bu sonucun çıkmasında kredi kartı sahibi olmayan yarının cevapları da etkili olmuştur.

\begin{tabular}{|l|c|c|c|c|c|c|}
\hline \multirow{2}{*}{ Önermeler/Cevaplar } & \multicolumn{2}{|c|}{$\begin{array}{c}\text { Kredi kartına sahip olmak } \\
\text { insana güven verir. }\end{array}$} & \multicolumn{2}{c|}{$\begin{array}{c}\text { Kredi kart1 kullanmay1 } \\
\text { seviyorum. }\end{array}$} & \multicolumn{2}{c|}{$\begin{array}{c}\text { Kredi kartının yanında } \\
\text { olması insana güven verir. }\end{array}$} \\
\cline { 2 - 7 } & Frekans & Yüzde & Frekans & Yüzde & Frekans & Yüzde \\
\hline Hiç Katılmıyorum & 107 & 28,0 & 133 & 34,8 & 78 & 20,4 \\
\hline Katılmıyorum & 112 & 29,3 & 81 & 21,2 & 72 & 18,8 \\
\hline Ne Katıliyorum Ne Katılmıyorum & 74 & 19,4 & 77 & 20,2 & 87 & 22,8 \\
\hline Katıllyorum & 61 & 16,0 & 59 & 15,4 & 97 & 25,4 \\
\hline Tamamen Katıliyorum & 28 & 7,3 & 32 & 8,4 & 48 & 12,6 \\
\hline Toplam & 382 & 100.0 & 382 & 100.0 & 382 & 100.0 \\
\hline
\end{tabular}

Tablo 10. Kredi Kartı Sahipliğinin Kişiye Verdiği Güven

Tablo 11 'de yer alan önermeler ve bu önermelere ne kadar katıldıklarını gösteren cevapların dağılımı kredi kartı işlemlerinin kişiye verdiği güveni yansıtmaktadır.

\begin{tabular}{|l|c|c|c|c|c|c|}
\hline \multirow{2}{*}{ Önermeler/Cevaplar } & \multicolumn{2}{|c|}{$\begin{array}{c}\text { Kredi kartı ile internet } \\
\text { veya telefon üzerinden } \\
\text { alışveriş yapmanın hiçbir } \\
\text { sakncası yoktur. }\end{array}$} & $\begin{array}{c}\text { İnternet veya telefon } \\
\text { üzerinden yapılan } \\
\text { alışverişlerde kredi kart1 } \\
\text { kullanmak tehlikelidir. }\end{array}$ & \multicolumn{2}{|c|}{$\begin{array}{c}\text { Kredi kartı ile alisveriş } \\
\text { yapmak güvenlidir. }\end{array}$} \\
\cline { 2 - 7 } & Frekans & Yüzde & Frekans & Yüzde & Frekans & Yüzde \\
\hline Hiç Katılmıorum & 44 & 11,5 & 60 & 15,7 & 33 & 8,6 \\
\hline Katılmıyorum & 82 & 21,5 & 91 & 23,8 & 55 & 14,4 \\
\hline Ne Katıliyorum Ne Katılmıyorum & 118 & 30,9 & 125 & 32,7 & 162 & 42,4 \\
\hline Katıllyorum & 97 & 25,4 & 78 & 20,4 & 89 & 23,3 \\
\hline Tamamen Katıliyorum & 41 & 10,7 & 28 & 7,3 & 43 & 11,3 \\
\hline Toplam & 382 & 100.0 & 382 & 100.0 & 382 & 100.0 \\
\hline
\end{tabular}

Tablo 11. Kredi Kartı İşlemlerinin Kişiye Verdiği Güven

Buna göre kredi kartı ile internet ortamında ve genel olarak fiziki olan ve olmayan ortamlarda işlem yapmak hakkında çoğunlukla kararsız kalınırken, fikirler olumlu yönde olmaya çok küçük bir oranla daha yatkındır. Benzer bir tutum önermenin olumsuz ifadesini ortaya koyan cümlede de yukarıda Tablo 11 'de görülmektedir. Aşağıda yer alan Tablo 12'de ise kredi kartı kullanma bilincini ve sorumluluğunu yansıtan önermeler ve bu önermelere hakkında katılımcıların görüşleri yer almaktadır. Buna göre, kredi kartı sözleşmesini okuyup imzaladığını söyleyene yakın oranda kişi kredi kartı kullanımı sonucunda doğacak yükümlülüklerin bilincinde olduklarını belirtmişlerdir. Ancak anket çalışmasının ilk bölümünde yer alan bir soruya verilen cevapla bu durum çelişmektedir. Söz konusu durum Tablo 13'te yer alan "Internet ortamında oluşturduğunuz aboneliklerinizde (sosyal medya, alışveriş siteleri vb.) ve alışverişlerinizde müşteri sözleşmelerini okuyor musunuz?” sorusuna verilen cevaba göre, katılımcıların yaklaşık yarısı sözleşmeleri okumakta, yaklaşık yarısı ise okumamaktadır.

\begin{tabular}{|l|c|c|c|c|}
\hline \multirow{2}{*}{} & \multicolumn{2}{|l|}{$\begin{array}{l}\text { Kredi kartı kullanımı sonucu doğacak } \\
\text { yükümlülüklerimin bilincindeyim. }\end{array}$} & \multicolumn{2}{|c|}{$\begin{array}{l}\text { Kredi kartını temin eden bankanın } \\
\text { imzalattığ sözleşmeyi okudum ve } \\
\text { öyle imzaladım. }\end{array}$} \\
\cline { 2 - 5 } & Frekans & Yüzde & Frekans & Yüzde \\
\hline Hiç Katılmıyorum & 17 & 4,5 & 79 & 20,7 \\
\hline Katılmıyorum & 30 & 7,9 & 49 & 12,8 \\
\hline Ne Katılıyorum Ne Katılmıyorum & 35 & 9,2 & 61 & 16,0 \\
\hline Katılıyorum & 117 & 30,6 & 89 & 23,3 \\
\hline Tamamen Katılıyorum & 183 & 47,9 & 104 & 27,2 \\
\hline Toplam & 382 & 100.0 & 382 & 100.0 \\
\hline
\end{tabular}

Tablo 12. Kredi Kartı Kullanma Bilinç ve Sorumluluğu 


\begin{tabular}{|c|c|c|c|}
\hline \multicolumn{4}{|c|}{ İnternet ortamında oluşturduğunuz aboneliklerinizde (sosyal medya, alışveriş siteleri vb.) ve alışverişlerinizde müşteri } \\
sözleşmelerini okuyor musunuz?
\end{tabular}

Tablo 13. Sözleşmelerin Okunması

Aşağıda yer alan Tablo 14'te katılımcıların çoğu kredi kartı ve nakit parayı ayrıştırmaktadır. Bununla birlikte kredi kartı kullanımının kendilerini daha zengin hissettirdiği varsayımına ise katılmamaktadırlar. Bu durum alışveriş işlemlerinin gerçekleşmesinde nispeten katılımcıların bilinçli davranmaya çalıştıkları tezini desteklemektedir.

\begin{tabular}{|l|c|c|c|c|}
\hline \multirow{2}{*}{} & \multicolumn{2}{|c|}{$\begin{array}{c}\text { Kredi kartı ile nakit para kullanımı } \\
\text { arasında fark yoktur. }\end{array}$} & \multicolumn{2}{c|}{$\begin{array}{c}\text { Kredi kartı kullandığımda kendimi } \\
\text { daha zengin hissediyorum. }\end{array}$} \\
\cline { 2 - 5 } & Frekans & Yüzde & Frekans & Yüzde \\
\hline Hiç Katılmıyorum & 119 & 31,2 & 171 & 44,8 \\
\hline Katılmıorum & 112 & 29,3 & 91 & 23,8 \\
\hline Ne Katıliyorum Ne Katılmıyorum & 73 & 19,1 & 61 & 16,0 \\
\hline Katıliyorum & 43 & 11,3 & 35 & 9,2 \\
\hline Tamamen Katılıyorum & 35 & 9,2 & 24 & 6,3 \\
\hline Toplam & 382 & 100,0 & 382 & 100,0 \\
\hline
\end{tabular}

Tablo 14. Kredi Kartı ile Yapılan Işslemlere Olan Bakış

\section{Sonuç}

Çalışmada, Kırklareli Üniversitesi öğrencilerinin kredi kartına bakış, tutum ve yaklaşımları incelenmiştir. Yapılan araştırma sonucunda katılımcıların yaklaşık yarısına kadar olan kısmının kredi kartı kullandıkları tespit edilmiştir. Bununla beraber, kredi kartı sahipliğinde erkekler oran olarak kadınlardan fazladır. Kredi kartı sahiplik oranı, beklenilen düzeyin altında gerçekleşmiştir. Günümüzde parasal işlemlerin akıllı telefonlardan bilgisayar vasıtasıyla sanal ortamda yapılma hızı göz önünde bulunursa öğrencilerin bu durumu adapte olmaları beklenmiştir. Ancak gerek gelir durumunun düşük olması gerek ailelerin kredi kartı ile öğrencilerin harcamalarını yapmalarını tercih etmemeleri, beklenmeyen sonucu doğurmuştur denilebilir. Bununla beraber, elde edilen bu sonuç, daha önce yapılmış benzer çalışmalardan da böylece ayrışmıştır. Kredi kartı yapılan harcamaların temel ihtiyaçlara yönelik olduğu ve en fazla elde edilen gelir kadar (500 TL) harcama yapıldığı tespit edilmiştir. Öğrencilerin büyük kısmı harcamalarının çoğunu geri ödemektedir. Öğrencilerin bursluluk ve çalışma durumlarını yansıtan oranlar düşük iken, KYK öğrenim kredisine sahip olanların sayısı tüm öğrencilerin yaklaşık yarısına tekabül etmektedir. Gelir arttırıcı ek kaynaklara sahipliğin düşük olması kredi kartı sahipliğine ve harcama miktarı ile türüne etki etmektedir. Öğrencilerin kredi kartına sahiplik konusundaki tutumları olumsuz olmakla birlikte kredi kartı vasıtasıyla yapılan işlemlere de güven duymamaktadırlar. Ayrıca kredi kartı kullanımında bilinçli ve sorumlu olduklarını iddia etseler de faktörün bir nevi kontrol sorusu olan sözleşmelerin okunması ile ilgili soruya daha büyük oranda olumsuz yanıt verilmesi cevaplardaki çelişkiyi yansıtmaktadır. Bu hususta, öğrencilerin düşündükleri ve değil uygun olan cevabı vermeye eğilimli oldukları iddia edilebilir. Sonuç olarak bu bilgiler ışığında, Kırklareli Üniversitesi öğrencilerinin bankacılık piyasasındaki en temel araçlardan biri olan kredi kartını tahmin edilen düzeyde kullanmadığı ve bu piyasaya entegre olmadıkları görülmektedir. Bu durum bankalar için bir firsat yaratırken, gençler üzerinde ilerde oluşabilecek finansal risk ve problemleri azaltmaktadır.

\section{Kaynakça}

- $\quad$ Akbulut, M. C., \& Özbolat, M. (2015). Beypazarı MYO Öğrencilerinin Kredi Kartı Kullanımlarına Yönelik Bir Araştırma. Bankacılık ve Sigortacılık Araştırma Dergisi, 2(7-8), 34-52.

- Bankalararası Kart Merkezi. (2017). Bankalararası Kart Merkezi Faaliyet Raporu [Faaliyet Raporu]. Retrieved from BKM website: https://bkm.com.tr/wpcontent/uploads/2018/07/2017_BKM_FAALIYET_RAPORU.pdf

- Bankalararası Kart Merkezi. (2019, January). 2018 Y11ı Değerlendirme Toplantısı Bülteni. Retrieved March 18, 2019, from https://bkm.com.tr/wpcontent/uploads/2019/01/bkm_2018_yil_degerlendirme_toplantisi_bulten.pdf

- İstinlice, N. (2017). Üniversite Öğrencilerinin Kredi Kartı Tercih Etme Nedenleri Önem Sıralaması: Anadolu Üniversitesi Öğrencilerine Yönelik Bir Araştırma. Journal of Current Researches on Social Sciences, 7(3), 125-138. https://doi.org/10.26579/jocress-7.3.9 
- Jabine vd., T. (1984). Cognitive Sciences and Survey Methods. In Cognitive Aspects of Survey Methodology: Building a Bridge Between Disciplines (pp. 73-100). Retrieved from https://www.nap.edu/read/930/chapter/4

- Koç Holding AŞ. (2018, ubat). Bizden Haberler. (456), 1-56.

- Schnell, R., \& Kreuter, F. (2005). Separating Interviewer and Sampling-Point Effects. Journal of Official Statistics, 21(3), 389-410. 


\title{
Kırgızistan'da Öznel Refah ve Güvenlik Subjective Well-being and Safety in Kyrgyzstan
}

\author{
Asst. Prof. Dr. Mahmut Erdoğan (Kyrgyzstan-Turkey Manas University, Kyrgyzstan) \\ Asst. Prof. Dr. Ainura Turdalieva (Kyrgyzstan-Turkey Manas University, Kyrgyzstan) \\ Asst. Prof. Dr. Raziya Abdiyeva (Kyrgyzstan-Turkey Manas University, Kyrgyzstan)
}

\begin{abstract}
The safety is a fundamental component of quality of life. In addition personal safety satisfaction becomes the vital component of subjective well-being in Kyrgyzstan. The investigation of safety on personal level will measure personal perceptions and attitudes toward local living conditions in the countries and national security, respectively.

The aim of this paper is to examine the connection and relationship between safety satisfaction and subjective well-being in Kyrgyzstan, support the hypothesis that safety is positively correlated with subjective well-being. Our study conducted on 'Life in Kyrgyzstan' survey for 2013 for Kyrgyzstan. In addition, obtained results will help to deeply understand this relationship and foster economic policy.
\end{abstract}

\section{Giriş}

Son yıllarda kişilerin öznel refahı ve onun ekonomik büyümedeki önemi ile ilgili çalıșmalar hızla artış göstermektedir. Öznel refah kişilerin kendi durumları ile ilgili sübjektif görüşleridir. Öznel refah durumu kişilerin sağlığını, çalışmadaki verimliliğini ve kişiler arası ilişkilerini doğrudan etkilemektedir. Dolayısıyla ekonomik büyümede de önemi büyüktür.

Güvenlik yaşam kalitesinin temel unsurlarından biridir. Kişisel düzeyde güvenlik bireylerin yerel bölgelerin emniyetlilik derecesi ve ulusal seviyede güvenlik ile ilgili algılamaları ve tutumlarını bildirmektedir. Bu görüşlerine yerel bölgelerde suçların sayısı ve ağırlı̆̆ı, devletin sunduğu emniyet hizmetinin kalitesi etkilemektedir.

Bireylerin güvenlikle ilgili tutum ve algılamaları onların öznel refahlarını ve yaşam kalitesini doğrudan etkilemektedir. Çalışmanın amacı Kırgızistan'da öznel refah ile güvenlik arasındaki ilişki 'Life in Kyrgyzstan' 2013 verileri ile incelemektir. Girişi izleyen ikinci bölümde literatür taraması, üçüncü bölümde veri ve yöntem, dördüncü bölümde bulgular ve son bölümde de sonuç ve öneriler sunulacaktır.

\section{Literatür}

Öznel refahı gelir, sağlık, medeni durum, yaş, cinsiyet, iş tatmini, eğitim, beslenme ve barınak gibi faktörler etkilemektedir (Veenhoven, 1991; Diener ve Biswas-Diener, 2002; Oishi v.d., 1999). Öznel refah sağlık ve yaşam beklentisi ile ilişkili olduğu bilinmektedir. Pettay (2008) yaşam memnuniyeti yüksek olanların sağlıklı kiloya sahip olma, uygun bir şekilde egzersiz yapma ve beslenme ihtimalini yüksek olduğunu bildirmiştir. Eğitim de doğrudan ve dolaylı olarak öznel refahla ilişkilidir. İş tatmini ve öznel refah seviyesi eğitim sektöründe hem eğitim verenlerin hem de eğitim alanların, sağlık hizmetinde de hem doktorların ve hem de tedavi görenlerin etkinliği ve verimliliğini etkilemektedir.

Güvenlik tehdit ve tehlikeden uzak olma halidir ve bu bir duygusal tepkidir. Dış tehlikelerden, risklerden veya tehlikelerden korunma hissidir. Güvensizlik algıları, bireyin kendi yaşamını üzerindeki kontrolü kaybetme, mülk kaybı, sosyal ilişkilerin kaybı veya hatta hayatın kaybı ile ilgili korku hissi olarak kendini gösterir. Güvensizlik algıları öznel iyi oluşu etkiler çünkü güvensizlik, bireyin çevresini yönetmeye ilişkin kontrol veya özerklik eksikliği anlamına gelir (Wills, 2014).

Kişisel güvenlik çoğu araştırmacılar tarafından öznel refahın en önemli unsurlarından biri olarak belirtilmiştir (Cummins, Eckersley, Pallant, Van Vugt and Misajon, 2003; Cummins, Eckersley, Lo, Davern, Hunter and Okerstrom, 2004; Cummins, 2012). Maslow (1943) kişilerin kendini gerçekleştirmelerinde ihtiyaç ve güdülerin piramit gibi olduğunu bildirmiştir. Piramitin temelinde fizyolojik ihtiyaçlar ve sonra güven ihtiyacı gelmektedir. Kişiler emniyetli, istikrarlı bir yapı ve düzen içinde yaşamayı, kargaşadan uzaklaşmayı ve iş güvence isterler. Bu ihtiyaçlar karşılanmadan üst psikolojik ihtiyaçlar karşılanmayacaktır (Paksoy, 2013).

Gündelik hayatta suç düzeyinin yükselmesi ve terörist saldırıların artması güvensizliği bildirmektedir. Güvensizlik durumu insanların kaygılarını arttırır, dünya görüşlerini boğar ve refahını hızlıca azaltır. Böylece, güvenlik refahın ve yaşam memnuniyetinin en önemli unsurlarındandır.

Güvensizlik insanların kaygılarını arttırarak acı çekmelerine neden olmaktadır. Moeller (2005) Güney Afrika'da yapılan araştırma sonucunda kentsel büyükşehir belediyelerinde kişisel güvenlik ile ilgili kaygıları ve suç korkusu yaşam memnuniyeti üzerinde önemli derecede negatif etkisinin olduğunu tespit etmiştir. Di Tella, MacCulloch, 
and Nopo (2009) suçla mağduriyetin kaygı ve diğer olumsuz duygularla pozitif bir ilişkisi olduğunu açıklamışlardır.

Öznel refah topluluk kalitesi, güvenlik algılaması ve hissi ile ilgili doğrudan ilişkilidir. Güvenlik ise yerel suçların seviyesi ve istatistiklere bağlıdır. Empirik çalışmalar suç ile yaşam kalitesi arasındaki ilişkiyi incelemişlerdir. Örneğin, Michalos ve Zumbo (1999) suçların azalması yaşam kalitesinin gelişmesi için önemli olduğunu açıklamışlardır. Møller (2005) Güney Afrika üzerine yaptığı çalışmasında fakirlik ve işsizlik yaşam kalitesi üzerinde suçla mağduriyete göre daha da büyük etkisinin olduğunu bildirmiştir.

Genel olarak güvenlik algılaması ve tutumu bireylerin öznel refahını önemli derecede etkilemektedir. Kişisel seviyedeki emniyet ve ulusal güvenlik hizmetinin kalitesi ve etkinliği, devlete güven, suçların sayısı ve cezalandırma sistemi bireylerin kendilerini güvenlik altında hissetmelerini ve öznel iyi oluşunu etkilemektedir.

\section{Veri ve Yöntem}

Bu çalışmada 'Life in Kyrgyzstan' 2013 yılına ait verilerden 10511 gözlem kullanılarak fertlerin yaşam memnuniyetlerini etkileyen güvenlik faktörleri genelleştirilmiş sıralı lojistik regresyon yöntemi ile incelenmiştir. $\mathrm{Bu}$ yöntemde açıklayıcı değişkenlerin bağımlı değişken odsuna etkisi eşit olmadığından bağımlı değişkenin her bir kategorisi için $\beta$ katsayıları farklıdır. Literatürde daha önceden yapılan çalışmalar göz önüne alınarak sıralı lojistik regresyon yönteminin paralel doğrular varsayımının ihlali halinde genelleştirilmiş sıralı lojistik modelin uygulanacağı belirtilmiştir (Arı ve Yıldız, 2016: 1366).

Bağımlı değişsen memnuniyet "Her şeyi göz önünde bulundurduğunuzda hayatınızdan ne kadar memnunsunuz?" anket sorusuna verilen cevaptır ve 0 "tamamen memnuniyetsiz" ile 10 "tamamen memnun" arasında değer almaktadır. Düşük değerli gruplardan kaçınmak amacıyla $0,1,2,3$ ve 4 cevapları "memnun değilim", 5, 6 ve 7 cevapları "memnunum" ve 8, 9, 10 ise "çok memnunum" gruplarını temsil edecek biçimde birleştirilmiştir (Boes ve Winkelmann, 2004: 16). Çalışmada Yükseköğretim mezunu olduğunu gösteren yükseköğretim değişkeni, etnik yapıyı gösteren Kırgız ise 1 diğerleri için 0 değeri alan Kırgız kukla değişkeni, fertlerin yaşını gösteren yaş değişkeni, kentte yaşayanlar için 1 diğerleri için 0 değerini alan kent kukla değişkeni, medeni durumu gösteren medeni değişkeni, erkek ise 1 kadın ise 0 değerini alan cinsiyet kukla değişkeni, birey çalışıyorsa 1 çalışmıyorsa 0 değerini alan istihdam kukla değişkeni, açıklayıcı değişkenlerdir. Ayrıca hanehalkı yıllık gelirinin logaritmik değeri gelir değişkeni olarak tanımlanmıştır. Güvenlik durumunu temsil için gece, tehlike, silah, şiddet artışı değişkenleri de modele dahil edilmiştir. Memnuniyet gruplarının yüzde dağılımı Tablo 1 'de sunulmuştur.

\begin{tabular}{lll}
\hline & S1klık & Yüzde \\
\hline Memnun değilim & 1,179 & 8.95 \\
Memnunum & 7,242 & 54.95 \\
Çok Memnunum & 4,758 & 36.1 \\
\hline Toplam & 13,179 & 100 \\
\hline
\end{tabular}

Tablo 1: Her Şeyi Göz Önünde Bulundurduğunuzda Hayatınızdan Ne Kadar Memnunsunuz?

Çalışmaya katılanların \%8,95'i hayatından memnun değilken, \%54,95'i hayatından memnun olduğunu ve \% $36,1^{\prime} \mathrm{i}$ ise hayatından çok memnun olduğunu ifade etmiştir. Bu durum genel olarak Kırgız toplumunun yapısı ile tutarlılık göstermekte olup hayatından memnun olmayanların oranı oldukça düşük düzeyde belirlenmiştir.

\begin{tabular}{lll}
\hline & S1klık & Yüzde \\
\hline Genç Yaş & 5,975 & 45.51 \\
Orta Yaş & 5,902 & 44.95 \\
Yaşl1 & 997 & 7.59 \\
\hline Toplam & 13,130 & 100 \\
\hline
\end{tabular}

Tablo 2: Katıllmcıların Yaşı

Araştırmaya katılanların \% 45,51'i 23 yaşından küçük gençlerden oluşurken, \%44,95'i $24-60$ yaş aralığında orta yaşlılardan oluşmaktadır. Buna ek olarak \%7,59’u 60 yaş üstü yaşlı kesimden oluşmaktadır. 


\begin{tabular}{lll}
\hline & Siklık & Yüzde \\
\hline Kırgız & 9,203 & 70.09 \\
Özbek & 1,909 & 14.54 \\
Rus & 765 & 5.83 \\
Dungan & 436 & 3.32 \\
Uygur & 272 & 2.07 \\
Tacik & 123 & 0.94 \\
Kazak & 58 & 0.44 \\
Diğer & 364 & 2.77 \\
\hline Toplam & 13,130 & 100 \\
\hline
\end{tabular}

Tablo 3: Katılımclların Milliyeti

Araştırma katılımcılarının \%70'i Kırgız, yaklaşık olarak \%15'i Özbek, \%6'sı Rus ve geriye kalanı diğer etnik gruplardan oluşmaktadır.

\begin{tabular}{lll}
\hline & S1klık & Yüzde \\
\hline$<120000$ & 2,759 & 67.57 \\
$120001-480000$ & 1,235 & 30.25 \\
$480000>$ & 89 & 2.18 \\
\hline Toplam & 4,083 & 100 \\
\hline
\end{tabular}

Tablo 4: Gelir Gruplarl

Katılımcıların \%67,57'sinin hane halk1 geliri y1llı 120000 somun altında, \%30,25'inin geliri ise 120000 ile 480000 som arasında dağılmaktadır. Katılımcıların sadece \%2,18'sinin 480000 somdan daha fazla gelire sahip olduğu tespit edilmiştir.

\begin{tabular}{lll}
\hline & Siklık & Yüzde \\
\hline Evet & 1,976 & 45.2 \\
Hayır & 2,396 & 54.8 \\
\hline Toplam & 4,372 & 100 \\
\hline
\end{tabular}

Tablo 5: Istihdam Edilme Durumu

Araştırmaya katılanların \%45,2'si istihdam edilirken, katılımcıların yarısından fazlası $(\% 54,8)$ istihdam edilmediğini belirtmiştir.

Çalışmada güvenlikle ilgili üç farklı soru yer almaktadır. Birincisi “Geceleri mahallede yalnız yürürken kendimi güvende hissediyorum”, ikincisi “Tehlikeli olduğunu düşündüğüm ve belirli yolları kullanmaktan kaçınırım” ve üçüncüsü ise "12 ay içerisinde büyük olasılıkla şiddet kurbanı olacağım"

\begin{tabular}{lll}
\hline & Sıklık & Yüzde \\
\hline Kesinlikle Katıliyorum & 2,547 & 33.43 \\
Katıliyorum & 1,544 & 20.27 \\
Kararsiz & 1,630 & 21.39 \\
Katılmiyorum & 1,150 & 15.09 \\
Kesinlikle Katılmiyorum & 748 & 9.82 \\
\hline Toplam & 7,619 & 100 \\
\hline
\end{tabular}

Tablo 6: Geceleri Mahallede Yalnız Yürürken Kendimi Güvende Hissediyorum

Geceleri mahallede yalnız yürürken kendini güvende hissetme ile ilgili sonuçlar Tablo 6'da sunulmuştur. Katılımcıların çoğunluğu $(\% 53,69)$ mahallede geceleri yalnız güvenli şekilde gezebildiğini belirtirken, sadece \%24,89 oranında katılımcı mahallede geceleri yalnız yürürken kendini güvensiz hissettiğini ifade etmiştir.

\begin{tabular}{lll}
\hline & Siklık & Yüzde \\
\hline Kesinlikle Katıliyorum & 2,100 & 27.56 \\
Katıliyorum & 1,629 & 21.38 \\
Kararsiz & 1,727 & 22.67 \\
Katılmiyorum & 1,062 & 13.94 \\
Kesinlikle Katılmiyorum & 1,101 & 14.45 \\
\hline Toplam & 7,619 & 100 \\
\hline
\end{tabular}

Tablo 7: Tehlikeli Olduğunu Düşündüğüm Belirli Yolları Kullanmaktan Kaçınırım 
Katılımcıların \%48,94'ü tehlikeli olduğunu bildiği ve düşündüğü yolları kullanmaktan kaçındığını ifade ederken, \%28,39'u tehlikeli yolları kullanmaktan çekinmediğini belirtmiştir. Katılımcıların \%22,67'si ise tehlikeli yolları kullanmaktan kaçınma konusunda kararsız fikir bildirmiştir.

\begin{tabular}{lll}
\hline & Sıklık & Yüzde \\
\hline Kesinlikle Katıliyorum & 135 & 1.02 \\
Katılıyorum & 596 & 4.52 \\
Kararsız & 1,741 & 13.21 \\
Katılmiyorum & 2,587 & 19.63 \\
Kesinlikle Katılmiyorum & 8,117 & 61.6 \\
\hline Toplam & 13,176 & 100 \\
\hline
\end{tabular}

Tablo 8: 12 Ay İçerisinde Mahallemde Silah Ateşlendiğini Duydum.

Toplumda katılımcıların kendilerini güvenli hissetmelerini araştırmak için sorulan " 12 ay içerisinde mahallemde silah ateşlendiğini duydum” sorusuna, katılımcıların büyük çoğunluğu $(\% 81,23)$ katılmadığını belirtmiş ve sadece \%5,54'ü silah atışı duyduğunu ifade etmiştir.

\begin{tabular}{lll}
\hline & Siklık & Yüzde \\
\hline Kesinlikle Katıliyorum & 87 & 1.14 \\
Katıliyorum & 542 & 7.11 \\
Kararsız & 1,524 & 20 \\
Katılmiyorum & 1,843 & 24.19 \\
Kesinlikle Katılmıyorum & 3,623 & 47.55 \\
\hline Toplam & 7,619 & 100 \\
\hline
\end{tabular}

Tablo 9: 12 Ay İçerisinde Büyük Olasılıkla Şiddet Kurbanı Olacă̆ım

\section{Bulgular}

Toplumda katılımcıların kendilerini güvenli hissetmelerini araştırmak için sorulan "12 ay içerisinde büyük olasılıkla şiddet kurbanı olacağım” sorusuna, katılımcıların büyük çoğunluğu $(\% 71,74)$ katılmadığını belirtmiş ve sadece \%8,2'si şiddet kurbanı olacağını ifade etmiştir. Toplum gelecek dönem itibariyle şiddetin artışını beklememektedir.

\begin{tabular}{|c|c|c|c|c|}
\hline & Değișken & Katsayı & Standart Hata & Odds Oranı \\
\hline \multirow{5}{*}{$\begin{array}{l}\text { 1. kategoriye karş1 } 2 . \\
\text { ve } 3 . \text { kategori }\end{array}$} & yükseköğretim & -0.106 & -0.188 & 0.899 \\
\hline & Kırg1z & $0.143^{*}$ & -0.075 & 1.153 \\
\hline & yaş & $-0.0102 * * *$ & -0.002 & 0.989 \\
\hline & kent & -0.073 & -0.081 & 0.929 \\
\hline & medeni & $0.437 * * *$ & -0.082 & 1.547 \\
\hline \multirow{3}{*}{ (Karşılaştırma 1) } & cinsiyet & 0.053 & -0.070 & 1.054 \\
\hline & istihdam & -0.037 & -0.074 & 0.964 \\
\hline & loggelir & $0.0794 * *$ & -0.039 & 1.082 \\
\hline \multirow{6}{*}{$\begin{array}{l}\text { (Mutsuz olanlara } \\
\text { karş1, mutlu ve çok } \\
\text { mutlu olanlar) }\end{array}$} & kurban & 0.004 & -0.056 & 1.003 \\
\hline & gece & 0.013 & -0.029 & 1.013 \\
\hline & tehlike & $-0.147 * * *$ & -0.026 & 0.863 \\
\hline & silah & $0.226 * * *$ & -0.049 & 1.253 \\
\hline & șiddetartıș1 & -0.028 & -0.047 & 0.972 \\
\hline & sabit & $0.968 * *$ & -0.480 & 2.633 \\
\hline \multirow{6}{*}{$\begin{array}{l}\text { 1, 2. kategoriye karş1 } \\
\text { 3. kategori }\end{array}$} & yükseköğretim & $-0.249 * *$ & -0.115 & 0.779 \\
\hline & Kirg1z & $0.306^{* * *}$ & -0.046 & 1.357 \\
\hline & yaş & $-0.00405 * * *$ & -0.001 & 0.995 \\
\hline & kent & 0.013 & -0.049 & 1.013 \\
\hline & medeni & $0.119 * *$ & -0.051 & 1.126 \\
\hline & cinsiyet & 0.025 & -0.041 & 1.025 \\
\hline \multirow{3}{*}{ (Karşılaştırma 2) } & istihdam & $0.120 * * *$ & -0.044 & 1.127 \\
\hline & loggelir & $0.144 * * *$ & -0.023 & 1.154 \\
\hline & kurban & $0.0963 * * *$ & -0.033 & 1.101 \\
\hline \multirow{5}{*}{$\begin{array}{l}\text { (Mutsuz ve mutlu } \\
\text { olanlara karşı, çok } \\
\text { mutlu olanlar) }\end{array}$} & gece & $0.0372 * *$ & -0.017 & 1.037 \\
\hline & tehlike & $-0.162 * * *$ & -0.015 & 0.851 \\
\hline & silah & $0.0567 *$ & -0.030 & 1.058 \\
\hline & şiddetartışı & $0.120 * * *$ & -0.026 & 1.127 \\
\hline & sabit & $-3.224 * * *$ & -0.297 & 0.039 \\
\hline
\end{tabular}

Tablo 10: Genelleştirilmiş Sıralı Logit Model Sonuçları 
Olabilirlik Oran (LR) Testi ile Genelleştirilmiş Sıralı Logit Modelin geçerliliği test edilmiş ve model olabilirlik $X^{\wedge} 2=425,21$ ve $(p<0,000)$ değeri ile anlamlı olduğu belirlenmiştir. Genelleştirilmiş Sıralı Logit Modelde açıklayıcı değişkenlerin bağımlı değişkene etkisi her kategoride birbirinden farklı olmakta ve her kategoride değişkenlerin odds oranları da değişmektedir. Bu sebeple koşturulan sıralı lojistik regresyon modellerinde eğimler birbirinden farklı olmaktadır.

$\mathrm{Bu}$ modelde mutsuz olanlara karşı, mutlu ve çok mutlu olanlar için kategori karşılaştırması, 2. ve 3. grupta bulunan mutlu ve çok mutlulara ait değişkenlerin, 1. grupta yer alan mutsuzlara göre oddsunu ne kadar değiştirdiği biçiminde yorumlanmaktadır.

Bireylerin hayatından memnun olmasını etkileyen faktörlerden birisi etnik köken olup, Kırgız etnik köken değişkeni bir ferdin, 1. Kategoride yer alma olasılığına göre 2. ya da 3. kategoride yer alma olasılığını 1,153 kat artırmaktadır.

Kırgızistan'da bireylerin yaşam memnuniyetini etkileyen faktörlerden birisi de yaştır. Yaş değişkeni bir bireyin, 1. Kategoride yer alma olasılığına göre 2. ve 3. kategoride yer alma olasılığını 0,989 daha azaltmaktadır. Medeni durum da bireylerin yaşam memnuniyetini etkileyen faktörler içerisinde anlamlı bulunmuştur. Medeni durum değişkeni bir bireyin, 1. kategoride yer alma olasılığına göre 2. ve 3. kategorilerde yer alma olasılığını 1,547 kat daha artırmaktadır. Benzer biçimde bireylerin yaşam memnuniyetini etkileyen faktörler içerisinde aylık gelir değişkeni anlamlı bulunmuştur. Aylık gelir değişkeni bir ferdin, 1. Kategoride yer alma olasılığına göre 2,3. kategorilerde yer alması olasılığını 1,082 kat daha artırmaktadır. Güvenlik açısından yaşam memnuniyetini etkileyen tehlikeli olduğu düşünülen yolları kullanma değişkeni ve mahallede silah atışı yapılması değişkeni anlamlı bulunmuştur. Tehlikeli yolları kullanma değişkeni bir bireyin, 1. kategoride bulunma olasılığına göre 2 . ve 3. kategoride yer alma olasılığını 0,863 kat daha azaltmaktadır. Bununla aksi yönde mahallede silah atışı değişkeni

İkinci panelde, 3. Kategorideki açıklayıcı değişkenlerin, 1 ve 2. kategori grubuna göre oddsunu ne kadar artırdığı ya da azalttığı biçiminde yorumlanır. Fertlerin yaşam memnuniyetini etkileyen faktörler arasında yükseköğretim değişkeni anlamlı bulunmuştur. Yükseköğretim derecesine sahip olma değişkeni bir ferdin, 1 ve 2. Kategoride yer alma olasılığına göre 3. Kategoride yer alma olasılığını 0,779 kat daha azaltmaktadır. Bununla ters biçimde, hayat memnuniyetini etkileyen faktörlerden birisi olan etnik köken değişkeni anlamlı belirlenmiştir. Kırgıı etnik köken değişkeni bir ferdin, 1. ve 2. kategoride yer alma olasılığına göre 3. kategoride yer alma olasılığını 1,357 kat daha artırmaktadır. Bireylerin yaşam memnuniyetini etkileyen faktörlerden yaş değişkeni anlamlı çıkmıştır. Yaş değişkeni bir ferdin, 1. ve 2. kategoride yer alma olasılığına göre 3. kategoride yer alma olasılığını 0,995 kat daha azaltmaktadır. Fertlerin yaşam memnuniyetini etkileyen faktörlerden medeni durum değişkeni anlamlı bulunmuştur. Medeni durum değişkeni bir bireyin, 1. ve 2. kategoride yer alma olasılığına göre 3. kategoride yer alma olasılığını 1,126 kat daha artırmaktadır. Bireylerin yaşam memnuniyetini etkileyen faktörlerden istihdam edilme durumu değişkeni anlamlı tespit edilmiştir. İstihdam değişkeni bir bireyin, 1. ve 2. kategoride yer alma olasılığına göre 3. kategoride yer alma olasılığını 1,127 kat daha artırmaktadır. Gelir değişkeni fertlerin yaşam memnuniyetini etkileyen faktörlerden olup anlamlı bulunmuştur. Bu panelde yaşam memnuniyetini etkileyen güvenlik ile ilgili değişkenlerin tümü anlamlı bulunmuştur. Şiddet kurbanı olmak yaşam memnuniyetini etkileyen faktörlerden biridir ve şiddet kurbanı olma değişkeni bir ferdin 1. ve 2. kategoride yer alma olasılığına göre 3 . kategoride yer alma olasılığını 1,101 kat daha artırmaktadır. Gece mahallede yalnız yürürken kendini güvende hissetme değişkeni yaşam memnuniyetini etkileyen faktörlerden biridir. Gece güvende yürüme değişkeni bir bireyin 1. ve 2. kategoride yer alma olasılığına göre 3. kategoride yer alma olasılığını 1,037 kat daha artırmaktadır. Tehlikeli olduğu düşünülen yollardan uzak durma değişkeni de güvenlik açısından yaşam memnuniyetini etkileyen faktörlerden birisidir. Tehlikeli yollardan uzak durma değişkeni bir ferdin 1. ve 2. kategoride yer alma olasılığına göre 3. kategoride yer alma olasılığını 0,851 kat daha azaltmaktadır. Mahallede silah sesinin varlığı da yaşam memnuniyetini etkileyen faktörlerdendir. Mahallede silah sesi duyma değişkeni bir vatandaşın, 1 . ve 2 . kategoride yer alma olasılığına göre 3. kategoride yer alma olasılığını 1,058 kat daha artırmaktadır. Önceki yıla oranla şiddet artışı da yaşam memnuniyetini etkileyen bir faktördür. Önceki yıla göre şiddet artışı bir bireyin, 1. ve 2. kategoride yer alma olasılığına göre 3. kategoride yer alma olasılığını 1,127 kat daha artırmaktadır. Genelleştirilmiş Sıralı Lojistik Modelin uyum iyiliği göstergelerinden Sözde (Pesudo) R2 değeri 0,022’dir.

\section{Sonuç}

Bu çalışmada, Kırgızistan’da bireylerin güvenlik algısının öznel refaha etkisi 2013 yılında 10511 gözlem ile incelenmiştir. Literatürdeki mevcut çalışmalar incelendiğinde Kırgızistan’da güvenlik ve öznel refah ilişkisini sıralı lojistik regresyon ile inceleyen çalışmaların fazlaca olmadığı belirlenmiş olup, bu çalışma bölge açısından literatüre katkı sağlayacaktır.

Çalışma bulguları, bireylerin güvenlik algıları ve yaşam memnuniyetleri arasındaki ilişki bakımından, bireylerin şiddet kurbanı olma, gece güvende yürüme, mahallede silah sesi duyma ve önceki yıla göre şiddetin artış göstermesi değişkenlerinin 3. kategoride bulunma olasılığını artırdığını gösterirken, tehlikeli yollardan uzak durma değişkeni ise 3. kategoride bulunma olasılığını azalttığını göstermiştir. 
Bununla birlikte demografik açıdan bakıldığında, yüksek eğitim ve yaş değişkenleri 3. kategoride bulunma olasılığını azalttığını gösterirken, Kırgız etnik yapısında olma, medeni hal, cinsiyet, istihdam ve gelir değişkenlerinin ise 3. kategoride bulunma olasılığını artırdığını ampirik olarak kanıtlamıştır.

Sonraki çalışmalar, panel veri yöntemleri ve sıralı lojistik yöntemlerle geliştirilerek konu hakkında daha derin bilgiler sağlanmasına katkı verecektir.

\section{Kaynakça}

- Ar1, E., \& Yıldız, Z. (2016). Bireylerin Yaşam Memnuniyetini Etkileyen Faktörlerin Sıralı Lojistik Regresyon Analizi İle İncelenmesi. Journal of International Social Research, 9(42), 1362-1374.

- $\quad$ Boes, S., \& Winkelmann, R. (2004). Income and happiness: New results from generalized threshold and sequential models.

- Cummins, (2012). Safety and subjective well-being: A perspective from the Australian unity well-being index. In D. Webb \& E. Wills-Herrera (Eds.), Subjective well-being and security. New York: Springer. Social Indicators Research Series, 46.

- Cummins, R. A., Eckersley, R., Pallant, J., van Vugt, J., \& Misajon, R. (2003). Developing a national index of subjective wellbeing: The Australian unity wellbeing index. Social Indicators Research, 64, p. 159-190.

- $\quad$ Di Tella, R., MacCulloch, R., \& Nopo, H. (2009). Happiness and beliefs in criminal environments. Research Department Publications 4605, InterAmerican Development Bank, Research Department.

- Diener, E., \& Biswas-Diener, R. (2002). Will money increase subjective well-being? Social Indicators Research, 57, 119-169.

- Maslow, A. H., (1943). A theory of human motivation. Psychological Review, 50 (4), 370-396.

- Michalos, A. C. ve Zumbo, B. D., (1999). Public services and the quality of life. Social Indicators Research, 48, 125-156.

- Moeller, V. (2005). Resilient or resigned? Criminal victimization and quality-of-life in South Africa. Social Indicators Research, 72(3), 263-317.

- $\quad$ Oishi, S., Diener, E., Lucas, R., \& Suh, E., (1999). Cross-cultural variations in predictors of life-satisfaction: Perspectives from needs and values. Personality and Social Psychology Bulletin, 25(8), 980-990.

- Paksoy, (2013). Davranış Bilimleri, (editör), 1.baskı, Elma Basım Yayınevi, İstanbul

- Pettay, R. F. (2008). Health Behaviours and Life Satisfaction in College Students. Kansas State University. Unity well-being index: An overview. Social Indicators Network News, 76, p. 1-4.

- Veenhoven, R., (1991). Is happiness relative? Social Indicators Research, 24, p.1-34. 


\title{
Türk Ekonomisinin Bilgi Ekonomisi Kapsamında Performansına Dair Bir Değerlendirme
}

\section{An Evaluation of Turkish Economy's Performance Under the Information Economics}

\author{
Prof. Dr. Zeynep Karaçor (Selçuk University, Turkey) \\ Ph.D. Candidate Mücahide Küçüksucu (Necmettin Erbakan University, Turkey) \\ Ph.D. Candidate Sevilay Konya (Selçuk University, Turkey)
}

\begin{abstract}
Economics is the art of providing unlimited human needs with scarce resources as it comes to teaching. Very few of these resources have been used in such a way that they are ready in nature. Almost all of the goods and services that can meet the needs are obtained by the application of human labor (labor force) and capital to commodity. In recent years, labor capital and commodity factors were first added to entrepreneurs and then technology. Thus, the system we call the production process emerges.

This study based on the information economy, the information economics indicator with Turkey's latest data is intended to demonstrate the performance. First of all, after the conceptual framework of the information economics, its distinctive qualities and development process, the effects of these developments on societies and economies will be evaluated. For the intended purpose, indicators such as R\&D activities and R\&D personnel employment, patent application and registration numbers, number of scientific publications and access to information were examined in Turkish economy. Finally, Turkey made the comparison with developed countries in economic terms and has been observed that the desired level of the Turkish economy in terms of the information economics.
\end{abstract}

\section{Giriș}

Bilginin üretilmesi, kullanılması ve yayılması olarak ifade edilebilecek teknolojik yetenek, ekonomik büyüme ve uluslararası rekabet gücünün ve dolayısıyla toplum refahının en önemli belirleyicileri olmuştur. Teknolojik gelişmişlik bağlamında önde olan ülkelerde ekonomik faaliyetlerin büyük çoğunluğunu, bilgi yoğun faaliyetlerin oluşturmaktadır. Günümüzde, mal ve hizmet üretim süreci, büyük oranda bilgi kullanımı gerektiriyor olmasından dolayı ekonomiler, "Bilgi Ekonomisi" ya da "Bilgiye Dayalı Ekonomi" kavramı ile ifade edilmeye başlanmıştır. Bilgi ekonomisine geçiş süreci üretimden pazarlamaya bütün ekonomik faaliyetlerde yapısal bir dönüşüm olarak ifade edilmektedir (Saygilı, 2003).

İktisatçılar, ekonomik değişimlerin temel unsurlarından birinin bilgi olduğunu ve yirminci yüzyılın başlarından itibaren, analizlerinde bilgi kavramına yer vermeleri gerektiğini fark etmişlerdir. Bu tarihten, bilgi ekonomisi konusu ile ilgili iktisat yazınında son dönemde önemli artışlar olmuştur (Fidan, 2013). Yeni ekonomi savunucuları küreselleşme ve bilgisayarlaşmayı modern ekonomide endüstriyel dönemlerden temelde farklı şekilde biçimlendirilen yeni güç olarak görmektedir. Bu fikirler dikkat çekmesine rağmen, yeni ekonominin gerçekte ne anlama geldiği veya nasıl tanımlanması ve değerlendirilmesi gerektiği konusunda henüz bir fikir birliği yoktur (Stiroh, 2000).

Günümüzde bilgi kaynağına ulaşmış olan ekonomiler zengin ekonomi olarak nitelendirilmektedir. Bu nedenle bu çalışmanın amacı Türk ekonomisinde bilgi ekonomisi performansını ortaya koymaktır. Çalışmamızda öncelikle, önemine atfen bilgi ekonomisinin kavramsal çerçevesine yer verilmiştir. Daha sonra Türk ekonomisinin bilgi ekonomisi adına performans göstergelerine değinmek için, Ar-Ge harcamaları, merkezi yönetim bütçesinden Ar-Ge harcamaları için ayrılan pay ve bu payın sosyo-ekonomik hedefler doğrultusunda dağılımı, patent başvuru ve tescil sayıları, bilimsel yayınlar verilerine yer verilmiştir. Daha sonra OECD ülkeleri çerçevesinde Bilgi Ekonomisi Endeksi (KEI) ve alt bileşenlerine yer verilerek mukayese yapılmıştır. Sonuç bölümünde ise genel değerlendirmelerde bulunulmuştur.

\section{Bilgi ve Bilgi Ekonomisinin Kavramsal Çerçevesi}

Bilgi ekonomisi kavramına değinmeden önce bilgi kavramına kısaca değinmek anlamlı olacaktır. Türk Dil Kurumu'na göre bilgi, insan aklının erebileceği olgu, gerçek ve ilkelerin bütünü olarak tanımlanmaktadır.

Çağımızda savaşın ve uluslararası rekabetin temelini bilgi oluşturmaktadır. Bu anlamda ise bilgiyi elinde bulunduran gücü de elinde tutmaktadır. Bilgi toplumu yapısının ortaya çıkması ile birlikte sanayi ekonomisinde temel üretim faktörlerine (doğa, sermaye, işgücü, girişimci) bilgi de dahil olmaktadır. Bu doğrultuda bilgi ekonomisini sanayi ekonomisinden ayıran temel farklılıklar, bilginin üretim faktörü kapsamında değerlendirilmesi, 
bilgi kullanımı ve üretimindeki artıştır. Günümüzde ise girdi ve çıktının bilgi olduğu bir yapı ortaya çıkmaktadır (Şanlısoy, 2015).

Bilgi faktörü, üretimde kullanılan öncelikli girdilerden biridir. Üretim için kullanılan bilgi miktarının yükseltilmesi üretilen ürünlerin katma değerini arttırmaktadır. Ekonomik yapıları bilgiye dayalı olan ülkeler daha rekabetçi konuma gelmektedir. Bununla birlikte yapısal değişimler ortaya çıkmaktadır. Üretimi yapılan mal ve hizmetlerin niteliğinde değişmeler oluşmakta, rekabet kuralları sert boyutlara ulaşmaktadır. Bu çerçevede ise bilgi üretimi mal üretiminden daha da önemli boyutlara ulaşmaktadır. Bu durum ise bilginin üretiminin artmasına ve ekonomik bir güç durumuna gelmesine neden olmuştur (Ekizceleroğlu, 2011).

İnsanlık tarihinde son birkaç yüzyılda önemli değişiklikler olmuştur. Bilgi ekonomisi bu dönemde ortaya çıkmış, gelişme ve ilerleme evresinin son aşaması olmuştur. 1785 yılında başlayıp 68 yıl devam eden ilk aşama Fransız devrimi ile sanayi devrimi sürecini kapsamaktadır. Bu dönemde su ve buhar gücü yaygın olarak kullanılmıştır. Demiryolu yapımı nedeniyle ulaşım ve taşıma maliyetlerine büyük ölçüde düşüşler yaşanmıştır. İkinci aşama ise 20.yüzyılın başına kadar devam etmiş ve bu süreçte içten yanmalı motor ve elektrik gücünün temel olduğu çeşitli kimyasalların imalat sürecinde kullanılmıştır. İçten yanmalı motorların, elektrik ve kimyasal maddelerin günlük yaşama girdiği üçüncü aşama modern iktisadi ve sosyal yaşamın başlangıcını oluşturmaktadır. 1950’li yıllarda başlamış olan ve 1990'lı yıllarda olgunlaşma dönemine ulaşan elektronik çağ yerini yeni medya, dijital ağlar ve yeni temel teknolojilerin ürün ve üretim süreçlerinde esaslı bir role sahip olduğu bilgi ekonomisi aşamasına bırakmaktadır. Bütün bu gelişmeler ışığında yeni ekonomi olarak adlandırılan süreç ortaya çıkmıştır. Bu süreç yani bilgi ekonomisi bilginin bulunması, işlenmesi ve dönüştürülmesi ile beraber dağıtım süreçlerini kapsamaktadır. İfade edilen üç temel süreç bilginin bulunması, işlenmesi, dağıtımını ve iletişimini sağlayan bilgisayar sisteminin fiziksel araçları ile beraber, insan yardımı ile kontrol mekanizması yazılımı ile işlerlik kazanmaktadır. Bilgi ekonomisi kapsamında değerlendirilen mal ve hizmetlerin en önemli özelliği, bilginin üretim faktörü olarak ön planda olmasıdır. Bilgi ekonomisi sektörlerinde beşeri, fiziksel ve entelektüel sermayeyi güçlü bir şekilde tamamlayan bir görev üstlenmiştir (Aktan ve Vural, 2016).

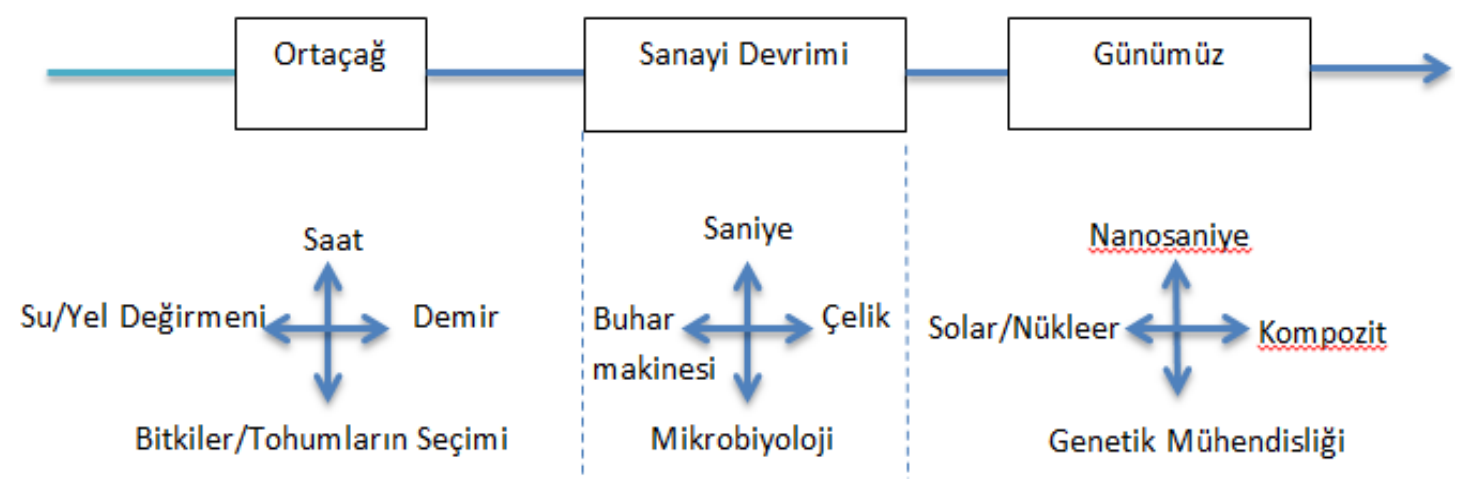

Şekil 1. Zaman, Madde, Yaşam ve Enerji: Zaman İ̧̧erisindeki Değişim Kaynak: World Bank, 2007.

Bilgi insanlığın gelişiminde belirleyici bir öneme sahiptir. Başlarda ateşin bulunması kabileler içinde ve kabileler arasında önemli ilerlemelere neden olmuştur. Daha sonraları ise ilkel toplumlar, binlerce yıl hayatta kalabilmeleri için gerekli olan bitkiler, hayvanlar ve mineraller hakkında bilgi biriktirmişlerdir. Neolitik dönem (M.Ö. 10.0005.000) bitki tohumlama, çiftçilik teknikleri, metalürji, alet yapımı vb. gelişmeler sayesinde dünyanın çeşitli bölgelerinde (Mezopotamya, Güney Çin, Orta Amerika ve Batı Afrika) daha verimli tarım uygulamaları getirmiştir. Bu bilgi yavaş yavaş genişlemiş ve nesilden nesile aktarılmak üzere yazılı olarak depolanmıştır. Avrupa, Rönesans patlamasını ortaya çıkaracak bilim, sanat ve diğer bilgi geliştirme alanlarının oluşması için Ortaçağ' 'n sonlarında yeniden bir araya gelmiştir. Transistörün icadı ve mikroelektronik devriminin aşamaları boyunca, bilgi işlemede hızlı bir ilerleme kaydedilmiştir. Bilgisayar hızındaki ve işlem gücündeki bir artış diğer teknolojik sıçramaları kolaylaştırmıştır. Genetik ve ilgili biyoteknolojideki gelişmeler, yaşam bilimlerinde ve uygulamalarında muazzam ilerleme sağlamıştır. Maddenin manüpülasyonundaki gelişmeler, yeni malzemeler ve nanoteknolojilerin icat edilmesine yol açmıştır. Son olarak enerji alanında gelişmeler ortaya çıkmıştır. Teknolojik ilerlemeler bir dizi önemli değişikliğe neden olmuştur. Örneğin mikoelektronik ve telekominükasyondaki gelişmeler, olağanüstü kısa bir sürede derin bir küresel etkiye sahipken nanoteknolojinin tam etkisi henüz görülmemiştir (World Bank, 2007).

Bilgi ekonomisi kavramı Fritz Machlup tarafından ortaya atılmıştır. Avustralyalı iktisatçı 1962 yılında Amerika'da bilginin üretimini ve dağılımını ölçen bir çalışma yayınlamıştır. 1958 yılı için ABD'de bilgi ekonomisi oranını GSMH'nın \% 29'u olarak tespit etmiştir. Machlup tarafindan yapılan hesaplamalar literatürde bilgi ekonomisi politikaları ve ölçümü olarak yer almıştır. Bu ilk dalga 1970’lere rastlamaktadır. M.U. Porat Machlup’un tekniğini kullanarak Ulusal Hesaplar Sistemi verileri ile bilgi ekonomisi miktarını ABD için hesaplamıştır. Porat 1967 yılı için Amerika'da GSMH'nın \% 46’sını ve emek gelirinin \% 53’ünü bilgi 
ekonomisinin oluşturduğunu belirlemiştir. İkinci dalga ise 1990 yılında başlamış ve günümüzde hala devam etmektedir (Godin, 2008).

Peter Drucker, 1989 yılında Yeni Gerçekler isminde bir kitap yayınlamıştır. Kitap 1975-1989 dönemi arasında ekonomide meydana gelen belli başlı olayları ele almış ve yeni bir dünya düzeninin varlığına atıf yapmıştır. Çağımızda ise yeni dünya düzeni kavramı bilgi ekonomisi ile ifade edilirken, literatürde ise digital ekonomi, yeni ekonomi, bilgiye dayalı ekonomi, te-ekonomi, sayısal ekonomi, enformasyon ekonomisi, ağ ekonomisi, öğrenen ekonomi, elektronik ekonomi, ağlaşmış ekonomi, e-ekonomi, ağırlıksız ekonomi kavramları ile eş anlamlı olarak kullanılmaktadır (Işık, 2012).

Bilgi ekonomisinin üzerinde uzlaşılmış bir tanımına literatürde bulunmasa da, genel kabul gören ayrım geniş ve dar olmak üzere iki kapsamda bilgi ekonomisi tanımı mevcuttur. Geniş anlamda bilgi ekonomisinin tanımlanması geçmişte ekonomik politikaya rehberlik eden temel ekonomik kavramlar küresel rekabet ve hızlı teknolojik değişim çağında önemsiz hale gelmesi ile ortaya çıkmıştır. Dar anlamda ise ekonominin çıtı ve verimlilik artışı eğilimini hızlandırmada bilgi iletişim teknolojisinin rolü ile olmuştur (Bosworth ve Triplett, 2000).

Literatürde yeni ekonomi kavramı ile ilgili dar anlamda yapılan tanımlarda bilgisayar ve bilgisayarla ilgili mal ve hizmetlerin üretimi ve ekonomik etkilerinin yanı sıra, bilgi ve iletişim teknolojileri ile diğer mal ve hizmetlere vurgu yapılmaktadır (Erdoğan, 2004). Nordhaus bilgi ekonomisi kavramını dar anlamda tanımlamıştır. Nordhaus'a göre bilgi ekonomisi makine, elektrik ekipmanı, telefon ve telgraf yazılımları olarak tanımlanmaktadır (Nordhaus, 2001). Gordon'a göre ise bilgi ekonomisi bilgisayar donanımı, yazılım fiyatlarındaki düşüş oranındaki ivme ve telefon hizmetleri, bilgisayar gücü ve telekomünikasyon kabiliyetindeki üssel büyüme hızının ve internet gelişme hızının bir sonucudur (Gordon, 2000). Masi ve diğerlerine göre bilgi ekonomisi bilgi iletişim teknolojilerindeki üretim, benimseme ve yayılmasından kaynaklanan verimlilikte daha yüksek bir büyüme hızına bağlı olarak uzun vadeli yüksek büyüme ile nitelendirilen bir ekonomidir (Masi ve diğerleri, 2001).

Bilgi ekonomisinin geniş anlamda tanımlamalarında ise teknolojik yenilik ve globalleşmenin ekonomideki istihdam ve üretim yapısındaki etkiler ortaya çıkmaktadır (Öztürk ve Başar, 2002). Landefeld ve Fraumeni bilgi ekonomisini geniş anlamda tanımlamıştır. Landefeld ve Fraumeni’ye göre bilgi ekonomisi reel GSYH ve kişi başına reel GSYH'da güçlü büyüme, verimlilikte artış, daha yüksek karlılık, daha yüksek yatırım oranları, düşük enflasyon, düşük işsizlik ve gelir artışı olarak tanımlanmaktadır (Landefeld ve Fraumeni, 2001).

Bilgi ekonomisinin dört unsuru bulunmaktadır. Bunlar; yerli ve yabancı inovasyonların geliştirilmesi ve ticarileştirilmesi için gerekli olan inovasyon politikaları, kurumları ve teşvikleri, yani ulusal bir inovasyon sisteminin oluşturulması, insan kaynakları gelişimi, özellikle bilgi uzmanları havuzu ve teknolojiden oluşan işgücü havuzu ile ulusal eğitim sisteminin geliştirilmesi, bilgi ve İletişim teknolojileri (BİT), bilgi ekonomisinin gelişimi için elverişli bir iş ortamıdır (World Bank, 2004).

Bilgi ekonomisinin özellikleri şunlardır (Kevük,2006):

- Bilgi ekonomisi bilginin katma değer yarattığını kabul eder.

- Bilgi ekonomisi dijital bir ekonomidir.

- Bilgi ekonomisi yeni bir ekonomidir.

- Bilgi ekonomisi şebeke ekonomi niteliğindedir.

- Bilgi ekonomisinde sanallaşma önemli rol oynamaktadır.

- Bilgi ekonomisinde üretim miktarı arttıkça üretim maliyeti azalmaktadır.

- Bilgi ekonomisi bir ağ ekonomisidir.

- Bilgi ekonomisi sürtüşmesiz bir ekonomidir.

- Bilgi ekonomisinde aracılar büyük ölçüde ortadan kalkmaktadır.

- Bilgi ekonomisi bilgi mallarını ortaya çıkarmıştır.

- Bilgi ekonomisinin hakim sektörü üçlü (bilgisayar, iletişim ve eğlence) bir oluşumdur.

- Bilgi ekonomisi bazı sosyal problemleri de beraberinde getirmektedir.

- Bilgi ekonomisi yenilik temelli bir ekonomidir.

- Bilgi ekonomisi küresel bir ekonomidir.

- $\quad$ Bilgi ekonomisinde üretici ve tüketici farkı belirsizleşmektedir.

- Bilgi ekonomisi bir hız ekonomisidir.

Yeni ekonomi yani bilgi ekonomisi kavramı 12 temel karakteristik üzerine kurulmuştur. Bunlar; bilgi, dijitalleşme, sanallaşma, küçük parçalara ayırma, ağ iletişimi, aracının olmaması, yakınlaşma, yenilikçilik, tüketerek üretme, globalleşme(küreselleşme), doğrudanlık ve uyumsuzluktur (Tapscott,1996).

Bilgi ekonomisine dönüşüm teşvik edilmesi gereken bir süreçtir. Dünya ekonomilerinin daha çok bilgi yoğun boyut kazanmasında kamu sektörünün rolü oldukça büyüktür. Bilgi ekonomisinin verimlilik, rekabet ve büyüme gibi getirileri için aktif kamu müdahalesine gereksinim duyulmaktadır. $\mathrm{Bu}$ nedenle de güçlü bir altyapının oluşturulması önemli bir konu olmaktadır. Bu nedenle beşeri sermaye ihtiyacının giderilmesi, araştırma ve geliştirme faaliyetlerinin teşvik edilmesi, fikri mülkiyet haklarının korunması, girişimcilik kültürünün arttırılması ve ulusal geliştirme sisteminin kurulması kamu sektörünün bilgi ekonomisi kapsamında yapması gereken 
alanlardır. Günümüzde gelişmiş bir ekonomi olmak için bilgi ekonomisine dönüşüm sağlanmalıdır (Ekizceleroğlu, 2011).

Bilgi ve teknoloji kavramı iktisat literatüründe uzun yıllar boyunca yer almıştır. Adam Smith ve Karl Marks teknolojinin insanı özgürleştirmek için temel güç olduğunu ifade etmişlerdir. Alfred Marshall bilgiyi ekonomik büyümenin temel lokomotifi olarak tanımlamıştır. Friedrich List ise yaşadığı dönem içinde sanayi sektöründe Almanya'nın İngiltere karşısında geri kalmasını klasik iktisatçıların bilim ve teknolojiye yeterince önem vermemesinden kaynaklandığını ifade etmiştir. Aynı zamanda List, ulusal yenilik sistemlerinin geliştirilmesine liderlik etmiştir. Charles Babbage, yaşadığı dönemde teknolojik değişmenin kapsamının ekonomik analizini yapan ilk iktisatçı olmuştur. Aynı zamanda Charles Babbage modern bilgisayarın ilk mucididir. İktisat teorisinde öncü olarak nitelendirilebilecek bu çalışmalar Neoklasik iktisatçılar tarafindan geri plana atılmıştır. Teknolojik değişmelerin etkilerini en iyi analiz yapan Neoklasik iktisatçı Joseph Schumpeter'dir. Schumpeter'a göre ise ekonomik değişmeyi yaratan en önemli unsur yeniliktir. Daha sonraki dönemlerde ise çoğu iktisatçı farklı teknolojik performans ile ekonomik büyüme aşamaları arasındaki ilişkiyi gelişmiş ülkeler açısından tarihsel veriler kullanarak ele almışlardır (Adaçay, 2008-2009).

\section{Türk Ekonomisinin Bilgi Ekonomisi Performansı}

Çalışmamızın bu bölümünde, bilgi ekonomisinin kapsamı ve önemi vurgulanmış olduğundan Türk ekonomisinin bilgi ekonomisi bağlamında performansı ele alınacaktır. Öncelikle Ar-Ge harcamalarına değinildikten sonra Ar-ge personel sayıları, merkezi yönetim bütçesinden Ar-Ge faaliyetleri için ayrılan pay ve patent tescil ve başvuru sayıları bilgi ekonomisi performansını değerlendirme noktasında anlamlı olacaktır.

OECD ülkeleri ile Türk ekonomisini mukayese ederken de kullanacağımız en anlamlı veri Türkiye'de Ar-Ge harcamalarının GSYH' ya oranıdır. Bu orandaki değişimi 2014-2017 yılları arasında analiz ettiğimiz zaman 2014 yılında 0,86'ya ulaşan Ar-Ge/GSYH oranı 2017 yılında 0,96 olarak kaydedilmiştir. Bu büyük bir değişime işaret etmektedir.

Toplam Ar-Ge harcaması 2014 yılında 17,5 milyar TL iken, 2017 yılında 29,8 milyar TL'ye yükselmiştir. Geçen dört yılda Ar-Ge harcamasında görülen artış oldukça dikkat çekicidir. Harcamanın bileşenlerine bakıldığı zaman büyük bölümü personel harcamaları olarak görülmektedir. 2014 yılında Ar-Ge personeline yapılan toplam harcama 9,2 milyar TL iken 2017 yılında 15,1 milyar TL'ye yükselmiştir. Ar-Ge faaliyetlerinin devamlılığı hususunda en önemli harcama kalemi olan yatırım harcamaları ise 2014 yılında 2 milyar TL seviyesinden 2017 yılında 3 milyar TL düzeyine çıkmıştır. 2017 yılında devletin Ar-Ge yatırım harcaması 566 milyon TL’ye, özel sektörün 1,1 milyar TL'ye ve yükseköğretim kurumlarının 1,4 milyar TL'ye ulaştığı gözlemlenmektedir. Ar-Ge yatırım harcaması açısından lokomotif sektörün yükseköğretim kurumları olduğu açıkça görülmektedir.

\begin{tabular}{|c|c|c|c|c|}
\hline & 2014 & 2015 & 2016 & 2017 \\
\hline $\begin{array}{c}\text { Gayrisafi yurtiçi Ar-Ge harcaması / } \\
\text { GSYH }\end{array}$ & 0.86 & 0.88 & 0.94 & 0.96 \\
\hline Toplam Ar-Ge harcaması & 17598117442 & 20615247954 & 24641251935 & 29855477805 \\
\hline Ar-Ge personel harcaması (TL) & 9219848997 & 11054399404 & 12308650274 & 15167428953 \\
\hline Diğer cari Ar-Ge harcamaları (TL) & 6140815114 & 7210787469 & 9569443464 & 11586259745 \\
\hline Ar-Ge yatırım harcamas1 (TL) & 2237453331 & 2350061081 & 2763158198 & 3101789107 \\
\hline Mali ve mali olmayan şirketler & 8760019770 & 10308737689 & 13359011600 & 16980836067 \\
\hline Ar-Ge personel harcamas1 (TL) & 4365472509 & 5272535462 & 6447876085 & 8944197691 \\
\hline Diğer cari Ar-Ge harcamaları (TL) & 3362671966 & 4077339639 & 5822105491 & 6932002429 \\
\hline Ar-Ge yatırım harcaması (TL) & 1031875295 & 958862588 & 1089030024 & 1104635947 \\
\hline Genel devlet & 1705399800 & 2130766481 & 2338372843 & 2858435052 \\
\hline Ar-Ge personel harcaması (TL) & 873771617 & 976677137 & 1104236867 & 1218108005 \\
\hline Diğer cari Ar-Ge harcamaları (TL) & 520436968 & 599847914 & 797911223 & 1074321829 \\
\hline Ar-Ge yatırım harcaması (TL) & 311191215 & 554241430 & 436224753 & 566005218 \\
\hline Yükseköğretim & 7132697872 & 8175743784 & 8943867493 & 10016206686 \\
\hline Ar-Ge personel harcaması (TL) & 3980604871 & 4805186805 & 4756537322 & 5005123257 \\
\hline Diğer cari Ar-Ge harcamaları (TL) & 2257706180 & 2533599916 & 2949426750 & 3579935487 \\
\hline Ar-Ge yatırım harcaması (TL) & 894386821 & 836957063 & 1237903421 & 1431147942 \\
\hline Ar-Ge insan kaynağı (Sayı) & 213686 & 224284 & 242213 & 266478 \\
\hline Mali ve mali olmayan şirketler & 73737 & 77551 & 83873 & 101404 \\
\hline Genel devlet & 13903 & 14217 & 13372 & 12828 \\
\hline Yükseköğretim & 126046 & 132516 & 144968 & 152246 \\
\hline Ar-Ge insan kaynağı (TZE) & 115444 & 122288 & 136953 & 153552 \\
\hline Mali ve mali olmayan şirketler & 61945 & 66667 & 72579 & 87918 \\
\hline Genel devlet & 12230 & 12328 & 11799 & 11345 \\
\hline Yükseköğretim & 41269 & 43293 & 52576 & 54289 \\
\hline
\end{tabular}

Tablo 1.Ar-Ge Faaliyeti Istatistikleri Kaynak: Türkiye İstatistik Kurumu. 
Ar-Ge faaliyetinde istihdam edilen personel sayısı ele alındığı zaman 2014 yılında yaklaşık 213 bin kişi iken, 2017 yılında bu sayı 266 bin civarına yükselmiştir. Sektörler açısından bakıldığında, yükseköğretim kurumlarının en büyük payı alarak, bu sahada 2014 yılında 126 bin civarında personel istihdam etmekte iken 2017'de 152 bin civarında personel çalıştırdığı görülmektedir. Devletin istihdam ettiği personel sayısı 2014 yılında 13 bin olarak kaydedilmişken 2017 yılında 12 bin kadardır. Özel kesim 2014 yılında 73 bin Ar-Ge personeli istihdam etmekte iken, 2017 yılında 101 bin personel çalıştırdığı göze çarpmaktadır. Ar-Ge faaliyetinde bulunan işgücünün tam zaman eşdeğerliliğinde çalışmasını dikkate alacak olursak 2014 yılında 115 bin iken 2017 yılında 153 bin seviyesine çıktığı görülmektedir.

\begin{tabular}{|c|c|c|}
\hline Yll & Ar-Ge Harcamaları(milyon TL) & Dolaylı Ar-Ge Destekleri(milyon TL) \\
\hline 2010 & 4188 & 518 \\
\hline 2011 & 4961 & 614 \\
\hline 2012 & 5305 & 752 \\
\hline 2013 & 6853 & 835 \\
\hline 2014 & 6733 & 1282 \\
\hline 2015 & 8037 & 1653 \\
\hline 2016 & 9116 & 2126 \\
\hline 2017 & 10710 & 2871 \\
\hline 2018 & 12950 & - \\
\hline
\end{tabular}

Tablo 2.Merkezi Yönetim Bütçesinden Ar-Ge Harcamaları için Ayrllan Pay Kaynak: Türkiye İstatistik Kurumu.

Merkezi yönetim bütçesinden Ar-Ge faaliyetlerine ayrılan paylar da şüphesiz Türk ekonomisinin bilgi ekonomisine dair performans göstergelerinden biridir. 2010-2018 yılları arasında 4,1 milyon TL olan Ar-Ge harcamalarının 12,9 milyon TL'ye ulaştı̆̆ı görülmektedir. Ar-Ge çalışmalarına ilişkin; indirim, istisna ve muafiyetleri kapsayan dolaylı Ar-Ge destekleri ise 518 bin TL'den 2,8 milyon TL'ye yükselmiştir.

Bir diğer önemli husus sosyo-ekonomik hedefler bağlamında Ar-Ge harcamalarının yapıldığı alanların belirlenmesidir.

\begin{tabular}{|c|c|c|c|c|c|c|c|}
\hline Yil & $\begin{array}{l}\text { Yeryüzünün } \\
\text { Keşfi ve } \\
\text { Kullanımı }\end{array}$ & Çevre & $\begin{array}{l}\text { Uzayın Keşfi } \\
\text { ve Kullanımı }\end{array}$ & $\begin{array}{c}\text { Altyapi } \\
\text { Faaliyetleri }\end{array}$ & Enerji & $\begin{array}{l}\text { Endüstriyel } \\
\text { Üretim ve } \\
\text { Teknoloji }\end{array}$ & Sağlık \\
\hline 2010 & 2,6 & 1,2 & 1,1 & 0,5 & 1,9 & 9,4 & 2,7 \\
\hline 2011 & 2,4 & 1,7 & 0,7 & 0,4 & 1,7 & 7,9 & 1,3 \\
\hline 2012 & 2,6 & 1,2 & 0,3 & 0,4 & 1,5 & 9,0 & 1,1 \\
\hline 2013 & 1,8 & 0,8 & 0,1 & 0,7 & 1,0 & 12,4 & 0,2 \\
\hline 2014 & 2,3 & 0,9 & 0,2 & 0,4 & 0,6 & 14,7 & 0,3 \\
\hline 2015 & 2,7 & 1,9 & 0,3 & 2,6 & 2,2 & 14,1 & 2,2 \\
\hline 2016 & 1,8 & 1,3 & 0,3 & 6,4 & 1,7 & 9,9 & 1,9 \\
\hline 2017 & 2,3 & 1,0 & 0,3 & 4,4 & 1,6 & 9,4 & 2,6 \\
\hline 2018 & 2,0 & 0,9 & 0,2 & 4,0 & 1,6 & 7,7 & 2,1 \\
\hline Y1l & Tarım & Eğitim & $\begin{array}{l}\text { Kültür, } \\
\text { eğlence }\end{array}$ & $\begin{array}{l}\text { Siyasi ve } \\
\text { Sosyal } \\
\text { Yapılar }\end{array}$ & $\begin{array}{l}\text { Bilgi Gelişimi- } \\
\text { Üniversite Fonları } \\
\text { ile Sağlanan }\end{array}$ & $\begin{array}{c}\text { Bilgi Gelişimi- } \\
\text { Diğer } \\
\text { Kaynaklar } \\
\end{array}$ & Savunma \\
\hline 2010 & 2,7 & 1,6 & 0,0 & 0,5 & 49,4 & 6,3 & 20,0 \\
\hline 2011 & 3,0 & 1,2 & 0,0 & 0,9 & 53,2 & 7,7 & 18,0 \\
\hline 2012 & 2,5 & 1,9 & 0,0 & 1,0 & 56,4 & 7,9 & 14,1 \\
\hline 2013 & 1,9 & 0,9 & 0,0 & 0,4 & 47,5 & 6,6 & 25,6 \\
\hline 2014 & 1,9 & 2,4 & 0,7 & 0,4 & 54,6 & 9,3 & 11,4 \\
\hline 2015 & 3,2 & 3,3 & 0,1 & 1,0 & 53,2 & 2,6 & 10,7 \\
\hline 2016 & 2,6 & 6,4 & 0,1 & 0,5 & 51,3 & 2,8 & 13,1 \\
\hline 2017 & 2,5 & 5,3 & 0,0 & 0,5 & 48,2 & 4,4 & 17,3 \\
\hline 2018 & 3,1 & 5,0 & 0,0 & 0,7 & 41,2 & 3,1 & 28,5 \\
\hline
\end{tabular}

Tablo 3. Sosyo-Ekonomik Hedeflere Göre Merkezi Yönetim Bütçesinden Ar-Ge Faaliyetleri İçin Yapılan Harcamaların Oranı (\%) Kaynak: Türkiye İstatistik Kurumu.

Ar-Ge harcamalarının belirli sosyo-ekonomik hedeflere yönlendirilmesi, ülkenin bilgi ekonomisi bağlamında performans ölçütlerinden biri olacaktır. 2010 yılından 2018 yılına kadar yeryüzünün keşfi ve kaynakların kullanımı üzerine yapılan harcamaların yatay bir gelişim içinde olduğunu ifade etmek mümkündür. 2010 yılında \%2,6 iken dönem içinde fazla dalgalanma göstermeksizin 2018 yılında \%2 olarak gerçekleşmiştir. Çevreye ilişsin ayrılan pay da 2010 yılında \%1,2 iken 2018 yılında \%0,9 olarak kaydedilmiştir. Uzayın keşfi ve kullanımı ise dikkat çekici ölçüde ayrılan kaynağın yıldan yıla azaldığı bir görünüm arz etmektedir. 2010 yılında \%1,1 iken 2018 yılında ciddi bir gerileme ile \%0,2 olmuştur. Buna karşın altyapı faaliyetleri için yapılan Ar-Ge harcamaları aynı dönemlerde \%0,5 olan seviyesinden \%4'e yükselmiştir. Enerji alanında merkezi yönetim Ar-Ge harcaması 
2010 yılında \%1,9 iken, 2014 yılına kadar gerileyerek \%0,6 olduğu, bu tarihten sonra yeniden yükselerek \%1,6 ile dönemi kapattığı görülmektedir. Endüstriyel üretim ve teknolojiler için sarf edilen Ar-Ge harcaması oranı 2010'da \%9,4 iken, dönem içinde \%14,7 düzeyine kadar çıkmış ve 2018 yılında \% 7,7 olarak gerçekleşmiştir. Sağlık kesimine yapılan Ar-Ge harcamalarına bakıldığında oran, 2010 yılında \%2,7 iken 2013 yılında \%0,2'ye kadar gerilemiş, 2018 yılında ise \%2,1 düzeyine yükselmiştir. Tarım sektörüne ayrılan Ar-Ge harcaması payı 2010 yılında \%2,7 iken 2018 yılında \%3,1 olarak gerçekleşmiş ve dönem içinde yatay bir seyir izlemiştir. Eğitim için yönlendirilen Ar-Ge harcamasına bakıldığında, 2010 yılında \%1,6 iken, 2018 yılında \%5 seviyesine yükseldiği görülecektir. Kültür-eğlence sahası için Ar-Ge harcamaları dönem içerisinde en küçük paya sahip alandır. Merkezi yönetim bütçesinden siyasi ve sosyal yapılar, süreçler için ayrılan pay 2010 yılında \%0,5 iken, 2018 y1lında \%0,7 olarak gerçekleşmiştir. Üniversiteler aracılığıyla bilginin gelişimi için yapılacak Ar-Ge harcamalarına ayrılan oran 2010 yılında \%49,4 iken 2018 yılında \%41,2 olarak kaydedilmiştir. İlgili dönemde en yüksek değer \%56,4 olup 2012 yılına işaret etmektedir. Merkezi yönetimin Ar-Ge harcaması kompozisyonunda şüphesiz en dikkat çekici sahalardan biri savunmadır. 2010 yılında savunma için ayrılan pay \%20 iken, 2012 yılında \%14,1'e gerilemiş ve hemen ardından 2013 yılında \%25,6 olarak gerçekleşmiştir. 2015 yılında \%10,7'ye gerilerken 2018 yılında \%28,5 oranına ulaşarak en önemli ikinci kalem olmuştur.

Merkezi yönetimin Ar-Ge harcamalarını yönlendirmesine bakarak bugün en önemli sahaların, bilgi gelişimi için üniversiteler, savunma, endüstriyel üretim ve teknoloji, eğitim ve altyapı olarak sıralandığı açıkça görülmektedir. $\mathrm{Bu}$ rakamlar politikaların hangi alanları öncelediğini ve vurguladığını ifade etmesi açısından oldukça önemlidir.

Bilgi ekonomisine dair performans değerlendirmesinde bir diğer önemli kriter, patent başvuru sayılarıdır. Bu değerlendirme kapsamında karşımıza şu veriler çıkmıştır:

\begin{tabular}{|c|c|c|c|c|c|c|c|c|c|c|c|c|}
\hline \multirow{2}{*}{ Yil } & \multicolumn{5}{|c|}{ Yerli } & \multicolumn{5}{|c|}{ Yabanc1 } & \multirow{2}{*}{$\begin{array}{l}\text { Genel } \\
\text { Toplam }\end{array}$} & \multirow{2}{*}{$\begin{array}{l}\text { Genel } \\
\text { Artış } \\
\text { Oranı }\end{array}$} \\
\hline & $\begin{array}{c}\text { Türk } \\
\text { Patent }\end{array}$ & PCT & EPC & Toplam & $\begin{array}{l}\text { Artış } \\
\text { Oranı }\end{array}$ & $\begin{array}{c}\text { Türk } \\
\text { Patent }\end{array}$ & PCT & EPC & Toplam & $\begin{array}{l}\text { Artış } \\
\text { Oranı }\end{array}$ & & \\
\hline 2010 & 3120 & 60 & 70 & 3250 & $25.58 \%$ & 77 & 100 & 4916 & 5093 & $9.46 \%$ & 8343 & $15.22 \%$ \\
\hline 2011 & 3962 & 43 & 82 & 4087 & $25.75 \%$ & 120 & 100 & 5934 & 6154 & $20.83 \%$ & 10241 & $22.75 \%$ \\
\hline 2012 & 4360 & 74 & 109 & 4543 & $11.16 \%$ & 78 & 154 & 6824 & 7056 & $14.66 \%$ & 11599 & $13.26 \%$ \\
\hline 2013 & 4345 & 54 & 129 & 4528 & $-0.33 \%$ & 95 & 175 & 7257 & 7527 & $6.68 \%$ & 12055 & $3.93 \%$ \\
\hline 2014 & 4654 & 112 & 95 & 4861 & $7.35 \%$ & 149 & 183 & 7182 & 7514 & $-0.17 \%$ & 12375 & $2.65 \%$ \\
\hline 2015 & 5302 & 50 & 160 & 5512 & $13.39 \%$ & 251 & 238 & 7957 & 8446 & $12.40 \%$ & 13958 & $12.79 \%$ \\
\hline 2016 & 6153 & 88 & 204 & 6445 & $16.93 \%$ & 407 & 211 & 9715 & 10333 & $22.34 \%$ & 16778 & $20.20 \%$ \\
\hline 2017 & 7994 & 181 & 450 & 8625 & $33.82 \%$ & 202 & 178 & 10278 & 10658 & $3.15 \%$ & 19283 & $14.93 \%$ \\
\hline 2018 & 7114 & 42 & 193 & 7349 & $-14.79 \%$ & 137 & 173 & 10845 & 11155 & $4.66 \%$ & 18504 & $-4.04 \%$ \\
\hline
\end{tabular}

Tablo 4. Patent Başvuru Sayıları Kaynak: https://www.turkpatent.gov.tr/TURKPATENT/statistics/

Türkiye'de 2010-2018 yılları arasında yerli patent başvurularında artış oranlarına bakıldığında 2010 yılında bir önceki yıla göre \%25 iken 2013 yılında \% -0,33 düzeyine gerilediği görülmektedir. Dönemin en yüksek artış oranı 2017 yılında \%33 olarak kaydedilmişken, 2018 yılında \%-14,79 gibi ciddi bir orana gerilediği göze çarpmaktadır. Yabancı patent başvurularında 2010 yılında bir önceki yıla göre \%9 düzeyinde bir artış görülmüşken 2014 yılında \%-0,17'ye gerilemiştir. 2018 yılında yabancı patent başvurusu artış oranı \%4'tür.

\begin{tabular}{|c|c|c|c|c|c|c|c|c|c|c|c|c|}
\hline \multirow{2}{*}{ Yil } & \multicolumn{5}{|c|}{ Yerli } & \multicolumn{5}{|c|}{ Yabanc1 } & \multirow{2}{*}{$\begin{array}{l}\text { Genel } \\
\text { Toplam }\end{array}$} & \multirow{2}{*}{$\begin{array}{l}\text { Genel } \\
\text { Artış } \\
\text { Oranı }\end{array}$} \\
\hline & $\begin{array}{c}\text { TÜRK } \\
\text { PATENT }\end{array}$ & PCT & EPC & Toplam & $\begin{array}{l}\text { Artış } \\
\text { Oran1 } \\
\end{array}$ & $\begin{array}{c}\text { TÜRK } \\
\text { PATENT }\end{array}$ & PCT & EPC & Toplam & $\begin{array}{l}\text { Artış } \\
\text { Oranı } \\
\end{array}$ & & \\
\hline 2010 & 507 & 66 & 69 & 642 & $40.79 \%$ & 83 & 110 & 4675 & 4868 & $-5.55 \%$ & 5510 & $-1.78 \%$ \\
\hline 2011 & 714 & 59 & 74 & 847 & $31.93 \%$ & 56 & 67 & 5569 & 5692 & $16.93 \%$ & 6539 & $18.68 \%$ \\
\hline 2012 & 879 & 44 & 102 & 1025 & $21.02 \%$ & 28 & 53 & 6710 & 6791 & $19.31 \%$ & 7816 & $19.53 \%$ \\
\hline 2013 & 1068 & 33 & 143 & 1244 & $21.37 \%$ & 43 & 68 & 7570 & 7681 & $13.11 \%$ & 8925 & $14.19 \%$ \\
\hline 2015 & 1471 & 96 & 163 & 1730 & $38.29 \%$ & 33 & 123 & 8214 & 8370 & $14.99 \%$ & 10100 & $18.41 \%$ \\
\hline 2016 & 1563 & 48 & 183 & 1794 & $3.70 \%$ & 64 & 91 & 9125 & 9280 & $10.87 \%$ & 11074 & $9.64 \%$ \\
\hline 2017 & 1713 & 44 & 207 & 1964 & $9.48 \%$ & 47 & 96 & 10317 & 10460 & $12.72 \%$ & 12424 & $12.19 \%$ \\
\hline 2018 & 2558 & 39 & 208 & 2805 & $42.82 \%$ & 197 & 88 & 10792 & 11077 & $5.90 \%$ & 13882 & $11.74 \%$ \\
\hline
\end{tabular}

Tablo 5. Patent Tescil Sayllarl Kaynak: https://www.turkpatent.gov.tr/TURKPATENT/statistics/

Patent tescil sayıları da bilgi ekonomisi performansını ortaya koymak açısından önem arz etmektedir. Yerli patent tescili 2010 yılında bir önceki yıla göre \%40 oranında artmışken, 2014 yılında \%0,56 ve 2018 yılında \%42 düzeyinde artmıştır. Yabancı patent tescil sayısına bakıldığında 2010 yılında bir önceki yıla göre tescillenen patent sayısı \%-5 oranında azalmıştır. 2012 yılında \%19 artan yabancı patentleri 2018 yılında \%5 civarında bir artış gözlemlenmektedir.

Türkiye'nin bilgi ekonomisi performansı açısından edinebildiğimiz bir diğer gösterge bilimsel yayın sayısıdır: 


\begin{tabular}{|c|c|c|c|c|}
\hline & Yıl & Yayın Sayısı & Atıf Sayısı & Etki Değeri \\
\hline Toplam & $2011-2015$ & 225090 & 996946 & 345.65 \\
\hline
\end{tabular}

Tablo 6. Bilimsel Yayın Sayıları Kaynak: https://cabim.ulakbim.gov.tr/bibliyometrik-analiz/turkiye-bilimselyayin-performans-raporlari/turkiye-illerinin-bilimsel-yayin-performansi-2011-2015-raporu/

2011-2015 yılları arasında 225 bin adet bilimsel yayın yapılmış olup, bu yayınlara yapılan atıf sayısı 996 bin dolayındadır. Bu yayınların etki değeri 345 olarak ölçümlenmiştir.

Türkiye'nin OECD ülkeleri arasında bilgi ekonomisi kapsamında bulunduğu konumu değerlendirmek adına bilgi ekonomisi indeksi ve bilgi indeksi başta olmak üzere bazı verilerin ele alınması anlamlı olacaktır. Bilgi Ekonomisi Endeksi (KEI), ekonomik büyüme ve gelişmenin sağlanabilmesi için söz konusu ekonomik yapıda bilginin etkin kullanılıp kullanılmadığını ortaya koymaktadır. Endeks değeri 10'a yaklaştıkça ülke bilgi ekonomisi olmaya yaklaşmaktadır. Endeks, ekonomik teşvikler, eğitim, yenilik, bilgi ve iletişim teknolojileri alt endekslerinden müteşekkildir. Bilgi Endeksi (KI) ise, ülkenin; bilgiyi yaratma, uyarlama ve yayma yeteneğini ortaya koymakta iken değerin 10’a yaklaşması beklenmektedir.

\begin{tabular}{|c|c|c|c|c|c|c|c|}
\hline $\begin{array}{c}\text { Sira } \\
\text { No }\end{array}$ & Ülkeler & KEI & KI & $\begin{array}{c}\text { Ekonomik } \\
\text { Teşvikler }\end{array}$ & İnovasyon & Eğitim & BİT \\
\hline 1 & İsveç & 9.43 & 9.38 & 9.58 & 9.74 & 8.92 & 9.49 \\
\hline 2 & Finlandiya & 9.33 & 9.22 & 9.65 & 9.66 & 8.77 & 9.22 \\
\hline 3 & Danimarka & 9.16 & 9.00 & 9.63 & 9.49 & 8.63 & 8.88 \\
\hline 4 & Hollanda & 9.11 & 9.22 & 8.79 & 9.46 & 8.75 & 9.45 \\
\hline 5 & Norveç & 9.11 & 8.99 & 9.47 & 9.01 & 9.43 & 8.53 \\
\hline 6 & Yeni Zelanda & 8.97 & 8.93 & 9.09 & 8.66 & 9.81 & 8.30 \\
\hline 7 & Kanada & 8.92 & 8.72 & 9.52 & 9.32 & 8.61 & 8.23 \\
\hline 8 & Almanya & 8.90 & 8.83 & 9.10 & 9.11 & 8.20 & 9.17 \\
\hline 9 & Avustralya & 8.88 & 8.98 & 8.56 & 8.92 & 9.71 & 8.32 \\
\hline 10 & İsviçre & 8.87 & 8.65 & 9.54 & 9.86 & 6.90 & 9.20 \\
\hline 11 & İlanda & 8.86 & 8.73 & 9.26 & 9.11 & 8.87 & 8.21 \\
\hline 13 & ABD & 8.77 & 8.89 & 8.41 & 9.46 & 8.70 & 8.51 \\
\hline 14 & İngiltere & 8.76 & 8.61 & 9.20 & 9.12 & 7.27 & 9.45 \\
\hline 15 & Belçika & 8.71 & 8.68 & 8.79 & 9.06 & 8.57 & 8.42 \\
\hline 16 & İzlanda & 8.62 & 8.54 & 8.86 & 8.00 & 8.91 & 8.72 \\
\hline 17 & Avusturya & 8.61 & 8.39 & 9.26 & 8.87 & 7.33 & 8.97 \\
\hline 19 & Estonya & 8.40 & 8.26 & 8.81 & 7.75 & 8.60 & 8.44 \\
\hline 20 & Lüksemburg & 8.37 & 8.01 & 9.45 & 8.94 & 5.61 & 9.47 \\
\hline 25 & İsrail & 8.14 & 8.07 & 8.33 & 9.39 & 7.47 & 7.36 \\
\hline 30 & İtalya & 7.89 & 7.94 & 7.76 & 8.01 & 7.58 & 8.21 \\
\hline 40 & Şili & 7.21 & 6.61 & 9.01 & 6.93 & 6.83 & 6.05 \\
\hline 69 & Türkiye & 5.16 & 4.81 & 6.19 & 5.83 & 4.11 & 4.50 \\
\hline 72 & Meksika & 5.07 & 5.13 & 4.88 & 5.59 & 5.16 & 4.65 \\
\hline
\end{tabular}

Tablo 7. OECD Ülkelerinin Bilgi Ekonomisi İndeksine Göre Siralanması, Kaynak: World Bank, Knowledge for Development, KI and KEI Indexes, 2012

Tabloya bakıldığında, bilgi ekonomisi endeksine göre; İsveç, Finlandiya ve Danimarka en önde gelen OECD ülkeleri olarak dikkat çekmektedir. Bilgi ekonomisi indeksinin alt bileşenlerine göre değerlendirme yapılacak olursa, ekonomik teşvikler bakımından sıralama değişmiş Finlandiya, Danimarka ve İsveç ilk üçte yer alan ülkeler olmuşlardır. İsviçre, İsveç, Finlandiya inovasyon anlamında en önde gelen ülkelerdir. Eğitim bileşeni açısından ilk üç ülke; Yeni Zelanda, Avustralya ve Kanada olmuştur. Son olarak bilgi iletişim teknolojileri açısından en önde gelen ülkeler; İsveç, Lüksemburg ve Hollanda'dır.

Türkiye bu rapora göre, OECD ülkeleri arasında kendisine son sıralarda yer bulmuştur. Ardından yalnızca Meksika gelmektedir. Bilgi ekonomisinin alt bileşenlerinden olan ekonomik teşvikler hususunda görece en iyi performansın sergilendiği, Türkiye'nin en yetersiz olduğu sahanın ise eğitim olduğu göze çarpmaktadır.

\section{Sonuç ve Değerlendirme}

Bilgi ekonomisi, kapitalizmin ve globalizmin ekonomik anlamda bir yansıması olarak tezahür etmektedir. İktisadi faaliyetlerin bilgiyi öncelediği, tüm süreçlere bir girdi olarak bilgiyi dahil ettiği yani bilgi temelli bir ekonomidir. Bilgi ekonomisi; bilginin elde edilmesi, işlenmesi ve transformasyonu ve dağıtımı süreçlerinden müteşekkildir. Günümüz ekonomik şartlarında, hem mikro bazda işletmelerin ve hem de makro bazda ülke 
ekonomisinin başarısı bilginin üretilmesi, bilginin ele geçirilmesi, içselleştirilmesi ve etkin bir şekilde kullanılabilmesine bağlıdır.

Çalışmamız kapsamında Türkiye'nin bilgi ekonomisine dair performans ölçütlerini belirlemeye çalışarak bunları gözler önüne serdik. Öncelikle bilgi ekonomisi kapsamında Ar-Ge harcamaları/GSYH göstergesinde 2014-2017 yılları arasında yaşanan değişime bakıldığı zaman oranın 0,86 'dan 0,97 'ye hızla yükseldiği göze çarpmaktadır. Merkezi yönetim bütçesinden Ar-Ge faaliyetleri için ayrılan pay 2010 yılında 4,1 milyon TL iken, 2018'de 12,9 milyon TL'ye ulaştığı görülmektedir. Ar-Ge çalışmalarına ilişkin; indirim, istisna ve muafiyetleri kapsayan dolaylı Ar-Ge destekleri ise, 518 bin TL'den 2,8 milyon TL'ye yükselmiştir. Merkezi yönetimin Ar-Ge harcamalarını yönlendirmesine bakıldığında önem verilen sahaların, bilgi gelişimi için üniversiteler, savunma, endüstriyel üretim ve teknoloji, eğitim ve altyapı olarak sıralandığı açıkça görülmektedir. 2010-2018 yılları arasında patent başvuru ve tescil verileri de bilgi ekonomisinin gücünü ortaya koyma açısından önemlidir. Yerli patent başvuruları 2010 yılında 3250, tescillenen 642 iken, 2018 yılında 7349 başvuru yapılmış tescillenen patent sayısı 2805 olarak kaydedilmiştir. Patent ve markalaşma anlamında ciddi bir gelişme olduğu göze çarpmaktadır.

Türkiye'nin OECD ülkeleri arasında bilgi ekonomisi kapsamında bulunduğu konumu değerlendirdiğimiz zaman, her ne kadar analiz ettiğimiz komponentler arasında zaman içinde bir ivmelenme olsa da, son sıralarda yer aldığı göze çarpmaktadır. Ancak Dünya Bankası'nın son raporunun 2012 yılında yayınlandığı göz önünde bulundurulursa, bugün ortaya çıkacak olan sıralamada kendisine daha üst sıralarda yer bulacağı aşikardır.

Merkezi yönetimin Ar-Ge faaliyetlerine ayırdığı bütçenin artırılması gerekmekte iken, bu harcamaların doğru yönlendirilmesi de oldukça önemli bir husustur. Uzay araştırmaları gibi önemli bir sahanın yıllar geçtikçe daha az bütçelendirilmesi dikkat çeken bir eksikliktir.

\section{Kaynakça}

- Adaçay, F.R. 2008-2009. "Bilgi Ekonomisinin Mikro Ekonomik Analizi: Eleştirel Bir Bakış”. FBE Journal View of Social Economic and Business Studies, Volume: 10/11, p. 1-25.

- Aktan, C.C . ve Vural,İ.2016. "Bilgi Toplumu, Yeni Temel Teknolojiler ve Yeni Ekonomi”. Yeni Türkiye, Say1: 88. Cilt 1, Bilim ve Teknoloji Özel Sayısı.

- Bosworth,B.P. ve Triplett, J. E. 2000.“What's New About The New Economy? It, Economic Growth and Productıvity”.https://www.brookings.edu/wp-content/uploads/2016/06/20001020.pdf,Erişim Tarihi: 28.03.2019.

- Ekizceleroğlu, C. 2011. “Türkiye’de Bilgi Ekonomisi ve Bilgi Yoğun Malların Dış Ticareti (1969-2009)”. Marmara Üniversitesi İ.I.B.F. Dergisi, Cilt: XXX, Say1: 1, p.209-228.

- Erdoğan, S. 2004. "İktisat Politikası Uygulamaları Üzerindeki Etkisi Açısından Yeni Ekonomi”. Kocaeli Üniversitesi Sosyal Bilimler Enstitüsü Dergisi, 2, p.38-48.

- Fidan, H. 2013. "İktisadi Açıdan Bilgi Kavramı Ve Bilgi Kavramına Yaklaşımlar Üzerine Bir İnceleme”. Süleyman Demirel Üniversitesi Vizyoner Dergisi, Cilt: 4, Sayı: 9, p. 94-104.

- Godin, B.2008. “The Knowledge Economy: Fritz Machlup's Construction of Synthetic Concept, Project on the History and Sociology of S\&T Statistics". Working Paper No: 37.

- Gordon, R.J. 2000. "Does the "New Economy" Measure up to the Great Inventions of the Past?".NBER Working Paper No. 7833.

- $\quad$ http://www.tdk.gov.tr/index.php?option=com_gts\&arama=gts\&guid=TDK.GTS.5c9e8895d588c9.60138931 , Erişim Tarihi: 20.03.2019.

- https://cabim.ulakbim.gov.tr/bibliyometrik-analiz/turkiye-bilimsel-yayin-performans-raporlari/turkiyeillerinin-bilimsel-yayin-performansi-2011-2015-raporu/, Erişim Tarihi: 31.03.2019.

- https://pdfs.semanticscholar.org/db41/73c3a1236dd7ae038539aec240124e9bcb8d.pdf, Erişim Tarihi: 29.03.2019.

- $\quad$ https://www.turkpatent.gov.tr/TURKPATENT/statistics/ Erişim Tarihi: 31.03.2019.

- Işsk, C. 2012. Bilgi Ekonomilerinde Rekabet Üstünlüğü Oluşturulmasına Etki Eden Ar-Ge, İnovasyon, Patent Ve Bilgi Teknolojilerinin Ekonomik Analizi: Türkiye Ekonomisi Üzerine Bir Uygulama.Doktora Tezi, Atatürk Üniversitesi Sosyal Bilimler Enstitüsü, İktisat Anabilim Dalı, Erzurum.

- Kevük, S. 2006. "Bilgi Ekonomisi”. Journal of Yasar University, Volume: 1, Number: 4, p. 319-350.

- Landefeld, J. S. ve Barbara M. F. 2001. "Measuring the New Economy". BEA Papers 0011, Bureau of Economic Analysis.

- Masi, P.D., Estevão,M. ve Kodres,L. 2001.“Who Has a New Economy?”,Finance and Development, Vol : 38, No: 2,https://www.imf.org/external/pubs/ft/fandd/2001/06/demasi.htm, Erişim Tarihi: 27.03.2019.

- $\quad$ Nordhaus, W.D. 2001. "Productivity Growth and The New Economy". NBER Working Paper 8096. 
- Öztürk, L, Başar, S . 2002. "Yeni Ekonomi ve Elektronik Ticaret: Dünyadaki Gelişmeler ve Türkiye Açısından Bir Değerlendirme”. Atatürk Üniversitesi İktisadi ve İdari Bilimler Dergisi, 16 (3-4), p. 11-30.

- Saygılı, Ş. 2003. Bilgi Ekonomisine Geçiş Sürecinde Türkiye Ekonomisinin Dünyadaki Konumu. T.C. Başbakanlık Devlet Planlama Teşkilatı, Yayın No.DPT: 2675.

- Stiroh, K..J. 2000. "Is There a New Economy?”.

- Şanlısoy, S. 2015. “Türk Cumhuriyetleri’nin Bilgi Ekonomisi Analizi”. Optimum Ekonomi ve Yönetim Bilimleri Dergisi,2(2), p.101-122.

- Tapscott, D. 1996. "The Digital Economy: Promise And Peril In The Age Of Networked Intelligence”. https://pdfs.semanticscholar.org/a832/0ab8d4a6c0a1d0578c6e01288b03cb00de4a.pdf, Erişim Tarihi: 28.03.2019.

- Türkiye İstatistik Kurumu, http://www.tuik.gov.tr/PreTablo.do?alt_id=1082, Erişim Tarihi: 31.03.2019.

- World Bank, 2004. "Turkey Knowledge Economy Assessment Study”.Private and Financial Sector Unit Europe and Central Asia Region The World Bank Washington, D.C.

- World Bank, 2007. “Building Knowledge Economies, Advanced Strategies for Development”. WBI Development Studies, Washington, D.C.

- World Bank, 2012. “Knowledge for Development, User Guide, KI and KEI

Indexes”. http://info.worldbank.org/etools/kam2/KAM_page5.asp, Erişim Tarihi: 01.04.2019. 


\title{
Kariyer Planlaması ve Kişilik Özellikleri Arasındaki İlişkinin Belirlenmesine Yönelik Otel İşletmelerinde Bir Araştırma
}

\section{Finding the Relationship between Individual Career Planning and Personality Features in Hotels}

\author{
Prof. Dr. Mehmet Sarışık (Sakarya Applied Sciences University, Turkey) \\ Ph.D. Candidate Hasan Önal Şeyhanlığlu (Sakarya Applied Sciences University, Turkey
}

\begin{abstract}
In this study, it is aimed to examine the relationship between personality traits and career planning trends of tourism management employees. The data required for the study were obtained from a total of 391 employees in five and four-star five-city hotels in Ankara. The collected data were analyzed by quantitative methods to test the relationship between variables. First, the correlation coefficients between the sub-dimensions of the scales were calculated. Then, t-test and variance (One-way Anova) analysis were used to determine possible differences between career planning dimensions and demographic characteristics. As a result of the study, it was found that there was a positive and significant relationship between extrovert personality type and career planning while a negative significant relationship was found between neurotic personality type and career planning.
\end{abstract}

\section{Giriş}

Hizmet endüstrisinde önemli bir yere sahip olan turizm işletmeleri, doğası gereği emek yoğun özelliği taşır ve bu açıdan en çok ihtiyaç duydukları kaynaklardan birisi işgücüdür. Özellikle değişen koşullarda ortaya çıkan küresel rekabet ve bilgi sermayesinin her geçen gün önemini arttırması, insan kaynağını ve emeği daha da ön plana çıkarmıştır. Post modern yaklaşımların etkin olduğu yönetim uygulamalarında rekabet özellikle insan kaynağı üzerine kurgulanmaya başlamıştır. Günümüz turizm işletmeleri yapısında değişen çevre koşulları uzun dönemde ayakta kalabilmeyi güçleştirmiş ve yaratıcı yıkım denilen entelektüel sermayesi olmayanın yok olmaya mahkûm olduğu acımasız bir ortam sağlamıştır. Bu gelişmeler göz önüne alındığında turizm işletmeleri örgütünün ve çalışanlarının gelişmesi için kariyer planlaması yapmak ve onları bu planlamaya yönlendirmelidir. Çalışanın sahip olduğu sorumluluğu yerine getirmesinin yanında, kendini geliştirmesi, yenilemesi, eğitmesi, eksiklerini tamamlaması ve bilişsel donatısını artırması beklentisi söz konusudur. Ayrıca çalışanlar gelecekte göreceli olarak daha iyi bir statüde olabilmek ve buna bağlı daha yüksek bir ücret elde edebilmek için de kariyer planlamasını dikkate almalıdırlar. Kariyer, genel itibariyle kişilerin tercih ettikleri işler, hayatları süresince bulundukları mevkiler, statüler, tutum ve davranışları içeren bir süreç (Aytaç, 2005:8) olarak tanımlanmıştır. Turizm işletmelerinde de personel güçlendirmenin önemli bir parçası olarak dikkat çekmiştir. Turizm işletmelerinde daha kaliteli hizmet sunabilmek ve müşteri tatmini için kalifiye personele olan ihtiyaç yüksek düzeydedir. Bunun yanında çalş̧anlar da kariyer gelecekleri için bir takım hedef ve planlamaların içerisindedirler. Kariyer planlaması yaparken hem turizm işletmelerinin hem de çalışan bireyler gereken hassasiyeti göstermeleri gerekir. Zira işletmeler ve çalışanlar geleceğe yönelik amaçlarını birleştirerek endüstride daha iyi bir konuma gelmeyi öngörürler.

Kişilik, bir kişinin diğer bireylere tepki göstermek veya onlarla etkileşim halinde olmak için kullandığı yolların tümü (Robbins ve Judge, 2016:135) şeklinde açıklanmıştır. Günümüzde kişilik faktörü ve özellikleri çalışanların ve örgütlerin başarısı açısından önemli bir konudur. Turizm endüstrisinin emek-yoğun yapıya ve konuklarla sürekli etkileşim içerisinde olma özelliğine bağlı olarak yetişmiş, kendisini geliştiren, eğitimli ve gelecek için kariyer hedefleri olan çalışanlara ihtiyacı oldukça fazladır. Bu işletmelerde personel seçim ve tedarik sürecinde çalışılacak bireylerin diğer özelliklerinin ve yeteneklerinin yanı sıra kişilik yapıları da dikkate alınması gerekir. Zira endüstri yap1 itibari ile dinamik, yenilikçi ve değişen çevre koşullarından etkilenen bir özelliğe sahip olduğundan çalışanların da kişilik nitelikleri açısından bu yapıya yatkın olmaları arzu edilir. Endüstrinin en önemli sorunlarından ikisi mevsimsel olma (sezonluk) ve personel devir hızının yüksekliğidir. Bu durum personelin istihdamını, eğitimini ve işletme açısından yetiştirilmesini de zora sokar. Ayrıca mevsimsellik özelliği personel hareketliliğini hızlandırarak örgüt ve çalışanlar üzerinde umut kırıcı sonuçlar ortaya koyabilir.

$\mathrm{Bu}$ çalışma üç bölümden oluşmaktadır. Birinci bölüm konuyla ilgili yazın taramasına bağlı olarak kuramsal çerçeveye ve daha önce yapılan benzer araştırmaların sonuçlarına yer verilmiştir. İkinci bölümde araştırmanın yöntemi ve bulgularına ilişkin bilgiler sunulmuştur. Son kısımda ise araştırmaya ilişkin tartışma, sonuç ve öneriler özetlenmiş̧tir.

\section{Kariyer Planlaması}

Kariyer planlaması genel bir yaklaşımla kariyer hedeflerini koyma, işlerin ve kariyer yollarının analizini yapma, olasılıkları olan örgütleri belirleme, başvurma ve elde etme süreci olarak (Kozak, 2001; Dinçer vd., 2015; Taşlıyan 
vd., 2011; Kılıç ve Öztürk, 2009) tanımlanmıştır. Başka bir tanıma göre kariyer planlaması, organizasyondaki kariyer yollarını belirleyerek örgütün gereksinimini sağlayacak işgörenleri elde etmek amacıyla personeli uygun işlere göre yerleştirmek olarak (Zikic ve Klehe, 2006: 393) açıklanmıştır. Barutçugil ise (2004: 320) çalışmasında kariyer planlamayı, işgörenlerin değerleri, ihtiyaçları ile iş deneyimleri ve firsatları arasında en uygun ilişkiyi kurmayı hedefleyen sorun çözme ve karar alma süreci olarak ifade etmektedir.

Konuya ilişkin yapılan çalışmalar mercek altına alındığında kariyer planlamasına ilişkin farklı katılımcılarla farklı sonuçların elde edildiği dikkat çekmektedir. Chuang ve ark. (2007) çalışmalarında lisans öğrenimi gören toplam 360 turizm öğrencisiyle bir çalışma gerçekleştirmişler ve öğrencilerin mesleğe bağlılık, kariyer planlaması ve mesleki seçimleri gibi konular üzerine değerlendirme yapmışlardır. Bu analiz sonucu ise cinsiyet, mevcut istihdam durumu, kariyer kararı öz yeterliliği ve kariyer sonucu beklentisi gibi parametrelerin endüstride kalıcılığ öngördüğü ve uygun yetenek, beceri ve iş tecrübesi yüksek olan öğrencilerin kariyer planlamaya ve kariyer seçimlerine ilgilerinin daha yüksek olduğu sonucuna ulaşmışlardır.

Richardson (2010) çalışmasında Avustralya'daki lisans öğrencilerinin kariyer tutum ve davranışlarını ele almıştır. Çalışmada keşfedici ve nicel yöntemler bir arada kullanılmıştır. Çalışma bulguları arasında öğrencilerin \%50'den fazlasının turizm dışı kariyer yapma isteğinde oldukları ve ankete katılan iş (staj) tecrübesine sahip öğrencilerin yollarına endüstride devam etmeyi düşünmedikleri sonucu ortaya çıkmıştır. Ayrıca öğrencilerin \%91,7'sinin endüstrideki çalışmamasının ana sebebinin iş tecrübesi eksikliklerinden kaynaklandığı saptanmıştır.

Lertwannawit ve ark. (2009) araştırmalarında Tayland'daki turizm çalışanlarının kariyer yetkinlikleri ile kariyer başarısı arasındaki ilişkiyi incelemişlerdir. Kariyer başarısındaki ölçütlerin; bilgisayar ve dil becerileri, iş ahlakı, ekip çalışması, liderlik ve misafirperverlik alanlarındaki bilgi ve beceriler ile sınırlı olduğu sonucuna ulaşmışlardır. Restoran, havayolu, seyahat ve tur işletmelerinde çalışan toplam 800 kişiden elde edilen veriler 1şığında kariyer yetkinliği ile kariyer başarısı arasında orta derece bir ilişki saptanmıştır. Sonuç olarak bilgisayar, dil becerileri, takım çalışması, liderlik, turizm ve otelcilik bilgisi ve becerilerinin kariyer başarısını doğrudan etkilediğini bulmuşlardır. Eğitim programları da başarıya arttıran diğer faktör olarak dikkat çekmektedir. Kim ve ark. (2009) çalışmalarında Kore'de lüks nitelikli otellerde çalışan genel müdürlerin kariyer yolları ve tutumlarını incelemişlerdir. Araştırmanın sonucunda kariyer planlaması ve yollarına önem veren yöneticilerin lüks otellerde genel müdürlük pozisyonuna daha kolay ulaştıkları ortaya çıkmıştır.

Roney ve Öztin'in (2007) araştırmaları Türkiye'deki turizm öğrencilerinin kariyer algılarına yöneliktir. Toplam 450 turizm öğrencisine uygulanılan anketin sonucunda katılımcıların algılarının nötr olduğunu ortaya çıkmıştır. Turizm okuma isteği, mezun olduktan sonra turizmde çalışmaya istekli olmak ve turizm kariyer yapmak bu ifadeler arasında dikkat çekmektedir. Ulama ve ark. (2015) çalışmalarında lisans düzeyinde eğitim alan toplam 677 öğrenciden turizmde kariyere ilişkin veriler toplamışlardır. Bu veriler sonucunda katılımcıların \% 62'sinin turizm endüstrisinde diğerlerinin farklı sektörlerde çalışma hayatına devam etmeyi düşündükleri ve genellikle yaşı küçük olanların daha yüksek yaş gruplarındakilere, alt sınıfta olanların üst sınıflara ve staj yapmayan/çalışmayanların staj yapan/çalışanlara göre farklı görüşlere sahip oldukları ortaya çıkmıştır. Avcı ve Turunç (2012) çalışmalarında, kariyer memnuniyetini doğrudan ve dolaylı etkileyen dönüşümcü liderlik ve örgüte güven ile bu etkide lider-üye etkileşiminin aracılık rolünü ele almışlardır. Bu amaçla, Muğla ilinde faaliyet gösteren otellerdeki toplam 293 çalışandan anket tekniği ile veri toplanmıştır. Dönüşümcü liderliğin ve örgüte güvenin kariyer planlaması ile doğrudan ilişkili olduğu sonucuna ulaşılmıştır.

\section{Kișilik}

Kişilik kavramı, kişilerin iç süreçlerini, davranışlarını, hareket tarzlarını ve hissettiklerini etkileyen ve bu yönüyle iç dünyada gelişen tüm duygusal, içsel ve bilişsel süreçleri kapsayan bir olgu (Burger, 2006; Tatl1lığlu, 2010; Özyer vd., 2012; Şeyhanlığlu, 2018; Yılmaz; 2018) şeklinde açıklanabilir. Başka bir tanıma göre ise kişilik, bir bireyin diğer bireylere tepki göstermek veya onlarla etkileşim içinde olmak için kullandığı yolların tümüdür (Robbins ve Judge, 2016:135). Güney (2006:185) çalışmasında bu kavramı bir kişinin tüm ilgilerinin, tutumlarının, hareketlerinin davranışlarının, yeteneklerinin, konuşma şeklinin, giyim tarzının ve çevresine karşı uyumunun niteliklerini kapsayan olgu şeklinde ifade etmektedir.

Neill ve Xaio (2010) çalışmalarında ABD'deki otel yöneticilerinin kişilik özelliklerinin duygusal tükenmişliğine etkileri araştırmak için 36 otelin 544 yöneticisinden veri toplamışlardır. Sonuçta otel yöneticilerinin duygusal tükenmelerinin sadece iş ve örgütsel özelliklerinden değil aynı zamanda kişilik özelliklerinden de etkilendiği ortaya çıkmıştır. Kim ve ark. (2007) ise ABD'nin Washington eyaletindeki 8 lüks otel çalışanından toplanan veriler ışığında beş kişilik faktör özelliklerinin (uyumluluk, duygusal tutarlılık, dışa dönüklük, açıklık ve öz disiplin) iş tükenmişliği üzerindeki etkileri incelemişlerdir. Araştırmanın sonucunda iş tükenmişliği ve kişilik özellikleri arasında ilişki saptanmış olup, en önemli unsurun uyumluluk boyutu olduğu tespit edilmiştir. Brownell (1994) yöneticiler üzerine bir araştırma gerçekleştirmiştir. Araştırmada kariyerde kişilik ve cinsiyetin rolü yöneticiler üzerinden incelenmiştir. Çalışma sonucunda erkek yöneticilerin bayanlara göre hedef yönelimlerinin daha güçlü olduğu, dürüstlüğün ise kariyer gelişimi açısından cinsiyet odaklı değil kişilik odaklı bir unsur olduğu ortaya çıkmıştır. Mendez ve Hine (2017) çalışmalarında toplam 10 Güney Amerika ülkesinin web siteleri bazında kişilik 
konumlandırması değerlendirmişlerdir. Bu konumlandırmayı yaparken web sitesi içerik analizleri ve yazışma analizi gibi farklı bir yöntembilim kullanmışlardır. Sonuçta Ekvator açık ve anlaşılır bir kişilik tipine sahipken Brezilya ve Paraguay'ın tecrübeli ve vicdanlı bir kişilik tipine sahip olduğu tespit edilmiştir. Peru, Şili, Arjantin ve Uruguay ise dışa vurumculuk ve duygusal istikrar taşıyan bir kişilik tipine sahip oldukları sonucuna ulaşılmıştır. Son olarak Bolivya, Venezüella ve Kolombiya baskın olmayan kişilik tipine sahiptirler.

Solmaz ve ark. (2014) araştırmalarında turizm eğitimi alan lisans ve ön lisans öğrencilerinin girişimci kişilik özelliklerini tespit etmeye çalışmışlardır. Sakarya ve Bolu Abant İzzet Baysal Üniversitelerinde eğitim alan 308 lisans ve ön lisans öğrencilerinden toplanan veriler ışığında turizm öğrencilerinin önemli bir kısmının girişimci kişilik özelliğine sahip olduğu tespit edilmiştir. Bunun yanında, girişimci kişilik özellikleri bakımından lisans ve ön lisans öğrencileri arasında anlamlı bir farklılık olduğu görülmüştür. Aslan ve ark. (2012) ise turizm eğitimi alan öğrencilerin kişilik özellikleri ile sektöre uyumları arasındaki ilişkiyi mercek altına almışlardır. Toplam 924 katılımcıdan elde edilen bulgular ışığında öğrencilerin baskın (ön plana çıkan) kişilik özelliklerinin sorumluluk sahibi ve yumuşak başlı oldukları ve kişilik-iş uyumunun; çalışanlar, işletme ve toplum açısından pozitif sonuçlar ortaya çıkardığını vurgulamışlardır. Pelit ve ark. (2010) araştırmalarında turizm endüstrisi personelinin kişilik özelliklerini belirlemek amacıyla Ankara ve Aydın illerinde faaliyet gösteren turizm işletmelerindeki toplam 340 çalışandan veri toplamışlardır. Sonuçta çalışanların A tipi kişilik özelliklerine yatkın olduklarını tespit etmişlerdir. Deniz (2016)çalışmasında Nevşehir'deki butik otellerinde çalışan personelin kişilik özellikleri ve sosyalleşme düzeylerinin, sergiledikleri duygusal emek davranış stratejileri üzerindeki etkilerini belirlemeyi amaçlayan bir çalışma gerçekleştirmiştir. Sonuçta nevrotik kişiliğin duygusal uyumsuzluğu pozitif ve anlamlı bir şekilde etkilediği, örgütsel bağlllı̆ı̆ı duygusal uyumsuzluğu negatif ve anlamlı bir şekilde etkilediği saptanmıştır. Sosyalleşmenin duygusal çaba, iş tatmini ve örgütsel kabullenme üzerinde olumlu etkisi olduğu ortaya çıkmıştır.

\section{Yöntem}

$\mathrm{Bu}$ araştırmanın temel amacı, Ankara'daki şehir otellerinde çalışan bireylerin kişilik özellikleri ile bireysel kariyer planlamasına ilişkin görüşleri arasındaki farklılığı belirlemektir. Personelin kişilik özellikleri (a)dışa dönüklük ve (b)nevrotiklik şeklinde sınırlandırılmıştır. Turizm çalışanları üzerinde yapılan çalışmalarda bireyin kişilik özellikleri ile incelenmeye çalışılan değişkenler ele alındığında özellikle kişilik tarafının bu iki boyutta incelendiği dikkat çekmektedir (Gürsoy vd. 2011). İlgili yazında turizm çalışanlarının kişilik özellikleri ile kariyer planlaması arasındaki ilişkiyi konu edinen araştırmaların sayısı oldukça sınırlıdır. Çalışmada otel çalışanlarına yöneltilen sorulara açısından görüş farklılıklarının varlı̆̆ı uygun analiz teknikleriyle test edilmiştir.

Öncelikle veri elde edebilmek adına anket formu geliştirilmiştir. Anket formu üç bölümden ve 54 ifadeden oluşmaktadır. Formun ilk bölümünde kariyer planlamasını ölçmek için Rottinghaus vd. (2005) tarafindan geliştirilen "Kariyer Geleceği Ölçeğì" (Career Futures Inventory) yer almaktadır. İnsan kaynakları yönetimi alanında yapılan araştırmalarda bireysel kariyer planlamasına ilişkin malumat (bilgi) edinmek için genellikle kariyer geleceği ölçeğinden faydalanıldığı görülmektedir (Kalafat, 2012). Ölçek Türkçe 'ye Kalafat (2012) tarafından 25 ifade ve üç boyut olarak uyarlanmıştır. Anket formunun ikinci bölümünde kişilik faktörünü ölçmek için beş faktörlük kişilik ölçeğinin iki boyutu olan "dışa dönüklük" ve "nevrotiklik" boyutları kullanılmıştır. Ölçek, Goldberg (1990) tarafından Beş Büyük Kişilik Faktörü Ölçeğinden uyarlanmıştır. "Dışa dönüklük" ve "nevrotiklik" boyutlarının her biri 10'ar adet ifade ile ölçülmüştür. Üçüncü bölümde ise katılımcıların yaş, cinsiyet, eğitim durumu, çalıştıkları pozisyon, çalıştıkları bölüm ve gelir durumu gibi demografik faktörler ile sektördeki tecrübe süresi gibi sorular açı ve kapalı uçlu olarak yöneltilmiştir. Örneklem büyüklüğü, \%5 hata payına göre Yazıcıŏ̆lu ve Erdoğan'ın (2011) geliştirdiği tablodan yararlanılarak oluşturulmuştur. Bu bağlamda \%5 payına göre 384 sayısı örneklem büyüklüğ̈̈ yeterli olarak kabul edilmektedir.

Araştırma verileri, 1 Ekim-1 Kasım 2018 tarihleri arasında Ankara'da faaliyet gösteren iki beş yıldızlı ve üç dört yıldızlı otel işletmesinden 406 katılımcıyla birebir görüşmeler sonucunda elde edilmiştir. Toplanan anket formlarından kullanıma uygun olmayan 15 form çıkarılmış ve 391 anket üzerinden veri seti oluşturulmuştur. Anketlerden elde edilen veriler, SPSS istatistik paket programı kullanılarak veriler analiz edilmiştir. Verilerin parametrik test tekniklerine uygunluğunun ardından iki bağımsız değişken arasında farklılık olup olmadığını ölçmek için bağımsız t-testi (Independent T-test), ikiden fazla bağımsız değişken arasında farklılık olup olmadığını ölçmek için ANOVA (One-way Anova) testi ve kariyer planlaması ile kişilik arasındaki ilişkiyi ölçmek içinde korelasyon analizleri kullanılmıştır.

\section{Bulgular}

\subsection{Demografik Özelliklere İlişkin Bulgular}

Katılımcıların demografik özelliklerine ilişkin tanımlayıcı bilgiler Tablo 1'de sunulmuştur. Katılımcıların $\% 58,1$ 'i erkeklerden oluşmakta olup, önemli bir kısmı lise mezunu ve evlidir. Yarıya yakını kat hizmetleri ve yiyecek içecek bölümlerinde ve $\% 75$ 'i alt kademe pozisyonlarda çalışmaktadır. Toplam $\% 25$ olan yöneticilerin önemli bir bölümü alt ve orta kademeden oluşmaktadır. Katılımcıların yarıdan fazlası aylık 3000 TL'nin altında 
gelir düzeyine sahiptir. Ek olarak, katılımcıların yaş ortalaması 34,5 ve aynı işletmede çalışma yılı ortalaması 12,2 yıl sektördeki (meslekte) çalışma yılı ortalaması ise 13,7 yıl olarak ortaya çıkmıştır

\begin{tabular}{|c|c|c|}
\hline & $\mathbf{N}$ & $\%$ \\
\hline \multicolumn{3}{|l|}{ CINSIYYET } \\
\hline Erkek & 227 & 58.1 \\
\hline Kadın & 164 & 41.9 \\
\hline Toplam & 391 & 100 \\
\hline \multicolumn{3}{|l|}{ Medeni Durum } \\
\hline Evli & 222 & 56.8 \\
\hline Bekâr & 169 & 43.2 \\
\hline Toplam & 391 & 100 \\
\hline \multicolumn{3}{|l|}{ Eğitim Durumu } \\
\hline İlköğretim & 62 & 15.9 \\
\hline Lise & 166 & 42.5 \\
\hline Ön lisans & 99 & 25.3 \\
\hline Lisans ve üzeri & 64 & 16.4 \\
\hline Toplam & 391 & 100 \\
\hline \multicolumn{3}{|l|}{ Departman } \\
\hline Ön Büro & 82 & 21 \\
\hline Yiyecek ve İçecek & 101 & 25.8 \\
\hline Kat Hizmetleri & 92 & 23.5 \\
\hline Diğer (Güvenlik, Muhasebe vd.) & 116 & 29.7 \\
\hline Toplam & 391 & 100 \\
\hline \multicolumn{3}{|l|}{ İsyerindeki Pozisyon } \\
\hline Çalıșan & 295 & 75.4 \\
\hline Yönetici & 96 & 24.6 \\
\hline Toplam & 391 & 100 \\
\hline \multicolumn{3}{|l|}{ Aylık Ortalama Ücret } \\
\hline $1600-1999 \mathrm{TL}$ & 134 & 34.3 \\
\hline $2000-2999 \mathrm{TL}$ & 212 & 54.2 \\
\hline 3000 TL ve üzeri & 45 & 11.5 \\
\hline Toplam & 391 & 100 \\
\hline
\end{tabular}

Tablo 1: Katıllmcıların Özelliklerine İlişkin Bulgular Tablosu

\subsection{Geçerlilik ve Güvenilirlik Analizlerine İlişsin Bulgular}

Güvenirlilik anketteki iç tutarlılığı ölçmektedir. Ölçeklerin güvenilirlik katsayılarını hesaplamak için, Cronbach Alpha Katsayısı kullanılmıştır. Bu katsayı ölçüm araçlarında yer alan maddelerin birbiriyle tutarlığını ölçmektedir. Tablo 2'de kullanılan ölçeklerin güvenirlilik katsayılarına yer verilmiştir. Çalışmada ölçme araçlarının geçerlilik sorununu ortadan kaldırmak, için literatürde geçerliliği olan ölçeklerden faydalanılmış ve Türkçe diline yönelik geçerleme çalışmaları göz önüne alınmıştır. Bu çerçevede, hem "Kariyer Geleceği Ölçeği" hem de "Beş Faktör Kişilik Ölçeği" ölçme aracı olarak güvenilir kabul edilmiştir.

\begin{tabular}{|l|c|}
\hline \multicolumn{1}{|c|}{ ARASTIRMANIN ÖLCCEKLERI } & ALPHA $(\alpha)$ \\
\hline \multicolumn{1}{|c|}{ Kariyer Geleceği Ölçeği } & \\
\hline Kariyer uyumluluğu & 0.82 \\
\hline Kariyer iyimserliği & 0.90 \\
\hline İş piyasalarına ilișkin algılanan bilgi & 0.87 \\
\hline \multicolumn{1}{|c|}{ Kișilik Ölçeği } & \\
\hline Dişa Dönüklük & 0.72 \\
\hline Nevrotiklik & 0.92 \\
\hline
\end{tabular}

Tablo 2: Ölçeklerin Güvenilirlik Katsayıları

\subsection{Kişilik-Kariyer Planlaması İlişkisi}

Kişilik ile kariyer planlaması arasındaki ilişkinin varlığını ve bu ilişkinin yönünü ve derecesini belirlemek amacıyla korelasyon analizi uygulanmıştır. Tablo 3'de bu bilgiler sunulmuştur. 


\begin{tabular}{|l|l|l|l|l|l|l|l|}
\hline & Ort. & S.S. & $\mathbf{1}$ & $\mathbf{2}$ & $\mathbf{3}$ & $\mathbf{4}$ & $\mathbf{5}$ \\
\hline 1. Uyum & 3.10 & .54 & - & & & & \\
\hline 2. İyimserlik & 3.01 & .22 & $\mathbf{. 8 9 * *}$ & - & & & \\
\hline 3. Bilgi & 3.06 & .54 & $\mathbf{. 4 7 * *}$ & $\mathbf{. 2 2 * *}$ & - & & \\
\hline 4. Dışa Dönüklük & 3.06 & .51 & $\mathbf{. 4 6 * *}$ & $\mathbf{. 1 9 * *}$ & $\mathbf{. 2 4 * *}$ & - & \\
\hline 5. Nevrotiklik & 2.86 & .98 & $\mathbf{- . 5 5 * *}$ & $\mathbf{- . 2 3 * *}$ & $\mathbf{- . 3 3 * *}$ & $\mathbf{- . 6 9 * *}$ & - \\
\hline
\end{tabular}

Tablo 3: Kişilik-Kariyer Planlaması İlişkisi

Korelasyon analizi sonucu, literatürde vurgulandığı şekilde kariyer planlaması değişkenleri ile dışa dönüklük arasında pozitif ilişki varlığı saptanmıştır $(\mathrm{p}<0,05)$. Ayrıca kariyer planlaması değişkenleri ile nevrotiklik arasında ise negatif yönlü bir ilişkinin varlığı dikkat çekmektedir.

Korelasyon katsayıları incelendiğinde, kariyer planlaması değişkenlerinin tümü ile kişilik boyutları değişkenleri arasındaki ilişkinin aynı seviyede olmadığı görülmektedir. Dışa dönüklük ile kariyer uyumluluğu arasında anlamlı ve pozitif ilişki konusudur. Dışa dönüklük ile kariyer iyimserliği arasında da anlamlı ve pozitif ilişki vardır. İş piyasalarına ilişkin algılanan bilgi ile dışa dönüklük arasında da pozitif ve anlamlı ilişki olduğu saptanmıştır.

Korelasyon analizi sonucu, nevrotiklik ile kariyer planlama ölçeğinin alt boyutları arasında ise negatif yönde bir ilişki ortaya çıkmıştır. Bu bağlamda, nevrotiklik ve kariyer uyum arasında $(\mathrm{r}=-0.55)$, nevrotiklik ile kariyer iyimserliği arasında $(\mathrm{r}=-0.23)$ ve nevrotiklik ile iş piyasalarına ilişkin algılanan bilgi arasında $(\mathrm{r}=-0.33)$ anlamlı ve negatif ilişki söz konusudur.

\subsection{Katılımcıların Demografik Özellikleri ve Kariyer Planlaması Boyutları Arasındaki Farklılık Analizlerine İlişkin Bulgular}

Toplanan verilerin normallik dağılım grafikleri, çarpıklık ve basıklık değerleri ile kullanılan ölçeğin niteliği dikkate alınarak farklılık analizleri için parametrik test tekniklerine başvurulmuştur.

$\mathrm{Bu}$ açıdan $t$-testi veya Anova testi ile analizler gerçekleştirilmiştir. Analizler sonucunda sadece cinsiyet ve işletmedeki pozisyon ile kişilik özellikleri arasında anlamlı farklılık bulunmamıştır. Medeni durum, gelir durumu ve eğitim durumlarında ise anlamlı farklılıklar elde edilmiştir.

Araştırmaya katılanların medeni durumunun kariyer planlama boyutlarına ilişkin niteliklerinin farklılık gösterip göstermediğini tespit etmek için t-testi yapılmış ve sonuçlar Tablo 4'de verilmiştir. Analiz sonucunda "iyimserlik" boyutu ile medeni durum arasında anlamlı farklılık tespit edilmiştir.

\begin{tabular}{|c|l|c|c|c|c|c|}
\hline & Cinsiyet & $\mathbf{N}$ & $\overline{\mathbf{x}}$ & Std. Sapma & $\mathrm{t}$ & $p$ \\
\hline \multirow{2}{*}{ İyimserlik } & Bekâr & 169 & 3,0586 &, 22474 & 3,167 & $\mathbf{0 , 0 0 2}$ \\
\cline { 2 - 5 } & Evli & 222 & 2,9873 &, 21747 & & \\
\hline
\end{tabular}

Tablo 4: Medeni Durum ile Kariyer Planlama Boyutları İlişkisine Yönelik Fark Tablosu

Araştırmaya katılanların eğitim durumları ile kişilik özelliklerine ilişkin niteliklerin farklılık gösterip göstermediğini tespit etmek amacıyla One-way Anova testi yapılmış ve sonuçlar Tablo 5'de gösterilmiştir.

\begin{tabular}{|l|l|c|}
\hline & F & $p$ \\
\hline Uyum & 8,777 & $\mathbf{0 , 0 0 0}$ \\
\hline Bilgi & 2,750 & $\mathbf{0 , 0 4 3}$ \\
\hline
\end{tabular}

Tablo 5: Eğitim Durumu ile Kariyer Planlama Boyutlarına İlişkin Anova Sonuçları

Anova sonucuna göre, kariyer planlamanın "uyum” ve "bilgi” boyutlarının eğitim durumu değişkenine göre anlamlı farklılığa sahip olduğu tespit edilmiştir. Kariyer uyumu bağlamında farklılık ilköğretim ile önlisans, lisans ve üzeri arasında olduğu belirlenmiştir. Ön lisans, lisans ve üzeri mezunlarının ilköğretim mezunlarına göre daha kariyer uyumunda daha iyi oldukları ortaya konulmuştur. İş piyasalarına ilişkin bilgi konusunda lisans ve üzeri mezunlarının lise mezunlarına göre daha hakim oldukları belirlenmiştir.

Araştırmaya katılanların çalıştıkları gelir durumu ile kişilik özelliklerine ilişskin niteliklerin farklılık gösterip göstermediğini saptamak amacıyla One-way Anova testi yapılmış ve elde edilen bulgular Tablo 6'da sunulmuştur.

\begin{tabular}{|c|l|c|}
\hline & $\mathrm{F}$ & $p$ \\
\hline Uyum & 3,936 & $\mathbf{0 , 0 2 0}$ \\
\hline
\end{tabular}

Tablo 6: Gelir Durumu ile Kariyer Planlama Boyutlarına İlişkin Anova Sonuçları

Anova sonucuna göre, kariyer planlamanın "uyum” boyutu gelir durumu değişkenine göre anlamlı farklılığa sahip olduğu tespit edilmiştir. Kariyer uyumu bağlamında farklılık 1600-1999 TL ile 3000 TL ve üzeri gelire sahip olan bireyler arasında olduğu belirlenmiştir. Gelir düzeyi arttıkça kariyer uyumu gerçekleşmektedir. 


\section{Sonuç}

Çă̆ımızın hâkim konularından biri olan artan rekabet koşulları göz önüne alındığında işletmeler piyasaya hâkim, esnek çalışma şartlarına uyan, teknolojik gelişimlere karşı uyum sağlayan ve sonuç odaklı çözümler üreten insan kaynağına ihtiyaç duyarlar. Bu kapsamda hizmetler endüstrisinde ve/veya turizm sektöründe yer alacak olan potansiyel çalışanların kişilik özellikleri ve bu kişilik özelliklerine uygun kariyer planı yapması önem arz etmektedir. Bu noktada işletmeler istihdam edilen insan kaynağına doğru bir kariyer planlaması yapması hem bireyin geleceği noktasından hem de örgütün geleceği bağlamında başarı sağlayan önemli bir husustur. Bireyler yaşamının önemli bir kısmını oluşturan iş yaşamında seçilen meslek ve buna uygun yapılan kariyer planları bireyin toplumdaki yerini, bireyin referans gruplarını vb. etkiler. İşletmeler ise kalifiyeli, başarılı çalışanları bünyesinde barındırmak için büyük çaba harcarlar. Bunun yanında turizm sektörü emek yoğun bir sektör olduğu için işletmeler kalifiyeli elemanların kişilik özelliklerine uygun bireylerin istihdamı konusuna önem verebilir hatta bunu bir insan kaynağ1 stratejisi olarak benimseyebilirler.

Yapılan literatür taramasına göre, çalışanların kişilik özelliklerinin kariyer olgusu üzerindeki etkisi daha önce yapılan çalışmalarda incelenmiştir (bkz. Roney ve Öztin, 2007; Temeloğlu ve Aksu, 2016; Richardson, 2010; Lertwannawit vd., 2009; Pelit vd., 2010). Ayrıca araştırma otel işletmelerindeki çalışanların kariyer planlamasının kişilik üzerindeki etkisi üzerine yapılmıştır. Çalışmada katılımcıların demografik özellikleri kariyer planlaması üzerine etkisi de incelenmiştir.

Araştırmanın analiz kısmında ise ilk olarak elde edilen verilerin Cronbach's Alfa güvenilirlik kat sayılarına bakılmış ve analiz sonucu ölçeklerin güvenilirlik seviyelerinin yüksek olduğu saptanmıştır. Ardından araştırmada korelasyon analizi yapılmıştır. Korelasyon analizi sonucunda, kariyer planlaması boyutları (uyumluluk, iyimserlik, bilgi) ile dışa dönüklük arasında pozitif ve anlamlı bir ilişki bulunmuştur. Bu sonuç, turizm sektöründe istihdam edilecek kişilerin kişilik özelliği olarak dışa dönük bireylerin tercih edilmesi gerektiğini ve dışa dönük kişilerin başarı bağlamında işletmeye katkısı olacağı düşünülmektedir. Diğer bir önemli sonuç, kariyer planlaması boyutları (uyumluluk, iyimserlik, bilgi) ile nevrotiklik arasında negatif ve anlamlı bir ilişki bulunmuştur. Bu önemli bulguları destekler nitelikte yapılan çalışmalar literatür taraması sonucu ulaşılmıştır (bkz. Şeyhanlığlu, 2018; Çakıcı ve Özdamar, 2018; Deniz, 2016; Teng, 2008; Richardson, 2010). Bu sonuçlar, hem dışa dönüklük ile kariyer planlama ilişkisi sonucunu destekler niteliktedir hem de turizm çalışanları üzerine yapılmış olan farklı araştırmaların sonuçları ile benzerlikler göstermektedir. Araştırmanın diğer sonuçlarında bekâr ve evli katılımcılar arasında kariyer iyimserliği boyutunda farklılık gözlenmiştir. Bu sonuç, kariyer iyimserliği bağlamında bekâr çalışanların evli çalışanlara göre daha kariyer odaklı olduğu sonucuna ulaşılmıştır. Diğer elde edilen bulgular göz önüne alındığında. Eğitim durumu yüksek olan bireylerin kariyer uyumu ve bilgisi boyutları açısından eğitim seviyesi düşük olan bireylere oranla kariyer anlamında daha etkin oldukları ortaya çıkmaktadır. Aynı şekilde gelir durumu açısından kariyer uyumu boyutunda gelir seviyesi yüksek bireylerin, gelir seviyesi düşük olan bireylere göre kariyer bağlamında daha istikrarlılardır.

Tüm bu sonuçlar ışı̆̆ında bazı öneriler ifade etmek mümkündür. Bu bağlamda, işletmelere önerimiz dışa dönük bireylerin istihdamının nevrotik kişilik tipine sahip bireylere göre daha çok tercih etmeleridir. Bireylere ise önerimiz daha çok kişilik tiplerine göre kariyer seçimlerini yapmalarıdır. Akademisyenlere önerimiz ise bu konunun farklı sektörlerde araştırılıp incelenmesidir. Çünkü farklı bulgulara elde edilebilir. Bunun yanında bu konunun farklı ülkelerde çalışmaya açık olmasıdır. Kültürel ve kişilik durumlarından kaynaklı farklı sonuçlar ortaya çıkabilir. Yapılacak çalışmaların literatüre katkı sağlanacağı düşünülmektedir.

\section{Kaynakça}

- Aslan, Ünüvar, ve Başoda (2012). Turizm Eğitimi Alan Öğrencilerin Kişilik Özelliklerinin Belirlenmesi ve Turizm Sektörüne Uyumu Açısından Değerlendirilmesi. Anatolia: Turizm Arastirmalari Dergisi, 23(2).

- Avci ve Turunç (2012). Dönüşümcü Liderlik ve Örgüte Güvenin Kariyer Memnuniyetine Etkisi: Lider-Üye Etkileşiminin Aracılık Rolü. Journal of Alanya Faculty of Business/Alanya Isletme Fakültesi Dergisi, 4(2).

- Aytaç (2005). Çalışma Yaşamında Kariyer Yönetimi Planlaması, Gelişimi ve Sorunları. Bursa: Uludağ Üniversitesi Yayını.

- Burger (2006). Kişilik, Çev. İ.D. Sarığlu, (1.Baskı), İstanbul: Kaknüs Yayınları.

- Brownell (1994). Personality and Career Development: A Study of Gender Differences. Cornell Hotel and Restaurant Administration Quarterly, 35(2), 36-43.

- Chuang, Goh, Stout, ve Dellmann-Jenkins (2007). Hospitality Undergraduate Students' Career Choices and Factors Influencing Commitment to The Profession. Journal of Hospitality \& Tourism Education, 19(4), 2837.

- Deniz (2016). Kişilik ve Sosyalizasyonun Duygusal Emek Üzerindeki Etkisi: Butik Otel Örneği. Anatolia: Turizm Araştırmaları Dergisi, 27(2), 273-289. 
- Dinçer, Akova, ve Kaya (2013). Meslek Yüksekokulu Turizm ve Otel İşletmeciliği Programı Öğrencilerinin Kariyer Planlaması Üzerine Bir Araştırma: İstanbul Üniversitesi ve Gümüşhane Üniversitesi Örneği. Elektronik Mesleki Gelişim ve Araştırmalar Dergisi, 1(2), 42-56.

- Goldberg (1990). An Alternative Description of Personality: The Big Five Factor Structure, Journal of Personality and Social Psychology, 59: 1216-1229.

- Gursoy, Boylu, ve Avci (2011). Identifying the Complex Relationships Among Emotional Labor and Its Correlates, International Journal of Hospitality Management, Cilt 30, Say1 4, ss.783-794.

- Kalafat (2012). Kariyer Geleceği Ölçeği (KARGEL): Türk Örneklemi İçin Psikometik Özelliklerin İncelenmesi, Türk Psikolojik Danışma ve Rehberlik Dergisi, Cilt: 4, Sayı: 38, ss.169-179.

- Kozak (2001). Konaklama İsletmelerinde Kariyer Planlaması. Eskişehir: Anadolu Üniversitesi Yayınları.

- Kim, Chun, ve Petrick (2009). Career Path Profiles of General Managers of Korean Super Deluxe Hotels and Factors İnfluencing Their Career Development: Vocational İnsights for HTM Students and Hotel Employees. Journal of Hospitality, Leisure, Sports and Tourism Education (Pre-2012), 8(2), 97.

- Kim, Shin, ve Umbreit (2007). Hotel Job Burnout: The Role of Personality Characteristics. International Journal of Hospitality Management, 26(2), 421-434.

- Lertwannawit, Serirat, ve Pholpantin (2009). Career Competencies and Career Success of Thai Employees in Tourism And Hospitality Sector. International Business and Economics Research Journal, 8(11), 65-72.

- O'Neill ve Xiao (2010). Effects of Organizational/Occupational Characteristics and Personality Traits on Hotel Manager Emotional Exhaustion. International Journal of Hospitality Management, 29(4), 652-658.

- Özyer, Orhan, ve Orhan (2012). Sağlık Sektöründe Çalışanların Demografik Özellikleri, Kişilik Özellikleri ve Kültürel Değerleri Üzerine Bir Çoklu Durum Çalışması/A Study Of Demographic Traits, Personality Traits And Cultural Values of Workers in Health Sector. Mustafa Kemal Üniversitesi Sosyal Bilimler Enstitüsü Dergisi, 9(19).

- Özdamar ve Çakıcı (2018). Turizm Eğitimi Alan Öğrencilerin Dışadönüklüklerinin Otel Departman Tercihine Etkisinde Hizmet Yönelimlerinin Aracılık Rolü. Nevşehir Hacı Bektaş Veli Üniversitesi SBE Dergisi, 8(1), 135-159.

- Pelit, Türkmen, ve Yarmacı (2010). Turizm Sektöründeki İşgörenlerin Kişilik Özelliklerini Değerlendirmeye Yönelik Bir Araştırma. Sosyal ve Beşeri Bilimler Dergisi, 2(1).

- Richardson (2010). Generation Y's Perceptions and Attitudes Towards A Career in Tourism and Hospitality. Journal of Human Resources in Hospitality \& Tourism, 9(2), 179-199.

- Robbins ve Judge (2016). Essentials of Organizational Behavior. Englewood Cliffs, New Jersey: Prentice Hall.

- Rojas-Mendez ve Hine (2017). Countries' Positioning on Personality Traits: Analysis of 10 South American National Tourism Websites. Journal of Vacation Marketing, 23(3), 233-247.

- Roney ve Oztin (2007). Career Perceptions of Undergraduate Tourism Students: A Case Study in Turkey. Journal of Hospitality, Leisure, Sport and Tourism Education, 6(1), 4-17.

- Rottinghaus, Day, ve Borgen (2005). The Career Futures Inventory: A Measure of Career Related Adaptability and Optimism. Journal of Career Assessment, Cilt: 13, Say1: 1, ss.3-24

- Sabuncuoğlu (2016). Insan Kaynakları Yönetimi. Bursa: Alfa Aktüel Yayıncılık.

- Solmaz, Aksoy, Şengül ve Sarış̧ı (2014). Üniversite Öğrencilerinin Girişimci Kişilik Özelliklerinin Belirlenmesi: Turizm Lisans ve Ön Lisans Öğrencileri Üzerine Bir Alan Araştırması. KMÜ Sosyal ve Ekonomik Araştırmalar Dergisi, 16(26). 41-55.

- Şeyhanlığlu (2018). Bireysel Kariyer Planlaması ve Kişilik Özellikleri Arasındaki İlişki: Turizm Çalı̧̧anlarl Örneği. Yüksek Lisans Tezi, Muğla Sttkı Koçman Üniversitesi Sosyal Bilimler Enstitüsü, Muğla.

- Taşlyyan, Arı ve Duzman (2011). İnsan Kaynakları Yönetiminde Kariyer Planlama ve Kariyer Yönetimi: İIBF Öğrencileri Üzerinde Bir Alan Araştırması. Organizasyon ve Yönetim Bilimleri Dergisi, 3(2).

- Tatlılığlu (2010). Farkl Öz-Anlayış Düzeylerine Sahip Üniversite Öğrencilerinin Karar Vermede Özsaygı, Karar Verme Stilleri ve Kişilik Özelliklerinin Değerlendirilmesi . Doktora Tezi, Selçuk Üniversitesi, Eğitim Bilimleri Enstitüsü Anabilim Dalı, Konya.

- Temeloğlu ve Aksu (2016). Turizm Eğitimi Alan Öğrencilerin Kişilik Özelliklerinin Turizmde Kariyer Yapma İstekleri Üzerindeki Etkisi: Çanakkale Onsekiz Mart Üniversitesi Örneği. Uluslararast Sosyal Araștırmalar Dergisi, 9(43), 1512-1521. 
- Teng (2008). The Effects of Personality Traits and Attitudes on Student Uptake in Hospitality Employment. Internetional Journal of Hospitality Management, 27(1), 76-86.

- Ulama, Batman ve Ulama (2015). Lisans Düzeyinde Turizm Eğitimi Alan Öğrencilerin Kariyer Algılamalarına Yönelik Bir Araştırma: Sakarya Üniversitesi Örneği. Bartın Üniversitesi İIBF Dergisi, 6(12), 339-366.

- Yazıcığlu ve Erdoğan. SPSS Uygulamalı Bilimsel Araştırma Yöntemleri. Ankara: Detay Yayıncılık.

- Yılmaz (2018). Stres Faktörleri ile Stresle Başa Çıkma Arasındaki İlişkinin Kişilik Tipine Göre Incelenmesi: Ankara İtfaiyesi Çalışanları Üzerine Bir Uygulama. Yüksek Lisans Tezi, Ufuk Üniversitesi Sosyal Bilimler Enstitüsü, Ankara.

- Zikic ve Klehe (2006). Job Loss as A Blessing in Disguise: The Role of Career Exploration and Career Planning in Predicting Reemployment Quality, Journal of Vocational Behavior, 69, 391-409. 


\title{
Otel Web Sitelerinin İçerik Analizi Yöntemiyle Değerlendirilmesi: Bişkek'te Bir Araştırma
}

\section{Evaluation of Hotel Websites Using Content Analysis: A Study in Bishkek}

\author{
Asst. Prof. Dr. Azamat Maksüdünov (Kyrgyzstan-Turkey Manas University, Kyrgyzstan)
}

\begin{abstract}
With the rapid expansion of the internet corporate websites are becoming an important tool of communication with target markets. The target markets of the hotels go beyond the borders of the country and can be anywhere in the world. Effective use of the corporate web sites is an important factor that affects the success of hotel enterprises in the competitive environment. In this context, the main purpose of this study is to evaluate hotels' web sites in Bishkek and to reveal the situation in terms of characteristics that should be in their web pages. A total of 30 hotel websites have been reviewed. Data was obtained from hotel web sites using an evaluation form. Percentage and frequency techniques were applied to analyze the data and results are given by hotel types (three or four stars). According to the results, it was found that hotels' web sites are not sufficient in terms of required features and both three and four star hotels demonstrate same performance. In particular, it can be said that the hotel web sites are very poor in terms of information about the destination. Hotels should benefit from the results of academic studies and, if necessary, to conduct their own researches in order to have an effective web sites.
\end{abstract}

\section{Giriş}

Günümüzde internet kullanımı her geçen gün artmaktadır. Dünya nüfusunun $\% 55$ 'inin (4,3 milyar) internet kullanıcısı olduğu bilinmektedir (İnternetworldstats, 25.03.2019). Internet teknolojilerinin gelişmesi, bilgili ve her konuda bilgiye erişebilme imkanı olan yeni pazar bölümünün ortaya çıkmasına neden olmuştur. Bu durum işletmeleri geleneksel iletişim araçlarıyla birlikte internet teknolojilerini de kullanmaya mecbur kılmaktadır. $\mathrm{Bu}$ çerçevede işletmelerin kurumsal web siteleri hedef pazar ile iletişim kurmak için en önemli araç olarak karşımıza çıkmaktadır (José vd., 2006). Turizm alanında faaliyet gösteren otel işletmeleri için konunun önemi daha da artmaktadır.

Otel işletmeleri dünyanın her bir yanından gelecek olan müşteri gruplarına hitap ettikleri için internet üzerinden yürüttükleri pazarlama faaliyetlerini uluslararası seviyede ve yüksek standartlarda tutmak zorundadırlar. Ancak işletmelerin bulunduğu politik, ekonomik, sosyo-kültürel ve teknolojik koşullara bağlı olarak pazarlama faaliyetleri de farklılık gösterebilmektedir (Maksüdünov, 2007). Dolayısıyla, özellikle geçiş döneminde olan ülkelerde işletmelerin pazarlama anlayıșı ve internette pazarlama faaliyetlerine yönelik araştırmaların yapılması önem arz etmektedir. Bir geçiş ekonomisi olan Kırgızistan'da özel sektörün geliştirilmesine yönelik araştırmalara ihtiyaç duyulmaktadır.

Bu bağlamda henüz piyasa ekonomisine geçiş sürecinde olan Kırgızistan'ın başkenti Bişkek şehrindeki otel işletmelerinin web sitelerinin değerlendirilmesi çalışmanın temel amacını oluşturmaktadır. Bu çerçevede aşağıdaki sorulara cevap aranmıştır:

S1: Otel web sitelerinde olmasl gereken bilgi ve özellikler ne derece mevcuttur?

S2: Otel türüne göre web sitelerinin özelliklerinde farkllliklar var mıdır?

\section{Literatür}

Otellerin hedef pazarı ülke sınırlarının dışına çıkmakta ve dünyanın her yerinde olabilmektedir. Seyahate çıkmayı planlayan insanların gidecekleri ülkedeki konaklama imkanları ile ilgili bilgi edinmek için başvurdukları kaynakların başında otellerin web siteleri gelmektedir (Vincent, 2003). Günümüzde tüketiciler, geleneksel bilgi kaynakları yerine, interneti, konaklama rezervasyonları için çevrimiçi rezervasyonu tercih etmektedirler. Dolayısıyla, işletmelerin tüketici ihtiyaçlarına cevap verebilecek özellikleri taşıyan web sitelerine sahip olmaları önem arz etmektedir (Ateş ve Boz, 2015).

Literatürde konuyla ilgili yapılan oldukça fazla çalışma (Baloglu ve Yakup, 2006; Bayram ve Yaylı, 2009; Stringam vd., 2010; Kelly vd., 2011; Ping-Ho vd., 2013; Ateş ve Boz, 2015; Pamukçu ve Arpac1, 2016) bulunmakla birlikte, Kırgızistan örneğinde yapılan sınırlı sayıda çalışma bulunmaktadır (Oktay ve Şenol, 2008; Kantarcı vd., 2017).

Baloglu ve Yakup (2006) Türkiye'deki seçilmiş bazı lüks otellerin web sitesi tasarımı (etkileşim, navigasyon ve işlevsellik açısından) ve internette pazarlama uygulamaları üzerine bir araştırma yapmışlardır. Otellerin interneti pazarlama aracı olarak tam potansiyeliyle kullanamadıkları ortaya konulmuştur. Web sitelerinin hava koşulları, 
güncel döviz kurları, destinasyonla ilgili linkler, animasyon ve grafikler gibi özellikler ile geliştirilmesi gerektiği dile getirilmektedir.

Yine Türkiye'de Bayram ve Yaylı (2009) tarafından otel işletmelerinin web siteleri içerik analizi yöntemiyle değerlendirilmiş ve web sitelerinde kullanılan özellikler tespit edilmiştir. Yapılan çalışmanın sonuçlarına göre, analiz kapsamındaki işletme web sitelerinde bilgi sağlayıcı özellik bulunduğu, otel ve oda resimlerinin ağırlıklı olarak kullanıldı̆̆ 1 , siteye kolay ulaşım, iletişim ve ulaşım bilgisi, çoklu dil seçeneği ve ana sayfaya kolay ulaşım gibi özelliklerin en çok kullanıldığı, döviz çeviricisi, sıkça sorulan sorular (SSS), farklı ödeme seçeneği, rezervasyon hattı gibi özelliklerin en az kullanıldı̆̆ tespit edilmiştir.

Stringam vd. (2010) otel web sitesi tasarımının sitenin cazibesi ve satın alma olasılı̆̆ üzerindeki etkisini araştırmışlardır. Araştırma ile geliştirilmiş grafiksel web sitesi tasarımının daha çok tercih edildiği, sitenin kullanım kolaylığ 1 , marka sadakatine yönelik site içeriği ve site estetiğinin önemli olduğu ortaya konulmuştur.

Kelly vd. (2011) ABD’de yaptıkları araştırmada, web sitesi sezgiselleri ve onların satın alma olasılığı üzerindeki etkisi ele alınmıştır. Rezervasyon kararlarının web sitesinin estetik cazibesi ile pozitif ilişkili olduğu tespit edilmiştir. Ayrıca, otelin web sitesinde fotoğrafların bulunmasının rezervasyon kararını etkileyen en önemli faktör olduğu ortaya konulmuştur. Satın alma kararlarını etkileyen diğer özellikler; kullanım kolaylığı, renk, bağlantı kullanılabilirliği, web sitesi karmaşasının olmaması ve arayüzün orjinal görünümde olması şeklinde ifade edilmiştir.

Ping-Ho vd. (2013) tarafindan dört kıtada faaliyet gösteren otel işletmelerinin web siteleri analiz edilmiştir. Web siteleri; işlevsellik, yenilik, etkileşim, pazarlama, navigasyon, çevrimiçi işlemler ve hizmet boyutlarıyla değerlendirmeye tabi tutulmuştur. Araştırma sonuçlarına göre, kıtalar arasında otel web sitelerinin özellikleri bakımından farklılıkların olduğu belirlenmiştir. Avrupa'daki otellerde web sitelerinde çevrimiçi destek ve çoklu dil seçenekleri önplana çıkarken, Asya'daki otellerde gerçek zamanlı etkileşim hizmetleri ve gizlilik politikaları önplana çıkmaktadır. Diğer taraftan, Afrika'daki otellerin web sitelerinde seyahat ipuçları ve hava durumu bilgisi ağırlık kazanırken, Amerika'daki otellerin web siteleri Web 2.0 özellikleri bakımından öne çıkmaktadır.

Ateş ve Boz (2015) tarafından Çanakkale'de faaliyet gösteren otel işletmelerinin web siteleri erişilebilirlik ve kullanım açısından değerlendirilmiştir. Web siteleri; işletme ve tesis ile ilgili bilgiler, rezervasyon ve müşteri hizmetleri, iletişim ve ulaşım bilgileri, çevresel çekiciliklerle ilgili bilgiler ve web sitesi yönetim bilgileri olmak üzere altı boyutta incelenmiştir. Araştırma sonuçlarına göre, otel işletmelerinin kurumsal web sitelerini oluşturdukları, ancak etkin bir şekilde kullanmadıkları ve gerekli güncellemeleri yapmadıkları sonucuna ulaşılmıştır.

Pamukçu ve Arpacı (2016) daha önceki çalışmalardan farklı olarak helal konseptli otel işletmelerinin web sitelerini değerlendirmişlerdir. Değerlendirmede farklı bir boyut olarak helal anlayış bilgisi eklenmiştir. Araştırma sonucunda, Türkiye'de faaliyet gösteren helal konseptli otel işletmelerinin web sitelerinde helal anlayış bilgilerine yeteri kadar yer verilmediği, otellerin sadece \%20'sinin web sitesinde helal anlayış bilgisinin mevcut olduğu tespit edilmiştir.

Oktay ve Şenol (2008) Bişkek’te faaliyet gösteren 19 otel işletmesinin web sitesini analiz etmişlerdir. Araştırma sonuçlarına göre, Bişkek’te faaliyet gösteren otel işletmelerinin web sitelerinin çoğunluğunun sadece bilgi sağlayıcı özelliğe sahip olup, birkaçı dışında otellerin birbirinden farklılık arz etmeyen, sıradan ve etkisiz web sayfalarına sahip oldukları sonucuna ulaşılmıştır.

Kantarcı vd. (2017) tarafindan yapılan bir diğer araştırmada ise Kırgızistan'da faaliyet gösteren konaklama işletmelerinin performansları TripAdvisor sitesinde konaklama işletmeleriyle ilgili yazılmış gerçek yorumlara dayalı olarak incelenmiştir. Yapılan çalışmanın sonuçlarına göre, konaklama işletmelerinin genel performansının iyi olduğu, ancak konaklama işletmelerindeki servis kalitesinin beklentilerin altında olduğu tespit edilmiştir.

Konuyla ilgili literatür genel olarak değerlendirildiğinde, otel web sitelerinin müşterileri bilgilendirmek, etkilemek ve satın almaya ikna etmek için önemli bir pazarlama aracı olduğu söylenebilir. Müşterilerin rezervasyon kararlarının otel web sitesinin estetik cazibesi ve kullanım kolaylığı ile pozitif ilişkili olduğu daha önceki çalışmalarda kanıtlanmıştır (Stringam vd., 2010; Kelly vd., 2011). Dolayısıyla, konaklama sektöründe faaliyet gösteren otel işletmeleri etkin bir web sitesine sahip olmalı ve web sitesini pazarlama aracı olarak kullanabilmelidir. İnternette pazarlama sadece büyük zincir oteller için değil, küçük oteller için de ucuz ve etkili bir araç olabilmekte ve kullanıldığı ölçüde rekabet avantajı sağlamaktadır (Baloglu ve Yakup, 2006). Bişkek’te faaliyet gösteren otel işletmelerinin çoğunluğunu küçük ve orta boy işletmeler oluşturmaktadır. Bu işletmeler için rekabette başarılı olmanın yollarından bir tanesi internet teknolojilerinden yeterli düzeyde yararlanabilmeleridir.

\section{Yöntem}

Araştırmada Bişkek’te faaliyet gösteren otel işletmelerinin web sitelerinin durumunun ortaya koyulması hedeflenmiş ve araştırma tarama modeli ile gerçekleştirilmiştir.

Web sitelerinin değerlendirilmesinde işletme bilgileri, tesis bilgileri, rezervasyon ve müşteri hizmetleri, iletişim bilgileri, web sitesi yönetimi bilgileri, yerel özelliklerle ilgili bilgiler olmak üzere altı boyuttan oluşan bir 
değerlendirme formu kullanılmıştır. Her boyut kendi içerisinde sekiz adet alt sorudan oluşmaktadır. İlgili formun geliştirilmesinde konuyla ilgili daha önce yapılmış çalışmalardan yararlanılmıştır (Baloglu ve Yakup, 2006; Bayram ve Yayl1, 2009; Ateş ve Boz, 2015; Pamukçu ve Arpac1, 2016). Daha sonra araştırma kapsamına giren otellerin web siteleri içerik analizine tabi tutulmuştur.

2017 yılı istatistiklerine göre Kırgızistan'da tüzel kişiliği olan otel işletmelerinin sayısı 181 olup, bunların \%62'si (112) Bişkek şehrinde bulunmaktadır (KC Milli İstatistik Komitesi, 25.03.2019). Bu araştırma ise y1ldız sınıflandırması yapılmış ve web sitesi olan otel işletmeleri ile sınırlıdır. Araştırma kapsamına alınacak otellerin listesini belirlemek için Booking.com sitesinden yararlanılmıştır. Verilerin toplandığı tarih (05/08/2018) itibariyle, Booking.com sitesinde Bişkek’te bulunan üç yıldızlı 17, dört yıldızlı 18 ve beş yıldızlı 4 otel olduğu görülmüştür. Ancak beş yıldızlı otellerin sayıca az olması, üç ve dört yıldızlı bazı otellerin web sitelerinin olmaması nedeniyle araştırmada sadece üç (15) ve dört (15) yıldızlı otellerin web siteleri incelenmiş, beş yıldızlı oteller kapsam dışı bırakılmıştır. Değerlendirmeye alınan otellerin ismini, türünü, Booking.com'da aldığı puanları ve web sitelerini içeren ayrıntılı liste EK1'de sunulmuştur.

Verilerin toplanmasında her otelin web sitesi bir kez ziyaret edilmiş ve veri toplama formundaki kriterlere göre değerlendirilmiştir. Değerlendirme formunda web sitesinde aranan özellik var ise «1» ve yok ise «0» şeklinde işaretlenmiştir. Toplanan veriler otellerin türüne (üç veya dört yıldızlı) göre yüzde ve frekans analizlerine tabi tutulmuş ve yorumlanmıştır.

\section{Bulgular ve Yorumlar}

Oteller web sitelerinde işletme hakkında bilgiye (hem dört hem de üç yıldızlı otellerin \%86,7'si) ve logolarına (dört yıldızlı otellerin \%100'ü ve üç yıldızlı otellerin \%93,3’ü) yer vermektedirler (Tablo 1). Bu çalışmada kariyer bilgisi olarak adlandırılan insan kaynakları politikası ve işletmedeki boş pozisyonlar hakkında bilgi, dört yıldızlı otellerin \%26,7'sinde, üç yıldızlı otellerin \%13,3'ünde bulunmaktadır. İşletmenin daha önce ulusal veya uluslararası kurum ve kuruluşlardan aldığı ödüllerle ilgili bilgilere dört yıldızlı otellerin \%20’sinde, üç yıldızlı otellerin \%13,3'ünde yer verilmiştir.

\begin{tabular}{|c|c|c|c|c|c|c|c|c|c|}
\hline \multirow{3}{*}{ Göstergeler } & \multicolumn{4}{|c|}{$4 *$ Oteller } & \multicolumn{4}{|c|}{$3 *$ Oteller } & \multirow{3}{*}{$\sum$} \\
\hline & \multicolumn{2}{|c|}{ Var } & \multicolumn{2}{|c|}{ Yok } & \multicolumn{2}{|c|}{ Var } & \multicolumn{2}{|c|}{ Yok } & \\
\hline & $\mathbf{n}$ & $\%$ & $\mathbf{n}$ & $\%$ & $\mathbf{n}$ & $\%$ & $\mathbf{n}$ & $\%$ & \\
\hline Hakkımızda & 13 & 86,7 & 2 & 13,3 & 13 & 86,7 & 2 & 13,3 & 30 \\
\hline Örgüt șeması & 0 & 0,0 & 15 & 100 & 0 & 0,0 & 15 & 100 & 30 \\
\hline Kariyer bilgisi & 4 & 26,7 & 11 & 73,3 & 2 & 13,3 & 13 & 86,7 & 30 \\
\hline Vizyon & 0 & 0,0 & 15 & 100 & 0 & 0,0 & 15 & 100 & 30 \\
\hline Misyon & 0 & 0,0 & 15 & 100 & 0 & 0,0 & 15 & 100 & 30 \\
\hline Logo & 15 & 100 & 0 & 0,0 & 14 & 93,3 & 1 & 6,7 & 30 \\
\hline Slogan & 1 & 6,7 & 14 & 93,3 & 4 & 26,7 & 11 & 73,3 & 30 \\
\hline Ödüller & 3 & 20,0 & 12 & 80,0 & 2 & 13,3 & 13 & 86,7 & 30 \\
\hline
\end{tabular}

Tablo 1. İşletme Bilgilerine İlişkin Bulgular

İşletmelerin web sitelerinde slogan kullanma durumları oldukça düşüktür. Dört yıldızlı otellerin sadece bir tanesinde $(\% 6,7)$ ve üç yıldızlı otellerin ise \%26,7'sinde slogan kullanılmıştır. Pazarlama açısından logo ile sloganın birarada olması ve her türlü ortamda bulunması markalaşma adına çok önemlidir. Araştırma kapsamındaki oteller açısından bu çok büyük bir eksiklik olarak görülebilir. Ayrıca işletmenin örgüt şeması, vizyon ve misyon ifadeleri hiçbir otelin web sitesinde bulunmamaktadır. Genel olarak üç ve dört yıldızlı otellerin web siteleri işletme bilgileri boyutunda benzer bir görünüm sergilemektedir.

Araştırma kapsamındaki otellerin web sitelerinde tesis hakkında bilgilerin ne düzeyde olduğuna ilişkin bulgular Tablo 2'de sunulmuştur.

\begin{tabular}{|c|c|c|c|c|c|c|c|c|c|}
\hline \multirow{3}{*}{ Göstergeler } & \multicolumn{4}{|c|}{$4 *$ Oteller } & \multicolumn{4}{|c|}{$3 *$ Oteller } & \multirow{3}{*}{$\Sigma$} \\
\hline & \multicolumn{2}{|c|}{ Var } & \multicolumn{2}{|c|}{ Yok } & \multicolumn{2}{|c|}{ Var } & \multicolumn{2}{|c|}{ Yok } & \\
\hline & $\mathbf{n}$ & $\%$ & $\mathbf{n}$ & $\%$ & n & $\%$ & n & $\%$ & \\
\hline Kapasite & 3 & 20,0 & 12 & 80,0 & 8 & 53,3 & 7 & 46,7 & 30 \\
\hline Oda bilgileri & 15 & 100 & 0 & 0,0 & 15 & 100 & 0 & 0,0 & 30 \\
\hline Restoran/Bar & 15 & 100 & 0 & 0,0 & 8 & 53,3 & 7 & 46,7 & 30 \\
\hline Toplantı salonu & 11 & 73,3 & 4 & 26,7 & 4 & 26,7 & 11 & 73,3 & 30 \\
\hline Eğlence/Spor & 9 & 60,0 & 6 & 40,0 & 3 & 20,0 & 12 & 80,0 & 30 \\
\hline Hediyelik eşya & 2 & 13,3 & 13 & 86,7 & 3 & 20,0 & 12 & 80,0 & 30 \\
\hline Fotoğraflar & 15 & 100 & 0 & 0,0 & 14 & 93,3 & 1 & 6,7 & 30 \\
\hline Tanıtım filmi & 5 & 33,3 & 10 & 66,7 & 2 & 13,3 & 13 & 86,7 & 30 \\
\hline
\end{tabular}

Tablo 2. Tesis Bilgilerine İlişkin Bulgular 
Oda bilgileri ve tesis fotoğrafları hem dört yıldızlı (\%100) hem de üç yıldızlı (\%100) otellerin web sitelerinde bulunmaktadır. Restoran/bar hizmetleri hakkında bilgi ise dört yıldızlı otellerin \%100'ünde, üç yıldızlı otellerin $\% 53,3$ 'ünde yer almaktadır. Toplantı salonları, eğlence ve spor alanları hakkında bilginin üç yıldızlı otellere göre (\%26,7 ve \%20,0), dört yıldızlı otellerde $(\% 73,3$ ve \%60,0) daha fazla olduğu görülmüştür. Bu durum dört yıldızlı otellerin tesislerinin daha büyük olması ve sözkonusu imkanlarının daha fazla olması ile açıklanabilir. Tesis bilgileri boyutunda her iki grup otellerin web sitelerinde tesis kapasitesi, hediyelik eşya satan birimleri ile ilgili bilgi ve tanıtım filmlerinin en az düzeyde olduğu tespit edilmiştir. Kapasite bilgisi üç yıldızlı otellerin \%53,3’ünde ve dört yıldızlı otellerin \%20,0'sinde bulunmaktadır. Tanıtım filmleri dört yıldızlı otellerin \%33,3'ünde ve üç yıldızlı otellerin \%13,3'ünde mevcuttur. Tesis bilgisi bulguları ile (Tablo 2) işletme bilgisi bulguları (Tablo 1) birlikte değerlendirildiğinde, otel web sitelerinde tesis bilgilerinin daha yeterli düzeyde olduğu ve her iki gruptaki otellerin web sitelerinin birbirinden çok farklı olmadığı söylenebilir.

Otellerin web sitelerinde olması gereken en önemli özelliklerin başında rezervasyon ve müşteri hizmetlerine ilişkin bilgiler gelmektedir. Bu boyut ile ilgili bulgular Tablo 3 'te ayrıntılı olarak sunulmuştur. Online rezervasyon seçeneği dört yıldızlı otellerin \%100'ünde ve üç yıldızlı otellerin \%93,3'ünde mevcuttur. Diğer taraftan, rezervasyonları görebilme ve iptal edebilme özelliği, dört yıldızlı 2 otel hariç, hiçbirinde bulunmamaktadır. Müşteriler açısından önemli bir bilgi olan hizmet fiyatları bilgisi dört yıldızlı otellerin \%80'inde ve üç yıldızlı otellerin \%93,3'ünde bulunmaktadır. Ancak fiyatlar genellikle yerel para birimi olan Som üzerinden gösterilmiştir. Üç yıldızlı otellerin hiçbirinde fiyatın farklı para birimlerinde gösterilmediği, dört yıldızlı otellerin \% 53,3 'ünde bu özelliğin bulunduğu tespit edilmiştir. Uluslararası pazar bölümlerine hitap eden işletmeler açısından bu durum önemli bir eksiklik olarak görülebilir. Dört yıldızlı otellerin web sitelerinde online ödeme bilgisi \%66,7, otele giriş ve çıkış bilgisi \%60, promosyon bilgileri \%66,7 ve transfer hizmeti \%73,3 oranında bulunmaktadır. Üç yıldızlı otellerin web sitelerinde ise bu özelliklerin bulunma durumu sırasılyla, \%33,3 (online ödeme), \%40 (giriş-çıkış), \%33,3 (promosyon) ve \%26,7 (transfer hizmeti) şeklinde ortaya çıkmıştır. Genel olarak değerlendirildiğginde, farklı para birimlerinde fiyatın gösterilmesi, online ödeme, otele giriş-çıkış bilgisi, promosyon bilgisi ve transfer hizmetleri ile ilgili bilgilerin üç yıldızlı otellere göre, dört yıldızlı otellerin web sitelerinde daha fazla oranda bulunduğu söylenebilir.

\begin{tabular}{|c|c|c|c|c|c|c|c|c|c|}
\hline \multirow{3}{*}{ Göstergeler } & \multicolumn{4}{|c|}{$4 *$ Oteller } & \multicolumn{4}{|c|}{$3 *$ Oteller } & \multirow{3}{*}{$\sum$} \\
\hline & \multicolumn{2}{|c|}{ Var } & \multicolumn{2}{|c|}{ Yok } & \multicolumn{2}{|c|}{ Var } & \multicolumn{2}{|c|}{ Yok } & \\
\hline & n & $\%$ & $\mathbf{n}$ & $\%$ & $\mathbf{n}$ & $\%$ & $\mathbf{n}$ & $\%$ & \\
\hline Online rezervasyon & 15 & 100 & 0 & 0,0 & 14 & 93,3 & 1 & 6,7 & 30 \\
\hline Rezervasyonu iptal edebilme ve görebilme & 2 & 13,3 & 13 & 86,7 & 0 & 0,0 & 15 & 100 & 30 \\
\hline Fiyat bilgisi & 12 & 80,0 & 3 & 20,0 & 14 & 93,3 & 1 & 6,7 & 30 \\
\hline Farklı para birimlerinde fiyat & 8 & 53,3 & 7 & 46,7 & 0 & 0,0 & 15 & 100 & 30 \\
\hline Online ödeme & 10 & 66,7 & 5 & 33,3 & 2 & 13,3 & 13 & 86,7 & 30 \\
\hline Otele giriș-çıkıș bilgisi & 9 & 60,0 & 6 & 40,0 & 3 & 20,0 & 12 & 80,0 & 30 \\
\hline Promosyon bilgileri & 10 & 66,7 & 5 & 33,3 & 2 & 13,3 & 13 & 86,7 & 30 \\
\hline Transfer hizmeti & 11 & 73,3 & 4 & 26,7 & 6 & 40,0 & 9 & 60,0 & 30 \\
\hline
\end{tabular}

Tablo 3. Rezervasyon ve Müşteri Hizmetleri

Otellerin web sitelerinde bulunması gereken bir diğer önemli özellik iletişim bilgileridir. Web siteleri tek taraflı bilgi verme aracı olmaktan ziyade, hedef pazar ile etkili iletişim kurmaya elverişli bir araç olmalıdır. Bu boyutla ilgili elde edilen bulguların ayrıntıları Tablo 4'te sunulmuştur. Otellerin hemen hemen hepsinde telefon ve e-posta bilgileri mevcuttur. Üç yıldızlı otellerin sadece bir tanesinde e-posta bilgisinin olmadığı görülmüştür. Sözkonusu işletme açısından bu çok önemli bir eksikliktir. Üstelik e-posta hizmeti sıfır maliyetle sağlanabilmektedir. Telefon bilgilerinde de sabit hat yerine cep telefon numaralarının ağırlıklı olarak yer aldığı dikkat çekmektedir. Faks bilgisi dört yıldızlı otellerin \% 73,3'ünde, üç yıldızlı otellerin \%6,7'sinde mevcuttur. Ayrıca, otellerin büyük bir kısmı web sitelerinde otele ulaşım haritalarına (dört yıldızlı \%86,7 ve üç yıldızlı \%100) ve sosyal medya bağlantılarına (dört yıldızlı \%93,3 ve üç yıldızlı \%66,7) yer vermişlerdir. Ancak üç yıldızlı otellerin hiçbirinde geri bildirim formu, sıkça sorulan sorular (SSS) ve müşteri temsilcisi bilgileri bulunmamaktadır. Dört yıldızlı otellerde de durum pek farklı değildir. Bu bilgilere dört yıldızlı otellerin çok az bir kısmında (geri bildirim formu \%6,7, SSS \%13,3 ve müşteri temsilcisi bilgisi \%6,7) yer verilmiştir. Genel bir değerlendirme yapılacak olursa, araştırma kapsamındaki otellerin web sitelerinde etkileşim sağlamaya yönelik iletişim seçeneklerinin yeterli düzeyde olmadığı ve bu durumun otel türüne göre çok fazla değişmediği söylenebilir. 


\begin{tabular}{|c|c|c|c|c|c|c|c|c|c|}
\hline \multirow{3}{*}{ Göstergeler } & \multicolumn{4}{|c|}{$4 *$ Oteller } & \multicolumn{4}{|c|}{$3 *$ Oteller } & \multirow{3}{*}{$\sum$} \\
\hline & \multicolumn{2}{|c|}{ Var } & \multicolumn{2}{|c|}{ Yok } & \multicolumn{2}{|c|}{ Var } & \multicolumn{2}{|c|}{ Yok } & \\
\hline & $\mathbf{n}$ & $\%$ & $\mathbf{n}$ & $\%$ & n & $\%$ & $\mathbf{n}$ & $\%$ & \\
\hline Telefon & 15 & 100 & 0 & 0,0 & 15 & 100 & 0 & 0,0 & 30 \\
\hline Faks & 11 & 73,3 & 4 & 26,7 & 1 & 6,7 & 14 & 93,3 & 30 \\
\hline E-posta & 15 & 100 & 0 & 0,0 & 14 & 93,3 & 1 & 6,7 & 30 \\
\hline Geri bildirim formu & 1 & 6,7 & 14 & 93,3 & 0 & 0,0 & 15 & 100 & 30 \\
\hline SSS & 2 & 13,3 & 13 & 86,7 & 0 & 0,0 & 15 & 100 & 30 \\
\hline Ulașım haritası & 13 & 86,7 & 2 & 13,3 & 15 & 100 & 0 & 0,0 & 30 \\
\hline Müșteri temsilcisi bilgileri & 1 & 6,7 & 14 & 93,3 & 0 & 0,0 & 15 & 100 & 30 \\
\hline Sosyal medya bağlantıları & 14 & 93,3 & 1 & 6,7 & 10 & 66,7 & 5 & 33,3 & 30 \\
\hline
\end{tabular}

Tablo 4. Iletişim Bilgileri

Web sitesinde yer alan bilgilerin güncelliği, site içi arama motoru, yardım menüsü, sitenin yüklenme hızı gibi özellikler web sitesi yönetim bilgileri başlığ 1 altında toplanmış ve bu boyutla ilgili elde edilen bulgular Tablo 5 'te ayrıntılı olarak sunulmuştur. Her iki gruptaki otellerin \%93,3'ünde web sitesinde yer alan bilgilerin güncel olduğu sonucunda ulaşılmıştır. Ancak güncelleme tarihi ile ilgili bilgi hiçbir otelin web sitesinde bulunmamaktadır.

\begin{tabular}{|c|c|c|c|c|c|c|c|c|c|}
\hline \multirow{3}{*}{ Göstergeler } & \multicolumn{4}{|c|}{$4 *$ Oteller } & \multicolumn{4}{|c|}{$3 *$ Oteller } & \multirow{3}{*}{$\sum$} \\
\hline & \multicolumn{2}{|c|}{ Var } & \multicolumn{2}{|c|}{ Yok } & \multicolumn{2}{|c|}{ Var } & \multicolumn{2}{|c|}{ Yok } & \\
\hline & $\mathbf{n}$ & $\%$ & $\mathbf{n}$ & $\%$ & & $\%$ & n & $\%$ & \\
\hline Bilgilerin güncelliği & 14 & 93,3 & 1 & 6,7 & 14 & 93,3 & 1 & 6,7 & 30 \\
\hline Güncellenme tarihi & 0 & 0,0 & 15 & 100 & 0 & 0,0 & 15 & 100 & 30 \\
\hline Site içi arama motoru & 2 & 13,3 & 13 & 86,7 & 1 & 6,7 & 14 & 93,3 & 30 \\
\hline Site üveliği & 2 & 13,3 & 13 & 86,7 & 0 & 0,0 & 15 & 100 & 30 \\
\hline Yabancı dil seçenekleri & 14 & 93,3 & 1 & 6,7 & 13 & 86,7 & 2 & 13,3 & 30 \\
\hline Yardım menüsü & 1 & 6,7 & 14 & 93,3 & 0 & 0,0 & 15 & 100 & 30 \\
\hline Ana sayfaya kolay ulașım & 7 & 46,7 & 8 & 53,3 & 6 & 40,0 & 9 & 60,0 & 30 \\
\hline Sitenin hızlı yüklenmesi & 12 & 80,0 & 3 & 20,0 & 13 & 86,7 & 2 & 13,3 & 30 \\
\hline
\end{tabular}

Tablo 5. Web Sitesi Yönetimi Bilgileri

Yabancı dil seçeneği dört yıldızlı otellerin \%93,3'ünde ve üç yıldızlı otellerin \%86,7'sinde bulunmaktadır. Yabanc1 dil seçeneği bulunmayan otellerin web sitelerinin genellikle tek dilde ve Rusça olduğu görülmüştür. Yabancı dil seçeneği olan otellerde ağırlıklı olarak İngilizce, çok az sayıda Çince ve Almanca gibi seçeneklerin olduğu gözlemlenmiştir. Otellerin web sitelerinin genellikle (dört yıldızlı otellerde $\% 80$ ve üç yıldızlı otellerde $\% 86,7)$ hızlı olduğu, ancak site içi arama motoru, site üyeliği, yardım menüsü gibi özelliklerin çok az sayıda otelin web sitesinde bulunduğu belirtilmelidir. Genel olarak değerlendirildiğinde, üç ve dört yıldızlı otellerin web sitelerinin sözkonusu boyut bazında farklı bir durumda olmadığı söylenebilir.

Otellerin web siteleri işletme ve tesis dışında, bulunduğu bölge ile ilgili bir takım bilgileri içerebilmektedir. Bu konuda araştırma kapsamındaki otellerin durumu Tablo 6'da ayrıntılı olarak sunulmuştur. Sözkonusu özellikler bakımından Bişkek’teki otellerin web sitelerinin çok zayıf oldukları söylenebilir.

\begin{tabular}{|c|c|c|c|c|c|c|c|c|c|}
\hline \multirow{3}{*}{ Göstergeler } & \multicolumn{4}{|c|}{$4 *$ Oteller } & \multicolumn{4}{|c|}{$3 *$ Oteller } & \multirow{3}{*}{$\Sigma$} \\
\hline & \multicolumn{2}{|c|}{ Var } & \multicolumn{2}{|c|}{ Yok } & \multicolumn{2}{|c|}{ Var } & \multicolumn{2}{|c|}{ Yok } & \\
\hline & $\mathbf{n}$ & $\%$ & n & $\%$ & $\mathbf{n}$ & $\%$ & $n$ & $\%$ & \\
\hline Bölgenin genel tanıtımı & 3 & 20,0 & 12 & 80,0 & 0 & 0,0 & 15 & 100 & 30 \\
\hline Bölgedeki hava durumu & 2 & 13,3 & 13 & 86,7 & 0 & 0,0 & 15 & 100 & 30 \\
\hline Saat bilgileri & 0 & 0,0 & 15 & 100 & 0 & 0,0 & 15 & 100 & 30 \\
\hline Güncel döviz kuru & 1 & 6,7 & 14 & 93,3 & 0 & 0,0 & 15 & 100 & 30 \\
\hline Döviz çevirici & 1 & 6,7 & 14 & 93,3 & 0 & 0,0 & 15 & 100 & 30 \\
\hline Gezilecek yerler bilgisi & 3 & 20,0 & 12 & 80,0 & 3 & 20,0 & 12 & 80,0 & 30 \\
\hline Havaalanları & 1 & 6,7 & 14 & 93,3 & 0 & 0,0 & 15 & 100 & 30 \\
\hline Ulașım seçenekleri & 1 & 6,7 & 14 & 93,3 & 0 & 0,0 & 15 & 100 & 30 \\
\hline
\end{tabular}

Tablo 6. Yerel Özelliklerle İlgili Bilgiler

Gezilecek yerlerle ilgili bilgi hem üç yıldızlı hem de dört yıldızlı otellerin sadece \%20'sinde bulunmaktadır. Diğer özellikler üç yıldızlı otellerde hiç bulunmamakta, dört yıldızlı otellerin ise sadece bir kaçında bulunmaktadır. Bu boyutta da otel türüne göre farklılıkların olmadığ 1 ve genel olarak otel web sitelerinin yetersiz olduğu sonucuna ulaşılmıştır. 


\section{Sonuç ve Öneriler}

$\mathrm{Bu}$ araştırma ile, Bişkek şehrinde faaliyet gösteren otel işletmelerinin web sitelerinin olması gereken özelliklerin ve bilgilerin tamamını içermediği sonucuna ulaşılmıştır. Araştırılan altı boyut genel olarak ele alındığında, işletme hakkında bilgi, web sitesi yönetim bilgileri ve yerel özelliklerle ilgili bilgi boyutlarına göre, tesis hakkında bilgi, rezervasyon ve müşteri hizmetleri ve iletişim bilgileri boyutlarının daha yeterli düzeyde olduğu söylenebilir. Literatürde yer alan çalışmaların bir kısmında benzer sonuçların elde edildiğini görmek mümkündür (Bayram ve Yaylı, 2009; Ateş ve Boz, 2015).

İşletme bilgisi boyutunda işletmelerin logo ile birlikte slogan kullanmaları önerilebilir. Ayrıca, misyon ve vizyonlarını tanımlayıp web sitelerinde paylaşmaları da önem arz etmektedir. İşletmeler günümüzde sadece diş müşteriler için rekabet etmemektedir. İç müşteri olarak ele alabileceğimiz işgörenlere yönelik de bilgilerin olması yerinde olacaktır. Bu çerçevede otel işletmelerinin, işe alma süreçleri ve insan kaynakları politikaları ile ilgili bilgilere web sitelerinde yer vermeleri isabetli olacaktır. Web sitelerinin iki taraflı iletişim için elverişli olması önemlidir. Bişkek'teki otellerin web siteleri genel olarak yeterli bilgi içermekle birlikte, bazı eksikliklerin olduğu da gözardı edilmemelidir. İlgili otellerin web sitelerinde geri bildirim formlarına ve müşteri temsilcisi bilgilerine yer vermeleri önerilebilir. Ayrıca, web sitelerinde yardım menüsünün bulunması, ana sayfaya kolay ulaşım gibi özelliklerinin olmasına özen gösterilmelidir. Otel web sitelerindeki en yaygın eksikliğin yerel özelliklere ilişkin bilgilerin yetersiz olması olarak gösterilebilir. Web sitesini ziyaret eden turistlerin destinasyon hakkında; saat bilgisi, hava durumu, döviz kuru, gezilecek yerler gibi bilgileri de edinmek isteyebilecekleri unutulmamalıdır. Bu konuda Bişkek'te faaliyet gösteren işletmelerin çok zayıf durumda olduğu belirtilmelidir.

Web sitelerindeki bilgi ve özelliklerin içerisinden rezervasyon ve müşteri hizmetleri boyutu hariç diğer boyutlarda otel türüne göre (üç ve dört yıldızlı) çok fazla farklılık olmadığı söylenebilir. Çanakkale ili kapsamında Ateş ve Boz (2015) tarafından yapılan çalışmada da otel türüne göre farklılık olmadığı sonucuna ulaşılmıştır. Bu durum web sitelerinin ve internet teknolojilerinin sadece büyük oteller için değil, tüm işletmeler için ucuz ve etkili araç olması ile ilgili olabilir (Baloglu ve Yakup, 2006).

Genel olarak değerlendirildiğinde, Bişkek’teki otellerin web sitelerini pazarlama aracı olarak tam potansiyeliyle kullandıkları söylenemez. Bulgular neticesinde gözlemlenen web sitelerindeki bilgi ve özelliklerin eksikliklerinin yanı sıra web sitelerinde bulunan yazım hataları ve teknik eksiklikler de bu kanaati desteklemektedir. Bununla beraber daha önce yine Bişkek'te Oktay ve Şenol (2008) tarafindan yapılan çalışmanın sonuçları ile karşılaştırıldığında web sitelerinde bir gelişim olduğu belirtilmelidir. Otellerin sayısı ve yönetici kadrolarının bilgi ve tecrübeleri artmaktadır. Web sitelerinin pazarlama aracı olarak kullanımına ilişkin iyileşme sözkonusudur.

$\mathrm{Bu}$ çalışma sektörde faaliyet gösteren işletmeler açısından önemli ipuçlarını ortaya koymakla birlikte, bazı sınırlılıklara da sahiptir. Öncelikle çalışma sadece üç ve dört yıldızlı otel işletmelerini kapsamaktadır. Bir diğer önemli sınırlılık ise, çalışmada sadece web sitelerinde bulunması gereken bilgi ve özelliklerin olup olmadığına bakılmıştır. Bundan sonra yapılacak çalışmalar için örneklemin genişletilmesi ve web sitelerindeki özelliklerin işlevselliği ve kalitesinin de ele alınması önerilebilir.

\section{Kaynakça}

- Ateş ve Boz, 2015. "Konaklama İşletmelerinin Web Sitelerinin Değerlendirilmesi: Çanakkale Örneği”, JEBPIR, 1(1), ss. 63-84.

- Baloglu ve Yakup, 2006. "The Website Design and Internet Site Marketing Practices of Upscale and Luxury Hotels in Turkey”, Tourism Management, 27, pp. 171-176.

- Bayram ve Yaylı, 2009. “Otel Web Sitelerinin İçerik Analizi Yöntemiyle Değerlendirilmesi”, Elektronik Sosyal Bilimler Dergisi, 8(27), ss. $347-379$.

- https://www.booking.com, 05.08.2018

- https://www.internetworldstats.com/stats.htm, 25.03.2019

- José vd, 2006. "Determinants of Internet Use in the Purchasing Process", Journal of Business \& Industrial Marketing, 21(3), pp. 164-174.

- Kantarc1 vd, 2017. "Determining Hotel Performance Through Consumer Generated Travel 2.0 Reviews: A Case of Kyrgyzstan”, Manas Journal of Social Studies, 6(5), pp. 131-145.

- KC Milli İstatistik Komitesi, 2018. http://www.stat.kg/ru/statistics/turizm/, 25.03.2019

- Kelly vd, 2011. “To Book or Not to Book: The Role of Hotel Web Site Heuristics”, Journal of Services Marketing, 25(2), pp. 134-148.

- Maksüdünov, 2007. “KOBİ’lerin Pazarlama Anlayışının Belirlenmesine Yönelik Kırgızistan'da bir Araştırma”, 4. KOBI’ler ve Verimlilik Kongresi Bildiriler Kitabı, ss. 403-414.

- Oktay ve Şenol, 2008. “Konaklama İşletmeleri Pazarlamasında Etkin Web Sayfası Tasarımları:Bişkek’teki Otellerin Web Sayfaları Üzerine bir Araştırma", Alatoo Academic Studies, 7(2), ss. 226-242. 
- Pamukçu ve Arpac1, 2016. "Helal Konseptli Otel İşletmelerinin Web Sitelerinin Analizi”, Uluslararası Turizm ve Sosyal Araştırmalar Dergisi, 1, ss. 147 - 160.

- $\quad$ Ping-Ho vd, 2013. "Website Evaluation of the Top 100 Hotels Using Advanced Content Analysis and eMICA Model”, Cornell Hospitality Quarterly, 54(3), pp. 284-293.

- Stringam ve John, 2010. “Are Pictures Worth a Thousand Room Nights? Success Factors for Hotel Web Site Design", Journal of Hospitality and Tourism Technology, 1(1), pp. 30-49.

- Vincent, 2003. "Internet Usage by International Travellers: Reasons and Barriers”, International Journal of Contemporary Hospitality Management, 15(7), pp. 370-378.

\section{EK 1: Değerlendirmeye Alınan Otellerin Listesi}

\begin{tabular}{|c|c|c|c|c|}
\hline № & Oteller & Yıldız & $\begin{array}{c}\text { Booking.com puanı } \\
06 / 08 / 2018\end{array}$ & Site URL \\
\hline 1 & Solutel Hotel Bishkek & 4 & 9.4 & http://solutel.kg/ru \\
\hline 2 & Ambassador Hotel & 4 & 9,2 & http://www.ambassador.kg/ru \\
\hline 3 & Art Hotel & 4 & 9.1 & https://www.arthotel.kg/ \\
\hline 4 & City Hotel Bishkek & 4 & 9,0 & https://www.cityhotel.kg/ru \\
\hline 5 & Park Hotel Bishkek & 4 & 9,0 & http://www.parkhotel.kg/index.php/ru \\
\hline 6 & Plaza Hotel Bishkek & 4 & 8,9 & http://www.plazahotel.kg/ru/ \\
\hline 7 & Hotel Evropa & 4 & 8,9 & http://evropa.kg/ru \\
\hline 8 & Smart Hotel Bishkek & 4 & 8,8 & https://www.smarthotel.kg/ \\
\hline 9 & Garden Hotel & 4 & 8,8 & https://gardenhotel.kg/ \\
\hline 100 & Damas Hotel & 4 & 8,7 & http://www.damas.kg/ \\
\hline 11 & Rich Hotel & 4 & 8,7 & http://www.rich.kg/ \\
\hline 12 & Grand Hotel & 4 & 8,6 & http://grandhotel.kg/ru/ \\
\hline 13 & Golden Tulip Bishkek & 4 & 8,4 & www.goldentulipbishkek.com/en \\
\hline 14 & Bridges Hotel Bishkek & 4 & 8,4 & http://bridges.kg/ \\
\hline 15 & Club Hotel Dostuk & 4 & 8,1 & http://clubhotel.kg/ru \\
\hline 16 & Futuro Hotel Bishkek & 3 & 9,5 & http://www.futuro.kg/ru \\
\hline 17 & De’Mar Hotel Bishkek & 3 & 9,2 & http://www.demarhotel.kg/ \\
\hline 18 & Lumarc Hotel & 3 & 9,2 & https://lumarc-hotel.business.site/ \\
\hline 19 & Bugu Hotel Bishkek & 3 & 9,0 & http://www.buguhotel.kg/index.php \\
\hline 20 & Bishkek Centrum Hotel & 3 & 9,0 & http://centrumhotel.kg/ \\
\hline 21 & Asia Mountains -2 & 3 & 9,0 & http://asiamountains-hotels.com/am2/ \\
\hline 22 & My Hotel & 3 & 8,9 & http://myhotelbishkek.com/ \\
\hline 23 & Voyage Hotel & 3 & 8,9 & http://hotelkg.com/ \\
\hline 24 & Rixon & 3 & 8,8 & https://rixon.kg/ \\
\hline 25 & Baikhan Hotel & 3 & 8,6 & http://www.baikhan.kg/ \\
\hline 26 & Bishkek Boutique Hotel & 3 & 8,6 & http://www.bishkek-hotel.com/ru/ \\
\hline 27 & Asia Mountains-1 & 3 & 8,5 & http://asiamountains-hotels.com/am1/ \\
\hline 28 & Alpinist Hotel & 3 & 8,4 & http://www.alpinist.kg/ru \\
\hline 29 & Hotel Kausar & 3 & 8,4 & http://kausarhotel.kg/ \\
\hline 30 & Dostuk Hotel & 3 & 6,9 & http://www.dostukhotel.kg/ru/ \\
\hline
\end{tabular}




\title{
Kırsal Turizm Alanında Tarım ve Kırsal Kalkınmayı Destekleme Kurumu (TKDK) Destekleri: Kastamonu Örneği ARDSI Supports in the Rural Tourism Area: Example of Kastamonu
}

\author{
Fatih Gürel (Çankırı Karatekin University, Turkey) \\ Ph.D. Candidate Zehra Meliha Tengiz (Namık Kemal University, Turkey) \\ Ph.D. Candidate Osman İnan (Namık Kemal University, Turkey)
}

\begin{abstract}
Rural development; It is one of the most fundamental elements of countries' having a strong economy and developing. The most important activity area in rural development is rural tourism. Natural wealth, historical memories, local values, etc. recognition and promotion will bring social and cultural development together. In other words, "rural tourism" will be the most important door in the development of domestic and foreign tourism in Turkey and opening up to the world.

In the process of European Union accession process, the ARDSI, which is established by aiming to make the modern enterprises sustainable by increasing the welfare and livelihood of the citizens living in the countryside with the competitiveness at the international level, making stronger investments in domestic and foreign marketing, and increasing the welfare and livelihood level of our citizens living in the country, is the relevant institution of the Ministry of Agriculture and Forestry. Since 2011, ARDSI has invested approximately 3.8 billion TL in our country's economy. Within the scope of these investments, approximately 60000 people were employed, 14441 of whom were directly employed.

In Kastamonu, ARDSI has signed an investment agreement with 11 investors to date, exceeding 11.5 million TL. For that reason, Kastamonu has become a model city for our country in the tourism area of the rural development movement. In this study, general information about the rural tourism potential in Kastamonu and ARDSI was given first and rural tourism applications in Kastamonu province were examined.
\end{abstract}

\section{Giriş}

Turizm ya da gezim, dinlenmek, eğlenmek, görmek ve tanımak gibi amaçlarla yapılan geziler ve bir ülkeye veya bir bölgeye gezmen (turist) çekmek için alınan ekonomik, kültürel, teknik önlemlerin, yapılan çalışmaların tümüdür. Turistik gezi, insanların sadece bir yerden bir yere gitmesi değil kültürel, ekonomik ve toplumsal olarak da iletişim içinde olmalarıdır. Turizm sayesinde insanlar hem diğer ülkelerin, hem kendi ülkelerinde yaşadıkları bölgenin dışındaki güzelliklerin, hem de geçmişte yaşamış olan insanların bırakmış oldukları kültürel mirasın farkına vararak, gelecek kuşaklara daha yaşanılabilir bir dünya bırakmanın gerekliliğine inanarak hayata farklı açılardan bakabilirler. Turistler gittikleri ülke ya da bölgede gördükleri yerler karşılığında o yöre halkına para kazandırırlar. Dolayısıyla turizm ziyaret edilen ülke ve bölgenin ekonomisine büyük bir maddi katk1 sağlar (Kastamonu Kültür, 2019). Ülkemizde Turizm deyince genellikle akıllara deniz, kum ve güneş gibi unsurları içeren bir takım aktiviteleri getirmektedir.

Son yıllarda turizm algısı dünyadaki değişimle birlikte eş zamanlı olarak hızla değişmektedir. Turistik faaliyetler nitelik ve nicelik olarak çeşitlenmeye başlamıştır. Bu değişim, ülkemiz insanlarının standartlarını da değiştirmiş ve geliştirmiştir. Önümüzdeki yıllarda alışılmış turizm aktivitelerinin aksine çok daha farklı yeni aktivitelerin eski alışkanlıkların yerine ikame olması beklenmektedir. Dolayısı ile bu değişimi erkenden farkeden ve hazırlığını yapan ülkeler ve şehirler turizm alanındaki rekabete bir adım önde başlayacaktır. Gelir seviyelerinin artması, hayat standartlarının değişmesi yepyeni kültürleri ve alışkanlıkları beraberinde getirmektedir. Bu değişim kendisini turizm alanında da hissettirmektedir. Yenilik ve farklılık arayışı standart turizm kültürünün zamanla terk edilmesi kalabalık, gürültü ve kirlilikten uzak, doğallığın ön planda olduğu kırsal alanların cazibe merkezi haline gelmesi sonucunu doğurmuştur. Bu alanlarda insanlar her yönden daha sıcak ve tabii bir ortamı tercih etmektedirler.

Tüm bu genel değerlendirmeler ışığında yeni ve önemli bir kavram karşımıza çıkmaktadır. "Kırsal Turizm”. Kırsal turizmle ilgili kaynaklarda birbirinden farklı tanımlar yapıldı̆̆ı dikkatleri çekmektedir. Kırsal turizmin geniş ve birçok kırsal aktiviteyi içeren alternatif turizm faaliyetleri olduğu bu tanımların ortak birleşme noktasıdır. Yani kırsal turizm çiftlik turizmi, köy turizmi, yayla turizmi, mağara turizmi, av turizmi, açık hava doğa sporları turizmi, tarımsal turizm, ekoturizm ve alternatif turizm gibi farklı isimlerle de ifade edilmektedir. Zamanla bu alandaki tanım ve kavramlar daha da yerine oturacaktır. Tüm bu faaliyetlerin kırsal alanlarda gerçekleşmesi ve kırsal turizmin temelinde şehrin kaotik ortamından uzaklaşma ve kırsalda muhtelif ortamlarda konaklama, zaman geçirme, bir takım farklı meşguliyetler edinme olduğu düşünülecek olursa, kırsal turizm kavramının kuşatıcı ve çok geniş anlamlar taşıyan bir çalışma alanı olduğu anlaşılmaktadır. 
Kırsal turizm, güçlenmiş bir ekonomiye ulaşmada, ülkemiz ekonomisinin büyümesinde çok önemli rolü bulunan kırsal kalkınmanın yani kırsalda kalkınmanın vazgeçilmez unsurlarından biridir. Kırsal kalkınma kavramı birbirinden farklı parametreleri ihtiva eden bir kavramdır. Kırsal alanda çarkların çalışmaya başlaması aynı zamanda sosyal ve kültürel kalkınmayı da beraberinde getirir. Başka bir ifade ile kırsal kalkınma ülkemizin refah ve bilgi toplumu olma yolundaki hedeflerin kilit noktasıdır. Yaşadığımız yüzyıla, kaliteli, çeşitli, yenilikçi ve çevreye duyarlı üretimin teşvik edildiği, üreticilerin hayat standartlarına katkıda bulunan, kırsal ekonominin gelişmesine katkı sağlayan kırsal kalkınma odaklı yaklaşımlar damga vurmaktadır.

Kırsal turizm alanındaki çalışmaların desteklenmesi, müteşebbislerin önünün açılması gibi hususlar önem arzetmektedir. Türkiye, özellikle verimlilik ve rekabet gücünün artmasını sağlayacak etkin teknoloji kullanımı, kırsal ve tarımsal alt yapının ve tarım işletmelerinin yapısının iyileștirilmesine yönelik AB kaynaklarının en etkin şekilde kullanılmasını sağlayacak kurumsal yapılanmayı ve programlamayı gerçekleştirmek zorundadır. Aksi takdirde ülkemizin tarımı gerek Avrupa Birliği gerek dünya pazarları karşısında ciddi bir rekabet sorunu yaşayacaktır. Avrupa Birliğine adaylık süreci ülkemiz tarımının dünya ile bütünleşmesini sağlamada önemli bir rol oynamaktadır. Türkiye'nin bu firsatı çok iyi değerlendirmesi gerekmektedir. Avrupa Birliği kendi müktesebatına uyumu sağlamak ya da kolaylaştırmak adına üye, aday ve potansiyel aday ülkelere aynı zamanda Avrupa Komisyonu tarafından da onaylanmış bir takım özel programlar uygulamaktadır. Bu programlardan birisi Türkiye'nin de içinde bulunduğu IPARD (Katılım Öncesi Yardım Aracı Kırsal Kalkınma Bileşeni) Programıdır. Türkiye 2000'li yıllarda kırsal kalkınma alanında başlattığı kalkınma hamlesini, Avrupa Birliğine üyelik müzakereleri ile üyeliğe kadar götürecek olan yolda bir adım daha ileriye taşıyarak, IPARD Programı kapsamında Tarım ve Kırsal Kalkınmayı Destekleme Kurumunu faaliyete geçirmiştir. Ülkemizin Avrupa Birliğine üyelik sürecinde ortak tarım politikası kapsamında yürütülen müzakereler çok çetin geçmektedir.

Öncelikle Kastamonu'nun turizm ve kırsal turizm potansiyellerinin değerlendirileceği bu çalışmada daha sonra uzun yıllar süreceği düşünülen müzakere çalışmaları kapsamında, Katılım Öncesi Mali Yardım Aracının beşinci bileşeni olan Kırsal Kalkınma Bileşeninin (IPARD Programı) Türkiye uygulaması özet olarak ele alınıp, daha sonra TKDK Kastamonu İl Koordinatörlüğü örneği üzerinden daha özele inilerek sahadaki kırsal turizm uygulamaları ve çalışmaları incelenecektir. Çalışmada ilk bölümde Kastamonu ve kırsal turizm konusu incelenmiş, IPARD programının genel özellikleri kısaca ele alınmış, Tarım ve Kırsal Kalkınmayı Destekleme Kurumunun kırsal turizm alanında verdiği destekler hakkında genel bilgi verilmiştir. İkinci ve son bölümde ise TKDK'nın kurulduğu günden bugüne kadar genel olarak Türkiye ve Kastamonu ili özelinde kırsal turizm alanında yaptığ çalışmalar ve verilen destekler hakkında değerlendirmeler yapılmıştır.

\section{Materyal ve Metod}

Bu çalışmada kullanılan materyalin derlenmesinde Tarım ve Orman Bakanlığı tarafından yapılmış çalışmalar ve Türkiye'de kırsal turizm ve kırsal kalkınma çalışmaları, IPA, IPARD ve TKDK konusunda hazırlanmış tez, makale, rapor ve istatistik verilerinden yararlanılmıştır. Ayrıca IPA (Katılım Öncesi Yardım Aracı) ve IPA'nın beşinci bileşeni IPARD ile ilgili rapor ve belgeler incelenmiştir. TKDK tarafından hazırlanmış bilgi notları ile 2013-2018 yılında yayınlanmış "Yatırımlar Rehberi”"nde yer alan bilgiler bu çalışmanın temel verilerini oluşturmuştur.

Literatür ve internet taramalarına dayanarak hazırlanan bu çalışmada; öncelikle Kastamonu'nun kırsal turizm potansiyeline yer verilmiştir. Daha sonra Türkiye'de uygulanan IPA ve IPARD programı ve bu program kapsamında TKDK ele alınmıştır. Son olarak TKDK tarafından kırsal turizm alanında Türkiye ve Kastamonu ilinde yapılan çalışmalar detaylı olarak incelenmiş, mevcut durum tablolarla gösterilip, daha sonra sonuçlar hakkında genel değerlendirmeler yapılmıştır.

\section{Araştırma Bulguları ve Tartışma}

\subsection{Kastamonu İlinin Genel Tanıtımı}

Kastamonu Karadeniz bölgesinin, batı Karadeniz bölümünde bulunmaktadır. Kuzey Anadolu'nun Karadeniz'e doğru meydana getirdiği büyük çıkıntının geniş bir kısmını kaplamaktadır (Kastamonu Valiliği, 1973). Doğusunda Sinop ve Çorum, batısında Bartın ve Karabük, güneyinde Çankırı, kuzeyinde ise Karadeniz bulunmakta olup 135 $\mathrm{km}$ lik sahile sahiptir. Toprak genişliği bakımından komşu illerin en büyüğüdür. Toprak genişliği $13.108 \mathrm{~km}^{2}$ dir. İl yüzölçümünün \%74,6'sı dağlarla, \%21,6'sı platolarla ve sadece \%3,8'i de ovalarla kaplıdır (İbret, 2001).

Genel olarak engebeli arazilerden oluşmaktadır. Kastamonu, Kızılırmak' in başlıca kollarından olan Gökırmak' la kavuşmak üzere, Ilgaz dağı kütlesinin kuzey yamaçlarından inen "Kastamonu suyu" veya "Karaçomak" adını alan bir akarsuyun vadisi boyunda, zemini deniz seviyesinden 790 metre yükseklikte bulunan tekne şeklinde bir düzlügü işgâl eder (Baydil ve İbret, 1999). Kuzeyinde Küre dağları, güneyinde ise Ilgaz dağları yer alır. Kastamonu, kuzeyden Karadeniz, güneyden ise İç Anadolu karasal iklimleri arasında kalan bir geçiş iklimine sahip bulunmaktadır (İbret, 2001). Merkez İlçe'de yıllık sıcaklık ortalaması 9,7 C' dir. En soğuk geçen aylar ocak ve şubat, en sıcak geçen aylar ise temmuz ve ağustostur. Kastamonu'da yağışın aylara dağılımı oldukça düzenlidir. Kış dönemindeki yağışlar yıllık yağışın \% 18'ini, yaz yağışları ise \% 27'sini oluşturmaktadır Yağışların büyük 
bölümü ise bahar aylarında düşmektedir. Kastamonu ili bitki örtüsü bakımından oldukça zengindir. Küre ve Ilgaz milli parkları ülkemizin gür ormanlık alanlarındandır. Bu ormanlarda başta kayın olmak üzere karaçam, sarıçam, göknar, karaağaç, akçaağaç ve kestane gibi ağaç türleri bulunmaktadır. Genelde Karadeniz kıyısı boyunca geniş yapraklı gür ormanlar varken iç kesimlerde yaprağını dökmeyen ormanlar bulunur. İlin \% 58,5 i ormanlarla kaplıdır (Baydil ve İbret, 1999).

\subsection{Kastamonu İlinin Kırsal Turizm Potansiyeli}

Ülkemizin cennet köşelerinden biri olan Kastamonu, büyük şehirlerin gürültüsünden kaçmak isteyenlerin sığınabilecekleri bir huzur bölgesi, panoramik dağlarıyla, yemyeşil ovalarıyla, zümrüt sahilleriyle, zengin kültürel varlıklarıyla birçok alternatifler sunan bir tatil beldesidir. Kastamonu geleneksel Türk evi ve yakın dönem Osmanlı mimarisi örneklerinin yoğun olarak bulunduğu ender illerdendir. Kentsel sit kapsamına alınmış olan Kastamonu, Taşköprü, İnebolu, Küre ve Abana'nın eski mahalleleri ve yapıları ziyaretçilerde nostalji ve hayranlık uyandırır.

Kastamonu'nun turizm imkânları ve çeşitliliği yönüyle oldukça zengin olduğu görülmektedir. Tarihi boyunca pek çok medeniyete ev sahipliği yapmasıyla birlikte bu medeniyetlere ait birçok eseri bünyesinde barındırmaktadır. Höyükler, Tümülüsler, camiler, medreseler, hanlar, hamamlar, külliyeler, imaretler, gibi pek çok tarihi ve kültürel eserler Kastamonu'nun turistik değerini hayli artırmaktadır. Kastamonu "Evliyalar Şehri” olarak da anılır ve çeşitli yerlerinde birçok alim ve evliyanın türbe ve mezarları bulunmaktadır (Yaman, 2003; Aydoğdu ve Duman, 2017). Kastamonu ilinin yaklaşık 135 km.' lik bir sahil şeridi olup, Cide, İnebolu, Abana ve Çatalzeytin gibi ilçelerin kıyılarında geniş kıyı kumulları ve doğa manzaraları bulunmaktadır. Bu alanlar kırsal turizm ve deniz turizmine müsait alanlardır. Ayrıca bu kıyılar bozulmamış doğası ile yeşil ile mavinin bütünleştiği Türkiye'nin nadir yerlerindendir (İbret, 2004). İçerisinde bulundurduğu doğal ya da bilimsel özellikler sebebiyle kanunla belirlenmiş alanlar koruma altına alınarak "Milli park" olarak ilan edilir. Kastamonu'da Ilgaz ve Küre Milli parkları bulunmaktadır. Özellikle Ilgaz'da yer alan “Kış sporları turizm merkezi” ülkemizin önemli kayak merkezlerinden biridir. Kayak merkezinde 800 m. ve 1500 m. uzunluğunda iki adet kayak pisti, özel ve resmi kuruluşlara ait otel ve tatil köyleri bulunmaktadır. İl, doğa turizmi açısından da büyük bir potansiyele sahiptir. Mağaralar, yaylalar, kanyonlar, zengin flora ve fauna varlığı, ayrıca el sanatları, halk oyunları, geleneksel mutfağı, konakları, anıtları, müzeleri, sağlık ve spor turizmi için uygun alanları ilin diğer turizm zenginliklerindendir.

\subsection{Tarım ve Kırsal Kalkınmayı Destekleme Kurumu (TKDK) ve IPARD Programı}

Avrupa Birliği tarafından birlik müktesebatına uyumu sağlamayı kolaylaştırmak üzere farklı tarihlerde farklı içerikleri olan bir takım programlar uygulanmıştır. AB' ye aday ülkelere katılım öncesi mali yardım sağlamak üzere uygulanmakta olan programların en önemlileri; PHARE, SAPARD, ISPA, CARDS ve IPA gibi yardım araçlarıdır. Türkiye'de ilk defa uygulanan ve ülkemizi ilgilendiren program ise IPA'dır. Katılım Öncesi Yardım Aracı (IPA); aday ülkelere yönelik yardım mekanizmalarının dağınık yapısı nedeniyle Avrupa Birliği tarafından mevzuatın basitleştirilmesi amacıyla katılım öncesi mali yardımlarının tek çatı altında birleştirildiği programdır. Bu program 2007-2013 yılları arasında uygulanmak üzere hazırlanmıştır. Katılım Öncesi Mali İşbirliği Aracı (IPA) olarak adlandırılan bu yeni düzenleme ile Avrupa Birliği aday ve potansiyel aday ülkeleri tam üyeliğe hazırlamayı amaçlamaktadır. IPA'nın uygulanmasında temel gaye, aday ülkelere aynı finansman şartlarında fon sağlanması ve bu fonların kullanımında aday ülkelere daha geniş imkânlar tanımak olarak özetlenebilir. Çok daha önemli olan bir diğer husus ise fonların kullanımının AB tarafından çerçevesi belirlenmiş ve Avrupa Komisyonu tarafından akredite edilmiş ve aynı zamanda merkezi olmayan bir fonlama yönetim sisteminin oluşturulmasını zorunlu k1lmasidır.

IPA'nın beş farklı alt bileşeni bulunmaktadır. Bu bileşenler fonlama yapılacak alanların genel çerçevesini belirlemektedir. Bu program Türkiye ile birlikte aday ülkeler Hirvatistan, Makedonya, İzlanda ve Karadağ, potansiyel aday ülkeler, Arnavutluk, Bosna-Hersek, Sırbistan ve Kosova tarafindan da uygulanmaktadır. IPA'nın beş bileşeni aşağıda verilmiştir;
I. Geçiş Yardımı ve Kurumsal Yapılanma
II. Sınır Ötesi İşbirliği
III. Bölgesel Kalkınma
IV. İnsan Kaynaklarının Geliştirilmesi
V. Kirsal Kalkınma (IPARD)

IPA’nın Geçiş Yardımı ve Kurumsal Yapılanma ile Sınır Ötesi İşbirliği bileşenleri hem aday ülkeler hem de potansiyel aday ülkeler tarafından kullanılmaktadır. Bölgesel Kalkınma, İnsan Kaynaklarının Geliştirilmesi ile Kırsal Kalkınma bileşenleri ise sadece aday ülkeler tarafından kullanılabilmektedir. Türkiye aday ülke olarak beş bileşenden de faydalanma hakkına sahiptir.

IPA'nın beşinci bileşeni olan “Kırsal Kalkınma” (IPARD)’ın temel hedefi; aday ülkenin Kırsal Kalkınma Politikalarının, Topluluk Ortak Tarım Politikası uygulamalarına yakınlaşmasını desteklemektedir. IPARD fonları 2007-2013 dönemini kapsayan çok yıllık tek bir "Kırsal Kalkınma (IPARD) Programı” aracılığı ile kullanılacaktır. Program birliğe katılım öncesinde aday ülkelerin Ortak Tarım Politikasına uyumunun asgari düzeyde sağlanmasına destek olmak ve tarım sektörü ile kırsal alanların sürdürülebilir gelişimine katkıda bulunmak amacıyla ortaya 
konulmuştur. $\mathrm{AB}$ Komisyonunca teorik ve pratik çerçevesi çizilmiş olan bu programla aday ülkelerde desteklenecek olan tarım ve kırsal kalkınma faaliyetlerinin fonlanması amacıyla merkezi olmayan yönetim ilkesine bağlı Ödeme Ajansı (TKDK) kurulması öngörülmüştür.

IPARD Programı Gıda Tarım ve Hayvancılık Bakanlığı tarafından, Ulusal Kırsal Kalkınma Stratejisi ve Politika Çerçeve Belgesi (DPT 2006), Sektör Analizleri (2006), Kırsal Kalkınma Yatırımlarının Desteklenmesi Programı (2006), Tarım Strateji Belgesi (2006-2010), Dokuzuncu Kalkınma Planı (2007-2013) ve Ulusal Kırsal Kalkınma Planı (2010) esas alınarak hazırlanmıştır. Tarımsal ve kırsal alanların yapısal durumu analiz edilmiş, geliştirilmeye müsait, belirli bir üretim ilişkisi ve hacmine sahip alanlar nüfus, dağlık alan, tarımsal üretim değeri, milli gelire katkı vb. yönünden değerlendirilerek sektör analizleri yapılmış, desteklenecek alanlara ilişkin ülke görüşü $\mathrm{AB}$ Komisyonuna sunulmuştur. Komisyon ile karşılıklı görüşmeler neticesinde 2007-2013 dönemini kapsayan IPARD programı AB Komisyonun onayıyla 25 Şubat 2008 tarihinde kabul edilmiştir.

IPARD Programı ile ilgili süreç devam ederken programın uygulanması için varlığı gerekli ödeme ajansı olarak görülen Tarım ve Kırsal Kalkınmayı Destekleme Kurumu 18 Mayıs 2007 tarihinde 5648 sayılı kanunla kurulmuş ve öncelikli olarak belirlenen 42 ilde örgütlenmesini tamamlamıştır. TKDK'nın kuruluş amacı; ulusal kalkınma plan, program ve stratejilerinde öngörülen ilke ve hedefler çerçevesinde, Avrupa Birliği ve uluslararası kuruluşlardan sağlanan kaynakları da kapsayacak şekilde, kırsal kalkınma programlarının uygulanmasına yönelik faaliyetleri gerçekleştirmektir. İllerin belirlenmesinde gayrisafi yurtiçi hâsıla değerleri, iller arası karşılaştırmalı dış göç değerleri, kırsal alanların ve tarım sektörünün ildeki potansiyeli gibi kıstaslara göre seçim yapılmıştır.

IPARD programının hazırlığında birbirini takip eden 2 ayrı uygulama dönemi öngörülmüsşür. 2007-2009 yılları arası 20 ilde ilk aşamada yer alan illerin il koordinatörlükleri kurulmuştur. AB Komisyonu tarafından yetki devrinin alınması ile uygulama dönemi illeri proje kabulü için çağrı ilanlarına başlamıştır. Daha sonra 2010-2013 dönemi için mevcut 20 ile ek olarak 22 il daha ilave edilerek IPARD uygulayıcısı il koordinatörlüğü sayısı 42'ye yükselmiştir.

IPARD hibe destekleri Avrupa Birliği ve Türkiye arasında oluşturulan bir ulusal fondan karşılanmaktadır. Faydalanıcılar sunmuş oldukları projenin toplam uygun maliyetinin (uygun harcamalar toplam tutarı) \%50'si oranındaki kısmını kendi öz kaynaklarından karşılamaktadırlar. Bu kaynăga kullanıcı katkısı denmektedir. Geriye kalan tutar ise \%75 AB katkısına ilave olarak \%25 Türkiye Cumhuriyeti eş finansmanı ile ulusal fondan karşıllanmaktadır.

IPARD programında asgari hibe oranı $\% 50$ (kamu katkısı) olarak belirlenmiştir. Faydalanıcı tarafından sağlanan katkı ise maksimum olarak toplam uygun harcama miktarının \%50'sidir. Yatırımcı desteğe tabi olan harcamalarını katma değer, gelir ve gümrük vergisi gibi birçok vergiden muaf olarak yapmaktadır. Hayvansal üretim ile ilgili yatırımlarda faydalanıcının yaşına veya yatırımın yapıldığı yere göre (dağlık alan) hibe desteği oranı \%65'e kadar çıkmaktadır. TKDK tarafindan verilen hibeler yatırım konusu ve tutarlarına bağlı olarak en fazla 3 taksitte ödenebilmektedir. Bu durum yatırımların belli bir sermaye gücü olamadan gerçekleştirilmesini zorlaştırmaktadır. Program hedef kitle olarak çok küçük, küçük ve orta ölçekli işletmeleri muhatap olarak alsa dahi sistem kendi kendini koruyabilmek ve çalıştırabilmek için sermaye gücünü ön plana çıkarmaktadır. Tamamlanan yatırımların 5 yıl süre ile izlenmesi ve yatırımcının yatırımla ilgili tüm taahhütlerini yerine getirmesi söz konusudur (IPARD, 2018).

\subsection{TKDK Kırsal Turizmi Nasil Destekliyor?}

TKDK'nın kırsal turizm yatırım başlı̆̆ının amacı; mikro ve/veya küçük girişimciler veya çiftçiler tarafindan kurulacak pansiyon, yatak ve kahvaltt, konaklama ve restoran hizmetlerinin gelişimini, çiftlik turizmi tesislerinin kurulması ve geliştirilmesini ve turistik rekreasyonel faaliyetler (sportif aktiviteler, doğa gezisi, tarihi geziler gibi) için kurulan tesislerin gelişimini desteklemek şeklinde tarif edilmektedir (TKDK, 2019). Desteklemeler TKDK'nın her çağrı döneminde farklılık göstermesine rağmen özde aynıdır. Kırsal turizm yatırım başlığı (alt tedbiri) kapsamında makine-ekipman alımı, yapım işleri, hizmet alımı (genel harcamalar) ve görünürlük harcamaları desteklenmektedir. Kırsal turizme yönelik hazırlanacak projenin uygun harcamalar toplam tutarı; en az 15.000 Avro, en fazla 500.000 Avro olmalıdır. Destek oranı uygun harcamalar toplamının \%50'sidir. Kırsal turizme verilecek destekten faydalanmak için kamu tüzel kişilikleri hariç, ulusal kanunlarca tanınmış gerçek ve tüzel kişiler başvurabilir (kamu hissesi \%25'den fazla olan tüzel kişilikler uygun değildir).

Gerçek ve tüzel kişilerde; başvuru sahibi (tüzel kişilikte ise tüzel kişiliği temsil ve ilzama yetkili kişi) başvuru sunulduğu tarihte 65 yaşın üzerinde olmamalı yani 66 yaşından gün almış olmamalıdır. Çiftlik turizminin geliştirilmesi söz konusu olduğunda başvuru sahibi Çiftçi Kayıt Sistemine (ÇKS) kayıtlı olmalı veya gerçek kişi ise, çiftçinin Adrese Dayalı Nüfus Kayıt Sistemindeki hane halkından bir kişi çiftçi kayıt sistemine kayıtlı olmalıdır.

Proje sahibi 50 kişiden az çalışan istihdam edip, yıllık cirosu ve/veya bilançosu 8 Milyon TL'yi aşmayan mikro ve küçük ölçekli zanaatkârlar ve işletmeler kapsamında olmalıdır. Yatırımcı ulusal vergi sistemine kayıtlı olmalıdır. Ayrıca konaklama tesislerinde işletmesi için yatırım sonunda Turizm Tesislerinin Belgelendirilmesine ve Niteliklerine İlişkin Yönetmelik hükümlerine uygun olarak gerekli sertifikalara sahip olmalıdır. Yapılan yatırımla ilgili 5393 sayılı Belediye Kanunu ve pastaneler söz konusu olduğunda ise 5179 sayılı Gıda Kanunu veya 5996 
Veteriner Hizmetleri, Bitki Sağlı̆̆ı, Gıda ve Yem Kanunu hükümlerine uygun sertifikalara sahip olmalıdır. Konaklama tesisleri yatırım sonunda en fazla 25 oda kapasitesine sahip olmalıdır. Yatırımlar desteklenen illerin kırsal alanlarında nüfusu 20.000'in altında olan yerleşim birimlerinde aynı zamanda TKDK tarafindan yayınlanmış resmi kırsal alan listesinde ismi bulunan yerlerde uygulanmalıdır.

\subsection{TKDK, Kırsal Turizm ve Kastamonu}

TKDK 2011 yılından bu yana ülkemiz ekonomisine yaklaşık 3,8 milyar TL'lik yatırım kazandırmıştır. Bu yatırımlar kapsamında ise 14 bin 441 kişiye doğrudan olmak üzere toplamda yaklaşık 60 bin kişiye istihdam sağlanmıştır (TKDK, 2018).

Kastamonu İl Koordinatörlüğü 2. faz il olarak 15 Şubat 2012 tarihinde kurulmuş olup faaliyetine 2013 yılında başlamıştır. 2018 yılı Eylül ayına kadar dokuz çağrı dönemini geride bırakan kurum, Kastamonu'da ilk yatırım sözleşmesini ise 2013 yılında imzalamıştır. İnceleme ve değerlendirme çalışmaları tamamen sonuçlandırılmış olan dokuz çağrı döneminde Kastamonu'da 223 yatırımcı ile yaklaşı 97 Milyon TL'lık yatırım sözleşmesi imzalamıştır. Bu projelere yaklaşık 46 Milyon TL hibe desteği sağlanmıştır (Anonim, 2018).

TKDK tarafından Türkiye'de kırsal turizm alanında sözleşmeye bağlanan projelerle ilgili bilgiler Tablo 1'de verilmiştir. Tablo 1'de de görüldüğü üzere kırsal turizm alanında TKDK tarafından bugüne kadar Türkiye genelinde 652 proje desteklenmiştir. Bu projelerin yatırım tutarı 909 milyon TL'dir. Ülke genelinde TKDK tarafından kırsal turizm projelerine 427 milyon TL hibe desteği sağlanarak, bunun 190 milyon TL si ödenmiştir.

\begin{tabular}{|l|l|l|l|}
\hline $\begin{array}{l}\text { Sözleşmeye Bağlanan } \\
\text { Proje Sayısı }\end{array}$ & $\begin{array}{l}\text { Toplam Yatırım } \\
\text { Tutarı (TL) }\end{array}$ & $\begin{array}{l}\text { Toplam Destek } \\
\text { Tutarı (TL) }\end{array}$ & $\begin{array}{l}\text { Ödenen Hibe } \\
\text { Tutarı (TL) }\end{array}$ \\
\hline 652 & 909 Milyon & 427 Milyon & 190 Milyon \\
\hline
\end{tabular}

Tablo 1. TKDK Tarafindan Türkiye'de Kırsal Turizm Alanında Sözleşmeye Bă̆lanan Proje Sayıları Kaynak: Anonim, 2018

Kastamonu ilinin kırsal turizm alanında yaptı̆̆ı yatırımlarla ilgili bilgiler ise Tablo 2'te verilmiştir. Tablo 2'ye göre Kastamonu ilinde kırsal turizm alanında yaklaşık 10,5 Milyon TL yatırım değerine sahip 9 adet proje ile sözleşme imzalanmıştır. Bu yatırımlar sayesinde Kastamonu'ya sadece kırsal turizm alanında yaklaşık 4,5 Milyon TL hibe desteği verilmiştir. Tarım ve Kırsal Kalkınmayı Destekleme Kurumu kırsal turizm yatırımlarının \%1,38'ini Kastamonu ilinde gerçekleştirmiştir. Dağıtılan hibelerin \%2,22’si Kastamonu iline tahsis edilmiştir.

\begin{tabular}{|l|l|l|}
\hline $\begin{array}{l}\text { Sözleşmeye Bağlanan } \\
\text { Proje Sayısı }\end{array}$ & $\begin{array}{l}\text { Toplam Yatırım } \\
\text { Tutarı (TL) }\end{array}$ & $\begin{array}{l}\text { Toplam Destek } \\
\text { Tutarı (TL) }\end{array}$ \\
\hline 9 & $10.531 .126,02$ & $4.226 .090,97$ \\
\hline
\end{tabular}

Tablo 2. TKDK Kastamonu Il Koordinatörlüğ̈̈ Tarafından Kırsal Turizm Alanında Sözleşmeye Bağlanan Proje Sayıları Kaynak: Anonim, 2018

\begin{tabular}{|c|c|}
\hline Çă̆rı Dönemleri & İmzalanan Sözleşme Sayısı \\
\hline 9. & 1 \\
\hline 10. & - \\
\hline 11. & - \\
\hline 12. & 3 \\
\hline 13. & 4 \\
\hline 14. & - \\
\hline 15. & 1 \\
\hline Ipard2. 1. & 2(proje devam ediyor) \\
\hline TOPLAM & 9 \\
\hline
\end{tabular}

Tablo 3. Kastamonu İl Koordinatörlüğü Tarafından Çağrı Dönemlerine Göre Kırsal Turizm Alanında Sözleşmeye Bağlanan Proje Sayıları Kaynak: Anonim, 2018

İmzalanan sözleşmelerin çağrı dönemlerine göre dağılımını gösteren bilgiler Tablo 3 'te verilmiştir. Tablo 3 'te de görüldüğü üzere ilk çağrı dönemlerinde hibe desteklerine karşı ilgi oldukça azdır. İlgisizliğin birçok sebebi olduğu düşünülmektedir. Öncelikle yatırımcıların TKDK hibe desteklerinden yeterince haberdar olmadığı söylenebilir. Ancak kurumun ülke genelinde çok yoğun tanıtım ve bilgilendirme çalışması yaptığı bilinmektedir. Kastamonu'da kırsal turizm alanında proje iştahının yeterli seviyede olmadığı da düşünülebilir. İlerleyen yıllarda imzalanan sözleşme sayısında görülen artış bu görüşü de zayıflatmaktadır. TKDK mevzuatından kaynaklanan bir takım zorluklar yatırımcıları proje hazırlamaya karşı mesafeli olmaya zorlamış ta olabilir. İlk birkaç projenin hayata geçmesi, yatırımların problemsiz bir şekilde tamamlanması ve hibe ödemelerinin gerçekleşmesinin oluşturduğu çarpan etki sayesinde yatırım sayısında ciddi bir artış gözlemlenmiştir. 
TKDK Kastamonu İl Koordinatörlüğü tarafından kırsal turizm alanında sözleşmeye bağlanan projelerin ilçelere göre dağılımı Tablo 4'te verilmiştir. Tablo 4'e göre; kırsal turizm alanında en çok sözleşme imzalanan ilçe İl merkezidir. Yatırımların ilçelere göre dağılımı az farklılıklar göstermiştir. Kırsal turizmde önemli bir potansiyele sahip olan ilde özellikle Merkez ilçede farklı yatırım alanları desteklemeden yararlanmıştır. Restoran, kırsal turizm, konaklama turizme yönelik projeler ön plana çıkmıştır. Dolayısı ile kırsal turizm alanında hibe desteklerinden en çok payı Merkez ilçe almıştır.

\begin{tabular}{|c|c|r|r|r|r|}
\hline $\begin{array}{c}\text { YATIRIM } \\
\text { YERI } \\
\text { (ILÇE ADI) }\end{array}$ & $\begin{array}{c}\text { SÖZLEŞMEYE } \\
\text { BAGLANAN } \\
\text { PROJE SAYISI }\end{array}$ & $\begin{array}{c}\text { TOPLAM } \\
\text { YATIRIM } \\
\text { TUTARI (TL) }\end{array}$ & $\begin{array}{c}\text { TOPLAM } \\
\text { DESTEK } \\
\text { TUTARI (TL) }\end{array}$ & $\begin{array}{c}\text { ÖDEMESI } \\
\text { BITEN } \\
\text { PROJE } \\
\text { SAYISI }\end{array}$ & $\begin{array}{c}\text { ÖDENEN } \\
\text { HIBE TUTARI } \\
\text { (TL) }\end{array}$ \\
\hline ABANA & 2 & $2.452 .813,66$ & $1.058 .175,05$ & 2 & $1.021 .509,34$ \\
\hline ARAÇ & 1 & $1.398 .584,56$ & $677.697,32$ & 1 & $658.243,78$ \\
\hline DADAY & 1 & $1.764 .558,12$ & $685.604,86$ & 1 & $685.443,77$ \\
\hline MERKEZ & 4 & $4.061 .121,64$ & $1.545 .895,93$ & 4 & $1.527 .072,84$ \\
\hline TAŞKÖPRÜ & 1 & $854.048,04$ & $404.862,28$ & 1 & $333.821,24$ \\
\hline TOPLAM & 9 & $10.531 .126,02$ & $4.372 .235,44$ & 9 & $4.226 .090,97$ \\
\hline
\end{tabular}

Tablo 4. Kastamonu İl Koordinatörlüğü Tarafindan Kırsal Turizm Alanında Sözleşmeye Bağlanan Projelerin Ilçelere Göre Dă̆ılımı Kaynak: Anonim, 2018

Kastamonu ilinin 14 ilçesinde herhangi bir kırsal turizm yatırımı gerçekleşmemiştir. Bu ilçelerde önemli kırsal turizm potansiyelleri mevcuttur. Bu tesislerin bir program dahilinde turizm turlarına dahil edilmesi ile yeni konaklama tesislerine ihtiyaç olacağı aşikardır.

\begin{tabular}{|l|l|l|l|l|l|}
\hline $\begin{array}{l}\text { Konaklama } \\
\text { sayısı }\end{array}$ & $\begin{array}{l}\text { Restoran } \\
\text { sayısı }\end{array}$ & $\begin{array}{l}\text { Kirsal turizm } \\
\text { sayısı }\end{array}$ & $\begin{array}{l}\text { Havuz } \\
\text { sayısı }\end{array}$ & $\begin{array}{l}\text { Seyir terası, Restoran, } \\
\text { Piknik alanı }\end{array}$ & TOPLAM \\
\hline 5 & 1 & 1 & 1 & 1 & 9 \\
\hline
\end{tabular}

Tablo 5. Kastamonu İl Koordinatörlüğ̈̈ Tarafindan Kırsal Turizm Alanında Sözleşmeye Bă̆lanan Projelerin Yatırım Cinslerine Göre Dă̆ılımı Kaynak: Anonim, 2018

Kastamonu İl Koordinatörlüğü tarafından kırsal turizm alanında sözleşmeye bağlanan projelerin yatırım çeşitlerine göre dağılımı Tablo 5'da verilmiştir. Tablo 5'de görüldüğü üzere Kastamonu'da TKDK tarafından kırsal turizm alanında 9 farklı yatırım türünde sözleşme imzalanmıştır. En yoğun sözleşme ise konaklama türü yatırımlarla imzalanmıştır. Sahil ilçelerde ise havuz ve konaklama tesisleri ön plana çıkmıştır.

\section{Sonuç ve Öneriler}

TKDK Türkiye'nin Avrupa Birliği tarafından akredite edilmiş (yetki devri almış) ve taşraya bu denli yayılmış ilk ve tek kurumudur. TKDK tarafından kırsal turizm alanında verilen hibelerin, $\% 50$ faydalanıcı katkısı şartı ve hak ediş şeklinde iki taksitte ödeniyor olması, yatırımların belli bir sermaye gücü olmadan gerçekleştirilmesini zorlaştırmaktadır. Kırsal kalkınma programı hedef kitle olarak 50 kişiden az çalışan istihdam eden, yıllık cirosu ve/veya bilançosu 8 Milyon TL'yi aşmayan mikro ve küçük ölçekli zanaatkârlar ve işletmeleri muhatap olarak alsa dahi işletmelerin güvenliği ve sürdürülebilirliği açısından sermaye gücü ön plana çıkarmaktadır. TKDK kırsal turizm alanında çok önemli yatırımlara destek olmakta olup aynı zamanda TKDK çok farklı alanlarda ve özellikte kırsal turizm yatırımlarını desteklenmektedir.

Kastamonu kırsal turizm alanında önemli potansiyellere sahiptir. Türkiye genelinde yapılan yatırım ve ödenen hibe tutarı açısından orta sıralara yerleşmiştir. Sağlanan hibeler açısından Kastamonu Türkiye genelinde \%2,22'lik bir paya sahiptir. İlde kırsal turizm alanında proje iştahının artabileceğinin işaretidir.

Hibe desteklerine karşı ilgi genel olarak yıldan yıla artış göstermiştir. En fazla yatırım konaklama tesisleri alanında olmuştur. Yapılan inceleme ve değerlendirmelere bağlı olarak, turizm yatırımlarının daha da yaygınlaşması ve hibe desteklerinden daha fazla istifade edilebilmesi için TKDK'nın mevzuatında bir takım iyileştirmelere ihtiyaç olduğu düşünülmektedir. TKDK yatırımlarıyla dolaylı, dolaysız ilgili paydaş kurumlar arasında karşılaşılan aksaklıkları gidermeye yönelik çözüm üreten çalışmalar, çalıştaylar yapılmalı, karşılıklı protokoller imzalanmalıdır. Kırsal turizm potansiyeli olan alanlarda yatırımcıları yatırıma teşvik edecek şekilde master planlar ve yatırım planlamaları yapılarak müteşebbislere yol gösterilmeli ve önleri açılmalıdır. Bu sayede ildeki birçok potansiyel açığa çıkarılarak alternatif kırsal turizm yatırımları özendirilmelidir.

\section{Kaynakça}

- Anonim, 2018. Tarım ve Kırsal Kalkınmayı Destekleme Kurumu Kastamonu İl Koordinatörlüğü Bilgi Notu, Kırsal Kalkınma. TKDK Başkanlı̆̆ı Yayını, Ankara. 
- $\quad$ Aydoğdu ve Duman, 2017. "Destinasyon Çekicilik Unsuru Olarak Gastronomi Turizmi: Kastamonu Örneği”, Turizm ve Araştırma Dergisi, 6(1), p. 4-23.

- Baydil ve İbret, 1999. "Kastamonu Şehrinin Tarihi Gelişimi ve 1924/1925 Şehir Planı Üzerine Bir Değerlendirme", Kastamonu Ĕ̈itim Dergisi, 7(1), p. 3-18.

- IPARD, 2018. Katılım Öncesi Mali Yardım Aracı Kırsal Kalkınma Bileşeni (IPARD), Gıda Tarım ve Hayvancılık Bakanlığı, https://ipard.tarim.gov.tr/ (erişim tarihi 15.07.2018)

- İbret, 2001. "Küre’de Bakır Cevheri Üretimi ve Bakır Madenciliğinin Küre Ekonomisindeki Yeri”, I.Kastamonu Kültür Sempozyumu Bildirileri, p. 436.

- İ̉ret, 2004. "Kastamonu Nüfusunun Gelişim, Dağılım ve Yoğunluk Özellikleri”, Kastamonu Eğitim Dergisi, 12(1), p. 157-178.

- Kastamonu Kültür, 2019. Turizm Değerleri, http://www.kastamonukultur.gov.tr/TR-63872/turizmdegerleri.html (erişim tarihi: 30.03.2019)

- Kastamonu Valiliği, 1973. Kastamonu İl Yıllığı. Kastamonu Valiliği Yayınları, Kastamonu.

- TKDK, 2019. Kirsal Turizm ve Rekreasyon Faaliyetleri, https://www.tkdk.gov.tr/AltTedbir/kirsal-turizm-verekreasyon-faaliyetleri-10 (erişim tarihi: 04.01.2019)

- Yaman, 2003. "Kastamonu 2003 Turizm Envanteri Gezi Rehberi”, Kastamonu. 


\title{
Gastronomi Akımları ile Renklerin İlişkisi Üzerine Bir İnceleme An Investigation on the Relationship between Gastronomy Flows and Colors
}

\author{
Prof. Dr. Mehmet Sarışı1k (Sakarya Applied Sciences University, Turkey) \\ Ph.D. Candidate Nazlı Kardeş (Sakarya Applied Sciences University, Turkey)
}

\begin{abstract}
Considering that the color-rich foods evoke health-freshness and the importance of healthy eating understanding is taken into consideration today, the adoption of the colorful as the gastronomy flow, the interest in the flow to meet the need for prestige and status in the hierarchy of needs, and the current consumed by the social environment. they tend to share. What is the best consumption for man as a result of the study? When the question is approached with the understanding of image the best consumption for the people who enjoy the most, it is seen that it is possible to enjoy the taste of the human as well as the taste of the food. The aim of the study, which is based on the recent gastronomy movements, is the role of colors in the formation of gastronomy currents. to answer the question. For this purpose, many foreign researches have been examined in detail and social media shares related to gastronomy trends which are the research scope are examined. As a result of the study, it is revealed that the colors have an effect on the determination of gastronomy currents and that the colored food attracts more consumers and creates more fashion perception, and that the person who buys a fashionable product tends to share the fashion with the idea that it seems more prestigious and more statistical.
\end{abstract}

\section{Yöntem}

Bu çalışmada sosyal olguların bağlı oldukları çevrede araştırılmasını ve anlaşılmasını temel alan bir yaklaşım olarak tanımlanan nitel araştırma yöntemi kullanılmıştır. Çalışmanın varsayımının, daha önce yapılmış olan çalışmalardan toplanan bilgiler 1şı̆̆ında, elde edilmiş farklı sonuçların birbirleri ile ilişkilendirilmesiyle kanıtlanması amaçlanmıştır. Bu kapsamda renk kavramının bireyler üzerindeki çeşitli etkilerini ortaya koyan birçok yerli ve yabancı makale taranmış ve derinlemesine incelenmiştir. Elde edilen bilgiler bütüncül bir yaklaşım ile analiz edilmiştir. İlaveten son dönemlerde gastronomi alanında trend haline gelen sosyal medya paylaşımlarının içerikleri de incelenerek hangi rengin hangi paylaşım içeriklerinde daha çok bulunduğuna dair tablo oluşturulmuş ve çalışmanın sonunda renklerin gastronomi akımları üzerinde belirleyici bir etkisi olduğu sonucuna varılmıştır.

\section{Giriş}

Geçmişte zorunlu ihtiyaç olarak bilinen yiyecek içecek faaliyetleri günümüzde gelişen teknoloji, artan refah seviyesi, insanların seyahate karşı ve turizme karşı değişen algıları, sosyal yaşama verilen önemin gelişmesi ile birlikte sosyal ihtiyaç olarak ortaya çıkmaktadır (Uluçay;2017: 197; Güneş, Özata, Sormaz, 2015: 69). Bu gelişme ve değişmeler beraberinde farklı tat ve farklı görünümdeki yiyeceklerin deneyimlenmesi arzusunu getirmektedir. Yeme içme faaliyetleri artık bireyler için bir eğlence, boş zaman değerlendirme ve deneyimin unutulmaz hatıralar arasına dahil edilme süreci olmaktadır. Ayrıca son yıllarda yapılan çalışmalarda yiyecek içecek faaliyetinin statü, prestij ve bireyin kendini ifade etmesinde bir araç göstergesi olarak algılandığ 1 da ortaya konulmaktadır (Soner; 2013; Kargiglioğlu; 2015). Bununla birlikte internet kullanımının her geçen gün artması kişilerin internette harcadığ 1 zamanın ve internetin insanlar üzerine olan etkisinin artması ile birlikte tüketici taleplerini ve tüketicinin yemekten beklentisini değişmektedir. Gelişen dünyada tüketici yemeği fizyolojik ihtiyacı karşılamasının dışında, yemeğin sunulduğu mekanla, yemeğin görüntüsü, yemeğin renk uyumu ile hatta yemeği statü ve prestij unsuru göz önüne alındığında sosyal medyada paylaşımını yapabilecek güzellikte olması ile birlikte değerlendirilmektedir. Mennell, Van Otterloo ve Murchott çalışmasında gastronomiyi yemeği paylaşmak ve birlikteliğin önemini vurgulamak olarak sosyal yönüyle değerlendirmektedir (Aktaran Kirgiglioğlu, 2015: 14).

Tüketicinin yapılan sosyal medya paylaşımları, yemeğin rengi, popüler olan bir hizmeti tükettiğinde etrafta daha prestijli olarak algılandığı görüşü tüketicinin satın alma davranışını önemli ölçüde etkilemektedir. Ayrıca tüketicinin görsel olarak gördügü bir ürünü ve bu ürün hakkında yapılan olumlu yorumları ya da ürünün trend olmasının tüketicinin satın alma davranışında mevcut ürünün sözlü olarak anlatılmasından ya da broşürünün basılmasından daha etkili olduğu yapılan çalışmalara konu olmaktadır (Eröz ve Doğdubay; 2012: 144). Tüketicinin sürekli olarak değişen talebi ve bu talebi karşılamak isteyen işletmelerin yenilikleri her geçen gün devam etmekte ve yeni gastronomi akımlarını ortaya çıkarmaktadır. Bu gastronomi akımları incelendiğinde yeme içme davranışının gittikçe doğala döndüğü tüketicilerin yiyecek içeceğe katılan gıda boyalarından, yiyecek içeceğin geçirdiği çoklu işlemlerden, yağlı ve zararlı yiyeceklerden uzaklaştı̆̆ 1 ve bunun aksine tarlaya dönüş eğilimi gösterdikleri, besinleri doğal renkli ve çiğ tüketme eğiliminde oldukları, sağlıklı beslenme anlayışını benimsedikleri görülmektedir. 2018 yılında adından oldukça söz ettiren gastronomi akımları; 
- Siyah yiyecekler,

- Mor yiyecekler,

- Bowl food,

- Smoothie,

- Yenilebilir çiçekler,

- Sağlıklı beslenme,

- Raw food ve

- Doğal yiyecekler olarak sıralanabilir.

Bahsedilen gastronomi akımları ve sunum şekilleri incelendiğinde akımların ortak noktasının renkler ve sağlık olduğu sonucuna ulaşılmaktadır. Mor yiyecekler, besleyici etkisinin yanında, değişik etkenlerle hastalık oluşma riskini azaltıcı, sağlığı ve iyi hali geliştirici özelliklere sahip gıdalar olarak adlandırılan fonksiyonel gıdaların içerisinde yer almaktadır (Erbaş, 2006: 791). Kanseri önleyici, unutkanlığı önleyici, kalp rahatsızlıklarına iyi gelici özelliklerine ek olarak detoks etkisi de yaratan mor yiyecekler sağlıklı olmasının yanı sıra ilgi çekici ve canlı bir renk oluşundan dolayı gıda sektöründe oldukça ilgi görmektedir (Kasnak, 2014: 228; Hürriyet, 2019). Siyah, kahverengi ve yeşil tonlu yiyecekler ise; insana doğayı ve toprağı anımsattığı için tüketici de sağlıklı besin algısı yaratmaktadır (digitalage, 2019; Bozok, 2018: 251). Son zamanlarda dünyada oldukça popüler olan ve adından söz ettiren siyah yiyeceklere örnek olarak; siyah pirinç, siyah sarımsak, siyah soya fasulyesi, siyah mısır gösterilebilir (Bozok, 2018: 252). Bowl food, renkli kaselerin içerisinde çeşitli yiyeceklerin birbirileri ile renk uyumu içerisinde yerleştirilerek çekici bir görünüm oluşturularak sunum yapılan bir gastronomi akımıdır (Oggusto, 2019). Yenilebilir çiçek kavramı ise, mutfak tarihinde binlerce yıl öncesine kadar dayanmaktadır. Asırlar boyu şifa olarak ve geleneksel yemeklerin yapımında kullanılmıştır. Günümüzde trend haline gelen yenilebilir çiçek kavramı eklenilen yemeğin tadını ve kokusunu değiştirmekle kalmayıp aynı zamanda rengini de değiştirmektedir (Akşap, 2018:33; Şahin ve Kılıç, 2009:2; Gastromanya, 2019). Böylelikle yenilebilir çiçekler, tat ve koku algısında geniş bir yelpazeye hitap ettiği gibi görüntü olarak da görsel şölen sağlamaktadırlar. Yenilebilir çiçeklere örnek olarak Safran, Gül, Lavanta, Menekşe, Narçiçeği, Mine Çiçeği, Gelincik, Kabak çiçeği, Soğan çiçeği, Latin çiçeği, Mor Menekşe, Karanfil, melisa verilebilir (Şahin ve Kılıç, 2009: 5). Raw food ve sağlıklı beslenme trendi gastronomide doğal renk ve sağlıklı besinlere ortak nokta sağlayan akımlar olarak görülmektedir (Gastrofests, 2019). Son dönemlerdeki trendlerde, renklerin ve doğallığın ön planda olmasından yola çıkılarak renklerin yeni trendlerin oluşmasında etkisi olup olmadığı ortaya konulmaya çalışılmaktadır. Renklerin insan hayatında önemli bir yere sahip olduğu bir gerçektir. Bu gerçeğe bağlı olarak yapıllan çalışmada renklerin insanın psikolojisi ve satın alma davranışı üzerindeki etkilerini araştıran çalışmalar ve son dönemdeki trendlerin sağlıkla ilişkisinden yola çıkılarak renklerin sağlık ile olan ilişkisini anlatan araştırmalar da derinlemesine incelenmektedir.

\section{Renk Kavramının Gastronomi Faaliyetleri ile Olan İlişkisi}

Renklerin tarihin ilk zamanlarından beri insan üzerinde etkisi olduğu ve insanların davranışlarının olumlu ya da olumsuz yönde etkilediği üzerinde durulmaktadır. Yapılan çalışmalarda rengin insan psikolojisi, motivasyonu ve satın alma davranışı üzerinde etkisi olduğu ortaya konulmaktadır (Jalil, Yunus ve Said; 2011; Kahraman, Yıldırım ve Atılgan; 2016; Spance; 2015). Bu doğrultuda yemeğin renginin de insan üzerinde ilk izlenimi bıraktığı, motivasyon oluşturduğu ve satın almaya yönelttiği söylenebilir. Özcan, gidagundemi, Yılmaz ve Erden, hürriyet, Singh, umitunker ve Öztürk' ün çalışmalarında renklerin ifade ettikleri anlamlar ve bireylere hissettirdikleri noktalardan benzer şekilde bahsedilmektedir. Bu çalışmalardan hareketle renklerin çağrıştırdıklarını içeren bir tablo oluşturulmuş ve söz konusu akımlar ve bu akımların paylaşıldığı sosyal ortamlar incelenerek hangi rengin hangi akımda daha çok kullanıldığına yönelik bir tablo geliştirilmiştir. Gastronomi akımlarının incelendiği sosyal ortam etiketleri paylaşım sayılarının çokluğuna göre;

- \#healthyfood (57.065.171 içerik)

- \#healthyfoodie (457.000 içerik)

- \#rawfood (3.400.000 içerik)

- \#Bowlfood (46.700 içerik)

- \#foodbowl (44.800içerik)

- \#blackfood (15.800 içerik)

- \#smoothie (9.800.000 içerik)

- \#purplefood (17.000 içerik)

- \#edibleflowers (368.000 içerik) olarak belirlenmiştir.

Renklerin çağrıştırdıkları ve akımlardaki yerini gösteren çalışma Tablo.1'de yer almaktadır. 


\begin{tabular}{|c|c|c|c|}
\hline RENKLER & $\begin{array}{c}\text { RENGİN } \\
\text { ÇAĞRIŞTIRDIKLARI }\end{array}$ & $\begin{array}{l}\text { RENK İLE GÜNDEMDE } \\
\text { OLAN YIYYECEKLER }\end{array}$ & $\begin{array}{c}\text { RENGİN EN ÇOK } \\
\text { KULLANILDIĞI TRENDLER }\end{array}$ \\
\hline MOR & $\begin{array}{l}\text { Asalet } \\
\text { Lüks } \\
\text { İmparatorluk } \\
\text { Ciddiyet } \\
\text { Sağlık }\end{array}$ & $\begin{array}{l}\text { Mor incir } \\
\text { Mor havuç } \\
\text { Acai üzümü } \\
\text { Yaban mersini } \\
\text { Pancar } \\
\text { Mor Patates } \\
\text { Mor misır }\end{array}$ & $\begin{array}{l}\text { Mor yiyecekler trendi } \\
\text { Sağllklı beslenme trendi } \\
\text { Bowl food trendi } \\
\text { Yenilebilir çiçekler trendi } \\
\text { Smoothie }\end{array}$ \\
\hline YEŞİL & $\begin{array}{l}\text { Doğallık } \\
\text { Güvenlik } \\
\text { Sağlık }\end{array}$ & $\begin{array}{l}\text { Brüksel lahanas1 } \\
\text { Maydanoz } \\
\text { Marul } \\
\text { Ispanak } \\
\text { Dereotu } \\
\text { Salatalık } \\
\text { Roka } \\
\text { Avakado } \\
\end{array}$ & $\begin{array}{l}\text { Sağlıklı beslenme trendi } \\
\text { Bowl food } \\
\text { Smoothie }\end{array}$ \\
\hline $\begin{array}{ll}\text { SIYYAH } & \text { (KAHVE } \\
\text { TONLARI) } & \end{array}$ & $\begin{array}{l}\text { Lüks } \\
\text { Cesaret } \\
\text { Gelişmişlik düzeyi } \\
\text { Toprağa dönüş } \\
\text { Doğallık }\end{array}$ & $\begin{array}{l}\text { Siyah pirinç } \\
\text { Çörek otu } \\
\text { Chia tohumu } \\
\text { Siyah sarımsak } \\
\text { Siyah dut } \\
\text { Siyah fasulye } \\
\text { Bögürtlen } \\
\text { Siyah soya fasulyesi } \\
\text { Siyah mercimek } \\
\text { Siyah çay }\end{array}$ & Siyah yiyecekler trendi \\
\hline KIRMIZI & $\begin{array}{l}\text { Güç } \\
\text { Canlılık } \\
\text { Tazelik } \\
\text { Gençlik } \\
\text { Mutluluk } \\
\text { Kan basıncı artışı }\end{array}$ & $\begin{array}{l}\text { Domates } \\
\text { Kiraz } \\
\text { Çilek } \\
\text { Karpuz } \\
\text { Vişne } \\
\text { Nar } \\
\end{array}$ & $\begin{array}{l}\text { Bowl food } \\
\text { Smoothie } \\
\text { Sağl1klı beslenme } \\
\text { Raw food }\end{array}$ \\
\hline TURUNCU & $\begin{array}{l}\text { Vitamin } \\
\text { Enerji } \\
\text { Sağlık } \\
\text { Gösteriş }\end{array}$ & $\begin{array}{l}\text { Portakal } \\
\text { Mandalina } \\
\text { Havuç } \\
\text { Greyfurt } \\
\text { Kayısı } \\
\text { Bal kabağ1 } \\
\end{array}$ & $\begin{array}{l}\text { Sağliklı beslenme trendi } \\
\text { Smoothie } \\
\text { Bowl food trendi }\end{array}$ \\
\hline SARI & $\begin{array}{l}\text { Yaşam } \\
\text { Enerji } \\
\text { Sicaklık } \\
\text { Neşe }\end{array}$ & $\begin{array}{l}\text { Muz } \\
\text { Kavun } \\
\text { Misir } \\
\text { Limon } \\
\text { Ananas } \\
\text { Ayva } \\
\end{array}$ & $\begin{array}{l}\text { Sağliklı beslenme trendi } \\
\text { Smoothie } \\
\text { Bowl food trendi }\end{array}$ \\
\hline BEYAZ & $\begin{array}{l}\text { Doğal } \\
\text { Sade } \\
\text { Temiz } \\
\text { Katkısız madde } \\
\end{array}$ & $\begin{array}{l}\text { Süt } \\
\text { Yoğurt } \\
\text { Lahana } \\
\text { Papatya } \\
\end{array}$ & $\begin{array}{l}\text { Sağlıklı beslenme } \\
\text { Bowl food }\end{array}$ \\
\hline
\end{tabular}

Tablo 1. Renkler ve Gastronomi Trendlerindeki Yeri Kaynak: Singh, 2006; Yllmaz ve Erden, 2017; Gidagundemi; Hürriyet, 2019; Umitunker,2019; Özcan, 2017 ve Instagram Gastronomi Paylaşımlarından Derlenmiştir

Tabloda ifade edilen mor rengi son dönemlerde sağlık konusunda güdeme gelmekte ve yeni bir trend oluşturmaktadır. Mor rengin trend olduğunu gösteren birçok gazete, televizyon haberi (Sepas, 2019; Hürriyet,2018; Ntv, 2019) ve mor rengin sağlıkla olan ilişkisini gösteren birçok çalışma bulunmaktadır (Aoki, Kuze ve Kato; 2002; Öztan; 2006; hürriyet, 2018). Mor rengin vücutta ki hormonları ve salgı bezlerinin çalışmasını etkilediği bunun yanı sıra kanı temizlediği, akciğer, karaciğer, kalp ve böbreklerin çalışmasını düzenlemeye yardımcı olduğu bilinmektedir. Buradan yola çıkılarak mor rengin sağlıklı beslenme trendi ile ilişkisi olduğu sonucuna varılabilir. Mor rengin en fazla mor renkli yiyecekler trendinde kullanıldığ 1 tabloda belirtilmiştir. Aynı zamanda sosyal medyada oldukça gündemde olan ve trende yönelik kafeler açılan bowl food akımı, 46.500 lük paylaşımı olan \#bowlfood etiketi ve 44.600 içeriğe sahip olan \#foodbowl etiketleri ile birlikte incelenerek mor rengin bu trendde oldukça etkin kullanıldığı sonucuna varılmış ve tabloda mor rengin kullanıldığı trendler arasına yazılmıştır. Ayrıca yenilebilir çiçekler olarak kendini gösteren ve 368.000 içeriğe sahip olan \#edibleflowers etiket içeriğinde yapay olarak yapılmış ve yenilebilir olan çiçeklere ek olarak doğal çiçeklerinde yenilebilir olarak paylaşımının yapıldığı gözlemlenmiştir. Bu çiçeklerde öne çıkan renkler mor, pembe ve turuncu olarak 
görülmektedir. Bu nedenle mor rengi yenilebilir çiçekler trendi içerisinde gösterilebilir. Mor yiyeceklerin yiyecek içecek içerisinde kendisinden önemli derecede söz ettirmesine rağmen mor yiyecek trendi üzerine yapılmış çalışma bulunmamaktadır.

İlk olarak Japonya'da ortaya çıkan ve sosyal medya aracılığı ile tüm dünyaya yayılan siyah renkli yiyecekler de son dönem gastronomi trendleri arasında yer almış ve üzerine akademik çalışmalar yapılmaya başlanmıştır (Bozok ve Yalın: 2018). Siyah renkli yiyeceklerin dünyada ki bilinirliğinin artması aktif karbonlu yiyecekler ile gerçekleşmiştir. Siyah renk insana, lüksü, cesareti ve gelişmişlik düzeyini çağrıştırmasının yanı sıra siyah, kahverengi ve yeşil gibi doğaya ait renkler gelenekselden uzaklaşan ve daha çok şehir hayatında yaşayan insanlara doğaya dönüşü anımsatarak daha doğal algısı oluşturduğu gerçeği göz önünde alındığında doğal siyah yiyeceklerinde sağlıklı beslenmede ve siyah yiyecekler trendinde kendine yer bulması kaçınılmazdır. Siyah renginin en çok hangi trend içerisinde kendini bulduğunu anlamak için yaygın olarak kullanılmaya başlanan ve etkileşimi çabuk bir alan olan instagramda 15. 800'lük içeriğe sahip olan \#blackfood etiketinde siyah renk, aktif karbonlu yiyecekler ve doğal siyah yiyecekler olarak görülmektedir. Doğalı çağrıştıran toprak tonlu yiyeceklere bowlfood ve healthyfood akımında da rastlanmasına rağmen bowl food ve sağlıklı beslenme akımı siyah rengin öne çıktığı trend olarak ele alınmamıştır. Çünkü bowl food ve sağlıklı beslenme akımı daha çok canlı renkleri bir araya getiren bir akım olarak görülmektedir.

Sıcak renkler arasında yer alan kırmızı iştah açıcı bir renk olduğundan yiyecek içecek sektöründe oldukça fazla kullanılmaktadır. Kırmızı renginin hemen her trendde kendine bir yer bulduğu söylenebilir.

Yeşil insana doğalı çağrıştıran ve güvenlik duygusu uyandıran bir renktir. Yeşil renk insanlara yiyeceklerin daha sağlıklı olduğu ve sağlık açısından daha güvenli olduğunu çağrıştırmaktadır. Sağlıklı beslenme ve smoothie içeriklerinde yeşil oldukça fazla yer almaktadır. Trendlerin incelendiği sosyal medya ortamında yeşil renkli paylaşımlara en çok 57.000.000 içeriğe sahip olan \#healthyfood 46.500'lük gönderiye sahip olan \#bowlfood akımında rastlanmıştır. Smoothide de yer bulan yeşil rengi yer aldığı trendler arasına yazmak zor olmaktadır. Çünkü bu akımda kullanılan renk sayısı çok fazladır ve paylaşımlardan yola çıkılarak bu paylaşımlarda yeşile çok sık rastlanmadığı görülmektedir.

Beyaz renk insanlarda doğal, sade, temiz ve katıksız madde algısını oluşturmaktadır. Son dönemlerdeki trendler düşünüldükçe sebze, meyvelerin süt ve yoğurt ile harmanlanarak yapıldığı smoothie ve bowl food kaseleri bu algının doğruluğunu destekler niteliktedir.

Sıcak renkler arasında yer alan turuncu insanda bol vitaminli ve sağlıklı bir çağrışım uyandırmaktadır. Ayrıca turuncu insan psikolojisinde "bu ürün herkes için uygundur" imajı yaratmaktadır. Sağlıklı beslenme ve bowl food trendinde bu renk oldukça öne çıkmaktadır. Turuncu yiyeceklere örnek olarak, portakal, mandalina, greyfurt, havuç, kayısı, bal kabağı sayılabilir. Sarı ise en dikkat çeken renklerden biridir. Sosyal medyaya yönelik yapılan incelemelerde sağlıklı beslenme, bowl food ve smoothie akımında bu renge en çok rastlanmaktadır. Sarı renk yaşam, enerji, neşe ve sıcaklık kavramlarıyla ilişkilendirilmektedir. Sarı renkli yiyeceklere örnek olarak muz, limon, ananas, ayva, misır verilebilir.

Renklerin yiyecek ve içeceğin üzerindeki etkisi yadsınamaz bir gerçektir. Hatta yiyecekte bulunan renklerin yoğunluk derecesi, rengin parlaklığı ve tonu tüketicinin algısını açacak potansiyele sahip olmaktadır (Öztürk, 2014: 48). Yemeğin yanına koyulan renkli garnitürler ya da renkli baharatlar tüketici gözünde yemeğin daha canlı ve enerjik görünmesini sağlamaktadır. Mogoulus'un çalışmasında renklerin tat ile bir bütün olarak algılandığı yani bir yemeği yaparken sadece reçeteye uygun yapılması değil yemeğin tadın güzel olurken renginin de güzel olması üzerinde durulmaktadır. Çünkü tat ve renk birlikte müşteri memnuniyetini sağlamaktadır. Bu açıklama akıllara “ziyafet gözlerde başlar” sözünü getirmektedir. Renklerin bir sözsüz iletişim şekli olarak ürünlerde kullanımı ve tüketiciler üzerindeki etkileri bilinmektedir. Bu etkiyle birlikte renkler birçok sektörde etkili bir şekilde kullanılmaktadır. İnsan yaşantısında son derece önemli bir yere sahip olan renk kavramı üzerine birçok çalışma yapılmıştır. Singh, çalışmasında tüketicinin bir ürünü algılamaya 90 saniyede karar verdiği ve bu karar sürecinde \%90'ın renk olduğu sonucuna ulaşmaktadır. Yine Singh, çalışmalarında rengin insan psikolojisinde önemli derecede etkileri olduğunu ve doğru renk tercihinin tüketici üzerinde pozitif bir algı yarattığını ve restoranda kullanılan halıları, duvar renginin, perdelerin tüketiciyi etkileyerek ürün tercihinde rol oynadığını vurgulamaktadır. Singh'in Çalışmasında geçen ifadeden hareketle bir yiyecek içecek faaliyetini gerçekleştirirken çevrenin renk uyumunun ve yapısının önemli olduğu noktada yemeğin bizzat kendisinin rengi ve tabak içerisindeki uyumunun da tüketici tercihi üzerinde önemli olduğu söylenebilir. Magoulas, renklerin yemek seçimine nasıl etkileri olduğunu incelediği çalışmada, renklerin daha yemeği yemeden tat algısı oluşturduğu sonucuna varmaktadır. Yani insan gıdanın rengine bakarak gıda hakkında bir fikir sahibi olmaktadır. Rozin ise; tüketicinin rengine göre karar verdiği gıdaları algılanış yapısına göre gruplandırmaktadır. Pişmemiş, işlem geçirmemiş, rengi solmamış, doğal yiyecekleri "Sweet taste" olarak pişirildikten ve işlem geçirdikten sonra ise "bitter taste" olarak adlandırmaktadır. Sweet taste yiyecekleri ise kişide "güvenli gıda" algısı yaratan kavramla eşleştirmiş. Bitter taste yiyecekleri ise "güvensiz gıda" kavramı ile eşleştirmektedir. Bu bilgiden hareketle yiyecek içeceklerin renginin, tadını bilmesek dahi insanda sağlıklı ya da sağlıksız kavramına yönelik bir algı oluşturduğu sonucuna ulaşılmaktadır. Örneğin; Instagramda bowlfood akımına denk gelen bir tüketici sadece gördüğü renkli ve taze görünümden dolayı tüketicide sağlıklı ve güvenli algısı ve satın alma algısı oluşturabilir. Benzer bir sonuç yılmaz ve Erder'in 2017 yılında 
gerçekleştirdiği renklerin çorbaların tat algısı üzerindeki etkilerini belirlemeye Yönelik araştırmada ortaya konulmaktadır. Çalışmaya göre yemeğin rengin yemekten alınan lezzeti ve duyulan hazzı etkilediği sonucuna ulaşılmaktadır. Spance'nin çalışmasında ise insanların renklendirilmiş yiyeceklere karşı duyduğu ilginin daha fazla olduğu üzerinde durulmaktadır. Ancak bu bilgi günümüzde ki trendlerle ve günümüzde sağlıklı beslenme bilincinin gelişmesi ve doğallığın önem kazanması ile düşünülünce renklendirici ile hazırlanmış yiyeceklere olan ilgi fazla ise günümüzde doğal renkli yiyeceklere ve doğalı anımsatan renklere olan ilgi daha fazla olabileceği düşüncesi oluşmaktadır.

Bu bilgilere ek olarak günümüzde tüketicilerin daha bilinçli olması tatil ve tüketim tercihlerini yaparken daha seçici davranmaları, ekonomik ve teknolojik gelişmeler sağlık bilincinin gelişmiş olması insanların taleplerini etkilemektedir. Örneğin; Daha önceleri gıda boyalarıyla yapılmış pastalar gündemde olurken şimdilerde daha doğal görünümlü ve yapaylığa yer bırakmayan "naked cake" pastaların olması değişen talebe örnek gösterilebilir. İnsan davranışları ve talepleri sürekli olarak bir değişim içinde olduğundan taleplere karşıllık verebilmek amaciyla yeni gastronomi akımları oluşmaktadır ve oluşmaya da devam edeceği düşünülmektedir. Renkli yiyeceklerin sağlıklı ve tazelik algısı oluşturduğunu, bazı renklerin bazı sağlık kavramlarıyla ilişkilendirildiğini gösteren ve renklerin sağlık üzerinde etkisi olduğunu kanıtlayan birçok çalışmaya literatürde rastlanmaktadır (Spance; 2015; Jalil, Yunus ve Said; 2011; Çakııı; 2017; Karaca, Yıldırım ve Çakıcı ve Yıldız; 2015; Özcan; 2018). Çakıcı ve Yıldız; Restoran müşterilerinin sağlık bilincinin sağlıklı yeme davranışına etkisi üzerine yaptığı çalışmasında sağlık bilincini pozitif ve negatif sağlık bilinci olarak ayırmakta ve pozitif sağlık bilincini tüketicilerin sağlıklı tüketim gerçekleştirmeye eğilimli olması ve yediklerini sorgulaması olarak tanımlamakta negatif sağlık bilincini ise tüketicilerin gıdaların sağlıklı olup olmamasını sorgulamaması olarak tanımlamaktadır. Çakıcı ve Yıldız'ın çalışmasında tüketicilerin sağlık bilincinin oluşmaya başladığı sonucuna varılmaktadır. Benzer bir sonuç Royne vd. (2014) sağlık bilincinin, tüketicilerin ürünlerin yararlarını algılamada ve yararlı ürünleri kullanma eğilimi göstermede etkili olduğunu bulduğu çalışmada ortaya çıkmaktadır (aktaran Çakıcı ve Yıldız: 2015: 16). Roininen ise $(2001 ; 49)$ yaptığı araştırmada yiyecek içecek seçiminde en önemli noktanın sağlık ve tat kavramları olduğunu ortaya koymaktadır. Sağlık kavramının oluşması için vitamin, mineral, düşük yağ ve doğallığın önemini ortaya çıkarırken tat kavramının önemini yemekten zevk alma noktasında duyusal çekicilik ile birlikte vurgulamaktadır. $\mathrm{Bu}$ çalışmada yiyecek içecek seçiminde sağlık ve görsel çekiciliğin bir arada bulunması gerektiği ve doğallığın sağlığ yansıtan bir özellik olduğu sonucuna ulaşılmaktadır. Diğer araştırmalarda da doğallı̆̆ın renk olduğunu ve insanda çekicilik yarattığından bahsedilmektedir. Bu noktada rengin sağlığ gazetesinde "renkli beslen sağlıklı yaşa" başlı̆̆ altında yazılan haberde ise renkli yiyeceklerin göz alıcı olması ile görsel bir şenlik oluşturacağı hem de sağlık bilincinin günden güne daha çok geliştiği ülkemizde sağlkklı bir beslenme tarzı oluşturacağı anlatılmaktadır. Yapılan araştırmalara yönelik genel bir çıkarım yapıldığında; renklerin bireyler üzerinde çekici bir etki yarattığı farklı hisler uyandırdığı ve insanları satın almaya yönlendirdiği görülmektedir. Tüketici geçmiş yılların aksine doğalı benimsemekte ve doğalı sağlıkla ilişkilendirmektedir. Renkli besinlerin sağlık üzerinde etkilerinin olduğu ve insana sağlığı çağrıştırdığı da söylenebilir. Bu noktada günümüzde sağlık bilincinin oluştuğu göz önüne alınarak renkli yiyeceklerin kişiye daha sağlıklı olduğu izlenimi vermesi, renkli yiyeceklerin daha çekici olması ve satın alma isteğinin oluşması ile bu özelliklerin bir bütünü oluşturmasıyla gastronomi akımlarının şekillenmesine yön verdiği düşünülebilir.

\section{Renklerin Sosyal Medya ile Olan İlişkisi}

Yiyecek içecek faaliyetini sadece fizyolojik bir ihtiyaç olmaktan çıkması insanın prestij ve statü ihtiyacını karşılayan bir kavram olarak görülmesi yiyecek içecek faaliyetlerini farklı boyuta taşımaktadır. Teknolojinin gelişmesi ile birlikte kişilerin sosyal medyada harcadığı zaman ve sosyal medyadan etkilenme oranı artmaktadır (Eröz ve Doğdubay; 2012: 134). Kişilerin fotoğraf, video, haber, aktivite gibi içerikleri paylaşabildikleri çevrimiçi kaynaklar olarak tanımlanabilen sosyal medyada yapılan paylaşımlar kişilerin tercihlerinde etkili olabilmektedir (Barutçu ve Tomaş; 2013: 7). Gastronomi turisti motivasyon kaynaklarına bakıldığında;

- $\quad$ Fiziksel motivasyon kaynakları,

- Kültürel motivasyon kaynakları,

- Kişilerarası motivasyon kaynakları,

- $\quad$ Statü ve prestij motivasyon kaynakları ortaya çıkmaktadır (Soner; 2013: 46).

Statü ve prestij motivasyon kaynağının karşılanmasında sosyal medya önemli bir yere sahip olmaktadır. Gastronomi turisti, bir yemeği yemekten çok daha fazlasını beklemektedir. Bu doğrultuda yüksek kaliteli ürünler, hoş bir görsel, lezzet ve farklılık ile ilişkilidir. Tasarım, yenilikçilik ve yaratıcılık sonucu ortaya çıkan ürünler gastronomi turistleri için değer arttırıcı unsurların kilit noktalarıdır ve turistlerin karar alma sürecini anlamanın bir yolu olmaktadır. Gastronomi turistleri tercih edecekleri yiyecekte belirli bir anlam bulmayı istemektedirler. $\mathrm{Bu}$ yüzden bazen yiyecek içecek seçimlerini sağlıkla bazen ise güncel trendlerle şekillendirirler (Kargiglioğlu,2015: 19). Kişilerin statü ve prestij motivasyon kaynakları ile yakından ilişkili olan sosyal medya turistlerin seçimlerini etkileyen önemli bir yer haline gelmektedir. Örneğin; Turistler siyah yiyeceklerin yayılma noktası olan Japonya' ya giderek orada siyah yiyecek hizmeti sunan yerlerden yemeği tercih edebilirler. Trend haline gelen bir yemeği 
kendi çıkış yerinde ya da adı duyulmuş bir mekanda yemek de bir kimsenin statüsüyle ve yaşam tarzıyla ilişkili önemli bir faktör olabilir. Teknolojinin gelişmesi sosyal medyanın ortaya çıkmasına sebep olmuş, sosyal medya da fotoğraf çekme ve paylaşımını hızlandırmış, bu hızlanma da insan davranışlarında değişikliklere neden olmuştur. Sosyal medya kullanımına olan eğilimin artması ve teknolojik gelişmeler sayesinde fotoğraf üretimi ve paylaşımı dünyanın bir ucundan diğer ucuna uzanabilen gündelik bir aktivite haline gelmiştir (Kayılan, Akın ve Guluzade,2017:864). Böylelikle bir ülkede ortaya çıkan farklı bir görüş, turistlerin değişen taleplerini karşılayacak olan farklı bir girişim dünyada daha çabuk yayılarak turistler tarafindan daha çabuk benimsenmektedir. Turistler için yaşadıkları farklı deneyimleri çekmek ve paylaşmak vazgeçilmez bir aktivite haline gelmiştir. Tüketiciler sadece kurumsal sitelerin değil takip ettiği kişilerin, ünlülerin ya da trend olan fotoğrafların paylaşımlarından etkilenir hale gelmişlerdir (Kayılan, Akın ve Guluzade,2017:864). Sosyal medyanın tüketici tercihlerinde etkisi olduğunu ortaya koyan birçok araştırma yapılmıştır. Kim'in (2010: 69-72) ve Prideaux ve Conghan' ın (2010: 180181) yaptığı çalışmada fotoğrafların insanların seyahat motivasyonları üzerinde etkili olduğu sonuçları ortaya çıkmaktadır. Gönül, Akın ve Guluzade'nin (2017; 864-865) yaptığı çalışma sonucunda ise; adı duyulmuş trend olmuş, mekanlarda fotoğraf çekilmek ve paylaşmak turiste sosyal çevresinde statü kazandırdığı sonucunu ortaya çıkarmıştır. Eşitti ve Işık’ın (2015; 25-26) çalışmasında en çok onaylanan ifadeler “tüketicilerin sosyal medyada paylaştıkları deneyimlerden etkilenirim" ve "kendi deneyimlerimi paylaşırım" ifadeleri olmaktadır. Bunun yanı sıra araştırmaya katılan turistlerin sosyal medyada ünlenen ve diğer tüketiciler tarafindan paylaşım gören turistik ürünlere kurumsal sitelerde yapılan tanıtım ve paylaşımlardan daha fazla güvendikleri sonucuna ulaşılabilmektedir. Buradan hareketle tüketicilerin göze hoş geleni ve trend olanı sosyal medyada paylaşarak bende modayı takip ediyorum ve uyguluyorum imajı yaratarak sosyal çevresine kendini statülü olarak gösterdikleri söylenebilir.

Günümüzdeki gastronomi akımları çok renkli ve son dönem trendlerinden olan sağlıklı beslenme ile birleşince fiziksel motivasyon dışında statü ve prestij sağlama unsuru doğrultusunda yiyecek içeceğin satıldığı bölge, ülke, restoran vs. gitmek ve tüketimi gerçekleştirirken hem doyum sağlamak hem zevk almak hem de kendini ifade etmek anlamıyla gidebilecekleri söylenebilir. Örnek olarak sağlıklı beslenme bilincinin oluşmaya başladığ ülkemizde "healthy cafe" konseptlerinin artması ve kişilerin bu alanlara giderek hem sağlıklı beslenme trendine uyması hem de renkli yiyecek- içecekleri paylaşım yapması verilebilir. Kahraman, Yıldırım ve Atılgan'ın (2016:224) çalışmalarında renklerin sözlü iletişim araçları dışında kullanılan bir iletişin aracı olduğu üzerinde durulmuş ve bazen bir fotoğrafın sözlü iletişimden daha etkili olabileceği vurgulanmıştır. Turizmde prestij amaçlı tüketim oldukça yaygındır (Eröz ve Doğdubay; 2012: 134) bu nedenle sosyal medyada popüler olan bir ürün ya da tavsiye edilen bir ürün daha çekici olmaktadır. Güleç'in (2015: 80) gösterişçi tüketim alanında yaptığı çalışmanın sonucunda Veblen' in yaklaşımını destekler nitelikte bireyler, yalnızca ürünlerin kendisini değil, cezbedici imajları, sembolleri ile de ilgilenmeye başladıklarını ve daha yüksek düzeyde ve göstermelik bir şekilde tüketime başvurmaya başladıklarını ortaya koymuştur.

Bu sonuç bireylerin moda olanı benimsemeye ve tüketmeye daha yatkın ve moda olanı tükettiklerini göstermeye daha eğilimli hale geldikleri şeklinde yorumlanabilir. Bununla birlikte Ritzer (Aktaran Güleç 2015: 79) kitle iletişim araçlarının gösterişçi tüketime yönlendirdiğini vurgulamaktadır. Özellikle etkileşimli doğaları gereği iletişimi kişiselleştiren araçlar, yeni tüketim biçimleri önermektedir (Güleç; 2015: 79). Binbaşığlu ve Türk’ün (2018: 233-234) çalışmasının sonucunda ise yiyecek içecek fotoğraflarının tüketicinin tercihlerini etkilediği sonucuna varılmıştır. Benzer bir sonuç Pattanachai'nin (2015: 69) çalışmasında sosyal medyada paylaşılan yiyecek içecek fotoğraflarının tüketiciyi etkilediği ve cezbedici olduğuyla ortaya konulmaktadır. HTC telefonları 2016 yılında yaptığı bir çalışmada son 1 yılda yüklenmiş 250 bin fotoğrafi taratarak en çok paylaşılan ve beğenilen fotoğrafları ortaya koyan bir araştırma yapmış ve en çok paylaşılan fotoğraflar sırası ile aile, gezi-doğa, yemek, selamlaşma, kitap-şiir, etkinlik, spor ve hayvan olarak bulunurken en çok beğeni alan fotoğraflar ise sırasıyla kitapşiir, selamlaşma, spor, yemek, gezi- doğa, hayvan, etkinlik ve aile olarak ortaya çıkmaktadır (hurriyet,2018). Araştırmanın sonucunda yiyecek içecek faaliyetlerinin önemli oranda paylaşıma sahip olduğu ve paylaşım alanında 3. Sırada aile ve gezi-doğa paylaşımlarının gerisinde kalmasına rağmen beğeni de onları geçmiş olması dikkat çekmektedir. Bu fark tüketicilerin yiyecek içecek paylaşımlarına duyarlı olduklarını göstermektedir.

\section{Sonuç}

Geçmiş dönemlerdeki yiyecek içecek faaliyetleri algısının değişmesi ile birlikte her geçen gün yeni gastronomik akımlar oluşmaktadır. Günümüzde tüketici sadece doymak için değil hoş zaman geçirmek, mutlu olmak, kendini sosyal yaşantısını ifade etmek ve geçirdiği zamanı unutulmaz deneyimler arasına dahil etmek amacıyla yiyecek içecek faaliyetlerine katılmaktadır. Sosyal yaşantının ve statünün de hayatımızda önemli bir yer edindiği dönemde bazen herhangi bir meyve ya da herhangi bir sebze gündemde olurken bazen bir renk moda olabilmektedir. Tüketicilerin moda olanı tüketme, moda olanı giyme ya da moda olanı tükettiklerini gösteren paylaşımlar yapmalarının kendi prestij ya da sosyalliklerini gösterdikleri, kendilerini ifade ettikleri anlayışının olması, tüketicilerin moda olanı benimseme ve paylaşım yapma eğilimlerini ortaya çıkarmaktadır. Bu kapsamda 2018 yılında moda olan ve insanlar tarafından ilgi gören ve paylaşım yapmalarını sağlayan, haberlere konu olan siyah yiyecekler, mor yiyecekler, bowl food, smoothie, yenilebilir çiçekler, sağlıklı beslenme, raw food, doğal yiyecekler 
olarak adlandırılan gastronomi akımları incelenmiş ve akımların ortak noktaları renk ve sağlık olduğu sonucuna varılmıştır. Renkli olan yiyeceklerin sağlığı, tazeliği ve doğallı̆̆ çağrıştırmasının yanı sıra günümüzde sağliklı beslenme anlayışına daha çok önem verildiği de göz önüne alındığında gastronomi akımı olarak renkli olanı benimseme, ihtiyaçlar hiyerarşisi içerisinde yer alan prestij ve statü ihtiyacını karşılamak için de oluşan akıma daha çok ilgi duyma ve tükettiği akımı sosyal çevre ile paylaşma eğilimi gösterdikleri düşünülmektedir. Çalışmanın neticesinde insan için en iyi tüketim nedir? Sorusuna "insanın en çok zevk aldığı insan için en iyi tüketimdir" anlayışı ile yaklaşıldığında insanın zevk alması tadın yanı sıra yemeğin görseli ile bir bütün oluşturunca mümkün olabileceği görülmektedir. $\mathrm{Bu}$ noktada renklerin insanlar üzerinde etki ettiği, doğallığı/sağlığı çağrıştırarak tüketime sevk ettiği ve çekiciliği artırarak fotoğraflarda daha iyi bir görsel sağladığı ve paylaşıma daha müsait olduğu söylenebilir. Buna ek olarak tüketicilerin sosyal medya paylaşımlardan etkilenmeleri de ortaya çıkan akımın globalleşmesine ve daha çabuk benimsenmesine neden olmaktadır. Renklerin gastronomi akımlarını belirleme üzerinde etkisi olduğu ve renkli yiyeceklerin tüketicileri daha çok çektiği ve daha çok moda algısı yarattığı ayrıca moda olan bir ürünü satın alan kişinin daha prestijli ve daha statülü göründüğü düşüncesi ile moda olanı paylaşma eğiliminde oldukları ortaya konulmaktadır. Bu nedenle tüketicilerin renkli ve taze görünümlü yiyecekleri satın almaya daha çok yatkın olduğu düşüncesine ulaşılabilir. Renklerin yeni akımlarda ki bulunma durumuna göre araştırmanın kapsamını oluşturan gastronomi akımlarına yönelik sosyal medya paylaşım etiketleri incelenmiş ve renklerin akımlardaki yeri bir kez daha ortaya konulmuştur. Bu sonuç doğrultusunda yiyecek içecek kültürü açısından zengin ve yeniliklere açık ülkemizde renk kavramını göz önünde bulundurarak tasarım, yenilikçilik ve yaratıcılık sonucu ortaya çıkan gastronomi turistleri için değer arttırıcı nitelikler barındıran ürünler ortaya çıkarılması ülkemizin yeni trendler konusunda izleyici konumda değil lider bir konumda olması açısından önem arz etmektedir.

\section{Kaynakça}

- Ahbap, B. (2014). Renklerin Pazarlama Üzerindeki Etkisi, Yükseklisans tezi. İstanbul: İstanbul Kültür Üniversitesi.

- Akdağ, G. Sormaz, Ü. Özata, E. Ve Çetinsöz, B. (2016). "Sürdürülebilir Gastronomi Turizmi İçin Yeni Bir Alternatif: Surf\&Turf”. Journal Of Tourism And Gastronomy Studies, 4(1), S. 270-281.

- Akşap, Y. (2018). "Gatronomik Bir Değer Olarak Lavanta”.Uluslararası Global Turizm Araștırmaları Dergisi, 2(1), S. 32-41.

- Aoki, H. Kuze, N. Ve Kato, Y. (2002). "Anthocyanins isolated from purple corn (Zea mays L.)”. Foods And Food Ingredients Journal Of Japan.199

- Binbaşıŏlu, H. Ve Türk, M. (2018). "Y Kuşağının Yiyecek-İçecek İşletmesi Tercihlerinde Sosyal Medyanın Etkisi”, Turizm akademik dergisi, 1, s.221-237.

- Bozok, D. Ve Yalın, G. (2018). "Gastronomide Yeni Trend: Siyah Yiyecekler”. Güncel Turizm Araştırmaları Dergisi, 2(1), s.252-261.

- Çakıcı, C. Ve Yıldız, E. (2017). "Restoran Müşterilerinin Sağlık Bilincinin Sağlıklı Yeme Davranışına Etkisi”. Nevşehir Hacı Bektaş Üniversitesi SBE Dergisi, 8(1), s.1-22.

- C Cakıcı, C. Yıldırım, O. Ve Karaca O. B. (2015). "Gastronomi Turizminde Otlar, Ot Yemekleri ve Sağlıkla İlişkisi Üzerine Bir Değerlendirme”. Journal of Tourism and Gastronomy Studies, 3(3), s.22-47.

- Dehkordi, M. A. Ve Yonekura, S. (2018). "Attention Economy: A New Marketing and Growth Approach for Small and Medium Enterprises". International Journals of Advanced Research in Computer Science and Software Engineering, 8(2), s.79-86.

- Digitalage, geleceğin gastronomi trendleri, https://digitalage.com.tr/gelecegin-gida-trendleri/ (Erişim Tarihi 12.10.2019)

- Dünya Gida. Siyah Yiyecekler, http://www.dunyagida.com.tr/haber/siyah-renkli-yiyecekler-trend-olmayabaslayacak/7874 (Erişim Tarihi 14.10.2019)

- Eröz, S. Ve Doğdubay, M. (2012). “Turistik Ürün Tercihinde Sosyal Medyanın Rolü ve Etik İlişsisi”, Dokuz Eylül Üniversitesi İktisadi ve İdari Bilimler Fakültesi Dergisi, 27(1), s.133-157.

- Eşitti, Ş. Ve Işıı, M. (2015). "Sosyal Medyanın Yabancı Turistlerin Türkiye’yi Tatil Destinasyonu Olarak Tercih Etmelerine Etkisi”. Karadeniz Uluslararası Bilimsel Dergisi, 27, s. 11-33.

- Gastrofest, 2018 Yiyecek İçecek Trendleri, http://www.gastrofests.com/dunyadan-2018-yeme-icmetrendleri/ (Erişim Tarihi 10.02.2019)

- Gastromanya. Yenilebilir çiçekler, https://gastromanya.com/hem-saksida-hem-tabakta-guzel-yenilebilircicekler/_(Erişim Tarihi 02.02.2019)

- Gıda Gündemi, Gastronomi Trendleri http://www.gidagundemi.com/beslenme-ve-saglik/mutfak/2018yilina-damga-vuracak-10-gastronomi-trendi-h15833.html (Erişim Tarihi 02.02.2019) 
- Grunert, K.G. (2005). "Food Quality and Safety: Consumer Perception and Demand". European Review of Agricultural Economics, 32(3), s. 369-391.

- Güleç, C. (2015). “Thorsteın Veblen ve Gösterişçi Tüketim Kavramı”, Sosyal Bilimler Enstitüsü Dergisi, 38, s. $62-82$.

- Güneş,E, Özata, E ve Sormaz, Ü (2015). “Turizmde Gastronomi”, Sosyal Bilimler Dergisi, 1(2), s. 67-73.

- Haber Türk, Siyah Besinler, https:/www.haberturk.com/galeri/saglik/444528-mutfaginizdaki-7-siyahmucize-siyah-fasulye-siyah-mercimek-corek-otu-siyah-cay-siyah-soya-fasulyesi-siyah-pirinc (Erişim Tarihi 12.10.2019)

- Hız, G. (2011). "Gösterişçi Tüketim Eğilimi Üzerine Bir Alan Araştırması (Muğla Örneği)”. Organizasyon ve Yönetim Bilimleri Dergisi, 3 (2), s. 117-128.

- Hürriyet Gazetesi, İnstagramda Paylaşılan Fotoğraflar, http://www.hurriyet.com.tr/kelebek/hayat/ instagramda-en-cok-hangi-fotograflar-paylasiliyor-40041226 ( Erişim Tarihi 14.12.2018)

- Hürriyet gazetesi. Mor Yiyecekler, Sağlığınız için tüketmeniz gereken 11 mor yiyecek. Hürriyet. http://www.hurriyet.com.tr/lezizz/galeri-sagliginiz-icin-mutlaka-tuketmeniz-gereken-11-mor-yiyecek36921568/2 (Erişim Tarihi 10.02.2019)

- İçli, G. Ve Çopur, M. (2008). “Renklerin Pazarlama İletişimindeki Rolü”, Trakya üniversitesi sosyal bilimler dergisi, 10(1), s. 22-33.

- Jalil, N. A. Yunus, R. M. Ve Said, N. (2011).” Environmental Colour Impact upon Human Behaviour: A Review". Procedia - Social and Behavioral Sciences,35 ,s.54-62.

- Kahraman, N. Yildırım, K. Ve Atılgan, A. (2016). The Effects of the Color of Product on Quality Perception, Çötok, T. Ve Şahin, Y(ed). Social ScienceS: a FreSh Start (220-226). Prague.

- Karayılan, E. Akın, G. Ve Guluzade, P. (2017). "Fotoğrafların turist deneyimi üzerindeki pozitif ve negatif etkileri: kavramsal bir yaklaşım”, Y. Ramazan (ed), 1. International Sustainable Tourism Congress (Kastamonu Üniversitesi). s. 860-867

- Kargiglioğlu, Ş. (2015). Gaziantep’te Gastronomi Turizmi: Gaziantep’i Gastronomi Turizmi Kapsamında Ziyaret Eden Yerli Turistlerin Görüşleri Üzerine Bir Araştırma, Yükseklisans tezi. İzmir Katip Çelebi Üniversitesi, İzmir.

- Kasnak, C. 82015). “Doğal Antioksidanların Sınıflandırılması ve İnsan Sağlığına Etkileri”, Türk Tarım Gida Bilim ve Teknoloji Dergisi, 3(5), s.226-234.

- Magoulas, C. (2003). How Colour affects food choice (graduate tesis), University of Nevada, Las Vegas.

- Milliyet Gazetesi. Mor Yiyeceklerin Sağlıkla Olan İlişkisi, Mor yiyecekler kanserden koruyor. Milliyet. http://www.milliyet.com.tr/mor-yiyecekler-kanserden-koruyor-pembenar-galeri-sagliklibeslenme-2369778/ (Erişim Tarihi 10.02.2019)

- Milliyet Gazetesi. Renklerin Sağlıkla İlişkisi, http://www.milliyet.com.tr/renkli-beslen--uzun-yasa-pembenar-detay-sagliklibeslenme-539428/ (Erişim Tarihi 13.12.2018)

- NTV, Mor Yiyecekler, https://www.ntv.com.tr/saglik/mor-meyveler-zindelik-veriyor,Qu2q9rVrkuqtKkkGYP5Lw (Erişim Tarihi 10.02.2019)

- Oggusto Dergi, Gastronomi Trendleri, https://www.oggusto.com/blog/detay/855/2018-in-gastronomitrendleri.html_(Erişim Tarihi 14.10.2019)

- Ö̈zcan, M. (2017). “Renklerin tüketimde ve sağlıkta önemi”. Black Sea Journal of Agriculture, 1(3), s.83-88.

- Özdemir, B. (2010). "Dişarıda Yemek Yeme Olgusu: Kuramsal Bir Model Önerisi”, Anatolia: Turizm Araştırmaları Dergisi, 21(2), s.218-232.

- Öztan, T. (2006). Mor Havuç, Konsantresi, Şalgam Suyu, Nar Suyu Ve Nar Ekşisi Ürünlerinde Antioksidan Aktivitesi Tayini Ve Fenolik Madde Profilinin Belirlenmesi, (Yayınlanmamış Yüksek Lisans Tezi). İstanbul Teknik Üniversites, İstanbul.

- Pattanachai, K. (2015). The Impact Of Social Media Marketing On Fine Dining Choice Decision (Graduate thesis), Bangkok University, Bangkok.

- Posta, Mor Yiyecekler, https://www.posta.com.tr/yazarlar/dr-mehmet-oz/mor-yiyeceklerin-gucu-76474 (Erişim Tarihi 12.10.2019)

- Roininen, K. (2001). Evaluation Of Food Choice Behavior: Development And Validation Of Health And Taste Attitude Scales (graduate thesis). University of Helsinki, Helsinki.

- Sepaş Enerji, Sağlıklı Yaşamın Mor Trendi, https://https:blog.sepas.com.tr///saglikli-yasamin-renkli-trendimor-yiyecekler/ (Erişim Tarihi 10.02.2019) 
- Singh, S. (2006). "Current Research Development Impact Of Color On Marketing”. Browse Journals \& Books, 44(6), s.783-789.

- Sipahi, S. Ekincek, S. Ve Y1lmaz, H. (2017). "Gastronominin Sanatsal Kimliğinin Estetik Üzerinden İncelenmesi”. Journal of Tourism and Gastronomy Studies, 5(3), s. 981-396.

- Soner, F. (2013). Gastronomy Tourısm: A Solutıon For Small Citıes Marketıng And Regıonal Development, Yükseklisans tezi. Yeditepe Üniversitesi, İstanbul.

- Spence, C. (2015). “On the Psychological İmpact of Food Colour”, Spence flavour, 4(21). 2-16.

- Spence, C. Levitan,C. A. Shankar, M. Ve Zampini, M. (2010). "Does Food Color Influence Taste and Flavor Perception in Humans?". Chemosensory perception,3, s.69-84.

- S Şahin, Ö. Ve Kılıç, B. (2009). "Yiyecek İçecek İşletmeciliğinde Yenilebilir Çiçekler”, 17-18 Nisan 3. Uluslararası Gastronomi Sempozyumu(Antalya: Alanya).s. 179-199.

- Türkiye Zeka Vakfi, Renklerin Yiyecekler Üzerindeki Etkileri, https://www.tzv.org.tr/\#/haber/341_Erişim Tarihi 14.12.2018)

- $\quad$ Uluçay, D.M. (2017). “Gastronomi Turizmi İşletmelerinin Web Siteleri Üzerine Karşılaştırmalı Bir Değerlendirme”. Erciyes Iletişim Dergisi, 5 (2), s. 196-208.

- Uzman TV, Renklerin Pazarlamaya Etkisi, https://umitunker.wordpress.com/tag/satiscinin-rengi/ (Erişim Tarihi 12.10.2019)

- Yılmaz, H. Ve Erden, G. (2017). "Renklerin Çorbaların Tat Algısı Üzerindeki Etkilerini Belirlemeye Yönelik Bir Araştırma"'. Journal Of Tourism and Gastronomy studies, 5(special issue2), s. 265-275.

- Young, N. S. (2012). Food photographt snapshots to great shots (1.Bask1). Amerika: Peachpit Press. 


\title{
Анализ и Моделирование Неравномерности Экономического Роста Регионов Кыргызской Республики в Новых Условиях Analysis and Modeling of Uneven Economic Growth of the Regions of the Kyrgyz Republic in the New Conditions
}

\author{
Assoc. Prof. Dr. Kalybek Choroev (Kyrgyzstan-Turkey Manas University, Kyrgyzstan)
}

\begin{abstract}
During the years of independence, the unevenness (asymmetry) of the economic development of the regions of the Kyrgyz Republic sharply increased, the multiple gap between the regions increased according to the most important indicators of regional production, income level and poverty, the quality of life of the population. Regions of the country vary significantly in size, population size and density, level of economic development, natural and climatic conditions, national and historical features. All this causes significant differences in the needs of budget financing and tax bases of individual regions. Smoothing economic asymmetry is one of the most important issues of public administration. The core of the research toolkit should be the economic and mathematical model of economic growth in the region. In regional studies, the following factors of economic growth can be identified: natural resources; labor resources; main capital; volume of investment. In addition, new methods of overcoming socio-economic asymmetry include working out the mechanism of effective public-private partnership and everywhere to introduce long-term planning for the development of the region's economy. The preservation and development of the country as a state largely depends on the effective regional policy implemented in the country.
\end{abstract}

\section{1 Введение}

Решения задач устойчивого экономического роста регионов Кыргызской Республики в новых условиях требует разработки соответствующего прогнозно-аналитического инструментария, который позволял бы органам власти региона страны осуществлять научно обоснованные прогнозы развития региона с учетом требований ежегодных прогнозов социально-экономического развития страны в целом. Ядром такого инструментария должна являться экономико-математическая модель развития экономики в регионе, которая давала бы возможность в среднесрочной и долгосрочной перспективе оценивать границы роста валового выпуска и валового регионального продукта в зависимости от инвестиционных усилий, платежеспособного спроса, демографических факторов, поведения окружения, а также других аспектов устойчивого роста.

Концептуальной основой разработанной модели должен быть региональный воспроизводственный процесс. Разработка модели регионального экономического роста во всех ее стадиях (концептуальной, математической, имитационной) является чрезвычайно актуальной задачей. Многогранность и многоаспектность такого явления, как экономический рост, обусловили существующее многообразие подходов и методов к его моделированию и прогнозированию. В региональных исследованиях можно выделить следующие факторы экономического роста: природные ресурсы; людские ресурсы; основной капитал; объем инвестиции.

\section{2 Проблемы Моделирования Региональной Экономики}

Анализ современного состояния теории и практики моделирования и прогнозирования экономического роста показывает, что существуют два основных направления моделирования экономического роста. Первое направление предполагает построение производственных функций, увязывающих экономический рост с динамикой факторов производства. Второе направление связано с моделированием производства и потребления на основе межсекторных моделей и межотраслевого баланса. В первом случае экономика рассматривается как целостная, неструктурированная единица, на вход которой поступают ресурсы, а на выходе получается результат функционирования экономики в форме валовой добавленной стоимости или валового внутреннего продукта. Ресурсы рассматриваются как аргументы, а валовой внутренний продукт - как функция. Во втором случае экономика структурирована и состоит из конечного числа секторов или «чистых» отраслей, производящих один или несколько продуктов. Экономический рост моделируется на основе баланса спроса и предложения факторов производства в секторах экономики.

В настоящее время не существует ни одной теоретико-прикладной модели, которая бы учитывала еще один важный фактор - межрегиональную дифференциацию развития экономики. Этот фактор в свою очередь обусловлен состоянием отраслевой промышленной структуры в регионах и развитием конкурентных процессов на отраслевых рынках. Фактор социально-экономической асимметрии развития регионов значительно усложняет процесс моделирования экономического роста и делает несостоятельными выводы, полученные в основополагающих теориях и моделях экономического роста. 
В макроэкономических исследованиях структуры экономики на реиональном уровне можно использовать односекторную модель Р. Солоу. В этой модели региональная экономическая система рассматривается как единое неструктурированное целое, производит один универсальный продукт, который может, как потребляться, так и инвестироваться. Модель в агрегированном виде отражает процесс воспроизводства и позволяет анализировать соотношение между потреблением и накоплением. Более детально процесс воспроизводства отражает трехсекторная модель. Базовой моделью при рассмотрении структуры экономики по секторам в целом и занятости в частности является теория трех секторов, разработанная К. Кларком, а со временем дополненная Д. Беллом, Э. Тоффлером и У. Ростоу (Белл Д., 1999). Данная модель является актуальной и сегодня, но требует нового качественного наполнения. Сущность ее состоит в изменении структуры занятости и в изменении доли первичного, вторичного, третичного секторов в валовом внутреннем производстве.

Движение общества к индустриальному этапу развития происходит путем уменьшение занятости в первичном секторе (аграрном), затем во вторичном (индустриальном), и современный этап характеризуется увеличением занятости в третичном (сектор услуг). С помощью трехсекторной модели можно определить вектор движения к индустриальному обществу.

На современном этапе, новые интеграционные связи и выход на международный рынок, Кыргызстан осуществляет за счет отраслей сырьевого сектора: в структуре экспорта доминируют не готовые товары, а промежуточный продукт. В результате этих процессов увеличивается доля сырьевых отраслей, преимущественно первичного сектора, и частично увеличивается занятость в них. Данная тенденция характеризует регрессивность экономического развития, а также способствует редукции труда, которая вызвана перемещением высококвалифицированного труда из отраслей промышленности и строительство (вторичный сектор) в сырьевые отрасли (преимущественно первичный и третичный сектор).

В начале XXI в. для КР характеризовался более прогрессивными сдвигами в секторальной структуре, уменьшились сырьевой сектор и увеличивался сектор услуг. И сегодня возникают вопросы: отражает ли эти сдвиги индустриализации экономики; должен ли доминировать сектор услуг в структуре экономики; какие количественные пропорции секторов должны быть в структуре экономики, чтобы обеспечить качественный рост национальной экономики?

Ответы на эти вопросы можно найти только в дальнейшем исследовании проблем развития национальной экономики и технологического уровня развития экономики в процессе интеграции в Евразийский экономический союз (ЕАЭС), сучетом неравномерности развития региональной экономики. По нашему мнению, нынешние интеграционные процессы должны формироваться не только в направлении институциональных объединений, но и на основе реальных процессов разделения труда и кооперации.

Исторически сложившиеся социально-экономические, культурные связи Кыргызстана с странами ЕАЭС обусловлены многовековой совместной историей и разделением труда, которое имело место в предыдущей экономической системе, а также уровнем технологического развития. Развитие обрабатывающих отраслей первичного сектора, в частности сельского хозяйства, на данный момент возможно только между странами ЕАЭС. В результате данного направления интеграции, в КР должны сократится доля импорта товаров потребительского рынка из третьих стран за счет увеличения внутреннего производства.

\section{3 Трехсекторная Модель}

На наш взгляд улучшение секторальной структуры занятости на современном этапе в Кыргызстане возможно в результате выбора интеграционных направлений с учетом краткосрочного и долгосрочного периода. В краткосрочном периоде (3-5 лет) улучшить структуру занятости возможно в первичном секторе путем интеграции в ЕАЭС, а в долгосрочном (5-7 лет) - увеличение занятости в третичном секторе путем интеграции в международную экономическую систему. То есть движение к постиндустриальному обществу - это продолжительный процесс, который требует взвешенной стратегии развития национальной экономики и определения приоритетных векторов интеграции в краткосрочной и долгосрочной перспективе. Объективный процесс повышения производительности труда и замещение труда капиталом способствует увеличению занятости в третичном секторе. Но этот процесс требует исследования и поиска новых путей развития для роста.

Для разработки трехсекторную модель, как базовую модель примем модель Солоу. В качестве критерия оптимальности рассмотрим максимум производства предметов потребления в расчете на одного занятого в производственной сфере.

Производственную подсистему экономики можно разделить на три сектора:

- Материальный (нулевой) - сектор производит предметы труда: электроэнергию, сырье и др. Добывающая промышленность, электроэнергетика, производство сельхозпродукции, промышленность стройматериалов, грузовой транспорт, служебная связь, торговля. 
- Фондосоздающий (первый) - сектор производит средства труда: машины, оборудование, производственные здания и т.п.

- Потребительский (второй) - сектор производит предметы потребления. Потребительское гражданское строительство, переработка сельхозпродукции (легкая и пищевая промышленность), пассажирский транспорт, гражданская связь, торговля предметами потребления.

Предположим, что, за каждым сектором закреплены основные производственные фонды (ОПФ). Инвестиции и трудовые ресурсы могут свободно перемещаться между секторами. Тогда можно принять следующие условия:

- Технологический уклад считается постоянным и задается с помощью нелинейно-однородных неоклассических производственных функций

$$
X_{i}=F\left(K_{i}, L_{i}\right) \quad i=0,1,2
$$

- Общее число занятых $L$ (в производственной сфере) изменяется с постоянным темпом прироста $v$. Тогда $v$ в дискретном времени имеет вид ( $t$-номер года)

$$
v=\frac{L(t+1)-L(0)}{L(t)}
$$

при переходе к непрерывному времени принимает вид дифференциального уравнения

$$
\frac{d L}{d t}=v L, L(0)=
$$

$L^{0}$,

его решение $\quad L=L^{0} e^{v t}$.

- Лаг капиталовложений отсутствует.

- Коэффициенты износа ОПФ $\mu_{i}$ и прямых материальных затрат $\alpha_{i}$ секторов постоянны.

- Экономика замкнутая, т.е. внешняя торговля не рассматривается.

Из предположений (3 - 4) следует, что изменение за год ОПФ $i$-го сектора состоит из двух частей: износа $\left(-K_{i}\right)$ и прироста за счет валовых капиталовложений $\left(I_{i}\right)$, то есть $K_{i}(t+1)-K_{i}(t)=-\mu_{i} K_{i}+I_{i}(t), \quad i=$ $0,1,2$ или в непрерывном виде: $K_{i}(t+\Delta t)-K_{i}(t)=\left[-\mu_{i} K_{i}(t)+I_{i}(t)\right] \Delta t$ при $\quad \Delta t \rightarrow 0$

Получаем дифференциальное уравнение для ОПФ секторов:

$$
\frac{d K_{i}}{d t}=-\mu_{i} K_{i}+I_{i}, \quad K_{i}(0)=K_{i}^{0},
$$

ОПФ и число занятых в секторах $\left(K_{i}, L_{i}\right)$ являются мгновенными показателями, т.е. их значение можно измерить в любой момент времени. Выпуск секторов и инвестиции $\left(X_{i}, I_{i}\right)$ являются показателями типа поток, т.е. их значения накапливаются за год, начинающийся в момент $\mathrm{t}$.

Трехсекторная модель экономики:

$L=L^{0} e^{v t} \quad$ - число занятых;

$L_{0}+L_{1}+L_{2}=L-$ распределение занятых по отраслям;

$\frac{d K_{i}}{d t}=-\mu_{i} K_{i}+I_{i}, K_{i}(0)=K_{i}^{0}$ - динамика фондов по секторам;

$X_{i}=F\left(K_{i}, L_{i}\right) \quad i=0,1,2$ - выпуск продукции по секторам;

$X_{1}=I_{0}+I_{1}+I_{2}$ - распределение продукции фондосоздающего сектора;

$X_{2}=\alpha_{0} X_{0}+\alpha_{1} X_{1}+\alpha_{2} X_{2}-$ распределение продукции материального сектора.

Модель является динамической, имеет в своем составе линейные динамические элементы:

$$
\frac{d K_{i}}{d t}=-\mu_{i} K_{i}+I_{i}, \quad \frac{d L}{d t}=v L .
$$

Она нелинейная, поскольку выпуски секторов заданы нелинейными производственными функциями $X_{i}=F\left(K_{i}, L_{i}\right)$, и является многофазной, поскольку ее состояние представлено тремя переменными $K_{0}, K_{1}, K_{2}-$ взаимосвязанными с помощью балансов. В балансах появляется эмерджентность экономической системы, т.е. наличие у нее таких общих свойств, которые не присущи составляющим ее отдельным элементам: каждый сектор производит столько продукции, сколько нужно другим секторам и потребителям и на сколько хватит ресурсов.

Эндогенными (определяемыми с помощью модели) переменными являются ОПФ и выпуски секторов. Экзогенными (заданными из вне модели) переменными служат темп прироста занятых $v$, коэффициенты износа ОПФ, коэффициенты прямых материальных затрат, начальное значение числа занятых, и их начальное распределение.

Управление осуществляется путем распределения трудовых $\left(L_{0}+L_{1}+L_{2}=L\right)$ и инвестиционных $\left(X_{1}=I_{0}+I_{1}+I_{2}\right)$ ресурсов.

Для работы с трехсекторной моделью необходимо установить экзогенные параметры модели. Самая большая трудность - установление параметров производственных функций секторов. Допустим - это функции Кобба -Дугласа

$$
X=A_{i} K_{i}^{\alpha_{i}} L_{i}^{1-\alpha_{i}}, \quad i=0,1,2
$$

$A_{i}$ - коэффициент нейтрального технического прогресса; $\alpha_{i}-$ коэффициент эластичности по фондам. 


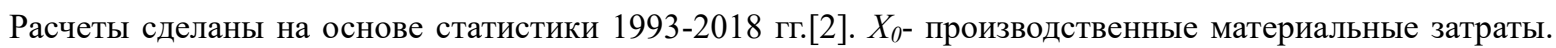
$X_{l^{-}}$показатель «Накопление» за вычетом «Производство предметов потребления». $X_{2}$ «Непроизводственное потребление». $K_{i}$ - определялись по показателям «Основные производственные фонды по отраслям». $L_{i}$ - определялись по показателям «Распределение населения, занятого в хозяйстве по отраслям».

Получены следующие ПФ секторов

$$
\begin{gathered}
X_{0}=3,32 K_{0}^{0,39} L_{0}^{0,61} \\
X_{1}=1,46 K_{0}^{0,56} L_{0}^{0,44} \\
X_{2}=2,73 K_{0}^{0,47} L_{0}^{0,53} \\
\alpha_{0}<\alpha_{1} \alpha_{0}<\alpha_{2} .
\end{gathered}
$$

Из определения коэффициентов эластичности следует: увеличение ОПФ сырьевых отраслей на $1 \%$ приводит к росту выпуска продукции на $\alpha_{0} \%$. Такое же увеличение ОПФ в фондосоздающих и потребительских отраслей приводит к росту выпуска продукции на $\alpha_{1} \%$ и $\alpha_{2} \%$. Поскольку $\alpha_{0}<\alpha_{1}, \alpha_{0}<\alpha_{2}$ то один и тот же относительный прирост фондов обеспечивает больший относительный прирост продукции в обрабатывающих отраслях по сравнению с соответствующим приростом продукции сырьевых отраслей.

Сырьевые отрасли технологически менее развиты, чем обрабатывающие - это распространенная экономическая закономерность.

Из использованных статистических данных известно, что ОПФ материального сектора составляют более половины ОПФ производственной сферы, а доля занятых составляет до трети от общего числа занятых в сфере материального производства. Доля ОПФ и доля занятых в фондосоздающем секторе примерно одинаковы. Таким образом, распределение ресурсов ассиметрично: большее число занятых в обрабатывающих отраслях, большая доля фондов - в сырьевых отраслях. Такая структура распределения ресурсов обусловлена следующими факторами:

1. Условия труда в сырьевых отраслях более тяжелые, чем в обрабатывающих, это определяет тенденцию перелива рабочей силы в обрабатывающие отрасли;

2. Сырьевые отрасли технологически менее развиты, это приводит к тенденции увеличения фондов в сырьевых отраслях, что компенсирует их меньшую фондоотдачу;

3. Фондосоздающий сектор, обеспечивающий воспроизводственный процесс, должен получать ресурсы в сбалансированном виде.

Изменить эту структуру можно с помощью специальной государственной структурной политики, например, через стимулирование инвестиций, в фондосоздающий сектор.

\section{4 Выводы}

По результатам проведенных исследований можно сделать следующие основные выводы:

- межсекторные модели являются более эффективным средством моделирования экономического роста страны в целом и его регионов;

- деятельность секторов экономики целесообразно моделировать обобщенной производственной функцией (ОПФ), работающей с двунаправленными потоками спроса и предложения материальных, капитальных и трудовых ресурсов;

- устойчивый экономический рост требует вполне определенных пропорций между выпусками в секторах экономики для каждого значения темпа экономического роста. Если данные пропорции не выполняются, то в экономике неизбежно возникает дисбаланс между спросом и предложением. Последнее приводит к росту запасов одних товаров и дефициту других, что вызывает торможение экономического роста;

- при переходе экономики с одного темпа роста на другой необходим переходный период, в течение которого лимитирующие сектора должны изменить свой потенциал под пропорции новой траектории роста;

- устойчивый экономический рост требует существенных инвестиций.

\section{Литература}

- Белл, Д. Грядущее постиндустриальное общество. Опыт социального прогнозирования [Текст] / Д. Белл. - М.: Academia, 1999. - С. 158.

- Статистический ежегодник Кыргызской Республики 1995-2018гг. www.stat. kg. 


\title{
Экономическое Развитие Кыргызстана в Контексте Углубления Интеграции
}

\section{Economic Development of Kyrgyzstan in Context of Deepening Integration}

\author{
Ph.D. Candidate Asel Dzhailova (Kyrgyz University of Economics, Kyrgyzstan)
}

\begin{abstract}
The article examines the forms and features of the development of integration processes and their impact on the macroeconomic development of Kyrgyzstan. An assessment of the socio-economic development of Kyrgyzstan within the EAEU is presented. Attention is focused on the positive trends in improving the structure of the national economy, developing its priority sectors and increasing the export and investment potential. Attention is drawn to the features of the conjugation of the economic development of Kyrgyzstan within the framework of the Chinese global project "The Economic Belt of the Silk Road". The features of trade, economic and investment cooperation with China. results of the implementation of large infrastructure projects. An assessment of macroeconomic development was carried out and the possibilities for the development of the deep integration of Central Asian countries in the fullest use of the economic potential of Kyrgyzstan were identified. The forms, directions and mechanisms of deepening trade, economic and humanitarian cooperation of Kyrgyzstan with the countries of Central Asia are substantiated.
\end{abstract}

\section{1 Введение}

В современном мире невозможно представить развитие отдельных, даже маленьких государств, без участия в глобальных интеграционных процессах. Участия в них является объективной необходимостью обеспечения устойчивого развития стран в русле мировых тенденций. Кыргызстан одним из первых в Содружестве Независимых Государств (СНГ) стал членом ВТО, что позволило провести крупномасштабные рыночные реформы. Членство в Шанхайской Организации Сотрудничества (ШОС) позволяет Кыргызстану, наряду с решением функций по обеспечению безопасности в регионе, также решать и экономические проблемы

В рамках ШОС Российская Федерация и Китайская Народная Республика проводят сбалансированную и активную политику по углублению интеграционных процессов. Усилия РФ направлены на развитие Евразийского экономического союза (ЕАЭС), КНР активно проводит политику в рамках реализации стратегической программы «Экономический Пояс Шёлкового Пути» (ЭПШП).

Кыргызстан с 2015 года стал полнокровным членом Евразийского экономического союза (ЕАЭС) и наращивает торгово-экономическое сотрудничество с партнерами по интеграционному формированию. Параллельно, в рамках реализации экономической стратегии КНР « ЭПШП», в республике реализуется ряд крупных инфраструктурных проектов при кредитной поддержке КНР. В последние годы также активизируются интеграционные процессы со странами Центральной Азии (ЦА), что выражается в росте взаимного товарооборота, реализации совместных взаимовыгодных проектов в различных отраслях экономики.

Несмотря на то, что за столь исторически короткий промежуток времени, в рамках ЕАЭС происходит рост взаимного торговли, динамично развиваются приоритетные отрасли национальных экономик, перспективы экономического союза оцениваются диаметрально противоположно, вплоть до отрицания ее жизнеспособности. В то же время, нельзя не заметить противопоставления ЕАЭС и экономической стратегии КНР «ЭПШП» [1].

Один из основоположников экономической целесообразности ЕАЭС российский исследователь С. Глазьев в противовес высказываниям об искусственности процессов интеграции на постсоветском пространстве, подчеркивает естественный характер евразийской интеграции, восстанавливающий существовавшее десятилетиями единое экономическое пространство в новых политических и экономических условиях [2]. В этом смысле, развитие евразийской интеграции, в котором Россия, несомненно, играет ведущую роль, ни в коей мере не может противоречить реализации экономической стратегии КНР, также преследующей цели расширения экономической интеграции, в том числе и с участием постсоветских государств.

Речь должна идти в русле сопряжения указанных двух глобальных экономических стратегий на евразийском пространстве. Развитие и углубление интеграционных процессов в ЕАЭС на основе проведения согласованной макроэкономической политики, должно обуславливать устойчивое развитие экономик государств-членов с использованием интеграционного потенциала Союза и конкурентных преимуществ каждой из стран. Активное участие в программе КНР «ЭПШП» позволит Кыргызстану 
модернизировать транспортную систему, развить альтернативные пути выхода на рынки третьих стран. Развитие экономического сотрудничества с братскими странами способствует формированию экономического союза в ЦА. Многовекторность развития интеграционных процессов и активное участии в них Кыргызстана приобретает стратегический характер в деле обеспечения устойчивого социальноэкономического развития страны на ближайшую и отдаленную перспективу.

\section{2 Основная Часть}

В период, предшествующей вступлению Кыргызстана в ЕАЭС, в социально-экономическом развитии страны продолжали усугубляться негативные процессы. В основном они были связаны с низким объёмами и даже спадом внешних инвестиций, оттоком капитала, сокращением доли промышленности в ВПП страны, снижением товарооборота и реэкспорта в страны Таможенного Союза, ростом бюджетного дефицита и внешнего долга страны. В рейтинге стран СНГ по основным макроэкономическим показателям Кыргызстан оказался на одном из последних мест. В результате сохранялась высокая внешняя миграция населения, особенно, молодежи, не росли доходы населения, усиливался разрыв в социальноэкономическом развитии регионов страны. В этих условиях, было принято, с учетом мнения большинства населения страны, единственно правильное историческое решение о вступление Кыргызстана в ЕАЭС.

Для эффективной трансформации национальной экономики в ЕАЭС Кыргызстану со стороны Евразийской экономической комиссии (ЕЭК), а также основных партнеров, в особенности Российской Федерации, были созданы наиболее благоприятные условия и оказывается необходимая финансовая помощь. На средства Российской Федерации был образован Российско-Кыргызский Фонд развития для предоставления долгосрочных кредитов на развитие среднего и крупного бизнеса в приоритетных отраслях экономики. По условиям межправительственного соглашения средства для функционирования данного фонда выделит Российская Федерация в сумме 500,0 млрд. долларов США. Для приведения таможенной инфраструктуры Кыргызстана в соответствии с нормами союза, адаптации аграрного сектора к техническим стандартам и требованиям евразийского рынка, продукция которого в основном экспортируется в страны ЕАЭС и развития системы современных лабораторий по фитосанитарному и ветеринарному контролю за качеством сельхозпродукции, со стороны ЕЭК Кыргызстану выделен технический грант на сумму 200,0 млн. долларов США.

За прошедший период с момента вступления Кыргызстана в ЕАЭС, в указанных направлениях совместной работы по адаптации национальной экономики в рамках интеграционного формирования, проделана существенная работа. К началу 2019 года только по линии Российско-Кыргызского Фонда развития, одобрено 1 тыс. 653 проекта на общую сумму 304 млн. долларов США. За этот период реализованы крупные инвестиционные проекты в республике и в ее регионах, что позволило ввести в действие ряд промышленных предприятий по выпуску строительных материалов, цементный завод, швейные и обувные фабрики, комбинат по производству макаронных изделий и др.. В аграрном секторе страны, по линии фонда, также реализуются ряд проектов по развитию промышленного садоводства, по переработке фруктов и овощей и т.д.. [3].

Построены и введены повсеместно во всех регионах республики ветеринарные лаборатории, оснащенные современными техническими средствами по контролю за качеством продукции АПК. Полностью завершена паспортизация и идентификация общественного скота и овец. Укреплена материально-техническая база пунктов пропуска и фито-санитарной службы республики. В результате значительно улучшилась работа по сертификации и выдаче лизенций на экспорт сельскохозяйственной продукции. В настоящее время работа по линии технической поддержки фито-санитарного и ветеринарного контроля завершается, что способствует проведению эффективной работы по приведению работ соответствия качества экспортируемой продукции стандартам ЕК. В результате будут полностью сняты технические барьеры для продвижения продукции отраслей АПК на рынки стран ЕАЭС.

Последовательная реализация этих мероприятий во взаимодействии с комплексом мер, осуществляемых в рамках « дорожной карты» по присоединению Кыргызстана к ЕАЭС, положительно отразилась на успешной трансформации национальной экономики. В целом, в экономическом развитии Кыргызской Республики в рамках ЕАЭС, наметились положительные тенденции, что проявляется в сравнительно высоких темпах роста ВВП, особенно, в реальном секторе экономики- обрабатывающей промышленности ( в легкой и пищевой промышленности ) и сельском хозяйстве, а также ее производства на душу населения.

Впервые за последние годы, отмечается динамика роста доли промышленности в производстве ВВП, что сказывается на положительных изменениях структуры национальной экономики. Постепенно стабилизируется торговый баланс, растет экспорт продукции, намечается приток инвестиций в основной капитал и рост кредитных поступлений, сокращается дефицит госбюджета и госдолга. Растет занятость населения, снижается уровень безработицы и бедности населения. Формирование единого рынка труда на евразийском пространстве, снятие барьеров в трудоустройстве отечественных мигрантов, привела к 
сокращению нелегальной миграции и значительному росту денежных переводов из стран ЕАЭС в Кыргызстан.

\begin{tabular}{|l|l|c|c|c|}
\hline Показатели & Ед.изм. & 2015 & 2016 & 2017 \\
\hline ВВП- всего & млр.долл.США & 6,7 & 6,8 & 7,6 \\
на душу населения & тыс.долл.США & 1163 & 1134 & 1220 \\
\hline Индексы ВВП & \% & 3,9 & 4,3 & 4,6 \\
\hline Прямые ин.инвестиции & млрд.долл.США & 1,5 & 0,8 & 0,5 \\
\hline Инв.в основной капитал & млрд.долл.США & 2,0 & 1,9 & 2,1 \\
\hline Обьем предост.кредитов & млрд.долл.США & 1,2 & 1,4 & 1,5 \\
\hline Среднемес.зарплата & долл. США & 209 & 212 & 223 \\
\hline Уровень инфляции & \% & 106,5 & 100,4 & 103,2 \\
\hline Уровень безработицы & \% & 7,6 & 7,2 & 6,9 \\
\hline Сальдо миграции & тыс.чел, +,- & $-4,2$ & $-4,0$ & 3,9 \\
\hline Дефицит ( -) госбюджета & млрд.сом & $-6,1$ & $-20,9$ & $-16,5$ \\
\hline Внешнеторговый оборот & млрд.сом & 5,6 & 5,4 & 6,3 \\
В т.ч., & & 1,4 & 1.5 & 1,8 \\
\hline Экспорт & - & 4,1 & 3,9 & 4.5 \\
\hline импорт & - & 67,1 & 59,1 & 59,9 \\
\hline Госдолг к ВВП & м & 1,5 & 1.8 & 2,2 \\
\hline Денежные переводы мигрантов & млрд.долл.США & & \\
\hline
\end{tabular}

Таблица 1:Основные Социально-Экономические Показатели Развития Кыргызской Республики В ЕАЭС Источник: Данные ЕЭК, Нацстаткома И Нацббанка КР

Данные тенденции в изменении основных показателей социально-экономического развития, в основном являются следствием позитивного эффекта от интеграции Кыргызстана в ЕАЭС. Снятие барьеров в торговле с традиционными партнерами в рамках ЕАЭС, является основным стимулирующим фактором роста производства, впервую очередь, в таких важных отраслях экономики, как перерабатывающая промышленность, сельское хозяйство. Легализация трудовой миграции, объёмы которой только в Российскую Федерацию, составляют порядка 700,0 тыс. человек, позволило почти в 1,5 раза увеличить объёмы официальных денежных переводов мигрантов в Кыргызстан. В настоящее время, объёмы денежных переводов мигрантов почти сравнялись с годовым бюджетом государства. В немалой степени, подобные денежные поступления играют роль своеобразного « драйва» социально-экономического развития страны.

Наметившиеся устойчивые и сравнительно высокие темпы роста ВВП страны в условиях ЕАЭС, непосредственным образом влияют на рост занятости и доходов населения, снижения безработицы и инфляции. Впервые за последние годы наметилась тенденция снижения дефицита госбюджета, роста внешнеторгового оборота при неизменности торгового сальдо, снижается госдолг по отношению к ВВП.

Практически за период функционирования экономики Кыргызстана в ЕАЭС, созданы реальные предпосылки динамичного развития и преодоления разрыва в уровне социально-экономического развития страны по сравнению с основными партнерами по ЕАЭС. Крайне важно отметить то обстоятельство, что экономика Кыргызстана показывает самые высокие и устойчивые темпы экономического роста среди всех государств-участниц стран ЕАЭС. За период 2015-2017 гг. темпы роста ВВП республики были соответственно на 6,$0 ; 4,4$ и 2,8 пункта выше среднего ее значения по ЕАЭС ( табл.2).

\begin{tabular}{|l|c|c|c|c|c|}
\hline Республики & $2013 г$. & $2014 \Gamma$. & $2015 г$. & $2016 г$. & 2017 г. \\
\hline Армения & 103,3 & 103,6 & 103,2 & 100,2 & 107.5 \\
\hline Беларусь & 101,0 & 101,7 & 96,2 & 97,5 & 102,4 \\
\hline Казахстан & 106,0 & 104,2 & 101,2 & 101,1 & 104,0 \\
\hline Кыргызстан & 110.9 & 104,0 & 103,9 & 104,3 & 104,6 \\
\hline Россия & 101,8 & 100,7 & 97,5 & 99,8 & 101,5 \\
\hline ЕАЭС & 102,1 & 101,1 & 97,9 & 99,9 & 101,8 \\
\hline
\end{tabular}

Таблица 2: Индексы Валового Внутреннего Продукта По Странам ЕАЭС (В Процентах К Предыдущему Году; В Постоянных Ценах) Источник: Данные ЕЭК и Нацстаткома КР 
Следует отметить, что достигнутые темпы роста ВВП республики, в основном обеспечены сравнительно высокими тепами развития промышленности республики. За период 2015-2017гг., в основных отраслях промышленности республики (горнодобывающей и обрабатывающей) достигнуты результаты в разы, превышающие соответствующие значения указанных отраслей по ЕАЭС. Так, при среднем росте продукции в горнодобывающей отрасли в странах ЕАЭС на 2,5 \%, в Кыргызстане продукция отрасли увеличилась почти в 1,5 раза: в обрабатывающей промышленности - соответственно рост составил 1,0 и $7,6 \%$.

Это связано, как было уже подчеркнуто, с вводом в действие новых и реконструкцией действующих предприятий в легкой и пищевой промышленности страны. В результате, экспорт продукции легкой промышленности ( одежда и обувь) в страны ЕАЭС ( Россия и Казахстан), вырос с 123,8 млн. долл. США в 2015 г. до 191,1 млн.долл.США в 2017 г., или в 1,55 раза. Продукция отрасли в экспортном потенциале республики занимает второе место (10,6 \%), после золота ( 30,0\%). Среди мировых экспортеров продукции легкой промышленности в страны ЕАЭС, Кыргызстан занимает 5 место, после КНР, Турции, Италии и Германии [4].

Также сравнительно высокими темпами развивается традиционно основная отрасль национальной экономики - агропромышленный комплекс. В республики продолжает достаточно высокими темпам увеличиваться производство и переработка технических культур- сахарной свеклы, хлопка и табака. Именно в условиях функционирования республики в ЕАЭС, в республике обеспечен значительное (в 5,06,0 раза) увеличение производства и переработки сахарной свеклы, что позволило решить проблему обеспеченности республики сахаром и ее экспорт на рынки ЕАЭС. Закрепляются достигнутые успехи в развитии животноводства, особенно, в производстве и переработке мясо-молочной продукции, которая в значительных объёмах также экспортируется на рынки ЕАЭС и третьих стран. Экспорт продукции АПК( овощи, фрукты, молочная продукция, хлопок) вырос с 149,-млн.долл.США в 2015 г. до 186 ,0 млн. долл.США в 2017 г., или на 27, 0\% [4]. Высокими темпами развивается и другие отрасли - строительство, торговля, транспорт. Указанные изменения в развитии приоритетных отраслей положительно сказалось на структурных сдвигах национальной экономики (табл.3).

\begin{tabular}{|l|c|c|c|c|c|c|c|c|}
\hline \multirow{2}{*}{ Республики } & \multicolumn{3}{|c|}{ В процентах к итогу } \\
\cline { 2 - 10 } & \multicolumn{2}{|c|}{ Сельское хозяйство } & \multicolumn{1}{|l|}{ Промышленность } & \multicolumn{2}{|c|}{ Строительство } & \multicolumn{2}{c|}{ Сфера услуг } \\
\cline { 2 - 10 } & 2015 & 2017 & 2015 & 2017 & 2015 & 2017 & 2015 & 2017 \\
\hline Армения & 19,3 & 16,7 & 18,2 & 20,0 & 10,5 & 8,2 & 52,0 & 55,1 \\
\hline Белоруссия & 7,2 & 8,9 & 28,7 & 31,0 & 9,0 & 6,0 & 55,1 & 54,1 \\
\hline Казахстан & 5,0 & 4,7 & 26,2 & 28,2 & 6,3 & 5,9 & 62,5 & 61,2 \\
\hline Кыргызстан & 16,0 & 14,2 & 18,9 & 21,0 & 9,5 & 9,5 & 55,6 & 55,3 \\
\hline Россия & 4.6 & 4,4 & 26,8 & 26,9 & 6.3 & 6,4 & 62,3 & 62,3 \\
\hline ЕАЭС & 4,9 & 4,7 & 26,7 & 27,1 & 6,4 & 6,3 & 62.0 & 61,9 \\
\hline
\end{tabular}

Таблица 3: Структура национальных экономик стран ЕАЭС Источник: Данные ЕЭК

В структуре ВВП республики, удельный вес промышленности вырос с 18,9 до 21,0 пункта, т.е., на 2,1 пункта. Промышленость республики, является единственной отраслью, увеличившей свой вклад в производство ВВП. Данное обстоятельство свидетельствует о восстановление отраслей промышленности и начале процесса широкой индустриализации экономики страны, что в предшествующий период развития республики, было значительно ослаблено.

Сфера услуг и строительство сохранили свои позиции. Тем не менее, следует отметить высокий уровень развития строительной индустрии в республике. Низкий уровень развития сферы услуг в республике по сравнению со средними значениями в ЕАЭС, свидетельствует о необходимости эффективной реализации потенциала данной отрасли, особенно в сфере туризма, отдыха, лечения.

Незначительно уменьшилась доля сельского хозяйства в структуре ВВП страны. Тем не менее, сельское хозяйство сохраняет статус приоритетной отрасли национальной экономики, о чем свидетельствует достаточно высокий ее удельный вес в ВВП страны. Несомненно, растущий спрос со стороны евразийского рынка, на экологическую продукцию сельского хозяйства, при успешном решении вопросов полной адаптации аграрного сектора страны, будет способствовать более динамичному развития данной отрасли в республике и увеличению ее вклада в ВВП.

Проведение многовекторной политики оказывает влияние на развитие интеграционных процессов, приводит к определенным изменениям направлений и структуры внешнеторгового оборота, притока инвестиций в Кыргызстан (табл.4). 


\begin{tabular}{|c|c|c|c|c|}
\hline & Ед.изм. & 2015 & 2016 & 2017 \\
\hline ЕАЭС: & & & & \\
\hline Внешнеторговый оборот & млн.долл.США & 2475,4 & 1962,6 & 2419.7 \\
\hline -экспорт & - & 410,2 & 418,0 & 562,7 \\
\hline -импорт & - & 2065,2 & 1544,6 & 1857,0 \\
\hline Инвестиции & - & 577,1 & 314,7 & 145.6 \\
\hline KHP: & & & & \\
\hline Внешнеторговый оборот & млн.долл.США & 1085,7 & 1548,5 & 1597.6 \\
\hline -экспорт & - & 36,2 & 80,1 & 97,5 \\
\hline -импорт & - & 1049,5 & 1468,4 & 1500,1 \\
\hline Инвестиции & - & 474,4 & 301,3 & 303,0 \\
\hline ЦА: & & & & \\
\hline Внешнеторговый оборот & млн.долл.США & 1012,3 & 1102,8 & 1229,8 \\
\hline -экспорт & - & 390,9 & 427,3 & 459,4 \\
\hline -импорт & - & 621,4 & 675,5 & 770,4 \\
\hline Инвестиции & - & 20,9 & 23,1 & 49,8 \\
\hline ВСЕГО: & & & & \\
\hline Внешнеторговый оборот & млн.долл.США & 5636,8 & 5463,7 & 6280,7 \\
\hline -экспорт & - & 1482,9 & 1544,6 & 1790,8 \\
\hline -импорт & - & 4153,9 & 3919,1 & 4489,9 \\
\hline Инвестиции & - & 1573,0 & 814,8 & 636,8 \\
\hline
\end{tabular}

Таблица 4: Экономическое сотрудничество Кьргызстана с ЕАЭС,КНР и ЦА Источник: Данные Нацстаткома КР

Несмотря на членство Кыргызстана в ЕАЭС, следует отметить, снижение взаимного товарооборота с 43,8 до 38,5 \%. Однако, в качестве положительного момента, надо отметить рост экспорта продукции Кыргызстана в общем товарообороте со странами ЕАЭС с 16,3 до 23,3 \%. В общем объёме иностранных инвестиций приток инвестиций из стран ЕАЭС в Кыргызстан также снизился с 36,8 до 22,9 \%, что связано с резким снижением инвестиций из России. Снижение инвестиций из стран ЕАЭС, свидетельствует о снижение их деловой активности и может негативно отразится на углубление интеграции Кыргызстана в ЕАЭС. Взаимовыгодная торговля в рамках ЕАЭС, должна последовательно дополняться реальным экономическим сотрудничеством, реализацией совместных экономических проектов на территории страны.

В настоящее время КНР, как и страны ЕАЭС, является основным торгово-экономическим партнером Кыргызстана. Следует отметить активность КНР в торгово-экономическом сотрудничестве с Кыргызстаном, что связано с вовлечением республики в процесс реализации экономической стратегии КНР «ЭПЩП». Данное обстоятельство привело к росту взаимного товарооборота Кыргызстана с КНР с 19,2 до 25,4 \%. Вместе с тем, следует отметить значительный дисбаланс во взаимной торговле в пользу КНР. Растет приток инвестиций из КНР, доля которого в общем объёме иностранных инвестиций в республику вырос с 30,0 до 47,6\%. Китайские инвесторы активно участвуют в реализации совместных проектов практически во всех отраслях экономики Кыргызстана, особенно, в сфере торговли, транспорта, коммуникации, горнодобывающей и обрабатывающей промышленности, электроэнергетики и развития инфраструктуры.

Также традиционно активно развивается сотрудничество со странами ЦА, где намечаются положительные тенденции. Взаимный товарооборот вырос с 17,9 до 19,5 \%, приток инвестиций с 1,2 до7,8 \%. Однако следует признать, недостаточность экономического сотрудничества Кыргызстана со всеми странами ЦА, за исключением Казахстана, который является основным торговым и экономическим партнером Кыргызстана в ЦА и тесному сотрудничеству с которой способствует обоюдное членство в ЕАЭС. Тем не менее, имеется большие потенциальные возможности экономического сотрудничества с Узбекистаном, Таджикистаном и Туркменией в сфере совместного использования гидроэнергетического потенциала, развития сельского хозяйства, туризма и т.д..

В целом уровень экономического развития республики неадекватна потребностям ее конкурентоспособного развития в рамках ЕАЭС. Сохраняется дисбаланс в торговле со странами ЕАЭС. Практически не развиваются кооперационно-интеграционные связи в сфере развития реальной экономики, снижаются инвестиции в реализацию совместных проектов, к участию которых не привлекается 
банковский капитал стран ЕАЭС. Несмотря на то, что экономика Кыргызстана интегрируется в рамках реализации экономической стратегии КНР, продолжает расти дисбаланс в торговле в пользу растущего импорта из КНР. Практически не происходит серьезных изменений во внешнеэкономических связях со странами ЦА.

\section{3 Выводы}

- с целью эффективной трансформации и конкурентоспособного экономического развития Кыргызстана в ЕАЭС следует активизировать привлечение инвестиций и кредитных ресурсов из фондов ЕАЭС для создания совместных предприятий в приоритетных отраслях - в сфере гидроэнергетики, горнодобывающей промышленности, агропромышленного комплекса, туризма и т.д.;

- создать благоприятные условия для привлечения в республику банковского капитала из стран ЕАЭС;

- для повышения экспортного потенциала страны на основе прямого договора с регионами России, создавать крупные региональные торгово-логистические центры;

- проводить целенаправленную работу по преодоления существующего дисбаланса в торговле с КНР, для чего активно использовать возможности ЕАЭС;

- активизировать торгово-экономическое сотрудничество со странами ЦА, особенно, с Узбекистаном, в рамках заключения межправительственных соглашений.

\section{Литература}

- Евразийский Экономический Союз в цифрах: краткий статсборник. Москва, ЕЭК, 2018.-206 с.

- Кыргызская Республика в Евразийском экономическом союзе : первые результаты.-Москва, 2018.$88 \mathrm{c}$.

- Платежный баланс Кыргызской Республики, 2017.-Бишкек, Нацбанк КР , 2018.-https://www.nbkr.kg

- Р.И.Хасбулатов. Россия между двумя субконтинетами в Евразии: преимущества и новые угрозы.Экономика регионов, 2017, т.3, вып.4.- с.1005-1015.

- С. Глазьев. Рывок в будущее. Россия в новых технологическом и мирохозяйственном укладах. Москва, Книжный мир,2018. -768c (с.585) 


\title{
О Прогнозе Развития Евразийского Экономического Союза On the Forecast of the Development of the Eurasian Economic Union
}

\author{
Prof. Dr. Jusup Pirimbaev (Kyrgyzstan-Turkey Manas University, Kyrgyzstan) \\ Dr. Zalkar Kamalov (University of Central Asia, Kyrgyzstan)
}

\begin{abstract}
The course of economic integration within the framework of the EAEU is proceeding according to a plan outlined in a document on the Union's development forecast until 2030, when first three countries were members of the EAEU - Russia, Kazakhstan and Belarus. Later, two more countries joined the union - Armenia and Kyrgyzstan. Then based on the real situation, additional adjustments were made. Many problems remain that need to be solved precisely in the field of integration, which, on the one hand, cause the need for an accelerated approach, and on the other, raise doubts about the prospects of this alliance. The article is aimed to study the causes of disputes, identifying factors contributing to the unification of participants, and developing an objective vision of the Union's development prospects. And also, based on the analysis of today's relationships among the members of the Eurasian Economic Union, appropriate conclusions and recommendations will be made for further relationship improvement by considering the perspectives of voluntary joining of other countries into the Eurasian Economic Union.

В текущем году исполняется пять лет Евразийскому экономическому союзу. Казалось бы, прошли времена споров, сомнений о необходимости создания данного союза. Однако сам ход реализации в жизнь идеи этого объединения, формирование, функционирование и укрепление взаимосвязей внутри союза вызывают неподдельный интерес как специалистов, так и народов стран-членов ЕАЭС. И это надо признать закономерным, если хотим реального жизнеутверждения главной цели союза. При этом следует иметь в виду два подхода к реализации цели союза: с одной стороны, речь идет о внутрисоюзном взаимодействии путем интеграции, модернизации и кооперации экономических отношений членов союза с учетом интересов сторон, с другой - о полноценном, масштабном функционировании в мировой экономике. Это сложный процесс, требующий профессионального подхода, с учетом современного состояния экономики и перспективы.
\end{abstract}

Если в первом случае требуется учитывать не только желание членов союза, но и опыт таких объединений, как ЕС, АТЭС, Меркосур, НАФТА и других в отношении эффективности и реального результата, с соблюдением правил ВТО; то во втором случае требуется не только добиваться привлекательности союза в международном пространстве, но и превращать его в один из центров решения международных экономических проблем. Дело не из простых. Поэтому поверхностное прогнозирование развития ЕАЭС, без изучения фактического хода реализации союзных принципов, результативности экономических взаимоотношений и без «ошущения» реальных результатов, является чисто политической риторикой. Такой вывод напрашивается при изучении противоречивых материалов СМИ, статей и прочих источников: одни признают прогрессивность создания союза, другие, наоборот, противопоставляют членов союза друг другу, указывая на стремление России к глобальной гегемонии, к расширению своего влияния в мировом масштабе. Такому беспочвенному разбросу мнений способствует эйфория независимости, прочно укоренившаяся в головах новоявленных политических деятелей постсоветского периода.

Взаимоотношения стран-членов ЕАЭС в международной торговле не могут оставлять равнодушными многие страны, интерес растет. Так, товарооборот между ЕАЭС и ЕС ранее составлял 48,9\%, по итогам 2018 года этот показатель снизился до $42,7 \%$. В то же время товарооборот с азиатскими странами увеличился с 40 до 45\%. Только инвестиции Китая, которые составляли в страны ЕАЭС в 2008 году 11 млрд. долл. США, увеличились к 2018 году до 25,7 млрд. долл. США, то есть рост составил 138\%. И уже идет речь об открытии представительства ЕАЭС в Китае. В 2019 году начались переговоры между ЕАЭС и ЕС в Брюсселе, открывающие перспективу в экономических взаимоотношениях. Экономический интерес, исходя из сложившегося положения, за такой короткий срок обязательно порождает политическое переосмысление, и это неизбежно. Главное, чтобы оно было без конспирологических теорий и не было направлено на разрушение и разложение благих намерений нового союза. А споры, направленные на усовершенствование и улучшение механизмов взаимоотношений внутри союза во благо жителей всех стран-членов, будут идти только на пользу.

\section{Экономические Показатели ЕАЭС На Текущий Момент}

Краткий обзор макроэкономических показателей, определяющих устойчивость экономического развития государств-членов ЕАЭС, приведен в соответствии с методикой ЕЭК. 
Дата обновления: 28.03.2019

\begin{tabular}{|c|c|c|c|c|c|c|}
\hline Показатель & $\begin{array}{c}\text { Государство- } \\
\text { член ЕАЭС } \\
\end{array}$ & $\begin{array}{c}\text { Единица } \\
\text { измерения } \\
\end{array}$ & 2015 & 2016 & 2017 & 2018 \\
\hline \multirow{5}{*}{$\begin{array}{l}\text { 1. Темпы роста валового } \\
\text { внутреннего продукта }\end{array}$} & Армения & \multirow{5}{*}{$\begin{array}{c}\text { проценты к } \\
\text { предыдущему } \\
\text { периоду }\end{array}$} & 3,2 & 0,2 & 7,5 & 5,2 \\
\hline & Беларусь & & $-3,8$ & $-2,5$ & 2,4 & 3,0 \\
\hline & Казахстан & & 1,2 & 1,1 & 4,1 & 4,1 \\
\hline & Кыргызстан & & 3,9 & 4,3 & 4,6 & 3,5 \\
\hline & Россия & & $-2,5$ & $-0,2$ & 1,5 & 2,3 \\
\hline \multirow{5}{*}{$\begin{array}{l}\text { 2. Валовой внутренний } \\
\text { продукт на душу населения по } \\
\text { паритету покупательной } \\
\text { способности }\end{array}$} & Армения & \multirow{5}{*}{ долл.США } & 8473 & 8612 & 9468 & - \\
\hline & Беларусь & & 18225 & 17975 & 18761 & - \\
\hline & Казахстан & & 25048 & 25280 & 26604 & - \\
\hline & Кыргызстан & & 3447 & 3694 & 3913 & - \\
\hline & Россия & & 23752 & 23185 & 23945 & - \\
\hline \multirow{10}{*}{$\begin{array}{l}\text { 3. Сальдо счета текущих } \\
\text { операций платежного баланса }\end{array}$} & Армения & \multirow{5}{*}{ млн.долл.США } & -272 & -238 & -328 & - \\
\hline & Беларусь & & -1831 & -1669 & -931 & - \\
\hline & Казахстан & & -5135 & -8874 & -5353 & - \\
\hline & Кыргызстан & & -1059 & -792 & -306 & - \\
\hline & Россия & & 67777 & 24517 & 35436 & - \\
\hline & Армения & \multirow{5}{*}{$\begin{array}{c}\text { проценты к } \\
\text { ВВП }\end{array}$} & $-2,6$ & $-2,3$ & $-2,8$ & - \\
\hline & Беларусь & & $-3,2$ & $-3,5$ & $-1,7$ & - \\
\hline & Казахстан & & $-2,8$ & $-6,4$ & $-3,3$ & - \\
\hline & Кыргызстан & & $-11,1$ & $-11,5$ & $-4,1$ & - \\
\hline & Россия & & 4,9 & 1,9 & 2,2 & - \\
\hline \multirow{5}{*}{$\begin{array}{l}\text { 4. Индекс реального } \\
\text { эффективного обменного } \\
\text { курса национальной валюты, } \\
\text { рассчитанный на основе } \\
\text { индекса потребительских цен* }\end{array}$} & Армения & \multirow{5}{*}{$\begin{array}{c}\text { проценты к } \\
\text { предыдущему } \\
\text { периоду }\end{array}$} & 5,8 & $-0,7$ & $-3,4$ & 0,5 \\
\hline & Беларусь & & $-3,6$ & $-8,4$ & $-4,7$ & 1,0 \\
\hline & Казахстан & & 5,0 & $-25,7$ & 7,3 & $-2,1$ \\
\hline & Кыргызстан & & 4,6 & $-1,7$ & 0,1 & 2,9 \\
\hline & Россия & & $-16,5$ & $-0,5$ & 15,9 & $-7,7$ \\
\hline
\end{tabular}

Таблица 1. Мониторинг показателей уровня и динамики развития экономик государств-членов ЕАЭС Примечание: * "+" укрепление нац. валюты к ин. валютам; "-" обесценение наи. валюты к ин. валютам. Источник: Департамент статистики Евразийской экономической комиссии.

Данные табл. 1 приведены с целью отобразить, как разняться оценивающие макроэкономические показатели в странах ЕАЭС, ведь главной задачей ЕАЭС является максимальное приближение их друг к другу. На начальном этапе деятельности стран в составе ЕАЭС эти показатели можно считать удовлетворительными, несмотря на медленное их изменение. Ибо происходят они в условиях очень сложных экономических взаимоотношений в мире, когда ведущие державы занимаются откровенной протекционистской политикой, а экономические права малых и развивающихся стран трудно регулируются ВТО, даже их экономические потенциалы становятся объектом перераспределения в пользу сильных стран. Поэтому медленные, но изменения макроэкономических показателей в сторону позитива являются базовым этапом постепенного и динамичного роста. Это даже сейчас можно реально ощутить.

Обновлено: 16.11 .2018

\begin{tabular}{|c|l|c|c|c|c|c|}
\hline \multicolumn{2}{|c|}{ Год/период } & Армения & Беларусь* & Казахстан & Кыргызстан** & Россия*** \\
\hline 2015 & январь-декабрь (год) & $-\mathbf{4 , 8}$ & 2,3 & $-2,2$ & $-1,4$ & $-2,5$ \\
\hline 2016 & январь-декабрь (год) & $\mathbf{- 5 , 5}$ & 1,7 & $-2,6$ & $-4,4$ & $-3,0$ \\
\hline \multirow{3}{*}{2017} & январь-март & $-1,4$ & 2,1 & 1,9 & $-0,9$ & 1,7 \\
\cline { 2 - 7 } & январь-июнь & $-1,5$ & 2,9 & 0,3 & $-1,9$ & 1,2 \\
\cline { 2 - 7 } & январь-сентябрь & $-2,3$ & 4,0 & $-7,3$ & $-1,8$ & 1,4 \\
\cline { 2 - 7 } & январь-декабрь (год) & $-\mathbf{4 , 8}$ & 2,1 & $-3,0$ & $-2,9$ & $-0,6$ \\
\hline \multirow{2}{*}{2018} & январь-март & $-1,7$ & 6,1 & $-0,4$ & 2,3 & 3,5 \\
\cline { 2 - 7 } & январь-июнь & 0,2 & 6,2 & $-2,5$ & 0,6 & 3,6 \\
\hline
\end{tabular}

Критерий, установленный Договором о ЕАЭС, - дефицит не более 3\% ВВП. римечания:

* По итогам 2017 г. - в соответствии с квартальной отчетностью данных.

** До января-декабря 2017 г. - без учета операциий Социиального фонда Кыргызской Республики.

*** C 2018 г. - без учета операциий внебюджетных единиц сектора государственного управления.

Таблица 2. Дефицитт(-) / профицит консолидированного бюджета сектора государственного управления, \% ВВП Источник: данные ЕЭК. 
Как видно из табл. 2, дефицит консолидированного бюджета, установленного Договором ЕАЭС не более 3\% ВВП, в целом по странам-членам ЕАЭС медленно, но регулируется в допустимых размерах, за исключением Беларуси. Причины этого находят в правовой недоработанности степени интеграции между странами-членами. Соответствующие корректировочные меры предпринимаются со стороны ЕЭК. Видимый профицит бюджета Кыргызской Республики 2018 года к концу этого же года опустился еще ниже вследствие корректировки его расходной части исходя из реального положения. В результате бюджет страны на 2019 год был принят с дефицитом 10 млрд. сомов. Это было связано с необходимостью обязательного обеспечения социальных выплат, ведь, начиная с 2016 года, Кыргызстан позиционирует себя как социальное государство, что закреплено в Конституции страны. Чтобы не допустить влияния дефицита бюджета на экономические процессы в республике, со стороны России было выделено 30 млрд. долл. США безвозмездной помощи по просьбе высшего руководства страны. Нужно подчеркнуть, что это является помощью на покрытие дефицита бюджета, а не грантом, который можно использовать по усмотрению правительства. Хотя выделенные средства исходят из двусторонних отношений между Россией и Кыргызстаном, их нужно рассматривать в контексте реализации основной цели ЕАЭС по сближению экономических положений стран-членов.

Обновлено: 16.11 .2018

\begin{tabular}{|c|l|c|c|c|c|c|}
\hline \multicolumn{2}{|c|}{$\begin{array}{c}\text { Год/на конец } \\
\text { периода }\end{array}$} & Армения & Беларусь & Казахстан & Кыргызстан & Россия \\
\hline 2015 & декабрь & 43,7 & 32,6 & 17,5 & $\mathbf{5 7 , 3}$ & 11,4 \\
\hline 2016 & декабрь & $\mathbf{5 1 , 5}$ & 41,5 & 19,2 & $\mathbf{5 8 , 9}$ & 11,9 \\
\hline \multirow{3}{*}{2017} & март & $\mathbf{5 1 , 0}$ & 39,9 & 18,7 & $\mathbf{5 9 , 3}$ & 11,7 \\
\cline { 2 - 7 } & июнь & $\mathbf{5 1 , 1}$ & 43,2 & 18,4 & $\mathbf{6 0 , 1}$ & 11,6 \\
\cline { 2 - 7 } & сентябрь & $\mathbf{5 1 , 6}$ & 43,0 & 19,6 & $\mathbf{6 1 , 2}$ & 11,8 \\
\cline { 2 - 7 } & декабрь & $\mathbf{5 3 , 4}$ & 42,1 & 19,3 & $\mathbf{5 9 , 7}$ & 12,0 \\
\hline \multirow{2}{*}{2018} & март & $\mathbf{5 2 , 8}$ & 40,4 & 18,9 & $\mathbf{5 7 , 4}$ & 11,6 \\
\cline { 2 - 7 } & июнь & $\mathbf{5 0 , 3}$ & 39,3 & 18,7 & $\mathbf{5 7 , 1}$ & 11,4 \\
\hline
\end{tabular}

Критерий, установленный Договором о ЕАЭС, - не более 50\% ВВП

Таблица 3. Долг сектора государственного управления, \% ВВП Источник: данные ЕЭК.

Приведенные данные показывают, что, несмотря на ощутимый объем задолженности государственного управления Армении и Кыргызстана, общее положение каждой страны-члена ЕАЭС находится в пределах допустимых критериев Договора о ЕАЭС - не более 50\% ВВП. За последние два года в Кыргызстане наблюдается тенденция снижения уровня долга. Это связано со списанием долга со стороны РФ. Кроме того, в последнее время между Кыргызстаном и Россией подписано несколько соглашений по экономическим взаимоотношениям на общую сумму 6,3 млрд. долл. США. Такого ощутимого экономического соглашения страна не подписывала за все время независимости после СССР. В совокупности объем соглашения превышает весь объем внешнего долга республики. Реализация на практике мероприятий соглашения даже с половинным экономическим эффектом приведет к значительному сокращению внешного долга по отношению к ВВП. Тем самым открывается возможность при необходимости ускорения экономического роста дополнительного внешнего заимствования. Соглашения охватывают основные отрасли экономики Кыргызстана, которые имеют реальный потенциал экономического роста. Так, из общего объема соглашений более 3 млрд. долл. США связано с развитием энергетической и горнодобывающей отраслей, более 1 млрд. долл. США - с промышленностью и 450 млн. долл. США - с развитием АПК.

Такой объем средств поддержки развития этих отраслей ведет к качественным изменениям в экономическом положении Кыргызстана и в то же время носит обязывающий характер по их практической реализации, предусматривая создание соответствующих хозяйственных механизмов. Во-первых, энергетика и добывающая отрасли являются основным объектом внимания правительства КР за все время независимости. Это связано с горьким опытом производства золота компанией «Кумтор», эффект от которого так и остался незаметным. Его влияние на общее положение экономики страны оказалось «никаким». Стоит напомнить, что с нулевого года цены на золото выросли в 42 раза в мире, а эти изменения страна-производитель не ощущает. Более того, практика показала негативное влияние этого опыта на принадлежность всех недр Кыргызстану как собственности. Во-вторых, развитие промышленности в стране предусматривается через интеграцию и модернизацию. Муссируется вопрос на Евразийском пространстве о роли кооперации в производственном секторе, заслуживающий внимания для разработки новых механизмов взаимоотношения. В-третьих, речь идет о развитии сельского хозяйства страны как основной отрасли АПК. Такой подход требует изменения отношения государства к мелким крестянским и фермерским хозяйствам, укрупнению сельскохозяйственного сектора вокруг АПК. В животноводстве - 
через индустриализацию, а в растениеводстве - путем развития перерабатывающего сектора, объединяющего вокруг себя мелких производителей. Эти меры должны сопровождаться изменением форм собствнности в сельском хозяйстве.

Обновлено: 16.11 .2018

\begin{tabular}{|l|l|c|c|c|c|c|c|}
\hline \multicolumn{2}{|c|}{ Год/период } & Критерий & Армения & Беларусь & Казахстан & Кыргызстан & Россия \\
\hline 2015 & декабрь & $\mathbf{1 0 4 , 9}$ & 99,9 & $\mathbf{1 1 2 , 0}$ & $\mathbf{1 1 3 , 6}$ & 103,4 & $\mathbf{1 1 2 , 9}$ \\
\hline 2016 & декабрь & $\mathbf{1 0 3 , 9}$ & 98,9 & $\mathbf{1 1 0 , 6}$ & $\mathbf{1 0 8 , 5}$ & 99,5 & $\mathbf{1 0 5 , 4}$ \\
\hline \multirow{3}{*}{2017} & март & $\mathbf{1 0 4 , 9}$ & 99,9 & $\mathbf{1 0 6 , 4}$ & $\mathbf{1 0 7 , 7}$ & 102,8 & 104,3 \\
\cline { 2 - 8 } & июнь & $\mathbf{1 0 6 , 1}$ & 101,1 & $\mathbf{1 0 6 , 5}$ & $\mathbf{1 0 7 , 5}$ & 104,1 & 104,4 \\
\cline { 2 - 8 } & сентябрь & $\mathbf{1 0 6 , 0}$ & 101,0 & 104,9 & $\mathbf{1 0 7 , 1}$ & 103,3 & 103,0 \\
\cline { 2 - 8 } & декабрь & $\mathbf{1 0 7 , 5}$ & 102,6 & 104,6 & 107,1 & 103,7 & 102,5 \\
\hline \multirow{3}{*}{2018} & март & $\mathbf{1 0 7 , 4}$ & 103,7 & 105,4 & 106,6 & 102,7 & 102,4 \\
\cline { 2 - 8 } & июнь & $\mathbf{1 0 5 , 8}$ & 100,9 & 104,1 & $\mathbf{1 0 5 , 9}$ & 100,8 & 102,3 \\
\cline { 2 - 8 } & сентябрь & $\mathbf{1 0 6 , 2}$ & 103,5 & 105,6 & 106,1 & 101,2 & 103,4 \\
\hline
\end{tabular}

Критерий, установленный Договором о ЕАЭС, - не более 5 n.п. к уровню инфлячии

в государстве-члене с наименьшим значением.

Таблица 4. Уровень инфляцฺии (индекс потребительских иен), к соответствующему месяиу предыдущзего года, \% Источник: данные ЕЭК.

Несмотря на международные экономические санкции по отношению к России, что, безусловно, негативно сказывается на экономике и других странах-членах ЕАЭС, уровень инфляции находится в целом ниже установленного критерия в пространстве ЕАЭС - не более 5 п.п.

Налаживается в позитивную сторону и взаимная торговля между странами-членами ЕАЭС. Это видно по данным табл. 5 о взаимной торговле Кыргызской Республики со странами ЕАЭС за неполный 2018 год. Большая доля экспорта и импорта Кыргызстана объективно отражает нацеленность экономики КР на внутренний рынок ЕАЭС и открывает возможности расширения торговли через механизмы ЕАЭС со многими зарубежными странами, через зоны свободной торговли, взаимодействие ЕАЭС и ЕС, договоры ЕАЭС с ведущими экономическими державами.

Следует подчеркнуть, что дальнейший рост ВВП в целом ЕАЭС должен сопровождатся стремлением к сбалансированности отраслей экономики. На сегодняшний день по ЕАЭС в целом увеличение добычи полезных ископаемых составляет 1,8 раза, строительного производства $-7,1 \%$, валового накопления также 7,1\%. Первые два показателя, связанные с горной добычей и строительством, должны открывать максимальную возможность для пропорционального роста связанных с ними отраслей, Это прежде всего технологии, обеспечивающие рост добавленной стоимости и подъем сбалансированности отраслей в целом. А увеличение валового накопления должно стать основой составления бюджета, обеспечивающего стимулирующие меры.

\begin{tabular}{|c|c|c|c|c|c|c|c|c|c|}
\hline & \multicolumn{3}{|c|}{ Объем взаимной торговли-всего } & \multicolumn{3}{|c|}{ Экспорт } & \multicolumn{3}{|c|}{ Импорт } \\
\hline & 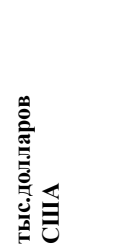 & 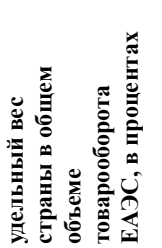 & 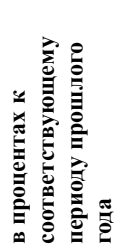 & 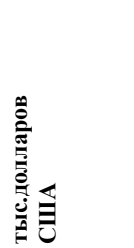 & 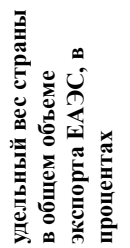 & 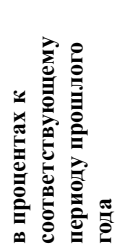 & 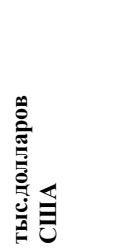 & 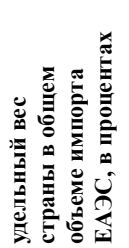 & 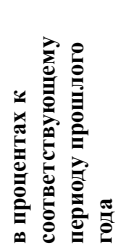 \\
\hline $\begin{array}{l}\text { ВСЕГО } \\
\text { в том числ }\end{array}$ & 1900297,5 & 100 & 96,0 & 466153,4 & 100 & 101,2 & 1434144,1 & 100 & $\mathbf{9 4 , 5}$ \\
\hline Армения & 481,3 & 0,0 & 49,7 & 130,7 & 0,0 & 0,0 & 350,6 & 0,0 & 33,3 \\
\hline Беларусь & 33424,1 & 1,8 & 32,1 & 5829,9 & 1,3 & 90,6 & 27594,2 & 1,9 & 28,2 \\
\hline Казахстан & 620098,7 & 32,6 & 92,7 & 206338,3 & 44,3 & 88,4 & 413760,4 & 28,9 & 95,0 \\
\hline Россия & 1246293,3 & 65,6 & 103,5 & 253854,5 & 54,5 & 114,9 & 992438,9 & 69,2 & 100,9 \\
\hline
\end{tabular}

Таблица 5. Основные показатели взаимной торговли Кыргызской Республики со странами ЕАЭС в январе - октябре 2018 г. Источник: Национальный статистический комитет КР, 20182.

\section{Прогнозы развития ЕАЭС}

Все обсуждения и споры, связанные с прогнозированием развития ЕАЭС, можно рассматривать в рамках трех основных направлений. 
1. Количественное или географическое расширение для развития ЕАЭС.

2. Развитие ЕАЭС через управленческие структуры внутренних взаимоотношений.

3. Развитие управленческой структуры ЕАЭС.

Первое направление далеко от целей и задач ЕАЭС, носит чисто политический характер, связанный со стереотипами деления на Запад-Восток, противопоставлением экономических систем, идеологическим противостоянием вплоть до военного. Поэтому многие полагают, что ЕАЭС непременно будет стремиться к географическому расширению своего влияния. Однако апологеты ЕАЭС считают, что географическое расширение не является самоцелью. Но и категорически не отрицают возможного расширения, прежде всего, исходя из желания и соответствия новых вступающих стран требованиям ЕАЭС.

Нам представляется логичным, когда одним из основных требований к вступлению выступает наличие общей границы и близость экономической системы к странам-членам ЕАЭС. Это намного упрощает разработку общих стандартов маркировки товаров и определение брендов, развитие общей инфраструктуры и организацию транспортной системы, а также обеспечение взаимоприемлемой стабилизации внутренного рынка от возможного влияния различных экономических катаклизмов: применения различных экономических санкций к одному из членов ЕАЭС, кризисов, наносящих ощутимый экономический ущерб, погодных условий и техногенных катастроф.

Поэтому предложение президента Кыргызской Республики Жээнбекова С.Ш. о принятии Таджикистана и Узбекистана в соответствии с их желанием в состав ЕАЭС вызвано объективной логикой создания ЕАЭС. Тем более идет ускоренная их интеграция со странами ЕАЭС. Конечно, это зависит от готовности признания и выполнения этими странами всех требований, предъявяемых странам-членам ЕАЭС.

Здесь большое значение имеют взаимоотношения ЕАЭС с другими региональными экономическими объединениями или отдельными странами через зоны свободной торговли, что способствует совершенствованию взаимоотношений региональных экономических объединений и их укреплению, свободе действий с другими странами во внешнеэкономической деятельности. Надо также учитывать, что в деятельности ЕАЭС предусмотрено участие стран в статусе наблюдателя.

Второе направление связано с управлением деятельностью ЕАЭС через высший совет экономического союза, объединяющий первых лиц стран-членов, который определяет стратегическое направление ЕАЭС и принимает ключевые решения, а также созданием постоянно действующего наднационального управленческого органа - Евразийской экономической комиссии со структурой, координирущей деятельность различных секторов экономики внутри союза и имеющей полномочия подписания меморандумов, соглашений и договоров международными сообществами, а также отдельными зарубежными странами от имени ЕЭК, причем впоследствии при принятии соответствующих решений они становятся достоянием каждой страны-члена союза. Пока многие решения ЕЭК, принимаемые по экономическим вопросам внутри союза, носят рекомендательный характер. Это, скорее, результат осторожности и поиска экономической целесообразности решений, принимаемых наднациональной управленческой структурой, и к тому же проявление неутраченного состояния эйфории независимости постсоветского пространства.

Однако практика требует внести свои коррективы в работу наднациональной структуры управления. На саммите глав государств ЕАЭС президент Кыргызской Республик Жээнбеков С.Ш. внес предложения о повышении полномочий ЕЭК в обеспечении эффективности ее работы. Видимо, он имел в виду низкую степень общей исполняемости рекомендаций ЕЭК странами-членами союза, а также недостаточный уровень взаимодействия соответствующих министерств и ведомств этих стран по реализации рекомендуемых мер, можно допустить, конечно, и просто некомпетентность кадров из-за отсутствия опыта совместной работы. Полагаем, что повышение полномочий сейчас является вынужденной мерой, направленной на усиление действенности принимаемых решений ЕЭК в целях своевременного обеспечения запланированных работ в условиях формирования и становления ЕАЭС. С другой стороны, следует думать о степени ответственности соответствующих министерств и ведомоств стран-членов по срокам исполнения принятых решений. Это требует организации системной работы структур управления каждой страны по укреплению деятельности союза.

Помощник председателя коллегии ЕЭК Чалая Ю.Ю. в своей лекции в НИУ ВШЭ на тему «История, логика, результаты и перспективы развития Евразийского экономического союза (ЕАЭС)» определяет три возможных сценария развития ЕАЭС.

1. Статус-кво. В данном сценарии по-прежнему остаются различные препятствия на пути к общему рынку, но при этом выполняются положения договора о союзе.

2.Транзитно-сырьевой мост. Этот сценарий предполагает сотрудничество стран в таких сферах, как транспорт, логистика, таможня и инфраструктура для реализации транзитного потенциала ЕАЭС. 
3.Реализация собственного центра силы. Третий вариант включает в себя уже уровень интеграции, который проявляется в кооперационных проектах и совместных ответах государств-членов ЕАЭС на глобальные вызовы мирового развития.

В этом контексте осуществляет свою деятельность ЕЭК по реализации проекта до 2025 г., которая должна завершить к концу этого срока создание единого рынка энергетики, финансов, транспорта, фармацеи, туризма и других секторов экономики по мере возможности. Поэтому наличие прогнозных видений независимо от того, соответствуют они или нет деятельности наднациональной структуры управления открывает возможности для совершенствования механизмов развития союза в целом.

Третье направление связано с появлением новых сфер сотрудничества внутри союза, что может привести к расширению структуры наднационального управления. На последних саммитах высшего совета экономического союза все больше выходит на первый план тема углубления сотрудничества в социальной сфере экономики, включая образование, культуру, науку и здравоохранение. Наверное, нет необходимости оспаривать важность этих сфер, без поддержки которых обеспечение реальной цели ЕАЭС маловероятно. Именно в этой области достигается ощутимость деятельности ЕАЭС среди населения, живущего в общем пространстве союза. Безусловно, именно в этой сфере рождаются подходы к взаимодействию, совершенствуются и укрепляются механизмы союзного общежития.

В этой связи считаем, что назрела необходимость подумать о рациональном расширении структуры наднационального управлении в социальной сфере экономики. Это позволит достичь не только желаемого материального, но и неоценимого духовного эффекта, обогащая страны-члены союза достижениями в этой области, порождая новые традиции общих ценностей внутри союза.

Также считаем целесообразным создание центра координации движения, размещения и обеспечения жизнедеятельности трудовых ресурсов, осуществляющих реализацию общесоюзных программ или вкладывающих свою ленту в развитие экономики других стран союза. Речь идет о координации движения, связанного именно с трудовыми ресурсами, а не мигрантами. Учитывая ограниченность объема статьи, мы сознательно упустили научную полемику вокруг прогнозирования развития ЕАЭС, достаточно полно освещаемую в экономической литературе и дискуссионных клубах.

\section{Выводы}

1. Сколько бы ни говорили о прогнозировании развития ЕАЭС, оно должно иметь созидательный характер. А поскольку союз находится на стадии формирования и становления, то политическая риторика вокруг перспектив развития ЕАЭС является беспредметной.

2. Споры и суждения о расширении союза и сотрудничества в международном масштабе считаем полезными для своевременного внесения соответствующих корректив в деятельность союза.

3. Следует обеспечить механизмы тесного и продуктивного взаимодействия соответствующих структур управления отдельных стран союза для своевременного обеспечения реализации решений, принятых высшим советом экономического союза.

4. Подчеркиваем необходимость ведения постоянной работы, чтобы жители союза реально ощущали, что находятся внутри отвечающего их интересам союза.

\section{Литература}

- Аналитический обзор результатов мониторинга дефицита консолидированного бюджета и долга сектора государственного управления в государствах-членах ЕАЭС. Департамент макроэкономической политики ЕЭК.

- Взаимная торговля товарами Кыргызской Республики с государствами-членами Евразийского Экономического Союза в январе-октябре 2018 г. - Бишкек, 2018.

- Внешняя торговля ЕАЭС с АСЕАН: отчет ЕЭК, январь-август 2017 г.

- Внешняя торговля ЕАЭС с Китаем: отчет ЕЭК, январь-август 2018 г.

- Внешняя торговля ЕАЭС со странами ЕС: отчет ЕЭК, январь-август 2018 г.

- Информация о результатах мониторинга уровня инфляции в государствах-членах ЕАЭС. Департамент макроэкономической политики ЕЭК.

- Обзор совместного исследования Всемирного банка и Евразийской экономической комиссии: цифровая повестка ЕАЭС-2025: перспективы и рекомендации. 


\title{
Проблемы Реализации Стартап Проектов в Кыргызской Республике
}

\section{Problems of Implementation of Startup Projects in the Kyrgyz Republic}

\author{
Ph.D. Candidate Aizhan Rakhmanalieva (Kyrgyz-Russian Slavic University, Kyrgyzstan)
}

\begin{abstract}
Today in the Kyrgyz Republic one of the sources of sustainable economic development can be considered the development of small and medium enterprises. It acts as a driving force of economic growth, because contributes to the creation of new jobs, poverty reduction and the development of civil society. In international practice, entrepreneurship development is mostly provided by a small innovative business, the best management approach of which is project management.

In connection with the intensification of interest in scientific and technological developments, it is necessary to note the emergence of a new direction of companies - a startup. Unlike foreign countries, where this practice is widespread and actively supported by the state, the development of the practice of startups in Kyrgyzstan is actually at an early stage.

Accordingly, in the domestic literature, such a phenomenon as a "startup" is not considered, and in the foreign one, the features of the local market are not taken into account.

In the definition of a startup, the word "search" is also important, because it demonstrates a key difference from enterprises that operate in mature markets.

The life cycle of a startup project has a more complex structure than a traditional project.

The article describes the quantitative indicators of Startup-Ecosystems of Kyrgyzstan, as well as key factors affecting its development. The most significant factors affecting the environment for developing and implementing startup projects have been identified.
\end{abstract}

\section{1 Введение}

В современных условиях предприятия все чаще работают в бизнес-экосистеме, т.е. более широкой сети связанных предприятий, предлагающих конкретные продукты или услуги. И т.к. стартапы, как и предприятия, невозможно рассматривать вне окружающей их среды, рассмотрим стартап деятельность в рамках обзора стартап-экосистемы Кыргызской Республики.

Стартап-экосистема создается людьми, стартапами на разных этапах и различными типами организаций (физическими или виртуальными), взаимодействующими как система для создания и масштабирования новых компаний-стартапов. В эту систему могут входить самые различные организации (рис.1): университеты, финансирующие организации, вспомогательные организации (например, инкубаторы, акселераторы, кооперативные пространства и т.д.), исследовательские организации, организации поставщиков услуг (например, юридические, финансовые услуги и т.д.) и крупные корпорации.

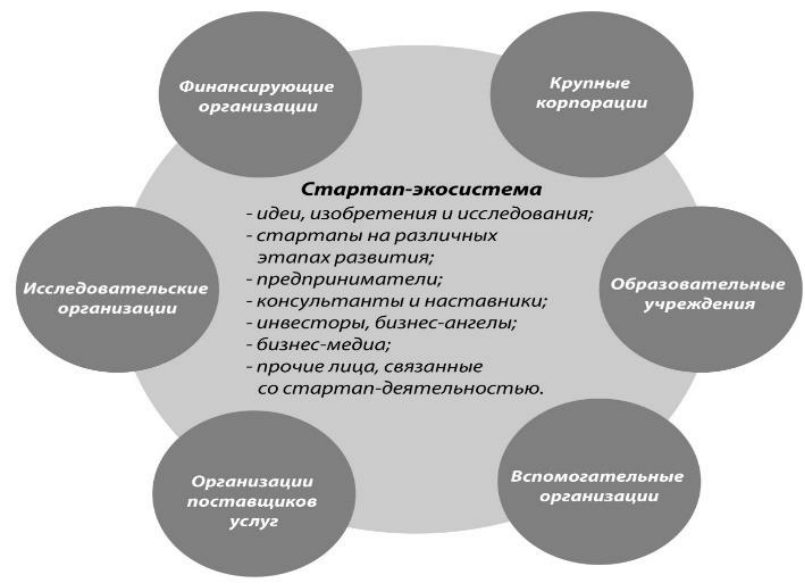

Рисунок 1. Структура Стартап-Экосистемь

Различные части экосистемы охватываются различными организациями и реализуют на конкретных этапах развития необходимые ей функции. 
Поскольку начальные экосистемы мы определяем сетью взаимодействий между людьми, организациями и их средой, они могут быть разных типов, но обычно они более известны как стартап-экосистемы конкретных городов или онлайн-сообществ.

Кроме того, важными компонентами стартап-экосистемы являются ресурсы, такие как навыки, время и деньги. Эти виды ресурсов получают в основном от людей и организаций, активных участников стартапэкосистем. Все это способствует наращиванию потенциала для создания новых стартапов или укреплению уже существующих.

Важное влияние на экосистему оказывают факторы макро- и микросреды. Внешние факторы, такие как инвестиционный климат, демографическая, социально-экономическая, политическая, технологическая, экологическая среда контролируют общую структуру экосистемы и то, как она работает. Внутренние факторы не только контролируют процессы структуры экосистемы, но также контролируются ими и часто подвергаются циклам обратной связи. К таким факторам относятся научно-технический потенциал, финансово-экономический потенциал, кадровый потенциал стартапа и так далее.

\section{2 Основная Часть}

Говоря о Кыргызстане, можно сказать, что в стране наблюдаются первые положительные сдвиги, но это, скорее, отдельные позитивные исключения, а не полноценные тренды, которые бы определяли развитие стартап-индустрии.

В стартап-экосистеме Кыргызстана за последние 15 лет было реализовано менее 100 стартап проектов. При этом далеко не все проекты отвечают «обязательным» характеристикам стартапа. Можно выделить единичные факты выхода стартапов на международный рынок или получения иностранных инвестиций. Но надо помнить, что получение инвестиций - это еще не успех, а только начало пути к его достижению.

В Кыргызстане осуществляют деятельность 42 образовательных учреждения, связанных с подготовкой предпринимателей, управленцев и программистов-разработчиков, но количество, не всегда означает качество.

По инициативе КАРПОУ в 2013 году был создан Парк Высоких Технологий (ПВТ). До 2028 года (в течение 15 лет с момента создания парка) резиденты ПВТ освобождены от налогов и выплат по страховым взносам. Организации оплачивают только 1\% от выручки в дирекцию ПВТ на организацию деятельности. Также для работников резидентов ставка подоходного налога составляет всего 5\%. По состоянию на начало 2019 года в ПВТ осуществляли деятельность 37 компаний-резидентов, общий годовой оборот которых составляет 7 млн долларов.

На данный момент в Кыргызстане действует 1 бизнес-инкубатор Ideagrad, который является стартапинкубатором в городе Бишкек. Он поддерживает начинающих предпринимателей в регионе путем предоставления им всесторонней программы обучения и наставничества вместе с небольшим стартовым капиталом. Инкубаторм Ideagrad было реализовано совсем небольшое количество проектов, большее количество которых на сегодняшний день не функционирует.

Также, в Бишкеке проводятся различные мини-конкурсы проектов, финансируемые различными компаниями, неправительственными организациями и донорами.

На реализацию стартап проекта непосредственное влияние оказывает среда, в которой различные внутренние и внешние силы способствуют или мешают достижению целей проекта. Все эти условия и факторы в совокупности образуют окружение проекта, влияние которого необходимо учитывать в процессе планировании и реализации проекта.

Факторы, по объекту воздействия, можно поделить на две группы:

- факторы, воздействующие на всё предприятие (например, изменение цен на нефть, газ; изменение законодательства);

- факторы, воздействующие на отдельные элементы предприятия.

По отношению к предприятиям их можно разделить на внутренние и внешние. К внутренним отнесем: состояние технологического оборудования предприятия, экономическую ситуацию на предприятии; состояние производственных мощностей, уровень кадровой политики и так далее. К внешним же факторам отнесем факторы внешней среды - это государственная политика; правовая база предпринимательской деятельности; состояние финансово-кредитной системы государства; состояние внутреннего и внешнего рынков.

Составляющие окружения проекта в зависимости от уровня их возникновения представлены на рисунке 2 (Заренков В.А., 2010). 


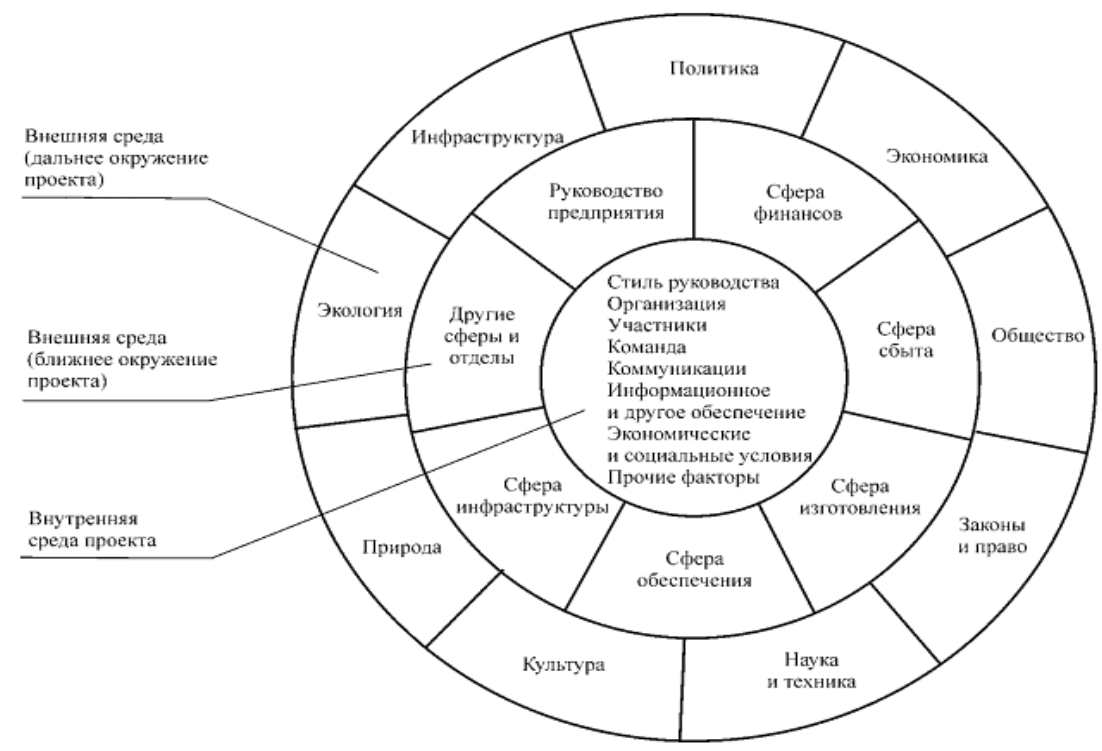

Рисунок 2. Окружение Проекта

По природе возникновения факторы делятся на 5 групп:

1) человеческие: соответствие работника занимаемой должности, мотивированность поведения сотрудников;

2) интеллектуальные: инновационный уровень техничексих и организационных решений, уровень образования персонала;

3) природные: условия климата, наличие полезных ископаемых;

4) финансовые: залоговая стоимость предприятия, доходность, состояние оборотных средств;

5) правовые: правовая база предпринимательской деятельности, законодательная поддержка инвестиций, налоговое законодательство.

При анализе факторов окружения проекта необходимо учитывать взаимосвязанность факторов внешней среды, таких как уровень силы (корреляция), с которой изменение одного фактора воздействует на другие факторы, сложность, динамичность и неопределенность.

В современном мире степень внешней привлекательности и развитости страны определяется международными рейтингами. Регулярному изучению со стороны аналитиков указанных институтов подвергается и Кыргызстан. Делается это для того, чтобы выявить закономерности в динамике и улучшении имиджа и внешней привлекательности страны. Эти выводы позволяют оценить, успешна ли Кыргызская Республика в достижении устойчивости в долгосрочной и краткосрочной перспективе в различных областях, и определить, насколько взаимосвязаны проводимая правительством Кыргызской Республики политика и динамика прогресса, отображаемая международными рейтингами.

Наибольшую ценность для исследования предоставляют следующие индексы и рейтинги:

1) Ведение бизнеса (Doing Business) - позволяет изучить бизнес-среду в стране и выявить прогрессивные (способствующие развитию) и сдерживающие факторы.

2) Глобальный индекс инноваций. Данный индекс полезен тем, что в контексте стартап-проектов, мы должны рассмотреть степень инновационной активности и проработанности в стране.

3) Индекс глобальной конкурентоспособности. Данный индекс имеет некоторую связь с рейтингом ведения бизнеса, поскольку также отражает и анализирует различные факторы ведения бизнеса.

В таблицах 1 - 4 представлены детальные данные по Кыргызстану по указанным выше рейтингам за последний год. 


\begin{tabular}{|c|c|c|c|c|c|c|}
\hline Темы & $\begin{array}{l}\text { DB } 2019 \\
\text { Рейтинг }\end{array}$ & $\begin{array}{l}\text { DB } 2018 \\
\text { Рейтинг }\end{array}$ & $\begin{array}{l}\text { Изменение } \\
\text { в рейтинге }\end{array}$ & $\begin{array}{c}\text { DB } 2019 \\
\text { ПР* (\% } \\
\text { пунктов) }\end{array}$ & $\begin{array}{c}\text { DВ } 2018 \\
\text { ПР (\% } \\
\text { Пунктов) }\end{array}$ & $\begin{array}{l}\text { Изменение в } \\
\text { показателе } \\
\text { ПР } \\
\text { (\% пункта) } \\
\end{array}$ \\
\hline Глобально & 70 & 75 & $\uparrow 5$ & 68,33 & 65,76 & $\uparrow 2,75$ \\
\hline Создание предприятий & 35 & 30 & $\downarrow 5$ & 92,97 & 92,94 & $\uparrow 0,03$ \\
\hline $\begin{array}{l}\text { Получение разрешений } \\
\text { на строительство }\end{array}$ & 29 & 32 & $\uparrow 3$ & 77,10 & 76,85 & $\uparrow 0,25$ \\
\hline $\begin{array}{l}\text { Подключение к системе } \\
\text { электроснабжения }\end{array}$ & 164 & 163 & $\downarrow 1$ & 46,01 & 45,71 & $\uparrow 0,30$ \\
\hline $\begin{array}{l}\text { Регистрация } \\
\text { собственности }\end{array}$ & 8 & 8 & - & 90,27 & 90,23 & $\uparrow 0,04$ \\
\hline Получение кредитов & 32 & 32 & - & 75,00 & 75,00 & - \\
\hline $\begin{array}{l}\text { Защцита миноритарных } \\
\text { инвесторов }\end{array}$ & 38 & 42 & $\uparrow 4$ & 66,67 & 61,67 & $\uparrow 5,00$ \\
\hline Налогообложение & 150 & 148 & $\downarrow 2$ & 56,55 & 56,55 & - \\
\hline Международная торговля & 70 & 79 & $\uparrow 9$ & 80,74 & 73,34 & $\uparrow 7,40$ \\
\hline $\begin{array}{l}\text { Обеспечение исполнения } \\
\text { контрактов }\end{array}$ & 131 & 141 & $\uparrow 10$ & 50,42 & 47,64 & $\downarrow 2,78$ \\
\hline $\begin{array}{l}\text { Разрешение } \\
\text { неплатежеспособности }\end{array}$ & 82 & 130 & $\uparrow 48$ & 47,62 & 37,67 & $\uparrow 9,95$ \\
\hline \multicolumn{7}{|c|}{$\begin{array}{l}\text { * ПР - данный показатель позволяет проследить удаленность каждой страны от «передового рубежа» - то есть от } \\
\text { наилучшего результата по каждому из показателей «Ведения бизнеса» - по всем странам, входящим в исследование «Ведение } \\
\text { бизнеса» с самого начала включения каждого из индикаторов в исследование «Ведение бизнеса». Удаленность каждой странь } \\
\text { от «передового рубежа» измеряется по шкале от } 0 \text { до 100, где } 0 \text { представляет наихудиий результат, а } 100 \text { представляет } \\
\text { «предовой рубеж». }\end{array}$} \\
\hline
\end{tabular}

Таблица 1. Рейтинг Ведения Бизнеса (Doing Business), 2018-2019г2. Источник: The World Bank, Doing Business - Measuring Business Regulations.

Исходя из данных таблицы 1, позиции Кыргызстана по «Ведению бизнеса» повысились на 5 пунктов по сравнению с данными 2018 года. Среди стран СНГ рейтинг выглядит следующим образом: Грузия занимает 6 место, за ней следуют Литва (14), Эстония (16), Латвия (19), Азербайджан (25), Казахстан (28), Россия (31), Беларусь (37), Армения (38), Молдова (44), Украина (71), Узбекистан (76) и Таджикистан (128). Азербайджан занимает второе место в списке государств мира с наибольшим количеством улучшений за последний год.

Согласно данным доклада Всемирного банка в Кыргызстане в первую очередь должны быть улучшены показатели по следующим направлениям: подключение к системе электроснабжения, налогообложение, обеспечение исполнения контрактов и разрешение платежеспособности.

Далее приведен Глобальный индекс инноваций (The Global Innovation Index) - глобальное исследование и сопровождающий его рейтинг стран мира по показателю развития инноваций по версии международной бизнес-школы INSEAD. Исследование проводится в 126 странах мира, рейтинг основывается на 82 различных показателях. Авторы исследования считают, что успешность экономики связана как с наличием инновационного потенциала, так и условий для его воплощения.

Глобальный Индекс Инноваций рассчитывается как взвешенная сумма оценок двух групп показателей:

1) располагаемые ресурсы и условия для проведения инноваций (Innovation Input): институты; человеческий капитал и исследования; инфрастурктура; развитие внутреннего рынка; развитие бизнеса.

2) достигнутые практические результаты осуществления инноваций (Innovation Output): paзвитие технологий и экономики знаний; результаты творческой деятельности».

3) Далее в таблицах 2 и 3 приведен рейтинг Кыргызстана за последние годы, а также оценка отдельных индикаторов рейтинга.

\begin{tabular}{|l|c|c|c|c|c|c|}
\hline \multicolumn{1}{|c|}{ Год } & $\mathbf{2 0 1 3}$ & $\mathbf{2 0 1 4}$ & $\mathbf{2 0 1 5}$ & $\mathbf{2 0 1 6}$ & $\mathbf{2 0 1 7}$ & $\mathbf{2 0 1 8}$ \\
\hline Место в рейтинге & 117 & 112 (из 143) & 109 (из 141) & 103 (из 128) & 95 (из 127) & 94 (из 126) \\
\hline Баллы & 27,0 & 27,8 & 28,0 & 26,6 & 28,01 & 27,56 \\
\hline
\end{tabular}

Таблица 2. Позициия Кыргызстана В Глобальном Индексе Инноваичий (ГИИ) Источник: WIPO, Global Innovation Index, 2013-2018. 


\begin{tabular}{|c|c|c|}
\hline Показатель & $\begin{array}{c}\text { Баллы } \\
\text { (от } 0 \text { до 100) } \\
\end{array}$ & $\begin{array}{c}\text { Место в рейтинге } \\
\text { (из 126) }\end{array}$ \\
\hline Innovation Input Sub Index & 37,99 & 85 \\
\hline Innovation Output Sub Index & 17,4 & 101 \\
\hline Государственное управление & 50,7 & 98 \\
\hline Политическая среда & 31,7 & 114 \\
\hline Политическая стабильность и безопасность & 49,5 & 96 \\
\hline Эффективность правительства & 22,9 & 118 \\
\hline Нормативно-правовая база & 55,1 & 98 \\
\hline Верховенство закона & 13,9 & 119 \\
\hline Бизнес среда & 65,3 & 78 \\
\hline Человеческие ресурсы & 29,9 & 68 \\
\hline Образование & 58,7 & 23 \\
\hline Инфраструктура & 36,0 & 94 \\
\hline Информационно-коммуникационнье технологии & 44,1 & 90 \\
\hline Доступ к ИКТ & 45,4 & 93 \\
\hline Использование ИКТ & 29,1 & 96 \\
\hline Логистическая производительность & 4,3 & 122 \\
\hline Сложность рынка & 46,1 & 67 \\
\hline Получение кредита & 50,5 & 28 \\
\hline Инвестиции & 41,4 & 59 \\
\hline Сложность бизнеса & 27,3 & 79 \\
\hline Инновационные связи & 14,9 & 120 \\
\hline $\begin{array}{l}\text { Сотрудничество в области исследований между } \\
\text { университетами и отраслями }\end{array}$ & 25,5 & 117 \\
\hline Уровень кластерного развития & 30,0 & 116 \\
\hline Поглощение знаний & 30,6 & 65 \\
\hline Технологические и исследовательские результать & 19,5 & 82 \\
\hline Создание знаний & 10,5 & 67 \\
\hline Влияние знаний & 27,4 & 95 \\
\hline Сертификация ISO 9001 & 0,2 & 124 \\
\hline Высокотехнологичные производства & 0,0 & 94 \\
\hline Распространение знаний & 20,5 & 61 \\
\hline Результаты разработки новых продуктов & 14,8 & 115 \\
\hline Разработка новых бизнес-моделей & 39,0 & 118 \\
\hline Разработка новых товаров и услуг & 10,9 & 89 \\
\hline Интернет-активность & 2,2 & 87 \\
\hline Общие домены верхнего уровня & 0,1 & 116 \\
\hline
\end{tabular}

Таблица 3. Оценка Основных Индикаторов Кыргызстана В ГИИ, 2018 Источник:WIPO, Global Innovation Index 2018.

По мнению экспертов, наиболее слабыми показателями в Кыргызстане оказались:

- инновационные связи (14,9 балла, 120 место в рейтинге из 126);

- логистическая производительность (4,3 балла, 122 место в рейтинге);

Наиболее высокие показатели Кыргызстан получил за простоту открытия бизнеса и кредитования (32 и 29 места соответственно); количество компаний, предоставляющих услуги бизнес-тренингов (8 место в рейтинге).

В 2017-2018 в рейтинге глобальной конкурентоспособности Кыргызстан занял 102 место из 137 стран с 3,9 баллами из максимума в 7 баллов, поднявшись на 9 строчек в рейтинге (в 2016 году Кыргызстан занимал 111 место с 3,75 балла). Хотя это наихудший результат среди всех стран СНГ, вошедших в рейтинг.

Основой рейтинга служит «Глобальный индекс конкурентоспособности», учитывающий 113 индикаторов, объединенных в 12 «опорных» категорий, данные по которым приведены в таблице 4. 


\begin{tabular}{|l|c|c|}
\hline \multicolumn{1}{|c|}{ Показатель } & $\begin{array}{c}\text { Баллы } \\
\text { (от 1 до 7) }\end{array}$ & $\begin{array}{c}\text { Место в рейтинге } \\
\text { (из 137) }\end{array}$ \\
\hline Инновации & 2,7 & 126 \\
\hline Размер (объем) рынка & 2,8 & 117 \\
\hline Инфраструктура & 3,0 & 102 \\
\hline Технологическая готовность & 3,2 & 127 \\
\hline Сложность бизнеса & 3,3 & 100 \\
\hline Государственное управление & 3,3 & 86 \\
\hline Эффективность рынка труда & 3,7 & 89 \\
\hline Развитие финансового рынка & 3,8 & 81 \\
\hline Высшее и дополнительное образование & 4,0 & 88 \\
\hline Эффективность товарного рынка & 4,2 & 75 \\
\hline Макроэкономическая среда & 4,4 & \\
\hline Здоровье и начальное образование & 5,7 & \\
\hline
\end{tabular}

Таблица 4. Показатели Рейтинга Глобальной Конкурентоспособности, Кыргызстан 2018 Год Источник: World Economic Forum, The Global Competitiveness Report, 2018

Показатели в таблице отсортированы от худшего результата к лучшему. В рамках данного исследования самые слабые показатели пришлись на развитие инноваций (126 место), размер рынка (117 место), сложность бизнеса (127 место) и эффективность рынка труда (113 место).

В рамках всемирного экономического форума был проведен опрос предпринимателей для выявления наиболее проблемных факторов для ведения бизнеса. Респондентам было предложено выбрать пять сдерживающих факторов развития бизнес-среды в их стране и ранжировать по позиция от 1 (самый проблемный) до 5. В результате для Кыргызстана были получены следующие данные (см. диаграмму 1.).

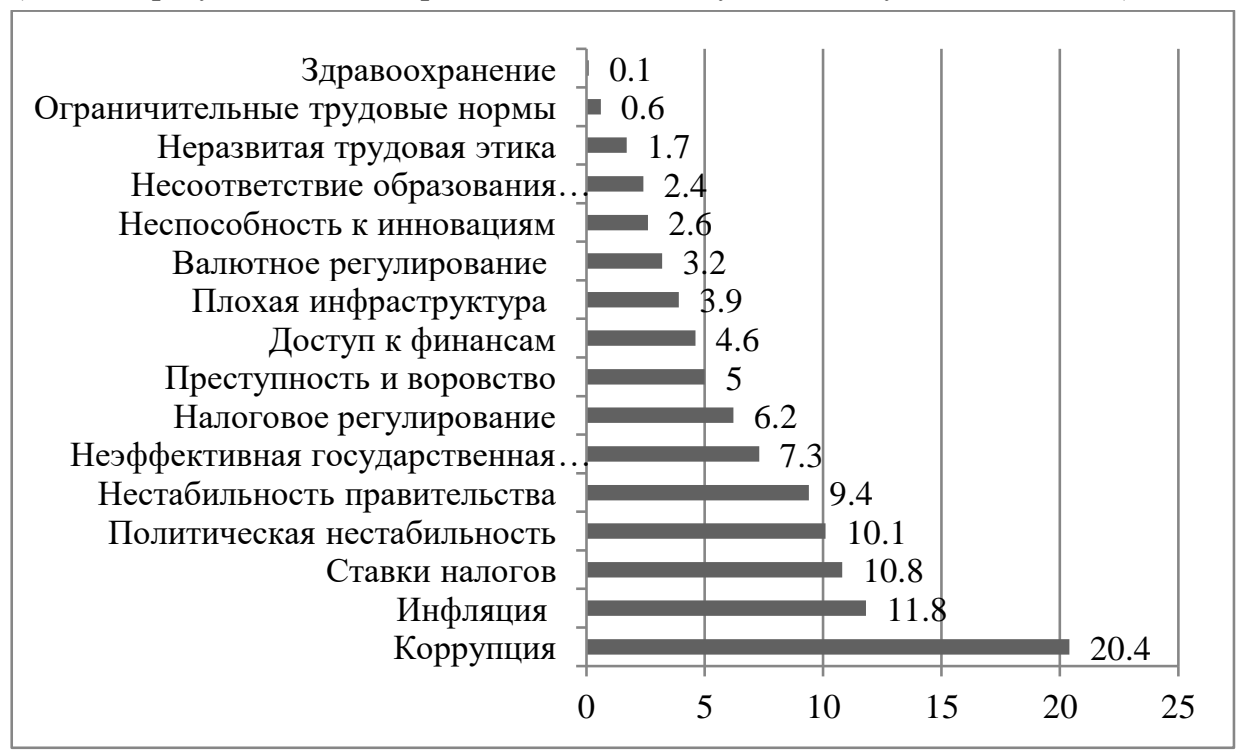

Рисунок 3. Сдерживающчие Факторы Развития Бизнес-Среды В Кыргызстане

Подводя итог можно выделить следующие наиболее весомые факторы, воздействующие на среду разработки и реализации стартап проектов:

- система государственной поддержки предпринимательства;

- $\quad$ развитие инфраструктуры (доступ к электричеству, логистические пути);

- уровень развития ИКТ-сферы;

- у уровень развития образования и связи университетов с бизнес-структурой;

- человеческий потенциал;

- уровень развития предпринимательской культуры;

- доступ к финансам (отдельно: уровень развития венчурного финансирования);

Несмотря на возрастающую сложность управления проектом и неопределенность окружающей среды, риск выхода на международный рынок может быть оправдан по разным причинам. Все причины формирования и развития международного бизнеса целесообразно разделить их на две группы (Пэн, Платонова,2015):

1) причины, определяющие необходимость (неизбежность) возникновения такой категории бизнеса; 
2) причины, обусловливающие возможность осуществления международного бизнеса.

Говоря о выходе стартапа на международный рынок необходимо понимать об естественных ограничениях, таких как:

- различия социально-экономических и правовых систем;

- вмешательств государств в экономику и политика протекционизма;

- колебания обменных курсов;

- традиционные конфликты;

- идеологические разногласия;

- религиозные ограничения.

Проблемы, с которыми сталкивается любой из проектов при выходе на международный рынок можно разделить на 2 категории: объективно существующие (не зависящие ни от проекта, ни от его команды) и субъективно существующие (проблемы, которые возникают в результате действий или решений руководителей проекта).

Опустив приведенные выше примеры факторов, ограничивающих возможности выхода на рынки зарубежных стран, остановимся на наиболее весомых аспектах, требующих детального рассмотрения.

1. Особенности законодательства. Правительство страны может расширить сферу правового влияния, потребовав, чтобы компании, имеющие штаб-квартиры в данной стране, соблюдали ее национальное законодательство во всех других странах, где они осуществляют операции. Данный принцип экстерриториальности в большой степени осложняет бизнес.

2. Логистика. В случае, если стартап работает с реальным физическим продуктом, - одной из самых больших проблем становится разработка системы логистики. Клиент должен получить заказ максимально быстро, с минимальными издержками времени.

3. Культурный фактор. В каждой стране существуют свои обычаи, свои правила и запреты. Прежде чем запускать стартап на территории другой страны, компании следует выяснить, как зарубежный потребитель воспринимает те или иные товары и как он пользуется ими. Отличаются страны друг от друга и принятыми в них нормами поведения в деловом мире. Поэтому перед проведением переговоров специалисты компании должны проконсультироваться в отношении этих особенностей.

В случае, когда мы говорим о стартапе, быстрый рост и, соответственно, увеличение базы клиентов и продаж - обязательное условие. Таким образом, выход на международный рынок - событие необратимое. По сути, стартапер проходит тот же путь, что и при разработке проекта на внутреннем рынке, но вынужден принимать решения в условиях большей неопределенности в силу ограниченности информации (не всегда есть возможность посетить страну лично перед запуском проекта). Если стартап предлагает виртуальный продукт, основными препятствиями для выхода на зарубежный рынок станут языковой и социальнокультурный факторы. Чтобы достигнуть международного масштаба проекту необходима операционная поддержка, такая как: комплексная информационно-технологическая инфраструктура, советники по налогам, нормативам и законодательству, а также команда, которая будет обеспечивать продажи, клиентов и техподдержку $24 / 7$.

Важно привлекать местных специалистов. Их опыт и знание локальных особенностей позволит оценить актуальность продукта или адаптировать его под потребности потребителя.

Подводя итог анализа текущего состояния и условий развития стартап деятельности в Кыргызской Республике, можно с уверенностью констатировать, что стартап-экосистема в стране находится на начальной стадии своего развития. Это подтверждается отсутствием понятия «стартап» в законодательной базе. Из преимуществ можно отметить несколько сложившихся организаций, среди которых Парк Высоких Технологий и стартап-инкубатор Ideagrad.

Проводя оценку факторов, формирующих окружение стартап проекта, можно сделать заключение, что внутренние факторы имеет для стартапа намного больший вес, нежели внешние факторы. Исключением является лишь случай с политикой, построенной на принципах централизованной власти, где предприятие в первую очередь зависит от условий внешней среды.

Несмотря на благоприятные, в целом, условия для предпринимательства в Кыргызстане, в стране существует ряд проблем, без устранения которых развитие стартап-экосистемы невозможно. Рассмотрим все сдерживающие факторы и пути их решения в следующей главе.

Одно из крупнейших исследований стартап-деятельности в мире было проведено аналитическим агентством CB Insights, которое изучило самые популярные причины закрытия стартапов (см. диаграмму 2). Важно отметить, что к краху компании чаще всего приводили сразу несколько факторов одновременно, поэтому сумма всех показателей превышает $100 \%$.

Подобных исследований в Кыргызстане никогда не проводилось, поэтому для выявления проблем автором был проведен анализ факторов, влияющих на разработку и реализацию стартап проектов. Для 
анализа внешней среды были использованы данные Национального Статистического комитета, а также данные исследований различных международных консалтинговых компаний.

Остановимся на наиболее весомых выявленных проблемах стартап-экосистемы Кыргызстана.

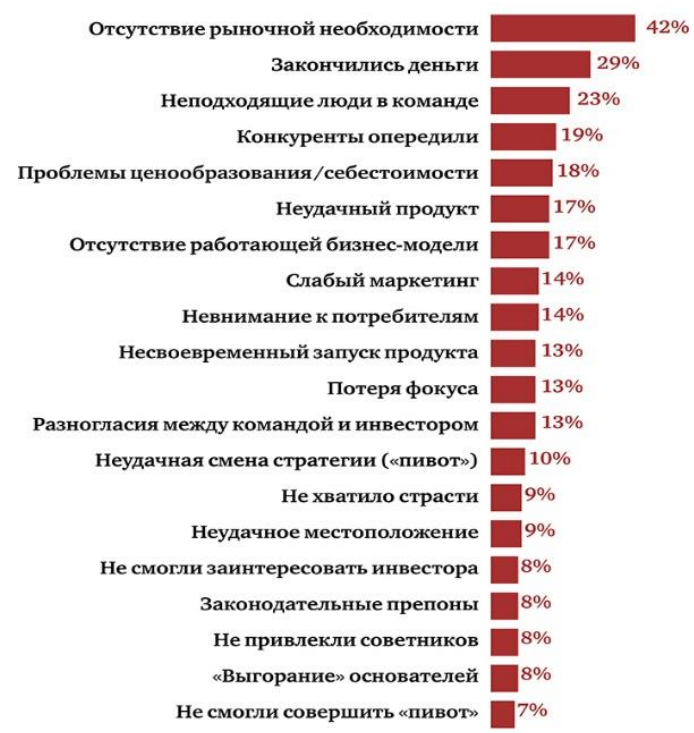

Рисунок 4. Топ 20 Причин Закрытия Стартапов Источник: The Top 20 Reasons Startups Fail CB Insights Report, Www.Cbinsights.Com

В Кыргызстане принят Закон о государственной поддержке предпринимательства, однако, требования этого закона не выполняются. Не принимаются государственные программы поддержки предпринимательства, а Государственный фонд поддержки малого и среднего бизнеса при Правительстве КР в результате реорганизации его в микрокредитную компанию потерял основную задачу - осуществлять финансово-инвестиционные и консультационные функции в сфере поддержки и развития частного предпринимательства.

Лишь единицы инвесторов Кыргызстана обладают полным набором всего, что необходимо для финансирования стартапов:

- достаточными финансовыми средствами;

- достаточной экспертизой для поддержки и помощи стартапам из разных индустрий;

- сетью знакомств и репутацией среди зарубежных инвесторов, чтобы иметь возможность привлекать их в со-инвесторы, а они, в свою очередь, могли бы взять на себя дальнейший вывод компаний на свой рынок.

В Кыргызстане также нет полноценных венчурных фондов. В то же самое время нет достаточного количества стартапов, выросших до размера, необходимого для получения инвестиций более поздних раундов. В итоге мы попадаем в замкнутый круг: нет инвесторов потому, что нет стартапов, и нет стартапов потому, что нет инвесторов.

Практически все стратегии социально-экономического развития страны и регионов не учитывают трудовые ресурсы как основной фактор производства. В этих документах не указывается реальная потребность в трудовых ресурсах по численности и по структуре профессий. Это существенно ограничивает возможности государственного регулирования рынка труда.

Экономика республики не создает достаточного количества рабочих мест, соответствующих растущим потребностям населения. Рынок труда в Кыргызстане является трудоизбыточным (Бийбосунова, Асанбекова, 2016). Сегодня на одно вакантное место претендует в среднем по республике более 11 человек, сильно распространены неформальная и неполная занятость. В то же время, в стране имеет место структурный дефицит рабочей силы и рабочих мест. Не хватает специалистов высокой квалификации из числа инженерно-технического состава, рабочих технических специальностей.

Инфраструктура рынка труда функционирует недостаточно эффективно и не может в полной мере решать задачу сокращения времени для работодателей и работников при взаимном поиске. Существующие частные агентства занятости и информационно-консультационные центры нуждаются в развитии институционально, функционально и технически. 


\section{3 Заключение}

Проблемы, мешающие росту стартап деятельности, лежат в различных сферах: в законодательстве и его исполнении, отсутствии нормативно-правовой основы для развития стартап проектов, неэффективной институциональной структуре привлечения и продвижения инвестиций, в высоком уровне коррупции в регулятивных органах и незащищённости прав собственности частных предпринимателей. Это, в конечном итоге, ведёт к потере устойчивости экономической системы. Указанные причины сведены в единую таблицу SWOT-анализа.

\begin{tabular}{|c|c|}
\hline $\begin{array}{l}\text { Сильные стороны: потенциально позитивные } \\
\text { внутренние факторы }\end{array}$ & $\begin{array}{l}\text { Слабые стороны: потенциально негативные } \\
\text { внутренние факторы }\end{array}$ \\
\hline $\begin{array}{l}\text { 1. Либеральная инвестиционная законодательная база } \\
\text { 2. Внедрена риск-ориентированная система при } \\
\text { проведении налоговых и иных проверок, введены } \\
\text { проверочные листы } \\
\text { 3. Сокращена и систематизирована лицензионно- } \\
\text { разрешительная система } \\
\text { 4. Безвизовый режим для развитых стран и внедряется } \\
\text { электронная виза } \\
\text { 5. Высокий потенциал развития IT индустрии в связи с } \\
\text { принятием Закона о Парке высоких технологий } \\
\text { 6. Внедрение механизмов и критериев режима } \\
\text { стабилизации в инвестиционном законодательстве } \\
\text { 7. Реализация на правительственном уровне политики } \\
\text { по снижению теневой экономики } \\
\text { 8. Использование механизмов и и потенциал } \\
\text { государственно-частного партнерства для улучшения } \\
\text { состояния инфраструктуры } \\
\text { 9. Создание Агентства по продвижению инвестиций } \\
\text { 10. Разнообразие природно-климатических и историко- } \\
\text { культурных ресурсов страны позволяет формировать } \\
\text { огромное количество вариантов туристического } \\
\text { продукта }\end{array}$ & 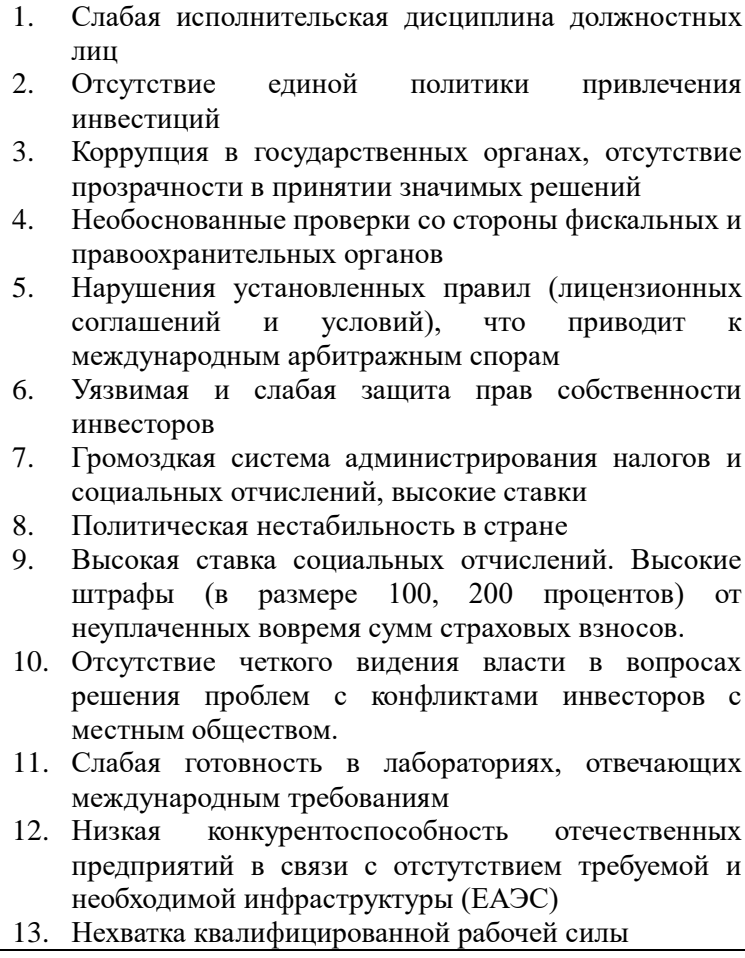 \\
\hline $\begin{array}{l}\text { Возможности: потенциально позитивные } \\
\text { внешние факторы }\end{array}$ & $\begin{array}{l}\text { Угрозы: потенциально негативные внешние } \\
\text { факторы }\end{array}$ \\
\hline 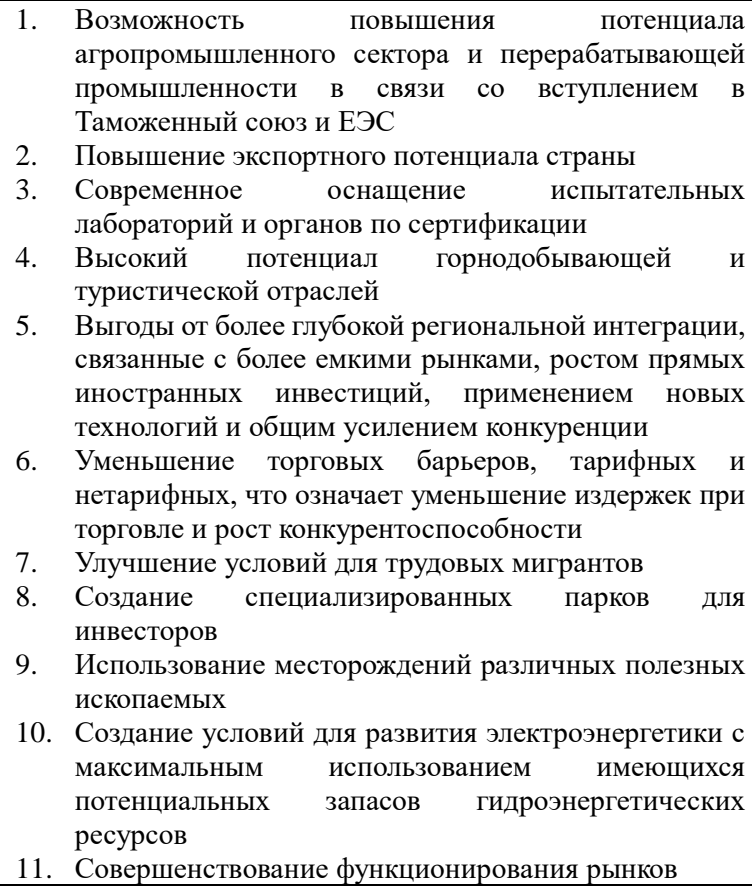 & 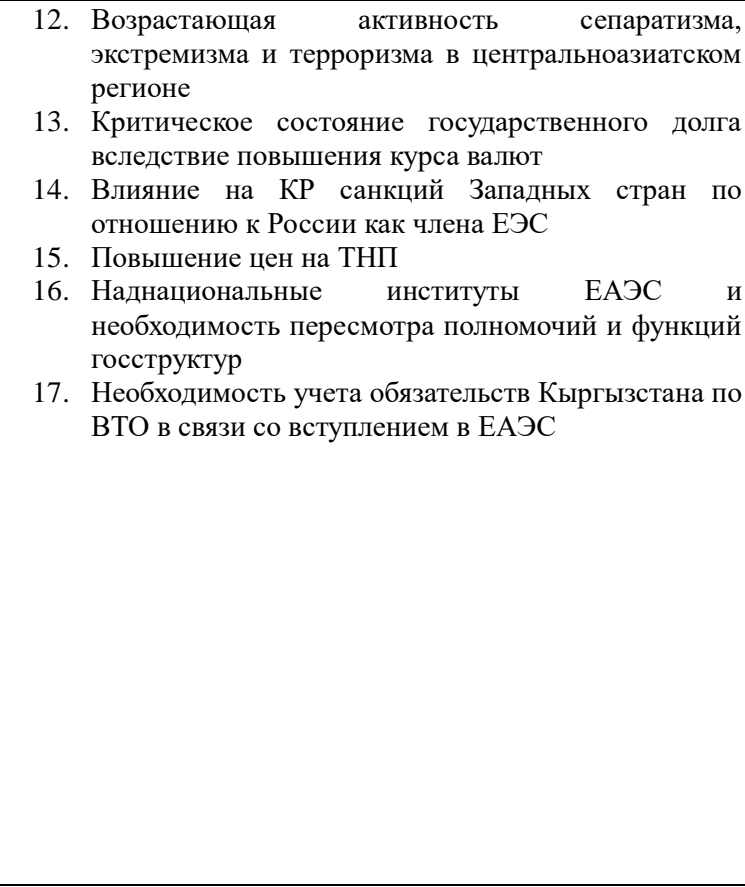 \\
\hline
\end{tabular}

Таблица 5. SWOT Анализ Стартап-Экосистемы Кыргызской Республики Источник: Халилова, 2016 
Существует ряд внутренних проблем, которые связаны непосредственно со стартапами и которые также нуждаются в устранении:

Проблема низкой мотивации авторов бизнес-идей на их практическую реализацию, что обусловлено отсутствием простых инструментов, характеризующих технологию развития стартапа и возможность его успешной реализации.

Проблема качества проектов возникает как следствие неполноты компетенций авторов бизнес-идей и отсутствия возможности улучшения проекта с помощью взаимодействия с другими участниками системы. Каждый стартап уникален и поэтому общих инструментов работы с проектами недостаточно, необходим индивидуальный подход к модернизации каждого стартапа.

Проблема коммерциализации результатов производственных проектов заключается в отсутствии видения бизнес-составляющей стартапа. Как правило, основатели развивают технологию и продукт, но не понимают, как его вывести на рынок и заработать на нём.

Несмотря на все трудности и препятствия во внешней среде, основной причиной закрытия стартапа в первый год жизни является несоответствие продукта рынку. Это связано как с недостаточным исследованием рынка, конкурентов, потребителя, так и недостаточной фокусировкой на продукте. К сожалению, на данный момент в Кыргызстане сектор исследований и разработки (research and development) развит еще очень слабо. У начинающих предпринимателей нет необходимых опыта и знаний, а понятия «исследование рынка» и «разработка продукта» (или «product development») не культивированы в предпринимательской среде.

Таким образом, можно отметить, что потенциал команды имеет намного большую роль в успехе стартапа, нежели окружающая его среда. Следовательно, на государственном уровне необходимо усовершенствовать не только правовую среду, но и развивать соответствующие институты, инфраструктуру и предпринимательскую среду.

\section{Литература}

- Бийбосунова С.К., Асанбекова Н.О. Оценка занятости и безработицы на современном рынке труда Кыргызской Республики, Российское предпринимательство, 2016, Том 17№1 с.125-132

- $\quad$ Заренков В.А. Управление проектами - СПб, 2010

- Курпаяниди К.И. «DOING BUSINESS 2017: EQUAL OPPORTUNITIES FOR ALL» как инструмент оценки эффективности регулирования предпринимательской среды в Узбекистане, Экономика $u$ финансы (Узбекистан), 2017 №4, с. 31-44

- Курпаяниди К.И. Некоторые вопросы оценки качества институциональной и предпринимательской среды в Узбекистане, Экономический анализ: теория и практика, 2015, № 14(413), с. 56-64.

- Моргунов В.И., Моргунов С.В. Международный маркетинг - М.: Дашков и К, 2017.

- Пэн С., Платонова Е.Д. Характеристика международного бизнеса и институтов его развития в современной экономике, Экономика и сочиим, 2015 № 2-3(15) с.1618-1628

- Халилова М.В. Обеспечение инвестиционной безопасности Кыргызстана как элемент экономического развития, Вестник КРСУ. 2016. Том 16. № 2, с. 91-95.

- The Top 20 Reasons Startups Fail CB Insights Report, 2016 // www.cbinsights.com

- The World Bank, Doing business - Measuring Business Regulations //www.doingbusiness.org

- WIPO, Global Innovation Index 2018. // www.wipo.int/publications/

- World Economic Forum, The Global Competitiveness Report, 2018 //www.weforum.org/reports/the-globalcompetitveness-report-2018 


\title{
Умная Специализация Как Возможность Роста Инновационной Активности Регионов Кыргызской Республики
}

\section{Clever Specialization as an Opportunity to Increase Innovation Activity of the Regions of the Kyrgyz Republic}

\author{
Ph.D. Candidate Diliara Suleeva (Kyrgyz-Russian Slavic University, Kyrgyzstan)
}

\begin{abstract}
In recent years, great attention has been paid to the problems of developing innovation activities in the Kyrgyz Republic. They became the most discussed in the country, and modernization and industrialization are the main directions of the current state policy of Kyrgyzstan. The objective need for the implementation of scientific and other innovations in the country, taking into account regional particularities, determines the relevance of the research chosen. The article considers the possibility of implementing an effective regional innovation system based on the so-called "smart" specialization in the Kyrgyz Republic. The economy of the republic is extremely important constantly developing innovation process, and it should not end only on the acquisition of expensive innovative equipment. It is necessary to develop the whole system with the obligatory involvement of the regions. This is the only way to rely on the successful development of innovations.
\end{abstract}

The paper analyzes the main directions of innovation development at the regional level. The problems of promoting the innovation ecosystem in Kyrgyzstan in general, and innovation processes in agriculture, in particular, have been identified.

Ни для кого не секрет, что Кыргызстан находится в состоянии поиска своей модели экономического роста: нам нужны хорошие накопления человеческого капитала, более благоприятные условия для инвестирования и предпринимательской деятельности, ну, и конечно же, разработка и внедрение новых технологий. Вполне очевидно, что в условиях постоянного дефицита бюджета необходимо более тщательно отслеживать расходы, включая их концентрацию и эффективность.

При этом, если социальной политике акцентироваться на выполнении своей распределительной функции (в первую очередь, это проблема сохранения социальной стабильности в регионах); то инновационная политика в перспективе должна стать более дифференцированной в соответствии с потенциалом и эффективностью создания и распространения новых знаний и технологий в регионах Республики.

В своей статье нам бы хотелось выявить приоритеты и предложить мероприятия по формированию эффективной инновационной политики с учетом так называемой умной специализации.

Мировой опыт показывает, что одним из самых эффективных механизмов распространения новых технологий является формирование территориальных инновационных систем, или экосистем. При этом, безусловно, региональная инновационная политика должна быть направлена на выявление и поддержку территорий, которые обладают большим потенциалом.

Уже не первый год зарубежные исследователи ведут дискуссию о том, на каком пространственном уровне следует изучать и поддерживать инновационные процессы: одни, разрабатывая сложные модели придерживаются позиции (Pyka, Foster, 2015), что именно региональные факторы инновационной активности более значимы по сравнению с внутрифирменными; другие - делают ставку на национальный уровень в целом (Feldman,1999).

Изучение потенциала регионов основывается на теории «перетока знаний» и неявных знаний. Бесспорно, особенность знаний заключается в их неделимости, в возможности использовать неограниченное количество раз и ограниченной возможности исключения других агентов из процессов пользования ими. Вот почему активная инновационная деятельность одного агента порождает положительные внешние эффекты для других. Этот процесс «перетока знаний», как правило, локализуется в рамках отдельных регионов: с одной стороны, экономятся средства от концентрации, с другой усиливается эффект от разнообразия.

Весьма поучительной можно считать инновационную политику многих европейских стран, основанную на формировании региональной инновационной стратегии. Разработка такой стратегии предполагает делегирование дифференцированных полномочий регионам, т.е. определяются приоритетные направления перспективного развития каждого региона с учетом его сильных сторон и особенностей.

Так, в рамках умной специализации разработаны и активно используются региональные инновационные стратегии в Испании, Италии Великобритании и Германии.

Залогом успеха данного мероприятия послужила поэтапность и оперативный мониторинг. 
На наш взгляд, в Кыргызстане также можно с успехом использовать умную специализацию регионов. Только крайне важно для начала построить экосистему инноваций, т.е. такую специфическую среду, в которой бы себя комфортно чувствовали все участники инновационного процесса.

Нам бы хотелось остановиться на рассмотрении некоторых направлений региональной инновационной политики (собственно их и можно считать базисом инновационной экосистемы в Кыргызстане).

В первую очередь, по нашему мнению, это эффективность человеческого капитала с позиции создания новых знаний. Ни для кого не секрет, что в нашей республике достаточно высокий процент дипломированных работников, так по данным статистики, в целом по республике около 20 \% работающего населения имеет высшее образование, естественно, в крупных городах этот показатель еще выше (в среднем каждый третий житель), и в столице - более 36,1 \%. По количеству ВУЗов на число жителей наша страна тоже находится не на последнем месте! Но вопрос в другом: насколько хороших и реально востребованных специалистов мы выпускаем. По данным Главного управления занятости, ежегодно более $34 \%$ выпускников вузов не имеют возможности трудоустроиться по причине недостаточного опыта и не востребованности на рынке труда полученной специальности. Если учесть, что из ежегодного выпуска в 40000 человек, большая половина из них, это экономисты и юристы (а в последние два-три года еще и медики), то картина получается весьма удручающая.

Да, и мы сами, работники системы образования, все чаще задаемся вопросом: а многое ли из того, чему мы учим пригодится нашим студентам? Смогут ли они себя реализовать с таким багажом знаний? Будет ли у них возможность принимать полезные креативные решения?

К сожалению, у нас еще не закончился процесс становления и коммерциализации Вузов, причем как «отдельно двигающегося субъекта кыргызской экономики» - у вуза своя политика, у предпринимателей своя, государство и наука вообще смотрят как будто со стороны. Никто не против предпринимательской самостоятельности вузов, но нынешняя система подготовки кадров, по нашему мнению, не может положительно сказываться на инновационном развитии республики. В перспективе именно вузы должны стать ядром региональных инновационных экосистем, которые будут создавать предпринимательскую среду, по сути выполняя функцию созидателя новых знаний при обязательном тесном взаимодействии с бизнесом, местным сообществом и государством. Университеты будут выполнять эффективные фундаментальные и прикладные исследования, которые станут источником новых идей, проектов и малых инновационных предприятий. Поэтому вузам нужно стараться как можно больше сотрудничать с потенциальными креативными работодателями. С одной стороны, будет сокращен процент безработных выпускников, с другой - благодаря такому тесному сотрудничеству, они не будут проходить долгий период адаптации, а бизнес получит именно нужных и востребованных специалистов. По сути, это элементы хорошо забытого старого советского подхода планомерного распределения выпускников и отход от стереотипа - если я получил диплом о высшем образовании, то должен жить исключительно в столице. Почему нельзя заинтересовывать выпускников интересными предложениями по развитию регионов. Можно и нужно. Только важно отходить от принятого шаблона. В идеале, создание нескольких крупных инновационных предприятий и открытие во взаимосвязи с ними вузов, где будут готовить специалистов именно для этих предприятий.

Переходим к следующему направлению региональной инновационной политики - поддержка предприятий инноваторов. Следует отметить, что это направление находится в очень тесной взаимосвязи с вышеизложенной проблемой повышения качества человеческого капитала. Организация и проведение различных конкурсов инновационных проектов и их дальнейшее финансирование, начиная со студенческой скамьи, помогает молодежи быть более уверенными и убедительными в высказывании своих идей. Будучи преподавателем инновационного менеджмента мне не раз приходилось наблюдать за поведением студентов во время защиты их инновационных проектов: какой мощный поток энергии! Приятно вдвойне, когда через несколько лет встречаешь своего выпускника, а он с блеском в глазах начинает рассказывать об успешной реализации своего бизнес-проекта, благодаря за то, что научила не только основам бизнес-проектирования, но и помогла уверовать в состоятельность идеи.

Деловая активность малых инновационных предприятий, возможно, очень даже интересный ход для развития кыргызской экономики. Приятно видеть, как ценят за рубежом вещи, сшитые у нас, как быстро раскупается черешня, курага, бадан, а наше мясо... Можно продолжать этот список до бесконечности, но основной проблемой в продвижении продуктов малого бизнеса в республике - остается ее конкурентоспособность. В своих работах мы не раз затрагивали вопросы развития инновационных направлений бизнеса в Кыргызстане (Сулеева, 2013). В перспективе открывается хорошая платформа для инновационной активности именно малых инновационных предприятий, поскольку они могут быть более мобильными и чувствительными к рыночным колебаниям, что для инновационных продуктов крайне важно - принял рынок продукт, ты успешен; нет - долго придется расплачиваться за маркетинговые просчеты. 
Следующее направление - это максимальная взаимосвязь государства и бизнеса. Вполне очевидно, что в инновационном процессе предпринимателям, особенно начинающим, крайне сложно добиться успеха без реальной поддержки и взаимодействия с государством. Причем, чем выше интенсивность такого взаимодействия, тем более активным становиться сам инновационный процесс, больше создается инновационных продуктов и технологий, а, соответственно, и государство развивается более быстрыми темпами.

Предпринимателям, особенно в регионах очень непросто чувствовать рынок, тем более спрос на инновационные продукты. Очевидно, что самостоятельно реализовывать инновационные проекты они не спешат. Особенно в сельском хозяйстве. Можно долго вспоминать как развито было мясо-молочное направление в республике или какая урожайность была у плодовых культур раньше...в советское время, но сейчас многие направления возродились и продолжают развиваться, а самое главное, над многим еще нужно и можно работать. "Инновационных прорывов" в этом направлении можно ждать прежде всего от тонкорунного производства (хорошо забытое старое направление), ведь на качественную кыргызскую шерсть спрос был всегда; есть он и сейчас.

Вполне очевидно, что недостаточно использовать новые технологии только для производства, необходимо налаживать эффективные связи и улучшать способы доставки, т.е. использовать логистические схемы. Важно уловить необходимую взаимосвязь: государство предоставляет не просто льготные кредиты, а именно создает условия для эффективных диффузных процессов. К примеру, пользуется спросом наше мясо за рубежом, но легально вывозить его достаточно сложно, потому что нет единой системы : фермер - стандартизированная бойня - покупатель. Нет между ними четкой согласованности. В итоге, бойни с новым инновационным оборудованием простаивают, а фермеры продолжают работать со своими прежними покупателями, обогащая теневой сектор экономики.

Тем не менее, в экономике Кыргызстана очень много направлений для эффективного развития инновационных процессов, поэтому крайне важно задействовать государственный механизм поддержки инновационных предприятий (Сулеева, 2015). Кыргызской экономике нужен мощный инновационный рывок и “умная” региональная специализация должна этому поспособствовать.

\section{Литература}

- Сулеева, 2013. “Перспективы венчурного финансирования в Кыргызстане», Вестник КРСУ, Том 13, 2, C.57.

- Сулеева, 2015. “Проблемы несовершенства инвестиционного процесса в Кыргызской Республике», Современнье тенденции развития науки и технологий, 9, С.123.

- $\quad$ Pyka, Foster, 2015. The Evolution of Economic and Innovation Systems. Business \& Economics.

- Feldman, 1999. The geography of innovations. Boston: Kluwer Academic Publishers. 


\title{
Обучение Предпринимательству Как Драйвер Устойчивого Развития: Опыт Сибирского Института Управления - Филиала Российской Академии Народного Хозяйства и Государственной Службы При Президенте Российской Федерации
}

\section{Teaching Entrepreneurship as Driver of Stable Development: Experience of Siberian Institute of Management (SIM) - Branch of the Russian Presidential Academy of National Economy and Public Administration (PANEPA)}

Asst. Prof. Dr. Tatyana Gurunyan (The Russian Presidential Academy of National Economy and Public Administration, Russia)

\begin{abstract}
Entrepreneurship is one of the sources of economic growth. For the purposes of stable development UNO considers it necessary to increase the number of people possessing entrepreneurship skills. In this connection, a concern is caused by an alarming tendency: entrepreneurship activity of young people in Russia is decreasing. The international project GUESSS shows that in Russia every second student is going to become an entrepreneur in five years after the graduation, but only about ten percent are ready to start their own business. Entrepreneurial competences are not sufficiently formed at university. For solving this issue an abstract-logical approach was used on the basis of system analysis of the formation of entrepreneurial competences in universities. The analysis was carried out basing on the data of international project GUESSS, and the results of research work in SIM-branch of RANEPA. The department of economy and finances of SIM introduces qualitatively new methods of teaching entrepreneurship to students. The analysis was carried out of the activity of students in the Investment club. Thus, it is proved that an entrepreneurial structure at university and project activity are the key factors of forming entrepreneurial competences of students. Also the agenda of stable development should be integrated into educational programs. The introduction of the best practices of teaching entrepreneurship in universities of EAEU countries will promote the business climate and become one of the drivers of stable development of regional integration.
\end{abstract}

\section{1 Введение}

Предпринимательство - один из источников экономического роста, и драйвер устойчивого развития. Ведь предпринимательство в современном мире представляет собой важный фактор разработки и коммерциализации инноваций, создания рабочих мест и формирования конкурентной среды. Поэтому в Целях устойчивого развития ООН установлена необходимость развития микро, малых и средних предприятий, увеличения числа людей, обладающих навыками для занятий предпринимательством $(\mathrm{OOH}$, 2019). Среди ключевых направлений Национального проекта РФ «Малый бизнес и поддержка индивидуальной предпринимательской инициативы» рассматривается улучшение условий ведения предпринимательской деятельности, расширение доступа субъектов малого и среднего предпринимательства (далее - МСП) к финансовым ресурсам, акселерация субъектов МСП, популяризация предпринимательства (Правительство России, 2019).

В связи с этим тревожной тенденцией выступает снижение предпринимательской активности среди молодежи в России и других странах ЕАЭС, стремление строить карьеру, прежде всего в крупных корпорациях, на государственной службе. Во многом это связано с институциональными проблемами национальных экономик стран ЕАЭС. Согласно отчету Doing Business 2019, к указанным проблемам относятся высокие административные барьеры, сложности в осуществлении международных операций и защиты прав инвесторов (Всемирный банк, 2019). Исследовательский проект Global University Entrepreneurial Spirit Students' Survey показывает, что в России каждый второй студент собирается стать предпринимателем через пять лет после окончания вуза, но лишь около десяти процентов из них готовы стать начать собственный бизнес (GUESSS, 2018). Предпринимательские компетенции недостаточно формируются в российских вузах: «К сожалению, российские вузы, за редким исключением, пока участвуют в обучении предпринимательству очень слабо, да и регулярного обмена опытом и лучшими практиками почти нет» (Чепуренко, 2017). Во всем мире университеты выполняют роль координатора предпринимательского поведения студентов. Участие в программах обучения предпринимательству 
положительно коррелирует с общей предпринимательской активностью и экономическим эффектом от создаваемых фирм (Martin, 2013). Исследование данных по студентам 28-ми стран мира показывает, что обучение предпринимательству в университете положительно связано с предпринимательскими намерениями студентов на статистически значимом уровне (Беляева и т.д., 2017).

Цель работы: определить направления совершенствования формирования предпринимательских компетенций студентов для улучшения бизнес-климата стран ЕАЭС и выполнения целей устойчивого развития. Методы исследования: использован абстрактно-логический подход на основе системного анализа формирования предпринимательских компетенций в вузах. Анализ проводится на основе данных международных проектов Global University Entrepreneurial Spirit Students' Survey, и результатов научноисследовательской работы, выполненной под руководством автора в СИУ-филиале РАНХиГС.

Рассмотрены применяемые подходы к обучению в сфере предпринимательства и инвестирования, и результаты исследований предпринимательских намерений студентов и общего бизнес-климата страны. Показано, что вузы пока не выполняют роль координаторов предпринимательского поведения студентов, и предпринимательские компетенции не формируются на должном уровне. Это ухудшает бизнес-климат страны, и противоречит целям устойчивого развития.

Факультет экономики и финансов СИУ-филиала РАНХиГС внедряет качественно новое обучение предпринимательству студентов, слушателей программ ДПО и партнеров. Предлагается система формирования предпринимательских компетенций студентов в рамках практикоорентированного подхода. В статье представлены лучшие практики обучения предпринимательству на факультете экономики и финансов СИУ-филиала РАНХиГС. К ним относится деятельность в рамках студенческого Инвестиционного клуба, как предпринимательской структуры вуза. Анализируются результаты участия студентов в проекте по разработке бизнес-планов предприятий реального сектора экономики в рамках межвузовского сотрудничества с поддержкой органов власти. Консультирование студентами предпринимателей по вопросам привлечения финансирования, получения государственной и муниципальной поддержки, венчурных инвестиций формирует компетенции студентов в сфере привлечения финансовых средств.

Обосновывается, что деятельность студентов в организации и проведении бизнес-форумов и венчурных ярмарок региона, проведение кейс-чемпионатов по разработке бизнес-моделей конкретных предприятий в рамках обучения по образовательным программам факультета формирует готовность студентов к «предпринимательским шагам» сразу после окончания вуза.

Модель обучения предпринимательству в СИУ-филиале РАНХиГС может рассматриваться в качестве примера эффективного взаимодействия вуза, бизнес-сообщества, органов государственной власти.

\section{2 Модель Обучения Предпринимательству в СИУ-Филиале Ранхигс}

Обучение предпринимательству в СИУ - филиале РАНХиГС реализуется прежде всего в рамках профиля бакалавриата «Инвестиционный анализ», направление подготовки «Экономика». Образовательная программа профиля направлена на подготовку высокопрофессиональных экономистов, владеющих инвестиционным анализом, необходимым для разработки и реализации инвестиционных проектов в условиях глобальной трансформации рынков и перехода к инновационной экономике. Программа отвечает важной политической и экономической цели - укреплению инвестиционного потенциала. Профессиональная деятельность выпускников профиля связана с многочисленными аспектами управления инвестициями. Студенты осваивают способы привлечения инвестиций, инвестиционное проектирование, методы оценки эффективности инвестиций в реальном и финансовом секторе экономики. Студенты учатся проводить экспертизу бизнес-планов инвестиционных проектов. У студентов формируются знания, умения, навыки для консультирования предпринимателей по вопросам привлечения финансирования, получения государственной и муниципальной поддержки, венчурных инвестиций. По окончании обучения студенты будут уметь играть на бирже, проводить консультирование по продуктам финансовых рынков, прогнозировать состояние мировой экономики, управлять иностранными инвестициями, организовывать собственные стартапы.

Студенческий Инвестиционный клуб организован для формирования профессиональных и предпринимательских компетенций, лидерских качеств студентов профиля бакалавриата «Инвестиционный анализ». Направления деятельности Инвестиционного клуба реализуются в партнерстве с органами власти, другими вузами, и бизнес-сообществом региона.

В современных условиях актуализируется практикоориентированная модель высшего образования. Необходимо усиление практической составляющей учебного процесса. Решению этой проблемы способствует участие студентов в деятельности Инвестиционного клуба. Студенты получают практические навыки предпринимательской деятельности, развиваются их профессиональные компетенции, формируются soft skills, которые необходимы для потенциального предпринимателя, особенно инновационного. Это умение принимать решения в условиях неопределенности, правильно 
переживать временные неудачи и падения, навыки формирования команд, успешного ведения переговоров. Студенты получают умения гибко менять алгоритм своих действий в зависимости от наличных ресурсов и ограничений, очень важные для предпринимателя (Gibb, 2002). Т.е умения и навыки, которые в корне отличают предпринимателя от наемного работника. По результатам исследований, российская модель предпринимательского образования включает недостаточное количество курсов и других форм обучения, формирующих soft skills (Чепуренко, 2017).

Инвестиционный клуб вносит вклад и в решение важной институциональной задачи: содействие предпринимателям региона, прежде всего в сфере технологий и реального сектора экономики. Малому бизнесу необходима консалтинговая поддержка при разработке бизнес-планов, заявок на получение субсидии. Это подтверждается многочисленными международными и российскими исследованиями. Исследования, проводимые в СИУ-филиале РАНХиГС, также демонстрируют дефицит доступной консалтинговой поддержки, необходимость дополнительной инфраструктуры акселерации бизнеса (Гурунян, и т.д., 2017). Президент РФ, Правительство и экспертное сообщество в качестве главной задачи развития страны рассматривают укрепление инвестиционного потенциала. В условиях политических рисков резко сокращаются иностранные инвестиции, происходит бегство капитала. Поэтому первоочередной задачей экономического регулирования становится содействие привлечению инвесторов, в том числе мелких, в регионах страны. Исследования показывают, что регионы России обладают значительным природным, трудовым и интеллектуальным потенциалом. Но у многих начинающих и действующих предпринимателей не хватает компетенций в сфере бизнес-планирования, привлечения инвестиций, и потенциал регионов не используется в полной мере.

Инвестиционный клуб представляет собой структурное подразделение кафедры экономики и инвестиций, и действует с соблюдением требований закона РФ «Об образовании», Национальной доктрине образования Российской Федерации до 2025 г., Типового положения о высшем учебном заведении, Устава института и Положения об Инвестиционном клубе. Инвестиционный клуб может рассматриваться в качестве объекта предпринимательской инфраструктуры вуза.

Основные направления деятельности Инвестиционного клуба:

1. Тренинги со студентами профиля «Инвестиционный анализ» по тематике бизнес-планирования, получения государственной и муниципальной поддержки, венчурных инвестиций, грантов Фонда содействия инновациям и др.

2. Гостевые лекции и мастер-классы представителей бизнеса, органов власти, ответственных за инвестиционную и инновационную политику, поддержку предпринимательства.

3. Участие в организации и проведении бизнес-форумов, инвестиционных выставок, венчурных ярмарок региона.

4. Разработка бизнес-планов и внедрение инвестиционных проектов в партнерстве с техническими вузами.

5. Организация совместных предприятий с менторами из бизнеса.

6. Консультирование предпринимателей региона и разработка заявок для получения государственной и муниципальной поддержки в виде субсидий, грантов начинающим предпринимателям.

7. Консультирование организаторов стартапов и экономическое обоснование заявок для привлечения венчурных инвестиций, грантов Фонда содействия инновациям.

8. Проведение интервьюирования предпринимателей в рамках НИР «Институциональное регулирования инвестиционно-инновационной деятельности МСП в условиях перехода к цифровой экономике».

9. Разработка онлайн-курса, образовательных программ, программ ДПО с использованием опыта деятельности Инвестиционного клуба.

10. Организация малого инновационного предприятия (МИП) по оказанию консалтинговых услуг предпринимателям и населению.

В деятельность Инвестиционного клуба вовлечены ведущие преподаватели кафедры экономики и инвестиций, студенты 1-4 курсов направления подготовки «Экономика». Логика деятельности Инвестиционного клуба заключается в том, что учебные курсы в сфере предпринимательства и инвестирования дополняются образовательными мероприятиями различной направленности и сложности. Студентов младших курсов мы стараемся вовлекать в тренинги, научные мероприятия, мастер-классы экспертов, менторов из бизнеса. Студенты со 2-го курса начинают участвовать в качестве волонтеров в бизнес-форумах, венчурных ярмарках. Студенты 3-го и 4-го курсов активно разрабатывают бизнес-планы начинающим предпринимателям, заявки на гранты Фонда Содействия инновациям, собственные предпринимательские проекты. Опыт деятельности Инвестиционного клуба отражается в научных статьях преподавателей и студентов, разработке новых учебных курсов, программ ДПО. В результате меняется 
направление обучения, которое становится более практикоориентированным. Представим более подробно основные направления деятельности Инвестиционного клуба.

Межвузовское направление деятельности Инвестиционного клуба началось на основе сотрудничества кафедры экономики и инвестиций СИУ-филиала РАНХиГС и кафедры биологии, биоресурсов и аквакультуры Новосибирского государственного аграрного университета (НГАУ) при поддержке Департамента природных ресурсов и охраны окружающей среды Новосибирской области. И направлено на разработку бизнес-планов и реализацию инвестиционных проектов по рыбоводству. Дело в том, что Новосибирская область богата водными природными ресурсами (река Обь с притоками, множество озер). Но этот природный потенциал используется не в полной мере. Рыбоводство - крайне важное направление импортозамещения. Поэтому развитие производств по выращиванию товарных видов рыб крайне актуально. На первом этапе проекта состоялась встреча преподавателей кафедры и студентов профиля с зав. кафедрой биологии, биоресурсов и аквакультуры НГАУ. Эксперт познакомил студентов с основами технологий разведения рыб. Затем состоялась сессия по разработке проектов на площадке НГАУ. Участники сессии разделились на три группы. Каждая группа состояла из студентов СИУ, магистрантов НГАУ и действующих предпринимателей. Задачей каждой группы стала разработка бизнес-планов инвестиционных проектов рыбоводческих хозяйств по одному из трех направлений (сиговые, лососевые и карповые). Преподаватели кафедры экономики и инвестиций проводили консультирование по экономически вопросам. Преподаватели кафедрой биологии, биоресурсов и аквакультуры помогали участникам сессии решить спорные технологические вопросы.

В результате было разработано 3 бизнес-плана рыбоводческих хозяйств. Проекты дорабатывались при дистанционном взаимодействии участников каждой группы в течение месяца.

В ноябре 2017 года преподаватели и студенты СИУ провели бизнес-игру «Составление бизнес-плана предприятия» в рамках международной бизнес-школы для молодых ученых и предпринимателей «Аквакультура» на II Новосибирском Агропродовольственном форуме. Представленные бизнес-планы рыбоводческих хозяйств стали предметом широкого обсуждения участников бизнес-школы. Среди них были предприниматели регионов России, Казахстана, Киргизии, Азербайджана. Студенты получили умения и навыки бизнес-планирования, работы в команде, опыт публичных выступлений.

Обсуждалась и возможность дальнейшего сотрудничества кафедры и начинающих предпринимателей в сфере консалтинговой поддержки. Такие запросы поступают и от предпринимателей других сфер деятельности, поэтому проект развивается на базе межвузовского взаимодействия с вузами технической направленности. Представление бизнес-планов предпринимательскому сообществу возможно в рамках бизнес-форумов, венчурных ярмарок, встреч с предпринимателями в бизнес-инкубаторах. Проводится работа по созданию малого инновационного предприятия (МИП) по оказанию обучающих и консалтинговых услуг населению и предпринимателям. В рамках МИП будет осуществляться межвузовское взаимодействие.

Важным направлением деятельности Инвестиционного клуба является консалтинговое содействие предпринимателям в разработке заявок. Консультирование предпринимателей региона и разработка заявок для получения государственной и муниципальной поддержки, венчурных инвестиций, грантов Фонда содействия инновациям осуществляется силами студентов под руководством преподавателей. Разрабатывая заявки, студенты получают умения и навыки в сфере привлечения ресурсов для финансирования проектов. Студенты учатся вести переговоры, делегировать полномочия. Приведем пример разработки заявки на получение гранта Фонд содействия развитию малых форм предприятий в научно-технической сфере (Фонда содействия инновациям) по программе «Старт-1» в январе 2019 года. В рамках программы осуществлется поддержка начинающих стартапов. Участники Инвестиционного Клуба оказали содействие в формировании заявок по разработке НИР по теме «Проектирование и создание опытного образца энергокомплекса с технологией утилизации кофейных отходов в современное биотопливо» для ТОО «Континет-Сервис». Создание инновационного продукта - современного биотоплива на основе кофейной гущи - приведет к значительному технологическому, экономическому и экологическому эффекту. Исполнители задания провели анализ конкурентных рынков, направлений коммерциализации, разработали бизнес-модель. Вторая заявка на этот конкурс была на выполнение НИР «Создание энергоэффективной технологии отопления» для компании ООО «СИБЭКСПОЦЕНТР». При разработке заявок студентка 4-го курса руководила деятельностью студентки 3-го курса.

В качестве примера дискуссионных площадок с представителями органов власти отметим проведение Межвузовского круглого стола памяти В. И. Огородникова на тему «Управление инвестициями и инновациями в экономике», организованный кафедрой экономики и инвестиций. Круглый стол прошел 1 декабря 2018 года в СИУ. Было заслушано 11 докладов, большая часть которых не оставила аудиторию равнодушной и вызвала полемику среди участников, в том числе среди студентов. В докладе заместителя министра экономики Новосибирской области, начальника управления инвестиционной политики и территориального развития министерства экономического развития Новосибирской области Л. Н. Решетникова обосновывалась растущая инвестиционная привлекательность нашего региона в связи с 
государственной поддержкой, и в то же время, обозначились трудности и препятствия для частных инвесторов. Студенты получили знания об инвестиционной политике региона.

Студенты профиля «Инвестиционный анализ» приняли участие в организации и проведении мероприятий V Юбилейного Сибирского экономического форума малого и среднего предпринимательства (СЭФ-2018): «Делаем бизнес с Азией», проходившего 22-23 ноября 2018 года в МВК «Новосибирск Экспоцентр», в качестве волонтеров. Студенты были вовлечены в мастер-класс от бизнес-школы Сколково «Чему российские компании могут поучиться у китайского бизнеса?», практические кейсы успешных российских компаний экспортеров, Биржу контактов, круглый стол по защите экспортеров и пр. У студентов сформировались знания о предпринимательской деятельности в сфере ВЭД. Студенты должны были проявить ответственность, навыки формования команд, способность вести переговоры.

Большой интерес у студентов вызывает участие в кейс - чемпионатах. Кратко приведем пример кейсчемпионата «Предприниматель нас рассудит». Команды студентов должны разработать инвестиционный проект расширения реальной компании. Информационную базу для разработки проекта любезно предоставил один из добросовестных предпринимателей г. Новосибирска. Готовые проекты оценивает жюри, состоящее из экспертов в сфере бизнеса. Возглавляет жюри предприниматель, для предприятия которого и разрабатывается проект. Победившую команду ждут интересные призы.

Большой интерес вызывает видеокейс «Франшиза-удачный старт». Цель кейса - показать, что франчайзинговые предприятия обладают высокой устойчивостью и эффективностью, и очень подходит малому бизнесу. Это быстрый и эффективный способ обучения предпринимательским стандартам.

Для определения карьерных планов студентов, корректировки направлений деятельности и тем тренингов, гостевых лекций проводится анкетирование студентов с помощью онлайн-анкеты. Часть вопросов составлено по методике исследовательского проекта GUESSS «Глобальное исследование предпринимательского духа студентов», что позволяет провести сравнительное исследование и определить эффективность Инвестиционного клуба.

Опыт деятельности Инвестиционного клуба найдет отражение в онлайн-курсе «Экономика предпринимательства и политика поддержки предпринимательской деятельности» (учебник и сборник кейсов). В соответствии с Национальным проектом РФ до 2024 года «Образование», необходимо разрабатывать инновационные методы обучения, онлайн-курсы, образовательные платформы в рамках цифровой образовательной среды.

С созданием малого инновационного предприятия (МИП) по оказанию обучающих и консалтинговых услуг большее количество начинающих предпринимателей сможет получить помощь при разработке бизнес-планов, заявок на получение финансовой и имущественной поддержки, грантов и венчурного инвестирования. В соответствии с законодательством, МИП имеет право на льготную аренду площадей и использование упрощенной системы налогообложения. МИП будет активно сотрудничать с вузами филиальной сети, с вузами г. Новосибирска, с объединениями предпринимателей и Агентством инвестиционного развития Новосибирской области, АНО Агентством по привлечению инвестиций в Сибирь. МИП станет значимым элементом инновационной инфраструктуры СИУ-филиала РАНХиГС.

Риски деятельности Инвестиционного клуба заключаются, прежде всего, в снижении интереса студентов к участию в связи с увеличением занятости в учебном процессе к концу семестра, отсутствием денежного вознаграждения, и др. Но существует возможность получения альтернативного вознаграждения в виде грантов, участия в конференциях и форумах на основе обширного практического материала. Большое значение имеет и то, что во время мероприятий студенты знакомятся с потенциальными работодателями. Часто студенты проходят на предприятиях-партнерах практику с возможностью дальнейшей стажировки и трудоустройства.

\section{3 Количественные и Качественные Показатели Эффективности}

Студенты профиля «Инвестиционный анализ» СИУ-филиала РАНХиГС в результате участия в проекте получают навыки консультирования в сфере инвестиций, у них формируются профессиональные компетенции и лидерские качества, soft skills в сфере предпринимательства и инвестирования. Студенты приобретают опыт деловых коммуникаций, работы в команде. Определяют направления НИРС. Разрабатыватю собственные предпринимательские проекты.

Ежегодно увеличивается количество студентов, участвующих в проекте. Улучшаются показатели НИРС. Всего 20 студентов представили проект на конференциях различного уровня, подучены призовые места. Особенно значимым достижением считаем то, что студентами ежегодно представляются дипломы в форме стартапов. В 2019 году 8 выпускников профиля «Инвестиционный анализ» открыли собственное дело. Это двадцать восемь процентов выпускников. По данным данными исследовательского проекта GUESSS, в среднем только 10 процентов студентов планируют начать свое дело сразу после окончания вуза. Опрос студентов показал, что около 65\% видят себя в предпринимательстве через пять лет после вуза. 
Подготовлены заявки для участия во «Всероссийском конкурсе молодежных проектов», проводимых Росмолодежью, заявки для получения трейвел-гранта для участия студентов в Форуме по инновационному предпринимательству.

Преподаватели используют материалы проекта для инновационного обновления учебных курсов и разработке новых курсов, публикации статей публикация статей (ВАК, РИНЦ, Scopus), в том числе на английском языке, выступлении на конференциях. Применяют опыт клуба при разработке новых образовательных программ: ОП бакалавриата «Экономика и регулирование предпринимательской деятельности», ОП магистратуры «Инвестиции и инновации в экономике». Вносят творческий вклад в создание объекта интеллектуальной собственности (онлайн-курс), программ ДПО. Приобретают контакты с бизнес-сообществом, НКО, органами государственной власти. Организуют МИП по обучению и предоставлению консалтинговых услуг населению.

Вуз, на базе которого реализуется проект, участвует в сетевом межвузовском взаимодействии, повышается его имидж в глазах сообщества. В перспективе при организации МИП расширится инновационная инфраструктура вуза.

Предприниматели региона получат дополнительный вид поддержки, примут участие в молодежном проекте. Приобретут компетентных сотрудников при трудоустройстве выпускников. Показателем результативности можно считать количество реализованных бизнес-проектов, количество заполненных и поддержанных заявок.

\section{4 Модель Тиражирования Лучших Практик Обучения Предпринимательству в СИУ-Филиале Ранхигс в Вузы России И ЕАЭС}

Для улучшения предпринимательской экосистемы необходимо предлагать бизнес-сообществу новые формы взаимодействия с вузами. Сотрудничество экономических факультетов вузов и бизнеса развивает профессиональные компетенции выпускников, формирует soft skills в сфере предпринимательства, когнитивные и социально-поведенческие навыки. Это повышает конкурентоспособность выпускников, дает возможность удачного трудоустройства. Выпускники, участвовавшие в Инвестиционном клубе, работают в организациях разных форм собственности, в качестве коммерческих и финансовых специалистов и управленцев; в органах государственного и муниципального управления, ответственных за поддержку предпринимательства и формирование бизнес-климата. И конечно, выпускники успешно управляют собственным бизнесом, в том числе в сфере технологического предпринимательства, организуют стартапы. В рамках Инвестиционного клуба предприниматели получают дополнительную поддержку. Увеличивается число государственных грантов, субсидий, реализованных бизнес-планов. Повышается эффективность предпринимательской деятельности.

Поэтому опыт Инвестиционного клуба обладает значительным потенциалом тиражирования. Руководителем проекта получены письма о тиражировании. Коллеги из Липецкого филиала РАНХиГС пишут: «Считаем перспективным направлением развития проекта «Проектный офис», учитывая опыт проекта «Студенческий инвестиционный клуб», расширение сотрудничества с некоммерческими организациями, профессиональными объединениями работодателей, бизнес-структурами...Будем признательны на предоставление методических материалов и банка презентаций в рамках взаимного сотрудничества! Выражаем готовность участвовать в круглых столах, семинарах, других методических и научных мероприятия в сфере практикоорентированного обучения (возможно, в режиме ВКС)». Коллеги из Алтайского филиала планируют «...использовать лучшие практики «Студенческого инвестиционного клуба» в своей деятельности. Речь идет об участии студентов в качестве волонтеров в региональных экономических форумах. Особенно важно для усиления практикоориентированности учебного процесса оказание студентами консалтинговой поддержки начинающим предпринимателям».

Тиражирование проекта осуществляется по следующим направлениям:

1. Освещение деятельности Инвестиционного клуба при выступлениях на форумах, конференциях, круглых столах различного уровня. Коллеги могут задать вопросы, обсудить интересующие направления деятельности. Приведем примеры выступлений. Представлен доклад «Инновации в обучении предпринимательству: опыт СИУ-филиала РАНХиГС» на III Международной конференции «Инновационная экономика и менеджмент: методы и технологии», МГУ, Москва, 1617 мая 2018 года. Лучшие практики обучения предпринимательству в СИУ были продемонстрированы представителем кафедры экономики и инвестиций в рамках доклада «TRAINING ENTREPRENEURSHIP IN THE SIU-BRANCH OF THE RANGHIGS IS A CONTRIBUTION TO THE FORMATION OF THE BUSINESS CLIMATE OF THE REGION» на международной конференции «Современные проблемы государственного управления в постсоветской Евразии», Назырбаев Университет, Астана, Казахстан, 5-6 октября 2018 года. 
2. Организация круглого стола «Вклад образования в предпринимательскую экосистему» на базе СИУфилиала РАНХиГС в 2019 году. В круглом столе примут участие представители филиалов РАНХиГС, вузов г. Новосибирска и стран ЕАЭС (Казахстана и Киргизии). Возможно, некоторые коллеги выступят в режиме ВКС.

3. Публикация научных статей в сборниках (например, в сборнике методических материалов «Лучшие практики в образовании и профориентации»). Представление опыта практикоориентированного проекта в рецензируемых научных журналах списка ВАК: «Российское предпринимательство», «Экономика предпринимательства», «Высшее образование в России», «ЭКО», «Инновации», в других изданиях.

4. 4.Консультирование (при необходимости) руководителем проекта коллег из филиалов и других вузов, в которых проходит тиражирование проекта. Стажировки представителей филиалов, других вузов в Сибирский институт управления, для ознакомления и последующего масштабирования опыта Инвестиционного клуба.

5. Организация онлайн-батла проектов по формированию бизнес-планов для получения гранта начинающему предпринимателю в филиальной сети. Онлайн-батл может выступить в качестве инструмента тиражирования деятельности Инвестиционного клуба.

6. Разработка онлайн-курса «Экономика предпринимательства и политика поддержки предпринимательской деятельности» (учебник и сборник кейсов). Онлайн-курс представляет лучшие практики деятельности Инвестиционного клуба. В материалы курса включены самые востребованные и апробированные бизнес-кейсы, мастер-классы авторитетных экспертов. Онлайнкурс может быть размещен на сайте СИУ-филиала РАНХиГС. И доступен филиалам после подписания соглашений. При размещении на Национальной платформе открытого образования будет доступен другим вузам.

Отметим, что для успешного тиражирования в вузах на экономических факультетах должны быть преподаватели, готовые посвятить время руководству и участию в качестве ответственных исполнителей деятельности Инвестиционного клуба. С учетом нашего опыта считаем, что среди студентов будет достаточное количество участников проекта. В вузах, где разрабатываются технологические проекты, существует потребность в экономическом сопровождении. Для налаживания сотрудничества с бизнессообществом рекомендуем обратиться в Советы предпринимателей, предпринимательские союзы, инвестиционные агентства.

\section{5 Заключение}

В конечном итоге тиражирование проекта сети позволит обогатить предпринимательскую экосистему, улучшить инвестиционной климат регионов России и других старан ЕАЭС. Таким образом, наличие предпринимательской инфраструктуры в вузе, проектной деятельности в сфере предпринимательства и инвестирования, образовательных программ представляют собой ключевые факторы формирования предпринимательских компетенций студентов. Содействие компаниям региона силами студентов и преподавателей повышает эффективность предпринимательской деятельности в регионе. Особенно важно такое содействие начинающим предпринимателям (GEM, 2017/2018).

Внедрение лучших практик обучения предпринимательству в вузах стран ЕАЭС будет способствовать улучшению бизнес-климата и станет одним из драйверов устойчивого развития региональной интеграции.

\section{Литература}

- Беляева Т.В., Ласковая А.К., Широкова Г.В. (2016) «Обучение предпринимательству и формирование предпринимательских намерений студентов: роль национальной культуры», Российский журнал менеджмента, Т.41, 1, С.77.

- Всемирный банк, 2019. Doing Business, Оценка Бизнес Регулирования, http://russian.doingbusiness.org

- Гурунян Т.В., Щербина О.Ю., В.В. Завадовский О.Ю., Каменская Н.Ю., 2017. Модель инвестиционно-инновационного лифта для малого и среднего предпринимательства. Изд-во СибАГС, Новосибирск.

- ООН, 2019. Цели в области устойчивого развития, Россия 2019, https:// https://www.un.org/sustainabledevelopment/ru/

- Правительство России, 2019. Приоритетный проект «Малый бизнес и поддержка индивидуальной предпринимательской инициативы» («Индивидуальное и малое предпринимательство (ИМП)»), http://government.ru/projects/selection/654/

- Чепуренко А. Ю., (2017) «Как и зачем обучать предпринимательству: полемические заметки», Вопросы образования, 3, С. 252. 
- GEM Национальный отчет ГЛОБАЛЬНЫЙ МОНИТОРИНГ ПРЕДПРИНИМАТЕЛЬСТВА, Россия, 2017/2018, https://gsom.spbu.ru/files/docs/gem_russia_2017-2018.pdf

- Gibb A. (2002) «In Pursuit of a New "Enterprise" and "Entrepreneurship" Paradigm for Learning: Creative Destruction, New Values, New Ways of Doing Things and New Combinations of Knowledge», International Journal of Management Reviews» vol. 4, 3, pp. 233-269.

- GUESSS Глобальное исследование предпринимательского духа студентов, национальный отчет. Россия 2018, https://gsom.spbu.ru/files/folder_11/guesss_2018_rus_final_v1.pdf

- Martin B., McNally J.J., Kay M. J. (2013) «Examining the Formation of Human Capital in Entrepreneurship: A Meta-Analysis of Entrepreneurship Education Outcomes», Journal of Business Venturing, vol. 28, 2, pp. 211-224. 


\title{
ЕАЭБ Өлкөлөрүндө Айыл-Чарба Тармагын Колдоо Чаралары
}

\section{Government Support of the Agricultural Sector in the EAEU Countries}

\author{
Asst. Prof. Dr. Damira Baigonushova (Kyrgyzstan-Turkey Manas University, Kyrgyzstan) \\ Asst. Prof. Dr. Junus Ganiev (Kyrgyzstan-Turkey Manas University, Kyrgyzstan) \\ $\mathrm{Ph} . \mathrm{D}$. Candidate Mairam Baigonusheva (Marmara University, Turkey)
}

\begin{abstract}
As it is known, in 2010, a customs union with three participants, Belarus, Russia and Kazakhstan, was formed on the territory of the former Soviet Union. In 2015, the union moved to another stage, the economic union. In 2015, Kyrgyzstan became a full member of this union and is currently trying to adapt to new economic conditions. In particular, the Agricultural Policy Department of the Eurasian Economic Commission is currently actively working on the development and implementation of common agricultural policy. Kyrgyzstan, despite the limited territory for agricultural production, is an agricultural country and has a comparative advantage in this sector. Therefore, the country should take an active role in the development of a common agricultural policy and create favorable conditions for the development of the own agrarian sector and use advantages. The purpose of this work is to analyze the developed plans and policies of the Agricultural Policy Department of the Eurasian Economic Commission, as well as conduct a comparative analysis with the common agricultural policy of the European Union, and at the end to make proposals.
\end{abstract}

\section{1 Киришуу}

Азык-түлүк коопсуздугу дүйнө жүзүндө бардык өлкөлөрдүн негизги маселелеринин бири болуп саналат. Өзгөчө өлкө калкын экологиялык жактан таза азык-түлүк менен камсыз кылуу маселеси барган сайын актуалдуу болуп баратат. Мындан тышкары, 2006-жылдагы сыяктуу спекуляциялык иш-аракеттер, санкциялар жана учурдагы саясий кырдаал да кризистик абал келип чыкпашы үчүн, өкмөттөрдү бул тармакка көңүл бурууга мажбурлоодо. Ошондуктан Евразия экономикалык биримдиги масштабында да, өлкөлөр масштабында да тиешелүү чаралар көрүлүүдө. Алсак;

- Арменияда «Азык-түлүк коопсуздугун камсыздоо жөнүндө мыйзам жана 2011-жылы Азык-түлүк коопсуздугун камсыздоо концепциясы кабыл алынган. Ал кезде азык-түлүктө өзүн-өзү камсыз кылуу деңгээли 58\%ды түзсө, концепция боюнча 2020-жылга чейин бул көрсөткүчтү 84\%га жеткирүү максат кылынган. Учурда өлкөнүн азык-түлүк коопсуздугунун орточо деңгээли 70\%ды түзүүдө.

• Беларусь Республикасында Улуттук азык-түлүк коопсуздугун камсыздоо концепциясы жана бир катар айыл-чарбасын өнүктүрүү мамлекеттик программалары кабыл алынган. Концепциянын приоритеттүҮ багыттары катары материалдык-техникалык базаны кайрадан калыптандыруу, жаңы, эффективдүү технологияларды колдонуу, экологиялык таза продукцияларды өндүрүү сыяктуу максаттар белгиленген. Беларусь өлкөсүнүн Улуттук илимдер академиясынын изилдөөлөрү боюнча, 2010-жылдан тарта азыктүлүккө болгон ички талап толугу менен канааттандырылып, азык-түлүк коопсуздугу толук түрдө камсыздалган. Өлкөнүн азык-түлүк коопсуздугунун орточо деңгээли 100\%дан жогору. Учурда айыл-чарба продукцияларында өлкөнүн тышкы соодасында профицит орун алууда. Бирок экспорттун 85-90\%ы ЕАЭБ өлкөлөрүнө багытталууда.

• Казахстанда 2020-жылга чейин стратегиялык өнүктүрүү планы кабыл алынып, анда айыл-чарбасынын экспорттук потенциалын жалпы экспортто 8\%га чейин көбөйтүү максат кылынган. «Казахстан - 2050» стратегиясында агро-өнөр жай экспортун кеңейтүү, аймактык жана дүйнөлүк талапты камсыздоо сыяктуу максаттар белгиленген. Өлкөнүн азык-түлүк коопсуздугунун орточо деңгээли 70\%ды түзүүдө.

- Кыргызстанда 2008-жылы «Кыргыз Республикасынын азык-түлүк коопсуздугун камсыздоо жөнүндө» мыйзам кабыл алынып, анын негизинде 2009-жылы Өкмөттүн азык-түлүк коопсуздугунун көзөмөлдөнүшү жана көрсөткүчтөрү боюнча токтому чыккан. Бул токтомдун негизинде Айыл чарба, тамак-аш өнөр жайы жана мелиорация министрлиги квартал сайын өлкөнүн негизги азык-түлүктөр боюнча азык-түлүк коопсуздугунун камсыздалуу деңгээлин аныктап турат: нан азыктары, картофель, жашылчалар, мөмөжемиштер, эт, чийки сүт, кумшекер, жумуртка жана өсүмдүк майы. Өлкөнүн азык-түлүк коопсуздугунун орточо деңгээли 80\%ды түзүүдө.

• 2010-жылы Россияда 2020-жылга чейин Россия Федерациясынын азык-түлүк коопсуздугу доктринасы кабыл алынган. Азык-түлүк коопсуздугунун абалын аныктоо үчүн критерий катары белгилүү продукцияларда жергиликтүү өндүрүштүн үлүшү негиз алынган: дан азыктары 95 пайыздан кем эмес, 
кумшекер 80 пайыздан кем эмес, өсүмдүк майы 80 пайыздан кем эмес, эт жана эт азыктары 85 пайыздан кем эмес, сүт жана сүт азыктары 90 пайыздан кем эмес, балык азыктары 80 пайыздан кем эмес, картофель 95 пайыздан кем эмес, тамак-аш тузу 85 пайыздан кем эмес. Өлкөнүн азык-түлүк коопсуздугунун орточо деңгээли 89\%ды түзүүдө. Өзгөчө уй эти, каймак май, сыр жана быштак, жүзүм, алма жана алмурут азыктарында ЕАЭБ өлкөлөрүнөн келген импортту эске алганда да, камсыз болуу деңгээли 80\%дан төмөн болууда (ЕЭК, 2015а).

Жалпы ЕАЭБ масштабында караганда, Союздун өзүн-өзү камсыздоо деңгээли өзгөчө жүзүм, алма, алмурут, каймак май, сыр, быштак, уй эти сыяктуу азыктарда 80\%дан төмөн болууда (ЕЭК, 2015а). Калган негизги азык-түлүк продукцияларында ЕАЭБнин өзүн-өзү камсыз кылуусу жетиштүү деңгээлде деп айтууга болот. Бирок учурдагы негизги маселелердин бири - бул бирдиктүҮ, координациялуу саясаттын жоктугу жана өлкөлөрдүн жеке кызыкчылыктарынын Союздук кызыкчылыктан жогору турушу. Муну тастыктап көрсөтүү максатында бул эмгекте ЕАЭБ өлкөлөрүндө айыл-чарбасынын учурдагы абалын жана өлкөлөрдүн айыл-чарбасын колдоо чараларын салыштырмалуу анализдөө максат кылынды.

\section{2 ЕАЭБ Өлкөлөрүндө Айыл-Чарбасынын Учурдагы Абалы}

Евразиялык экономикалык комиссиянын маалыматтары боюнча, 2018-жылы ЕАЭБ өлкөлөрүнүн айылчарба өндүрүшү жалпысынан 108,9 миллиард долларды түзгөн. Анын төрттөн үчү Россияга тиешелүү болсо, 11,8\%ы Казахстан, 8,6\%ы Беларусь, 2,7\%ы Кыргызстан жана 1,8\%ы Армения тарабынан өндүрүлгөн. Дүйнөлүк Банктын маалыматтары боюнча, 2017-жылы айыл-чарба өндүрүшүнүн өлкөлөрдүн ИДПсындагы үлүшү Армения менен Кыргызстанда 10\%дан жогору болсо, Беларусь өлкөсүндө дээрлик 8\%, Россия менен Казахстанда жана жалпы Биримдиктин масштабында болжол менен 4\% болгон. Демек, ЕАЭБде Армения, Беларусь жана Кыргызстан үчүн айыл-чарбасынын мааниси салыштырмалуу жогорураак экенин белгилөөгө болот.

\begin{tabular}{|l|c|c|c|c|}
\hline & $\begin{array}{c}\text { Учурдагы } \\
\text { бааларда айыл- } \\
\text { чарба } \\
\text { өндүрүшүнүн } \\
\text { көлөмү }\end{array}$ & $\begin{array}{c}\text { Айыл-чарба } \\
\text { өндүрүшүнүн } \\
\text { ЕАЭБдеги } \\
\text { үлүшү, \% }\end{array}$ & $\begin{array}{c}\text { Айыл-чарба } \\
\text { өндүрүшүнүн } \\
\text { өлкөнүн } \\
\text { ИДПсындагы үлүшү, } \\
\%(2017-ж .)\end{array}$ & $\begin{array}{c}\text { Ички дүн } \\
\text { продукциянын } \\
\text { ЕАЭБдеги үлүшү, } \\
\% \text { (2017-ж.) }\end{array}$ \\
\hline Армения & 1918,0 & 1,76 & 14,9 & 0,64 \\
\hline Беларусь & 9325,1 & 8,57 & 7,8 & 3,0 \\
\hline Казахстан & 12793,8 & 11,75 & 4,4 & 0,98 \\
\hline Кыргызстан & 2960,8 & 2,72 & 12,3 & 86,96 \\
\hline Россия & 81861,6 & 75,2 & 4,0 & 100,0 \\
\hline ЕАЭБ, жалпысы & 108859,3 & 100,0 & 4,3 & \\
\hline
\end{tabular}

Таблица 1. ЕАЭБ өлкөлөрүндө айыл-чарба продукцияларынын өндүрүшү, млн. АКШ доллары (2018-ж.) Булак: ЕЭК, 2019; Дүйнөлүк Банк, data.worldbank.org

Негизги айыл-чарба өсүмдүктөрүнүн арасынан дан жана буурчак эгиндеринен 2018-жылы жалпысынан 141,6 млн тонна түшүм алынса, анын 79,7\%ы Россияга, 14,3\%ы Казахстанга туура келген. Кант кызылчасы 47,3 млн тонна өндүрүлүп, анын 87\%ы Россияга, 10\%ы Беларусь өлкөсүнө тиешелүү болгон. Картофель 33,9 млн тонна өндүрүлсө, анын 66\%ы Россия, 17\%ы Беларусь, 11\%ы Казахстан, 4\%ы Кыргызстан тарабынан чыгарылган. 21,2 млн тонна жашылчалардын 64\%ы Россия, 19\%ы Казахстан, 8\%ы Беларусь, 5\% Кыргызстан тарабынан өндүрүлгөн. Дан жана буурчак эгиндери менен кант кызылчасынын өндүрүшү негизинен эки өлкөдө топтолсо, картофель жана жашылчалардын салыштырмалуу бардык өлкөлөргө бирдей жайылганын көрүүгө болот. Өзгөчө Кыргызстанда бул түшүмдөрдүн көп өстүрүлөөрүн белгилөөгө болот.

\begin{tabular}{|c|c|c|c|c|}
\hline & $\begin{array}{c}\text { Дан жана буурчак } \\
\text { эгиндери }\end{array}$ & Кант кызылчасы & Картофель & Жашылчалар \\
\hline$E A Э Б$ & 141556,0 & 47323,9 & 33959,7 & 21155,4 \\
\hline Армения & 337,65 & 0,5 & 415,1 & 628,2 \\
\hline Беларусь & 6150,6 & 4806,3 & 5865,1 & 1745,9 \\
\hline Казахстан & 20276,8 & 504,5 & 3807,0 & 4082,0 \\
\hline Кыргызстан & 1888,9 & 773,0 & 1446,6 & 1094,9 \\
\hline Россия & 112902,0 & 41239,6 & 22425,9 & 13604,5 \\
\hline
\end{tabular}

Таблица 2. Негизги айьл-чарба өсүмдүктөрүнүн өндүрүшү, миң тонна (2018-ж.) Булак: ЕЭК, 2019.

Мал чарбачылыкка кайрылсак, Евразиялык экономикалык комиссиянын маалыматтары боюнча, 2019жылдын 1-январына карата ЕАЭБде жалпысынан 31,3 млн бодо мал, 27,4 млн чочко, 47,9 млн майда мал жана 644,7 млн үй канаттуулары болгон. Россиянын үлүшү майда малда 48\%, бодо малда 58\%, чочко менен 
канаттууларда 85\%ды түзгөн. Казахстандын үлүшү канаттууларда 7\%, бодо малда 23\% жана майда малда $39 \%$ га жеткен. Беларусь өлкөсүнө майда малдардын 0,3\%ы, канаттуулардын 8\%ы, чочколордун 10\%ы жана бодо малдын 14\%ы туура келген. Бодо малдын 5\%ы, канаттуулардын 1\%ы, майда малдын болсо 13\%ы Кыргызстанга тиешелүү болгон. Демек канаттуулардын көпчүлүгү Россияда болсо, майда малдын жарымынан көбү Казахстан менен Кыргызстанда. Бодо малдын 80\%ынан көбү Россия менен Казахстанга тиешелүү.

\begin{tabular}{|c|c|c|c|c|c|c|c|c|c|c|}
\hline & \multicolumn{2}{|c|}{ Бодо мал } & \multicolumn{2}{|c|}{$\begin{array}{c}\text { Анын ичинде } \\
\text { уйлар }\end{array}$} & \multicolumn{2}{|c|}{ Чочколор } & \multicolumn{2}{|c|}{$\begin{array}{c}\text { Майда мал, } \\
\text { млн. баш }\end{array}$} & \multicolumn{2}{|c|}{$\begin{array}{c}\text { Канаттуулар, } \\
\text { млн. баш }\end{array}$} \\
\hline & саны & $\%$ & саны & $\%$ & саны & $\%$ & саны & $\%$ & саны & $\%$ \\
\hline $\begin{array}{l}\text { ЕАЭБ } \\
\text { (Армениядан } \\
\text { тьишкары) }\end{array}$ & 31255,5 & 100,0 & 13797,5 & 100,0 & 27430,3 & 100,0 & 47,9 & 100,0 & 644,7 & 100,0 \\
\hline Беларусь & 4341 & 13,9 & 1498 & 10,9 & 2841 & 10,4 & 0,15 & 0,3 & 51,2 & 7,9 \\
\hline Казахстан & 7137,9 & 22,8 & 3569,2 & 25,9 & 802,7 & 2,9 & 18,7 & 39,0 & 44,45 & 6,9 \\
\hline Кыргызстан & 1627,3 & 5,2 & 812,6 & 5,9 & 51,3 & 0,2 & 6,17 & 12,9 & 6 & 0,9 \\
\hline Россия & 18149,3 & 58,1 & 7917,6 & 57,4 & 23735,4 & 86,5 & 22,9 & 47,8 & 543 & 84,2 \\
\hline
\end{tabular}

Таблица 3. Негизги айыл-чарба жаныбарларынын саны, миң баш (2019-жылдын 1-январына карата) Булак: ЕЭК, 2019. Армения боюнча бул датага карата расмий маальмат болгон эмес.

Айыл-чарба продукцияларын кайра иштетүү өнөр-жайынын эт азыктары, өсүмдүк майы, акшак, нан азыктары жана кумшекер өндүрүшүндө Россиянын үлүшү 80-90\%ды түзүүдө. Каймак май, сыр, ун өндүрүшүнүн үчтөн экисин Россия өндүрсө, Беларусь өлкөсү каймак май менен сырдын, Казахстан ундун үчтөн бирине жакын бөлүгүн өндүрүшүүдө. Кыргызстан менен Армениянын үлүштөрү көбүнчө 1\%дан төмөн болууда.

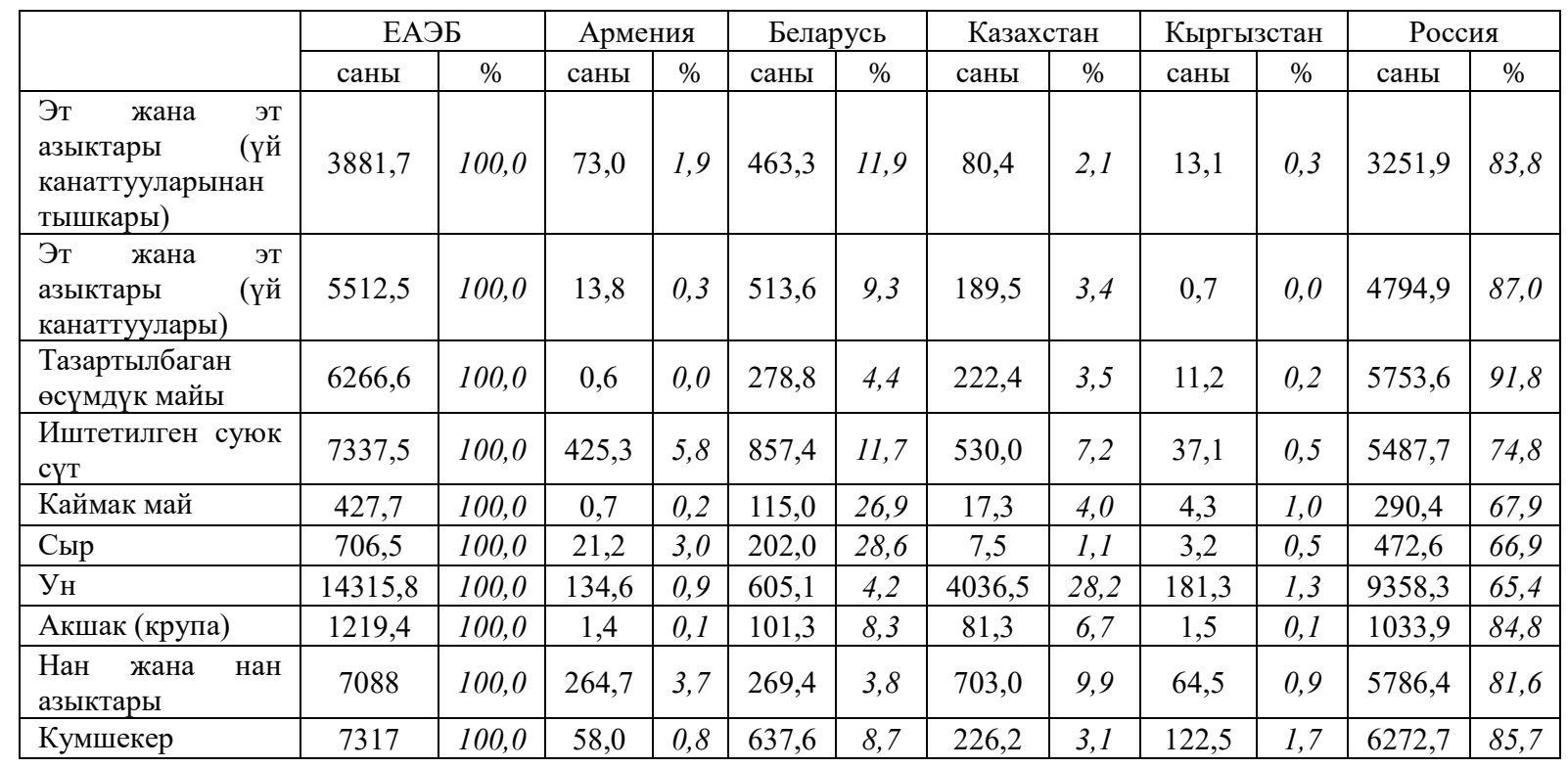

Таблица 4. Тамак-аш жана кайра иштетүҮ өнөр-жай продукцияларынын кээ бир түрлөрүнүн өндүрүщү, миң тонна (2018-ж.) Булак: ЕЭК, 2019

Айыл-чарба продукцияларынын тышкы соодасы боюнча жалпы абал төмөнкүдөй: Беларусь өлкөсү үчүн ЕАЭБ негизги рынок болуп саналса (экспортунун 89\%ы), калган мүчөлөр Биримдиктен азыраак көзкаранды: Россия 16\%, Казахстан 21\%, Армения 58\% жана Кыргызстан 49\%. Үчүнчү өлкөлөрдөн импорт көз-карандылыгы жагынан болсо Россия алдыда турат. Анын айыл-чарба жана азык-түлүк продукциялары боюнча импортунун 89\%ынан көбү үчүнчү өлкөлөргө туура келет. Бул көрсөткүч Арменияда 76\%, Беларусь өлкөсүндө 74\%, Казахстанда 57\% жана Кыргызстанда 38\%. ЕАЭБ өлкөлөрүнүн кошумча наркы жогору айыл-чарба продукцияларынын экспорту жалпы айыл-чарба экспортунун 6\%ын түзсө, импортто бул көрсөткүч дээрлик 20\%ды түзөт. Демек, чийки зат экспортун азайтып, иштетилген продукцияларды экспорттоого көбүрөөк көңүл буруу зарылчылыгы бар.

\section{3 Айыл-чарбасын колдоо чаралары}

Айыл-чарба тармагына дүйнөнүн алдыңкы экономикаларында дагы субсидия чаралары, импорттон коргоо, жеңилдиктер жана атайын жөнгө салуу сыяктуу мамлекеттик колдоолор көрсөтүлөт. Бирок ошол 
эле учурда бул колдоолордун кээ бир түрлөрү эл аралык соодада баа айырмачылыктарын жаратуу менен атаандаштыкта акыйкатсыздыктарды жараткандыгы үчүн эл аралык деңгээлде жөнгө салынат, башкача айтканда, кээ бир колдоо түрүнө белгилүү чектер коюлса, кээ бирлерине толугу менен тыюу салынган.

Айыл-чарба тармагына ички колдоолорго чектөөлөрдүн киргизилиши боюнча алгачкы талкуулар Соода жана тарифтер боюнча жалпы келишимдин (ГАТТ) катышуучулары тарабынан Кеннеди (1961-1962-жж.), Токио раунддарында (1973-1975-жж.) башталган. Анткен менен, бардык мүчөлөрдүн кызыкчылыктарына туура келген жалпы формула Уругвай раундундагы (1986-1994-жж.) сүйлөшүүлөрдөн кийин кабыл алынган. Аталган раундда Дүйнөлүк соода уюмун (ДСУ) түзүү чечими дагы кабыл алынып, кийин эл аралык сооданы көзөмөлдөө боюнча иш-чаралардын баары ушул уюмга жүктөлгөн (Евразиялык экономикалык комиссия, 2015b:3-4). Ошентип, учурда айыл-чарбага колдоо көрсөтүүдө колдонулуучу ар кандай инструменттер боюнча колдоонун көлөмүн белгилөөчү жана анын ишке ашуусун көзөмөлдөөчү органдардын эң башында ДСУ турат.

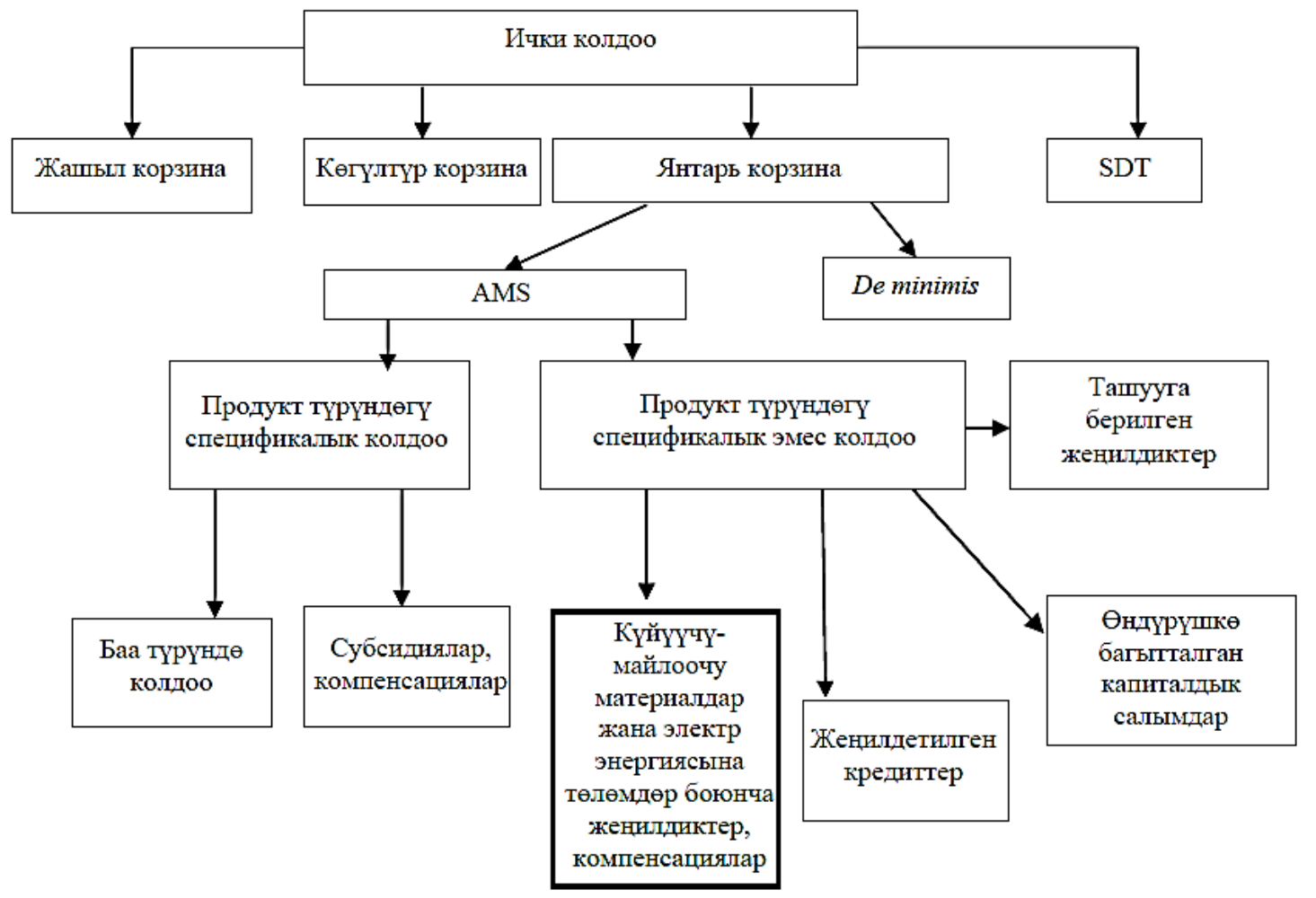

Схема 1. ДСУнун келишими алкагында айыл-чарбасына көрсөтүлгөн ички колдоолордун жалпь көрүнүшү Булак: Евразиялык экономикалык комиссия, 2016:4.

Айыл-чарбасын өнүктүрүүдө учурда өлкөлөр тарабынан көптөгөн чаралар (инструменттер) колдонулууда. ДСУ аларды эл аралык соодага тийгизген таасирлерине карата жол чырактын түстөрүнө салыштыруу менен үч корзинага (топко) бөлүп карайт: жашыл корзина - соодага минималдуу таасир бергени үчүн толугу менен уруксат берилген чаралар, сары корзина (ошол эле учурда янтарь корзина деп да айтылат) - кыскартылуусу керек болгон чаралар жана кызыл корзина - толугу менен тыюу салынган чаралар. ДСУнун келишиминде кызыл корзина каралбагандыгына карабастан, сары корзина бул корзинадан тышкаркы бардык чараларга толугу менен тыюу салынгандыгын билдирет. Кошумча катары көгүлтүр корзина киргизилген. Ага өндүрүштү кыскартуу программаларына байланыштуу субсидиялар кирет. Атайын жана дифференцияланган режим (special and differential treatment: SDT) түшүнүгү субсидиялар боюнча өнүгүп келе жаткан өлкөлөргө жалпы эрежелерден тышкары берилген, өзгөчө укуктарды түшүндүрөт. Схема 1 де ДСУнун келишими алкагында айыл-чарбасы үчүн ички колдоолордун жалпы көрүнүшү чагылдырылган. ДСУнун эрежелерине ылайык, мүчө өлкөлөр жашыл корзинага тиешелүү чараларды эч тоскоолдуксуз колдоно алышат. Мисалы, ветеринардык кызматтар, өсүмдүктөрдүн абалын жакшыртуу, зыяндуу курт-кумурскалар менен күрөшүү боюнча кызматтар, дыйкандарга кеңешкөмөк кызматтары, инфраструктураны жакшыртуу чаралары, өзгөчө кырдаалдарда төлөм жүргүзүү, тармакка байланыштуу илимий изилдөөлөрдү каржылоо ж.б.

Жашыл корзинага тиешелүү бул чараларга тең катар мамлекет өндүрүштү чектөө программасы алкагында фермерлерге түз төлөмдөрдүн негизинде субсидияларды берүү (көгүлтүр корзина), өнүгүп келе жаткан мамлекет болсо, айыл-чарбаны өнүктүрүү программаларын каржылоо (сооданы минималдуу бурмалоочу деңгээлде, б.а. «de minimis» деңгээлинде) чараларын колдоно алат. Бул сооданы бурмалоочу 
«янтарь корзинасынын» эң жогорку чегин көрсөтөт. Өнүккөн өлкөлөр үчүн бул жалпы айыл-чарба өндүрүшүнүн 5 пайызынан көп эмес, өнүгүп келе жаткан өлкөлөр үчүн 10 пайызынан көп эмес деп белгиленген. Бул көлөм сооданын бурмаланышына минималдуу таасир тийгизет деп кабыл алынып, буга уруксат берилген. Кээде ДСУ мүчөсү муну милдеттенме катары кабыл алат. Андай учурда бул чекти сөзсүз сактаганга мажбур болот (ЕЭК, 2015b:7). Башка колдоо чараларын «Жалпы колдоо чараларынын» (Aggregate Measurement of Support: AMS) чегинде гана колдонууга мүмкүн. Уругвай раундунда мүчө өлкөлөр 1986-1988-жылдардагы баага негизделген AMS көрсөткүчтөрүн төмөндөтүүнү чечишкен: өнүккөн өлкөлөр 1995-жылдан баштап 6 жылдын ичинде 20\%га, өнүгүп келе жаткан мүчө өлкөлөр 10 жылдын ичинде 13,3\%га төмөндөтүүгө тийиш болгон, ал эми начар өнүккөн өлкөлөрдөн кыскартуу талап кылынган эмес (ЕЭК, 2016:5; ЕЭК, 2018:4). Бул бир тараптан начар өнүккөн өлкөлөрдүн абалынын жакшыруусун көздөсө, экинчи тараптан аталган өлкөлөрдө айыл-чарбаларын колдоо чараларынын ансыз да аздыгына байланыштуу болгон.

Жыйынтыктап айтканда, учурда өлкөлөр арасындагы көп тараптуу соода жүргүзүүнүн системасы иштелип чыккан жана ал айыл чарба тармагын колдоо чараларын колдонууну жөнгө салуу механизмдеринин негизинде иштейт.

Учурда дүйнөнүн көптөгөн өлкөлөрүндө айыл-чарбасын колдоо чаралары көрүлүүдө. Алсак, Израиль, АКШ, Тайланд, Украина, Аргентина, Вьетнам, Грузия, Индонезия, Молдова, Пакистан, Тунис, Өзбекстан ж.б. Интеграциялардын арасынан Европа Биримдигинин тажрыйбасы өзгөчө маанилүү. Бирдиктүү айылчарба саясатына (common agricultural policy) Европа Биримдигинин бюджетинин болжол менен жарымы коротулат (Bayraç ve Yenilmez, 2005:24). БирдиктүY айыл-чарба саясаты өлкөлөрдүн айыл-чарба саясаттарынын экономикалык жана саясий жактан бирдиктүү башкаруу принцибине таянат (Karluk, 2002:208). ЕБнин 2020-жылга чейинки стратегиясында Бирдиктүү айыл-чарба саясатынын максаттарында рационалдуу өсүү, туруктуу өсүү жана масштабдуу өсүү элементтерине салым кошуу да эске алынып, реформага керектүү инструменттер ушунун негизинде түзүлгөн. Башкача айтканда, технологияларды жакшыртуу, продукциялардын кошумча наркын жана сапатын өстүрүү, органикалык айыл-чарбасын өнүктүрүү максаттары көздөлүүдө (Olcay, 2016:107). 2014-2020-жылдары ЕБ бюджети айыл-чарбасын колдоого 373 миллиард евро каражат бөлүүнү пландаган. Бул жылына орточо 53 миллиард евро дегенди билдирет. Фермерлерге түздөн-түз төлөмдөр эки фонддун негизинде улуттук жана аймактык органдар аркылуу жүргүзүлөт (ЕЭК, 2017:6): Европа айыл-чарба кепилдик фонду (European Agricultural Guarantee Fund) жана Европанын элетти өнүктүрүү боюнча айыл-чарба фонду (European Agricultural Fund for Rural Development). ЕАЭБ мүчөлөрү да Европа Биримдигинин Бирдиктүү айыл-чарба саясатынан үлгү алуулары зарыл. Учурда ар бир өлкө өз алдынча саясат жүргүзүүдө.

ЕАЭБ аймагында Кыргызстан менен Армениядан башка өлкөлөрдө айыл-чарбасына мамлекет тарабынан маанилүү колдоо көрсөтүлүүдө. Бул эки өлкөдө айыл-чарбасына көрсөтүлгөн мамлекеттик колдоонун көлөмү айыл-чарба өндүрүшүнүн 0,5 пайызынан төмөн болууда. ДСУнун шарттарына ылайык муну жок дегенде 5 пайызга чейин көтөрүү мүмкүнчүлүгү бар.

Евразиялык экономикалык комиссиянын (ЕЭК, 2015b) маалыматтары боюнча, 2013-жылы Россия Федерациясы айыл-чарбасына 9,8 миллиард доллар өлчөмүндө колдоо көрсөтсө, Казахстан бул багытта 1,2 миллиард, Беларусь 2,4 миллиард доллар короткон.

Биримдикке мүчө өлкөлөрдө сооданы бурмалоочу колдоолор «жашыл корзинага» караганда басымдуулук кылууда. Беларусь өлкөсүндө бул жалпы колдоонун 83,2\%ын, Казахстанда 68,7\%ын жана Россияда 70,2\%ын түзүүдө. Мунун айыл-чарба өндүрүшүнүн дүң көлөмүнө катышын караганда, Беларусь өлкөсүндө ал 2013-жылы 7,4\%ды, Казахстанда 3,5\%ды жана Россияда 2,7\%ды түзгөн.

ЕАЭБ өлкөлөрүндө сооданы бурмалабай турган чаралар катары илимий изилдөөлөрдү каржылоо, зыянкечтер жана оорулар менен күрөшүү, маалымат таратуу, кеңеш-көмөк көрсөтүү, инспекциялык кызматтар сыяктуу иш-аракеттер жасалууда.

Сооданы бурмалоочу чаралар катары жеңилдетилген насыя берүү, жер семирткичтерге, урукка, тоютка кеткен чыгымдарды компенсациялоо, породалуу малдарды жана канаттууларды багууга колдоо көрсөтүү, түшүмдү, малды, канаттууларды камсыздандыруу чыгымдарын компенсациялоо сыяктуу мамлекеттик колдоолор ишке ашырылууда.

Өлкөлөрдүн арасында маанилүү айырмачылыктар да бар. Сооданы бурмалоочу чаралардын арасында Беларусь жана Россия өлкөлөрүндө насыяларды тейлөө боюнча чыгымдарды каржылоо чоң үлүштү (сооданы бурмалоочу чаралардын 39,6 жана 39,2 пайызы) ээлейт. Казахстанда болсо мындай каражаттын негизги бөлүгү энергия ресурстарына кеткен чыгымдарды компенсациялоого жана мал чарбачылык продукцияларын өндүрүүгө берилген субсидияларга багытталууда. Россияда продукт түрүндөгү спецификалык колдоо катары 2013-жылы зыгыр өндүрүшүн жана бодо мал, бугу, жылкы, чочко, канаттууларды багууну субсидиялоо, сүт, эт, жумуртка жана жүн өндүрүшүнө субсидия берүү чаралары көрүлгөн. Беларусь өлкөсүндө зыгыр жана картофель өндүрүшүнө, эт жана сүт мал чарбачылыгына субсидия берилген. Казахстан мал чарбачылыгынын өнүгүшүнө кеңири масштабдуу колдоо көрсөткөн. 
Евразиялык экономикалык комиссиянын (2015b:123) маалыматтары боюнча, Биримдикте сооданы бурмалоочу чаралар басымдуулук кылууда. Чыныгы биримдикке айлануу үчүн, ЕАЭБ масштабында бирдиктүү айыл-чарбасын колдоо фондун түзүп, өзгөчө начар өнүккөн аймактарга көбүрөөк колдоо көрсөтүү механизмдерин иштеп чыгуу зарыл. Антпесе, Биримдиктин ичинде нааразычылыктардын көбөйөөрү бышык.

\section{4 Корутунду}

Жалпылай караганда, төмөнкүдөй жыйынтыктарды чыгарууга болот:

- Азык-түлүк коопсуздугуна ЕАЭБге мүчө бардык өлкөлөрдө өзгөчө маани берилүүдө. Бирок ЕАЭБ масштабында караганда, Союздун өзүн-өзү камсыздоо деңгээли өзгөчө жүзүм, алма, алмурут, каймак май, сыр, быштак, уй эти сыяктуу азыктарда 80\%дан төмөн болууда. Калган негизги азык-түлүк продукцияларында ЕАЭБнин өзүн-өзү камсыз кылуусу жетиштүү деңгээлде деп айтууга болот.

• 2018-жылы ЕАЭБ өлкөлөрүнүн айыл-чарба өндүрүшү жалпысынан 108,9 миллиард долларды түзгөн. Анын 75,1\%ы Россияга тиешелүү болсо, 11,8\%ы Казахстан, 8,6\%ы Беларусь, 2,7\%ы Кыргызстан жана 1,8\% Армения тарабынан өндүрүлгөн. Россия эң ири экономика катары чоң үлүштү алганы менен, салыштырмалуу караганда ЕАЭБде Армения, Беларусь жана Кыргызстан үчүн айыл-чарбасынын маанисинин жогорураак экенин белгилөөгө болот.

- Дан жана буурчак эгиндери менен кант кызылчасынын өндүрүшү негизинен эки өлкөдө топтолсо, картофель жана жашылчалардын салыштырмалуу бардык өлкөлөргө бирдей жайылганын көрүүгө болот. Өзгөчө Кыргызстанда бул азыктар көп өстүрүлүүдө.

- Канаттуулардын көпчүлүгү Россияда болсо, майда малдын жарымынан көбү Казахстан менен Кыргызстанда. Бодо малдын 80\%ынан көбү Россия менен Казахстанга тиешелүү.

• Каймак май, сыр, ун өндүрүшүнүн үчтөн экисин Россия өндүрсө, Беларусь өлкөсү каймак май менен сырдын, Казахстан ундун үчтөн бирине жакын бөлүгүн өндүрүшүүдө. Кыргызстан менен Армениянын үлүштөрү бул продукцияларда 1\%дан төмөн болууда.

• Беларусь өлкөсү үчүн ЕАЭБ негизги рынок болуп саналса, калган мүчөлөр Биримдиктен азыраак көзкаранды. Үчүнчү өлкөлөрдөн импорт көз-карандылыгы жагынан болсо Россия алдыда турат. Анын айылчарба жана азык-түлүк продукциялары боюнча импортунун 89\%ынан көбү үчүнчү өлкөлөргө туура келет.

- ЕАЭБ өлкөлөрүнүн кошумча наркы жогору айыл-чарба продукцияларынын экспорту жалпы айылчарба экспортунун 6\%ын түзсө, импортто бул көрсөткүч дээрлик 20\%ды түзөт. Демек, чийки зат экспортун азайтып, иштетилген продукцияларды экспорттоого көбүрөөк көнүл буруу зарылчылыгы бар.

- Учурдагы негизги маселелердин бири - бул бирдиктүү, координациялуу саясаттын жоктугу жана өлкөлөрдүн жеке кызыкчылыктарынын Союздук кызыкчылыктан жогору турушу.

- Атап айтканда, ЕАЭБ аймагында Кыргызстан менен Армениядан башка өлкөлөрдө айыл-чарбасына мамлекет тарабынан маанилүү жардам берилсе (2013-жылы Россия Федерациясы айыл-чарбасына 9,8 миллиард, Казахстан 1,2 миллиард, Беларусь 2,4 миллиард доллар өлчөмүндө колдоо көрсөткөн), бул эки өлкөдө айыл-чарбасына көрсөтүлгөн мамлекеттик колдоонун көлөмү айыл-чарба өндүрүшүнүн 0,5 пайызынан төмөн болууда. Бул ансыз да экономикалары алсыз болгон бул эки мүчөнүн жергиликтүү өндүрүшүн ансайын артка тартууда.

- Евразиялык экономикалык комиссиянын маалыматтары боюнча, Биримдикте сооданы бурмалоочу чаралар басымдуулук кылууда жана колдоо чараларында өлкөлөрдүн арасында маанилүү айырмачылыктар да бар.

- Ошондуктан ЕАЭБ масштабында ЕБнин тажрыйбасынан пайдаланып, бирдиктүү айыл-чарбасын колдоо фондун түзүп, өзгөчө начар өнүккөн аймактарга көбүрөөк колдоо көрсөтүү механизмдерин иштеп чыгуу зарыл.

- Ошондой эле, ЕАЭБ масштабында прогноздоо жана пландоо иштерин жүргүзүп, айыл-чарба өндүрүүчүлөрүнө маалыматтык колдоо көрсөтүү керек. Мында өзгөчө эл аралык адистешүүгө көңүл буруп, бардык мүчөлөрдүн бирдей өнүгүшүн биринчи планга коюу зарыл.

• Евразиялык экономикалык комиссиянын «адистешүүнү өнүктүрүү үчүн улуттук импортту алмаштыруу программаларын иштеп чыгууда Биримдиктеги өнөктөштөрдүн экспортун эске алуу керек» деген сунушуна өзгөчө көңүл буруу керек.

\section{Булактар}

- Arslan Olcay C., 2016. “Avrupa 2020 Stratejisi Doğrultusunda Ortak Tarım Politikasının Değişim Trendleri ve Yönelimleri”. Ankara Avrupa Çalışmaları Dergisi 15(2), ss.97-124.

- Bayraç H.N. ve Yenilmez F., 2005. “Türk Tarımının AB Ortak Tarım Politikasına Uyum Çalışmaları ve Olası Ekonomik Etkileri”. Eskişehir Osmangazi Üniversitesi Sosyal Bilimler Dergisi 6(1), ss.23-42. 
- $\quad$ Karluk S.R., 2002. Türkiye Ekonomisi, İstanbul: Betaş Yayınları.

- Евразийская экономическая комиссия, 2015a. «Мониторинг продовольственной безопасности ЕАЭС: 2014». www.eurasiancommission.org

- Евразийская экономическая комиссия, 2015b. «Анализ мировых тенденций государственной поддержки сельского хозяйства». www.eurasiancommission.org

- Евразийская экономическая комиссия, 2016. «Обзор мирового опыта предоставления государственной поддержки сельского хозяйства». www.eurasiancommission.org

- Евразийская экономическая комиссия, 2017. «Государственная поддержка сельского хозяйства: развитые и развивающиеся страны». www.eurasiancommission.org

- Евразийская экономическая комиссия, 2018. «Государственная поддержка сельского хозяйства: споры в рамках ВТО, модели поддержки в развивающихся странах». www.eurasiancommission.org

- Евразийская экономическая комиссия, 2019. «Обзор производственных показателей АПК государств - членов Евразийского экономического союза за 2018 г. (предварительные данные)». www.eurasiancommission.org 


\title{
Проблемы Питания в Кыргызской Республике и Пути Их Рещения
}

\section{Nutrition Problems in the Kyrgyz Republic and the Ways of Their Solution}

\author{
Prof. Dr. Bermet Djurupova (Kyrgyz University of Economics, Kyrgyzstan) \\ Prof. Dr. Jusup Pirimbaev (Kyrgyzstan-Turkey Manas University, Kyrgyzstan) \\ Dr. Gulmira Samatova (Kyrgyzstan-Turkey Manas University, Kyrgyzstan)
}

\begin{abstract}
The article is devoted to the assessment of food consumption in the region. The aim of the study is to develop the main directions of improving the food security of Kyrgyzstan in the future. It is revealed that the absolute number of the world population suffering from malnutrition, according to modern estimates, increased from about 804 million in 2016 to almost 821 million in 2017. This trend serves as a clear warning that, if not intensified efforts, the task of the SDGs to eliminate hunger by 2030 will not be achieved The research toolkit includes mathematical methods for processing statistical data, an assessment of the energy and nutritional value of food consumed by the population. The scientific novelty of the study is to identify the factors that limit food consumption and the assessment of the nutritional value of the products used. The research results can be applied to further scientific developments in the direction of providing the market with various types of products.
\end{abstract}

\section{1 Введение}

Одной из важнейших проблем современных экономических и социальных отношений продолжает оставаться продовольственная проблема. Обеспечение населения планеты продовольствием в достаточном количестве и ассортименте представляет сложную проблему, включающую комплекс вопросов производства продовольственной продукции, конъюнктуры национального и мирового продовольственных рынков, конкурентоспособности и платежеспособности страны, уровня доходов и структуры питания населения, социальной политики государства.

Продовольственная безопасность Кыргызстана заключается в том, чтобы обеспечить физическую и экономическую доступность продовольствия для населения в количестве, необходимом для ведения активного и здорового образа жизни. Она является важным фактором социальной стабильности общества и жизнеобеспечения страны. Вопрос обеспечения продовольственной безопасности для Кыргызстана в последние годы приобретает актуальное значение и его решение правительство определило в качестве одной из главных своих задач.

В стратегии развития Кыргызской Республики подчеркнута необходимость обеспечения продовольственной безопасности на современном этапе и в перспективе. Большое значение в связи с этим приобретает исследование состояния продовольственного рынка КР в условиях интеграции в Евразийский Экономический Союз (ЕАЭС).

В Концепции повышения продовольственной безопасности государств - участников СНГ, принятой Решением Совета глав правительств СНГ 19 ноября 2010 года, продовольственная безопасность определяется как состояние экономики государства, при котором за счет собственного производства обеспечивается продовольственная независимость страны и гарантируется физическая и экономическая доступность основных видов продовольствия и чистой питьевой воды для всего населения в количестве и качестве, необходимых для активной, здоровой жизни и реализации демографической политики (ecis.info, 2010).

\section{2 Обзор Литературы}

Обеспечение продовольствием, достижение его экологической чистоты всегда являлось первостепенной проблемой человечества. Продовольственный вопрос широко анализировался во многих отраслях науки, связана деятельность таких секторов экономики, как сельское хозяйство, переработка сельскохозяйственного сырья, общественное питание, а также перевозка, торговля, обслуживание и др.

Продовольственный вопрос охватывает не только потребление, но и производство и передвижение продуктов питания от производителя к потребителю. Хороший анализ и обоснованные прогнозы потребления продовольственных товаров с учетом платежеспособности населения позволяют решать многие задачи управления производством и удовлетворением структуры питания, приоритеты развития отраслей агропромышленного комплекса, обеспечение сбалансированности спроса и предложения и др (Концепция повышения продовольственный безопасности государств -участников СНГ: утверждена 
Решением Совета глав правительств СНГ о концепции повышения продовольственной безопасности государств, 2008).

Понятие «безопасность питания» возникло в середине 90-х годов со стороны ЮНИСЕФ и Всемирной организации здравоохранения (ВОЗ) (в центре понятия безопасности питания стоят потребление продовольствия на уровне домохозяйства или отдельного человека) и предложил следующее определение: «Безопасность питания может быть определена как надлежащий уровень питания с точки зрения белков, калорий, витаминов и минералов всех членов домохозяйства в любое время» (Commitee on World Food Security, 2011).

На основе Всемирного продовольственного саммита в Римской декларации закреплено новое определение (с учетом современных условий): «Продовольственная безопасность существует тогда, когда все люди в любое время имеют физический и экономический доступ к достаточному количеству безопасных и питательных пищевых продуктов, который позволяет удовлетворять их пищевые потребности и предпочтения для ведения активного и здорового образа жизни».

«Ликвидация голода, обеспечение продовольственной безопасности и улучшение питания и содействие устойчивому развитию сельского хозяйства» были выделены в самостоятельную цель.

Эта цель является всеобъемлющей и сформулирована вокруг восьми задач - пять из них касаются результатов в области развития, три имеют отношение к средствам осуществления. Данные задачи включают ряд понятий, начиная с голода, неполноценного питания, производительности и дохода мелких фермерских хозяйств, устойчивости методов сельскохозяйственного производства и заканчивая защитой генетических ресурсов в растениеводстве и животноводстве, охватывая в целом все четыре слагаемых продовольственной безопасности и питания (наличие продовольствия, доступ, использование и стабильность (fao.org/ docrep,1996).

\section{3 Методология и Результаты}

Шкала восприятия отсутствия продовольственной безопасности (ШОПБ) - это новый усовершенствованный метод оценки отсутствия продовольственной безопасности, в котором особое внимание уделяется доступу к продовольствию. На основе предварительной оценки информации, собранной по всему миру на индивидуальном уровне, проблема отсутствия продовольственной безопасности наиболее остро стоит в странах Африки к югу от Сахары и в Южной Азии. Результаты исследований с применением методики ШОПБ также указывают на то, что для взрослого населения отсутствие продовольственной безопасности практически везде более выражено среди женщин, чем среди мужчин.

С 2000 по 2015 год число отстающих в росте детей сократилось во всех регионах, за исключением стран Африки к югу от Сахары, где оно выросло. Доля детей в мире в возрасте до пяти лет с избыточным весом с 2000 по 2015 год выросла с 5,1 до 6,2 процента (ФАО, МФСР и ВПП. 2016.)

Исходя из вышеизложенного перед производителями нашей страны встает задача обеспечения населения Кыргызстана продуктами питания, имеющие высокую энергетическую и пищевую ценность, это может быть осуществлено только при разработке новых продуктов здорового и функционального назначения, что является наиболее актуальной на сегодняшний день [Fram, vd, 2015).

В настоящее время для граждан Кыргызской Республики существует ряд негативных последствий, связанных с неполноценным питанием. По данным медицинской статистики и ряда исследований КР испытывает существенное «двойное бремя» неправильного питания, а именно:

1) недостаточного употребления основных питательных веществ (белков, жиров, витаминов и микроэлементов) и калорий с серьезными осложнениями для физического и когнитивного здоровья и развития детей, физического и репродуктивного здоровья женщин детородного возраста (железодефицитная анемия, йододефицитные заболевания, врожденные пороки развития из-за фолиевого дефицита, низкая масса тела при рождении, истощение, задержка роста детей, высокая заболеваемость и смерть 22\% детей до 5-ти лет от обычных болезней детского возраста обусловливается сопутствующим нарушением питания ;

2) проблемы переедания, использования в питании трансгенных жирных кислот (ТЖК), углеводов и солей с повышенным риском возникновения таких неинфекционных заболеваний (НИЗ), как заболевания сердца и сосудов (повышенное артериальное давление, ишемическая болезнь сердца), сахарный диабет 2-го типа и некоторые виды злокачественных новообразований. По данным МЗ КР в течение ряда лет болезни сердца и сосудов продолжают занимать первое место в структуре причин смертности населения (50,5\%, РМИЦ), на втором месте - новообразования (11\%, РМИЦ).

В Кыргызской Республике, если в 2015г. энергетическая ценность рациона питания (2212 ккал/день) населения в целом и трудоспособной его части, была выше, чем минимальная норма потребления (2101 ккал/день), (утверждено постановлением правительства КР (от 6 ноября 2009 года № 694)), то в 2017г. 
имело место ее снижение на 5,1\% и 0,2\%, по сравнению с данными от 2015 г (2097 ккал/день) и минимальной нормой потребления (2101 ккал/день) соответственно. По результатам исследований видно, что практически все эти годы имело место недостаточное употребление белков (мясо, молочные продукты и бобовые) и жиров (растительные масла) в среднем на 23,3\% и 16,9\% соответственно (nbkr.kg, 200-2017).

Энергетическая потребность населения восполняется за счет мучных и кондитерских (сахара) изделий и картофеля, поскольку большинство жителей КР (74\% всего населения, 76.7\% мужчин и 71.1\% женщин) употребляют меньше 5 порций овощей и фруктов в день (МЗ КР, ВОЗ, 2013) при рекомендуемых 5-9 порций (в среднем не менее 400 г/с).

Большую тревогу вызывает недостаточное питание среди детского населения. Так, в рационе питания детского населения (1-17 лет) в течение 2015-2017гг. имело место выраженный дефицит употребления не только белков (на 27,5\%) и жиров (на 22,7\% и), но и энергии (на 2,5-2,8\%). У детей в возрасте от 1-3 года недостаток белков (на 46,8-45,2\%), жиров (на 44,1-40,7\%) составляет почти половину, а дефицит энергии (на 26,1 - 22,5\%)- одну четвертую часть от минимальной потребности в них за сутки (Н.Турдубекова и др.).

По данным исследований Министерства Здравоохранения среди населения КР имеет место высокая распространенность железодефицитной анемии (37,8\% беременных и 34,2\% небеременных женщин, 42,6\% детей), скрытого дефицита железа (41\% женщин), дефицита фолатов (42\% небеременных женщин), йододефицитных заболеваний (61,6\% беременных женщин и 43,1\% детей школьного возраста), избыточной массы тела и ожирения (35,7\% женщин и $9 \%$ детей первых 5-ти лет жизни), недостаточной массы тела (7,3\% женщин и 18\% девочек $15-19$ лет).

По данным исследований Министерства Здравоохранения среди населения КР имеет место высокая распространенность железодефицитной анемии (37,8\% беременных и 34,2\% небеременных женщин, 42,6\% детей), скрытого дефицита железа (41\% женщин), дефицита фолатов (42\% небеременных женщин), йододефицитных заболеваний (61,6\% беременных женщин и 43,1\% детей школьного возраста), избыточной массы тела и ожирения (35,7\% женщин и 9\% детей первых 5-ти лет жизни), недостаточной массы тела (7,3\% женщин и 18\% девочек $15-19$ лет).

В Кыргызстане в 2014 г. у 13\% детей в возрасте до 5-ти лет отмечалась задержка роста. Распространенность задержки роста среди детей в Жалал-Абадской $(21,3 \%)$ и Нарынской $(16,4 \%)$ областях несколько выше, чем в среднем по республике. Одной из причин высокой распространенности задержки роста в указанных областях, очевидно, является более выраженный дефицит употребления детьми раннего возраста калорий (на 20,6\% и 20,6\%), белков (на 41,9\% и 41\%) и жиров (на 57,6\% и 47,5\%) по сравнению со средними данными по республике, соответственно: на19,8\%, 38,7\% и 35,5\% [10].

Другой важной проблемой, связанной с неполноценным питанием, является высокое содержание трансгенных жирных кислот (ТЖК) и соли в продуктах питания населения КР. Так, по данным совместного выборочного исследования МЗ КР и ВОЗ (2016) за счет одной усредненной порции еды домашнего приготовления и из сети общественного питания жители страны получают от 70,8 до 170,4\% ТЖК и 82,9$99,0 \%$ - соли от рекомендуемого максимального ежесуточного их потребления. С избыточным поступлением в организм человека ТЖК, сахара и соли связано развитие избыточной массы тела и ожирения, заболеваний сердца и сосудов (высокое артериальное давление, инфаркт, инсульт и др.), диабета 2-го типа и некоторых форм злокачественных новообразований.

Это только данные по дефициту белков, жиров, углеводов. По недостаточности микро и макронутриентов исследований почти что нет.

Низкая производительность сельского хозяйства негативно влияет на объемы отечественного производства сельскохозяйственной продукции и приводит к низкой конкурентоспособности отечественных сельхозпроизводителей. Сельскохозяйственное производство в Кыргызстане получает прямую и косвенную поддержку в виде льготного кредитования и сниженной налоговой нагрузки. Однако размеры поддержки сельских товаропроизводителей в странах - основных контрагентах по торговле сельхозпродукцией несопоставимо больше.

В стране имеет место устойчивый рост населения. Среднегодовой темп прироста составляет 2,0\%, городское население растет с темпом 2,2\% и сельское - с темпом 1,9\% (2016 г.) [10].

Согласно прогнозам ООН, прирост населения в текущем десятилетии может составить минимум 900 тысяч человек.

\section{4 Заключение}

Вступление Кыргызстана в ЕАЭС создает условия для превращения аграрного сектора республики в одного из активных участников регионального агропродовольственного рынка на евразийском экономическом пространстве. Решение этой задачи зависит от адекватности обоснованности аграрной политики, способной обеспечить эффективное использование благоприятных природно-экономических условий для наращивания агроэкспортного потенциала страны (Джурупова и Саматова, 2016). 
В связи с этим, сельскохозяйственное производство при обеспечении продовольственной безопасности должен быть адекватным динамичному росту населения. Товаропроизводителей в странах основных контрагентах по торговле сельхозпродукцией несопоставимо больше. Низкий уровень жизни населения, большая доля бедных препятствует обеспечению питательными веществами, в достаточном количестве, которые необходимы для обеспечения нормальной жизнедеятельности. Кроме этого, создаются устойчивые риски потребления опасных для здоровья и некачественных, вредных продуктов, которая предлагается торговлей из-за слабой инфраструктуры по обеспечению безопасности пищевых продуктов питания, недостаточной информированности граждан о правильном питании. Закон КР «О продовольственной безопасности» (от 4 августа 2008 года № 183 не охватывает весь комплекс составляющих продовольственной безопасности: наличие, доступность, использование, стабильность. Не учитывает новые возможности, связанные со вхождением КР в ЕАЭС.

В связи с этим, основными направлениями агропродовольственной политики в условиях углубления интеграции должны стать:

- улучшение структуры питания в КР должна проводиться за счет увеличения производства продуктов питания с повышенным содержанием белка, витаминов и других макро и микронутриентов. С этой целью государство должно проводить стимулирование сельскохозяйственных производителей и переработчиков, которые позволят насытить внутренний рынок качественной сельскохозяйственной продукцией;

- необходимо усилить требования к безопасности и к качеству продуктов питания внутреннего рынка;

- информирование населения по вопросам правильного питания, безопасности пищевых продуктов и ориентация их на потребление качественной и безопасной продукции, позволит им улучшить свой статус питания. Это должно происходить путем разработки государством мер, государством, позволяющим улучшить состояние питания в республике;

- государство должно разработать механизмы поддержки питания детей, социально уязвимых слоев населения исходя из минимального энергетического баланса питания, требований к качеству;

- защита внутреннего продовольственного рынка должна происходить с учетом принятых в ЕАЭС разрешенных уровней мер поддержки сельского хозяйства;

- необходимо ввести предприятия по производству продуктов детского питания, обогащенных железом, витаминами и другими необходимыми биологически активными веществами и продуктов здорового питания;

- обеспечение достаточной и стабильной сельскохозяйственной продукцией, и продовольствием внутреннего рынка, а также финансирование программы продовольственной безопасности в полном объеме и своевременно - должна быть основной задачей Правительства.

\section{Литература}

- Committee on World Food Security [Text]: thirty-seventh ses. CES: 2011: Final report. - Rome, 2011. - 39 p.

- Fram, M.S., Bernal, J. \& Frongillo E.A. (2015). The Measurement of Food Insecurity among Children: Review of literature and concept note, Innocenti Working Paper No.2015-08, UNICEF Office of Research, Florence.

- Бюллетень Национального банка Кыргызской Республики 2008-2017 гг [Электронный ресурс]. Режим доступа http://www.nbkr.kg. - Загл. с экрана.

- Джурупова Б.К., Саматова Г.Ж. Проблемы и пути решения продовольственной безопасности и питания в Кыргызской Республике // Наука вчера, сегодня, завтра: сб. ст. по матер. XXXV междунар. науч.-практ. конф. № 6(28). - Новосибирск: СибАК, 2016. - С. 139-143.

- К Концепция модернизации социально-эономического раэвития Кыргызской Республики на период до 2015 г / - Бишкек: ЦЭС при МЭРиТ КР, 2008. - 128c

- Концепция повышения продовольственной безопасности государств - участников СНГ: утверждена Решением Совета глав правительств СНГ о Концепции повышения продовольственной безопасности государств - участников СНГ от 19 ноября 2010 года [Электронный ресурс]. - URL: ecis.info/foto/pages/20000.doc

- Кыргызстан в цифрах [Текст]: месяч. публ. - Бищкек: Нацстаком, 2009. - 332 с.

- Национальный статистический комитет Кыргызской Республики. Годовые отчеты [Электронный pecypc]. - Режим доступа http://www.stat. kg. - Загл. с экрана.

- $\quad$ О качестве и безопасности пищевых продуктов [Текст]: закон Кырг. Респ. офиц. текст. - Бишкек: [б.и.], 2007. -8 с. 
- Отчет по итогам мониторинга и оценки результатов реализации Стратегии развития социальной защиты населения КР за 2012 - 2014 годы (Раздел «Социальная защита семей и детей, находящихся в трудной жизненной ситуации») - Н.Турдубекова, Н.Ташпаева, Г.Ибраева, А.Кызалкова Б.: ОсОО «ЛайнПринт», 2014.-49 с.

- Римская декларация по всемирной продовольственной безопасности [Электронный ресурс]. - Режим доступа: http://www.fao.org/docrep/003/w3613e/w3613e00.НТМ. - Загл. с экрана.

- ФАО, МФСР и ВПП. 2016. Мониторинг продовольственной безопасности и питания в поддержку осуществления Повестки дня в области устойчивого развития на период до 2030 года: подведение итогов и планы на будущее. Рим, ФАО. 


\title{
Создание Цепи Ценности Экспорта Меда Value Chain in Export Honey
}

\author{
Assoc. Prof. Dr. Akylbek Umetaliev (Kyrgyz State Technical University, Kyrgyzstan)
}

\begin{abstract}
This paper examines creating a value chain in export honey from the Kyrgyz Republic. The annual production is 12,000 tons, 500 tons are exported. The Supply Chain Operation Reference (SCOR model) at three stages of optimization of honey production has been adapted. The following research methods were used: desk study, survey of producers and consumers, interviews with relevant organizations, personal observations retailers. At the initial stage of optimization, recommended to maintain planning of the number of bee colonies. How to effectively use natural resources for bee colonies - finding useful flora (a flowering mass of plants to collect nectar) and finding areas with the best climate (temperature, humidity, sunshine, air movement) are the objectives of action plan for interim stage. The natural mountain landscape, the sun, air, water give honey special qualities, therefore, at the final stage of market promotion, honey must acquire potential status as a unique product. For honey producers there are two optimal options for export. The first is the packaging of honey in a container of $0.1-0.21$., and positioning it as an expensive premium product. High marketing costs are offset by high added value in the supply chain. The second is the delivery of honey in large containers of 20-30 1., for further packaging, already in the territory of the buyer. An attractive choice for honey producers with guaranteed product sales and high profitability of sales. Research results increase honey production up to $30 \%$ and export volume up to $7 \%$.

В данной статье исследована проблема роста объема экспорта меда производимая в Кыргызской Республике. Ежегодный объем производства меда 12.000 тонн, экспортируются только 500 тонн. Создание цепи поставок меда с добавленной стоимостью обеспечивающее натуральные и особые свойства меда является целью данного исследования. Адаптирована референтная модель оперирования цепью поставок на трех этапах оптимизации производства меда. Применены методы исследования: кабинетное или анализ вторичной информации, анкетирование производителей и потребителей меда, интервью профильных и смежных организаций, личные наблюдения по условиям розничных продаж. На начальном этапе оптимизации рекомендуется выдержать надлежащее планирование количества пчелосемей. Как эффективно использовать природные ресурсы для пчелосемей - поиск полезной флоры (цветущей массы растений для сбора нектара) и поиск местности с наилучшим климатом (температура, влажность, солнечность, движение воздуха) являются задачами плана действий промежуточного этапа. Неповторимый, натуральный горный ландшафт, солнце, воздух, вода придают меду особые качества (уникальность), следовательно, на конечном этапе продвижения на рынок мед должен приобретать потенциальный статус как уникальный продукт. Для производителей меда в стране есть два оптимальных варианта для экспорта. Первое - расфасовка меда в тару 0,1-0,2 л., и позиционировать как дорогой продукт премиум класса. Высокие издержки на маркетинг компенсируются высокой добавленной стоимостью в звеньях цепи поставок. Второе - поставка меда в больших тарах 20 - 30 л., для дальнейшей расфасовки уже на территории покупателя. Привлекательный выбор для производителей меда гарантией сбыта продукции и высокой рентабельностью продаж. Результаты исследований увеличивает объем производства меда до 30 \% и объем экспорта до $7 \%$.
\end{abstract}

\section{1 Введение}

В Кыргызской Республике вырабатывается ежегодно около 12 тысячи тонн меда. Ежегодный объем рассчитан на основе потребляемого количества расходных материалов для пчеловодства из-за отсутствия точных данных со стороны профильных ведомств и пчеловодов по произведенному объему меда. Официальный экспорт оценивается около 500 тонн в год, но при этом существуют также незафиксированные объемы экспорта, охватываемые туристами и линейкой дополнительной продукции меда с добавками как орехи и сухофрукты разных видов. Расширяется география экспорта меда, кроме стран входящих в ЕАЭС мед экспортируется в Монголию, Турцию, Катар, ОАЭ, Японию и Малайзию. В 2018 году Кыргызстан экспортировал в Китай мед на 767 тысячи долларов, что больше по сравнению с показателем прошлого года на 6 \%. В образовании цепочки добавленной стоимости для экспортной цепи поставок меда одним из важных критериев является качество продукта, и оно должно быть контролируемо на первичном этапе производство продукта. Практика последних лет показывает, что для экспорта меда наряду с такими требованиями как вкусовые качества, цвет продукта, специфичные целебные свойства, также особо важен состав продукта без токсичных и фармакологических веществ. По данным Ассоциации переработчиков меда только до 7 процентов ежегодно произведенного объема меда в стране прошли лабораторные исследования и получили соответствующую сертификацию для экспорта. Новый метод эффективного планирования и управления рисками во внутренних цепях поставок (in-bound supply chain) и во внешних цепях поставок (out-bound supply chain) служат механизмом реализации продвижения меда 
на экспорт. Целью данной исследовательской работы является проектирование новой модели оперирования цепью поставок (SCOR) для меда с индикаторами качества и объема экспорта. Реализация цели предполагает решение следующих задач: а) адаптировать эффективную модель оперирования цепью поставок меда; б) планировать операции в цепи поставок с внедрением двух индикаторов - качество меда как товара и объем производимого меда; с) разработать механизм трансформации меда как уникальный продукт с добавленной стоимостью.

\section{2 Методология Исследования}

Для проведения исследования по данному проекту был применен экспертный метод с применением следующих инструментов: кабинетное исследование или анализ вторичной информации - статистические данные, интернет ресурсы, отчеты потребителей и производителей меда; анкетирование производителей и потребителей меда; опрос и интервью профильных и смежных предприятий; личные наблюдения и анализ сети оптовых и розничных продаж. Адаптирована модель оперирования цепью поставок (SCOR-model), позволяющая описать и создать основу для совершенствования цепей поставок конкретного продукта компании. Границы модели определяются от поставщика до потребителя продуктов, и описывает так называемую «расширенную» цепь поставок как на нижнем рисунке 1.

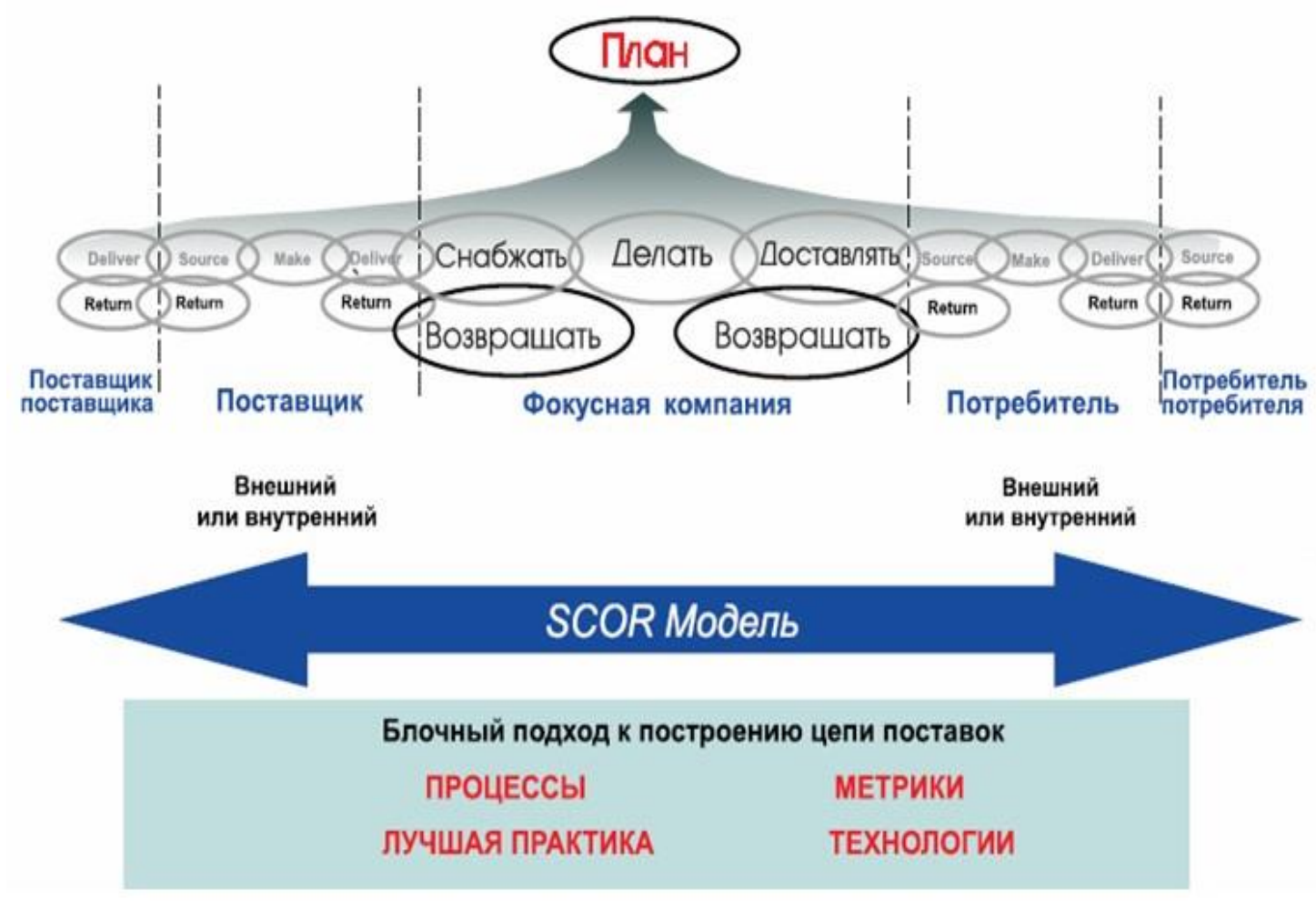

Рисунок 1. Схема Модели Оперирования Цепью Поставок (SCOR Model).

\section{3 Создание Цепи Ценности Экспорта Меда}

Как показано на рисунке, в создаваемой цепи поставок для любого продукта должен быть описан единый процесс производства в цепи, индикаторы измерения оценки процесса производства, применяемые технологии и сравнение с лучшей практикой. Проектирование или реорганизация существующей цепи поставок меда осуществляется планированием процесса производства (делать) меда предпринимателями (фокусная компания) на трех этапах - начало процесса, промежуточный процесс и окончание процесса. На начальном этапе производства меда рекомендуется выдержать надлежащее планирование действий по уходу за пчелами и по ведению пчеловодства. По принятой методике проводить кормление и подготовку улей на пассивный сезон и зимовку, соблюдение режима температуры и вентиляции улей для обеспечения здорового ухода за пчелами. Подготовительные мероприятия охватывает лечение естественными препаратами как органические кислоты (муравьиная, щавельная), эфирные масла, лекарственные растения. Оптимальной целевой группой являются жители сельской местности с существующим активом в виде земельной доли, с действующим бизнесом растениеводства и животноводство. Также, требуется помещение и обязательно легковая автомашина повышенной проходимости, тягач с прицепом платформой и летательные аппараты (дроны). Для пчеловодства количеством 25-35 улей необходимо 2 человека с полной занятостью со знанием и опытом работы. Самым критичным риском в пчеловодстве 
становится идентификация улей и племенная работа пчел, потому что участились падежи пчел из-за болезней и снизился их продуктивность. Как временные меры пчеловоды начали импортировать семенные пчелы из разных стран Карпатского региона. Поэтому в Кыргызской Республике налаживается племенная работа и уже зафиксировано 5 племенных ферм, занимающихся разведением пчел. На промежуточном этапе производства меда в качестве постоянного фактора выступают природные ресурсы. Биотическая часть окружающей среды: флора - цветущая масса растительного мира для сбора нектара. Абиотическая часть окружающей среды: водные ресурсы, пространство для пчел с умеренной рельефной поверхностью и с доступной местностью, солнечные дни, оптимальная температура, влажность и циркуляция воздуха. Для увеличения производимого объема меда с учетом географических условий мест сбора меда рекомендуется спланированная кочевка с учетом движения цветения растений. В качестве промежуточного результата можно засчитать факт потенциального повышения урожайности сбора меда на 20 - $30 \%$. Данные получены из проведенного эмпирического исследования студентами после опроса фермеров: Салахудинова Марата - пчеловода с 20-летним опытом житель города Балыкчи, Иссык-Кульской области и Алымжана Малдыбай уулу - пчеловод с 5-летним опытом житель города Сокулук, Чуйской области. Они добились роста сбора меда на примере кочевки с солнечных районов Чуйской области в Иссык-Кульскую область по мере цветения лугов и предгорий с апреля по июнь в зависимости от температурных условий этого периода года. Конечный этап производства меда совмещен с процессом реализации меда. Проведенные исследования по адаптации модели оперирования цепью поставок меда предполагает увеличение объема экспорта меда до 10 процентов и укрепит его потенциал как уникальный продукт. В технологическом плане мед относится к категории продуктов, которые не ставят специальные сложные технические требования для хранения и транспортировки. Температурный диапазон для оптимального хранения всех целебных специфичных свойств меда составляет от 8 до 20 градусов по Цельсию; мед нельзя замораживать, а также он теряет целебные свойства при температуре свыше 35 градусов по Цельсию. Для подлинности и оригинальности разновидностей меда нужен строгий учет вида и мест производства меда. Практика показывает, что в экспорте меда наметились две главные тенденции. Первая - ближние страны, в частности Китай заинтересован в закупке меда крупными партиями в тарах 20-30 килограммов, далее реализовать его уже на своей территории. Такой вариант гарантирующий сбыт продукции и покрытие всех операционных расходов с рентабельным уровнем бизнеса привлекателен для пчеловодов. Вторая упаковка меда в тарах 0,1-0,2 килограммов и позиционировать как дорогой продукт премиум класса. Ключевая задача - гарантия уникальности продукта, привлекательности и надежности упаковки. Высокие издержки на маркетинг компенсируются высокой добавленной стоимостью в звеньях цепи поставок. Имеется уже опыт экспорта меда в Монголию, Турцию, Катар, ОАЭ, Японию и Малайзию. Действующий маркетинговый механизм ограничен периодическими выставками меда, и заинтересованные потребители напрямую находят контакты и закупают нужную продукцию. Следовательно, очень важно распространение информации о кыргызском меде через площадки в сети интернета как Facebook и другие. Эти ресурсы социальных сетей активно используются огромными массами пользователей. Если использовать надлежащим образом механизмы и возможности продвижения продукции через эти информационные ресурсы, то спрос на мед возрастет независимо от сезона визита туристов. Все вышеуказанные действия должны синхронно и совместно координировать синхронно и совместно Союзы и Объединения, созданные самими пчеловодами. Созданные Союзы и Объединения являются самоуправляемыми, проводят консультации, обучение пчеловодов и представляет их интересы при экспорте меда. По оценке Казима Каракетова, Президента Кыргызского Союза пчеловодов реализация предложенных рекомендаций позволит увеличить производство меда до 30 процентов и экспорт меда до 10 процентов.

\section{4 Результаты}

Идентификация и регулярное обновление племени пчелиной семьи для исключения болезней и повышения продуктивности пчел.

Контроль среды обитания пчел новейшими технологиями для исключения запретных препаратов в составе меда.

Постоянное и своевременное перемещение пчелиной семьи в оптимальные сроки созревания флоры.

Усилить координирующую и самоуправляемую функцию Союза пчеловодов как единого органа в процессе регулирования экспорта меда.

Наладить распространение информации о кыргызском меде через площадки в сети интернета как Facebook и другие.

\section{Литература}

- Джерард Кэчон, Христиан Тервиш, 2011. Соответствовать Спросу и Предложению: Введение в операционно-производственное управление. 3- издание. МакГроу-Хил. 
- Кыргызским медом заинтересовался Китай, http://rus.azattyk.org/a/27555152.html.

- Лукинский В. С., 2008. Модели и методы теории логистики: Учебное пособие. 2-е изд. Питер.

- Мед Кыргызстана охватывает международные рынки, http:/www.mongoliaeconomy.com/kyrgyzstanhoney-conquers-international- markets

- Мед Кыргызстана признали лучшим, https://rg.ru/2013/10/17/luchshii.html

- Полезные свойства меда, http://kakmed.ru/raznoe-o-mede.

- Роналд Бэллоу, 2003. Логистика Предпринимательства: Управление цепями поставок 3-е издание. Пирсон Прентис Холл, Ballou.

- Стивен Намиас, 2004. Анализ Производства и Операционно-производственного управления, 5 издание. МакГроу-Хил.

- Сунил Чопра, Питер Майндл, 2003. Управление цепями поставок: Стратегия, Планирование и Операционное управление. 5-е издание. Пирсон Прентис Холл.

- Щербаков В. В., Мерзляк А. В., Коскур-Оглы Е. О., 2011. Автоматизация бизнес-процессов в логистике: Учебник для вузов. Стандарт третьего поколения. Питер. 


\title{
Формирование Рыночной Модели в Финансировании Здравоохранении Кыргызской Республики
}

\section{Formation of a Market Model in the Financing of Health Care in the Kyrgyz Republic}

\author{
Prof. Dr. Damira Japarova (Kyrgyzstan-Turkey Manas University, Kyrgyzstan)
}

\begin{abstract}
Due to the collapse of the Union, there was a reduction in funding for health care costs, as well as deterioration in the infrastructure and quality of medical services. The transitional economy in the Kyrgyz Republic has identified additional features in the health system. The main ones are the low level of funding, the presence of the shadow market of medical services, inefficient structure and the prevalence of high-cost hospital treatment. The market mechanism is developing, however, without state regulation.

The Kyrgyz Republic continues to reform its health-care system. The task was to improve the methods of their financing. New mechanisms for financing medical services have been introduced. Despite the reduction in the number of hospitals, the number of patients treated in hospitals has increased.
\end{abstract}

\section{1 Введение}

Переходная экономика в Кыргызской Республике определила дополнительные особенности в системе здравоохранения. Она несет в себе наследие системы, монопольно предоставляющей медицинские услуги. Основные из них - это низкий уровень финансирования, наличие значительного по масштабам теневого рынка медицинских услуг, неэффективная структура и преобладание высокозатратного стационарного лечения. В советское время в экономической литературе здравоохранение рассматривалось как отрасль непроизводственной сферы. И в этих условиях ресурсы этой сферы деятельности образуются согласно остаточному принципу финансирования. Финансирование отрасли и работа лечебно-профилактических учреждений осуществлялось на основе нормативов, спускаемых до каждого медицинского учреждения органами государственного управления. В таких условиях нет мотивации труда и экономических стимулов, а также оценки его результатов. Организаторы здравоохранения оценивали объем средств на содержание медицинских учреждений без поиска альтернативных вариантов вложения ограниченных ресурсов [Шейман И.М. Экономика здравоохранения, 2000.].

В этих условиях невозможно получить ответы на вопросы: строить или реконструировать больницу, лечить пациента в стационаре или в поликлинике, взять нового врача или больше заплатить работающему врачу? В итоге имела место перегрузка стационаров, недооценка возможностей амбулаторнополиклинических учреждений, что вела к большим экономическим потерям. Результатом являлась низкая эффективность использования ресурсов. Непризнание этого влечет за собой уравниловку, низкое качество медицинской помощи, и в конечном итоге, низкий социальный эффект.

\section{2 Основная Часть}

В связи с распадом Союза система здравоохранения Кыргызстана испытала серьезные негативные последствия, связанные с сокращением финансирования расходов на здравоохранение, а также ухудшением инфраструктуры и качества предоставляемых медицинских услуг. С 1996 г. в здравоохранении республики на основе реформирования и изменений законодательной базы здравоохранения произошел переход от государственной медицины к бюджетно-страховой. Введена система обязательного медицинского страхования.

Наличие теневого рынка медицинских услуг говорит о том, что рыночный механизм развивается, однако без государственного регулирования. Неофициальная плата выступает как не регулируемое государством дополнение к рыночной цене медицинских услуг, что невозможно отменить или уничтожить.

Существует резкая диспропорция в обеспечении кадрами, в регионах ощущается недостаток врачей. Так, в городе Оше на 10000 насееления приходится 13 врачей, в Таласской области, Нарыне и в других отдаленных от центров регионах - менее 9. Наблюдается значительный отток врачей в Бишкек и Чуйскую область, а также в ближнее зарубежье. Только за 2016 г. выехало за границу 100 дипломированных врачей [Необходимо неотлагательно остановить отток семейных врачей.]. Средняя заработная плата врачей, работающих в поликлиниках, в 2017 г. достигла лищь 12105сом, врачей стационаров - 13006 сом [Отчет об итогах деятельности Фонда обязательного медицинского страхования при Правительстве Кыргызской Республики за 2017 год]. В связи с низкой заработной платой квалифицированные врачи уезжают в Россию, 
Казахстан и в дальнее зарубежье, их места занимают молодые специалисты, только что окончившие медицинский институт и медицинское училище.

В системе здравоохранения Кыргызской Республики имеются два основных источника финансирования: государственный и частных лиц. Они представляют собой потоки внутренних расходов. Частные средства финансирования здравоохранения - это выплаты за лечение средств доходов домохозяйств. Пациенты осуществляют официальные и неформальные расходы за оказываемые им медицинские услуги, кроме того, покупают лекарства за собственные средства.

Среди всех доходов Единого плательщика республиканский бюджет является главным источником финансов, направляемых на поддержку государственных лечебных организаций. Средства из Социального фонда застрахованных граждан и государственного бюджета для незастрахованных граждан, поступающих согласно Программе государственных гарантий, образуют Фонд обязательного медицинского страхования (ФОМС). К категории застрахованных граждан за счет государственного бюджета относятся граждане в возрасте 70 лет и выше, дети, не достигшие 5-летнего возраста, студенческая молодежь, граждане, имеющие инвалидность. Для того чтобы показать реальные тенденции, рассмотрим динамику расходов Единого плательщика. Это можно увидеть по данным таблицы 1 . Рост расходов республиканского бюджета в номинальных показателях за 2017 г., по сравнению с 2009 г., составил 2,4 раза. или составил 9 514,7 млн. сом против 4008,3 млн. сом в 2009 г (табл.1).

Национальной программой «Манас Талими», нацеленной на осуществление реформы финансовой системы в сфере здравоохранения, предусмотрено снизить значимость бюджетов местного уровня [Национальная программа реформы здравоохранения Кыргызской Республики «Манас таалими» на 20062010 годы]. В связи с этим в последние годы местные бюджеты практически не участвуют в финансировании здравоохранения на территории КР, кроме Бишкека.

\begin{tabular}{|l|c|c|c|c|c|c|c|c|c|c|}
\hline $\begin{array}{l}\text { Основн. } \\
\text { источн. }\end{array}$ & 2009 & 2010 & 2011 & 2012 & 2013 & 2014 & 2015 & 2016 & 2017 & $\begin{array}{c}2017 \text { г. в } \\
\% \text { к } 2009 \text { г. }\end{array}$ \\
\hline Респуб. бюджет & 4008,3 & 4216,5 & 6056,7 & 7920 & 8481,4 & 8177,1 & 8551,9 & 9081,8 & 9514,7 & 237,4 \\
\hline ФОМС & 765,4 & 774,4 & 1062,2 & 1210 & 1390 & 1856,8 & 1855,7 & 1916,0 & 2270,4 & 250,3 \\
\hline Частные & 333,8 & 347,2 & 434,5 & 538,4 & 660,3 & 841,8 & 924,1 & 1328,5 & 1414,4 & 397,9 \\
\hline Всего & 5107,5 & 5338,1 & 7553,4 & 9668,4 & 10531,7 & 10875,8 & 15590,9 & 12326,5 & 13199,5 & 241,3 \\
\hline
\end{tabular}

Таблица 1 - Динамика общих расходов здравоохранения Кыргызской Республики (млн. сом) Источник: Данные ФОМС КР за 2009-20172

Однако несмотря на определенный рост финансирования сектора здравоохранения, доля расходов государства в бюджете КР остается незначительной, составляя порядка 10\%, или продолжается традиционный остаточный принцип финансирования системы здравоохранения. По данным табл. 2 , расходы на здравоохранение по отношению к ВВП за анализируемый период почти не изменились. Рассмотрим динамику расходов государства по источникам финансирования. Анализ источников бюджета Единого плательщика показывает, что доля финансовых ресурсов, поступивших из республиканского бюджета за анализируемый период, увеличилось лишь на $0,9 \%$.

\begin{tabular}{|l|c|c|c|c|c|c|c|c|c|c|}
\hline $\begin{array}{l}\text { Основн. } \\
\text { источн. }\end{array}$ & 2009 & 2010 & 2011 & 2012 & 2013 & 2014 & 2015 & 2016 & 2017 & $\begin{array}{l}2017 \text { г. в \% } \\
\text { к } 2009 \text { г. }\end{array}$ \\
\hline бюджет & 2,0 & 1,9 & 2,0 & 2,1 & 2,8 & 2,6 & 2,1 & 2,02 & 2,9 & $+0,9$ \\
\hline ФОМС & 0,38 & 0,35 & 0,34 & 0,37 & 0,45 & 0,43 & 0,37 & 0,39 & 0,54 & $+0,16$ \\
\hline Частн. & 0,16 & 0,16 & 0,15 & 0,15 & 0,2 & 0,2 & 0,2 & 0,9 & 0,25 & $+0,09$ \\
\hline Всего & 2,54 & 2,41 & 2,49 & 2,62 & 3,45 & 3,23 & 2,67 & 3,31 & 3,2 & $+0,66$ \\
\hline
\end{tabular}

Таблица 2 - Расходы на здравоохранение по отношению к ВВП (\%). Источник: Данные ФОМС КР за $2009-20172$

Однако следует отметить, что за период с 2009-2017 гг. произошел определенный рост количества граждан, получающих социальные пособия. Это увеличение количества детей, пожилых людей пенсионного возраста и категорий населения, получающих социальные пособия.

Но при этом финансирование указанных категорий населения не пересматривалось. Поэтому финансирование лечения детей, пенсионеров и инвалидов далеко не соответствует реальным потребностям указанных категорий населения. Таким образом, низкий уровень бюджетных расходов и поступлений по ОМС объясняется тем, что на протяжении многих лет происходило недофинансирование сектора здравоохранения. 
По данным таблицы 3, недофинансирование составило в 2016 г. 169292,9 сом, или 56,3\% от потребностей, рассчитанных в денежных средствах. Если учесть, что потребности, с учетом ограниченности ресурсов, рассчитаны по минимуму, и они не покрываются, это и является причиной декларативного характера. Программы государственных гарантий в Кыргызстане. И лица, оставшиеся без работы, и студенты остаются за пределами Программы государственных гарантий. Они не могут рассчитывать на медицинскую помощь со стороны государства. Если учесть, что данная категория населения представляет собой потенциальный трудовой ресурс на рынке труда, то ее качество будет влиять на развитие реального сектора экономики.

\begin{tabular}{|l|c|c|c|}
\hline \multicolumn{1}{|c|}{$\begin{array}{c}\text { Категория } \\
\text { населения }\end{array}$} & Потребность & $\begin{array}{c}\text { Профинан- } \\
\text { сировано }\end{array}$ & $\begin{array}{c}\text { Профинансиро- } \\
\text { вано в \% к } \\
\text { потребностям }\end{array}$ \\
\hline Дети до 16 лет & 284,689 & 160,397 & 56,34 \\
\hline Пенсионеры & 771,812 & 598,37 & 77,5 \\
\hline Лица, получающие социальные пособия & 126,61 & 105,01 & $* 3,3$ \\
\hline Безработные & 4641.6 & $*$ & $*$ \\
\hline Военнослужащие & 829.5 & $*$ & $*$ \\
\hline Студенты & 200,26 & $*$ & $*$ \\
\hline Всего & 400,029 & 230,736 & $*$ \\
\hline
\end{tabular}

Таблица 3 - Исполнение средств ОМС, выделяемых из республиканского бюджета на социальные категории населения Кыргызской Республики за 2016 г. (млн. сом.)*Финансирование не предусматривается. Источник: Данные Министерства здравоохранения КР за 2016 г

Статистика свидетельствует, что львиная доля средств, которые государство предоставляет сфере здравоохранения, идет на помощь льготникам. Это большой показатель - 94\%, для остальных средств явно не хватает для обеспечения лечения и профилактики заболеваний граждан, которые вынуждены сами (и граждане, и работодатель) финансировать оказываемые услуги. Таким образом, декларируется одно, а в реальности мы наблюдаем иные экономические условия. Для того чтобы получить медицинскую помощь, необходимо нести все больше и больше расходов, поскольку они беспрерывно растут. Как было отмечено выше, базовая программа ОМС покрывает лишь 57\% минимальных потребностей социальных категорий населения, которые нуждаются в бесплатном лечении. И для решения проблем со здоровьем, чтобы выжить они должны самостоятельно оплачивать медицинские услуги. Как показывает практика, этот процесс стихийный и бессистемный. Нет продуманной и объективно обусловленной стратегической программы замены бесплатных услуг на платные. Поэтому встретить что-то подобное в официальных или законодательных материалах не приходится. Несмотря на это, она реально существует.

Связь видится в существовании старых прейскурантов. Датируемые еще 2008 г., некоторые расценки ниже себестоимости затрат на препаратные процедуры. Например, это касается рентгена и развернутого анализа крови. Так в городе Таласе рентген работает только для стационара и стоит 50 сом. Цены на анализы не покрывают затраты. Технология старая, томографии нет. Ультразвук стоит 25 сом, обследование желчного пузыря и печени - 38 сом, прокол гайморовой пазухи - 64 сом, вскрытие паратонзилярного абсцесса - 47 сом. А в частной клинике только общий анализ крови стоит 160-300 сом. Исследование методом анкетирования показало, что пациент, обративший в лечебное заведение по поводу хирургической операции, зачастую вносит, кроме сооплаты, дополнительные средства. Среди опрошенных по этому поводу высказалось 26,9\% пациентов. Этим можно объяснить, почему многие высказываются за легализацию дополнительно вносимых средств. Из обследованных пациентов за легальную оплату медицинской помощи высказалось 70,2\% [Джапарова, Д. Экономический анализ системы здравоохранения в КР. Проект КТУ «Манас»].

На вопрос пациентам поликлиники: «Считаете ли нужным платить медицинским работникам за качество лечения?»- 36,4\% ответили «да». При этом 67,8\% пациентов поликлиник абсолютно не знают о перечне 24 бесплатных медицинских услуг по Программе государственных гарантий. И 41,2\% пациентов считают, что гарантировать качественное лечение можно только путем оплаты медицинских услуг. В настоящее время одни и те же медицинские работники и на одном и том же оборудовании оказывают и платные, и бесплатные услуги. В этих условиях не обойтись без нарушений и теневых доходов в системе здравоохранения.

Из числа опрошенных пациентов 58\% считают, что качественное лечение можно получить только путем оплаты лечения, и 28,6\% опрошенных пациентов оплачивают медицинские услуги в руки врачам [Джапарова, Д. Экономический анализ системы здравоохранения в КР. Проект КТУ «Манас» 2014г.]. При этом удельный вес поступлений от частных выплат, как сооплата и официальная плата за медицинские услуги, поступающие в доходы Единого плательщика, составляет лишь 10,8\%. Это значит, что реальная оплата за услуги имеет неофициальную форму [Джапарова, Д. Мотивация труда медицинских работников 
в Кыргызстане - путь повышения качества медицинских услуг, 2016г.]. Высказывая свою позицию в этом вопросе, отметим, что не считаем взяткой платежи, которые попадают в руки врача по неформальным каналам. В системе финансирования здравоохранения не разработан регулирующий механизм. Мы не можем отменить неофициальные платежи, которые в этих условиях дополняют рыночную цену. И это никем не регулируется. Значит, правы те, кто требует легализовать эти дополнительные платежи. Тем самым они будут на виду, и их можно будет регулировать. Специальные средства, или поступления от платных услуг, должны стать источником собственного фонда поликлиники или больницы, используемого в первую очередь для повышения доходов работников, предоставляющих медицинские услуги. А пока эти средства, как дополнительный взнос за оказанную медицинскую услугу (это может быть плата за медицинские препараты, презенты доктору и его помощникам, денежные средства за операционное вмешательство) поступают, минуя кассу.

\begin{tabular}{|l|c|c|c|c|c|c|c|c|c|c|}
\hline Терри-тории & 2009 & 2010 & 2011 & 2012 & 2013 & 2014 & 2015 & 2016 & $\begin{array}{c}2016 \\
\text { к } 2009 \text { в } \\
\%\end{array}$ \\
\hline г. Бишкек & 32,1 & 33,8 & 42,0 & 63,8 & 95,8 & 287,6 & 244,0 & 254,4 & 792,5 \\
\hline Области & & & & \\
\hline Чуйская & 10,1 & 13,1 & 16,2 & 19,6 & 26,0 & 33,7 & 49,0 & 66,7 & 660,4 \\
\hline Ошская & 15,3 & 28,3 & 39,0 & 51,5 & 56,5 & 62,4 & 101,4 & 119,0 & 777,7 \\
\hline Баткенская & 2,0 & 3,2 & 5,8 & 6,5 & 8,5 & 21,2 & 17,6 & 29,4 & 1470 \\
\hline Джалал-Абад. & 5,6 & 7,7 & 9,2 & 10,9 & 16,6 & 30,8 & 50,0 & 87,0 & 1554 \\
\hline Иссык-Куль. & 5,5 & 6,4 & 7,8 & 10,3 & 14,8 & 19,7 & 47,5 & 31,2 & 567,3 \\
\hline Нарынская & 1,3 & 1,6 & 2,3 & 3,4 & 4,0 & 7,6 & 15,9 & 19,2 & 1477 \\
\hline Таласская & 0,6 & 0,9 & 1,0 & 2,0 & 3,2 & 3,8 & 6,7 & 23,5 & 3926 \\
\hline Всего & 73,0 & 95,0 & 123,3 & 168,0 & 225,4 & 466,8 & 532,1 & 630,4 & 863,6 \\
\hline
\end{tabular}

Таблица 4- Поступление специальных средств в систему здравоохранения Кыргызской Республики в разрезе территорий за 2009-2016 г2. (млн. сом.) Источник: Данные ФОМС КР за 2009-2016г2.

Специальные средства, поступающие в учреждения здравоохранения за оказанные дополнительные услуги гражданам за оплату, возросли в целом по республике за 8 лет в 8,6 раза (табл. 2.8). Однако их доля в бюджете здравоохранения не превышает 6\%. Это значит, что значительная часть платы за услуги приобретает форму «неформальных платежей».

Поступление по регионам неравномерное. Наиболее высокий рост наблюдается в Таласской (в 39,5 раза), Баткенской (14,7 раза) и Ошской (7,8 раза) областях (см. табл. 2.8). В г. Бишкеке, Чуйской и Иссык-Кульской областях темпы роста поступлений спецсредств примерно одинаковые.

Это можно объяснить тем, что ввиду отсутствия технологии лечения и диагностики в регионах, больные вынуждены ехать в столицу или в областные центры и производить оплату медицинских услуг. Рассмотрим направления расходования спецсредств по поставщикам медицинских услуг по статьям затрат. Как видно из табл. 2.9, спецсредства медицинских учреждений возросли в целом более чем в 8,4 раза. Из них средства, направляемые на финансирование первичной медико-санитарной помощи, выросли в 3,4 раза, а на стационары - в 8,2 раза. За 2008-2016 гг. рост финансирования за счет специальных средств основных статей расходов, как расходов на медикаменты, составляет всего $23 \%$ и питание - 7,4\%. Причем большая часть средств направлена на увеличение заработной платы медперсонала, оплату коммунальных услуг и прочие расходы. Таким образом, больные люди, которые нуждаются в государственной поддержке, доплачивают заработную плату врачей, при этом незначительная доля их средств используется для лечения и питания в стационарах.

В рамках базовой программы ОМС оказывается и помощь на уровне поликлиник, служб скорой помощи и профилактики. Это первичный уровень медицинской помощи. Согласно экспертизе качества медицинских услуг на первичном уровне, дефекты лечения составили 46,4\%. Для выяснения причин рассмотрим структуру и динамику расходов Программы госгарантий по поставщикам медицинских услуг. 


\begin{tabular}{|c|c|c|c|c|c|c|c|c|c|}
\hline Показатели & 2009 & 2010 & 2011 & 2012 & 2013 & 2014 & 2015 & 2016 & $\begin{array}{r}2016 \\
\text { г. в \% к } \\
2009 \text { г. } \\
\end{array}$ \\
\hline \multicolumn{10}{|c|}{ Удельный вес ПГГ по поставщикам медицинских услуг, \% } \\
\hline $\begin{array}{l}\text { Стационарная } \\
\text { помощь }\end{array}$ & 60,4 & 58,1 & 60,0 & 61,1 & 76 & 70 & 71 & 71 & +10.6 \\
\hline $\begin{array}{l}\text { Амбулаторная } \\
\text { помощь }\end{array}$ & 39,6 & 41,9 & 40,0 & 38,9 & 24 & 30 & 29 & 29 & -10.6 \\
\hline Всего & 100 & 100 & 100 & 100 & 100 & 100 & 100 & 100 & - \\
\hline
\end{tabular}

Таблица 5 - Динамика и структура расходов Программы государственных гарантий по поставщчикам медиџинских услуг за 2009-2016 г2. Источник: Данные ФОМС КР за 2009-2016г2.

Из табл. 3.5 видно, что 71\% средств Программы государственных гарантий направляется на оказание стационарной помощи, которая увеличился в 2016 г. по сравнению с 2009 г. на 10,6\%, напротив, расходы на амбулаторную помощь сократились на ту же сумму. И за последние годы продолжается тенденция преимущественного финансирования стационарного лечения по сравнению с оказанием первичной санитарно-профилактической помощи населению. Напомним, что для всех регионов с 2010 г. были введены единые нормативы финансирования [57]. Это касается учреждений первичной медико-санитарной помощи. Норматив на душу населения - это средний расчетный показатель. Он рассчитывается на одного обслуживаемого или прикрепленного жителя. Поправочные коэффициенты корректируются.

\section{3 Выводы}

Человеческий фактор является основной производительной силой и главным ресурсом страны, поэтому необходимо пересмотреть приоритет сферы здравоохранения и увеличить средства, выделяемые государством.

Необходимо пересмотреть объем финансирования из республиканского бюджета для лечения граждан, достигших пенсионного возраста, детей, не достигших 16 лет, граждан, живущих на социальные пособия. Чтобы было соответствие государственных гарантий их реальному финансированию, необходимо конкретизировать виды бесплатной медицинской помощи в рамках госгарантий и платных медицинских услуг.

Наличие теневого рынка медицинских услуг говорит о том, что рыночный механизм развивается, однако без государственного регулирования. Неофициальная плата выступает как не регулируемое государством дополнение к рыночной цене медицинских услуг, что невозможно отменить или уничтожить.

Необходимо регулировать процесс замены бесплатной помощи на платные услуги, сейчас он стихийный. Следует разработать новые прейскуранты и легализировать платные медицинские услуги по новым ценам на медицинские услуги.

Специальные средства, или поступления от платных услуг должны стать источником собственного фонда поликлиники или больницы, используемого в первую очередь для повышения заработной платы медицинских работников. Поступление спецсредств и их использование должно быть прозрачным, что повысит ответственность и заинтересованность врачей и руководителей организаций здравоохранения.

\section{Литература}

- Джапарова, Д. Мотивация труда медицинских работников в Кыргызстане - путь повышения качества медицинских услуг / Д. Джапарова // Ekonomics. - М., 2016. - №9 (18). - C. 14-20.

- Джапарова, Д. Экономический анализ системы здравоохранения в КР. Проект КТУ «Манас» № 2013.SOB.08 / Д. Джапарова, Д. Ч. Бектенова. - Бишкек, 2014.

- Каратаев М.М. Реформа системы финансирования здравоохранения в новых экономических условиях (на примере Кыргызстана) Экономика здравоохранения. 2000.- № 2/3.- С. 18-20

- Национальная программа реформы здравоохранения Кыргызской Республики «Манас таалими» на 2006-2010 годы // http://cbd.minjust.gov.kg/act/view/ru-ru/57155?cl=ru-ru.

- Необходимо неотлагательно остановить отток семейных врачей. http://zdorovie.akipress.org/news: 21995

- Отчет об итогах деятельности Фонда обязательного медицинского страхования при Правительстве Кыргызской Республики за 2017 год [Текст]. - Бишкек: ФОМС при Правительстве КР, 2018.

- Отчеты об итогах деятельности Фонда обязательного медицинского страхования при Правительстве Кыргызской Республики за 2009-2016 гг. Бишкек: ФОМС при Правительстве КР, 2017.

- Шейман И.М. Экономика здравоохранения / 2000. N 6. с. 47 -55. 


\title{
Проблемы и Перспективы Развития Инфраструктуры Туризма в Кр \\ Problems and Perspectives of Tourism Infrastructure Development in the Kyrgyz Republic
}

\author{
Prof. Dr. Anara Kamalova (Kyrgyz National University, Kyrgyzstan)
}

\begin{abstract}
Tourism business development perspectives mostly depend on the level of infrastructure. Tourism infrastructure includes a group of industries which provides passive tourism balance. It has its own resources: natural, recreational, production assets - service enterprises, personnel, relations with other sectors of economy, providing accommodation, feeding, recreation, information and transport services for tourists. Tourism infrastructure contributes to the adequate functioning of tourist's leisure.

Despite all efforts to develop tourism in Kyrgyzstan, good results of its development are not yet observed, the share of tourism in GDP still remains very low. Tourism infrastructure is developing very poorly. Today, tourism rests solely on natural beauty, only beach tourism remains developed, in recent years, recreation at ski resorts has become more or less popular.

Taking into account all the above, in this article we will try to assess the current state of development of the republic's tourism infrastructure, identify the main problems inhibiting the development of quality tourist services and identify the main directions for the development of tourism infrastructure in the future. Creating a quality level of tourism infrastructure, in our opinion, is one of the factors for increasing the share of tourism in the GDP of the Kyrgyz Republic.
\end{abstract}

\section{1 Введение}

Перспективы развития туристического бизнеса во многом зависят от уровня развития его инфраструктуры. Инфраструктура туризма - это группа производств, обеспечивающих пассивный туристический баланс. Она имеет собственные ресурсы: природные, рекреационные, производственные фонды - предприятия обслуживания, кадры, связи с другими секторами экономики, обеспечивающие размещение, питание, отдых, информационное и транспортное обслуживание туристов. Инфраструктура туризма способствует нормальному функционированию отдыха туристов.

Несмотря на все усилия по развитию туризма в Кыргызстане, хороших результатов его развития пока не наблюдается, доля туризма в ВВП пока еще остается очень низкой. Инфраструктура туризма развивается очень слабо. Сегодня туризм держится только на природной красоте, остается развитым только пляжный туризм, в последние годы более или менее популярным стал отдых на горнолыжных базах.

Как мы отмечали в предыдущих статьях, туризм в Кыргызстане является приоритетной отраслью развития экономики. Благодаря последовательной реализации политики открытости и осуществлению рыночных реформ в республике, в настоящее время уже сложился рынок туристических услуг, в котором на сегодняшний день преобладает доля частного сектора.

На сегодняшний день существующая инфраструктура туристических услуг в республике пока что не отвечает потребностям активно развивающегося туризма, однако, она может стать основой для создания более современной инфраструктуры, отвечающей мировым стандартам и учитывающей экологические требования.

\section{2 Элементы Туристического Продукта и Основные Туристические Услуги}

Как известно, турпродукт состоит из следующих составляющих: 1) транспорт; 2) размещение; 3) питание; 4) привлекательность; 5) сопровождение и 6) снабжение. Состав туристического продукта наглядно можно посмотреть на диаграмме 1.

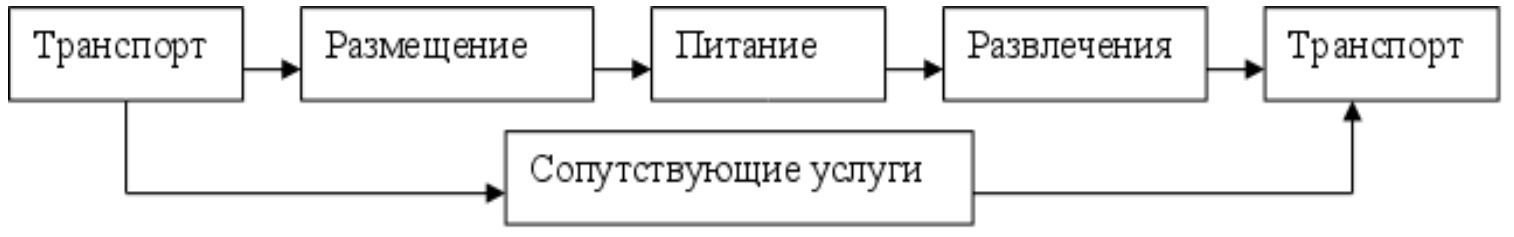

Диаграмма 1. Элементы Турпродукта 
Производители и организаторы этих составляющих являются основными предприятиями, формирующими ВВП отрасли. Туристические компании в Кыргызстане предоставляют довольно широкий спектр услуг. Основными туристическими услугами, которые предоставляют данные компании, являются:

- $\quad$ резервирование и продажа авиабилетов;

- $\quad$ резервирование гостиниц и транспорта;

- размещение и встреча туристов;

- оказание услуг по оформлению загранпаспортов, виз, страховых полисов;

- услуги гида-переводчика;

- организация туров и поездок;

- $\quad$ предоставление транспортного и экскурсионного обслуживания с помощью своих ресурсов, а также с помощью зарубежных партнеров;

- $\quad$ оказание прочих услуг.

\section{3 Анализ Развития Инфраструктуры Туризма в Кыргызской Республике}

Итак, из выше рассмотренного материала понятно, что туристическая фирма формирует туристический пакет из услуг предприятий различных отраслей. Предприятия, участвующие в формировании турпакета, образуют инфраструктуру туризма.

\begin{tabular}{|l|c|c|c|c|}
\hline & \multicolumn{2}{|l|}{ Всего } & в том числе: & \multicolumn{2}{c|}{\begin{tabular}{c} 
санаторно- \\
курортные \\
\cline { 2 - 4 }
\end{tabular}} & гостиницы & $\begin{array}{c}\text { предприятия } \\
\text { отдыха и } \\
\text { туризма }\end{array}$ & 100 \\
\hline $\begin{array}{l}\text { Кыргызская } \\
\text { Республика }\end{array}$ & 11715 & 1220 & 967 & 4 \\
\hline Баткенская область & 77 & 48 & 25 & 9 \\
\hline $\begin{array}{l}\text { Джалал-Абадская } \\
\text { область }\end{array}$ & 195 & 117 & 69 & 30 \\
\hline $\begin{array}{l}\text { Иссык-Кульская } \\
\text { область }\end{array}$ & 785 & 264 & 491 & 2 \\
\hline Нарынская область & 197 & 86 & 109 & 6 \\
\hline Ошская область & 80 & 44 & 30 & 3 \\
\hline Таласская область & 44 & 36 & 5 & 15 \\
\hline Чуйская область & 163 & 102 & 45 & 26 \\
\hline г. Бишкек & 616 & 422 & 168 & 5 \\
\hline г. Ош & 131 & 101 & 25 & \\
\hline
\end{tabular}

Таблица 1. Число Предприятий И Организаций Сферы Туризма Источник: Туризм В Кыргызстане 20132017 Гг. Статсборник КР

По состоянию на 1 января 2018 года в Кыргызской Республике зарегистрировано около 107 тыс. хозяйствующих субъектов, как юридические лица, их филиалы и представительства, так и физические лица, деятельность которых связана со сферой туризма. Из общего числа хозяйствующих субъектов (юридических и физических лиц) - 11,7 тыс., или 10,9 процента зарегистрированы как предприятия, оказывающие услуги в области рекреации и отдыха (услуги гостиничных хозяйств, базы отдыха, рестораны, лечебно-оздоровительные профилактории). В основном, такие хозяйствующие субъекты расположены в г. Бишкек - 4,9 тыс. субъектов $(42,4 \%)$ и курортной зоне Иссык-Кульской области - 1,7 тыс. субъектов (14,5 \%). Индивидуальной предпринимательской деятельностью в сфере туризма занято более 94 тыс. физических лиц, или 88,0\% от общего числа зарегистрированных хозяйствующих субъектов.

Туристов в республике обслуживают 1220 гостиниц, 967 предприятий отдыха и туризма, 100 санаторнокурортных учреждений, а также физкультурно-оздоровительные учреждения, специализированные торговые предприятия, природные парки и заповедники, автотранспортные предприятия, рестораны, рекламные агентства и др. Число предприятий и организаций сферы туризма на 1 января 2018 года представлены в Таблице 1 .

Основной поток туристов проходит через организованный и неорганизованный сектор. Частный, т.е. неорганизованный сектор туристической индустрии Кыргызстана начал формироваться с началом перестройки в конце 90-х годов, когда создавалась реальная возможность для существования частного предпринимательства. Несмотря на то, что на сегодняшний день в Кыргызстане насчитывается порядка 25 
тысяч хозяйствующих субъектов, связанных со сферой туризма, если смотреть реально, приемом туристов занимаются около трех десятков частных фирм, которые принимают 50\% туристов.

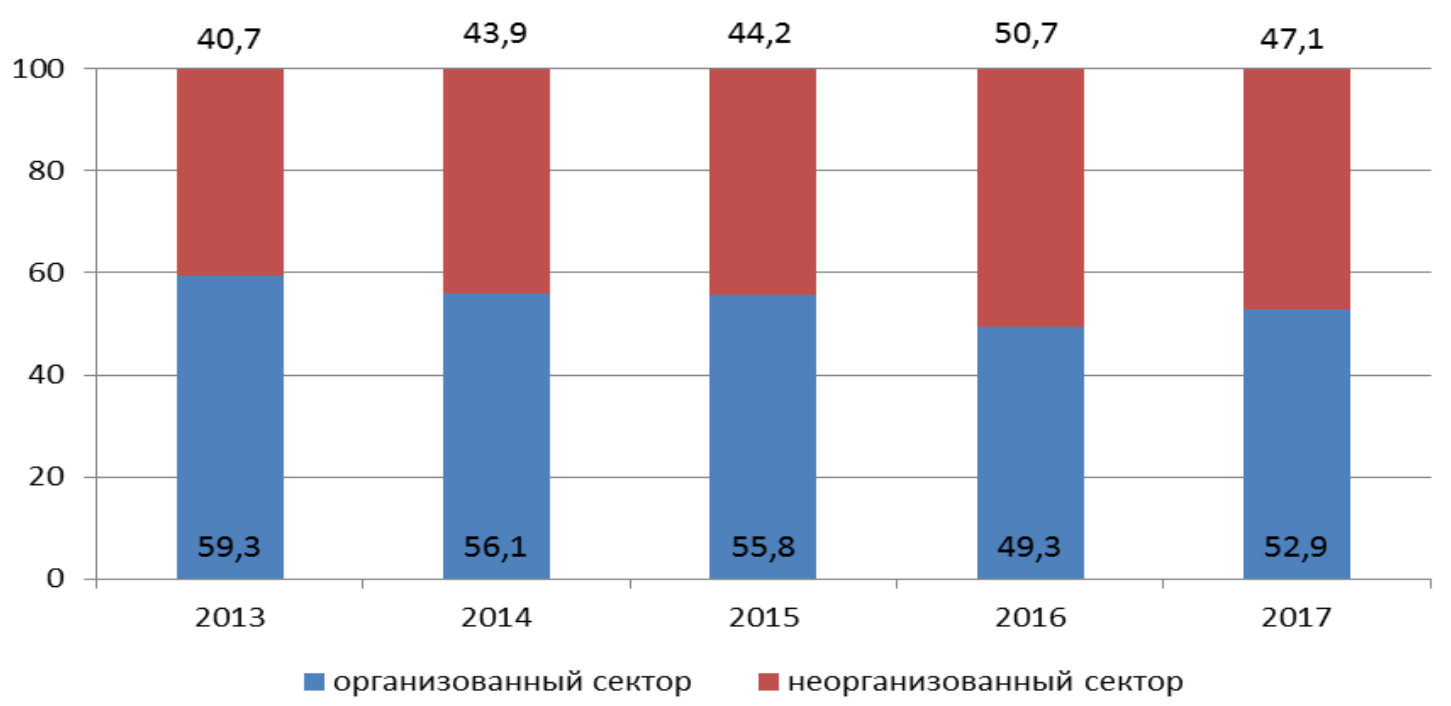
График 1. Туристы, Отдохнувшие В Организованном И Неорганизованном Секторе Туризма (В
Прочентах К Итогу)

Инфраструктура туризма в Кыргызстане представлена совокупностью средств размещения, транспортных средств, объектов питания, развлекательного, познавательного, делового, оздоровительного, спортивного и иного назначения. Очевидно, что отрасль туризма предполагает параллельное развитие всех элементов и взаимных связей социально-экономического комплекса. При таком условии достигается максимальная эффективность. Кроме того, наряду с основными сегментами функционируют и дополнительные, предоставляющие сопутствующие услуги, такие как, банковские и финансовые, информационные, услуги страхования, услуги связи и др.

Таким образом, основополагающими элементами инфраструктуры туризма являются:

- транспортная индустрия (воздушный, водный, автомобильный, железно-дорожный транспорт);

- гостиничная индустрия (гостиницы, специализированные средства размещения);

- $\quad$ индустрия питания (рестораны, кафе, бары, столовые и другие предприятия по поставке готовой пищи);

- $\quad$ индустрия развлечений (парки, театры, цирки, музеи и др.).

Исходя из выше сказанных, далее проведем анализ развития элементов инфраструктуры туризма в республике по этим элементам в отдельности.

Туристские перевозки являются одним из важнейших элементов туристской индустрии. Перевозки туристов в Кыргызской Республике осуществляются автомобильным, воздушным, и железнодорожным транспортом. Каждый элемент транспортной инфраструктуры туристической отрасли Кыргызстана имеет свои специфические особенности. Так, например, в связи с географическим положением, в Кыргызстане наиболее развитым является автомобильный транспорт. Менее развитыми являются водный и железнодорожный транспорт; наибольшее количество зарубежных туристов в последние годы прибывают в Кыргызстан воздушным транспортом.

Кыргызская Республика расположена в центре Евразии, на стыке перспективных авиационных, транспортных и экономических артерий между Европой и Азией. Главная задача в этой области - сделать республику доступной для зарубежных туристов, наладив прямые международные воздушные сообщения, для чего необходимо провести ряд мероприятий, в том числе завершить реконструкцию аэропорта "Манас"; создать условия для функционирования на рынке авиационных перевозок конкурентоспособных авиакомпаний, зарегистрированных на территории Кыргызской Республики; повысить безопасность полетов и качество обслуживания пассажиров.

Согласно данным Национального статистического комитета КР, в 2017 году всеми видами транспорта перевезено 6921,4 тысячи человек (Таблица 2). 


\begin{tabular}{|l|c|c|c|c|c|}
\hline Показатели & $\mathbf{2 0 1 3}$ & $\mathbf{2 0 1 4}$ & $\mathbf{2 0 1 5}$ & $\mathbf{2 0 1 6}$ & $\mathbf{2 0 1 7}$ \\
\hline Перевезено туристов - всего & 6087,2 & 6275,9 & 6412,1 & 6420,2 & 6921,4 \\
\hline Воздушным транспортом & & & & & \\
\hline въездные международные & 370,4 & 387,6 & 385,8 & 308,0 & 408,1 \\
\hline выездные международные & 392,6 & 364,6 & 305,1 & 303,6 & 419,4 \\
\hline внутренние & 287,2 & 486,1 & 509,4 & 500,7 & 657,0 \\
\hline Железнодорожным транспортом & & & & & \\
\hline въездные международные & 44,4 & 25,3 & 15,7 & 12,7 & 12,8 \\
\hline выездные международные & 59,9 & 31,7 & 20,3 & 15,3 & 15,2 \\
\hline внутренние & 13,8 & 10,7 & 13,8 & 18,6 & 17,6 \\
\hline Автомобильным транспортом & & & & & \\
\hline выездные & 58,4 & 66,2 & 53,1 & 49,9 & 83,1 \\
\hline в дальнее зарубежье & & & & & \\
\hline в страны СнГ & 58,4 & 66,2 & 53,1 & 49,9 & 83,1 \\
\hline внутренние & 4860,5 & 4903,7 & 5108,9 & 5211,4 & 5308,2 \\
\hline
\end{tabular}

Таблица 2. Перевозки Туристов По Видам Сообщений (Тыс. Человек) Источник: Туризм В Кыргызстане 2013-2017 Гг. Статсборник КР

Таким образом, в 2007 г. по сравнению с 2016 г. число перевезенных туристов в Республике увеличилось на 7,8\%. Как видно из Таблицы 2, наибольшее количество туристов прибывают в Кыргызстан воздушным транспортом.

Важное значение для развития туризма в республике имеет реконструкция автомагистралей Бишкек-Ош, Бишкек-Нарын-Торугарт, Бишкек-Балыкчи-Каракол, Ош-Иркештам, а также автомобильных дорог, ведущих к историко-архитектурным и историческим достопримечательностям страны. Указанные направления дорожных магистралей полностью совпадают с основными нитками маршрутов Великого Шелкового пути. Организация путешествий туристов по этим автотрассам может стать одним из основных доходных видов туризма на Великом Шелковом пути.

Для обеспечения высокого качества обслуживания туристов, необходимо соответствующим образом обустроить указанные автотрассы, улучшить качество дорожного полотна, повысить безопасность автотрасс, оборудовать трассы указателями и информационными табло на иностранных языках и т.д. Важное значение имеет строительство объектов дорожного сервиса первой необходимости (придорожных гостиниц, платных стоянок, пунктов общественного питания и других объектов отдыха и развлечений).

\begin{tabular}{|l|c|c|c|c|c|}
\hline Показатели & $\mathbf{2 0 1 3}$ & $\mathbf{2 0 1 4}$ & $\mathbf{2 0 1 5}$ & $\mathbf{2 0 1 6}$ & $\mathbf{2 0 1 7}$ \\
\hline Все доходы & 9506,4 & 9127,0 & 8445,8 & 8200,2 & 11430,2 \\
\hline в том числе, полученные от перевозок: & & & & & \\
\hline воздушным транспортом & 8361,8 & 7966,8 & 6935,1 & 6670,0 & 9820,4 \\
\hline железнодорожным транспортом & 511,6 & 400,3 & 246,8 & 175,7 & 203,5 \\
\hline автомобильным транспортом & 633,0 & 759,9 & 1263,9 & 1354,5 & 1406,3 \\
\hline
\end{tabular}

Таблица 3. Перевозки Туристов По Видам Сообщений (Тыс. Человек) Источник: Туризм В Кыргызстане 2013-2017 Гг. Статсборник КР

Доходы от перевозок туристов всеми видами транспорта в 2017 году увеличились по сравнению с предыдущим годом на 39,3\% и составили 11430,2 млн.с (Таблица 3).

Гостиничное хозяйство является главным составляющим туристской индустрии, без которой невозможно развитие отрасли. Индустрия гостеприимства выступает одной из важнейших отраслей экономики в большинстве стран мира, поскольку она является одной из наиболее высокодоходных. Все государства проявляют большую заинтересованность в развитии этой отрасли. Гостиничная индустрия представлена такими средствами размещения, как гостиницы, мотели, придорожные и пляжные гостиницы, а также специализированные средства размещения. Специализированные средства размещения представляют собой заведения, которые помимо представления размещения, выполняют какую-нибудь специализированную функцию. Например, оздоровительные заведения или конгрессцентры.

В Кыргызстане гостиничная индустрия представлена 172 гостиницами, общий гостиничный фонд которых составляет 4229 номеров. В 2017 году численность размещенных лиц составила 224,2 тыс. человек. Единовременная вместимость составляет 6663 койки-места (Таблица 4). 


\begin{tabular}{|l|l|l|l|l|l|}
\hline Показатели & $\mathbf{2 0 1 3}$ & $\mathbf{2 0 1 4}$ & $\mathbf{2 0 1 5}$ & $\mathbf{2 0 1 6}$ & $\mathbf{2 0 1 7}$ \\
\hline Число гостиниц, ед. & 146 & 171 & 184 & 176 & 172 \\
\hline Численность размещенных лиц, тыс. человек & 205,9 & 205,0 & 222,1 & 219,4 & 224,2 \\
\hline Число всех номеров, ед. & 2851 & 3084 & 3951 & 4062 & 4229 \\
\hline Единовременная вместимость, койка-место & 4615 & 5714 & 6420 & 6773 & 6663 \\
\hline Предоставлено койки-суток, тыс. & 355,0 & 295,9 & 359,6 & 411,4 & 451,9 \\
\hline Средняя стоимость койки- суток для нерезидентов, сомов & 1521 & 1552 & 1512 & 1464 & 1800 \\
\hline
\end{tabular}

Таблица 4. Основные показатели работы гостинии Источник: Туризм в Кыргызстане 2013-2017 г2. Статсборник КР

Индустрия питания в Кыргызстане, в последнее время развивается быстрыми темпами. Данная индустрия представлена ресторанами, кафе, барами, столовыми и другими предприятиями по поставке готовой пищи. Данные Нацстаткома показывают, что объем услуг, предоставленных ресторанами, барами, столовыми и другими предприятиями по поставке готовой пищи за период с 2013 по 2017 год увеличился на 50,3. Таким образом, в 2017 году объем услуг, произведенных индустрией питания составил 9,3 млрд. сом (Таблица 5).

Среднегодовой темп рост за последние пять лет составляет 137,9%. Это говорит о довольно стабильном развитии индустрии питания в Кыргызстане.

\begin{tabular}{|l|l|l|l|}
\hline \multirow{2}{*}{ Годы } & \multirow{2}{*}{ млн. сомов } & \multicolumn{2}{|c|}{ В процентах } \\
\cline { 3 - 4 } & & к предыдущему году & к 2013 году \\
\hline 2013 & 6184,8 & & 100,0 \\
\hline 2014 & 7338,8 & 118,7 & 118,7 \\
\hline 2015 & 8312,9 & 113,3 & 134,4 \\
\hline 2016 & 9166,7 & 110,3 & 148,2 \\
\hline 2017 & 9294,0 & 101,4 & 150,3 \\
\hline
\end{tabular}

Таблица 5. Объем Услуг, Предоставленных Ресторанами, Барами, Столовыми И Другими Предприятиями Общепита Источник: Туризм В Кыргызстане 2013-2017 Гг. Статсборник КР

Индустрия развлечений Кыргызстана представлена парками, театрами, цирками, музеями и другими развлекательными заведениями. Сюда также включается посещения заповедников и природных парков. Особенностью Кыргызстана, в этом плане, являются 13 природных национальных парков, 10 заповедников и 69 заказников и памятников природы.

На начало 2018 г. в республике функционировали 21 театр, 65 музеев, 1035 библиотек, 651 учреждение клубного типа.

Профессиональные театры в республике имеют государственную форму собственности. Наиболее развита их сеть в г. Бишкеке (8) и Ошской области (4). В 2017 г. театральными коллективами показаны 1694 спектакля и представления, из которых 463 - гастрольные и выездные за пределы своего города. Число зрителей составило около 183 тыс. чел. Наиболее посещаемыми театрами стали Государственный академический русский драматический г. Бишкек, Ошский узбекский музыкально-драматический и Нарынский драматический театр.

Музеи республики располагают фондами в размере более 313 тыс. экспонатов. Число экспонатов, требующих реставрации, в 2017 г. составило 6,9 тыс. Наибольшим числом экспонатов располагают музеи г. Бишкек (90,5 тыс.) и музеи Ошской области (33,1 тыс.). В музеях, открытых для посещений, доля выставленных экспонатов составила 27,2 процента, а в отдельных областях этот показатель значительно выше, чем по республике в целом. Так, в Таласской области он составил 97,7\%, Баткенской - 72\%, ИссыкКульской области - 57,9 \%. Во всех музеях республики не экспонировалось 131,6 тыс. экспонатов (72,8\%). Так, в музеях г. Бишкек удельный вес выставленных экспонатов составил всего лишь 9,5\%, Ошской области - 10,4\% от наличных фондов.

В 2017 г. музеи посетили около 555 тыс. человек. Наибольшее число посетителей отмечено в г. Бишкек (261,6 тыс., или 47\%) и Таласской области (97,7 тыс., или 17,6\%). Однако, в отдельных областях посещаемость остаётся низкой: в Баткенской она составила 9,4 тыс. человек (1,7\%), Нарынской - 18 тыс., $(3,2 \%)$ за год. В истекшем году музеями проведено 9,6 тыс. экскурсий с экскурсоводом. Наибольшее количество экскурсий проведено в Таласской $(2,8$ тыс.) и Ошской $(0,9$ тыс.) областях. Доля посетителей, принявших участие в экскурсиях с экскурсоводом, в целом по республике составила 37,7\%. Из сведений о техническом состоянии музеев видно, что более трети из них требуют капитального ремонта. 
Несмотря на некоторый количественный рост инструментов инфраструктуры туризма, качественное состояние оставляет желать лучшего. По данным проведенного опроса сотрудниками НИСИ с участием международных организаций от 31.03.2019, на вопрос: «Что по твоему мнению, является минусом в Кыргызстане для туристов?». Самый высокий ответ стал: «Неразвитость инфраструктуры туризма в республике» (Рисунок 1).

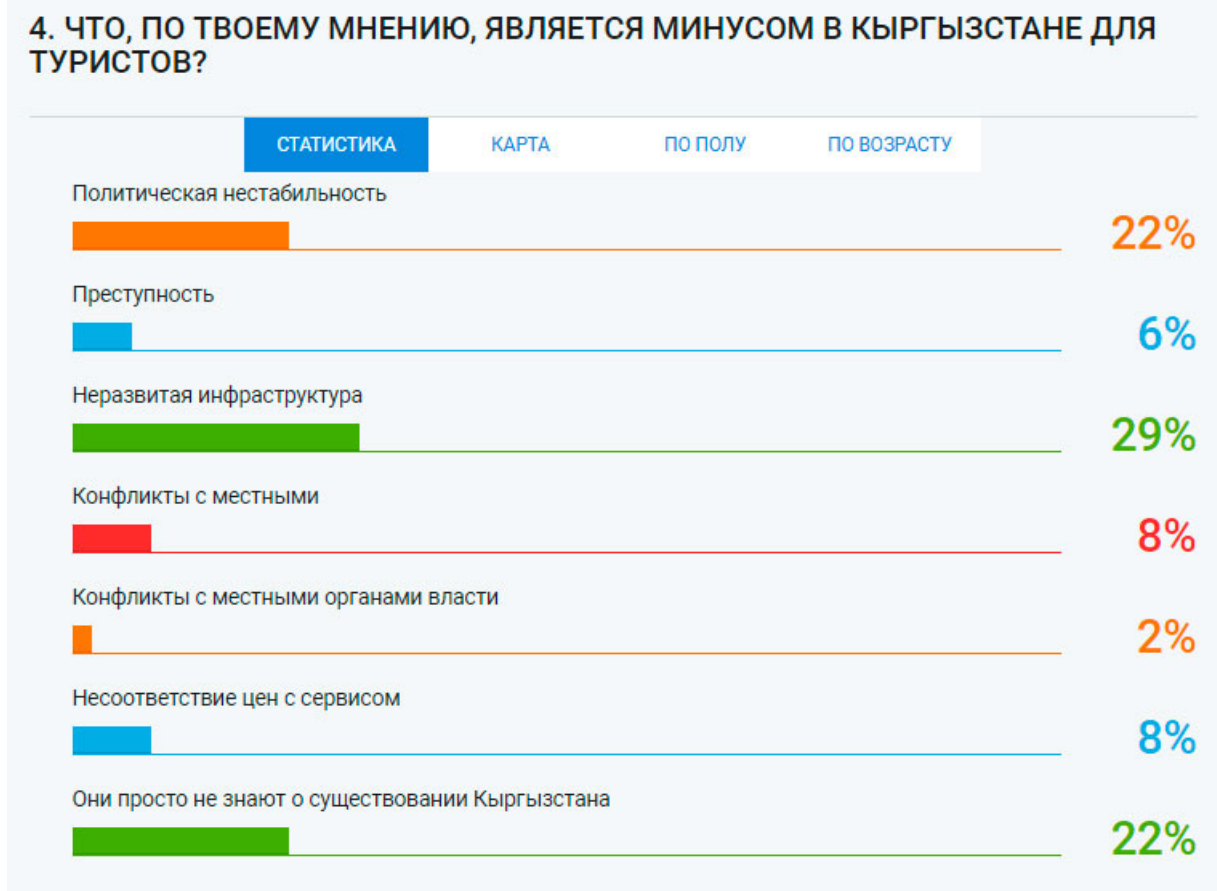

Рисунок 1. Результаты Опроса О Негативных Условиях Для Туристов В Кыргызстане

\section{4 Проблемы и Пути Решения Улучшения Состояния Инфраструктуры Туризма Республики}

К сожалению, Кыргызстан на сегодня является страной с неразвитой инфраструктурой, не имеющей выхода к морю. Слаборазвитая инфраструктура бросается в глаза каждому путешествующему по стране. По мнению международных экспертов, проблема инфраструктуры препятствует не только туризму, а развитию всех секторов экономики Кыргызстана.

До 1991 года туристическая система СССР, руководимая профсоюзами, развивалась в направлении предоставления дешевого отдыха для трудящихся и не была интегрирована в мировую систему туризма. Естественно, что после распада СССР огромное туристическое хозяйство оказалось совершенно не пригодным к работе в новых условиях. Начало 90-х годов было периодом поиска новой модели развития туризма, однако до сегодняшнего дня эффективных путей развития этих объектов не найдены. Эти туристические объекты находятся в очень плохом состоянии, на наш взгляд, государство само должно управлять этими объектами или создать государственно-частное партнёрство. Можно оживить опыт работы этих предприятий как было при Союзе, т.е. можно и нужно наладить прямые связи с крупными промышленными предприятиями стран ЕАЭС, составляя долгосрочные договора, распространяя путевки коллективу этих предприятий.

Как мы выше рассмотрели, воздушный транспорт является доминирующим видом транспорта для иностранных туристов, но в Кыргызстане все еще воздушное сообщение имеет ряд недостатков- только четыре международных авиаперевозчика осуществляют регулярные международные рейсы в страну, внутренние рейсы часто задерживаются или отменяются, багажная политика и практика не соответствуют стандартам; путешественники жалуются на потери багажа или небольшой вес бесплатного провоза багажа. Иностранные авиакомпании не могут продавать билеты и проверять количество мест на внутренних рейсах. Многие иностранные туристы воспринимают услуги и безопасность внутренних рейсов, как не соответствующие стандартам, и не хотят летать. Все авиакомпаний Кыргызстана теперь занесены Европейским Союзом в черный список и запрещены для полетов.

Как известно, аэропорты для международного туризма являются главными воротами страны, даже его визитной карточкой, поэтому необходимо модернизировать международные аэропорты республики, для того, чтобы они соответствовали международным стандартам, также правительству необходимо тесно сотрудничать с Международной организацией гражданской авиации, чтобы снять запрет ЕС на 
авиакомпании Кыргызстана и провести технико-экономическое обоснование осуществимости регулярных рейсов в страны ЕС.

На наш взгляд, внедрение системы электронной визы (E-visa) в Таза Коом в новую систему электронного правительства даст большой толчок к развитию международного туризма в стране, здесь нельзя забывать о необходимости пересмотра и оптимизации политики пограничного контроля, таможни, оформления билетов и багажа.

Дороги республиканского, особенно областного и местного уровней и некоторые виды инфраструктуры развиты очень слабо, включая гостиницы, расположенные вдоль дорог, остановки для отдыха, географические знаки и навигационные системы, находятся либо в плохом состоянии, либо вообще отсутствуют. Несмотря на значительные инвестиции в восстановление основных магистралей, дороги, ведущие к основным туристическим достопримечательностям Иссык-Кульской и других областей, остаются в неудовлетворительном состоянии.

Во многих областях в гостиницах, аптеках, пунктах медицинской помощи и остановках отдыха нет никаких указательных знаков на иностранных языках, хотя бы на английском. Система водоснабжения и водоотведения областного и местного уровней устарела и перегружена. В некоторых местах на озере Иссык-Куль мусор разбросан даже на пляже, не ведется их регулярный вывоз, нет туалетов. В Ошской и Джалал-Абадской областях качество питьевой воды не соответствует стандартам. В сельских районах часто отключают свет, т.е. электроснабжением обеспечиваются населенные пункты нерегулярно.

Другой важной составляющей структуры отрасли являются общеобразовательные институты. Сюда относятся предприятия и организации по подготовке кадров для отрасли. Сегодня в республике их более 15. Ежегодная потребность отрасли составляет около 350 специалистов различного уровня в год. Из них до 10 человек - высшего управленческого персонала, около 40 - человек среднего управленческого персонала, око-ло 100 человек - низового управленческого персонала и около 200 человек исполнительского уровня. Выпуск специалистов с высшим образованием по республике в 2018 году составил 298человек. В основном они управленцы среднего и низового уровня. Подавляющая часть выпускников остается невостребованной отраслью из-за несо ᄀответствия потребностям производителей турпродукта. Подготовка или переподготовка высшего управленческого персонала не проводится. Кроме того, существует нехватка многоязычных гидов и переводчиков, инструкторов в таких турах, как горные лыжи, альпинизм и рафтинг. Многие сотрудники отелей и курортов не имеют соответствующей подготовки и навыков в сфере гостиничного обслуживания, что вызывает негативные отзывы и жалобы иностранцев. Кратковременная сезонность туристической деятельности, высокая текучесть и низкое качество работы персонала еще больше усугубляют проблему.

Формальные знания и практические навыки студентов, обучающихся в сфере туризма и гостеприимства, не соответствуют ни международным стандартам, ни фактическим потребностям туристической отрасли в Кыргызстане. В 2018 году только 298 выпускников, специализирующихся по предмету “Социальнокультурные услуги и туризм”, получили дипломы в высших учебных заведениях страны - Академии туризма, Высшей школе туризма и гостиничного дела в Кыргызско-турецком университете «Манас» и Бишкекской академии финансов и экономики. Остальные работники являются выпускниками других ВУЗов, которые далеки от туризма, поэтому они не обладают необходимыми знаниями и навыками. На наш взгляд, необходимо пересмотреть государственные стандарты обучения специалистов в области туристического бизнеса, а также необходимо провести аттестацию работников отрасли и улучшить работу по лицензированию туристических фирм.

Устранение вышеперечисленных проблем связанные с улучшением инфраструктуры туризма может стать основой для создания более современной инфраструктуры, отвечающей мировым стандартам и учитывающей экологические требования, при этом требуется общее усилие всех субъектов туристического бизнеса, начиная государственных органов заканчивая простыми работниками туристических фирм.

\section{Литература}

- Асыкулов Т., 2012. "Орехово-плодовые леса Кыргызстана как рекреационный ресурс". Вестник Кыргызского национального государственного университета.

- Ватанабль, Т. и др., 2009. "Туризм в Памиро-Алайских горах, Юг Кыргызской Республики". Географические исследования.

- Всемирная туристская организация Организации Объединенных Наций, 2017. Кыргызстан: основные показатели по странам. http:/www.e-unwto.org/doi/abs/10.5555/unwtotfb0417010020112015201609

- Всемирный совет по туризму и путешествиям, 2017. Статистический сборник по туризму. Данные по 2011-2015. https://tool.wttc.org

- Закон Кыргызской Республики. "О Туризме". Бишкек, в редакции от 10 мая 2017.

- Максудинов А., Камалова А, 2016. Маркетинг услуг. Бишкек 
- Национальный Статистический Комитет Кыргызской Республики, 2018. Туризм в Кыргызстане. Статистический сборник. Бишкек

- НИСИ КР, 2018. Улучшение инфраструктуры поможет развитию туризма в Кыргызстане. http://www.nisi.kg/139-m-report/384-nisi-uluchshenie-infrastruktury-pomozhet-razvitiyu-turizma-vkyrgyzstane.html

- Правительство Кыргызской Республики, 2016. Постановление o 192. "О Программе Правительства Кыргызской Республики по развитию туризма до 2020 года". Бишкек 


\section{Author Index}

Abdiyeva, Raziya (Kyrgyzstan-Turkey Manas University, Kyrgyzstan) 160,393

Acet, Hakan (Selçuk University, Turkey) .265

Akbulut, Çetin İlhan (Kavram MYO, Turkey) 140

Algan, Neşe (Çukurova University, Turkey) $.56,126,179$

Antalyalı, Ömer Lütfi (Kyrgyzstan-Turkey Manas University, Kyrgyzstan) ......................................254

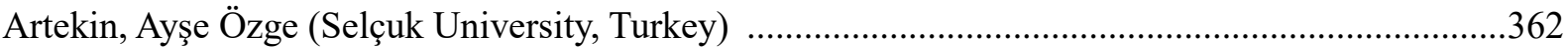

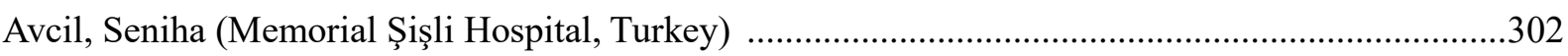

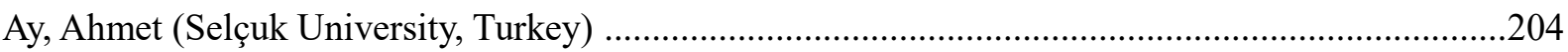

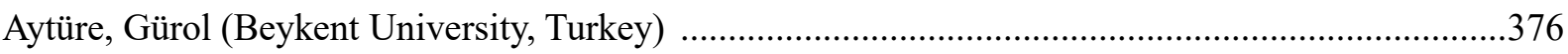

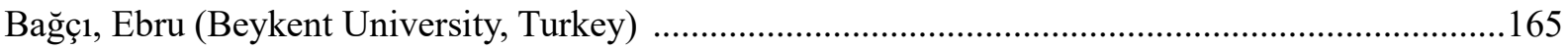

Baigonusheva, Mairam (Marmara University, Turkey) .....................................................................476

Baigonushova, Damira (Kyrgyzstan-Turkey Manas University, Kyrgyzstan) ...........................271, 476

Bal, Harun (Çukurova University, Turkey) ................................................ 1, 38, 62, 84, 187, 197, 279

Başaran, Burçin (Namık Kemal University, Turkey) ..........................................................................294

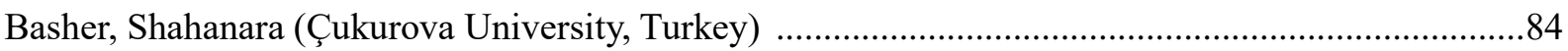

Bayraktar, Murat (Çukurova University, Turkey) ……....................................................................56

Besim, Mustafa (Eastern Mediterranean University, TR of Northern Cyprus) ...........................118, 131

Boobekova, Kadiyan (Kyrgyzstan-Turkey Manas University, Kyrgyzstan) .......................................160

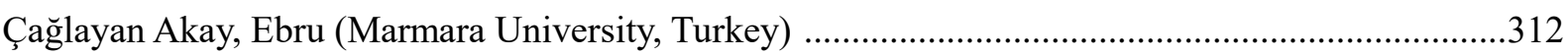

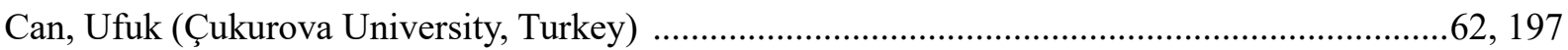

Can, Zeynep Gizem (Çukurova University, Turkey) ..............................................................62, 197

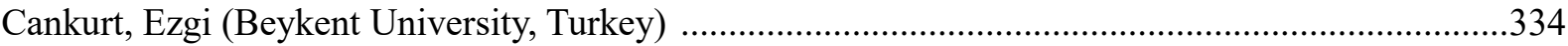

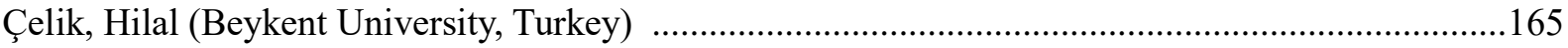

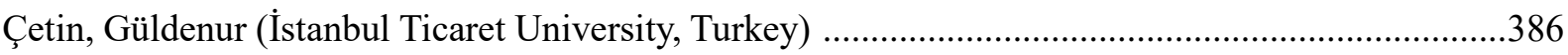

Choroev, Kalybek (Kyrgyzstan-Turkey Manas University, Kyrgyzstan) .............................................439

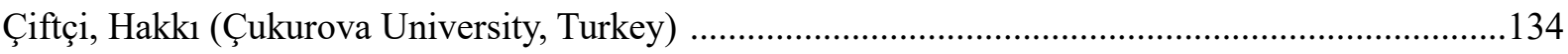

Deynekli, Adnan (Bahçeşehir University, Turkey) .............................................................................331

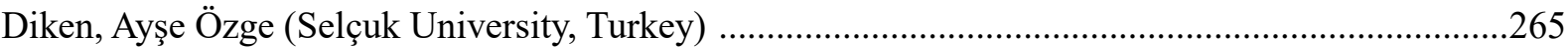

Djurupova, Bermet (Kyrgyz University of Economics, Kyrgyzstan) ……….....................................483

Dzhailova, Asel (Kyrgyz University of Economics, Kyrgyzstan) ......................................................443

Eğri, Canan Özge (Kirklareli University, Turkey) ….........................................................................386

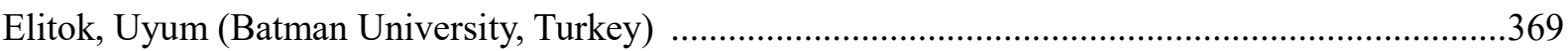

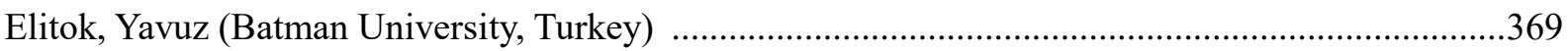

Elsalih, Osama (Eastern Mediterranean University, TR of Northern Cyprus) ....................................118

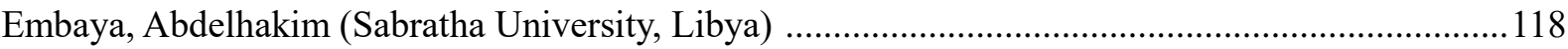

Erdoğan, Esma (Çukurova University, Turkey) ….............................................................1, 187, 279 
Erdoğan, Mahmut (Kyrgyzstan-Turkey Manas University, Kyrgyzstan) .393

Eroğlu, Feyzullah (Pamukkale University, Turkey)

Eroğlu, Şeyma Gün (Muğla Sitkı Koçman University, Turkey)

235,246

Esaa, Ayat Abdelrahim Suliman (Çukurova University, Turkey)

Ganiev, Junus (Kyrgyzstan-Turkey Manas University, Kyrgyzstan) 271,476

Gencer, Ayşen Hiç (Beykent University, Turkey) . .98

Göktaş, Pınar (Süleyman Demirel University, Turkey) .254

Gürel, Fatih (Çankırı Karatekin University, Turkey) .423

Gurunyan, Tatyana (The Russian Presidential Academy of National Economy and Public Administration, Russia) .468

Hacığlu Deniz, Müjgan (İstanbul University, Turkey) 321

Hiç, Özlen (İstanbul University, Turkey) 321

Ibrahim, Mohamed Isse (İstanbul Commerce University, Turkey) 106

Ildırar, Mustafa (Çukurova University, Turkey) .279

İnan, Osman (Namık Kemal University, Turkey) .423

İrmiş, Ayşe (Pamukkale University, Turkey) .235

İşcan, Erhan (Çukurova University, Turkey) $38,126,179$

İsmihan, Mustafa (Eastern Mediterranean University, TR of Northern Cyprus) 131,289

Japarova, Damira (Kyrgyzstan-Turkey Manas University, Kyrgyzstan) .492

Kamalov, Zalkar (University of Central Asia, Kyrgyzstan) 449

Kamalova, Anara (Kyrgyz National University, Kyrgyzstan) .497

Karaçor, Zeynep (Selçuk University, Turkey) $. .29,399$

Karaman, Ebru (Beykent University, Turkey) .343

Kardeş, Nazlı (Sakarya Applied Sciences University, Turkey) .430

Köksal, Melike (Selçuk University, Turkey) .204

Konya, Sevilay (Selçuk University, Turkey) $. .29,399$

Küçüker, Mustafa Can (Atılım University, Turkey) .289

Küçüksucu, Mücahide (Necmettin Erbakan University, Turkey) $.29,399$

Maksüdünov, Azamat (Kyrgyzstan-Turkey Manas University, Kyrgyzstan) ......................................416

Mamun, Abdulla Hil (Çukurova University, Turkey) .............................................................................

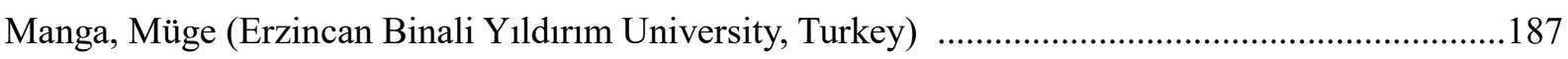

Milosheska Gavrovska, Milica (Komercijalna Banka AD Skopje, Macedonia) ...................................71

Okay Toprak, Aslı (Kırklareli University, Turkey) 171,386

Oralkan, Ayca (Beykent University, Turkey) .112

Oraman, Yasemin (Namık Kemal University, Turkey) .294

Oskonbaeva, Zamira (Kyrgyzstan-Turkey Manas University, Kyrgyzstan) ………............................312

Özdemir, Lutfiye (İnönü University, Turkey) .369

Özdemir, Zekai (Istanbul University, Turkey) 
Özdil, Tuncer (Manisa Celal Bayar University, Turkey)

Özen, Ufuk (Beykent University, Turkey) .165

Özkan, Gürsel (Turkish State Council, Turkey) .352

Özmen, Mehmet (Çukurova University, Turkey) . .45

Öztopçu, Aslı (Maltepe University, Turkey) 153

Palandökenlier, Berk (Çukurova University, Turkey) .. ...1 1

Pektaş, Eren (Beykent University, Turkey)

Pirimbaev, Jusup (Kyrgyzstan-Turkey Manas University, Kyrgyzstan) $. .449,483$

Rakhmanalieva, Aizhan (Kyrgyz-Russian Slavic University, Kyrgyzstan) ........................................455

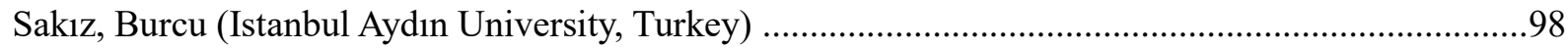

Samatova, Gulmira (Kyrgyzstan-Turkey Manas University, Kyrgyzstan) ……...................................483

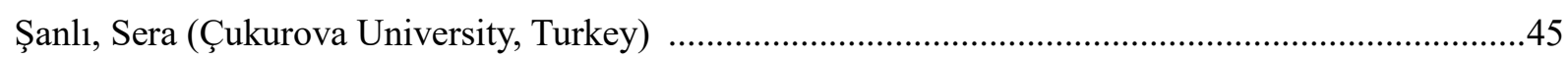

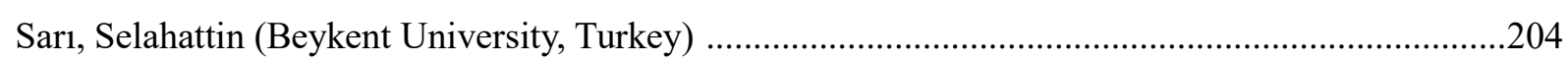

Sarışık, Mehmet (Sakarya Applied Sciences University, Turkey) ...........................................408, 430

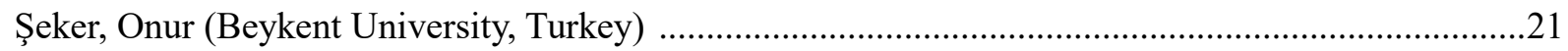

Serin Oktay, Duygu (Çukurova University, Turkey) …...................................................11, 126, 179

Sertoğlu, Kamil (Eastern Mediterranean University, TR of Northern Cyprus) ...........................118, 131

Şeyhanlığlu, Hasan Önal (Sakarya Applied Sciences University, Turkey) .......................................408

Slaveski, Trajko (Ss. Cyril and Methodius University, Macedonia) ....................................................71

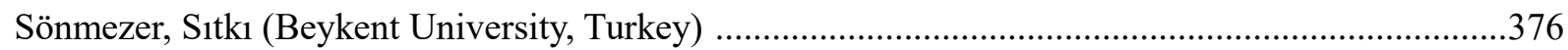

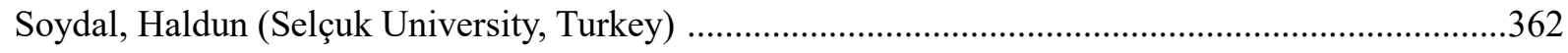

Suleeva, Diliara (Kyrgyz-Russian Slavic University, Kyrgyzstan) ....................................................465

Tekeoğlu, Muammer (Çukurova University, Turkey) .....................................................................126

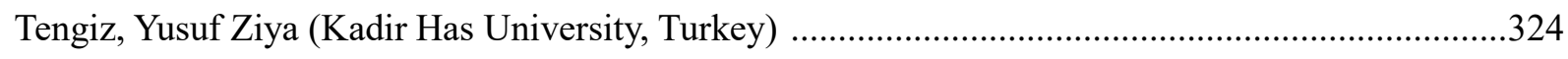

Tengiz, Zehra Meliha (Namık Kemal University, Turkey) ...............................................294, 324, 423

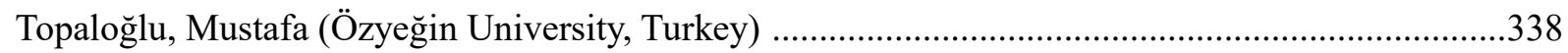

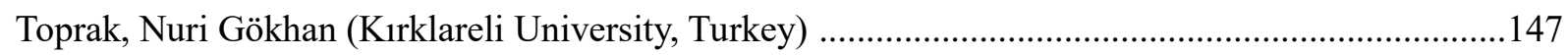

Turdalieva, Ainura (Kyrgyzstan-Turkey Manas University, Kyrgyzstan) .................................212, 393

Umetaliev, Akylbek (Kyrgyz State Technical University, Kyrgyzstan) …….....................................488

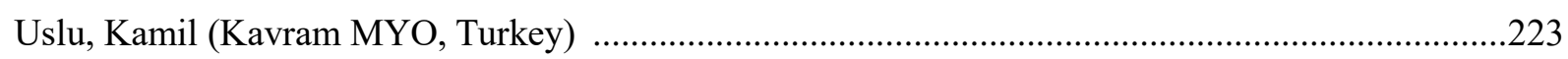

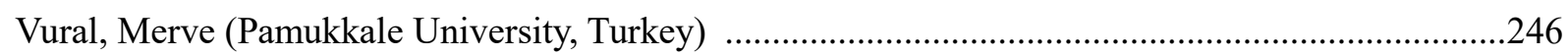

Y1lmaz, Cengiz (Konya Food and Agriculture University, Turkey) .................................................212

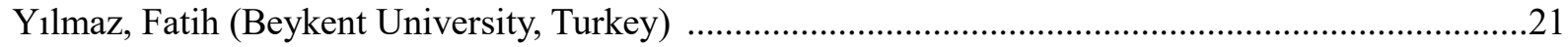


